\title{
Discurso y sociedad: contribuciones al estudio de la lengua en contexto social
}

José Luis Blas Arroyo, Manuela Casanova Avalos; Mónica Velando Casanova (eds.)

7g. Avalos; 1 is

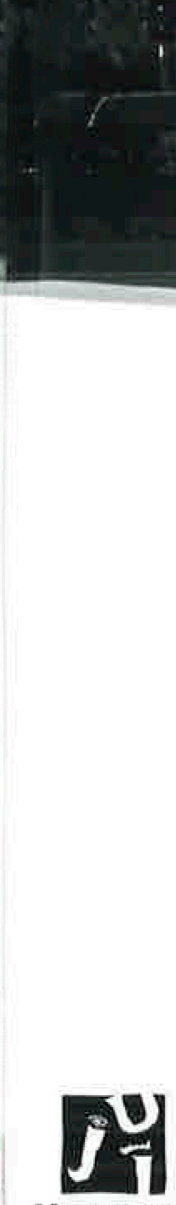




\section{DISCURSO Y SOCIEDAD}

\section{CONTRIBUCIONES AL ESTUDIO DE LA LENGUA EN CONTEXTO SOCIAL}




\section{COL·LECCIÓ «ESTUDIS FILOLÒGICS» \\ Direcció: Lluís B. Meseguer}

1. Valoriana. Estudis sobre l'obra d'Enric Valor

2. La Escuela de Nueva York. John Ashbery y la nueva poética americana

3. Revisiones críticas del teatro alternativo británico 1968-1990

4. El discurs prefabricat. Estudis de fraseologia teòrica i aplicada

5. Discourse Analysis and Terminology in Languages for Specific Purposes

6. Methodology and New Technologies in Languages for Specific Purposes

7. Estudio toponímico del término municipal de Puertomingalvo (Teruel)

8. Language Learning in the Foreign Language Classroom

9. Estudios sobre lengua y sociedad

10. Oral Skills and Proposals for the Classroom

11. Aspectos empíricos de la traducción artesana y automática del verbo GET

12. From Cha to Tea

13. Pragmatic Competence and Foreign Language Teaching

14. Tendencias actuales en los estudios filológicos anglonorteamericanos

15. Internet in language for specific purposes and foreing language teaching.

16. Internet in linguistics, translation and literary studies

17. Linguistics studies in the academic and professional English

18. Computer-Mediated Lexicography in the Foreing Language Learning Context

19. Cognitive and discourse approaches to Metaphor and Metonimy

20. El Pensament de Salvador Dalí en el llindar dels anys trenta

21. La comparación con como en la Crónica Medieval: de Alfonso X a López de Ayala

22. Teaching and Learning the English Language from a Discourse Perspective

23. Discurso y sociedad. Contribuciones al estudio de la lengua en contexto social

24. Language@twork 
Col·lecció «Estudis Filològics»

Núm. 23

\section{DISCURSO Y SOCIEDAD}

\section{CONTRIBUCIONES \\ AL ESTUDIO DE LA LENGUA \\ EN CONTEXTO SOCIAL}

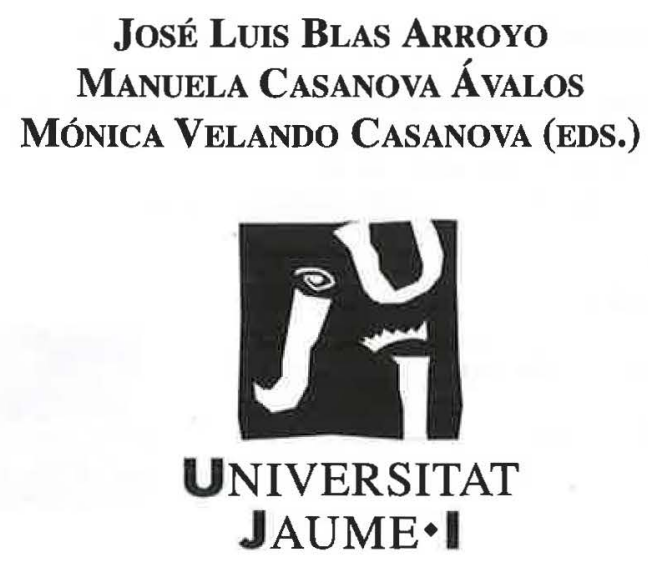


BIBLIOTECA DE LA UNIVERSITAT JAUME I. Dades catalogràfiques

DISCURSO Y SOCIEDAD: contribuciones al estudio de la lengua en contexto social / José Luis Blas Arroyo, Manuela Casanova Ávalos, Mónica Velando Casanova (eds.). - Castelló de la Plana: Publicacions de la Universitat Jaume I, D.L. 2006

p.; cm. - (Estudis filològics ; 23)

Bibliografía. $\mathfrak{x}$ Textos en castellà, català i anglès.

ISBN 84-8021-538-0

1. Sociolingüística. I. Blas Arroyo, José Luis, ed. lit. II. Casanova Ávalos, Manuela, ed. lit. III. Velando Casanova, Mónica, ed. lit. IV. Universitat Jaume I. Publicacions, ed. V. Sèrie.

$81^{\prime} 27$

Cap part d'aquesta publicació, incloent-hi el disseny de la coberta, no pot ser reproduïda, emmagatzemada, ni transmesa de cap manera, ni per cap mitjà (elèctric, químic, mecànic, òptic, de gravació o bé de fotocòpia) sense autorització prèvia de la marca editorial.

(C) Del text: els autors, 2006

(C) De la present edició: Publicacions de la Universitat Jaume I, 2006

Edita: Publicacions de la Universitat Jaume I. Servei de Comunicació i Publicacions Campus del Riu Sec. Edifici Rectorat i Serveis Centrals. 12071 Castelló de la Plana Tel. 9647288 19. Fax 964728832 http://sic.uji.es/publ e-mail:publicacions@uji.es

ISBN 84-8021-538-0

Imprimeix: Gràfiques Color Imprés, s.lıu, - Castelló

Dipòsit legal: CS-07-2006

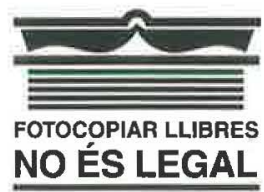




\section{ÍNDICE}

\section{Presentación}

José LuIs BlAs ARroyo (Universitat Jaume I)

\section{Ponencias plenarias}

Albert Bastardas Boada (Universidad de Barcelona)

La evolución de la diversidad lingüística: comprender para proponer

FRANCisco Gimeno MEnÉndez (Universidad de Alicante)

Sociolingüística histórica: el proceso de formación

de las lenguas románicas

Humberto López Morales (Universidad de Puerto Rico (catedrático emérito) y Secretario de la Comisión Permanente de las Academias de la Lengua Española)

El estudio de la variación sintáctica: Precisiones metodológicas 81

José Antonio Samper Padilla (Universidad de Las Palmas de Gran Canaria) Disponibilidad léxica y sociolingüística

María José Serrano Montesinos (Universidad de La Laguna)

Acción e interacción social en variación sintáctica y discursivo-pragmática 121

\section{Sección I: Análisis del discurso}

Ruth Aguila Tejeda (unam, México)

Mestizaje lingüístico en la literatura femenina chicana.

M. Belén Alvarado Ortega (Universidad de Alicante)

Las fórmulas rutinarias ¿actos o subactos?

AMPARo Ayora del Olmo (Universitat Jaume I)

Aspectos sociolingüísticos en la narrativa en castellano

del escritor valenciano José Luis Aguirre 163 
M $^{a}$ Del Mar Balboa Carbón (Universidad Complutense de Madrid)

El concepto de gramaticalización dentro de la lingüística cognitiva:

el caso de be + -ing

ABIR Bouzemmi (Universidad Complutense de Madrid)

The image of women in english slang: language and gender ideology

Àngels CAmpos (Universidad Católica de Valencia)

La funció crítica de l'emissor en el discurs acadèmic:.

Contrast interdisciplinar

JOAN COBA FEMENIA (Universitat de València)

Les relacions entre comunitats de parlants a través de les dites

i frases fetes populars dels nostres pobles

José Antonio Díaz Rojo (Consejo Superior de Investigaciones

Cientificas), Ricard Morant Marco (Universidad de Valencia),

Debra Westall PIXton (Universidad Politécnica de Valencia)

You are what you eat! Health Claims and Spanish Nutritional Discourse

Ramón L. Fernández y SuÁrez y M Ma Jesús de Teresa Paredes

(Universidad Politécnica de Madrid)

Aplicación de contenidos socio-culturales en la docencia

del español para estudiantes forestales en Finlandia

Laura Filardo Llamas, Elena GonZÁleZ-Cascos JiménEZ y

MARTA Ma GutiÉRreZ RodríguEZ (Universidad de Valladolid)

Conflicting language? Ideological representations in

northern irish political discourse

Ángela García Canelles (Universitat Jaume I)

La ironía socrática: un compromiso social más allá de la dialéctica

ético-filosófica

VICTORIA GASPAR VeRdú (Universitat Jaume I)

El compromiso social del teatro de Brecht

ISABEl Gómez Díez (Universidad de Amberes)

La influencia de los nacionalismos en el discurso de la lingüística actual: Análisis del discurso del Congreso de Diversidad lingüística, Sostenibilidad y Paz del Forum de las culturas de Barcelona 2004 263 
M José Gómez OrTtz (Universidad Politécnica de Madrid)

Deporte y discurso social: dos registros en el género del plan de entrenamiento deportivo

Josep À. MAS (Universitat Politècnica de València)

La llengua de l'audiència en televisió: implicacions ideològiques

des del col-loquial a l'estàndard 287

GianPiero Pelegi y Carmen González Royo (EOI de Sagunto/

Universidad de Alicante)

Sátira política y sistema

ENRIC RAMIRO ROCA (Universitat Jaume I)

Una joventut típica i tòpica (Aproximació sociolingüística a la inmigració valenciana en el batxillerat).

M $^{\mathrm{a}}$ Milagros del Saz Rubio (Universidad Politécnica de Valencia)

Buying the product, buying the stereotype: Covert portrayals

of ethnic minorities in TV advertising

JAVIER VELLÓN LAHOZ (Universitat Jaume I)

La gestión social del vocabulario: el discurso mediático, entre

la especialización y el habla. De la 'deslocalización' industrial

a la ideológica

LUIS Veres CoRTÉs (Universidad Cardenal Herrera-CEU)

Sociolingüística y totalitarismo

\section{Sección II: Estudios sobre variación linguiística}

Miguel Ángel Aujón Oliva (Universidad de Salamanca)

Variación sintáctica y estilo en el género periodístico

de las cartas al director 355

ana Blanco Canales (Universidad de Alcalá de Henares)

Estudio de actitudes y creencias lingüísticas en Alcalá de Henares.

Su aportación al análisis sociolingüístico de los datos .367

Luis EscorIza Morera (Universidad de Cádiz)

Variación léxica y grado de formalidad 
Silvia Güell Segarra, Miquel-Àngel Pradilla Cardona, Anna Saura Vizcarro, Joan Anton Verge Caballer y Magda Bulldó Escoté (Universitat Rovira $i$ Virgili)

Pervivència de la realització fricativa labiodental a Valls 391

Antonio Ma LóPEZ GonzÁlez (Instituto Bilingïe Hispano-Polaco de Poznan, Polonia)

Presencia y ausencia de los pronombres personales sujetos en la radio local almeriense

Amalia Pedrero González (Universidad San Pablo-CEU de Madrid)

Diatopía de disfemismos y eufemismos en el ámbito hispánico.

Ana Ma Pérez Martín (Universidad de Las Palmas de Gran Canaria)

El debilitamiento de la /-s/ en El Hierro: cálculo probabilístico

Miquel-Àngel Pradilla Cardona, Silvia Güell Segarra, Anna Saura Vtzcarro, Joan ANton Verge Caballer y Magda Bulldó Escoté (Universitat Rovira $i$ Virgili)

Les representacions del variacionisme en l'àmbit de la llengua catalana

Mónica Velando Casanova y Javier Vellón Lahoz (Universitat Jaume I)

La feminización del léxico profesional: entre la norma y el uso

\section{Sección III: Bilingüismo y contacto de lenguas}

Raquel Casesnoves Ferrer (Universitat Pompeu Fabra)

Contrastes demográficos y sociolingüísticos en el proceso de la normalización del euskera, del catalán y del gallego en la década comprendida entre 1991 y 2001

Margarita R. DÉniz HeRnández (Universidad de Siena, Italia)

La presencia de españolismos en el italiano de hoy:

una aproximación sociolingüística

ARTURo FERnÁndeZ-Gibert (California State University, San Bernardino) El desplazamiento lingüístico y su documentación:

primeros síntomas del desplazamiento del español en la prensa del Nuevo México territorial, 1846-1912 493 


\section{Carmen Fernández Martín (Universidad de Cádiz)}

Gibraltar's multilingual past, monolingual society in the future?:

a quantitative and qualitative analysis of the tree main varieties spoken

in the rock

Juan José Hernández Medina (Universidad de Almería)

Los elementos sociolingüísticos en la correspondencia

comercial-turística alemana: propuestas para su enseñanza

en las clases de alemán para fines turísticos

ABILI JuRAdo DueÑas (IES Riba-roja de Túria, València), EMPAR

RoDrigo CAÑETE (Col-legi Mare de Déu del Socors, Benetússer, València)

La literatura com a símptoma d'una situació de conflicte lingüístic:

tres novel-les valencianes del segle XXI

JuAn José Martínez SiERRa (Universitat Jaume I)

Defining terms: bilingualism, interpretation, translation, and cultural awareness. A case study

Adolf PIQuer Vidal (Universidad de Salamanca)

Canvi de codi als mitjans de comunicació valencians 551

Empar Rodrigo Cañete y Abili JuRado Dueñas (Collegi Mare de Déu del Socors, Benetússer, València/ıEs Riba-roja de Túria, València) Informe sobre l'ús del valencià en la indústria del moble a l'horta sud. Resultat de les entrevistes 561

\section{Sección IV: Cortesía verbal}

Marta Albelda (Universitat Politècnica de València)

Disconcordancia entre atenuación/cortesía e intensificación/descortesía

en conversaciones coloquiales

María Bernal Linnersand (Universidad de Estocolmo)

Actos corteses, descorteses y anticorteses en la conversación coloquial española

Josefa CONTRERAS FERnÁNDEZ (Universitat Politècnica de València) Imagen social española versus imagen social alemana 
Ma Dolores García Pastor (Universitat de València)

Face-aggravation in context: a tentative methodological framework

Ma Elena Gómez SÁnChez (Universidad Europea de Madrid)

Cortesía y eufemismo: los sustitutos eufemísticos en la prensa

y la defensa de la propia imagen

Nieves Hernández Flores (Escuela Superior de Comercio de Copenhague) Actividades de autoimagen, cortesía y descortesía:

tipos de actividades de imagen en un debate televisivo

Silvia KaUl de MarlanGieon (Universidad Nacional

de Río Cuarto, Argentina)

El género horóscopo: cortesía e ideología

ANTONi MAESTRe Brotons (Universitat d'Alacant)

La comunicació entre homes i dones en els contes de Quim Monzó:

una anàlisi des del punt de vista de la cortesia lingüística

M JoSEP MARÍN JORDÀ (Universitat Politècnica de València)

Cortesia lingüística i debat electoral

Laura Mariottini y Franca Orletti (Università degli Studi Roma Tre)

La construcción de la identidad y la expresión de la cortesía/descortesía verbal en los chats

Manuel Padilla Cruz (Universidad de Sevilla)

Hacia una nueva definición de la cortesía

Miguel Ángel SaRmiento Salinas (Universidad de Estocolmo)

La cortesía verbal y su correlación con la identidad

étnica en contextos de etnias en contacto 711

\section{Sección V: Disponibilidad léxica}

José Antonio Bartol HeRnÁNDEZ y NaTividad HernáNDEZ MuÑoZ (Universidad de Salamanca)

Proyecto del léxico disponible de España 725 
Manuela Casanova Ávalos (Universitat Jaume I)

La disponibilidad léxica en la Comunidad Valenciana

Rubén ChaCón BELTRán (UNED)

Disponibilidad léxica en el aprendizaje de inglés como lengua

extranjera por hispanohablantes adultos

GÉrard Fernández Smith (Universidad de Cádiz), Ana Ma Rico Martín (Universidad de Granada), Ma José MolIna García (Universidad de Granada) y Mª́ ÁNGELES JIMÉNEZ JIMÉNEZ (Universidad de Granada)

Proyecto sobre la disponibilidad léxica en alumnos preuniversitarios de Melilla

M $^{\mathrm{a}}$ BEgOÑa Gómez DEVIS y FranCESC LLOPIS RODRIGo (Universitat de València)

La disponibilitat lèxica a València: criteris d'edició 779

Clara Eugenia Hernández Cabrera y Marta Samper HernándeZ (Universidad de Las Palmas de Gran Canaria)

Nivel educativo e índices de disponibilidad 791

Maribel SERRANo ZaPATA (Universitat de Lleida)

Consecuencias del contacto de lenguas en Lérida: interferencias detectadas en las encuestas de disponibilidad léxica 


\section{PRESENTACIÓN}


El presente volumen contiene las actas del II Congreso sobre Lengua y Sociedad, que, organizado por las áreas de Lengua y Literatura Españolas de la Universitat Jaume I, tuvo lugar entre los días 9 y 11 de noviembre de 2004. De los 75 trabajos que se presentaron en dicho congreso, las actas reúnen un total de 62, correspondientes a 5 ponencias plenarias y 57 comunicaciones, lo que representa una proporción elevada de lo que científicamente dio de sí aquella reunión académica. Lamentablemente, algunos congresistas no pudieron entregarnos en tiempo y forma el texto de sus contribuciones, lo que explica que no aparezcan en estas páginas.

Como tuve oportunidad de explicar en la presentación oficial del congreso, éste respondía a la voluntad de continuidad que para los organizadores representaban unas I Jornadas, que se habían celebrado cuatro años antes y que por entonces se habían limitado a una serie de conferencias a cargo de reconocidos especialistas, así como algunas mesas redondas sobre diversos temas relacionados con la sociolingüística. Pues bien, a diferencia de aquellas jornadas, por cierto culminadas dos años más tarde también con la edición de sus actas, bajo el título de Estudios sobre Lengua y Sociedad, en esta ocasión decidimos reunir a una muestra mucho más significativa de investigadores en torno a nuestro objeto de estudio. El resultado fue la inscripción de un centenar de congresistas, procedentes de 42 universidades y centros de investigación repartidos por una quincena de países diferentes.

Entre los miembros de la comisión organizadora de estos congresos -y de otros, esperamos, en el futuro- ha primado la idea de que merecía la pena dedicar un encuentro científico autónomo, como el que da cuerpo a las presentes actas, para el análisis y el debate en torno a la influencia recíproca que se dispensan dos realidades con las que convivimos a diario: la lengua, o las lenguas con las que nos comunicamos con los demás, y la sociedad que nos rodea. Pese a la amplitud y a lo rotundo de estas influencias, reconocidas, además, desde antiguo, todavía es difícil encontrar espacios de discusión independientes en la disciplina lingüística, excepcionalidad que se torna casi en anecdótica por estos pagos. Por fortuna, los encuentros de lingüistas no son infrecuentes en nuestro país, y ahí están para demostrarlo los numerosos simposios, jornadas y demás variantes 
congresuales que organizan periódicamente diversas instituciones universitarias y científicas. Y sin duda a ellos acuden, a veces con un punto de timidez y hasta en ocasiones de marginación, quienes se interesan por los temas que se desarrollan en estas páginas. Sin embargo, las ocasiones para la discusión autónoma en torno a los temas que se dan cita en estas actas, y que comparten un interés común por los aspectos sociales del discurso, son mucho más escasas. Quizá una excepción a este panorăma lo representan aquellas reuniones académicas que tienen lugar en sociedades bilingües, donde ciertamente lo social tiene una relevancia decisiva en la discusión científica, aunque lastrada no pocas veces por limitaciones temáticas, y'hasta por qué no decirlo, ideológicas.

Los responsables del II Congreso sobre Lengua y Sociedad quisimos huir, justamente, de estas limitaciones y programamos un congreso que queríamos generoso. Generoso, en primer lugar, en lo temático, ya que en nuestras intenciones no figuraba un simposio estrictamente sociolingüístico, sea cual sea la interpretación que otorguemos a esta disciplina, tan pujante en los estudios linguísticos contemporáneos, como todavía de límites algo indefinidos y polémicos. De ahí que durante aquellos días, y junto a contenidos ineludibles en un congreso de estas características, como los estudios sobre fenómenos de variación desde perspectivas sincrónicas o diacrónicas, o los que tradicionalmente se otorgan a la llamada sociología de lenguaje (el bilingüismo social, las actitudes lingüísticas, etc. ), en las aulas de la universidad castellonense aparecieron también otras aportaciones teóricas y metodológicas, en los que las perspectivas sociales y funcionales del análisis se dan la mano para el estudio de fenómenos tan relevantes como la cortesía verbal, los fenómenos lingüísticos derivados del contacto de lenguas o infinidad de aspectos sociopragmáticos sobre diversos discursos públicos y privados. El reflejo de esta heterogeneidad temática lo representan las cinco secciones en que se dividen las comunicaciones presentadas al Congreso y que, junto al capítulo de «Ponencias plenarias», completan el contenido del presente volumen. Por orden de aparición, estas secciones corresponden a estudios clasificados en los siguientes apartados: 1) Análisis del discurso, 2) Estudios sobre variación lingüística, 3) Bilingüismo y contacto de lenguas, 4) Cortesía verbal, y 5) Disponibilidad léxica.

Ahora bien, junto a la diversidad temática el lector encontrará también en estas páginas una cierta diversidad idiomática. Junto al español, lengua en la que se presentaron la mayoría de las ponencias y comunicaciones del Congreso, el libro recoge también una significativa muestra de artículos escritos en catalán e inglés. A mi juicio, la comunicación científica debería huir de la uniformidad lingüística que imponen algunos interesadamente y en la persecución de este objetivo los editores del presente volumen hemos querido aportar nuestro modesto grano de arena.

Como presidente del comité organizador del II Congreso sobre Lengua y Sociedad quisiera concluir estas breves palabras introductorias agradeciendo la 
colaboración prestada por diversas instituciones y personas, que hicieron posible la realización de aquél, y con ello, la subsiguiente publicación de estas actas. En primer lugar, quisiera agradecer la ayuda brindada por algunas instituciones que ya colaboraron con nosotros en convocatorias pasadas y que volvieron a hacerlo en la presente ocasión. Es el caso de empresas castellonenses como BP Oil y Tau Cerámica, que nos brindaron su ayuda económica, y lo mismo cabe decir de organizaciones públicas y privadas, como la fundación Bancaixa, la Generalitat Valenciana, el Ministerio de Educación, el Exmo. Ayuntamiento de Castellón o la propia Universitat Jaume I, sede del congreso. Y si la ayuda económica de estas instituciones ha resultado decisiva, no menos determinante lo fue la generosa contribución de numerosos profesores, alumnos y personal administrativo de la Facultad de Ciencias Humanas y Sociales de la Universitat Jaume I, que se ofrecieron desinteresadamente para cumplir las más diversas tareas. A todos ellos, nuestro más sincero agradecimiento.

José LUIS BLAS ARROYO

PRESIDENTE DE LA COMISIÓN ORganizadora 


\section{PONENCIAS PLENARIAS}




\title{
LA EVOLUCIÓN DE LA DIVERSIDAD LINGÜÍSTICA: COMPRENDER PARA PROPONER
}

\author{
Albert Bastardas Boada \\ Universidad de Barcelona
}

\section{INTRODUCCIÓN}

V

IVIMOS en esta circunstancia histórica un aumento exponencial del contacto lingüístico. En lo que se ha convenido en llamar la nueva era de la «globalización», los Estados tradicionales se integran en unidades políticoeconómicas más amplias, tienen a la vez que reorganizarse internamente para dar cuenta de la propia diversidad de sus grupos humanos constituyentes, se exponen a las nuevas tecnologías de la comunicación, y reciben migraciones importantes de procedencia muy distinta, y todo en el marco de una conciencia superior de la unidad de la especie y, simultáneamente, de su diversidad cultural y de las crisis de la bio- y de la linguodiversidad. El momento es, pues, apasionante y de alta complejidad, dado que la realidad nos demanda la ineludible revisión de gran parte de nuestras creencias y configuraciones tradicionales.

Desde el plano lingüístico, lo que tenemos específicamente encima de la mesa es el problema de la organización lingüística de la humanidad, es decir, de una especie biológicamente única pero culturalmente diversa a causa fundamentalmente de su dispersión y fragmentación históricas y, a la vez, de su enorme potencial de creatividad. ¿Cómo reunirnos de nuevo en un espacio comunicativo común, asegurando la intercomunicación, y a la vez, manteniendo lo que ya hemos construido en la diversidad de situaciones en que nos hemos tenido que desarrollar? La gran cuestión deviene, pues, ¿cómo hacer posible la comunicación entre todos los humanos y a la vez el mantenimiento de la diversidad lingüística, que también amamos y que nos define grupalmente?

\section{LAS EXPERIENCIAS Y LOS MIEDOS}

Como sabemos, muchas experiencias históricas de contacto lingüístico han terminado llevando a la desaparición a muchos códigos, que han resultado sustituidos por otros en las funciones comunicativas de los grupos que los sostenían (Bastardas, 1996; Montoya, 1996). Y es esta conciencia de la posibi- 
lidad de entrar en una situación "amenazante» para su continuidad lingüística la que frena contemporáneamente la decisión de muchos grupos humanos de adoptar lenguas de intercomunicación más generales. El ejemplo europeo es claro a este respecto: se prefiere oficializar veinte lenguas a debatir con claridad y profundidad la posibilidad de adopción de un código común. No obstante, el recurso al subterfugio de la denominación «lenguas de trabajo» indica la presión de las necesidades prácticas cotidianas de comunicación, que, tarde o temprano, deberán ser afrontadas explícitamente, y más si se quiere realmente avanzar en el proceso social de integración europea. De hecho, las instituciones marcan sus políticas pero las crecientes relaciones tanto comerciales como académicas y personales necesitan resolver sus problemas de intercomprensión $\mathrm{y}$, por tanto, toman decisiones al respecto que, como sabemos, tienden claramente hasta ahora a favorecer una lengua -el inglés- muy por encima de las otras.

Una mirada rápida a los distintos casos de políticas lingüísticas existentes en la actualidad demuestra que, en la gran mayoría de situaciones, se tiende a priorizar uno u otro de los grandes objetivos, es decir, o bien se apuesta por la preservación clara de las lenguas, haciendo entonces difícil la intercomunicación, o bien se asegura la intercomunicación pero a costa de llevar a la marginalidad los otros idiomas y de producir frecuentemente su completo abandono, en un marco de estigmatización de estas lenguas y de denigración incluso de sus propios hablantes. Que las soluciones no son fáciles lo demuestra, por ejemplo, el hecho de que en el caso más citado por los conservacionistas, como es Suiza, se haya llegado ya a plantear por parte de algunos sectores la adopción del inglés como interlengua, con el fin de hacer posible la comunicación entre sus distintas comunidades lingüísticas, y a la vez, con el resto de Europa y del mundo. Por otra parte, los regímenes unilingües estrictos, con clara hostilidad para con las lenguas no-oficiales de los grupos minorizados, pueden desembocar, como hemos visto, en situaciones de alta insatisfacción e inestabilidad política, con desenlaces frecuentemente violentos y/o de gran odio entre las comunidades.

El resultado de toda esta problemática tiende a ser: a) una condena del «bilingüismo» individual por parte de los grupos minorizados, dado que constatan que su bilingüización asimétrica les lleva al abandono de su lengua propia forzados por el contexto de subordinación en que tienen que vivir, o bien, b) a temer la instauración de una interlengua (por ejemplo en Europa) por parte de los grupos hasta ahora unilingües, dada la poliglotización masiva que esta medida ocasionaría, con lo que pasarían también a percibirse como grupos «amenazados» en su supervivencia cultural. La (re)integración comunicativa supragrupal de la humanidad, deviene, así, un problema de difícil solución, dado que los distintos colectivos no quieren desaparecer como tales, con lo que la adopción de medios de comunicación comunes se retarda o 
queda incompleta, con los perjuicios que esto conlleva para el avance hacia la intercomprensión de los humanos como especie única (Bastardas, 2002).

Con toda probabilidad, la mayoría de los seres humanos sería feliz si pudiera conciliar intercomunicación y mantenimiento y desarrollo de las lenguas propias. ¿No podríamos hallar un modelo que hiciera esto posible?

\section{LAS CAUSAS DE LA SUSTITUCIÓN LINGÜÍSTICA}

Responder a esta crucial pregunta nos debe llevar a la (re)exploración de los llamados procesos de «sustitución lingüística», para tratar de comprenderlos mucho mejor que hasta ahora y ver si cabría la posibilidad de evitar sus consecuencias negativas. Aunque la historia nos muestra una gran cantidad de casos en que la bilingüización masiva de un colectivo lingüístico ha terminado en el abandono completo de su lenguá propia, otras situaciones podrían sugerir que, en otras condiciones, la bilingüización no tiene por qué llevar ineluctablemente a la sustitución lingüística como un mecanismo histórico de obligado cumplimiento. El bilingüismo masivo, así, sería una condición necesaria pero no suficiente para la causación de la extinción lingüística, como de hecho ya afirmó hace unos años el sociólogo Stanley Lieberson (1981) cuando advertía que debíamos distinguir entre las causas de la bilingüización y las de la sustitución, dado que no tenían por qué ser las mismas. Un hecho es, pues, la adopción de un idioma (para determinadas funciones), y el otro, diferente, es su abandono funcional total y la adopción completa de otro código para todas las tareas comunicativas. Otro sociólogo importante, Norbert Elias (1982), nos indicó útilmente también que

en el tratamiento del problema de la necesidad de las evoluciones sociales [era necesario] distinguir claramente y nítidamente la afirmación de que una figuración B ha de seguir necesariamente a una figuración A y la afirmación de que una figuración A necesariamente tendría que preceder a una figuración B.

Es decir, que lo que es un hecho es que la bilingüización tiene que haberse producido antes para que pueda haber abandono del código de origen. Pero lo que es menos claro es que por el solo hecho de esta bilingüización -o poliglotización- los individuos tengan necesariamente que abandonar su lengua primera, por ejemplo, para hablar con sus hijos. Otros factores, pues, deberían explicar este segundo fenómeno.

Muy probablemente, la bilingüización masiva lleva a la sustitución en situaciones caracterizadas por una total subordinación política -lo que con- 
lleva la falta de autocontrol colectivo del grupo-, un pobre desarrollo económico, una imagen y discursos autodenigrativos, un grupo de referencia dominante y potente, $y$, en general, un conjunto de representaciones negativas respecto a la lengua propia, favorecedoras del cambio de lengua en la transmisión intergeneracional -con lo que se causa la interrupción de la reproducción lingüística. En cambio, por ejemplo, no se encuentra sustitución lingüística en la Suiza alemánica -cuando de hecho es una clara bilingüización en el estándar general germanófono- o bien en Luxemburgo, en que su lengua propia convive en distribución funcional con el francés y el alemán, dominados por todos sus ciudadanos. En estos y otros casos vemos cómo, aunque se produzca una bilingüización o poliglotización funcional de la práctica totalidad de la población, ésta no abandona su código para las actividades sociales cotidianas ni lo deja de transmitir familiarmente,, con lo que la nativización lingüística en la próxima generación está asegurada. Muy probablemente, pues, no es el bilingüismo el que causa necesariamente per se la sustitución lingüística, sino las condiciones contextuales en que se da este fenómeno.

\section{LA PERSPECTIVA DE COMPLEJIDAD Y LA POLÍTICA LINGÜÍSTICA}

Gestionar la coexistencia de la linguodiversidad y de la comunicación humana general requiere probablemente cambios importantes en nuestras maneras de pensar y en las imágenes de las representaciones con las que concebimos el mundo. Una de las cuestiones en la que debemos estar más alerta es en nuestra gran tendencia al pensamiento dicotomizante. Estamos tremendamente inclinados a pensar nuestras categorías de la realidad en términos de contraposición y antagonismo, lo que puede ser fatal para nuestra comprensión de los hechos socioculturales, frecuentemente imaginados como si se trataran de fenómenos con las mismas propiedades que los elementos físicos (y, en especial, los sólidos). Y ocurre que es mucho mejor -es decir, nos acercamos más a la realidad- si nos acostumbramos a pensar en términos de $y$ que de $o$. Es decir, debemos apostar más por una lógica «inclusiva» que por una de «exclusiva» (Bastardas, 2003 a). Si pensamos en la existencia de las lenguas desde $y$ y no desde $o$, podemos dar cuenta mucho mejor del hecho de que una gran parte de la humanidad no es unilingüe sino precisamente multilingüe, de que un individuo puede ser competente en varias lenguas y no en una sola, y de que, convenientemente organizadas, las sociedades humanas pueden funcionar en lenguas diversas y no sólo en una. Ocurre lo mismo con las identidades: no hace falta ser «f» $O$ «g»; podemos ser una cosa $y$ la otra, 
dado que no tienen por qué tener características necesariamente excluyentes, como en cambio sí puede ocurrir con los objetos físicos.

Desdicotomizar el pensamiento nos abre creativamente la mente y podemos así empezar a imaginar configuraciones mucho más adecuadas para la superación de los (falsos) dilemas a que nos lleva el pensamiento simplificador. Podemos postular "políticas glocales», «naciones universales», «poliglotismos oficiales en $\mathrm{X}, \mathrm{Y}, \mathrm{y} \mathrm{Z}$ », «Estados polinacionales», «identitades múltiples», «diferenciaciones homogeneizantes», etc. Éste es el camino claramente postulado por el paradigma de complejidad, que parte ya de la noción simultánea de una realidad configurada por una «complementariedad antagonista», que nos demuestra la necesidad de enlazar los términos (aparentemente) contrarios, ya que con toda probabilidad, existen en la realidad de forma interdependiente e imbricada. Como dice uno de sus grandes promotores, Edgar Morin, «el pensamiento complejo es un pensamiento que une los contrarios [...]. Unir lo que se opone y superarlo por el principio del bucle recursivo, autogenerador» (Spire, 1999).

No obstante, adoptar la perspectiva de complejidad tampoco es la panacea total, sino que lo que produce es llevarnos a otra dimensión problemática, que es la de la organización. ¿Cómo vamos a hacer posible esta unificación de elementos contrarios? ¿Cómo va a ser posible que las lenguas coexistan sin perder funcionalidad, y que los colectivos humanos se perciban complementariamente como miembros de unidades distintas? Pensar a través de y y no de $o$ en el plano de las lenguas es más fácil en el nivel de las competencias individuales que en el de las sociedades humanas. Muchos de nosotros podemos saber más de una lengua y vemos que no ocurre nada, que la competencia en una lengua no nos quita la competencia en la otra -a pesar de algún fenómeno de interferencia que pueda producirse. Pero en el nivel sociopolítico, evitar que los hablantes de una lengua subordinada en constante contacto con otra dominante no lleguen a ver la suya propia como negativa o prescindible exige medidas políticas claras y acertadas, que puedan compensar o reparar las desigualdades que pudieran darse entre los grupos lingüísticos en presencia. Como sabemos, el equilibrio funcional se puede romper si los grupos históricos pasan a creer de forma masiva que será mejor transmitir a los hijos su segunda lengua en vez de la lengua de origen.

Los poderes públicos, pues, serán los primeros responsables de llevar a cabo una organización del uso social de las lenguas que las haga ver como plenamente útiles, dignas y prestigiosas. Los principios que tradicionalmente han inspirado la organización del plurilingüismo oficial han sido los llamados de «territorialidad» o de «personalidad». Es decir, un Estado con diversidad lingüística se organiza basándose en una yuxtaposición de unilingüismos oficiales en los distintos territorios o bien pluralizándose lingüísticamente en 
todo su ámbito de soberanía dando al ciudadano la posibilidad de elección lingüística, se encuentre donde se encuentre (Bastardas \& Boix, 1994). A pesar del buen funcionamiento de estos principios en muchos casos, hay que tener en cuenta que, habitualmente, se aplican en situaciones en que la mayoría de los individuos tienden a ser monolingües, con lo que, a nivel colectivo, no se resuelve satisfactoriamente el problema de la intercomunicación general. Esto es lo que se puede detectar, por ejemplo, y como ya se ha dicho al principio, en el caso suizo o también en el belga, en que cada vez con más frecuencia se debe recurrir al inglés como lengua franca entre sus diversos grupos.

Si pensamos en el plano ya europeo, ¿cómo nos vamos a entender cotidianamente entre los ciudadanos y entre las empresas u otras organizaciones de distinto origen lingüístico (aparte de las relaciones formales con las instituciones -que éstas sí pueden prever servicios multilingües) si no aceptamos la poliglotización? Creo que una posible vía de solución podría basarse en la aplicación de un nuevo principio basado en el concepto de 'subsidiariedad' ya presente en la tradición comunitaria europea. Este principio, hasta ahora sólo político-administrativo y que reclama que las decisiones sean tomadas siempre que sea posible en el nivel más cercano a los ciudadanos y no en niveles superiores, podría ser adaptado a la dimensión sociolingüística proponiendo que «todo lo que pueda llevar a cabo una lengua 'local' no debe hacerlo otra de más 'global'». Es decir, se impulsaría el conocimiento efectivo y masivo de otras lenguas $-\mathrm{y}$, en especial, de la/s que fuera/n adoptada/s como vehicular/es en las supraunidades de integración- pero otorgando como principio general la preeminencia funcional a la lengua de cada grupo lingüístico históricamente constituido. Esta reserva de funciones para las lenguas «locales» tiene que ser clara y precisa, a fin de que la poliglotización masiva no evolucione innecesariamente hacia un abandono de los códigos de menos radio comunicativo. Es por esta razón que, al lado de los principios de poliglotización y subsidiariedad, es necesario introducir el de «funciones públicas exclusivas» para las lenguas locales, para que puedan disponer de un núcleo importante de usos reservados, que no deben ser realizados por las lenguas más generales. Así, todos los códigos podrán ser percibidos como plenamente útiles y eficaces, con lo que se favorece su continuidad y plena utilidad.

Estos nuevos principios no solamente pueden ser interesantes para la solución de los problemas lingüísticos que surgen cuando los grupos humanos se integran en unidades político-económicas más amplias, sino también en aquellos casos, a menudo difíciles, en que conviven amplios colectivos linguiísticos en un mismo territorio. La distribución funcional no-jerarquizada de las lenguas, con funciones exclusivas para cada uno de los códigos, favorece el hecho de que cada grupo tenga que saber y usar la lengua del otro, con lo que se contribuye al equilibrio de la situación y, habitualmente, a la 
mejora de la percepción de las lenguas «locales», con lo que se pueden parar los procesos de abandono que puedan estar produciéndose y además ganar hablantes, dado que incitará a la bilingüización de los individuos que tengan el código dominante como lengua inicial. Dado que estamos en la Comunidad Valenciana, podríamos sugerir que este esquema podría ser quizás útil para mejorar la situación actual de su lengua propia.

Pasando a un nivel más general, continental o mundial, en la aplicación de los principios que hasta ahora he expuesto los poderes públicos deben ciertamente velar por la evolución sociolinguística para evitar la tendencia a los usos abusivos de las lenguas más generales, en especial por parte de las grandes empresas, comerciales o mediáticas. Para el éxito del modelo -por ejemplo, para conseguir una Europa con una interlengua aceptada felizmentehace falta tener mucho cuidado en el mantenimiento del equilibrio ecológico entre las lenguas locales y la/s más general/es. Y, en este aspecto, es fundamental que los idiomas con más poder no quieran ocupar más espacios y funciones que aquéllos que estrictamente les correspondan. Las regulaciones precisas de los poderes públicos y la concienciación ecolingüística de las poblaciones e instituciones deberán, pues, intervenir para asegurar un equilibrio lingüístico ecosistémico y dinámico (Bastardas, 2003 b).

\section{CONCLUSIONES: PARA UNA PAZ LINGÜÍSTICA PLANETARIA BASADA EN UNA ORGANIZACIÓN «SOSTENIBLE» DE LA HUMANIDAD}

Pensar como debería ser más exactamente esta «sostenibilidad lingüística» es también responsabilidad de los lingüistas, por lo que creo que sería interesante en estos próximos años que pudiéramos aumentar nuestras investigaciones y nuestros conocimientos sobre la evolución de las situaciones sociolingüísticas de la humanidad. Salvando todas las distancias -que las hay-, una posible e interesante guía de navegación es ver lo que ya han hecho los ecólogos sostenibilistas en el plano del medio ambiente. Así, adaptando lo que el profesor Ramon Folch decía en una entrevista sobre la sostenibilidad en general (Reales, 1999), y en la línea de lo que he venido exponiendo, podríamos decir que la sostenibilidad lingüística sería un proceso de transformación gradual del actual modelo de organización lingüística de la especie humana, que tendría el objetivo de evitar que la bilingüización o poliglotización colectiva de los seres humanos tuviera que comportar necesariamente el abandono de las lenguas propias de los distintos grupos culturales (Bastardas, 2005). Desde una ética sostenibilista, pues, la diversidad de los sistemas de comunicación de los distintos grupos de la especie es claramente también un 
valor a proteger, y no como curiosidad «antropológica» sino por la intrínseca e irrenunciable dignidad de las personas y sociedades humanas.

Las analogías con la sostenibilidad medioambiental -si aceptamos su ética y sus valores convenientemente adaptados al plano lingüístico- iluminan adecuadamente la problemática de muchas situaciones sociolingüísticas actuales. Por ejemplo, sus teorizadores, como Jacobs (2000: 67), afirman que «'sostenible' se aplica corrientemente a la práctica de no extraer recursos naturales a una velocidad más rápida y ávida que la que necesiten los recursos para renovarse ellos mismos». Es decir, que también en las relaciones medioambientales el objetivo es siempre conservar el equilibrio fundamental que hace posible el propio mantenimiento del ecosistema y de sus componentes. Si llevamos esta perspectiva a la sostenibilidad lingüística, podríamos afirmar que el contacto lingüístico sostenible será aquél que no produzca exposición o uso lingüísticos en lengua alóctona a una velocidad o presión tan altos que haga imposible la continuidad estable de las lenguas autóctonas de los grupos humanos. Así, el carácter sostenible de una bilingüización masiva vendrá dado por la comparación entre el grado de valoración y funciones de la lengua no-propia y el de la lengua propia del grupo. Si el primero es menor, el contacto masivo y la bilingüización es sostenible. Si es mayor, la bilingüización no es sostenible y la lengua propia se degradará y desaparecerá muy probablemente en unas décadas.

El proceso actual de globalización tiene la virtud, como mínimo, de poner en contacto grupos humanos muy poco relacionados hasta ahora, y de crear masivamente -quizás por primera vez- una conciencia común de especie y de hábitat planetario compartido. Debemos, pues, colectivamente plantearnos cómo vamos a organizarnos lingüísticamente, qué valores queremos que predominen en estos aspectos, y cómo vamos a llegar a los objetivos que nos fijemos. La necesidad de encontrar nuevos principios que, desde la escala planetaria a la local, puedan configurar organizaciones estables de la convivencia en la diversidad, es urgente y perentoria.

Termino enunciando cinco puntos que creo que son cruciales para la paz lingüística en esta nueva etapa de la humanidad, desde el punto de vista de hacer compatible sus necesidades de intercomunicación con las del mantenimiento y desarrollo de los grupos lingüísticos que la constituyen, teniendo como marco los valores y principios de la sostenibilidad lingüística. Deberíamos, en consecuencia:

1. Promover la poliglotización de las personas, a la vez que frenar los usos abusivos de las grandes interlenguas, y extender la ideología de la igualdad y la solidaridad lingüísticas.

2. Dignificar la autoimagen de los grupos lingüísticos no-mayoritarios y subordinados. 
3. Permitir que estos grupos lingüísticos puedan controlar en la medida de lo posible su propio espacio comunicativo, de forma que puedan regular autónomamente los usos lingüísticos públicos.

4. Distribuir las funciones comunicativas dotando de funciones exclusivas y efectivas a los códigos de los grupos lingüísticos históricos en situación de subordinación.

5. Hacer conscientes los gobiernos, las empresas y las sociedades en general, de la importancia de conseguir la sostenibilidad linguística, incitándolos a incorporar de forma habitual los estudios necesarios de impacto sociolingüístico en sus procesos de toma de decisiones.

\section{REFERENCIAS BIBLIOGRÁFICAS}

Bastardas I BoAda, A. (1996): Ecologia de les llengües. Medi, contactes $i$ dinàmica sociolingüística, Barcelona, Proa.

- (2002): «Política lingüística mundial a l’era de la globalització: diversitat i intercomunicació des de la perspectiva de la 'complexitat'», Noves $S L$. Revista de Sociolingüística, [en línea], http://www6. gencat.net/llengcat/noves/hm02estiu/metodologia/bastardas1_9.htm (Versión en inglés: «World language policy in the era of globalization: diversity and intercommunication from the perspective of 'complexity'», http://www6. gencat.net/llengcat/noves/hm02estiu/metodologia/a_bastardas1_9.htm (Versión en castellano: (2003) «Política mundial del lenguaje en la era de la globalización: diversidad e intercomunicación desde la perspectiva de la complejidad», Dimensión antropológica (México) 28: 15-41).

- (2003 a): «Lingüística general: elementos para un paradigma integrador desde la perspectiva de complejidad», LinRed [en línea], http:// www2.uah.es/linred/articulos_pdf/LR_articulo_111120032.pdf.

- (2003 b): «Ecodinámica sociolingüística: comparaciones y analogías entre la diversidad lingüística y la diversidad biológica», Revista de llengua $i$ dret, 39: 119-148.

- (2005): Cap a una sostenibilitat lingüística, Barcelona, Centre d'Estudis de Temes Contemporanis, Generalitat de Catalunya.

BASTARDAS, A.; BoIX, E. (eds.) (1994): ¿Un estado, una lengua? La organización política de la diversidad lingüística, Barcelona, Octaedro.

ELIAS, N. (1982): Sociología fundamental, Barcelona, Gedisa (trad. castellana de Was ist Soziologie?, Juventa Verlag München, 1970.)

JACOBS, J. (2000): The nature of economies, Toronto, Random House.

LIEBERSON, S. (1981): Language Diversity and Language Contact (selección de Anwar S. Dil), Stanford, Cal., Stanford University Press. 
Montoya, BraUli (1996): Alacant: la llengua interrompuda. Valencia, Denes. REALES, Llứs (1999): «Una conversa amb Ramon Folch», Idees, 2 (disponible también en línea: http://www.idees.net/idees_numero.asp?IdIDEES=2.

SPIRE, ARNAUd (1999): «L'intelligence de la complexité. Entretien avec Edgar Morin», en SPIRE, ARNAUD (1999): La pensée-Prigogine, París, Desclée de Brouwer. 


\title{
SOCIOLINGÜÍSTICA HISTÓRICA: EL PROCESO DE FORMACIÓN DE LAS LENGUAS ROMÁNICAS
}

\author{
Francisco Gimeno Menéndez \\ Universidad de Alicante
}

\section{INTRODUCCIÓN}

匹 A formación de las diversas lenguas románicas desde un mismo diasistema latino cuestiona la simplificación de las hipótesis basadas solamente en los sistemas lingüísticos. Desde este punto de vista, la sociolingüística histórica revisa y actualiza los procesos históricos del cambio lingüístico, como hipótesis verificables entre las poblaciones actuales. En nuestros días, la sociolingüística histórica ha abierto nuevas posibilidades al conocimiento de la dinámica social y contextual del cambio lingüístico, y se ha desarrollado con el estudio de la reconstrucción de la lengua del pasado, dentro del contexto social de la comunidad de habla, a partir de las investigaciones empíricas sobre el «cambio lingüístico» en curso, la criollización y la sustitución lingüística.

La sociolingüística ha añadido, en efecto, una nueva coordenada: las relaciones sistemáticas entre los datos de las variables lingüísticas y los factores lingüísticos y sociales. Particularmente, una teoría sociolingüística del multilingüismo social ofrece una nueva alternativa (socialmente auténtica) para la investigación teórica y metodológica de la variación y evolución lingüísticas en general, y constituye de acuerdo con $\mathrm{H}$. Schuchardt y A. Meillet una contribución capital para la lingüística histórica. Es más, el pasado y el presente de la Europa románica es incomprensible sin alusión a unas coordenadas actuales sobre el multilingüismo social, en el que se delimitan claramente los términos de «sustitución lingüística» y «cambio lingüístico» (aunque se encuentren estrechamente relacionados), y se plantea específicamente la referencia a los estudios sobre la conservación y sustitución lingüísticas.

La sustitución lingüística es el desplazamiento del uso habitual de una lengua por el de otra, mientras que el cambio lingüístico se plantea el proceso de la trasformación en la estructura interna de la lengua, a través del tiempo, espacio, sociedad y situación. En el proceso de formación de las lenguas romances no sólo está implicada la propia evolución interna del latín medieval no reformado, sino que también aparece envuelto el desplazamiento de los 
vernáculos prerromanos por el latín, con la extensión y auge del cristianismo por todo el antiguo mundo romano. Mientras que la trasformación «interna» del latín ha merecido la única atención de los investigadores, la sustitución de los vernáculos nunca hasta ahora ha sido motivo de investigación. En la medida en que hallamos un posterior desplazamiento paulatino del latín medieval reformado por los romances en la documentación escrita, la atención debe centrarse én las cuestiones de cambio en las funciones sociales de las variedades implicadas.

Además, en nuestros días, una investigación antropológica de la historia propone la deducción de dimensiones del pasado, y las comprueba empíricamente en el presente. Sólo de esta manera revisaremos y superaremos las hipótesis de dialectología histórica y funcionalistas que han prevalecido durante todo el siglo pasado, y ofreceremos una auténtica historia social de la formación de las lenguas románicas.

1.1. A partir de la polarización del vocabulario y de la escisión morfológica y sintáctica, Lüdtke (1968: 247-57) caracterizó la situación social que va desde la época de Augusto hasta la de Carlomagno como diglosia. En ella se manifestaba la separación incipiente del latín entre variedad espontánea y variedad culta codificada, y el distanciamiento cada vez mayor entre ambas variedades. Con la reforma cultural carolingia (a favor de una diferenciación nítida entre lengua romance y latín codificado y de la fijación escrita de las lenguas románicas occidentales) desaparecería la diglosia anterior, y se crearía una situación bilingủe nueva, caracterizada por el dualismo latín / lengua nacional.

Esto ocurriría primeramente en Francia, Marcas hispanas y norte de Italia, y después a imitación de la primera en otros países románicos. Con todo, la fijación escrita de las lenguas románicas occidentales es posterior a la época de dicha materialización de las lenguas celtas y germánicas vecinas, la cual comienza con el gótico en el siglo IV, y se apoya en el hecho de que en los países no románicos la fijación escrita de las lenguas nacionales representaba un importante medio para la expresión de la alta cultura. Y a imitación de sus vecinos, los hablantes románicos se decidirían a considerar la posibilidad de la materialización escrita de sus nuevas variedades romances.

La decisión del Concilio de Tours (813) acerca de que los sermones había que traducirlos oralmente a la lengua popular (romance o no) motivó que también fueran redactadas muestras escritas en dicha variedad, y desarrolló paulatinamente una literatura incipiente en lengua francesa u occitana, que son las más antiguas variedades populares de la Romania. Durante los siglos XI y XII, el latín medieval reformado fue no sólo la lengua oficial, sino también la 
lengua literaria de más alto rango, del mismo modo que el griego en el Imperio romano oriental, o que el árabe y el hebreo en la Península Ibérica. Entre estas lenguas tradicionalmente reconocidas y los demás vernáculos, la langue d'oül y la langue d'oc alcanzaron una especie de posición intermedia al final del siglo XI y, sobre todo, durante el siglo XII. En particular, a finales del siglo XI, la misma localización septentrional y el diferente grado de romanización de las tierras de la lengua de oil permitieron la aparición del poema épico de la Chanson de Roland, mientras que en occitano surgió la poesía trovadoresca.

\section{LATÍN TARDÍO, LATÍN MEDIEVAL Y ROMANCE}

El latín medieval (no reformado y reformado) tiene una característica fundamental: es un registro escrito, cuando generalmente lo que se habla no es latín. Es una lengua aprendida, aunque no signifique precisamente bien aprendida. El latín medieval es, pues, el latín escrito (y en determinadas ocasiones incluso oral), a partir del momento en que la lengua materna -diasistema primario- de los hablantes no es ya latín, sino una variedad distinta. No es fácil determinar cuándo el latín medieval dejó de ser variedad vernácula de comunicación del Occidente -para unos, el siglo VI o viI, para otros muy a comienzos del siglo VIII (Banniard, 1992: 17-29)-. No en vano, el problema de la dislocación de la Romania sigue siendo uno de los más debatidos de la lingüística románica.

2.1. El auténtico motivo del paso de la relativa unidad del latín común a la pluralidad de las variedades neolatinas, según Tagliavini (1949/1969: 363-4), estaría en la influencia concomitante de los tres factores aducidos por varios autores (G. Gröber, C. Merlo y W. von Wartburg):

a) la discrepancia cronológica de la colonización de las varias provinciae o regiones;

b) la diferencia de las lenguas de sustrato, y

c) las divergentes influencias ejercidas en el curso de los siglos por pueblos que se superpusieron a la gente que hablaba romance.

Serían múltiples, pues, las causas de la formación de las lenguas romances y de su progresiva diferenciación. A medida que se debilitaban los nexos de la unidad con el desmoronamiento del Imperio romano de Occidente, ante el empuje de los pueblos bárbaros, asistiríamos a una lucha entre la antigua fuerza centrípeta y nuevas fuerzas centrífugas, y surgiría la armonía del nuevo mundo linguístico neolatino. La reconstrucción del registro oral (considera- 
blemente distinto del escrito) de las diversas lenguas neolatinas en el período de los orígenes resultaría a veces imposible. Aun cuando podamos determinar con exactitud suficiente los más antiguos testimonios de cada una de las variedades romances, habríamos de limitarnos necesariamente al examen de los monumentos escritos, que son siempre posteriores a la formación de las variedades neolatinas como lenguas familiares.

Es bien sabido que (después de la caída del Imperio romano de Occidente) el latín se convirtió en el idioma oficial de la Iglesia romana, y continuó siendo escrito y hablado (más lo primero que lo segundo). Los modelos literarios serían siempre los clásicos, y el mayor esfuerzo para los escritores medievales sería manejar una lengua que ya no se hablaba (al menos, en casa). Mientras mayor fuera la cultura de quien escribía en latín, más puro sería su latín. Pero el humilde escribano y el modesto cura traicionaban en la forma de su latín un dominio escaso de la lengua, y traslucirían con palabras y construcciones no clásicas la única variedad que poseían realmente. Su intención sería escribir en latín, mas su falta de cultura les impediría lograr una forma perfecta o siquiera correcta. Los textos latinos altomedievales están plagados de coloquialismos, pero sólo rara vez aparecerían frases o palabras escritas intencionalmente en romance.

Las primeras manifestaciones escritas del romance son las glosas, escribe Tagliavini (1949/1969: 637-59). Las glosas son explicaciones (o compilaciones de explicaciones) de palabras difíciles y oscuras, ora por medio de sinónimos, ora mediante perífrasis o auténticos comentarios. Los glosarios son colecciones de dichas explicaciones, sometidas a diversas ordenaciones (bien siguiendo párrafo por párrafo el texto glosado, bien en forma de verdadero repertorio alfabético). Es obvio que cualquier texto no fácilmente comprensible por su forma o contenido se prestaba a ser glosado. De esta suerte, tenemos glosas de textos religiosos, de los clásicos y frecuentemente de textos jurídicos. Se reanudaba así un uso antiguo, prohibido por Justiniano después de la promulgación del Digesto. Sin embargo, las glosas de valor lingüístico son las más interesantes para la historia de la lengua, ya por la palabra que explican, ya por el carácter de la explicación (que pueden contener palabras romances - no atestiguadas de otro modo- o testimonios de otra lengua).

El Glosario de Reichenau de finales del siglo VIII fue redactado en Francia septentrional, y recoge expresiones de la Vulgata con perífrasis o palabras latinas más populares, seguidas al final por otras palabras en orden alfabético. No habría intención de escribir en romance, aunque éste se trasparente con frecuencia. Otro ejemplo es el pequeño glosario de las Glosas de Kassel, escrito a principios del siglo IX en Freising (Baviera), el cual presenta glosas con palabras latinas (de aspecto próximo al romance) y con palabras 
germánicas. Por lo que toca a la parte latina, no cabe duda de que se encuentran muchos elementos romances, y de que tiene un carácter más románico que el Glosario de Reichenau, pero no parecería tampoco justificado considerar este texto como neolatino. Asimismo, en los documentos occitanos de los siglos VII-IX aparecen glosas que son testigos de la individualidad que había alcanzado allí el romance. Las glosas son, pues, documentos inapreciables para los romanistas, pero no podrían considerarse monumentos escritos en una lengua decididamente romance, ya que la intención de los compiladores no sería en modo alguno escribir en romance. Los Serments de Strasbourg (842) son el más antiguo texto escrito en francés y el más antiguo testimonio histórico-lingüístico de una lengua románica.

En general, las glosas a los documentos medievales se entendieron inicialmente, tanto si presentaban la correspondencia latín-latín o latínromance, como creación de un copista o un lector, con el fin de facilitar la comprensión de determinadas palabras (en ocasiones, su función sintáctica) a otros lectores sucesivos del mismo texto. Luego se formaron los glosarios, para una más completa ayuda interpretativa. Con el propósito de destacar algunas aportaciones de notable interés para el conocimiento del español en la fase primitiva de su historia, González Ollé (2004: 14-5) ha ofrecido unas observaciones filológicas al códice emilianense 46 de la Real Academia de la Historia (designado como Glosario Turza). Cada uno de los glosarios suponía la recopilación, más o menos extensa y homogénea (mejor o peor ordenada) de glosas procedentes de muy diversos manuscritos. Naturalmente, también se fundían o refundían, a su vez, las propias recopilaciones previas, aunque no debe descartarse la posible composición original de algunos glosarios (por lo general, en este caso) de carácter temático.

Durante bastante tiempo, el estudio de los glosarios se ha manifestado más atento a la procedencia de las glosas constituyentes que a los efectos de su aplicación. El interés hacia ellos se ha incrementado a partir de haberse podido probar en casos bien precisos que también cumplían otra función: los glosarios monolingües latinos habían estado destinados asimismo a procurar la mejora y el enriquecimiento léxico de determinadas obras. Es decir, a sustituir palabras usuales por otras tenidas como más correctas, cultas, efectistas, etc., o, simplemente, inusitadas y aun oscuras, que escapaban a los conocimientos estilísticos de los usuarios.

2.2. Herman (1975/1997: 137-47) ha opinado que el fin de la historia del latín termina con el siglo VII y las primeras décąas del siglo vIII. En el curso de la primera mitad del siglo viII, los cambios estructurales de la lengua produjeron en la Galia una ruptura comunicativa entre la lengua materna usada por todo el mundo y el latín heredado de los textos. Sin embargo, dicha fecha 
no sería necesariamente común a todos los territorios romanizados, y dependería de las particularidades de la evolución del sistema lingüístico en las diferentes regiones. En Italia, por ejemplo, las primeras pruebas de una diferenciación consciente entre la lengua de todo el mundo y la práctica escrita del latín proceden sólo de la segunda mitad del siglo x. Las diferencias en la fecha del «nacimiento» de las lenguas románicas se deberían a factores que todavía están por determinar. Así es probable que el carácter temprano y radical de ciertas evoluciones en la lengua de la antigua Galia (por ejemplo, la caída generalizada de las vocales en sílaba final -salvo $a$ - acaecida en galorrománico entre el siglo vII y el VIII) contribuyera a acelerar la transición en esta región. El mecanismo de la evolución del latín hacia el estadio romance y la interacción de los factores «externos»e «internos» están todavía muy lejos de ser puestos al descubierto, y de ser descritos con la precisión y el rigor deseables.

Asimismo, cabe aducir ya en época imperial la diversidad interna (geográfica, social y situacional) del latín de las varias regiones del Imperio. Hay razones muy sólidas que permiten suponer que el latín, desde la época del Imperio, tenía variedades de carácter regional, que afectaba sobre todo a la pronunciación y quizás a ciertos elementos morfológicos, y en los períodos más tardíos de su evolución, incluso dialectos. En cierta manera, las diferentes variedades romances representan los dialectos medievales del latín: no hay solución de continuidad. Así como no hay límites geográficos rígidos entre las lenguas particulares, los límites cronológicos entre las fases sucesivas de la lengua son una ficción de nuestra mente, y suelen haber -como entre los geolectos mejor caracterizados- variedades intermedias o de transición (Penny, 2000: 45-56). El proceso de trasformación del latín al romance se relaciona, pues, con la diversificación lingüística de la Romania (debida a las diversas circunstancias históricas, geográficas y sociales) y con el lento y continuo proceso de desenvolvimiento.

2.3. Dentro del mayor proyecto historiográfico sobre el latín tardío y medieval, Banniard (1992) se ha cuestionado los fenómenos de conciencia lingüística a través de los problemas de comunicación (dentro de una historia literaria de la antigüedad tardía y cristiana), sobre el proceso de formación de las lenguas románicas, desde el siglo IV al IX en el Occidente latino. Comentaremos prolijamente esta obra, a fin de intentar indagar las dinámicas caracterizadoras de las diversas situaciones sociales de las diferentes comunidades de habla, entre las coordenadas de normalización o sustitución lingüística. Su primer axioma sería el siguiente: hubo una estrecha correlación entre la conciencia lingüística de los locutores letrados y el grado de intercomprensión entre éstos y sus oyentes (o interlocutores) iletrados. Dicha 
relación pondría en juego dos modos de comunicación en contacto (escrito y oral). El dominio de la comprensión podría dividirse en tres categorías principales: «comunicación vertical» (entre locutores letrados latinófonos y oyentes iletrados), "comunicación horizontal» (entre letrados de diferentes países o entre iletrados de etnias distintas) y «comunicación vertical que reunía locutores letrados y oyentes iletrados provenientes de países diversos».

De este modo, su primera preocupación cronológica sería determinar cuándo han aparecido los primeros signos de una ruptura definitiva en la comunicación vertical latina, a partir de la encuesta dialectológica en una selección de autores y testimonios de la producción escrita de los siglos IV al IX (Agustín, Gregorio el Grande, Isidoro de Sevilla, hagiógrafos merovingios, Alcuino y los reformadores carolingios, y los escritores mozárabes de la España musulmana). Dichos conjuntos de textos procurarían al menos (sin ofrecer una presentación fiel de la lengua hablada popular) una representación o un reflejo en el que los eruditos reconocían la lengua de sus interlocutores iletrados. La dialectología moderna ofrecería un soporte teórico para proporcionarnos la capacidad de afinar fructíferamente en la problemática latina y romance.

Los letrados modelarían su habla de acuerdo con la tradición escrita que la escuela les habría conformado. Los iletrados no dispondrían más que de la comunicación oral. El orador cristiano se encontraría como un mediador obligatorio entre estos dos órdenes de comunicación, que no podrían permanecer extraños uno al otro, ni encerrados en dos compartimentos estancos. El latín vulgar sería la lengua hablada popular, es decir, utilizada por unos locutores no (o poco) influenciados por los modelos escolares o literarios. Ante la necesidad de un modelo lógico y flexible, Banniard propondría dos niveles de la lengua en contacto polimórfico el uno con el otro (latín hablado y latín escrito) y tres períodos cronológicos de la antigüedad latina (arcaico, clásico y tardío). Las etapas posteriores (latinidad medieval y románica) se extenderían en el mismo período (entre el 650 y el 800 ), aunque la Romania romance se situaría estrictamente a partir del año 750 en la Galia del norte y África, y en el siglo x en Italia del norte y del centro. El fin de la comunicación vertical latina se establecería en la España mozárabe en el siglo IX.

El renacimiento carolingio se hace depender netamente de la antigüedad tardía, sobre la cual los más recientes trabajos sitúan su final en los siglos VII y VIII. Las evoluciones fonéticas y fonológicas que afectaron al latín oral en los siglos II y III de nuestra era lo transformarían en latín tardío (y no en protorromance), y la comunicación vertical funcionó porque no hubo grandes divergencias entre la elocución de los oradores (y los lectores) y la pronunciación espontánea de los iletrados. 
No obstante, los testimonios son a veces difíciles de interpretar. Así, por ejemplo, este autor se pregunta cómo se establecerían las relaciones entre la comunicación escrita y la oral en la Hispania del siglo vir, y cuáles serían las posiciones del latín y de la lengua hablada popular en tiempos de Isidoro de Sevilla. A pesar de que su propio dominio del latín (junto a la influencia de la tradición literaria y religiosa, su gusto personal por la cultura aristocrática y la ambición excesiva de purismo lingüístico) podría constituir un serio obstáculo para la percepción de la realidad lingüística de su época, las alusiones y los indicios presentes en la obra de Isidoro mostrarían que el latín era la única lengua común de España. Cada vez que exigía recitar de memoria el credo o el pater a sus fieles iletrados era la ocasión para observar la nula confrontación con su lengua hablada, y sería una muestra de que el latín era la lengua viva en el siglo VII.

Es bien cierto que la liturgia de la misa ( $u$ otros oficios) exige una participación de la población, pero ésta suele ser bastante pasiva, reducida a ciertas frases estereotipadas, y que no tienen necesariamente por qué ser comprendidas por los fieles. Ésta es la opinión de Velázquez (2003: 32, n. 54), en relación con el valor de la liturgia y de las oraciones (o de las letanías) recitadas por el pueblo. El enriquecimiento léxico (y un cierto preciosismo en el estilo que se observa en la liturgia visigótica) caminaría paralelo y sin encontrarse con los niveles de inteligibilidad de la población. Son piezas literarias populares, pero no por ello comprendidas plenamente (a veces poco comprensibles en rigor) y, mucho menos, representativas de la lengua hablada, a pesar de que diversos rasgos de ésta pueden ser detectados en ella. La memorización de un texto y su seguimiento escrupuloso no significa que se comprenda. Las obras gramaticales de Isidoro no presentan, pues, una visión directa de la lengua viva de su época, sino una descripción cuidadosa de la norma lingüística, cuando todavía la lengua hablada popular era la latina, a pesar de las alteraciones que muestran las pizarras visigóticas (Martín, 2002; Velázquez, 2003).

No sería suficiente establecer (a través de un testimonio tan importante como el canon 17 del Concilio de Tours en el año 813) que una crisis aguda de la comunicación había estallado en la Galia, sino que sería conveniente preguntarse todavía si esta ruptura era reciente en la fecha indicada (o si deberían buscarse las primeras manifestaciones hasta casi medio siglo antes), ya que a menudo ha sido interpretado como una manifestación oficial tardía de un acontecimiento oficioso antiguo. Sin embargo, se trataría de la confirmación de una toma de conciencia por parte de los locutores letrados sobre que la lengua hablada popular no era ya latín (ni tardío, ni vulgar), y de que esta percepción de una diferencia insuperable (para que fuera necesaria una verdadera traducción) se había producido en un período relativamente breve (alrededor de una generación). 
En rigor, la reforma de Tours no recaería ni tan acelerada ni tan resueltamente en el sur occitano, aunque los conflictos fueron allí menos agudos. Sin embargo, en el siglo IX, el viejo occitano no sería ni más ni menos discernible del latín oral tardío que el antiguo francés, a pesar de que todos los dialectos franceses no evolucionaron con la misma rapidez (así, por ejemplo, el caso del picardo), y todos los dialectos de «oc» no cambiaron con la misma lentitud (así, por ejemplo, en el caso del nord-occitano: el auvernés y el lemosín). Si verdaderamente los locutores letrados tuvieron conciencia de una mutación lingüística general irreversible, dicha toma de conciencia dependería más de su atención al problema y de la precisión de los mecanismos intelectuales de los que disponían para resolverlo, que de los contrastes dentro de la evolución general de los protorromances.

La correspondencia misma de Alcuino (hasta su muerte) insiste en la importancia vital de la predicación de la Iglesia, y sobre el contacto que se establece gracias a ella con el público de los fieles, así como felicita a Carlomagno de que se encuentre en curso un retorno imperativo a verdaderas normas en la cancillería real. Hasta el año 796 al menos, Alcuino fue uno de los protagonistas de la reforma carolingia, y colaboró en la progresiva resolución de una serie de disposiciones legales, cuyo fin era doble:

a) el desarraigamiento completo de las tradiciones paganas todavía vivas sobre las tierras cristianas, e instauración de un modo de vida piadoso para todos los laicos, $y$

b) la formación de los obispos y sobre todo de los presbíteros capaces de llegar a estos resultados, con la incitación a comunicarles su saber y a mostrarles el ejemplo de su conducta a sus fieles.

Dichas tentativas de restauración eclesial no podrían tener éxito sin la base de un sistema de comunicación general, apropiado y eficiente, con la renovación de la normativa latina tardía y cristiana, tras los desórdenes y las negligencias de la época precarolingia (siglos VII y VIII) que habían permitido no sólo la mayor corrupción de la lengua de los iletrados, sino el deterioro del buen latín.

En efecto, durante el tiempo de una generación, las ordenanzas capitulares multiplicaron unas disposiciones que en todos los campos de actividad (pero sobre todo, en los concernientes a la educación, la cultura y la religión) deberían conducir al pueblo cristiano hacia una verdadera restauración lingüística de la Biblia y del ritual de la misa, una normalización del latín (medieval no reformado) difundida e impuesta entre los cuadros religiosos y en las masas de los fieles. Dicha restauración lingüística y cultural habría revestido para los fieles un doble aspecto. Por un lado, se les había pedido que 
tuvieran un papel activo, y debían conocer, comprender y recitar las oraciones. Hacia el año 804, una ordenanza capitular obligaba por la fuerza a que todos los cristianios aprendieran de memoria el credo, el pater y la señal de la cruz, bajo sanciones de negar la administración del sacramento del bautismo a un niño (o pagano) y la amenaza de violencia física. Por el otro, habían de contentarse con un papel pasivo, y escuchar con atención las homilías, las Vidas, las preces de la misa y las lecturas de las Escrituras, cuyos textos los rescribían los letrados con su propia intención (369). La fe, la conducta y también el habla de los simples fieles (uulgus) se encontrarían sometidos bruscamente a la criba de una censura que se volvió más activa y exigente. De la misma manera, la liturgia se esforzó en integrar la masa de asistentes (que los siglos anteriores habían ignorado) a los rituales.

La corte real carolingia era bilingüe (el alemán y el latín), y el propio Carlomagno no se había contentado con hablar su variedad materna (el fráncico), sino que se había aplicado a aprender lenguas extranjeras. Adquirió un tal dominio del latín que lo hablaba tan bien como el alemán, aunque no logró escribirlo. Además sabía comprender mejor el griego que hablarlo. El renacimiento intelectual puramente carolingio se ha presentado atinadamente como una ejecución de una «corrección normativa», cuyas pautas expresaban sin debilidad una voluntad de retorno a las reglas de la antigüedad tardía cristiana, dentro de los dominios respectivos de la administración, la liturgia, la instrucción y la lengua. Dicha decisión no sería suscitaba ni provocada por Alcuino y sus colegas, sino que remontaba a Pipino el Breve y a Bonifacio. El sabio monje habría contribuido con vigor a acentuar una evolución que correspondía profundamente a las exigencias, fines y medios de la nueva dinastía monárquica. La adquisición de la norma erudita daba acceso a un nivel de cultura que le promocionaba sobre los demás, cualesquiera que fueran sus méritos dentro de las perspectivas de una instrucción cristiana.

Sin embargo, en el caso de Alcuino, la «ilusión latina» y su pasión por la antigüedad le conducirían a una actitud muy elitista, bajo la cual se revelaba un desprecio a la gran masa de los simples fieles y un recelo grave a su manera de ver. Dicha rigidez de modelos mentales (a través de los cuales podría establecerse la relación entre las formas populares y las formas cultas de los hablares) explicaría por qué no habría comprendido que el latín de los iletrados no era corregible, y que en definitiva éste no era un latín más de los iletrados, sino una nueva lengua salida del latín. La contradictoria determinación de Alcuino (para conseguir la corrección gramatical y la efectiva predicación generalizada) llevaría después de su muerte a la cristalización conceptual de dos lenguas (atestiguadas en el Concilio de Tours), ya que no se podría emplear simultáneamente una lengua cada vez más difícil de comprender por los fieles analfabetos, y exigir su participación acumulada en la vida religiosa del reino. 
2.4. La hipótesis de Banniard (1992: 405-6) es que desde el año 789 habría reacciones de inquietud frente a la reforma, por parte del nivel más humilde del clero (párrocos de pueblo y curas de parroquia), quienes serían los últimos beneficiarios de la reforma, y los primeros en compartir las dificultades que los fieles experimentaron frente a las nuevas exigencias. $Y$ algunos obispos se encontrarían más preocupados por el hecho de las realidades sociolingüísticas, para intentar comprender los problemas creados por la aplicación de la reforma, sobre los que tendrían unos ecos indirectos por el conducto de su clero. Todo ello empujaría la situación de la comunicación vertical latina hacia un conflicto lingüístico, cultural e incluso de culto, y plantearía la radicalización de una diferencia y cierto extremismo lingüístico, que provocaría por reacción la renuncia a la reforma de la lengua popular. Hacia el año 810, la renovación cultural del ritual sacramental terminaría por acarrear unas modificaciones litúrgicas, que al mismo tiempo agravaron las tensiones surgidas en la recepción del mensaje cristiano por los oyentes analfabetos.

El segundo parágrafo del canon 17 del Concilio de Tours (813) sería la «partida de nacimiento de las lenguas románicas», y dice así: «Y que cada uno de ellos (los obispos) se aplique a traducir llanamente estas mismas homilías en el latín de los iletrados o en alemán, de manera que todos sin excepción puedan entender más fácilmente cuanto se les diga». El latín de iletrados podría referirse tanto a la lengua de «oc», como a la de «oïl» (aunque debe dudarse de que la conciencia de tales distinciones interiores en el galorrománico hubiera aparecido ya) o a cualquier otra lengua románica.

Por consiguiente, en este primer cuarto del siglo IX, de dicha evolución decisiva saldría la crisis que desembocó en una ruptura dentro del tejido de la comunicación general latina, y después en una fragmentación de la latinidad en los diferentes romances. El problema esencial sería entonces el de discernir la verdadera posición social de la lengua hablada popular. De hecho, el voluntarismo cultural de Alcuino y los letrados que rodeaban al soberano la habrían ignorado deliberadamente. La realidad lingüística habría opuesto su resistencia al idealismo del reformador. Un cambio importante de política cultural se impondría para que la misión pastoral pudiera reencontrar su eficacia, como en los siglos privilegiados de la expansión cristiana bajo el Imperio. Pero sería preciso renunciar a una identificación absoluta con ese pasado glorioso: la continuidad lingüística latina colectiva no podría erigirse más sobre un plan de igualdad con la tradición religiosa cristiana imperial de antaño.

La aparición de una scripta que buscara la trascripción de la lengua oral popular sin salirse del molde de la escritura clásica dependería, por una parte, de la toma de conciencia de que una lengua nueva existía (irreductible a la antigua), y por la otra, de la decisión (tomada por los que tuvieran el poder) de 
dar a esa lengua un estatuto escrito. A través de los autores y los testimonios considerados de los siglos IV al IX en el Occidente latino, podría constatarse hasta qué punto la lengua de Roma era viva y dinámica en los siglos V y VI, pero que no era más que un instrumento muy deteriorado y amenazado a partir de finales del siglo viII. En este sentido, debería cuidarse de juzgar la lengua hablada del siglo vI al viII como un todo, ya que dos secciones sincrónicas sucesivas mostrarían unas profundas evoluciones. La lengua hablada popular habría conservado una amplia mayoría de rasgos latinos hasta el año 650 . Dentro de cada país y en fechas distintas, la lengua oral popular habría pasado de un grado en el que todavía presentaba una estructura del latín tardío a un estadio característico del protorromance, en el espacio de un período relativamente breve: entre dos y cuatro generaciones (figura 1.)

\begin{tabular}{|c|c|}
\hline & $\begin{array}{l}\text { 0-anterior al 450: el latín es la } \\
\text { lengua común }\end{array}$ \\
\hline PERÍODO I: ROMANIA LATINA & $\begin{array}{l}\text { 1) = 450-650: aparición y multipli- } \\
\text { cación de los giros nuevos con la } \\
\text { sustitución de los giros clásicos } \\
\text { 2) } 650 \text { : umbral crítico del equilibrio } \\
\text { entre rasgos latinos y rasgos } \\
\text { romances. (Italia ¿750?) }\end{array}$ \\
\hline PERÍODO II & $\begin{array}{l}\text { 3) }=650-750: \text { polimorfismo genera- } \\
\text { lizado (Italia } ; 850 ? \text { ) }\end{array}$ \\
\hline $\begin{array}{l}\text { PERÍODO III: } \\
\text { ROMANIA ROMANCE }\end{array}$ & $\begin{aligned} \text { 4) }= & 750-800: \text { abandono de la } \\
& \text { capacidad de expresión latina } \\
& \text { con rasgos clásicos (Italia ¿900?) } \\
5 \text { ) }= & 800 \text { y siguientes: abandono de la } \\
& \text { capacidad de recepción de la } \\
& \text { lengua latina (Italia ¿950?) }\end{aligned}$ \\
\hline
\end{tabular}

FIGURA 1. Comunicación y cambio lingüístico. Resumen cronológico del cambio linguiístico en el Occidente latino (según Banniard, 1992: 534)

La comunicación vertical latina se mantendría en la primera mitad del siglo VIII. No habría hiato alguno entre la lengua escrita tradicional y la lengua oral cotidiana, y se caracterizaría dicha época por una situación de polimor- 
fismo, donde las formas antiguas y las nuevas alternan en el texto. Asimismo, los redactores pasarían de un registro a otro sin tener conciencia de pasar de un sistema a otro distinto. Por una parte, trascribirían vulgarizándolas más o menos frases enteras de la lengua escrita, y por la otra, adaptarían bajo una forma escrita latinizante fragmentos del hablar cotidiano. Sin embargo, en la segunda mitad de dicho siglo aparecen unos textos (todavía dentro de la trama de un tejido «latino») en los que la lengua vulgar se vislumbraría con contornos más precisos, aunque no se mostraría aún como entidad autónoma en la conciencia de los letrados.

Así, por ejemplo, una parodia del latín jurídico (la Loi salique) que fue redactada en la Galia del norte hacia el año 770 presenta una mezcla lingüística, donde no podría determinarse con precisión si se trata en su caso de un texto de latín romanizado, y ni siquiera si estamos en presencia de un texto de romance latinizado. La identidad fonética de la lengua hablada sería indudablemente más perceptible después del año 750 que anterior al 650 , ya que ciertas evoluciones fonéticas importantes se habrían consumado entre el final del siglo vir y el principio del siglo VIII (enmudecimiento de las vocales finales excepto la $-a$, cerrazón de la $-a$ final en $-e$, diptongación de la $-o$ larga cerrada y de la $-e$ larga cerrada acentuadas en sílaba abierta, las cuales pasan respectivamente poco a poco a ou y ei, y diptongación (supuesta) de la $-a$ acentuada en sílaba abierta, que pasa a $e$ cerrada).

El nivel cultural del clero hacia el año 803 era bajo, y presentaba lagunas culturales y lingüísticas. Los curas de las parroquias no sabían seguramente más que apenas leer. En estas condiciones, dichos clérigos se encontrarían seguramente en una posición muy incómoda, entre un obispo que les hostigaría para obligarlos a mejorar su instrucción y su expresión, y un público más habituado a oír a unos pastores que hablarían casi como ellos mismos, y que no se preocuparían de educarlos en unos niveles superiores de lengua latina. No se trataría, pues, de diglosia ni de bilingüismo, sino de una trasformación en la que los rasgos romances y los latinos se mezclaban en el interior de un mismo continuo. Con sus propias palabras,

Les glissements, les disparitions et les remplacements respectifs des traits latins par des traits romans se sont produits à travers des couches superposées depuis les infrastructures profondes stables jusqu'aux superstructures évanescentes, en passant par des structures moyennes métastables, dont l'évolution individuelle varie en fonction inverse de leur degré de robustesse (530).

En el siglo IX, la España musulmana no conoció como la Galia carolingia una restauración linguíística y cultural fundada sobre la iniciativa de un poder 
central revigorizado. Además, el latín de la Península había sido menos evolutivo que el de las Galias, y los factores externos de mutación provocados por el renacimiento carolingio faltaban aparentemente en España. Sin embargo, una identidad estructural aparecería entre la manifestación de los letrados mozárabes (Álvaro y Eulogio de Córdoba y el abad Sansón) y ciertos aspectos de la mentalidad de los intelectuales carolingios, y podría postularse una influencia indirecta de la reforma carolingia, hasta el punto de que la continuidad linguística latina estaba en peligro. En este sentido, es poco probable la posición de R. Wright (1982) sobre que los efectos de la reforma y del renacimiento carolingios no se hayan hecho sentir con eficacia en España más que a partir del siglo XI (Concilio de Burgos, 1080).

La comunicación vertical latina se rompería, provocada por el desarrollo de tres fenómenos estrechamente asoćiados: a) la islamización; b) el retroceso de la latinidad, y c) la transición al romance. Los textos latinos de Álvaro y Eulogio nos muestran que el siglo IX cordobés era un tiempo de crisis para la cristiandad hispánica, y ésta presentaría unos caracteres análogos a los hechos que provocaron más al norte de Europa la reacción cultural y el renacimiento de la época carolingia. Las vacilaciones y las confusiones muy numerosas de los textos demuestran la presión ejercida por el uso cotidiano de la lengua hablada popular sobre los letrados mozárabes, particularmente en el nivel de la morfología, hasta el punto de que asistiríamos a la transición de dicha variedad al estadio romance desde mediados del siglo IX en Córdoba. Eulogio y Álvaro se entregaron a la misión de combatir lo que consideraban una degradación inadmisible del patrimonio latino, y su palabra obstinadamente tradicional se hizo inaccesible a los iletrados. Desde luego, se trataría de divergencias esporádicas bruscamente generalizadas, que conducirían a la cristalización de la nueva lengua mozárabe, dos generaciones más tarde de la ruptura de la comunicación en la Galia y del canon conciliar de Tours.

2.5. En nuestros días, debemos reconocer las limitaciones teóricas de los presupuestos dialectológicos. Es bien cierto que (frente a una dialectología descriptiva de los dialectos históricos con las soluciones de las leyes fonéticas) se ha contemplado una dialectología preocupada en la determinación de períodos y áreas que presentaran cualitativamente rasgos caracterizadores. Sin duda, el paso dado por esta dialectología funcional ha sido enorme, pero la necesidad creciente de una mayor revisión teórica y metodológica en la investigación sobre la variedad y variación lingüística es una exigencia diaria e irreversible. De esta manera, la dialectología y la sociolingüística ofrecen hoy algo más que la presentación estática «de los numerosos ejemplos contemporáneos: las hablas varían profundamente no solamente por la sintaxis, la morfología y el vocabulario, sino también por la tonalidad, el 
timbre, el matiz según las regiones, las clases sociales, los barrios, etc.» (Banniard, 1992: 230).

Es preciso, por consiguiente, culminar el análisis dialectológico, a partir de una mayor renovación teórica y metodológica. El estudio dialectológico debe plantear hoy algo más que el polimorfismo de conjuntos de fenómenos peculiares, y las variedades geográficas de la lengua deben caracterizarse como sistemas comunicativos efectivos y realizables. Las variaciones no pueden relegarse a la categoría de "variación libre», donde las realizaciones superficiales se catalogaron por los dialectólogos a mediados del siglo pasado bajo el concepto de 'polimorfismo', y se descartaba la determinación de la variabilidad de la lengua por factores lingüísticos y sociales (López Morales, 1989, 1994; Gimeno, 2003 a).

La propia equiparación de los términos de compétence active y compétence passive con las denominaciones generativas idealizadas de perfomance y competence, tal como explica Banniard (1992: 552) en su apartado de terminología linguística, es un puro contrasentido. Además, los conceptos formulados de 'compétence active' («capacidad en la expresión de un mensaje dentro de un registro dado») y 'compétence passive' («capacidad en la recepción de un mensaje dentro de un registro dado») nada tienen que ver con la propuesta sociolingüística de Hymes (1971) sobre la compleja competencia comunicativa de los miembros de la comunidad de habla bilingüe, la cual justifica la utilización de los términos de competencia activa y competencia pasiva, y aluden además a la asimetría de la competencia comunicativa de los hablantes reales que disponen de una competencia receptiva mayor que la productiva. La hipótesis de trabajo acerca de que la capacidad en la recepción de un mensaje dentro de un registro dado desaparece entre los iletrados, en función directa de la decadencia de la capacidad en la expresión latina de un mensaje, dentro de un registro dado en los letrados (Banniard, 1992: 531), no tiene sustento teórico alguno, ya que el propio uso de la comunicación vertical por parte de los locutores letrados es claramente insuficiente por sí sola, para la prolongación de la capacidad receptiva de los iletrados, la cual está en función de su propia competencia comunicativa y la específica de su particular comunidad de habla.

Asimismo, la lengua no cambia por niveles lingüísticos, ni por conjunción o selección unilateral de rasgos antiguos y nuevos, sino por transiciones continuas de la gramática social de la comunidad de habla, y supone una reestructuración constante y regular de la gramática multilectal de las sucesivas generaciones de hablantes, dentro de la comunidad de habla. Contra un supuesto autónomo del cambio lingüístico por niveles, o por abandono de giros clásicos y aparición de giros nuevos, debemos asumir hoy una teoría gramatical del cambio lingüístico. Frente a una diacronía parcial de los 
diversos niveles lingüísticos (e incluso, de todos descriptivamente) de las lenguas románicas, debemos asumir en nuestros días una historia social de las competencias comunicativas de las sucesivas generaciones de hablantes, dentro de las diversas comunidades de habla románicas (López Morales, en prensa; Gimeno, 1995: 27-39; 2003 b). Desde dicho punto de vista, no puede sugerirse lo que propone Banniard (1992: 394):

La lengua hablada popular no había sido aceptada ciertamente sin reservas por los oradores cristianos. Sin embargo, desde el siglo IV al vil, éstos habían adaptado su lengua a las restricciones de la comunicación vertical: imitando en cierta medida la expresión de los simples fieles, o al menos, buscando un compromiso entre sus inclinaciones intelectuales de eruditos y sus obligaciones de eficacia pastoral.

Ni puede aceptarse (por su imprecisión simplista) que la desaparición de la latinidad signifique -como escribe Banniard (1992: 532, n. 176)- que el latín ha dejado de ser la lengua de comunicación general (¡en pleno siglo IX!), y la lengua oral popular de ser considerada como una variante incorrecta, pero mejorable del latín. Ni mucho menos que defina la muerte del latín como la desaparición de esta lengua como instrumento de comunicación espontánea, adquirida de manera natural desde la infancia, fuera de toda práctica pedagógica especial (12). Y es que hay un desconocimiento completo de las funciones sociales de la lengua, en concreto de la dicotomía estándar/ vernáculo, de acuerdo con el ámbito de uso (público frente a privado). En nuestro caso, significa la inexplicable relegación del papel primordial del latín como lengua de la cultura y de la liturgia de la Europa occidental hasta el siglo XVIII y XIX (Díaz y Díaz, 1981). Es más, cualquier estudio que desee conocer el contexto social y cultural de la Edad Media no puede reducirse a meras cuestiones linguísticas sobre el latín tardío y medieval, sino que debe prestar atención a otros aspectos, como el de libros y lecturas y el propio desarrollo de la enseñanza en la Edad Media (Gimeno, 1995: 79-95 y 107-20; 2004: 196205.

2.6. Recientemente, Bustos Tovar (2000) ha destacado la imbricación de la oralidad en la escritura latina, dentro del interés de los glosarios para la historia de la lengua. La necesidad de las glosas se haría más evidente a medida que se consolidó la disociación idiomática entre la escritura y la oralidad, proceso que ocurre para Hispania entre los siglos VIII y XI. Las glosas romances de documentos latinos son las primeras que atestiguan en toda la Romania la plena distinción entre las dos lenguas (latín y romance) (Bustos Tovar, 2004 a). No obstante, la consideración pragmática de la relación oralidad y escritura 
es un aspecto de la cuestión que encubre e ignora la descripción social de la dicotomía estándar/vernáculo (de acuerdo con el parámetro ámbito de uso) y la propia situación de superioridad e inferioridad funcionales de las variedades implicadas. La dimensión contextual (o situacional) de la lengua es una proyección de la dimensión social, aunque funcione diferentemente.

Frente a la «hipótesis de las dos normas lingüísticas» o a la de una comunicación (vertical u horizontal) latina o protorromance, que son descripciones siempre externas a los hablantes, debemos circunscribirnos empíricamente a la concreta dinámica de las variedades sociales y contex-tuales de la lengua, en función del ámbito de uso en el que se encuentra inmerso el hablante, dentro de su comunidad de habla. Un enfoque de la etnografía de la comunicación no toma nunca como marco de referencia una norma lingüística, un registro (oral o escrito), un conjunto de textos escritos o una lengua dada, sino que debe partir de una comunidad de habla como contexto social y cultural, la cual (como unidad de análisis) es mucho más amplia que el texto o discurso (Hymes, 1964; Gimeno, 1987). En este sentido, las regularidades globales a gran escala que rigen entre variedades y funciones socialmente reconocidas se analizan por medio de los ámbitos de uso. El ámbito de uso es el conjunto de situaciones sociales típicamente restringidas por una serie común de reglas de comportamiento lingüístico. Situaciones sociales y ámbitos de uso revelan, pues, los vínculos existentes entre el micro y el macronivel de la sociología del lenguaje (Fishman, 1971).

Dentro de la función social de la lengua, son fundamentales las variedades sociales y contextuales de la lengua, en función del ámbito de uso de la familia (o privado) frente al ámbito de uso de la educación (o público), es decir, vernáculo vs. estándar. Así, por ejemplo, el vernáculo es la variedad adquirida por el niño en su primera y segunda infancia, dentro del ámbito familiar, y el estándar es la variedad codificada de una lengua que sirve de modelo a una comunidad de habla, y que se aprende en el ámbito escolar (Gimeno 1990: 25-49; en prensa 1). El vernáculo es, por consiguiente, una variedad oral adquirida en el ámbito familiar, mientras que el estándar es una variedad aprendida en el ámbito escolar y primariamente escrita. Por lo demás, también es insuficiente la preocupación por indagar si había bilingüismo o monolingüismo en la etapa protorromance, ya que al fin y al cabo lo que interesa son las funciones sociales de las variedades implicadas ( $y$ si hay un cambio en dichas funciones), y la referencia en general a los estudios sobre la conservación y la sustitución lingüística. 


\section{DIGLOSIA ESTRICTA Y AMPLIA}

La definición clásica y estricta de diglosia fue dada por Ferguson (1959: 336), y se limitaba a las situaciones de dos variedades moderadamente divergentes de la misma lengua, en las que la variedad alta no era la lengua materna de nadie. Dicho concepto inicial recibió varias interpretaciones, y posteriormente fue revisado y ampliado por Fishman (1967) a las comunidades multilingües, y en general a todas las situaciones sociales en las que se utilizan cualesquiera variedades lingüísticas (lenguas, geolectos, sociolectos, registros, etc.) con funciones diferentes. Se comprende así bajo diglosia amplia cualquier situación estable a largo plazo que presente una variedad alta (A), vehículo normal en la comunicación pública o formal, y una variedad baja (B) empleada en la interacción privada o familiar (Gimeno y Gimeno, 2003: 31-48).

3.1. Posteriormente, deben conocerse además la difusión y el rendimiento de ambos conceptos de diglosia (estricta y amplia). Hudson (1992) ofreció una amplia reseña bibliográfica sobre la diglosia de 1.092 entradas, generalmente en inglés, entre los años 1959 y 1992, y apuntó que el interés no ha decrecido, ya que la mitad de dichas fichas fueron publicadas en los diez últimos años (es decir, entre 1983 y 1992). Un examen de los datos en dicha bibliografía revela que hay todavía un amplio desacuerdo en determinar qué clases de situaciones sociolingüísticas deberían ser consideradas como casos de diglosia.

Últimamente, Hudson (2002 $a, 2002 b$ ) ha suscitado una discusión teórica sobre la diglosia, y ha propuesto un resumen global de una teoría de la diglosia y un epílogo sobre la discusión teórica. En apoyo de la preocupación de Ferguson por las fuentes y los resultados de las diferentes situaciones lingüísticas, uno de sus propósitos era inducir una distinción viable entre los fenómenos de la diglosia (estricta y amplia), y motivar global o parcialmente la discusión teórica de cada una de ellas, en los términos del origen social, el curso de desarrollo y las consecuencias a largo plazo para los repertorios lingüísticos de las comunidades de habla.

Nuestra hipótesis de trabajo sugiere soluciones comprensivas y explicativas, con la valoración prácticamente ecléctica de la difusión y utilización de los distintos conceptos y las diversas denominaciones (diglosia estricta frente a diglosia amplia), dentro de una respuesta a los nuevos desafíos que presenta la investigación sociolingüística, en marcos más amplios de normalización o sustitución lingüística y de una historia global de la lengua. A pesar de que no se ha discutido el fondo de la cuestión, debe tenerse en cuenta que la propuesta de Ferguson (1959) intentaba caracterizar minuciosamente una determinada situación sociocultural (diglosia) en el desarrollo de la estan- 
darización lingüística, y contribuir a resolver los problemas que planteaban la descripción en algunas asunciones de la lingüística sincrónica y la comprensión de los procesos del cambio lingüístico (sustitución lingüística, en mi opinión) dentro de la lingüística histórica.

La sustitución lingüística es un caso especial del cambio lingüístico que implica, entre otros hechos, el desplazamiento progresivo de una variedad por otra, en los diferentes grupos y redes sociales y en los diversos ámbitos de uso, dentro de una comunidad de habla. No llegó a cuestionarse, por ejemplo, si en la evolución de la diglosia con la enseñanza de la variedad alta (A) hay dinámicas de movilidad social o no, con el fin de diferenciar estrategias diversas de desplazamiento lingüístico y situaciones distintas cualitativamente de la diglosia.

En efecto, Ferguson confesó en su mismo artículo que su estudio debía ser considerado como preliminar, ya que se requería mucha mayor acumulación de datos históricos y descriptivos (326), y expresó una petición de ampliar su estudio con fenómenos relacionados, siempre que pudiera elaborarse un marco general de referencia para el análisis del uso de una o más variedades de lengua, dentro de una comunidad de habla (340). Es más, entre los ejemplos de diglosia de otros tiempos y lugares, citó el caso del latín y las lenguas romances emergentes, durante un período de algunas centurias en varias partes de Europa (337). El vernáculo romance era usado en la conversación ordinaria, pero el latín era la lengua de la Iglesia y de su bibliografía.

En este sentido, Banniard (1992: 505-11) ha argumentado que el concepto de diglosia estricta no puede dar cuenta exacta de los procesos lingüísticos implicados en el Occidente latino, desde el siglo $\mathrm{v}$ al siglo viIr, y ha criticado la escueta aplicación generalizada del concepto por Ferguson al Occidente latino y su imprecisión cronológica, aunque a su parecer éste se había decantado por fijar el inicio de la diglosia románica en el siglo IX, tras el renacimiento carolingio. La propia discusión teórica del concepto y la limitación a la aportación primera de Ferguson sitúan la controversia dentro de niveles especulativos y obsoletos, donde cualquier supuesto teórico es meramente libresco y alejado de la investigación actual.

3.2. Las limitaciones del pasado en la lingüística histórica se superarán en la medida en que nuestra preocupación se ciña a análisis sobre los problemas de conservación y sustitución lingüísticas, a partir de teorías más generales y actuales sobre el cambio personal, social y cultural. Lamentablemente, la conservación y la sustitución lingüística han sido poco estudiadas en el pasado y reducidas, dentro de la problemática de la historia de la lengua, a meros capítulos internos del relevo linguístico discreto (tales como romani- 
zación, arabización, etc.), sin referencia alguna a la progresiva reducción en las funciones sociales de la lengua subordinada. Recientemente, la sociolingüística histórica ha abierto nuevas posibilidades al conocimiento de la dinámica social y contextual de los procesos históricos del cambio lingüístico (Gimeno, 1995).

En particular, el latín medieval no reformado era un registro escrito, cuando lo que se hablaba ya no era latín. A pesar de que no es fácil determinar en qué tiempo el latín medieval dejó de ser variedad vernácula del Occidente románico, es muy posible que comenzara a partir de la primera mitad del siglo VIII en la Galia del norte. Lo cierto es que esța situación general sería uno de los ejemplos (citado también por Hudson, 2002 a: 42) de diglosia, sin tener en cuenta que representa la etapa en que las variedades maternas de los hablantes eran los protorromances, unas variedades distintas del latín. En un primer momento, en efecto, el latín medieval no reformado (como variedad superpuesta autónoma) relegaría los vernáculos romances a unas variedades sociales heterónomas, y conduciría a una diglosia estricta.

Sin embargo, con la aparición de las primeras muestras romances escritas en la primera mitad del siglo IX, el proceso de formación de las lenguas románicas evidencia la anterior transición (y más ejemplar) de una diglosia estricta a una diglosia amplia sin solución de continuidad, y borra cualquier tipo de especulación sobre la naturaleza fundamentalmente diferente de la diglosia y el multilingüismo social en sus orígenes sociales. Dicha evolución no se produjo en el mundo islámico, y la situación de diglosia estricta se ha mantenido hasta nuestros días. Esa continuidad lingüística y cultural (más que la etiología, la distancia lingüística o el desequilibrio de poder exhibido en la diglosia amplia entre las lenguas) debería hacernos reflexionar sobre el propio curso evolutivo de la diglosia y las soluciones a largo plazo, con el fin de resolver las relaciones subyacentes que presentan la diglosia y el multilingüismo social.

Por otro lado, ya no sólo es fundamental la característica del uso condicionado o reglamentado de cada variedad con una función social diferente, sino también la estabilidad de la situación, junto a la movilidad social (con el desplazamiento lingüístico correspondiente) que facilita la enseñanza de la variedad alta (A). Así se contribuye a una mejor comprensión de las relaciones que se plantean entre la situación de diglosia amplia (relativamente estable a largo plazo, con movilidad social) y el «conflicto lingüístico» (o activación de la configuración estática de la diglosia amplia sin movilidad social, dentro de una dinámica progresiva de sustitución lingüística). Por supuesto que dicho concepto no tiene nada que ver con la utilización que se ha hecho fuera de la sociología del lenguaje (Banniard, 1992: 405; véase supra parág. 2.4). 


\section{DIGLOSIA AMPLIA Y CONFLICTO LINGÜÍSTICO ROMÁNICOS}

Las situaciones sociales del contacto entre lenguas han planteado tres procesos (convergencia, no convergencia y divergencia), y nos sugieren que los grupos sociales están modificando continuamente su variedad para reducir, mantener o acentuar las diferencias lingüísticas (y sociales), en función de su percepción del contexto de interacción (figura 2).

En líneas generales, la covariación de dos o más (sub)sistemas en el repertorio lingüístico de una comunidad de habla puede inscribirse dentro de las soluciones siguientes:

a) interferencia, entendida como la superposición simultánea de dos variedades lingüísticas en el mismo elemento;

b) cambio de código, o importación lingüística (total o parcial), sin integración lingüística alguna;

c) calco, o sustitución léxica sin importación, y

d) préstamo, entendido como la integración lingüística y social de un elemento foráneo.

Esto constituye lo que se llama el apartado de la trasferencia lingüística, bien conocido por todos los estudiosos actuales del multilingüismo social (Blas Arroyo, 1991; Gimeno y Gimeno, 2003: 101-35). Otro apartado menos considerado (pero hoy irrenunciable) lo compone la trasferencia cultural, que implica el mestizaje social y el mestizaje cultural de los pueblos multilingües.

En particular, la trasferencia lingüística y la trasferencia cultural pueden relacionarse y se resuelven en dos dinámicas mutuamente excluyentes (si bien las relaciones y conexiones entre ambos procesos pueden ofrecer una aportación especial, en función de las diversas situaciones sociolingüísticas), a saber:

a) amalgama, o reestructuración lingüística de dos variedades particulares en una nueva gramática (L3), y

b) sustitución lingüística, como abandono de una variedad particular (B) en beneficio de otra (A).

La amalgama o criollización (al contrario que la sustitución linguiística) tiende hacia un sistema morfológico y sintáctico más complejo. La figura 2 nos presenta, pues, nítidamente la delimitación entre la sustitución lingüística y el cambio lingüístico en las situaciones actuales del contacto de lenguas. Así, por ejemplo, el spanglish no es un caso de amalgama, sino de atrofia lingüística y de sustitución del español por el inglés. La estrecha relación de la 
sustitución lingüística y el cambio lingüístico supone la necesidad de integrarlos en el proceso de la formación de las lenguas románicas, aunque nunca se hayan establecido su delimitación ni su significación.

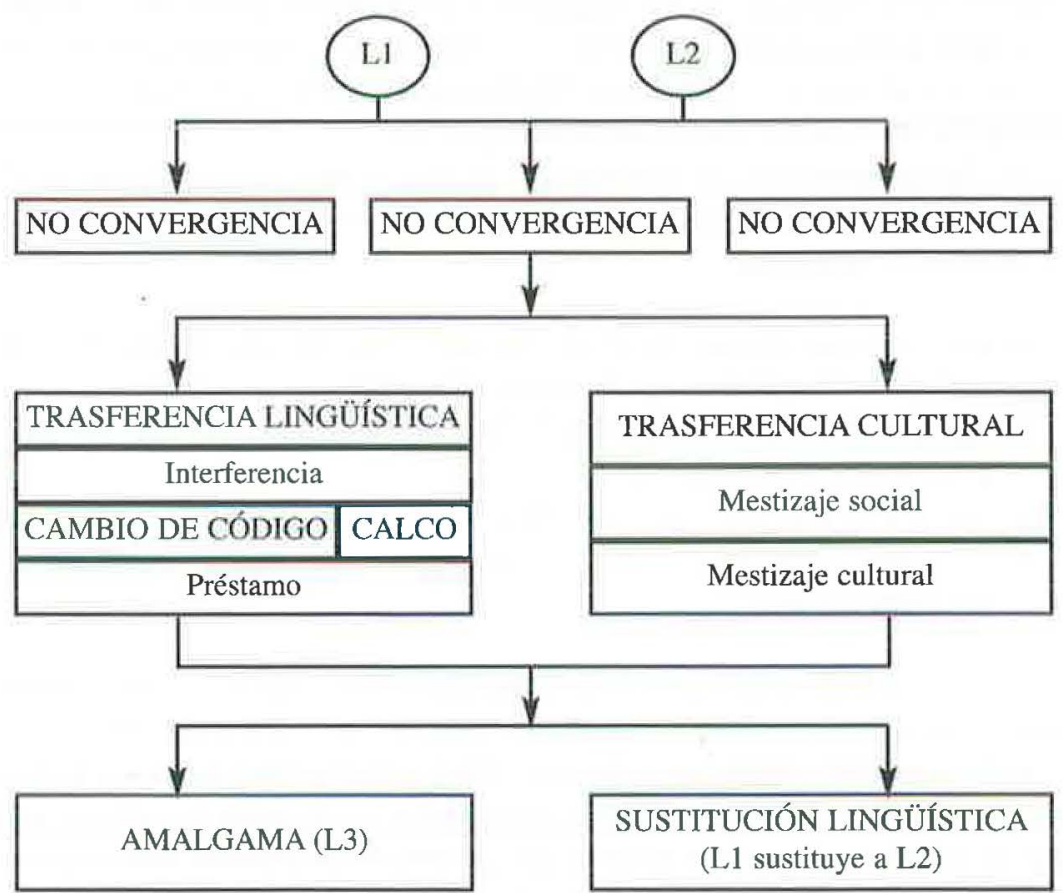

FIGURA 2. Configuración general del cambio lingüístico sobre las situaciones sociales del contacto de lenguas

4.1. En las pasadas décadas se ha replanteado la cuestión de la posible analogía entre la génesis de las lenguas criollas y el origen de las lenguas románicas, y no ha habido una respuesta contundente. Así, por ejemplo, Alarcos (1982: 18 y 47-8) sugirió que el dialecto rural de la antigua Cantabria fue originariamente casi un criollo o una lengua franca utilizada durante siglos por bilingües vasco-románicos. El latín mal aprendido por los indígenas hispánicos del norte (con la inclusión de la cuenca del Duero) dio origen a unas cuantas modalidades de lengua hablada en los antiguos territorios de los pueblos primitivos (galaicos, astures, vácceos, cántabros, turmogos, austrigones, várdulos, caristios, vascones, berones y pelendones), agrupados administrativamente por los romanos en diversos conventos jurídicos (lucense, asturicense, cluniense y cesaraugustano). 
Schlieben-Lange (1977) ofreció una visión histórica de las discusiones acerca de si el desarrollo de las lenguas románicas habría correspondido o no a un proceso de "criollización», y había propuesto un empleo heurístico de la posible analogía entre ambos tipos de procesos lingüísticos (romanización y criollización), con el fin de enriquecer nuestros conocimientos de los universales lingüísticos en el dominio de la historia de la lengua. Si bien es cierto que la lingüística románica ha logrado un conocimiento considerable de los procesos de romanización, desde un punto de vista lingüístico, deben reinterpretarse estos resultados en términos sociolingüísticos.

Entre las opiniones ofrecidas por anteriores lingüistas, citó la propuesta de Meillet sobre la criollización del latín, a pesar de que anteriormente había expuesto afirmaciones totalmente contrarias (Meillet, 1929). En la morfología del romance común, la mayoría de los rasgos arcaicos de tipo indoeuropeo que el latín arcaico todavía conservaba en gran número aparecerían eliminados, así como muchos de los nuevos matices que el latín había conseguido. Con la función de servir como «lengua franca» a un gran imperio, el latín tendería a simplificarse y a guardar sobre todo lo que tenía como banal. El latín coloquial llegaría a ser una variedad que los hombres más variados y los menos cultivados podían manejar, es decir, una herramienta cómoda y apta para cualquier mano.

Por el contrario, Jespersen habría ofrecido en su introducción a la lingüística general la primera noticia sobre el rechazo total a la comparación entre variedades pídgines y criollas, de una parte, y variedades romances, de otra. No habría habido ruptura en el desarrollo de las lenguas romances, y la tradición del latín y de su sistema gramatical no se habría interrumpido, ni habría sufrido una completa trasformación. Aunque podría suponerse que en una primera etapa inicial de la conquista romana podría haberse dado alguna variedad oral latina simplificada, no se podría equiparar a una condición de pídgines y criollos.

Asimismo, Lüdtke en su historia del léxico románico ofrecía todavía una visión más clara. Si bien la situación de los actuales criollos es comparable a la de las variedades romances de la Edad Media, la estructura de la lengua muestra una diferencia fundamental: una reducción tan considerable de la morfología y del vocabulario -tal y como muestran los pídgines y criollosno ha tenido nunca lugar en el latín hablado ni en las variedades romances populares.

En suma, hace más de veinte años, Schlieben-Lange juzgaba que sería arriesgado decidirse sobre el origen de las lenguas romances por una de estas dos posibilidades: 
a) una situación diglósica en la que una de las lenguas (o una de sus variedades) cumpliría las funciones oficiales, mientras que la otra quedaría relegada a las relaciones no formales, o

b) la aparición de una lengua de relación (ya fuera una de las lenguas, una forma simplificada de una de ellas, o una lengua mixta) que no desempeñaría más que funciones reducidas (por ejemplo, una estricta relación comercial).

En nuestros días, puede objetarse a la primera hipótesis que la diglosia caracteriza un proceso relativamente estable, y nunca puede determinar la aparición de las lenguas romances. La enseñanza escolar del estándar facilita el desplazamiento lingüístico del vernáculo correspondiente, junto a la movilidad social. Con respecto al segundo supuesto, puede replicarse que las características lingüísticas e históricas de los vernáculos romances son completamente diferentes de los lectos -basilecto, acrolecto y mesolectoscriollos, ya que no se desarrollan a partir de un pidgin, ni se diferencian en el nivel sintáctico tan profundamente como el basilecto del acrolecto, a pesar de que los continuos de habla (temporal, geográfico, social y contextual) y el continuo criollo parecen ser aspectos diferentes de los procesos de transición e inserción del proceso general e histórico del cambio lingüístico (Gimeno, 1981, $1984 a, 1990,1995)$.

Han pasado algunos años de la falta de precisión en la utilización del término de sustitución lingüística, y debemos evitar cualquier tipo de ambigüedad terminológica entre sustitución lingüística y cambio lingüístico, entre atrofia lingüística y amalgama. Además, todavía debería matizarse hoy que si bien encontramos una considerable simplificación en la morfología nominal de las lenguas románicas, no sucede así con la morfología verbal, que ha conservado bastante bien el paradigma verbal latino. En particular, en español el sistema morfológico se ha hecho en ciertos aspectos más complejo que el latino (así, por ejemplo, se han formado un tiempo «perfecto»-además del «pretérito»-, un condicional y un futuro de subjuntivo) (Alvar y Pottier, 1983: 151-88; Penny, 1991: 153-65; Lapesa, 2000: 730-79).

4.2. Conviene precisar, sin embargo, un punto decisivo en la reelaboración y matización del concepto de diglosia amplia. En los Países Catalanes la elaboración teórica de Fishman (1967) ha conocido una especial fortuna, y aunque al principio no se planteó ninguna crítica a la aplicación del análisis de diglosia amplia a la sociedad catalana, muy pronto se produjeron divergencias en cuanto a su extensión y alcance (Montoya y Gimeno, 1995: 88-100). Los primeros usos del término conflicto lingüístico, según Kremnitz (1990: 61), son del siglo XIX, aunque la consideración de la lengua como 
objeto de conflictos sociales es más antigua. Antecedentes claves de la introducción del término en la lingüística actual han sido Terracini (1951) y Haugen (1966).

En efecto, a pesar de los prejuicios neoidealistas, Terracini (1951) planteó en los conflictos de lenguas y de cultura la sustitución del galo por el latín del imperio romano, a través de las coordenadas de máxima fusión cultural, mínima conciencia de la sustitución y máxima semejanza originaria de las dos lenguas en tensión. En un conflicto lingüístico desempeñaría un papel decisivo el momento de cohesión social que se materializa en la lengua. Cualquier forma de sustitución lingüística resulta de la fusión de dos sistemas lingüísticos y dos tradiciones culturales, y por consiguiente debe ser estudiada desde la perspectiva del bilingüismo social. Ahora bien, para que este bilingüismo pueda provocar una sustitución lingüística deberían darse dos condiciones:

a) una mezcla efectiva de conjuntos de personas que hablen dos lenguas distintas, aunque la entidad relativa de ambos grupos no sea un factor decisivo, $\mathrm{y}$

b) una diferencia de prestigio, a partir de que uno de los conjuntos considere al otro como portador de una forma superior de civilización.

La sustitución de una lengua puede verificarse a través de la extinción de sus hablantes, o mediante la exclusión del uso en los diversos ámbitos (parlamento, predicación, escuelas...), por la imposición intencional de la nueva lengua (Vàrvaro, 1972-1973, 1978).

En este sentido, no es aventurado suponer que el origen remoto de las lenguas románicas se encuentra en los procesos antiguos de desplazamiento de unos vernáculos prerromanos (con movilidad social) por el latín, dentro de unas situaciones claras de diglosia amplia. Con la extensión y auge del cristianismo por todo el antiguo mundo romano hasta el siglo VI, dichas situaciones relativamente estables habrían derivado (excepto en el caso del euskera) a conflictos lingüísticos, donde se habría producido la sustitución de los vernáculos prerromanos por el latín. Lausberg (1963, I: 91) aludió a la dificultad de determinar la época de desaparición de las lenguas prerromanas, y a que parece haberse mantenido más tiempo que ninguna otra lengua el galo (en algunos puntos de Suiza quizá hasta el siglo v).

En ambos períodos (de diglosia amplia y de conflicto lingüístico) se darían los correspondientes compromisos gramaticales de interferencia, cambio de código, calco y préstamo, dentro de un proceso complejo de mestizaje social y cultural. Dicha hipótesis explicaría la pervivencia posterior de rasgos prerro- 
manos en el proceso de formación de las lenguas romances, la cual dio lugar a la conocida teoría románica del sustrato linguiístico (Gimeno, 1998: 478-83).

Así lo corrobora Tagliavini (1949/1969: 150), cuando menciona que en la romanística se parte del latín formado ya, si bien (para seguir los procesos de origen y desenvolvimiento de las lenguas romances) es necesario referirse a menudo a las fases arcaicas, o a los varios sustratos a los que se superpuso el latín en el curso de los siglos y en su expansión histórica. Sobre la teoría de los estratos linguíísticos, el propio Vidos (1956: 203) ofreció la referencia de «que en el fondo, sustrato, superestrato y adstrato no son sino expresiones metafóricas para indicar las influencias lingüísticas de los pueblos vencidos, vencedores y convivientes, respectivamente». El mismo historiador Wolf (1971: 74), cuando resumió que «en la Galia la acción del superestrato confirmó y reforzó la acción de los sustratos», no se percataba de qủe la dicotomía vencedor/vencido ofrecía el mismo resultado (confirmaba y reforzaba las influencias lingüísticas), y de que eso significaba que la acción era independiente de esa coordenada impropia, y que las únicas variables a considerar eran las diversas condiciones sociales y culturales de los pueblos implicados.

Una vez más, recordaré la cita de Weinreich (1953: 4), a partir de las palabras de Haugen:

\begin{abstract}
Asimismo, el lingüista que construye teorías sobre la influencia de las lenguas (pero no tiene en cuenta el marco sociocultural del contacto de lenguas) deja su análisis suspendido (por así decirlo) en el aire, ya que lo que se dice acerca de los sustratos y superestratos debe continuar considerándose estratosférico, a menos que lo observemos empíricamente en el comportamiento de los hablantes.
\end{abstract}

Ha llegado, pues, el momento de que los lingüistas superemos el obsoleto supuesto de los estratos linguísticos, auténticos cajones de sastre y simples remedos del capítulo bilingüe, y aceptemos la presente propuesta de la sociolingüística histórica sobre la configuración general del cambio lingüístico, a partir de las situaciones sociales del contacto de lenguas. Frente a las etiquetas rutinarias y exiguas de sustrato, superestrato y adstrato, debemos precisar qué hechos de trasferencia lingüística (interferencia, cambio de código, calco o préstamo) y de trasferencia cultural (mestizaje social o cultural) aparecen implicados en qué dinámica mutuamente excluyente (amalgama o sustitución lingüística), dentro de las estrategias convergentes del cambio lingüístico sobre las situaciones sociales del contacto de lenguas (Gimeno, $1984 b ; 1995:$ 39-53).

Asimismo, Wartburg (1950: 131-40), a propósito de la peculiar posición del francés dentro de la Romania occidental (a partir de las circunstancias de 
la invasión germánica franca), aseguró tener comprobada la convivencia de dos lenguas en la Galia del norte, desde el siglo v hasta por lo menos la mitad del siglo IX, y esta relación mutua (donde participaron al principio sobre todo las clases dirigentes, y más tarde se hizo general al pueblo franco) condujo a la neorromanización tardía y lenta de los francos desde el siglo VI, y a la sustitución del alemán (fráncico) por el latín merovingio en el norte de Francia, pero al mismo tiempo imprimió en el latín del reino franco y del burgundio un sello más innovador que lo distinguió del occitano y del iberorrománico.

4.3. Nuestra aportación, fruto de nuestra experiencia de campo (bien sociológica, bien dialectológica), se ha inscrito en el análisis de los principales procesos de evolución sobre la conservación y la sustitución lingüística en la Comunidad Valenciana. A través del examen de la organización y el desplazamiento del vernáculo valenciano del repertorio lingüístico de las comunidades de habla alicantinas, se ha planteado si corresponde a la propia situación de la diglosia amplia o a la de un conflicto lingüístico (con movilidad social o sin ella, respectivamente), entre las coordenadas de normalización o sustitución lingüística. Así, por ejemplo, hemos constatado, a partir de encuestas sociolingüísticas, el desplazamiento del vernáculo valenciano por el castellano estándar en el ámbito del intercambio económico de la región de Alicante, sin movilidad social objetiva, dentro de una clara situación de conflicto lingüístico.

El ámbito de uso del intercambio económico (tiendas, comercios, grandes almacenes y entidades bancarias) se caracteriza por un menor grado de formalidad que el ámbito de uso público. Las actuaciones bilingües en el ámbito público están reglamentadas desde la aparición de la diglosia amplia en el siglo XVI, con el desplazamiento del valenciano por el castellano estándar. La dinámica geográfica (por regiones) y social (por ámbitos de uso) de la sustitución lingüística en la Comunidad Valenciana durante el siglo xx puede observarse en la gradación o escalonamiento de la regresión de la frontera catalana meridional, (a partir de la confrontación entre los índices compuestos de las actuaciones bilingües del ámbito familiar y del económico), que presenta un valor medio en el ámbito familiar y un valor máximo en el ámbito económico, en función del bilingüismo activo (o pasivo) con predominio del valenciano o del castellano (cuadro 1). Los tres ámbitos de uso (público, privado y de intercambio económico) se encuentran involucrados claramente en el proceso de formación de las lenguas románicas. 
CuAdro 1. Dinámica geográfica y social de la sustitución lingüística en la Comunidad Valenciana durante el siglo XX, a partir de los indices compuestos () de la actuación bilingüe en el ámbito familiar y el económico, en función de las áreas de bilingüismo activo (o pasivo) con predominio del valenciano o del castellano.

\begin{tabular}{|l|l|l|}
\hline & ÁMBITO FAMILIAR & \multicolumn{1}{|c|}{$\begin{array}{c}\text { ÁMBITO } \\
\text { ECONÓMICO }\end{array}$} \\
\hline $\begin{array}{l}\text { Área de bilingüismo ac- } \\
\text { tivo con predominio del } \\
\text { valenciano }\end{array}$ & $\begin{array}{l}\text { ALCOI -GANDIA }(3,1) \\
\text { CASTELLÓ }(2,7) \\
\text { VALĖNCIA }(2,6)\end{array}$ & $\begin{array}{l}\text { ALCOI-GANDIA }(2,4) \\
\text { CASTELLÓ }(2,1) \\
\text { VALĖNCIA }(2)\end{array}$ \\
\hline $\begin{array}{l}\text { Área de bilingüismo } \\
\text { activo con predominio } \\
\text { del castellano }\end{array}$ & ALACANT $(2,1)$ & $\begin{array}{l}\text { ALACANT }(1,4) \\
\text { ORIOLA }(1) \\
\text { REQUENA-SOGORB (1) }\end{array}$ \\
\hline $\begin{array}{l}\text { Área de bilingüismo } \\
\text { pasivo con dominio del } \\
\text { castellano }\end{array}$ & $\begin{array}{l}\text { ORIOLA }(1,1) \\
\text { REQUENA-SOGORB }(1,1)\end{array}$ & \\
\hline
\end{tabular}

El proceso social de castellanización de la sociedad valenciana se inició con una situación de diglosia amplia, a principios del siglo XVI. Dicha situación de decadencia cultural siguió una dirección horizontal y selectiva (siglos XVI-XIX) y una dirección descendente y espontánea (siglo XIX). La aparición de los medios de comunicación social y la instrucción general en el castellano estándar han desbordado sus anteriores límites en el siglo xx, y han originado un conflicto lingüístico, en el que la sustitución lingüística se ha independizado de la movilidad social objetiva (Mollà, Alpera, Gimeno et al., 1989; Gimeno, 1986, 2000).

El modelo general e histórico de la sustitución linguística en el caso de las comunidades autóctonas sería el de la progresiva reducción en las funciones sociales de la lengua subordinada: el desplazamiento comienza con el abandono de dicha variedad lingüística en los contextos públicos y formales ( $\mathrm{y}$ su restricción a las funciones familiares e informales), y acaba con su desaparición, cuando se interrumpe la trasmisión familiar de esa variedad a los hijos. Además, el desplazamiento se hace gradual en un ámbito de uso determinado, de manera que la variedad recesiva pasa por una etapa de utilización variable, antes del uso exclusivo de la variedad expansiva. Asimismo, la sustitución lingüística fomenta la simplificación sintáctica y léxica de la variedad recesiva, los cambios de código y los calcos, los cuales responden a proble- 
mas generales de atrofia lingüística. La teoría de la identidad social proporciona un análisis de las estrategias de cambio social, con el fin de lograr una diferenciación psicolingüística positiva, y determina la dinámica de conservación o sustitución lingüística (Gimeno y Gimeno, 2003: 59-64).

\section{ETAPAS Y PERÍODOS DEL PROCESO DE FORMACIÓN}

La denominación tradicional de este tema (orígenes de las lenguas romances) es posible que implique una toma de posición de cierta ambigüedad. Al igual que la diferenciación geolectal, el auténtico proceso de formación de las lenguas románicas es objetivamente gradual y acumulativo (aunque subjetivamente no lo sea), y nunca debemos suponer un hablante último de latín medieval ni un hablante primero de cualquier variedad románica. No podemos preguntarnos, pues, sobre los orígenes de las lenguas romances, ni del español. Las variedades históricas del latín pueden ordenarse a lo largo de un continuo temporal, a modo de una cadena en la que cada par de variedades adyacentes son mutuamente inteligibles, aunque no lo sean los extremos opuestos de esa cadena.

Es decir, si partimos de la hipótesis de que no ha habido rupturas totales en la línea de continuidad de la peculiaridad lingüística de las lenguas románicas, desde el remoto pasado latino al presente, no puede sugerirse, por una parte, que los orígenes de las lenguas románicas se encuentren en la aparición de las primeras muestras romances escritas (primera mitad del siglo IX), sino en la propia diversificación de los vernáculos romances (sobre todo, a partir de la primera mitad del siglo viII en la Galia del norte, y también en función de las diversas situaciones sociales de las diferentes comunidades de habla), y por la otra, el mismo nombre puede ofrecer además el equívoco de que se trata solamente de los orígenes escritos de las lenguas romances.

Tagliavini (1949/1969: 10) lo resume bien en su prefacio a la tercera edición de su manual, con las siguientes palabras: «He procurado llevar el examen de los orígenes de las lenguas neolatinas hasta sus primeros testimonios literarios, dejando a otros, más competentes que yo, el análisis de los valores culturales, literarios y estéticos». Frente a eso, optamos por evitar términos equívocos, y adoptar una denominación del tema coherente con el planteamiento de ofrecer un supuesto verosímil sobre el proceso de formación de las diversas lenguas románicas, desde un mismo diasistema latino.

Por lo demás, nuestra propuesta asume una hipótesis de trabajo que sea verificable empíricamente en el presente, ya que cualquier otra suposición (no importa cuán artificiosa o brillante sea) debe confinarse a simples especulaciones (Lüdtke, $1996 a, 1996$ b, 1996 c, 1998; López García, 2000). Debe- 
mos dejar constancia de la necesidad de contar con el soporte de un marco sociolingüístico interdisciplinario de multilingüismo social, ya que impide que nos movamos en una pura nebulosa (tal como explica por sí sola la vacilación temporal, geográfica y social de las investigaciones precedentes), y es la única manera de superar las limitaciones del pasado. En nuestros días, a través del aislamiento de las variables dependientes del cambio de código y del calco léxico, hemos confirmado la hipótesis inicial acerca de una configuración general del cambio lingüístico, sobre las situaciones del contacto de lenguas (Gimeno y Gimeno, 2003). Nuestra aportación ofrece, pues, una teoría global de las relaciones entre la lengua y la sociedad, la cual puede comprender y explicar los problemas históricos de conservación y sustitución lingüísticas.

5.1. Desde la primera mitad del siglo viII, el contexto social y cultural de la Galia y del Occidente románico correspondería a una situación general de diglosia románica (estricta en un principio, amplia posteriormente). La variedad normalizada sería el latín medieval (no reformado y reformado, posteriormente), usado como registro escrito y oral formal, y los romances serían las variedades orales familiares e informales (francés, occitano, catalán, navarro, aragonés, retorromano, italiano, asturiano, leonés, mozárabe y gallego). La enseñanza escolar del estándar facilitaría el desplazamiento del vernáculo correspondiente, junto a la movilidad social (figura 3). Las glosas latinas y los glosarios latinos son las primeras muestras escritas y los testimonios histórico-lingüísticos más antiguos de las lenguas románicas.

La reforma cultural de la corte carolingia no pudo hacer desaparecer nunca la diglosia anterior en Francia, los condados de la Marca Hispánica y el norte de Italia, ya que suponía sólo la revitalización y reforma del latín medieval, a finales del siglo VIII. Y mucho menos se puede pensar que la reforma carolingia instauró la diglosia (Banniard, 1992: 532, n. 174). Antes bien, dicha reforma activaba la diglosia amplia anterior, y provocaba un conflicto lingüístico con la sustitución de los vernáculos romances, sin movilidad social.

Sólo la reacción pastoral (de dicha sustitución, provocada por la imposición de un nuevo latín medieval) que fue impulsada por el canon 17 del Concilio de Tours (813), para instruir a sus feligreses en la fe cristiana, puede explicar la aparición de las primeras muestras romances escritas, desde la primera mitad del siglo IX, y la primera normalización lingüística de los vernáculos. Dicha rectificación estaba dirigida a los mismos clérigos a los que se exhortaba al mismo tiempo, para que usaran el latín medieval reformado en otras ocasiones. Las prescripciones del Concilio de Tours parecen ser práctica aceptada en el 847 (Wrigth, 1982: 189). En este sentido, Lausberg (1956/1962, I: 106) cita en nota la frase de Griera ( $\ll$ La Iglesia es la 
madre de las lenguas romances»), y comenta que la Iglesia se hizo bilingüe: era la portadora del latín literario y, al propio tiempo, de las lenguas populares romances.

1) ETAPA PROTORROMANCE (siglo VII - segunda mitad del siglo XI)

$1^{\text {er }}$ período (siglo VII). SITUACIÓN DE DIGLOSIA ESTRICTA:

a) estándar: latín medieval no reformado, y

b) vernáculos: romances, (francés, occitano, catalán, navarro, aragonés, retorromano, italiano, asturiano, leonés, mozárabe y gallego).

$2^{\circ}$ período (finales del siglo VIII). SITUACIÓN DE DIGLOSIA AMPLIA:

a) estándar: latín medieval reformado, y

b) vernáculos: romances, (francés, occitano, catalán, navarro, aragonés, retorromano, italiano, asturiano, leonés, mozárabe y gallego).

3er período (principios del siglo IX). SITUACIÓN DE CONFLICTO LINGÜÍSTICO:

a) SUSTITUCIÓN DE LOS VERNÁCULOS por el latín medieval reformado, propiciada por la reforma carolingia, y

b) REACCIÓN PASTORAL: Concilio de Tours (813).

$4^{\mathrm{o}}$ período (primera mitad del siglo IX - primera mitad del siglo XI). NORMALIZACIÓN LINGÜÍSTICA DE LOS ROMANCES (francés, occitano, catalán, navarro, aragonés, retorromano, italiano, asturiano, leonés, castellano, mozárabe y gallego-portugués):

a) PRIMER TEXTO EN PROSA (francés): Serments de Strasbourg (842);

b) juramento del pleito capuano (960);

c) primeras glosas romances hispanas: códice emilianense 46 de la RAH (964), y

d) juramentos de fidelidad occitanos del castillo de Lautrec (985).

$5^{\circ}$ período (segunda mitad del siglo xi). SITUACIÓN DE CONFLICTO LINGÜÍSTICO:

a) SUSTITUCIÓN DE LOS VERNÁCULOS por el latín medieval reformado, propiciada por la reforma gregoriana, y

b) excepto el francés (Chanson de Roland) y el occitano.

2) ETAPA ANTIGUA Y MEDIEVAL (finales del siglo XI- finales del siglo Xv). NORMALIZACIÓN LINGÜÍSTICA DE LOS ROMANCES (francés, occitano, catalán, navarro, aragonés, italiano, asturiano, leonés, castellano, gallego y portugués)

FIGURA 3. Etapas y períodos del proceso de formación de las lenguas románicas, dentro del Occidente románico 
Es más, la presencia y la abundancia de los testimonios protorrománicos que aparecen en la Península Ibérica (es decir, no sólo en Cataluña, Aragón y Navarra, sino también en Castilla, Asturias y Galicia) desde el siglo Ix (Lapesa et al., 2003) nos sugieren que la estrategia pastoral de implantación obligatoria del vernáculo en el ámbito de uso público no habría conocido fronteras geopolíticas, ni escalonamientos cronológicos. Otra cuestión muy distinta sería la materialización escrita de los vernáculos, siempre posteriores a la aparición de las primeras manifestaciones superficiales de las muestras léxicas, o la verificación de la conciencia lingüística de los propios escritores o eruditos sobre el reconocimiento de la ruptura definitiva entre las variedades implicadas (latín medieval reformado y romances).

La propuesta de Wright (1997: 478-9) presentaba la extensión gradual de la nueva percepción del bilingüismo entre latín y romance al resto de la Romania (excepto Rumanía), influida sin duda por las divisiones geopolíticas del imperio carolingio. La Italia septentrional, la Provenza y Cataluña comenzarían a adquirir las nuevas normas del latín medieval reformado durante el siglo IX. En la Provenza parece que pronto se elaborarían normas escritas locales del occitano, las cuales se utilizaron desde el siglo XI en algunos documentos jurídicos, y también por poetas catalanes y por algunos italianos. El legado de la cultura carolingia se expandiría en los momentos iniciales del renacimiento del siglo XII para alcanzar el resto de la Península Ibérica, Cerdeña, el Pontificado y el resto de la Italia meridional. Asimismo, propuso que hasta el renacimiento del siglo XII todos los textos (o al menos, la mayoría de ellos, con excepción del contexto eclesiástico) podrían leerse en voz alta con la fonética vernácula habitual.

A propósito de la fijación escrita de los vernáculos romances, Banniard (1991) se preguntó si hubiera sido una figura clave en aquella época el primer gran erudito germánico R. Maurus, el mejor alumno de Alcuino. Tras el acceso al arzobispado de Maguncia que le llevó a convocar y dirigir los programas de varios concilios, Maurus decidió plantear el necesario compromiso lingüístico para la utilización de la propia lengua alemana del pueblo, y describió con detalle la necesidad de la traducción. En efecto, el canon II del Concilio de Maguncia del año 847 repetía el canon 17 del Concilio de Tours. Desde el siglo viII, los sínodos y concilios de las áreas anglosajonas y germanohablantes requerían a los predicadores para que enseñaran la doctrina cristiana a los fieles iletrados. La apuesta cada vez mayor de Maurus (hacia la práctica linguística de una forma escrita para el alemán) animaría a los intelectuales del área occidental en el desarrollo gradual de la idea de que se necesitaba otro nuevo sistema escrito romance. 
La reforma del latín medieval y el uso de traducciones en beneficio de las poblaciones germanófonas en la primera mitad del siglo IX podrían suscitar en los eruditos la posibilidad de una toma de conciencia lingüística sobre la nueva materialización escrita del romance. Sin embargo, dicha materialización (que suponía además la propia referencia culta e ilustrada a la función literaria del latín medieval reformado) no puede deberse sólo a la simple imitación de las lenguas celtas y germánicas vecinas, ya que las situaciones sociales de la fijación escrita de sus lenguas nacionales eran totalmente dispares.

Más bien, la compatibilidad de exigencias contrarias por parte de los mismos gestores eclesiásticos determinó el proceso de materialización escrita de las lenguas romances, y la progresiva extensión de dicha actividad a distintos grupos sociales y a otras comunidades de habla del Occidente cristiano europeo (así, por ejemplo, francés, occitano, catalán, navarro, aragonés, retorromano, italiano, asturiano, leonés, castellano, mozárabe y gallego-portugués). Los Serments de Strasbourg (842) son el texto escrito más antiguo de una lengua románica en francés, propiciado por la conciencia bilingüe latino-germánica de la comunidad cultural franco-románica de la Francia septentrional, menos ligada a la tradición latina (Vidos, 1956: 336-7).

5.2. Desde principios del siglo IX, en que asciende al trono de Pamplona la dinastía Jimena (con Sancho Garcés I), se afirma en el Reino la idea de reconquista y ocupación de nuevos espacios, con el asentamiento de navarros en las tierras de La Rioja. Cierbide (2003: 17-8) cita la deducción de Lacarra acerca de que el monasterio de Leire, a mediados del siglo IX, sólo fue posible gracias a la influencia carolingia y al impulso dado por la reforma de San Benito Aniano, sin que se suplantara por ello la tradición hispano-visigótica. Y S. de Moxó (1979: 81-2) añade que (a pesar de que podemos pensar en la función colonizadora del prestigioso monasterio de Leire) se observa mejor tal función en los monasterios riojanos de Albelda y San Millán de la Cogolla, donde la atención prestada hacia ellos por los monarcas pamploneses del siglo $\mathrm{x}$ se debió principalmente a la conveniencia de fundar dos centros de repoblación, a partir de los cuales poder asegurar el dominio de un territorio y la explotación de sus recursos (García de Cortázar, 1969; J. García Turza, 2000). Cataluña, Aragón y Navarra (en particular, La Rioja) son, pues, casos especiales del desarrollo carolingio del latín medieval reformado y del romance escrito en la España cristiana.

Entre los numerosos glosarios latinos que fueron elaborados en la Europa altomedieval, destacan por su extensión y riqueza el códice emilianense 46 de la Real Academia de la Historia y el códice emilianense 31 de la Real Academia de la Historia, así como por su antigüedad y posible origen emilianense el códice emilianense 24 de la Real Academia de la Historia (García Turza y García Turza, 1997, 2000; Díaz y Díaz, 1979: 143-7; C. 
García Turza, 2000). El manuscrito Em. 46 es un auténtico diccionario enciclopédico, ya que supera las 20.000 glosas, y es el modelo fundamental de dos glosarios silenses de la Biblioteca Nacional de París (núms. 1296 y 1297). Se trata de un manuscrito escrito en letra visigótica redonda y concluido el año 964 en el escriptorio de San Millán de la Cogolla, el cual refleja fielmente la influencia del renacimiento carolingio, y evidencia la existencia indudable de relaciones culturales entre el norte peninsular hispano y el resto del Occidente cristiano europeo (letras fuertemente influidas por la escritura carolingia, numerosas glosas escritas en alemán, trascripción de un poema del escritor aquitano H. Níguelo, dedicado a su rey Pipino, en un latín medieval reformado, etc.). Sin lugar a dudas, dicho glosario tuvo como modelo, según Vivancos (2000: 314), un códice escrito en minúscula carolina.

Asimismo, uno de los conjuntos textuales más abigarrados y ricos de toda la herencia codicológica hispana de la Alta Edad Media lo constituye el códice Albeldense (o Vigilano) de la Biblioteca del Real Monasterio de El Escorial (ms. D.I.2.), con abundantes glosas y varias de ellas romances. El códice fue realizado durante los años 974-976 en el monasterio de San Martín de Albelda por Vigila y su equipo, y consta de tres partes fundamentales (el Liber Canonum, las Epistolae decretales y el Liber Judicum) (Fernández Flórez y Herrero de la Fuente, 2002; C. García Turza, 2003).

5.3. En el códice emilianense 46 de la Real Academia de la Historia, encontramos ya primeras glosas escritas del romance hispánico (año 964, véase supra) (García Turza y García Turza, 2001, 2002). Las glosas latinas y las glosas romances (así, por ejemplo, morteras, apeiro, de suso, iosum...) (Lapesa et al., 2003, s.s. v.v. morteras, desuso e iuso; Corominas y Pascual, 1980-1991, s. v. aperar) de ese manuscrito visigótico evidencian la continuidad de la tradición hispano-latina junto a la influencia carolingia, en una nueva situación de normalización lingüística, donde el conflicto lingüístico anterior se había superado, y las funciones sociales de las lenguas (latín medieval reformado y romance) quedaban moderadas y circunscritas a la necesidad de acatar las prescripciones del canon 17 del Concilio de Tours (Wright, 2002; González Ollé, 2004).

Una buena prueba de nuestra hipótesis de trabajo viene constituida por el documento de donación «post obitum» del matrimonio Hermenegildo y Cita al monasterio de San Justo y Pastor en Rozuela (León) del año 959, cuyo reverso contiene la «Lista de quesos gastados por el despensero del convento» del año 975.

El recto del documento (la donación) sigue los formularios jurídicos propios de este tipo bastante generalizado en la documentación altomedieval, donde la organización y la disposición del documento dependían más de su 
estructura y de las fórmulas que lo integraban, que de la propia lengua latina. Escrito en latín medieval no reformado (a pesar de la plena vigencia de la reforma carolingia) y en letra cursiva visigótica, la convivencia latín-romance podría responder a una deficiente formación latina (muy lejana a la claridad y corrección del latín de la Galia), junto a la conservación de la propia peculiaridad de la tradición hispano-visigoda, no exenta de detalles eruditos. El uso de las preposiciones, la presencia constante del artículo, la conformación del paradigma verbal, el empleo de los demostrativos o posesivos muestran el trasfondo romance que subyace en la lengua latina usada en la documentación conservada en los archivos medievales leoneses. El criterio de uso de una parcial conservación del paradigma casual no responde en modo alguno a la aplicación de los criterios funcionales que regían el caso en latín (Fernández Catón, coord., 2003: 37-9 y 45-68).

Sin embargo, dicho latín medieval no reformado cumplía la propia referencia culta e ilustrada de la función literaria del latín medieval reformado, de acuerdo con la particular tradición hispano-visigoda. La hipótesis de R. Menéndez Pidal (1926/1950: 454-60) sobre la vigencia de un tercer sociolecto (el latín popular arromanzado de los semicultos, frente al latín culto de los eruditos) en los documentos notariales leoneses de los siglos x y XI es una suposición irreal y ficticia, ya que se trata de un mero registro escrito y por supuesto latino. Es más, debe asumirse a su lado un latín foral, que ofrece el mayor romanceamiento, y puede permitir la más verosímil reconstrucción de los romances peninsulares (Gimeno, 1995: 153-71).

El verso del documento (Nodicia de kesos) es una simple anotación económica de inventario de bienes consumidos, con finalidad administrativa, y con un precedente que se remonta a unas notas sobre pizarra visigótica (Notitia de casios). Escrito en romance y en letra semicursiva visigótica con una gran libertad de trazado, el monje Jimeno muestra su competencia comunicativa para plasmar la gramática del vernáculo de su comunidad de habla (sintaxis, léxico y fonología), aunque observemos las diversas variantes morfológicas y grafemáticas superficiales, y nos ofrece otra prueba del bilingüismo oral de la Iglesia, tras la reacción pastoral de Tours (813). A pesar de que esta anotación es insólita en la documentación medieval leonesa, su presencia sin fecha en el verso del pergamino supone que la donación del anverso ya se ha cumplido, y que dicho documento se encuentra en el monasterio de Rozuela.

El uso del dorso para la anotación de los quesos consumidos aquel año (o el anterior) refleja los siguientes supuestos: a) conciencia lingüística del monje sobre el nuevo vernáculo romance; b) conocimiento de antecedentes sobre la materialización escrita de otros vernáculos romances en otros contextos románicos, y c) la voluntad de materialización escrita del vernáculo y de su persistencia por parte del monje, junto al latín medieval del recto. Dicha 
yuxtaposición ofrece un argumento incuestionable de la vigencia de un latín medieval y un romance en España antes de la implantación de la reforma gregoriana en el Concilio de Burgos, frente a la rígida hipótesis (claramente insuficiente) de R. Wright (1982), acerca de la única vigencia de vernáculos, incluso escritos por quienes sabían o pretendían saber latín. Concretamente, en el texto romance aparece de un modo claro la necesidad de materializar la nueva realidad románica en León, como consecuencia de la nueva situación de normalización lingüística de los vernáculos, donde la función social de la variedad romance se incrementa (con respecto a las prescripciones del canon 17 del Concilio de Tours) al ámbito de intercambio económico.

5.4. Sin embargo, no se daban las condiciones del gran cambio social, económico y cultural de la segunda mitad del siglo XI y del XII, las cuales fueron las que determinaron el verdadero proceso de normalización de las lenguas románicas y la consolidación de los textos romances escritos. A partir de la segunda mitad del siglo XI, la reforma gregoriana (a través de la eficiente irradiación cluniacense) activó nuevamente el conflicto lingüístico anterior (excepto en el caso del francés y del occitano), donde la sustitución de los vernáculos por el latín medieval reformado se realizaba sin movilidad social objetiva. En dicho período se darían unas coordenadas de interferencia, cambio de código y calco entre estándar y vernáculos, y se desencadenaría una mayor sanción pública a la innovación del latín medieval reformado y la radicalización de la diferenciación linguística y social de las variedades implicadas. No obstante, el proceso de secularización de la cultura propiciada por la educación carolingia y la reforma gregoriana hizo de la escuela catedralicia y episcopal una institución urbana en los siglos bajomedievales.

Con la expansión de las actividades comerciales a finales del siglo XI y a lo largo del siglo XII, el crecimiento demográfico en las nuevas ciudades se produjo en amplias zonas de la cristiandad occidental (el llamado renacimiento del siglo XII), así como la propia actividad de las escuelas urbanas (donde tendrían mayor vigencia la argumentación racional). Y frente a la sustitución (y la aculturación) de los vernáculos se materializó un auténtico proceso complejo de normalización linguíística en el que las lenguas (romance y latín medieval reformado) y los hablantes se encontraban inmersos, con el desplazamiento paulatino del latín medieval reformado por los romances en la documentación escrita, al mismo tiempo que se reforzó su papel de lengua de la cultura y de la liturgia en el conjunto de la Europa occidental.

Dicha situación social, económica y cultural (solución última del conflicto lingǘstico) fue la condición general e histórica del verdadero desarrollo de la normativización de los primeros vernáculos románicos (francés, occitano, catalán, navarro, aragonés, italiano, leonés, castellano, gallego y portugués), y en 
particular de la propia consolidación general de la escritura romance. Particularmente, en occitano tenemos la primera introducción gramatical (siglo XIII, aunque aplicada a la composición poética) que se ha conservado de una lengua neolatina, Las rasós de trobar, obra del escritor catalán Vidal de Besalú. Sobre la situación específica y los primeros testimonios escritos del sardo, dalmático y rumano, véase Tagliavini (1949/1969: 686-96 y 708-28).

El crecimiento innovador en el campo de la cultura y del desarrollo intelectual, así como en otras facetas de la actividad humana y económica, fue el gran factor «externo» del cambio social que puso a la Edad Media en la senda de la modernidad. En suma, la historia social de las lenguas románicas se materializa así en nuevas propuestas verificables del presente, sobre una posible reconstrucción global de los hechos lingüísticos y sociales ocurridos en el proceso de formación de las lenguas romances.

5.5. El vernáculo castellano no surgió como proceso de criollización, sino como propio desenvolvimiento de la dinámica diferenciadora (temporal, geográfica, social y contextual, Meillet, 1929: 73-82) del romance, sobre todo, a partir de la primera mitad del siglo IX. El romance castellano surgía, pues, de un latín coloquial utilizado por los pueblos astures, cántabros y vascones, quienes durante mucho tiempo se habían opuesto a la lengua y cultura romanas, y no eran continuadores de la mejor tradición latina de la Península Ibérica. La normalización lingüística primera de los vernáculos hispánicos permitió la aparición de las primeras muestras léxicas románicas y los primeros textos románicos en los siglos IX, $\mathrm{x}$ y XI, de acuerdo con las prescripciones de Tours, junto a la conservación de la propia peculiaridad de la tradición hispano-visigótica.

Sin embargo, sería a finales del siglo XI y principios del siglo XII, cuando comienza a manifestarse claramente la auténtica normalización de los vernáculos hispánicos y la consolidación de la escritura romance, la cual respondía a las nuevas condiciones del gran cambio social, económico y cultural del renacimiento del siglo XII. Una buena prueba de dicho proceso se daría en las glosas romances emilianenses del códice Em. 60 de la RAH y en las glosas romances silenses del códice add. 30853 de la Biblioteca del Museo Británico. Las primeras datarían de la segunda mitad del siglo XI (a partir del año 1075), y las segundas deberían situarse en los últimos años del siglo XI (o en los comienzos del siglo XII), las cuales podrían responder a una reacción benedictina contra la renovación latina propiciada por la reforma cluniacense (favorecida por la Corona). En particular, el texto romance unitario de la plegaria (fol. 72r) del códice Em. 60 mostraría la competencia comunicativa del glosador para plasmar la gramática del vernáculo románico de su comunidad de habla, así como la diferenciación nítida de dos variedades 
lingüísticas diferentes (latín medieval reformado y romance) y su plena conciencia lingüística (Gimeno, 1995: 61-78; Díaz y Díaz, 2000; Hernández, 2000; Ruiz Asencio, 2000).

De ahí que en esta segunda etapa Menéndez Pidal (1926/1950: VII-VIII) encontró que «el latín de los diplomas estaba más desprovisto de romanismos interesantes [...] por la interposición de un siglo entero de latín escolástico depurado». Dicho cambio social va a originar no sólo la mayor innovación del latín foral, sino también -y sobre todo- la materialización de los textos escritos notariales y forales en romance, con el establecimiento general de la escritura romance (Fuero de Avilés, 1155) (Lapesa, 1948; Barrero y Alonso, 1989; Gimeno, 1995: 107-20).

En suma, planteamos los pormenores de dos normalizaciones lingüísticas (primera y segunda) correspondientes a las reacciones a dos reformas culturales (carolingia y gregoriana), en dos etapas distintas (protorromance y antigua), y la coherente ordenación cronológica de los sucesivos testimonios escritos, dentro de la historia social de los romances hispánicos.

Desde la sociolingüística histórica, es impensable que pueda justificarse en nuestros días la afirmación última de Bustos Tovar (2004 b: 304), acerca de que si las Glosas emilianenses y silenses se hubieran escrito en la segunda mitad del siglo $\mathrm{x}$ o a lo largo del siglo XI no cambiaría sustancialmente su valor histórico, como primer testimonio relevante del nacimiento de las lenguas romances peninsulares en la escritura. En efecto, cualquier texto responde a un determinado contexto social y cultural, ya que la lengua se materializa a partir de específicas situaciones sociales. En nuestro caso, la situación histórica de los reinos hispanocristianos en ambas etapas era completamente diferente, y las dinámicas sociales y contextuales del proceso de formación de los romances hispanos eran absolutamente dispares. A una primera de resistencia cristiana y de fragmentación hispana en los siglos vIII a X (años 711-1025), siguió una segunda de aparición de una nueva sociedad y de reanudación de los vínculos políticos y culturales europeos (años 1025-1212) (Gimeno, 1995: 95-106; García de Cortázar, 2004).

Por consiguiente, frente a una vieja historia de la lengua cada día más simplista y miope, reclamamos hoy más que nunca una revisión y superación de los prejuicios del pasado. Nuestra propuesta plantea una nueva historia social de la lengua, que tenga en cuenta no sólo las variedades temporales y geográficas de las lenguas, sino también las variedades sociales y contextuales de las mismas, y que preconice una reconstrucción global de la lengua, cultura y sociedad, desde un punto de vista de la antropología social y cultural. Han pasado cincuenta años desde que Weinreich (1953: 3-6) llamara la atención sobre la necesidad de completar las descripciones lingüísticas, con las coordenadas antropológicas y psicológicas del contexto sociocultural, y ya es hora de que tengamos en cuenta su enriquecedora sugerencia. 
5.6. Los primeros textos escritos en romance a mediados del siglo XI en la Península Ibérica, según Wright (1997: 477-9), seguirían el principio intrínsecamente fonográfico desarrollado en Francia: la morfología, la sintaxis y el vocabulario vernáculos podrían representarse en la escritura con una ortografía que usaba las correspondencias entre letra y sonido ya establecidas e inherentes a las nuevas pronunciaciones del latín medieval reformado, pero se usarían al revés, para producir nuevas ortografías de palabras que fueran diferentes de las ya existentes formas latinas estándares de las mismas unidades léxicas. Los primeros indicios de copistas (que intentarían escribir palabras con una nueva ortografía creada mediante la aplicación a los sonidos iberorrománicos locales de las correspondencias entre sonido y letra del francés) se pueden localizar en varias de las famosas glosas adjuntadas en el siglo XI a dos manuscritos de La Rioja. A pesar de ello, parece como si en el siglo XIr la mayoría de los centros culturales continuaran con el método anterior de técnicas locales parcialmente regularizadas tendentes a pulir palabras, morfemas y sonidos, sobre todo para textos legales.

La afloración del romance en la escritura no es sólo una cuestión de grado de cultura que diferencia a los textos del latín medieval no reformado, ni sólo de índole cultural la causa de las trasferencias entre el romance y el latín escrito, como ha opinado Frago (1998: 85) en los problemas lingüísticos y culturales del paso del romance a la escritura. Además, debemos cohonestar (a partir del canon 17 del Concilio de Tours) la historia social del desarrollo eclesiástico de una nueva conciencia linguística sobre la fijación escrita del romance (extendida a otros grupos sociales y a otras comunidades de habla) con la propia referencia general a la función social del latín medieval reformado. No obstante, no puede sostenerse a la vista de todo lo que hemos expuesto la afirmación de que:

La iglesia tenía una percepción muy distinta del valor de la lengua latina, así como medios humanos idóneos para que en ella se redactaran sus documentos de cualquier nivel estilístico, por lo cual en su seno se dieron las mayores resistencias a la adopción del vulgar (92).

\section{CONCLUSIONES}

El mecanismo de la evolución del latín medieval hacia el estadio romance y la interacción de los factores lingüísticos y sociales han estado lejos de ser puestos al descubierto en el pasado, y de ser descritos con la precisión y el rigor deseables. La formación de las diversas lenguas románicas (desde un mismo diasistema latino) cuestiona la simplificación de las hipótesis basadas solamente en los sistemas lingüísticos. Es más, en dicho proceso de formación no sólo está 
implicada la propia evolución interna del latín medieval no reformado, sino que también aparece envuelto el desplazamiento de los vernáculos protorromances por el latín medieval reformado, el cual era propiciado por la reforma carolingia.

Mientras que la trasformación «interna» del latín ha merecido la única atención de los investigadores, la sustitución de los vernáculos nunca hasta ahora ha sido motivo de investigación. En la medida en que hallamos un posterior desplazamiento paulatino del latín medieval reformado por los romances en la documentación escrita, la atención debe centrarse en los estudios de conservación y sustitución lingüísticas. Además, una investigación antropológica de la historia propone la deducción de dimensiones del pasado, y las comprueba empíricamente en el presente. Nuestra propuesta parte de una teoría sociolingüística del multilingüismo social, que ofrece una nueva alternativa, y conecta más íntimamente que en el pasado la lingüística histórica y la dialectología con las ciencias sociales.

6.1. El dilema del pasado inmediato que planteaba la cuestión del origen de las lenguas románicas entre los procesos de romanización y criollización puede resolverse en nuestros días, ya que las características lingüísticas e históricas de las variedades romances son completamente diferentes del basilecto criollo. Es más, la diglosia caracteriza un proceso relativamente estable, y nunca puede determinar la aparición de las lenguas romances.

La sociolingüística histórica ofrece propuestas verificables del presente para alumbrar hipotéticamente los procesos históricos del cambio lingüístico. Por otra parte, ya no sólo es fundamental en la caracterización de la situación social de la diglosia el uso condicionado o reglamentado de cada variedad con una función social diferente, sino también la estabilidad de la situación, junto a la movilidad social con el desplazamiento lingüístico correspondiente que facilita la enseñanza de la variedad alta (A).

De esta manera se contribuye a una mejor comprensión de las relaciones que se plantean entre la situación de diglosia amplia (relativamente estable con movilidad social) y el «conflicto linguístico» (sin movilidad social, dentro de una dinámica progresiva de sustitución lingüística). Asimismo, se precisa el concepto definido hace más de cuarenta años, y se enriquece esa tipología de las situaciones sociales, la cual conducirá hacia una teoría más global de las relaciones entre la lengua y la sociedad, y en particular a la comprensión y explicación de los problemas históricos de conservación y sustitución lingüísticas.

En nuestro caso, supone la revisión y la superación de las hipótesis de dialectología histórica y funcionalistas que han prevalecido durante todo el siglo pasado, así como la necesidad de actualizar las historias de la formación de las lenguas románicas. Frente a una diacronía autónoma de los diversos 
niveles lingüísticos (e incluso, de todos descriptivamente) de las lenguas románicas, debemos asumir en nuestros días una historia de las situaciones sociales y de las coordenadas de normalización o sustitución lingüística de las sucesivas generaciones de hablantes, dentro de las diversas comunidades de habla románicas.

6.2. Nuestra propuesta sobre las relaciones entre los factores lingüísticos y sociales implicados en el proceso de formación de las lenguas romances se ciñe, pues, a los siguientes apartados:

1. La formación de las lenguas románicas se encuentra en los procesos antiguos de diferenciación (temporal, geográfica, social y contextual) del latín medieval no reformado, sobre todo, a partir de la primera mitad del siglo viII en la Galia del norte.

2. Las glosas latinas y los glosarios latinos son las primeras muestras escritas y los testimonios histórico-lingüísticos más antiguos de las lenguas románicas. El análisis histórico y sociolinguístico de los glosarios altomedievales constituye uno de los más valiosos medios de conocimiento y reconstrucción de los procesos de formación de las lenguas romances, como primeras muestras escritas de la diferenciación temporal, geográfica, social y contextual del latín medieval no reformado.

3. Desde la primera mitad del siglo viII, el contexto social y cultural de la Galia y del Occidente románico corresponde a una situación general de diglosia románica (estricta en un principio, amplia posteriormente). La variedad normalizada sería el latín medieval (no reformado y reformado, posteriormente), usado como registro escrito y oral formal, y los romances serían las variedades orales familiares e informales. La enseñanza escolar del estándar facilitaría el desplazamiento del vernáculo correspondiente, junto a la movilidad social.

4. La reforma cultural de la corte carolingia no pudo hacer desaparecer nunca la diglosia anterior en Francia, los condados de la Marca Hispánica y el norte de Italia, ya que suponía sólo la revitalización y reforma del latín medieval, a finales del siglo viII. Y mucho menos se puede pensar que la reforma carolingia instauró la diglosia. Antes bien, dicha reforma activaba la diglosia amplia anterior, y provocaba un conflicto lingüístico con la sustitución de los vernáculos romances, sin movilidad social. Sólo la reacción pastoral (de dicha sustitución) impulsada por el Concilio de Tours (813) puede explicar la aparición de las primeras muestras romances escritas, desde la primera mitad del siglo IX, y la primera normalización lingüística de los vernáculos. La estrategia pastoral de implantación obligatoria del vernáculo en el 
ámbito de uso público no habría conocido fronteras geopolíticas, ni escalonamientos cronológicos.

5. La materialización escrita del romance no puede deberse sólo a la simple imitación de las lenguas celtas y germánicas vecinas, ya que las situaciones sociales de la fijación escrita de sus lenguas nacionales eran totalmente dispares. Más bien, la compatibilidad de exigencias contrarias por parte de los mismos gestores eclesiásticos determinó el proceso de materialización escrita de las lenguas romances, y la progresiva extensión de dicha actividad a distintos grupos sociales y a otras comunidades de habla del Occidente cristiano europeo. Los Serments de Strasbourg (842) son el texto escrito más antiguo de una lengua románica en francés.

6. A partir de la segunda mitad del siglo XI, la reforma gregoriana activó nuevamente el conflicto lingüístico anterior (excepto en el caso del francés y del occitano), donde la sustitución de los vernáculos por el latín medieval reformado se realizaba sin movilidad social objetiva. En dicho período se darían unas coordenadas de interferencia, cambio de código y calco entre estándar y vernáculos, y se desencadenaría una mayor sanción pública a la innovación del latín medieval reformado y la radicalización de la diferenciación lingüística y social de las variedades implicadas.

7. Con la expansión de las actividades comerciales a finales del siglo XI y a lo largo del siglo XII, el crecimiento demográfico en las nuevas ciudades se produjo en amplias zonas de la cristiandad occidental, así como la propia actividad de las escuelas urbanas. Y frente a la sustitución (y la aculturación) de los vernáculos se materializó un auténtico desarrollo complejo de normativización lingüística en el que las lenguas y los hablantes se encontraban inmersos, con el desplazamiento paulatino del latín medieval reformado por los romances en la documentación escrita, al mismo tiempo que se reforzó su papel de lengua de la cultura y de la liturgia en el conjunto de la Europa occidental.

8. Las condiciones del gran cambio social, económico y cultural del siglo XII fueron las que determinaron el verdadero proceso histórico de normalización lingüística de las primeras lenguas románicas y la propia consolidación general de la escritura romance. El crecimiento innovador en el campo de la cultura y del desarrollo intelectual, así como en otras facetas de la actividad humana y económica, fue el gran factor «externo» del cambio social que puso a la Edad Media en la senda de la modernidad. 


\section{REFERENCIAS BIBLIOGRÁFICAS}

Alarcos, E. (1982): El español, lengua milenaria (y otros escritos castellanos), Valladolid, Ámbito.

Alvar, M.; E. PotTier (1983): Morfología histórica del español, Madrid, Gredos.

BANNIARD, M. (1991): «Rhabanus Maurus and the vernacular languages», en WRIGHT, R. (ed.) (1991: 164-74).

- (1992): Viva voce: Communication écrite et communication orale du IVe au IXe siècle en Occident Latin, París, Institut des Études Augustiniennes.

BARRERo, A. M.; M. L. Alonso (1989): Textos de derecho local español en la Edad Media. Catálogo de fueros y costums municipales, Madrid, CSIC.

Blas ARroyo, J. L. (1991): «Problemas teóricos en el estudio de la interferencia lingüística», RSEL, 21, 2: 265-89.

Bustos Tovar, J. J. DE (2000): «El uso de glosarios y su interés para la historia de la lengua», en IGLESIA, J. I. (coord.) (2000: 329-55).

- (2004 a): «La escisión latín-romance. El nacimiento de las lenguas romances: el castellano», en CANO, R. (coord.) (2004: 257-90).

- (2004 b): «Las Glosas Emilianenses y Silenses», en CANO, R. (coord.) (2004: 291-307).

CANo, R. (coord.) (2004): Historia de la lengua española, Barcelona, Ariel.

Cierbide, R. (2003): «Comentarios lingüísticos al Becerro antiguo de Leire (siglos X-XII) y a la documentación del Priorato de Artajona (11001150)», en Perdiguero, H. (ed.), (2003: 13-23).

Corominas, J.; Pascual, J. A. (1980-1991): Diccionario crítico etimológico castellano e hispánico, 6 vols. Madrid, Gredos. Nueva ed. de J. Corominas, Diccionario crítico etimológico de la lengua castellana, 4 vols. Berna-Madrid, 1954-1957.

CRIADO DE VAL, M. (ed.) (2001): Los orígenes del español y los grandes textos medievales Mio Cid, Buen Amor y Celestina, Madrid, CSIC.

DiL, A. S. (ed.) (1972): Language in sociocultural change. Essays by J. A. Fishman, Stanford, Calif., Stanford University Press.

DíAZ Y DÍAZ, M. C. (1979): Libros y librerías en la Rioja altomedieval, Logroño, Diputación Provincial.

- (1981): «El cultivo del latín en el siglo X», $A E F$, IV: 71-81.

- (2000): «A vueltas con las glosas», Actas del Congreso Internacional «El Cid, poema e historia», Burgos, Ayuntamiento de Burgos, 293-5.

Ferguson, C. A. (1959): «Diglossia», Word, 15: 325-40.

FERnández CÁTón, J. M. (coord.) (2003): Documentos selectos para el estudio de los orígenes del romance en el Reino de León. Siglos X-XII, edn. facsímil, León, Fundación Monteleón. 
Fernández Flórez, J. A.; M. Herrero de la Fuente (2002): «El códice albeldense (o vigilano) de la Biblioteca del Real Monasterio de El Escorial, Ms. D.I.2.», en GARCíA TURZA, C. (coord.) (2002: 117-73).

Fishman, J. A. (1967): «Bilingualism with and without diglossia; diglossia with and without bilingualism», Journal of Social Issues, 23, 2: 29-38. Rev. «Societal bilingualism: Stable and transitional», en DIL, A. S. (ed.) (1972: 135-52).

- (1971): «The sociology of language: An interdisciplinary social science approach to language in society», en FisHMAN, J. A. (ed.) (1971), I: 217-404.

- (ed.) (1971): Advances in the sociology of language, 2 vols., La Haya, Mouton.

FRAGO, J. A. (1998): «El paso del romance a la escritura: problemas culturales y lingüísticos», en XXIV Semana de Estudios Medievales de Estella. Renovación intelectual del Occidente europeo (siglo XII), Pamplona, Gobierno de Navarra. 63-98.

García de Cortázar, J. A. (1969): El dominio del monasterio de San Millán de la Cogolla (siglos X a XIII). Introducción a la historia rural de Castilla altomedieval, Salamanca, Universidad de Salamanca.

- (2004): «Resistencia frente al Islam, reconquista y repoblación en los reinos cristianos (años 711-1212)», en CANO, R. (coord.) (2004: 239-56).

García Turza, C. (2000): «Notas sobre los glosarios latinos de Hispania», Actas del Congreso Internacional "El Cid, poema e historia», Burgos, Ayuntamiento de Burgos. 297-302.

- (2003): Las glosas del códice albeldense (Biblioteca del Real Monasterio de El Escorial, Ms. D.I.2.). Edición y estudio, Logroño, Fundación San Millán de la Cogolla.

- (coord.) (2002): Los manuscritos visigóticos: estudio paleográfico y codicológico. I. Códices riojanos datados, Logroño, Fundación San Millán de la Cogolla.

- ; García Turza, J. (1997): Fuentes españolas altomedievales. El códice emilianense 46 de la Real Academia de la Historia, primer diccionario enciclopédico de la Península Ibérica. Ed. y estudio de..., Logroño, RAH y Fundación Caja Rioja.

— ; García Turza, J. (2000): «El glosario latino del códice emilianense 24 de la Real Academia de la Historia», en Investigación humanística y científica en La Rioja. Homenaje a Julio Luis Fernández Sevilla y Mayela Balmaseda Aróspide, Logroño, IER. 107-35.

- ; García Turza, J. (2001): «La datación y la procedencia de las glosas emilianenses y silenses: anotaciones críticas a los nuevos planteamientos», en CRIAdo De VAL, M. (ed.) (2001: 33-47). 
- García Turza, J. (2002): «El códice emilianense 46 de la Real Academia de la Historia», en García Turza, C. (coord.) (2002: 77-115).

GARCÍA TURZA, J. (2000): «La transmisión cultural hispana y el Renacimiento Carolingio», en IIGLESIA, J. I. (coord.) (2000: 17-38).

Garvin, P. L.; Y. Lastra (eds.) (1974): Antología de estudios de etnolingüística y sociolingüística. México, UNAM.

GIMENO, F. (1981): «Dimensiones del multilingüismo», RSEL, 11, 2: 341-73.

- (1984 a): «Multilingüismo y multilectismo», ELUA, 2: 61-89.

- (1984 b): «El sustrato lingǘrstico y el seseo valenciano de la comunidad de habla alicantina», en Miscel.lània Sanchis Guarner, Barcelona, Abadia de Montserrat, 1992. II: 161-84.

- (1986): «Sustitución lingüística en las comunidades de habla alicantinas», ELUA, 3 (1985-1986): 237-67.

- (1987): «A propósito de comunidad de habla: "The social dimension of dialectology" de J. P. Rona» Actas del I Congreso Internacional del Español de América (San Juan de Puerto Rico, 1984), Madrid, APLE, 689-98.

- (1990): Dialectología y sociolingüística españolas, $2^{\mathrm{a}}$ ed., Alicante, Universidad de Alicante, 1993.

- (1995): Sociolingüística histórica (siglos X-XII), Madrid, Visor Libros.

- (1998): «La sustitución lingüística de las lenguas prerromanas por el latín», Actas del IV Congreso Internacional de Historia de la Lengua Española. Logroño, Universidad de La Rioja, II: 475-83.

- (2000): «Evolución social de las lenguas en la Comunidad Valenciana», en Lengua y discurso. Estudios dedicados al Prof. Vidal Lamíquiz, Madrid, Arco/Libros. 399-406.

- (2003 a): «Historia de la dialectología y sociolingüística españolas», en Con Alonso Zamora Vicente (Actas del Congreso Internacional «La lengua, la Academia, lo popular, los clásicos, los contemporáneos...»), Alicante, Universidad de Alicante, I: 67-84.

- (2003 b): «Gramática y variación en el origen del acusativo preposicional», en Lengua, variación y contexto. Estudios dedicados a Humberto López Morales, Madrid, Arco/Libros, II: 625-37.

- (2004), «Situaciones sociolingüísticas dispares en el proceso de formación de las lenguas romances», Aemilianense. Revista Internacional sobre la génesis y los orígenes históricos de las lenguas romances, 1: 171-223.

- (en prensa 1 ), «A propósito de lengua y dialecto: el estándar», AFA (Homenaje al Prof. Manuel Alvar).

- ; M. V. Gimeno (2003): El desplazamiento lingüístico del español por el inglés. Madrid, Cátedra.

GoebL, H. et al. (eds.) (1996/1997): Contact linguistics. An international handbook of contemporary research, 2 vols. Berlín, Walter de Gruyter. 
GonZÁLEZ OlLÉ, F. (2004): «Observaciones filológicas al códice emilianense 46 (Glosario Turza), con algunas de sus aportaciones a la historia lingüística española», en LÚDTKE, J.; C. SCHMITT (eds.): Historia del léxico español. Enfoques y aplicaciones. Homenaje a Bodo Mïller, Madrid, Iberoamericana. 13-37.

HAugen, E. (1966): Language conflict and language planning: The case of modern Norwegian, Cambridge/Mass., Harvard University Press.

Herman, J. (1975/1997): El latín vulgar. Barcelona, Ariel.

HERNÁNDEZ, C. (2000): «Glosas y glosarios ¿Consultaron un vocabulario los autores de las emilianenses y silenses?», Actas del Congreso Internacional «El Cid, poema e historia», Burgos, Ayuntamiento de Burgos. 303-7.

- (2003): «A vueltas con el origen del castellano», en Perdiguero, H. (ed.), (2003: 139-45).

Hudson, A. (1992): «Diglossia: A bibliography review», Language in Society, 21: 611-74.

- (2002 a): «Outline of a theory of diglossia», IJSL, 157: 1-48.

- (2002 b): «Diglossia, bilingualism, and history: Postscript to a theoretical discussion», IJSL, 157: 151-66.

Hymes, D. (1964): «Hacia etnografías de la comunicación», en GARVIN, P. L.; Y. LASTRA (eds.) (1974: 48-89).

- (1971): «On communicative competence», en PRIDE, J. B.; J. Holmes (eds.) (1972: 269-93).

Iglesia Duarte, J. I. (coord.) (2000): La enseñanza en la Edad Media, Logroño, Instituto de Estudios Riojanos.

KremnitZ, G. (1990): Multilingüisme social. Aspectes institucionals, socials $i$ individuals, Barcelona, Edicions 62.

LAPESA, R. (1948): «Asturiano y provenzal en el Fuero de Avilés», en Estudios de historia lingüistica española, Madrid, Paraninfo, 1984: 53-122.

- (2000): Estudios de morfosintaxis histórica del español. Ed. de R. CANo y M. T. ECHENIQUE, Madrid, Gredos.

- et al. (2003): Léxico hispánico primitivo (siglos VIII al XII). Versión primera del Glosario del primitivo léxico iberorrománico. Proyect. y dirig. inicialm. por R. MENÉNDEZ PIDAL, redact. por R. LAPESA y con la colab. de C. García, ed. de M. SECo, Madrid, Espasa Calpe.

LAUSBERG, H. (1956/1962): Linguiíística románica. Reimp., 2 vols. Madrid, Gredos, 1970/ 1973.

LÖFSTEDT, E. (1959): Il latino tardo. Aspetti e problemi, Brescia, Paideia, 1980.

LÓPEZ GARCÍA, A. (2000): Cómo surgió el español. Introducción a la sintaxis histórica del español antiguo, Madrid, Gredos.

LóPEZ Morales, H. (1989): Sociolingüística, $3^{\mathrm{a}}$ ed., Madrid, Gredos, 2004. 
- (1994): «La investigación dialectal sincrónica en Hispanoamérica: presente y futuro», Actas del Congreso de la Lengua Española, Madrid, Instituto Cervantes. 767-87.

- (en prensa): «Sociolingüística histórica», Actas del VI Congreso Internacional de Historia de la Lengua Española, Madrid.

LÜDTKE, H. (1968): Historia del léxico románico, Madrid, Gredos, 1974.

- (1996 a): «Changement linguistique», en GoEBL, H. et al. (eds.) (1996/1997), I: 526-40.

- (1996 b): «Entre llatí i romànic: amb especial consideració del català», Actes del X Col.loqui Internacional de Llengua i Literatura Catalanes, Barcelona, Abadia de Montserrat, III: 57-67.

- (1996c): «Rectificaciones acerca de la posición histórica del español en el marco románico», en MARTínEz, A. (ed.) (1996: 49-67).

- (1998): El cambio linguiístico, Barcelona, UAB.

MARTín, J. C. (2002): La Renotatio librorum Domini Isidori de Braulio de Zaragoza (muerto en el 651). Introducción, edición crítica y traducción, Logroño, Fundación San Millán de la Cogolla.

Martínez, A. (ed.) (1996): Estudios de filología hispánica (Estudios linguiisticos y literarios), Granada.

MEILLET, A. (1921-1936): Linguistique historique et linguistique générale, $2^{\mathrm{a}}$ edn., 2 vols, París, Klincksieck, 1951.

- (1929): «Le développement des langues», en MEILLET, A. (1921-1936), II: $70-83$.

MeIsel, J. M. (ed.) (1977): Langues en contact - pidgins - creoles, Tübingen, G. Narr.

MenÉndez Pidal, R. (1926/1950): Orígenes del español. Estado lingüístico de la Península Ibérica hasta el siglo XI, $8^{\mathrm{a}}$ ed., Madrid, Espasa-Calpe, 1976.

Metzeltin, M. (2004): Las lenguas románicas estándar. Historia de su formación y de su uso, Uviéu, Academia de la Llingua Asturiana.

MOLLÀ, D.; L. AlPERA; F. GIMENo et al. (1989): Enquesta sociolingüística al País Valencià, 1985, 4 vols., microf. Alicante, Universidad de Alicante.

MONTOYA, B.; F. Grmeno (1995): «Status quaestionis: sociolingüística catalana», Lingiuística, 7: 87-138.

Moxó, S. DE (1979): Repoblación y sociedad en la España cristiana medieval, Madrid, Rialp.

Penny, R. (1991): Gramática histórica del español, Barcelona, Ariel, 1993.

- (2000): Variación y cambio en español, Madrid, Gredos, 2004.

Perdiguero, H. (ed.) (2003): Lengua romance en textos latinos de la Edad Media. Sobre los orígenes del castellano escrito, Burgos, Universidad de Burgos. 
PRIDE, J. B.; J. Holmes (eds.) (1972): Sociolinguistics. Selected readings, Harmondsworth, Penguin.

Ruiz Asencio, J. M. (2000): «Puntualizaciones sobre las glosas», Actas del Congreso Internacional «El Cid, poema e historia», Burgos, Ayuntamiento de Burgos. 309-11.

SCHLIEBEn-LANGe, B. (1977): «L'origine des langues romanes - Un cas de créolisation?», en Mersel, J. M. (ed.) (1977: 81-101).

TAGLIAVINI, C. (1949/1969): Orígenes de las lenguas neolatinas. Introducción a la filología romance, $5^{\text {a }}$ ed. México, Fondo de Cultura Económica, 1973.

Terracini, B. (1951): "Cómo muere una lengua», en Conflictos de lenguas y de cultura, Buenos Aires, Imán. 11-42.

VÀrvaro, A. (1972-1973): «Storia della lingua: passato e prospettive di una categoria controversa», I ( $R P h, 26,1: 16-51)$ y II $(R P h, 26,3: 509-31)$.

- (1978): «Come muore una lengua», en La lengua e la società. Le ricerche sociolinguistiche. Nápoles, Guida Editori. 101-13.

VELÁzQueZ, I. (2003): Latine dicitvr, vvlgo vocant. Aspectos de la lengua escrita y hablada en las obras gramaticales de Isidoro de Sevilla. Logroño, Fundación San Millán de la Cogolla.

VIDOs, B. E. (1956): Manual de linguiística románica, Madrid, Aguilar, 1973.

Vivancos, N. C. (2000): «De nuevo sobre la cronología de las glosas silenses», Actas del Congreso Internacional «El Cid, poema e historia». Burgos, Ayuntamiento de Burgos. 313-6.

WARTBURG, W. vON (1950): La fragmentación lingüística de la Romania, $2^{\mathrm{a}}$ ed., Madrid, Gredos, 1971.

WeINREICH, U. (1953): Languages in contact. Findings and problems, $7^{\mathrm{a}}$ ed., La Haya, Mouton, 1970.

WolfF, P. (1971): Origen de las lenguas occidentales, 100-1500 d. C., Madrid, Guadarrama.

WRIGHT, R. (1982): Latín tardio y romance temprano en España y la Francia carolingia, Madrid, Gredos, 1989.

- (1997): «La normalización lingüística en la Península Ibérica durante la Edad Media: ventajas e inconvenientes», Moenia, 3: 471-87.

- (2002): «Léxico romance en los glosarios de San Millán», Actas del V Congreso Internacional de Historia de la Lengua Española, Madrid, Gredos, II: 2421-6.

- (ed.) (1991): Latin and the Romance Languages in the Early Middle Ages, Londres, Routledge. 


\title{
EL ESTUDIO \\ DE LA VARIACIÓN SINTÁCTICA: \\ PRECISIONES METODOLÓGICAS
}

\author{
Humberto López Morales \\ Universidad de Puerto Rico, Río Piedras \\ Asociación de Academias de la Lengua Española, Madrid
}

\section{INTRODUCCIÓN}

PESAR de lo importante que resultan los aspectos metodológicos en el estudio
de la variación sintáctica, con excepción de Sankoff $(1988 a, 1988 b)$ y Silva Corvalán (1997), que han estudiado este asunto de manera monográfica, estas observaciones se encuentran -cuando se encuentran- desperdigadas en páginas que apuntan hacia otros contenidos. A pesar de estos valiosos intentos, en la actualidad todavía permanecen interrogantes de mucho peso.

La variación sintáctica ha sido un tema discutido desde el momento mismo en que G. Sankoff (1972) trató de demostrar que la variación ocurría también, además de la fonológica, en otros niveles de lengua. Apoyada en los resultados de su análisis sobre la marca de futuro en tok pisin, en la elisión del complementador que (Sankoff, Sarrasin y Cedergren, 1971) y en la variación del indefinido on con tu/vous (Laberge, 1977) en el francés canadiense, la autora concluía que la extensión del análisis variacionista más allá de las fronteras de la fonología no era un salto conceptualmente difícil. Lo que servía de pauta para estos análisis era el «paralelismo semántico», pues el concepto original de variación presuponía que dos o más oraciones, diferentes en su estructura formal, significaran exactamente lo mismo.'

Los problemas a los que se enfrentaba la propuesta de G. Sankoff eran que en la sintaxis, 1) los casos de variación no eran tan frecuentes en el discurso, ${ }^{2}$

1. Es verdad que en nuestros días el acercamiento a la variación sintáctica posee otras alternativas. Weiner y Labov (1983: 35) propusieron que «no había razón para confinar el estudio de la variación a formas altemativas de 'decir lo mismo'», y aunque aún no estaban resueltos del todo algunos problemas metodológicos, "sería posible obtener igual beneficio estudiando los casos en que una misma forma era usada con diferentes significados». Sin embargo, sobre esta otra posibilidad, de momento, solo disponemos de ideas interesantes pero muy poco desarrolladas.

2. Con el agravante de con casillas vacías o con cifras muy bajas en ellas dejan de funcionar adecuadamente algunos programa informáticos y en consecuencia el aparato estadístico de la investigación 
2) los contextos de la variación sintáctica presentaban dificultades para ser identificados y definidos adecuadamente, y 3 ) el más importante de todos, que la sintaxis no era un componente independiente, sino que, por el contrario, debía contar -por lo menos-con la semántica.

Tras esta propuesta - como es sabido- surgieron preocupaciones muy diversas. Por una parte se dudaba de que sin una teoría bien organizada de los significados se pudiera extender el examen cuantitativo de la variación a la sintaxis (Lavandera, 1978); por otra, se aceptaba la existencia de la variación, pero -en ciertos casos- limitada solo a contextos determinados (aunque estos fueran mayoritarios), situación que llevaba de inmediato a la necesidad de especificar o reducir el concepto de 'significado' (Lavandera, 1978; Weiner y Labov, 1983; Sankoff, $1988 a$, 1988 b; Silva Corvalán, 2001).

Pero, además, surgieron otras propuestas, nacidas de la multiplicidad de criterios existentes para satisfacer la afirmación de que con la variación sintáctica el hablante dispone de maneras diferentes de 'decir lo mismo' (López Morales, 1990: 82-83 y n. 14; Silva Corvalán, 1997). Para los que piensan que este 'decir lo mismo' es un asunto exclusivamente semántico, basta con que las oraciones cumplan con el requisito de ser sinónimos referenciales y de tener el mismo valor de verdad. Sin embargo, son varios los investigadores que creen que para que se entienda que el hablante 'dice lo mismo' no bastan estos criterios (Jacobson, 1989; Lefebvre, 1989), sino que debe haber también paralelos en las estructuras pragmática e informativa de las oraciones. Es evidente que el aspecto puramente semántico, aunque garantiza la sinonimia, no contempla, entre otras cosas, ni la intención comunicativa del hablante ni su deseo de informar sobre algo en particular (Silvertein, 1976; Bolinger, 1977; Thibault, 1980; Romaine, 1981 a y sobre todo 1984).

Una postura más radical es la de aquéllos que niegan tajantemente la posibilidad de que la variación sintáctica exista, puesto que parten de la base de que todo cambio formal en una oración, no importa lo reducido del mismo, implica forzosamente un cambio de significado semántico y, a veces, también pragmático (García, 1985, 1986). ${ }^{3}$ No faltaron los que pensaban que la noción misma de variación sintáctica era confusa (Deulofeu, 1992) y que los postulados labovianos necesitaban de un cambio completo de perspectiva.

3. El asunto se torna más drástico aún si ha de aceptarse lo señalado por la semántica cognoscitiva de que aun tratándose de la misma oración (exactamente la misma), si esta aparece en dos lugares diferentes del mismo discurso, como es forzoso, ya no significan lo mismo. 
Pero sea cual sea la postura teórica adoptada, el análisis de los datos manejados en cualquier investigación de variación sintáctica presenta problemas metodológicos, puesto que es necesario demostrar que las oraciones examinadas significan o no significan lo mismo desde el punto de vista semántico, pragmático e informativo. La preocupación que asalta de inmediato es saber cómo se lleva acabo esta tarea.

\section{LA INTROSPECCIÓN}

Algunos autores, herederos indirectos de la tradición chomskiana, acuden preferentemente a la introspección de su competencia lingüística para 'demostrar' la (in)existencia de variación sintáctica. Es el caso, por ejemplo, de García (1986) en su análisis de ciertas estructuras 'dequeístas' en varios dialectos americanos del español.

La autora rechaza de plano que el (de)queísmo sea solo cuestión de régimen, fenómeno arbitrario aunque obligado por la selección verbal, sino que la alternancia de/ $\emptyset$ obedece a una diferencia de significado: cuando aparece de, la relación entre el sujeto y lo que sigue a de «es siempre menos segura, más parcial, menos directa, que en los casos en que falta de».

Es evidente que el fenómeno descansa en la función sintácticosemántica de juntar constituyentes: para ello podemos recurrir bien a de bien a $\varnothing$, pero si lo hacemos directamente ( $\sin d e$ ) no se especifica la relación que existe entre ellos. Teniendo en cuenta la presión a la que está sometido el hablante en su actuación oral, es posible que la imprecisión nexual de $\varnothing$ afecte también a la de de. De todos modos, contrastada con otras preposiciones, ya de es muy imprecisa semánticamente. Si ello ocurre, el omitir de no conlleva un gran riesgo de malentendido, ya que la presencia de que señala que dos constituyentes han sido combinados. Si de puede omitirse con tanta facilidad, es la forma ideal para juntar dos partes de forma tan poco explícita como lo hace $\varnothing$, aunque no de modo tan directo: la autora afirma que de permite unir «a distancia»; las partes quedan ligadas, pero no yuxtapuestas.

Los contrastes señalados sugieren que «cuando (canónicamente) la cláusula va introducida por de su relación con el verbo es menos total, más inmediata, que en los casos en que de no aparece: una cláusula (des)vinculada por de puede verse -y usarse-como expresión del -subraya la autora- distanciamiento del hablante que no quiere comprometerse totalmente con el contenido de la cláusula» (García, 1986: 64). La conclusión que se desprende de estas premisas es que las construcciones con de, sean 
canónicas o no (el llamado propiamente dequeísmo) ${ }^{4}$ tienen un significado semántico y pragmático diferente, el de distanciamiento y escaso compromiso, tanto en la 'norma' como fuera de ella, sobre todo en Caracas y en Buenos Aires.

García llama la atención sobre los siguientes ejemplos canónicos:

1. Pedro necesita $\emptyset$ que le presten dinero.

2. Pedro tiene necesidad de que le presten dinero.

Tras las premisas anteriores, las oraciones (1) y (2) no son sinónimas, describen aproximadamente la misma situación en el mundo real (son paralelos referenciales) pero difieren en el enfoque; en el primer caso la cláusula funciona como complemento directo del verbo. en el segundo, como complemento de un nombre. Como en el verbo se cifra la referencia al sujeto, la conexión entre este y la cláusula es más íntima y directa aquí que en los otros casos. La necesidad de Pedro se siente más directa y urgente en (1) que en (2). La oposición se da, pues, entre [verbo] [cláusula] frente a [verbo + sustantivo] de [cláusula].

La autora trabaja con los textos de la 'norma culta' de Caracas, Santiago de Chile y Buenos Aires (basada en los respectivos corpora publicados), pero no le fue posible analizar todos los casos, en especial en lo que a contextos se refiere, circunstancia importante porque su hipótesis descansa en el hecho de que las dos alternativas semánticas posibles $($ de/ $\varnothing)$ deberán preferirse en «diferentes tipos de contexto». Pero al tratarse de un análisis muy parcial no le es posible asentar sus interpretaciones en una sólida base distributiva, por lo que el componente hermeneútico de su investigación cobra una magnitud excepcional, acercándola peligrosamente a cierto subjetivismo introspectivo, imposible de verificar empíricamente. Queda claro que si la elección de una forma (de) u otra $(\varnothing)$ por parte del hablante reflejara su deseo de decir cosas diferentes o de mostrar diferentes intenciones comunicativas, como se pretende, esta pretensión empezaría a adquirir cierto aire de realidad si se descubriesen patrones de distribución complementaria en los contextos.

Desde el punto de vista estrictamente sociolingüístico esta propuesta constituye una auténtica preocupación. El dequeísmo caraqueño (Bentivoglio y D'Introno, 1977: 63) aparece entusiastamente patrocinado por el estrato sociocultural medio $(53.1 \%)$, pero no tanto por el alto $(29.7 \%)$ ni por el bajo

4. La autora comienza su trabajo analizando casos de dequeísmo canónico (por ejemplo, «tengo miedo de que venga»), y explicando las diferencias que cree percibir entre estos y las estructuras sin de («temo que venga»), tanto semánticas como de intencionalidad comunicativa del hablante, para después extender estos razonamientos a las formas censuradas. La moraleja es que el dequeísmo es absolutamente necesario, pues este conlleva una importante diferencia semántica, a la que los hablantes no quieren renunciar. No hay razón para su estigmatización. 
(17\%); de verificarse la propuesta de García, los hablantes de nivel medio estarían manejando un recurso lingüístico con implicaciones cognoscitivas, ausente o presente (pero no con la misma frecuencia) en otros sujetos, los que, naturalmente, no serían capaces de percibir tales diferenciaciones. Al no existir esta forma de expresar tal contraste semántico, los hablantes acudirían a otro recurso (u otros), quizás más explícito, a la hora de actuar lingüísticamente, pero este que se propone pasaría inadvertido en la comprensión o quizás interpretado de forma distinta al significado supuesto. La comunicación quedaría maltrecha. ${ }^{5}$

Este trabajo (García, 1986), y otros de parecida índole, se apoyan en consideraciones subjetivas: cuando se afirma que la oración $\mathrm{X}$ y la oración $\mathrm{Y}$ significan (semántica o pragmáticamente) cosas diferentes, el criterio manejado para emitir el veredicto ha sido, bien la introspección, el escudriñar en la competencia lingüística de un hablante determinado, bien el deseo expreso de ser coherente con unos principios teóricos dados. Resulta (cuando menos) curioso comprobar que estos trabajos carecen de base empírica que corrobore la postura asumida, mucho más si se tiene en cuenta que, aunque la variación sintáctica per se no es asunto de naturaleza sociolingüística, ha sido en el seno de esta disciplina donde se han desarrollado las principales discusiones.

\section{EL ANÁLISIS DE CONTEXTOS}

Una opción más atinada para intentar demostrar que dos o más oraciones, diferenciadas en su forma, pueden tener diversos significados semánticos, pragmáticos o informativos, es el examen de los contextos.

Silva Corvalán (2001: 134-135), que distingue dos niveles de significación: el referencial o lógico, independiente del contexto, invariable, y el semántico-discursivo o pragmático, (posiblemente) variable según el contexto, propone descubrir este segundo significado acudiendo al análisis contextual. Si este examen dejara en claro que solo existe sinonimia lógica

5. Los modernos estudios sobre el dequeísmo comienzan en 1977 , con un cuidadoso trabajo de Rabanales. A partir de aquí la bibliografía se ha venido enriqueciendo paulatinamente, pero solo García (1986) y parcialmente Mollica (1991), basado en el portugués de Brasil, mantienen esta interpretación. Bentivoglio (1976, 1980-1981), Quilis (1986), Gómez Molina y Gómez Devis (1995), y Schwenter (1999), aunque con matices, piensan en un fenómeno de ultracorrección. Scherre y Naro (1991) anotan que la presencia de de que, en el portugués brasileño, aumenta su frecuencia cuando aparece de en un contexto anterior, y Martínez Sequeira (2000, apud Silva Corvalán, 2001: 187) sugiere que, en Costa Rica, de funciona como marcador de información focal. 
entre las oraciones que se estudian, estaríamos ante formas distintas de 'decir lo mismo'. Si, por el contrario, tuviera cada una de ellas un significado pragmático específico, no serían auténticas variantes, pues los hablantes las utilizarían para propósitos comunicativos diferentes.

En su estudio sobre la duplicación de clíticos 'acusativos' en Santiago de Chile

3. Libros no quiero / No quiero libros.

4. Libros no los quiero.

la investigadora, tras un fino análisis contextual, encuentra que son los factores [determinante] y [definido] con sus valores positivo y negativo los que favorecen la copia.

$\begin{array}{lc} & \% \text { copias } \\ \text { [- determinante, - definido] } & 13 \\ \text { [+ determinante, - definido] } & 43 \\ \text { [- determinante, + definido] } & 84 \\ \text { [+ determinante, + definido] } & 95\end{array}$

Si los contextos se traducen en [- determinante, - definido] las copias solo alcanzan el $13 \%$; si son clasificables como [+ determinante, - definido], el $43 \%$; si lo son como [- determinante, + definido], el $84 \%$ y, por último, si la traducción contextual es $[+$ determinante,+ definido], el 95\%. Parece quedar claro que son los valores positivos de estos rasgos los que covarían con la duplicación clítica.

Este resultado podría indicar que entre uno y otro tipo de oración existen diferencias pragmáticas, puesto que las oraciones con duplicación de clíticos conllevan necesariamente procesos de topicalización. Si a pesar de ello se descubriera que son paralelos semánticos, entonces el factor topicalidad y su representación sintáctica serían irrelevantes (no portarían ningún significado pragmático) o, en todo caso, de haber diferencias en algunos casos, habrían quedado neutralizados en el discurso de estos hablantes.

Los estudios de Sedano (1994) y de Troya (1998) sobre las formas de expresión de la futuridad: ir a + infinitivo y la paradigmática en -ré también podrán servirnos de ejemplo. Sabido es que para algunos investigadores ambos casos constituyen «formas diversas de decir lo mismo»; para otros, en cambio, conllevan diferencias de significado. Una de las hipótesis que se han presentado con respecto a la distinción semántica de estas posibilidades es que las perífrasis indican «futuridad segura», mientras que las formas en -ré significan «futuridad incierta». 
Sedano intenta corroborar empíricamente esta hipótesis analizando ambas estructuras en el español de Caracas. Escogió de su corpus solo aquellos casos de perífrasis y de formas en -ré, que estuviesen acompañados por expresiones como 'estar seguro', 'saber' y, también, por las opuestas 'no estar seguro', 'no saber'.

$$
\text { estar seguro, saber no estar aseguro, no saber }
$$

$\begin{array}{lll}\text { ir a }+ \text { infinitivo } & 12 & 2 \\ \text { futuro en }- \text { ré } & 0 & 8\end{array}$

Su intención era estudiar el tipo de covariación que producían ambos conjuntos de datos. Los casos que cumplían con este requisito de contextualidad fueron 22:12 con 'estar seguro', 'saber', y 10 de los contrarios. El resultado fue de gran interés: los 12 casos de 'estar seguro', 'saber' aparecían con ir a + infinitivo, es decir, el $100 \%$, aunque en realidad se trataba de pocos ejemplos; en los de 'no estar seguro', 'no saber', 8 iban acompañados de formas en -ré, y 2 , de perífrasis. Aunque no se trataba de una distribución absolutamente complementaria, se encontraba muy cerca de serlo.

Troya, por su parte, vuelve sobre el asunto, en este caso estudiando el español de Las Palmas de Gran Canaria. Su metodología es aquí réplica de la de Sedano, lo que fácilmente nos permite establecer comparaciones.

$$
\text { estar seguro, saber no estar aseguro, no saber }
$$

$\begin{array}{lll}\text { ir a }+ \text { infinitivo } & 7 & 4 \\ \text { futuro en -ré } & 0 & 4\end{array}$

En sus materiales, poco abundantes también -15 ejemplos-, los siete casos de 'estar seguro', 'saber' llevaban perífrasis, pero de los ocho opuestos, 4 estaban acompañados de formas en -ré y otros 4 eran de ir $a+$ infinitivo. Es decir, que mientras el $100 \%$ de los ejemplos de 'futuridad segura' estaban unidos a la perífrasis, en los de 'futuridad no segura', los casos estaban divididos en el $50 \%$. Es innegable que ante estos resultados no es posible concluir que cuando el hablante selecciona la perífrasis es que quiere mostrar una futuridad segura, ni viceversa. La alternancia se comporta con libertad, pues ambas formas comparten los mismos contextos en la mitad de las ocasiones.

Por otra parte, también se había pensado en que ir a +infinitivo conllevaba el significado de 'futuridad cercana', y la forma sincrética, 'futuridad distanciada'. Es verdad que ya antes algunos investigadores (Moreno de Alba, 
1985) habían declarado que era muy difícil establecer si el hablante usaba la forma en -ré para acciones mediatas y la perífrasis para acciones inmediatas; en el español culto de la ciudad de México, las dos formas se usaban indistintamente, en distribución libre; luego eran diferentes formas de decir 'lo mismo'.

Troya vuelve sobre este tema en su investigación canaria, y siguiendo de cerca la posición de de Jonge $(1991,1998)$ sobre la clasificación de los adverbios temporales, establece un análisis de covariación entre ambas formas de futuridad y lo que de Jonge llama adverbios temporales 'de presente' (ahora, hoy, esta noche, etc.).

adv. de presente

$\begin{array}{lcc} & \% & \% \\ \text { ir a + infinitivo } & 69.2 & 43 \\ \text { futuro en -ré } & 30.8 & 57\end{array}$

Si se tratara de una distribución complementaria, prueba importante (pero no definitiva) para demostrar que las perífrasis hacían referencia a una futuridad cercana, la diferencia semántica entre estas y los futuros paradigmáticos empezaría a tener apoyo empírico. Pero acompañando a los adverbios temporales de presente aparecían ambas formas: ir $a+$ infinitivo en unos dos tercios de las ocasiones, y el futuro sincrético, en un tercio de ellas. Todo lo más que pudiera afirmarse aquí es que existe una cuestión de preferencias contextuales, pero nada que indique efectivamente que la perífrasis conlleve el significado de futuridad cercana, opuesto este al de futuridad distanciada, que sería propio de las formas paradigmáticas. ${ }^{6}$

La investigación de la lingüista canaria que comento se adentra en otros análisis de covariación: con las personas gramaticales, el tipo de verbo y el tipo de oración, y en todos esos casos llega a la misma conclusión a la que habían llegado otros (Moreno de Alba, 1977; Gómez Manzano, 1988): relaciones estadísticas laxas, casuales y fortuitas. Es decir, formas diferentes de 'decir lo mismo'

6. Blas Arroyo (2000) ha estudiado también la expresión de futuridad, pero en textos literarios españoles. Tras un análisis muy fino y pormenorizado concluye -en línea con lo argumentado por Poplack y Turpin (1999)- que la expresión de futuro verbal se manifiesta en su corpus como variantes de una misma expresión lingüística; ninguna de ellas es privativa de contexto alguno, por lo tanto, son formas distintas de 'decir lo mismo'. Su corpus estuvo integrado por tres obras de Buero Vallejo (Historia de una escalera, El tragaluz, Las trampas del azar) y cuatro de Alonso de Santos (Pares y nines, La última pirueta, ejempios ambas de lengua estándar, y La estanquera de Vallecas, Bajarse al moro, de tono coloquial-jergal). 
Sin embargo, como en todos los casos de covariación, convendría tener presente que estos resultados no son obligatoriamente causales. La covariación positiva entre conjuntos de datos de superficie no debería ser la clave -al menos, no únicamente- para afirmar que la presencia de ciertos factores determina la realización de X, es decir, que todo ello pertenece a la competencia lingüística de los hablantes (López Morales, 1993-1994). No hay que olvidar que este tipo de variación -como todas- se detecta a posteriori, tras el análisis de un corpus producido ya, y que, por lo tanto, los factores que parecen motivarla se descubren entonces, es decir, post factum, no como presentes antes de la actuación, lo que hablaría a favor de una elección consciente.

Si a esto se añade que en estos estudios la cantidad de casos encontrados es sumamente escasa, se explica sobradamente que se requiere prudencia a la hora de ofrecer los resultados de la investigación. Encontrar que una forma tiene una mayor frecuencia en un contexto determinado no autoriza automáticamente a afirmar que ello implica por fuerza la existencia de distinciones semánticas o pragmáticas, vivas en la competencia de los hablantes. Datos como los de Sedano (1994) y los de Silva Corvalán (1980$81,1981)$ sí nos autorizan a 'suponer' o a 'sospechar' que pudiéramos estar ante tales diferencias, como con cautela bien proponen estas investigadoras.

Es verdad que ciertos factores externos al análisis pueden ayudarnos: no parece posible, por ejemplo, desconocer el hecho de que las formas de ir $a+$ infinitivo como expresión de futuridad está desbancando a las formas paradigmáticas con -ré, luego es lícito 'suponer' también que la frecuencia en general mayoritaria de las perífrasis en todos los contextos solo reproduzca esta realidad.

\section{LAS PRUEBAS EMPÍRICAS}

Hace ya tiempo que Sankoff (1988 b) recordó la imposibilidad de tener acceso directo a las intuiciones e intenciones comunicativas del hablante. Pensaba que la única forma que se tenía de lograrlo era a través de sus enunciados, ni siquiera descansando en la interpretación que hace el propio

7. Sus palabras son precisas: «As for sociodemographic, situational or stylistic factors, there is seldom any justification to treat them as choices to mutual influences of phonological or syntactic performance processes; whether a speaker marks a specific occurrence of a specific norm with a plural morpheme should be analysed as having an immediate effect on the speaker's age or sex, the interlocutors present or the degree of formality adopted. If any such factors is to be analysed as a choice, this must be considered as having occurred prior to performance choices, in some temporal, generative or hierarchical sense». 
oyente de sus mensajes, con excepción de las respuestas que ofrece en el caso de discursos conversacionales. Aun los hablantes mismos, después de reflexionar, pudieran creer que su selección lingüística estuviese motivada por una intención comunicativa particular, pero no cabe duda de que se trataría siempre del producto de una introspección hecha a posteriori. Ello nos lleva a concluir que no hay modo de saber si la elección de una forma está realmente inspirada por $\mathrm{cl}$ interés del hablante en transmitir diferencias sutiles o, por el contrario, si se trata simplemente de una elección entre posibles alternativas paralelas. ${ }^{8}$

Aunque los ejercicios señalados por Sankoff presenten dificultades de envergadura, existen otras pruebas empíricas que pueden sernos de ayuda a la hora de determinar si determinados fenómenos lingüísticos forman parte de la competencia del hablante o son enteramente casuales. En este sentido es posible recurrir a unas pruebas en las que se enfrente al sujeto a unos pequeños textos descriptivos creados ad hoc y pedirles después que lo 'traduzcan', seleccionando de entre dos oraciones aquella que indique mejor el significado del texto. Por ejemplo:

Pedro está en una situación económica muy difícil. Perdió su trabajo hace un mes, tiene mujer y cinco hijos que mantener y se ha quedado sin ahorros.

a. Pedro necesita que le presten dinero.

b. Pedro tiene necesidad de que le presten dinero.

Pedro se quedó sin trabajo hace una semana, pero su situación económica no es dificil: es soltero y dispone de ahorros.

a. Pedro necesita que le presten dinero.

b. Pedro tiene necesidad de que le presten dinero.

Ante este y otro ejercicio rigurosamente paralelo en cuanto a las estructuras que se estudian, colocado más adelante en la prueba, el sujeto tiene tres diferentes alternativas: a) actuar de acuerdo a la hipótesis manejada (García, 1986), en cuyo caso, seleccionaría 9a y 10b, respectivamente; b) comportarse de manera contraria a la hipótesis, marcando $9 \mathrm{~b}$ y $10 \mathrm{a}$, y c) actuar arbitrariamente: 9a, 9b/10a,10b. Si se tratara del primer caso, la hipótesis

8. Sankoff señala también que en el proceso de descubrir tales intenciones (o de negarlas) el investigador puede estar motivado por consideraciones teóricas, normativas o críticas. No puede pasarse por alto el papel de las implicaciones sociológicas de quien enjuicia la función de las formas, algunas estigmatizadas por la comunidad. 
quedaría corroborada, pues los sujetos entienden que al ser muy grave la situación económica de Pedro deberían traducirla por la oración «Pedro necesita que le presten dinero». Si triunfara el segundo caso, se confirmaría que estas dos oraciones no significan 'lo mismo' para los sujetos, aunque no en el sentido que propone García. La tercera opción indicaría claramente que ambas oraciones son paralelos semánticos para los hablantes.

La muestra quedó integrada por 296 sujetos que produjeron 592 respuestas por cada par, 1,184 en total: para este estudio estaba dividida en tres submuestras: a) Gran Canaria, b) Levante [Alicate y Valencia] y c) Castilla [Zamora, Salamanca y Ávila]. En el análisis de algunos fenómenos supuestamente variables, convenía unir las tabulaciones, pues las tres submuestras se comportaban de manera idéntica. Éste fue uno de los casos. Los resultaron dejaron en claro que la gran mayoría de los hablantes utilizaba una u otra oración indistintamente (93.6\%), lo que evidencia que para ellos no eran opciones semánticas distintas, sino formas alternas de decir 'lo mismo'.

A esta misma prueba se sometieron otras oraciones, entre ellas las activas y sus pasivas plenas correspondientes.

Las gramáticas tradicionales anteriores al siglo $\mathrm{XX}$, salvo contadísimas excepciones, $\mathrm{y}$ muchas otras del siglo $\mathrm{xx}$, siempre han considerado que las activas (Juan pintó la casa) y sus pasivas plenas (La casa fue pintada por Juan) tenían la misma identidad semántica; de aquí los ejercicios escolares de convertir activas en pasivas, y viceversa, en los que subyacía la idea de que ambas eran sinónimas. Aunque con la llegada de los estructuralismos la casi unanimidad anterior quedó algo maltrecha, siempre se trató de una postura mayoritaria.

A pesar de que los modelos chomskianos vinieron a revisar tantas cosas, lo relativo a las activas y las pasivas en nada cambió. Es verdad que en el primero de ellos -1957- Chomsky había indicado de pasada que si las oraciones pasivas iban acompañadas de cuantificadores se advertían algunas diferencias entre estas (se refería a reacciones intuitivas) y sus activas correspondientes. Esta observación motivó que otros estudiosos creyeran que no había equivalencia semántica entre ellas. Pero la herencia del estructuralismo formalista vigente entonces en los Estados Unidos triunfó aquí como en otros muchos aspectos. Salvo esas excepciones, que no se volvieron a mencionar, las activas y las pasivas correspondientes poseían una misma estructura interna en común (Katz y Postal, 1964; Chomsky, 1965: 128-132) puesto que la interpretación semántica de ambas era la misma. A la hora de ejemplificar el proceso por el cual dos diferentes historias transformatorias convertían la misma estructura subyacente en oraciones de superficie diferenciadas sintácticamente, la mayoría de los manuales que difundían este modelo transformatorio inicial acudían, precisamente, a las activas y a sus correspondientes pasivas. 
Aunque en la actualidad un número importante de lingüistas esté de acuerdo en reconocer paralelos semánticos entre activas y sus correspondientes pasivas plenas, son muchos los que piensan que la diversidad de las estructuras pragmáticas de ambos tipos de oraciones implica que, a pesar del paralelo semántico, el hablante dice con ellas 'cosas diferentes'.

Estas diferencias parecieron quedar muy claras tras la publicación de un influyente artículo de Givón (1990), en el que afirma que las operaciones de transitividad que caracteriza a la voz pasiva son, fundamentalmente, de índole pragmática, no de carácter semántico; se trata realmente de un cambio de énfasis por parte del hablante y de su intencionalidad comunicativa, manifestada en el cambio de tópico de la oración.

Pero la posible diferenciación pragmática de estas estructuras fue puesta en tela de juicio por los estudiosos de la teoría de la información, que piensan que parte de lo que hasta ahora se ha estado atribuyendo al ámbito de la pragmática es asunto que concierne a la estructura informativa de las oraciones. Postulan que lo pragmático se opone a lo lingüístico en rasgos como no codificado/codificado, inferencial/automático, implícito (implicatura) / explícito. Muchas funciones informativas, en cambio, están perfectamente codificadas; existen incluso estructuras sintácticas explícitamente utilizadas para focalizar segmentos de secuencias: las mismas pasivas plenas son claros ejemplos de ello.

'Decir lo mismo', pero no 'informar de lo mismo' es el punto que plantean los que diferencian con cuidado los niveles 'representativo' e 'informativo' de las lenguas. Este último no ha sido tomado en consideración en el estudio de activas y pasivas plenas correspondientes hasta hace muy poco tiempo. Según esta postura, ambos tipos de oraciones poseen la misma estructura representativa, pero modifican su organización informativa. El hablante conforma sus mensajes de acuerdo a las supuestas necesidades informativas del interlocutor, imaginando lo que sabe y lo que ignora, y de acuerdo a ello, ordena su mensaje en dos funciones sintagmáticas: la información conocida, a través del soporte o tema, y la desconocida, a través de aporte o rema. El ordenamiento no marcado es tema-rema.

En el caso de las activas (Juan pintó la casa) asistimos al ordenamiento no marcado. La información conocida es Juan pintó, y la desconocida es la casa, como indicaría la pregunta que pudiera motivar esta aseveración: ¿qué pintó Juan? En la pasivas, en cambio, la pregunta generadora es: ¿quién pintó la casa?, por lo que la casa debe ocupar la posición de tema. A pesar de ello, la casa sigue siendo el término de esta estructura y Juan, el agente. No han variado ni las funciones ni las relaciones semánticas. Las secuencias 'dicen lo mismo'; no hay diferencia semántica alguna, y tampoco pragmática, por lo que puede concluirse que la pasiva es la consecuencia formal de un fenómeno informativo. 
Volviendo a las especificaciones de D. Sankoff, la pregunta a la que se debería dar respuesta es la siguiente: ¿puede comprobarse que las diferencias pragmáticas, apuntadas aquí y allá una y otra vez, sin haber efectuado rigurosos análisis contextuales ni de otra naturaleza, forman realmente parte de la competencia de los hablantes?

En la prueba empírica a que se hizo alusión arriba solo se han tomado en cuenta aquellas pasivas de participio que cuentan con un correlato activo; su estructura queda entendida como 'sujeto + un predicado perifrástico (auxiliar ser + participio) + un complemento agente'. Se comprenderá fácilmente que el alcance de este trabajo es limitado, puesto que no toma en cuenta otras formas de indicar pasividad con las que cuenta el español, pero puede ser un buen ejemplo para lo que nos proponemos llegar a saber: si existen o no diferencias de significado (semántico, pragmático o informativo) entre ellas en la competencia de los hablantes. ${ }^{9}$

Como en todos los casos, cada sujeto leía en solitario dos situaciones dadas; en ellas se ponía énfasis especial en un elemento (marcado en negrita, además), Juan:

Juan acompañó a su prima a comprar la casa. Juan insistió en que la comprara. Juan mismo se ofreció a pintarla.

Tras la lectura, se escogía la oración que mejor tradujera lo dicho en el texto estímulo:

a. Juan pintó la casa

b. La casa fue pintada por Juan.

Se trataba de ver, en una palabra, qué elementos el sujeto prefería topicalizar en cada caso. Las posibilidades eran tres: el sujeto topicalizaba: a) favoreciendo la perspectiva pragmática, b) sistemáticamente en contra de esta perspectiva, y c) arbitrariamente. Los datos apuntaron contundentemente

9. Estas estructuras han dado pie a interesantes estudios y cuestionamientos. En cuanto a la pasiva de participio, se duda de su carácter verdaderamente pasivo, debido a sus semejanzas con las estructuras atributivas; se cuestiona también el tipo y el número de verbos introductores que se aceptan como componentes de estas cláusulas, y se discute si el participio por sí solo puede o no formar cláusulas pasivas. Los trabajos más actualizados (Pino, 2000), examinan también lo relativo a la estructura sintáctica de estas pasivas plenas, el participio, el verbo en forma impersonal, el sujeto, del complemento agente y las restricciones de uso. Sin embargo, no hay demasiadas novedades sobre la estructura semántica de las activas y las pasivas plenas correspondientes, si exceptuamos las inquietantes dudas que ofrece el hecho de que no siempre las construcciones pasivas de participio cuentan con un correlato activo transitivo, por una parte, y que las restricciones, a veces muy severas, de estas pasivas hacen imposible que algunos tipos puedan convivir con sus activas (cuando las hay) en Ios mismos contextos. Nótese, sin embargo, que sobre nuestro tema no hay avances significativos 
a la topicalización indiscriminada $(90.1 \%$, y dentro de este tipo de respuesta, un curioso $16 \%$ de especificaciones añadidas: 'es lo mismo'). Aunque no es posible aquí presentar todos los detalles de esta investigación (López Morales, 2001), este resultado es de nuevo tan elocuente - la enorme mayoría de los sujetos no distingue diferencias de significado pragmático en estas estructuras- que parece concluyente que entre algunos análisis teóricos y la competencia de los hablantes media un gran trecho.

Para corroborar empíricamente los reclamos de la teoría de la información sobre estas mismas estructuras, se construyó otra prueba empírica que tenía la siguiente estructura: una serie de preguntas y dos posibles respuestas:

a. ¿Quién pintó la casa?

Juan pintó la casa.

La casa fue pintada por Juan.

b. ¿Qué pintó Juan?

Juan pintó la casa.

La casa fue pintada por Juan.

Es evidente que aquí las respuestas posibles eran solo dos: a) se escogía la oración que confirmaba la propuesta informativa - «La casa fue pintada por Juan» y «Juan pintó la casa» respectivamente--, o b) se seleccionaban las respuestas de manera arbitraria. La tabulación demostró que solo el $18.7 \%$ de la muestra ${ }^{10}$ hizo la selección correspondiente a los presupuestos informativos, mientras que el $81.2 \%$ prefirió otras respuestas, completamente ajenas al patrón esperado.

Lo más aleccionador de estos estudios empíricos, a pesar de los reparos que puedan hacérseles," es la invitación que nos hacen a reflexionar sobre la

10. En esta ocasión solo dispongo de datos procedentes de una pequeña encuesta preliminar, que maneja una muestra nada representativa. Tómense, por lo tanto, estos resultados con extrema cautela.

11. Gutiérrez Ordóñez, en comunicación personal, tuvo la gentileza de comunicarme lo siguiente: en el caso de 1 , Juan es siempre sujeto y agente; en 2 , en cambio, no ocurre lo mismo con casa, pues aunque la casa es siempre el centro de atención, no sicmpre ocupa la función de sujeto: «Luisa se compró una casa» (término pero no sujeto), «La casa no era nueva» (sujeto pero no término), «La casa necesitaba...».' (sujeto pero experimentante), y «Juan se ofreció a pintarla', en la que la organización es la misma que una estructura activa (Juan es sujeto y agente de pintar; una casa es complemento directo y término de pintar). Por todo ello, no cree que la disposición informativa condicione la estructura pasiva, como supone la prueba.

Por otro lado, en la segunda prueba los sujetos solo podían seleccionar una de las dos respuestas ofrecidas (la activa y la pasiva plena correspondiente); sin embargo, un sujeto decidió por su cuenta dar una tercera respuesta: ¿quién pintó la casa? La pintó Juan. ¿Quién saludó al senador? Lo saludó Mario. En estas respuestas, el informante topicalizó (no con la estructura pasiva clásica) de acuerdo a los presupuestos informativos presentados arriba. De haberse ofrecido esta y otras respuestas posibles, los datos hubiesen podido cambiar considerablemente. 
sintonía que debe existir entre explicaciones teóricas de los fenómenos lingüísticos y las correspondientes corroboraciones empíricas de que las mismas forman parte en realidad de la competencia de los sujetos de alguna comunidad de habla.

\section{CONCLUSIÓN}

Las propuestas que surgen naturalmente tras haber repasado los materiales anteriores es que no se descuide el estudio de la lengua en su contexto social (muestras representativas, corpora adecuados, análisis cuidadoso, aparato estadístico) $\mathrm{y}$, también, que se acuda a todo tipo de prueba que permita distinguir de manera algo más segura entre las coincidencias fortuitas que puedan advertirse en ciertos análisis y la demanda de algunos imperativos teóricos (por muy asentados que estén y compartidos que sean), y la realidad lingüística, la competencia sociolingüística de los hablantes.

\section{REFERENCIAS BIBLIOGRÁFICAS}

Bentivoglio, P. (1976): «Queímo y dequeísmo en el habla culta de Caracas» en AID, F. M.; M. C. Resnick; B. SACIUK (eds.) (1976): 1975 Colloquium on Hispanic Linguistics, 1-18, Washington, D.C., Georgetown University Press.

- (1980-81): «El dequeísmo en Venezuela: ¿un caso de ultracorrección?», Boletín de Filología [Universidad de Chile], 705-719.

Bentivoglio, P.; F. D'Introno (1977): «Análisis sociolingüístico del dequeísmo en el habla de Caracas», Boletín de la Academia Puertorriqueña de la Lengua Española, 6,1: 58-82.

Blas Arroyo, J. L. (2000): «Aspectos de la variación lingüística en la lengua escrita: la expresión de futuridad en el español literario», Lingüística Española Actual, 22: 161-200.

BOLINGER, D. (1977): Meaning and form, Londres-Nueva York, Longman.

Chomsky, N. (1957): Syntactic structures, La Haya, Mouton.

- (1965): Aspects of the theory of syntax, Cambridge [MA], The M.I.T. Press.

- (1981): Lectures on government and binding, Dordrecht, Foris.

DEulofeu, J. (1992): «Variation syntaxique: recherche d'invariants et étude des attitudes des locuteurs devant la norme», Languages, 108: 66-78.

GARCíA, É. (1985): «Shifting variation», Lingua, 67: 189-224.

- (1986): «El fenómeno (de)queísmo desde una perspectiva dinámica del uso comunicativo de la lengua» en Moreno de AlBA, J. (ed.) (1986): Actas del 
II Congreso Internacional sobre el español de América, México, D.F., Universidad Nacional Autónoma de México.

Grvón, T. (1990): «Voice and de-trasitivization» en Syntax. A functionaltypological introduction, II, Amsterdam-Philadelphia, Iohn Benjamins, 563-644.

Gómez MANZano, P. (1988): «La expresión del futuro absoluto en el español hablado en Madrid y Méxicn», Anuario de Letras, 26; 67-86.

Gómez Molina, J. R.; B. Gómez Devis (1995): «Dequeísmo y queísmo en el español hablado de Valencia: factores linguísticos y sociales», Antiario de Lingüística Hispánica, 11: 193-220.

JACOBSON, S. (1989): «Some approaches to syntactic variation» en FASOLD, R. W.; D. SCHIFFriN (ed.) (1989): Language change and variation, Washington, D. C., Georgetown University Press.

JONGE, R. de (1991): «El futuro en -ré e ir a + infinitivo es español moderno», Hispanic Review, 59: 331-333.

- (1998): «La interpretación de datos numéricos en el análisis lingüístico: numerus omen est», Lingiilística.

Katz, J.; P. Postal (1964): An integrated theory of linguistic description, Cambridge [MA], MIT Press.

LABERGE, S. (1977): Étude de la variation des pronoms sujets définis et endéfinis dans le français parlé à Montréal [tesina inédita], Montréal, Université de Montréal.

LABOv, W. (1978): «Where does the sociolinguistic variable stop? A response to Beatriz Lavandera», Texas Working Papers in Sociolinguistics [Austin: Southwest Educational Development Laboratory], 44: 1-17.

LAKOFF, G. (1970): Linguistic and natural logic, Ann Arbor, University of Michigan.

LAVANDERA, B. (1978): «Where does the sociolinguistic variable stop?», Language in Society, 7: 171-182.

LEFREBVRE, C. (1989): «Some problems in defining syntactic variables: The case of wh- questions in Montreal French» en FASOLD, R. W:; D. SCHIFFRIN (ed.) (1989): Language change and variation, Washington, D. C., Georgetown University Press.

López Morales, H. (1990): «La sociolingüística actual» en Moreno, F. (ed.) (1990): Estudios sobre variación lingüística, Alcalá de Henares, Universidad de Alcalá.

- (1993-94): «Precisiones sobre el concepto de competencia sociolinguística», Boletín de Filología [Universidad de Chile], 34: 257-270.

- (2001): «Linguistic variation revisited», Proceedings of the First Conference on Language Variation in Europe, Barcelona, Universitat Pompeu Fabra. 
MCCONNELl-Ginet, S. (1982): «Adverbs and logical form: a linguistic realistic theory», Language, 58: 144-184.

MolliCA, M. C. (1991): «Processing and morpho-semantic effects in complementation in Brazilian Portuguese», Language variation and change, 3: 265-274.

Moreno de Alba, J. (1977): «Vitalidad del futuro de indicativo en la norma culta del español hablado en México» en LoPE BLANCH, J. M. (ed.) (1977): Estudios sobre el español hablado en las principales ciudades de América, México, Universidad Nacional Autónoma de México.

- (1985): Valores de las formas verbales en el español de México, México, Universidad Nacional Autónoma de México.

PINO, M. (2000): Las construcciones pasivas e impersonales transitivas en español (tesis doctoral inédita), Madrid, Universidad Complutense.

Pollán Valiña, C. (1999): Hechos de variación en el empleo de algunas formas verbales en gallego y castellano de Galicia (tesis doctoral), Santiago, Universidad de Santiago de Compostela.

Poplach, S.; D. TurPIN (1999): «Does the future has a future in (Canadian) French?»Probus, 11: 1-20.

Quilis SANZ, $M^{\mathrm{a}}$ J. (1986): «El dequeísmo en el habla de Madrid y en la telerradiodifusión española», Boletín de la Academia de la Lengua Española, 14: 139-150.

ROMAINE, S. (1981 a): «On the problem of syntactic variation: A reply to Beatriz Lavandera and William Labov», Texas Working Papers in Sociolinguistics [Southwest Educational Development Laboratory], 82: 2-38.

- (1981 b): «The status of variable rule in sociolinguistic theory», Journal of Linguistics 17: 93-119.

- (1984): «On the problem of syntactic variation and pragmatic meaning in sociolinguistic theory», Folia Linguistica, 18: 3-4, 409-437.

SANKofF, D. (1988 a): «Variable rules» en Ammon, U.; N. Ditmar; K. J. MATTHEIER (ed.) (1988): Sociolinguistics/Soziolinguistik. An International Handbook of the Science of Language and Society/Ein internationals Handbuch zur Wissenschaft von Sprache und Gesellschaft, Berlín-Nueva York, Walter de Gruyter, 21: 989-997.

- (1988 b): «Sociolinguistics and syntactic variation» en NEWMEYER, F. (ed.) (1988): Linguistics: The Cambridge Survey, IV: Language: The sociocultural context, Nueva York, Cambridge University Press, 140-161.

SANKOFF, G. (1972): «Above and beyond phonology in variable rules» en BAILEY, C. J. y R. W. SHUY (ed.) (1972): New ways of analyzing variation in English, Washinton, D. C., Georgetown University Press, 44-61.

SAnkofF, G.; R. SARRASIN; H. Cedergren (1971): «Quelques considerations sur la distribution de la variable que dans le français de Montréal», 
comunicación presentada al Congrès de l 'Association Cannadiennefrançaise por l'Avancement des Sciences.

SCHERRE, M. M.; A. NARO (1991): «Marking in discourse: Birds of a feather», Language variation and change, 3: 23-32.

SCHWENTER, S. A. (1999): «Evidentialitaly in Spanis morphosyntax: A reanalysis of (de)queísmo» en SERrAno, M. J. (ed.) (1999): Estudios de variación sintáctica, Madrid, Iberoamericana, 65-87.

SEdAno, M. (1994): «El futuro morfológico y la expresión ir a + infinitivo en el español hablado en Venezuela», Verba, 21:225-240.

Silva Corvalân, C. (1980-81): «La función pragmática de la duplicación de pronombres clíticos», Boletín de Filología [Universidad de Chile], 31: $561-570$.

- (1981): «Extending the sociolinguistic variable to syntax. The case of pleonastic clitics in Spanish», en Sankoff, D.; H. Cedergren (ed.) (1981): Variation omnibus, Edmonton, Linguistic Researc, Inc., 335 342.

- (1997): «Variación sintáctica en el discurso oral: problemas metodológicos» en Moreno, F. (ed.) (1997): Trabajos de sociolingüística hispánica, Alcalá de Henares, Universidad de Alcalá, 115-135.

- (2001): Sociolingiilística y pragmática del español, Washington, D. C., Georgetown University Press.

Silvertein, M. (1976): «Shifters linguistic categories and cultural description», Meaning in Anthropology, Albuquerque, University of New Mexico Press, 11-57.

Thibault, P. (1980): «Le français parlé: étude sociolinguistiques», Le français parlé: étude sociolinguistiques, Edmonton, Linguistic Research, Inc.

Troya Dénz, M. (1998) Perífrasis verbales de infinitivo en la norma linguiística culta de Las Palmas de Gran Canaria, Madrid-Las Palmas, Real Academia Española-Editorial de La Universidad de Las Palmas de Gran Canaria.

Weiner, E. J.; W. LABov (1983): «Constraints on the agentless passive», Journal of Linguistics, 19: 29-58. 


\title{
DISPONIBILIDAD LÉXICA Y SOCIOLINGÜÍSTICA
}

\author{
José Antonio Samper Padilla \\ Universidad de Las Palmas de Gran Canaria
}

\section{INTRODUCCIÓN}

$\mathbf{H}$

oy no podemos hablar de disponibilidad léxica en el mundo hispánico sin referirnos al proyecto que, encabezado por Humberto López Morales, estudia el léxico disponible prácticamente en toda España y en amplias zonas de América.

En un reciente trabajo (Samper, Bellón y Samper Hernández, 2003) expusimos un panorama de lo que han significado estas investigaciones de léxico-estadística en nuestro ámbito lingüístico. En ese extenso artículo -extenso porque ya había una importante producción que había que resumir y comentar- destacamos los criterios metodológicos comunes a todos los equipos, explicamos cómo se habían concretado los resultados en cada una de las sintopías, analizamos los datos que aportaba la consideración de los diversos factores sociales, repasamos los trabajos de distinta orientación que habían realizado los diversos equipos de investigación e incluso nos atrevimos a señalar algunos caminos que podrían seguirse en el desarrollo del proyecto.

Pues bien, hoy puedo decirles que la fuerza de los hechos nos ha obligado a pensar en la elaboración de otro artículo que dé noticia del avance del proyecto en estos últimos dos años. Porque el número de trabajos recientes es realmente llamativo. Pensemos que el año pasado se leyeron tres tesis doctorales de este proyecto: Juan José Bellón defendió su trabajo sobre Córdoba, M. ${ }^{a}$ Begoña Gómez Devís presentó el suyo sobre la provincia de

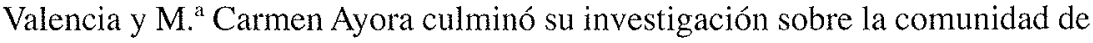
Ceuta. Además de estos estudios, en el mismo año 2003 se presentaron otras dos tesis que investigaban la disponibilidad de alumnos de edades inferiores a las que se contemplan en el proyecto panhispánico; son los trabajos sobre Almería, realizado por Antonio García Megía, y sobre Las Palmas de Gran Canaria, elaborado por Marta Samper Hernández. En ambos casos se indaga la progresión cuantitativa y cualitativa del léxico disponible. Son, por tanto, estudios de adquisición (y no de la norma comunitaria adulta), pero su respeto a la metodología del proyecto permite que podamos incorporar algunos de sus resultados en esta conferencia. Por otro lado, no podemos olvidar que en el 
plazo de un año, si sus autoras mantienen el mismo ritmo de trabajo que llevan hasta ahora, podremos contar con al menos tres nuevas tesis doctorales que aportarán los datos y los análisis consecuentes de Alicante, comunidad en la que trabaja Esther Martínez Olmos, de Lérida, que estudia Maribel Serrano Zapata, y de Castilla-La Mancha, investigada por Natividad Hernández Muñoz. Por lo pronto, estas dos últimas investigadoras ya nos han ofrecido resultados parciales de los trabajos futuros en sus memorias de licenciatura.

Las contribuciones de estas tesis doctorales se ven complementadas por tres libros, publicados este mismo año de 2004, en que se recogen los correspondientes diccionarios de léxico disponible: el de Valencia, obra de José Ramón Gómez Molina y M.a Begoña Gómez Devís; el de Aragón, recientemente editado por el grupo coordinado por M." Luisa Arnal, y el de Cuenca, de Natividad Hernández Muñoz. En los estudios introductorios de todos ellos se pueden leer importantes consideraciones teóricas y metodolóm gicas.

Si a ello añadimos las varias decenas de artículos en revistas, de capítulos de libros y de comunicaciones a congresos (algunos de ellos aún inéditos), se comprenderá que estamos hablando de uno de los proyectos más productivos del mundo hispánico. Recordemos que hoy se están estudiando prácticamente todas las comunidades españolas, con muy contadas excepciones (Murcia, La Rioja, Navarra, Baleares, Extremadura). Esto quiere decir que ha habido incorporaciones recientes, como las de los grupos de investigación que trabajan en Barcelona, Cantabria, Málaga y Jaén.'

Pero no solo ha habido una expansión notoria en España; también en Hispanoamérica nuevos investigadores se han incorporado a esta empresa con total entusiasmo. Esto es lo que ocurre con los equipos de Colombia, del Caribe colombiano y de Honduras, que han empezado sus trabajos este mismo año. También en Costa Rica, Víctor Sánchez Corrales y Marielos Murillo han realizado las encuestas del nivel preuniversitario y hoy preparan la edición de los materiales. Del mismo modo Max S. Echeverría se ha propuesto el estudio de la disponibilidad chilena con los mismos criterios metodológicos del proyecto.

Muchas de estas novedades pueden consultarse en la página electrónica Dispolex (http://www.dispolex.com) que cuidan desde la Universidad de Salamanca José Antonio Bartol y Natividad Hernández Muñoz.

1. Además, en Madrid, el equipo formado por Florentino Paredes (Universidad de Alcalá) y por Luis Guera y M." Elena Gómez (Universidad Europea de Madrid) ha diseñado una muestra que supera con creces la cifra estipulada en las bases metodológicas del proyecto, ya que se ha pensado en llegar a 600 informantes de 24 centros educativos ( 14 públicos y 10 privados) de la comunidad (comunicación personal de los autores). 
El avance del proyecto ha sido, pues, espectacular en estos últimos años. En ello también ha influido el que haya habido un contacto muy estrecho entre sus componentes. Han sido frecuentes los encuentros en distintos congresos y se han favorecido las estancias de jóvenes investigadores en los centros de trabajo de estudiosos con más experiencia (por ejemplo, en la universidad finlandesa de Turku, en la que Alberto Carcedo ocupa la cátedra de Lengua Española). Asimismo, a través del correo electrónico se han resuelto con rapidez muchas dudas de los equipos que inician sus investigaciones y se han discutido los problemas metodológicos que plantean los distintos análisis. Y además el año pasado, en el mes de abril, tuvo lugar una reunión de los responsables de los grupos en San Millán de la Cogolla, continuación de la primera realizada en Bilbao en 1999. En los dos días de las jornadas se discutieron intensamente los aspectos más conflictivos de la investigación y se adoptaron acuerdos para que los trabajos fueran coordinados.

Como puede verse, no es poco lo que este proyecto ofrece. Detrás de todos estos logros está la labor infatigable de Humberto López Morales, que ha conseguido algo realmente difícil: que estudiosos de muy distinta procedencia y formación colaboren en una investigación de gran alcance con unos métodos comunes que, sin duda, han de favorecer las comparaciones y la consecución de unos resultados aplicables a todo el ámbito hispánico.

\section{LA DISPONIBILIDAD LÉXICA}

Dado que no todo el público que llena esta sala está familiarizado con los estudios de disponibilidad, creo que conviene informar brevemente sobre algunas cuestiones propias de estas investigaciones.

El primer trabajo sobre léxico disponible, llevado a cabo en los años cincuenta del siglo pasado por Gougenheim, Michéa, Rivenc y Sauvageot, estuvo enmarcado en un ambicioso proyecto que perseguía facilitar la adquisición del francés a los hablantes extranjeros. En el mundo hispánico los análisis de léxico disponible se iniciaron en 1973 con los trabajos realizados en la isla de Puerto Rico por López Morales.

Cuando hablamos del léxico disponible, nos referimos a un léxico que vive potencialmente en los hablantes y que se actualiza solo cuando se producen ciertas asociaciones. Está constituido por las llamadas palabras temáticas, aquéllas que están vinculadas a un tema determinado; cuando se dan las condiciones apropiadas el vocablo disponible se presenta en la mente del hablante de forma inmediata y natural. El estudio de estas unidades, que 
presentan poca estabilidad estadística, no puede basarse, como es fácilmente comprensible, en criterios de frecuencia. Para obtener los datos que nos permitan establecer el léxico disponible de una comunidad se ha de recurrir, pues, a unas pruebas asociativas controladas, un modo artificial de conseguii que afloren a la superficie esas palabras de las que disponen los hablantes para su uso inmediato.

Paià ello se utilizan unos estímulos tcmáticos amplios, los llamados «centros de interés». En todos los estudios del proyecto hispánico figuran 16 ('Partes del cuerpo', 'La ropa', 'Partes de la casa (sin los muebles)', 'Los muebles de la casa', 'Alimentos y bebidas', 'Objetos colocados en la mesa para la comida', 'La cocina y sus utensilios', 'La escuela: muebles y materiales', 'Tluminación, calefacción y medios de airear un recinto', 'La ciudad', 'El campo', 'Medios de transporte', 'Trabajos del campo y del jardín', 'Los animales', 'Juegos y distracciones' y 'Profesiones y oficios'), que coinciden con los que establecieron los estudiosos franceses como manifestación de los sectores semánticos más representativos universalmente (Gougenheim et al., 1967). Además de esos 16 campos, algunos investigadores del proyecto han añadido otros con la finalidad de buscar un tipo de léxico distinto. De este modo, muchos equipos han estudiado el ámbito de 'Los colores' y algunas de las últimas investigaciones han incorporado ciertos centros de interés que favorecen la aparición de un vocabulario más abstracto. Así, por ejemplo, Ayora (2003) trabajó los campos 'Defectos y cualidades físicos y morales' y 'Acciones'; y Hernández Muñoz (2004) estudió 'La inteligencia'.

El simpic enunciado de los centros de interés permite ver que enire ellos hay diferencias muy acusadas en el grado de asociación que propician. Algunos -como 'La ciudad'o 'El campo'-- abren un abanico muy amplio de relaciones -concretas y abstractas- por la extensa gama de matices que evocan, mientras que otros son muy restringidos: tal es el caso de 'Objetos colocados en la mesa para la comida' o de 'Iluminación, calefacción y medios de airear un recinto'.

Los resultados cuantitativos han mostrado en todas las investigaciones del proyecto que los centros de interés no ofrecen el mismo grado de productividad. En el cuadro siguiente pueden verse los promedios de respuestas por alumno que alcanza cada uno en los últimos estudios y que confirman los resultados que habían aportado los trabajos anteriores (Samper, Bellón y Samper Hernández, 2003: 57-59): ${ }^{2}$

2. Estos datos proceden de los trabajos de Gómez Molina y Gómez Devís (2004), Ayora (2003), Arnal et al (2004), Hernández Muñoz (2004), Serrano (2003), Bartol (en prensa) y Samper Hernández (2003), según el orden en que figuran en el cuadro. 
CUADRO 1. Promedios de palabras por centros de interés en investigaciones recientes del proyecto

\begin{tabular}{|c|c|c|c|c|c|c|c|}
\hline C.I. & Valencia & Ceuta & Aragón & Cuenca & Lérida & Soria & $\begin{array}{c}\text { Las } \\
\text { Palmas } \\
\text { (escolares) }\end{array}$ \\
\hline 01 CUE & 27 & 25.7 & 26.4 & 16.6 & 27.1 & 24.8 & 19.7 \\
\hline 02 ROP & 26.6 & 21.1 & 23.6 & 22.9 & 23.7 & 23.2 & 16.4 \\
\hline 03 CAS & 15.7 & 16.3 & 17 & 18.7 & 13.9 & 17 & 11.8 \\
\hline 04 MUE & 14.8 & 16.3 & 15.8 & 17.5 & 12.4 & 16.4 & 13.1 \\
\hline 05 ALI & 27.8 & 26.4 & 28.3 & 26.9 & 25.8 & 27.7 & 20.6 \\
\hline 06 MES & 16.2 & 17.1 & 17.7 & 20.6 & 14.4 & 17.7 & 10.8 \\
\hline 07 COC & 20.5 & 19.8 & 20.5 & 19.6 & 16.3 & 20.5 & 13.5 \\
\hline 08 ESC & 22.5 & 22.4 & 24.1 & 26.5 & 22.5 & 26.1 & 19.4 \\
\hline 09 ILU & 12.5 & 11.3 & 14 & 16.3 & 11.6 & 15.6 & 7.6 \\
\hline 10 CIU & 23.8 & 24.3 & 23.3 & 24 & 22.8 & 24 & 17.1 \\
\hline 11 CAM & 20.8 & 20.6 & 22.2 & 21.2 & 19.3 & 22.5 & 14.6 \\
\hline 12 TRA & 18.6 & 17.8 & 19.7 & 18.2 & 17.5 & 19.8 & 12.4 \\
\hline 13 TRC & 11.7 & 10.8 & 13.2 & 17.4 & 9.2 & 13.1 & 6.7 \\
\hline 14 ANI & 28.7 & 28.3 & 29.9 & 27.1 & 26.8 & 29.2 & 21.8 \\
\hline 15 JUE & 19.1 & 19 & 20.3 & 24.1 & 16.8 & 21 & 12 \\
\hline 16 PRO & 21.9 & 22.8 & 23.4 & 23.8 & 20.2 & 22.9 & 13.3 \\
\hline
\end{tabular}

La información de este cuadro revela que en todas las comunidades hay tres ámbitos muy productivos: el 14 'Los animales' (que, en general, obtiene los mejores resultados, con unos promedios que superan siempre las 26 palabras y en algún caso llega a rozar las 30), el 05 'Alimentos y bebidas' (que normalmente se encuentra en el segundo lugar) y el 01 'Partes del cuerpo' (que logra, con la única excepción de Cuenca, un promedio que oscila entre las 25 y las 27 palabras).

En el otro extremo, los centros de interés 09 'Iluminación, calefacción y medios de airear un recinto' y 13 'Trabajos del campo y del jardín' son generalmente los que ofrecen menos rendimiento. El que sistemáticamente queden relegados a los últimos lugares implica que estamos ante áreas léxicas cerradas y poco familiares para los informantes de este tipo de estudios.

Podemos pensar que estos resultados tienen un carácter universal puesto que se dan también tanto en una investigación que toma como encuestados a alumnos de cursos escolares inferiores (vid. los datos que figuran en la columna de la derecha del cuadro anterior, tomados del trabajo de Samper Hernández en Las Palmas de Gran Canaria), como en la que se hizo a estudiantes universitarios salmantinos (Borrego y Fernández Juncal, 2003: 169). 
Además del número de palabras hay otro criterio fundamental para estudiar los distintos centros de interés: la cantidad de vocablos (o palabras diferentes) que generan. Este factor informa de la homogeneidad o heterogeneidad de las respuestas de los encuestados, es decir, de la mayor o menor amplitud de las asociaciones de cada uno de los campos léxicos analizados. También en este caso son notorias las divergencias:

CUADRO 2. Total de vocablos por centro de interés en investigaciones recientes del proyecto

\begin{tabular}{|c|c|c|c|c|c|c|}
\hline CI. & Valencia & Ceuta & Aragón & Cuenca & Lérida & $\begin{array}{c}\text { Las Palmas } \\
\text { (escolares) }\end{array}$ \\
\hline 01 CUE & 339 & 309 & 356 & 192 & 195 & 274 \\
\hline 02 ROP & 330 & 335 & 332 & 190 & 175 & 273 \\
\hline 03 CAS & 263 & 276 & 346 & 208 & 134 & 302 \\
\hline 04 MUE & 308 & 307 & 363 & 222 & 124 & 341 \\
\hline 05 ALI & 561 & 612 & 649 & 409 & 262 & 549 \\
\hline 06 MES & 256 & 302 & 324 & 213 & 151 & 301 \\
\hline 07 COC & 372 & 473 & 520 & 301 & 181 & 403 \\
\hline 08 ESC & 473 & 512 & 669 & 477 & 204 & 566 \\
\hline 09 ILU & 256 & 289 & 442 & 353 & 140 & 287 \\
\hline 10 CIU & 755 & 809 & 989 & 511 & 285 & 737 \\
\hline $11 \mathrm{CAM}$ & 967 & 847 & 1224 & 628 & 297 & 734 \\
\hline 12 TRA & 280 & 348 & 403 & 223 & 138 & 266 \\
\hline 13 TRC & 491 & 578 & 547 & 380 & 167 & 545 \\
\hline 14 ANI & 467 & 407 & 542 & 399 & 223 & 416 \\
\hline 15 JUE & 546 & 702 & 894 & 558 & 273 & 643 \\
\hline 16 PRO & 715 & 675 & 761 & 484 & 295 & 789 \\
\hline
\end{tabular}

Los datos del cuadro precedente permiten ver que hay áreas asociativas que en todas las investigaciones superan el valor medio: 11 'El campo', 10 'La ciudad', 15 'Juegos y distracciones' y 16 'Profesiones y oficios' suelen ocupar las cuatro primeras posiciones en la mayoría de los trabajos. Por el extremo opuesto, los centros de interés que en general se sitúan en las últimas posiciones son 04 'Los muebles de la casa', 06 'Objetos colocados en la mesa 
para la comida', 01 'Partes del cuerpo', 03 'Partes de la casa ( $\sin$ los muebles)', 02 'La ropa' y 12 'Medios de transporte'.

Otra cuestión sobre la que debemos dar una información sucinta es la relativa a las condiciones en que se desarrollan las pruebas para recoger el léxico disponible. En todas las investigaciones del proyecto panhispánico se utiliza el sistema de listas abiertas con un límite temporal de dos minutos para cada centro de interés, un límite que se ha considerado como el más apropiado para la edad de los informantes. Además, las listas abiertas ofrecen la posibilidad de realizar variados análisis cuantitativos, especialmente de carácter sociolingüístico.

En relación con el modo de recolección del material, los informantes responden a las encuestas por escrito. Hay razones de tipo práctico que justifican tal decisión: las pruebas escritas ofrecen la gran ventaja de que permiten obtener un material abundante en pocas sesiones ya que pueden realizarse de forma colectiva.

Los sujetos son estudiantes de 18 años aproximadamente (alumnos de COU o de segundo de bachillerato, en la organización actual de la enseñanza en España). El propósito de estas investigaciones es, pues, la descripción de la norma léxica disponible de los adultos. ${ }^{3}$

\section{LA DISPONIBILIDAD Y LOS FACTORES SOCIALES}

El proyecto panhispánico de disponibilidad ha incorporado muchas innovaciones que constituyen un buen ejemplo de las posibilidades de análisis que abren estos listados léxicos. Uno de los aspectos más novedosos es el sistema de medición del índice de disponibilidad de los vocablos y el contar con programas informáticos, fácilmente manejables, que simplifican extraordinariamente la labor de los investigadores. La búsqueda del mejor sistema de tratamiento de los datos no ha terminado con los conocidos y fecundos intentos de Lorán y López Morales (1983) y de López Chávez y Strassburger Frías $(1987,1991)$. En su reciente tesis doctoral, García Megía (2004) propone un modelo que, de acuerdo con sus conclusiones, es más fiel al concepto de disponibilidad puesto que el cálculo de los índices depende más de la posición de cada palabra en los listados y del total de entradas que de la frecuencia.

3. El estudio de Borrego y Fernández Juncal (2003), con estudiantes de cuarto curso de Filología Hispánica de la Universidad de Salamanca y su comparación con los resultados provenientes de la investigación con alumnos preuniversitarios de la misma comunidad (Galloso, 2002), confirma con datos cuantitativos la validez de la hipótesis de que el vocabulario actualizado por los preuniversitarios puede considerarse un exponente apropiado de la «norma comunitaria adulta» (López Morales, 1999: 28). 
Otra importante novedad del proyecto panhispánico es la consideración de la incidencia de los condicionantes sociales en los índices de disponibilidad, un aspecto que no fue tenido en cuenta por los precursores franceses y canadienses. Pensemos que Gougenheim et al. realizan sus investigaciones a mediados del siglo pasado, cuando aún no se habían desarrollado los principios y los criterios metodológicos propios de la sociolingüística.

Frente a esto, los equipos hispánicos de disponibilidad, formados en la mayoría de los casos por estudiosos variacionistas, han considerado que los resultados de estas investigaciones lexicoestadísticas son muy útiles para analizar la variación léxica según distintos condicionantes sociales. Como un factor favorable más para tal aplicación, hay que recordar, tal como ha indicado López Morales (1999: 25), que los estudios sociolingüísticos del léxico disponible no tropiezan con los graves inconvenientes teóricos que afectan a la variación léxica, en cuanto han adoptado una perspectiva eminentemente cuantitativa.

En esta conferencia analizaré dos de las variables sociales contempladas por todos los equipos del proyecto, 'sexo' y 'nivel sociocultural'. ${ }^{+}$Con esa finalidad compararé los datos -cuantitativos y cualitativos- de las investigaciones más recientes con las aportaciones de los trabajos anteriores para comprobar si en aquéllos se llega a resultados similares o si, por el contrario, hay novedades que requieran un análisis distinto. También expondré algunas consideraciones sobre los caminos emprendidos y sobre otros que podrían tomarse.

Empezaré con algunas reflexiones sobre los resultados que ha aportado la perspectiva cuantitativa en estas investigaciones. Cuando se han analizado los datos de algunos de los condicionantes sociales, distintos estudiosos han destacado muchas veces el aito índice de convergencia, la notable igualdad cuantitativa de los diversos grupos, puesto que las diferencias proporcionales no suelen ser muy acusadas.

Realmente ese resultado - la escasa diferencia- no debería considerarse sorprendente si se tiene en cuenta el universo relativo del que se extraen las

4. Quedan fuera de muestro interés hoy la consideración de las variables 'tipo de centro escolar' y 'zona geográfica (rural/urbana)', presentes en todos los estudios hispánicos. Tampoco se contemplarán los factores que se tienen en cuenta en las investigaciones en comunidades bilingies ('lengua materna', 'lengua de uso familiar' y 'modelo de enseñanza monolingide/bilingie'), ni otros que han sido estudiados solo en determinados trabajos ('situación de los centros públicos urbanos', que se consideró en Gran Canaria, 'zonas costeras y áreas del interior', diferencia incorporada en Almería y Cádiz, 'regionalidad', analizada en Chile, o 'turno escolar', trabajado en una investigación mexicana). Tampoco haremos referencia a las variables que incluyen los estudios de disponibilidad de español como lengua extranjera ('nivel de estudios', 'conocimiento de otras lenguas' y 'lengua materna'). 
muestras: como hemos dicho, todas las muestras del proyecto están constituidas por jóvenes de alrededor de 18 años, estudiantes del último curso preuniversitario, que viven en comunidades donde predomina la educación mixta y que mayoritariamente tienen un carácter urbano o semiurbano. Es decir, partimos de muestras poco heterogéneas.

Además, creemos que no debe infravalorarse el papel desempeñado por los centros escolares, los cuales, si han realizado con eficacia la labor que les corresponde, habrán reducido o eliminado -me refiero ahora al nivel socioculturalalgunas deficiencias lingüísticas con las que acceden a ellos los alumnos de las familias menos favorecidas socialmente. Tendríamos que comprobar si esto sucede especialmente en aquellos centros de interés que podríamos calificar como «académicos» o «escolares», es decir, aquéllos que reciben atención dentro de los programas oficiales de enseñanza y que, por tanto, constituyen objeto de estudio específico. Pensemos en un campo léxico como 'Partes del cuerpo': las designaciones técnicas de la anatomía se estudian en materias curriculares (como Ciencias de la Naturaleza) y lógicamente pasan a formar parte del acervo léxico de los alumnos. En ese caso las desigualdades iniciales, producto de los diferentes niveles socioculturales de las familias, han podido mitigarse para dar lugar a un vocabulario en el que están muy presentes los tecnicismos asimilados a través del estudio. Esta igualación puede observarse, por ejemplo, en los términos que designan los órganos sexuales: en las sintopías españolas investigadas, el primer término, en índice de disponibilidad, para nombrar el órgano masculino es pene (que aparece entre las posiciones 14 y 36 en los listados de Asturias, Cádiz, Valencia, Aragón, Cuenca, Córdoba y Ceuta, siete nóminas que he consultado al azar). ${ }^{5}$ Los tabúes y los eufemismos aparecen siempre en lugares mucho más retrasados: un término como genital(es) figura en casi todas las sintopías estudiadas cerca de la posición 100, salvo en Cádiz y Córdoba, comunidades donde se sitúa en la decena de los 70; los tabúes obtienen un índice de disponibilidad menor y, por consiguiente, ocupan lugares más retrasados en los listados (en general, por encima del lugar 200; el único que se sitúa entre los 100 primeros vocablos, en las siete listas consultadas, es picha en Cádiz).

Se podría argüir que las condiciones en que se desarrolla la encuesta -en un ambiente escolar- pueden influir en la prelación de los tecnicismos entre los informantes, pero el que su posición en los diferentes listados sea tan destacada confirma que esos vocablos se han integrado plenamente en el lexicón del hablante y están listos para ser usados, probablemente antes que los sinónimos parciales que los sustituyen en otros estilos más informales.

5. Son los trabajos de Carcedo (2001), González Martínez (2002), Gómez Molina y Gómez Devís (2004), Arnal et al. (2004), Hennández Muñoz (2004), Bellón (2003) y Ayora (2003), respectivamente. 
Así pues, el papel del centro escolar, el que las muestras sean relativamente homogéneas en cuanto están formadas por alumnos del mismo nivel educativo y también que el curso escolar sea ya relativamente avanzado y no tenga carácter obligatorio, son causas que pueden explicar que las diferencias léxicas entre los alumnos no sean más relevantes cuantitativamente. Por otro lado, no debemos olvidar que analizamos unos datos lingüísticos que son el producto de unas pruebas que buscan el léxico más directamente disponible. En estas condiciones lo esperable -a pesar del desencanto inicial que suele producir esto en algunos jóvenes estudiosos- es encontrarnos con un amplio léxico común.

La presencia de ese léxico común se observa también al comparar las distintas comunidades geográficas. En este sentido se está más cerca de obtener el llamado léxico general, el compartido, que el que nos separa diatópicamente. Y esto es lógico porque en este léxico concreto e inmediato, ese que se puede usar directamente cuando se habla de un determinado tema, debe encontrarse esa amplia base que constituye el español común, el que asegura la unidad de la lengua. Por eso llamó tanto la atención el resultado de una investigación de López Chávez (1992) que señalaba un índice de compatibilidad bajísimo entre las cuatro sintopías hispánicas que analizaba (Puerto Rico, República Dominicana, Madrid y Gran Canaria). Los estudios de Alba (1998) y Samper (1999), así como otros posteriores (González Martínez y Orellana, 2000; Samper, Hernández Cabrera y Bellón, 2003; Carcedo, 2003) han mostrado un mayor grado de convergencia dialectal.

No obstante, y a pesar de la homogeneidad esperable por las condiciones de las muestras y los objetivos generales de la investigación, los resultados aportan diferencias sociales ( $y$, por supuesto, dialectales) que no deben dejar de destacarse, a pesar de que las cifras no nos ofrezcan distancias tan marcadas como las que podrían resultar de muestras más heterogéneas, con más diferencias iniciales entre los encuestados.

Esto último es lo que hace que sean más relevantes las diferencias que encontramos, que 2 puntos de distancia en la media de un centro de interés

6. Nos serviremos de un solo ejemplo, contundente, de lo que decimos. Carcedo (2003: 208), al comparar las 20 palabras de máxima disponibilidad del centro de interés 'Partes del cuerpo' en dos comunidades geográficamente alejadas (Asturias y Puerto Rico), encontró nada menos que 18 términos comunes (los dos que faltan en cada lista aparecen en lugares más retrasados, pero próximos, en la otra). Estamos seguros de que podríamos ampliar la base de comparación a otras muchas sintopías (como hace el propio Carcedo con Cádiz) y seguiríamos encontrando un resultado muy semejante porque esos 18 vocablos compartidos (ojo, cabeza, brazo, piema, nariz, dedo, mano, pie, oreja, boca, rodilla, cuello, corazón, uña, pelo, diente, estómago y pulmón) forman parte indudable del español general y figuran siempre en los primeros lugares de todos los listados de léxico disponible. También debemos recordar, como indica Hernández Muñoz (2004), que las palabras más disponibles en este centro de interés son aprendidas a una edad relativamente temprana. 
puedan resultar realmente significativos. Por eso hemos de valorar muy positivamente la investigación de Gómez Molina y Gómez Devís (2004) porque ellos se han preocupado de contrastar qué diferencias entre los distintos factores son estadísticamente significativas mediante la aplicación de pruebas como el análisis factorial simple, el análisis de regresión simple, los coeficientes de correlación múltiple y el análisis factorial de componentes principales. Es este un camino que puede aportar fiabilidad y dar respaldo a las apreciaciones, presumiblemente justificadas pero impresionistas, de algunos trabajos.

Por otro lado, creo que debe insistirse en la oportunidad de la consideración cualitativa de algunos casos de variación léxica. Ejemplos de formas alternantes como las indicadas por Moreno Fernández (1998: 29) pueden ser analizados con mucho provecho en nuestros materiales de disponibilidad, ya que estos permiten, por ejemplo, cotejar los índices de $(a)$ las unidades (como guagualautobuis, papa/patata en Gran Canaria) de distinta procedencia que coinciden en una determinada comunidad, $(b)$ las formas (como estómagol barriga, nucalcogote) adscritas a distintos niveles sociales o a diferentes estilos y $(c)$ las formas tabúes y las eufemísticas (como las designaciones de las partes del cuerpo).

\subsection{El factor 'sexo'}

Esta variable, de acuerdo con los criterios metodológicos acordados en la reunión de Bilbao, ha sido contemplada en todas las investigaciones del proyecto.

En los trabajos más recientes se sigue manteniendo una característica que ya habíamos indicado para los estudios anteriores. En todas las comunidades, como puede verse en el cuadro siguiente,? se constata una superioridad numérica de las alumnas, que llegan a alcanzar un porcentaje muy elevado en la muestra aragonesa y en la conquense. En unos casos esto se debe al procedimiento aleatorio de selección: el factor 'sexo' no se preestratifica, ya que suele estar condicionado por razones prácticas; normalmente se seleccionan unos determinados centros de enseñanza, pero en ellos se pasa la encuesta a los grupos que están disponibles en un momento determinado. En otros casos, los investigadores han procurado ya en el diseño de la muestra que las proporciones de hombres y mujeres se adecuen a la distribución que se observa en los universos estudiados.

7. Los datos han sido tomados de los trabajos de Gómez Molina y Gómez Devís (2004), Serrano (2003), Blasco, Torres, Pérez Edo y Forment (2003), Amal et al. (2004), Hennández Muñoz (2004), Bartol (en prensa) y Ayora (2003). 
CUADRO 3. Distribución de los sujetos según la variable 'sexo' en trabajos recientes del proyecto

\begin{tabular}{|c|c|c|}
\hline Comulnidades & Hombres & Mujeres \\
\hline Valencia & 208 & 257 \\
\hline Lérida & 20 & 28 \\
\hline Barcelona & 178 & 222 \\
\hline Aragón & 132 & 285 \\
\hline Cuenca & 42 & 75 \\
\hline Soria & 45 & 55 \\
\hline Ceuta & 122 & 144 \\
\hline
\end{tabular}

Este rasgo, común a todas las investigaciones del proyecto panhispánico, no se observa, sin embargo, en los estudios de disponibilidad realizados con encuestados de otras edades. En la investigación experimental que llevó a cabo en Las Palmas de Gran Canaria, Samper Hernández (2003), que utilizó un criterio aleatorio de selección, contó con una muestra compuesta por 166 alumnos y 154 alumnas de primaria y secundaria $(51.9 \%$ y $48.1 \%$, respectivamente). Esto mismo ocurre en el estudio almeriense de García Megía, pues también aquí los porcentajes de niños y niñas son del $51.7 \%$ y del $48.3 \%$, respectivamente. Parece que en los cursos inferiores la representación de los dos sexos en las aulas es distinta a la que se observa al final de la enseñanza media.

En el artículo de presentación de los logros alcanzados por el proyecto (Samper, Bellón y Samper Hernández, 2003) ya destacábamos que en la mayoría de los trabajos, tanto en este como en el otro lado del Átlántico, se ponía de manifiesto una gran homogeneidad general en las respuestas aportadas por hombres y mujeres. Por ejemplo, Benítez (1994) encontró en Madrid un alto porcentaje de léxico convergente: en la mayoría de los campos se supera el $50 \%$ de coincidencias entre los dos sexos, un porcentaje alto si consideramos que el investigador trabaja con el total de vocablos. Benítez concluye que las divergencias probablemente tenderían a disminuir. Muy pocas diferencias encontraron también Mateo (1998) en Almería y Carcedo (2001) en Asturias. Son datos que coinciden con los aportados por los primeros investigadores franceses (Gougenheim et al., 1967) y por Dimitrijevic (1969). Después de lo que indicamos sobre las muestras, estos resultados no son sorprendentes.

Sin embargo, queremos llamar la atención sobrc las aportaciones de otros trabajos. Por ejemplo, López Morales, aunque también destacó la escasa incidencia del sexo de los informantes en los resultados de las encuestas de 
Puerto Rico, constató la superioridad de los estudiantes varones en tres grados de la enseñanza elemental. Este mismo hecho lo observa Galloso (2002) en el distrito universitario de Salamanca, puesto que sus datos ofrecen una superioridad cuantitativa de los hombres en Zamora y Salamanca.

Frente a estos últimos resultados, muchos de los estudios realizados tanto en la América hispanohablante como en España, aunque coinciden en señalar la poca relevancia del factor sexo, destacan una ligera superioridad léxica de las mujeres.

Los estudiosos chilenos de la Universidad de Concepción (Echeverría et al., 1987) fueron los primeros en poner de manifiesto que las chicas destacaban en ciertos centros de interés tradicionalmente relacionados con el rol social femenino, como 'La ropa' y 'La cocina'. En la misma línea, el único campo léxico en el que los alumnos aportaban más palabras era el de 'Herramientas'. Posteriormente, en un estudio de 1999, Valencia y Echeverría reforzaron parcialmente estas conclusiones, pues de nuevo las niñas producían un mayor número de palabras en campos como 'Alimentos y bebidas', 'La cocina', 'La casa', 'La ropa' y 'Los muebles de la casa'. Esta peculiaridad, aunque normalmente no conlleva diferencias numéricas notables, se refleja en muchos de los estudios sobre disponibilidad léxica. Así, Butrón (1989: 35) subrayó que las chicas puertorriqueñas percibían «una gama más variada y amplia» de colores que los chicos.

En la muestra analizada por Samper y Hernández Cabrera (1997), las mujeres grancanarias superan abiertamente a los hombres en 'Alimentos y bebidas' y 'Los colores', y también, aunque de forma algo menos destacada, en 'La ropa', 'Los muebles de la casa', 'Objetos colocados en la mesa para la comida' y 'La cocina'. Los hombres, por su parte, destacan ligeramente en centros más relacionados con el rol social masculino: 'Iluminación, calefacción y medios de airear un recinto', 'El campo', 'Medios de transporte' y 'Juegos y distracciones'.

En Cádiz y en Córdoba, González Martínez (1997) y Bellón (2003), respectivamente, observaron también la relación entre determinados campos léxicos (como 'La ropa', 'Los muebles de la casa' y 'La cocina') y el incremento de la producción léxica de las mujeres. Los hombres ofrecen porcentajes más altos de incorporación de palabras en "Irabajos del campo y del jardín' y en 'Iluminación, calefacción y medios para airear un recinto'. Tampoco debemos olvidar que en el estudio del distrito salmantino de Galloso que antes citábamos, las mujeres de Ávila y Salamanca aventajan a los hombres en 'La ropa', 'Alimentos y bebidas' y 'La cocina', de manera paralela a los últimos trabajos reseñados.

¿Qué resultados nos proporcionan las nuevas investigaciones? Aunque todavía no tenemos cifras de todas, algunas aportan datos de gran interés. Por 
ejemplo, en Valencia las chicas superan a los chicos tanto en la media general (20.8 vs. 19.6 de media) como en la particular de 15 centros. Entre los campos diferenciados a favor de las mujeres figuran, entre otros, los de 'La ropa', 'Alimentos y bebidas' y 'La cocina'.

En otra investigación reciente, la de Ayora en Ceuta (2003: 132), nos encontramos asimismo con que, dentro del equilibrio general que destaca la autora, las mujeres superan a los hombres, por más de dos puntos de promedio, en tres centros de interés, precisamente 'Alimentos y bebidas', 'La cocina' y 'Los colores'. También en la comunidad leridana, estudiada por Serrano (2003), las alumnas obtienen en 'La ropa' y en 'Alimentos y bebidas' unos porcentajes claramente superiores (más de 3 puntos de diferencia) a los que presentan sus compañeros. Son resultados semejantes a los que aporta Bartol (en prensa) para Soria, provincia donde las mujeres superan a los hombres en quince de los dieciséis centros; de nuevo, 'La ropa'; 'Los muebles de la casa', 'Alimentos y bebidas' y 'La cocina' figuran entre los más diferenciados.

La investigación grancanaria de diversos cursos escolares de Samper Hemández (2003) confirma los datos anteriores. La autora observa una gran semejanza en el grado de disponibilidad léxica de chicos y chicas, pero resalta que, al igual que en otros estudios, las niñas aventajan a los niños en los campos de 'La ropa', 'Los muebles de la casa', 'Alimentos y bebidas', 'La cocina' y 'Los colores'.

No deja de ser curioso que en la población juvenil actual se sigan manteniendo esas diferencias cuantitativas en centros de interés asociados tradicionalmente con los papeles masculino y femenino. Es un aspecto en cierta medida inesperado que, por consiguiente, ha de seguir analizándose en próximos estudios, Habría que considerar asimismo si la correlación del factor 'sexo' con otros de los condicionantes contemplados en las investigaciones (por ejemplo, el factor urbano/rural) puede arrojar luz sobre matices diferenciadores que los datos globales no permiten distinguir con claridad. Análisis como el propuesto por Bellón (2003) pueden ser útiles para comprobar diferencias de disponibilidad entre grupos reducidos de hablantes.

Hasta ahora nos hemos referido solo a aspectos cuantitativos. Pero el análisis cualitativo de los vocablos puede darnos también una información valiosa sobre la existencia de posibles divergencias en el léxico actualizado en las encuestas por hombres y mujeres. En este sentido es muy interesante el detallado análisis comparativo que hacen Gómez Molina y Gómez Devís (2004) de las 50 primeras palabras de cada subgrupo en Valencia. Como cabía esperar, hombres y mujeres comparten un elevado porcentaje $(85 \%)$ de ese léxico, que puede considerarse en gran medida prototípico. Sin embargo, las diferencias tienen mucha relevancia porque se trata del léxico dc disponibilidad más inmediata. Así, por ejemplo, en el centro 5 resalta la preferencia de los chicos por las bebidas frente a las chicas, que incorporan 
más alimentos. Donde los roles tradicionales se manifiestan más nítidamente es en el campo 'Juegos y distracciones' con la aparición, en los listados de los chicos, de squash, motociclismo, consola, waterpolo, fútbol sala, paddle..., mientras que las chicas sitúan en esa franja de disponibilidad vocablos como cuerda, patinar, aeróbic, goma o gimnasia rítmica.

Hernández Muñoz (2004) no halla gran diferencia en el léxico actualizado por hombres y mujeres en Cuenca, pero su análisis se basa, en esta ocasión, en los diez primeros vocablos de cada grupo, una franja que propicia precisamente la aparición del léxico prototípico del campo, el más común. No obstante, Hernández Muñoz aclara que las chicas presentan algunos términos propios (entre los que se encuentran nombres de juegos como comba, muñeca y bailar) o muestran preferencia por profesiones como enfermero/a y psicólogo/a.

Samper Hernández (2003) encontró asimismo una alta homogeneidad en el léxico disponible de ambos sexos en el segmento que supone el 75\% de frecuencia acumulada. La estudiosa canaria expone que las menores coincidencias afloran en los centros 'Juegos y distracciones' y 'La ropa'. Las divergencias en los juegos se concretan en la aparición en los listados femeninos exclusivamente de palabras como ballet, conejito de la suerte o crucigrama, frente a boxeo, coche teledirigido, coger olas o fumar, solo nombrados por los alumnos. Además, otros términos muestran una disponibilidad marcadamente más alta entre las niñas (casitas, peluche, ciertos juegos de mesa) mientras que la situación contraria se produce en vocablos como lucha canaria, paddle, surf o waterpolo.

Como hemos indicado, en los estudios hechos hasta el momento ha predominado la perspectiva cuantitativa, que ha resultado sorprendentemente pertinente en algunos centros de interés y ha confirmado las apreciaciones sobre el sexismo léxico que se han venido indicando en distintos trabajos (García Mouton, 1999: 70-71). Pero no cabe duda de que estas pruebas basadas en asociaciones abiertas también ofrecen diferencias cualitativas de interés. Hasta ahora las comparaciones de este tipo se han ceñido a las primeras posiciones, aquellas que recogen un vocabulario prototípico, poco propicio para el establecimiento de grandes diferencias; habría que comprobar si las tendencias que atisbamos hoy se concretan más nítidamente en parcelas más amplias de los listados (por ejemplo, con la aparición mayor o menor de ciertos subgrupos léxicos dentro de cada uno de los campos) y también habría que analizar cómo se organizan determinadas formas alternantes en ambos sexos.

\subsection{La variable 'nivel sociocultural'}

El interés por relacionar el caudal léxico disponible con las diferencias socioculturales supone una de las más importantes innovaciones de los estudios 
hispánicos, ya que ni las primeras investigaciones francesas (Gougenheim et $a l, 1967)$, ni la de Dimitrijevic (1969), ni las que se realizaron en la órbita de la escuela canadiense contemplaron la variable 'nivel sociocultural'.

La impontancia de este condicionante en la determinación de las diferencias léxicas entre los hablantes ha sido puesta de manifiesto desde los primeros estudios de López Morales $(1973,1979)$ y ha sido confirmada prácticamente por todas las investigaciones sobre disponibilidal léxica que se han realizado en Hispanoamérica y en España. Los resultados han venido ofreciendo tina asociación fuerte cntre disponibilidad y nivel socioeconómico, ya que aquélla disminuye notoriamente en los sociolectos más bajos. El cuadro siguiente refleja lo que venimos diciendo:

CuADro 4. Promedio de respuestas según nivel sociocultural en distintas investigaciones hispánicas.

\begin{tabular}{|c|c|c|c|}
\hline & 1 & 2 & 3 \\
\hline R. Dominicana & 18 & 16.5 & 13 \\
\hline Gran Canaria & 22 & 20.7 & 19.9 \\
\hline Cádiz & 19.1 & 18.6 & 18.2 \\
\hline Córdoba & 21.2 & 20.1 & 19.3 \\
\hline Bilbao & 21.6 & - & 19.8 \\
\hline Soria & 22.6 & 21.3 & 20.6 \\
\hline Asturias & 20.5 & 19 & 18.2 \\
\hline
\end{tabular}

Para valorar adecuadamente estos resultados cuantitativos, no debemos olvidar las apreciaciones que hemos indicado sobre la relativa homogeneidad de las muestras. A ellas hemos de añadir, ahora más específicamente, que los criterios de clasificación sociocultural de nuestros encuestados son indirectos puesto que no nos basamos en las posibles diferencias culturales de los propios informantes -que, al fin y al cabo, cursan el mismo nivel escolar-- sino en las distancias culturales, laborales y económicas entre sus padres.

La variable 'nivel sociocultural' estratifica la muestra con claridad. Como indica Carcedo (2001: 74) al comentar los datos de Asturias, los resultados confirman la estrecha vinculación entre el vocabulario disponible que tienen los encuestados y su nivel sociocultural: los sujetos del estrato alto ofrecen en todos

8. Los datos de este cuadro provienen de los trabajos de Alba (1995), Samper y Hernández Cabrera (1997), González (2002), Bellón (2003), Etxebarria (1999), Bartol (en prensa) y Carcedo (2001). 
los centros de interés un mayor número de respuestas que los del medio, y estos, a su vez, mayor cantidad que los del nivel bajo. Del mismo modo, Blas Arroyo y Casanova (2003), al comentar la disponibilidad de 246 alumnos castellonenses en 8 campos léxicos, insisten en la significación del entorno sociocultural en que se desenvuelven los alumnos, si bien es cierto que las diferencias que ellos constataron son relevantes solamente en el caso de los dos grupos extremos.

Las últimas investigaciones realizadas en España confirman las conclusiones que esbozamos más arriba.. ${ }^{9}$ En Soria (Bartol, en prensa) el promedio de los informantes del nivel alto es más elevado que el del resto en doce campos léxicos. En Valencia (Gómez Molina y Gómez Devís, 2004) también se observa una innegable relación entre nivel sociocultural y léxico disponible; las diferencias más notorias se producen en los centros 'Partes del cuerpo', 'La ciudad', 'Profesiones y oficios' y 'Alimentos y bebidas'. Los datos ceutíes proporcionados por Ayora (2003) son igualmente corroboradores: al analizar la media de producción de palabras por centro de interés, se obtiene una diferencia considerable, que fluctúa de dos a cuatro puntos, entre los informantes de los sociolectos alto y bajo.

Los resultados por niveles educativos que aporta Samper Hernández (2003) en su investigación experimental de dos grupos socioculturales extremos muestran unas distancias más marcadas que las que ofrecen, en general, los estudios del proyecto panhispánico: en ningún centro de interés la diferencia es inferior a dos puntos de promedio. Pero lo que llama más la atención de sus datos es que la separación mayor entre los dos niveles socioculturales se produzca en el último curso analizado, lo que indica que las diferencias léxicas entre los grupos sociales no se aminoran, sino que por el contrario tienden a aumentar conforme progresa la edad de los encuestados.

A las diferencias numéricas constatadas se unen otras de carácter cualitativo que interesa destacar. Ya en la primera investigación hispánica de disponibilidad, a López Morales le llamó poderosamente la atención la existencia de un léxico no compartido por todos los niños, puesto que vocablos como tórax, epidermis o cromosoma solo eran actualizados por el grupo socioeconómico más altô. En cuanto a los datos cualitativos reflejados por las investigaciones españolas recientes, Gómez Molina y Gómez Devís (2004) señalan que en Valencia ésta constituye la variable sociológica que presenta menor convergencia conceptual. Las diferencias más importantes entre los tres sociolectos valencianos se manifiestan, en el margen de las 50 primeras palabras, en los centros de interés 'Trabajos del campo y del jardín', 'Juegos y

9. No tendré en cuenta los datos de la investigación de Lérida porque Serrano (2003) aclara que el número de encuestados del nivel alto que utilizó en el análisis inicial no es suficientemente representativo. 
distracciones' (con un vocabulario claramente caracterizador de cada estrato) y 'Profesiones' (cl nivel alto incluye notario, veterinario, cirujano, administrador, oftalmólogo, matemático; el medio, administrativo, ganadero, químico; y el bajo, prostituta, piloto, militar, obrero, pescadero). Destaco este centro porque también en el estudio de los distintos niveles escolares de Las Palmas es el campo en que se observan más discrepancias cualitativas entre los sociolecios. Los alumnos del nivel sociolectal bajo no incorporan voces como ministro, notario o ginecólogo, mientras que en los listados del alto faltan freganchín, vigilante de seguridad o limpiar. Habría que analizar si este centro de interés presenta este mismo comportamiento cualitativo en otros geolectos.

Hernández Muñoz indica que en Cuenca las respuestas del nivel sociocultural alto y medio presentan más coincidencias que las del bajo en las diez primeras posiciones. Hay que destacar que en el centro 'La cocina' el nivel bajo ofrezca en las dos primeras posiciones sartén y olla ( $\mathrm{y}$, un poco después, cazo, cazuela), que figuran en lugares mucho más retrasados en los otros dos estratos, los cuales incluyen más términos referidos a los electrodomésticos.

El análisis de las diferencias socioculturales en el léxico disponible puede aportarnos una información muy importante sobre determinados conjuntos de variantes en una comunidad de habla. Puede estudiarse, por ejemplo, la competencia entre un dialectalismo y el término del español general o entre dos dialectalismos: la disponibilidad más inmediata de uno de ellos en el nivel sociocultural más alto puede ser indicio de su aceptación social $y$, por consiguiente, de su permanencia futura, dada la edad de nuestros informantes. Hernández Cabrera y Samper Hernández (en prensa) han estudiado algunas parejas de estas lexías en la disponibilidad del centro de interés 'La ropa' y las han puesto en relación con los datos aportados por las encuestas de norma culta y norma popular en la capital grancanaria. De este modo han observado cómo algunas diferencias entre la norma culta y la norma popular tienen un perfecto paralelo en los resultados de la disponibilidad. Así se ve, por ejemplo, en la preferencia de los niveles más altos por el anglicismo suéter, frente al otro término también procedente del inglés, pulóver, más usado en los otros niveles.

En otros casos, los datos de disponibilidad muestran un comportamiento común de los jóvenes al conservar la norma comunitaria en un ejemplo de variación estable (como ocurre en chaquetalamericana), o al inclinarse por la voz más frecuente entre las generaciones anteriores, con el abandono progresivo de la que ya era francamente minoritaria (boinalbilbaína). En otros momentos puede constatarse el cambio generacional, con tendencia al triunfo de la forma estándar en el español de España, sobre todo si coincide con la preferida por la norma culta urbana: pendiente/zarcillo. El cambio puede deberse en otros ejemplos a la tabuización de un vocablo: los jóvenes de la comunidad 
grancanaria se comportan, como es frecuente, relegando el término marcado (sostén) y favoreciendo el predominio de la voz más neutra (sujetador).

Los datos que hemos recogido en las líneas precedentes ponen de manifiesto la indudable importancia de esta variable para explicar las diferencias en la disponibilidad léxica de los miembros de las distintas comunidades de habla. Es sumamente raro encontrar una comunidad donde no sea perceptible su incidencia; por otro lado, en muchas ocasiones constituye el factor que establece la discriminación social más acusada. De ahí el notable acierto de los equipos hispánicos de disponibilidad al incorporar un factor que aporta una información tan relevante, no solo desde el punto de vista estrictamente sociolingüístico sino también por su aplicación en el terreno de la enseñanza de la lengua.

\section{CONCLUSIONES}

Las páginas anteriores han servido para exponer sumariamente algunos de los logros del proyecto panhispánico de disponibilidad. Entre ellos destaca la atención que en él se ha dedicado a la incidencia de los factores sociales, algunos de los cuales han sido contemplados por vez primera en esta magna investigación, sin antecedentes en estudios previos de disponibilidad.

El análisis de los condicionantes sociales ha puesto de manifiesto que el factor que suele explicar la variación comunitaria de forma más acusada es el nivel sociocultural, aunque también es muy relevante el papel que en algunas zonas desempeña el tipo de centro escolar (público o privado), que no hemos podido comentar en esta ocasión. El condicionante 'sexo' ofrece en muchas sintopías unas divergencias léxicas que reflejan la separación de actividades e intereses entre hombres y mujeres, un resultado sorprendente en comunidades modernas, aunque es cierto que puede interpretarse como la pervivencia residual de unas diferencias tradicionales que van perdiéndose. La incidencia del factor 'sexo' constituye un capítulo abierto, que debe ser abordado en estudios futuros.

A pesar de que la selección de la muestra y la propia finalidad de la investigación no propicien la manifestación de una variación social muy marcada, nuestros resultados suponen la confirmación, una vez más, de que la lengua constituye una realidad heterogéneamente ordenada, en la linea de lo propugnado desde sus primeros pasos por la sociolingüística variacionista.

\section{REFERENCIAS BIBLIOGRÁFICAS}

Alba, O. (1995): Léxico disponible de la República Dominicana, Santiago de los Caballeros, Pontificia Universidad Católica Madre y Maestra. 
- (1998): «Variable léxica y dialectología hispánica», La Torre. Revista de la Universidad de Puerto Rico, 7-8: 299-316.

Arnal, M. ${ }^{\text {a }}$ L. (coord.); R. Castañer; J.M. Enguita; V. Lagưéns; A. B. Molné (2004): Léxico disponible de Aragón, Zaragoza, Libros Póntico.

Ayora Esteban, M." C. (2003): Disponibilidad léxica en Ceuta: aspectos sociolinguiuisticos (tesis doctoral inédita), 3 tomos, Universidad de Sevilla.

Bartol Hernández, J. A. (en prensa); "El léxico disponible de la provincia de Soria. Primeros datos», en Homenaje a Manuel Alvar, Zaragoza, Institución Fernando el Católico, MS

Bellón Fernández, J. J. (2003): Léxico disponible de la provincia de Córdoba (tesis doctoral inédita), 2 tomos, Universidad de Las Palmas de Gran Canaria. Benítez Pérez, P. (1994): «Convergencia y divergencia en el léxico de alumnos de COU», Revista de Estudios de Adquisición de la Lengua Española (REALE), 2: 39-45.

Blas Arroyo, J. L.; M. Casanova Ávalos (2003): «La influencia de la red educativa y del entorno sociocultural en la disponibilidad léxica. Estudio de las comunidades de habla castellonenses», en SÁnchez Miret, F. (ed.): Actas del XXIII Congreso Internacional de Lingiilistica y Filología Románica, $V$, Tübingen, Max Niemeyer.

Blasco Mateo, E.; A. Torres Torres; M. ${ }^{a}$ Á. Pérez Edo; M. ${ }^{a}$ M. Forment FERNÁNDEZ (2003): «La disponibilidad léxica en la provincia de Barcelona: aspectos metodológicos», comunicación presentada en el XXXIII Simposio de la Sociedad Española de Lingüística (Gerona, diciembre 2003), MS.

Borrego Nifto, J.; C. Fernández Juncal (2003): «iEn qué cambia la universidad la disponibilidad léxica de los preuniversitarios?», en MORENO, F. ET AL. (eds.): Lengua, variación y contexto. Estudios dedicados a. Humberto López Morales, I, Madrid, Arco/Libros, 167-178.

Butrón, G. (1989): «Aspectos sociolingüísticos de la disponibilidad léxica», Asomante, 1-2: 29-37.

Carcedo González, A. (2001): Léxico disponible de Asturias, Turku, Departamento de Español de la Universidad de Turku.

- (2003): «Unidad y variedad diatópica de la disponibilidad léxica del español: comparación de los inventarios de Puerto Rico, Cádiz y Asturias», en Moreno, F. ET al. (eds.): Lengua, variación y contexto. Estudios dedicados a Humberto López Morales, I, Madrid, Arco/Libros, 199-225.

DimtTrIJevic, N. R. (1969): Lexical availability, Heidelberg, Julius Gross Verlag. Echeverría, M. S.; M. ${ }^{a}$ O. Herrera; P. Moreno; F. Pradenas (1987): «Disponibilidad léxica en Educación Media», Revista de Lingüística Teórica y Aplicada, 25: 55-115.

EtXebarRIa Arostegui, M. (1999): «Disponibilidad léxica y enseñanza de la lengua materna en el área metropolitana del Gran Bilbao», en SAMPER 
Padilla, J.A. et al. (eds.): Actas del XI Congreso Internacional de la ALFAL, II, Las Palmas de Gran Canaria, Universidad de Las Palmas de Gran Canaria.

Galloso Camacho, M. ${ }^{a}$ V. (2002): El léxico de los estudiantes preuniversitarios en el distrito universitario de Salamanca, Salamanca, Universidad de Salamanca.

García Megía, A. (2003): La disponibilidad léxica en la ciudad de Almería (tesis doctoral inédita), 2 tomos, Universidad de Almería.

García Mouton, P. (1999): Cómo hablan las mujeres, Madrid, Arco/Libros.

Gómf7. Devís, M. ${ }^{a}$ B. (2003): La disponibilidad léxica de los estudiantes preuniversitarios valencianos: reflexión metodológica, análisis sociolingiiistico y aplicaciones (tesis doctoral), Universitat de València.

Gómez Molina, J.R.; M. ${ }^{a}$ B. Gómez Devís (2004): La disponibilidad léxica de los estudiantes preuniversitarios valencianos. Estudio de estratificación sociolingüistica, Valencia, Universitat de València (anejo núm. 56 de Quaderns de Filologia).

González Martínez, A. (1997): Disponibilidad léxica de Cádiz, Universidad de Cádiz, tesis doctoral.

- (2002): La disponibilidad léxica de los alumnos preuniversitarios de la provincia de Cádiz, Cádiz, Universidad de Cádiz.

González Martínez, A.; P. Orellana Ramírez (2000): «Cotejo de los léxicos disponibles de Cádiz y Zamora», Documentos de Español Actual (DEA), 2: 139-160.

Gougenheim, G.; R. MichéA; P. Rivenc; A. Sauvageot (1967 [1964]): L'elaboration du français fondamental ( $1^{\text {cr }}$ degré). Étude sur l'établissement d'un vocabulaire et d'une grammaire de base (nouvelle édition refondue et augmentée), París, Didier.

Hernández Cabrera, C. E.; M. Samper Hernández (en prensa): «Léxico disponible, norma culta y norma popular», en Homenaje a Manuel Alvar, Zaragoza, Institución Fernando el Católico. MS.

Hernández Muñoz, N. (2004): El léxico disponible de los estudiantes conquenses, Salamanca, Universidad de Salamanca.

López Chávez, J. (1992): «Alcances panhispánicos del léxico disponible», Lingüística, 4: 26-124.

López Chávez, J.; C. Strassburguer Frías (1987): «Otro cálculo del índice de disponibilidad léxica», en Presente y perspectiva de la investigación computacional en México. Actas del IV Simposio de la Asociación Mexicana de Lingüistica Aplicada, México, UNAM.

- (1991): «Un modelo para el cálculo del índice de disponibilidad léxica individual», en López Morales, H. (ed.), La enseñanza del español como lengua materna, Río Piedras, Universidad de Puerto Rico, 91-112. 
López Morales, H. (1973): Disponibilidad léxica en escolares de San Juan, MS.

- (1979): «Disponibilidad léxica y estratificación socioeconómica», en López MORales, H.: Dialectología y sociolinginistica. Temas puertorriqueños, Madrid, Hispanova de Ediciones, 173-181.

- (1999): Léxico disponible de Puerto Rico, Madrid, Arco/Libros.

LORÁN, R.; H. I,ÓPF, MORAIEs (1983): «Nouveau calcul de l'indice de disponibilité», MS.

Máteo Garcia, M. ${ }^{a}$ V. (1998): Disponibilidad léxica en el cou almeriense. Estudio de estratificación social, Almería, Universidad de Almería.

Moreno Fernández, F. (1998): Principios de sociolinguiística y sociología del lenguaje, Barcelona, Ariel.

Samper Hernández, M. (2003): Evolución de la disponibilidad léxica en estudiantes grancanarios de enseñanza primaria y secundaria (tesis doctoral inédita), 2 tomos, Universidad de Salamanca.

SAMPER PAdilla, J. A. (1999): «Léxico disponible y variación dialectal: datos de Puerto Rico y Gran Canaria», en Morales, A. ET AL. (eds.): Estudios de lingüistica hispánica. Homenaje a María Vaquero, San Juan de Puerto Rico, Universidad de Puerto Rico, 550-573.

Samper Padilla, J. A.; C.E. Hernández Cabrera (1997): «El estudio de la disponibilidad léxica en Gran Canaria: datos iniciales y variación sociolingüística», en AlmEidA, M.; J. DORTA (eds.), Contribuciones al estudio de la lingiística hispánica. Homenaje a Ramón Trujillo Carreño, II. Santa Cruz de Tenerife, Cabildo de Tenerife-Montesinos, 229-239.

Samper Padilla, J. A.; C. E. Hernández Cabrera; J. J. Bellón Fernández (2003): «Comparación de los léxicos disponibles de Gran Canaria y Córdoba», en Estudios sobre el español de Canarias. Actas del I Congreso Internacional sobre el español de Canarias, II, Islas Canarias, Academia Canaria de la Lengua, 1077-1099.

Samper Padilla, J. A.; J. J. Bellón Fernández; M. Samper Hernández (2003): «El proyecto de estudio de la disponibilidad léxica en español», en Ávila, R.; J. A. SAmPER; H. UedA et AL.: Pautas y pistas en el análisis del léxico hispano(americano), Frankfurt-Madrid, Vervuert-Iberoamericana, 27140

Serrano Zapata, M. (2003): Análisis sociolingüístico del léxico castellano disponible en la ciudad de Lleida (trabajo de investigación del programa de doctorado "Teoría del texto y su contexto", inédito), Universitat de Lleida.

VAlencia, ^.; M. S. Echeverría (1999 a): Disponibilidad léxica en estudiantes chilenos, Santiago de Chile, Universidad de Chile y Universidad de Concepción. 


\title{
ACCIÓN E INTERACCIÓN SOCIAL EN VARIACIÓN SINTÁCTICA Y DISCURSIVO-PRAGMÁTICA
}

\author{
María José Serrano Montesinos \\ Universidad de La Laguna
}

\section{INTRODUCIÓN}

$\mathbf{L}$ A parte morfosintáctica o gramatical de las lenguas es la más estable por una sencilla razón; preserva la unidad lingüística y permite la factibilidad de la comunicación entre sus hablantes. Pero este hecho no significa que no sea variable y que dicha variación no esté correlacionada con factores sociales. La variación a este nivel, como ya he señalado en otras ocasiones (Serrano, 1994, $1999 a, 2002$ ), está en estrecha dependencia con determinadas estructuras formales de la gramática.

Está generalmente establecido el término variación sintáctica para referirse a la posible correlación sociolingüística entre este plano y los factores sociales; de hecho, se trata de una perspectiva enmarcada en la sociolingüística de la variación o laboviana. Es indiscutible que la sintaxis puede estar igualmente correlacionada con factores sociales, si aceptamos la función social de toda lengua. Sin embargo, es posible que no todas las variantes sintácticas (como las fonológicas o las léxicas) constituyan opciones socialmente marcadas. En estos casos, la terminología apropiada sería variación sintáctica, es decir, la que está controlada exclusivamente por factores internos. Cuando la(s) alternancia(s) permite(n) correlaciones socialmente significativas, el término que se debería utilizar es el de variación sociosintáctica. Sin embargo, dado que el segundo caso es mucho más frecuente que el primero o, lo que es lo mismo, las variantes sintácticas suelen tener correlaciones con factores sociales ya desde el momento en que constituyen opciones o variantes comunicativas, no es desacertado seguir denominando variación sintáctica a lo que realmente es variación socio-sintáctica. Pero aún hay más precisiones que hacer: la variación sintáctica raramente es exclusivamente sintáctica, pues de forma casi general, se puede decir que la variación sintáctica es también discursiva, porque siempre se inserta en un discurso y su análisis va a requerir la valoración de un examen discursivo en el que aparecen las variantes. Por último, la variación sintáctica puede ser pragmática, además de discursiva porque, como he sugerido, es casi siempre 
necesario recurrir a ella para interpretar el alcance de la variación, sobre todo en el terreno de la significación, el más complejo y difícil de determinar. De todas formas, no siempre todas las variantes sintácticas participan de todos estos niveles a la vez y de la misma forma, como tendremos ocasión de comprobar. Por otra parte, el término «variación sintáctica» se extiende por definición tanto a los casos de variación exclusivamente sintáctica (prácticamente inexistente en un sentido estrictamente sintáctico, de ahí que aparezca en este trabajo entre comillas), como a los casos de variación sintáctica que interactúan con el discurso y la pragmática, que son los más comunes.

En lo que respecta al tema central de este trabajo, esto es, el factor social en el estudio de la variación sintáctica, he de señalar que dicho factor ha de entenderse en un sentido amplio; esto es, hay que estudiarlo en relación con lo comunicativo, debido a esa inserción discursiva y pragmática de la sintaxis.

La intención comunicativa, valor comunicativo y socio-comunicativo son elementos constantes que se desprenden de las variantes que encontramos en la lengua oral. Hay que señalar que la consideración de este factor no es nueva en sociolingüística ya que se ha aplicado, en gran medida, a las diferencias linguiísticas entre hombres y mujeres. Diversos autores han comprobado que las mujeres son tendentes a utilizar más elementos lingüísticos de negociación tales como marcadores discursivos (vale, venga, pues), realizan más actos de habla indirectos (_puedes prestarme el lápiz), más estrategias de cortesía positiva (si quieres... si puedes... disculpa que te pregunte) (Lakoff, 1975), utilizan con mayor frecuencia los diminutivos (chiquito, espera un poquito) y tienen un estilo conversacional internamente orientado a través del uso de casos participativos y propositivos (Smith, 1979).

También se ha observado un mayor número de uso de eufemismos entre las mujeres (Trudgill, 1974: 84), así como que tienen distintas pautas conversacionales y conservan los turnos de habla con menos interrupciones que los hombres (Cestero, 1994). La pronunciación de las mujeres es más estándar o con corrección más retórica (Smith, 1979); en Estados Unidos, las mujeres pronuncian la $/ \mathrm{r}$ / postvocálica con mayor frecuencia que los hombres en construcciones como cary bare (Smith, 1979: 441-442). Ellos por su parte, tienden a utilizar un discurso más directo y a evitar el uso de marcadores menos directos o de negociación (bueno, la verdad) (Serrano, 1999 b, 2001).

En un nivel más amplio, también ha sido comprobado que las mujeres tienen una mayor tendencia a preservar las pautas normativas y prestigiosas de la variedad o lengua que practican en su comunidad de habla, mientras que los hombres han revelado, en más de una ocasión, tendencias totalmente opuestas, lales como mayor uso de expresiones tabuizadas, construcciones o frases subestándares (Labov, 1983, 2001; Fasold, 1990, Trudgill, 1974, Romaine, 1996). Por otra parte, Goffman $(1959 / 1987,1981)$ ha señalado que la relación 
entre el discurso y el género es un componente más de la organización de la interacción social que se manifiesta ya desde la infancia (Kendall y Tannen, 2003: 551).

Todo esto no revela otra cosa que diferencias comunicativas asociadas a factores sociales, esto es, diferencias de representar y de enfocar la realidad con la lengua, derivadas de la distinta socialización de hombres y mujeres que sucede en todas las sociedades del mundo. Cabe esperar, por tanto, que además de hombres y mujeres, sean también miembros de otros grupos sociales los que tengan diferentes estilos comunicativos y que estos puedan ser asociados a las distintas variantes sintácticas utilizadas.

En este sentido, Lavandera (1984) ya había advertido la posibilidad de que, cuando se estudian las variantes sintácticas, entren en relación diferentes estilos comunicativos asociados a ellas; tal es el caso de su estudio de las formas verbales en las oraciones condicionales; si se compara el uso del indicativo (tengo) con el del condicional (tuviera) y se obtienen diferencias de uso entre distintos grupos sociales, se está señalando implícitamente que los grados de probabilidad real o posible asociados a cada una de estas formas verbales son la evidencia de la existencia de estilos socio-comunicativos diferenciados, lo cual podría dar lugar a interpretaciones clasistas o racistas de tales divergencias.

Ya desde hace mucho tiempo se ha insistido en que los distintos usos sociales de la lengua deben su valor social al hecho de que tienden a organizarse en sistemas de diferencias que a su vez reproducen el sistema de las diferencias sociales en el orden simbólico de las separaciones diferenciales (Bourdieu, 1985: 28). Esto significa que las diferencias sociales se acompañan de diferencias en el uso de la lengua, por lo que no parece desacertado afirmar que seguramente esas diferencias sociales que se reflejan en el uso de la lengua vengan acompañadas de diferencias en los estilos comunicativos o, lo que es lo mismo, diferencias en representar lingüísticamente una referencia compatible en un contexto determinado. Así, siguiendo a Bourdieu (1985: 11), las relaciones de comunicación por excelencia (los intercambios lingüísticos) constituyen relaciones de poder simbólico donde se actualizan las relaciones de fuerza entre sus locutores y los grupos a los que pertenecen. Por lo tanto, lo comunicativo está íntimamente relacionado con la posición del hablante con respecto al carácter de la audiencia y con un concepto clave: la interacción entre los miembros de dicha audiencia. Cabe afirmar que sólo de la observación de la interacción es posible extraer los factores que han incidido en el proceso socio-comunicativo.

Como señala Garfinkel (1967), los hablantes actúan en su devenir cotidiano dando sentido y construyendo las identidades sociales a través del uso lingüístico. Asegura así que interactuar es contar la interacción, esto es, 
el mismo hecho de interactuar lingüísticamente evidencia la interacción social, lo cual implica, por otra parte, que la realidad social es el producto de la interpretación concreta de los actos comunicativos, construyéndose y negociándose cada vez que se habla o, incluso, durante el decurso de un mismo acto comunicativo. Son los participantes, a través de sus interacciones quienes construyen y mantienen la realidad social (Tusón, 2002: 135). Toda sociedad está estratificada y, por ello, la comunicación entre clases supone una situación crítica (como ha dicho Bourdieu, 1985: 15) para la lengua utilizada. En este sentido quiero insistir que la sintaxis no es una excepción, por más que se haya señalado que no está involucrada en los procesos sociales del mismo modo que otros planos lingüísticos.

El primer concepto que hay que tener en cuenta es el contexto y las claves $o$ indicios de contextualización, que son los elementos que técnicamente dan lugar y producen el valor comunicativo. Gumperz considera que el contexto hay que entenderlo de dos maneras: como trasfondo social y cultural (las reglas del juego) y como los acontecimientos inmediatos que se van desarrollando y surgiendo en los eventos del habla (2003: 221). Así, la clave o indicio de la contextualización (término acuñado por este autor como contexualization che) se refiere a cualquier signo verbal que sirva para construir el campo contextual que conduce la interpretación del mensaje correctamente; de esta forma, fenómenos como el code-switching, la entonación, el uso de una forma verbal frente a otra (he cantado/canté), los marcadores del discurso, la ausencia o presencia del pronombre, son claves de contextualización, que permiten interpretar el mensaje en la forma culturalmente adecuada. Hay que enfatizar en la culturalidad de esas claves, ya que son variables de lengua a lengua e incluso dentro de una misma lengua.

Veamos a continuación cómo inciden dichas claves en los distintos tipos de variación sintáctica:

\section{a) Variación «exclusivamente» sintáctica}

Es necesario subrayar el hecho de que existen casos de variación sintáctica que no está marcada socialmente o en las que el efecto de los factores sociales es irrelevante. Aunque esto no le valdría simplemente el adjetivo de sintáctica, es cierto que algunas variantes de este plano carecen de una proyección social significativa, bien porque no se ha hallado, bien porque no se ha procedido a su estudio. Un ejemplo de este segundo caso es el del estudio de la variación entre los adjetivos demostrativos en español efectuado por Ranson (1999). La autora observa la existencia de variación en la posición antepuesta o postpuesta de los adjetivos este, ese, aquel: 
(1) Hecho como este piso yo no he visto ninguno / Venía en el piso este

(2) Viste mi sobrina, esa rubia que vive ahí / El hermano de mi prima esa, que quería que le hicieras la entrevista

(3) El dormitorio aquel... cuatrocientas mil / Aquel dormitorio...

Aunque describe los factores estrictamente sintácticos (presencia de adverbios temporales: mañana, este año, posición antepuesta y postpuesta) no puede prescindir del análisis de otros discursivos (función deíctica del adjetivo en relación con la frase, efecto positivo o negativo según la posición, etc). Se observa en esos usos una función emocional expresada por el hablante cuando postpone el adjetivo, que se podría considerar como marcada, de forma que le indica al oyente que interprete un valor afectivo positivo cuando usa la variante postpuesta (1999: 140). En la variación «sintáctica» podemos analizar cómo la posición del adjetivo demostrativo constituye una clave de contextualización que indica al oyente que infiera un contenido comunicativo afectivo si la variante va postpuesta (Ranson, 1999): «El piso este que hemos visto». En muchas variedades del español este orden no es irrelevante con respecto a su valor comunicativo; en español de Canarias, el adjetivo demostrativo este postpuesto, acompañado de una entonación especial, puede contextualizar un valor negativo: El vestido este que te pusiste el otro día, Qué le pasa a la chica esta...

En ese caso, el hablante sitúa la inferencia que debe adquirir el oyente para la correcta interpretación del mensaje, esto es, combina su intención comunicativa con un recurso cultural y lingüísticamente apropiado.

Otro caso de variación denominada estrictamente sintáctica y sin covariación social es el del fenómeno de la de la subida de los clíticos (Silva Corvalán, 2001: 184). En principio, los clíticos pueden aparecer sintácticamente a la izquierda del verbo en algunas perífrasis: Puedo hacerlo mañana / Lo puedo hacer mañana, Quiero verlo / Lo quiero ver. Los autores que han analizado el fenómeno comprueban que esta variación está relacionada con la semántica del verbo auxiliar, de forma que con aquellos verbos menos gramaticalizados y con mayor contenido léxico (tales como querer) el clítico tiende a aparecer en posición preverbal: Lo quiero ver / Lo sé hacer. Por el contrario, con aquellos verbos más gramaticalizados y por lo tanto, menos léxicos, el clítico tiende a la postposición: Puedo verlo, Voy a verlo. Al estar la variante sintáctica condicionada a su relación semántica con el verbo, comprobamos nuevamente que no es posible hablar de variación sintáctica en términos estrictos, más bien se trata de un caso de variación sintácticosemántica. Por su parte, Torres Cacoullos (1999) ha profundizado en el caso de la variación existente en la subida de los clíticos en la lengua española, tanto en textos diacrónicos como sincrónicos. Este fenómeno, presente en construcciones como: Me estoy cansando / estoy cansándome, está condicio- 
nado de forma muy íntima con factores sintácticos (que la autora denomina mecánicos), tales como: la presencia de una expresión de gerundio que puede o no absorber el clítico:

Entonces, se bajan de la cama descalcitos o sucios; lo que sea, tengo que estarlos mirando (vs. estar mirándolos)

El tipo de verbo que aparece en forma de gerundio (estar, $i r$, o la perífrasis estar + gerundio: Va agarrándo/le le va agarrando, así como la presencia de material lingüístico entre el verbo principal y el verbo que acompaña el clítico: Va caminando por la calle mayor y agarrándole, son los elementos que restringen la variación. Torres Cacoullos precisa minuciosamente todos los elementos sintácticos que intervienen en està variación y concluye que tanto en textos antiguos como en otros actuales procedentes de la ciudad de México la subida de los clíticos obedece a un fenómeno puramente sintáctico en el que se ha formalizado la fusión del gerundio con el clítico (agarrándole, mirándolos) en detrimento de la aparición del clítico postpuesto, consumando así un proceso de gramaticalización de una forma sintáctica. Sin embargo, concluye que el ascenso del clítico presenta un mayor número de ocurrencias en enunciados conversacionales que en textos formales (1999: 165).

En el cuadro siguiente se comparan las frecuencias de la subida de los clíticos en español antiguo y en el español de México:

\begin{tabular}{|l|c|c|c|c|}
\hline \multicolumn{5}{|c|}{ Frecuencias de subida de clíticos con diferentes verbos } \\
\hline & Estar & Ir & Andar & Seguir \\
\hline Español Antigúo & $71 \%(20)$ & $97 \%(77)$ & $90 \%(9)$ & ---- \\
\hline Ciudad de México & $89 \%(103)$ & $93 \%(53)$ & $75 \%(21)$ & $80 \%(4)$ \\
\hline
\end{tabular}

En cuanto a los factores sociales, tampoco esta autora pasa a estudiar la posibilidad de que esta variación esté constreñida socialmente, pero intuitivamente es poco probable que lo esté, dada su naturaleza fuertemente formal o interna.

\section{b) Variación sintáctico-discursiva}

Los estudios de variación sintáctica necesitan por fuerza el auxilio de otras herramientas metodológicas para poder definir adecuadamente el contexto de la variación. En el apartado anterior, las variantes presentadas dejaban entrever en mayor o menor medida algunos elementos discursivos; y es que no puede ser de otra forma, porque la sintaxis se halla enmarcada siempre en un discurso 
particular y sólo de la conjunción con unos u otros factores del mismo es posible explicar óptimamente la naturaleza de la variación sintáctica. Un caso de variación sintáctica que está en estrecha dependencia de factores discursivos es la expresión de la forma pronominal de sujeto, una variante sintáctica clásica que ha sido analizada por muchos autores.

(4) Son veinte casos que tú/0 te los tienes que aprender

(5) Yo/0, desde luego, nunca pensé que iba a pasar eso (Serrano, 2002: 30)

El estudio de la expresión del sujeto se realiza conforme al hecho normativo de que en español la expresión del sujeto es opcional, por lo tanto, la presencia del pronombre debe entenderse como una variante de su ausencia con alguna motivación comunicativa, dado que si formalmente no es necesario el sujeto, funcionalmente da indicios de serlo. Según Silva Corvalán (2001: 154) los factores recurrentes que aparecen en estas variantes sintácticas son:

-El establecimiento del tópico oracional o de una unidad discursiva:

(6) Yo, lo que pienso es que debería dársele una oportunidad a este nuevo presidente

-La expresión de información focal (nueva o contrastiva):

(7) Lo sabíamos, nosotros lo sabíamos antes de que se nos comunicara a nosotros

-La clarificación del referente del sujeto:

(8) Venía a comer ella todos los días

-La correferencialidad con el sujeto precedente:

(9) Yo hablo bien español, pero el francés lo hablo muy mal

Este último factor parece ser el que resultó estadísticamente más representativo en todos los casos, según esta autora. A pesar de la rentabilidad que supone la explotación del uso del pronombre en todas esas circunstancias discursivas, los resultados en cuanto a su correlación social no son tan homogéneos. En su investigación sobre el español hablado en Caracas, Bentivoglio (1987) no encuentra patrones sociales significativos, aún cuando pasa a analizar la distribución social. En los resultados encuentra que la clase alta y la baja obtienen unos porcentajes iguales en lo que respecta a la expresión del pronombre sujeto de primera persona (yo): clase alta (40\%), clase baja (40\%), 
así como entre hombres $(41 \%)$ y mujeres $(40 \%)$. Se trata, por tanto, de una variante sintáctico-discursiva sin correlación social significativa.

Para este fenómeno de variación, la clave de la contextualización depende de la intención pragmática del oyente y la inferencia que pretenda proporcionar al oyente; si el hablante utiliza tú como en el ejemplo: «Son veinte casos que tú te los tienes que aprender», la clave o el indicio no está en señalar la persona sujelo de la acción (tú lo tienes que aprender) sino el hecho de indicar al oyente que interprete una referencia generalizadora (son veinte casos que hay que aprender). Así pues, pragmáticamente tíi no significa tú. Se trata este de un recurso culturalmente establecido en español. Igual ocurre con el caso de la primera persona (yo) que es recurrente cuando se inicia un nuevo turno en la conversación dando como clave contextualizadora que se desea o se tiene intención de iniciarlo: Pues yo... yo lo que creo... yo ayer fui...

Otro ejemplo de variación sintáctico-discursiva es el estudio del uso del infinitivo en la lengua oral como forma alternante al subjuntivo en oraciones completivas (Serrano, 2004 a):

(10) Que toca el bombo basto. Y, ¿qué van a hacer? Que toca de oído el tío. Y, ¿qué van a hacer entonces? De momento (a) Manolo el del bombo le van a poner profesor de solfeo. Si, anda, para que toque el bombo con partitura (para tocar el bombo con partitura).

(11) Eso estorba a Guardiola además. Y todo sólo sirve para que le metan (para meterle) tres goles. Entonces, cuando quita, dos defensas resulta que ese equipo sólo recibe un gol y mete cinco.

La alternancia entre estas dos formas verbales obedece, por una parte a factores estrictamente gramaticales y que, además, son restrictivos de la posibilidad de que se produzca la alternancia, tales como el tipo de verbo de la oración subordinada (transitivo o intransitivo), la mención de sus correspondientes objetos directos y la presencia de material linguístico entre la preposición y la frase completiva. Además de esos factores estrictamente sintácticos, la vinculación de estas variantes sintácticas con características del discurso es muy relevante. La gestión del tema (argumentativo, narrativo, expositivo y descriptivo), la gestión de la información (nueva, conocida), así como la gestión personal (apelativa: yo, uno); elocutiva: tú, vosotros, ellos e impersonal) fueron factores determinantes de la alternancia: 


\begin{tabular}{|l|cr|cr|}
\hline \multicolumn{5}{|c|}{ FACTORES DISCURSIVOS } \\
\hline & \multicolumn{2}{|c|}{ Para +infinitivo } & \multicolumn{2}{c|}{ Para+subjuntivo } \\
\hline Gestión del tema & & & & \\
Argumentativo & $12 / 378$ & $3 \%$ & $132 / 196$ & $67 \%$ \\
Narrativo & $65 / 378$ & $17 \%$ & $50 / 196$ & $25 \%$ \\
Expositivo & $153 / 378$ & $40 \%$ & $10 / 196$ & $5 \%$ \\
Descriptivo & $148 / 378$ & $39 \%$ & $4 / 196$ & $2 \%$ \\
\hline Gestión de la información & & & & \\
Nueva & $125 / 378$ & $33 \%$ & $123 / 196$ & $63 \%$ \\
Conocida & $253 / 378$ & $66 \%$ & $73 / 196$ & $37 \%$ \\
\hline Gestión personal & & & & \\
Apelativa (yo, uno) & $38 / 378$ & $10 \%$ & $66 / 196$ & $34 \%$ \\
Elocutiva (tú, vosotros, ellos) & $98 / 378$ & $26 \%$ & $117 / 196$ & $60 \%$ \\
Impersonal & $242 / 378$ & $64 \%$ & $10 / 196$ & $5 \%$ \\
\hline
\end{tabular}

Del análisis de los factores discursivos estudiados podemos también establecer regularidades que afectan al uso de una y otra forma. La gestión del tema es un factor que distribuye de forma desigual la oración completiva; así, aquéllas con infinitivo aparecen con mayor frecuencia en temas expositivos y descriptivos que en los argumentativos o narrativos, donde el subjuntivo obtuvo mayor representación (Serrano, 2004 a: 143).

El infinitivo actúa como clave contextualizadora que señala que la gestión del tema del que se habla es más descriptiva que narrativa o argumentativa, pues para estas dos últimas suele ser más frecuente la aparición de la forma flexionada en competencia con el subjuntivo.

Además, la clave contextualizadora en este fenómeno de alternancia es la de alertar al oyente para que asigne un referente concreto al agente del verbo subordinado: «Un muneco tiene, para que tenga valor educativo», cosa que no ocurre cuando se utiliza el infinitivo, en la que la presuposición orienta al oyente hacia una inferencia impersonal: «Te declararía fiesta oficial el cuarenta de mayo para quitarnos el sayo del miedo a la libertad», que, por otra parte, no cumple esa función de asignar un referente concreto (incluso aunque aparezca acompañado de un clítico).

En el siguiente diálogo ambos hablantes tienen una postura argumentativa con respecto a un hecho (que Manolo el del bombo no toca bien), al final del mismo, el hablante B emplea el subjuntivo en la completiva para anclar la inferencia de una posición argumentativa (para que toque el bombo con partitura), que no se la proporcionaría el uso del infinitivo (para tocar el bombo con partitura), posible en este co-texto y además, para centrar la 
referencia personal en el sujeto del debate (Manolo), que tampoco se lo proporcionaría el infinitivo. La clave contextualizadora en este ejemplo es el uso del subjuntivo, que le indica al oyente que infiera: «reafirmo mi posición».

A:Que toca el bombo basto.

$B: Y$, ¿qué van a hacer?

A: Que toca de oído el tío.

$\mathrm{B}:$ Y, ¿qqué van a hacer entonces?

A: De momento (a) Manolo el del bombo le van a poner profesor de solfeo.

B: Si, anda, para que toque el bombo con partitura (vs. para tocar el bombo con partitura) (Serrano, $2004 a: 138$ )

Asimismo, el infinitivo contextualiza hacia la generalización o a la impersonalidad, esto es, proporciona una inferencia para ser interpretado en este sentido, como los numerosos ejemplos donde viene expreso sin subordinacion: Yo estudiar, estudio; Lo que es coner, no he comido nada. La interacción entre hablante y oyente(s) o audiencia consiste en describir los procesos de producción y de interpretación, con todo lo que conlleva (valores, posiciones sociales, conflictos, etc.).

Se puede llegar así a la conclusión de que en variación sintáctica no son muchos los casos que puedan definirse estrictamente como «sintácticos», pues, de un modo u otro, hay otros factores que la condicionan: los discursivos son uno de ellos, pero además están los pragmáticos, estrechamente vinculados con los primeros y que muestro a continuación.

c) Variación sintáctico-discursivo-pragmática

En mi estudio sobre las formas verbales de las oraciones condicionales en la ciudad de La Laguna (Serrano, 1994) advertí que en el aislamiento de las variantes que iban a ser estudiadas intervenían factores discursivos determinantes. Para el caso de las oraciones condicionales reales consideré que el tiempo de la prótasis o condicionante, al estar discursivamente antepuesto a la oración principal o subordinada, influía de forma notable en la forma verbal que debería aparecer en ella. Así por ejemplo, para una variante en la que ambas formas aparecen en indicativo: «Si no tienes agua, no puedes lavar» apareció como dato muy significativo el hecho de que aparece el indicativo en la apódosis cuando ambas formas del periodo aparecen negadas $(94 \%, .78)$, probablemente para contrarrestar la asertividad propia del modo indicativo cuando se desea exponer un enunciado negativo (Serrano, 1994: 118). En cambio, cuando la prótasis no aparece negada, la probabilidad de que aparezca negación en la apódosis resultó ser mucho menor $(19 \%, .43)$ (Serrano, 1994: 121), lo cual 
además coincidió con el cambio en la forma verbal de la misma, construyéndose así en condicional: «Si tengo que salir y llueve, me abrigaría». Asimismo, en esta investigación recurrí a criterios pragmáticos para demostrar que los cuatro grupos de oraciones condicionales (reales, potenciales, irreales de pasado e irreales referidas al no pasado) mantenían invariable la referencia o la significación. Dichos procedimientos pragmáticos fueron hechos explícitos antes de proceder al estudio lingüístico y a sus respectivas correlaciones sociales: así pues, señalé que es posible establecer variantes de significación en un nivel de abstracción en el que entran en juego otros elementos siendo el significado pragmático (tomado y considerado por oposición al cognitivo, literal o convencional) el que está presente en la variación. De la misma forma que, aisladamente, dos palabras pueden parecer sinónimas si no se analizan los contextos de distribución, en las variantes sintácticas, el significado será el mismo debido tanto a la distribución lingüística de las mismas (que se estudia ad hoc) como al contexto comunicativo específico en el que se encuentre (Serrano, 1994: 54). Así pues, en primer lugar, fue definido ese contexto general aislando las variables según el grado de probabilidad pragmática de cada oración condicional (real, potencial, irreal referida al pasado e irreal referidas al no pasado). Por ejemplo, de un contexto comunicativo de realidad como el siguiente (Serrano, 1994: 40):

(12) Si no encuentras aparcamiento... bueno eso para mí, normalmente, lo que hay es que lo dejo el coche en casa y bajo caminando, normalmente en Santa Cruz si voy... igual lo dejo en las afueras, veces, si vas de compras o eso, es preferible, lo suelo hacer así, si no me hago a la idea, y normalmente encuentro sitio donde aparcar, lo normal es que lo deje quieto y que venga caminando, pero es cuestión de acostumbrarte.

...se extraen tres enunciados con valor condicional:

1. Si no encuentras aparcamiento... bueno... eso, para mí, normalmente lo que hay es que lo dejo el coche en casa y bajo caminando

2. Si voy... igual lo dejo en las afueras

3. Si vas de compras o eso, es preferible, lo suelo hacer así

En la primera oración (condicional real) actúa todo el discurso desde el comienzo, porque se parte de las implicaturas básicas de la conversación, esto es, la pregunta (y consecuentemente la respuesta) se implican en términos de realidad. Dado que el indicativo es un modo adecuado (aunque no necesario) para expresar circunstancias pragmáticamente insertadas en un contexto de realidad, la elección del indicativo en este caso obedece tanto a su propio significado, como a las demandas del discurso comunicativo donde aparece 
(Serrano, 1994: 59). En la segunda oración, no intervienen todas y las mismas circunstancias; se sigue partiendo de una implicatura que es el contexto anterior y por eso se sigue insertando la frase en un marco pragmáticamente real. Sin embargo, no parece estar condicionada por el contexto siguiente, por lo que la aparición del indicativo se manifiesta como una consecuencia del contexto precedente real. La tercera oración está asimismo condicionada por cl contexto pragmático real, aunque la implicación inicial conespondiente a lá pregunta está más difuminada y es, por lo tanto, menor (Serrano, 1994: 59-60).

El procedimiento para determinar variables y variantes en todos los tipos de oraciones condicionales fue el de observar el contexto pragmático de inserción de cada una de las frases, teniendo en cuenta el discurso comunicativo del que se extraían. Además, mi posición sobre el significado en este trabajo concreto se resume como la evidencia de que en un mismo contexto situacional comunicativo las formas de las oraciones condicionales, aún cuando su significado cognitivo, literal o convencional sea diferente, obtienen el mismo valor socio-comunicativo, actualizando por tanto su significado en las emisiones en las que aparece (Serrano, 1994: 66). Las oraciones condicionales en la ciudad de La Laguna obtuvieron correlaciones sociales significativas, pudiendo observar, además, indicios de algunos cambios en marcha (Serrano, 1995,1996).

Al hilo de esto, las formas verbales son claves contextualizadoras tal $y$ como se ha sugerido en el estudio de la variación sintáctico-discursivopragmática de las oraciones condicionales. En las condicionales potenciales, esto es, aquellas cn las que cl grado de probabilidad se sitúa en lo 'posible', las formas verbales que alternan son el subjuntivo (pr)-indicativo (ap) y el subjuntivo $(p r)$-condicional (ap):

(13) Si mi hijo suspendiera, no lo dejaba (vs. dejaría) que repitiera curso

(14) Si me sacara la lotería, me compraba (vs. compraria) un piso

(15) Si me lo ofrecieran otro trabajo, lo cogería (cogía) sin pensarlo dos veces

Los indicios o claves de contextualización en las estructuras condicionales son los que anclan el grado de probabilidad que el oyente quiere que infiera el hablante; su intención comunicativa viene dada por la modulación del grado de probabilidad que asigna a la secuencia a través de la forma verbal. Así pues, cuando el hablante quiere insertar su inferencia en un grado mayor de probabilidad de cumplimiento de lo expresado utiliza el indicativo en la apódosis: «Si me dieran tres meses (de vacaciones), a la playa seguro que me iba». Con todo, es posible que dicha inferencia de probabilidad sea suministrada no solamente por la forma verbal, sino también por el co-texto de la oración, de forma que la sentencia anterior, puede tener el mismo grado aunque se formulara en condicional (... a la playa seguro que me iría), porque 
toda la información da por 'posible' la probabilidad dentro del conjunto de inferencias universales y del conocimiento compartido de la realidad, esto es, el hecho de que es posible tener más vacaciones (o tiempo libre) así como el hecho de que se pueda ir a la playa en vacaciones, enmarcan al enunciado en la mencionada inferencia. El indicativo en la apódosis no hace otra cosa que ser coherente con todo el enunciado de significado potencial. Indicativo y subjuntivo alternan pues, en la apódosis de las oraciones condicionales pragmáticamente potenciales. El valor interactivo de la comunicación con las formas verbales en las condicionales resulta de anclar el grado de probabilidad, mediante el cual le indica al oyente que presuponga su intención comunicativa.

La distribución social de la alternancia muestra que el condicional es más frecuentemente usado por las mujeres de los niveles medio-bajo (83\%) y medio-alto $(71 \%)$ y por los jóvenes del estrato más alto (89\%). El indicativo es más usado por los hombres de los niveles bajo (43\%) y medio-alto (35\%) (Serrano 1994: 130-131 y 134-135). En principio parece factible suponer que ambas variantes conviven de forma estable, aunque el condicional, al ser la forma normativa, goza de un mayor prestigio que el indicativo.

En los casos de variación discursivo-pragmática se hace más obvia la clave de contextualización, y esto es porque los componentes lingüísticos de este tipo de variación, como he señalado, están totalmente insertados en el nivel discursivo-pragmático.

\section{d) Variación discursivo-pragmática}

Una de las facetas más innovadoras en los estudios del discurso ha sido y sigue siendo la del estudio de los elementos denominados marcadores del discurso, categoría amplia que engloba a los conectores, a los operadores, a los organizadores y a los enlaces extraoracionales. La metodología discursiva permite estudiar y analizar estos elementos como partes de la oración con una función concreta en la frase, en la secuencia y en la emisión que puede aportar información muy valiosa en lo que respecta al significado de las mismas. Estas unidades habían sido relegadas a las categorías de «muletillas», «interjecciones», «conjunciones», $\sin$ que su auténtico valor en la frase fuera debidamente analizado.

El marcador discursivo es considerado como una hipercategoría (Cortés, 2002: 348; Llorente Arcocha, 1996) y la única condición necesaria para que un elemento lingüístico pueda ser adscrito a la clase de los marcadores del discurso es que funcione como tal, o que su aparición esté asociada a la realización de actos pragmático-discursivos destinados no al sentido proposicional del discurso, sino a la organización de las acciones y contenidos 
que el hablante realiza a lo largo del proceso comunicativo. La función principal de los marcadores es la de proporcionar coherencia y cohesión al enunciado y a la emisión y, a partir de ahí, se desgajan los distintos valores de cada uno de ellos. A esto hay que añadir que sería casi imposible emitir una frase sin un marcador, por cuanto ésta vendría carente de sentido e incompleta. Sin embargo, ha señalado Portolés (1998) que la cohesión no es un fin en el uso de los conectores, sino una consecuencia. I os hablantes no los emplean para lograr un texto coherente, los utilizan para que el oyente obtenga las inferencias pertinentes en los enunciados. A esto habría que matizar que dicho resultado es el producto de una intención comunicativa que el hablante materializa en el uso de un marcador concreto, por lo que hay que deducir que existe una acción de producción e interpretación.

Un ejemplo es el de los marcadores del discurso en una situación de contacto de lenguas, como el llevado a cabo por Sankoff et. al (1997) en Montreal entre jóvenes hablantes anglófonos bilingües (inglés-francés), concretamente, la generación nacida entre 1960 y 1975, el periodo donde la inmersión en francés en las escuelas fue posible. Los hablantes procedían de una escuela en un barrio bilingüe donde había un programa de inmersión en francés así como un alto número de clases de francés. Se analizó el uso de los marcadores del discurso en entrevistas realizadas en francés y se clasificaron estos elementos de acuerdo a tres características:

a) Marcadores con un correlato en inglés:

(16) Ah oui, on était comme une des seuls, on était peut-être cing dans mon année qui parlaient le deux langues, puis c'était comme "wow", tu sais

Oh, yeah we were like the only ones, there were about five of us in my year that spoke both languages so it was like "wow", you know.

b) Marcadores sin un equivalente en inglés:

(17) Quand j'ai commencé mes tours de natation synchronisée là, j’ai trouvé il$y$-avait plus des, des, des francophones

When I started my synchronized swimming classes -, I found there were more French speakers

c) Marcadores sin un equivalente en inglés pero con un elemento que comparte la misma función:

(18) Mais je pense que c'était comme l'appreciation de l'art. Fait que c'est ca But I think it was like art appreciation. It follows that, that's it 
Aunque el trabajo tenía como objetivo estudiar el uso de los marcadores del francés por hablantes anglófonos, los informantes fueron también entrevistados en inglés para poder comparar la frecuencia de los marcadores. Los marcadores del inglés más frecuentemente usados fueron: I mean, like, so, well y you know. En las entrevistas, de una duración de quince minutos, el uso de los marcadores en la entrevista en inglés tuvo una frecuencia de 65.3 marcadores en los 15 minutos, mientras que en francés la frecuencia sólo alcanzó 24.5. Obviamente esta distribución no fue homogénea, pues hubo hablantes que usaban más marcadores que otros.

Los resultados demuestran que el uso de los marcadores del francés cuando se habla en esta lengua por parte de los jóvenes anglófonos aumenta de forma espectacular según el grado de conocimiento y de inmersión que han tenido en la lengua francesa. Esto significa que los hablantes con una menor destreza en francés eran menos tendentes a usar marcadores, lo cual daba lugar, por otra parte, a un discurso menos coherente y cohesivo que el de aquellos otros que usaban los marcadores comunicativamente apropiados en cada momento. Además se tuvo en cuenta el hecho de que los hablantes podían interactuar en francés en numerosas ocasiones dado en barrio bilinguie en el que vivían. Así pues, se concluye, por una parte, que la habilidad para dominar otra lengua que no es la nativa pasa por el dominio del uso de estas unidades, que organizan y enclavan los actos de habla y permiten una comunicación más fluida y precisa; los marcadores, según las autoras (Sankoff et. al., 1997: 214), son una muestra más del uso vernacular de la lengua, esto es, no es posible eliminarlos sin que eso tenga un efecto negativo sobre la norma, en este caso, del francés. Es por eso por lo que los hablantes que aprenden francés en una situación de bilingüismo serán más competentes lingüísticamente si conocen la inserción apropiada de estos elementos. Por otra parte, la correlación social de esta situación lingüística resultó ser muy significativa; distintos grupos sociales se inclinaban por el uso de uno y de otro marcador. Entre los hombres, el marcador bien (well), similar a là fue más frecuente que entre las mujeres. Bon (sin equivalente en inglés) resultó ser más frecuente en un estilo informal y se halló una distribución similar entre hombres y mujeres. La correlación de alors (equivalente a so en inglés) resultó significativa con la clase social; aquellos jóvenes con una mejor posición dentro de la muestra estudiada preferían el uso de este marcador. Por el contrario, las clases sociales inferiores fueron más tendentes al uso de fait que (equivalente a so en inglés).

El valor socio-comunicativo de estas unidades y sus distintas claves de contextualización, puestas de manifiesto a través de las variantes sintácticas (discursivas o discursivo-pragmáticas) están distribuidos por la escala social de forma diferente. Esto es, distintos grupos sociales utilizan de forma 
heterogénea dichos recursos comunicativos que no son otra cosa que el resultado de la interacción socio-comunicativa en la lengua cotidiana. Dichos recursos son regulares, sistemáticos y además tienen una inserción cultural determinada que permite que puedan participar en esos procesos de presuposiciones e inferencias, pero, además, son referente de la posición social (real o virtual) que el hablante toma ante su interlocutor, lo cual significa que el uso de las variantes está correlacionado, por una parte, con las necesidades comunicativas del momento de habla $\mathrm{y}$, por otra, con las características sociales del hablante. El intercambio socio-comunicativo es un proceso reflexivo de acción y reacción entre los participantes en un momento comunicativo de habia.

En los casos de variación discursivo-pragmática se hace más obvia la clave de contextualización, y esto es porque los componentes lingüísticos de este tipo de variación, como he señalado, están totalmente insertados en el nivel discursivo-pragmático; la función meramente gramatical o sintáctica queda totalmente oscurecida. Por ejemplo, todos los marcadores discursivos proveen al discurso de un valor específico, culturalmente establecido, que aporta la clave de la interacción. Cuando un hablante dice: venga, lo dicho, o vale, bueno, pues, mira, está proporcionando al oyente las inferencias para que interprete en un sentido determinado su secuencia.

\section{CONCLUSIONES}

Cabe afirmar con contundencia que en variación sintáctica es imprescindible contar con el factor comunicativo, porque es el que tiende el puente entre lo lingüístico y lo social $\mathrm{y}$, aunque, de forma generalmente implícita, todos los estudios de variación sintáctica han tenido que recurrir de alguna forma al valor comunicativo que conllevan las variantes, éste no ha sido tratado con la rigurosidad y con la importancia requeridas. Como señalan Calsamiglia y Tusón (1999: 15), los hablantes tienen a su disposición un repertorio comunicativo, que puede estar formado por una o más lenguas, por diferentes variedades lingüísticas y -añado yo- por distintas variantes dentro de esas variedades. Esas variantes no constituyen siempre un repertorio, porque el hablante no siempre es capaz de elegir (para elegir debería conocer todo el repertorio, y esto no siempre es así), pero cuando tiene a su disposición esas opciones, estarán controladas - de forma consciente o no- por unas constantes de tipo social (características de los usuarios) y de tipo comunicativo (factores del contexto y de la intcracción), que, aunque heterogéneas, están sujetas a principios de regularidad y funcionalidad (Serrano, 2002). 
Asimismo, en la variación sintáctica es asimismo fundamental observar la interacción como un proceso que pone en marcha la negociación que va desde recibir lo que se nos dice a ver cómo son recibidas nuestras contribuciones verbales (Gumperz, 2003: 218). Considero que esa interacción es la que permite entender el significado de las secuencias en un sentido concreto y que, precisamente ese significado no sea el denotativo, literal o convencional (como han querido ver algunos detractores de la variación sintáctica), pues lo que emerge de la interacción es compartir o no compartir interpretaciones, tal y como establece Gumperz (2003: 218). El significado en variación sintáctica se actualiza en el acto de habla correspondiente, como ya he apuntado en otros trabajos (Serrano, 1994, $1999 b, 2004 b$ ), y promueve un valor único y específico en cada acto comunicativo o de habla.

Ese valor comunicativo y, por lo tanto, social es el que permite dar consistencia a la realización social del plano gramatical o morfosintáctico de las lenguas. En palabras de Bourdieu (1985: 13), lo que circula en el mercado lingüístico no es la lengua, sino discursos estilísticamente caracterizados que se colocan a la vez del lado de la producción y del lado de la recepción. Así pues, cada hablante asume una posición social frente a su interlocutor(es) o audiencia que estará condicionado por tres características fundamentales:

a) Su conciencia como pertenencia a un grupo social (sexo o género, clase social, generación, raza etnia, grupo marginal, etc.). Estos rasgos funcionan como un mosaico, esto es, es evidente que todo hablante como ser social participa de varias características sociales a la vez, pero también es posible que, en un contexto socio-comunicativo determinado sobresalga una característica más que otra; por ejemplo, una mujer, de la segunda generación y de una clase social media-alta, puede hacer más relevante su condición de ser mujer que la de ser una buena profesional, ante una conversación con otra mujer que gire en torno a crianza de niños en un contexto físico informal, puede que use una mayor cantidad de variantes prototípicas de esa gestión del tema, pero también puede hacer un empleo más exagerado de marcadores discursivos vacíos ( $m i$ niña, no sé, vamos a ver), de diminutivos (cremita, chiquito), etc. Posiblemente elementos lingüísticos como esos no los usaría en otras situaciones comunicativas en las que, además de ser mujer, exhiba su condición de profesional cualificado. Incluso, en la gestión de ese mismo tema, es muy probable que esa misma mujer no utilice el mismo estilo comunicativo si se trata de una compañera de trabajo que comparte sus mismas características sociales. 
b) El contexto físico de la comunicación, entendido como espacio situacional donde tiene lugar el encuentro comunicativo. Este espacio condicionará el nivel de formalidad y se asociará, a su vez, al grado de simetría social de los participantes en el acto comunicativo.

c) El nivel de simetría o asimetría social establecido entre hablante y oyente, que puede ser real o virtual. Además de su conciencia de pertenecer a un grupo o grupos sociales determinados, el hablante se adapta al grado de exigencia social que cree ver en su interlocutor derivado de ese nivel de simetría que también cree ver con él mismo. Puede ser real si el hablante toma una posición acorde con sus propias características sociales o puede ser virtual si, en ese momento comunicativo, los roles sociales se distienden y no se actúa exactamente conforme a lo que se esperaría de su condición social. Un hablante de la primera o segunda generación puede cambiar sus pautas de interacción social con una persona de mayor edad por la que, culturalmente, se le deba respeto Así pues es posible que ese hablante joven no utilice todo el repertorio de formas lingüísticas que conoce por situarse asimétricamente con respecto a su interlocutor.

Para desentrañar los mecanismos sociolingüísticos que subyacen a la interacción comunicativa, tal y como hemos visto en los ejemplos expuestos, disponemos de toda una gama de indicios que nos pueden llevar a comprender el uso en función de ella. La lengua, la cultura, la sociedad y el individuo son las claves de un proceso creativo que se actualiza en el discurso.

\section{REFERENCIAS BHBLIOGRÁFICAS}

Bentivoglio, P. (1987): Los sujetos pronominales de primera persona en el habla de Caracas, Universidad Central de Venezuela

Bourdieu, P. (1985): Language and symbolic power, Cambridge, Polity Press.

Calsamiglia, H. y A. Tusón (1999): Las cosas del decir. Manual de Análisis del Discurso, Barcelona, Ariel.

Cestero, A. M. (1994): «Alternancia de turnos de habla en lengua española: la influencia del sexo y la edad de los interlocutores», Pragmalinguiística, 2: $123-149$.

CORTÉs, L. (2002): Los estudios del español hablado entre 1950 y 1999, Madrid, Arco-Libros.

FASOLD, R. (1990): The Sociolinguistics of Language, Oxford, Blackwell. 
Garfinkel, E. (1967): Studies in Ethnometodology, Nueva York, Prentice Hall. GOFFMAN, E. (1959/1987): La presentación de la persona en la vida cotidiana, Madrid, Amorrotu.

- (1981): Forms of talk, Philadelphia, University of Pennsylvania Press.

GUMPERZ, J. (2003) «Interactional sociolinguistics: a personal perspective», en SCHIFFrin, et al., 215-228

Kendall, S. y D. TANnen (2003): «Discourse and Gender», en Schiffrin et al. (eds), 548-567.

Labov, W. (1972/1983): Modelos sociolingüísticos, Madrid, Cátedra.

- (2001): Principles of linguistic change. Social factors, Oxford, Blackwell. LAKOFF, R.(1975): «Language in context», Language, 48: 907-927.

LaVANDERa, B. (1984): Variación y significado, Buenos Aires, Hachette.

LlORENTE ARCOCHA, M. T. (1996): Organizadores de la conversación. Operadores discursivos en español, Salamanca, Publicaciones de la Universidad Pontificia.

PORTOLÉs, J. (1998): Marcadores del discurso, Madrid, Ariel.

RANSON, D. (1999): «Variación sintáctica del adjetivo demostrativo en español», en SERRANo (ed), 121-142.

Romaine, S. (1996): El lenguaje en la sociedad, Barcelona, Ariel.

Sankoff, G., P. Thibault, N. Nagy; H. Blondeau; M. O. Fonollosa y

L. GAGNON (1997): «Variation in the Use of Discourse Markers in a Language Contact Situation», Language Variation and Change, 9: 191-217.

SCHERER, K. Y H. GiLes (1979): Social markers in speech, Cambridge, University Press.

SCHIFFrIN, D. (1994): Approaches to discourse, Oxford, Blackwell.

Schiffrin, D., D. Tannen y Heidi E. Hamilton (2003): The Handbook of Discourse Analysis, Oxford, Blackwell.

SERRANO, M. J. (1994): La variación sintáctica: formas verbales del periodo hipotético en español, Madrid, Entinema.

- (1995): «Sobre un cambio sintáctico en Español Canario: del indicativo al subjuntivo y condicional», Hispania, 78: 178-189.

- (1996): Cambio sintáctico y prestigio lingüístico, Madrid/Frankfurt, Iberoamericana/Vervuert.

- (1999 a): Estudios de variación sintáctica, Madrid/Frankfurt, Iberoamericana/Vervuert.

- (1999 b): «Bueno como marcador de inicio de turno y contraposición: estudio sociolinguístico», International Journal of the Sociology of Language, 140: 91-109.

- (2001): «The socio-communicative function of two discourse markers in Spanish», Estudios de Sociolinguiística, 21, 1: 101-122. 
- (2002): Aproximación a la Gramática del Discurso del Español, Múnich, Lincom Europa.

- (2004 a): «Entre la gramática y el discurso: subjuntivo e infinitivo en un contexto socio-comunicativo", Estudios de Sociolinguitstica, 5, 1:129-150.

- $(2004 b)$ : «La interacción entre sociolingüística, semántica y discurso», Oralia, 7: 181-205.

Sinva Corvalán, C. (2001): Sociolingüística y Pragmática del español, Georgetown, University Press.

SMITH, J. (1979): «Sex markers in speech» en SCHERER Y GILES, (eds): 109146.

TORRES CACOULlos, R. (1999): «Construction frequency and reductive change: diachronic and register variation in Spanish clitic climbing», Language Variation and Change, 11: 143-170.

TrudgILL, P. (1974): The social differentiation of English in Norwich, Cambridge, University Press.

Tusón, A. (2002): «El análisis de la conversación: entre la estructura y el sentido», Estudios de Sociolingiuística, 3, 1: 133-153.

Wolfram, W. (1969): A sociolinguistic description of Detroit Negro Speech, Washington, Center for Applied Linguistics. 


\section{SECCIÓN I ANÁLISIS DEL DISCURSO}




\title{
MESTIZAJE LINGÜÍSTICO \\ EN LA LITERATURA FEMENINA CHICANA
}

\author{
Ruth Aguila Tejeda \\ unam, México
}

Deslenguadas. Somos los del español deficiente.

We are your linguistic nigthmare, your linguistic aberration, your linguistic mestizaje, the subject of your burla.

Because we speak with tongues of fire we are culturally crucified.

Racially, culturally and linguistically somos huérfanos -we speak and orphan tongue.

Anzaldúa (1999: 80)

\section{INTRODUCCIÓN}

D

ENTRO de la narrativa femenina chicana, las funciones y el empleo del español y del inglés son básicamente cuestiones emotivas. En cada texto, las situaciones relacionadas con la familia ascendente, abuelos, tíos, padres se impone el uso del español; mientras que en situaciones externas al vínculo familiar o entre personajes más jóvenes como hijos o sobrinos, predomina el inglés. Ambas lenguas son el medio de expresión de sentimientos y el texto que se produce es un texto mestizo en más de una forma. Es por esto que me atrevo a decir que la elección de la lengua a emplear es decisión del sentimiento que surge en el cuerpo de la autora. La lengua contenida por el cuerpo, un cuerpo mestizo.

Si el mestizaje es una constante en la mayoría de los pueblos de Latinoamérica, en la producción de las escritoras chicanas y latinas residentes en Estados Unidos se encuentra concentrado este fenómeno: un mestizaje lingüístico casi natural, simbiosis de dos lenguas estructuralmente diferentes que, a fuerza de compartir territorios geográficos, llegan a una convivencia aparentemente armoniosa, pero cuya utilización simultánea o alternada obedece frecuentemente a códigos sociológicos y psicológicos muy sutiles.

Los territorios geográficos no son siempre estados colindantes; sin embargo, la frontera viva del español con el inglés sí es un fenómeno continuo y 
cambiante dada la sostenida migración de latinos en busca de una vida mejor y un trabajo de mayor remuneración que la de sus países de origen como son los casos de la particular situación de Puerto Rico, la aparición de importantes minorías como la cubana de Florida, la mexicana de California y Texas y la puertorriqueña de Nueva York, además del extenso, y ya bien asentado, mundo chicano con sus nuevos brotes en los más diversos y apartados puntos de la Unión Americana.

Se trata pues de una literatura fronteriza, más allá del sentido geográfico de la palabra, puesto que su temática nace en la encrucijada entre dos mundos. Las mujeres que se citan aquí, tanto autoras como protagonistas, navegan entre dos orillas, dos culturas, dos mentalidades y, sobre todo, dos lenguas: inglés y español. Esta última lengua se halla en situación de inferioridad social con respecto a la otra: menor prestigio del español en los Estados Unidos con respecto al inglés debido al inferior nivel económico y social de las minorías hispanohablantes. Las consecuencias y frecuentes determinantes del uso o inhibición del español son por un lado: un exagerado deseo de integración, que se manifiesta a veces por un rechazo y hasta menosprecio de la lengua materna, deseo de olvidar los orígenes lo que llevaría a un proceso de asimilación y, por otro, el orgullo de la propia identidad cuando el inmigrante latino ha llegado a una clara conciencia de la misma, produciéndose el efecto contrario, la revalorización y exacerbación de la cultura de origen y la crítica de la cultura de adopción. La especialista Rosaura Sánchez (1985: 61-70) parece tener muy en cuenta la situación social del emigrante al afirmar que al mismo tiempo que el español se pierde en algunos contextos, se resiste en otros con la misma intensidad, produciendo una circunstancia lingüística heterogénea y contradictoria.

Por mi parte concuerdo con la autora Olvido García Valdés (1997: 45-70), cuando dice que el mestizaje lingüístico, el chicano, es el medio de expresión bilingüe de los sentimientos en las escritoras chicanas, y aludiendo a la obra de Wittgenstein, Invesitigaciones filosóficas, establece que:

...pensamiento, lenguaje y forma de vida son indiscernibles. Forma de vida parece aquí equivaler a cultura. Se trataría de encontrar posibles vías de apertura, de quiebra de un universo lingüístico conformador. $Y$ una de esas vías de apertura parece ser el lenguaje de las emociones: Un lenguaje límite, un abrir las palabras y las cosas, característica femenina por excelencia.

Al releer la cita anterior es posible también comprobar que tenía razón Virginia Woolf al afirmar que la sintaxis literaria inventada por los hombres era demasiado rígida para la psicología femenina. Y que la lengua no existe en sí, sólo existen nuestros actos de habla, ya que cualquiera de nosotros habla de 
modo diferente la misma lengua, produciéndose así tantas lenguas como hablantes, y cada uno de nosotros deja su huella individual emotiva en su formulación lingüística. Dicho aspecto se reafirma en la literatura femenina chicana ya que una de sus características básicas es la oralidad.

Para hablar de la emociones, de la emotividad femenina en la literatura es indispensable mencionar que las mujeres de los contextos literarios chicanos son, sobre todo, sirvientas, secretarias, desempleadas, costureras, obreras no calificadas, abuelas analfabetas, niñas perdidas entre dos mundos. Se trata de mujeres sin preparación, aprisionadas en un sistema familiar y social opresivo, donde el binomio familia-trabajo presenta dos ámbitos en los que la mujer es la subalterna del hombre. En la casa le sirve, en el trabajo acata sus órdenes. Los dos mitos culturales que aparecen en este espacio de la mujer latina parecen ser Eva y Penélope. La mujer latina es al mismo tiempo víctima y causante del problema, ya que perpetúa esta situación al educar de diferente manera a los hijos varones y a las hijas, en desventaja desde el nacimiento.

Las mujeres de origen mexicano viven a menudo en un mundo de terror y violencia donde carecen de la más mínima independencia y su único sueño es escapar de ese mundo sórdido; sin embargo, y a pesar de este afán de liberarse del patriarcado, no pierden el respeto por la familia, la comunidad, el barrio y su gente; lo que les produce luego un complejo de culpa que no todas saben o pueden superar.

El factor común de las escritoras chicanas cuyas protagonistas viven estas situaciones, es evidentemente la búsqueda de la identidad de una mujer nueva, liberada de prejuicios sociales, así como la crítica de las instituciones sociales $y$ familiares.

La obra de la autora chicana Sandra Cisneros es especialmente representativa de los aspectos mencionados. En sus dos colecciones de relatos The House on Mango Street (1991) y Woman Hollering Creek and Other Stories (1992), se presenta a la mujer que lucha en un mundo bicultural y machista por obtener su identidad social y personal. Esta mujer es víctima de todos los mitos y tabúes hispanos que la han situado en segundo plano, siempre como madre y esposa antes que como mujer. Evoluciona entre dos mundos: la escuela, mundo anglosajón y el la familia, su mundo chicano. En este ir y venir de un ámbito a otro, de un idioma a otro. Las mujeres de Sandra Cisneros, como las Cherrie Moraga, Ana Castillo, Mary Helen Ponce, Sylvia Lizárraga, Gloria Velásquez, Helena María Viramontes, Alice Gaspar de Alba, entre otras, han perdido parte de su identidad y han desarrollado relaciones de amor y odio muy particulares con las dos lenguas en que se desenvuelven sus vidas. Ambos sentimientos son vividos simultáneamente, dependiendo de circunstancias socioculturales, económicas y familiares. 
En su trabajo sobre Sandra Cisneros, María Beltrán-Vocal (1995) señala el claro rechazo de la lengua española que manifiestan personajes como la niña Micaela, centrándolo en la persona de su abuela. En el caso de la niña Esperanza, cuyo nombre es claramente simbólico y heredado de su abuela, lo traduce al inglés para explicar su significado, pero lo rechaza porque no quiere convertirse en una mujer sometida a la fuerza, como aquella primera Esperanza,

Este papel de los abuelos, dentro de la problemática intergeneracional, como lo presenta en el prólogo de su Antologia de cuentistas chicanas, Rosamel Benavides (1993), es, además de sumamente importante, el elemento que une lingüísticamente pasado y presente. El abuelo o la abuela, los que cmigraron, son el único nexo con el mundo anterior, nexo que a veces se rechaza, por traer a la memoria un pasado de miseria y de ignorancia.

Los fragmentos a continuación ilustran la diversa interacción español, inglés en la creación literaria femenina chicana:

1. ...as Latinas living in the U.S., the issues of bilingualism and bi-culturalism are crucial. In este libro, we wish to stretch la imaginación, help the reader become accustomed to seeing two languages in a book, learning to make sense of a thing by picking up snatches here, phrases there, listening and reading differently. Cuentos validated the use of «spanglish» and «tex mex». Mixing English and Spanish in our writing and taking is a legitimate and creative response to accultiration. It doesn't mean that we are illiterate or assimilated as we are sometimes labelled by de Anglo and Latin American elite, Our audience is first and primarily the bicultural reader: The Latina in the U.S. Cuentos is written for her sensibility. Hopefully, one day the book can be translated entirely into Spanish to reach a wider Spanish-speaking audience. *(We have not italicised the Spanish or footnoted the translations in order to have the text visually reffect the bi-culural experience). (Gómez, Moraga y Romo- Camona, 1983).

2. Quiero decir that I know on the surface of things, this is not to make any sense. I spoke English at home: on the surface of things I not supposed to teet that my language has been stripped from me -1 am «bon American» College English educated, but what I must admit is that I have felt in my writing that the English was not cutting it. Entiendes? That there is something else, deep and behind my heart and I want to hold it hot bold in my hands of my writing and it will not come out sounding like English. Te prometo. No es inglés. And I have to wonder, is tit so that I have felt «too much» too emotional» «too sensitive» because I was trying to translate my feelings into English cadences? (Moraga y Castillo, 1998).

3. «Los Acknowledgements». Mi querido Público: [...] Praise to la bien bien linda Julie Grau, my editor. Ay, Julie, believe me, I am eternally gratefull for your unflagging cariño, patience and sensitive through the labor of this book. Gracias a la Divina Providencia que me mandó la muy powerful y miraculous literary 
protectora, Susan Bergholz, La Brava. Hay que echar gritos, prender velitas, hacer backflips. Te abrazo con mi corazón, Susan, por todo. Damas y Caballeros, un fuerte fuerte aplauso for my most special reader, the most special friend. El Dennis Mathis, Mi Ojitos. (Cisneros, 1991).

4. - ¿Ya hiciste la tarea? Gabriela mueve la cabeza y lo ve por debajo de sus cejas. - ¿Qué tienes que hacer? - Spelling y penmenchip.-Bueno, pos apúrate pa' que no la tengas que hacer el Saturday. You know the rules. - Ah, Daddy, this is a vacation. - ¿Qué vacation ni qué nada! Siempre haces lo mismo y por eso te castiga tu abuelo. Andale, ponte a hacerla. (Gaspar de Alba, 1993).

5. - ¿Qué me compraste, daddy? ¿Los pencils pa’ la escuela? - pregunta ella jadeante con los ojos saltándole como pájaros negros. Pepe no contesta: le da a bolsa del pan y los huevos y recoge las otras dos. Camina muy despacio, mientras Gabriela hace un mamaleche imaginario hacia la puerta, llevando la bolsa en la mano.

-No se te vaya a caer, eh?

-No dady, yo sé cómo. You know what?

- Habla español, hija, tu abuelo te va a pegar.

Gabriela se detiene en sus brincos y voltea la cara hacia su padre:

$-¿$ Por qué tengo que hablar 'spañol? This is a free country.

Pepe se agacha en cuclillas y baja la voz:

-Free or not, young lady, you talk Spanish in this house. It's his house, ¿me entiendes?

La niña empieza a saltar de nuevo.

- Yes, daddy, I mean, sí, papi.

(Gaspar de Alba, 1993).

En cuanto al lenguaje chicano podemos decir que existe más de un habla chicana, más de un dialecto. Esto se debe básicamente a que muchos de los personajes chicanos, son bilingües, con el dominio de un español estándar y un inglés estándar; otros sólo tienen dominio del inglés, pero hablan español en diferentes porcentajes y competencias. La fluidez de idioma predominante determina el uso y comodidad de cada hablante en la vida real y en el mundo literario. En ambos mundos se presenta el fenómeno lingüístico llamado codeswitching, spanglish o chicano. El término definitivo no ha quedado establecido todavía, pero cualquiera de estos términos describe la interacción alternada de dos lenguas en contacto: español e inglés. Sin embargo, el chicano también incluye palabras nuevas que no pertenecen a ninguna de las dos lenguas en contacto, sino que surgen de la combinación gramatical de ambas, por ejemplo verbos en inglés conjugados en español (wachear de to watch, parkear de to park); así como también la traducción literal de cognados (company es traducido como companía pero en referencia a visitas: pórtate bien tenemos companía en casa), y otras veces se traduce basándose en el 
sonido (grocery suena a cognado de grocería, así que se puede ir a la tienda de grocerias por comestibles). Finalmente,' tampoco hay que olvidar el mundo hispano del siglo XVI que dejó en el, ahora sur de Estados Unidos, una variedad de arcaísmos (semos, truje, ansina) que continúan en uso entre muchos de los hispanohablantes.

Gloria Anzaldúa (1999: 77) define a esta lengua entre fronteras como Chicano Spanish. Ina lengua que evoluciona y se enriquece con la adopción e invención de nuevas palabras, pero sobre todo que está viva. Anzaldúa, al igual que el resto de las autoras chicanas, creció bajo el estigma de hablar español como lengua prohibida en el ámbito escolar. Para otras, no pocas, las lenguas prohibidas eran dos: español en la escuela e inglés en casa. ${ }^{2}$

La represión lingüística es una constante en la sociedad angloamericana. Históricamente, la escuela ha sido en vehículo principal para lograr la asimilación de los diferentes grupos étnicos y promover las normas y valores culturales y lingüísticos angloamericanos. Así que, de forma intermitente, se han alentado o prohibido programas escolares bilingïes.

La población hispanohablante en edad adulta guarda en su memoria más de una escena de marginación, humillación y castigo por hablar español en clase, a la hora del lunch o incluso en áreas de esparcimiento. Durante décadas, muchas de las escuelas en los estados fronterizos imponían el mandato de «No Spanish Rules», lo que obligaba a los niños hispanohablantes a crear una frontera mental entre la lengua social y la familiar. La misma Anzaldúa nos ofrece su testimonio al respecto de lo que ella denomina «terrorismo linguístico»:

I remember being caught speaking Spanish at recess - that's was good for the three licks on the knuckles with a sharp ruler. I remember being sent to the corner of the classroom for «talking back» to the Anglo teacher when all I was trying to do was tell her how to pronounce my name. «lf you want to be American, speak 'American.' If you don't like it, go back to Mexico where you belong.»

I want to speak English. Pa'hallar buen trabajo tienes que saber hablar el inglés bien. Qué vale toda tu educación si todavia hablas inglés con un 'acent,' my mother would say, mortified that I spoke English like a Mexican. At Pan American University, I, and all Chicano students were required to take two speech classes. (Anzaldúa, 1999: 75).

1. En mi opinión el denominado caló merece una mención aparte, pues los cambios que sufre son más locales y temporales y su aparición en textos literarios chicanos es más esporádica que el resto de las características de la lengua chicana.

2. Ver cuentos «El pavo» de Alice Gaspar de Alba y « Ojalá que no!» de Lorraine Torres, en la antología de Rosamel Benavides (1993). En ambos se trata el tema el tema de la lengua como algo prohibido dependiendo el contexto. 
El autor Ed Morales (2002: 5) define el término spanglish de una forma más globalizada, abarcando ámbitos más allá del lingüístico. Refiere, por supuesto, un cruce de fronteras geográficas, pero también culturales raciales, sociales, políticas e ideológicas. Este cruce es de ida y vuelta, y cada vez más rápido y efectivo gracias a los medios masivos de comunicación. Y a pesar de que para casi todo el mundo la palabra spanglish hace referencia a algo negativo, bastardo, híbrido, producto de una mezcolanza, los latinos deliberadamente sustituyen con español palabras, terminaciones y frases en inglés, aun cuando son bilingües.

Spanglish harshest critics feel that its practitioners are in danger of becoming illiterate, much the way Marshall McLuhan once predicted rock and roll would destroy literacy. Surf any Spanish-language Internet site and you'll find this phrase: Click el mouse aquí.

Los programas escolares con todos sus intentos para evitar el uso del español no han podido detener el avance del spanglish. La Proposición 227 «English Only», hecha por Ron Unz en junio de 1998, es una de las iniciativas más recientes para evitar el uso del español. Con la manipulada frase de «English for the Children» se han desmantelado los programas de educación bilingüe, que hasta entonces funcionaban en el estado de California, sin ningún sustento pedagógico. Por supuesto las reacciones no se han hecho esperar, sobre todo en un estado que comprende la mayor población de origen mexicano. Pero este problema no es de índole local o estatal, ni siquiera nacional, sino que afecta de manera universal en esta era de globalización.

El Decálogo para una educación intercultural del pedagogo Francesc Carbonell (2000) propone articular una educación cívica, intercultural y antirracista a partir de diez normas que fomentan el respeto por las personas, la construcción de identidades responsables y unos aprendizajes significativos para todo el alumnado. La breve introducción a este decálogo es en tono bíblico y muestra la ambivalencia que puede contener un concepto como el lenguaje.

En verdad, en verdad os digo que eran tiempos de gran confusión. Habitaban en las aulas toda clase de gentes y razas, y oíanse en ellas todas las lenguas. Y mientras unos decían que era una bendición de los cielos, otros que era una enorme desgracia.

Existe también la contraparte, acá de este lado, en México los puristas de la lengua dicen que el español está en peligro, si no de desaparecer gracias a sus 400 millones de hablantes, sí de empobrecerse debido al más frecuente uso 
del spanglish a la que considera una «jerga creada por la población de origen hispano en Estados Unidos que no habla bien ninguna de las dos lenguas». (AFP, 2004)

En la actualidad, muchos chicanos de las áreas urbanas (quienes con mayor frecuencia conforman el mundo de la literatura), hablan y entienden un tercer idioma, el llamado calo, pocho o pachuco. Esta variación lingüística ha adquirido, para muchos investigadores anglosajones, el nombre de chicano; sin embargo, no es exclusiva de los llamados «cholos», pues casi todo el mundo chicano está impregnado de una mezcla de español e inglés, alteración de estructuras gramaticales y vocabulario con fenómenos semánticos y fonéticos híbridos, además de la invención de neologismos y de las variantes regionales.

Una clasificación de esta lengua entre fronteras que presenta Gloria Anzaldúa (1999: 77) puede servir de guía para entender mejor las variantes de chicano:

And because we are a complex, heterogeneous people, we speak many languages. Some of the languages we speak are:

1. Standard English

2. Working class and slang English

3. Standard Mexican Spanish

4. Standard Spanish

5. North Mexican Spanish dialect

6. Chicano Spanish (Texas, New Mexico, Arizona and California have regional yariations)

7. Tex-Mex

8. Pachuco (called caló).

A través de su literatura, las chicanas están recuperando su voz, legitimizando este mestizaje linguístico. Aunque en la vida real todavía sea difícil confrontar la autocensura como lo declara Gloria Anzaldúa (1999: 80): «Even among Chicanas we tend to speak English at parties or conferences. Yet, at the same time, we're afraid the other will think we're agringadas because we don't speak Chicano Spanish».

Hasta hoy, la creación de prosa chicana ha sido en su mayoría en inglés; sin embargo, cada vez se incluyen más y más palabras o frases en español, y en chicano, e incluso el número de publicaciones chicanas en español ha empezado a crecer. El mestizaje lingüístico, spanglish o lengua chicana es perseverante y alcanzará un lugar en la Literatura con mayúscula. 


\section{REFERENCIAS BIBLIOGRÁFICAS}

AGENCIA INTERNACIONAL DE NOTICIAS (AFP) (2004): «El español, en la batalla por la supervivencia», Milenio Diario, 3 de febrero, 42.

AnZaldú, G. (1999): Borderlands/La Frontera: The New Mestiza, San Francisco, Spinsters/Aunt Lute Press.

Beltrán Vocal, M. (1995): «La problemática chicana en dos obras de Sandra Cisneros: The House... y Woman Hollering...», Letras Femeninas, vol. XxI, Ed. Univ. of Nebraska, Lincoln, 15-25.

Benavides, R. (ed.) (1993): Antología de cuentistas chicanas, Estados Unidos de los ' 60 a los '90, Santiago de Chile, Editorial Cuarto Propio.

CARbonell, F. (2000): «Decálogo para una educación intercultural», Cuadernos de pedagogía, 290.

Cisneros, S. (1991): The House on Mango Street, Nueva York, Vintage Books.

- (1992): Woman Hollering Creek and Other Stories, Nueva York, Vintage Books.

- (1995): La casa en Mango Street, México, Alfaguara.

- (1996): El arroyo de la llorona y otros cuentos, Nueva York, Vintage Books.

García Valdés, O. (1997): «Un sentimiento penetra el cuerpo», Revista de Occidente, 190: 45-70.

Gaspar De Alba, A. (1993): «El pavo» en AA.VV. (eds): Antología de cuentistas chicanas, Estados Unidos de los '60 a los '90, Chile, Editorial Cuarto Propio.

Gómez, A., C. Moraga y M. Romocarmona (eds.) (1983): Cuentos: Stories by Latinas, Nueva York, Kitchen Table, Women of Color Press.

Moraga, C.; A. Castillo (eds.) (1998): Esta puente, mi espalda. Voces de mujeres tercermundistas en los Estados Unidos. USA, ISM Press.

Morales, E. (2002): Living in Spanglish. The search for Latino identity in America, Nueva York, St. Martin's Griffin.

SÁNCHEZ, R. (1985): Beyond Stereotypes. The Critical Analysis of Chicana Literature, USA, Ed. María Herrera-Sobek./ Binghamton Bilingual Press/Editorial Bilinguie. 



\title{
LAS FÓRMULAS RUTINARIAS ¿ACTOS O SUBACTOS?
}

\author{
M. Belén Alvarado Ortega \\ Universidad de Alicante
}

\section{INTRODUCCIÓN}

$\mathbf{E}$ $\mathrm{N}$ este trabajo nos encargamos de verificar una de las características más importantes de las fórmulas rutinarias, su independencia semántica. Para ello, comprobaremos, bajo la luz de la teoría de Briz y el grupo Val.Es.Co. (2003), si las fórmulas rutinarias son enunciados independientes como anuncia Gloria Corpas en su Manual de Fraseología Española (1996: 132) o si, por el contrario, son enunciados que, semánticamente, no se pueden separar del contexto en el que se producen.

Para llevar a cabo nuestro objetivo, nos basaremos en la teoría sobre fórmulas rutinarias que establece Gloria Corpas en su Manual de 1996 y en la aplicación del sistema de unidades, que propone Briz y el grupo Val.Es.Co. en el 2003, sobre dichas fórmulas. Nuestros ejemplos de conversación coloquial están extraídos del CREA (Corpus de Referencia del Español Actual de la Real Academia Española) y del ALCORE (Alicante Corpus del Español). Por tanto, analizaremos ejemplos orales reales de conversación para aplicar la teoría de Briz y el grupo Val.Es.Co. y comprobar así si las fórmulas rutinarias son enunciados independientes o no. Comenzaremos con la definición y con los rasgos que da Corpas (1996) para nuestro objeto de estudio.

\section{FÓRMULAS RUTINARIAS}

Tomamos el término que da Corpas (1996: 170), fórmulas rutinarias, para estos enunciados, puesto que su aportación a los estudios fraseológicos supone la ordenación justificada y la caracterización lógica de estas unidades, ya que en otros autores, no existía una definición uniforme para estas estructuras fraseológicas y las han agrupado bajo diversos nombres. Entre ellos han destacado Julio Casares (1969 (1950), Alberto Zuluaga $(1980,1992)$ y Florian Coulmas (1981).

Así, las fórmulas rutinarias están compuestas por dos o más palabras que se encuentran, en cierto modo, ritualizadas, es decir, que se utilizan en 
situaciones concretas de la vida cotidiana para expresar emociones y sentimientos del hablante como iPor fin!, ¿Qué quieres que te diga?, Por supuesto, o simplemente sirven para organizar y hacer transcurrir la conversación como y bueno, y tal, y eso. Corpas en 1996 establece una primera clasificación de las fórmulas rutinarias y distingue entre fórmulas rutinarias discursivas y fórmulas rutinarias psico-sociales. Nos centraremos en las primeras, puesto que son las que mayor índice de frecuencia presentan en la conversación coloquial.

Aparte de clasificar las fómulas rutinarias, la autora las sitúa a su vez en la tercera esfera fraseológica que denomina enunciados fraseológicos, y que se «caracterizan por constituir actos de habla, y por presentar fijación interna (material y de contenido) y externa, es decir, constituyen cadenas autónomas del habla y se formulan con entonación independiente, como corresponde a su carácter de unidades mínimas de comunicación» (Corpas 1996: 132). Por tanto, según esta afirmación, las fórmulas rutinarias son enunciados independientes, esto es, tienen un significado propio y son aislables dentro del contexto en el que se producen, más tarde comprobaremos si en los ejemplos orales reales este rasgo se cumple. A continuación, describiremos el sistema de unidades que propone Briz y el grupo Val.Es.Co. (2003) para la conversación coloquial.

\section{SISTEMA DE UNIDADES}

Este sistema de unidades, como sus autores indican, está basado en criterios pragmáticos para ser aplicado al estudio del español coloquial, en nuestro caso lo aplicaremos a las fórmulas rutinarias. Se caracteriza porque (Briz y Val.Es.Co., 2003: 13).

está estucturado en niveles, la diferencia entre to monológico y lo dialógico marca un hiato que separa dos tipos de unidades diferentes. Es jerárquico, porque las unidades del orden inferior son los constituyentes inmediatos de la unidad del orden superior: Es recursivo, porque permite la iteración de ciertas unidades, y está agrupado en dimensiones, porque se distinguen tres tipos de unidades: en primer lugar, aquellas que pertenecen a un orden estructural, en el que se muestra cómo las agrupaciones de los sucesivos constituyentes construyen un mensaje; en segundo lugar, un orden social en el que se ve la influencia que los participantes ejercen sobre la estructura resultante. Por último, un nivel informativo en el que se muestra cómo se divide, informativamente hablando, un mensaje.

Las unidades que organizan el sistema son: subacto, acto, intervención, intercambio, turno, alternancia de turno y diálogo. Las unidades que 
aplicamos en nuestro estudio son el acto y el subacto, puesto que la característica principal del acto es la aislabilidad y con ella comprobaremos si las fórmulas rutinarias son o no enunciados independientes. Si se da el primer caso, es decir, si son independientes, estaríamos frente a actos, mientras que si se da el segundo caso y no son independientes, nos encontraríamos con subactos. Por tanto, a continuación explicaremos en que consisten estos dos términos.

\subsection{Acto}

Briz y el grupo Val.Es.Co. (2003: 31) definen acto como «unidad estructural monológica, jerárquicamente inferior a la intervención, de la que es su constituyente inmediato, que posee las propiedades de aislabilidad e identificabilidad en un contexto dado». Por tanto, como vemos en esta definición y como habíamos dicho anteriormente, la característica principal del acto es la aislabilidad que posee, es decir, la capacidad que tiene para constituirse en un contexto lingüístico dado, y la identificabilidad, esto es, es reconocible. Además de estas características, los autores señalan que el acto suele poseer una única fuerza ilocutiva (pregunta, rechazo, etc.), y tiene un contorno melódico propio.

Todas estas propiedades del acto se asemejan y, en cierto modo, se corresponden con las que enumera Corpas para las fórmulas rutinarias, ya que no debemos olvidar que su clasificación de 1996 está realizada según la carga ilocucionaria que posee cada fórmula. Por tanto, según lo dicho anteriormente, las fórmulas rutinarias deberían constituir actos en sí mismas, es decir, cada fórmula rutinaria debería ser un acto independiente y aislable del resto. Más tarde comprobaremos, en la parte práctica, si esto ocurre realmente en el español oral.

\subsection{Subacto}

El subacto es la unidad inferior inmediata al acto. Se caracteriza por «constituir un segmento informativo e identificable en una conversación» (Briz y grupo Val.Es.Co., 2003: 45). Cuando se afirma que es un segmento informativo entendemos que expresa valores como los de condición, causa o consecuencia, a diferencia del acto que posee fuerza ilocutiva propia. Por tanto, un acto puede comprender diferentes subactos, pero no al contrario. El subacto también difiere del acto porque comprende un grupo de entonación que delimita los diferentes segmentos de habla mínimos que hay en la conversación coloquial. Además, se distinguen dos tipos de subactos según la importancia informativa que posean: subacto sustantivo y subacto adyacente. 


\subsubsection{Subacto sustantivo}

El subacto sustantivo está formado por segmentos constitutivos de acto que tienen contenido proposicional (Briz y grupo Val.Es.Co., 2003: 49). Según su papel estructural en la organización interna del acto podemos distinguir a su vez entre subactos sustantivos directores y subactos sustantivos subordinados. Los primeros son los poseedores de la fuerza ilocutiva de la intervención, mientras que los segundos se hallan supeditados semántica o pragmáticamente a los subactos sustantivos directores. En cualquier caso, sólo puede haber un subacto sustantivo director en cada acto, ya que si no estariamos hablando de dos o más actos.

\subsubsection{Subacto adyacente}

Los subactos adyacentes están formados por «elementos extraproposicionales que aportan información no incluible en la forma lógica de un enunciado; tal sería el caso de los modalizadores» (Briz y grupo Val.Es.Co., 2003: 50), pero existen diferentes tipos de subactos adyacentes, según anuncian Briz y grupo Val.Es.Co. (2003: 51-52), que dependen de la relación que adquieran con el subacto sustantivo. Así, tenemos los subactos adyacentes textuales que funcionan organizando y distribuyendo el discurso, sin carga semántica; los subactos adyacentes interpersonales que implican la interacción de hablante y oyente; y los subactos adyacentes modalizadores, que matizan el subacto sustantivo al que se adhieren.

Las fórmulas rutinarias que no sean aislables ni enunciados independientes, es decir, que no sean actos, serán subactos dentro de un acto. Además, se podrán clasificar de acuerdo a la tipología que hemos dado anteriormente de subactos.

\section{APLICACIÓN}

A continuación, aplicaremos toda la teoría que hemos expuesto hasta el momento y analizaremos ejemplos orales reales de fórmulas rutinarias discursivas para saber si son enunciados independientes, tal y como enuncia Corpas (1996), y por tanto actos, o por el contrario, no lo son y son subactos. Nos centraremos en tres ejemplos sobre fórmulas rutinarias discursivas y, concretamente, en las líneas que aparecerán en cursiva para identificar actos, ya que son el contexto linguístico inmediato de la fórmula. Además, estudiaremos los subactos que se dan dentro del acto en el que se da la fórmula, puesto que nuestro interés radica en comprobar si son enunciados independientes o no. 


\subsection{Fórmulas rutinarias discursivas}

Primeramente, definiremos que se entiende por fórmula rutinaria discursiva. Corpas en su manual (1996: 189-190) afirma sobre las fórmulas rutinarias discursivas que:

desempeñan un papel muy importante en la estructuración de los intercambios conversacionales, regulando la interacción, organizando y precisando lo que se dice, resaltando alguna parte, enlazando unos tópicos con otros, y permitiendo a los interlocutores tomar la palabra, mantener el turno u orientar el cambio de éste.

Según esta afirmación, podemos ver que las características esenciales de las fórmulas rutinarias discursivas coinciden con los diferentes tipos de subactos que hay. A pesar de que la autora distingue entre fórmulas de transición y fórmulas de apertura y cierre, nosotros nos centramos, sobre todo, en las fórmulas discursivas de transición, puesto que sus valores dependen del contexto en el que se produzcan. En ocasiones, el contenido semántico de dichas fórmulas se pierde en su totalidad $y$, simplemente, realizan funciones en el discurso, es decir, se comportan de manera similar a los marcadores discursivos. De ahí que sean fórmulas discursivas de transición, ya que el hablante las utiliza para regular la interacción, seguir la conversación, ordenar, pensar lo que va a decir después, etc.

En nuestro análisis, estudiaremos $Y$ tal, Y bueno e $Y$ eso, ya que son las que mayor índice de frecuencia de uso tienen en nuestros corpora, y que, por tanto, predominan en el español oral. Y les aplicaremos el sistema de unidades para determinar si son o no actos. Comenzamos con el análisis de $Y$ tal.

\subsection{Y tal}

$Y$ tal aparece en nuestros corpora orales en 170 ocasiones y en todas ellas tiene carácter de fórmula discursiva, aunque con valores diferentes. En este trabajo, no nos detendremos en analizar cada uno de estos valores, ya que fueron estudiados detenidamente en Alvarado (2004), sino que simplemente analizaremos una conversación al azar en la que aparece nuestra fórmula para ver si ésta cumple el rasgo de independencia que enuncia Corpas (1996). Veamos el siguiente ejemplo:

(1) $128<\mathrm{H} 4\rangle$ : Bueno, yo es que, yo es que no soy creyente, o sea... no, el tema yo pienso que... no soy creyente $y$, por lo tanto, ni practico... pero... mi cierto respeto como... como a cualquier cosa, se le debe tener. Mi respeto por aquella gente que es creyente... y no lo dice; es decir, no va, no va, no va vanaglorián- 
dose, no sé decir exactamente el término. No se va... haciendo un poquito el gallito, diciendo: Soy creyente, voy a misa, me confieso y tal . No, yo pi... yo son los que son creyentes y lo llevan con su silencio son los que más respeto, los que más respeto... me ofrecen. Pero, ya te digo que no, no, ni creo en la religión, ni creo en este tipo de cosas, o sea, soy un poquito, pues más... dejado.

(AlCore, Covja, Grupo 1)

A pesar de que hemos reproducido toda la intervención en la que aparece la fórmula $Y$ tal, para conocer el contexto situacional en el que se enuncia, nos centraremos en las líneas que aparecen en cursiva, ya que es el contexto linguístico inmediato en el que aparece dicha formula; y así, identificar fácilmente los actos que hay en ellas.

En esas líneas, encontramos dos actos. Un primer acto es «No se va... haciendo un poquito el gallito», puesto que se caracteriza por su aislabilidad dentro del contexto en el que se produce. El segundo acto es «diciendo: Soy creyente, voy a misa, me confieso y tal», puesto que es aislable e identificable, además esta introducido por un verbo que posee fuerza ilocutiva (decir). Es en este último acto donde aparece la fórmula rutinaria y tal. Por tanto, analizaremos a continuación, los diferentes subactos que pueden aparecer en ese acto.

Si analizamos el acto «diciendo: Soy creyente, voy a misa, me confieso $y$ tal», observamos que hay cinco subactos. «Diciendo» es el subacto sustantivo director que aparece en el fragmento, puesto que posee contenido proposicional. El resto de subactos son sustantivos subordinados, ya que se hayan supeditados al anterior. Así, estos cuatro subactos sustantivos subordinados son «soy creyente», «voy a misa», «me confieso», e «y tal».

En este caso, la fórmula rutinaria de transición es un subacto sustantivo subordinado dentro de un acto, ya que no es aislable dentro del contexto en el que se produce, pero sí identificable. Su significado viene dado por ese contexto y se refiere a las funciones propias que tendría un creyente, es decir, es un cierre enumerativo y equivaldría a etcétera. Por tanto, a pesar de que esta fórmula podría funcionar como diferentes tipos de subactos según el valor que posea en su contexto; en todos los casos, y tal no respondería a las características propias que enuncia Corpas (1996) para las fórmulas rutinarias, y no sería un enunciado independiente, sino dependiente. A continuación, pasamos a analizar otra fórmula discursiva de transición, y bueno.

\subsection{Y bueno}

Y bueno es una fórmula discursiva de transición en la conversación pero, a diferencia de la fórmula anterior, ésta presenta valores metadiscursivos, ya 
que el hablante utiliza la fórmula para estructurar su discurso. Esto hace que esté próxima a la función que realizan los marcadores discursivos. Esta fórmula aparece en los corpora analizados en 150 ocasiones con cuatro valores diferentes (Alvarado, 2004). En el ejemplo número 2, el hablante la emplea para retomar el hilo conductor de la conversación y volver al tema principal:

(2) $470<$ E1 $>$ : O yo... yo me acuerdo de... yo... cuando iba al colegio, me acuerdo que... o sea, yo iba a primero de E.G.B. A lo mejor, y... pasaba a lo mejor y decía alguien: Culo y todos rojos, colorados, vamos, impresionante. $Y$ ahora ... hace... hace poco se me ocurrió ir a mi coleg... a mi antiguo colegio. Me pasé por el pabellón de los nanos... Y bueno, iba con una amiga y los nanos: Tía buena... como te pille... te voy a hacer lo que no te imaginas, te la voy a esto por todas partes. Y digo, eso, que vamos, que ni se nos ocurriría. Y aparte, que no saben ni lo que están diciendo, pero... todo eso se lo están metiendo... en la tele y ... por todas partes.

(Alcore, Covja, Grupo 2)

En este ejemplo, el hablante está contando una anécdota personal y utiliza $y$ bueno para reorientar el tema y volver a retomar el hilo discursivo. El uso reorientativo de $y$ bueno es característico del discurso oral, ya que en él surgen frecuentemente tópicos conversacionales paralelos que desvían el tema principal hacia otro tema relacionado o no con el primero.

Si nos centramos en las líneas que aparecen en cursiva, observamos que $y$ bueno actúa como reformulador en la conversación, puesto que está uniendo actos. Además, tendríamos cuatro actos: el primero es «Me pasé por el pabellón de los nanos», el segundo es «Y bueno, iba con una amiga y los nanos: Tía buena», el tercero es «como te pille, te voy a hacer lo que no te inaginas» y el cuarto es «te la voy a <risas> esto <sic> por todas partes $<$ lestilo directo $>$ ». Todos ellos son actos, puesto que son enunciados aislados e independientes. A partir del segundo acto están introducidos por el estilo directo, criterio que propone Briz y el grupo Val.Es.Co. (2003: 34) para delimitar actos.

Nos centramos en el segundo acto que es el que posee la fórmula rutinaria discursiva «Y bueno, iba con una amiga y los nanos: Tía buena». El acto está compuesto por tres subactos sustantivos y por un subacto adyacente. El primer subacto sustantivo que encontramos es «iba con una amiga», puesto que posee información efectiva; además, se trata de un subacto sustantivo subordinado, ya que el subacto sustantivo director es el que posee el segmento informativo más fuerte $y$, en este caso, es «y los nanos», que contiene el tema de su intervención en la conversación. «Tía buena» es otro subacto sustantivo subordinado. El único subacto adyacente textual que hay en este acto es $y$ 
bueno. Y bueno es la fómula rutinaria discursiva de transición y su función en este contexto es reformular y unir actos. Por tanto, no funciona como un enunciado independiente tal como decía Corpas (1996), es decir, no es un acto, sino que es un subacto adyacente textual que funciona organizando y distribuyendo el flujo de habla (Briz y grupo Val.Es.Co., 2003: 51).

\subsection{Y eso}

La última fórmula rutinaria discursiva de transición que vamos a analizar es y eso. Esta fórmula favorece la continuación de la conversación sin que se produzca una ruptura del hilo discursivo. Aparece en nuestros corpora en 100 ocurrencias con dos valores diferentes en función metadiscursiva, ya que puede funcionar como remitente a otros conocimientos compartidos por el interlocutor o como conclusivo (Alvarado: 2004).

Veamos un contexto en el que se utiliza dicha formula:

(3) $393<H 4>[\ldots]$ a los amigos los veo todos los dias, tomo café aqui en la universida $<(d)>\ldots$, por las noches quedamos a las once también para tomar café... por la mañana no nos vemos... <risas> si, café de once a una y media de la noche, y eso, los amigos los veo to $<(d)>0$ los días...

(Alcore Covja, Grupo 2)

En este ejemplo, y eso aparece con valor conclusivo en la intervención y recopilador de información. Este uso de y eso se acerca a las funciones propias de los conectores, al igual que pasaba con algunos valores de $y$ bueno. El hablante, tras dar una serie de argumentos en su intervención, reordena los mismos y da una conclusión final introducida con y eso.

Si nos fijamos en las líneas que aparecen en cursiva, observamos que hay seis actos, ya que todos ellos son aislables e identificables en el contexto en el que se producen. El primero de ellos es «a los amigos los veo todos los días»; el segundo es «tomo café aqui en la universida $\langle(d)>»$; el tercero «por las noches quedamos a las once también para tomar café $(-\rightarrow)$ ); el cuarto «por la mañana no nos vemos... »; el quinto es «si, café de once a una y media de la noche»; y el sexto y último es «y eso, los amigos los veo to $<(d)>0 s$ los dias...».

Nos centramos en el último acto que es el que posee la fórmula discursiva de transición, y analizamos los subactos que hay en él. Observamos dos subactos: un subacto sustantivo director que es el portador de la fuerza ilocutiva de la intervención «los amigos los veo to $\langle(d)>0$ los días», y un subacto adyacente textual y eso, puesto que funciona organizando el habla y uniendo actos al igual que la fórmula anterior. 
Por tanto, esta fórmula rutinaria discursiva de transición tampoco posee los rasgos de autonomía en el habla que enumeraba Corpas (1996: 132), puesto que si los manifestara sería un acto y no un subacto.

\section{CONCLUSIÓN}

Para concluir destacaremos que en este trabajo hemos analizado, a partir de la clasificación de Corpas (1996) y bajo la propuesta del sistema de unidades conversacionales de Briz y el grupo Val.Es.Co. (2003), tres fórmulas discursivas de transición, y tal, y bueno e y eso en contextos orales reales. De nuestro análisis podemos resaltar que, en contextos orales, estas fórmulas no cumplen los rasgos de independencia que poseen los enunciados fraseológicos, tal y como enunciaba Corpas en su manual de 1996, puesto que si los poseyeran serían actos y no subactos. Sin embargo, en nuestro estudio, hemos comprobado que esas tres fórmulas discursivas funcionan como subactos, puesto que son identificables pero no aislables.

$Y$ tal, en el contexto de uso que hemos analizado, funciona como un subacto sustantivo subordinado, y a pesar de que en cada contexto puede funcionar como diferente tipo de subacto, en ninguno de ellos es un acto, puesto que siempre cumplirá el rasgo de identificabilidad pero no el de aislabilidad. Esto mismo ocurre con y bueno y con y eso, ya que ambos funcionan en el contexto analizado como subactos adyacentes textuales, pero podrán funcionar como diferentes subactos dependiendo del valor que posean en el contexto en el que se produzcan.

Por tanto, al aplicar la teoría de Briz y el grupo Val.Es.Co, comprobamos que para las fórmulas rutinarias discursivas no se cumplen los rasgos que daba Corpas en su manual de 1996, puesto que no pueden ser independientes del contexto en el que se producen, sino que siempre van a depender semántica y pragmáticamente de él. Así, no se puede afirmar tajantemente que ninguna fórmula sea un enunciado completo sin antes realizar un análisis profundo sobre ella.

\section{REFERENCIAS BIBLIOGRÁFICAS}

Alvarado Ortega, B. (2004): «Las fórmulas discursivas de transición en la variedad juvenil universitaria del español hablado en Alicante», Interlingiiística, 14: 416-419.

Azorín, D.; J. L. JIMÉNEz (1999): Corpus oral de la variedad juvenil universitaria del español hablado en Alicante, Alicante, Instituto de Cultura Juan Gil-Albert. 
Azorín, D. (coord.) (2002): ALCORE. Alicante Corpus del español, Edición en CD-ROM, ISBN: 84-7908-684-X.

BrIZ, A; grupo Val.Es.Co. (2003): «Un sistema de unidades para el estudio del lenguaje coloquial», Oralia, 6: 7-61.

CASARES, J. (1969 (1950)): Introducción a la lexicografía moderna, Madrid, Revista de Filología Española, Anejo LII.

Corras, G. (1996): Manual de fraseología española, Madrid, Gredos.

CORPAS, G.; K. MoRvaY (2002): «Los estudios de fraseología y fraseografía en la península ibérica», Annales Universitatis Scientiarium Budapestinensis de Rolando Eotvos Nominatae, Xxv: 167-184.

Coseriu, E. (1986 (1977)): Principios de semántica estructura, Madrid, Gredos.

Coulmas, F. (ed.) (1981): Conversational Routine. Explorations in Standardized Communication Situations and Prepattened Speech, Vol. II, La Haya, Mouton.

REAl ACADEmia Española, CREA: Corpus de referencia del español actual, Www.rae.es

Rurz GuRILlo, L. (1992 (publicado 1996)): «Sobre la fraseología coloquial: corpus e investigación», Actas del I Congreso Internacional de AESLA, Granada.

- (1998): La fraseología del español coloquial, Barcelona, Ariel.

Searle, J. (1986(1969)): Actos de habla, Madrid, Cátedra.

ZAMORA, P. (2005): «Fraseología periférica e non solo» en Fraseologia contrastiva, Universidad de Murcia y Universidad de Leipzig, Eds. R. Almela, E. Trives y G. Wotjak, págs. 65-80.

Zuluaga, A. (1980): Introducción al estudio de las expresiones fijas, Tübingen, Max Hueber, Verlag.

- (1992): «Spanisch: Phraseologie», en Holtus, G; M. Metzeltin; CH. ScHмIтT (eds.) (1992): Lexikon der Romanistischen Linguistik. Tübingen, Max Niemeyer, Verlag. 


\title{
ASPECTOS SOCIOLINGÜÍSTICOS EN LA NARRATIVA EN CASTELLANO DEL ESCRITOR VALENCIANO JOSÉ LUIS AGUIRRE
}

\author{
Amparo Ayora del Olmo \\ Universitat Jaume I
}

$\mathbf{E}$ STE trabajo trata de aplicar un enfoque sociolingüístico (bilingüismo social y contacto de lenguas) a la narrativa en castellano del escritor José Luis Aguirre nacido en Valencia (31-1-1931). Se trata de ver cómo está relacionada su obra con la historia cultural, con la política lingüística y con el contexto social de la comunidad bilingüe en la que transcurre la acción de sus novelas y cuentos.

Comprobamos cómo se refleja la situación de bilingüismo en la comunidad de habla valenciana a través de su obra literaria. Señalamos las razones que nos explican su actitud lingüística,' su elección del castellano sobre el valenciano como lengua de creación. Analizamos después qué funciones desempeñan en su obra las variaciones diastráticas, diafásicas y diatópicas (Coseriu, 1981), derivadas de la situación de convivencia de ambas lenguas en nuestra comunidad de habla. Citamos algunos ejemplos de interferencia lingüística y cambio de código, conceptos a los que ha dedicado diversos estudios el profesor J. L. Blas (1993 y 1994).

Los primeros estudios sociolingüísticos, basados en la división de clases sociales, presuponían un comportamiento lingüístico homogéneo en los grupos establecidos, en virtud de las variables externas. Otros sociolingüistas defendían la variación en el interior del grupo social y el abandono del concepto de «clase» por otra estructura más dinámica: la red social (social network) (Romaine, 1996: 87-122). Este concepto tiene en cuenta los diferentes hábitos de socialización de los individuos de una comunidad y permite revelar diferencias dentro de las clases mismas, habida cuenta de que las redes de interacción superan los límites de las clases sociales.

$\overline{1 . ~ J o s e ́ ~} R$. Gómez Molina define la actitud como «disposición valorativa del hablante hacia fenómenos lingüísticos específicos y hacia modalidades lingüísticas» en Blas Arroyo et al. (2002: 56). 
Lotman (1982) define el texto artístico como «lenguaje de lenguajes» a través del cual el receptor toma conciencia de las normas, convenciones, códigos sociales e ideologías que se incorporan a la estructura del texto como materiales extralingüisticos.

El enfoque pragmático de la novela excede los límites del texto y tiene en cuenta las relaciones que establece con el exterior a través del autor y el lector; que están enmarcadas en un sistema cultural y en las que incide el momento de su creación o de su lectura. La novela es según C. Bobes Naves (1998: 247) «un hecho social que aparece en unas circunstancias históricas y personales determinadas, que constituyen un acto de habla sui generis».

A través de los textos narrativos de José Luis Aguirre, especialmente de aquéllos que responden al llamado realismo social y objetivismo o behaviourismo, que tratan de representar la realidad sirviendo como testimonio de la misma, podemos conocer la particular visión de José Luis Aguirre de la situación lingüística valenciana.

Tenemos en cuenta la representación del habla de los personajes de sus novelas y cuentos, y por tanto de su propia actitud hacia las lenguas que conviven en esta comunidad de habla. Descubrimos así qué factores sociales condicionan los comportamientos lingüísticos y la valoración de las distintas modalidades del habla en esta situación de lenguas en contacto?

Nos centramos en la situación de cambio que se produjo en la relación de presigio del castellano con respecto al valenciano a partir de la entrada de la democracia en 1975 y la aprobación del Estatuto de Autonomía del País Valenciano que reconoció el valenciano como lengua oficial de la comunidad.

Consideramos importante señalar qué entiende José Luis Aguirre por «literatura valenciana».

Francisco Almela y Vives (1934: 6-7) manifestaba:

Desde luego, tratándose de la literatura en valenciano, no se hablará como no sea incidentalmente por alguna razón especial de los escritores que, siendo valencianos por su nacimiento, se manifestaron, como escritores, en latín, en árabe, en castellano.

Frente a esta afirmación, José Luis Aguirre en su conferencia titulada Introducción a la literatura valenciana actual (Aguirre, 1979: 3-4) propone

2. Para conocer la situación de las lenguas en contacto en la comunidad de habla valenciana se pueden consultar los estudios de D. Mollá y otros (1986), J. L. Blas (1994: 143-156) y R. Ninyoles (1996).

3. Pronunciada en Valencia, en los locales de la Real Sociedad Económica de Amigos del País, el 19 de junio de 1979. 
como tesis la idea de que la literatura valenciana abarca a todo aquél que escribe en esta tierra, al margen de la lengua que utilice.

Siguiendo a Pero Grullo, autor de cuya autoridad nadie duda, la literatura valenciana será, es, toda la literatura que se hizo y se hace en el País Valenciano. Tal vez el título de esta charla haya podido inducir a error. Al decir Literatura Valenciana, quizás más de uno haya pensado que iba a referirme con exclusividad a la Literatura valenciana que se escribe en catalán en el País Valenciano.

En este texto ofrece como criterios para explicar el significado del adjetivo «valenciano» el geográfico, el temático, el editorial y el biográfico, que sirven a José Luis Aguirre para definir qué es literatura valenciana y son precisamente los que condicionan su propia obra de creación y se reflejan en ella, la geografía en los ambientes y espacios, su tiempo en las referencias intertextuales (música, cine, literatura, juegos...) y su biografía en la caracterización de los personajes y en los temas que aborda.

Vamos a señalar en los textos de José Luis Aguirre qué aspectos están relacionados con la convivencia del castellano y el valenciano, lenguas en contacto en las ciudades de Valencia y Castellón, lugares donde ha realizado su labor creativa, donde las variedades intralingüísticas o interlingüísticas están jerarquizadas y que han influido en el marco sociocultural de nuestro autor, y que éste reproduce en su obra. Ricardo Bellveser comentaba en un artículo de 1979 sobre la presentación de la serie «Malva» de la Editorial Prometeo y de la novela de Aguirre Los jardines de Artemisa cómo Vicent Andrés Estellés había señalado que los temas de la novela están enraizados en el País Valenciano, y había terminado lamentando que para su producción Aguirre sólo hubiese utilizado el castellano.

La justificación de la elección de Aguirre del uso del castellano sobre el valenciano como lengua de creación, la podemos encontrar en causas de las cuales se ocupa la sociolingüística. El castellano es la variedad propia de la alta burguesía valenciana, la lengua de prestigio, frente a la consideración social del valenciano, en el momento que nos ocupa, adecuado para temas literarios propios del pintoresquismo y paisajismo sentimental, asociado a una clase social inferior.

José Luis Aguirre, que escribe en castellano, se preguntaba en su artículo titulado «Discriminaciones», publicado en el diario Mediterráneo (21-10-92): « ¿Se puede discriminar, e incluso incriminar, a un escritor por la lengua que emplee? ¿O por razones geográficas?», y terminaba declarándose a favor del bilingüismo: «Sobre todo, seamos humildes y, si pudiera ser, cuatrilingües por lo menos».

Podemos afirmar que en el País Valenciano se produjo un cambio a partir de la entrada de la democracia en 1975 y de la posterior aprobación en 1983 de la 
Llei d'Ús i Ensenyament del Valencià que reconocía el valenciano como lengua oficial, porque hasta ese momento el español cubría los dominios formales (la educación, gobierno, cultura, etc.) y el valenciano los informales (hogar, amigos, etc.) más en el medio urbano que en el rural. A partir de entonces, en ciertos ámbitos gubernamentales (la Generalitat Valenciana) y culturales (las universidades) se consideró como lengua de prestigio el valenciano, hecho que marcó un cambio significativo en la relación de las dos lenguas en contacto.

En la comunidad de habla del área metropolitana de Valencia se usan cuatro variedades lingüísticas, el castellano estándar (CS), el valenciano estándar (VS), el castellano no estándar (CNS) y el valenciano apitxat o central (VNS), según nos recordaba José R. Gómez Molina (2002: 59) en las I Jornadas sobre Lengua y Sociedad celebradas en 2000 en esta Universitat Jaume I, en las que también señaló que el grupo de mayor edad ( $>55$ años) al que pertenece José Luis Aguirre, valoró en su estudio de forma más positiva y jerárquica las modalidades CS y vNS y que ha mejorado notablemente la consideración del valenciano respecto del castellano desde 1983 a la actualidad en cuanto a su situación de prestigio. Para José Luis Blas (2002: 161) estas diferencias de prestigio sociolingüístico dependen del grado y duración del estado de contacto de lenguas.

La burguesía y las clases acomodadas de Valencia adoptaron el castellano como lengua de prestigio, ya que no consideraron el valenciano como símbolo de identidad de su pueblo como ocurrió en Cataluña. Debemos destacar la importancia de la política de planificación linguiística en la mejora de prestigio del valenciano a través del sistema de educación bilingüe implantado por la Conselleria de Cultura, Educació i Ciència con las diferentes modalidades: PEV (Programa d'Ensenyament en Valencià), pIV (Programa d'Inmersió lingüística Voluntaria) y PIP (Programa d'Incorporació Progresiva).

Además de la variante clase social y edad, influye en la elección por parte de José Luis Aguirre del castellano como lengua de creación su faita de competencia comunicativa en valenciano, pues no era su lengua materna y su formación tuvo lugar en un ambiente españolista en una época que ni siquiera se impartía ningún tipo de educación en valenciano, cuyo uso quedaba restringido a la enseñanza de alguna canción popular o algún cliché utilizado en el registro coloquial del ámbito escolar o familiar. Contamos con testimonios del propio Aguirre sobre su falta de competencia del catalán en una entrevista que le hizo Julio A. Máñez (1996: 8):

P... eran como dos grupos, ¿no?, el de Fuster, Ventura, etcétera, y el de Laín, López Piñero, Mariano Peset [...] ¿Tenía algo que ver el problema de la lengua? R-Ese problema no existía entonces. Fuster era tan inteligente y tan comprensivo que no había peleas sobre eso. Yo le pasaba las cosas que iba escribiendo y él me daba las suyas. Ningún problema. A veces Sanchis 
Guarner sugería que yo hablase en valenciano, pero yo le respondía que nunca podría hablarlo tan bien como él...

La postura de Aguirre frente al «problema» de la lengua queda patente en una entrevista de Víctor Mut (1998: 10-11) para Mediterráneo:

P- ¿Cuál es a su juicio la mejor solución para resolver el problema linguístico?

R- Que se llame valenciano o catalán es lo de menos, lo que está claro es que la sintaxis es la misma con sinónimos y frases acuñadas como en cualquier lengua. Insisto en que hay que acogerse a Les Normes del 32, que resolvieron en su día el citado problema.

El propio José Luis Aguirre se sorprende en su trabajo «Las últimas cartas de José Aguirre al poeta Querol» dedicado a Luis Guarner, de que la correspondencia que intercambiaron su bisabuelo José Aguirre Matiol y el poeta Querol estuviese escrita íntegramente en castellano:

Lo primero que en ellas nos extraña -al igual que en las que Querol escribió a Aguirre- es que están escritas en castellano. Ni una sola frase cariñosa o familiar aparece en valenciano. Siendo ambos hombres importantes de la Renaixença, por sus obras literarias y por sus actividades, usando ambos de la lengua vernácula en el hogar o en sus jocundas excursiones o reuniones, esta castellanización es sintomática y curiosa. La Renaixença no pasó de ser algo epidérmico, superficial; un eco romántico y nacionalista, casi mimético, respecto a las de Provenza y Cataluña. Una diversión de burgueses conservadores y acomodados. Cuando lograban evadirse del tráfago de los negocios, la tartana de Aguirre iba recogiendo a los amigos y desde el momento que dejaban la ciudad por la Puerta de Serranos hacia Bétera, se prohibía terminantemente hablar en prosa castellana, debiendo hacerlo en verso valenciano [...] Renaixentistes y poetes de week-end -los he llamado en otra ocasión- porque no había pueblo detrás, no había política detrás, no hubo Cataluña detrás [...] Aquellos hombres podían pensar en valenciano, hablarlo, pero en cuanto salían de casa y se enfrentaban con el mundo de los negocios o con cualquier manifestación culta, empleaban el castellano.

Las razones de fondo son las mismas que le llevan a escribir a él mismo en castellano. En el aspecto lingüístico Aguirre no traiciona a su clase, ${ }^{4}$ coincide con ella al considerar el castellano como lengua de prestigio. No fue el valenciano la lengua materna de José Luis Aguirre, ya que su madre no lo hablaba y él creció en un ambiente de burgueses que sólo utilizan el valenciano

4. La Guía de Valencia contiene abundante material autobiográfico que deja clara su situación de niño burgués. 
«para desahogos poéticos que llenaban sus horas de ocio o de aburrimiento. Poetas de week-end» (Aguirre, 1979: 3-4), por eso únicamente quedaba restringido su uso a «románticas actividades de canto al medio rural comparable a un mero juego de tiempo libre de un grupo de valencianos movidos por la nostalgia de tiempos pasados, época dorada de la lengua valenciana que ahora intenta resucitar este patriciado urbano», de estos «hombres de la Renaixença que [...] no pudieron ir más allá de donde fueron: en cincuenta años es imposible deshacer una inercia de quinientos» como señala Aguirre en su conferencia de la Real Sociedad Económica de Amigos del País (Valencia, 19-679, p. 12).

Su primera novela, Pequeña vida (1955), que se desarrolla integramente en la ciudad de Valencia, concentra la mayor cantidad de elementos valencianos. En ella se sirve del personaje Torá, que es de origen balear, para mostrar la interferencia linguiística de la lengua vernácula (1955; 76): « Sempre habláis, habláis como viejas sempre!».

En la caracterización de algún personaje de sus cuentos, siempre de clase social humilde, como el tío Soca, Dionisio, o Vicente de El miedo, y otros del cuento El tonto, se recurre también a su forma de hablar, incluidos los gestos o el uso del valenciano, la «dulce parla levantina, abierta y arrastrada»: « ¿Tú tens alguna cosa en Marieta?», «Enguany em pense [...] los de l'Anglaterra...», «Tú, al treball...», «Res, talla més avall...». «Maria, Maria, te vullc» (El Miedo), «Quin pulmó», «Això no res», "Mira que eres bruto, xiquet...», «iXe, quin tio!», «Això fon l'any deu» (El Tonto). Este uso del valenciano caracteriza normalmente a personajes rústicos por lo que cumple una función diastrática. Se trata de un recurso característico de las narraciones realistas y objetivistas.

El cuento El borinot de la Magdalena (1987) está plagado de expresiones y motivos costumbristas, muchos de ellos en valenciano, que en la mayoría de casos cumplen una función diatópica, en las que podemos constatar tanto el cambio de código como la interferencia linguística: «són com tu $i$ avant», «xano, xano»," «paraetes», «bescollà», «aguileta»," «la gatata, esclat de llum», «festa plena», «els arrels», «els rocins», «Xe, no sigues borinot», «paella», etc. En alguna ocasión nos da el equivalente en castellano: «porrat», «así en fino, un tentempié».

Algunos nombres aparecen vulgarizados por el habla y la fonética popular «don Visiente». Toma también frases populares que a veces reproducen interferencia lingüística: «en Sequiol "se veremos" las caras» (estructura vulgar «se vorem» en lugar de «ens veurem»), «Castelló capital de carabasses al balcó», «orelluts», «animalot, animalot, ara que venen les figues, ara t'has

\footnotetext{
5. Andar lentamente.

6. Equivale a peseta a la que se refiere por el águila del escudo.

7. Abejorro.
} 
mort»r. Además de las expresiones en lengua valenciana, cita nombres comunes «gosser $a\rangle^{8}$ y propios como Lidón ${ }^{9}$ o la Panderola. ${ }^{10}$ Notemos la alternancia de uso del castellano (sobrino) y el valenciano ( $f i l l, n e t$ ) en el siguiente ejemplo: « ¿Y ese quién es? Sí, hombre, el fill del filador, o el net del fuster del carrer de tal o el sobrino del botiguer del carrer Colón, o...» (1987: 3).

La criada de la novela La excursión (1983) dice «este xiquet és un Holofernes». En el relato El último verano $(1986)^{11}$ se recurre al cambio de código para reproducir en estilo directo las palabras de una mujer que vende pescado y pregunta en valenciano: «senyoret, ¿vol peix?». La condición humilde de la misma viene marcada no sólo por el uso del dialecto sino también por la fórmula de tratamiento de jerarquía «senyoret» que la sitúa en el nivel inferior con respecto al receptor, por tanto estamos ante un uso tanto diatópico como diastrático y diafásico del valenciano que nos indica que el hablante es de zona geográfica valencianoparlante, de nivel sociocultural bajo y vende pescado, por tanto se expresa en el registro vulgar de la lengua.

José Luis Aguirre, a través del narrador de la novela Pequeña vida que cuenta la historia en primera persona, utiliza un castellano que presenta alguna interferencia lingüística léxica y sintáctica del valenciano. La palabra «mineta» la toma del ámbito religioso y es la variedad popular para referirse a las candelas o lamparillas de aceite o parafina: «La tía rezaba el rosario [...] ante un cristo de marfil muy antiguo iluminado por las minetas de aceite» (Pequeña Vida, 1955: 71).

En algunos casos, la interferencia afecta a la sintaxis de una construcción valenciana calcada al castellano, por ejemplo, «le era lo mismo» en lugar de «le daba lo mismo»: «Hacía como que buscaba, pero en el fondo le era lo mismo» (1955: 183).

Encontramos alguna expresión genuina valenciana: «Sí, mis amigos -sonrió Alejo con las del veri» (1955: 112). El significado en castellano es, aproximadamente, «tragando veneno» (verí, catalán = veneno, castellano). Otras palabras en valenciano aparecen en el texto para referirse a las costumbres y fiestas: «dispará» (de una traca, 1955: 197), «barraca» y «alquería» (casas de labranza de Valencia y Castellón, respectivamente, 1955: 277), «fallas» (fiestas en honor de San José en Valencia, 1955: 184).

Podemos deducir que el habla habitual de un personaje es la lengua valenciana

8. Vagancia.

9. Nombre femenino, castellanización de Lledó, nombre de árbol cuya traducción correcta al castellano sería «almez».

10. Nombre metafórico (panderola = escarabajo) usado, por su color negro, para referirse a un popular tranvía que unía Castellón con El Grao y Almazora. Véase el apéndice «Textos poéticos, musicales y literarios referentes al tranvía del O. G. C.» en el libro de Juan Peris Torner, El Tranvía a vapor de Onda al Grao de Castellón de la Plana. 1888-1963. Premio Ciudad de Castellón 1993, Castellón, Ayuntamiento, 1994, pp. 236-240.

11. «El último verano» (1986: 64-65), Artes Gráficas Armengot S.A., Castellón. 
teniendo en cuenta la pronunciación abierta de las vocales y el prestigio del castellano por la castellanización de algún término valenciano (1955: 80):

\begin{abstract}
Y el humilde cura del pueblo, tratando de disimular sus modales zafios y el acento abierto de su habla. En cierta ocasión, al despedirse, queriendo ser amable y mundano había ensayado un elogio de la comida. - Todo muy bueno, pero para mí lo mejor, «los muelles». Todos habían quedado muy intrigados, hasta descubrir que el cura había querido referirse al pescado, a los «molls», cierta clase de pesca muy apreciada en los pueblecitos costeros de Levante. La traducción del término había corrido por completo de su cuenta.
\end{abstract}

En la novela Las raices (1957) que ambienta en una finca de recreo familiar en la costa levantina, sin señalar el nombre, aparece el diminutivo «Blayet» del nombre valenciano Blai, Blas en castellano (1957: 118), con una función diatópica que ayuda a situar la historia en zona valencianoparlante, uso que refuerza la alusión a la casa de labranza, la «barraca» (1957: 180) y al calzado típico del labrador valenciano, «abarcas de esparto y vetas negras» (1957: 110). El cochero utiliza el valenciano «iperduda!» (1957: 45) para referirse a una yegua. De la música tradicional cita una «albás (1957: 5), composición para el entierro de un niño recién nacido, y de la tradición oral la figura del «papús» que explica como «especie de ogro hambriento» (1957: 365) que conocemos en castellano como el «coco». Encontramos un caso de interferencia del valenciano en la expresión «hacerse un cigarro» (1957: 86) por «fumarse un cigarro».

En Los solitarios (1973) incorpora, con el mismo valor diatópico, los apellidos catalanes «Chordá» con representación de fonética «apitxada» y «Raventós». Construye un ambiente mediterráneo a través de la música: una «jota en valenciano» (1973: 57) y una «habanera» (1973: 39), composiciones propias de la costa valenciana; de los juegos (1973: 34): «chamelo» (dominó) y «sambori» (infantil), y de la gastronomía: «paella» y «butifarra» catalana con «pa amb tomàquet» 1973: 46).

En resumen, la elección de José Luis Aguirre del castellano como lengua de creación es el resultado de condicionamientos de su clase social de origen. Hemos mostrado su interpretación de la situación lingüística en el País Valenciano a través de su obra narrativa. José Luis Aguirre reproduce en ella su visión de la comunidad de habla valenciana y su actitud con respecto a las lenguas en contacto, castellano, como lengua de prestigio reservada a los personajes de nivel sociocultural alto y medio-alto, y el valenciano y el castellano no estándar como variantes para caracterizar a personajes de nivel bajo normalmente pertenecientes al medio rural. Esta visión es coherente con la edad de la generación a la que pertenece y a su nivel sociocultural ya que posee estudios universitarios y procede de una familia de la alta burguesía valenciana, 
a la que corresponde el uso mayoritario del castellano estándar afectado por la interferencia del valenciano no estándar. El cambio de código lo utiliza para introducir en estilo directo la intervención de un hablante valencianoparlante o para reproducir expresiones populares que se insertan en el nivel coloquial de la lengua y palabras que por representar conceptos propios de las costumbres valencianas pasan al castellano con la misma forma (paella, disparà...).

Si además de los argumentos sociales planteados como determinantes para la elección del castellano para escribir, tenemos en cuenta la influencia de su biografía en su obra, comprenderemos que difícilmente «actualizaría» Aguirre a los personajes burgueses expresándose en valenciano. Por ello, reserva este sociolecto para caracterizar a algunos personajes de condición social humilde.

\section{CORPUS UTILIZADO (OBRAS DE J. L. AGUIRRE)}

Pequeña Vida (1955): Melilla, Imprenta Militar.

Las Raices (1958): Premio Valencia de Literatura 1957, Valencia, Diputación. Las últimas cartas de José Aguirre al poeta Querol (1973): BSCC Tomo XLIX, 3: 229-238.

Los solitarios (1975): finalista Premio Eugenio Nadal 1972, Col. Áncora y

Delfín, Barcelona, Destino.

La risa y el llanto (1976): Premio Armengot 1975, Castellón, Armengot. Los jardines de Artemisa (1979): Valencia, Prometeo.

Introducción a la literatura valenciana actual (1979): Valencia, Servicio de

Publicaciones de la Real Sociedad de Amigos del País.

Motín de cuenteros. Una canción desesperada VV. AA. (1979): Valencia, Prometeo.

La excursión, Finalista Premio Eugenio Nadal 1982,

$1^{a}$ edición Col. Áncora y Delfín, Barcelona, Destino, 1983.

$2^{\mathrm{a}}$ edición Col. Grandes autores españoles del siglo XX, Barcelona, Orbis, 1985. «El borinot de la Magdalena» Castelló Diario (21-11-1987).

La señora (1993): Castellón, Ayuntamiento.

Cuando éramos jóvenes (1996): Castellón, Ayuntamiento.

Carrusel (2001): Castellón, Ayuntamiento.

Los visionarios. Otra tragedia americana (2003): Castellón, Ayuntamiento.

\section{REFERENCIAS BIBLIOGRÁFICAS}

Almela y Vives, F. (1934): La literatura Valenciana, Valencia, Publicaciones del Archivo Municipal, Excmo. Ayuntamiento de Valencia. 
Bajtín, M. (1986): Problemas literarios y estéticos, La Habana, Arte y literatura.

Bell.veser, R. (1979): «La presentación de la serie "Malva" de Prometeo, un acto infrecuente en el panorama valenciano», en el Diario Las Provincias de Valencia, 3-V-79, p. 30.

BLAS, J. L. (1993): La interferencia lingiiística en Valencia, (dirección catalán $\rightarrow$ español), Castellón, Servicio de Publicaciones de la Universitat Jaume I. (1994): "Valenciano y Castellano. Actitudes linguísticas en la sociedad valenciana», Hispania 77 : 1 .

- (2002): «Introducción a los fenómenos del contacto de lenguas en las comunidades de habla castellonenses», en BLAS, J. L. et al. (ed.) (2002).

BLAS, J. L. et al. (ed.) (2002): Estudios sobre lengua y sociedad, Castellón, Servicio de Publicaciones de la Universitat Jaume I.

BOBES NAves, C. (1998): La novela, Madrid, Síntesis.

Coseriu, E. (1981): Lecciones de lingiiística general, Madrid, Gredos.

Gómez Molina, J. R. (2002): «Lenguas en contacto y actitudes linguísticas en la Comunidad Valenciana», en BLAS, J. L. et al. (ed.) (2002).

LABOV, W. (1972/1983): Modelos sociolinguiisticos, Madrid, Cátedra.

- (1996): Principios del cambio lingiiústico, Vol. I: Factores internos. Dos tomos, Madrid, Gredos.

Lotman, Y. M. (1982): Estructura del texto artístico, Madrid, Istmo.

Mánez, J. A. (1996): «La terraza: José Luis Aguirre, escritor», El País (Comunidad Valenciana), 16-09-96, p. 8.

Mayoral, J. A. (Comp.) (1987): Pragmática de la comunicación literaria, Madrid, Arco Libros.

Milroy, L. (1981): Language and Social Networds, Oxford, Blackwell.

MOLLA, D. et al. (1986): Estudi sociològic sobre la problemàtica sociolinguística a la Comunitat Valenciana, València, Generalitat Valenciana, Conselleria de Cultura, Educació i Ciència.

Moreno Fernández, F. (1990): Metodología sociolingiiística, Madrid, Gredos.

- (1998): Principios de sociolinguística y sociología del lenguaje. Ariel, Barcelona.

Mut, V. (1998): «José Luis Aguirre, catedrático y escritor», Mediterráneo, 2203-98, pp. 10-11.

Ninyoles, R. (1996): Sociologia de la ciutat de València, València, Germania. ROMAINE, S. (1996): «Patrones sociolingüísticos», El lenguaje en la sociedad: una introducción a la sociolingüística, Barcelona, Ariel Linguística.

RotAETXE, K. (1988): Sociolingiiística, Madrid, Síntesis.

SeArle, J. (1990): Actos de habla, Madrid, Cátedra.

Tordera, S. (1978): Hacia una semiótica pragmática, Valencia, F. Torres.

WeInREICH, U. (1996): Llengües en contacte, Alzira, Bromera. 


\title{
EL CONCEPTO DE GRAMATICALIZACIÓN DENTRO DE LA LINGÜÍSTICA COGNITIVA: EL CASO DE BE + -ING
}

\author{
Ma del Mar Balboa Carbón \\ Universidad Complutense de Madrid
}

\begin{abstract}
T a gramaticalización es un proceso de cambio lingüístico por el cual un Welemento léxico pasa a formar parte de una clase gramatical; o bien una forma gramatical se gramaticaliza aún más. Gran parte de los estudios realizados dentro de la linguística histórica se centran en este fenómeno como proceso y causa final del cambio lingüístico. Pero, ¿cómo funciona la gramaticalización? Para comprenderlo mejor pondremos como ejemplo el caso de la evolución de la estructura inglesa be + -ing. Esta construcción tiene su origen principalmente en dos estructuras de inglés antiguo: Beon/wesan + -ende, y la forma preposicional de origen celta verbo + on $+-u n g(e)$. Son dos estructuras de orígenes distintos pero con significados similares, y cuyas diferentes evoluciones diacrónicas hicieron que acabaran teniendo semejanza formal: debido al debilitamiento de las terminaciones verbales, la desinencia -ende acabó desapareciendo, y en su lugar, por influencia del sustrato celta y la construcción preposicional, fue sustituida por-ung/-ing. A su vez, en la construcción preposicional, la preposición fue debilitándose gradualmente hasta que finalmente desapareció. En definitiva, ambas estructuras sufrieron procesos de gramaticalización que llevó a la aparición de una única forma de progresivo.
\end{abstract}

TABLA 1

\begin{tabular}{|c|c|c|c|}
\hline $\begin{array}{c}\text { He is/goes } \\
{[\text { on hunting] }}\end{array}$ & locativo & cualquier verbo & forma completa \\
\hline He is [a-hunting] & locativo & verbo to be & forma debilitada \\
\hline He [is a-hunting] & progresivo & verbo to be & forma debilitada \\
\hline He [is hunting] & progresivo & verbo to be & forma actual \\
\hline
\end{tabular}


TABLA 2

\begin{tabular}{|c|c|c|c|}
\hline $\begin{array}{c}\text { ferdon [worigende]/ } \\
\text { was [larende] }\end{array}$ & adverbial & cualquier auxiliar & forma completa \\
\hline $\begin{array}{c}\text { Hie waron } \\
\text { blissiende] }\end{array}$ & atributo & beon/wesan & forma completa \\
\hline He was [feohtende] & adverbial & solo beon/wesan & forma completa \\
\hline He[wæs feohtende] & progresivo & sólo beon/wesan & forma completa \\
\hline He [wes fighting] & progresivo & to be & $\begin{array}{c}\text { cambio de } \\
\text { desinencia }\end{array}$ \\
\hline
\end{tabular}

Según Hartis y Campbell (1995: 92), la gramaticalización es un tipo de macrocambio, que abarca toda una serie de microcambios. De entre ellos, el principal es el «reanálisis», de ahí que en ocasiones se llame reanálisis al proceso entero de gramaticalización. El reanálisis supone un cambio en la interpretación de la construcción, pero no en la forma de la misma. Es decir, la estructura interna de una construcción se ve alterada, pero la superficial se mantiene intacta.

Por ejemplo:

He was huntente

He was huntente

Harris y Campbell (1995: 72), y Timberlake (1977), opinan que el reanálisis se origina a raíz de una situación ambigua, quc provoca quc una misma estructura pueda ser interpreta de diversas maneras. Una de ellas será la antigua forma de análisis, que puede ser aplicada a todos los casos, y otra será la nueva, que sólo se aplica en algunas situaciones pero que con el tiempo acabará imponiéndose.

En muchos casos esta situación ambigua se produce debido a una «recategorización». Esto es precisamente lo que ocurrió con el progresivo inglés: en un principio el participo de presente funcionaba como un adjetivo (atributo), pero gradualmente fue perdiendo su valor adjetivo y adquirió uno verbal. Es decir, se produjo un cambio de categoría de uno de los elementos, lo que a su vez provocaría el posterior reanálisis de la estructura. A esto se añadió la desaparición de los prefijos que indicaban que un verbo no era durativo, lo que pudo favorecer el uso de la forma perifrástica (Strang, en Núñez Pertejo 2001: 160). Langacker denomina constructional simplicity a este tipo de recategorización. Consiste en la sustitución de categorías marcadas por otras menos marcadas, y construcciones marcadas por otras más comunes (1977: 129). Según esto, el uso de verbos con un determinado tipo de afijos para expresar perfectividad habría perdido fuerza 
expresiva, y esto habría hecho necesario el uso de una nueva construcción para distinguir las formas progresivas. De esta manera, beon/wesan + -ende paso de ser una opción poco frecuente para indicar duración a convertirse en la forma obligatoria de expresar dicho significado.

Tanto el reanálisis como la recategorización son producto de la búsqueda de la transparencia en el lenguaje, es decir, están basados en la idea de que, en un código lingüístico ideal, a cada unidad formal le corresponderá una unidad semántica. Sin embargo, esta situación es contraproducente desde el punto de vista de la economía lingüística porque haría necesaria la existencia de muchas estructuras, y no siempre se da. Por otra parte, el oyente a veces necesita que una misma información se repita dentro del enunciado para que no se pierda a causa de una comunicación distorsionada. Lass (1997) parte, precisamente, de la idea de que las lenguas no son del todo transparentes y que, de hecho, poseen elementos redundantes. Estos elementos son, en su opinión, una de las bases del cambio lingüístico. Examptation es un término tomado de la Biología evolutiva y que en Lingüística implica la reutilización de elementos existentes en la lengua pero que cumplían una función diferente. Esto ocurrió con beon/wesan + -ende. Esta construcción ya existía en inglés antiguo pero era poco frecuente y sólo cumplía alguna de la funciones que be + -ing tiene en la actualidad.

La reestructuración de los elementos de una lengua puede explicarse por la subjetivización que los hablantes hacen de formas gramaticales concretas. Traugott define la subjetivización como «un fenómeno gradual, por el cual formas y construcciones que inicialmente expresaban, en primera instancia, significados concretos, léxicos y objetivos, llegan a realizar, a través de un uso repetido en contextos sintácticos locales, funciones progresivamente más abstractas, pragmáticas y basadas en el emisor» (Hilferty y Cuenca, 1999: 163). Inicialmente, Traugott estableció tres principios generales que determinan el cambio léxico y gramatical según la teoría de la subjetivización:

1) Evolución desde significados basados en la situación externa descrita a significados basados en la situación interna -evaluativa/perceptiva /cognitiva. Por ejemplo, según Lass, que la perífrasis progresiva tenga su origen en una estructura preposicional es natural, ya que la progresividad representa un estado en el que se está, esto es, un tipo de proceso locativo, indicado por la preposición.

2) Evolución desde significaddos basados en la situación externa o interna descrita a significados basados en la situación textual. En el caso de be + -ing, paso de servir para indicar una acción en proceso a convertirse en la forma de expresar un marco de referencia temporal en el que se sitúa una acción en forma simple. 
3) Los significados tienden a situarse progresivamente en el estadocreencia/actitud del hablante respecto a la situación. En este último apartado situaríamos funciones emotivas de $b e+-i n g$, como por ejemplo el «I'm lovin' it» de McDonalds.

Se trata, pues, de la reutilización de elementos ya existentes en la lengua y que en muchos casos cambian de categoría, lo que origina un reanálisis de la estructura. ¿Cómo se produce esta recategorización? La teoría de los prototipos dice que todas las categorías son graduales, abiertas y de límites difusos. Se crean en torno a un prototipo, que es el elemento principal, y el resto se sitúan más o menos lejos del prototipo según su grado de semejanza de familia. De esta manera, estas categorías son al mismo tiempo rígidas, por la relación de semejanza de sus elementos con el prototipo, y flexibles por la gradación de sus miembros y sus límites difusos. Partiendo de este planteamiento inicial se entiende que un elemento pueda cambiar de categoría porque se trata de un elemento marginal (dentro de la categoría), cuya pertenencia a una u otra es difusa.

En resumen, la gramaticalización consta de una serie de microcambios graduales que están relacionados entre sí por su papel dentro del proceso de gramaticalización, y que provocan como resultado un cambio en las estructuras que lo sufren. Sin embargo, seguimos sin conocer uno de sus aspectos más importantes: su origen, qué motiva su aparición. Porque la gramaticalización no es una fuerza explicativa sino descriptiva. El concepto de gramaticalización nos permite describir los procesos que tienen lugar en muchos cambios lingüísticos, pero no explica las razones por las que estos cambios han tenido lugar. Como decía al principio de esta comunicación, la gramaticalización (o reanálisis) se ha entendido como la causa de muchos cambios linguísticos. Éstos se producirían para adecuarse al nuevo análisis de la estructura. Pero, ¿cuál es el motivo de dicho reanálisis? También podemos ver este fenómeno a la inversa y suponer que el reanálisis es el resultado de esos cambios menores de los que hablamos, pero entonces tendríamos que preguntarnos qué factores han podido determinar que esos microcambios hayan tenido lugar. Es en definitiva, una pescadilla que se muerde la cola. Un cambio lingüístico no se produce por una única causa, sino que siempre se conjugan diversos factores. En ocasiones, las explicaciones estrictamente linguiísticas son insuficientes para entender el origen de un cambio ya que, el lenguaje es una entidad muy compleja en la que debemos analizar factores estructurales, pero también sociales y psicológicos (Langacker, 1977: 99)

La Lingüística Cognitiva defiende que una lengua forma parte del sistema cultural de la comunidad en la que se origina, y como tal está sometido a los cambios históricos y culturales de ésta. Así, Osthoff y Brugmann (Haspelmath, 
1999: 591) explican: «[...] que la lengua no es una cosa que se encuentre fuera o por encima de la gente y lleve una vida independiente de ellos, sino que tiene su verdadera existencia sólo en el individuo». Este individuo, además, forma parte de una comunidad, dentro de la cual interacciona con otros individuos lingüística y culturalmente. La lengua es, en definitiva, un hecho social y cultural, por lo que no puede entenderse sin su relación con otros hechos sociales y culturales que la influencian y modifican.

A su vez, entendemos la cultura como un conjunto de prácticas y representaciones mentales que comparte una comunidad de individuos (Bernárdez, 2001; 2003). Los seres humanos se enfrentan a la realidad a través de sus sentidos y posteriormente la tamizan en el pensamiento. Whorf hablaba del concepto de habitual thought World, un microcosmos individual que permite a cada persona medir y comprender el macrocosmos de la realidad en la que vive (Lucy, 1992: 43). Este microcosmos está determinado en cierta medida por la cultura de cada individuo. Todos los seres humanos poseemos unas capacidades cognitivas similares, y unos principios generales que la regulan. Sin embargo, cada cultura establece unas preferencias a la hora de utilizar esos principios en situaciones que tienen valores culturales o étnicos concretos. Estas preferencias poco a poco acaban institucionalizándose y la motivación que las produjo se va volviendo más opaca, hasta el punto de que los integrantes de la propia comunidad terminan por desconocer los factores que propiciaron su origen. Cuando esto sucede, ese punto de vista, que en principio sólo era una preferencia frente a otras muchas opciones, se convierte en EL punto de vista por el que se debe medir el funcionamiento del universo.

A su vez, estas preferencias también se ven afectadas por el lenguaje, incluso en la existencia de construcciones especializadas para expresar esa «realidad», y que, sin embargo, no existen en otras lenguas. Estas preferencias institucionalizadas conforman lo que Pierre Bourdieu denominó habitus. El habitus son las diversas costumbres sociales (es decir, se trata de un fenómeno intrínsecamente cultural, pero también lingüístico), que los individuos adquieren en su práctica cotidiana de interacción con los otros. La adquisición del habitus puede ser implícita, con ejemplos a imitar, o explícita, a través de instituciones como la escuela o la familia. Lo mismo sucede con la adquisición del lenguaje, donde el niño imita el habla de sus mayores, pero donde también existe un refuerzo por parte de los adultos para que el niño hable como ellos, es decir, que aprenda las convenciones que ellos utilizan.

Si entendemos la lengua como parte de un sistema cognitivo cultural, es razonable pensar que las alteraciones culturales que pueda sufrir ese sistema afectarán también al uso de la lengua. En el estudio del cambio lingiuístico y de la gramaticalización debemos buscar pues, no sólo los procesos internos de la lengua sino también los factores socio-culturales en los que esos cambios se 
enmarcan. Por ejemplo, el origen y desarrollo de be + -ing coincide con una serie de acontecimientos históricos de gran relevancia cultural. Uno de esos acontecimientos es la cristianización de Gran Bretaña. Casualmente, la concepción cultural que los pueblos germánicos tenían sobre el tiempo es radicalmente distinta de la judeocristiana. La concepción germánica era cíclica, basada posiblemente en su experiencia directa con la naturaleza, y su visión de la vida en términos de grupo. La cristiana, sin embargo, es fundamentalmente lineal: una línea que se extiende hasta el infinito y sobre la que se sitúan los sucesos. Esta con-cepción es precisamente la que permite dar una dimensión histórica a los acontecimientos.

Es significativo que precisamente uno de los posibles orígenes de las formas de progresivo sea una construcción locativa. Bybee (1994: 148) afirma que en las gramaticalizaciones se mantienen parte del significado original, y en el caso de be + -ing sería situar a un agente en medio de una actividad (Bybee, 1994: 133). En esta definición se aprecia claramente el uso de la metáfora, culturalmente judeo-cristiana, «el tiempo es espacio». Es decir, al igual que la construcción preposicional servía para situar a algo o a alguien en un punto en el espacio, la perífrasis progresiva sitúa al sujeto dentro del tiempo, como si éste fuera un plano espacial.

En definitiva, la Lingüística Histórica no puede seguir limitando su campo de estudio a las causas internas del cambio lingüístico, y más concretamente de los procesos de gramaticalización. Puesto que el lenguaje es un hecho cultural y colectivo, debe tener en cuenta los agentes, las motivaciones, los propósitos, la situación socio-cultural en la que se producen, etc, para poder ofrecer una perspectiva más amplia en la que situar los cambios estructurales de esa lengua. Muchos de los factores que determinan la aparición de una gramaticalización seguirán siendo desconocidos, pero descubriremos muchos otros que nos permitirán entender mejor el desarrollo histórico de una lengua, y su relación con el sistema cultural al que pertenece.

\section{REFERENCIAS BHBLIOGRÁFICAS}

BERnÁRdeZ SANCHís, E. (2004): «Individual Cognition and Social Activity: on the Application of Pierre Bourdieu's Habitus to Cognitive Linguistics», AELCO, Zaragoza.

- (2003): «Intimate Enemies? On the Relations between Language and Culture», conferencia, Universidad católica de Braga, Portugal.

- (2001): «La Cognición como Enlace del Lenguaje y la Cultura», conterencia, Universidad de Córdoba. 
Bybee, J.; R. Perkins; W. Pagliuca. (1994): The Evolution of Grammar. Tense, Aspect and Modality in the Languages of the World, Chicago, the University of Chicago Press.

Grvón, T. (1995): Functionalism and Grammar, Amsterdam, John Benjamins. Harris, A.; L. CampBell. (1995): Historical Syntax in Cross-Linguistics Perspectives, Cambridge, Cambridge U.P.

Haspelmath, M. (1999): «Are the Principles of Grammatical Change?», Journal of Linguistics, 35: Cambridge University Press

Hilferty, J.; M. J. CuENCA (1999): Introducción a la Lingüística Cognitiva, Barcelona, Ariel Lingüística.

LANGACKeR, R. W. (1977): «Syntactic Reanalysis» en Charles Li (ed.) Mechanisms of Syntactic Change, Texas, University of Texas Press.

LASs, R. (1997): Historical Linguistics and Language Change, Cambridge, Cambridge U.P.

LuCy, J. A. (1992): Language Diversity and Thought, Cambridge, Cambridge U.P.

Núñez Pertejo, P. (2001): The Progressive in the History of English with Special Reference to the Early Modern English Period: a Corpus-Based Estudy, Santiago de Compostela, Universidad de Santiago (tesis doctoral). Palmer, G. (1996): Linguíistica Cultural, Madrid, Alianza Editorial.

Romaine, S. (1981): «Syntactic Change as Category Change by Re-analysis and Diffusion: some Evidence from the History of English» en MrCHAEL DAVENPORT et al. (eds.) (198Q): Current Topics in English Historical Linguistcs, Odense, Odense U.P.

Tejada, P. (1999): El Cambio Lingüístico, Madrid, Alianza Editorial.

TimberlaKe, A. (1977): «Reanalysis and Actualization in Syntactic Change» en Charles Li (ed.) (1977): Mechanisms of Syntactic Change, Texas, the University of Texas Press. 



\title{
THE IMAGE OF WOMEN \\ IN ENGLISH SLANG: \\ LANGUAGE AND GENDER IDEOLOGY
}

\author{
ABIR Bouzemmi \\ Universidad Complutense de Madrid
}

T was often thought that the study of people's use of language was quite
separate from the study of the embedding of gender in language (Eckert and Ginet, 2003). From the linguistic point of view, language was viewed as a system beyond the reach of those who use it. However, nowadays there is little doubt that people project gender into the world around them. Indeed, language and gender's studies are interested in the relationship between language and our ideas about men and women, and how language plays a complex part in the reflecting and sustaining gender divisions in society.

This article is a sociolinguistic study of the representation of gender in the English slang. Slang will be used as an instance of how language plays an important role in building ideologies about how women are viewed in society. Slang, an everyday informal language, is a rich linguistic area for research in language, gender and ideology.

Language hides ideology, and ideology is embedded in language. That is why there has been an increased attention to what people do with language. Ideology is the system of beliefs by which people explain, account for, justify their behaviour, and interpret and assess that of others. Any selection at the linguistic level encloses an ideological position. Language is, to a great extent, what makes an individual "man" or "woman", and language is what describes and shapes the ideas and differences about both. These gender stereotypes, manifest in language reflect the different perceptions people have about women and men (e.g. less attractive women are perceived as masculine, and less attractive men are seen as feminine). Poynton (1985: 52) states that:

women are valued positively when they are young, beloved, married, and the producer-nurturer of children, but negatively when they are sexual, unmarried, verbally aggressive, demanding rights, or aspiring to govern themselves and others.

Moreover, language and power are intimately related. Language plays a critical role in the attainment and the exercise of power and indexes the power relationships of the society, reinforcing and naturalising them. Language and 
gender has long been a part of women's studies. Feminists have been engaged in the project of resisting dominant discourse. By calling into question the discourses that privilege men, they have shifted and can continue to shift the power imbalances that disadvantage women. In fact, feminists' critics of language in relation to gender have focused on words of all language use that overtly trivialises women, and which cultivates stereotypes about them. Feminist have criticised the way women are often defined in terms of physical attributes such as hair-colour (a blonde, a redhead), attractiveness to man, or otherwise (beauty, for instance). They have also taken issue with the extent to which women are defined in terms of home and family, and in particular, in terms of their relationship with men.

The primary source of information for this paper is colloquial and informal language, or slang, including dirty words and other language, that is not commonly used in a polite society. The inclusion of the different slang terms in this paper, would offend some readers, but their inclusion is meant to provide a realistic representation of language use, and not to be sensational or abusive. Indeed, Slang expressions have been collected from corpuses such as dictionaries and slang surveys. In the dictionary English Slang (1997), we found 25 terms designated for women and other only 4 for men. In Contemporary British Slang: An up to date guide to the slang of modern British English (1999), we found 25 terms designated for women and other 14 for men. This multitude of the slang terms that are designated to women is flagrant as compared to men's. The other two corpuses are: the UCLA slang list (1988), by graduate students at the University of California at Los Angeles, and Sutton's survey by undergraduate students at Berkeley (fall 1991, spring 1992) and which provide 170 slang terms for women.

Thinking critically about slang increases our understanding of how the system of social classification, called gender, confers more power on males. Slang terms in the selected dictionaries to refer to women as young girls are expressed by names of animals like bird, cat, cow, chick, dragon. Cat's mother is another term, which means young and insignificant female person. Moreover, we find in these dictionaries other slang terms that carry the same significations as young girl or woman, but not necessarily using the metaphor of animals. For instance, we find better half, bint, bit of skirt, broad, cunt, dutch, the missus, sheila, as well as, carving knife, fork and knife, (these two remind the role of woman as a housewife and having the role of a cook, rather than any other important role), her indoors, charming wife, plates and dishes, mother of pearl which all mean wife. Another important group of terms referring to woman by her body parts contain terms such as boobs and knockers, meaning the breasts, bum (the buttocks), cunt, a very offensive term which refers to vagina, fanny refers to either the buttocks or the female 
genitals. Tom Thumb is another term for the buttocks. Lallies has been used to refer to woman's legs, and bristols and squashy bits to refer to her breasts. In addition to the labeling of women by her body parts, trollies and trolleys is a crude term, (used always in the plural), and refers to a woman's panties or knickers. Flash of light is a slang term which means a gaudily dressed woman. Moreover, a woman, when she is not sexually labeled, slang language is rich with terms which refer to her as silly and insignificant; even when she is attractive. This means that it does not matter if they are silly as long as they are attractive (bimbo and bit of fluff are other examples). Unattractive and ugly women are insulted as well. The examples are the following: crow, boiler, face like the back (end) of a bus, face that would stop a clock, face like the side of a house, ratbag, are all terms which refer to a spectacularly unattractive female visage. Attractive women, on the other hand, are referred to as dish or dishy, looker, and as Jill, dolly and ducky. A promiscuous woman is labeled as bitch (very offensive).

UCLA slang list is another corpus used in this article and is a work carried out by Pamela Munro and her graduate students at the University of California at Los Angeles (UCLA during 1988). This work is used and cited in Sutton (1985: 283).

According to the UCLA list, it is "bad" for women to be heifer (fat), skank (unattractive), dimbo (dumb), turboslut (too free sexually), bitch (assertive), nun (prudish), trap (a woman who does not display interest in a man without having sex). Conversely, it is "good" to be attractive such as betty, filet, freak, treat, Wilma, etc. (Sutton, 1985: 285). Unless women are seen by men as attractive, they are fat, dumb, evil, and sexually promiscuous. $90 \%$ of the words for women in the UCLA slang list describes women in a negative way, compared to only $46 \%$ of the words for men (Sutton, 1985: 283). There are no words for fat, assertive, or dumb men, and only one word each for ugly men (lou), and sexually promiscuous men (mr. groim). Even this latter term could be rated as negative; "it is rather cute and funny, but roadwhore, skag, and wench (all meaning "promiscuous female') are all clearly insults" (Sutton, 1985: 284).

The next slang survey to be mentioned in the article is done by undergraduate students at Berkeley and it follows the pattern of UCLA slang list very closely, in the sense that the majority of the slang terms for women are negative and describe woman as sexual partner: call girl (a prostitute hired by telephone), hooker (a hustler), scrubber, slag (meaning immoral woman) or simply pro, meaning prostitute. A lesbian is a dike, a less, or a lessie. In the family way, in the club, in the pudding club, pregger, all are terms meaning pregnant woman. The same as young girls or women, an older woman can be referred to in slang language as boiler, golf widow. Thus, except boosy-boots 
(domineering or bossy woman) and Lady Muck (a self-important and pretentious woman), which more or less could be positive, they are not appreciated."In fact", the examples that accompany these terms show that it not really appreciated for a woman to be as such (compare the lwo examples that accompany these two very slang terms: "Please, get that boosy boots out of here!" and "Oh! These two really do think they're Lord and Lady Muck").

The slang survey at Berkely is a well constructed survey and very useful because of the data it provides. The slang terms were collected from undergraduates at Berkeley in a large lecture class in linguistics, hold in fall 1991 and spring 1992. There is a higher percentage of negative words for women than positive, and the positive words all focus on the attractiveness of women to men as sexual partners. There are also words with animal reference. Some are especially creative, like hell pig, which combines the domesticated animal metaphor (sexually available) with a strong contradictory image of demons or nightmare. Nocturnal, too, implies a woman who lives in darkness and preys on others - a wild animal, uncontrollable. Heifer fits the domestic animal paradigm, also implying youth and possibly virginity due to unattractiveness; a cute and submissive timid woman is a fawn. Another interesting variation is: swamp sow, which combines "both the domestic animal image and the image of nastiness" (Sutton, 1985:286). Both bambi and thumper fit the class of women as pets (cute, cuddly, with large eyes and high voices). Puddy might be a mutated form of pussy, but it is hard to tell whether this is a reference to genitalia or to cats. Mutt is a common term for ugly women, perhaps less aggressive than bitch but still on the animal scale.

Furthermore, students mentioned slang terms that reflect men's perceptions of the appearance and "odor" of women's genitalia, though they explained that such terms are often extended to refer to women themselves, not just their genitalia. For instance, they mentioned the words tuna and clam (also bearded clam). More creative terms for women's genitalia are food images - hot dog bun, pink taco. There are other terms built on hole like: cheesehole, slam hole, stimey hole. These terms as Sutton (1985: 286) argues "support Penelope's (1990) observation of the paradigmatic woman as 'holes, receptacles, containers --things they [men] can or want to fuck"",

Terms for attractive women picture women as attractive only if men find them sexually desirable, and even then, they are still viewed as objects, especially as food: cheesecake, honey, nectar, peach. The acronym MILF ('mother I'd like to fuck') is particularly interesting, because it singles out older women and expresses the condescension of men toward them. The other terms can still be seen as offensive, with one exception: elegant.

The terms for a promiscuous woman are similar and based on either skank or its variation stank and also the word ho or hobag. The word offered as a 
male parallel to hobag was hoebuck. This latter seems a prime example of the kind of radical difference similar to that between master/mistress, as Sutton (1985: 287) put forth saying:

buck has entirely positive connotations - man as an animal with strength, speed, and aesthetic value; bag is either the common word for 'old woman', or, more likely, is from douchebag. A man who has sex often is to be admired; a woman, despised.

This paper has carried out an overview of the ideological representation of women in English slang. Slang vocabulary has served as an instance of the stereotypes about women in society. Most and probably all contemporary societies are characterised by some degree of male dominance: the view of women as passive sexual objects, as devoted mothers, and as beautiful wives has been taken for granted by scholars. Generally, women are seen to be dangerous, dirty, and polluting, as something to be set apart. However, although women are seen a superfluous, they are vitally important to men: they are needed as wives and as procreators who produce workers and heirs. We can come up to the following conclusions:

- The results of Sutton's survey are the same as the UCLA slang survey. Sutton's words are again pertinent: "It is acceptable to be thin, smart (not too smart), passive, and sexually available (but not sexually promiscuous). It is not acceptable to be fat, ugly, aggressive, or sexually unattractive to men" (1985: 287). As Robin Lakoff (1975) pointed out, women are still defined by their sexual relation to men.

- Being male or female affects how we act in the world, how the world treats us, and this includes the language we use and the language used about us.

- Another key idea of this article is that the focus on gendered categories in society makes it impossible for individuals to move through life in a nongendered way.

- The primary sources of information were slang surveys and dictionaries. Dictionaries are liable to reflect the prejudices of their compilers, and the culture of the time. It is important, then, to compile the dictionary "on the basis of a wide range of language use, not just using predominantly male written sources as has been the norm in the past" (Talbot, 1998: 224).

- The need for a gendered identity forces women to see themselves through men's eyes and to cultivate feminine characteristics that they expect men to want from them (being emotional, sensitive, passive, and dependent). As a consequence, "women's self-esteem is caught up in their appearance and desirability to others. Particularly to men" (Talbot, 1998: 260). 
- We should argue that men do not take positions of power by their own efforts alone. Women participate in the construction of hegemonic masculinity (the passivity of women and their acceptance of a dominating husband, partner, friend, father, or brother) thinking that it is natural that men protect women.

Finally, there have been some attempts to change gender language, and to change the unchanged ideology, though it is too difficult. I end this article with a curious comment by Sutton $(1985: 290)$ stating that "without revolution, resistance and redefinition of long held concepts of femininity and masculinity can be a long, hard process. Perhaps being a ho or a bitch is a start". She explains this by the fact that when women call each other "ho", they acknowledge that they are women who have sex and earn their own money; when they call each other bitch, they acknowledge the realities of this man-made world, and affirm their ability to survive in it.

\section{BIBLIOGRAPHY}

Eckert, P. and M. C. Ginet (2003): Language and Gender, Cambridge, Cambridge University Press, $1^{\text {st }}$ ed.

Hill GuY, J. M. and D. Hill (1997): English Slang, Madrid, Anglo-Didáctica, D.L.

JAMES, E. (1999): Contemporary British Slang: An up-to-date guide to the slang of modern British English, NTC/Contemporary Publishing Group, Inc.

LAKOFF, R. (1975): Language and Woman's Place, New York, Harper and Row.

Poxnton, C. (1985): Language and Gender: Making the difference, Victoria, Deakin University.

SutTon, L. (1985): «Bitches and Skanky Hobags. The place of women in Contemporary Slang», in HALL, K and M. Bucholtz (eds.) (1985): Gender Articulated. Language and the socially constructed self, New York, Routledge.

Talbot, M. (1998): Language and Gender: An introduction, Cambridge, Polity Press. 


\title{
LA FUNCIÓ CRÍTICA DE L'EMISSOR EN EL DISCURS ACADÈMIC: CONTRAST INTERDISCIPLINAR
}

\author{
Àngels CAmpos \\ Universidad Católica de Valencia.
}

\section{INTRODUCCIÓ}

D UES de les característiques més repetides en els manuals sobre textos acadèmics han estat l'objectivitat i la universalitat. La lluita contra l'emissor, que, com a mediador de la paraula, pot restar-li protagonisme a l'objecte científic ha estat una constant al llarg dels segles. A més de la cerca d'objectivitat, en l'àmbit acadèmic, s'ha aspirat a l'existència d'un únic discurs: cal perseguir trets homogenis que superen les barreres lingüístiques i que permeten la comunicació entre la comunitat científica internacional.

En aquest treball, intentarem mostrar que aquests dos trets són ideals impossibles d'assolir (i, probablement, innecessaris), ja que el discurs acadèmic es troba subjecte a paràmetres lingüístics i també a les característiques pròpies de cada disciplina científica. Per això, analitzem el diferent grau de càrrega crítica en textos científics d'àmbit acadèmic i la manera com aquesta es vehicula en el discurs de tres disciplines: lingüística, dret i física. Partim d'un corpus trilingüe amb textos originals en català, castellà i anglés constituiit per 367.330 paraules, format per ressenyes $i$ articles de polèmica publicats recentment (entre 1989-2001) en revistes amb un nivell d'especialització alt pertanyents a les tres matèries esmentades. Aquestes disciplines representen les diferents branques de la ciència: ciències humanes, ciències socials $i$ ciències experimentals, respectivament.

L'anàlisi dels textos es basa en l'aplicació d'un model de classificació de les marques de primera persona (desinències verbals, pronoms personals i possessius) i dels mecanismes d'impersonalització (construccions passives i impersonals) que oculten l'emissor (Campos, 2004). Aquest model, elaborat a partir dels principis metodològics de l'anàlisi del discurs i la lingüística cognitiva, té en compte el referent extratextual de l'emissor i la funció que aquest desenvolupa en el discurs. 


\section{UNA PROPOSTA DE CLASSIFICACIÓ DE LA FUNCIÓ DE L'EMISSOR EN ELS TEXTOS}

La dixi personal i la classificació dels diversos tipus de nosaltres ha despertat molt d'interés per part d'alguns lingüistes. L'objectiu de la majoria de les classificacions (Benveniste, 1966; Haverkate, 1984; Siewierska, 1984; Scheibman, 2002) és delimitar el referent cxtratextual al qual es refcreix la marca gramatical. En treballs específics sobre discurs científic, aquest aspecte també ha rebut molta atenció $i$, en general, es presenten classificacions que sols tenen en compte el referent extratextual (Ciapuscio, 1992; Hernández Sacristán, 1999); ara bé, alguns estudis comencen a fixar-se en la funció que l'emissor desenvolupa en el text (Tang \& John, 1999; Gallardo, 2003) i fins i tot a combinar els dos aspectes (Kuo, 1999).

En aquesta linia de recerca, s'inscriu la nostra proposta extensa que hem presentat en Campos ( 2004), les bases de la qual sintetitzem tot seguit. Des del punt de vista de la funció que l'emissor desenvolupa en el text, podem distingir-ne 6 tipus: escriptor, atacant, analista (dins el qual hi ha la variant de l'analista experimental), declarant, exemple $\mathrm{i}$ experimentador, $\mathrm{i}$ les hem agrupades en tres grans grups: organitzatives, argumentatives $i$ expositives (actives $i$ passives). Aquestes funcions comporten una gradació de major a menor implicació de l'emissor amb el missatge: les organitzatives i les argumentatives són les que impliquen un major compromís de l'emissor amb allò que diu; en canvi, a través de les expositives passives, l'emissor es desvincula més del missatge.

TAULA 1. Les funcions de l'emissor

\begin{tabular}{|l|l|l|}
\hline Agrupació de les funcions & Funció & Definició \\
\hline Organitzatives & Escriptor & $\begin{array}{l}\text { L'emissor organitza el text i } \\
\text { remet a parts anterior i } \\
\text { posteriors. }\end{array}$ \\
\hline \multirow{2}{*}{ Expositives actives } & $\begin{array}{l}\text { L'emissor emet judicis } \\
\text { negatius sobre una obra o } \\
\text { teoria. }\end{array}$ \\
\hline Analista & $\begin{array}{l}\text { L'emissor explica i valora } \\
\text { positivament. }\end{array}$ \\
\cline { 2 - 4 } & Declarant & $\begin{array}{l}\text { L'emissor constata un fet } \\
\text { sense valoració. }\end{array}$ \\
\hline Expositives passives & $\begin{array}{l}\text { L'emissor es presenta com a } \\
\text { mostra d'una teoria. }\end{array}$ \\
\hline
\end{tabular}


En aquest article, ens centrem únicament en la funció argumentativa d'atacant, amb la qual l'emissor mostra un grau màxim d'implicació i de subjectivitat, ja que emet judicis negatius sobre una obra o una teoria.' Es tracta d'una funció molt compromesa en el sentit que l'emissor atempta contra la imatge positiva del receptor. La funció d'atacant es manifesta a través de les marques de persona, però també pot ocultar-se sota mecanismes d'impersonalització.

En els exemples que presentem a continuació, es pot observar la funció crítica a través de diverses marques de persona. En (1), l'emissor es presenta en primer pla i fa una crítica dirceta, bé a través de la primera persona del singular (1a), o bé a través d'un plural exclusiu que equival al jo (1b).

(1) $a$. This echoes the use of the word "undeddabb" in mathematical logic describe propositions which, in a given system, cannot be proven or disproven. $I$ doubt this analogy should be pushed too far. (Dang3)

$b$. Sin perjuicio de lo anterior, no podemos compartir la extensión de la teoría citada a los casos en los que los delitos se convierten después en faltas. (Dcast1)

En canvi, en (2), l'emissor intenta diluir la presència en una col-lectivitat que comprén emissor i receptor (2a) o bé un collectiu professional $(2 b)$. D'aquesta manera, minva la seua implicació en la crítica.

(2) a. Però és fàcil veure que sempre podem trobar direccions per a les quals la desigualtat de Bell no es satisfà. (Fcat2)

b. O bé el que cal és postular que de manuscrits gramaticals afins o comparables al del metge de Sant Feliu de Codines n'hi devia haver hagut en una quantitat respectable i que només la fatalitat, o l'escàs treball dels historiadors, ens ha impedit de tenir-ne notícia? (reslingcat5)

Igual com hem vist en els casos de les marques de persona, amb els mecanismes d'impersonalització, també pot observar-se una gradació de menor a major grau d'ocultació de l'emissor. Així, en l'exemple (3), la

1. La funció opinion-holder and originator de Tang i John (1999) també abraçaria la funció d'atacant, en la mesura que aquests autors no fan distinció entre valoracions positives $\mathrm{i}$ negatives. Gallardo (2003) tampoc no fa aquesta distinció i, per tant, la funció d'atacant s'inclouria en el que anomena avaluació. 
construcció impersonal esdevenimental permet descobrir més fàcilment l'emissor atacant:

(3) Potser caldria objectar que hauria d'aparèixer més sovint la marca popular (equivalent, per cert, en el $D G L C$, a familiar, acotació aquesta darrera que en el DIEC té un ús més estricte). (Lcat1)

Les construccions impersonals reflexes, sols existents en castellà i català, amaguen una mica més la presència de l'emissor, tal com ens mostra aquest exemple:

(4) Se echa de menos, sin embargo, la cita de alguna obra reciente [...] y de algún caso csclarecedor en los años cercanos a la publicación del libro. (resDcast 1)

Per últim, les construccions passives, reflexes (5a) i sobretot perifràstiques (5b), són les que impliquen un grau major d'ocultació i, per tant, la crítica sembla desvincular-se de l'opinió de l'emissor:

(5) a. ... els objectius d'aquest llibre són molt més ambiciosos; aquesta visió de conjunt tan àmplia fa que sovint s'hi troben carències en aspectes molt puntuals. (resLcat1)

b. We could add «holes in the pattern», the do so type tests, and intersubjectively validated intuitions (see the foregoing discussion) as further kinds of powerful evidence that can be adduced against monosemic analyses. (Lang4)

\section{LA IUNCIÓ D'ATACANT ATRAVÉS DE LCS MARQUES DE PERSONA}

El nostre corpus ens mostra que, a pesar del caràcter expositivoargumentatiu dels gèneres que hem triat, la funció d'atacant no és la predominant en aquests textos ni a través de marques de persona, ni a través de mecanismes d'impersonalització. No obstant això, presenta xifres interessants que convé comentar.

Encara que els percentatges d'aquesta funció no són gaire elevats, en la taula 2 es pot observar que, en les ciències humanes, és molt més freqüent l'atac (català: $11.4 \%$ i $20,2 \%$; castellà: $8.6 \%$ i $11,2 \%$; anglés: $9.7 \%$ i $3.5 \%$ ) que no en les ciències experimentals (català: $2.5 \%$ i $2.2 \%$; castellà: $7 \%$ i 
4.2\%; anglés: $4.5 \%$ i $1.3 \%$ ), tant amb marques de persona com amb mecanismes d'impersonalització. Així mateix, la diferència entre les ciències socials i les ciències experimentals no és gaire remarcable. Si tenim en compte la variable llengua, les divergències entre disciplines es fan més notables en els textos en català i sobretot sota mecanismes d'impersonalització (marques de persona: lingüística: 11.4\%; dret: 5.3\%; física: $2.5 \%$. Mecanismes d'impersonalització: lingüística: $20.2 \%$; dret: $3.5 \%$; física: $2.2 \%)$.

TAULA 2. La funció d'atacant

\begin{tabular}{|c|l|c|c|c|}
\hline Llengïes & & Lingüística & Dret & Física \\
\hline \multirow{3}{*}{ Català } & Marques de persona & $60(11.4 \%)$ & $10(5.3 \%)$ & $5(2.5 \%)$ \\
\cline { 2 - 5 } & $\begin{array}{l}\text { Mecanismes } \\
\text { d'impersonalització }\end{array}$ & $27(20.2 \%)$ & $8(3.5 \%)$ & $5(2.2 \%)$ \\
\hline \multirow{2}{*}{ Castellà } & Marques de persona & $26(8.6 \%)$ & $19(6.9 \%)$ & $9(7 \%)$ \\
\cline { 2 - 5 } & $\begin{array}{l}\text { Mecanismes } \\
\text { d'impersonalització }\end{array}$ & $16(11.2 \%)$ & $13(6.1 \%)$ & $10(4.2 \%)$ \\
\cline { 2 - 5 } & $\begin{array}{l}\text { Marques de persona } \\
\text { Mecanismes } \\
\text { d'impersonalització }\end{array}$ & $29(9.7 \%)$ & $18(5.6 \%)$ & $13(4.5 \%)$ \\
\hline
\end{tabular}

Pel que fa a la vehiculació a través de marques de persona, la funció d'atacant presenta diferències ressenyables entre matèries, tot i que els resultats més interessants, pel que fa al. tipus de marques utilitzades, es produeixen entre llengües. Els tipus de marques que hem distingit són quatre (taula 3): la primera persona del singular (jo); nosaltres exclusiu, que equival al jo; nosaltres inclusiu, que inclou l'emissor i el receptor en diversos graus d'implicació; i el nosaltres generalitzador, que fa referència a l'emissor com a representant d'un grup més o menys nombrós. 
TAula 3. Tipus de marques de persona

\begin{tabular}{|l|l|l|}
\hline \multicolumn{1}{|c|}{ Marca de persona } & \multicolumn{1}{|c|}{ Tipus } & Referent extratextual \\
\hline la persona del singular & Jo & emissor \\
\hline la persona del plural & $\begin{array}{l}\text { Nosaltres } \\
\text { exclusiu } \\
\text { Nosaltres } \\
\text { inclusiu } \\
\text { Nosaltres } \\
\text { generalitzador }\end{array}$ & $\begin{array}{l}\text { emissor + receptors } \\
\text { emissor + una comunitat } \\
\text { delimitada (científics) o no } \\
\text { (tothom) }\end{array}$ \\
\hline
\end{tabular}

Les conclusions més rellevants que hem extret de l'anàlisi del corpus es resumeixen en aquests punts (taula 5 de l'annex):

a) En totes les llengües, s'observa una gradació entre les diverses branques de la ciència. En les ciències humanes, l'emissor es presenta més freqüentment sota la funció d'atacant; en canvi, el percentatge va minvant en les ciències socials $i$, sobretot en les ciències experimen-tals. No obstant això, cal destacar que el català és la llengua on es fa més evident aquesta gradació (lingüística: $11.4 \%$; dret: $5.3 \%$; física: $2.5 \%$ ), mentre que en castellà (lingüística; $8.6 \%$; dret: $6.9 \%$; física; $7 \%$ ) i en anglés (lingüística: $9.7 \%$; dret: $5.6 \%$; física: $4.5 \%$ ) les diferències entre les disciplines són molt més insignificants.

b) Pel que fa al tipus de marca de persona que s'usa més freqüentment per a aquesta funció, convé marcar que els resultats obeeixen als patrons propis de cada llengua. En aquest sentit, l'anglés sol usar majoritàriament la primera persona del singular (jo), perquè en aquesta llengua es tendeix a la referencialitat; per contra, el català i sobretot el castellà fan servir el nosaltres de manera més general, sobretot el nosaltres exclusiu.

c) Tot i els resultats generals que hem exposat en b), cal tenir en compte que els textos de lingüística en català i els de física en castellà constitueixen un cas aïllat, ja que fan un ús considerable de la primera persona del singular (lingüística català: $6.1 \%$; física castellà: $5.4 \%$ ). Així doncs, l'anglés sembla tenir un discurs científic més homogeni, mentre que en les altres llenguies, hi ha més diferències entre disciplines.

d) Per disciplines, els textos de dret del nostre corpus són els que més s'aparten de les característiques generals que hem esmentat. Així, en 
català i en anglés, s'observa més expressió de la crítica a través del plural inclusiu i generalitzador (català: 2,6\%; anglés: $1,7 \%$ ). Per tant, hi ha un intent major en aquesta matèria de diluir la crítica o d'implicar tota una comunitat legal o nacional en l'atac per tal de donar-li més força.

\section{LA FUNCIÓ D'ATACANT A TRAVÉS DELS MECANISMES D'IMPERSONALITZACIÓ}

Els mecanismes d'impersonalització són menys abundants que les marques de persona. Tot i que, en principi, semblava esperable que l'emissor atacant recorreria sovint a aquestes estratègies per a protegir la imatge, els resultats del corpus ens mostren uns percentatges molt reduïts en especial en dret i en física. Així mateix, s'observen divergències lingüístiques que afecten els diferents tipus de construccions triats. La taula 4 ens mostra els diversos tipus de construccions que hem distingit i que impliquen diferents graus d'ocultació semàntica, tal com hem comprovat en els exemples de 3,4 i 5.

TAULA 4. Classificació dels mecanismes d'impersonalització (criteri semàntic)

\begin{tabular}{|c|c|c|}
\hline \multirow{3}{*}{$\begin{array}{c}+ \text { (MANIFESTACIÓ DE } \\
\text { L'EMISSOR })\end{array}$} & Català I castellà & ANGLES \\
\hline & $\begin{array}{l}\text { Impersonal amb subjecte } \\
\text { no referencial }\end{array}$ & $\begin{array}{l}\text { Impersonal amb subjecte } \\
\text { expletiu }\end{array}$ \\
\hline & $\begin{array}{l}\text { Impersonal amb subjecte } \\
\text { inespecific (hom/uno) }\end{array}$ & $\begin{array}{l}\text { Impersonal amb subjecte } \\
\text { inespecific (one) }\end{array}$ \\
\hline \multirow{3}{*}{$\begin{array}{c}\text { - (MANIFESTACIÓ DE } \\
\text { L'EMISSOR) }\end{array}$} & $\begin{array}{l}\text { Impersonal reflexa } \\
(s e+\text { verb en veu activa) }\end{array}$ & Impersonal passiva \\
\hline & Passiva reflexa & \multirow{2}{*}{ Passiva perifràstica } \\
\hline & Passiva perifràstica & \\
\hline
\end{tabular}

Els efectes generals que es poden dibuixar a partir dels resultats de la taula 6 (annex) són els següents:

a) Entre les tres matèries, es manté la gradació que havíem observat amb les marques de persona: major quantitat d'atac en lingüística que no pas en física. Així mateix, com ocorria amb les marques de persona, en el cas del català és on les diferències es fan més evidents, sobretot entre lingüística $(20.2 \%)$ i dret $(3.5 \%)$. 
b) Pel que fa a les construccions que s'utilitzen, convé destacar que en linguística, tant en castellà com en català, encara que les impersonals reflexes són les construccions més freqüents, es fa un ús bastant abundant de les impersonals esdevenimentals i amb subjecte incspccífic, que oculten menys l'emissor (català: 7.5\%; castellà: $4.2 \%$ ). En el cas de l'anglés, les passives perifràstiques són les que més s'utilitzen en les tres disciplines.

c) L'augment del grau de crítica és proporcional a l'augment de les impersonals esdevenimentals i de subjecte inespecífic, és a dir, una actitud més crítica es correspon amb una voluntat de menor ocultació i una major implicació de l'emissor.

d) Si comparem les taules 5 i 6 , podem concloure que un major grau de crítica sota marques de persona comporta també un major grau de crítica sota mecanismes d'impersonalització. Per disciplines, és en lingüística on s'assoleixen percentatges més elevats (català: 20.2\%; castellà: 11.2\%; anglés: $3.5 \%$ ). En canvi, si ens fixem per llengües, caldria destacar les xifres del castellà en dret i física, que presenten una major proporció de crítica sota els mecanismes d'impersonalització (dret: $6.1 \%$; física: $4.2 \%$ ).

\section{CONCLUSIONS}

Segons els resultats que hem pogut extreure del nostre corpus, podem concloure que la funció de l'emissor està condicionada per les característiques pròpies de cada disciplina, mentre que la manera com es fa la vehiculació o ocultació depén de paràmetres lingüístics. Així, en relació amb les funcions, les ciències humanes tendeixen a aportar un grau major d'opinió negativa $i$, per tant, la funció d'atac es fa més present. Cal tenir en compte que aquestes ciències es construeixen a partir d'opinions i de valoracions, mentre que les ciències socials $\mathrm{i}$ experimentals se centren en els objectes, la qual cosa comporta una davallada de la funció d'atacant. Aquest fet es fa més palés en la física, matèria en què les xifres poden invalidar una teoria $i$, per tant, l'emissor no ha d'afegir cap valoració.

Quant a la manifestació d'aquesta valoració negativa, es tendeix a exposar la crítica de manera directa, és a dir, no s'observa una necessitat d'ocultar la imatge a través de mecanismes d'impersonalitzáció. No obstant això, convé destacar que l'anglés és la llengua en què la crítica és menys freqüent $i$, a més, tendeix a ocultar-se sota mecanismes d'impersonalització que comporten una ocultació màxima. Aquest resultat coincideix amb el de l'estudi de Salager-Meyer, Alcaraz i Zambrano (2003). Aquestes autores observen, a 
partir d'un corpus de textos mèdics, que, en castellà, la crítica directa assoleix percentatges més elevats que en anglés, però la tendència al llarg dels anys és la igualació entre les dues llengües, contràriament al que ocorre en francés.

Quant a la vehiculació de l'atac a través de marques de persona, la variable llengua esdevé més rellevant. Així, totes les disciplines en anglés opten per una major referencialitat, mentre que el català i en especial el castellà fan un ús abundant del nosaltres exclusiu. A pesar d'aquestes tendències generals, convé destacar que els textos de física en castellà s'aparten d'aquest model i tendeixen a un ús major de la primera persona del singular. Aquest fet pot estar motivat per la importància de l'anglés en aquesta matèria, en què les revistes especialitzades es fan majoritàriament en aquesta llengua. Igualment, els textos de lingüística en català tendeixen a un major ús de la primera persona del singular per a vehicular la crítica. En aquest cas, pensem que caldria relacionarho amb el fet que els textos lingüístics en català que formen part del nostre corpus estan vinculats amb aspectes lingüístics de l'àmbit català, un àmbit reduït, en què l'autor es veu amb més autoritat per a exercir una crítica directa.

Per últim, pel que fa a les construccions d'impersonalització, hem pogut observar que com menor és el percentatge de la funció d'atacant, hi ha una major tendència a fer ús de les construccions que comporten més ocultació, tal com ocorre en anglés.

\section{REFERÉNCIES BIBLIOGRÀFIQUES}

Benveniste, E. (1966): Problèmes de linguistique générale, París, Galllimard. CAMPOS, À. (2004): La inscripció de la persona en el discurs acadèmic: un estudi contrastiu català-castellà-anglés, València, Universitat de Valencia. www.tdx.cesca.es/TDX-0519105-131352/index-an.html.

CAmpos, À; M. J. MARín; M. J. CuenCA (2004): «Las marcas de primera persona en el debate electoral», en Soares da Silva, A.; A. Torres; M. GonÇALves (eds.) (2004): Linguagem, Cultura e Cogniçao: Estudos de Linguística Cognitiva (Actas del I Congreso Internacional de Lingüística Cognitiva), Coimbra, Almedina, vol. II: 279-298.

CiAPuscio, G. E. (1992): «Impersonalidad y desagentivación en la divulgación científica», Lingüística Española Actual, XIV/2: 183-205.

Gallardo, S. (2003): «La inscripción de los interlocutores en artículos científicos y libros de texto», en Ferreira, G. I L. Bruno (eds.) (2003): Actas del IX Congreso de la Sociedad Argentina de Lingüística, Universidad Nacional de Córdoba, novembre de 2002. [CD-Rom]

Haverkate, H. (1984): Speech Acts, Speakers and Hearers, Amsterdam, John Benjamins Publishing Company. 
HERNÁNDEZ SACRISTÁN, C. (1999): Culturas y acción comunicativa: introducción a la pragmática intercultural, Barcelona, Octaedro.

Kuo, C. H. (1999): «The use of personal pronouns: role relationships in scicntific journal articles», English for Specific Purposes, 18(2): 121-138.

Salager-Meyer, F; Ma Á. Alcaraz Ariza; N. Zambrano (2003): «The scimitar, the dagger and the glove: intercultural differences in the rethoric of criticism in Spanish, French and English medical discourse», English for Specific Purposes, 22: 223-247.

Scheibman, J. (2002): Point of View and Grammar: Structural Patterns of Subjectivity in American English Conversation, Amsterdam, John Benjamins.

SIEWIERSKA, A. (1984): The passive: a Comparative Linguistic Analysis, New Hampshire, Croom Helm.

TANG, R. i S. JOHN (1999): «The ' $I$ ' in identity: Exploring writer identity in student academic writing through the first person pronoun», English for Specific Purposes, 18: \$23-\$39. 
ANNEX

TAULA 5. La funció d'atacant a través de les marques de persona

\begin{tabular}{|c|c|c|c|c|}
\hline Llengües & $\begin{array}{c}\text { Marques de } \\
\text { persona }\end{array}$ & Lingiiística & Dret & Física \\
\hline \multirow{6}{*}{ Català } & Total & $60(11.4 \%)$ & $10(5.3 \%)$ & $5(2.5 \%)$ \\
\hline & Jo & $34(6.1 \%)$ & $2(1.1 \%)$ & $2(1 \%)$ \\
\hline & Nosaltres & $26(5.3 \%)$ & $8(4.2 \%)$ & $3(1.5 \%)$ \\
\hline & $\begin{array}{r}\text { Nosaltres } \\
\text { exclusiut }\end{array}$ & $15(3.1 \%)$ & $3(1.6 \%)$ & $0(0 \%)$ \\
\hline & $\begin{array}{r}\text { Nosaltres } \\
\text { exclusiu }\end{array}$ & $6(1.2 \%)$ & $2(1 \%)$ & $3(1.5 \%)$ \\
\hline & $\begin{array}{l}\text { Nosaltres } \\
\text { generalitzador }\end{array}$ & $5(1 \%)$ & $3(1.6 \%)$ & $0(0 \%)$ \\
\hline \multirow{6}{*}{ Castellà } & Total & $26(8.6 \%)$ & $19(6.9 \%)$ & $9(7 \%)$ \\
\hline & Jo & $3(1 \%)$ & $3(1.1 \%)$ & $7(5.4 \%)$ \\
\hline & Nosaltres & $23(7.6 \%)$ & $16(5.8 \%)$ & $2(1.6 \%)$ \\
\hline & $\begin{array}{r}\text { Nosaltres } \\
\text { exclusiu }\end{array}$ & $18(6 \%)$ & $13(4.7 \%)$ & $1(0.8 \%)$ \\
\hline & $\begin{array}{r}\text { Nosaltres } \\
\text { inclusiu }\end{array}$ & $4(1.3 \%)$ & $3(1.1 \%)$ & $0(0 \%)$ \\
\hline & $\begin{array}{l}\text { Nosaltres } \\
\text { generalitzador }\end{array}$ & $1(0.3 \%)$ & $0(0 \%)$ & $1(0.8 \%)$ \\
\hline \multirow{6}{*}{ Anglés } & Total & $29(9.7 \%)$ & $18(5.6 \%)$ & $13(4.5 \%)$ \\
\hline & Jo & $26(8.8 \%)$ & $11(3.6 \%)$ & $11(3.8 \%)$ \\
\hline & Nosaltres & $3(0.9 \%)$ & $7(2 \%)$ & $2(0.7 \%)$ \\
\hline & $\begin{array}{r}\text { Nosaltres } \\
\text { exclusiu }\end{array}$ & $2(0.6 \%)$ & $1(0.3 \%)$ & $1(0.3 \%)$ \\
\hline & $\begin{array}{r}\text { Nosaltres } \\
\text { inclusiu }\end{array}$ & $1(0.3 \%)$ & $1(0.3 \%)$ & $1(0.3 \%)$ \\
\hline & $\begin{array}{l}\text { Nosaltres } \\
\text { generalitzador }\end{array}$ & $0(0 \%)$ & $5(1.4 \%)$ & $0(0 \%)$ \\
\hline
\end{tabular}


TAULA 6. La funció d'atacant a través dels mecanismes d'impersonalització

\begin{tabular}{|c|c|c|c|c|}
\hline Llengües & $\begin{array}{c}\text { Mecanismes } \\
\text { d'impersonalització }\end{array}$ & Linguística & Dret & Física \\
\hline \multirow{5}{*}{ Català } & Total & $27(20,2 \%)$ & $8(3.5 \%)$ & $5(2.2 \%)$ \\
\hline & $\begin{array}{c}\text { Imp. } \\
\text { esdevenimentals } \\
\text { i subj. inespecífic }\end{array}$ & $10(7.5 \%)$ & $3(1.3 \%)$ & $2(0.9 \%)$ \\
\hline & $\begin{array}{c}\text { Impersonals } \\
\text { passives }\end{array}$ & - & - & - \\
\hline & $\begin{array}{l}\text { Construccions } \\
\text { reflexes }\end{array}$ & $15(11.2 \%)$ & $4(1.8 \%)$ & $3(1.3 \%)$ \\
\hline & $\begin{array}{c}\text { Passives } \\
\text { perifràstiques }\end{array}$ & $2(1.5 \%)$ & $1(0.4 \%)$ & $0(0 \%)$ \\
\hline \multirow{5}{*}{ Castellà } & Total & $16(11.2 \%)$ & $13(6.1 \%)$ & $10(4.2 \%)$ \\
\hline & $\begin{array}{c}\text { Imp. } \\
\text { esdevenimentals } \\
\text { i subj. inespecífic }\end{array}$ & $6(4.2 \%)$ & $1(0.4 \%)$ & $1(0.4 \%)$ \\
\hline & $\begin{array}{l}\text { Impersonals } \\
\text { passives }\end{array}$ & - & - & - \\
\hline & $\begin{array}{l}\text { Construccions } \\
\text { reflexes }\end{array}$ & $7(4.9 \%)$ & $11(5.2 \%)$ & $9(3,8 \%)$ \\
\hline & $\begin{array}{c}\text { Passives } \\
\text { perifràstiques }\end{array}$ & $3(2.1 \%)$ & $1(0.5 \%)$ & $0(0 \%)$ \\
\hline \multirow{5}{*}{ Anglés } & Total & $8(3.5 \%)$ & $2(1.8 \%)$ & $3(1.3 \%)$ \\
\hline & $\begin{array}{l}\text { Imp. } \\
\text { esdevenimentals } \\
\text { i subj. inespecific }\end{array}$ & $1(0.4 \%)$ & $0(0.0 \%)$ & $1(0.4 \%)$ \\
\hline & $\begin{array}{l}\text { Impersonals } \\
\text { passives }\end{array}$ & $2(0.9 \%)$ & $0(0 \%)$ & $0(0 \%)$ \\
\hline & $\begin{array}{l}\text { Construccions } \\
\text { reflexes }\end{array}$ & - & - & - \\
\hline & $\begin{array}{c}\text { Passives } \\
\text { perifràstiques }\end{array}$ & $5(2.2 \%)$ & $2(1.8 \%)$ & $2(0.9 \%)$ \\
\hline
\end{tabular}




\title{
LES RELACIONS ENTRE COMUNITATS \\ DE PARLANTS A TRAVÉS DE LES DITES \\ I FRASES FETES POPULARS \\ DELS NOSTRES POBLES
}

\author{
JoAn Coba Femenia \\ Universitat de València
}

\section{INTRODUCCIÓ: DELIMITACIÓ DEL CONCEPTE DE FOLKLORE}

$\mathbf{E}$ $\mathrm{N}$ aquest treball intente revitalitzar el concepte de folklore, tan desprestigiat en els últims temps, partint del fet que el mot en qüestió no vol dir una altra cosa que cultura popular. Així doncs, la meua comunicació reivindica aquest concepte $\mathrm{i}$ incideix sobre el fet que la cultura popular pot ser molt útil en l'ensenyament de la llengua. Entenc que pot ser utilitzada com un instrument de cohesió social perquè vull remarcar que, durant segles, les dites i frases fetes populars han actuat com a element aglutinador dels ciutadans $i$ ciutadanes d'un poble, tot oposant-los als veïns dels pobles dels voltants. Hi actuava el criteri de la diferenciació.

Doncs bé, opine que encara resulta molt interessant fer conéixer, per exemple, què pensaven els nostres avantpassats manisers (de Manises, L'Horta) dels veïns quartans (de Quart de Poblet, enemic tradicional i secular). He triat com a exemple el meu poble i el seu enemic tradicional. Al mateix temps resulta interessant comprovar què es pensava dels ciutadans dels pobles dels voltants (Xirivella, Mislata, València, etc.) De la mateixa manera, i ampliant l'espectre, resultarà curiós per al lector comprovar què pensaven els valencians dels castellans o dels catalans, i en què es basaven les seues apreciacions, si és que hi havia alguna motivació hipotètica que les justificara. En la comunicació faig veure que les rivalitats entre els pobles són la font bàsica de la cultura popular.

No obstant això, en sentir parlar de folklore, algunes persones l'identifiquen ràpidament amb la Pantoja, Rocío Jurado o María del Monte. Ara no em referisc a eixe folklore, és clar. Al contrari, el meu treball parla sobre dites $i$ frases fetes populars, orals normalment, que ha conservat el folklore tradicional i que tenen al nostre poble com a protagonista. Això també és folklore, és el folklore. L'altre folklore que he avançat abans és una banalització del folklore de veres, i no mereix ara la nostra atenció. 
La veritat és que s'ha parlat tant de la paraula folklore en els últims temps que el terme s'ha envilit, s'ha desprestigiat. I, de rebot, la disciplina que estudiava el folklore, l'etnografia ha quedat desprestigiada també. Per això, com que la paraula folklore ens porta connotacions negatives, que ara no ens interessen, podem traduir-la al català: folklore vol dir cultura popular, ja ho he dit abans. I açò, cal deixar-ho clar ara, al principi, perquè d'eixa manera estem tots més tranquils: quan parlen de folklore ens esten referint a la cultura popular.

És a dir, a la cultura popular elaborada per les classes humils del nostre territori, de la nostra comarca, feta pels llauradors i artesans arrelats a la terra cultivada, aferrats a la tradició, reacis a les innovacions tècniques, no inclinats a les modes que sempre han sotmés els senyorets de la ciutat. Una cultura que, potser, es troba a les portes de desaparéixer, absorbida sense remei per la civilització tècnica, urbana i massificada. Dones bé, una bona part de les dites tòpiques o locucions que coneixeran tot seguit han estat replegades de llavis dels llauradors de les diverses comarques, en alguns casos persones analfabetes, que no per això deixaven d'estar cultivades a la seua manera.

Ara bé, tot seguit he de dir una cosa: en parlar d'aquestes qüiestions sempre $m$ 'agrada fugir del lirisme innecessari. Hi ha persones que, en posar-se a parlar d'allò popular, s'entendreixen ràpidament. És curiós, però els costums i les maneres de pensar de la gent dels pobles, produeixen a molts que es diuen refinats una estranya nostàlgia, i encara més si els comentaris van referits a èpoques pretèrites.

Així, sovint, les aproximacions a la cultura popular presenten a l'home antic de poble com un individu ple de supersticions, desitjos i treballs. El pinten com un ser que riu, un líric que viu en un ambient propici. Els propis llauradors fugien també d'aquesta idea i crearen la seua pròpia dita:

\section{(1) Llauradorets, però no pardets.}

Entenent aquesta última paraula com a persona rústica $i$ ximple. $O$ siga, que llauradors, sí però bajoques, no. Dones bé, nosaltres també hem desconfiat de totes aquelles descripcions folklòriques de l'home tradicional (utilitzant ara el terme folklòric en el sentit més pejoratiu possible). Hem de rebutjar també les preteses excel'lències d'aquest gènere de vida, i més en època antiga. L'home antic, el llaurador, generalment, no s'extasiava contemplant la pineda allà en la ratlla de l'horitzó a poqueta nit, $\mathrm{i}$ tampoc no gaudia amb els càntics dels ocellets de bon matí ni s'alçava per la nit a veure el cel estelat. Ben al contrari, treballava en una ocupació duríssima en jornades que ens espantarien a qualsevol de nosaltres. Així doncs, de lirisme, el just, l'imprescindible i d'estampes idíl-liques, les estrictament necessàries. 


\section{LES RIVALITATS ENTRE POBLES: FONT DE LA CULTURA POPULAR}

Doncs bé, i si la nostra aproximació a la cultura popular no està basada en lirismes gratuïts, ¿en què es basa? Es basarà, pel contrari en les rivalitats naturals entre pobles veïns, en els costums particulars de cada vila, en els oficis tradicionals, en els productes característics, en els episodis més o menys anecdòtics o fantàstics de la nostra història local o comarcal. Tots aquests temes han sigut font copiosa de dites, tradicions i frases fetes populars en tot el territori valencià $\mathrm{i}$ tot això, perquè -com ha dit algun estudiós sobre els valencians-- solem viure projectats més cap a fora que cap a dins, ens preocupem tant o més per la forma que pel contingut (d'això saben molt els nostres llauradors). Al mateix temps contemplem el veí amb atenció intensa i gens dissimulada, disposats a trobar en ell els errors que tan benèvolament ens disculpem a nosaltres mateixos. Ja sabeu allò de

(2) Cap geperut es veu el gep, ni cap banyut les banyes.

Les nostres observacions sobre els veïns solen ser ben agudes $\mathrm{i}$ ben apassionades. Critiquem agrament el veí quan el refrany ens diu sàviament que:

(3) Si vols dir mal d'algú, mira primer qui ets tu.

Faig remarca sobre el fet que durant molts segles, la força que amb més pressió ha actuat sobre la gent ha sigut el fet de pertànyer a una mateixa ciutat, i encara més si es tracta d'una entitat menor de població, és a dir d'un poble. De fet, durant molts segles la consciència de formar part d'una comunitat rural era un sentiment precís i quotidià, molt més clar, molt més directe que el fet de pertànyer al País Valencià o a Espanya. Els nostres avantpassats primer eren del poble i després ja parlaríem. Allò que els cohesionava i que els unia era la condició de ser de Quart, en el meu cas, igual que als de Xirivella, Paterna o Manises -que són pobles de la rodaliaels unia la seua condició de ciutadans i ciutadanes d'eixos pobles.

I d'aquesta autoafirmació com a poble, ben fàcilment es pot passar a l'animadversió, l'enemistat cap als altres. És ben humà, ben comprensible arribar a creure i sentir que el grup humà o la comunitat de què formem part és la més digna i preferible entre totes les existents. És ben habitual, això. Qui no s'ha cregut en alguna ocasió el més important del món? Qui no ha cregut en alguna ocasió que el seu poble és el més bonic del món?

Actuant així, afirmem una separació entre la nostra manera de ser i la dels hòmens i les dones d'una altra localitat, d'una altra comarca o d'un altre país. 
Després del que portem dit no és d'estranyar que siguen abundosos els refranys o locucions que afirmen valors del grup comunitari propi. Vegeu-ne aquests, dels quals, potser, n'heu sentit algun:

(4) Alacant, la millor terreta del món.

(5) Dones i mangranes / d'Alcora són les més preciades.

(6) Valenciana fón ma mare / $\mathrm{i}$ mon pare valencià; / la xica que jo festege / valencianeta serà.

Segons Sanchis Guarner, en aquesta vanitat exuberant contrasten els valencians centrals i meridionals amb els castellonencs. Mentre que els pri-mers els valencians centrals i meridionals-solen ser amb freqüència fanfarrons i pagats d'ells mateixos, els castellonencs solen manifestar, opina l'autor, una austera contenció.

Acabem d'assenyalar que un primer grup de les dites i frases fetes populars afirmen els valors d'un grup comunitari determinat. Doncs bé, el segon grup és consequiència del primer: d'afirmar els valors propis per damunt dels altres es pot passar fàcilment a manifestar antipatia o menyspreu envers alguna localitat immediata. El veí és sempre considerat com l'enemic pitjor. Molts d'aquests antagonismes responen a odis que es manifesten entre la gent del camp i la de la ciutat, els de la muntanya i els de les planures, els mariners $\mathrm{i}$ els llauradors de terra endins.

Així, haurem de reconéixer que la cultura popular valenciana de caràcter burlesc és molt abundant, sobretot la que nega els valors d'una localitat vëna. Mireu aquests exemples referits a pobles de tot el territori valencià:

(7) En Canals, / bords i criminals.

(8) En Ayora / la que no es puta llora.

(9) De ponent, / ni vent ni gent (aquesta molt generica i despectiva cap a tots els pobles que els valencians tenim a l'oest de nosalires).

(10) Xica, qui s'ha mort? No, ningú, un foraster.

(11) En Nules / entra de cara / i ix de recules.

(12) Per Xert / passa despert.

\section{L'ANTIGUITAT DE LES DITES I FRASES FETES POPULARS}

Si ens preguntem per l'antiguitat de totes aquestes dites, hem d'assenyalar que, en general, són realment molt antigues. Algunes apareixen citades en reculls i lexts literaris de lemps moll passals. Fins i tot, en algun cas, les podem remuntar a l'Edat Mitjana, sobretot al període comprés entre el segle XI i XV. 
És ben notòria l'afició de l'home medieval a resumir els judicis en forma de sentències d'aquesta classe. I és també ben cert que encara els refranys eren molt vius en èpoques més properes. Parlant de l'antiguitat de les dites, mireune aquesta relacionada amb Castelló de la Plana i que es remunta a 1251:

(13) Entre Borriana i Borriol / ha nascut un fillol, / i val més lo fillol / que Borriana i Borriol.'

\section{ELS TEMES MÉS FREQÜENTS EN LES DITES I FRASES FETES POPULARS}

Segons Caro Baroja (2003), per exemple, les manifestacions d'hostilitat són molt més freqüents que no les que alaben alguna qualitat dels veïns, però no només entre els valencians. El realçament dels elements negatius de la gent de les localitats properes és més frequient. I com que la majoria dels tòpics són despectius, en general, resultarà més fàcil de replegar-los a les localitats veïnes, que no en boca dels al·ludits mateixos.

I és que la majoria dels elements de la cultura popular són fills de la burla i de la ironia més que no de l'odi. La ironia exagera els perfils de les coses, les deforma $\mathrm{i}$ les caricaturitza. Sovint aquesta ironia ha nascut del recel i de la desconfiança cap al veí. Ironitzant sobre el veí manifestem una diferenciació.

En alguns casos la falsedat dels tòpics és palmària per a un home del segle XXI. Així, ocorre que certs refranys, rondalles, cançons es repeteixen monòtament al llarg de la nostra geografia. Per exemple, aquesta frase l'he sentida per a les torrentines (ciutadanes de Torrent, a L'Horta):

(14) Torrentina, puta fina.

Però és habitual en el País Valencià sentir-la per a les xativines, sogorbines, bocairentines, callosines, ontinyentines, etc. És a dir, l'única base d'aquestes dites tòpiques és l'assonància de l'adjectiu fina amb el gentilici de la localitat a què s'atribueixen. Com que fina rima amb un grapat de gentilicis en femení, s'ha aplicat tradicionalment a les ciutadanes de molts dels nostres pobles. Ara bé, algunes de les dones al-ludides en aquesta dita es defenien i deien:

1. He reproduït les dites extretes de Sanchis Guarner (1968) tal com les recull l'autor, tot consignant per tant dialectalismes, col-loquialismes o fins i tot allò que hui diríem faltes d'ortografia. Així, doncs, no he adaptat les dites a la parla estàndard per fidelitat a l'original. 
(15) Segorbina, / puta fina. /-Si es de Altura, / más segura. (És la resposta de les sogorbines ofeses a les seues veïnes del poble d'Altura).

Haurem de concloure, doncs, que molts d'aquests dictats tòpics preexistents no podrien ser considerats com a definidors del caràcter del poble concret a què s'apliquen. Doncs bé, aquestes mostres d'antipaties recíproques expressades per la nostra gent responen a sentiments naturals en l'home i la dona; són universals, no és una cosa exclusiva dels valencians, ni molt menys. Les dites en qüestió -la majoria burlesques- les trobem en tots els països, en totes les cultures populars, de les quals constitueixen un capítol molt important.

En aquesta línia diuen molts que els valencians tenim un gust i una capacitat per a la sàtira molt remarcable i que usem sovint de paraulotes, sobretot en el llenguatge afectiu. Sincerament i a pesar de tot, crec que hem d'esforçar-nos a fer veure que nosaltres no som més corrosius, més càustics que altres pobles del món encara que haurem de reconéixer que sovint se'ns adjudica una capacitat especial per a la broma i la grolleria que no ens deixa en molt bon lloc, als valencians. Per tant, opine que en aquest terreny del folklore desmuntar tòpics també ha de ser una funció prioritària del professorat.

El que sí que crec que és clar és que coneixent aquestes dites tòpiques ens podem introduir dins l'ànima que ha donat forma a un poble, millor que si ho fem a partir de mostres més cultes i elaborades.

\section{CLASSIFICACIÓ DE LES DITES IFRASES FETES POPULARS}

Intentem una classificació de les dites i frases fetes populars. Moltes de les dites que presente tenen a pobles castellonencs com a protagonistes; les he triades expressament, és clar:

A) En primer lloc les classificarem respecte a la causa que pot justificarne, hipotèticament, algunes, tot i que hem arribat a la conclusió en aquesta comunicació que moltes són absolutament immotivades.

A.1. Dones bé, hem dit ja que molts dels tòpics immotivats no tenen cap altre fonament que la rima d'una paraula pejorativa amb el topònim. Mireu-ne aquests:

(16) A Benicarló / tots tenen cara de bacó.

(17) De Betxí, / ni dona ni rossí, / ni res que siga d'allí.

A.2. En altres ocasions, són cançons que han estat aplicades a moltes localitals, algunes anb una gratuïtal absoluta. Mireu-ne aquesta: 
(18) En Ribesalbes fan festes / i les paguen els fadrins / que relinxen com a bèsties / $\mathrm{i}$ bramen com a rossins.

A.3. Ocorre, a vegades, que la localitat perjudicada amb la cançoneta, ha alterat la forma de l'estrofa o ha canviat algun dels seus versos, convertint així la crítica en alabança. Mireu: els castellonencs anticlericals cantaven aquesta cançó amb aire despectiu:

(19) Castellón de la Plana, / ¿qué tienes dentro? / -Entre frailes y curas, / un regimiento.

Però els del sector més proper a l'església canviaren els versos i els contestaven:

(20) Castellón de la Plana, / ¿qué tienes dentro? / -Hermosura y dinero / y entendimiento.

B) En segon lloc, intentarem classificar les dites i frases fetes en funció de la forma.

B.1. N'hi ha algunes que són descriptives, sovint expressen la situació topogràfica del poble o dels pobles, sense entrar en més valoracions:

(21) Fondeguilla en un barranc, / la vall en una costera, / Xinxes baix lo camí ral, / Moncofa, la granotera.

B.2. En algunes ocasions, les dites tenen un caràcter dialogat, perquè els naturals d'una localitat que se sentien ofesos pel contingut de la cançoneta retrucaven, com hem comprovat abans amb un altre exemple. Comproveu-ho també amb aquests versos que deien als de Nules criticant-los de buscar sempre motius de disputa $\mathrm{i}$ allò que ells contestaven:

(22) En Nules / beu i no t'atures. / -Beu i passa, / fill de la gran bagassa!

B.3. Entre les cançons de temàtica religiosa, n'hi ha moltes amb elements referits als sants patrons de cada poble. N'he triat una del meu poble, permeteu-m'ho:

(23) San Onofre, rey de Hungría, / a Cuarte vino a parar, / y los gabachos de Aldaya / se lo querían llevar.

O aquesta altra que deien les embarassades quan el part estava pròxim:

(24) Gloriós i portentós Sant Onofre, / fes que s’òbriga prompte este cofre. 
C) En tercer $110 c$, classificarem les dites i frases fetes en funció dels assumptes que tracten.

C.1. N'hi ha unes on el tema és, simplement, una qüestió geogràfica o topogràfica relacionada amb el poble:

(25) Entrc Altca i la Vila, / pren tila.

C.2. Unes altres fan referència a qüestions meteorològiques. Una molt coneguda $\mathrm{i}$ atribuäble, pràcticament, a qualsevol muntanya important del territori és aquesta:

(26) Si Muntsià fa capell / pica espart i fes cordell.

C.3. En altres ocasions les dites o frases fetes fan referència a construccions d'cdificis o noves instal-lacions de serveis. Observeu-ne aquesta relacionada amb el popular tren castellonenc anomenat «La panderola»:

(27) De Castelló a Onda / va el tren que vola; / per això tots li diuen / la Panderola.

C.4. Entre els tòpics que podem anomenar antropològics, en destaquem alguns que són una simple relació de gentilicis:

(28) Los de Xert són xertolins, / los de Tírig, tirijans, / a Cervera, cerverins / i a Paníscola, panisclans.

C.5. No falten tampoc les dites tòpiques que fan referència als malnoms dels habitants d'un determinat poble o pobles:

(29) Els de Torís són pitxorros (perquè les torisanes per a traginar els cànters $i$ botiges, se'ls posaven damunt el cap).

(30) Els d'Alberic són rateros (a Xàtiva els ho deien perquè sembla que es menjaven les rates d'aigua que abundaven en la marjal d'arròs).

C.6. També hi ha tòpics referits a la manera de vestir, de pentinar-se o de ficar-se guapos i guapes:

(31) L'alegria del fadrí / és un mocador de pita, / una manta morellana / i una xica ben bonica. 
D) El quart grup de dites i frases fetes populars tracta d' assumptes agrícoles, el cultiu típic del poble, els productes del seu camp...

D.1. Mireu-ne aquestes que fan referència als oficis peculiars de cada localitat o a la seua indústria local:

(32) Mal any de sardina, / Vinaròs a la ruïna.

(33) Alboraiera, / xufera.

D.2. A vegades, es tracta de tòpics que es refereixen a la classe de vida quc es fa a la localitat, criticant-la quasi sempre des d'algun poble veí. Mireu aquesta cançoneta replegada a Cullera:

(34) A València vull anar / a vore les cosidores, / que cusen sense didal / i tallen sense estisores.

O els de Sueca que diuen que les dos L-L de l'escut de la ciutat de València són les inicials de la paraula lladre i que signifiquen:

(35) Lladres per dins, / lladres per fora / i lladres per la vora.

E) Els esdeveniments motivats per les enemistats dels pobles veïns o simplement per successos ocorreguts han produït molts tòpics. Per exemple, les dones de Cullera tenien fama, quan eren fadrines, de:

(36) Tindre més nóvios que caragols hi ha,

i quan es casaven es corria la veu que ara observaven poc la fidelitat conjugal. A Sueca, es contava aquesta història:

(37) Diu que una cullerota disputava en una altra, i que per ofendre-la li deia: -Qui seràs tu, que només tens tres hòmens!

F) Un altre grupet de tòpics, molt nombrós, estaria format per aquells en els quals la delicadesa no sol ser la característica bàsica de la sàtira popular. N'hem presentat alguns ja i podríem afegir-ne molts més, tots ells de caràcter marcadament groller:

(38) Les xiques de Torreblanca / totes van a segar brossa; / s'escarramen a la séquia / i se renten la carxofa. 
G) I finalment, volem fer esment d'un últim grup de refranys i adagis, molt abundants per cert, que tenen a la dona com a protagonista, i que sovint són d'una agror veritablement sorprenent. N'he triat només tres:

(39) Dona formosa, fava o vanitosa.

(40) Cartes, dones i vi trauen l'home de si.

(41) Dona gelosa no reposa.

És pertinent plantejar ara una qüestió: per què la dona, en justíssima defensa, no ha creat refranys satiritzant l'home? I si els va crear, per què no han pres cos en el llenguatge i no ens han arribat? Qui ha creat majoritàriament els refranys, frases fetes, proverbis, etc., que estem coneixent ara, els hòmens o les dones?

La resposta a totes aquestes preguntes potser se n'ix del marc estricte d'una comunicació i ateny qüestions de més importància social. Tot i això, si intentàrem respondre les qüestions anteriors arribariem a entendre per què els refranys de temàtica sobre la dona presenten tants vituperis, insults i calúmnies. Fóra un bon motiu per a reflexionar sobre la pretesa igualtat de la dona en la societat actual i comparar-la amb la situació de fa uns segles.

\section{CONCLUSIONS}

Ara, en l'apartat de les conclusions, insistim una miqueta més sobre el concepte de folklore.

Algú pot pensar que la cultura popular és un tema menor, sense importància, i certament ho és quan s'utilitza per a entendrir el personal o de manera lírica per a enyorar-nos del passat. Si és un tema menor, per què dedicar-li, doncs, el nostre temps estudiant aquesta quiestió quan hi ha tants aspectes importants de la nostra cultura a penes encetats? Per què dedicar-li, doncs, una comunicació a un tema aparentment intrascendent?

Bé, sóc dels que pensa -amb Sanchis Guarner-que no hi ha temes menors, sinó tons menors, maneres menors de tractar els temes. En aquest sentit, els professors hem d'intentar estar a l'altura de les circumstàncies i tractar el tema del folklore amb el rigor que es mereix, fugint de qualsevol tendència lírica. Per una altra banda, pense que és injust i poc intel-ligent ironitzar sobre el folklore. El folkore lingüístic, tan lligat a l'etnografia, encara ens val per ensenyar llengua, sempre que el nostre acostament siga digne i seriós, allunyat de banalitzacions i ridiculitzacions.

També opine que coneixent aquestes dites tòpiques podem introduir les persones dins l'ànima que ha donat forma a un poble, al nostre poble, millor que si ho fem a partir de mostres més cultes i elaborades, com he dit ja. Les 
dites, en definitiva, ens ajuden a reflexionar sobre allò que ens uneix als pobles veïns i allò també que ens separa. Són, a més, una forma interessant, opine, d'acostar-nos a la manera particular d'entendre la vida dels nostres avantpassats, als que no sempre hem valorat com cal.

$\mathrm{Si}$ els he fet veure en aquesta comunicació que darrere de tantes i tantes cançonetes o frases que ens han arribat de pares a fills hi ha, com a mínim, l'esperit d'un poble que alena, em donaré per satisfet. Si, a més, entre tots ens hem adonat que:

(42) Les llengües no són tisores, però són més talladores encara millor.

\section{REFERÈNCIES BIBLIOGRÀFIQUES}

AlPerA, L. (1992): «Manuel Sanchis Guarner, investigador de la cultura popular», dins Ferrando, A. (ed.) (1992): Miscel-lània Sanchis Guarner, València, Publicacions de l'Abadia de Montserrat i Departament de Filologia Catalana de la Universitat de València, 31-36.

CAPó, B. (1992): Costumari valencià. Coses de poble, Picanya, Edicions del Bullent.

Caro Baroja, J. (2003): Los pueblos de España (2 volums), Madrid, Alianza Editorial.

CONCA, M. (1992): Els refranys catalans, València, Editorial 3 i 4.

Griñó I GuZMÁn, A. (2002): «Sant Onofre, la Passejà, els Amics de la Passejà», conferència impartida a Quart de Poblet el 6 de juny de 2002.

SANCHIS GUARNER, M. (1968): Els pobles valencians parlen els uns dels altres (4 volums), València, Edicions 3 i 4, (ed. 1982-1983).

Sancho, P. i C. SANCho (1993): Contes per als néts (El Quart de Poblet de primers de segle), València, Ajuntament de Quart de Poblet, (ed. 1998).

SANXIS I FORRIOLS, J. LL. (2002): Fraseologia popular. Inspirada en el món agrícola i religiós, València, Edicions Brosquil. 


\title{
YOU ARE WHAT YOU EAT! HEALTH CLAIMS AND SPANISH NUTRITIONAL DISCOURSE
}

\author{
José Antonio Díaz RoJo \\ Consejo Superior de Investigaciones Científicas \\ Ricard Morant Marco \\ Universidad de Valencia \\ Debra Westall Pixton \\ Universidad Politécnica de Valencia
}

\section{INTRODUCTION}

$\mathbf{T}$ HE objective of our on-going research is to gain insight into the social values and cultural beliefs of modern-day Spaniards through an examination of the language used to discuss foods, nutrition and human health. ${ }^{1}$ Our research is guided by the hypothesis that today's supermarkets offer consumers an astonishing array of foods, beverages and health products with which to fill their grocery baskets. These products are reflections of changes in our diets and in our society as a whole. Modern foods are products of global agro-food industries, environmentally-sound farming practices, manufacturers' product diversification and advanced technological innovations, all of which are presented to consumers using the highly-persuasive, health-oriented, nutritional discourse common to food marketing.

We have adopted a multidisciplinary perspective for our research, documenting both written and oral text-types in Spanish such as those from food advertising and television commercials, food labels and product packaging, manufacturers' promotional literature and scientific articles in addition to conversations with experts and consumers. We have recorded the wording, messages and other forms of communication regarding the nutritional and health benefits of foods and paid special attention to the nutrition and health claims made on certain food products.

The analysis of our corpus reveals that the dissemination of scientific and medical research in areas of nutrition and human health has contributed

1. Our research is funded by FEDER and the Spanish Ministerio de Ciencia y Tecnología (Project BFF2003-01374). Technical assistance was also provided through the Grupo de Investigación GLOSINTEC of the Universidad Politécnica de Valencia. 
greatly to the popularization of neologisms, loanwords and other lexical elements as well as to the scientification of our language and culture, especially our foods. On the one hand, terminology specific to the high-profile agro-food industry has been transferred into our daily lives and everyday language to designate, for example, imported foods (canteloupo), farming techniques (dry farming), laboratory procedures (análisis sensorial), industrial processes (comida precocinada) or scicntific findings (taninos). On the other hand, a variety of linguistic resources is used in Spanish to describe the foods now available and to specify the effects of these foods on the human organism. Metaphors, euphemisms, semantic vagueness, hyperbole and humor are but a few of the linguistic resources frequently used in nutritional discourse and specifically in the health claims made on foods (Diaz Rojo et al., 2005). Marked by such specific terminology and creative linguistic resources, these claims aim to persuade consumers that human health depends far more on one's individual lifestyle and personal choices (i.e. the foods we eat) than on one's way of life in modern society (i.e. our environmental, socio-economic, genetic and other health determinants).

To highlight the novelties characterizing contemporary nutritional discourse in the Spanish language, this paper has been divided into two sections. First, we shall discuss recent changes in our foods and diets, focusing on five basic ingredients which have blended in such a way so as to modify not only our shopping and eating habits, but also our language and society. Second, we shall identify three types of health claims common in food advertising and, with examples from our working corpus, examine the linguistic resources used in these persuasive messages. It is through this study that we hope to draw attention to the kinds of foods we currently eat, to critically reflect on the ways we speak about them, and to perhaps determine the modern meaning of the popular saying «you are what you eat!».

\section{INGREDIENTS FOR CHANGE IN SPANISH NUTRITION}

The causes for cultural and linguistic changes regarding foods, nutrition and health may be identified through a visit to our community market, the perfect setting for a socio-linguistic study as suggested by Morant and Peñarroya (2000). By examining the contents of our grocery baskets, we may identify five basic ingredients for change as reflected in the types of foods currently available to consumers: 1) exotic foods, products cultivated for a global food market; 2) natural foods, products certified to be environmentallysafe and nutritionally wholesome; 3) personalized foods, products designed to satisfy every nutritional need and individual palate; 4) transgenic foods, 
controversial products of advanced biotechnology; and 5) functional foods, products scientifically tested to be nutritious as well as beneficial for the human organism. Each of these items is a reflection of changing social habits and cultural beliefs; thus, each deserves a brief examination.

First of all, we know that economic globalization has led to the introduction of a spectacular selection of exotic foods along with the incorporation of their foreign lexical denominations. In Valencia, the land of orange groves and rice fields, imported fruits such as the lichi, mango, papaya or kiwi are available year-round while exotic rices such as arroz Basmati or Basmati Brajma from India or arroz salvaje (wild rice) from North America are marketed by the Spanish food manufacturer Nomen. The exotic aura of Nomen's Arroz salvaje con arroz largo y verduras is promoted making direct reference to its traditional origins, its gastronomical prestige, its exquisite taste, its delightful texture and, naturally, its nutritive properties:

El Arroz Salvaje, también conocido como Zizania o Grano de Agua, es un cereal que crece silvestre en amplias zonas de lagos de Canadá y Norte de Estados Unidos. Durante siglos fue alimento básico de los indios Chippewa. En la cocina occidental ha ganado gran prestigio por su exquisitez, que le ha hecho merecer el calificativo de «caviar de los cereales». Es muy apreciado por su característico sabor y su textura crujiente, agradable al paladar. Además, es muy rico en proténas y fibra.

Secondly, while becoming familiar with the exotic, consumers are increasingly concerned over modern, industry-based agricultural practices that endanger our environment, our food supply and consequently, our health. As a result, in recent years there has been an increase in the demand for alimentos naturales, orgánicos, ecológicos or biológicos. These adjectives, true lexical emblems of our time, identify products that are cultivated or produced according to established environmentally-sound standards and are certified to be free of potentially harmful, contaminating chemicals, toxic substances and the like. The nutritional discourse on the Matines label is clearly representative of this return to lo natural:

Los huevos de gallinas criadas al aire libre recuperan las tradiciones de crianza de nuestros abuelos. Muy cerca de su lugar de compra tenemos las granjas para poder ofrecerle un producto de máxima frescura. El contacto con el campo hace que la alimentación a base de cereales confiera al huevo un sabor como el de antes. Con la garantía de Matines. ${ }^{2}$

2. The promotional message on the front label of this egg carton reads as follows: « 6 huevos camperos de gallinas criadas al aire libre y alimentadas a base de cereales. Matines ¡recuperando el sabor tradicional!». 
Thirdly, to satisfy customer demand and increase their market shares, manufacturers have opted for an extraordinary diversification of food products, each designed to reflect changes in individual tastes or to address specific nutritional requirements. This has also resulted in a diversification of food terminology as verified on milk cartons. Whole, skimmed and low-fat milk (leche entera, desnatada, semidesnatada) is now subjected to specific laboratory procedures and additional lexical specification: leche modificada en grasa, leche desnatada con fibra soluble. Hyponyms are added to enhance the description: leche rica en calcio, leche de soja con jalea real. On the label for Puleva Omega3, we find the message leche enriquecida en ácidos grasos Omega3, ácido oleico y vitamina $E$, the additional key words and concepts in the nutritional discourse on its label being proof of an increasing scientification of our language and culture:

Los hábitos de vida saludables y una alimentación equilibrada y rica en grasas insaturadas influyen en los niveles de triglicéridos y en el equilibrio del colesterol. [...] PULEVA OMEGA3 integra en su composición los valores nutricionales de la leche con los del ácido oleico y los ácidos grasos Omega3, atendiendo a la importancia que tienen para nuestro organismo. [...] LA ÚNICA QUE HA DEMOSTRADO CIENTIFICAMENTE QUE AYUDA A REDUCIR LOS NIVELES DE COLESTEROL.

Having filled our shopping basket with exotic, natural and diversified foods, we shall examine our last two «ingredients» which serve to illustrate the changes in Spanish nutritional discourse. Biotechnology, through genetic, chemical or biological manipulation, has created new foods and food products whose scientific denominations are now popular and well known, though some are more readily accepted than others. On the one hand, biotechnology has brought transgenic foods or alimentos transgénicos to the Spanish table, if only in discussions on the subject of foods. Although the term transgenic has acquired a somewhat negative connotation over the past decade, it essentially refers to the techniques of enhancing the beneficial genetic characteristics of basic crops in order to protect plants from pests in the field (Bacillus thuringiensispara in maiz $B t$ ) or to increase the nutritional value of the food (provitamin A and beta carotene in golden rice). On the other hand, biotechnology has also brought the concept of functionality to the foods we eat. Functional foods or alimentos funcionales are aliments scientifically proven not only to nourish our bodies and enhance our health, but they are also believed to treat or even prevent disease. Spaniards are now familiar with the bifidus activo in liquid yogurts and the live cultures in Actimel, thanks in part to the nutritional discourse on food labels: 
Cada Actimel contiene más de 10.000 millones de L. CASEI IMUNITASS que ayudan a tu organismo a defenderse contra las agresiones externas que recibe cada día.

In brief, nutritional discourse on food packaging facilitates the popularization of scientific research into foods as well as the incorporation of scientific terminology into the everyday language of Spaniards. Yet this access to nutritional information has not necessarily made consumers any more knowledgeable or discriminating in terms of their shopping, cooking and eating choices. Proof of this is the tendency to classify foods as bad or good. Needless to say, this is a simplistic view, as that of a typical spaghetti-western. Bad foods naturally include junk food (comida basura) or fast food (comida rápida), cuisine and lexical denominations originating in the United States of America: perritos calientes, hamburguesas, donuts, palomitas de maíz, etc. (Westall Pixton, 2003). By contrast, good foods are those which are part of the "Mediterranean" diet. Though the phrase was coined abroad and later calqued into Spanish as la dieta mediterránea, this geographic reference is used to exalt our "traditional" diet as indicated even on typically "bad" foods like Lay's potato chips: Lay's Mediterráneas Artesanas - Elaboradas con 100\% Aceite de Oliva. According to food advertisers, eating well means ingesting olive oil or becoming part of the cultura del aceite de oliva, as suggested in one recent television commercial for Carbonell olive oil. This advertisement features multi-accented Spanish speakers reciting Antonio Machado's «Los olivos» (1917) together with a peninsular Spanish speaker delivering the final message:

¡Olivares y olivares!

¡Olivares, coloridos!

Bajo la luz argentada.

Olivar, por cien caminos,

tus olivitos irán caminando

a cien molinos.

Estamos uniendo el mundo en la cultura del aceite de oliva.

Carbonell, el aceite de oliva español, $\mathrm{n}^{\circ} 1$ en el mundo.

Olive oil is the key ingredient in the Mediterranean diet and is essential for consumers who seek a satisfying blend of the exotic, the natural, the personalized and the functional as well as the traditional in their diets. This blend of imported social behaviors, technological and scientific applications and changing cultural beliefs is thus patent in our shopping, cooking and eating habits as well as in the language we currently use to discuss foods, nutrition and human health. 


\section{HEALTI CLAMMS (RECLAMOS DE SALUDD) IN STANISH NUTRITIONAL DISCOURSE}

Never are these aforementioned changes more evident than in the communication of nutrition and health claims made on foods. We all know that the promotion of food products by means of nutrition and health claims is perhaps the most frequently-used resource for manufacturers and advertisers, who voluntarily add nutritional or health-related information as a part of their overall marketing strategy. The European Commissioner for Health and Consumer Protection, David Byrne (2003), defines health claims as the messages "which state, suggest or imply a relationship between a foodstuff (or one of its constituents) and health". These health claims, which may or may not be scientifically based or even meaningful to consumers, aim to persuade us that the intake of a nutrient, that is eating a specific food or ingesting a special food product, will ensure good health. With items taken from our corpus of Spanish nutritional discourse, we shall identify nutrition and health claims commonly included in food labeling, presentation and advertising and highlight certain linguistic resources used in these persuasive messages. ${ }^{3}$

First, typical nutrition claims (reclamos nutricionales) describe the «presence, absence or level of a nutrient contained in a foodstuff» (Commission of the European Communities, 2003 a: 2). These claims rely heavily on adjectives like low or rich, for example: bajo en calorías, grasas, sal or rico en calcio, vitaminas, fibra natural. Similar are the comparative claims which indicate a reduction or increase in a particular ingredient, such as that of Spanish olives con 35\% menos de sal. Nutrition claims like this one thus suggest a relationship between an ingredient like salt and a particular health condition, in this case, hypertension.

A second kind of health claim is the "disease-risk reduction" claim. generally known in Spanish as the reciamo medicinal. This claim directly links a nutrient with a particular disorder by relating the effect of a food or nutrient on an individual's health, specifying its preventive, therapeutic or medicinal properties on the organism as seen these two claims:

Los probióticos mejoran el estado inmunológico y el equilibrio de la flora intestinal.

Los ácidos grasos Omega3 y los antioxidantes naturales disminuyen el riesgo de padecer enfermedades cardiovasculares.

3. Our definitions and general classification of nutrition and health claims are based on documents available from the Commission of the European Communties (http://europa.eu.int). 
Since these types of claims clearly establish a causal relationship between a nutrient and a disease or a pathological condition, European legislation has so far strictly limited their use, and claims of this type are now permitted only when there is significant scientific agreement. ${ }^{4}$ This is the case of Flora proactiv, a margarine which reduces cholesterol levels, as indicated on the packaging:

[el] primer alimento funcional para reducir el colesterol aprobado por la Unión Europea, que garantiza su seguridad y eficacia. [Decisión de la Comisión 24/07/2000 reglamento (CE) $n^{\circ} 258 / 971$.

It is the third type, the functional or specific function claim (reclamo no medicinal) which has proven to be the most interesting for our research into changes in Spanish nutritional discourse. There are three reasons for focusing on these claims: 1) they are abundant; 2) they are creative, linguistically speaking, and 3) they use subtle language and plays on words, making them not only more accessible to the target audience, but is also much more persuasive, as evidenced in the recent television commercial for Puleva Omega3 milk:

La mitad de la población española tiene el colesterol alto y no lo sabe. Para evitar el atasco que el colesterol produce en tu circulación, Puleva Omega3 ayuda a regular tus niveles de colesterol y triglicéridos. Millones de españoles ya toman dos vasos diarios de Puleva Omega3 y lo notan. Puleva Omega3, Cuídate.

Functional claims describe the role of a nutrient in the normal physiological state or anatomical development of the human body. In other words, they specify the effects of a nutrient on the body's natural functioning, including its normal physical and chemical processes, which naturally translates to good health. Examples include claims which associate calcium and

4. Current Spanish legislation regulating this type of claim is cited in Díaz Rojo, et al. (2005): «El Real Decreto $1334 / 1999$ de 31 de julio por el que se aprueba la norma general de etiquetado, presentación y publicidad de los productos alimentarios, prohíbe "[atribuir] a un producto alimenticio propiedades preventivas, terapéuticas o curativas de una enfermedad, ni [mencionar] dichas propiedades [...]", con objeto de no inducir' a error al comprador. (Boletín Oficial del Estado, 24-8-1999: 31410-31418). La ley española, pues, prohíbe los mensajes publicitarios (en anuncios o en el etiquetado) que proclaman los efectos curativos o profilácticos de un alimento, llamados en español reclamos de salud (en inglés health claims)». The European case is presented in MEMO/03/188, which clearly specifies that proposed regulation would permit certain 'scientifically substantiated' health claims since "scientific substantiation is the basis for ensuring truthful and meaningful information to consumers regarding the nutritional and health benefits of the food they buy" (Commission of the European Communities, $2003 \mathrm{~b}$ ). 
bone mass or growth, common in the advertising of milk, yogurts and other dairy products. The television commercial for ViveSoy de Pascual is a good example:

Female News Anchor: [...] el gran éxito de la bebida de soja ViveSoy de Pascual de cuyo sabor y beneficios para la salud disfrutan ya miles de personas...

Male News Anchor: Pues eso...

Fcmalc Ncws Anchor: Y es que hablar de ViveSoy es hablar de los isoflayones de la soja y su aportación al bienestar de las mujeres en temas que nos afectan especialmente...

Male News Anchor: Pues...

Female News Anchor:.. y los ácidos grasos Omega3 y Omega6 de la soja, que al ayudar a regular el nivel de colesterol, tan beneficiosos son para el corazón.. Male News Anchor: Pues de todo corazón, ahora sí nos vamos...

Narrator: ViveSoy de Pascual. Lo que vives hoy, te protegerá mañana.

Selective blending of medical discourse and scientific terminology together with attractive images (the subject of our next research task) allows advertisers to make astonishingly persuasive yet amazingly vague claims such as "what you live today will protect you tomorrow!" and thus establish a totally subjective vision of human health. Functional claims are generally based not on objective medical or scientific findings or individual factors of a social, economic, genetic or environmental nature but rather on personal experiences and sensations. To transmit this vision, key words clescribe normal physiological conditions and thus good health: equilibrio, bienestar, renovación, defensas, crecimiento, vitalidad and energia, the latter being wellutilized as documented on the packaging for LU's Galletas Principe MegaMañana. This Spanish manufacturer presents its product with a variety of linguistic resources. There are loan phrases such as Cantidad Diaria Recomendada (Recommended Daily Allowance) along with creative, catch phrases like Dorada iEnergía toda la mañana!* (referring perhaps to the "golden" wheat pictured next to the superhero Principe MegaMañana on the front panel). This slogan is restricted (*) by the fine print at the bottom of the side panel: *...gracias a un desayuno equilibrado con Príncipe MegaMañana! Elements of scientific or medical discourse are also essential as exemplified by the abbreviation edp on the front of the package and the explanation of energía de difusión progresiva (time-released energy) on the back:

Un nuevo concepto de energía. La energía duradera EDP. Los nutricionistas de LU han demostrado que el cuidadoso proceso de elaboración de Príncipe MegaMañana preserva los glúcidos lentos de los cereales que proporcionan 
energía al organismo de manera lenta y progresiva. Por eso galletas Príncipe MegaMañana ayudan a que tus hijos estén llenos de energía hasta el mediodía. ${ }^{5}$

The intention of food manufacturers and food advertisers is clear. They aim to sell consumers good health just like any other food product or commodity on the market today. Wellness (i.e. a comfortable lifestyle, natural surroundings, personal vitality and capacity for social relations) can be purchased in our neighborhood supermarket, the chosen setting for this sociolinguistic study.

In this paper our purpose has been to highlight characteristics of Spanish nutritional discourse as illustrated with items included in our working corpus. By reflecting on recent changes in our foods and diets and by analyzing health claims common in food labeling and advertising, we may draw three conclusions. First, nutritional labels, food packaging and advertising provide consumers with essential product information and associated health facts. Second, these sources of information together with health claims play a key role in the dissemination of scientific findings, transferring specific terminology and enhancing our lexical diversity in popular nutritional discourse. Finaliy, the study of the kinds of foods we currently eat and the ways we speak about them sheds new light on our social behavior and linguistic expression while giving new meaning to the popular saying "you are what you eat!"

\section{ACKNOWLEDGEMENTS}

The authors are grateful to Dr. Francisco García Sobrecases (Universidad de Valencia, Dpto. Economía Aplicada) for graciously resolving questions of methodology as well as to Dr. Javier Martínez Monzo (Universidad Politécnica de Valencia, Dpto. Tecnología de los Alimentos) for his enlightening explanation of food science and human nutrition.

5. The nutritional information on this label is clearly aimed at mothers of young children. It is also worth noting the promotional slogans made for two brands of milk, clearly illustrating claims, however vague they may actually be, and targeting specific consumers and conveniently including the key word energia: 1) Puleva, aimed at youngsters: Max, Energia + Crecimiento, associates milk with growth and energy, common in the normal development of a child; 2) Lechera Central Asturiana, directed at adult consumers: Jalea real, Energía y vitalidad. La forma más natural de disfrutar el día con energía. Are consumers to believe that if they drink royal-jelly enriched milk, its natural energy will somehow make them enjoy the whole day? 


\section{WORKS CITED}

Commission of the European Communities (2003 a): Proposal for a regulation of the European Parliament and of the Council on nutrition and health claims made on foods, $\operatorname{COM(2003)~424~Final.~[July]~2003/0165~}$ (COD), Brussels, pp. 34. http://europa.eu.int/eur-lex/en/com/pdf/2003/ com2003_0424cn01.pdf (Consulted December 2004).

Commission of tHe European Communities $(2003 \mathrm{~b})$ : «The proposed Regulation on health and nutrition claims: Myths and Misunderstandings,》> 1 October 2003, MEMO/03/188, Brussels, pp. 4. http://europa.eu.int/$\mathrm{comm} / \mathrm{food} /$ food/labellingnutrition/claims/index.en/htm. (Consulted December 2004).

ByRne, D. (2003): «Health Nutrition and Labelling,» Address by the European Commissioner for Health and Consumer Protection to the Environment, Public Health and Consumer Protection Committee of the European Parliament, 19 February 2003, SPEECH/03/87, Brussels, pp. 7. http://europa.eu.int/comm/health/ph_determinants/life_style/nutrition/spe ech_nutrition_en.htm (Consulted December 2004).

Diaz Rojo, J. A.; R. Morant Marco; D. Westall Pixton (2005): «Lenguaje y nutrición: un aperitivo interdisciplinar», in Actas del XXII Edición del Congreso Internacional de la Asociación Española de Linguiística Aplicada (AESLA) 2004, Valencia, AESLA / Universidad Politécnica de Valencia (pending publication).

Morant, R.; M. Pentarroya (2000): Llengulatge a la Carta, 2." edició augmentada $i$ corregida (1" Edición, Diciembre 1996), Moncada (Valencia), Fundación Universitaria San Pablo C.E.U.

Westall PiXton, D. (2003): North American Influence on 20th Century Peninsular Spanish Lexicon, Unpublished Doctoral Dissertation, Valencia, Universidad de Valencia. 


\title{
APLICACIÓN DE CONTENIDOS SOCIO-CULTURALES EN LA DOCENCIA DEL ESPAÑOL PARA ESTUDIANTES FORESTALES EN FINLANDIA
}

\author{
Ramón L. FERnández y Suárez \\ $\mathbf{M}^{\mathrm{a}}$ Jesús de Teresa Paredes \\ Universidad Politécnica de Madrid
}

\section{INTRODUCCIÓN}

\begin{abstract}
I A eurt Forestal de la Universidad Politécnica de Madrid en la que ambos L prestamos servicio como profesores titulares en la Unidad Docente de Inglés, tiene en vigor desde hace más de 10 años un convenio de colaboración con el Instituto Forestal de Pieksamäkki en Finlandia. Esta institución está encuadrada dentro del organigrama docente del Politécnico de Mikkeli y el nivel académico de su alumnado es equivalente al de nuestros alumnos, así como son similares las edades de los mismos. Enmarcados en dicho convenio vienen celebrándose desde hace años unos intercambios de profesores y alumnos que ambas partes han enriquecido en múltiples aspectos. Nuestra tarea allí se ha venido desarrollando en dos vertientes a través del programa Erasmus:
\end{abstract}

a) Docencia de Inglés Técnico para Especialidades Forestales, que es una asignatura común a ambos planes de estudio $\mathrm{y}$,

b) Docencia de español básico enfocado a los Estudios Forestales de dicho instituto finlandés, lo cual constituye una asignatura de libre elección para los estudiantes de dicho centro.

\section{EL ENTORNO FORESTAL FINLANDÉS}

Finlandia, como bien sabemos, es un país escandinavo con una entidad étnica propia entre dos mundos bien distintos. Desde occidente ha recibido, a partir de sus origenes como nación, la fuerte impronta cultural de los suecos y desde levante las presiones políticas y culturales de Rusia, con toda la carga de elementos orientales que ello pudo suponer. De modo que la historia del país puede resumirse como una paciente lucha por integrar 
elementos culturales contrapuestos y al mismo tiempo mantener sin mermas su propio y rico acervo cultural, que como en otros países del continente, pongamos por caso Polonia, constituye quizás la médula de su carácter nacional. La lengua finesa, con un origen aún no del todo claramente establecido, guarda relación en apariencia con la lengua de los magiares que dieron origen al húngaro contemporáneo, así como con otras lenguas bálticas más minoritarias, como el estonio. No obstante, ha do destacarsc quo dentro del territorio de Finlandia coincide otra población de origen ártico, los lapones, con su propia identidad etno-cultural y que viven perfectamente integrados en el mundo político finés.

Esbozado el entorno socio-cultural finlandés, bueno es que a modo de complemento pasemos a resumir una aproximación geográfico-económica que nos permita justificar mejor nuestra actividad en dicho centro.

Con una extensión de $337.030 \mathrm{Km}^{2}$, Finlandia posee una población no muy superior a los 5 millones de habitantes. Su principal riqueza son los bosques, que ocupan una extensión aproximada de 20 millones de hectáreas. Lo cual viene condicionado por su situación geográfica, determinante de sus matices climáticos. De modo que la producción de madera y de sus derivados constituyen la mayor actividad productiva del país. El paisaje finlandés es verde y también blanco de nieve durante una buena parte del año. Ello no sólo condiciona la actividad económica sino también la vida cultural. Este país de alto desarrollo tecnológico ha creado entre otras cosas una vasta red de bibliotecas de diversa índole que hoy en día, apoyándose en los avances de la cibernética, mantiene una muy amplia y eficaz difusión de la cultura.

Así las cosas, producir madera y comercializarla son elementos clave para el sostenimiento de ese alto nivel de vida al que hacíamos referencia, hecho que se ve favorecido por el relativamente corto número de población. A consecuencia de ello, el país mantiene y desarrolla constantemente sus vínculos con otros países de Europa, y otros continentes entre los cuales Iberoamérica constituye un objetivo comercial de primer orden. Hacia estos países exporta no sólo madera y derivados sino también tecnología relacionada con su producción, explotación y tratamientos industriales. Los técnicos e ingenieros forestales finlandeses viajan de continuo a determinados países suramericanos para prestarles apoyo mediante cursos y transferencia de tecnología. Igualmente de dichos países se trasladan a Finlandia, alumnos, profesores e industriales a formarse y enriquecer sus conocimientos. Las empresas, por otra parte, también constituyen sus propios canales de comunicación y todo ello va tejiendo una red económico-cultural que necesita inexcusablemente de la lengua española para su sano desanollo. He ahí, pues, la clave para comprender el deseo creciente en el mundo forestal finlandés por 
el estudio de nuestra lengua y en especial por lo que podríamos llamar el argot profesional que a lo largo de casi dos siglos se ha desarrollado en la península en torno al mundo del bosque y la tecnología de la madera.

Si bien las especies explotables no siempre son coincidentes, le presencia de familias comunes entre nuestros bosques y los suyos constituye un factor que fortalece el intercambio de conocimientos, lo cual a su vez nos sitúa como país puente en una posición de privilegio para que se requiera nuestra colaboración no sólo en los campos técnico-científicos, sino también en el orden lingüístico. Nuestros montes de coníferas tienen en Finlandia émulos de mayores dimensiones y diferente rendimiento pero los modos de explotación pueden, dentro de las limitaciones naturales, considerarse equivalentes.

\section{EL SISTEMA EDUCATIVO Y LA ENSEÑANZA DE LAS LENGUAS EN FINLANDIA: EL FINÉS, EL SUECO Y EL INGLÉS}

La enseñanza finlandesa, obligatoria en sus dos etapas iniciales, ofrece alternativas profesionales con orientación técnica y superior a partir de los 16 años, lo que crea un marco de pronto rendimiento para aquellos jóvenes que no aspiran a realizar estudios universitarios. Los recursos técnicos de que disponen los centros y que están a disposición del alumnado son de elevada cualificación. Entre las características que repercuten en dicha circunstancia está la presencia de una población (hoy minoritaria y que reside principalmente en la región suroccidental del país) de habla sueca que ve favorecida su lengua no sólo por su empleo en el mundo oficial, sino también en la radio y la televisión. El finés se enseña y utiliza en todas las esferas y regiones del país, compartiendo preeminente oficialidad con la lengua de los suecos. Pero, y demostrando en ello un carácter fundamentalmente práctico, a estas lenguas se une desde los niveles iniciales la enseñanza del inglés. Los jóvenes fineses al término de las primeras etapas de la educación básica, esto es alrededor de los 16 años, son capaces de entender y expresarse con relativa facilidad en la lengua inglesa, lo cual produce como consecuencia una población adulta que en el peor de los casos puede utilizar dos lenguas para su comunicación interna y con una gran parte del mundo exterior. Lógicamente a la hora de diseñar un curso de español básico tuvimos este aspecto en cuenta como se comentará a continuación.

A todo lo anterior hay que añadir que, siendo Finlandia un país con un $100 \%$ de alfabetización, su población puede ser considerada en su conjunto con un muy alto nivel para la recepción de información, lo cual es perceptible en un notorio y general afán de apertura hacia el mundo exterior por parte de su población. Todo ello les confiere un especial rasgo que desde el punto de 
vista etnográfico les define como gente abierta, aunque no sin rasgos de cierta timidez, y que generalmente demuestra una gran curiosidad por cuanto procedente del exterior pueda actualizar saberes y ampliar horizontes culturales.

\section{PLANIFICACIÓN Y PUESTA EN MARCHA DE UN CURSO DE ESPANOL BÁSTCO PARA ESTUDLANTES FINLANDESES DE INGENIERIA FORESTAL}

Cuando se propuso dar un curso de Español básico a estudiantes de ingeniería forestal en el Instituto Forestal de Pieksamäkki supusimos que se nos plantearían algunas dificultades. Dificultades derivadas del uso de diferentes idiomas por parte de los estudiantes y de nosotros los docentes, y dificultades por la peculiar idiosincrasia de la sociedad española y la sociedad finlandesa. Con el tin de establecer posibles parámetros a la hora de diseñar el curso de español, se entregó a los alumnos un cuestionario en inglés (ver Anexo) sobre lengua y cultura española con el fin de saber hasta qué punto los finlandeses conocían las culturas hispanas.

\section{PECULIARIDADES EN EL ASPECTO LINGÜÍSTICO}

Sin duda uno de los mayores inconvenientes con los que nos enfrentamos fuc cl desconocimiento del idioma finés por nuestra parte. A nuestra ignorancia hubo que sumar que el finés es un idioma particularmente difícil por dos motivos. En primer lugar, por su estructura, ya que es un idioma flexivo -tiene 15 declinaciones distintas- lo que hace que las palabras sean extremadamente largas y difíciles de retener, y en segundo lugar, por su origen, lo cual hacía imposible encontrar un referente lingüístico conocido por nosotros para descodificar cualquier término. Por otra parte, las contestaciones de los estudiantes fineses a preguntas sobre su conocimiento del español, constataron la existencia de palabras «tópico», tales como «paella» u «olé», fórmulas simples de afirmación - «sí»- o de cortesía - «gracias», «por favor»- y otras palabras no muy frecuentes en España pero comunes en Iberoamérica como «caramba«o «hasta la vista» y probablemente adquiridas por aparecer insertadas en películas norteamericanas de gran popularidad.

Ante esta situación de «desencuentro» comunicativo la única opción era utilizar un idioma puente, en este caso el inglés. Como ya se ha comentado, en Finlandia la enseñanza de idiomas se considera fundamental y el inglés se ha convcrtido casi en una lengua alternativa, con permiso del sueco. Los estudiantes conocen el inglés y tienen una buena competencia en la compren- 
sión de textos o en la expresión escrita. Sin embargo, en parte por el carácter retraído de los fineses y en parte por la falta de necesidad en su utilización oral -no olvidemos que los estudiantes del Instituto Forestal de Pieksämäki provienen del centro rural del país, que es la zona que más población está perdiendo en los últimos años-, la competencia de los estudiantes en las destrezas que requieren la expresión oral no es óptima. En este sentido, es complicado que el estudiante finés participe activamente en el desarrollo de una lección. No obstante el inglés resolvió algunos problemas: la existencia de rasgos gramaticales en el español que no posee el finés, e.g. el género o el artículo, se presentaba a priori como un escollo pero que al poseer el idioma inglés estos mismos rasgos el estudiante ya estaba familiarizado con ellos. Pero paradójicamente, fueron precisamente los aspectos en que coinciden inglés y español, principalmente léxicos, en donde mayor dificultad se presentaba. Por ejemplo, hay palabras en el idioma inglés, tales como «migratory/migratorio», que al tener raíz latina resultaban difíciles de comprender por los estudiantes fineses. Era, por lo tanto necesario tener siempre en cuenta que no todo lo que pensamos que es fácilmente comprensible lo es ciertamente.

\section{PECULIARIDADES SOCIOCULTURALES}

Existe un desconocimiento mutuo entre la sociedad española y la finesa. Esto lo podemos ver a nivel más básico entre el profesor y el estudiante. Existen los tópicos y prejuicios por parte de ambos. Habitualmente los españoles pensamos en Finlandia como un lugar frío, que lo es, casi siempre cubierto de nieve, y con muchos lagos y renos, que también los hay. Poco más podemos decir de sus rasgos naturales. En lo que se refiere a sus caracteres culturales quizás sepamos algo de los lapones, de la sauna, -probablemente la única palabra que conozcamos en finés-, de Nokia y, si nos gusta la música, nos suene Sibelius. A las preguntas planteadas en el cuestionario los estudiantes fineses demostraron el mismo desconocimiento. Entre los personajes famosos sólo mencionaron a Antonio Banderas, Julio Iglesias y Carlos Sainz. Del ciudadano español piensan que es perezoso, despreocupado e impuntual y las carácterísticas paisajísticas que les vienen a la cabeza sobre España son el mar y la montaña. A la pregunta, «¿en qué aspecto nos parecemos españoles y fineses?» contestaron «la costa» $\mathrm{y}$ «los rallies» y a la pregunta sobre en qué aspecto nos diferenciamos la respuesta fue «en el clima y los hábitos», aunque no especificaron a qué habitos se referían. 


\section{EXPLOTACION DIDÁCTICA CONTRASTIVA DE AMBAS IDENTIDADES}

Entre tanto desconocimiento lingüístico y cultural mutuo pensamos que deberíamos aplicar la enseñanza del español a un contexto que compartiéramos los dos. Ese contexto era el forestal y, por extensión, todo lo relativo a la naturaleza y el medio ambiente. El plan de estudios (lel Iristiluto Forestal de Pieksamäkki es similar al de nuestra escuela y por lo tanto los estudiantes estarían familiarizados con los contenidos de los materiales que les presentaríamos y, además, estarían interesados, supuestamente, por lo forestal en la misma medida que nosotros o nuestros estudiantes en Madrid. Más aún, todos ellos manifestaron su interés eñ aprender español por considerarlo importante para su futuro laboral.

Así fue como se decidió elaborar un curso de español básico dentro de un contexto, o si se quicre, aplicado, a la ingeniería forestal.

Los textos, de creación propia, que utilizamos versan sobre temas forestales -silvicultura, zoología forestal, ecología, aprovechamiento forestal, gestion del medioambiente, etc. $-\mathrm{y}$ las situaciones comunicativas que planteamos se desarrollan en entornos académicos y profesionales forestales. Y con el fín de abarcar todas las temáticas y situaciones posibles, en los materiales que abordamos, se incluyen tanto aspectos divergentes en las dos culturas como aspectos convergentes. Entre los aspectos diferentes que se tratan se hace especial hincapié en la cuestion léxica incidiendo en dos tipos de temática:

a) Textos que incluyen palabras en español que se refieren a procedimientos forestales, a especies o a elementos paisajísticos que sólo son parte de la tradición forestal española o existen en España y por extensión a algunas áreas del Mediterráneo. Tal es el caso de términos como «dehesa», «monte bajo», «encina», «alcomoque» o, «alcorque». Estos términos se traducen al inglés o bien se explica bien su contenido ya que a veces es difícil, si no imposible, encontrar una correspondencia en inglés. De hecho es básica la utilización de un soporte de vídeo para obtener una idea más clara de la especie o el paisaje al que el texto se refiere. Con el fin de solventar la dificultad de su correcta comprensión se les presenta el término en un texto sobre un tema específico junto con otros fáciles de reconocer debido a su similitud formal con los mismos en inglés y que denominamos «asimilados»:

La dehesa es un tipo de paisaje característico de algunas zonas de España. En él hay árboles, e.g. encinas, pinos, y pradera. Algunos animales comen los frutos de los árholes y la hierha de la pradera. I a madera del tronco se usa como combustible. 
En este extracto de uno de los textos que se emplean aparecen en color rojo los términos nuevos que se van a introducir. Otros términos importantes para la comprensión del texto, los llamados «asimilados», tienen su correspondiente inglés bastante identificable: «pino» es pine, «zona» es zone, «tronco» es trunk o «hierba» se puede traducir como grass o herb, dependiendo de la especie.

b) Textos que incluyen términos españoles que hacen referencia a procedimientos y prácticas que son usuales en España pero prohibidas en Finlandia, como la «resinación» (resin tapping), o improbables de encontrar en ese país, como la «la delimitación de fincas» (fencing) ya que en Finlandia el paso libre por cualquier tipo de propiedad es un derecho.

Entre los temas más coincidentes entre los dos países, se incluye terminología de especies comunes («pino/pine», «pícea/spruce», «abedul/birch», «roble/oak», etc.), procedimientos que se realizan en los dos países («corta y quema/slash-and-burn», «clareo/thinning», «apeo/felling», «sistema de corta a hecho/clearcutting system»...) y otras actividades relacionadas con el mundo de la ecología y de la protección de la naturaleza, hacia la que los fineses son particularmente sensibles («certificación/forest certification», «biodiversidad/biodiversity», «sostenibilidad/sustainability»...).

Ahora bien, como subraya Street, culture is a verb, en otras palabras, es dinámica, proceso, actividad. Por lo tanto cualquier intento de integrar estudios culturales, aunque sea a través de la concepción que se tiene de la naturaleza y el valor que se le otorga a la misma, necesita que el alumno de alguna manera se «involucre» en las experiencias reales del grupo social que habla la lengua objeto de estudio. El siguiente paso que se debería realizar, pues, sería mostrar al alumno finés esa realidad para, a través de ella, conocer mejor el entorno cultural español. En este sentido la etnografía se presenta como una herramienta muy recomendable, aunque en el caso que nos ocupa se ve limitada ya que los estudiantes fineses no se pueden desplazar a España para observar y participar plenamente en una situación comunicativa real.

Entre los procedimientos de recogida de datos más utilizados por el etnógrafo se encuentran la introspección, la participación y observación, la observación y la entrevista. Lógicamente, por lo anteriormente dicho, los estudiantes fineses sólo podrían seguir los dos últimos procedimientos. La observación se llevaría a cabo a partir de videos realizados en nuestra escuela mostrando diversas situaciones en el contexto académico: clases prácticas, charlas entre estudiantes españoles, 
clases teóricas, eic. La entrevista, hoy por hoy, sólo se podría realizar a los profesores españoles $y$, mediante «chats» previamente concertadas entre estudiantes fineses de Pieksämäki y estudiantes españoles de Madrid. En la actualidad la Unidad Docente de Inglés de la EUTI Forestal está trabajando sobre este proyecto aunque aún llevará cierto tiempo su puesta en marcha.

\section{CONCLUSIONES}

Para finalizar cabría concluir con unas reflexiones que se ajustan a lo que pensamos sería necesario tener en cuenta a la hora de planificar un curso de las características que hemos mencionado, y cstas serían:

a) hay que identificar los posibles problemas de índole lingüística $y$ etnológica ya que si no, no se lograrán los objetivos;

b) se debe emplear un contexto referencial que ambos, alumnos y profesores, dominen y por el que muestren interés;

c) debemos servirnos de medios audiovisuales o apoyos informáticos atractivos que inclinen a los alumnos favorablemente a la percepción de los contenidos docentes y las situaciones comunicativas reales que se pretenden trasmitir;

d) es de destacar que el hecho de la procedencia socio-cultural del alumnado condiciona de forma inequivoca el método de aproximación docente. Pudíanos, pues, hablar de «métodos» personalizados.

\section{REFERENCIAS BIBLIOGRÁFICAS}

DAMEN, L. (1987): Culture Learning: the Fifth Dimension in the Language Classroom, Reading MA, Addison Wesley Publishing Company

JORDAN, A.; JAEGER, K. and LORETSEN, A.,(eds) (1995): Intercultural Competence II, A New Challenge for Language Teachers and Trainers in Europe, Aalborg University Press

Nurmi, K.;VANAmo A.(eds.) (1999): Finland's Forests -jobs, income and nature values, Helsinki, Ministry of Agriculture and Forestry

Roberts, C.; Byram, M.; Barro, A.; Jordan, Sh. and Street, B. (2001): Language Leamers as Ethnographers, Clevendon, Multilingual Matters Ltd.

SAvile-Trorke M. (1989): The Ethnography of Communication: An Introduction, $2^{\mathrm{ms}}$ edition, Blackwell 


\section{ANEXO}

\section{QUESTIONNAIRE TO BE FILLED BY STUDENTS OF SPANISH AS A FOREIGN LANGUAGE}

1. Have you ever been to Spain?

2. What do you know about Spain and Latin America?

3. Can you mention any prominent Spaniard? Latin American?

4. How would you say a typical Spanish type is? (funny / outdoor type / etc.)

5. When you think of Spain, what natural or geographic aspect do you think of?

6. Excluding EUROS, try and say any aspects shared by your country and Spain.

7. Try and say any aspects you can remember which are different in both countries.

8. Why are you studying Spanish?

a) Because I like languages

b) Because I'm interested in Spanish culture.

c) Because I'd like travelling in Spain and/or Latin America.

d) Because it's important for my curriculum.

e) Because it's important for my professional future life.

9. Did you know any Spanish word before starting your studies? Which ones?

10. Give a score from 1 (for the least) to 5 (for the maximum) to your need for learning Spanish.

11. Which aspect of Spanish language is the hardest for you?
a) Grammar
b) Reading comprehension
c) Oral comprehension
d) Writing
e) Oral expression
f) Pronunciation

12. Which aspect of Spanish language is the easiest for you?
a) Grammar
b) Reading comprehension
c) Oral comprehension
d) Writing
e) Oral expression
f) Pronunciation

13. Which among the grammar aspects of Spanish language is the hardest one for you? 


\title{
CONFLICTING LANGUAGE? IDEOLOGICAL REPRESENTATIONS IN NORTHERN IRISH POLITICAL DISCOURSE
}

\author{
Laura Filardo Llamas \\ Elena GonZÁlez-Cascos Jiménez \\ Marta Ma GutiérRez RodríGuez \\ Universidad de Valladolid.
}

\section{INTRODUCTION}

W

E can start this paper by looking at an extract from Colin Bateman's novel

Divorcing Jack, which provides us with a perfect example, and summary, of the ideas we intend to present. The main character, Dan Starkey, explains to a foreign journalist the problems of finding a definition of Northern Irish ${ }^{1}$ identity (Bateman, 1995: 46)

'And stick to calling it Northern Ireland, although you'll hear variations. If you're a Loyalist, you'll call it Ulster, if you're a Nationalist you call it the North of Ireland or the Six Counties, if you're the British Government you call it the Province.'

'And what do you call it, Mr Starkey?'

'Home.'

We can see in this quote, some of the ideas we will develop all throughout this paper. First of all, the extract reflects the importance of language, and its relation to society in NI. Second, some of the actors in NI society are presented. Finally, the difficulty of understanding and defining a conflicting society like the NI one is hinted in the paragraph.

Sociolinguistics, in its broadest conception, tries to explain the relationship between language use and society. As Fairclough (1989: 7) states, "it is thanks to sociolinguistics that the socially constituted nature of language practice can be taken as a general premiss of critical language study". ${ }^{2}$ In this paper, we

1. From now on, any reference to Northern Ireland will appear as NI.

2. This study follows a Critical Discourse Analysis (CDA) approach. We do not intend to look deeply at this matter, but, as Wodak (1989: xiv) explains, among the aims of critical linguistics are to "make mechanisms of manipulation, discrimination, demagogy and propaganda, explicit and transparent" and "to enable us to interpret and understand how and why reality is structured in a certain way". 
intend to focus only on one aspect of this relationship between language and society, which is the representation of that society through language. We can then say that discourse is made of chains of propositions which establish a "discourse world", defined by Chilton (2004: 54) as:

The 'reality' that is entertained by the speaker, or meta-represented by speaker as being someone else's believed reality. There are various meaning ingredients that go into these discourse realities, but the essential one is the projection of 'who does what to whom, when and where'.

If we apply this sociolinguistic approach to NI, we find that the function of discourse in NI is "the production of symbolic and ideative constructs through which reality is understood" (Hazleton, 1996: 16-7). As a consequence, in segregated societies discourse represents divided and often opposing interpretations of political reality, reflecting and influencing popular and elite concerns.

Since we cannot analyse every type of discourse produced in NI, we have decided to take political discourse as representative of the whole NI society, where different actors express their national identity through the language used to define the situation. Moreover, we believe that political texts can be considered as an example of the characteristics of the language related to each of the communities ${ }^{3}$ in NI. Thus, as Hidalgo Tenorio (2002: 256) states:

People in general, and politicians in particular, are members of a distinctive social group with one specific ideology. Language is one of the ways by means of which each of us marks out the social group we belong to and, consequently its convictions.

\section{CONTEXTUALIRATION}

Before analysing any type of discourse we need to contextualize it. First of all, we will look at the people involved in NI society and the political developments.

Following Whyte's internal interpretation (1990: 195-205) we will take into account the unionist/loyalist community and the nationalist/republican one. According to this explanation of NI circumstances, the conflict is due

3. "Community is a word which does not have a precise meaning in NI, although it is particularly used in the plutse the "iwo communities" to refer to the opposing nationalist and unionist groupings" (Dunn \& Dawson 2000: 53-4). 
to two cohabiting communities arguing about the constitutional status of the NI area. On the one hand, we find the unionist/loyalist community, whose main objective is to keep NI within the United Kingdom jurisdiction. This group is mainly linked to the Protestant religious denomination. On the other hand, we have the nationalist/republican community, who aims at the reunification of the island under the Irish government and who is usually tied to the Catholic Church. (Dunn \& Dawson, 2000: 171, 288). We have identified two main ideologies, but within them we can find a subgroup with those who approve the use of violence to achieve their intended goals. That is the main characteristic of both loyalist and republican groups (Dixon, 2001: 6)

In the second place, we also need to understand contemporary NI history to be able to locate the discourses we are going to analyse. Thus, we will make a brief summary of the main events that have taken place in NI ever since the conflict broke out in $1968 .{ }^{4}$ As we have just mentioned, the starting point of what has become known as The Troubles is placed on 5th October 1968 because of the violent outcome of a protest organised in the city of Londonderry by Catholics who were claiming their civil rights.

The Civil Rights Movement was determinant in making the Catholic community aware of the abuses that were occurring under the Stormont Government, led mainly by Unionist politicians. Violence kept escalating until it reached its highest peak in 1972, when the British Government suspended the NI Parliament and established direct rule. Previously, other attempts had been made to try to save the situation, such as the deployment of the British troops in NI streets, or the introduction of internment without trial to fight terrorism.

Since 1972, the British and Irish governments and NI political parties have tried to solve the problem in different ways. In 1973, the Sunningdale Agreement was signed, trying to establish power-sharing between unionists and nationalists alongside an all-Ireland body. Nevertheless, the unionist community organised a strike that managed to bring down this proposal in 1975 while violence kept rising.

The following years were characterised by a Long War between the British government and the Irish Republican Army (IRA). In 1976, the British government ended the Special Category Status for paramilitary prisoners, in an attempt to set a new criminalization policy. As a consequence of this new policy, we find the Republican Hunger Strikes of 1980-81, which mark out

4. The data used to summarise the history of the NI conflict are taken from the following sources: Bew \& Gillespie (1999); Elliott \& Flackes (1999); Dixon (2001); McKittrick \& McVea (2001); (Feeney 2004). 
the initiation of modern Sinn Féin (SF) in constitutional politics, following a new dual strategy called The Armalite and The Ballot Box.

The next important political development took place in 1985, when the Anglo-Irish Agreement (AIA) was signed by the British and Irish governments. The Unionist community firmly opposed this agreement because they believed it gave the Irish government an important input in the ruling of NI, and this marked their political behaviour in the aftermath of the AIA. On the other hand, the republican movement continued with the dual strategy, and while the IRA maintained their violent campaign, SF moved into the political arena and contested every election that took place. At the same time republican representatives entered in secret contacts with the British government, the Irish government and the nationalist community.

This resulted in the Downing Street Declaration signed by the British and Irish governments in 1993 and in the 1994 IRA ceasefire, followed by a round of multi-party talks, in which members of the unionist and nationalist communities took part. Nevertheless, unionists and the British government asked the IRA to decommission some of its weapons if they wanted SF to enter these negotiations. This condition was not fulfilled and the IRA returned to violence in 1996, to call a new ceasefire in July 1997, following the election of a Labour British government. This resulted in new negotiations, which concluded with the signing of a new Agreement in 1998 by both unionists and nationalists.

Ever since 1998, NI political developments have been aimed at the implementation of the Peace Agreement. Nevertheless, NI has suffered from scveral political crises, in which violence has not becn as present as in the previous 30 years. One of the most important obstacles for the unionist community is the lack of decommissioning by the IRA, whereas the nationalist community asks for a complete devolution of powers to the NI Assembly. In 2002, the NI Assembly was suspended, following allegations of IRA spying at Stormont - the Parliament building. After several attempts to reach a solution, Assembly elections were called for 2003.

Although we have briefly summarised the whole NI conflict, our research is focused on the developments following the 1998 Agreement. After that moment political developments are not determined by violence, but by what Dixon (2001: 37) has called "a war of words", in which political elites, pressure groups, and normal people try to influence an observer's understanding of the conflict through the language they use to describe it. That is, then, the main focus of our research: trying to establish the different linguistic uses which indicate political ideology, in this case, focusing on the 2003 Assembly election. 


\section{METHODOLOGY AND TEXT SELECTION}

As we have already explained, the purpose of this paper is to analyse how ideology is manifested in language. Since we cannot look at all the possibilities for space reasons, we will only focus on the lexicon used to describe different aspects of NI society. As we have just mentioned, NI is now immersed in a war of words in which "definitions of words are strongly contested" (Dixon, 2001: 37), making them become almost another weapon. Moreover, in his explanation of the reflection of power through linguistic processes, Fowler $(1985: 69)$ establishes the lexicon as one of the linguistic components through which power, and ideology, can be transmitted, as it reflects and expresses the interests of a given group.

The study of words has traditionally been done by semantics. Nevertheless, the problem with that discipline is that it has usually been separated from context (Chilton, 2004: 48). We believe it is not necessary to emphasise again the importance of context in NI. Notwithstanding, we will mention again that it determines the knowledge shared by the people emitting the utterances and those receiving them.

We will not look in detail at the theoretical basis, but the analysis in this paper is broadly based on Saeed's (1997: 23-47) conception and explanation of semantics, which we believe is tightly intermingled with pragmatics. He basically identifies two approaches within this theory. On the one hand, we can find denotational or referential semantics, which aims at establishing a link between the words, and the symbols and entities they refer to. This process is based on the objective world in which utterances are produced, i.e. the context is not taken into account. On the other hand, we can find representational semantics, where individuals take into account their mental representation of reality to interpret the link between words and symbols. Chilton (2004: 50) applies this second approach to political discourse, and establishes that "it has to do with the notion of 'world' itself, since the use of language in political discourse can be seen as a form of competition among political actors wishing to promote, to have accepted, their own particular "world"".

Hence, we can identify two basic layers in the analysis. First, we need to establish which is the NI circumstance the word is referring to, i.e. see its denotational meaning. While fulfilling this level of analysis, it is also important to take into account that sometimes we can also find that both communities use the same word to refer to different entities. In this case, we find words having what Fairclough (1995: 112-4) calls an "ambivalence potential", that is, they may have different senses. If this occurs, we have to compare the word's "dictionary meaning" with its meaning in specific texts, 
using context to "disambiguate" the meaning of words, i. e., to establish the entity they are referring to.

Second, we also need to look at the representation of NI political developments that could be inferred from that linguistic form, i.e. look at its representational meaning and the image of NI it is trying to present. Once again, context is essential for establishing the representation of the world. Hearers use their MRs $s^{5}$ to deduce the implicit meaning of the noun, or noun phrase, used to refer to a certain entity.

Once the methodology has been briefly explained, we need to establish the texts we are going to study. These fulfil three criteria. First, their production time is the Assembly elections that took place in 2003. Second, the producers of the texts are the two most radical parties representing both the nationalist and unionist community in NI: the Democratic Unionist Party (DUP) and Sinn Féin (SF). Finally, the document-type is the election manifesto presented by each party.

\section{ANALYSIS AND EXAMPLES}

To begin with, and since we cannot analyse all the different names used to refer to reality in NI, we present a table which highlights the most recurrent different linguistic uses we have found in the 2003 Assembly election manifestos published by the DUP and SF. However, we do not present here a collcction of all the differences we have found, but just a summary of the most striking ones. Following the two layers of analysis established above, we will look at the ideological representations of the most common lexical items that appear in table 1.

5. According to cognitive psychology, "you do not simply 'decode' an utterance, you arrive at an interpretation through an active process of matching features of the utterance... with representations you have stored in your long-term memory" (Fairclough, 1989: 10-11). 
TABLE 1. Lexical forms used by the DUP and SF in the 2003 Assembly-election manifestos

\begin{tabular}{|l|l|}
\hline LEXICAL FORMS USED BY THE DUP: & LEXICAL FORMS USED BY SF \\
\hline $\begin{array}{l}\text { [Northern Ireland] Assembly } \\
\text { Constitutional settlement } \\
\text { Accountable democratic government }\end{array}$ & $\begin{array}{l}\text { Six-County Assembly } \\
\text { First Assembly }\end{array}$ \\
\hline $\begin{array}{l}\text { Belfast Agreement } \\
\text { Trimble's Agreement }\end{array}$ & Good Friday Agreement \\
\hline Closing of army bases & Demilitarisation \\
\hline $\begin{array}{l}\text { Concessions (made by the British } \\
\text { government) }\end{array}$ & $\begin{array}{l}\text { Commitments (by the British } \\
\text { government) }\end{array}$ \\
\hline $\begin{array}{l}\text { Destruction of weaponry } \\
\text { Removal of terrorist structures and } \\
\text { weaponry } \\
\text { Decommissioning of weaponry }\end{array}$ & Putting arms beyond use \\
\hline Londonderry & Derry \\
\hline $\begin{array}{l}\text { Northern Ireland } \\
\text { The Province } \\
\text { Ulster }\end{array}$ & $\begin{array}{l}\text { The North of Ireland } \\
\text { The Six Counties } \\
\text { Six-County state }\end{array}$ \\
\hline $\begin{array}{l}\text { Official Unionists (for the UUP) } \\
\text { Trimble's team }\end{array}$ & Ulster Unionists (to refer to the UUP) \\
\hline Sinn Fein/IRA & $\begin{array}{l}\text { Sinn Féin and Republicans } \\
\text { Sinn Féin }\end{array}$ \\
\hline $\begin{array}{l}\text { Terrorist prisoners } \\
\text { Political prisoners }\end{array}$ & Unionist paramilitaries \\
\hline $\begin{array}{l}\text { The people of Northern Ireland } \\
\text { The People of Ulster }\end{array}$ & Irish people \\
\hline $\begin{array}{l}\text { The Republic of Ireland } \\
\text { The 26 counties }\end{array}$ & South [of Ireland] \\
\hline $\begin{array}{l}\text { The Troubles } \\
\text { War }\end{array}$ & $\begin{array}{l}\text { Conflict } \\
\text { RIR (Royal Irish Regiment) } \\
\text { RUC (Royal Ulster Constabulary) }\end{array}$ \\
\hline Crown Force - or PSNI \\
\hline
\end{tabular}

a. The text included within brackets is not part of the lexical item, but it is added for clarification purposes. Square brackets are used to indicate that those words do not always appear.

b. The lack of accent in Sinn Fein is not a mistake, but the way it is used by the DUP in an aftempt to anglicise the name of the party, which is originally in Irish Gaelic. 
We will begin by looking at the lexical forms used to refer to places, starting by looking at the name given to the location where the political debate happens. The DUP refers to it as Northern Ireland, the Province and Ulster and $\mathrm{SF}$ uses the North of Ireland, the Six Counties or Six-County state. The first part of the analysis is quite obvious, since by looking at these words, we know that they are denotating the six-county area covering the North of the island of Ireland, and which is officially known as Northen Ieland. Nevertheless, we can see that each of the lexical forms represents a different world view.

We can identify two ideological representations in the Unionist discourse. First, they recognise the legitimacy of NI as separate from the rest of the island by using its official name. Second, they emphasise the fact that the six counties that make up NI were, and remain part, of the province of Ulster. By so doing, they seem to implicitly claim the nine counties of Ulster ${ }^{6}$ as part of NI. This idea is accentuated by the use of the term the Province, which refers again to one of the four provinces of Ireland.

If we look at the linguistic forms used by SF, we also find two ideological traits. They neglect the legitimacy of NI by avoiding the use of the official term while highlighting that, for them, NI should be united to the rest of the island of Ireland when they use the North of Ireland. Moreover, they stress the fact that NI is made of the Six Counties which do not form part of the Republic of Ireland, and which were "partitioned" in 1922, as well as the lack of a "logical" reason for that division.

These ideas are recurrent in the names given to the Southern part of the island. The DUP emphasises the legitimacy of NI by calling the South the Republic of Ireland, which is the official name of the country. Moreover, distance from the Southern part of the island is expressed, by emphasising that there are two different countries in the island. Meanwhile, SF refers to it as the 26 counties, focusing on the division of the island on two illegitimate parts. By designating this place as the South of Ireland, they keep expressing that the island is indivisible and it should be an integral political entity.

It is also interesting to look at the ways in which political parties are referred to. Although we have identified two cases in table 1, we will only explain one of them: the reference used to describe SF. Unionists, and mainly the DUP, believe that SF is inextricably linked to the IRA, thus they refer to it as Sinn Fein/IRA which sometimes also appears as IRA/Sinn Fein-. This

6. Ulster, one of the four provinces of the island of Ireland, is made of nine counties. Three of these counties -Monaghan, Cavan y Donegal- were not included in NI when it was tormed, to maintain the unionist-protestant majority of the new state. (Hennessey 1997: $5-6)$ 
construction implies that, according to the unionist view, SF still supports violence, and they can be held responsible for the IRA actions. We also mentioned before that they avoid using the accentuated form of "Féin" to anglicise the Gaelic word. It seems to us that this is done for two reasons: while denying the right to use the Irish language in NI they are also depriving the party's name of its meaning in Gaelic, ${ }^{7}$ and on a deeper level, ney keep legalising NI existence.

On the contrary, SF refers to itself as Sinn Féin. The effect of this lexical unit is the opposite one of the DuP: they legitimise the role of the Irish language, and maintain their claim over the whole island of Ireland as an independent entity not "colonised" by the British Empire. Moreover, we can see that in the noun phrase Sinn Fein and Republicans they try to separate themselves from the use of violence, since republicans is the term usually employed to refer to those who advocate for the use of violence as a means to achieve a united Ireland.

Another aspect we can look at is the naming of the Peace Agreement signed in 1998. The Dup calls it the Belfast Agreement, focusing on the place where it was signed - Stormont castle in Belfast. We could also say that they try to stress the idea that the agreement was reached in the NI area, since Belfast is the capital city of NI. Moreover, we can see that they usually have a negative perception of this Agreement - their whole election campaign was focused on the negotiation of a new agreement, their slogan being "it's time for a fair deal". By referring to this document as Trimble's Agreement, they contest the leadership of the Ulster Unionist Party (UUP) and they dissociate themselves from the signing of the 1998 Agreement and remind us that they did not support it. We can see that they try to transmit the idea, which is repeated all throughout the DUP manifesto, that David Trimble lacks the strength to oppose republican demands and that, because of that, he cannot negotiate on behalf of the unionist community.

SF also highlights some of the features of the Agreement by calling it the Good Friday Agreement (GFA). This Agreement was signed on 10th April 1998, which was Good Friday. However, this has deeper ideological implications, as it is linked to the importance of Easter for the republican and nationalist community. According to republicanism, one of the key events that helped SF to become an important political party was what has become known as «Easter Rising» in 1916, when a group of Irish nationalists upraised against British direct rule. By focusing on the date that the GFA was signed, contemporary nationalists seem to be trying to establish a link between both moments in Irish history.

7. Sinn Féin is the Gaelic equivalent for "we ourselves" although it is often mistranslated as "ourselves alones". (Dumn and Dawson, 2000: 251). 
We will finally look at one of the most controversial issues when describing the circumstances in NI, which is the type of prisoners evolving from the conflict. First of all, we need to identify the referent, which is the prisoners belonging to paramilitary organisations, either loyalist or republicans, and who use violence as a means to achieve, or defend, their political goals. By describing them as terrorist prisoners, the DuP focuses on the violent role of these persons, since terrorism can be definted as the systemic use of violence to achieve some political goal. On the contrary, we can see two ideological representations in SF uses. They use unionist paramilitaries to refer to the loyalist organisations, and emphasise the use of violence by those belonging to the opposite community. Moreover, they implicitly establish a link with military-like organisations, such as the British Aimy, the Royal Irish Regiment (RIR), or the B Specials, focusing on one of their most common claims: collusion between loyalist and British forces. On the contrary, when describing republican prisoners as political prisoners, SF legitimises the use of violence, and emphasises the political role of the organisations that perpetrate the crimes. We can, then, see that while unionists focus on the process and the costs it may provoke, nationalists do it on the goals to be achieved by those means. As Conor Cruise O'Brien argues, "the use or not of the term 'terrorism' has a bearing on how long the political violence is likely to continue and how many lives it will cost" (Dixon, 2001: 37). We believe that this last example shows the need for analysing political discourse and the legitimisation procedures that can be found in it, even more in divided societies when the use of a word instead of another could have violent consequences.

\section{CONCLUSION}

After looking at the lexical items used to describe the situation in NI, we could say that the most important aspect of the analysis is the representational value words have. By representing the world in a specific way, determined by the choice of words, political parties in NI present an abstract view of their society, which does not reflect the complexity of reality there. Hence, language seems to be conflicting, and sometimes contradictory, as the images presented could even be opposed.

Political parties in NI use this type of linguistic constructions as a new type of "war" in their struggle to achieve power. If the lexical items used become accepted, the ideology they express is implicitly legitimised and, thus, their view of Nr will prevail over their opponent's one.

Moreover, political parties in NI could be considered as a "microcosm" of NI society. The discourses uttered by political parties index a concrete 
ideology, and a national identity, which is also shared by the members of the community to which they belong. Thus, the language chosen reflects the language used by inhabitants in other aspects of their life.

To conclude, we could say that the inextricable link between language and society in NI is more than proved. $\mathrm{NI}$ is a place where language is used as another way of "telling" which of the communities people belong to. Thus, the political examples that appear in this paper are no more than a reflection of other examples we could have found in other discourse types, such as novels, murals, paramilitary songs, newspapers, or even everyday conversations.

\section{BIBLIOGRAPHY}

Bateman, C. (1995): Divorcing Jack, London, Harper Collins.

BEW, P.; G. GILLESPIE (1999): Northern Ireland. A Chronology of the Troubles. 1968-1999, Dublin, Gill \& Macmillan.

Chilton, P. (2004): Analysing Political Discourse. Theory and Practice, London, Roütledge.

Dixon, P. (2001): Northern Ireland. The Politics of War and Peace, Basingtoke, Palgrave.

Dunn, S.; H. Dawson (2000): An Alphabetical Listing of Word, Name and Place in Northern Ireland and the Living Language of Conflict, New York, The Eldwin Mellen Press.

DUP (2003): Fair Deal Manifesto 2003, Belfast, Democratic Unionist Party.

Elliott, S.; W. D. Flackes (1999): Northern Ireland. A Political Directory. 1968-1999, Belfast, Blackstaff.

FaIrClough, N. (1989): Language and Power, Essex, Longman.

- (1995): Critical Discourse Analysis. The Critical Study of Language, London, New York, Longman.

FEenEy, B. (2004): A Pocket History of the Troubles, Dublin, O'Brien.

FOWLER, R. (1985): «Power» in VAN DIJK, T. A. (ed) (1985): Handbook of Discourse Analysis. Vol 4. Discourse Analysis in Society, London, Academic Press.

HAZLETON, W. A. (1996): National Identity and Political Discourse in Divided Societies, Miami, The Author.

Hennessey, T. (1997): A History of Northern Ireland. 1920-1996, Dublin, Gill and MacMillan.

Hidalgo Tenorio, E. (2002): «"I Want to Be a Prime Minister", or What Linguistic Choice Can Do for Campaigning Politicians», Language and Literature, 11.3: 243-61. 
MCKITTRICK, D.; D. MCVEA (2001): Making Sense of the Troubles, London, Penguin.

SAEED, J. I. (1997)[2001]: Semantics, Oxford, Blackwell.

SF (2003): Agenda for Government. Clár Rialtais. Sinn Féin Assembly Election Manifesto 2003, Belfast, Sinn Féin.

WhYTE, J. (1990): Interpreting Northern Ireland, Oxford, Clarendon Press.

Wodak, R. (ed) (1989): Language, Power and Ideology. Studies in Political Discourse, Amsterdam, Philadelpia, John Benjamins. 


\title{
LA IRONÍA SOCRÁTICA: UN COMPROMISO SOCIAL MÁS ALLÁ DE LA DIALÉCTICA ÉTICO-FILOSÓFICA
}

\author{
Ángela García Canelles \\ Universitat Jaume I
}

$\mathbf{E}$

N su sentido etimológico la ironía proviene del vocablo griego eironeia, que significa una forma de interrogar simulando ignorancia. Lingüísticamente hablando, y desde la perspectiva de la pragmática, se la define como la expresión consistente en decir lo contrario de lo que se piensa en un cierto tono burlesco. ${ }^{1}$ Dicho tono le viene dado por la implicación en ella del elemento paródico o burlesco, el cual está en estrecha relación con la acepción de ironía que proviene de la farsa trágica o de la comedia bufa de la comedia ática griega (s. IV a. C.). En ella aparecían en el escenario dos personajes antagonistas, de los cuales uno, el alazón, fátuo y fanfarrón, exageraba vociferando las cualidades físicas y psíquicas del segundo, el eiron; este último, discreto y modesto, vencía con su sagacidad y astucia a su adversario, a costa del menosprecio de que era objeto, ridiculizándole y poniéndole en evidencia. No obstante, pensar que la ironía es fruto sólo de una práctica del ocio, mero juego lingüístico o puro arte retórico, es restarle facultades a este concepto. En efecto, la ironía resulta demasiado moral para ser sólo puro arte, como es asimismo demasiado cruel para reducirla a pura expresión cómica o humorística. Sin embargo, la ironía es a la vez moral y cómica o mejor tragicómica, pues sirve para mitigar o dar rienda suelta a la ansiedad existencial del ser humano. Pero no hay que olvidar que el irónico es aún más libre que el que tan sólo ríe, ya que puede ser que este último ría por el mero hecho de no llorar. El irónico, conocedor del peligro que encierra su juego, juega con él para decir la verdad, empleando para ello una forma indirecta de hablar, sirviéndose de la inversión. El juego irónico puede resultar muy apasionante, pero también arriesgado e, incluso, puede acabar mal, como le sucediera a Sócrates o a Cristo o a tantos otros a lo largo de la historia, pagando por él un alto precio.

Partiendo de este planteamiento inicial sobre la ironía, nos proponemos demostrar en este trabajo: primero, que la ironía, denota una superioridad

1. Sobre el sentido etimológico y sobre la definición de ironía cf. Chantraine (1999: 426) y Lausberg (1968: Il, 85 ss.). 
psíquica e intelectual, así como un perfecto dominio del lenguaje del que la ejercita. Segundo, que por medio del discurso irónico entran en acción, además de las competencias lingüísticas, también las culturales e ideológicas de sus interlocutores, por lo que no se puede reducir éste a mcras opcracioncs de pragmática o de retórica. Tercero, que la ironía imprime carácter, estructura el discurso de forma dialéctica y es significativa para la inserción de éste en el entorno social en y para el que fue creado. Consecuentemente, la ironía está ligada a un contexto socio-cultural, sin el cual sus propias simulaciones perderían toda su eficacia.

Es dicho carácter social de la ironía el que nos lleva a observar que ésta, en determinados momentos históricos, toma una dimensión metafísica que va más allá de su sentido etimológico y de su definición preliminar, manifestándose como una actitud trascendental ante la vida que hace que el sujeto irónico entre en conflicto no sólo con su entorno, sino también consigo mismo. Este compromiso social de la ironía se observa en toda su magnitud en la ironía socrática, lo que justifica su interés y elección para esta investigación, dado que ésta ha hecho escuela a lo largo de la trayectoria evolutiva de la ironía como forma de discurso.

Para su estudio tomaremos como corpus Los Diálogos de Platón, ya que Sócrates, como buen irónico, no escribió ni elucubró sobre la ironía, sino que la experimentó y vivió coherentemente hasta sus últimas consecuencias. Platón recoge en ellos toda la doctrina que éste transmitiera en sus conversaciones o diálogos con sus discípulos incondicionales, reflejando su preocupación por educar en la responsabilidad a los atenienses. I a filosofía socrática se propagó a lo largo de la historia gracias a estos diálogos platónicos. Existe, sin embargo, una sutil diferencia entre el Sócrates auténtico y el que nos ofrece Platón, pues no hay que olvidar que este último no se le puede considerar como un irónico propiamente dicho; no obstante, en su tratamiento de la ironía socrática hay un elemento irónico que no está precisamente basado en un conflicto interno puramente existencial de la esencia del ser humano, como ocurre en la filosofía socrática. En Platón dicho elemento es más bien fruto de un planteamiento retórico-poético muy particular de esa esencia, dándole un tono dramático, trágico, si se quiere, pero siempre desde una perspectiva relativa y no totalmente absoluta. Así pues, no se le puede considerar únicamente como un pensador, sino también como un poeta dramático a la hora de leer sus Diálogos. ${ }^{2}$

2. Acerca de la interpretación de la filosofía socrática que hace Platón en sus Diálogos Guardini (1987: 12-15, 28); Haury (1955: 224); Kierkegaard (1991: 28) y Walser (1981: 30). 
Indiscutiblemente, el destino trágico de Sócrates se ha convertido en el transcurso del tiempo en una de las cuestiones fundamentales de la historia del pensamiento occidental no sólo filosófico, sino también social. La vigencia de su doctrina a lo largo de los siglos se debe precisamente a que Sócrates no fue un filósofo sistemático ni un teórico sujeto a la pura dialéctica y a la retórica, sino más bien todo lo contrario. Fue un hombre sumamente crítico e irónico consigo mismo y con los demás, extraordinariamente observador, que llevó a la práctica coherentemente su pensamiento ético-filosófico y vivió enteramente comprometido con su realidad existencial. ${ }^{3}$ No fue, pues, un simple expcrimentador de teorías o métodos ajenos, sino que su experimento fue su propia existencia, su preocupación por el bien del ser humano, por la justicia y la verdad (Plantón, 1981: I, 178):

¿Qué merezco sufrir o pagar porque en mi vida no he tenido sosiego, y he abandonado las cosas de las que la mayoría se preocupa [...]? No iba donde no fuera de utilidad para vosotros o para mi, sino que me dirigía a hacer el mayor bien a cada uno en particular [...]; iba allí, intentando convencer a cada uno de vosotros de que no se preocupara de ninguna de sus cosas antes de preocuparse de ser él mismo lo mejor y lo más sensato posible.

No es que Sócrates tuviera madera de mártir ni fuese un provocador derrotista ni un nihilista que buscase deliberadamente su propio destino fatal, sino que cuando éste se le vino encima, lo afrontó con la misma dignidad y con idéntica ironía con las que vivió, sabiendo encajar con igual coherencia y serenidad vida y muerte. Son pocos los hombres a quienes se les presenta la ocasión de ser absueltos de una acusación de muerte por admitir ciertas contradicciones en su actitud ante la vida, y menos aún son los que en la elección prefieren la muerte. Sócrates fue uno de ellos. Al margen del dolor que pudiera sentir ante una muerte inevitable, su capacidad de elección era nula. La actitud adoptada procedía de un impulso interno al que Sócrates no se podía oponer. Era la simbiosis que él había realizado entre conocimiento y moral, esto es, el compromiso ético-social (Platón, 1981: I, 167 ss.):

Voy por todas partes sin hacer otra cosa que intentar persuadiros, a jóvenes y viejos, a no ocuparos ni de los cuerpos ni de los bienes antes que del alma ni

3. Con respecto al comportamiento irónico de Sócrates afirma Kierkegaard: «Hier begegnen wir den ironischen Subjekt. Für den Ironiker hat die gegebene Wirklichkeit ihre Giltigkeit ganz und gar verloren, sie ist ihm eine unvollkommene Form geworden, die allenthalben lästig wirkt» (1991: 263). Al respecto dirá Hegel: «Das Prinzip des Sokrates ist, daß er zur Wahrheit durch sich selbst gelangen müsse. Es ist die Rückkehr des Bewußtseins in sich.» (1970: II, 443). 
con tanto afán, a fin de que ésta sea lo mejor posible, diciéndoos: 'No sale de las riquezas la virtud para los hombres, sino de la virtud, las riquezas y todos los otros bienes"..

La facilidad de «encontrarse» con sus interlocutores a través de su dialéctica dialogante y de atraerles seductoramente a sus propias ideas, no por imposición, sino por convencimiento, es lo que le hace ser tan original y lo gue demuestra su personalidad irónica (Platón, 1981: I, 173 y 180):

Si cuando yo estaba hablando y me ocupaba de mis cosas, alguien, joven o viejo, deseaba escucharme, jamás se lo impedí a nadie [...], antes bien me ofrezco, para que me pregunten, tanto al rico como al pobre, y lo mismo si alguien prefiere responder y escuchar mis preguntas.

El mayor bien para un hombre es precisamente éste, tener conversaciones cada dia acerca de la virtud y de los otros temas de los que vosotros ne habéis oído dialogar cuando me examinaba a mí mismo y a otros.

La agilidad de sus diálogos y la capacidad de adaptación de sus ideas ante la vida práctica fue lo que nás atrajo a sus interlocutores, ya que su dialéctica no era fruto de elucubraciones absurdas, sino consecuencia de su profunda inquietud por la injusticia social de que era objeto el ser humano. Su actitud coherente con su pensamiento ético es lo que le diferencia de los sofistas, ${ }^{4}$ de ahí que se le considere como un sofista muy sui generis, pues se comprometió enteramente en la defensa de la verdad y del bien que proclanó a ultranza (Platón, 1981: 1, 171):

No hay hombre que pueda conservar la vida, si se opone noblemente a vosotros o a cualquier otro pueblo y si trata de impedir que sucedan en la ciudad muchas cosas injustas e ilegales; por el contrario, es necesario que el que, en realidad, lucha por la justicia, si pretende vivir un poco de tiempo, actúe privada y no públicamente [...]. No cedería ante nada contra lo justo por temor a la muerte, y al no ceder, al punto estaría dispuesto a morir.

Para hablar de la ironía socrática hay que conocer la filosofía de Sócrates y, consecuentemente, su actitud ante la vida, ya que dio con su comportamiento testimonio constante de lo que fue su pensamiento. A

4. Kierkegaard: «Fürs Erste hat dies seinen Grund in der Polemik des Sokrates wider die Sophisten; diese vermochten sich schlechterdings nicht mit der Wirklichkeit zu vertragen, ihre Spekulation wurde zuletzt so hochfliegend, ihre Beredsamkeit so überspannt, daß sie zuguterletzt vor lauter Ideen überhaupt nichts mehr sagen konnten» (1991: 15). Al respecto véase también Vlastos, (1987: 93). 
Sócrates se le ha considerado el último de los sofistas. Su problemática es, en el fondo, la de éstos, pero la actitud que adopta ante ella y el enfoque que le da es lo que le hacen ser el iniciador de la época de oro del pensamiento griego. Contra el escepticismo y el relativismo positivista de los sofistas, solamente preocupados por el éxito en las palestras de la política, Sócrates propone algo completamente nuevo: el convencimiento de que únicamente la verdad puede salvar al hombre. El objetivo de su magisterio no era puramente ético, sino claramente socio-político: $\mathrm{Su}$ preocupación por su ciudad y por los atenienses y su educación. Para ello se sirvió de lo ético, guiando al hombre por medio de la dialéctica y de la oratoria, pero a dónde. Ante esta pregunta la respuesta socrática es totalmente distinta de la de los sofistas: al hombre hay que conducirlo hacia el bien, hay que mejorarlo. Y qué es el bien: según el relativismo sofista, el bien es lo que cada uno, con su dialéctica demuestra ser como tal. Sócrates intenta superar este relativismo prestando un bien para todos, un bien común y universal.

Sócrates hubiera podido increpar a sus interlocutores de forma directa, diciéndoles las mismas cosas, haciéndoles ver sus errores y proclamar así su disconformidad, empleando para ello un ataque hostil. Se hubiera podido enfrentar a ellos con la dialéctica arrolladora del que se siente intelectualmente superior. Ello, sin embargo, le habría hecho fracasar rotundamente, pues se hubiera visto atrapado en la misma situación que atacaba. Por eso opta por el método indirecto, es decir, por la ironía, la cual le permite ponerse dentro de la situación y de sus circunstancias al tiempo que estar por encima de ellas, en virtud del distanciamiento que le brinda el juego irónico. De este modo, Sócrates se comporta como si fuera insignificante e ignorante, y, bajo la máscara aparente de dejarse instruir, instruye a los demás (Platón, 1981: I, 229 ss. y 239,242$):^{5}$

Sóc. - !Ea! Enséñame, Eutifrón, para que me haga más conocedor. Eut. - En otra ocasión, Sócrates; ahora tengo prisa y es tiempo de marcharme. Sóc. - Te alejas derribándome de la gran esperanza que tenía de que, tras aprender de ti lo que es pío y lo que no lo es, me libraría de la acusación de Meleto demostrándole que, instruido por Eutifrón, era ya experto en las cosas divinas y que ya nunca obraría a la ligera ni haría innovaciones respecto a ellas por ignorancia, y, además, que en adelante llevaría una vida mejor. .

5. Acerca el carácter positivo de la ironía socrática opina Guardini: »Daß seine Ironie wirklich diesen positiven Charakter hat, zeigt sich daran, daß er nicht, wie die Sophisten sicher und anspruchsvoll vor den Anderen hintritt, sondern sich die Situation mit hineinnimmt; daß er sich nicht als Wissenden aufspielt und Vortrag hält, sondern selbst fragt und sucht» (1987:26). Al respecto veáse también Walser, (1981: 40). 
Él cree que la ironía es mucho más eficaz y sutil, más inteligente e intelectual que el método directo para dirigirse a los demás. Por medio de ella lo negativo aparece con mayor relevancia y lo contradictorio con mayor potencia, precisamente por la falta de violencia, por esa apariencia inofensiva e ingenua que le brinda el juego basado en la inversión y en la paradoja irónica o armonización de elementos opuestos, en suma, en la simu-latio. Pero creer que la ironía socrática es sólo un juego, una mera figura retórica, un tono conversacional elegantemente burlón y suspicaz, al tiempo que un ejercicio reservado a las mentes ágiles, sería minusvalorar a Sócrates. ${ }^{6}$ Su ironía es mucho más ambiciosa a la vez que altruista y, por tanto, positiva, por cuanto que su intención no se fundamenta en la ridiculización y aniquilamiento del interlocutor, sino todo lo contrario. Su preocupación es la de atraer a este último con el fin de ayudarle a encontrar-se, a que entre en conflicto consigo mismo, conduciéndole a la luz y abrién-dole los ojos a la verdad. Su método es pedagógico y está basado en la reflexión, en el diálogo y en la seducción psíquica, ${ }^{7}$ e, incluso, va más allá, pues ese método que emplea para los demás se lo aplica a él mismo, ya que Sócrates no está contento con su propia esencia ni con su existencia ni con las circunstancias que le rodean. Por eso hay que admitir que la ironía socrática es altamente positiva, ya que con su aparente «ignorancia» juega a representar, no para ridiculizar a su interlocutor, sino para motivarle a que tome conciencia de sí mismo, a la vez que supone un reto para el propio sujeto irónico. De ahí que se haya hecho tan célebre su polémica frase irónica «yo sólo sé, que no sé nadà. (Platón, 1981: 1, 158). Al pronunciar Súcrates esta frase, no está diciendo ni lo que en realidad piensa ni lo que realmente es, pues cuando afirma no saber nada, sin duda alguna, lo dice convencido de que sabe algo, ya que esta expresión sólo puede decirla aquel que es conocedor de la situación real que está viviendo. Esta frase es fruto de una profunda reflexión de quien es consciente de sus propias limitaciones y que, a partir de ellas, intenta avanzar a través de su «ignorancia» hasta alcanzar la luz de la verdad. Dado que él tenía conocimiento de su falta de sabiduría o de su ignorancia, ello demuestra ya que esta expresión no tiene ningún carácter

6. En relación con esa doble función implícita en la ironía socrática afirma Kierkegaard: «Die Ironie aber ist wiederum der Flamberg, das zweischneidige Schwert, das Sokrates als ein Mordengel über Griechenland schwang [...]. Die harmonische Einheit der schönen Individualität wird von der Ironie gestört, und in gewissem Massen wird sie auch in Sokrates gestört, in jeglichem Moment wird sie in ihm vernichtet, verneint» $(1991: 217,219)$.

7. Sobre esta seducción psíquica de la ironía socrática sostiene Guardini: «Worauf es Sokrates ankommt, ist aber eine innere Lockerung, eine geistige Bewegung, ein tebendiges Verhältnis zur Wahrheit. So sucht seine Ironie die Mitte des Menschen zu beunruhigen und zu spannen, damil auch ihr jene. Rewegung hervnrgehes (1987: 26). 
positivo, esto es, no se la puede entender literalmente, de lo que se deduce su intención totalmente irónica. De este modo, si su conocimiento hubiese sido un conocimiento de "algo», esta expresión significaría, en último término, una forma meramente conversacional, retórica. Pero el hecho que Sócrates tenga consciencia de su ignorancia, es ya el comienzo de un conocimiento de algo, y ese conocimiento es aquel que mantiene a Sócrates en la sintonía irónica. ${ }^{8}$

La ironía socrática es la negación de la propia esencia que atrae al interlocutor, tanto más, cuanto éste más atento está a lo que se le dice. Se puede deducir, pucs, que csta ironía es esencialmente contradictoria, ya que en ella se encuentran elementos opuestos como lo positivo y lo negativo," realidad e ilusión, los cuales, lejos de excluirse, se combinan armónicamente. Una realidad con la que no se está conforme porque el «yo» socrático es sumamente consciente de su mediocridad, de su esencia contradictoria; sin embargo, también es poseedor de esa ilusión de cambiar profundamente; pero no es un iluso, ya que conoce perfectamente sus limitaciones y sabe que esas ansias de cambio no las podrá llevar totalmente a término. Por esta razón su ironía es existencial, esencialmente trágica, diletante y contradictoria, ${ }^{10}$ reflejo externo de sus exigencias vitales necesarias para sentirse a gusto consigo mismo, objetivo que conseguirá sólo en parte. De ahí que Sócrates opte por el lenguaje indirecto. Su tono velado, inverso y simulado será el más apropiado para hacer caer en la cuenta a su interlocutor, atrayéndole así a su causa.

La fealdad física de Sócrates y la belleza de su alma contribuyeron al éxito de su ironía, haciendo aún más real lo que era simple simulatio, lo que hace que su ironía fuese más natural y lógica dentro de esa falta de lógica propia del proceder irónico. La verdadera significación de la ironía socrática no consiste en hacer concreto lo abstracto, pues si así fuera, ésta perdería su riqueza histórica, indispensable para comprender su mensaje." El mérito de Sócrates fue precisamente lo contrario, esto es, demostrar lo abstracto sirviéndose de lo

8. Referente al contenido irónico y a la interpretación de esta famosa frase que le dan los estudiosos de la ironía socrática Hegel (1970: II, 255 s., 458, 461); Kierkegaard (1991: 275).

9. Sócrates es positivo en tanto que la negación infinita contenga en sí una infinitud, y es negativo porque esa infinitud no es para él una revelación, sino un límite. A este respecto Fichte (1970: 51, 65); Kierkegaard (1991: 222 s., 266).

10. Es lo que Jankélévitch denomina la «buena mala conciencia» (1987: 56). Con respecto al espíritu existencial y contradictorio de la ironía socrática también Guardini (1987: 27).

11. Hegel se identifica más con el Sócrates platónico que con el verdadero Sócrates, por lo que entiende la ironía socrática como ironía platónica, es decir, como un tono o forma conversacional más que como la pura negación del ser. Al respecto véase Kierkegaard (1991: 28 ss., $122 \mathrm{ss})$. 
concreto a su alcance y avanzar en ese sentido; por eso no le hicieron falta ni las brillantes disertaciones retóricas ni las oscuras elucubraciones que, más que dar luz, servían para confundir las mentes sencillas.

La ironía socrática significa liberación de la subjetividad y, con ella, exaltación de la individualidad, símbolo de la personalidad. Pero esta ironía rompe la armonía que reina en la unidad de esa personalidad en el momento en que pone en conflicto la propia conciencia del irónico y lc conducc a la negación de su propia esencia, lo que algunos autores denominan la «negatividad absoluta e infinita», ${ }^{12}$ esto es, el límite de la libertad de dicha subjetividad. La ironía socrática invita a considerar las cosas con un cierto distanciamiento. Sócrates indica por la vía de la autonegación el camino por el cual se abandona cualquier resultado tanto a priori como a posteriori. Su ironía está marcada por el compromiso ético-social, por lo que su sujeto ha de resistirse a su seducción para, así, poder dominarla y dominarse a sí mismo y no caer en el puro ejercicio retórico-poético.

Es una ironía que interroga constantemente. No hay que olvidar que Sócrates es un sofista muy particular que juega muy seriamente con la sofística. Su espíritu es el del humanista que representa, con su espíritu contradictorio, la buena y, a la vez, la mala conciencia de los atenienses (Platón, 1981: 1, 181 s.):

Quizá creéis, atenienses, que yo he sido condenado por faltarme las palabras adccuadas para haberos convencido, si yo hubiera creído que era preciso hacer y decir todo, con tal de evitar la condena. Pues bien, he sido condenado por falta no ciertamente de palabras, sino de osadía y desvergüenza, y por no querer deciros lo que os habría sido más agradable oír [...]. Pero ni antes creí que era necesario hacer nada innoble por causa del peligro, ni ahora me arrepiento de haberme defendido así, sino que prefiero con mucho morir habiéndome defendido de este modo, a vivir habiéndolo hecho de ese otro modo..

Su naturaleza dinámica pone en ridículo la unidad absoluta que defiende el monismo de Parménides, ${ }^{13}$ supeditándolo a la gratificante variedad de las diferencias. Es el fundador de una sabiduría humana, elevada y sutil, sobre cuyo terreno se ejercitará el análisis de Aristóteles. Sócrates desconcierta a los ciudadanos atenienses, aturdiéndoles con su dialéctica y sus preguntas que van más allá de la pura oratoria retórica, apoyándose en el testimonio vivo de su

12. Kierkegaard: «Die Ironie als die unendliche und absolute Negativität ist die leichteste und unscheinbarste Bezeichnung der Subjektivität.» (1991: 3; cf. también ibid:: 266, 268 ss.). Al respecto, también Fichte (1970: 51).

13. Parménides defiende a ultranza la unidad estática del cosmos, rechazando con ello todo dinamismo y pluralidad de formas y cualquier mutación que dé lugar a nuevas formas. 
propia conducta crítica e irónica. Su figura y su pensamiento están llenos de agilidad y su dinamismo es contagioso, movilizando lo inmóvil, contestando lo incontestable. Con su astucia está en constante alerta, experimentando esa desconfianza propia del irónico. Es original, creativo y auténtico.

El pensamiento griego creía que un alma bella sólo podía residir en un cuerpo bello. Sócrates representa la primera escisión de este concepto. Su ironía le lleva a simular con el propio ejemplo. Entiende por bello el resplandor que irradia el bien y lo verdadero. La máscara socrática es el reflejo paradójico de su fealdad física y de su belleza moral. Su aspecto físico contradice su pensamiento lúcido; sus discursos se conciben en un doble sentido, sirviéndose, para ello, de la inversión irónica. Sócrates es «falsamen-te» claro, pues finge admirar el virtuosismo y simula el respeto a las tradicio-nes. Finge con falsa ingenuidad caer en las trampas que le tienden sus enemigos, pero todo ello es pura maniobra refinada. Tiene la habilidad de confundirse en el ambiente que le rodea sin dejarse absorber por él, adoptando las formas establecidas y los prejuicios de la sociedad (Platón, 1981: I, 176 s):

Pues no está sentado el juez para conceder por favor lo justo, sino para juzgar; además, ha jurado no hacer favor a los que le parezca, sino juzgar con arreglo a las leyes. Por tanto, es necesario que nosotros no nos acostumbremos a jurar en falso y que vosotros no os acostumbréis, pues ni unos ni otros obraríamos piadosamente.

Ese respeto aparente que demuestra con su ironía llegará a resultar ofensivo y humillante para sus enemigos; es el conformismo irónico, en continua inversión del pro al contra y viceversa. Sócrates no teme el escándalo ni escandaliza por puro placer, sino para educar a los atenienses. Fue en todo momento el espejo y el látigo de sus conciudadanos; para ello simula y representa la propia conducta de su pueblo, escandalizando a los mismos sujetos del escándalo. De esta forma intenta redimir a los hombres que, como él, no se sienten cómodos ni con el sistema ni con ellos mismos, comunicándoles el ansia de conocerse y definirse. Con sus incesantes preguntas hace que sus interlocutores leguleyos se avergüencen, reduciéndoles al silencio. Esta táctica le hace ser un sujeto incómodo para aquellos que en su conciencia desean permanecer en el error, del cual intenta liberarlos con su dialéctica y su ejemplo, experimentando un doble deseo de curiosidad y rechazo por su espíritu analítico y escrutador. Así pues, Sócrates resultaba para muchos atenienses un vagabundo non grato que ejercitaba con exquisita humildad el arte del diálogo, pero que detrás de esa apariencia humilde y discreta dejaba entrever la necesidad de mostrarse agresivo y mordaz; por eso su ironía esgrime una agudeza sutil, dialéctica, cargada de amargura y esperanza a la 
vez. Con esta táctica labró su propio destino fatal, obligándole sus enemigos a beber la cicuta para acallar la mala conciencia. Pero de nada sirvió, ya que este noble filósofo tuvo tiempo de definirles antes de morir, dejándoles en herencia su propia muerte. Ésta será su verdadera victoria, según profetizara él mismo, y permanecerá viva entre todos los que, como él, buscan la justicia y la perfección de espíritu (Platón, 1981: I, 182 s.):

\begin{abstract}
Deseo predeciros a vosotros, mis condenadores, lo que va a seguir a esto. En efecto, estoy yo ya en ese momento en el que los hombres tienen capacidad de profetizar, cuando van ya a morir [...]. Van a ser más los que os pidan cuentas, ésos a los que yo ahora contenía sin que vosotros lo percibierais [...]. Pues, si pensáis que matando a la gente vais a impedir que se os reproche que no vivís rectamente, no pensáis bien. Este medio de evitarlo ni es muy eficaz, ni es honrado. El más honrado y el más sencillo no es reprimir a los demás, sino prepararse para ser lo mejor posible.
\end{abstract}

Maestro en el arte de conocer a los hombres, ya lo había previsto descle que fue acusado de adorar a falsos dioses y de pervertir a los jóvenes, y también, desde el primer instante, aceptó su destino con gran serenidad y dignidad. Precisamente, esa serenidad y audacia le privaron de los mejores medios de defensa. Puesto en el trance de beber la cicuta, atacó la sentencia con impasibilidad irritante para sus enemigos. Y en vez de dirigir su elocuencia dialéctica irónica en probar de modo directo la falsedad de las acusaciones que le imputaban, prefirió poner en evidencia la maldad de los que le calumniaban, para que cayesen, no por la acción de sus palabras, sino por el peso de la verdad y la justicia, por las que siempre había luchado. Pero el hombre que había pasado toda su vida defendiendo el bien y la justicia, no podía rebelarse contra la ley, ni siquiera discutirla. Así pues, dulce y serenamente esperó la muerte y, al llegar ésta, la acogió con la más conmovedora tranquilidad, teniendo, incluso, palabras amables para su verdugo cuando éste se disculpaba por lo que le obligaban a hacer y reconocía su inocencia (Platón, 1981: III, 138):

¿Qué educado es este hombre! A lo largo de todo este tiempo me ha visitado y algunos ratos habló conmigo y se portaba como una persona buenísima, y ved ahora con qué nobleza llora por mí. Conque, vamos Critón, obedezcámosle, y que alguien traiga el veneno, si está triturado y si no, que lo triture el hombre.

Su sentido de la justicia era tan coherente con sus obras que sus últimas palabras fueron: «Critón, le debemos un gallo a Asclepio. Así que págaselo y no lo descuides» (Platón, 1981: III, 142).

La hermosa muerte de Sócrates fue el digno final de su sencilla, pero elevada, vida. Su muerte no fue la del hérne que, inconsciente de In que hare, 
realiza un acto humanamente insensato en un momento de locura; tampoco fue la del mártir que da una cosa que desprecia, la vida, en espera de un bien infinitamente mayor; ni la de un cínico que, desesperado por el pesimismo de la derrota, no ve en ella otra salida. Su muerte fue la del filósofo que muere para coronar la obra de su vida, de la que nada espera para él.

La muerte de Sócrates se ha convertido en un símbolo de liberación, en un escándalo apasionante, en una semilla fecunda, en un malestar duradero, en esa mala conciencia que nos hace sentir incómodos, en un hecho polémico y controvertido, como lo fuera su propia vida. La ironía socrática responde solamente a una táctica basada en la analítica y en el diálogo, esto es, en la comunicación, ${ }^{14}$ por tanto, es todo un comportamiento humano y social. Su semilla ha fecundado, haciendo brotar toda una descendencia de fillósofos contestatarios que, como él, han convulsionado la tradición del pensamiento filosófico.

\section{REFERENCIAS BIBLIOGRÁFICAS}

Chantraine, P. (1999): Dictionaire étymologique de la langue grecque. Histoire des mots, París, Klincksieck.

FICHTE, J. G. (1970): Grundlage der gesamten Wissenschaftslehre, Hamburgo, F. Meiner Verlag.

Guardini, R. (1987): Der Tod des Sokrates. F. von Heinrich (ed.). MagunciaPaderborn, Grünewald-Schöningh.

Haury, A. (1955): L'Ironie et l'Humour chez Ciceron, Leiden, E. J. Brill.

Hegel, F. (1970): Werke, 20 vols. E. von Moldenhauer; K. Michel (eds.). Francfort del Meno, Shurkamp.

JANKÉLÉVICHT, V. (1987): L' ironia (traducción al italiano de FERnANDA CANEPA, Génova), Il Melangolo.

KierkegaARD, S. (1991): Der Begriff der Ironie mit ständiger Rücksicht auf Sokrates, (traducción al alemán de E. Hirsch. E. Hirsch; H. Gerdes) (eds.), Gütersloh, GTB Siebenstern.

LAUSBERG, H. (1968) Manual de retórica literaria, 3 vols. (traducción al castellano de J. Pérez RiesCo), Madrid, Gredos.

Platón (1981): Diálogos, 5 vols. (traducción al español de J. Calonge y otros). Madrid, Gredos.

Vlastos, G. (1987): «Socratic Irony», Classical Quarterly, 37: 79-96, Cambridge, Claredon Press.

14. Vlastos: "Socratic irony is not unique in acknowledging the burden od freedom which is unherent in all significant communication» (1987: 95). 
WaLser, M. (1981): Selbstbewußtsein und Ironie, Frankfurter Vorlesugen, Francfort del Meno, Shurkamp. 


\title{
EL COMPROMISO SOCIAL DEL TEATRO DE BRECHT
}

\author{
Victoria Gaspar Verdú \\ Universitat Jaume I
}

\section{INTRODUCCIÓN}

$\mathbf{E}$

$\mathrm{N}$ este artículo ofrecemos la visión comprometida política y social de uno de los mayores dramaturgos del siglo xx, Bertolt Brecht. Su recuperación del teatro épico, junto con el empleo de la parábola política, la oposición al teatro burgués y el empleo del efecto distanciamiento producen ante el público un teatro cargado de crítica social y política. Bertolt Brecht ofrece en su tiempo un teatro con nuevos temas, tales como las reflexiones sobre el abuso de la ciencia por parte de los políticos o las parábolas pacifistas en plena dictadura nazi, por las cuales fue perseguido y tuvo que huir al exilio. Como veremos en este artículo, Brecht transmite al espectador una postura siempre crítica que incita a la reflexión ante la realidad política. En definitiva, un teatro de denuncia lleno de compromiso social.

\section{BRECHT Y EL TEATRO PROLETARIO ALEMÁN}

Los orígenes de la cultura proletaria alemana se sitúan en la ciudad de Berlín, a principios del siglo Xx durante mayo de 1919, cuando dos autores teatrales $H$. Schüler y E. Piscator se erigen como fundadores del teatro proletario. La influencia de esta corriente de teatro proletario emprendida por ambos autores, no tardaría en reflejarse posteriormente en los escritos de B. Brecht, debido a la toma de contacto con estos autores.

En aquellos años denunciaba Piscator en su obra Das Politische Theater, que el teatro proletario estaba vacío de contenido. Aludía con ello a que el escenario del teatro proletario de Berlín no presentaba ningún tema que verdaderamente interesara al proletariado. A esta oferta de obras poco interesantes para el público proletario se sumaba el gran fracaso de la primera manifestación del Programm des proletarischen Theaters de Piscator. Eran realmente malos tiempos para el teatro proletario. Sin embargo, en 1922, la segunda manifestación del programa de teatro proletario gozó de gran éxito. Entre sus principios se incluyeron la subordinación de la intención artística al 
fin revolucionario y la propagación consciente en el escenario de las ideas de la lucha de clases. Es decir, en el año 1920 nos encontramos en Alemania con un auge de la cultura proletaria y con Brecht bebiendo de estas fuentes como dramaturgo en sus años de juventud.

A finales de 1921 el movimiento de la cultura proletaria anuncia uno de sus objetivos primordiales inspirado en el movimiento proletario soviético: nutrir al proletariado con nuevos conocimientos. Brecht se adhiere a esta idea y especifica la lucha de clases como componente necesario del teatro contemporáneo en sus escritos teatrales Schriften zum Theater I. Asimismo plasmó los fundamentos del teatro proletario en su volumen Schriften zum Theater I, dentro del capítulo «Die Deutsche revolutionäre Dramatik», el drama revolucionario alemán, y en los epígrafes Sowjettheater und proletarisches Theater, teatro soviético y teatro proletario, junto con Der soziologische Raum des biirgerlichen Teaters, el ámbito sociológico del teatro burgués.

La amalgama de influencias que confluyen en Brecht es realmente variada. Dispone de conocimientos del teatro asiático y soviético, colabora con W. Benjamin y $\mathrm{K}$. Valentin, y tiene un contacto muy intenso y fructífero con Piscator. Ambos autores fueron los grandes renovadores del teatro de la época, aunque cada uno siguiera un camino diferente al otro. Por un lado, Piscator no se alejaba de los medios convencionales de la identificación con el espectador, lo cual estaba en total desacuerdo con el distanciamiento y la crítica de Brecht, pero sí se adelantó técnicamente a éste en la introducción de proyecciones en el escenario y en el empleo de bandas corredizas junto con la plataforma giratoria cn cl csccnario. Brecht, aunque menos adelantado en técnica que Piscator, ofrecía ya desde sus primeras obras un distanciamiento y temas que incitaban a la crítica política en el espectador.

Los protagonistas de la renovación teatral en Alemania a principios del siglo xx fueron sin duda Brecht y Piscator. Se basaron en el distanciamiento, en la no identificación del espectador con la obra y sus personajes, se basaron en el teatro dirigido al proletariado como medio de protesta y llevaron al escenario la problemática social de las clases trabajadoras, sus inquietudes y anhelos. Propagaron conscientemente en el escenario las ideas de la lucha de clases como nadie lo había hecho hasta entonces.

\section{EL TEATRO ÉPICO COMO TEATRO DE DENUNCIA POLÍTICA Y SOCIAL}

Brecht se impregna de diversas culturas antes de concebir su teatro épico. Bebe de variadas fucntcs tcatralcs, cntrc cllas cl tcatro asiático, el teatro de Moscú y el teatro griego. Como autor de izquierdas y comunista convencido 
que es, incluye en su teatro épico el fin revolucionario apoyando la propagación consciente en el escenario de las ideas de la lucha de clases. Por ello no es de extrañar que el teatro épico de Brecht esté concebido como un teatro que invita a la crítica y reflexión política y social por parte del público. Aquí radica la concepción del teatro de Brecht como denuncia. Incluso este autor afirma que el texto teatral, además de entretener, debe tener intención didáctica.

Brecht elabora en sus años de juventud las bases de lo que él denomina teatro épico y las plasma en tres volúmenes, los llamados Schriften zum Theater. Rechaza al teatro antiguo en el capítulo «Über eine nicht Aristotelische Dramatik» (1967: 315-330), justificando que no lo considera adecuado para los fines revolucionarios del proletariado: «Wir finden im alten Theater eine ausgebildete Technik vor, die es gestattet, den passiven Menschen zu beschreiben» (1967: 317). Igualmente rechaza en sus escritos teóricos al teatro burgués al afirmar: «Die Übernahme des bürgerlichen Theaters für die revolutionären Zwecke des Proletariats sehen einige von uns als einen sehr einfachen Vorgang an» (1967: 317), y lo critica por la pasividad, el ensimismamiento y los escrúpulos morales que transmite al espectador. Finalmente se decanta por el teatro épico como el adecuado a nuestra era y afirma: «Das moderne Theater ist das epische Theater» (página 319).

A lo largo de este artículo analizaremos el compromiso social de Brecht al emplear parábolas político-sociales cargadas de dura crítica. Con Brecht nos encontramos ante un autor comunista declarado que observa el teatro como medio para expresar sus ideas políticas y que se sirve de las parábolas para realizar su denuncia política y social. Muchas de las obras teatrales de Brecht son denuncias o parábolas de tema humanista o antibélico. Ya hemos mencionado que Brecht evita a toda costa la identificación de la audiencia con los personajes de la obra para conseguir la reflexión del público y apela constantemente a la conciencia del espectador proponiendo una crítica de los hechos representados en escena. Con sus parábolas apunta a la habilidad del espectador de trasladar los hechos presentados en escena a la realidad política del momento.

\section{LA LLEGADA DE BRECHT Y SU COMPAÑIIA TEATRAL A LONDRES}

Tras haber bebido en Alemania durante los años veinte de fuentes e ideas revolucionarias para su teatro, Brecht expande estas ideas por Europa. La primera aparición de Brecht en un escenario británico se sitúa en los años treinta con las producciones The Seven Deadly Sins of the Bourgueoisie, claro ataque a las ideas burguesas de la época, con Lotte Lenya como protagonista, 
y bajo el título Anna, Anna (1933). Junto a ésta, estrena Señora Carrar's Riftes (1938) en el Unity Theatre,' dura crítica a la pasividad de Europa occidental ante la guerra civil española. Ambas producciones constituyen su primera aparición en las tablas londinenses con temas comprometidos social y políticamente.

En 1956 vuelve Brecht a Londres, en esta segunda ocasión con su compañia Berliner Ensemble, hecho que supuso una revolución en el drama británico (Willet, 1964). La nueva etapa que se inauguraba en Inglaterra con la llegada de la Berliner Ensemble a Londres estuvo caracterizada por las ideas erróneas que en Gran Bretaña se habían gestado previamente respecto a Brecht como defensor de ideas comunistas y obras propagandísticas. En efecto, se generalizó la imagen de este autor como exclusivamente político y simpatizante de izquierdas. Famosos críticos teatrales como G. Devine o K. Tynan lo tacharon duramente de autor fraudulento e ídolo de intelectuales comunistas y perversos. No obstante, K. Tynan no tardó en reconocer a Brecht como ejemplo de excelencia en escritura teatral y compromiso ideológico. Su tercera aparición en Londres fue el 9 de agosto de 1965. Por entonces la compañía de Brecht Berliner Ensemble volvía a irrumpir en la escena británica, esta vez en el National Theater con Arturo Ui, dura crítica al nazismo y a la figura de Hitler, y con Tage der Commune, dos de sus obras más propagandísticas ya estrenadas dos décadas antes durante el auge del nacionalsocialismo en Alemania. Los críticos se entusiasman con estas obras y desde la primera representación ya las califican de precisas, apasionadas y políticamente comprometidas (Holland, 1978).

\section{CRÍTICA Y ESTRATEGIAS TEATRALES EN EL TEATRO DE BRECHT}

Brecht se debatía en sus años de joven dramaturgo entre la conveniencia de crear un teatro para la diversión, basado en la concepción aristotélica del teatro, o crear un teatro con fines didácticos. Finalmente, opta por un teatro que evita la identificación con el público y provoca la reflexión en él. Para éste autor era importante representar el entorno en el que vivían los hombres, comprender los procesos de la historia y trasladar estos hechos al escenario. Por ello plasmó en las tablas su creciente interés por los temas políticos y sociales. Concibió el escenario con función didáctica y sobre él mostró hechos socialmente correctos e incorrectos.

Como estrategias teatrales, el teatro didáctico ofrecía escenarios que narraban con carteles que contradecían el argumento, es decir narraban lo contrario

1. Véase Innes, (1992: 121-136). 
de lo que representaban los actores en escena, incitando con ello al público a la crítica y la reflexión. También empleaba con fruición escenarios paralelos y simultáneos para que el público comparara y dedujera situaciones sociales justas e injustas y comportamientos correctos frente a los incorrectos. Con frecuencia disponía dos escenarios simultáneos, uno arriba y otro abajo, por ejemplo en Baal o Herr Puntilla und sein Knecht Matti, donde representa-ba un comportamiento correcto y otro abusivo de un grupo social respecto al otro. Esta estrategia la emplea igualmente en sus obras Die Mutter, Rundköpfe und Spitzköpfe, Baal, Herr Puntilla und sein Knecht Matti, entre otras.

Gracias a la estrategia del Verfremdungseffect o efecto distanciamiento, Brecht hace posible en sus obras una crítica consciente en el público. Entre las estrategias distanciadoras se encuentra el empleo del coro, un coro que interrumpe de súbito la acción de los actores e irrumpe cantando o narrando en mitad de la acción, con lo que logra distancia y reflexión en el público. Esta es una estrategia recuperada por Brecht del teatro griego.

Asimismo logra distanciamiento con la utilización de máscaras por los actores, con el diseño de escenarios simultáneos y paralelos, con carteles que aparecen colgados de una cuerda sobre el escenario y narran el pasado o futuro de lo que va a pasar en la obra, con el cambio repentino de música a actuación, etc. Debido al efecto distanciamiento, el público en ningún momento se identifica con los personajes, sino que permanece en todo momento consciente de que es espectador, y no se abandona sin capacidad crítica al argumento.

Con el teatro didáctico este autor denunció ábiertamente las miserias de su época y mostró al mundo los horrores del racismo y la dictadura nazi en obras como Arturo Ui y en Rundköpfe und Spitzköpfe, representadas en Europa y en Estados Unidos. Puso en evidencia las miserias e inutilidad de las guerras en piezas como Die Mutter o Mutter Courage. Tampoco quedaron exentas de crítica la deshumanización, la soledad de las grandes ciudades y el capitalismo en Die Sieben Todsünden y Mahagonny. En Mann ist Mann realiza una magnífica crítica a los políticos y al empleo deshumanizado que hacen de jóvenes soldados como auténtica carne de cañón.

Entre sus obras llenas de crítica y denuncia resulta magistral Die Mutter, escrita según su autor al más puro estilo de las piezas didácticas y verdadera denuncia de la miseria a la que están sometidas las clases trabajadoras en esa época. Muestra la evolución de una madre que, aunque temerosa en un principio, evoluciona hasta convertirse en una verdadera revolucionaria social. En Die Mutter un coro comunista muy multitudinario liderado por Pelagea Vlassova irrumpe al final de la obra y denuncia crímenes de guerra y el enriquecimiento oculto de los políticos con el negocio de las armas. En obras como Mahagonny se pasaban películas y proyecciones al fondo del escenario que representaban las cifras estadísticas de desempleo que de nuevo contradecían al argumento de la obra. 
Los personajes de las obras teatrales de Brecht eran prototipos y representaban a las clases sociales a las que pertenecían. Gracias a ellos ofreció al público la posibilidad de reflexionar sobre la situación social de la época. Aquí radica la didáctica y la reflexión de su teatro.

\section{LA DENUNCIA ANTIBRELICA: PARÁROLAS POLITICAS CONTRA LA GUERRA}

Brecht utiliza la técnica de alejar sus historias en el tiempo dirigiéndolas hacia el pasado o hacia el futuro. El resultado del alejamiento de la historia en el tiempo y espacio es de gran impacto, ya que inevitablemente lleva al espectador a hacer una reflexión, sobre todo en el caso de las parábolas políticas. El crítico F. Doménech (1998: 78) apunta lo siguiente sobre el empleo de la parábola por Brecht:

Bertolt Brecht sigue impresionando a los públicos que se acercan a sus obras [...] porque cuenta la verdad con o sin parábolas. Sus obras, inocuas o no, siguen siendo verdaderas e iluminadoras de la época que le tocó vivir. Y esa época no es tan distinta de la nuestra.

Entre las parábolas sociales o humanistas destacan Der Gute Mensch von Sezuan y Der Kaukasische Kreidekreis. En ellas presenciamos las tribulaciones de un personaje protagonista, lleno de bondad de valores humanos, que se ahoga en un mundo carente de valores. Brecht no olvidó que los conflictos sociales aparecen entre las clases sociales poderosas y las oprimidas. De ahí que en plena segunda guerra mundial escribiese otra parábola, esta vez sobre el abuso entre clases sociales, Herr Puntilla und sein Knecht Matti. Con ella hace una dura crítica a la clase de los terratenientes y a la de los sirvientes.

Destacan en este autor de modo especial las parábolas políticas contra la guerra, tema siempre constante en sus producciones. Por ello encontramos numerosas obras de marcado carácter antibélico, entre ellas Furcht und Elend des Dritten Reiches, Der Aufhaltsame Aufstieg des Arturo Ui, Die Ausnahme und die Regel, Mutter Courage y Die Mutter. En ellas Brecht critica con dureza el abuso de poder, la violencia o el delirio de grandeza de los dictadores. Como intelectual alertado, ya en los años treinta por el ascenso de Hitler al poder, dedicó algunas de sus obras en forma de parábola a advertir al mundo sobre la amenaza de quien él llamaba «pintor de brocha gorda». Esto lo plasma en sus obras de denuncia contra Hitler y el tercer Reich, concretamente en Furcht und Elend des Dritten Reiches (1938) y Der Aufhaltsame Aufstieg des Arturo Ui (1941). 
Este autor no cometió en su tiempo el error de criticar directamente los hechos políticos que estaban sucediendo, sino que esta realidad política la alejó en el tiempo y en el espacio para ofrecer al público una clara traslación de la obra y su argumento a la realidad contemporánea. En el caso de Rundköpfe und Spitzköpfe o Arturo Ui, hizo un claro ataque al fascismo en plena dictadura nazi al mismo tiempo que una magistral caricatura del dictador alemán Adolf Hitler. En estas obras trasladó el argumento a un país sin nombre y una época indeterminada y sustituyó a los judíos perseguidos por los hombres de cabezas puntiagudas. Tras la representación de éstas, sufrió persecuciones y huyó a Dinamarca y más tarde a Estados Unidos.

Otra fantástica parábola antimilitarista sobre la guerra nos ofrece Brecht con Mutter Courage und Ihre Kinder (1938-1939). Esta obra es una crónica sobre la guerra de los treinta años y transmite a sus espectadores que los grandes negocios en la guerra no son hechos por los hombres pequeños y que la guerra destruye las virtudes humanas incluso en aquellos que las poseen. Sin lugar a dudas, Mutter Courage es la gran parábola brechtiana contra la guerra. En ella la protagonista, una figura doliente de mujer, destaca sobre cualquier otro personaje. El escenario, provisto de plataforma giratoria, se encuentra decorado en numerosas escenas por el carro de Madre Coraje como único elemento ornamental. Pasan los años, los lugares, caen en las batallas ricos y pobres, poderosos y humildes, Madre Coraje sigue en escena cada vez más sola y mísera, pero siempre acompañada de su carro. La guerra acabará destruyendo a su familia y a su pobre negocio, un carromato de compra-venta en los campos de batalla. Durante el deambular de Madre Coraje por Alemania, Brecht muestra la presencia de personajes partidarios de la guerra, como la protagonista y un predicador, y deja entrever al espectador la visión de la guerra como negocio.

Finalizamos con dos parábolas de tono antibélico: Die Gewehre der Frau Carrar, una obra basada en la guerra civil española, en la que Brecht muestra de nuevo su tono antibélico y critica la pasividad de Europa ante esta guerra. La siguiente es Der Prozess des Lukullus, parábola de claro tono antibélico, en la que denuncia al gran Lúculo, conquistador de Asia, que se somete a un juicio tras su muerte. En este juicio el pueblo llano y la justicia se encargan de condenar al dictador por asesino, por la destrucción, la violencia y las matanzas que ha ocasionado de ochenta mil hombres muertos en campaña. Todo esto provocará su irreversible condena.

\section{REFERENCIAS BIBLIOGRÁFICAS}

Brecht, B. (1963): Breviario de Estética Teatral, Buenos Aires, La Rosa Blindada Ed. 
BRECHT, B. (1967): Gesammelte Werke, Frankfurt a.M., Suhrkamp Verlag, en 20 vol.

- Band 1, Der Jasager und der Neinsager, Die Mutter.

- Band 4, Mutter Courage und Ihre Kinder, Der Gute Mensch aus Sezuan, Herr Puntilla und sein Knecht Matti, Der Aufhaltsame Aufstieg des Arturo Ui.

- Band 15, Schriften zum Theater 1.

- Band 16, Schriften zum Theater II, capítulo «Kleines Organon für das Theater》, ptos 1-10.

BRECHT, B. (1984): El Compromiso en Literatura y Arte, HeCHT, W. (ed.), Barcelona, Ed. Península.

CASTRI, M. (1978): Por un Teatro Político: Piscator, Brecht, Artaud, Madrid, Akal.

INNES, C. (1992): Modern British Drama, 1890-1990, Melbourne, Cambridge University Press.

DOMÉNECH, F. (1998): «Maneras de decir la verdad», en $A D E, n^{\circ} 70$, Oct 98 , $77-82$.

HOLLAND, P. (1978); «Brecht, Bond and the Practice od Political Theatre», Theater Quarterly, 8: 24-33.

SÁnchez MARTínez, J. A. (1992): Brecht y el Expresionismo: Reconstrucción de un Diálogo Revolucionario, Castilla la Mancha, Serv. Publicaciones Univ. Castilla la Mancha.

WILLET, J. (1964): The Theatre of Bertolt Brecht, London, Methuen.

- (1986): Brecht: On Theatre: The Development of an Aesthetic, London, Methuen. 


\title{
LA INFLUENCIA DE LOS NACIONALISMOS EN EL DISCURSO DE LA LINGÜÍSTICA ACTUAL: ANÁLISIS DEL DISCURSO DEL CONGRESO DE DIVERSIDAD LINGÜÍSTICA, SOSTENIBILIDAD Y PAZ DEL FÓRUM DE LAS CULTURAS DE BARCELONA 2004
}

\author{
ISABEL GómEz DíEz \\ Universidad de Amberes
}

\section{INTRODUCCIÓN}

$\mathbf{M}$ I objetivo es comprobar la influencia de los movimientos sociales más importantes de la postmodernidad, como son la globalización y los nacionalismos en el discurso de la lingüística actual.' Para ello analizo el discurso de un congreso que tuvo lugar en el Fórum de las culturas en mayo de 2004 llamado Diversidad Lingüística, Sostenibilidad y Paz. ${ }^{2}$

El corpus analizado lo constituyen las ponencias presentadas en este congreso, que está integrado por :

- dos ponencias inaugurales a cargo de Elda Moreno, representante del consejo de Europa y P. Maragall presidente de la Generalitat;

- siete conferencias plenarias que abordan el tema de la diversidad lingüística, la sostenibilidad y la paz;

1. Esta comunicación forma parte de un trabajo más amplio sobre las huellas del postmodernismo en la lingüística actual. Remitimos al lector interesado a «El discurso de la lingüistica en la postmodernidad: análisis del recurso del diálogo de diversidad linguística, sostenibilidad y paz en el Fórum Universal de las culturas de Barcelona 2004» en (2004) Language designs, vol. 6. Granada: Método ediciones.

2. Las causas que me han llevado a elegir este discurso como representativo del discurso de la sociolingüística actual son: a) La popularidad del Forum. b) El programa de este congreso explícitamente pretende que éste sea un fopo para generar un debate productivo de donde surjan propuestas que puedan contribuir a contrarrestar el proceso de homogeneización linguística a que está sometido el planeta. c) El congreso está organizado por Linguapax, ONG con sede en Barcelona cuyo objetivo es la promoción de las políticas que protejan la diversidad linguiística y que fomenten el aprendizaje de diversas lenguas. Defiende los derechos de lenguas regionales o minoritarias, entre ellas, el catalán, en este punto comparte objetivos con el nacionalismo catalán. 
- 50 talleres de media hora de duración sobre: 1) modelos positivos de políticas lingüisticas; 2) estudios de casos de revitalización y estandarización lingüística; 3) balance de investigación sociolingüística. Nuevas corrientes y paradigmas; 4) legislación y derechos lingüísticos; 5) agentes de la defensa de la diversidad lingüística. ${ }^{3}$

Partimos en este trabajo de los principios de la filosofía de la ciencia de tipo externalista y de la sociología de la ciencia, que tratan de ver cómo los movimientos sociales configuran la ciencia (Fernández Pérez, 1986). Ángel López García y Ricard Morant (1998), que aplican este método a la historia de la linguística, observan que:

Puede decirse que los períodos históricos de concentración de poder han sido acompañados por tradiciones linguísticas de raigambre racionalista y los períodos disgregadores han visto surgir tradiciones lingǘ́sticas atomizadoras. Al deseo imperialista de reunir multitud de pueblos bajo un mismo mando y bajo una misma ley corresponde la opción gnoseológica que cree descubrir unas mismas pautas bajo la inmensa diversidad de lenguas de los hombres. Al deseo nacionalista de afirmar la autonomía de cada pueblo por contraposición a los demás corresponde la opción gnoseológica que enfatiza sobre todo las diferencias entre las lenguas y que proclama a cada una como expresión del espíritu del pueblo que la habla.

El análisis lo haremos en dos niveles: 1) en el macronivel del sentido del discurso, intentamos identificar los tópicos del discurso (Van Dijk, 2000); 2) en el nivel léxico: analizamos los contextos de aparición de términos relacionados con el nacionalismo. Este análisis contribuirá a desvelar la ideología que subyace al discurso del congreso, que, como veremos, podemos calificar de postmodernista, anti-globalizadora, nacionalista y ecologista.

\section{LA INTLUENCIA DG LOS NACIONALISMOS EN LA LINGÜISTICA}

Los nacionalismos se conciben en el congreso como reacciones ante la globalización. Bastardas (2002) dice a propósito:

Aquesta extensió del contacte lingǘstic i de la necessitat de poliglotització a més i més persones dels conjunts humans fins ara no-minoritaris en el sentit tradicional del terme, està produint en alguns d'aquests grups sentiments d'amenaça cultural i reaccions defensives contra aquest fet.

3. La totalidad de los textos se encuentran en tormato PDF en la pàgina WEB de Linguapax: www.linguapax.org 
Por lo tanto, los nacionalismos se pueden englobar dentro de los movimientos anti-globalización. "Antiglobalización" es un término-paraguas que cubre movimientos muy diferentes pero podemos identificar denominadores comunes: 1) la biodiversidad es buena y la extinción mala, 2) el nivel de decisión más adecuado es el local. Estas dos premisas son las espinas dorsales de las ponencias que constituyen nuestro corpus.

La creencia de la bondad de la diversidad en sí misma es uno de los argumentos usados por los movimientos nacionalistas que se remonta al romanticismo alemán, concretamente a Herder (1744-1803) y a Isaiah Berlin -quien habla de «fisionomías de las culturas». Para el primero, la diversidad de lenguas y culturas es una cosa buena y bella en sí misma, mientras que la imitación lleva a la corrupción y al estancamiento. Según este argumento, cada cultura nacional contribuye de una manera única a la diversidad de las culturas humanas. Si se asume que la etno-nación es la unidad natural de cultura, la preservación de la diversidad cultural equivale a la protección institucional de la pureza de cada cultura nacional (Standford Philosophy Enciclopedia s.v. 'nationalism').

En las conferencias que configuran nuestro corpus la relación entre diversidad biológica y cultural da lugar al concepto de 'diversidad biocultural', en el que se inspiran las organizaciones de defensa de las lenguas minoritarias como Terralingua (www.terralingua.org), (Annamalai, 2004).

\begin{abstract}
Diversity is the natural state of the world. It is the quintessence of the evolutionary process as found in the natural world in the multiplicity of flora and fauna called biological diversity and in the constructed world in its multiplicity of cultures called cultural diversity. Language diversity is part of the co-evolution of humans with ecological diversity comparable with the evolution of biological diversity. It is the core component of the ecologically evolved cultural diversity that enables representation and transmission of the fundamental aspects of cultures for acquisition by the succeeding generations of the community and for interaction with other contemporary communities. It is natural for cultural diversity to emerge and sustain itself through language diversity. It is established empirically that the diversity in nature and culture are integrally related and they are connected with the development of ecosystems and with their sustainability. This has given rise to the concept of bio-cultural diversity as a unified phenomenon.
\end{abstract}

El concepto de «biodiversidad» forma parte de un movimiento más amplio del que las ponencias del corpus son representativas: la ecologización del discurso de la lingüística, cuya consecuencia es la emergencia de una nueva rama la «ecolingüística», rama que según $\mathrm{A}$. Fill (2000) investiga el rol del lenguaje en el desarrollo y en las posibles soluciones de problemas ecológicos y medioambientales. Según Harré et al. (1999), la ecologización de la lingüís- 
tica se nota en dos aspectos: 1) en el número creciente de metáforas importadas del discurso tradicional medioambientalista y 2) en la demostración de que el lenguaje no está separado del medioambiente y por lo tanto es un fenómeno ecológico. La metáfora base de la que se parte es la de la lengua como organismo vivo: «Aunque ciertamente los sistemas lingüís-ticos no son ellos mismos sistemas biológicos, "el entorno está en su interior", y no son comprensibles si no introducimos en ellos su entomo de seres humamos organizados socioculturalmente» (Bastardas, 2003).

Esta metáfora nos lleva a la incorporación del contexto como objeto de estudio de la (socio)lingüística. La perspectiva ecológica que concibe la relación entre dos especies, tiene siempre en cuenta el medio en el que se desarrolla la relación (Bastardas, 1996). La introducción del contexto tiene consecuencias metodológicas, ya que el contacto de lenguas no será enfocado como un fenómeno binario, sino como uno ternario. Bastardas (2004) expresa esta superación de las dicotomías estructuralistas con el término «Linguesfera» que se refiere a la relación entre las lenguas y su entorno: ya no se puede hablar de la relación entre lengua A y lengua B sino entre Lengua-y-suentornoA y lengua-y-su entornoB. Una de las metáforas que se utiliza más para la defensa de las lenguas minoritarias es la de "peligro de extinción", así lo expresa en el congreso Hornberger (2004):

Three themes of the ecology metaphor are salient to me in writings on the ecology of language, [...] These are: that languages, like living species, evolve, row, change, live, and die in relation to oller languages and also in relation to their environment; what we can call the language evolution and language environment themes. A third theme is the notion that some languages, like some species and environments, may be endangered and that the ecology ovement is about not only studying and describing those potential losses, but also counteracting them; this I call the language endangement theme.

May (2001) apunta que, a pesar de que esta metáfora subraya la gravedad de la pérdida de lenguas, tiene desventajas: refuerza el punto de vista de que la pérdida de lenguas es una parte inevitable del ciclo de la evolución linguística y oscurece los factores sociales y políticos que intervienen en la pérdida de una lengua. Efectivamente si las lenguas se comportan como seres vivos, inevitablemente estarán sujetas a la ley de selección natural de Darwin que sostiene que solo las más aptas sobrevivirán mientras que las más débiles están condenadas a desaparecer. Ponentes como Annamalai (2004) de la organización Terralingua reaccionan vivamente ante esta conclusión, argumentando que la debilidad o la fortaleza no son cualidades inherentes a las lenguas, sino que son propiedades impuestas desde el exterior. Una lengua se vuelve débil cuando el 
ecosistema que incluye es trasformado o destruido por usurpación. La transformación es tan repentina y masiva que la lengua no tiene oportunidad para adaptarse a las nuevas circunstancias, con lo que se le niega la selección natural.

En cuanto a la supremacía de lo local, los ponentes argumentan que la única manera de combatir la globalización es dando poder a las comunidades locales. Como observa Ostler (2004), por primera vez desde los nacionalismos del siglo XIX en la década de los noventa, las pequeñas comunidades empezaron a reivindicar su poder y los gobiernos nacionales empezaron a apoyarlas: «Worldwide there seems to be been growing a new sense: "small communities have something that hig ones lark"» (Ostler, 20n4). T a mayoría de los talleres cuenta experiencias de revitalización de lenguas donde los protagonistas son los propios hablantes: «The role of local agency in the defence of minority languages: Indigenous language committees in Northwest Cameroon», «El empoderamiento de las comunidades indígenas en México». En la misma línea de la primacía de lo local, Bastardas aplica el principio de subsidiaridad -rector de la política de la Unión Europea como se expresa en la Carta de las Regiones de Europa ${ }^{4}$ - a la lingüística: «Podríem traduir aquest principi políticoadministratiu en un principi glotopolític que, de manera general, establís el criteri que "tot ailò que pugui fer una liengua 'local' no ho ha de fer una llengua més 'global"'” (Bastardas, 2002).

Sin embargo, paralelamente a la defensa de la autonomía de las comunidades se postula la intervención de organismos internacionales que limiten la discrecionalidad de los estados. La intervención se justifica porque los hablantes de las lenguas minoritarias 1) no tienen suficientes recursos para revitalizarlas; y 2) no son conscientes de la importancia de revitalizarlas y asocian la lengua colonial al desarrollo económico y social (Bastardas, 2002):

Cal [...] disposar de models que ens permetin dinyar possibilitats efectives d'intervenció segons les distintes situacions, les diferents etapes evolutives, i els desiguals contextos en què aquells poden tenir lloc [...] Cal que des dels organismes internacionals es faci arribar a aquests i altres països la necessitat i la justícia de basar la seva organització linguística en la perspectiva de la complexitat $i$ en la subsidiarietat, dins del marc d'una nova ètica.

4. La versión en español de La Carta Europea de las regiones está disponible en http://www.calre.net y dice al respecto del principio de subsidiaridad: «Destacan que la dimensión regional representa, para la dinámica institucional y para el desarrollo económico, un nivel adecuado de autoridad en aplicación del "principio de subsidiariedad" y de "proximidad": uno de los principios fundamentales del sistema de gobierno europeo, como se recuerda en el Libro Blanco de la Comisión europea sobre la Gobernanza Europea que reconoce a las regiones y a los ayuntamientos el papel de mediadores entre el ciudadano y las instituciones comunitarias y recomienda una estrecha cooperación entre las instituciones europeas, los gobiernos nacionales y las administraciones regionales y locales». 
En este punto hallamos una contradicción en el discurso: se condena la injerencia del Estado en los asuntos de las comunidades locales, pero se permite la injerencia de los organismos internacionales en las decisiones estatales. En otras palabras, se ataca la globalización en cuanto hace desaparecer las culturas minoritarias pero se le permite actuar cuando se trata de limitar el poder de los Estados. El blanco de la crítica es claramente el Estado, y en concreto el modelo de nación-estado que se afianza en el siglo XIX. Si analizamos los contextos de aparición del término «estado» en el corpus, vemos que la visión de éste coincide con la de los nacionalismos. Estos normalmente lo ven como una unidad política que pertenece a un solo grupo étnico-cultural y que se encarga de proteger y promulgar sus tradiciones (Miscevic, 2001).

The more a govemment through its laws and policies favours identification with the ethnic majority and their interests, the more the counter-reaction risks being violent, especially from a large indigenous people or national minority (De Varennes, 2004).

El Estado se conceptualiza como opresor y como incapaz de manejar la diversidad:

... indirectly they [these rights] can provide protection for linguistic, religious and culture communities by preventing the state from (1) imposing the characteristics of the majority on the minority against its will; (2) restricting the expression of linguistic religious or cultural characteristics among members of a minority; or (3) using unreasonable or unjustified distinctions which underline human characteristics(language, religion, ethnic origin.(De Varennes, 2004)

I a gran majoria dels Estats semblen trobar impossible o molt difícil d'estructurar-se políticament d'una forma que permeti alhora la continütat de la vida lingüistica dels seus collectius constituents i la intercomunicació necessària per a la vida en comú d'aquests conjunts... (Bastardas, 2002).

Si recorremos la historia de la lingüística en busca de las «tradiciones linguísticas atomizadoras» de las que hablan López García y Morant (1998), podemos identificar varias escuelas que han concebido el enlace entre lengua y nación como necesario e incuestionable. Metáforas como «espíritu del pueblo», «mentalidad colectiva» y «carácter nacional» conceptualizan este punto de vista. El comparativismo europeo exaltaba cada idioma por sus cualidades en comparación con las que le rodean, por ejemplo A. Schelegel exaltaba las lenguas flexivas sobre las aglutinantes. La metáfora de las lenguas como organismos vivos, tan en boga en el discurso de la lingüística actual y sobre 
todo en una de sus ramas emergentes, la ecolingüística, la encontramos precisamente en uno de los miembros más sobresalientes del comparativismo: A. Schleicher que en su obra Die Sprachen Europas in Systematischer Ubersicht (1850) usa términos de biología como "género», «especie» y «variedad» para clasificar las lenguas con la ayuda de árboles genealógicos. Ya en el siglo Xx, la hipótesis de Sapir-Whorf continúa esta línea de pensamiento postulando que la concepción del mundo de un pueblo es consecuencia de la estructura de su lengua. En cuanto a la lingüística actual, López García y Morant (1998) explican que la lingüística cognitiva se debate entre el particularismo y el universalismo, rasgo este muy postmoderno.

El concepto de lengua que encontramos en las ponencias del congreso del Forum que hemos analizado recoge esta tradición lingüística que enfatiza el lazo entre cultura y lengua y pone de relieve cómo la lengua influye nuestra manera de percibir el mundo:

I cal tenir en compte a més[sic] que els canvis linguiístics estan estretament relacionats amb l'evolució de la societat que parla cada llengua y amb la seva cultura fins al punt que es pot dir que la llengua reflexa o expressa la cultura del poble que la parla (Siguan, 2004).

Giroux tells us that 'Language represents a central force in the struggle for voice. Language is able to shape the way various individuals and groups encode and thereby engage the world' (Hornberger, 2004).

La lengua se concibe como la seña de identidad más importante y como vehículo de la cultura de un pueblo:

Second, language is not one of the many cultural artifacts of a community: it is the most fundamental of the cultural institutions that is instrumental in representing and transmitting other cultural creations. Discarding this cultural institution would mean losing every kind of cultural creativity. Furthermore, it would entail losing for ever all knowledge and values accumulated and codified in the threatened language (Annamalai, 2004).

The idea of holding the language intact, as a vehicle of communication, as a store of the treasure of the Nso' -people, has been the primordial aim of the Nso' Language Organisation because all these cultural values, the written language, the various norms, can only be stored in the Nso' language (Trudell, 2004).

En el congreso se parte de la premisa del poder constructor del lenguaje. Este poder se evidencia sobre todo en la creación de identidades híbridas en sociedades postcoloniales. Esta idea concuerda con la doctrina del construc- 
tivismo social, imperante en la postmodernidad, que postula que nuestros mundos están construidos por prácticas lingüísticas y sociales (Trudell, 2004):

From the colonial to the postcolonial world the struggle for identity is a struggle 0 write the lives of subject peoples, such writing being in the language of the victors (or in the language of the conquered transformed by the colonizer...) [...] Such selves are not formed by literacy; but the forging, both social and personal, of a "new" hybrid identity occurs in the cauldron of culture clash where literacy is both weapon and shield. Literacy is neither cause nor consequence; the process of self-fashioning is, rather, mediated by literacy,

En el corpus analizado se concibe la lengua como creadora de diferentes clases de realidades, filosofías, comportamientos y percepciones. Muchas generaciones de experiencia están cristalizadas en construcciones individuales, ítems léxicos o metáforas que, cuando se combinan, predisponen a sus hablantes a tener una cierta perspectiva de la realidad. La pérdida de una lengua implica la pérdida de una manera única de ver el mundo, de una unidad de nuestro conocimiento y entendimiento del pensamiento humano, una potencial solución alternativa para nuestros problemas (Hedley, 2004):

The world's languages represent alternative 'solutions' for human survival under varying ecological conditions. [..] The biocultural diversity movement is particularly concerned about protecting indigenous languages, for herein lies the knowledge from thousands of years of adapting to human-environment interfaces.

Las lenguas indígenas pueden contener soluciones alternativas para la supervivencia del ser humano y para resolver la crisis medioambiental. Incluso se llega a postular la superioridad de las lenguas indígenas sobre las mayoritarias (Hedley, 2004):

In fact, some experts claim that traditional huntergatherers have been the most successful of all humans in reaching a harmonious and flourishing relationship with their ecological surroundings, which makes the preservation of their languages even more compelling.

En el congreso se hace referencia tanto al nacionalismo de los estadosnaciones ${ }^{5}$ como al nacionalismo de naciones que carecen de estado, esto es, «nacionalismo infraestatal». Sin embargo, la forma de denominar a uno y otro es muy diferente. El término «nacionalismo» se usa la mayoría de las veces para referirse al nacionalismo de las grandes naciones europeas que nació

5. Para la distinción entre los conceptos de «estado-nación» y «nación-estado», ver Fishman (1972). 
después de la revolución francesa y aparece siempre en contextos negativos, mientras que los nacionalismos infraestatales son denominados con otros términos como «conflicto étnico», «conflicto de minorías», «identidad étnica» o «minoría nacional», y aparecen como víctimas del Estado. Este tratamiento diferenciado de ambos tipos de nacionalismo es revelador de la ideología del congreso. Ejemplificamos este diferente tratamiento con fragmentos de la conferencia de De Varennes (2004) y con la ponencia de P. Maragall (2004). El nacionalismo de la época moderna es retratado como un fenómeno que hay que superar y que tiene perniciosas consecuencias en el presente. En los escritos de los padres del liberalismo y del marxismo Mills y Engcls respectivamente- el único nacionalismo legítimo es el de las grandes naciones, mientras que el nacionalismo de las pequeñas nacionalidades se concibe como obstáculo para el progreso. Recordemos que el marxismo veía el nacionalismo como una herramienta de la burguesía para que el proletariado no adquiriera conciencia de clase (De Varennes, 2004).

Linguistic diversity for liberals and Marxists during the period of pure nationalism were obstacles to progress and development.

There have been in the last decade significant and numerous developments in Europe that signal a rejection of the old nationalism -not of the old Europe, just old nationalism - with a approach linking language diversity with respect for the rights of individuals.

For both Marxists and liberals, it was the "great nations" which were the carriers of historical development. The smaller nationalities and their languages and identities were regarded as backward and stagnant. They were expected to abandon their identity and assimilate into the majority nation: point final.

Por el otro lado, el nacionalismo catalán aparece rodeado de un aura romántica. Maragall (2004) conceptualiza la tensión existente entre el catalán y el español con la metáfora de una lucha («combat» y «falera») entre una «causa romántica, quixotesca» y las fuerzas de la globalización y la economía. Esta caracterización coincide en muchos puntos con las características que identifica Fishman (1972) en los nacionalismos de la época moderna:

\section{A) Unidad}

Fishman constata que las poblaciones no industriales, no urbanas y no alfabetizadas exhiben apegos locales de parentesco a las costumbres y estructuras sociales con las que tienen contacto directo. Frente a esto, el nacionalismo pretende crear un sentimiento de comunidad más amplio entre personas que llevan estilos de vida tan diferentes que nunca se llegarían a conocer. Esto lo lleva a cabo expandiendo características etnoculturales locales más allá de los lazos originarios y 
primordiales. Vemos este deseo de expansión en el discurso de Maragall (2004):

Si no hi hagués hagut una denominació comuna, si no hi hagués hagut unitat de la llengua ara no podríem defensar-ne la seva diversitat, defensa que necessitem, com he dit perquè la seva peculiaritat triomfi[...] L'hem de conrear, l'hem d'expandir, l'hem d'esponjar internament per a que hi càpiguen totes les variants $\mathrm{i}$ l'hem de portar més enllà de les seves fronteres internes $\mathrm{i}$ externes, imposant-lo amablement, amigablement..

\section{B) Nobleza}

Maragall asocia la lucha por el catalán con la lucha del mantenimiento de identidades, la diversidad y la imaginación contra la globalización; la homogeneidad, el aburrimiento, el simplismo, la comodidad contra la economía, el coste y la eficiencia (Maragall, 2004):

És una causa guanyadora perquè té a favor el vent de la revolta contra l'uniformisme

[...] Cal trobar formes i sobretot exemples per a demostrar que allò que es perd si es perd el català és superior a la comoditat que es guanya si tots els idiomes tendeixen a un de sol, o dos, o tres. És a dir: la imaginació contra l'economia, contra el cost i l'eficiència, contra el valor del temps estalviat

[...] El català és una causa a la que podem aliar milions de persones que no el parlen però que entenen la seva licitud. Una causa romàntica com la que va dur Byron a Grècia, o revolucionària com la que va dur Garibaldi a Rio Grande do Sul.

[...]No dic que el nostre idioma és una causa quixotesca per no escandalitzar

Es más, hace de la causa del catalán la abanderada de la causa de todas las lenguas minoritarias (Maragall, 2004):

Vull que entenguin que el combat per la llengua catalana (combat? millor falera) no és una falera que vivim en solitari, no és un combat egoista. La nostra causa és també la causa de totes les llengües del món que no tenen prou reconeguts els seus drets.

\section{C) Diversidad}

Per un principi universal de manteniment de les identitats i per tant de la diversitat -contra la homogeneitat, contra l'avorriment, contra el simplisme, contra la comoditat i per tant contra l'economia (Maragall, 2004).

El congreso alacua el nudelo polílico de estaulu-nación que nació después de la revolución francesa. Éste lleva aparejado la doctrina de la correspondencia 
unívoca entre un Estado, una nación y una lengua. May (2001) se refiere a esta doctrina con el término de «congruencia de nación-estado», que se traduce en el imperativo de que las personas que son ciudadanos de un estado deben ser miembros de la misma colectividad nacional.

En el nostre temps la teoria política del Estats nacionals sembla implicar que un Estat ha detenir una llengua oficial que no sols es la llengua oficial de l'Estat sinó el símbol de la unitat nacional el que implica marginar les altres llegues que es poden parlar en el territori estatal (Siguản, 2004).

Bajo esta doctrina se halla la premisa moderna de que la homogeneidad es igual a estabilidad mientras que la heterogeneidad se iguala a conflicto (Lyotard, 1979). Según Barbour (2000), esta creencia se ha visto reforzada en Europa por el hecho de que los Estados del oeste de Europa con un gran desarrollo político y económico como los Países Bajos, Gran Bretaña y Francia son monolingües, lo que ha llevado a asociar una única lengua con una mayor facilidad para operaciones económicas y políticas entre ciudadanos. Al contrario, el multilingüismo de los Balcanes se ha visto como una parte esencial de sus problemas (Siguan, 2004):

la pluralitat de llengües en un mateix espai polític apareix així com un factor de diferenciació i de manca d'estabilitat i per tant com una font de conflictes possibles mentre, a l'inversa, el parlar una mateixa llengua, el monolingüisme, sembla una garantia d'estabilitat. Per això no es estrany que tots els grans imperis hagin aspirat a refer a la inversa l'historia [sic] de la torre de Babel i a tornar a la situació en la que tots els humans parlaven la mateixa llengua, que era la llengua perfecta, la llengua rebuda directament de Deu.

La doctrina de congruencia entre estado, nación y lengua conduce a la supeditación de la supervivencia de una lengua a su vinculación con un Estado (Espadas, 2004):

Una de las concepciones menos propicias para [la protección al desarrollo lingǘstico diverso] es la que establece como necesaria la correspondencia entre un Estado, una nación y una lengua, en tanto vincula, a veces explícitamente, la capacidad de supervivencia y desarrollo de una lengua al establecimiento de un Estado de la nación hablante de ella: Esta concepción, típicamente europea, tiene como consecuencia ineludible el pronóstico de la desaparición de la enorme mayoría de las lenguas del mundo, en tanto corresponden a pueblos cuyas condiciones demográficas y territoriales han eliminado desde ya cualquier posibilidad de constitución de un Estado independiente. 
En el congreso se caracteriza el modelo del estado-nación como modelo caduco y se propone como aiternativa el modelo de los Estados multinacionales:

El desarrollo de la diversidad linguística no puede tener más punto de partida que la revisión de fondo de las premisas existentes sobre la relación entre naciones y Estados. Esta revisión implica el reconocimiento de que sólo la redefinición -que puede querer decir reconstitución- de la mayoría de los Estados existentes hoy en día como Estados multinacionales puede sentar una base auténtica para la convivencia pacífica, articulada y funcional de pucblos diversos dentro de Estados únicos (Espadas, 2004)

A single language nation is likely to be the exception in future Europe [...] identification between state, nationality and language should be considered in the historical perspective and in a critical way that allows the development of multilingual and multicultural societies in the perspective of stronger european integration (Campani, 2004).

En el siglo XIX los estados europeos se lanzaron a la creación de lenguas nacionales. Cada estado eligió una lengua oficial de entre las diversas lenguas y dialectos hablados que erigió como «la lengua nacional» o «lengua oficial». ${ }^{6}$ Según May (2001), el modelo del estado nacional representa el triunfo del universalismo sobre el particularismo e implica el reemplazo de variedades lingüísticas dentro de las fronteras de la nación-estado por una lengua nacional en común. La lengua nacional se asocia con modemidad y progreso, mientras que las lenguas minoritarias son caracterizadas como tradicionales y obsoletas. En esta línea de pensamiento, la lengua «nacional» en el corpus aparece retratada como herramienta de supresión de las lenguas minoritarias. En países con un pasado colonial se asocia con la lengua de la potencia colonizadora (Bastardas. 2002):

.. el canvi de les pautes habituals necessitarà una clara justificació $\mathrm{i}$ legitimació ideològiques i/o pràctiques. Això pot venir facilitat pel discurs patriòtic de la «llengua nacional» que afavoreix la idea de la llengua única i general per a tots els ciutadans $[\ldots]$ en un procés de difusió asimètric segons els grups socials i

6. Ruiz Vieytez (2004) en su estudio comparado de las constituciones de los países miembros de la UE constata que hay constituciones como las de Malta, Suiza e Irlanda donde «lengua nacional» aparece por añadidura a «lengua oficial». Son países que proclaman más de una lengua oficial, en los que la denominación de «lengua nacional» implica el reconocimiento simbólico de la especial vinculación identitaria de la comunidad política con una o varias de sus lenguas oficiales (similar a «lengua propia» en estatutos de autonomía en España). Por otro lado, están Estados como Finlandia y Moldavia en cuyas constituciones no se hace referencia al concepto de lengua oficial, sino solo al de lengua nacional, por lo tanto en estos segundos casos parece que «lengua nacional» y «lengua oficial» son sinónimos. 
geogràfics, la dita «llengua nacional» serà adoptada primer com a varietat de les comunicacions institucionalitzades i després transferida a les individualitzades per una generació ja competent, que, a la vegada, la transmetrà ja com a nativa a la pròxima generació, la qual ja coneixerà poc els vernacles antics i farà d'aquesta varietat rebuda en forma d'estàndard formalitzat.

En el contexto español esta asociación de «lengua nacional» con imposición y anulación de las demás lenguas nacionales se ve reforzada por el monopolio que el discurso de Franco hizo del adjetivo «nacional»: los rebeldes se autodennminan «frente nacional» $n$ «nacinnales»; el golpe de estadn se. denomina «levantamiento nacional», el movimiento que instaura la dictadura es el «movimiento nacional».

\section{CONCLUSIÓN}

En conclusión, hemos visto que el discurso del congreso de Diversidad Lingüística, Sostenibilidad y Paz se adhiere a los principios de los movimientos antiglobalización. Sin embargo, cae en contradicciones: mientras se ataca la globalización en tanto que resta poder de decisión a las comunidades locales, se justifica la intervención de organismos intemacionales que erosionan la soberanía estatal. En concreto, el objeto de todas las críticas es el modelo del estado-nación que implica una relación unívoca entre estado, nación y cultura y que utiliza la lengua nacional para imponer la cultura de la mayoría a las minorías. La ideología anti-estatal se deja ver en el diferente tratamiento de los nacionalismos estatales e infraestatales, como hemos podido ver en las confe-rencias de De Varennes (2004) y Maragall (2004). En cuanto al concepto de la lengua, se recoge la tradición del romanticismo alemán que ve un lazo indisoluble entre lengua y cultura. Las lenguas, al igual que hizo la gramática comparativa del siglo XIX, se representan como seres vivos y los fenómenos de contacto, sustitución y pérdida se conceptualizan con la ayuda de metáforas de la ecología. La pérdida de una lengua se iguala a la pérdida de una manera única de ver el mundo y una potencial solución a los problemas medioambientales.

\section{REFERENCIAS BIBLIOGRÁFICAS}

\section{TEXTOS DEL CORPUS}

Conferencias pronunciadas en el diálogo sobre Diversidad Lingüística, Sostenibilidad y Paz mantenido en el Fórum de las Culturas de Barcelona del 
20 al 23 de mayo de 2004. Todas las conferencias están disponibles en formato PDF en el sitio wEB de Linguapax: http:/www.linguapax.org/congres04.

ANNAMALAI, E. «The public perception of language diversity».

ABBI, A. «Vanishing diversities and submerging identities».

BASTARDAS, A. «Cap a una "Sostenibilitat lingüística": concepts, principis i problentes de la organització comunicativa dels humans al segle xxi».

BEUKES, A. M. «The first ten years of democracy: language policy in South África».

CAMPANI, G. «The role of language in the mobilisation of ethnic and inmigrant minorities».

Casesnoves, $R$. «La base démolinguistique pour évaluer l'aménagenent linguistique dans un contexte bilangue».

COMrie, B. «Language diversity: a key to understanding human diversity».

CRYsTAL, D. «Creating a world of languages».

DE VARENNES, F. «Pax linguae, pax humanus: linguistic rigths as a foundation for peace».

DÍAZ DE LEZANA, A. «El desarrollo tecnolingüístico del euskera».

DUTCHER, N. «Language policy and education in multilingual societies:

Lessons from three poditive models (Guatemala, Eritrea and Papua New Guinea)».

Elimam, A. «Revaloriser les langues afin de les promouvoir?».

EsPADAS, U. K «La dimensión global del debate por los derechos lingiísticos en México».

ETXEBERRIA, E. «Logros y retos de la educación bilingüe en el País Vasco».

HEDLEY, A. «Sustainable development through biocultural diversity: The role of international nongovermental organizations».

HORNBERGLR, N. «Indigenous languahe revilalisation, biliteracy and student voice: instances from Qhechua, Guaraní and Maorí bilingual education».

MACDONNACHA, J. «The role of the university in meeting the needs of linguistic communities: an Irish case study».

Maragall, P. «Intervenció del president Maragall a la sessió inaugural del diàleg sobre diversitat lingüística, sostenibilitat i pau».

MORENO, E. «La libre circulation de l'esprit: définir des droits et assumer des responsabilités en matière linguistique».

MousTAOUI, A. «Conflicto lingüístico y política linguíistica en Marruecos: una propuesta de análisis».

OSTLER, N. «The defence of language diversity».

Plá Coelho, R. S. «A juridical approach to linguistic diversity in Europe: considerations regarding adopting a catalog of basic language rights for national, international and European Union lawss. 
ROMAINE, S. «Linguistic diversity, sustainable development and the future of the past».

Siguan, M. «Les llengües i la pau».

TRUDELL, B. «The role of local agency in the defense of minority languages».

\section{REFERENCIAS BIBLIOGRÁFICAS SECUNDARIAS}

Bardour, S. y C. CARMiciel (2000): Language and nationalism in Europe, Oxford, University Press.

Bastardas, A. (1996): Ecologia de les llengües. Medi, contacte i dinàmica sociolinguiística, Barcelona, Proa.

- (2002): «Política lingüística mundial a l'era de la globalització: intercomunicació i diversitat des de la teoria de la "complexitat"», conferencia pronunciada en El Congreso Mundial de Políticas Lingüísticas en Barcelona del 16 al 20 de abril de 2002, en http://www.linguapax.org.

- (2003) «Linguiística general: elementos para un paradigma integrador desde la perspectiva de complejidad», en LinRed (on-line), http://www2.uah.es/linred/articulos_pdf/LR_articulo__111120032.pdf, 11-11-2003, pp. 1-23.

BERETTA, A. (1993): «Cognitive and social determinants of discovery in SLA», Applied Linguistics, 14.

CUENCA, M. J. y J. HiLfERTY (1999): Introducción a la lingüística cognitiva, Barcelona, Ariel.

FERNÁNDEZ PÉrEZ, M. (1986): «La investigación lingüística desde la filosofía de la ciencia. A propósito de la lingüística chomskiana», Anuario Galego de Filoloxia. Anexo 28, Santiago de Compostela, Universidad de Santiago de Compostela.

FISHMAN, J. A. (1972): Language and nationalism. Two integrative essays, Rowley, Newbury House Publishers.

Harré, R.; J. Brockmeier; P. MÜHLHAusler (1999): Greenspeak: a study of environmental discourse, California, Sage Publications.

LAMíQuiz, V. ( 2002 ) «Lo lineal, lo blanco o negro y lo difuso (acerca del método en la lingüística del siglo XX)», Revista española de lingüística, 28, 1:29-47.

López García, A. y R. Morant (1998): «La posición de la lingüística cognitiva en el desarrollo histórico de los modelos gramaticales», en Cifuentes Honrubia, J. L. (ed.) (1998): Estudios de lingüística cognitiva, Alicante, Universidad de Alicante.

Lyotard, J. (1979): La condition postmodern, París, Galilée.

MAY, S. (2001): Language and minority rights, Essex, Pearson Education limited. Ríos RuLl, F. (1998): «Nacionalidades y regiones en el desarrollo del estatuto autonómico», RULL, 9 . 
RUiz VIEYTEZ, E. (2004) «Lenguas oficiales y lenguas minoritarias: cuestiones sobre su estatuto jurídico a través del derecho comparado», II Simposi internacional Mercator: Europa 2004: Un nou marc per a totes les llengïes disponible online http://www.ciemen.org/mercator/pdf/simpvieytez.pdf].

SCHLEICHER, A. (1850 [1852]): Die Sprachen Europas in Systematischer Ubersicht: Linguistische Untersuchungen, Bonn, I. B. König. [1852 traducción de Hermann Ewerbeck: Les Langues de l'Europe Moderne, Paris, Ladrange]

VAN Duk, T. (2000): «El estudio del discurso», en Discurso como estructura como proceso: estudios del discurso: una introducción multidisciplinaria, Volumen 1, Barcelona, Gedisa.

\section{RECURSOS EN INTERNET}

FILl, A. (2000): «Ecolinguistics webside»

[www.gewi.kfunigraz.ac.at/ed/project/ecoling]

Miscevic, N. (2001): Standford Philosophy Enciclopedia

[http://plato.stanford.edu]

Página de la oNG Linguapax: [www.linguapax.org]

Página de la ong Terralingua: [www.terralingua.org] 


\title{
DEPORTE Y DISCURSO SOCIAL: DOS REGISTROS EN EL GÉNERO DEL PLAN DE ENTRENAMIENTO DEPORTIVO
}

\author{
María José Gómez OrTiz \\ Universidad Politécnica de Madrid
}

\section{INTRODUCCIÓN}

Wos encontramos en la era de la comunicación, de la tecnología y a la vez 1 de la sociedad del conocimiento y de la información. Cada vez se es más consciente de que para que sean exitosos los avances de la investigación, éstos han de comunicarse, es decir, socializarse. No tendría sentido, de otro modo, el esfuerzo invertido. Para ello, la transmisión de los nuevos conocimientos generados ha de hacerse de la manera más efectiva posible. De este modo, los investigadores son conscientes de la importancia que tienen los aspectos retóricos y sociopragmáticos en el proceso de la comunicación (PérezLlantada, 2003).

Un ejemplo concreto de carácter global lo encontramos en el deporte. Desde que aparecen los juegos modernos, la práctica deportiva en equipo e individual se ha ido difundiendo poco a poco, pero de forma continuada. A su vez, el discurso deportivo ha seguido una evolución paralela y se ha adaptado a los cambios sociales y tecnológicos. Un hito importante es la irrupción del fitness en los años ochenta que no sólo hace extensiva la aplicación de la actividad física y deportiva a la práctica totalidad de la población, sino que también lleva a un alto grado de especialización de la misma. Todo ello conduce a la proliferación de textos relacionados con este campo específico en los más diversos medios: prensa diaria, revistas tanto divulgativas como profesionales, así como publicaciones académicas espe-cializadas. Por tanto, un público variado y extenso. Puede decirse que el deporte ha adquirido un papel central en nuestra sociedad, por lo que el estudio de sus textos puede resultar revelador de la relación que se establece entre el lenguaje y ésta.

Gumperz (1968) señala la importancia que tienen las actitudes del individuo en la conformación de la comunidad de habla y, menciona que, aunque las normas sociales de selección de variedades linguísticas varían según la situación y la comunidad, la regularidad que se manifiesta en el plano de las actitudes parece ser una constante en todas las comunidades. 
Siguiendo con la comuniciad de habla, que es aquélla que comparte un discurso específico, Hymes (1972) considera que se caracteriza no sólo por criterios lingüísticos, sino también por criterios socioculturales que ayudan a explicar ciertas normas de uso.

Desde un punto de vista didáctico, es importante el análisis de los tipos de textos producidos por una comunidad de habla en forma de géneros lingüísticos; ya que el alumno, para desarrollar la competencia comunicativa, no sólo debe poseer conocimientos de gramática, vocabulario y semántica, sino que también debe adquirir los modelos de comportamiento sociolinguístico de la comunidad a la que quiere pertenecer (Pérez-Llantada, 1998).

En el plano profesional y académico, Swales (1990: 24-27), estudia los rasgos principales de la comunidad que él llama discursiva y destaca los siguientes:

- la comunidad discursiva acuerda amplios objetivos públicos comunes,

- posee mecanismos de intercomunicación entre sus miembros,

- proporciona información y la transmite también en sentido inverso,

- emplea uno o más géneros para conseguir efectividad comunicativa,

- se caracteriza por un vocabulario específico, y

- está constituida por miembros que comparten unas mismas experiencias y conocimientos a nivel académico y discursivo.

Por otro lado, la teoría de la acomodación (estudiada entre otros por Giles, 1973; N. Coupland, 1991; Giles y N. Coupland, 1991) explica que cuando interactúan dos individuos cuyas normas de comportamiento lingüístico son diferentes, por ejemplo porque tienen registros diferentes, se produce una serie de estrategias comunicativas que tienen que ver con el deseo de los participantes de reducir estas diferencias. Son actitudes particulares de los individuos ante cada contexto. Esta actitud puede darse dentro de una misma comunidad discursiva con la intención de integrar dicha comunidad y, además, persigue unos efectos sociopragmáticos concretos.

En la presente comunicación se estudia, dentro del marco de la sociolingüística, el género lingüístico de los «planes de entrenamiento deportivo» y se muestra cómo dentro de éste, el lenguaje se adapta según el tipo de público al que va dirigido. Por un lado, está presente la actitud del individuo y sus estrategias comunicativas: el modo discursivo empleado, que tiene reglas que son adquiridas por él a través de su experiencia en la vida social.

Por otro lado, la comunidad discursiva a la que pertenece, le exige que la competencia comunicativa que posea debe incluir no sólo el conocimiento de las reglas lingüisticas, sino también el de las sociales que regulan los intercambios comunicativos (que afectan al lugar donde se produce la interacción, la 
finalidad o propósito de la misma, el grado de formalidad, el rol social de los interlocutores, la relación entre éstos, etc.) y todo un conocimiento cultural y pragmático que influye en la organización de los mensajes y en el modo en que estos se producen e interpretan (Hymes, 1972; Gumperz, 1972). En definitiva, se estudia un registro técnico, en sus vertientes formal e informal, como muestra de un tipo de discurso social perteneciente a otro más amplio (Chambers, 1995; Wardhaugh, 1998) y que se ha introducido profusamente en la sociedad actual.

\section{MÉTODO}

En este trabajo se comparan catorce textos correspondientes a un género lingüístico de carácter deportivo: los planes de entrenamiento. Son textos escritos y monolingües. Se estudian a través de dos estilos, formal e informal. Se analizan las audiencias, los propósitos comunicativos, los medios empleados, con el objeto de extraer las características propias pertenecientes a cada estilo.

Un plan o programa de entrenamiento se utiliza para distintas disciplinas deportivas y con objetivos diferentes. Estos son absolutamente necesarios para seguir unas pautas de mejora de la condición física del individuo, sin las que no se pueden obtener los resultados de acondicionamiento físico deseados.

Se han tomado de diversos autores y de distintas fuentes: revistas de divulgación, revistas especializadas, libros técnicos y de la red Internet.

\section{RESULTADOS}

Los resultados se presentan separando los dos estilos estudiados y, dentro de ellos, diferenciando primero entre la parte no lingüística y, después, entre los rasgos discursivos, de manera que tanto los aspectos sociales como los lingüísticos queden expuestos y se vea cómo se combinan y adaptan unos a otros.

\subsection{Registro con estilo formal}

Los textos se encuentran publicados en revistas especializadas, en actas de congreso o aparecen formando parte de artículos de investigación y tratan sobre un área específica del deporte.

La función principal que tienen es la de informar a la audiencia sobre un aspecto investigado que concierne a los programas de entrenamiento; a su vez, intentan presentar la validez de los nuevos datos o argumentos. 
El escritor es un especialista en la materia y sus lectores son especialistas o público semi-experto, por ejemplo estudiantes. Los interlocutores posibles son: de atleta profesional a atleta profesional, de entrenador cualificado a atleta profesional, de profesor a alumno. La audiencia a la que se presentan los textos es bastante concreta y tiene una formación profesional muy especializada. Como decíamos, la intención comunicativa que tiene es la de presentar un tipo de entrenamiento ya probado y que garantiza unos resultados específicos, y que la comunidad discursiva a la que se presenta, la acepta como de su interés.

La comunidad discursiva mencionada respeta las convenciones del género lingüístico de plan de entrenamiento. Estas convenciones se manifiestan con la siguiente macroestructura textual: tres secciones y cinco movimientos que organizan la información textual adecuadamente. La sección de introducción contiene los movimientos siguientes: 1) presentación del tipo de entrenamiento, y 2) recomendaciones iniciales sobre aspectos generales. La sección de desarrollo contiene: 3 ) consejos y recomendaciones detalladas especificas del plan de entrenamiento, y 4) el plan de entrenamiento en sí. Por último, la sección de conclusión la forma el último movimiento número 5) que contiene las recomendaciones finales generales.

En cuanto a las características discursivas, hay que destacar que aparecen con frecuencia las oraciones condicionales de primer tipo para dar una idea de confianza en el logro de los objetivos, también encontramos oraciones de relativo para especificar o explicar ciertos aspectos importantes. Las ideas en ol texto se presentan unidas principalmente por conectores semánticos de tipo contrastivo.

En los textos con discurso más formal es muy frecuente la pasivización en la introducción y en la conclusión con la intención de dar cuenta de los nuevos datos descubiertos.

En general, se emplean oraciones subordinadas, verbos modales para matizar las afirmaciones, conectores semánticos para organizar las ideas, el plural de cortesía, sin olvidarnos de mencionar un tipo de vocabulario muy técnico con el que se presenta la información de forma clara y precisa que no deja sitio para ambigüedades. Para conseguir el estilo formal, los autores emplean el modo de exposición informativo o argumentativo, consiguiendo así favorecer la claridad y la objetividad.

Para finalizar, hay que resaltar que es muy importante la interacción que se consigue entre el emisor y el receptor mediante la aparición de imágenes seleccionadas que muestran la correcta ejecución del ejercicio físico. Estas ilustraciones colaboran al aportar entendimiento del mensaje, mostrando así su gran eficacia. 


\subsection{Registro con estilo informal}

Se trata de publicaciones que se encuentran en revistas de divulgación o en la red Internet con el fin de instruir, informar y aconsejar sobre un determinado plan de entrenamiento y su aplicación según el perfil de la persona y las necesidades concretas que tenga.

Los interlocutores posibles son: de especialista o semi-experto a aficionado o estudiante.

La comunidad discursiva emplea la misma macroestructura presentada anteriormente cn cl cstilo formal, pcro con la existencia de gran flexibilidad en las secciones y movimientos. El escritor las escoge sólo si está muy seguro de que así conecta mejor con su audiencia. No es de extrañar, por tanto, que la información, en ocasiones, se presente de forma muy esquemática, y que prescinda de determinados movimientos: concretamente del número uno (presentación del tipo de entrenamiento) y del número dos (recomendaciones iniciales sobre aspectos generales).

En cuanto a los rasgos discursivos, hay que destacar que los tiempos verbales más utilizados son el presente simple y el imperativo en las instrucciones de los ejercicios físicos. También aparecen verbos modales, sobre todo en las recomendaciones de los ejercicios físicos. Las oraciones son cortas y no presentan complejidad. El patrón discursivo que se emplea es principalmente informativo, ya que se aportan datos que son clave para el lector.

Un rasgo importante es el uso consciente de estrategias de tipo emotivoexpresivo de carácter más subjetivo, que implica una actitud por parte del emisor y una recepción de las mismas por parte del receptor. El escritor sabe que es necesario conocer bien a la audiencia y prever de antemano su schematic knowledge (Scovel, 1998: 129) que se basa en la experiencia acumulada con situaciones similares. En el caso de una audiencia poco experta, como es el caso, la actitud del autor hacia el texto y hacia su audiencia marca la modalidad textual. El texto es de carácter informativo y, para conseguir transmitir algo tan importante en esta área de conocimiento del deporte como es la motivación, el autor del texto presenta también rasgos informales del lenguaje como oraciones exclamativas, interrogativas, contracciones, uso de pronombres personales.

Es necesario mencionar otra estrategia muy importante que emplea el emisor, que es la selección de imágenes con las que conseguir una fuerte interacción con el receptor. En ocasiones, para reforzar ésta, emplea metáforas cuidadosamente escogidas que acompañan a dichas imágenes. Por ejemplo, en la instrucción de los ejercicios, encontramos metáforas visuales y verbales como las siguientes (Siler, 2000: 138): «estás oponiendo resistencia a un 
potente muelle sujeto entre el esternón y los tobillos» o «las piernas y el tronco son sendas flechas articuladas en las caderas». Estas metáforas se basan en la experiencia previa de la audiencia y en su relación con el mundo que le rodea y quedan muy relacionadas con los procesos de cognición y de interacción.

\section{CONCLUSIÓN}

La existencia de variantes lingǘsticas es utilizada por ambos grupos como un rasgo de diferencia social y académica entre sí.

El registro más formal emplea términos muy especializados, conocidos de antemano por su audiencia y, además, deteminados rasgos formales como conectores semánticos, definiciones, oraciones condicionales. Se aprecia acomodación mutua entre escritor-lector en este estilo, al seguir ambos las convenciones sociales y linguísticas establecidas.

El registro informal emplea el modo imperativo para dar instrucciones deportivas. Otro rasgo observable son las oraciones cortas, que colaboran con la claridad del mensaje emitido. También se aprecia escasa aparición de verbos modales o pasivas y muchos rasgos informales del lenguaje que contribuyen a la interacción entre emisor y receptor. En el estilo informal, se produce un esfuerzo de acomodación grande por parte del escritor mediante la elección de estrategias que le permitan conseguir el objetivo de la comunicación.

En conclusión, se pone de manifiesto el papel principal del lenguaje a la hora de diferenciar grupos sociales y profesionales. La conducta lingüística de los participantes muestra estratificación social, que a su vez refleja creencias y actitudes subjetivas: flexibilidad en la macroestructura, actitud subjetiva y acomodación a la audiencia, rasgos de tipo expresivo y apelativo. Son rasgos conscientes, son actitudes de acomodación para conseguir el objetivo de comunicarse. La variante formal no necesita esforzarse para conseguir la fluidez de la comunicación, mientras que la variante informal hace uso de más estrategias, escogidas por el emisor para que la comunicación llegue correctamente: complicidad, cercanía con el lenguaje escogido, elección de imágenes adecuadas.

Resulta evidente, al estudiar los dos estilos de este género lingüístico, que el lenguaje está condicionado socialmente y que es la misma sociedad la que determina el discurso y las estrategias que se deben seguir según el contexto. 


\section{REFERENCIAS BIBLIÓGRAFICAS}

Aguado de Cea, G.; I. Álvarez de Mon y Rego; M. García; P. Durán (eds.) (2003): Las lenguas para fines específicos y la sociedad del conocimiento, Madrid, Universidad Politécnica de Madrid.

Chambers, J. (1995): Sociolinguistic Theory. Linguistic Variation and its Social Significance, Oxford, Blackwell Publishers.

Coupland, N. (1991): Language, society \& the elderly, Oxford, Basil Blackwell.

Fortanet, I.; S. Posteguillo; J. Palmer; J. Coll (eds.) (1998): Genre Studies in English for Academic Purposes, Castelló de la Plana, Universitat Jaume I.

GILES, H. (1973): «Accent mobility: a model and some data», Anthropological Linguistics, 15: 87-105.

Giles, H. y N. Coupland (1991): Language: Contexts and Consequences, Buckingham, Open University Press.

GUMPERZ, J. (1968): «The speech in community» en GUMPERZ, J. (1971: 114128).

- (1971): Language in social groups, Stanford, Stanford University Press.

- (1972): «Sociolinguistics in small groups» en Pride, J.; J. Holmes (eds.) (1972: 203-224).

HYMES, D. (1972): «On communicative competence» en PRIDE, J.; J. HOLMES (eds.) (1972: 269-293).

Pérez-Llantada, C. (1998): «Re-thinking Rhetorical Strategies in Academic Genres» en Fortanet, I.; S. Postegulllo; J. PAlmer; J. Coll (eds.) (1998: 79-89).

- (2003): «How to do things with words: Metadiscourse strategies in technical communication» en Aguado de CEA, G.; I. Álvarez de Mon y Rego; M. Garcia; P. Duran (eds.) (2003: 117-122).

Pride, J.; J. Holmes (eds.) (1972): Sociolinguistics, Harmondsworth, Penguin. Siler, B. (2000): El método Pilates, Barcelona, Oniro.

Scovel, T. (1998): Psycholinguistics, Oxford, Oxford University Press.

Swales, J. M. (1990): Genre Analysis: English in Academic and Research Settings, Cambridge, CUP.

Wardhaugh, R. (1998): An Introduction to Sociolinguistics, Londres, Blackwell. 


\title{
LA LLENGUA DE L'AUDIÈNCIA EN TELEVISIÓ: IMPLICACIONS IDEOLÒGIQUES DES DEL COL·LOQUIAL A L'ESTÀNDARD
}

\author{
Josep À. MAS \\ Universitat Politècnica de València
}

\section{INTRODUCCIÓ}

T a llengua de l'audiència en els espais de participació dels mitjans de Lcomunicació audiovisual presenta punts d'interés remarcables per a l'estudi de la variació lingüística, especialment de la funcional o diafàsica, dita també estilística. Per esmentar-ne un de purament pràctic, hi ha els avanços en la qualitat dels sistemes d'enregistrament i reproducció, els quals poden fer prescindible en ocasions la feixuga tasca de la transcripció. Un de teòric és que els mitjans de comunicació constitueixen una de les escasses oportunitats de parlar en públic per a aquells qui no han de fer-ho per obligació professional. Per tant, també són una de les exigües ocasions d'analitzar la manera com s'acos-ten als registres formals.

En el cas valencià, l'anàlisi es complica -i s'enriqueix- bastant per l'existència de diversos models de Ilengua, incloent-hi el fet que el més propagat en el marc escolar i el de RTVV divergeixen en alguns casos significatius. Així, les diferències entre el model del mitjà i el d'un parlant anònim que hi participe s'hauran d'interpretar, al marge de les deficiències en la competència lingüística, a partir de les connotacions ideològiques que cadascun dels models implica. Per tant, per a aquesta mena de treball s'imposa una metodologia multidisciplinària que vaja des de les propostes de les disciplines que s'ocupen de la llengua en ús (com ara la sociolingüística en sentit ampli i la pragmàtica, ja de per si punt de trobada de perspectives diverses) a les teories i les eines de l'anàlisi crítica $-\mathrm{o}$ ideològica- del discurs (d'origen $\mathrm{i}$ interessos declaradament miscel-lanis). 


\section{LA VARIACIÓ PUNCIONAL ALS MITJANS DE COMUNICACIÓ AUDIOVISUAL}

Existeix un tòpic que relaciona massa estretament la llengua dels mitjans de comunicació amb l'estàndard linguístic. El podem trobar en manuals de divulgació, però també en la bibliografia especialitzada. En un treball recent (Navarro i Rull, 2000: 269) s'utilitzava precisament aquest context com l'element definidor del concepte d'estàndard lingüístic: "Considerem que l'estàndard és allò que se sent i es llegeix als mitjans de comunicació de masses». Cal afanyar-se a aclarir que no sembla una definició amb pretensions acadèmiques, sinó que se li pot suposar un valor purament instrumental per al desenvolupament de les idees que els autors proposen en aqueli article. D'una altra manera no s'explicaria el doble reduccionisme que implicaria una identificació absoluta, en el sentit que l'estàndard només es troba en els mitjans i que en els mitjans només s'utilitza l'estàndard.

Perquè és obvi que l'equivalència és reduccionista. En el primer sentit, a ningú no se li amaga que l'estàndard es pot trobar en altres usos a banda dels propis dels mitjans de comunicació. Tradicionalment s'esmenten els àmbits formals com els propis d'aquesta varietat linguística (vegeu, per exemple, Bibiloni, 20003: 21-22), entre els quals destaquen l'escola i, efectivament, els mitjans de comunicació. En l'altre sentit, no cal fer anàlisis massa aprofundides per a observar que els mitjans de comunicació, especialment els audiovisuals, contenen una gran quantitat de situacions comunicatives molt diverses quant als graus de formalitat, les quals comporten necessàriament usos lingüístics igualment distanciats. Ningú no s'esperaria avui un ús lingüístic idèntic entre un documental de divulgació científica i un talk show, per exemple.

Fa l'efecte, però, que la tendència identificadora té més força en aquesta direcció. De fet, qui parla de la llengua dels mitjans de comunicació sense més especificacions s'està referint normalment a aquells usos formals que amb més avinença consideraríem estàndard. Almenys parcialment, això es podria explicar a partir de la denominació mitjans d'informació, ja ben poc usada, que implicava una preponderància absoluta dels informatius, mentre que la resta de la programació esdevenia secundària. Així, s’identificaria la llengua del mitjà amb la dels informatius, que sí que constitueixen un àmbit adequat per a la varietat formal. El més important, d'acord amb alguns autors (Salvador, 1990: 220):

Els informatius són, a més, un dels gèneres amb més rellevància sociolingüística dins el món dels media en la mesura que resulten el més representatiu de l'ideal d'estàndard d'una llengua, la més pública de les senes 
varietats parlades i el més prestigiós dels estils orals. El públic, en un procés circular, es manifesta ultrasensible al llenguatge modèlic dels noticiaris, el qual esdevé així, com conclou Allan Bell, «el guardià de la llengua estàndard».

Ara bé, s'ha de tenir en compte que la variació lingüística no és idèntica dins el marc dels mitjans que fora, en la vida real. Per dir-ho clar i ras: el registre colloquial més informal no existeix en els mitjans de comunicació. Això es pot considerar també una conseqüència del que estem comentant: la identificació teòrica (en sentit molt ampli) de la llengua dels informatius amb la del mitjà sencer fa que el seu model lingüístic tendisca a estendre's a la resta de la programació.' Sens dubte, aquesta extensio és possibilitada i afavorida per una característica diferencial dels mitjans de comunicació respecte de l'àmbit familiar o privat: la comunicació sempre hi és pública.

Si es vol dir amb termes propis de l'anàlisi de la variació funcional, la clau es troba en la diferència respecte del factor tenor en la caracterització del col-loquial familiar i la llengua dels mitjans. Mentre que en el primer cas el tenor interpersonal és prototípicament interactiu entre parlants que es coneixen $i$, per tant, el tenor funcional és informal, en els mitjans de comunicació sempre s'ha de suposar una gran quantitat de desconeguts entre els receptors, la qual cosa portarà el parlant a elevar el nivell de formalitat. Això és aplicable tant al professional del mitjà que presenta aquell talk show que esmentàvem com al membre del públic que hi participa ocasionalment, tot i que no de la mateixa manera. El ventall de possibilitats de l'audiència és molt més ric de matisos i d'implicacions. Els seus textos, doncs, més interessants d'analitzar.

Estem al-ludint al fet que mentre que els professionals estan subjectes a la normativa lingüística interna del mitjà, al llibre d'estil, el públic, no. És indubtable que la mimesi amb el model referencial del mitjà serà una tendència. No debades se sol anomenar els mitjans de comunicació com els principals agents de difusió de l'estàndard, al costat de l'escola. Però l'impuls d'imitar-ne el model pot ser matisat si no neutralitzat per un altre factor, el realment determinant, al nostre parer, a l'hora de realitzar el control sobre la

1. Incloent-hi els espais de ficció, on aquesta contaminació pot entorpir la identificació de l'espectador. Diversos autors (Polanco, 1990; Paloma, 1999; Lacreu, 2002) han argumentat la necessitat d'un model clar (o diversos: tants com paraestàndards) de llengua col-loquial, que s'hauria de situar en un punt dolç entre la versemblança i la correcció. A més del que estem comentant, se sol adduir la situació precària que encara viu el català en l'àmbit de la fícció audiovisual com a causa de la mancança. D'altra banda, la mateixa demanda de model per al col-loquial es pot interpretar com un símptoma de la circumstància sociocultural: en altres contextos la preocupació és únicament de reflectir amb el màxim de fidelitat la llengua parlada. Darrerament hi ha alguns autors que proposen un acostament més desacomplexat al nostre colloquial, com ara Camps (dins Creus i altres, 2000: 112) i especialment Saragossà (2003). 
parla pròpia: la ideologia del parlant. Aquesta pot portar-lo a adoptar un altre «llibre d'estil», o almenys a usar-ne algunes variants peculiars que podem anomenar marcadors ${ }^{2}$ per tal de marcar la seua adhesió a algun grup social que no s'identifica amb el mitjà en quiestió -amb la ideologia del mitjà en qüestió.

Els exponents més clars i més universals del que s'està dient són de tipus lèxic. Si una persona és convidada a participar en un debat radiofònic o televisiu sobre política internacional, per posar un exemple recurrent de l'actualitat candent, es pot referir al mateix grup amb els termes resistència o terroristes, tria que el situarà ideològicament. El moderador, en canvi, és ben probable que tinga instruccions precises sobre com anomenar-lo. Les quals, al seu torn, són consequiència de la línia ideològica de l'emissora per a la qual treballa, evidentment.

Però les paraules no són els únics elements lingüístics portadors d'ideologia. D'acord amb Van Dijk (2003: 69), totes les formes que poden canviar a causa d'alguna característica del context són susceptibles d'interpretar-se en clau ideològica. ${ }^{3}$ Raonament que porta directament i ràpida a postular la necessitat d'incloure la perspectiva de l'anàlisi crítica (o ideològica) del discurs en els treballs sobre variació funcional, tal com ha posat de manifest Vicent Salvador (2003). Si apliquem aquestes consideracions a l'argumentació sobre els models lingüístics que estàvem fent, haurem de concloure que aquests constitueixen l'exemple més clar i més fort de la importància de la ideologia en la variació lingüística. De fet, qualsevol model linguiístic s'hauria d'entendre com una proposta d'organització de la variació lingüística en funció d'uns criteris ideològics determinats.

\section{IDEOLOGIES I MODELS LINGÜÍSTICS VALENCIANS}

En el cas valencià, les implicacions ideològiques dels models lingüístics són especialment complexes i punxants. Josep Lacreu (2002: 24.1-251) en diferencia quatre: secessionista, particularista, convergent i integracionista, a partir de «la voluntat d'acostar-se al llenguatge viu dels valencians, o la voluntat d'aproximar-se als altres dialectes catalans» (2002: 246). És obvi que,

2. Manllevem el teme de Biber (1994: 34), que l'utilitza per a referir-se als «trets lingiístics distintius que només es troben en registres concrets». Per a l'accepció que hi donem ací, caldria canviar «registres» per" «models lingüístics».

3. En aquest treball seguim la definició d'ideologia d'aquest autor: «las ideologías son las creencias fundamentales de un grupo y de sus miembros» (Van Dijk, 2003: 14). També convé tindre present la primera implicació de la definició: el que fa que les creences es puguen considerat ldeologiques és que no les assumelxen igualment tots els grups d'una mateixa societat. La polèmica és, doncs, la base de la ideologia. 
entre nosaltres, la major o menor densitat de formes endodialectals no és atribuïble a una mera qüestió d'estil. De fet, resulta temptador superposar aquesta classificació dels models de llengua a la tipologia de grups ideològics del País Valencià que proposava Rafael Xambó (1997: 231-258) segons la seua posició respecte de la normalització lingüística, si es té en compte que el primer no utilitza mai el valencià en situacions públiques: assimilistes castellanistes/espanyolistes, anticatalanistes, bilingüistes espanyolistes, bilingüistes valencianistes $i$ normalitzadors.

Tanmateix, només es pot considerar que l'equivalència és (quasi) exacta cntrc el grup anomcnat anticatalanista i el model secessionista. Després, podríem dir que l'integracionista només es troba en els anomenats normalitzadors, però en absolut de manera generalitzada. Probablement, el més freqüent hi és el convergent però, fins i tot, no s'hauria de descartar algun exemple de particularista. Entre els grups del mig també cal esperar una correspondència inexacta amb els models centrals de Lacreu, perquè ací les fronteres són menys clares, tant entre els grups com entre els models. Vegemho, doncs, amb una mica més de deteniment.

L'anticatalanista-secessionista constitueix el nostre cas extrem d'ideologització de model lingüístic: la voluntat de marcar la distància respecte dels altres grups porta els membres d'aquest a utilitzar no ja unes variants distintives dins de l'estàndard, sinó a crear una normativa diferenciada. Cosa que és conseqüent amb un dels seus postulats ideològics principals -l'únic, segons Xambó- que no és un altre que l'existència d'una llengua valenciana independent. Així, en el plànol estrictament lingüístic, aquesta ideologia s'ha qualificat sovint amb l'expressió cortina de fum, segons la qual la defensa aferrissada d'aquell principi bàsic emmascararia la manca de voluntat de contribuir a l'expansió de l'ús social de la llengua. Afirmació avalada per la quasi nul-la reivindicació, més allà de declaracions emfâtiques, d'una major presència del valencià en els àmbits que ocupa quasi exclusivament el castellà.

No obstant això, s'ha de tindre en compte que la ideologia linguiística d'un grup forma part d'un complex sistema ideològic, on es relaciona amb altres subconjunts de creences. Entre les quals destaca la ideologia al voltant de la identitat social, atés que la manera com s'entén la mateixa relació entre els conceptes centrals d'aquests conjunts, llengua i nació, pot ser-és, en el nostre cas- altament ideològica (altament conflictiva). A ningú no se li oculta que l'autonomia que postulen per al valencià respecte del català, encarnats respectivament i bàsica en l'apitxat i el barceloní, deriva de la voluntat de distingir al màxim la identitat social valenciana de la catalana. La causa d'aquesta concatenació resideix en el vincle essencial de la relació entre llengua i nació (o poble, o regió), sorgit en el romanticisme alemany, i que té una expressió perfecta en aquesta citació de Fitche que hem trobat en Mollà 
(2002: 111): «Allà on es troba una llengua independent, hi ha també una nació independent que té el dret a dirigir els seus assumptes... i a governar-se a si mateixa».

Es tracta exactament del mateix esquema subjacent al (sub)grup dels anomenats normalitzadors que utilitzen el model integracionista. ${ }^{4} \mathrm{El}$ contrast es troba en la llengua de referència que, d'acord amb l'esquema romanticoessencialista, dóna lloc a la nació: ara es considera que com que la llengua és catalana, l'única identitat social rellevant (nacionalitat) és la catalana i es relega tot allò valencià al camp de les peculiaritats regionals. Incloent-hi les variants diatòpiques, amb independència que siguen admeses per la normativa del mateix Institut d'Estudis Catalans. Potser cal recordar que ens estem referint a un stibgrup molt poc nombrós dins el nomalitzador, on el més frequient és l'ús del model convergent.

En realitat, aquests dos extrems són els més minoritaris, amb diferència, cn la societat valenciana $i$ en els usos formals de la llengua. Tanmateix, com assenyala Xambó (1997: 239), «en els moments de més intensitat del conflicte, els bilingüistes de tota mena, que són la immensa majoria, es polaritzen en un o altre sentit». I són identificats -representats, si es vol-com a membres del grup extrem que tenen més a la vora per part dels altres. Així, els grups més radicals acaben tenint més incidència en el debat sociopolític de la que els correspondria per raó del seu pes quant a grup o de la presència efectiva del seu model lingüístic en la comunicació pública valenciana.

De la seua banda, el model particularista, que arranca de les Nomes de Castelló i es desenvolupa teơricament als anys cinquanta amb els treballs de Sanchis Guarner i Carles Salvador, actualment té més presència social que mai $i$ arriba a fer ombra al convergent, que va dominar totalment les dècades dels setanta, vuitanta i primera meitat dels noranta. La competència entre els dos models en la darrera dècada s'origina amb l'arribada del valencià a la comunicació oral formal, on el principal mitjà quant a difusió, RTVV, aposta pel model particularista des del primer moment. Posteriorment, les victòries electorals del PP han eixamplat el model particularista cap als usos escrits, sobretot en l'Administració autonòmica i en algun dels ajuntaments en què governa - $i$, amb reticències, en el marc escolar.

4. Encara que hauria de resultar obvi, potser convé recordar que no és l'únic esquema ideològic possible pel que fa a la relació entre llengua i identitat social, tot i que sí que ha estat el més usat, si no continua sent-ho, per a la reivindicació lingüística per part dels grups nacionalistes. Però n'hi ha prou amb una ràpida ullada comparativa als mapa polític i lingüístic del món per adonar-se que la falta de coincidència és la norma. Per a una descripció de les ideologies linglisticoidentitàries més importants, es pot consultar Martínez (2002). 
Pel que fa a l'altre partit majoritari, el PSPV-PSOE, introductor del particularisme en l'oral formal, utilitza els dos models amb un cert predomini del particularista en l'oral i del convergent en l'escrit. Amb matisos, aquesta darrera opció és la que es pot dir que segueix la resta d'estaments més o menys compromesos amb la normalització lingüística, els quals, alhora, s'identifiquen més o menys amb posicions ideològiques diguem-ne, progressistes. Incloent-hi els partits polítics amb una certa representació institucional, EU i BLOC.

A falta d'estudis de camp sobre els models lingüístics dels partits polítics i els agents socials valencians, assenyalarem que, a títol d'exemple, ens estem referint a la preferència per un dels elements dels següents doblets tant en l'oral com en l'escrit, el primer dels quals correspondria al particularista i l'altre al convergent: este/aquest, servici/servei, hòmens/homes, huilavui... en el benentés que la llista estaria oberta en el sentit que s'hi incorporen i en desapareixen alguns elements a partir de polèmiques concretes. Com és obvi, les consideracions anteriors s'han fet a partir de l'anàlisi d'alguns textos orals i escrits, no prou sistemàtica per considerar-se un treball de camp però sí per a dibuixar unes línies mestres o tendències per al que ací ens interessa. Que no és una altra cosa que destacar el fet que l'ús d'un o d'un altre model pot situarnos en una bigarrada cruilla ideològica, on s'entrecreuen les línies identitària, de classe (esquerra-dreta), i pròpiament lingüística.

La qual cosa contribueix, sens dubte, a aquella polarització de què parlava Xambó. Un exemple a comentar n'és la virulència amb què alguns partidaris del model convergent, els qui l'identifiquen amb el veritable (para)estàndard, polemitzen, per no dir ataquen, l'Acadèmia Valenciana de la Llengua. Institució que, convindria no oblidar-ho, ha donat carta de naturalesa oficial al model particularista que utilitza però també a tots els altres llevat del secessionista. Dit d'una altra manera, treballa d'una manera contundent dins els paràmetres de la unitat de la llengua i de la codificació de Fabra. Un exemple nítid i ben actual de la manca de perill disgregador que suposa el model particularista n'és el gest de la Generalitat de Catalunya de donar per vàlida per al seu territori la traducció de la Constitució europea que ha fet aquesta institució. Com no podia ser d'una altra manera, si es té en compte l'origen fabrià del model lingüístic i, d'altra banda, l'emfàtica i tòpica declaració que diu que el català és una de les llengües amb menys variació de la romania.

Davant d'aquest panorama, no sorprén gens que el model linguístic dels mitjans de comunicació, especialment dels públics, siga font permanent de polèmica. ${ }^{5}$ De més a més, no s'ha de passar per alt el fet que en el nostre cas,

5. D'altra banda, la desaprovació acadèmica del llenguatge dels mitjans de comunicació es pot considerar quasi un universal, La qual cosa no deixa de ser lògica si es tenen en compte les diferents funcions de la llengua en l'educació i la comunicació de masses. 
que és l'habitual en aquest punt, els únics mitjans de tipus públic són els audiovisuals, ràdio i televisió, en els quals la comunicació és oral de manera exclusiva o predominant, respectivament. I, com és sabut, el criteri bàsic d'acostar la llengua a la de l'audiència que defineix el llenguatge periodístic s'acreix si la comunicació és oral, per allò que tots estem (pre)disposats a una distància major respecte de la nostra parla quan passem a l'escrit. No és tan clar ni fora de discussió, per tant, que el model lingüístic de RTVV siga tan desenraonat. Una altra quiestió és l'escassíssim rigor amb què s'hi segueix, fins al punt que sovint fa pensar que no en tenen, de model. El fet que ni s'estudie ni es critique l'allau de castellanismes, especialment fonètics, amb què alguns locutors ens torturen és també conseqüència de les polaritzacions que estem comentant.

\section{ELS MODELS LINGÜISTICS DE LAUDIENCIA}

El cas dels parlants, diguem-ne, anònims és ben diferent. Déiem al principi que no estan obligats a seguir cap model lingüístic sinó que poden triar entre el del mitjà o un altre. L'anàlisi de la seua parla, però, ha de tindre en compte una sèrie de qüestions prèvies a la interpretació ideològica. Per començar, que no tothom, ni de bon tros, milita en un partit polític o forma part d'una associació per la normalització lingüística. I encara, que els qui sí que ho fan no solen compartir totes $i$ cadascuna de les creences referents a tots els àmbits de la vida social, ni tan sols totes les referides a la llengua i a la identitat. Així, la identificació amb el model serà més clara en els extrems, ja que l'adscripció a aquests grups suposa una presa de posició que se sap minoritària, incòmoda. I un esforç extra d'aprenentatge, ja que no s'ensenyen en l'escola.

La competència lingüística és un tema molt important a l'hora de dur a terme aquest tipus d'anàlisi. En primer lloc, s'ha de tindre en compte l'edat dels subjectes. Podríem posar la barrera al voltant dels trenta-cinc anys: d'ací en amunt, el seguiment de qualsevol model de llengua serà especialment significatiu, atés que implica una voluntat expressa d'aprendre'l fora de l'ensenyament regular; l'habitual serà el no ús de formes normatives. Per contra, l'ús del model convergent i, en alguns casos, del particularista per part dels més jóvens no és susceptible per si mateix d'interpretació ideològica: senzillament, és el model que han aprés o estan aprenent en el seu centre educatiu. Quan es done contrast amb el del mitjà, la hipòtesi és que s'imposarà el model escolar, perquè tindrà unes connotacions de prestigi superior -gràcies, precisament, al món acadèmic.

Un alte aspecte a prendre en cunsideraciú respecte de la connpetència linguística és que cal partir de la base que aquesta és molt baixa en general, en 
qualsevol dels models, incloent-hi els escolars. Això fa que en anàlisis d'aquest tipus siga recomanable cenyir-se a l'anàlisi de marcadors, tal com s'han definit abans, més que no esperar models coherents. Al cap i a la fi, del que es tracta és d'esbrinar si té voluntat d'usar-ne un o un altre. Això implica pressuposar que el parlant que vulga significar-se ideològicament a través de la llengua però no tinga la formació adequada, mirarà d'usar i d'evitar algunes formes clarament distintives del model del seu grup i dels altres, respectivament.

Així les coses, quin recurs queda als parlants que no volen situar-se ideològicament quan parlen, posem per cas, de les festes del seu poble per la tele? Doncs, evidentment, no usar cap d'aquests models. Tenen al seu abast l'estàndard d'una altra llengua sense tantes subtileses, per no dir complica-cions. Però aquest recurs a la recerca de l'asèpsia ideològica ja no sempre és tan rendible. El pas al castellà serà, efectivament, una solució no marcada en la comunicació escrita i per part de parlants de més de trenta-cinc anys, als quals no se'ls suposa l'aprenentatge regular de la nostra llengua. En l'oral, per contra, el canvi de codi seria molt marcat en aquells àmbits on l'ús del valencià és normal, com ara en una intervenció en el plenari de l'ajuntament del poble o en un mitjà de comunicació que s'expressa en valencià, ni que siga parcialment.

L'oral, a més, permet el recurs de l'ús del col-loquial en totes les situacions, entés ara com el model lingüístic natural per contrast amb els que hem comentat ací, als quals no se sol accedir per transmissió intergeneracional. A partir d'aquella barrera d'edat i si no es tenen més dades del parlant, no hi ha manera de saber si aquest actua així per manca de competència o per voluntat expressa. En canvi, per davall d'aquest límit o si tenim dades de formació lingüística, el col-loquial en una situació formal s'haurà d'interpretar ideològicament com a indicador d'una voluntat expressa de no significar-se en els diversos arcs ideològics, bé perquè el parlant es vol reservar aquesta informació, bé perquè no s'identifica amb cap dels grups que s'hi pronuncien. $\mathrm{O}$ almenys, no amb els grups dominants.

A aquestes situacions de recerca o caiguda casual per falta de competència en el grau zero de compromís ideològic cal afegir l'ús del model convergent o, en menor mesura, del particularista per part de parlants escolaritzats en la llengua pròpia. De qualsevol manera, caldria afegir alguns decimals a aquest grau zero, perquuè el més probable és que coneguen l'existència, si més no, del model secessionista, respecte del qual es posicionaran en utilitzar l'escolar.

Tot això està referit, òbviament, a parlants que tenen el català com a llengua primera, o almenys, que porten molt de temps usant-lo i coneixen el conglomerat d'actituds i normes d'ús contradictòries que defineix la comunitat lingüística valenciana. Per als parlants nouvinguts podem suposar una situació 
semblant a la dels jóvens si han arribat a la llengua a través de l'ensenyament. El que deu ser més interessant és la situació d'aquells que s'estan integrant sociolingüísticament per les dos vies, l'escolar i la del carrer. Caldrà pressuposar que, en cas de conflicte entre un model d'estàndard i el model de llengua popular, s'hi imposarà el darrer, per la major potència integrativa, ateses les poques oportunitats d'ús públic de la llengua en què utilitzar el primer, que en la comunicació privada, si no provoca rebuig, almenys sí que estarà marcat com a diferent.

Aquestes premisses de partida són les que s'ha tingut en compte en una recerca en curs sobre aquesta qüestió, el corpus de la qual està format per la sèrie documental íntegra Entre els nostres, de 26 capítols, que va emetre Punt 2 el 2002. El format del programa dóna el protagonisme absolut als participants en termes lingüístics, ja que són els únics que parlen, fonamentalment en forma de monòlegs. Aquests són persones anònimes de la major part de comarques valencianes, de diversa formació cultural i posició econòmica i d'edats d'entre 17 i 90 anys aproximadament. Característiques que la converteixen en una mostra representativa de l'ús públic de la llengua per part dels valencians i les valencianes.

\section{A TALL DE CONCLUSIÓ}

La conclusió immediata de tot aquest entramat ha de ser negativa, per no dir pessimista, pel que fa a l'ús formal de la llengua. A banda do la recerca del grau zero per part dels parlants que s'ha comentat, el mateix Lacreu (2002: 249) dóna el nom d'algunes empreses (Telefónica, Hidroeléctrica i Mercadona) que han retirat escrits públics a causa de la polèmica que havia originat el model de llengua que utilitzaven. No se'ns diu quin era, però no és agosarat suposar que devia tractar-se d'un dels dos del mig, tan pròxims i tan allunyats alhora.

Aquest és l'estat de la qüestió. No cal detindre's en lamentacions o en hipotesis de passat, de l'estil de "s'hauria d'haver fet això o allò», "si no hagueren fet allò altre». El que cal és posar-se a treballar, en el nivell macro i en el micro, fent anàlisis, descripcions i interpretacions exemptes de judicis de valor distorsionants per tal d'arribar a una certa comprensió de la complexitat de la situació. A partir del qual es podrà -s'haurà de- fer propostes de futur, perquè la nostra és una disciplina essencialment compromesa. El que sembla fonamental per a l'avanç és la distinció entre les eines d'anàlisi i les argumentatives, ideològiques per definició (vegeu, per exemple, Nicolás, 1998: 191).

Siga com siga i amb totes les cautcles, inclosa la de la subjectivitat, cns podem atrevir a assenyalar alguna línia que sembla portar a un atzucac i alguna altra que 
podria obrir portes. A la vista de les intricades i diverses implicacions ideològiques dels distints models, és una pèrdua de temps estar postulant que allò òptim és la desaparició de tots llevat d'un. Això no passarà. De fet, el problema no és l'existència de diversos models en si, cosa habitual en totes les llengües en major o menor mesura, sinó la crispació derivada del seu ús ideològic. El qual permet aprofitaments, manipulacions i paradoxes poc denunciades, com ara la de mantenir postures ambigües o explícitament contràries respecte de la unitat de la llengua alhora que s'adopta el model particularista, basat en aquesta unitat. El fet que aquesta contradicció no siga posada de manifest amb vehemència pels altres grups, que semblen més interessats a subratllar una hipotètica proximitat perillosa del model particularista al secessionista, es pot interpretar també com un reflex del mateix joc ideològic.

Per tant, el repte sembla anar en dos direccions: d'una banda, afluixar la tensió entre els models, especialment els germans, fills de la codificació fabriana. Buscar-ne la convivència pacífica, si es vol dir així. De l'altra, posar en evidència totes les ambigüitats $i$ aclucades d'ull als grups marginals extrems per part dels grups polítics dominants, tot subratllant la incoherència entre algunes de les seues declaracions i la pràctica efectiva del (poc) ús de la llengua. No és una tasca fàcil, i a més, necessita de moltes bones voluntats. Podríem començar els filòlegs deixant d'atiar focs inútils i fent la nostra faena: investigar sobre la llengua i el país que tenim, no els que desitgem.

\section{REFERÈNCIES BIBLIOGRÀFIQUES}

BIBER, D. (1994): «An Analytical Framework for Register Studies», en BIBER, D. i E. FINEGAN (eds.) (1994): Sociolinguistic Perspectives on Register, Oxford-New York, Oxford University Press.

BibiLoni, G. $\left(2000^{3}\right)$ : Llengua estàndard $i$ variació lingüística, València, Tres i Quatre.

Creus, I.; J. JuliÀ; S. Romero (eds.) (2000): Llengua i mitjans de comunicació, Lleida, Pagès.

LACREU, J. (2002): «Els models de llengua del valencià», en CASANOVA, E.; J. MARTí; A. SARAGossà (eds.) (2002): Estudis del valencià d'ara, València, Denes.

MARTíneZ, F. A. (2002): «Consciència col-lectiva, identitat de grup i llengua: a propòsit del valencià, dels valencians $\mathrm{i}$ dels conceptes en les ciències socials», en Casanova, E.; J. Martí i A. SARAgossà, (eds.) (2002): Estudis del valencià d'ara, València, Denes.

Mollà, T. (2002): Manual de sociolingüística, Alzira, Bromera.

NAvarro, B. i X. Rull (2000): «Estàndard, dialecte, endodiglòssia: la llengua que tots volem», en Creus, I,; J. JULIÀ; S. Romero (eds.) (2000): Llengua i mitjans de comunicació, Lleida, Pagès. 
NiCOLÀs, M. (1998): La història de la llengua catalana: la construcció d'un discurs, València/Barcelona, Institut Interuniversitari de Filologia Valenciana/Publicacions de l'Abadia de Montserrat.

Paloma, D. (1999): «De la llengua catalana a les sèries de televisió», Anàlisi, 23: 73-92.

Polanco, L. B. (1990): «Reflexions sobre el model lingüístic dels mitjans de comunicació valencians», cn Frerando, T. (cd.) (1990): La llengua als mitjans de comunicació, València, Institut de Filologia Valenciana-Universitat de València.

PRADILLA, M. À. (2001): «L'establiment de la comunitat lingüística catalana», Idees, 10: 113-121.

SALVADOR, V. (1990): «Els registres orals», en FERRANDO, T. (ed.) (1990): La llengua als mitjans de comunicació, València, Institut de Filologia Valenciana-Universitat de València.

- (2003): «Pragmàtica i estilística», Noves SL, hivern 2003, http://www,gencat.net/lengcat/noves/hm03hivern.

Saragossà, A. (2003): Gramàtica valenciana raonada i popular, Gandia, CEIC Alfons el Vell.

VAN DiJK, T. A. (2003): Ideología y discurso, Barcelona, Ariel.

Xambó, R. (1997): «Ideologies lingüístiques i mitjans de comunicació al País Valencià», en MOLLÀ T. (ed.) (1997): Política i planificació lingüístiques, Alzira, Bromera. 


\title{
SÁTIRA POLÍTICA Y SISTEMA
}

\author{
Gianpiero Pelegi \\ Escuela Oficial de Idiomas de Sagunto \\ Carmen González Royo \\ Universidad de Alicante
}

\section{INTRODUCCIÓN}

$\mathbf{E}$ $\mathrm{N}$ una sociedad, se entiende por sistema social el conjunto de los procesos funcionales, ligados al sistema de producción. Un sistema se mantiene si los individuos que lo componen interiorizan determinados comportamientos funcionales al mismo en relación con su posición social. Los procedimientos mediante los cuales se condicionan la personalidad y el patrimonio cultural de los individuos y, por consiguiente, la orientación del comportamiento de sus miembros constituyen el denominado control social. Se logran así objetivos funcionales en beneficio del sistema mismo y sus clases dominantes, o de la estrategia de determinados grupos sociales. Este control social actúa, básicamente, según dos grandes líneas:

a) el llamado control primario que desarrolla mecanismos de persuasión para la conformidad con los roles fijados por el sistema; y

b) el llamado control secundario, que se encarga de los mecanismos represivos de las conductas no conformes con el esquema funcional del sistema.

Las conductas no conformes al sistema son aquéllas que no coinciden con las normas vigentes en la sociedad y con las expectativas de rol que incumben a las diferentes posiciones sociales. Dichas conductas significan, pues, un conjunto de comportamientos disfuncionales en el seno del sistema. A pesar de la complejidad para caracterizar tales comportamientos, queremos subrayar, ciñéndonos al tema que nos atañe, que se manifiestan mediante el rechazo de los medios y metas culturales propuestos por el sistema por parte de un determinado grupo social. Éste puede elaborar, en una fase sucesiva, medios y metas alternativos a los del sistema de partida, canalizándolos - tras una concienciación de su condición de clase social- hacia las contradicciones sociales existentes entre el grupo y el sistema, que, en una perspectiva estratégica, colectiva y organizada de lucha, pueden desembocar en la construcción de otro sistema alternativo al vigente.

Si un comportamiento no conforme es asumido por un grupo de individuos como organización de una cultura alternativa a la propuesta por el sistema, 
puede hablarse de una sub-cultura, que se colocará fuera y en contra del sistema, es decir, adquirirá el rango de contra-cultura.

\section{LA SÁTIRA COMO CONTRA-CULTURA}

\subsection{Definición}

En el Vocabolario della lingua italiana Zingarelli (1996), a la voz sátira corresponde «Componimento poetico che critica argutamente le debolezze umane», o «discorso, scritto, atteggiamento e sim. che ha piú o meno esplicitamente lo scopo di mettere in ridicolo ambienti, concezioni, modi di vivere e sim.». El Diccionario del español acthal (Millán; Seco; Andrés; Ramos; 1999), por su parte, define la sátira como «Crítica o censura de carácter irónico o burlesco» y también como «Escrito, discurso u obra artística en que se critica a alguien o algo, ridiculizándolos o burlándose de ellos». Lázaro Carreter y Correa Calderón (1975: 201) se refieren a sátira como la «Obra que ataca los defectos de alguien o de algo», en clara conexión con las referencias anteriores.

Dorfles (1989: 80) al hablar de «lo cómico» apunta una catalogación, que él mismo califica de «un tanto pedante», bajo cuyo amplio paraguas engloba a la sátira como una de las «especies» que, junto a la comicidad, el humorismo, humor y otras formas como «lo grotesco, lo bufonesco, lo burlesco, la befa, (son) más difíciles de situar en el lugar exacto». Siguiendo con su clasificación, «ironía, caricatura, sarcasmo, epigrama» son considerados por Dorfles como subgéneros de la sátira.

Recurrimos a otros autores para acotar el concepto y nos remitimos, en primer lugar, a la cita que nos aporta Northrop Frye (1979: 272) a propósito de la sátira: «ironie militante, ses normes morales sont relativament claires; elles lui permettent de prendre la mesure du grotesque et de l'absurde». Bajo una perspectiva menos genérica, Evrard (1996: 38) perfila su definición como sigue: «la satire $\left[{ }^{\circ}\right]$ désigne un texte au caractère argumentatif et persuasif qui vise à agresser et convertir l'interlocuteur [ [ $]$, fustigue les moeurs publiques ou les vices et ridicules de l'être humain».

Por último, Dario Fo (1987: 348) delimita el término como: «genere di composizione teatrale o poetica a carattere morale (o moralistico) impostato sull'ironia e sullo scherno dei luoghi comuni, delle consuetudini conformistiche e di tutti gli aspetti negativi di un costume dettato dalle regole restrittive o persecutorie di un potere». 


\subsection{EI discurso satírico}

La sátira como ironía militante, caracterizada así por Frye (1979) y en correspondencia con la afirmación de Evrard (1996: 38) para quien la sátira exige una actitud militante con relación a la vida, se sirve de todos los recursos propios del discurso cómico, en cuanto manifestación de la insatisfacción por parte del escritor satírico del estado actual de las cosas (Petro, 1982). La sátira, pues, sería el vehículo de dicha insatisfacción situándola siempre en contra de algo (los poderosos, el poder político, la iglesia, etc.), suscitando en el destinatario un efecto placentero notable ${ }^{1}$ y fomentando, de csta mancra, un cicrto grado de cohesión grupal. En relación con esto, Dorfles (1989) comenta la importancia de que una sociedad comprenda y comparta un evento desde la perspectiva crítica común para que éste adquiera la condición de cómico y se distancie irónicamente del suceso. Así se refiere a la impresión que le produjo asistir, muy joven, a un acto del duce durante la época fascista: «lo encontré tan irresistiblemente ridículo, con su torpe arrogancia, que luego no pude, durante todo el ventenio siguiente, creer (¡ni mucho menos “obedecer y combatir”!) en una idea en cuya base descubría solamente lo grotesco, y la carencia de todo humor». Y añade: «Este mínimo episodio me convenció ya entonces de la escasa capacidad de los italianos, casi en su generalidad, para identificar y apreciar lo cómico, y sobre todo lo humorístico» (Dorfles, 1989: 83).

El discurso satírico utiliza la argumentación indirecta para cimentarse, y, dado que juega con lo ridículo, es un tipo de comicidad en la argumentación que suscita necesariamente connivencia entre el emisor y el destinatario (Olbrecths-Tyteca, 1974: 174 y 185).

«La atracción del contraste, el reclamo de lo anómalo, la aspiración a lo imposible e insólito. Todo aquello que rompe y interrumpe la norma nos fascina, tanto si se trata de una "ruptura" positiva como negativa.» Dorfles (1989: 130) se refiere concretamente a la paradoja pero podemos aplicar esta afirmación también a la sátira por cuanto contiene de ruptura.

Angenot (1982: 31) fija, en su tipología del discurso, que la sátira, al igual que el panfleto y la polémica, es una categoría del discurso que define, en oposición a la narratividad, como entinemática, característica que queda subdivida en a) el discurso del saber; y b) el discurso doxológico. Mientras el primero se ocupa del conjunto de todos los campos del conocimiento, el segundo aceptaría de forma pasiva la opinión dominante, la doxa. Al discurso doxológico se contrapone la sátira que, según Angenot (1982: 34), ocupa la posición de un discurso antagonista. Quien hace sátira combate al adversario y carga en contra de su opinión.

1. Sobre la sátira y lo grotesco en la literatura moderna, véase Clark (1991). 


\subsection{La función de la sátiora}

La función de la sátira, o más bien de la intención del codificador de ésta, sería, según Hutcheon (1981: 145), crear en el destinatario/descodificador un particular estado afectivo, querido y subjetivo, que ha sido definido como ethos. La autora pone de relieve la importancia del texto, ${ }^{2}$ en cuanto elemento objetivo, para transmitir este ethos, entre codificador y descodificador de la sátira, ya que es únicamente en el texto y por el texto como se establece este tipo de relación. El texto estimula al descodificador provocándole una reacción que Hutcheon (1981: 145 y ss,) desglosa, desde el punto de vista pragmático, en tres distintos tipos de ethos, de estados afectivos:

a) irónico; marcado; dado que el estado afectivo que se establece entre codificador y descodificador es la burla está codificado de manera peyorativa. Recordemos que la ironía no respeta la máxima de la cualidad de Grice y la burla buscando comprensión en su auditorio cómplice.

b) paródico; no marcado, en la medida que este género es evaluable según tres niveles distintos: neutro; respetuoso; o contestatario. $Y$

c) satírico; marcado, ya que su discurso es de tipo agresivo, destructor. El ethos satírico es codificado de manera mucho más negativa con respecto al ethos irónico y el género satírico estaría definido precisa-mente por la «dérision ridiculisante à des fins réformatrices» (Hutcheon, 1981: 147).

\subsection{Sátira y parodia}

La diferencia entre sátira y parodia estriba básicamente en el blanco elegido (Hutcheon, 1981: 144). La primera tiene como objetivo corregir ciertos vicios del comportamiento humano, ridiculizándolos $\mathrm{y}$, por lo dicho hasta ahora, como rasgo formal con respecto a la parodia ostenta el de su marcada intencionalidad. La parodia puede considerarse un recurso cómico del que la sátira puede valerse como dispositivo estructural.

Ambas, sin embargo, suponen un juicio de valor debido al alejamiento irónico que sugieren, pues, en el caso de la parodia, la elección misma de un texto parodiado implica un acto crítico de evaluación de éste, si bien tal juicio de valor puede no ser necesariamente negativo. La sátira, por su parte, utiliza el alejamiento irónico para emitir siempre un juicio negativo sobre el objeto elegido como blanco. El arte paródico es, en primer lugar, más bien una

2. Genette (1982: 37), por su parte, en su rableau des pratiques hypertextuelles, define este proceso mediante una función trimembre, en la que la función satírica se halla en el procediniento de transformación estilistica degradante de un texto 1 en un texto 2 (travestissement), y mediante la imitación satírica de un texto 1 en texto 2 (charge). 
desviación de la norma para incluirla, posteriormente, como material de trasfondo interiorizado; es más, a veces puede apreciarse una especie de deferencia irónica hacia el texto parodiado.

\subsection{Sátira y sfottò}

Dario Fo (1997) establece diferencias bastante nítidas entre lo que él denomina sfottò y la sátira propiamente dicha. El sfottò, ${ }^{3}$ según Fo (1997: 1), surge por:

l'ironia fatta sui tic, sulla caricatura dei connotati più o meno grotteschi dei politici presi di mira, dei loro eventuali difetti fisici, della loro particolare pronuncia, dei loro vezzi, del loro modo di vestire, del loro modo di camminare, delle frasi tipiche che vanno ripetendo.

Este tipo de discurso cómico corresponde, según el actor italiano (1997: 2), a:

una chiave buffonesca molto antica, che viene di lontano, quella di giocherellare con gli attributi esteriori e non toccare mai il problema di fondo di una critica seria che è l'analisi messa in grottesco del comporta-mento, la valutazione ironica della posizione, dell'idologia del personaggio.

La sátira, en cambio, nace en paralelo a la tragedia, pues (Fo, 1997: 5-6):

là dove una forma satirica non possiede come corrispettivo la tragedia, tutto si trasforma in buffoneria. La tragedia come dramma della fame, come terrore e rifiuto della violenza in tutti i sensi, il problema del rispetto umano, il problema della dignità e della qualità della vita, il problema del rapporto con la morte, il problema dell'amore, della sessualità, è il grande catalizzatore del comico satirico. Dove manca quella spinta, le satire daranno sempre sul parodistico, sul fredduristico da vignetta o addiritttura sul 'puttanesco', sul 'pecoreccio'. Anche se il soggetto preso a pretesto è il medesimo, ad esempio il sesso, in un caso ci sarà una sana voglia di fantasia, di immaginazione, una sollecitazione di impulsi primari, di carica vitale; nell'altro caso proprio soltanto la 'toccacciata', il lazzo volgare, triviale fine a se stesso, e soprattutto gratuito.

Un discurso cómico basado en el sfottò podemos identificarlo fácilmente en la imitación, en la caricatura. Por ejemplo, las imitaciones hechas hace algún tiempo por Fuentes -el hombre sin personalidad- en el programa televisivo Crónicas marcianas, corresponderían a este tipo de discurso cómico. En ellas,

3. Utilizamos aquí el término empleado por Fo (1997: 2). El diccionario Zingarelli nos da esta definición del sfottò: «presa in giro» (esp. burla, escamio). 
en efecto, se perciben los rasgos definidos por Fo para este tipo de comicidad: los personajes políticos imitados y caricaturizados son denigrados no por sus ideas, posiciones, acciones, etc., sino por sus defectos físicos, pronunciación, etc. Por ejemplo, en la imitación del President Pujol, Fuentes no deja de toser en sus intervenciones, cierra los ojos mientras habla, se expresa en castellano pero con un marcado acento catalán. El sfottò se limita, pues, a un divertido entretenimicnto, a la denigración de un personaje famoso, pcro no va más allá del elemento lúdico en sí, sin entrar nunca en el fondo de la cuestión. Lo cómico de este tipo de discurso presenta una duración limitada en el tiempo.

Por el contrario, la sátira propiamente dicha se ocuparía de analizar, por ejemplo, por qué existe y en qué consiste el llamado pujolismo en Cataluña, o por qué la sanindad catalaña sẹ debe financiar con el dinero del medicamentazo, etc. Este tipo de discurso cómico podemos encontrarlo, por ejemplo, en la sá-tira Ubu President de Albert Boadella, con la que reproponen y adaptan la pieza clásica Ubu Rot, de Albert Jary, en la que la denigración sátinica no se linita tan sólo a los aspectos físicos como en el sfottò, sino que se propone como insatisfacción del actual estado de cosas mediante la crítica intran-sigente. La sátira, pues, toma una iniciativa militante, y se decide a «gettare l'occhio sulle vere magagne di questa gente [los políticos], le loro violenze più o meno mascherate, le loro arroganze e soprattutto le loro ipocrisie» (Fo, 1997: 2-3).

Los humoristas italianos Gino\&Michele, por ejemplo, utilizan un sfottò cuando colocan en su punto de mira a un famoso periodista italiano, Giuliano Ferrara, asesor de Silvio Berlusconi, entre cuyos rasgos físicos destaca la obesidad: «Giuliano Ferrara è cosí grosso che fa capoluogo di provincia». (Gino\&Michele-Molinari, 1992: 62).

Podemos establecer una tipología de la sátira militante para la que reseñamos, a continuación, algunos fragmentos extraídos del cómico italiano que documentan esta casuistica:

a) la denigración de las instituciones (magistratura, autoridades del estado, ejército, monarquía, regímenes políticos, etc.);

La reina Isabel, en la obra de Fo, Isabella due caravelle e un cacciaballe, agravia al ejército (Fo, 1977: 44):

ISABELLA Sì, voglio dire che ti sono concesse certe cose: il bottino, la razzia... Fan parte della legge di guerra. Poi quattro belle parole impettite: Patria! famiglia! Morale! sangue generoso versato dai nostri figli... e oplà, caschi in piedi.

FERDINANDO Aggiungi pure in piedi, ma immerso nello sterco fino al collo.

ISABELLA Questa è la ıagione del perché i militari al pan tuo cannminano semple a testa alta. Qui in Spagna, s'intende. 
b) la denigración de la religión; en el texto que proponemos se cuestiona la existencia de Dios y se humilla al Papa (Anónimo, en Gino \& MicheleMolinari, 1994: 22).

Papa: l'unico vice di una società che non vede mai il propio capo, neanche a Natale.

c) la denigración de los partidos políticos (Anónimo, en Gino \& MicheleMolinari, 1994: 12).

Risulterehhe che i due ladroni crncefissi accanto al Signore fossern sncialisti: infatti erano ladri e occupavano due posti su tre.

En este ejemplo se desacredita al antiguo Partido Socialista Italiano que se vio involucrado en numerosos casos de corrupción política.

d) la denigración de personajes importantes (políticos, empresarios, etc.) (Striscia la notizia, en Gino\&Michele-Molinari, 1994: 47).

21 gennaio 1991. A cinque giorni dall'inizio della guerra, l'opinione pubblica è riuscita finalmente a capire la differenza che c'è tra Saddam Hussein e George Bush: Saddam è un povero pazzo, Bush invece è ricco.

En el texto se desprestigia a estos dos importantes personajes políticos situándolos, mediante el juego de palabras con los epítetos «povero / ricco», al mismo nivel de locura aunque distinto de riqueza.

\section{CONCLUSIONES}

La sátira es, ante todo, irónica, agresiva, tendenciosa; puede ser formal-mente parodia y utilizar también diferentes formas de lo cómico. Expone defectos, ridiculiza las costumbres, denigra a sus blancos mediante un tono violento. Provoca la carcajada pudiendo caer, a veces, en la grosería y la injuria. Si su blanco es la sociedad, en el sentido más amplio del término, la sátira estigmatiza el mal, invierte los papeles establecidos, y sitúa en el rango de víctima a quien se halla en una posición de fuerza, a los poderosos, políticos, etc. La sátira, por tanto, puede manifestar una actitud no conforme a las reglas y los roles que la sociedad asigna a los individuos que la componen. Así pues, quien hace sátira establece un modelo que se halla diametralmente opuesto al de la realidad presente; dicho modelo es propuesto como una norma a seguir, no sólo como denuncia puntual de un determinado estado de cosas, sino como la expresión diáfana de una insatisfacción fundamental ante dicha situación, que es fijada mediante una con- 
notación peyorativa de la misma, cuya denuncia, y posterior inversión, se realiza mediante un discurso de tipo argumentativo y a la vez persuasivamente intransigente. En definitiva, la sátira puede conllevar una elevada cohesión grupal en tanto en cuanto portadora de un discurso alternativo al del sistema, convirtiéndose así en lo que hemos denominado más arriba contra-cultura.

\section{REFEREMCIAS BIBLIOGRÁIICAS}

ANGENOT, M. (1982): La parole pamphlétaire: contribution à la typologie des discours modernes, París, Payot.

Clark, J. R. (1991): The Modern Satiric Grotesque, Lexington, University Press of Kentucky.

DORFLEs, G. (1989) [1983]: Imágenes interpuestas. De las costumbres al arte y viceversa, (irad. E. Benítez y C. Alonso), Madrid, Espasa Calpe.

EVRARd, F. (1996): L'humour, París, Hachette.

Fo, D. (1977): Isabella, tre caravelle e un cacciaballe, Turín, Einandi.

- (1987): Manuale minimo dell'attore, Turín, Einaudi.

- (1997): Dialogo provocatorio sul comico, il tragico, la follia e la ragione, Bari, Laterza.

Frye, N. (1979): Anatomie de la critique, París, Gallimard.

Genette, G. (1982): Palimpsestes, París, Seuil.

Gino\&Michele-Molinari, M. (1992): Anche le formiche nel loro piccolo s'incazzano. Anno secondo, Milán, Baldini\&Castoldi.

- (1994): Anche le formiche nel loro piccolo s'incazzano. Volume quarto, Milán, Zelig.

Grice, P. (1988) [1967]: «Logica e conversazione», en SBISÀ, M. (ed.) (1988): Gli atti linguistici, Milán, Feltrinelli.

Hutcheon, L. (1981): «Ironie, satire, parodie», Poétique, 46: 140-155.

JaRDON, D. (1988): Du comique dans le texte litteraire, Bruselas, De BoeckDuculot.

lázaro Carreter, F. y E. Correa Calderón (1975): Cómo se comenta un texto literario, Madrid, Cátedra.

Millán, J. A.; M. Seco; O. Andrés; G. Ramos (1999): Diccionario del español actual, Madrid, Aguilar.

Olbrechts-TyteCA, L. (1974): Le comique du discours, Bruselas, Editions de l'Université de Bruxelles.

Petro, P. (1982): Modern Satire: four studies, Berlín, Mouton.

Zingarelli, N. (1996): Vocabolario della lingua italiana, Bolonia, Zanichelli, $12^{\circ} \mathrm{ed}$. 


\title{
UNA JOVENTUT TÍPICA I TÒPICA (APROXIMACIÓ SOCIOLINGÜÍSTICA \\ A LA IMMIGRACIÓ VALENCIANA EN EL BATXILLERAT)
}

\author{
EnRIC Ramiro Roca \\ Universitat Jaume I
}

\section{ESTAT DE LA QÜESTIÓ}

$\mathbf{L}$ 'OBJECTIU principal d'aquesta comunicació és mostrar els factors sociolingüístics en l'evolució social de la llengua en els estudiants de batxillerat de les diverses comarques valencianes: coneixement, ús i consciència identitària actuals; així com l'anàlisi dels estereotips valencians respecte a les Comunitats Autònomes de l'Estat espanyol. Es tracta, en definitiva, d'esbrinar els coneixements que tenen de les dues llengües cooficials així com la seua percepció sobre el país d'acollida i la resta de comunitats autònomes de 1'Estat espanyol. Com diu el professor Sangrador (1996: 15):

No comptem a l'Estat espanyol amb una llarga tradició d'investigacions empíriques sobre aquestes qüestions, la qual cosa resulta paradoxal en un país com el nostre, ple de singularitats i diferenciacions autonòmiques, $i$ tan prometedor per tant per a aquests tipus d'estudis.

Aquest panorama descoratjador contrasta, com passa a sovint, amb la proliferació dels estudis a l'àrea anglosaxona, tant per les actituds i imatges puntuals de tot tipus de grups nacionals, minories ètniques, etc., sinó també sobre el seu grau d'estabilitat o canvi amb el temps. Per aquest motiu hem intentat cercar a països d'altres cultures, vestigis sobre aquest tema en una doble direcció: estudis sobre les realitats multiculturals i lingüistiques, i anàlisis sobre les seues realitats percebudes, si bé el resultat ha estat més bé minso.

Avui en dia, quan som al segle XxI i ens trobem amb una Espanya «tan autonòmica i moderna», on la tecnologia ens envaeix $i$ els mitjans de comunicació i de transport revolucionen les distàncies, continuen existint estereotips? Són els mateixos? Podem descobrir-los? És evident que per poc que sigam receptius a les converses de la gent, ens adonarem de la 
gran quantitat i varietat d'imatges que tenim respecte dels «altres». Unes imatges que malgrat l'arribada de la democràcia, de l'estat de les autonomies $i$ de l'europeisme, es mantenen en moltes ocasions $i$ àdhuc augmenten la seua virulència com en el cas de la xenofóbia. L'educació és un àmbit on resulta imprescindible treballar aquestes actituds amb l'objectiu de crear contra-imatges per a intentar posar fre a l'activitat manipuladora que nés o menys conscientment provoquen certs sectors de població i determinats mitjans de comunicació. Exemplificacions hi ha moltes, com l'artificial tema de l'enfrontament lingüístic a Catalunya o el continu objectiu d'enfrontar als parlants d'una mateixa llengua diferent de l'espanyol. També ens podem trobar amb la tàctica del folklorisme com a instrument per a empobrir progressivanent a una comunitat cultural, a fi de poder-la assimilar fàcilment. Però a més d'aquestes dues formes d'enfrontament cru i directe o acossament diacrònic, existeix una altra emmascarada amb el nom d'una mal anomenada «interculturalitat» que presentada com a intercanvi, forma part d'un procés de substitució i erradicació de la comunitat minoritzada. És aquesta la que d'una forma més senzilla pot traduir-se en un llenguatge suposadament "progressista» i «universalista», si bé comparteix els mateixos objectius de substitució lingüística.

Les bases teòriques sobre les quals s'ha fonamentat el present treball es focalitzen al voltant de la Geografia de la Percepció i el Comportament com a tendència geogràfica que intenta conjugar l'espai absolut i l'espai relatiu vers l'espai complex, la Sociolinguística i la Didàctica com a ciència focalitzada en el procés d'ensenyament-aprenentatge. Ha estat el nostre objectiu arribar a una anàlisi que deixe indicat el camí de futures accions en l'àmbit social i en el món educatiu, amb la idea que possibilite una praxis a partir dels resultats. En total han estat 600 els adolescents entrevistats en trenta-cinc ciutats valencianes i seixanta instituts, amb una distribució paritàia per gèneres i un equilibri entre el factor demogràfic i el territorial. El sector de població seleccionat ha estat el comprés entre els 16 i 17 anys, per ser una etapa situada en la plena adolescència, $i$ on els alumnes tenen una edat molt propera a la mínima exigida per a exercir constitucionalment el dret a votar. També és aquesta una edat evolutiva que podríem anomenar de nivell convencional en un estudi moral, on pesen extraordinàriament les actituds de lleialtat al grup i d'una gran conformitat amb les imatges estereotipades en relació amb el comportament majoritari o «natural» com indica Kohlberg (1971). En definitiva, podríem concloure que és un col-lectiu on d'alguna forma es poden veure les futures tendències suciulingüístiques i polítiques $i$, al mateix temps, un sector de la població sobre el qual hi ha pocs estudis en profunditat en aquest camp. D'aquesta 
mostra total, hem seleccionat els alumnes immigrants que han nascut fora del País Valencià i que representaven un $20 \%$, i sobre ells hem realitzat els estudis que tot seguit presentem. La metodologia emprada ha consistit en un qüestionari que se'ls ha passat a grups d'adolescents de deu persones de forma individual en silenci absolut, i que a les comarques valencianoparlants estava en la llengua pròpia i a les comarques castellanoparlants en castellà. Prèviament, es varen seleccionar alguns centres educatius com a grup de contrast abans de projectar-lo sobre tot el territori autònom. Per últim, s'ha utilitzat l'entrevista personal en alguns casos a la majoria de les poblacions per a concretar o aclarir algunes de les contestacions, sense entrar en temes de completar respostes o corregir. Els temes d'anàlisi han estat:

1. Autopercepció sobre els coneixements del valencià i castellà.

2. Ús del valencià en diferents àmbits.

3. Actitud lingüística front a un desconegut.

4. Nom del territori en el que viuen.

5. Imatges i simpatia cap a altres comunitats autònomes.

6. Grau d'adscripció nacionalista.

7. Reconeixement de la comarca on viuen i la seua capitalitat.

8. Delimitació comarcal.

9. Imatges de la comarca on viuen.

10. Àmbit d'experiència espacial i viatges que han realitzat últimament.

11. Opinió respecte a l'oficialitat de la llengua en diferents àmbits.

12. Opinió respecte a les competències de la comunitat autònoma.

Malgrat una resistència personal a traure conclusions de les dades quantitatives, la seua corroboració amb especialistes i bibliografia corresponent, així com algunes preguntes que ens han servit per a la comprovació, ens ha deixat satisfets amb els resultats, encara que ens agradaria poder comptar amb altres estudis des de diferents comunitats autònomes per poder contrastar amb elles. Igualment, s'han agrupat els immigrants pel seu origen: catalanoparlants, espanyols i estrangers, si bé en aquesta ocasió no hi farem menció a aquesta diversitat donades les dimensions de la comunicació, ni tampoc a algunes de les preguntes com les referides a la comarca, capital, experiència espacial $\mathrm{i}$ viatges, nom del territori i delimitació comarcal que es troben en un àmbit més geogràfic. 


\section{RESULTATS}

Amb l'objectiu de poder comentar d'una forma més global els resultats, els hem agrupat en tres blocs, segons facen referència a les llengües cooficials, a la percepció respecte a les altres comunitats autònomes i a les opinions sobre el grau d'autogovern. La mostra estadística és de 114 individus repartits per tot el País Valencià, i encara que a la mostra total el gènere estava repartit al $50 \%$, els alumnes immigrants denoten un lleuger predomini de l'alumnat masculí amb un $54.4 \%$ sobre el $45.6 \%$ de l'alumnat femení. En la distribució territorial, les comarques del nord tenen un escàs $9 \%$, seguides de les comarques del sud amb un important $21 \%$ i on més es concentren són a les comarques centrals i del centre. ${ }^{\prime}$ Aquestes dues xifres ens confirmen una major presència dels xics adolescents i una major escolarització, així com una concentració dels nouvinguts a les comarques més centrals del nostre país, i un segon focus en augment creixent al sud. Igualment, hem confirmat també les dades sobre l'adscripció d'aquest alumnat als centres mantinguts amb fons públics, on hi van tots a excepció de quatre alumnes que representen un 3.5\% del total.

\subsection{Coneixement $i$ ús de les llengiies cooficials}

La primera pregunta consistia en puntuar de 0 (gens) a 10 (molt) el grau de percepció personal que tenia l'alumne sobre l'entendre, parlar, llegir i escriure tant valencià com castellà. Si ens fixem al quadre 1, podem comprovar que la percepció de coneixements sobre la llengua pròpia del país és relativament alta en comparació amb les dades de la mostra total per a ser persones que no han nascut ací, o bé també es podria interpretar que tampoc els valencianoparlants tenen unes xifres massa elevades. En qualsevol cas, podem concloure que la diferència total en les quatre habilitats lingüistiques és menor d'un punt sobre deu. Pel que respecta al castellà, les puntuacions pràcticament igualen a les dels nadius o les superen mínimament amb alguna dècima.

1. Hem considerat convenient diferenciar les comarques del centre del País Valencià de les comarques centrals per respectar l'esforç que estan realitzant els principals col-lectius culturals d'aquestes comarques junt als ajuntaments i mancomunitats de la zona, amb l'objectiu de donar-li entitat «real» a un conjunt de voluntats i característiques comuns que hi tenen. Actualment han constituït el XIEC (Xarxa d'Institucions d'Estudis Comarcals de les Comarques Centrals Valencianes) l'Associació d'Amics de la Costera, el Centre Alcoià d'Estudis Històrics i Arqueologics, el Centre d'Estudis I Investigacions Comarcals Alfons el Vell, l'Institut d'Estudis Comarcals de la Marina Alta, l'Institut d'Estudis de la Vall d'Albaida i l'Obra Social de Caixa Ontinyent. A més a més, editen la revista Espai del Llibre, i realitzen diverses investigaviuns sulue l'espai cunfuntal per les cunnaryes de lat Custeta, la Vall d'Albaida, la Safor, la Marina Alta, l'Alcoià, i el Comtat. 
QUADRE 1. Autopercepció sobre les habilitats lingüístiques bàsiques de les llengiies cooficials

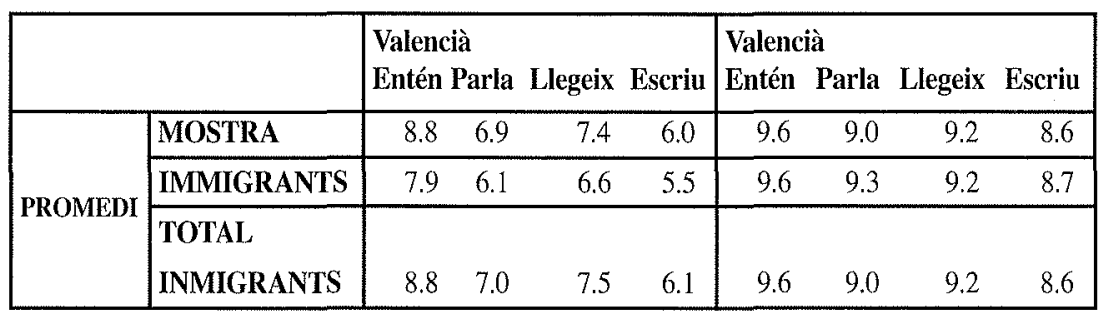

També hem analitzat l'ús del valencià en els diferents àmbits socials com havíem fet en els valencianoparlants per investigar el grau d'integració d'aquests adolescents i la seua comparació amb els nascuts al País Valencià. El resultat és el quadre 2 on efectivament les diferències ja són majors com es podia intuir. En l'àmbit familiar la distància és a la meitat i tot i tenint en compte als immigrants de Catalunya i Balears. De la mateixa forma passa en els àmbits de treball i les amistats, degut a la conformació de grups estables però sense que es puga parlar de guetització perquè la mateixa societat valenciana no té una identitat forta en l'àmbit lingüístic, malgrat que és el signe més destacat com afirma el professor Piqueras (1996). Tanmateix, són altres signes com les festes, la gastronomia $i$ el futbol en un primer terme, i possiblement els costums i el caràcter en un segon, aquells que li donen carta d'autèntica valenciania a aquesta societat. No obstant, en la pràctica de la lectura i l'escriptura, la distància s'acurta entre nadius i immigrants, possiblement per la mateixa dinàmica que comporta l'educació secundària obligatòria més que per voluntat pròpia ja que ni tampoc els valencians de naixement la practiquen d'una forma habitual.

QUADRE 2. Ús social del valencià en diferents àmbits

\begin{tabular}{|c|l|rrrrrr|}
\hline \multicolumn{2}{|c|}{} & \multicolumn{6}{|c|}{ ÚS DEL VALENCİ̀ } \\
\hline \multirow{3}{*}{ PROMEDI } & Familia & Treball & Amistats & Oci & Lectura & Escriptura \\
\cline { 2 - 9 } & MOSTRA & 4.6 & 4.4 & 4.3 & 3.9 & 4.8 & 4.3 \\
\cline { 2 - 9 } & IMMIGRANTS & 2.3 & 2.6 & 2.3 & 1.9 & 3.6 & 3.0 \\
\cline { 2 - 9 } & TOTA & & & & & & \\
& INMIGRANTS & 4.9 & 4.6 & 4.6 & 4.1 & 5.0 & 4.5 \\
\hline
\end{tabular}




\subsection{Tòpics i grau de simpatia cap a les comunitats autònomes de l'Lstat espanyol'}

En aquest segon bloc, anem a conéixer les paraules que millor defineixen a cadascuna de les regions i nacionalitats de l'Estat espanyol, així com el grau de simpatia que tenen els adolescents immigrants sobre elles, amb una puntuació de 0 (gens) a 10 (molt). Per a la seua anàlisi hem seleccionat únicament dues variables: la major o menor presencialitat de la comunitat, és a dir, si ha estat molt anomenada; i la mitjana aritmètica del grau de simpatia que tenien cap a ella.

Comparades les dues llistes (veure quadre 3), la dels nadius i la dels immigrants, no hi ha excessives diferències però si significatives. En primer lloc, destaca que la comunitat més anomenada per aquests nouvinguts és Andalusia amb un $84.2 \%$ front a Catalunya per part dels nascuts al país amb un $86.5 \%$. També és important, que per als immigrants, les comunitats de Madrid, Múrcia i Aragó principalment, i Galícia, Extremadura i País Basc tenen una menor presència, tot i la seua major o menor importància absoluta. En sentit contrari, les enumeracions són superiors en dos punts a les comunitats d'Andalusia, Astúries i la Rioja.

QuAdre 3: Presencialitat de les Comunitats Autonomes

\begin{tabular}{|l|ccc|c|}
\hline & Total & Immigrants & Total Immigrants & Diferència \\
\hline Andalusia & 81.8 & 84.2 & 82.1 & 2.1 \\
\hline Catalunya & 86.5 & 80.7 & 87.4 & -6.7 \\
\hline Pá́s Valéncià & 74.8 & 75.4 & 75 & 0.4 \\
\hline Madrid & 79.1 & 70.2 & 80 & -9.8 \\
\hline Galícia & 71.6 & 68.4 & 71.8 & -3.4 \\
\hline País Basc & 66.5 & 64.9 & 66.8 & -1.9 \\
\hline Castella-la Manxa & 56.7 & 57.9 & 56.8 & 1.1 \\
\hline Castelia-Lleó & 52.5 & 54.4 & 52.4 & 2 \\
\hline Cxúremadurà & 54.2 & 50.9 & 54.8 & -3.9 \\
\hline Aragó & 54.6 & 49.1 & 56.1 & -7 \\
\hline Balears & 46 & 47.4 & 46.3 & 1.1 \\
\hline Canàries & 45.6 & 47.3 & 46.1 & 1.2 \\
\hline Astúries & 42.8 & 45.6 & 43.4 & 2.2 \\
\hline Múrcia & 52.3 & 43.8 & 52.9 & -9.1 \\
\hline Navarra & 40.1 & 42.1 & 40.8 & 1.3 \\
\hline La Rioja & 40 & 42.1 & 40 & 2.1 \\
\hline Cantàbria & 28.8 & 29.8 & 29.2 & 0.6 \\
\hline
\end{tabular}

2. Sobre aquest tema, es pot consultar amb molt més detall Ramiro (2004). 
QUADRE 4: Grau de simpatia cap a les Comunitats Autònomes

\begin{tabular}{|l|ccc|c|}
\hline & Total & Immigrants & Total Immigrants & Diferència \\
\hline País Valencià & 9 & 7.8 & 9.2 & -1.4 \\
\hline Andalusia & 7.2 & 7.7 & 7.2 & 0.5 \\
\hline Canàries & 7.8 & 7.6 & 7.9 & -0.3 \\
\hline Navarra & 6.8 & 7.6 & 6.8 & 0.8 \\
\hline Astúries & 6.9 & 7.5 & 6.9 & 0.6 \\
\hline Balears & 7.8 & 7.4 & 7.9 & -0.5 \\
\hline Galícia & 7.3 & 7.3 & 7.4 & -0.1 \\
\hline Múrcia & 6.6 & 7.3 & 6.7 & 0.6 \\
\hline Cantàbria & 6.5 & 7 & 6.5 & 0.5 \\
\hline Castella-La Manxa & 6.6 & 6.9 & 6.6 & 0.3 \\
\hline Aragó & 7 & 6.7 & 7 & -0.3 \\
\hline La Rioja & 6.6 & 6.5 & 6.6 & -0.1 \\
\hline Castella-Lleó & 6.4 & 6.4 & 6.4 & 0 \\
\hline Extremadura & 6.2 & 6.4 & 6.2 & 6.2 \\
\hline País Basc & 5.3 & 6.3 & 5.1 & 1.2 \\
\hline Madrid & 5.3 & 5.8 & 5.3 & 0.5 \\
\hline Catalunya & 5.4 & 5.5 & 5.4 & 0.1 \\
\hline
\end{tabular}

Si observem el quadre 4 dedicat al grau de simpatia cap a les comunitats autònomes, tampoc reflecteix moltes diferències. En primer lloc es troba el propi País Valencià però amb una puntuació relativament menor: un $7.8 \mathrm{de}$ simpatia front al 9 dels nadius. A partir d'ací, el descens de puntuació és molt moderat i pràcticament van baixant dècima a dècima, constatant possiblement el poc grau de coneixement sobre elles. Tanmateix, hi ha algunes dades que cal destacar: en primer lloc la menor simpatia cap a les Illes Balears i Canàries i secundàriament cap a Aragó, Galícia i la Rioja. Pel contrari, hi ha una important percepció positiva cap al País Basc, que supera el punt de diferència, i Navarra, i a més distància cap a Múrcia, Andalusia, Madrid, Cantàbria, Astúries. L'explicació d'aquest contrast entenem que radica globalment en la menor influència que han tingut els mitjans de comunicació i les tradicions sobre ells i per tant, la menor impregnació de molts dels tòpics i estereotips que marquen a la població nascuda al País Valencià, així com el contacte real que han tingut amb diferents comunitats i cultures. 


\subsection{Opinions sobre el grat de cooficialitat i antogeverm}

En aquest tercer bloc hem investigat algunes qüestions relacionades amb el futur identitari del país, com és el grau de nacionalisme, l'actitud front als diferents nivells d'oficialitat del valencià i les perspectives sobre les possibles competències autonòmiques. En la primera d'elles se'ls va mostrar una línia recta amb dos extrems: ser valencià o ser espanyol, i en la qual havien de marcar una creu a la distància que consideraren convenient. Els resultats ens donen una mitjana general del 4.5 sobre 10 , de manera que el perfil del poble valencià tendeix cap a una dualitat compatible de valencià-espanyol amb una lleugera tendència cap a l'estatalisme. En el cas dels immigrants aquesta tendència espanyolista és més marcada, amb un 3.1 front al 4.7 dels nascuts al País Valencià, i més encara si els separem a aquests nouvinguts segons hagen nascut a terres dels Països Catalans amb un 3.6, a terres de la resta de l'Estat amb un 2.6 o a l'estranger amb un 0.8 .

QUADRE 5: Opinions sobre diferents graus d'oficialitat de la llengua

\begin{tabular}{|c|l|cccc|}
\hline \multicolumn{2}{|c|}{} & \multicolumn{4}{|c|}{ OFICIALITAT DE LA LLENGUA } \\
MM.CC. & "De" & "En" & Tot \\
\hline \multirow{3}{*}{ PROMEDI } & MOSTRA TOTAL & 1.0 & 1.0 & 1.2 & 1.4 \\
& IMMIGRANTS & 1.0 & 1.1 & 1.4 & 1.5 \\
& TOTAL IMMIGRANTS & 1.0 & 1.0 & 1.2 & 1.4 \\
\hline
\end{tabular}

QUADRE 6: Opinions sobre diferents graus de competències autonòmiques

\begin{tabular}{|c|l|ccccc|}
\hline \multicolumn{2}{|c|}{} & \multicolumn{5}{|c|}{ COMPETÈNCIES AUTONómiQUES } \\
Economia Política & Defensa & Cultura & Esports \\
\hline \multirow{3}{*}{ PROMEDI } & MOSTRA TOTAL & 1.9 & 2.2 & 2.5 & 1.7 & 1.5 \\
& IMMIGRANTS & 2.0 & 2.4 & 2.6 & 1.9 & 1.5 \\
& TOTAL IMMIGRANTS & 1.9 & 2.2 & 2.5 & 1.6 & 1.5 \\
\hline
\end{tabular}

Per altra part, se'ls preguntava si totes les regions amb llengua pròpia tenien dret at usar-la en diferents àmbits. En aquest sentit, la tendència al 0 volia dir que s'estava d'acord i la tendència al 2 que s'estava en desacord. Com podem comprovar al quadre 6 hi ha per part dels immigrants una certa indiferència cap al seu ús en els mitjans de comunicació i en que s'ensenye la 
llengua del país, mentre que hi ha una major oposició a l'ensenyament en valencià i especialment a que tot estiga en valencià. Si passem a l'última pregunta (veure quadre 6), aquesta feia referència al desig d'autogovern en diferents àmbits. L'escala en aquest cas era de 0 a 3 , de forma que quan la mitjana dóna més a prop del zero, s'estava més d'acord en que la comunitat autònoma tinguera la competència, si la xifra estava sobre 1.5 es pensava que era millor compartir-la amb el govern central i més a prop del 3 que estava reservada per a l'estat. Els resultats ens mostren una insignificant diferència entre els immigrants i els nadius, amb unes notes generals tendents a compartir les responsabilitats entre l'administració regional i estatal en esport i cultura, mentre en economia i sobretot en política i defensa s'estava pel model de l'estat centralitzat. A més d'aquestes mínimes diferències per collectius i per àmbits d'actuació, allò que més destaca és la majoritària posició en contra dels valencians amb independència del seu origen per assumir quotes de poder, una característica que els diferencia de la major part de comunitats autònomes.

\section{CONCLUSIONS}

No voldríem acabar aquest escrit sense perfilar algunes de les dades que hem analitzat al llarg d'aquestes pàgines. En primer lloc, cal remarcar que ens trobem amb un collectiu important d'immigrants a les nostres aules de batxillerat. Aquesta mostra estaria prou repartida per gèneres amb una lleugera majoria masculina i concentrats en les comarques centrals del País Valencià $i$ secundàriament a les comarques del sud, i la pràctica totalitat d'ells escolaritzats en centres públics.

En l'autopercepció sobre els coneixements de valencià hi ha menys diferència de la que es podia intuir pel seu origen geogràfic, mentre en castellà les xifres són iguals o superiors. On sí apareix ja una clara distància és en l'ús social que se situa a nivells molts baixos, però no tant en la pràctica de la lectura i escriptura com a conseqüència del sistema reglat d'ensenyament.

En el bloc de valoració i presència de les comunitats autònomes, les diferències se centren en Andalusia com a comunitat més anomenada front a Catalunya per part dels nadius, i una menor tendència a l'assumpció dels tòpics i estereotips que provoquen principalment els mitjans de comunicació i les tradicions. D'aquesta forma, la seua valoració és moderada i molt menor en el propi País Valencià que és considerat una comunitat més. Contràriament, tampoc els influeixen excessivament les marques negatives que poden tindre altres zones com Catalunya o el País Basc, o les positives que tenen les Illes Balears o les Canàries. 
Per últim, comparteixen junt als valencians de naixement però d'una forma més agreujada, l'escàs nacionalisme, la redü̈da reivindicació de l'oficialitat del valencià i la poca voluntat per assumir competències que prefereixen deixar en mans de l'estat, a excepció tal vegada dels esports i l'educació.

Tot $\mathrm{i}$ aquestes conclusions, val a dir que fins al moment la immigració adolescent dóna senyals d'integració en la societat valenciana, tal vegada per l'alt nivell de desvertebració i espanyolització, i per tant de facilitats per a «adnptar» a qualsevol cultura de l'Estat espanyol. Una altra cosa serien els estrangers que de forma progressiva van arribant als centres docents amb unes condicions difícils i que pràcticament són atesos per la bona voluntat del professorat. En aquest àmbit cal una inversió urgent de recursos materials i humans, amb un clara política institucional d'interculturalitat i una planificació adequada que supere el voluntarisme actual i comporte un seriós programa de convivència.

\section{REFERÈCIES BIBLIOGRÀFIQUES}

ANDRÉS, JOAN; JOSEP ANDRÉS; E. RAMIRO I ROCA (1998): «Llengua i territori a la Ribera Baixa», II Jornades d'Historia Local, Cullera, Ajuntament de Cullera.

Calvo Buezas, T. (1989): Los racistas son los otros. Gitanos, minorías y Derechos Humanos en los Textos Escolares, Madrid, Popular.

CASTELls, M. (1998): La era de la información: Economía, sociedad y cultura, II, El poder de la identidad, Madrid, Alianza.

Col-lectiu Amani (1994): Educación Intercultural. Análisis y resolución de conflictos, Madrid, Popular.

DELORS, J. (1996): La educación encierra un tesoro (Informe a la UNESCO de la Comisión Internacional sobre la educación para el siglo XXI), Madrid, Santillana-Ediciones UNESCO.

Dizz Nicolàs, J. (1999): Identidad nacional y cultura de Defensa, Madrid, Síntesis.

Dimaggio, P. (1997): «Culture and Cognition», Annual Review of Sociology, XXIII, 263-287.

GARCIA, J. (1994): «Nación, identidad y paradoja: Una perspectiva relacional para el estudio del nacionalismo», Revista Española de Investigaciones Sociológicas, 67: 165-183.

Gellner, E. (1983): Nations and Nationalism, Ithaca, Cornell University Press. - (1998): Nacionalisme, València, Universitat de València - Afers.

GIDDENS, A. (1995): Modernidad e identidad del yo, Barcelona, Edicions 62.

GoDKIN, M. A. (1985): «Identidad y lugar: aplicaciones basadas en las nociones de arraigo y desarrollo», en GARCía RAMON, Ma D. (ed.) (1985): 
Teoría y método en la Geografia Humana Anglosajona, Barcelona, Ariel Geografía.

Javaloy, F.; A. BeChini; J. M. CoRneJo (1990): España vista des de Cataluña:

Estereotipos étnicos en una comunidad plural, Barcelona, PPU.

KolHberg, L. (1971): «From Is to Ought», en Mishell, TH. (comp.) (1971):

Cognitive Development and Epistemology, New York.

KRISTEVA, J. (1991): Extranjeros para nosotros mismos, Madrid, Plaza-Janés. LiNZ, J. (1985): «From Primordialism to Nationalism», en TiRYaKian, E; R. LinZ; F. MARTí (1996): Nacions, estats $i$ fronteres, Vic (Barcelona), Eumo.

PINILLOS, J. L. (1960): «Estereotipos raciales de universitarios españoles, ingleses y norteamericanos», Revista de Psicología General y Aplicada, 76: 777-797. Piqueras, A. (1996): La identidad valenciana. La dificil construcción de una identidad colectiva, València, Escuela Libre Editorial - Edicions Alfons el Magnànim.

Quin, R.; B. MCMHON (1997): Historias y estereotipos, Madrid, Ediciones de la Torre.

RAMIRO I RoCA, E. (1995 a): «Les distàncies personals en un planeta real», BALMA núm. 1, Barcelona, Graó, 99-115.

- (1995 b): «Camins entre ciutats: alguna cosa més que quilòmetres», II Jornadas de Geografia Urbana, Alacant, AGE-Universitat d'Alacant.

- (1995 c): «Coneixement, ús i actituds envers la llengua des de la Geografia de la Percepció», Ir Congrés de l'Escola Valenciana, València, Federació d'Associacions per la Llengua, 321-328.

- (1996 a): «Percepció, Llengua i Secundària post-obligatòria», Segon Simposi del professorat de valencià de l'ensenyament mitjà i de l'educació secundària obligatòria, València, Servei d'Ensenyaments en Valencià de la Conselleria d'Educació i Ciència, 367-377.

- (1996 b): «Quina imatge es té dels catalans al País Valencià?», Escola Catalana, núm. 332.

- (1997): «Espacio percibido e imágenes territoriales (adolescentes, estudiantes e inmigrantes en el País Valenciano: ¿una realidad neutra?)», Dinámica Litoral-Interior vol. II, Santiago de Compostela, Asociación de Geógrafos Españoles - Universidad de Santiago de Compostela

- (1998): «Tòpics i estereotips: una clau per a treballar la interculturalitat i els valors», Actes de la cinquena trobada de sociolingüistes catalans, Barcelona, Departament de Cultura de la Generalitat de Catalunya.

- (2000): «La imagen del País Valenciano: ¿Un turismo tópico y típico?», Iber. Didáctica de las Ciencias Sociales, Geografia e Historia, 25, setembre 2000, 112-119. 
- (2003): «Una patera con recursos. (Reflexiones y recursos para tratar el tema de la multiculturalidad)», La enseñanza de la Geografia ante las nuevas demandas sociales, Toledo, Universidad de Castilla-La Mancha.

- (2004): Tòpics $i$ adolescència: una visió valenciana sobre les diferents autonomies, Castelló, Publicacions de la Universitat Jaume I.

Relph, E. (1976): Place and Placelessness, Londres, Pion.

Rodríguez SAnAbra, F. (1963): «Estereotipos regionales españoles», Revista de Psicología General y Aplicada, 68-69: 763-771.

Rodríguez, M. S.; J. M. SABUCEDo; C. ARCE (1991): «Estereotipos regionales y nacionales: del conocimiento individual a la sociedad pensante», Revista de Psicología Social, 6-1: 2-22.

Rogowskr, R. (ed.): New Nationalism of the Developed West: Toward Explanation, Boston, Allen \& Unwin.

ROS, M.; M. HulCr; I. CANO (1987): «Languages and intergroup relations in Spain», Journal of Langages and Social Psychology 6, 3-4: 225-243,

Ros, M.; M. Hurci; I. Cano (1990): «Categorización lingüística, identidad social y atribución social», en Musiru, G. (ed.) (1990): Procesos psicosociales básicos, Barcelona, PPU.

SANGRADOR, J. L. (1996): Identidades, actitudes y estereotipos en la España de las autonomias, Madrid, Centro de Investigaciones Sociológicas.

SEARLEs, H. F. (1960): The Nonhuman Environment, Nova York, Internacional University Press.

TAYLOR, CH. (2000): «Las fuentes de la identidad moderna», Debats, 68: 3045.

Tejerino, B. (1999): «El poder de los símbolos. Identidad colectiva y movimiento etnolingǘístico en el País Vasco», Reis, 88: 75-105.

ThOMPSON, R.; J. R. RudolPH (1992): Política etnoterritorial, Barcelona, Pomares-Corredor.

TuAn, Yl-Fu (1971): «Geography, Phenomenology amb the Study of Human Nature», The Canadian Geographer, 15: 181-182.

WenKart, A. (1961): «Regaining Identity Trough Relatedness», American Journal of Psychoanalysis, 21: 227-233. 


\title{
BUYING THE PRODUCT, BUYING \\ THE STEREOTYPE: COVERT PORTRAYALS \\ OF ETHNIC MINORITIES IN TV ADVERTISING
}

\author{
Ma Milagros del Saz Rubio \\ Universidad Politécnica de Valencia
}

\section{INTRODUCTION}

$7 \mathrm{HE}$ phenomenon of advertising has since long attracted a great deal of 1 attention from various disciplines such as psychology, sociology, marketing, communication, media, and cultural studies. As a tool of cultural reproduction, the discourse of the mass media exerts an enormous influence on the way we perceive and shape the world (Potter, 1954; Fox, 1984). Advertising reflects the values, norms and stereotypes that are most deeply rooted in our culture, while helping to create new meanings and values that are taken, learnt and reproduced by viewers without challenging their social construction (Davison, 1997).

A very recurrent theme in advertising is the use of stereotypical imagery as a shorthand way to reach and establish a connection with the audience and to make the purchase of the product advertised much more palatable. From a cognitive perspective, Lippman (1922) defines stereotypes as: «(i) an ordering process, (ii) a 'short-cut', (iii) referring to 'the world', and (iv) expressing 'our' values and beliefs». In other words, stereotypes help people make sense of society and the world through generalizations, patternings and typifications (Lippman, 1922: 12) to the point that a few visual and verbal traits can communicate complex information about a character or group (Pettigrew, 1981). Stereotypes can focus on such human characteristics as race, age, gender, religion, sexual preference, nationality, physical traits, etc. However, and in spite of the fact that not all stereotypes are bad (Allport, 1954), they tend to be based on generalizations about groups or individuals, or more precisely, prejudice rather than fact.

In this paper I analyse the discourse of several television (henceforth TV) ads from a corpus of Spanish and English TV commercials in order to show that some advertising practices do still endorse stereotypes about certain ethnic groups in the advertising campaign of their products. It is my contention that even what looks like positive stereotypes in some commercials should be treated with caution as the meanings they trigger in us may lead to other, less 
favourable ones and thus help perpetuate a world view that divides people along ethnic or national lines (Hodge and Kress, 1988; Giles and Powesland, 1997/1975).

\section{SOME BASIC NOTIONS FOR THE ANALYSIS OF A GROUP OF TV ADS}

My analysis of a group of TV ads is informed by the notions of covert overt types of information transmission (Sperber and Wilson, 1986; Tanaka, 1994/1999), which intertwine with the product-claim and reward dimensions (O' Donohoe, 1997; Crook, 2003), and by a multimodal approach to commercials, where not only the linguistic message but also the visual contents of advertising are taken into consideration (Barthes, 1964, 1977; Vestergaard and Schroeder, 1985; Cook, 1992; Kress and van Leeuwen, 2001; del Saz, in print, for a similar approach).

Information overtly conveyed about the product takes place within the product-claim level, where claims about the product are presented; whereas, additional information obtainable through the use of images, music and other non-verbal elements falls within the reward level where an implicit reward is promised in exchange for the purchase of the product. This latter dimension arises as the perfect locus where additional assumptions-placed alongisde a cline of more or less covertness - can be conveyed without the advertiser having overtly transmitted them.

The core premise for my analysis is the basic distinction between ostensive-inferential and covert means of communication (Sperber and Wilson, 1986; Tanaka, 1994/1999; Crook, 2003). Ostensive-inferential communication takes place when the communicator produces a stimulus «which makes it mutually manifest to communicator and audience that the communicator wants to make manifest or more manifest to the audience a certain set of assumptions» (Sperber and Wilson, 1987: 700). In contrast, in cases of covert communication, the speaker points out some information to the hearer but s/he does not make such an intention manifest. Thus, the hearer takes the largest share of the responsibility in recovering the speaker's meaning since s/he cannot have expectations of optimal relevance.

The notion of covert communication proves very useful especially when advertisers want to communicate additional assumptions about the product, the rewards to be obtained, the characters involved, etc., but want to avoid doing it explicitly. This is the case with TV ads that endorse stereotypes and rcinforcc ccrtain assumptions about the cthnic groups depicted, for instance, that all Caribbean people are laid-back and lazy, or that all Spanish and Italians 
are loud and impolite, albeit Latin lovers and passionate. Audiences are invited to recover covert assumptions of their own accord, while advertisers can only be blamed for the presentation of humorous representations of ethnic minorities that set the tone for the joke in the commercial.

My corpus of analysis is made up of TV ads aired during the last five years in Spain, the UK and the United States where certain ethnic groups are depicted in the mini-dramas (Leech, 1966). The products advertised range from basic commodities to spirits such as Malibu rum (Caribbean Islands), beer (Brazilians), beverages such as Coke (Indian) or foodstuff such as Colacao (Africans/Brazilians), yoghurt (Brazilians), etc. Due to space limita. tions, in this paper I have just analysed one product-Malibu rum-in order to corroborate how in the decoding process of the commercial explicitly communicated assumptions about the product intertwine with covertly transmitted information to favour the drawing of certain gratuitous assumptions about the ethnic groups which are humorously depicted or referred to in the ad.

\section{ANALYSIS AND RESULTS}

The analysis of the commercial proceeded along the following lines: first I analysed overtly transmitted linguistic information through the voice-over and from the mini-drama, and then showed how the audience is invited to recover further assumptions (within varying degrees of covertness) from the visual imagery offered and how they are added to the explicit ones for a complete and accurate reading of the commercial.

The product-claim level is almost absent from the rum commercial since no information about the product is offered, except for its content in alcohol $(20 \%)$. The voice-over opens the commercial addressing the audience with the following question:

VOICE-OVER: «¿Qué pasaría si en el Caribe se tomasen la vida tan en serio como el resto de los mortales?» [What would happen if people in the Caribbean Isles took life as seriously as everybody else?]

This question presupposes the following belief or idea about people living in the Caribbean Isles:

1) People in the Caribbean Isles do not take life as seriously as people from other parts of the globe. 
After this question, the commercial develops in the form of a mini-drama that illustrates a mock-stressful situation in which a group of passengers in a village somewhere in the Caribbean islands (presumably Barbados) yell at the bus driver for being late. After the mini-drama, the voice-over closes the commercial. The audience is not directly involved in the mini-drama and becomes a mere spectator. The exchange goes as follows:

\section{NARRATIVE/MINI-DRAMA (LINGUISTIC EXCHANGE)}

(1) Woman 1 (waiting at the bus stop): «Llegas 38 segundos tarde» / [You are 38 seconds late].

(2) Bus driver: «Señora, no por mi reloj» / [Not by my watch miss].

(3) Woman 1: «Llegas tarde y yo llegaré tarde porque tú llegas tarde» / [You are late and I'll be late because you are late].

(4) Woman 2: «1 minuto de retraso» / [1 minute late].

(5) Bus driver: «No por mi reloj» / [Not by my watch].

(6) Man 1 (inside the bus): «Rápido mi pez está malito» / [Come on quickly my fish is ill].

(7) Man 2: «Llegaré 2 minutos tarde» / [I will be 2 minutes late]

(8) Man 2: «Eh llego tarde a la reunión» / [Hey I am late for the meeting].

(9) Bus driver: «Me estáis estresaaando!» / [You are stressing me out!].

VOICE-OVER: «Si nos tomáramos la vida tan en serio, no tendríamos Malibu» [If we took life that seriously, we wouldn't have Malibu].

Below, I sketch how the TV ad unfolds, trying to capture what the visual imagery communicates:

VISUAL IMAGERY

a) $A$ woman is waiting for the bus in a rural road, presumably somewhere in the Caribbean Islands. A hen walks around freely picking at the road stones. b) A bus approaches.

c) The woman waves her hand so as to make the bus stop.

d) The bus driver opens the door and she says looking at her watch in a reproachful tone: «You're 38 seconds late».

e) The bus driver looks at his watch and replies: «Not by my watch».

f) The woman insists on the fact that they are late, this time pointing her finger at him menacingly, and says that she is going to be late because he is late. Her insistence draws the other passenger's' attention to their watches so as to check the time. 
g) The other passengers look at their watches in unison.

h) Another woman points at her watch and exclaims that they are one minute late.

i) The driver again checks his watch and denies the accusation.

j) A man holding his fish in his hands complains because they are wasting their time when his fish is ill.

k) We see how another passenger makes a phone call to say that he will be late.

1) A passenger travelling on the roof of the bus lowers his head and sticks it through the window to tell the driver that he is going to be late for a meeting.

m) The bus driver under such pressure from the passengers exclaims: «You're stressing me out!».

n) Next, we get a close-up of a bottle of Malibu being hold by a person, and the liquor is being poured into a glass. It is a Malibu on the rocks.

o) Finally, coinciding with the closing jingle from the voice-over, we get a shot of the glass of Malibu, the young chicken walking freely on the bar, and the logo of the Malibu palm on the right bottom.

Once the TV ad is completed, the spectator is left with the following overtly communicated pieces of information after reference assignment and contextualization within the genre of the commercial takes place:

1) People indigenous to the Caribbean Isles do not take life as seriously as people in other locations.

2) If we took life too seriously, we would not have Malibu. A corollary of this is the following:

3 ) It is thus a good thing for us that these people do not take life seriously.

4) Malibu rum is manufactured in the Caribbean islands.

5) Malibu has some $20 \%$ of alcohol content and is normally served on the rocks, as the final shot shows.

6) Malibu rum is associated with a time for relaxation, as a way of escaping from mundane worries and annoyances.

From this moment onwards, the audience is expected to decode and make sense out of the mini-drama, where the passengers yell at the bus driver for his delay. The verbal exchange between the driver and passengers helps infer new assumptions about what is going on. From the imagery here presented as (1)(5) in the mini-drama above, the audience is invited to recover the following as reinforced by visual imagery: 
7) These passengers are really upset and yell at the bus driver because he is 38 seconds late.

Notwithstanding, the information conveyed by the passenger in (6) in he mini-drama brings about a clash between the assumptions held by the audience and the new ones. Spectators are faced with an inconsistency between the implication that the fish might dic and thcir cncyclopacdic knowledge of the world, that is, the fact that fish are unable to breathe outside water. We are thus left with no other alternative but to judge this passenger as either rather «dim», or not to take the exchange seriously. With a lesser degree of certainty and only on the basis of visual imagery, the audience is also invited to recover, form or create the following assumptions about the inhabitants of the islands (8)-(12):

8) The inhabitants of this Caribbean location are not very sophisticated.

9) Their use of mobile technology is not very sophisticated.

10) They cary anmals inside the bus.

11) Some of them travel on the roof of the bus.

12) Normally, people who attend meetings travel in more fashionable means of transport.

The inconsistencies between what we see, the assumptions we form and our knowledge of the world, force us to discard the mini-drama as a real exchange and to take it as a mock-stressful one. Taking this as a starting point, weaker assumptions about the ethnic minority depicted can be inferred if wo combine the ones above with our knowledge of stress and stressful situations in developed countries:

13) People from the Caribbean Islands do not know how to deal with stressful situations.

14) They are used to leading relaxing lives, free from stress and worries.

15) They are so relaxed that they never get on time to places.

16) They are not genuinely worried about it.

17) They do not take life as seriously as we do.

If they do not take life seriously we could also infer that:

18) They are not reliable people.

19) They are lazy people because they do not work as hard as we do.

All this contrasts with the connotations evoked by the name of the rum, «Malibu», which triggers the idea of exotic beaches as a means of escaping 
from our real mundane annoyances, such as punctuality, meetings, etc. Thus, the reward level accounts for this idea of escapism at the expense of poking fun at a group of natives from the islands. However, the mini-drama does much more than promising the reward of beautiful beaches and a relaxing lifestyle.

The mini-drama responds to the advertiser's desire to present a humorous situation where s/he is playing off the stereotype that Caribbean inhabitants are the happy-go-lucky type of people, lazy and laid-back in their approach to life. The exchange aims the audience to recover the assumptions presented above, namely, that Caribbcan pcople do not lcad sophisticatcd lifestyles, that they are never stressed, and that they cannot be bothered by mundane issues, such as being late. This lack of worries which might at first sight look like a positive trait, inevitably triggers further weaker assumptions about the ethnic group depicted which are less innocuous than expected, especially because the commercial is constructed around an ethnic joke and demands the audience to take positions and choose the group with which s/he identifies (Lowe, 1986; Koller, 1988).

Thus, this commercial is derisive in so far as it poses the following question: do we want to be like the Caribbean inhabitants with their easy-go lifestyles, their lack of worries, but also with their backward means of transport, lack of intelligence, and in a word, with their underdeveloped way of life? Or, do we want, on the other hand, to be part of «the rest of the mortals» who, in spite of leading stressful and hectic lives, have the opportunity to escape from mundane worries by just drinking a Malibu on the rocks? The dividing line between «us» and «them» (Van Dijk, 1998) is a very fine one and it encourages the audience to take sides.

\section{CONCLUSIONS}

My analysis of this commercial has corroborated the contention that some advertising practices still seem to play off ethnic stereotypes. By tapping into ethnic stereotypes and by particularly presenting a humorous mini-drama, the advertiser covertly stresses what s/he thinks are basic cultural differences between Caribbean islanders and «the rest», that is, «us» as dwellers of developed societies and potential buyers of the product advertised. Notwithstanding, the advertiser cannot be held responsible for the covert assumptions inferred or indirectly pointed out since advertisers leave it up to the audience to either pick up on the information, or not (Taillard, 1999: 156).

By approaching the commercial with a tongue-in-cheek attitude, the advertiser makes one group look smarter than the other; thus, the use of humour has 
the dual purpose of being derisive with one, while enhancing the other (Lowe, 1986). Advertising practices such as the one analysed here reinforce widely held stereotypes by stressing the negative traits of certain ethnic groups and by ridiculing them. Even what at first sight looked like a positive stereotype, that is, people in the Caribbean enjoy life and do not take things too seriously, whereas, people in Western civilizations take things far too seriously and are always worried about time-turns out to be a source for prejudice against an ethnic minority.

The use of stereotypes of this sort in the mass media also contributes to their fixation in people's minds where they remain static and unchanging (Dyer, 1993), the consequence of this being that «what people perceive as 'real' is in fact real in its social consequences (Pettigrew, 1981 in Hewstone and Giles, 1997: 270), that is, on the way we perceive stereotyped groups or individuals». We should thus be aware and critical of practices such as the ones presented here, where ethnic minorities are portrayed through the filtered eyes of a majority white audience in order to sell a product. As it has been shown, stereotypical and inaccurate assumptions about ethnic minorities are conveyed and can be interiorized without questioning their creation, especially by young audiences, all this leading to the subtle prejudice against certain minorities of social inequality in the world.

\section{REFCEENCES}

Allport, G. (1954): The Nature of Prejudice, Reading, MA:, Addison-Wesley. BARTHES, R. (1964): Elements of Semiology (trans. ANNETTE LAVERS \& COLIN SMITH), London, Jonathan Cape.

- (1977): Image-Music-Text, London, Fontana.

Cook, G. (1992): The Discourse of Advertising, London, Routledge.

CROOK, J. (2003): «On covert communication in advertising», Journal of Pragmatics (in print).

Davison, P. (1997): Media Literacy Strategies for Gender Equity, At http://www.cfn.cs.dal.ca/CommunitySupport/AMLNS/violence.html, 1-4.

DEL SAZ, M. M. (in print): «The covert depiction of women in TV ads: from subjects to sexual objects», Proceedings of the First International Conference on Critical Discourse Analysis, Valencia, May 2004.

Dyer, G. (1993): The Matter of Images - Essays on Representations, London, Routledge.

Fox, S. (1984): The mirror makers, New York, Morrow. 
Giles, H. \& P. Powesland (1997/1975): «Accommodation theory», in COUPLAND, N. \& A. JAWORSKI (eds) (1997): Sociolinguistics: A reader, Basingstoke, Macmillan, 232-239. (Reprinted from GILes, H. \& P. PowesLand (1975): Speech Style and Social Evaluation, London, Academic Press, 154-170.)

HewstONE, M. \& H. GiLEs. (1997): «Social groups and social stereotypes», in

Coupland, N. \& A. Jaworski (eds.) Sociolinguistics: A Reader and Coursebook, Houndmills: Basingstoke, McMillan Press, Ltd, 270- 283.

Hodge, R. \& G. Kress (1988): Social Semiotics, Cambridge, Polity.

Koller, M. (1988): Humor and Society, Ilouston, Cap and Gown Press.

KRESs, G. \& T. van LeEUwen (2001): Multimodal Discourse: The Modes and Media of Contemporary Communication, London, Arnold.

Laroceve, E. (1989): «Racism Runs Through Canadian Society», in McKague, O. (ed.) (1989): Racism in Canada, Saskatoon, Fifth House Publishers, 73-76.

LEECH, G. (1966): English in advertising, London, Longman.

LIPPMAN, W. (1992): «Stereotypes, public opinion, and the press», in COHEN, E. (ed.) (1992): Philosophical issues in journalism, New York, Oxford University Press.

Lowe, J. (1986): «Theories of Ethnic Humor: How to Enter, Laughing», American Quarterly, vol. 38 (3): 439-460.

O'DonOHOE, S. (1997): «Leaky Boundaries: Intertextuality and young adult experiences of advertising», in NAVA, M. et al. (ed.) (1997): Buy This Book, London, Routledge, 257-276.

PetTigrew, T. F. (1981): «The mental health impact», in Bowser, B. P. \& R. G. HunT (eds.) (1981): Impacts of racism on white Americans (1st ed.), Beverly Hills, CA: Sage, 97-118.

POTTER, D. (1954): People of plenty: Economic abundance and the American character, Chicago, University of Chicago Press.

Sperber, D \& D. WILSON (1986): Relevance: Communication and Cognition, Blackwell Publishers, Oxford.

- (1987): «Presumptions of relevance», in Behavioral \& Brain Sciences, 10.4 .

TAIllard, M. O. (1999): «Persuasive communication: The case of marketing», UCL Working Papers in Linguistics, 11: 145-174.

TanaKa, K. (1994/1999): Advertising Language: A Pragmatic Approach to Advertisements in Britain and Japan, London, Routledge.

VAN DiJK, T. A. (1998): Ideology. A Multidisciplinary Approach, London, Sage. - (2001): «Multidisciplinary CDA: a plea for diversity», in WODAK, R. \& M. MEYER (eds.) (2001): Methods of Critical Discourse Analysis, London, Sage, $95-120$. 
VestegaArd, T. \& K. Schroeder (1985): The Language of Advertising, Oxford, Blackwell.

Wodak, R. \& J. Meyer. (2001): Methods of Critical Discourse Analysis, London, Sage Publications. 


\title{
LA GESTIÓN SOCIAL DEL VOCABULARIO: EL DISCURSO MEDIÁTICO, ENTRE LA ESPECIALIZACIÓN Y EL HABLA. DE LA 'DESLOCALIZACIÓN' INDUSTRIAL A LA IDEOLÓGICA
}

\author{
Javier Vellón Lahoz \\ Universitat Jaume I
}

T AS nuevas realidades sociales, el multiculturalismo y la globalización, el minorías sociales, la existencia de grupos de presión alejados de las elites dominantes, etc., han supuesto un reto para la lengua en aspectos centrales como el léxico y la variedad de funciones implicadas en su creación, difusión y asimilación por parte de la comunidad de hablantes. La necesidad de nombrar referentes con amplia repercusión simbólico-cognitiva en el ámbito social actualiza la idea de Pierre Bourdieu (1985: 69) sobre la lengua como representación de las relaciones de poder, de manera que «el uso del lenguaje [...] depende de la posición social del locutor». Se plantea así la legitimidad en torno a qué institución tiene autoridad para emitir discursos productivos sobre la lengua o, lo que es lo mismo, qué discursos públicos actúan sobre la competencia lingüística de los hablantes.

Las polémicas sobre los objetivos normativizadores enfrentan a las tradicionales entidades (las Academias, sobre todo) con agentes más dinámicos y creativos en el uso lingüístico, como son los escritores (es muy conocida la difusión mediática que tuvieron las palabras de García Márquez en el Congreso de Zacatecas sobre la ortografía), y, sobre todo, los manuales de estilo periodístico, siempre proclives a dar rápidas respuestas a los interrogantes planteados diariamente por los redactores. La rigidez de las convenciones normativas, por muy permeables que sean los académicos a las innovaciones -y las prevenciones lógicas ante ellas-, frente a la multitud de estímulos informativos a los que deben enfrentarse los periodistas, explica la divergencia de soluciones planteadas desde ambas instituciones, que llevó a un lector de El Mundo (18/6/04) a quejarse por la decisión del medio de utilizar el término 'imam' ('imames') frente a lo arbitrado por Manuel Seco en el Diccionario de dificultades del español, que prefería el clásico 'imán”: «¿Quién tiene razón, el profesor Manuel Seco o ustedes? Deberían uniformizar el vocablo utilizado?». 
En realidad, el debate entre agentes sociales va más allá de la disputa por el control de las vías de difusión de vocabulario. Agnès Callamard, coordinadora de investigación en el secretariado internacional de Amnesty International, a propósito de la polémica surgida en Francia sobre la feminización de los cargos ministeriales en los medios de comunicación, recordaba que tras las palabras puestas en circulación por la prensa hay cuestiones que cxcodon cl marco lingüístico, pucs hay sunc histoire, une découverte, une transformation, mais aussi une identité, un combat» (Le Monde Diplomatique, mars, 1998). En este contexto hay que situar las diatribas contra la RAE, aireadas convenientemente en las páginas impresas, como la de la lexicógrafa Eulàlia Lledó contra la postura de la Academia en la elaboración de la terminología referente a la violencia de género, en la que afirma: «la violencia sexual $[\ldots]$ se atribuye a las mujeres, con los hombres como víctimas» (El País, 11/7/04).

La vigencia social de los libros de estilo periodísticos, en su labor mediatizadora de las normas de uso, no es sólo una tradición británica, donde la BBC constituye una guía léxica y gramatical ante el vacío de otras instituciones normativizadoras, sino que tras la llegada de la democracia a España, el periodismo ha construido una dinámica discursiva capaz de afrontar las nuevas realidades sociales desde un ideario acorde con la etapa de libertades, como recuerda Pilar López (2000) en su revisión de los libros de estilo desde la perspectiva feminista.

\section{EL DISCURSO PERIODÍSTICO COMO AGENTE SOCIAL}

El fenómeno de la práctica lingüística vertebrada a través de los manuales de estilo de los medios, como verdaderas gramáticas de uso, posee notables implicaciones tanto internas como extralingüísticas. Blas Arroyo (2002: 6869), en su estudio sobre el término 'talibán' en la prensa escrita, destaca los factores de índole filológica, estructural e ideológica: la influencia de las presiones normativas, cómo se manifiesta esa presión, el ritmo de la difusión de los cambios, cuál es la fuente desde la que valorar dicha innovación, etc.

Ahora bien, para situar en su justa medida la incidencia social de los usos lingüísticos en los medios impresos, conviene partir de varias premisas vinculadas con el análisis del discurso:

a) El texto periodístico constituye lo que Vicent Salvador (2002: 107) denomina «un interfaz discursivo que articula el texto con el contexto», esto es, existe una interacción entre ambas entidades hasta el punto que, como insiste la teoría crítica de la información, el sistema político- 
económico del que los mass-media forman parte se inserta en la reproducción simbólica de lo que Habermas denominaba «el mundo de la vida». La lengua es parte integrante de los mecanismos de representación. b) Los medios de comunicación, y su influencia sobre el sujeto, no constituyen una excepción en el ámbito comunitario sino que, como indica Enric Saperas (2002: 123), «són una experiència associada a la seua vida quotidiana». Desde esta evidencia cabe entender la sentencia de Miquel Moragas (1998: 111) respecto a la cultura, la lengua y la comunicación: si bien los ciudadanos «guanyen llibertat respecte dels poders polítics [...] perden autonomia respecte dels poders econòmics, agrupats entorn dels nous conglomerats industrials, financers, tecnològics, teleindustrials».

c) Más aún, la relación comunicativa establecida entre el periódico y su público lector favorece el papel mediador de los medios en la formalización de la competencia discursiva y lingüística de los destinatarios pues, como señala Roger Flower (1991: 59), «a newspaper is an institution, a reader is a person [....] Socioculturally, the two modes mean different things ans authority speech suggesting informality and solidarity».

d) En último término, la responsabilidad formativa de los medios responde a la constitución de un discurso coherente, en sus objetiviza-ciones lingüísticas, esquemas explicativos, recreación de espacios simbó-licos, mecanismos argumentativos, etc. En este sentido, la significación institucionalizada del mensaje periodístico refleja el proceso general del Estado capitalista avanzado, tendente a delegar en esferas privadas responsabilidades de poder que tradicionalmente no le correspondían.

\section{LA DESLOCALIZACIÓN: EL TÉRMINO ESPECIALIZADO Y LA TRIBUNA MEDIÁTICA}

Con el fin de ilustrar la actividad de los medios de comunicación como agentes de dinámicas sociales, en este caso lingüísticas, el presente trabajo se centra en un término, 'deslocalización', que, dadas las circunstancias socioeconómicas de las industrias occidentales frente a las economías emergentes, aparece frecuentemente en noticias y comentarios. El análisis tendrá en cuenta los siguientes factores relacionados con el uso y la extensión social del vocabulario:

a) Factores internos (lingüísticos) y externos que explican la potencialidad evocativo-informativa del término.

b) La extensión en el uso en el propio ámbito del discurso periodístico ha de evaluarse teniendo en cuenta los entornos textuales: de los géneros 
informativos, más epidérmicos y sujetos al contexto, a los de opinión, en los que la argumentación abre nuevas posibilidades que amplían la autonomía del término.

c) Él fin último del proceso es observar la actuación de la prensa como mediadora entre los registros especializados y el habla y, por ello, como discurso capaz de generar dinámicas lingüísticas en la sociedad a favor o al margen de las normas institucionales.

El término 'deslocalización' posee las características necesarias para describir los diferentes estadios del proceso descrito.

En primer lugar, su origen lo convierte en vocablo atractivo para la práctica periodística por diferentes aspectos, entre los que destaca su origen especializado: proviene de la traducción literal del tecnicismo inglés outsourcing, y de su sinónimo offshore, ambos del dominio de la ciencia económica, y que hace referencia a la subcontratación de servicios a empresas cuya mano de obra es más barata que en otro país, en este caso occidental.

Si bien es cierto que existe una cierta movilidad del término entre campos de conocimiento (también se utiliza en química orgánica para hablar de la «deslocalización electrónica» y en psicología de la comunicación para referirse a los efectos sobre la percepción de la lectura en la red), sin duda el prestigio de la fuente económica resulta determinante en un ámbito muy permeable a las tendencias sociales, a lo que la antropología cultural denomina «ideología linguocultural» (Friedrich, 1993: 67) y que en la actualidad se consolida un torno al unden cconomicista.

La atracción hacia lo científico-tecnológico por parte del discurso periodístico proviene, en primer lugar, de su caracterización como discursonudo, entre un límite superior ocupado por el saber especializado, y un inferior, el de su función divulgativa. Pero, por otra parte, también apunta hacia la tipología de un estilo formal, identificador del lenguaje periodístico que, como indica Teun Van Dijk (1990: 114), se emparenta «con los lenguajes de elite que es el principal actor informativo en nuestros periódicos». La estructura asertiva típica de tales actos de habla reafirma su legitimidad informativa y su preeminencia como discurso dominante a través de estas formas que, desde su propia constitución morfológica, anuncian su origen especializado.

Es, precisamente, esa virtualidad metalingüística en la actualización del término la que representa otro aspecto determinante en su adopción y extensión. En efecto, Román Gubern (2000: 57) advertía que una de las singularidades del discurso periodístico es su vertiente hacia «la seducción espectacular», esto es, la palabra adquiere una dimensión casi táctil, potenciando una percepción emotiva que condiciona su valor significativo. 
Pues bien, términos como 'deslocalización' (y sus derivaciones léxicas), y otras similares ('externalización', 'internalización', etc.) poseen una composición morfosemántica que favorece su inclusión en la linealidad del discurso mediático:

-Como formas derivadas, construyen su significado a partir de un modelo general de cognición que puede definirse como «acciones, actividades o procesos» (Müller, 2002: 250-251). Precisamente, los elementos morfológicos implicados en la derivación (sufijos, prefijos), poseen una carga informativa considerable, activando lo que Mónica Castro (2001: 107) denomina «el efecto contextual», tanto más relevante en cuanto que se obtiene «por el menor esfuerzo de procesamiento posible».

-Por otra parte, como nominalización, pertenecen al sistema de los nominales de proceso, es decir, aquellos que, entre otras propiedades, tienen una estructura argumental $\mathrm{y}$, por ello, reducible a un marco sintáctico (Gràcia, 1995: 25-27) lo que aumenta sus posibilidades discursivas, como se verá.

-Además, formalmente transmite una imagen metalingüística que reproduce sus propios mecanismos constructivos, como queda patente en algunos usos, en el límite de la normativa, pero sintomáticos de la interpretación cognitiva de estos términos y su virtualidad expresiva. Tal es el caso del extenso artículo de opinión de Guillermo de la Dehesa ( «Deslocalización y externalización», El País, 19/6/04), en el que la palabra siempre aparece como 'des-localización'. La preeminencia del prefijo aspectual ilustra sobre cuáles son las claves perceptivas del vocablo en los medios de comunicación.

\section{LA INSERCIÓN DISCURSIVA: ETAPA METALINGÜÍSTICA}

Al margen de lo expuesto en el apartado anterior, resulta sorprendente la celeridad con la que la terminología se extiende a través de los periódicos y se consolida en la competencia discursiva de los comunicadores. En este fenómeno resultan relevantes las conclusiones de Teodoro León (1997: 10 y ss.) en torno a las fuentes del periodismo actual: se ha generalizado el «periodismo pasivo», es decir, el que adopta una actitud de simple transmisor de los flujos informativos generados desde complejos publicitario-financiero-institucionales, verdaderos controladores de las noticias que contribuyen a la construcción de los imaginarios colectivos.

Los canales discursivos para la difusión de vocablos -aquí ejemplificados con la palabra 'deslocalización'-, representan un recorrido en el que se ven impli- 
cados tanto el entorno sintagmático como los imperativos genéricos del texto y su inclusión en el marco global de la comunicación periodística. Dicho periplo, como se verá, es ilustrativo de las etapas que se siguen en el proceso de mediación entre la terminología especializada y la lengua general, esto es, «la estratificación lingüística horizontal» de la que habla Hernán Urrutia (1978: 191).

La primera de estas etapas de uso puede denominarse «metalingüística», en cuanto que el témino comienza siu singladura desvelando los mecanismos léxico-semánticos, sintáctico-argumentales y pragmáticos que permiten su ubicación en el paradigma discursivo de la textualidad periodística.

Desde la perspectiva léxico-semántica, el mecanismo caracterizador más habitual es el acompañamiento de una frase explicativa del significado de la palabra; por su parte, la dimensión sintáctico-argumental aporta las extensiones que fijan el límile argumental del vocablo en sintagmas como «la deslocalización industrial».

El Correo Gallego (17/1/04) propone un buen ejemplo introductorio, pues a lo dicho anteriormente añade el recurso tipográfico de las comillas, lo que contribuye a la focalización textual del nuevo vocablo:

El reciente anuncio de cierre de las fábricas $[. .$.$] ha situado en primer plano de$ actualidad la temida «deslocalización» de las multinacionales. A los grupos empresariales no les duelen prendas cuando hacen las maletas para trasladarse...

Menos retórico en la caracterización semántica resulta la crónica de Xabier Aja en el Deia (18/1/04):

El fenómeno de la deslocalización industrial ha empezado a afectar con fuerza al Estado español. El traslado de las fábricas desde Occidente a los países del Este....

Más canónica resulta la descripción metalingüística en El Mundo (18/1/04) con el uso de un conector explicativo:

La deslocalización, es decir, el fenómeno por el que las industrias se instalan en otros países con costes laborales...

El grado de integración del término en las rutinas periodísticas puede observarse, aún en esta primera fase, por su presencia no sólo en entornos tipificados por su retórica objetivadora de la realidad (noticias, crónicas, etc.), sino en géneros de opinión, en los que las estrategias argumentativas permiten una ampliación de las posibilidades connotativas y metafóricas. Éste es el caso de la columna de José García en El Periódico (23/1/04), en la que lo metalinguiístico y lo estilístico actúan en sincretismo: 
Un fantasma recorre Europa: la deslocalización. Una palabra indigesta para definir las migraciones industriales del oeste al este y del norte al sur en busca de climas más benignos para el negocio.

En esta misma dirección cabría valorar el titular de Cinco Días (13/2/04): «Vacunas contra la deslocalización».

\section{LA AMPLIACIÓN DE USOS LINGÜÍSTICOS}

En la fase anterior las posibilidades combinatorias del término eran reducidas, atendiendo a su condición de etapa introductoria en la que la unidad léxica limita su entorno sintagmático a un corto repertorio distributivo: acompañamiento de una noción genérica introductoria («el fenómeno de...», «el problema de...»), actualizaciones exclusivas por parte del morfema artículo, ubicación oracional centrada en la posición tematizada (bien al inicio-izquierda o pospuesta-derecha (López, 1996: 485).

La extensión en el uso, y su diversificación, comienza a adivinarse a partir de la ampliación de las estructuras semántico-sintácticas de su entorno. Como señala atinadamente Raquel Hidalgo (2003: 130), el fenómeno de la tematización de los constituyentes oracionales «es un proceso interactivo que conlleva una negociación con el receptor», lo que supone que la capacidad de integración lingüístico-discursiva de un asunto exige «la identificación de referentes en el orden textual».

Si en la primera etapa los activadores genéricos del vocablo eran evidentes (uso del artículo, el singular, la invariación morfológica), en esta puede observarse una mayor riqueza en lo que atañe a sus actualizadores más inmediatos:

-El uso del plural, que lo sitúa en el orden de la concreción contable: «Las deslocalizaciones acabarán en cinco años con el 10\%...» (ABC, 22/1/04); incluso en situaciones en las que la moción de número es innecesaria: «Los estudiantes buscan especializarse para evitar las deslocalizaciones» (El País, 3/8/04).

-La supresión de determinantes, lo que evidencia su carácter topicalizado en la interacción comunicativa así como su carácter semánticamente autónomo, vinculado, como indica Antonio Briz y M. Prunyonosa (1987: 72-73), a una tipología textual: «Una filial de Peugeot deberá pagar 600 años de salario por deslocalización» (La Vanguardia, 17/2/04). Más explícito es su uso titulando columnas: «Deslocalizaciones y otros peligros» (Eduardo Madina, El País, 6/9/04), «Deslocalizaciones» (Koldo Uncieta, El País, 8/7/04). 
-La presencia del actualizador «un» atribuye al vocablo, de nuevo, un índice de concreción importante que permite desarrollos posteriores mediante, por ejemplo, formas adjetivas inimaginables en los usos más genéricos. En la entrevista a Loyola de Palacio en El Correo (3/5/04) se le pregunta: « ¿Existe riesgo de una deslocalización de empresas que se sientan más atraídas...? »; en otra a Carlos Bustelo (El País, 5/9/04) el informador titula «El traslado de la CMT es una deslocalización en pequeño»; en una noticia de El Mundo (21/1/03) se señala «el hecho de que exista moneda única va a producir en teoría una deslocalización de los ahorros».

Desde una perspectiva sintáctica, la integración del vocablo puede seguirse a través de algunos fenómenos como los siguientes:

-Su conversión a la categoría verbal, ya no como forma que indica «cambio de estado» producido por un agente, sino en su versión como «pasivorefleja» (Westphal, 2001: 221), siguiendo la retórica propia del discurso periodístico. En ejemplos como «la industria se deslocaliza....» (María Maizkurena, El Correo, 27/4/04), «que el capital no se deslocalice...» (El Mundo, 21/1/03), «la producción de cítricos se deslocaliza» (El País, 25/4/04), la agentividad se difumina o permanece en el ámbito de las presuposiciones, mientras que la argumentación propuesta por la unidad verbal cobra relevancia y articula la secuencia de la cláusula.

-La elipsis es otro de los recursos para insistir en su preponderancia constructiva. Así, cn cste titular de El País (5/9/04) «La deslocalización cs un debate retórico y político», se echa en falta el núcleo que proyecta el contenido de la atribución («el problema de..., las causas...»).

- La versatilidad de los nexos preposicionales también es un síntoma de la extensión en el uso del término 'deslocalización' en la cadena oracional, así como en los vínculos sintagmáticos con otras categorías y en su ubicación funcional en el sistema morfosemántico. Si en la primera fase su posición coincidía con distribuciones de escasa implicación formal, en ésta el vocablo expande sus entornos de realización: «terminar con el abuso de la deslocalización» (El Correo, 15/5/04); «Rato dice que el gobierno se desvincula de la deslocalización» (Europa Press, 7/3/04); «El antídoto a la deslocalización» (La Vanguardia, 12/9/04); «Deslocalización en las cajas» (La Razon, 12/2/04). Se incluyen aquí ejemplos citados anteriormente en los que el término va introducido por preposiciones como «por», «contra», «hasta».

Tinalmente, también el componente léxico se ve afectado por esta implantación de la palabra en el discurso periodístico. Uno de los aspectos 
más notables de este fenómeno es el proceso mimético por el que se crean nuevas palabras relacionadas con su estructura morfológica: «Amenazas e implicaciones de la relocalización empresarial» (Fernando Luengo, El País, 23/8/04); «El turismo en Cataluña es un sector que no sufre desinversión, deslocalización ni cierre» (Pere Esteve en La Razón, 14/8/04).

Incluso en su vertiente semántica, la consolidación del concepto se observa en el recurso a la metáfora para referirse a él por implicatura. La negociación comunicativa llega así a un punto en el que el emisor cuenta ya con la competencia interpretativa del destinatario y así, en El Mundo (21/1/04) una información aparece titulada de la siguiente manera: «Cuenta atrás pará el fantasma que viene del Este».

\section{EXTENSIÓN TEMÁTICA Y DESARROLLO DISCURSIVO}

Bernardino M. Hernando (1990: 44) habla de «nido de lenguajes» para referirse a los diferentes subcódigos que se dan cita en los variados géneros textuales del periódico como institución discursiva. La acertada metáfora alude a la heterogeneidad tipológica y de lenguajes presente en los medios escritos más allá de la aparente uniformidad que se engloba en el denominado «estilo periodístico».

Por ello, la constatación de que el término 'deslocalización' ha cruzado el umbral de lo estrictamente especializado -las páginas de economía- supone la evidencia de que no sólo se está produciendo una diversificación del uso, sino también una variación en su entorno discursivo y, más aún, un claro avance hacia su estandarización. El hecho de que el nuevo contexto de aparición sea el de la noticia y, más concretamente de tema político, fomenta la percepción de su avance hacia los dominios del habla y su nivel de integración en la competencia del receptor medio.

En algunos casos es fácil adivinar el desplazamiento semántico puesto que el tenor de dicho movimiento es transparente: «... impedir la extradición del presunto etarra a España para deslocalizar su logística» (El Mundo, 8/11/03); «Javier Balza reconoció que en el proyecto no se contemplan partidas de apoyo al cambio de residencia, a la deslocalización de personas» (El Mundo, $4 / 11 / 02) ;$ «... ha explicado las dificultades en recabar pruebas determinantes contra células terroristas islámicas por su deslocalización» (El Mundo, 27/2/03).

En los ejemplos citados está presente el sentido léxico-semántico de «movimiento», propio del concepto original, así como su desarrollo argumental en torno al desplazamiento de objetos y entidades, en esta ocasión trasladado a nociones personales. 
Frente a ello, puede constatarse la existencia de usos cada vez más alejados de los esquemas semánticos iniciales, en los que la expansión metafórica comienza a difuminarse, síntoma de una tendencia hacia la estandarización del término. En la cita de El Correo (23/1/04), se entra de lleno en la referencia a cuestiones de orden ideológico, proyectando una fórmula alejada de la especialización inicial: "veían en ésta un claro peligro de deslocalización del PNV...» En el caso de El Mundo (3/10/01), se citan palabras de García Márquez, en las que una abstracción, ia lengua española, «se ha desiocali-zado» limando «asperezas y divergencias». La creatividad del hablante anun-ciada por Coseriu se deja ya sentir.

En último término, las noticias periodísticas ofrecen muestras relevantes de un uso, si no desvirtuado, sí al menos opaco respecto a las motivaciones primigenias: «se considera muy relevante la evolución de la numeración telefónica, por lo que debe abordarse la regulación de la deslocalización geográfica» (La Razón, 8/6/04); «el efecto más significativo es [...] la deslocalización de la convivencia» (La Razón, 23/8/04). La capacidad evocativa y composicional del vocablo se despliega aquí plenamente, lo que incide en su consideración como unidad sometida a un proceso discursivo que concluye en un cambio semántico, de realización sintagmática y en una transformación de su dimensión sociolingüística y variacionista.

El estadio final de este proceso apunta hacia la aparición de la palabra en columnas y artículos de opinión ajenos al terreno específico de la economía. Javier Cuervo reflexiona sobre el plagio (Levante, 6/6/04) señalando que «China le enseña al mundo que lo que es deslocalización es plagio». Más directamente político y cargado de ironía, Julio A. Máñez titula su colaboración en El País (16/2/04), « Y por qué no deslocalizan a Zaplana?».

Integrado en el discurso expositivo-argumentativo, sometido a las necesidades estilísticas de los ensayistas, el término se abre a un campo de amplias posibilidades, desligado de su función referencial-informativa, neutralizando, en parte, su sentido académico y potenciando otras virtualidades en contextos con límites más extensos que los originales.

\section{CONCLUSIÓN}

La actividad desplegada por los periódicos en el ámbito lingüístico constituye una dinámica de intervención social sujeta a todo tipo de intereses que abarcan los estrictamente comunicativos, más vinculados a las exigencias normativas, y los de índole cconómica, política c idcológica, más pendientes de la expresividad y del pragmatismo utilitario. 
Si en el caso concreto del lenguaje eufemístico la participación social de los medios cabe interpretarla como ideológica, en otros dominios menos comprometidos hay que dejar constancia de su efectividad como agentes revitalizadores -otros la calificarían de transgresora- del idioma, explotando, con su uso, la capacidad evocativa del léxico hasta extremos que, desde posiciones academicistas han sido objeto de censura. Más allá de estas preocupaciones -legítimas- por las «perversiones idiomáticas», los discursos mediáticos se sitúan como mediadores entre espacios sociales, que de otra manera no encontrarían ámbitos de intersección.

De la misma manera que los afanes divulgativos han convertido a la ciencia en una producción al alcance de amplios sectores sociales (a través de una curiosa práctica en la que convergen la difusión del conocimiento científico con la persuasión informativa y la espectacularidad lúdica), la prensa, como discurso-nudo entre lo textual y lo contextual, es capaz de generar esquemas de uso que amplían, reorganizan y transforman los entornos significativos y combinatorios de las palabras. El resultado es un proceso de asimilación por el que cualquier segmento hiperespecializado de los saberes científicos y su plasmación terminológica franquea sus límites de realización y sus fronteras sociales para ocupar su lugar en la competencia comunicativa del hablante.

\section{REFERENCIAS BIBLIOGRÁFICAS}

Blas Arroyo, J. L. (2002): «'¿Era Bin Laden un líder de los talibán?... ¿o de los talibanes?': presiones externas e internas en un fenómeno reciente de variación morfológica en español», Revista de Investigación Lingiiistica, 1, 5: 3-33.

Bourdieu, P. (1985): ¿Qué significa hablar? Economía de los intercambios linguiísticos, Madrid, Akal.

Briz, A. y M. Prunyonosa (1987): Sintaxi i semàntica de l'article, Valencia, Universitat de València.

Cantero, M. (2001): La morfopragmática del español, Múnich, Lincom Europa.

FLower, R. (1991): Language in the news. Discourse and ideology in the Press, Londres, Routledge.

FRIEDRICH, P. (1993): «Lenguaje, ideología y economía política», Revista de Antropología Social 2: 49-68.

GràcIA, LL. (1995): Morfologia lèxica. L'herència de l'estructura argumental, Valencia, Universitat de València.

GuBERN, R. (2000): El eros electrónico, Madrid, Taurus.

Hernando, B. (1990): Lenguaje de la prensa, Madrid, eudema. 
HIDALGO, R. (2003): «Orden de palabras y conversación: la tematización sintáctica como introductor de temas discursivos en el español hablado», Girón, J. L. y Otros (eds.): Estudios ofrecidos a al profesor José Jesús de Bustos Tovar, Madrid, Universidad Complutense, I, 125-134.

LóPEZ, Á. (1996): Gramática del español II. La oración simple, Madrid, Arco.

LópEZ, P. (2000): «La construcción mediática de género en los libros de estilo», en CokTEs, R, y OTRos (eds.) (2000): Feminismo: del pusudo al presente, Salamanca, Universidad de Salamanca, 85-117.

LEón, T. (1997): «Auditoría lingüística de la agenda de los medios», Congreso de la lengua española de Zacatecas, Centro Virtual Cervantes.

Moragas, M. (1998): «Canvis en la comunicació. Nous escenaris de la nominalització lingüística», en MoLLÀ, T. (ed.): La política lingiistica a la socienat de la informació, Alzira, Bromera, 107-127.

MUUller, H. (2002): «Principios cognitivos de la formación de palabras en español», VEGA, A. y OTros (eds.): Léxico y gramática, Lugo, Tris Tram, $249-259$.

SALVADOR, V. (2002): «Discurso periodístico y gestión social de los conocimientos: algunas observaciones sobre la didacticidad», Anàlisi, 28: 107120.

SAPERAS, E. (2002): «La premsa i la televisió com a actors polítics: sobre l'anàlisi de la mediació política i de la recepció de la comunicació política», en LORDA, C. y M. Ribas (eds.) (2002): Anàlisi del discurs polític. Producció, mediació i recepció, Barcelona, Universitat Pompeu Fabra, 123-134.

URrutia, H. (1978): Lengua y discurso en la creación léxica, Madrid, Cupsa. VAN Disk, T. A. (1990): La noticia como discurso. Comprensión, estructura y producción de la información, Barcelona, Paidós.

WeSTPHAL, G. (2001): «Léxico, gramática y las oraciones medias y pasivas reflejas del español», VEIGA, A. y OTROs (eds.) (2001): El verbo entre el léxico y la gramática, Lugo, Tris Tram, 221-231. 


\title{
SOCIOLINGÜÍSTICA Y TOTALITARISMO
}

\author{
Luis Veres Cortés \\ Universidad Cardenal Herrera-CEU (Valencia)
}

D ESDE la psicolingüística se nos ha dicho que «nadie inventa su propio lenguaje».(Hörmann, 1973: 17), sino que ese lenguaje es adoptado por una determinada comunidad lingüística, cuyos hablantes firman las cláusulas de una convención tácita cada vez que la ponen en práctica para comunicarse. Esta particularidad que convierte al lenguaje en un objeto transmisible de generación en generación lo presenta como el «más peligroso de todos los bienes» (Faye, 1974: 140) Por su carácter social y convencional el lenguaje es el poso en donde se aposenta la ideología de una comunidad. Y eso puede ser bueno o malo dependiendo de la ideología en concreto. De ahí, que Weisgerber, influido por el espíritu nacionalista de entreguerras, llegara a la conclusión de que la lengua representaba «el espíritu de la nación». Pero lejos de exageraciones cargadas de chauvinismo, lo cierto es que el lenguaje se apodera de numerosas experiencias conectadas con la personalidad de un individuo o de un grupo (Schaff, 1979: 294), incluidas aquéllas que hacen referencias a sistemas de valores: «la lengua no es una mera fotografía sino transformación espiritual de la realidad» (Weisgerber, 1979: 178). El léxico de una época está marcado por los acontecimientos de esa época, por el cuño de los hombres que lo utilizaron y por las causas al servicio de las cuales una determinada palabra sirvió fielmente como el soldado de un regimiento (Dubois, 1962: 129).

La idea de que el lenguaje cambia en relación con la realidad ya había sido formulada por Saussure y por la mayoría de los estudiosos del cambio semántico, desde Ullmann a Lyons o Baylon, pero no resulta menos cierto que el lenguaje queda marcado por la filosofía y la ideología que presiden un determinado periodo histórico. Roland Barthes señalaba que «las palabras más ligadas a la Edad Media son los cimientos mismos del sistema escolástico» (Barthes, 2002: 128), lo cual pone de relieve la marca de una época y de un sistema ideológico sobre las palabras de ese período. Por ello la historia de las palabras nos facilita probablemente mejor que cualquier otro medio una fuente para estudiar el mundo que nos rodea desde cimientos culturales (Rohlfs, 1979: 26) e ideológicos, y con toda seguridad la tarea de reconstruir el pasado y su ambientación es una tarea en donde la lexicología puede ofrecer una gran ayuda (Casado, 1985: 13). Pero, el mismo Barthes va más allá de ese marchamo histórico cuando señala que no hay lenguaje sin ideología (Barthes, 2002: 
177). Y ello es cierto si atendemos a lo que Bajtin señalaba a principios del siglo XX con el nombre de «imperativo linguístico», es decir, la aceptación por parte de los hablantes de las convenciones de un idioma en el momento en que ese idioma pasa de ser una abstracción de la lengua a ser una realización concreta del habla. Ese imperativo lingüístico supone la aceptación de la institución linguiística y de sus convenciones. El rechazo de este imperativo linguístico se puede observar en el uso de hablas jergales o en aquellas prácticas deformadoras que desde posiciones contraculturales o marginales subvierten las normas básicas de la gramática. Para estos hablantes, el idioma convencional es un registro perteneciente a lo establecido y la forma de manifestar su independencia de dicho estamento social es modificar el léxico y las estructuras de dicho registro idiomático. Del mismo modo que los surrealistas o los dadaístas atacaban en el período de las vanguardias históricas las bases de la institución artística, determinados grupos, más o menos marginales, manifiestan su ideología antisistema mediante una utilización idiomática, alejada de los cánones y normas académicas (Casado, 1978).

Desde posturas marxistas se ha relacionado el problema del lenguaje y sus filiaciones ideológicas con el aparato estatal dentro del cual se ven inmersos. Louis Althusser, en su trabajo, «Ideología y aparatos ideológicos de Estado» (Althusser, 1974) señalaba la existencia de determinadas realidades dependientes del Estado y cuya finalidad era la represión más o menos contenida. Por una parte, existía el Aparato Represivo del Estado (ARE), cuya finalidad es la represión directa; por otra parte, los AIE, Aparatos Idcológicos del Estado, cuya finalidad tambićn cra la represión, pcro csta vez de manera indirecta. Los AIE, frente al carácter unitario del ARE, son una pluralidad y pertenecen al dominio de lo privado, y no al público. Mientras que el ARE funciona básicamente a partir de la represión, los ARE funcionan mediante la ideología. De este modo, Althusser señala distintos Aparatos Ideológicos del Estado: el AIE religioso, el AIE familiar, el AIE jurídico, el AIE político, el AIE sindical, el AIE de la información (prensa, radio, televisión), el AIE cultural (letras, bellas årtes, deportes, etc.). En todos los AIE, como realidad humana, está presente el lenguaje que es el soporte natural de la transmisión de dichos sistemas ideológicos al servicio del Estado. La semiótica de la cultura ha destacado que toda ideología tiene su existencia material y esa existencia tangible no es ajena a la práctica discursiva, esto es, a la puesta en marcha de cualquier enunciado lingüístico. Como señala Talens (1980: 38), «las ideologías no son abstracciones teóricas sino que se manifiestan en la vida social de modo material, objetivo y concreto. Están unidas a actitudes y prácticas de conducta reguladas por ritos y códigos pcrfcctamentc matcriales, definidos, en cuanto tales, por las instituciones en que se insertan». 
A parecidas conclusiones había llegado Ferruccio Rossi-Landi (1974) al señalar que cualquier elemento del comportamiento humano estaba de un modo u otro programado, de manera que ningún acto comunicativo actúa fuera de una situación programada por los modos de producción y condicionada por las ideologías dominantes.

El concepto de ideología quedó acuñado en el siglo XVIII por el filósofo francés Destutt de Tracy. Para él, la ideología era una ciencia de las ideas, un estudio de cómo pensamos, hablamos y argumentamos. Esta concepción de la ideología y sus evidentes implicaciones linguísticas ha sido retomada por la gramática del discurso. Teun van Dijk (2003: 14) señala que «las ideologías son las creencias fundamentales de un grupo y de sus miembros». Para el lingüista holandés, el lenguaje es la práctica mayormente condicionada por la ideología, práctica que a su vez modifica en muchos casos a la propia ideología. La mayor parte de los discursos desprenden algún tipo de ideología en tanto que transfieren las creencias e ideas de un individuo perteneciente a determinado grupo, a determinada clase social, a determinada nacionalidad y a determinada sociedad. La importancia de esta realidad se fundamenta en que pocas veces las ideologías poseen un carácter trivial. Las ideologías son creencias sociales individuales, pero que también forman parte del modo de pensar del grupo al que pertenece o no el individuo. Las ideologías tratan temas importantes de la existencia humana, tratan de la vida y de la muerte, del nacimiento y de la reproducción, de la subsistencia de la especie, de la salud, del entorno natural de los humanos, de su clase social, de la pobreza y de la riqueza, del sexo o la raza.

$\mathrm{Y}$ lo cierto es que todo lenguaje es ideología, aunque determinados sistemas lingüísticos puestos al servicio del poder se constituyen como sistemas cerrados, como arsenales léxicos que normalmente se fundamentan en resemantizaciones, es decir, en nuevas acuñaciones del significado de un conjunto de palabras relacionadas entre sí y utilizadas en una misma dirección persuasiva. Como señala Klaus (1979: 161-162), «el poder de la palabra se hace patente cuando designa situaciones que ya no existen o que todavía no existen».

Tanto el III Reich como los gobiernos comunistas de los países del Este o la misma retórica en época de guerra de los Estados Unidos constituyen sistemas lingüísticos cerrados a disposición del poder. Todo sistema totalitario da lugar a su propio lenguaje totalitario, porque no es el lenguaje el culpable de ese totalitarismo, sino la ideología que lo engendra y que se manifiesta en el propio lenguaje. Sin el Mein Kampf no hubiera existido el lenguaje del Tercer Reich; sin las prédicas racistas de Sabino Arana no hubiera surgido ni ETA ni su retórica. Mertens (1980: 227-248) ha hablado de que la violencia cultural e intelectual se manifiesta en el lenguaje y ese poder irracional de la 
palabra se utiliza para facilitar la ascensión de un dictador, para retener el poder, para intimidar o asustar al pueblo, para calumniar al enemigo, para desprestigiar personas, países, organismos, instituciones, sociedades, adversarios o culturas.

Los ejemplos de reforzamiento de determinadas ideologías sobre su depósito natural, el lenguaje, se ve ampliado en momentos históricos en donde el totalitarismo se impone como única ideología que doblega el reto de ideologías o sistemas políticos, algo que olvidaron la mayoría de autores marxistas que sólo vieron la ideología en la sociedad burguesa. El siglo Xx ha sido una época rica en imposiciones, errores y abismos que han colocado al hombre a la cabeza de la ignominia. Y quizás dentro del gran número de aberraciones que caracterizarán al hombre del siglo xx, se sitúe la perversión del lenguaje. Como señala ese gran novelista que es Imre Kertész (2002: 1516) la facilidad con que el hombre se equivoca en las imprecisiones que son propias del lenguaje supone un gran desaliento en las actividades humanas, pero, a su vez, un gran peligro a causa del contagio de las palabras con las aberrantes ideologías del totalitarismo del siglo $\mathrm{xx}$.

Las razones de la existencia de este depósito de sedimentos en el que se convierte el lenguaje residen en que «en nuestro vocabulario y nuestra gramática habitan metáforas vacías y gastadas, figuras retóricas que están firmemente atrapadas en los andamiajes y recovecos del habla de cada día, por donde yerran como vagabundos o como fantasmas de desván» (Steiner, 2002: 13). Y lo cierto es que el siglo XX se pobló de ejemplos en el que las ideologías aberrantes inundaron con sus lodos el lenguaje. Hitler convirtió el Berlín de los años treinta en un reflejo de esa Alemania imperial que tenía que renacer de sus cenizas tras la humillación que había representado la firma del Tratado de Versalles, de modo que los edificios se convirtieron en un trasunto de esa ideología plagada de ansias de grandeza y de despotismos hacia el resto de sus congéneres. Y lo mismo ocurrió con el lenguaje. En la Alemania del nacionalsocialismo palabras como raza, pueblo o nación, llegaron a representar una ideología racista y adquirieron las connotaciones propias de esa ideología. Se exaltó el significado de la expresión raza nórdica, de modo que se creó el verbo aufnorden o nordizar (Adorno, 2001: 47). Incluso existió una Ahnenpass, una «patente de antepasados que consistía en un certificado de pureza racial» (Coseriu, 1987:12). De ahí que Bertold Brecht afirmase en 1934, poco después del ascenso de Hitler al poder, que «el que, en nuestros tiempos, dice población en lugar de pueblo y propiedad terrena en lugar de suelo, niega ya su apoyo a muchas mentiras» (Weinrich, 1966, citado por Casado, 1991: 65). Lo mismo ocurrió con la expresión Blut und Boden (sangre y suelo) cuyas reminiscencias de la realiclad de la guerra y de los cannpos de concentración se depositó en la unión de los vocablos para siempre (Coseriu, 
1977: 53). Incluso muchos judíos que deseaban borrar su ascendencia acudían a solicitar nombres y apellidos germánicos y muchos de esos nombres eran acuñados por funcionarios fanáticos cuya única ambición era humillar a su poseedor. Se trataba de los llamados galizische Ekelnamen -nombres repulsivos de Galitzia-, que fueron distribuidos a una multitud de ciudadanos polacos, nombres como Urin Kalfuss - pie calvo-, Dintenfass -tintero- o Streisand-arena secante-(Grunfeld, 1980: 16). El lenguaje dejaba así de ser imparcial ante la historia.

Este tipo de cambios que afectan a la significación son frecuentes en la lengua bajo determinadas condiciones históricas cuando una palabra se somete a numerosos empleos con una actitud muy precisa, dirigida normalmente desde un poder, de modo que «la asociación secundaria, se interprete como significado objetivo y reemplace a éste» (Coseriu, 1987: 14). De ese modo, en alemán la palabra Fremdarbeiter (obrero extranjero) paso a ser sustituida por Gastarbeiter (obrero huésped), con el fin de evitar aquellas significaciones propias de épocas tan deleznables.

Pero la ideología se manifestó en Alemania probablemente con mayor rotundidad que en cualquier otra nación, debido, con toda posibilidad, al autoritarismo de la ideología que imperaba desde pocos años antes de 1933. Así, los policías, como señala Klemperer en ese magnífico documento de época que son sus Diarios, pasaron a denominarse Polizeimeister, de modo que a la vez que esos hombres eran los representantes de la autoridad eran maestros de esa misma autoridad, entendida como la única ideología posible para gobernar al pueblo (Klemperer, 2003 b: 193). El nazismo facilitó el surgimiento de numerosos vocablos en los que subyacía la ideología de la época. De ese modo nació Untermensch (infrahombre) (Klemperer, 2003 a: 597) o se desarrolló el adjetivo fanático con connotaciones positivas -fanáticamente alemana-; el nombre de la fuerza aérea alemana Wehrmacht pretendía representar la grandeza y poderío del imperio (2003 a: 605) y esa grandeza fue de tal manera exaltada que, durante la II Guerra Mundial, el conflicto de 1914-1919 pasó a denominarse la pequeña guerra (2003 a: 730). La lengua alemana pasaba a ser así un valioso instrumento al servicio del orden y la propaganda imperante bajo el dominio del Reich. De hecho, el término genocidio no comenzó a utilizarse hasta 1942 (Hobsbawm, 2003: 32). Hasta entonces se hablaba de evacuaciones. El mismo Victor Klemperer anotará en sus diarios una cita de Günteher Ipsen en la que se manifestaban los excesos del idealismo dominante bajo los influjos del nacismo: «En el Estado nacionalsocialista, ya no se tiene a la lengua por un mecanismo, sino que se la reconoce y se la valora como una figura de naturaleza propia, como expresión de la vida anímica de la comunidad biológico-espiritual hombre-pueblo» (Klemperer, 2003 b: 539). Reflejos de este acaparamiento del idioma por parte 
de una determinada ideología fue un proceso de cosificación y degradación de lo humano que se manifestó paulatinamente en el fondo de la lengua alemana. Por ello no era extraño que Himler afirmase barabaridades como las siguientes (Poliakov, 1987: 15):

Nosotros alemanes, que somos los únicos que tratamos correctamente a los animales, trataremos correctamente a los animales humanos. Pero sería un crimen contra nuestra sangre preocuparse de ellos, darles un ideal que preparase a nuestros hijos y a nuestros nietos tiempos más difíciles.

Así pues, no resultaba extraño que, como reflejo de la ideología nacionalsocialista para hablar de personas detenidas en un campo de concentración se hablase de piezas, que la utilización del término hombre para referirse a una persona de religión judía resultase siempre irónica y desembocase de manera intencionada en el ridículo. Lo mismo ocurría en el gulag ruso: palabras como querido o humano sólo se utilizaban con sentido irónico o ridículo (Amis, 2004: 85). Se producía un proceso de cosificación, una cruel alegoría cuyas ramificaciones otorgaban numerosas denominaciones nuevas. A causa de estos hechos se hablaba del aprovechamiento de cadáveres, ya que éstos acababan convertidos en abono para los campos; Y nunca los judíos eran asesinados, sino que eran conducidos a la solución final; se decía que los miembros de la resistencia eran abatidos, manifestando todo el odio que se ponía en aquellas muertes, o bien se hablaba de que habían sido liquidados, aprovechando un vocablo procedente del lenguaje comercial y cuya razón de ser era el cumplimiento de una deuda (Klemperer, 2001: 218-219).

De este proceso de cosificación, que al fỉn y al cabo consistía en deshumanizar a las personas convirtiéndolas en los engranajes más rudimentarios de una maquinaria con ansias imperiales, se deriva el gran número de tecnicismos que comenzaron à utilizarse en ambientes no técnicos a partir de 1933. La República de Weimar introdujo sólo dos términos técnicos en el común de las conversaciones verankern (anclar) y ankurbeln (accionar la manivela, poner en marcha). En una época convulsa como la de Weimar, el deseo de estabilizar el país y el deseo de salir de la humillación de Versalles fue la causa de que se intentara anclar todo lo posible, incluidas las constituciones y se intentara poner en marcha también cualquier empresa. Pero el nazismo intensificó notablemente este proceso de tecnificación del lenguaje, puesto que detrás del lenguaje subyacía una consideración ideológica importante: el hecho de que el hombre no era más que la pieza, a todo ello, insignificante, de una maquinaria mucho más grande. De ese modo surgió la nucva utilización del vocablo gleischschalten (sincronizar, coordinar) aplicado a personas. Según Klemperer, este uso implicaba una consideración 
del hombre como una máquina que poseyera un pulsador. A partir de estos usos se entienden frases como las de Goebbels que hablan del pueblo alemán como una máquinaria de perfecto funcionamiento: «En un tiempo no muy lejano funcionaremos al número máximo de revoluciones en una serie de ámbitos».

El reflejo de la ideología en el lenguaje también se dio en otros países. En Italia la palabra plebiscito, utilizada por el gobierno de Mussolini como «unanimidad obligatoria» se vio sustituida por referendum con la misma finalidad que en la lengua alemana tras el derrumbe del nacionalsocialismo. El mismo proceso de sustitución afectó a términos como battaglia, folgorante, inconfondibile, inequivocabile o expresiones como travolgente entusiasmo o squisitamente político (Migliorini, 1975: 160). España tampoco ha resultado ajena a este proceso de proscripción de algunos vocablos: términos como servir, obedecer, docilidad, virtud, abnegación, o, incluso, unidad (Casado, 1991: 86), se ven desprestigiados por su uso abusivo durante la dictadura de Franco.

Indudablemente en este proceso sustitutivo se transparenta un cambio en las costumbres y los valores a causa del rechazo que provoca determinado espacio temporal en la historia de una sociedad concreta. Por ello resulta cierto el apunte señalado por Gadamer: que «en la decadencia de las palabras podemos observar los cambios de las costumbres y de los valores» (Gadamer, 1977: 539). Por ello, es cierto que «por las palabras que emplea o evita, el lenguaje enseña mucho sobre la constitución interna de una época» (Guardini, 1981: 223).

En el cine realizado durante el nazismo se eliminaron todas aquellas palabras, cuya etimología no era estrictamente alemana, a pesar de ser de uso común. Así pues, en los títulos de estas películas no aparece regie sino spielleitung, que aunque quiere decir lo mismo, reduce la categoría de los realizadores (De España, 2002: 16).

Sorprendentemente, la ideología racista y totalitaria también se manifestó en la lengua y en las acciones de quienes en mayor medida habían sufrido el holocausto: los seguidores del judaísmo. Como sistema religioso férreo y sujeto a duras leyes cuyo incumplimiento supone un sinfín de castigos, la religión judía también debía mostrar en el lenguaje. Un curioso libro, The Joys of Yiddish-Las alegrías del yiddish- de Leo Rosten recoge algunos detalles que se deslizan en la lengua yiddish. Para referirse a los gentiles, es decir, a aquellas personas que no son israelitas o descendientes de Moises, el yiddish posee varios vocablos. El primero es shaygest, cuyo significado es «chico o joven gentil», pero otros términos como sheqetz se definen como «mancha», como «animal impuro, criatura repugnante, abominación». En sentido coloquial puede significar «sinvergúenza, joven rebelde, joven gentil» (Shahak, 2004: 72-73). 
De hecho, la religión judía cuando habla de «amar a tu prójimo como a ti mismo», ese prójimo se entiende que es un gentil, ya que los no gentiles son considerados como seres abominables. A su vez, cuando se habla de «hombre», se entiende que ese hombre es judío, ya que el gentil no es merecedor de respeto. Del mismo modo que los nazis hicieron de los judíos la encarnación de los males de la patria, los judíos de la actualidad muestran un tremendo respeto por sus muertos, mientras que es una realidad la falta de respeto por los cementerios de gentiles.

Barbu explica que en las sociedades en proceso de democratización el lenguaje aristocrático deja paso al lenguaje popular. En un principio algunas palabras cambian de campo semántico: palabras del campo religioso, como credo, mártir o evangelio pasañ a tener significados políticos. A su vez las palabras de carácter nacionalista se cargan de significados emotivos, palabras como libertad, nación, patria, etc. (Barbu, 1953). Según Barbu, cuando el proceso democrático se ha asentado, las palabras pasan a tener una notable ambiguiedad y su significado depende de la interpretación de cada individuo o del posicionamiento del hablante. De hecho Tocqueville señalaba como una característica de las sociedades democráticas el gusto por las expresiones abstractas y su razón de ser está en la facilidad con que el lenguaje se somete a la manipulación. Esto es lo que ha ocurrido con palabras como sacrificio, correligionario o martirio, vocablos de procedencia religiosa y de uso común en la actualidad (Caro Baroja, 1989: 97).

El mismo proceso se dio en la Alemania del nacionalsocialismo cuando el libro de Hitler Mi lucha fue considerado la Biblia, la guerra mundial era una cruzada, una guerra santa, una guerra santa del pueblo, en la que hubo muertos que habían caído en combate marcados por una firme fe en el Führer, al que alguna historia de la literatura alemana nombraba como un redentor de la patria. La misma palabra Reich, cuyo significado cra reino, imperio, tenía algo de solemne, de religioso, que quedaba remarcado en algunos de sus compuestos Königreich, Kaiserreich, Gotenreich. Hay que recordar que hasta 1806 Alemania pertenecía a un régimen político denominado Sacro Imperio Romano Germánico.

Pero este hecho, curiosamente, también tiene una especial incidencia en aquellas situaciones en donde el terrorismo mantiene una presencia importante, es decir, en sociedades donde ese un rasgo que define la falta de asentamiento de su democracia. Es curioso, como señalaba ya el erudito que fue Julio Caro Baroja (1989: 75), que en el lenguaje de ETA se dé este transplante del plano religioso al político:

En el vocabulario de ETA y sus partidarios, los enemigos son los perros, como en el antiguo de origen religioso, había perros moros, perros judíos o perros 
cristianos. La muerte ajena es motivo de alegría. La propia, de dolor, de acusación. La tortura, la humillación, el maltrato de los presos del grupo produce un martirologio verdadero, con su culto, aniversarios y flores en sepulturas.

Esta transfiguración religiosa «anula aún más las limitaciones a la violencia y al derramamiento de sangre al retratar a las víctimas del terrorismo como si fueran infrahumanos y no merecieran seguir viviendo» (Hoffman, 1989: 137). Por ello el terrorismo israelí y el terrorismo islamista ha hablado de hijos de Satán, de perros o de gente de barro.

Foucault apuntaba que «lo que nos dejan las civilizaciones y los pueblos como monumentos de su pasado, no son los textos, sino más bien los vocabularios y la sintaxis» (Foucault, 1968: 92). Por ello el estudio del léxico y de los significados puede dar mejor que cualquier otra investigación la imagen de la cultura de una comunidad (Pagliaro, 1957: 185). El léxico de una lengua creará su modelo de mundo y ese mundo es trasladado a la opinión pública mediante los medios de comunicación. El problema reside en que muchos componentes de ese lenguaje que se traslada a los consumidores de los medios no es neutro. C. Kerbrat-Orecchioni considera que «toda unidad léxica es, en cierto sentido, subjetiva, dado que las palabras de la lengua no son otra cosa que símbolos sustitutivos e interpretativos de las cosas" (Kerbrat-Orecchioni, 1986: 91-92). Los medios en esas situaciones contribuyen a la «construcción social de la realidad» (Berger y Luckmann, 1968) y el lenguaje es el principal instrumento en dicha labor. El lenguaje contribuirá a confeccionar una cosmovisión más o menos generalizada en los hablantes y receptores de los mensajes: la experiencia, de este modo, vendrá determinada por la función representativa del lenguaje (Hernández Sacristán, 1999: 32-35).

He aquí uno de los riesgos más peligrosos que encierra el lenguaje: porque, si el lenguaje es ideología en todos sus usos, ese lenguaje se convierte en una perfecta arma de propaganda en boca, labios o pluma de cualquiera que desee imponer sus ideas y su concepción del mundo de manera subrepticia o con el fin de ocultar aquello que ni la ley ni la ética le permitirían transmitir en un principio. Con los lastres ideológicos del lenguaje se consiguen reproducir nuestros modelos mentales, nuestros estereotipos, en definitiva nuestras creencias fundamentadas en nuestra experiencia pretérita o presente. Esos modelos mentales quedan trasladados al lenguaje y también se manifiestan en determinados comportamientos y actitudes: «el lenguaje incluye la expresión y la composición de cómo construimos (o actualizamos) los modelos mentales» (Van Dijk, 2003: 35). Los signos, las palabras no son otra cosa que el intermediario entre el hombre y algo ajeno, algo sucedido, un acontecimiento o una ideología de quien usa esos mismos signos, esas mismas palabras (Núñez Ladeveze, 1976: 266). Por ello la ideología se convierte en el gran 
regulador de las prácticas sociales que facilita la acción conjunta de los individuos, pero también su exclusión, y a su vez, supone el soporte de las relaciones de dominio y poder. Como ha señalado Van Dijk, las ideologías «proporcionan los principios con que justificar, condonar o aceptar el abuso de poder» (Van Dijk, 2003: 48).

\section{BIBLIOGRAFÍA}

Adorno, T. W. (2001): Ensayos sobre la propaganda fascista, Barcelona, Voces y Culturas.

AlthUSSER, L. (1974): «Ideología y aparatos ideológicos de Estado», en Escritos, Barcelona, Laia, 7: 30.

AmIs, M. (2004): Koba el Temible. La risa y los Veinte Millones, Barcclona, Anagrama.

BARBU, Z. (1953): «Language in Democratic and Totalitarian Societies», Orbis, 1, 33-40.

BARTHEs, R. (2002) Variaciones sobre la escritura, Barcelona, Paidós.

BERGER, P. y LUCKMANN, T. (1968): La construcción social de la realidad, Buenos Aires, Amorrortu Editores.

Caro Baroja, J. (1989): Terror y terrorismo, Madrid, Plaza y Janés-Cambio 16.

CASADO M. (1978): Lengua e ideología, Pamplona, EUNSA.

- (1985): Tendencias en el léxico español actual, Madrid, Ed. Coloquio.

- (1991): Lenguaje y cultura, Madrid, Síntesis.

Coseriu, E. (1977): Principios de semántica estructural, Madrid, Gredos.

- (1987): «Lenguaje y política», en AlVAr, M. (ed.) (1987): El lenguaje político, Madrid, Fundación Friedrich Ebert e Instituto de Cooperación Iberoamericana.

Dijk, Teun A.VAn (2003): Ideologia y discurso, Barcelona, Ariel.

Dubors, J. (1962): Le vocabulaire politique et social en France de 1869 à 1872, París, Librairie Larousse.

ESPAÑA, R. DE (2002): El cine de Goebbels, Barcelona, Ariel.

FAYE, J. P. (1974): Los lenguajes totalitarios, Madrid, Taurus.

Foucault, M. (1968): Las palabras y las cosas, México D. F, Siglo XXI Editores.

Gadamer, H. G. (1977): Verdad y método, Salamanca, Sígueme.

Guardini, R. (1981): El poder, Madrid, Ediciones Cristiandad.

Grunfeldo, V. F. (1980): Profetas malditos, Barcelona, Planeta.

IIERINÁNDEZ SACRISTÁN, C. (1999): Culturas y acción comunicaliva. Introducción a la pragmática intercultural, Barcelona, Octaedro. 
HobsBawM, E. (2003): Años interesantes. Una vida en el Xx, Barcelona, Crítica. HofFman, B. (1989): A mano armada, Madrid, Espasa-Calpe.

Hörmann, H. (1973): Psicología del lenguaje, Madrid, Gredos.

Kerbrat-Orecchioni, C. (1986): La enunciación. De la subjetividad en el lenguaje, Buenos Aires, Hachette.

KERTÉSz, I. (2002): Un instante de silencio en el paredón. El holocausto como cultura, Barcelona, Herder.

Klemperer, V. (2001): LTI. La lengua del Tercer Reich, Barcelona, Minúscula.

- (2003 a): Quiero dar testimonio hasta el final. Diarios 1933-1941, V. I, Barcelona, Galaxia Gutemberg-Círculo de Lectores.

- (2003 b): Quiero dar testimonio hasta el final. Diarios 1942-1945, V. II, Barcelona, Galaxia Gutemberg-Círculo de Lectores.

Klaus, G. (1979): El lenguaje de los políticos, Barcelona, Anagrama.

Mertens, P. (1980): «Violence institutionnelle, violence democratique et répression», en DOMENACH y OTROS (eds.): La violence et ses causes, París, UNESCO.

Migliorini, B. (1975): Parole e storia, Milano, Rizzoli Editore.

NúÑez LAdeveze, L. (1976): El lenguaje de los «media», Madrid, Pirámide.

Pagliaro, A. (1957): Corso di glottologia, Roma, Ed. Ateneo.

Poliakov, L. (1987): Auschwitz (Documentos y testimonios del genocidio nazi), Barcelona, Orbis.

RoHLFs, G. (1979): Estudios sobre el léxico románico, Madrid, Gredos.

Rossi-LANDI, F. (1974): «Programación social y comunicación», en AA.VV. (eds.) (1974): Semiótica y praxis, La Habana, Casa de las Américas.

Schaff, A. (1979): Introducción a la Semántica, México D. F. Fondo de Cultura Económica.

ShahaK, I. (2004): Historia judía, religión judía, Barcelona, Círculo de Lectores. Steiner, G. (2002): Presencias reales, Barcelona, Destino.

TAlens, J. (1980): «Práctica artística y producción significante. Notas para una discusión», en AA.VV. (eds.) (1980): Elementos para una semiótica del texto artístico, Madrid, Cátedra.

WeIsgerber, L. (1979): Dos endoques del lenguaje. Lingüística y ciencia energética del lenguaje, Madrid, Gredos 


\section{SECCIÓN II ESTUDIOS SOBRE VARIACIÓN LINGÜÍSTICA}




\title{
VARIACIÓN SINTÁCTICA Y ESTILO \\ EN EL GÉNERO PERIODÍSTICO \\ DE LAS CARTAS AL DIRECTOR
}

\author{
Miguel Ángel Aujón Oliva \\ Universidad de Salamanca
}

\section{INTRODUCCIÓN}

L

A comunicación de masas posee para el análisis sociolingüístico la ventaja tipos de interacciones recurrentes (esto es, de géneros discursivos), pero que al mismo tiempo admite la participación de una notable variedad de hablantes, el desarrollo de diversas relaciones sociales y personales entre ellos y el abordaje de muy distintos asuntos. Es fácil comprender, pues, su utilidad para el estudio del lenguaje en la estructura social, entendida ésta no como construcción estática sino como realidad dinámica en continuo proceso de negociación y cambio. Diversos estudios han analizado aspectos sociales y estilísticos del lenguaje de los medios desde una perspectiva variacionista; entre ellos podemos citar los de Bell (1984, 1999), Coupland (2001), González (1991), y, en el contexto hispánico, Cutillas Espinosa (2003) y López González (2001), entre otros.

Con todo, dentro de esta línea de investigación no tenemos noticia de muchos trabajos dedicados específicamente a las cartas al director de un periódico; pero lo cierto es que constituyen uno de los géneros de mayor interés desde el punto de vista sociolingüístico, ya que es uno de los pocos en los que con bastante frecuencia se da voz a hablantes que no pertenecen a la profesión informativa ni desempeñan necesariamente actividades liberales o intelectuales (aunque es de suponer que la mayoría de ellos poseen cierto nivel educativo). En ellas podemos discernir pautas funcionales recurrentes, que las hacen reconocibles como género; pero al mismo tiempo permiten una notable libertad temática y formal. Aquí intentaremos contribuir al estudio de la variación estilística en el nivel morfosintáctico a través de la observación de este género.

Nuestro trabajo se basa en un corpus de textos procedentes de medios de comunicación locales (radio y prensa escrita) de la ciudad castellana de Salamanca, recogidos a lo largo de los años 2003 y 2004 . La parte de prensa escrita cuenta con textos de los tres periódicos de ámbito general que se editan 
diariamente en la capital salmantina (El Adelanto, La Gaceta y Tribuna de Salamanca). Dentro de él hemos seleccionado el subcorpus de las cartas al director, que posee una extensión de unas 9.000 palabras. A pesar de su reducido tamaño, proporciona un buen número de ejemplos para el análisis, al tiempo que no constituye un material excesivo para los límites de este trabajo.

\subsection{Las careas al director y sus estilos de comunicacion}

Se trata de una forma peculiar de comunicación epistolar, pues aunque nominalmente se dirige a un destinatario concreto, el director del periódico, es necesariamente pública; ello hace, además, que con frecuencia tenga otros destinatarios explícitos, siendo la apelación a aquél un mero pretexto para que la carta se publique en el diario. Por otro lado, estas cartas tienen por lo general una clara función argumentativa, similar a la de otros géneros de la prensa como el artículo de opinión. Si bien no es tan frecuente encontrar la voluntad de elaboración formal, incluso literaria, que es típica de éste último, no cabe duda de que los recursos lingüísticos, y en particular los que poseen algún valor sociosituacional, se manipulan para contribuir a una transmisión eficiente de lo que se desea comunicar. No sorprende, pues, la relevancia que adquieren los aspectos relacionados con el estilo.

Nos parece importante destacar que en muchas cartas se observan variaciones de nivel estilístico que, en ocasiones, parecen involuntarias. Como es fácil suponer, esto ocurre sobre todo cuando el estilo pretendido es de los que habitualmente se denominan formales o cuidados. En un mismo texto podemos hallar expresiones muy escogidas junto a otras notablemente coloquiales, así como ultracorrecciones, cuando el hablante emplea giros lingüísticos que considera propios de esos estilos formales pero, quizá debido a su falta de dominio de tales estilos, comete alguna incorrección formal o semántica o una inadecuación pragmática. Assí, obsérvese este breve fragmento:

(1) Yo, debido al golpe, perdí la conciencia, pero mi padre sufrió lesiones más graves y se hubiera desangrado si no le hacen estos chicos un torniquete en la pierna izquie[r]da y lo reaniman con el boca a boca y todo eso, hasta que llegó la ambulancia. $<$ Car-Ga-221203-6a $>1$

1. Las referencias de los ejemplos siguen el sistema de codificación que empleamos para el conjunto de nuestro corpus. En primer lugar se especifica el género discursivo (en este caso, siempre $\langle$ Car $\rangle=$ carta al director), después el código del diario $(<\mathrm{Ad}\rangle=$ El Adelanto $\langle$ Ga $\rangle$ $=$ La Gaceta $; \mathrm{Tr}\rangle=$ Tribuna $)$, la fecha del ejemplar en día, mes y año, y el número de la página en que aparece la carta, seguido de una letra identificativa cuando en el corpus hay más de una carta procedente de la misma página. A ne ser que se indique lo contario, lodos los énfasis tipográficos son nuestros. 
Si bien el enunciado se inicia en un estilo semiformal, manifestado en elementos como la locución debido a o el predicado sufrió lesiones más graves, para los que existen equivalentes aproximados de tono más informal, después encontramos rasgos coloquiales como el resuntivo y todo eso o el uso del presente de indicativo por el pluscuamperfecto de subjuntivo en la prótasis condicional (si no le hacen... y lo reaniman).

Pero éstas son sólo observaciones impresionistas sobre el valor estilístico de una serie de elementos. El hecho de trabajar con variables linguísticas tal como se definen en la teoría variacionista nos ofrecerá la ventaja de un cmpirismo mucho mayor, al tratarse de fenómenos lingüísticos cuantificables y cuya relación con ciertos elementos de la situación comunicativa puede demostrarse estadísticamente. Nuestra hipótesis fundamental es que la comentada variabilidad estilística a propósito de diversos aspectos lingüísticos habrá de reflejarse también en estas variables gramaticales.

\subsection{Variables sintácticas analizadas}

En Aijón Oliva (2004) proponemos un tipo de análisis de la variación morfosintáctica basado en la suposición de que la mayor parte de sus condicionamientos, tanto intralingüísticos como situacionales o estilísticos, son efecto y a la vez causa de los valores pragmáticos y discursivos de las variantes. Nuestro análisis se centra en el subsistema de los clíticos, ámbito que resulta especialmente relevante para los estudios variacionistas, dadas las peculiares características de estos elementos, y en particular su capacidad para representar referentes con distinto grado de animación, tematicidad discursiva, énfasis pragmático, etc. ${ }^{2}$ Los fenómenos que tendremos en cuenta son los siguientes:

a) La anteposición o posposición de los clíticos en las construcciones pluriverbales que admiten ambas colocaciones (v. g. Puedo hacerlo ( Lo puedo hacer).

b) La duplicación variable del complemento indirecto (CI) de tercera persona con un clítico lelles correferencial (v. g. [Le] di un libro a Juan).

Ambas variables parecen poseer similitudes en sus pautas de correlación con elementos de la situación comunicativa, que se derivan de las citadas propiedades inherentes a los pronombres átonos. De modo general, puede

2. Nuestra visión de los clíticos españoles posee muchas conexiones con el estudio de García (1975) sobre el sistema pronominal español. Nosotros tenemos en cuenta, además, otros conceptos propios de la pragmática, el análisis del discurso y la sociolinguíística, con el objetivo de profundizar en el estudio de la variación estilística. 
afirmarse que tanto la posposición de los clíticos en las perífrasis como la ausencia de duplicación del cI son típicas de los estilos planificados y formales, particularmente del lenguaje escrito: se dan más en aquellas situaciones de mayor reflexión metalingüistica y que prefieren, por ello, las variantes supuestamente más lógicas (permanencia del clítico con su verbo regente en el primer caso; ausencia de un elemento redundante en el segundo). Ello hace que estas variantes aparezcan más a menudo cuando el hablante transmite una imagen de solemnidad o de profesionalidad; cuando sus relaciones con el interlocutor son de distancia social o personal; cuando el discurso versa sobre un tema especializado, etc.

Los valores opuestos se dan en el caso de la anteposición de los clíticos en las perífrasis y de la duplicación del cla ambas son más frecuentes en estilos orales o menos planificados, se emplean para la configuración de imágenes casuales y de relaciones interpersonales de tipo informal o amistoso, para el tratamiento de temas cotidianos, etc. ${ }^{3}$

En un nivel pragmático-discursivo, es importante señalar que con las primeras variantes se concede mayor rematicidad a los referentes de los clíticos, se destaca su carácter de información nueva (y por ello, frecuentemente, su carácter objetucal), mientras que sus opuestas tienden a tematizar dichos referentes, a hacer que se consideren más presupuestos en el discurso (lo que es más propio de los referentes humanos). Estos valores comunicativos constituyen, a nuestro entender, una clave de las pautas de variación observadas: los distintos tipos de situaciones potencian el recurso a distintos significados pragmáticos. Podemos condensar lo expuesto en el siguiente cuadro:

\section{CuAdro 1}

\begin{tabular}{|l|l|l|}
\hline Variantes & $\begin{array}{l}\text { Valores } \\
\text { pragmático-discursivos }\end{array}$ & $\begin{array}{l}\text { Valores } \\
\text { estilísticos o situacionales }\end{array}$ \\
\hline $\begin{array}{l}\text { Anteposición } \\
\text { de los clíticos }\end{array}$ & $\begin{array}{l}\text { Menor énfasis en el sujeto } \\
\text { y el objeto como agente y } \\
\text { paciente/beneficiario }\end{array}$ & $\begin{array}{l}\text { Estilos menos planificados } \\
\text { más informales, sobre todo } \\
\text { orales }\end{array}$ \\
duplicación \\
del CI
\end{tabular}

3. Aijún Oliva M. A. (2005): paia la presentación y discusión de estos datus en nuestro corpus, así como para referencias de otros trabajos cuantitativos sobre estas variables. 


\begin{tabular}{|l|l|l|}
\hline Variantes & $\begin{array}{l}\text { Valores } \\
\text { pragmático-discursivos }\end{array}$ & $\begin{array}{l}\text { Valores } \\
\text { estilísticos o situacionales }\end{array}$ \\
\hline $\begin{array}{l}\text { Posposición de } \\
\text { los clíticos }\end{array}$ & $\begin{array}{l}\text { Mayor énfasis en el sujeto } \\
\text { paciente/beneficiario }\end{array}$ & $\begin{array}{l}\text { Estilos con elevada } \\
\text { planificación, más formales, } \\
\text { sobre todo escritos }\end{array}$ \\
y & $\begin{array}{l}\text { Mayor fuerza pragmática } \\
\text { de los enunciados, } \\
\text { del CI }\end{array}$ & $\begin{array}{l}\text { Imágenes de competencia } \\
\text { o seriedad, relaciones de } \\
\text { distancia, etc. }\end{array}$ \\
\hline
\end{tabular}

Aquí analizaremos cualitativamente algunos de estos valores situacionales tal como se manifiestan en textos reales pertenecientes a un género discursivo específico, al tiempo que intentaremos mostrar cómo las variables cooperan entre sí y con otros rasgos formales y semánticos para el logro de diversos propósitos comunicativos. Como se ha afirmado, los estilos lingüísticos no pueden describirse adecuadamente a través de uno solo o de unos pocos fenómenos, sino como tendencia a la coaparición de una serie de ellos (Finegan y Biber, 2001, entre otros).

\section{ANÁLISIS DE LA VARIACIÓN ESTILÍSTICA}

Siguiendo el modelo desarrollado en Aijón Oliva (2003), creemos que, en el estado actual de las investigaciones sobre lenguaje y situación, es conveniente mantener la consideración de ésta última como un complejo de elementos sociocognitivos interrelacionados que pueden resultar relevantes de cara a una elección lingüística, incluyendo entre ellos la propia intencionalidad del hablante (también Yaeger-Dror, $2001 \mathrm{y}$, desde un punto de vista etnográfico, Duranti, 2000, entre otros). Estamos de acuerdo con Bell (1984), Coupland (2001) y otros autores en que, por lo general, los aspectos más relevantes son aquéllos directamente relacionados con los participantes, y de modo especial las imágenes personales y sociales que estos configuran a través del lenguaje. Por esta razón, atenderemos principalmente a dos aspectos parcialmente distintos pero muy relacionados: la imagen de sí mismo que desarrolla el autor de una carta, y la relación que se establece entre ésta y la imagen otorgada al destinatario explícito de la misma. 


\subsection{La imagen propia configarada por el hablante}

Es importante para quien escribe una carta a un diario el desplegar, a través del uso linguíístico, una determinada visión de sí mismo. De hecho, las cartas ni siquiera se firman siempre con el nombre de su autor: pueden ser anónimas, pueden llevar la firma de un grupo o una institución, etc. Asimismo, el autor puede optar por añadir a su nombre títulos profesionales o caracterizaciones, o incluso sustituirlo por éstos; en nuestro corpus encontramos casos como médico, una alumna de $6^{\circ}$ de Primaria, Vicepresidente, Vicario General, etc. La aparición de datos como éstos difícilmente puede considerarse casual, y resulta muy indicativa de cómo el hablante desea presentarse ante quienes espera que lean su carta. Pero esta presentación se ve generalmente respaldada por la configuración formal del texto de la carta y, a su vez, por las variables morfosintácticas con valor estilístico.

El siguiente ejemplo pertenece a una carta firmada por una asociación local. En ella encontramos tres casos de posposición de los clíticos y dos de ausencia de duplicación del $\mathrm{Cl}^{;}$; esto es, hay un evidente predominio de las variantes que hemos señalado como propias de los estilos planificados y formales. Podemos entender tal preferencia como un medio semiótico del autor o autores para dotar a esta asociación de una imagen de seriedad o de competencia en la materia tratada, dado que dichas variantes se relacionan cuantitativamente con estos valores. Entre los casos de posposición de clíticos encontramos incluso uno con el se de pasiva refleja (pueden resolverse), contexto que, como se ha observado en otros trabajos, favorece claramente la anteposición:

(2) La Junta de Castilla y León comenzó a pagar $\emptyset$ hace unos meses a un médico de Atención Primaria de nuestra provincia 3,5 veces más que a los demás $|\ldots|$ Es la consecuencia de una sentencia judicial que condena por incomparecencia a la Junta de Castilla y León a pagar a este médico las horas de guardia como si fueran horas extraordinarias. $[. .$.$] consideramos que dichos problemas no pueden$

4. También hay un caso de duplicación, «se lo dieron por ganado a la parte demandante», que se explica sin duda por la elevada frecuencia de esta variante cuando aparece un clítico de complemento directo ( $y$ el de cr adopta, por ello, la forma se). Se ha afirmado a menudo que la variación de tipo intralingüístico normalmente tiene precedencia sobre la social y la situacional, o bien que las posibilidades de variación de estos últimos tipos se hallan contenidas en los límites de la variación interna. Aunque esto nos parezca sustancialmente correcto, debe hacerse alguna matización: como señala Wolfram (1993), una variable definida sociolingiiústicamente puede comprender más de un fenómeno del sistema lingüístico. Y es claro que la intencionalidad estilística del hablante puede invertir tendencias muy fuertes de la valación intena y llevar a soluciones poco frecuentes, como la posposición del clitico se en su valor impersonal o de pasiva refleja, que veremos en el ejemplo. 
resolverse por vía individual y aprovechando la incompetencia de quien debió presentarse a un juicio a defender el dinero público. Quien sea el responsable de tal escándalo debe dar explicaciones públicas y dimitir [...] y los que se queden al mando deben plantearse que el mayor activo de la Sanidad Pública son sus profesionales <Car-Ad-221203-6a>

Como veremos algo más abajo, también la intención polémica de la carta puede haber favorecido la preferencia por estas variantes; distintos elementos de la situación comunicativa cooperan para potenciar ciertas soluciones. Por otro lado, cuando se pretende una imagen más casual, como en aquellos casos en que el autor pretende expresar los problemas, preocupaciones e intereses del ciudadano común, las variantes de anteposición de clíticos y duplicación del CI son claramente las preferidas.

(3) ... ese mismo día me informan que se pueden comprar pero sólo vía telefónica. [...] Me quieren decir, ¿que yo que llamé de las primeras me corresponde la fila 9? Resulta que el número de filas numeradas son 15, ¿qué pasa con todas las que tengo delante?, ¿estaban todas reservadas?, ¿le han dado mis entradas a gente que ha llamado detrás de mí? <Car-Ga-051104-6>

\subsection{Interacción con la imagen del interlocutor}

Parece claro que el aspecto más relevante para explicar muchos casos de variación de estilo son las relaciones que se establecen y negocian progresivamente entre los hablantes que participan en una interacción. Es cierto que, en el caso de las cartas aparecidas en la prensa, no hay por lo general verdadera interacción (sería necesario que las cartas tuvieran una respuesta, lo que rara vez ocurre), sino que es únicamente el autor de la carta quien delinea las características de la relación con sus destinatarios, sin que estos últimos tengan la posibilidad de alterarlas o matizarlas. Es, pues, interesante observar cómo se efectúa tal delineación.

Ahora bien, el contacto en sociedad puede abordarse científicamente de muchas maneras y teniendo en cuenta aspectos muy distintos: diferencia o igualdad de estatus social, adscripciones grupales, conocimiento previo y empatía personal, etc. Todos ellos pueden ser relevantes en casos concretos, pero no resulta fácil relacionarlos en una teoría de valor general que pueda trascender la mera descripción de ejemplos. Uno de los intentos más valiosos de desarrollar una teoría sobre las relaciones humanas a través del lenguaje es el de los trabajos sobre la cortesía, procedentes de la pragmática pero con una clara aplicación sociolingüística. Los imperativos de la cortesía llevan al hablante, por lo general, a la búsqueda y preservación de una imagen positiva tanto para sí mismo como para su interlocutor, para asegurar que la interacción 
se desarrolla de manera socialmente aceptable; en otros casos, sin embargo, puede buscarse un enfrentamiento, si eso es lo que requieren los fines comunicativos. ${ }^{5}$ Todo ello se refleja con frecuencia en las variables sintácticas analizadas. Así, en las situaciones de polémica no existe interés por evitar el énfasis en los referentes de los clíticos y preservar con ello sus imágenes; se prefieren, por tanto, las variantes de la posposición y la ausencia de duplicación. Ya en el cjemplo (2) hemos podido intuir cómo no sólo la imagen pretendidamente seria y eficiente de la asociación que firma la carta, sino también la intención de polemizar con las instituciones públicas, pueden haber favorecido el predominio de esas variantes. Veamos ahora otros dos ejemplos claros, el primero con posposición del clítico y el segundo con ausencia de duplicación del cr:

(4) Quiero que Ana vea lo confundida que está al catalogar de bodrio al cine nacional. Como devorador de cine que soy, tengo que decitle que no he encontrado todavía una película extranjera que me haga llorar <Car-Ad-290704-6a>

(5) Con todo respeto $\emptyset$ pido a los periodistas que toquen temas de su especialidad o que conocen en profundidad <Car-Ad-170504-6>

La expresión con todo respeto en (5) demuestra que se plantea una tensión interactiva. Por el contrario, cuando el tono es amistoso, hay una mayor tendencia a las variantes supuestamente informales: en (6) vemos la preferencia por la duplicación del $\mathrm{Cl}$.

(6) Sólo le pido eso a los Reyes Magos, pero sé que poniendo un poquito de nuestra parte nosotros también podemos conseguirlo <Car-Ga-221203-6b>

Dicha variante (con un le empleado como plural, rasgo también más típico del lenguaje coloquial) contribuye a transmitir ese tono amistoso a la relación entre la hablante y los destinatarios de su petición. Con todo, en el mismo fragmento encontramos un caso de posposición del clítico, que en principio se relacionaría con valores interactivos diferentes. Es obvio que no son las ocurrencias aisladas de las variantes, sino el predominio relativo de unas u

5. Llevaría mucho espacio discutir los diversos conceptos de cortesía y de imagen (face) desarrollados a lo largo de veinticinco años desde Brown y Levinson, que a su vez recogen elementos de los trabajos de Groffman sobre la negociación de imágenes. En conjunto, estamos de acuerdo con la reciente propuesta de Watts (2003), que apuesta por acercar el concepto científico de cortesía a las percepciones del hablante común sobre lo que es cortés y lo que no, en una visión más etnográfica que universalista, y muestra el escaso fundamento empírico de la habitual distinción entre imagen positiva y negativa. 
otras en géneros discursivos o tipos de situaciones, lo que define los estilos de comunicación; además, a lo largo de un mismo enunciado o párrafo es posible transmitir significados pragmáticos diferentes, lo que se reflejará en la sintaxis.

\subsection{Otros elementos de la situación}

Aunque los factores estilísticos que hemos tenido en cuenta pueden dar cuenta de muchas elecciones lingüísticas de los hablantes, es necesario reconocer que no agotan la lista de aspectos que en un caso concreto pueden llevar a dichos hablantes a emplear cierto estilo de habla. De hecho, desde una perspectiva agentiva del estilo podríamos afirmar que los factores situacionales son tantos como significados puede querer transmitir un hablante. No hay más que pensar en aspectos tan elusivos como el tono o clave de un discurso y todos los matices que puede poseer. En (7), el tono lúdico o sarcástico lleva a la aparición de un clítico que es a la vez un caso de anteposición en una construcción verbal y de duplicación del cr:

(7) No se preocupe si algún personajillo queriéndole hacer la gracia al jefe, para hacer de la política una profesión, y no un servicio... <Car-Ga-310104-6>

Frente a ello, cuando el tono es serio y trascendental se tiende a preferir las variantes opuestas, con su mayor fuerza pragmática:

(8) España $\emptyset$ da la espalda a su propia historia. Nuestros héroes republicanos seguirán sintiéndose apátridas. <Car-Tr-260804-7b>

Recordemos, por otra parte, nuestras consideraciones precedentes sobre la vacilación estilística de muchos hablantes. Obsérvese lo que ocurre en esta carta, cuyo destinatario explícito es el alcalde de la ciudad:

(9) Como aficionado viejo a los toros, le quiero manifestar que las tradiciones están hechas para cumplirlas [...] Dice que no tiene competencia para cerrar el comercio por la tarde pero sí quiere imponemos a todos las corridas en los días que usted desea $[. .$.$] Menos mal que reconoce que no es un «enterao» taurino,$ porque mira que recomendar $\emptyset$ a Chopera que traiga miuras, domecq o pablos romero... <Car-Ga-070404-6a>

En la carta encontramos un caso de anteposición del clítico (le quiero manifestar) y otro de posposición (quiere imponernos), ambos con el mismo verbo regente. El que ello ocurra en un similar contexto lingüístico 
y con un mismo tono polémico puede interpretarse como vacilación. ${ }^{6}$ Hay también una ausencia de duplicación de Cl (recomendar a Chopera), especialmente significativa por ser el sintagma nominal correspondiente un nombre propio humano, contex to en el que la duplicación es con mucho la solución más habitual. Se inserta además en un enunciado de tono coloquial, con términos como enterao y expresiones enfáticas como mira que; la variante elegida puede, pues, resultar un tanto contradictoria con ese tono predominante.

La falta de control estilístico se relaciona de manera muy estrecha con aspectos como el nivel sociocultural de los hablantes: la carencia de destreza en géneros discursivos como el de las cartas al director, género de carácter público y de naturaleza inhercntemente planificada, puede llevar a soluciones lingüísticas que no son las esperables según las pautas de este tipo de interacción. Es fácil intuir la conexión de estas afirmaciones con la teoría de Finegan y Biber (2001) sobre la relación entre la variación sociodemográfica y la estilística: los diversos gupos sociales muestran una mayor frecuencia de aquellas variantes que son a su vez más típicas de las interacciones comunicativas en que sus miembros suelen tomar parte. Esta propuesta, si se evita en ella toda posible orientación valorativa, puede ser adecuada como conceptualización de las relaciones entre los diversos tipos de variación sociolingüística.

\section{CONCLUSIONES}

Hemos observado cómo los valores pragmático-discursivos de los pronombres átonos pueden rentabilizarse estilísticamente en la interacción social. Parecen ser relevantes los aspectos relacionados con la cortesía; el hablante tiende a preferir las variantes que tematizan o restan énfasis a los referentes humanos (anteposición del clítico y duplicación del $\mathrm{Cl}$ ) cuando

6. Aun así, también sería posible acudir al factor interno de la topicalidad o animación (Myhill, 1989), según el cual el clítico tiende a anteponerse cuando su referente es más tópico, más presupuesto en la situación discursiva, que el referente del sujeto. Según Myhill, en español la segunda persona gramatical parece ser más tópica que la primera. Ello explicaría bien nuestros dos ejemplos: en le quiero manifestar se antepone el clítico porque su referente, usted, es más tópico que el sujeto yo; por el contrario, en quiere imponemos el sujeto usted es más tópico que el objeto nos, y por ello no hay anteposición de este último. De cualquier forma, no parece haberse demostrado claramente que en español, a diferencia de lo que ocurre en otras lenguas, la segunda persona sea más tópica que la primera. Además, la forma usted posee características especiales que la acercan a la tercera persona, y de hecho su duplicación con clíticos no es tan categórica como la de los otros pronombres tónicos (Aijón Oliva, $2005 a$ ). 
quiere evitar un daño potencial para su propia imagen o para la de su destinatario explícito. Por el contrario, cuando se plantea algún tipo de polémica es más habitual que se destaquen esos mismos referentes a través de las variantes opuestas. Y todo ello se relaciona de manera estrecha y compleja con otros elementos de la situación comunicativa, tales como la imagen personal delineada por el hablante o lo que podríamos denominar tono interactivo.

La discusión precedente deja claro que el análisis de la variación de estilo es un campo de la sociolingüística en el que resulta especialmente necesaria la conjunción del análisis cuantitativo con los enfoques interaccionalistas. Al lado de la fundamentación empírica que proporcionan los datos estadísticos, es importante analizar, con la ayuda de nuestro conocimiento sociológico y etnográfico, qué significados intentan transmitir los hablantes en la comunicación (en este caso, comunicación epistolar y pública, pero también en cualquier otro tipo de interacción) y qué papel desempeñan las variables sociolingüísticas en su transmisión. Se trata de un campo en el que pueden lograrse grandes avances para la comprensión de las relaciones entre forma lingüística, significado pragmático y comunicación social.

\section{REFERENCIAS BIBLIOGRÁFICAS}

Aijón Oliva, M. A. (2003): La situación comunicativa: Propuesta de un modelo formal sociolingüístico, Trabajo de Grado, Universidad de Salamanca.

- (2004): «On Pragmatic and Communicative Meanings as an Explanation of Syntactic Variation: Two Cases with Spanish Clitics», comunicación presentada en el XXXIII Congreso NWAV, Ann Arbor, University of Michigan.

- (2005a): «Presencia o ausencia del clítico pleonástico del complemento indirecto: algunos factores lingüísticos y situacionales», Interlingüística, 15: 93-104.

- (en prensa $b$ ): «Los clíticos en las perífrasis de infinitivo y gerundio: algunos aspectos de variación situacional» en Actas del VI Congreso de Lingüística General.

BeLl, A. (1984): «Language Style as Audience Design», Language in Society, 13: 145-204.

- (1999): «Styling the Other to Define the Self: A Study in New Zealand Identity Making», Journal of Sociolinguistics, 3: 523-541.

Coupland, N. (2001): «Dialect Stylization in Radio Talk», Language in Society, 30: 345-375. 
Cutullas Espinosa, J. A. (2003): «Variación estilística en los medios de comunicación: Una aproximación cuantitativa a la teoría del diseño de la audiencia», Tonos Digital, 5 [http:// www.tonosdigital.com; consulta: 2-7$2004]$.

Duranti, A. (2000 [1997]): Antropología lingüistica, Madrid, Cambridge University Press.

ECKERT, P; J. R. RICKFORD (eds.) (2001): Style and Sociolinguistic Variation, Cambridge, Cambridge University Press.

Finegan, E.; D. Biber (2001): «Register Variation and Social Dialect Variation: The Register Axiom» en ECKERT, P.; J. R. RickFord (eds.) (2001).

GarCiA, E. C. (1975): The Role of Theory in Linguisicic Analysis: The Spanish Pronoun System, Amsterdam, North-Holland.

González, A. B. (1991): «Stylistic Shifts in the English of the Philippine Print Media» en Cheshre, J. (ed.) (1991): English around the World: Sociolinguistic Perspectives. Cambridge, Cambridge University Press.

López GonzÁlez, A. M. (2001): El lenguaje radiofónico de la ciudad de Almería: Estudio sociolingiiístico, Tesis doctoral, Universidad de Almería. MYHILL, J, (1989): «Variation in Spanish Clitic Climbing» en WaLsH, T. J. (ed.) (1989): Synchronic and Diachronic Approaches to Linguistic Variation and Change (GURT '88), Washington DC, Georgetown University Press.

WatTs, R. J. (2003): Politeness, Cambridge, Cambridge University Press.

Wolfram, W. (1993): «Identifying and Interpreting Variables», en PRESION, D. R. (ed.) (1993): American Dialect Research. Amsterdam/Philadelphia, John Benjamins.

YAeger-Dror, M. (2001): "Primitives of a System for "Style" and "Registcr"», cn ECKERT, P.; J. R. RICKFORD (eds.) (2001). 


\title{
ESTUDIO DE ACTITUDES Y CREENCIAS LINGÜÍSTICAS EN ALCALÁ DE HENARES. SU APORTACIÓN AL ANÁLISIS SOCIOLINGÜÍSTICO DE LOS DATOS
}

\author{
ana Blanco Canales \\ Universidad de Alcalá
}

\section{MARCO GENERAL DE LA INVESTIGACIÓN}

$\mathbf{E}$

L trabajo que aquí presentamos forma parte de una investigación más

amplia cuyo objetivo final fue el análisis sociolingüístico del habla de Alcalá, comunidad de gran interés por la situación de contacto de dialectos que vive desde hace ya cinco décadas.

Los objetivos fundamentales que perseguimos fueron, de un lado, analizar y describir las características de la fonética y de la morfosintaxis del habla de Alcalá y su relación con diversos factores lingüísticos y extralingüísticos, y de otro, examinar en qué fase de evolución se hallaban algunos procesos de gran difusión en el español, en especial, los de debilitamiento fonético y los de simplificación. En relación con esto último, nos pareció interesante intentar reconocer y valorar cuáles eran los posibles cambios en marcha y la dirección que estaban tomando, así como determinar la influencia ejercida por las hablas de los nuevos habitantes en el desarrollo de todos los fenómenos descritos.

Con el fin de ayudar a la consecución de estos objetivos, la investigación contó, como herramienta auxiliar de interpretación de los datos, con un estudio de creencias y actitudes lingüísticas, cuyos resultados presentaremos a lo largo de esta exposición.

No obstante, antes, es conveniente conocer algunos datos sobre Alcalá de Henares, fundamentales para entender el estudio de actitudes realizado.

\section{ALCALÁ DE HENARES}

Alcalá de Henares es una localidad situada a 30 kilómetros de Madrid. En ella conviven individuos de procedencia geográfica muy diversa, lo que, en determinado momento, propició el contacto de dialectos y el desarrollo de diferentes procesos de cambios lingüísticos. La población autóctona está en 
notable desventaja, pese a lo cual, ha sido la que ha impuesto su modelo lingüístico. La razón hay que buscarla en un sentimiento de orgullo del alcalaíno por pertenecer a esta ciudad, sentimiento que ha perdurado a través del tiempo, y que ni siquiera la decadencia de la ciudad tras el traslado de la Universidad a Madrid pudo hacer desaparecer, a pesar de que Alcalá perdiera el último reducto de su esplendor y se transformara en un pequeño centro rural, cuyo deterioro se fue acentuando con los años. Este proceso de ruralización se vio frenado en la década de los sesenta. Por esos años, Madrid comenzaba a presentar problemas de superpoblación. Con objeto de descongestionar la capital, la Administración central eligió el corredor Madrid-Guadalajara, al que pertenece Alcalá, como zona de industrialización. En pocos años, nuestra ciudad dejó de ser una zona estructurada en tomo a una mediocre agricultura y a una actividad industrial muy pobre y se convirtió en una importante zona de desarrollo económico. El resultado inmediato fue el aumento demográfico: en treinta años la población creció un 536 por cien (pasó de 25.123 habitantes a 159.723). El origen geográfico de los inmigrantes era muy variado, aunque predominaban con claridad castellanos, andaluces y extremeños. El alcalaíno acogió con agrado los cambios que la ciudad estaba experimentando, pues fueron años de auge y bienestar que supusieron una notable mejoría de su calidad de vida. En la actualidad, por el contrario, un sector importante de la población considera que la llegada masiva de inmigrantes y la desmedida industrialización han perjudicado gravemente a la ciudad. De esta forma, lo que en un principio fue entusiasmo y satisfacción, se ha transformado ahora en rechazo, tanto social como lingüístico.

\section{METODOLOGÍA DE LA INVESTIGACIÓN}

Las características socio-demográficas de Alcalá de Henares nos aconsejaron trabajar sobre una muestra de hablantes alcalaínos basada en el concepto de red social. Esto abría nuevas perspectivas a la investigación, pues nos permitía poner a prueba un concepto de interés en la obtención de materiales y, especialmente, en la explicación de hechos lingüísticos.

La red social con la que trabajamos en Alcalá de Henares estaba formada por 24 hablantes además del punto de anclaje, todos nacidos en esta ciudad con la excepción de los informantes 2 y 4 , de origen extremeño, que vinieron aquí durante su primer año de vida. De estas 24 personas, 13 eran mujeres y 11 hombres, con edades comprendidas entre los 16 y 84 años. No existía dentro de la red diversidad social relevante, pues todos sus miembros pertenecian a las clases baja y media-baja; sin embargo, si manifestaba diversidad en cuanto al nivel de instrucción. Así, encontramos desde 
informantes analfabetos o semi-analfabetos hasta otros con estudios superiores.

Para la obtención de los materiales de habla que serían objeto de nuestro estudio se utilizaron dos técnicas diferentes: la observación participativa y la entrevista, siguiendo muy de cerca la estrategia utilizada por W. Labov (1972) en su estudio de Harlem. Al igual que él, nos servimos también de dos exploradores, uno que pertenecía a la red y otro que estaba fuera de ella (la autora), con lo que quedó resuelta la problemática cuestión de introducirse en una red ajena y lograr el grado de confianza necesario para ser considerado prácticamente como parte suya.

Gracias a la primera de estas técnicas conseguimos una gran cantidad de material de habla espontánea, además de mucha información de carácter etnográfico. Con la segunda, la entrevista, pudimos obtener, por un lado, habla formal y, por otro, información para el análisis de creencias y actitudes. Este estudio nos permitió complementar los datos obtenidos por otras vías y supuso una ayuda fundamental en la interpretación de los resultados.

\section{ANÁLISIS DE CRENCIAS Y ACTITUDES}

El análisis de creencias y actitudes ha demostrado ser crucial para la investigación sociolinguística, por lo que está siendo incorporado a diferentes trabajos dentro de esta disciplina.' Problemas como el cambio lingüístico, situaciones de lenguas o dialectos en contacto, aprendizaje de segundas lenguas, pueden ser esclarecidos a través de un estudio de las actitudes de los hablantes; las planificaciones lingüísticas, siempre complejas, pueden beneficiarse y ser instrumentos eficaces con la ayuda de este tipo de estudios.

Desde la Etnografía de la Comunicación se ha puesto gran énfasis en esta cuestión, ya que se considera de primera importancia el sistema de valores compartidos por la comunidad para la investigación del proceso comunicativo (Saville-Troike, 1982). La misma definición de comunidad pasa por la consideración de las actitudes. ${ }^{2}$ Sin embargo, pese a que son numerosos los trabajos que de una u otra forma abordan el tema, la bibliografía específica es todavía insuficiente. ${ }^{3}$

1. Para el español, véanse los trabajos de I. Molina Martos (1998) o P. Martín Butragueño (1991).

2. En las definiciones labovianas de comunidades lingüísticas las actitudes desempeñan un papel importantísimo.

3. Un clásico es el artículo de R. Agheyisi y J. Fishman (1970: 137-157). Otras revisiones sobre la cuestión pueden verse en H. López Morales (1989: 231-242); y F. Moreno (1988: 91-110). 


\subsection{Cuestiones metodológicas: recogida de materiales}

La recogida de los datos tuvo lugar durante la entrevista que realizamos como exploradores externos. Se trataba de una encuesta parcialmente dirigida, de estructura abierta, de forma que los informantes pudieran decir todo aquello que creyeran oportuno sobre el tema. Esta modalidad presenta el gran inconventente de que las respuestas no son homogéneas, por lo que no pueden someterse a una cuantificación matemática muy cstricta. No obstante, optamos por ella porque para el informante es más fácil y todas las respuestas son válidas. Hemos comprobado que este tipo de preguntas suscita en muchos sujetos cierta incomprensión y mala interpretación. Con un cuestionario cerado algunas respuestas se deberían al azar y a un deseo de «salir del paso» (si no comprenden bien la pregunta, difícilmente la respuesta corresponderá con su opinión). Por el contrario, con la técnica que utilizamos, podíamos fomular de nuevo la pregunta cuando nos percatábamos de un error en la comprensión e insistir en ella -con moderaciốn- hasta aseguramos de que su contestación se ajustaba a nuestra demanda.

Para el análisis, agrupamos las respuestas similares y las distribuimos, cuando fue posible, por variables. El cálculo se limitó a los porcentajes para cada caso. Por lo demás, nuestras valoraciones y apreciaciones fueron de tipo cualitativo. En nuestra investigación, el estudio de actitudes y creencias constituyó una herramienta fundamental para la interpretación de los datos, pero no fue en sí el objeto final del trabajo. A través de esta incursión en la interioridad de nuestros hablantes, quisimos obtener informacion sobre el sistema de creencias a propósito de sus propias hablas y las de sus conciudadanos y ver a qué tipo de actitudes, positivas o negativas, daban lugar tales creencias. Ello nos ayudaría a detectar cuáles eran los hechos linguísticos cstigmatizados y cuáles otros gozaban de prestigio (cxplícito o implícito). A partir de aquí, podríamos examinar con mayor claridad la dirección que estaban tomando los cambios en marcha y valorar cuál era la tendencia que mostraba mayor presión sobre el habla de los alcalaínos, si era el desprestigio de ciertas variedades lingüísticas $-y$ por lo tanto, la defensa de su norma- o la firme expansión de algunos fenómenos, apoyada tanto en el peso numérico de los hablantes como en la propia evolución interna de la lengua.

\subsection{Análisis de los datos}

1. ¿Cómo cree que hablan los alcalainos? ¿Por qué?

El $64 \%$ de los informantes opina que los alcalaínos hablan bien o muy bien. Cuando les pedimos que explicaran-por-qué-lo_consideran-así, coincidieron en 
señalar que hablan «un castellano normal, sin acentos», «que se les entiende bien», «que pronuncian todas las letras», «que no sesean ni cecean».

Las restantes respuestas quedaron divididas como a continuación reflejamos:

- Regular: $5.8 \%$

- Igual que en todos los sitios: $11.7 \%$

- No sabe: $17.6 \%$

Ningún informante consideraba que en Alcalá se hable mal o peor que en otros lugares. En cuanto a la distribución de las respuestas, no existen diferencias en función de la edad, sexo o nivel de instrucción.

2. Alcalá está a la misma distancia de Madrid que de Guadalajara. ¿A qué lugar se parece más en la forma de hablar?

Los datos obtenidos no dejan lugar a dudas sobre el prestigio de la norma madrileña y la estigmatización de las hablas alcarreñas, asociadas siempre a los pueblos, con los que Alcalá ha mantenido constante relación. El ser centro de la comarca y contar con numerosos servicios ha hecho que los contactos que esta ciudad mantiene con los pueblos de Guadalajara sean mucho más frecuentes que los que establece con Madrid.

E1 77.7\% opina que el habla de Alcalá es igual o muy semejante a la de Madrid; el 5.5\% mantiene una postura más objetiva al señalar que tiene cosas de ambas; el mismo porcentaje dice no saber responder porque desconoce la cuestión; y el $11.1 \%$ ha señalado que no ha notado diferencias entre el habla de la capital y la de Guadalajara. En ningún caso se ha afirmado que la variedad lingüística alcalaína se asemejara a la alcarreña.

Tampoco en este caso sobresale especialmente ninguna de las variables sociales consideradas.

3. ¿Hablan mejor los alcalaínos o los que han venido de otros lugares?

Con las respuestas obtenidas hemos formado tres grupos, aunque el último es casi anecdótico, dada su escasa incidencia:

- Hablan mejor los alcalaínos: 48\%

- No sabe, son diferentes: $48 \%$

- Hablan mejor los de fuera: $4 \%$ 
Los dos grandes grupos en que quedan divididas las respuestas cuentan con informantes de todas las variantes sociales en proporciones similares. Sólo la variable nivel de instrucción manifiesta cierta relevancia, pues ofrece porcentajes opuestos. Así, entre los que han señalado que en Alcalá se habla mejor, el $62.5 \%$ pertenece, por su nivel educacional, al grupo A (instrucción elemental) y el $37.5 \%$, a los grupos B (instrucción media) y C (instrucción superior). La situación contraria la encontramos entre los agrupados en la segunda respuesta: el $62.5 \%$ posee una formación media o superior frente al $37.5 \%$, de nivel hajo.

\section{Entre los inmigrantes, ¿quiénes son los que hablan peor?}

Extremeños y andaluces se reparten por igual la mayoría de las respuestas (el $30.4 \%$ cada uno). El $13 \%$ ha señalado otros puntos geográficos (catalanes y gallegos - cuando hablan castellano-, pueblos de Castilla), pero, incluso en estos casos, con la excepción de un informante, se menciona también Andalucía y/o Extremadura. El 26\% ha mostrado su disconformidad con la relación entre el origen geográfico y la calidad del habla, pues «no hay hablas mejores o peores, son simplemente diferentes».

La mayoría de las mujeres $(80 \%)$ coincide en calificar a extremeños y/o andaluces negativamente; entre los hombres, sin embargo, existe mayor diversidad de opiniones. Los informantes que han indicado que las hablas no pueden ser comparadas en términos de calidad se caracterizan socialmente por pertenecer a la primera y segunda generación ( $83.3 \%$ y $16.6 \%$ respectivamente).

5. ¿Hablan igual los hombres que las mujeres? ¿Quiénes hablan mejor?

Las respuestas se han agrupado en cuatro apartados:

- No hay diferencias: $66.6 \%$

- Hablan mejor los hombres: $16.6 \%$

- Hablan mejor las mujeres: $11.1 \%$

- Distinto, pero ni mejor ni peor: $5.5 \%$

Como vemos, el porcentaje de los que consideran que el habla de hombres y mujeres es igual es considerablemente más alto que el resto. Los informantes puntualizaron sus opiniones y, en muchos casos, aludieron al cambio habido en las últimas décadas y que ha desembocado en la igualdad entre ambos sexos, hecho que se ha puesto también de manifiesto en sus formas de hablar.

En cuanto a la distribución de las respuestas por variables sociales, sólo cabe destacar dos aspectos: a) todos los que han encontrado diferencias en 
función del sexo, tanto a favor de los hombres, como de las mujeres, o sencillamente distintas, pertenecen a la primera generación, y dentro de ella, constituyen el grupo más joven; y b) el $100 \%$ de los que valoran positivamente el habla femenina son mujeres, y el $75 \%$ de los que de los que inclinan la balanza a favor del habla masculina son hombres.

Por otra parte, las mujeres establecen una relación entre grado de educación y lengua, mientras que son los hombres quienes, generalmente, aluden a la igualación actual, al pasado y reseñan que, entonces, las mujeres hablaban peor.

6. ¿Hablan igual las personas jóvenes que las mayores? ¿Quiénes hablan mejor?

Esta ha sido la cuestión donde ha habido un reparto más equitativo entre las respuestas:

- No hay diferencia: $23.5 \%$

- Hablan mejor los jóvenes: $23.5 \%$

- Hablan mejor los mayores: $29.4 \%$

- Ni mejor ni peor, distinto: $17.6 \%$

- No sabe: $5.8 \%$

Quienes consideran que el habla de los jóvenes es mejor justifican sus respuestas apelando a razones de índole cultural: han tenido acceso a una más larga y profunda educación. Los que opinan de forma contraria, se basan en el empobrecimiento léxico, los numerosos tacos y las limitaciones expresivas de la juventud.

7. ¿Cree que desde que ha llegado tanta gente de otros lugares ha cambiado el habla de Alcalá?

Hemos distribuido las respuestas en tres grupos:

- Sí ha cambiado: $46.5 \%$

- No ha cambiado: $38.46 \%$

- No sabe: $15.38 \%$

Muchas de las respuestas están basadas más en las suposiciones de nuestros informantes que en sus comprobaciones. Con frecuencia han matizado su contestación señalando «por lógica», «lo más normal», etc.; esto se da especialmente entre los que respondieron afirmativamente.

Sólo la variable nivel de instrucción parece tener algo de significación en la estratificación de las respuestas: entre los que creen que sí ha habido 
influencia predominan claramente los informantes del nivel de educación superior $(66.6 \%)$; el resto (33.3\%), lo componen individuos de formación media. Los que no creen que exista influencia alguna poseen formación elemental $(60 \%)$ o media $(40 \%)$.

\section{CONCIISIONES}

El primer aspecto que pone de manifiesto el análisis de los datos es la alta valoración que el alcalaíno hace de su modalidad lingüística. El prestigio del castellano junto con el de las grandes ciudades $-\mathrm{y}$ en este sentido, Madrid se halla a la cabeza- son los responsables de la satisfacción y seguridad con respecto a su habla. El castellano sigue siendo el modelo normativo, aunque ya no se trate del castellano puro de otros tiempos. Para el alcalaíno, la evolución de la lengua en las últimas décadas ha llevado a su adulteración, y esto se valora negativamente. La idea de que antes se hablaba en Alcalá un castellano puro que ahora se está perdiendo es una constante que se ha venido repitiendo a lo largo de muchas entrevistas. Pese a todo, el habla de Alcalá sigue gozando, en general, de gran estima,

La norma madrileña es el punto de referencia lingüística. La hipótesis planteada a nuestros informantes según la cual la proximidad a la provincia de Guadalajara y los sucesivos contactos con esta zona han podido desembocar en semejanzas en las hablas, ha sido totalmente rechazada. Muchos, incluso, se aventuran a decir que nunca ha habido parecidos y que las diferencias han sido siempre notables. No contamos todavía con material suficiente para verificar tal creencia, pero lo que sí podemos asegurar es que para el alcalaíno, orgulloso de su condición de ciudadano todo lo que pueda sonar a pueblo está fuertemente estigmatizado, más incluso que las variedades meridionales, y para ellos, el habla de Guadalajara, aunque sea capital de provincia, tiene el acento característico de las áreas rurales. Se puede afirmar, por lo tanto, que en Alcalá el fenómeno más estigmatizado es el de la entonación que se aleje de los esquemas madrileños. Por ello, cuando explican por qué en esta ciudad se habla bien o mejor que en otros lugares, insisten en que «no tienen ningún acento raro».

Andalucía y Extremadura son las regiones que han recibido las más duras críticas. Fenómenos como el seseo, el ceceo, la relajación y pérdida de consonantes implosivas e intervocálicas, el léxico -por ser autóctono o por ser pobre- $y$, como no, el acento, fueron los aspectos más señalados en el razonamiento a sus respuestas. Muchos matizaron que esto era así porque la mayor parte de los inmigrantes procedían de pueblos y por su bajo estatus sociocultural. De nuevo vemos que el desprestigio recae especialmente sobre las hablas de las zonas rurales. Puesto que en Alcalá de Henares la población de origen meridional constituye un grupo 
numéricamente muy importante, y la mayoría procede de áreas rurales y carece de una instrucción elemental, no nos ha de extrañar que sean estas dos regiones las que se han señalado con más insistencia.

Aunque la mayoría de los informantes no ha apreciado las diferencias existentes entre el habla de hombres y mujeres, son las mujeres quienes realizan las apreciaciones más sutiles sobre las cuestiones linguísticas que se han abordado durante las entrevistas. Esto coincide con las apreciaciones que aparecen en numerosos estudios sociolingüísticos y dialectales, y que indican que las mujeres poseen una conciencia lingüística clara y que se muestran muy sensibles hacia los hechos de la lengua (López Morales, 1989). ${ }^{4}$

Coinciden los informantes al señalar que ha habido un cambio en el habla femenina y que, aunque ahora es igual, en otros tiempos hubo diferencias significativas. El cambio se debe, en su opinión, a dos causas: la incorporación al léxico femenino de términos asociados con el masculino (los denominados corrientemente tacos), el aumento de tiempo de asistencia al colegio y, en general, su acceso a la cultura y al poder. Así, para los alcalaínos, las mujeres en el pasado eran «más finas, más cuidadosas» pero hablaban peor dada su escasa formación. En la actualidad, puesto que ha desaparecido esa preocupación por las normas sociales y gozan del mismo nivel de instrucción, no hay razón alguna para que existan diferencias.

Las diferencias encontradas en función de la edad se limitan únicamente al vocabulario y a los tratamientos. Ninguno es consciente de que existan diferencias de tipo fonético y menos aún morfosintáctico; sin embargo, el análisis lingüístico de los datos indica claramente que sí las hay, aunque hay que señalar que se aprecian de manera especial entre la segunda y la cuarta generación (se observa una tendencia involucionista que está llevando a aproximar las hablas de los dos grupos extremos: el cuarto y el primero).

El conocimiento de las actitudes y creencias de los alcalaínos junto con el de aspectos socio-demográficos y culturales ha contribuido a que entendamos e interpretemos con mayor claridad los resultados obtenidos. Gracias a ellos hemos podido explicar algunos aspectos del habla de la ciudad:

4. Véase también de este mismo estudio las pp. 118 -128, a propósito de la relación entre habla femenina y formas prestigiosas. El autor cita numerosos trabajos dentro del mundo hispánico (nota 12) en los que se corrobora esta conexión. Es también de gran interés para el tema que aquí tratamos «Style variation, sex and linguistic consciousness», Linx, 3 (1992), 43-54. En los estudios realizados por G. Salvador (1986: 182-189) y M. Alvar (1956: 1-34 y 1958: 279282) el habla femenina se ha manifestado más conservadora que la mas conservadora que la masculina; pensamos que este conservadurismo no se opone a la hipótesis del prestigio, sino que, por lo contrario, la refuerza, pues en muchas ocasiones las formas más tradicionales son también las que poseen mayor estima social. 
1. En primer lugar, el carácter normativo y conservador del habla de Alcalá, sus rasgos más definitorios. El alcalaíno siente una gran preocupación por los usos correctos y se muestra muy sensible hacia aquellos prestigiosos. En este sentido, la norma de referencia es la madrileña, y así lo han indicado reiteradamente durante la entrevista («castellano de toda la vida», «en Alcalá se habla como en Madrid»).

2. El triunfo $O$, al menos, la gran aceptación, de variantes que pueden considerarse innovadoras, como la inderdentalización de /d/ implosiva final, la elisión de $/$ d $/$ intervocálica, el reforzamiento fonético de la velar fricativa $/ x /$, el debilitamiento de $/ y /$, la transformación del grupo $/ \mathrm{KT} /$ en $/ ? \mathrm{t} /$, todas ellas contrarias a la tendencia general al conservadurismo. ¿Cómo se explica esto? La razón hay que buscarla en el rechazo de los rasgos dialectales foráneos, que se manifiesta tanto en la búsqueda de lo normativo como en el hecho de que, en los procesos innovadores en curso, las soluciones preferidas sean contrarias a las que se dan en otras hablas castellanas. El contacto de variedades no ha desencadenado, como era de esperar, procesos de transdialectalización (al menos, en la dirección de la variedad autóctona), sino que, muy por el contrario, ha reforzado los rasgos propios. El habla de Alcalá se debate entre esta oposición a lo foránero, la presión de la norma prestigiosa y la fuerte tendencia conservadora y normativa impuesta por sus circunstancias histórico-culturales.

3. El comportamiento lingüístico más normativo de las mujeres. En el estudio de actitudes las mujeres revelaron mayor preocupación; fueron ellas las que llevaron a cabo un análisis más profundo de la realidad lingüística. Esto se refleja en los datos obtenidos, pues salvo algunas excepciones, se decantaron un mayor número de veces que los hombres por las soluciones más puramente castellanas o madrileñas. Los individuos del sexo masculino, por su parte, parecen más indiferentes a tales cuestiones, y sólo optaron en más ocasiones que las mujeres por formas canónicas en el caso del leísmo y laísmo.

4. La preferencia de los individuos de la segunda generación por realizaciones no autóctonas. ¿A qué se debe? Ellos son los que han trabado relaciones más estrechas con los inmigrantes y los que se han mostrado menos reacios ante la llegada de los nuevos habitantes. Los datos relativos a la edad de los hablantes son muy reveladores y nos han permitido reconstruir la evolución de esta variedad lingüistica en las últimas cinco décadas. Las peculiaridades de cada grupo generacional describen los rasgos de cada etapa. Así, los hablantes más ancianos exhiben un habla muy conservadora en la que es posible oír ciertos vulgarismos de gran raigambre en las variedades rurales; la tercera generación muestra no sólo conservadurismo sino además un intento de corrección de algunos usos del grupo precedente. La segunda generación es, sin dudas, la más innovadora y en la que ha influido de manera más notable la presencia de los inmigrantes. Ellos son los que han mantenido contactos más 
estrechos con los nuevos habitantes y los que más beneficiados han salido con los cambios de la ciudad; son, asimismo, los que han mantenido una actitud más tolerante ante esta llegada. En el estudio de actitudes hemos podido comprobar que fueron precisamente los informantes de la segunda generación los que se mostraron menos críticos con la situación, los que manifestaron mayor grado de satisfacción y tolerancia, y los que se mostraron menos críticos también con las otras variedades lingüísticas. Todo esto explica que sean los que utilizan con mayor frecuencia realizaciones propias de otras hablas, en especial, meridionales. La primera generación ha llevado a cabo no sólo un proceso de freno, sino también de involución, recobrando los usos de sus mayores, aunque a diferencia de éstos, en su habla apenas se aprecia la presencia de vulgarismos y arcaísmos. No obstante, hay algunos procesos que están siendo impulsados por ellos, si bien es muy importante señalar que la dirección que están tomando estos cambios es totalmente la opuesta a la que se observa en otras variedades del castellano (refuerzo de $/ \mathrm{x} /$, interdentalización de /-d/, debilitamiento de /y/).

5. Las diferencias en el habla según la mayor o menor formalidad de la situación. Se observa en el habla de los alcalaínos un gran interés, al tiempo que esfuerzo, por mantener o recuperar los usos que ellos consideran correctos. Este interés por su lengua los hace ser plenamente conscientes de los cambios lingüísticos de las últimas décadas y de las diferencias con respecto a otras variedades, datos estos que nos han desvelado durante la entrevista. Ello explica que en situaciones formales aumente notablemente la atención que dispensan a su habla y disminuyan las realizaciones menos «correctas».

6. El rechazo absoluto de ciertas variantes, precisamente de aquellas que son propias de las hablas que gozan de menos estima entre los alcalaínos. El estudio de actitudes nos ha permitido comprender por qué una variedad tan conservadora y normativa como lo es la alcalaína está desarrollando tendencias innovadoras, y no es otra cosa que ese rechazo -dejémoslo en lingüísticohacia variedades desprestigiadas.

\section{REFERENCIAS BIBLIOGRÁFICAS}

AgHeYISI, R. y J. Fushman (1970): «Language Attitudes Studies. A Brief Survey of Methodological Approaches», Anthropological Linguistics, 12: 137-157. Alvar, M. (1956): «Diferencias en el habla de Puebla de Don Fabrique (Granada)», RFE, XL: 1-34.

- (1958): «El cambio -al, $-a r>e$ en andaluz», RFE, XLII: 279-282.

COOPER, R. y F. FISHMAN (1974): «The study of language attitudes», IJSL, 3: 5-19. 
LABOV, W (1972): Language in the Inner City, Philadelphia, Pennsylvania University Press.

LóPez Morales, H. (1989): Sociolinguiística, Madrid, Gredos.

- (1992): «Style variation, sex and linguistic consciousness», Lirlx, 3: 43-54.

Martín Butragueño, P. (1991): Desarrollos sociolingüísticos en una comunidad de habla, tesis doctoral inédita, Madrid, Universidad Complutense.

Molina Martos, I. (1998): La fonética de Toledo. Contexto geográfico y social, Alcalá de Henares, Servicio de Publicaciones de la Universidad de Alcalá.

MORENO FERNÁNDEZ, F. (1988): Sociolinguiística en EE.UU (1975-1985), Málaga, Ágora.

SAlvador, G. (1986): «Fonética masculina y fonética femenina en el habla de Vertientes y Tarifa (Granada)», en Estudios dialectológicos, Madrid, Paraninfo, 182-189.

Saville-Troike, M. (1982): The Ethnography of Communication, Oxford, Basil Blackwell.

WiLliams, F. (1974): «The identification of linguistic attitudes», Linguistics, $36: 21-32$. 


\title{
VARIACIÓN LÉXICA Y GRADO DE FORMALIDAD
}

\author{
Luis Esconiza Morera \\ Universidad de Cádiz
}

\section{EL ESTUDIO DE LA VARIACIÓN LINGÜÍSTICA}

$\mathbf{E}$ L concepto de variación lingüística se halla inevitablemente asociado a dos premisas básicas en el estudio del lenguaje: todo sistema lingüístico en un estado de lengua determinado se compone de un número finito de unidades linguiísticas mediante cuya combinación cualquier hablante puede producir infinitos mensajes, y cada una de esas unidades se manifiesta, a su vez, de diferentes maneras, en distintas realizaciones, en los usos particulares. En este sentido, W. Abraham (1974: 479), en su Diccionario de terminología lingüística actual, define una variante como una «realización o manifestación dada de una unidad lingüística del sistema». La búsqueda de las unidades linguiísticas en cada uno de los niveles de análisis lingüístico de las lenguas naturales (fonológico, morfológico, sintáctico, léxico o textual) ha constituido y constituye una de las preocupaciones fundamentales de gran número de investigaciones en el marco de la Lingüística. El estudio de las diferentes realizaciones o variantes de esas unidades, de una forma u otra, también. Aquellas corrientes que se han dedicado al intento de describir las unidades subyacentes a las lenguas, los elementos lingüísticos sistemáticos, han reivindicado de manera explícita o implícita la existencia de variación, ya que es ésta y no otra la causa de la dificultad a la hora de diferenciar lo que constituye una unidad (invariante) de lo que no es más que una simple versión o realización de dicha unidad. Además, la historia de la lingüística, y más concretamente de la semántica, ha recogido numerosos testimonios de investigadores atraídos por fenómenos como los de sinonimia y polisemia, basados en un doble proceso de identidad y diferenciación, y bajo los que se escondía en muchas ocasiones el mismo problema de la distinción entre invariantes y variantes. ${ }^{\prime}$ En el último tercio del siglo Xx y en el seno de una sociolingüística pujante, que reclama su lugar en el conjunto de las discipli-

1. Para una más detallada revisión de la presencia del concepto de variación linguiística en las corrientes estructuralista y generativa transformacional, así como en la historia de la semántica, Escoriza Morera (2003). 
nas lingüísticas, se recoge la tradición en torno al estudio de variantes linguísticas y se reivindica la variación como objeto de estudio. La denominada sociolingüística variacionista se preocupa del análisis de los usos linguiísticos, resuelta a descubrir hasta qué punto el cúmulo de realizaciones linguísticas de cualquier sistema es una serie indefinida de usos carente de interés en sí misma o, por el contrario, podemos agrupar y tipificar dichos usos y encontrar explicación, fundamentada en factores ya estrictamente linguísticos ya sociales, a su aparición en las diferentes comunidades hablantes. Los primeros estudios de corte variacionista, centrados en el nivel fonético-fonológico, demuestran la importancia de factores contextuales y socioculturales en la realización de diferentes producciones, desde un punto de vista acústico y articulatorio, de un mismo fonema. ${ }^{2}$ Tal tipo de investigaciones se fundamenta en la descripción de los sistemas fonológicos y en la distinción entre una ciencia fonética y una ciencia fonológica desarrolladas por la linguística previa. Ya en el primer tercio del siglo $\mathrm{xx}, \mathrm{N}, \mathrm{S}$. Trubetzkoy (1939) señalaba la utilidad de encontrar entre los sonidos de cada lengua las diferencias fónicas ligadas a diferencias de significación que subyacen a los mismos. Para la obtención de dichas diferencias fónicas pertinentes y el establecimiento de los fonemas de cualquier sistema lingüístico disponemos de la utilidad de la prueba de la conmutación, apoyada en el hecho de que los fonemas no poseen significado pero nos permiten diferenciarlos. Ideas de este tipo, repetimos, han servido de basamento teórico a una sociolingüística interesada en analizar el comportamiento real de los hablantes en la utilización de las diferentes realizaciones que servían a la lingüística interna para delimitar las unidades del sistema de la lengua.

\section{PROBLEMAS EN TORNO AL CONCEPTO DE VARIACIÓN}

Como mencionábamos más arriba, un concepto de variación ligado a la diferencia entre unidades del sistema y realizaciones de las mismas implica la existencia del fenómeno en todos los niveles de análisis lingüístico, pues en ninguno de ellos renuncia la lingüística a encontrar y delimitar las unidades

2. Existe una amplísima nómina de investigaciones en este sentido. Puede pensarse, por ejemplo, en los diferentes estudios realizados en español en tomo a diferentes realizaciones o variantes del fonema siseante fricativo sordo /s/, sobre todo en torno a los fenómenos de aspiración y elisión (por ejemplo, H. López Morales, 1979; H. Cedergren, 1983; C. Silva-Corvalán, 1989; J. A. Samper, 1990 o M. Á. Calero, 1993). En cualquier caso, las primeras investigaciones de este lipu se redizan en lun al ingles y en el ánbilu estadounidense. Ha de nutaniunase en este sentido la obra del autor norteamericano W. Labov (1966 y 1972). 
existentes en cada lengua. ${ }^{3}$ De esa forma lo plasman algunas obras lexicográficas en sus entradas tanto de variación como de variante. ${ }^{4}$ No obstante, el hecho de que la mayoría de investigaciones variacionistas se halla desarrollado en el nivel fonético-fonológico no es un hecho casual, ya que la diferencia entre los fonemas, unidades, recuérdese, no significativas, y el resto de unidades lingüísticas (significativas) ha de implicar necesariamente diferencias en la aplicación del concepto de variación, sin que haya que negarlo, como ocurre en ocasiones. En la delimitación de las variantes fonéticas se puede afirmar que todas las variantes comparten con el fonema que representan unos rasgos acústicos y articulatorios si bien se diferencian en otros. Además, la prueba de la conmutación nos permite comprobar si nos encontramos ante fonemas diferentes o no. Si aplicamos ese mismo esquema a unidades significativas (los elementos léxicos, por ejemplo) encontramos varios problemas como la ausencia en cualquier lengua de una definición en rasgos de las unidades del sistema (como ocurre con los fonemas) o la complejidad de la prueba de la conmutación, ya que hablar de cambio de significado en unidades compuestas a su vez de unidades significativas es tarea mucho más compleja, que entronca con distintos problemas relacionados con el propio concepto de significado.

En cualquier caso, no son pocos los autores, entre los que nos incluimos, que postulan la posibilidad y utilidad de hablar de variación lingüística en unidades significativas, hecho obvio desde el momento en que hablamos de unidades. Cosa distinta es que nos hallemos obligados a trabajar con otro concepto de variación ante la imposibilidad de adoptar la misma perspectiva utilizada por los fonetistas. Carentes de definiciones de unidades basadas en rasgos distintivos y reacios al uso de la prueba de la conmutación, la variación en unidades significativas sí toma de la fonética la misma idea de la existencia de elementos comunes y diferenciales entre variantes y entre éstas y las supuestas invariantes, constituyéndose este rasgo como definitorio del concepto y en el auténtico nexo de unión en el estudio de la variación en diferentes niveles de análisis lingüístico. ${ }^{5}$ Considerar variantes lingüísticas elementos

3. Por citar un autor, L. Hjelmslev (1943: 90-108), en sus Prolegómenos a una teoría del lenguaje, postula que el reconocimiento de las unidades lingüísticas (significativas o no significativas) de cualquier sistema es un objetivo fundamental del análisis estructural.

4. R. Cerdà Massó (1986: 298) afirma que la variación es la «manifestación de la diversidad espontánea de la realización lingüística en cualquiera de sus ámbitos» y E. Alcaraz Varó y $\mathrm{M}^{\mathrm{a}}$ A. Martinez Linares (1997: 586) recogen que «en lingiústica se llama variante a las distintas formas de una unidad lingüística sea del nivel que sea» (la negrita es nuestra).

5. De hecho, esa idea de un doble proceso de identidad y diferenciación entre cualquier hecho y otro considerado su variante también se halla presente en la palabra de la lengua común variación. Piénsese en lo que entendemos por variante de una canción, de una jugada ajedrecística, etc. 
superiores al fonema que comparten parte de su identidad implica una serie de consideraciones, algunas de ellas no exentas de problemas:

- en primer lugar, podemos distinguir variantes de contenido y variantes de expresión, en función de en cuál de los dos planos situemos tanto los rasgos compartidos como los diferenciales. La mayor parte de los estudios que atrontan la variación lingüística de unidades significativas suele centrarse en las variantes de expresión, es decir, en aqueilos elementos caracterizados por poseer una expresión diferente y, al menos, parte de su contenido común;

- en segundo lugar, y directamente relacionado con lo expuesto con anterioridad, la heterogeneidad en la delimitación de los planos de la expresión y, sobre todo, del contenido, facilita, como trataremos de analizar a continuación, diferentes maneras de sostener de manera teórica el carácter de variantes de los elementos lingüísticos, en virtud de los rasgos de contenido que tomemos como base de la comparación de variantes, y

- por último, la formalización de la invariante común a un grupo de supuestas variantes se dificulta, pudiéndose identificar a veces la supuesta unidad subyacente con la expresión de una de las variantes en lugar de suponer que la auténtica invariante habría de ser el concepto o el conjunto de rasgos de contenido comunes a todas las variantes, se encuentre formalizado en la lengua o no.

La sociolinguística variacionista se ha detenido en algunas de estas cuestiones, a pesar del menor desarrollo de los estudios en torno a la variación en niveles de análisis lingüístico compuestos de unidades significativas. La práctica totalidad de estudios se ha decantado, insistimos, por el análisis de la variación de expresión. Con respecto a los requisitos para considerar dos elementos lingüísticos como variantes de expresión antes de un estudio propiamente sociolingüístico, podemos distinguir, de manera general, ${ }^{6}$ dos claras tendencias a la hora de justificar una identificación de contenido entre elementtos de expresión diferente:

- de un lado, la de aquellos autores como W. Labov, H. López Morales o P. Carbonero, por citar algunos, que encuentran suficiente la existencia de una misma referencia y un mismo valor de verdad entre variantes para considerarlas como tales. Según este punto de vista, oraciones activas y pasivas en el ámbito sintáctico o elementos del español como pasta y

6. Para un mayor desarrollo de las ideas teóricas vertidas en el seno de la sociolinguística sobre el concepto de variación en unidades significativas, .H. López-Morales (2004: 68-92). 
dinero en el léxico, por ejemplo, podrían ser considerados variantes de expresión en virtud de lo que F. Moreno Fernández (1998: 121) denomina una equivalencia lógica.

- De otro, la de quienes, sobrepasando los aspectos designativos y adentrándose en el terreno discursivo, aducen una identidad en la intención comunicativa, a la que F. Moreno Fernández (1998: 122) denomina equivalencia pragmática, de los elementos tomados como variantes en la investigación sociolinguística. En esta línea, que conlleva la dificultad del conocimiento de la intención del hablante, se manifiestan en líneas generales autores como B. Lavandera, $\mathrm{M}^{\mathrm{a}} \mathrm{J}$. Serrano o C. Silva-Corvalán.

Desde nuestro punto de vista, ambas posturas representan dos (las más productivas hasta la fecha) de las múltiples posibilidades teóricas en el establecimiento de variantes de expresión en unidades significativas, ya que cada una hace hincapié en una parcela distinta del contenido de las unidades para buscar la identidad de elementos de expresión diferente, si bien no agotan las posibilidades teóricas en dicho nivel. En este sentido, partiendo de la existencia de cuatro niveles del significar (M. Casas Gómez, 1999: 59-63), significado, designación, sentido y denotación, podría sostenerse la identidad de contenido de unidades al menos de cuatro maneras generales (más allá de las discusiones teóricas en cuanto a la delimitación de cada uno de los niveles mencionados, en las que no nos detendremos aquí, por falta de espacio), dos ubicadas en el plano de la lengua (significado y designación) y dos en el discurso (sentido y denotación), dos fundamentadas en aspectos de tipo referencial (designación y denotación) y dos de tipo significativo (significado y sentido). ${ }^{?}$

Sin decantarnos ahora por ninguna de esas posibilidades en concreto, 10 que sí parece evidente, desde nuestro punto de vista, es la utilidad de cualquiera de esas concepciones de variación siempre y cuando posteriores estudios de carácter sociolingüístico demostraran el condicionamiento de factores linguísticos y sociales en el uso de las variantes, ya que ello permitiría, por encima de discusiones teóricas, avanzar en el conocimiento del uso de los sistemas lingüísticos y, en última instancia, del lenguaje, fin último de la lingüística en cuanto ciencia.

\section{EL ESTUDIO DE LA VARIACIÓN LÉXICA}

En los últimos años nuestro interés en el estudio de diferentes aspectos lingüísticos relativos al nivel léxico nos ha llevado a interesarnos, en diferentes

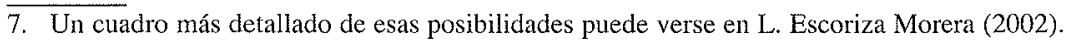


investigaciones, por el análisis de la variación léxica. Nuestro trabajo se sitúa, de manera concreta, en el campo de las variantes léxicas de expresión en español. Intentaremos mostrar en las páginas siguientes algunas de las características teóricas y, sobre todo, metodológicas, más relevantes y comunes a los diferentes estudios realizados, así como algunas de las principales conclusiones obtenidas en dichas investigaciones, fundamentalmente en lo que concieme a la influencia del grado de formalidad en el uso de dicha variación léxica.

El primer problema al que nos enfrentábamos era la propia delimitación de las variantes escogidas para un análisis de índole sociolingüística. Para ello, adoptamos una visión amplia en la elección de los elementos léxicos, ${ }^{8}$ que se caracterizaban, a nuestro juicio, por la posesión de una expresión diferente (aspecto evidente y no controvertido) y de un contenido común. Este úitimo hecho, bastante más complejo desde el punto de vista teórico, como comentábamos más arriba, en ei apartado anterior, venía avalado tanto desde un punto de vista abstracto, descontextualizado, como discursivo. La identificación de contenido de las variantes en el plano de la lengua se basaba en la existencia de una misma designación y en la evidencia de, si no una identificación total, una similitud de rasgos lingüísticos, intuida en nuestro conocimiento, como hablantes de la misma, de la lengua analizada y apoyada, ante la ausencia de auténticas descripciones en rasgos distintivos de las unidades léxicas del español, en el análisis de las definiciones de las variantes seleccionadas en el Diccionario de la Lengua Española de la Real Academia Española de la Lengua y el Diccionario de uso del español de María Moliner, en las que se encontraban definiciones idénticas, muy similares e incluso circulares, de forma que unos elementos de los que conformaban a nuestro juicio un grupo de variantes aparecían mencionados en las definiciones de otros. En el terreno discursivo la similitud en el contenido de las variantes elegidas se demostraba on el hecho de que ninguno de los informantes encuestados, como veremos a continuación, mostraba extrañeza ante la posibilidad de elegir entre las posibles variantes en cualquiera de los contextos lingüísticos utilizados en nuestras muestras.?

Todos los estudios efectuados, por cuestiones teóricas y metodológicas que nos mostraban la necesidad de operar con unidades menores a las comunidades lingüísticas, se han llevado a cabo en la comunidad de habla de

8. En primera instancia trabajamos con parejas de elementos léxicos como bonito/mono, para, en posteriores investigaciones, ir ampliando la nómina de palabras en la conformación de grupos de tamaño variable, generalmente de tres o cuatro elementos, del tipo bonito/monolindo/ bello.

9. En este sentido, hemos encontrado muy pocos casos en los que alguna de las variantes presentadas no haya sido escogida en la muestra en alguno de los contextos y ningún caso de vatiante to selecionada en tinguno de los contextos. 
Cádiz, a la cual pertenecemos. En todos los casos, también, hemos procedido a trabajar con muestras estratificadas mediante cuotas de asignación fija. Este hecho nos ha permitido, por una parte, asegurar más la representatividad de las muestras y, por otra, cotejar, lo que ha constituido desde el principio uno de nuestros intereses principales, la influencia de factores socioculturales en el uso de la variación léxica. Los factores preestratificacionales analizados hasta la fecha han sido los siguientes:

- la edad. En consonancia con otros trabajos en el mundo hispánico distinguimos tres estratos generacionales: informantes de entre 14 y 30 años, de entre 31 y 54 años y con más de 54 años;

- el sexo o género. Tuvimos siempre en consideración la distinción entre hombres y mujeres como principio general, y

- el nivel de estudios. A diferencia de otras investigaciones de carácter sociolingüístico que operan con el concepto de estrato sociocultural, fundamentado en la conjugación de factores como el nivel de ingresos, la profesión o el nivel de estudios de los informantes, en los estudios realizados hasta ahora en la comunidad de Cádiz hemos partido sólo del nivel de estudios como factor de influencia en el uso de variantes por su claridad en la delimitación, su facilidad en la distinción de los informantes y nuestra intuición acerca de su fuerza estratificadora. Normalmente distinguimos hablantes sin estudios o con estudios primarios como máximos alcanzados, hablantes con estudios secundarios como máximos alcanzados y hablantes con estudios universitarios.

Además, en orden a la información obtenida en las encuestas, hemos considerado otros factores socioculturales posteriores a la estratificación, tales como:

- el entorno sociocultural, basado en factores como el nivel de ingresos, la profesión o el nivel de estudios de los padres de los informantes,

- la vinculación con otras comunidades de habla, fundamentada en el número y carácter de los viajes realizados por el informante, así como en su relación con hablantes de otras comunidades distintas a la estudiada, y - el grado de contacto con la norma, reflejado en la relación del encuestado con los medios de comunicación.

Por último, en todas nuestras investigaciones prestamos especial atención a un factor, el grado de formalidad, en el que haremos hincapié en este texto, que condicionaba la configuración de las herramientas utilizadas para la obtención de datos, que no nos ayudaba a diferenciar a los informantes sino 
que era medido en cada uno de ellos y que ha resultado ser el más relevante en nuestro trabajo.

Más allá de la dificultad a la hora tanto de numerar y delimitar como de denominar los diferentes grados de formalidad que pueden establecerse en cualquier lengua, ${ }^{10}$ la evidencia de una escala que iría de lo más espontáneo a lo más formal en el uso de los sistemas lingüísticos avala la investigación de dicho aspecto descle und perspectiva sociolingüística. Han sido muchos los factores citados en la configuración de la formalidad de los usos, prácticamente todos los presentes en el esquema del acto comunicativo (emisor, receptor, contexto, situación, canal, etc.). Para nuestras investigaciones intentamos analizar diferentes usos, diferenciados en su grado de formalidad principalmente por las caracteتústicas del receptor y por el tema de la comunicación. Assí, hemos utilizado situaciones formales como el envío de una carta de denuncia al defensor del pueblo o la redacción de una noticia de temática seria y situaciones informales como la redacción de una carta entre amigos sobre aspectos lúdicos o la transmisión de chistes.

Desde el punto de vista metodológico, habida cuenta de que trabajamos siempre con encuestas de carácter escrito, esto nos llevó a la confección de textos ficticios que reprodujeran las condiciones comunicativas antes expuestas y en los que se diera la posibilidad de elegir por parte de los informantes entre las supuestas variantes léxicas de expresión de cada uno de los grupos seleccionados. De esta forma, las encuestas consistían fundamentalmente en este tipo de textos, además de cuestionarios sobre información personal utilizados para elaborar lus factores postestratificacionales citados como el entomo sociocultural, la vinculación con otras comunidades de habla o el grado de contacto con la norma. Véanse dos ejemplos de textos propuestos, uno formal y otro informal:

\section{Texto 1}

Sr. Defensor del Pueblo Andaluz:

Soy presidente de una comunidad de vecinos gaditana situada en un conocidolfamoso/célebre barrio de la ciudad. Desde hace años venimos padeciendo molestos olores así como ruidos en nuestras casas/domicilios/viviendas/residencias, procedentes de algunos locales comerciales de la zona, con los cuales no es fácil/simple/sencillo vivir, sobre todo en verano, y que nos privan de poder disfrutar de un lugar mono/lindo/bonito/bello y tranquilo como es este en el que vivimos.

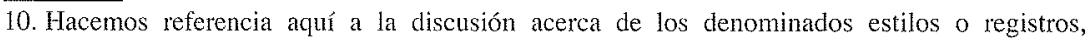
recubiertos con múltiples denominaciones del tipo coloquial, popular, familiar, espontáneo, casual, informal, formal, solemne, congelado, etc. 
Hace tiempo pusimos el tema en manos de un picapleitos/abogado/le-trado, el cual, tras confirmar lo malo/perjudicial/nocivo que resultaba el humo para nuestras familias, empezó/comenzó/inició los trámites habituales para denunciar a los responsables, aunque seguimos sin tener noticias. En vista de que las autoridades locales responsables se dedican, al parecer, a llenarse la panza/barriga/vientre y pasear en carro/cochelau-tomóvil por la ciudad en lugar de resolver los problemas de sus ciudadanos y que el caso nos exige cada vez más guita/parnélpastaldinero, hemos decidido solicitar su ayuda en la medida de lo posible. Algunas familias, después de cabrearse/mosquearselenfadarse por la falta de soluciones, se han pirado/largado/ido/marchado a otro sitio. Otros, que cada día estamos más canijos/flacos/delgados, cansados de currar/trabajar/laborar todo el día para poder vivir, desgraciadamente no tenemos esa posibilidad.

Para terminar/acabar/concluir/finalizar quiero expresarle mi gratitud por la labor que desempeña con todos los andaluces. Reciba un cordial saludo.

\section{Texto 2}

Querido Paco:

Acabo de concluir/terminar/finalizar/acabar las vacaciones y cada año me cuesta más volver a mi domicilio/residencia/casa/vivienda para comenzar/iniciar/empezar el trabajo. Pero no hay más remedio que laborar/trabajar/currar, es la única forma segura de ganar dinero/pas-talguita/parné. Además, el año que viene, entre el embarazo de Ana, los gastos del letrado/abogado/pica pleitos por lo de la demanda, el coche/automóvil/carro, al que quiero ponerle el aire acondicionado, etcétera, voy a tener que currar/trabajar/laborar el doble haciendo horas extras, si no, no va a ser sencillo/simple/fácil.

Ana está bien, más gordita con su vientre/barriga/panza de seis meses, al revés que yo que cada vez estoy más delgado/flaco/canijo. El médico le ha dicho que no haga esfuerzos y que intente no enfadar-se/mosquearse/cabrearse demasiado, que eso es nocivo/perjudicial-/malo en su estado de salud. Ahora le ha dado por ver progra-mas del corazón y se traga la vida y milagros de todo el que sea céle-brelfamoso/conocido. Cuando pase esta racha de gastos queremos mar-charnos/irnos/largarnos/pirarnos unos días a Asturias. Hace dos años estuvimos allí dos semanas y era todo tan bello/bonito/lindo/mono que estamos deseando volver. Si os apuntáis, ya sabes.

Te dejo, que tengo cosas que hacer. Dale un beso a María y los niños y escribe o llama de vez en cuando, descastado. Un abrazo, Luis.

Para el procesamiento de los materiales obtenidos nos hemos servido de diferentes herramientas informáticas como los programas SPSS O AQUAD (Analisis of Qualitative Data)" y de algunas de las pruebas más habituales en

11. El primero de ellos, ampliamente conocido, en su versión 10.0 y el segundo, creado por G. L. Huber para el análisis de datos cualitativos (G. L. Huber y otros, 2002) en su versión 5.7. 
estudios de tipo estadístico. Los distintos resultados obtenidos hasta ahora nos permiten extraer algunas conclusiones generales acerca del grado de formalidad y el estudio de la variación léxica. En lo que respecta al propio factor grado de formalidad, podemos afirmar que, a pesar de que no resulte sencillo precisar cuántos registros podemos distinguir en el uso de la lengua, ${ }^{12}$ es innegable no sólo su existencia, sino su influencia en la variación léxica. En nuestras investigaciones la formalidad se ha mostrado como el factor sociocultural que, de manera aislada, más condiciona la preferencia en el uso de una u otra de las variantes de expresión de un mismo grupo por encima de otros como el sexo o género, la edad o el nivel de estudios. ${ }^{13}$ En este sentido se observan variantes cuya aparición está abrumadoramente ligada a comunicaciones bien formales (es el caso en nuestras investigaciones, por ejemplo, de domicilio, vivienda, perjudicial, nocivo, iniciar y automóvil) bien informales (como ocurre con pasta, cabrearse, mosquearse, canijo y currar, entre otras). Con respecto a la variación léxica en general podemos concluir, a partir de nuestras indagaciones, que parece oportuno defender el concepto de variación en el marco de las unidades significativas por su utilidad descriptiva acerca del uso de las lenguas, aunque no deberíamos identificar el concepto de invariante en estos niveles de análisis lingüístico con ninguna de las formalizaciones linguísticas estudiadas sino con lo que hay de común bajo todas ellas. Del mismo modo, al igual que resulta evidente la necesidad de utilizar un concepto de variación diferente al manejado en el nivel fonético-fonologico, parece imprescindibie el desarrollo de herramientas metodólogicas específicas para el estudio de la variación lingüística en unidades significativas como los elementos léxicos.

\section{REFERENCIAS BIBLIOGRÁTICAS}

ABRAHAM, W. (1974): Diccionario de terminología lingiaística actual, (versión española de F. Meno Blanco), Madrid, Gredos, 1981.

Alcaraz Varó, E.; Ma A. Martínez Linares (1997): Diccionario de linguística moderna, Barcelona, Ariel.

CAlero Fernández, M. Á. (1993): Estudio sociolingiiístico del habla de Toledo, Lleida, Publicaciones de la Universidad de Lleida, Pagès Editors.

12. Es decir, extraer unidades discretas del continuo que supone la formalidad, problema relativamente habitual en el estudio del lenguaje y resuelto en multitud de ocasiones mediante diferentes convenciones.

13. Bien es cierto que en muchas ocasiones grado de formalidad y nivel de estudios actúan de manera conjunta en el patrocinio de variantes. 
Casas Gómez, M. (1999): Las relaciones léxicas, Beihefte zur Zeitschrift für Romanische Philologie, Band 299, Tübingen, Max Niemeyer.

Cedergren, H. (1983): «Sociolingüística» en López Morales, H. (coord.) (1983), Introducción a la lingïística actual, Madrid, Playor.

Cerdà MASsó, R. (COORD.) y OTROS (1986): Diccionario de Lingüística, Madrid, Anaya.

EsCORIzA MORERA, L. (2002): «Posibilidades teóricas en el establecimiento de variantes léxicas» en MuÑoz NúNEEZ, Ma D.; A. I. RodríGUEZ-PIÑERo ALCALÁ; G. Fernández Smith; V. Benítez Soto (eds.) (2002): IV Congreso de Lingüística General, Cádiz, del 3 al 6 de abril de 2000, Cádiz, Área de Lingüística General de la Universidad de Cádiz, Servicio de Publicaciones de la Universidad de Cádiz, Servicio de Publicaciones de la Universidad de Alcalá.

- (2003): Perspectivas de análisis en el ámbito de la variación lingïística, Documentos de Investigación Lingüística, 9, Cádiz, Universidad de Cádiz.

Fernández Smith, G.; L. Escoriza Morera (2004): «Variación léxica y texto: análisis cualitativo del grado de formalidad en contexto con AQUAD», Pragmalingüística, 12: 73-89.

HJelmslev, L. (1943): Prolegómenos a una teoría del lenguaje, (versión española de J. L. Díaz de Liaño), Madrid, Gredos, (1971, $2^{\text {a ed.). }}$

Huber, G. L.; G. Fernández Smith; O. Lorenzo Quiles; L. Herrera Torres (2002): Análisis de datos cualitativos con AQUAD Cinco para Windows, Granada, Grupo Editorial Universitario.

LABOV, W. (1966): The social stratification of English in New York City, Washington, Center for Applied Linguistics.

- (1972): Sociolinguistic Patterns, Philadelphia, University of Pennsylvania Press.

López Morales, H. (1979): Dialectología y Sociolingüística. Temas Puertorriqueños, Madrid, Hispanova de Ediciones.

- (2004): Sociolingiiística, Madrid, Gredos.

Moliner, $M^{\mathrm{a}}$. (1966): Diccionario de uso del español, I. A-G, Madrid, Gredos. - (1967): Diccionario de uso del español, II. H-Z, Madrid, Gredos.

Moreno Fernández, F. (1998): Principios de sociolingiuística y sociología del lenguaje, Madrid, Ariel.

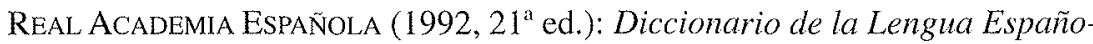
la, Madrid, Espasa-Calpe.

SAmper, J. A. (1990): Estudio sociolingüístico del español de Las Palmas de Gran Canaria, Las Palmas de Gran Canaria, La Caja de Canarias.

Silva-Corvalán, C. (1989): Sociolingüística. Teoría y análisis, Madrid, Alhambra.

Trubetzkoy, N. S. (1939): Principios de fonología, (traducción de D. García Giordano con la colaboración de L. J. Prieto), Madrid, Cincel, 1973. 


\title{
PERVIVÈNCIA DE LA REALITZACIÓ FRICATIVA LABIODENTAL A VALLS
}

\author{
Sílvia Güell Segarra \\ MAGda Buldó Escoté \\ Miquel-Àngel Pradilla Cardona \\ Anna Saura Vizcarro \\ Joan Anton Verge Caballer \\ (Universitat Rovira i Virgili)
}

\section{OBJECTIU}

$\mathbf{L}$

'objectiu d'aquesta comunicació és exposar els resultats d'un treball exploratori realitzat a la ciutat de Valls sobre la pervivència de la realització fricativa labiodental sonora en aquesta població. Abans d'entrar en la caracterització metodològica i la descripció dels resultats obtinguts, farem una breu caracterització del marc teòric en què s'ha desenvolupat el treball, la sociolingüística de la variació.

\section{MARC TEÒRIC}

La sociolingüística de la variació és un model teòric que sorgeix a partir de la publicació, l'any 1968, de l'article de Weinreich, Labov i Herzog «Empirical Foundations for a Theory of Language Change» («Fonaments Empírics per a una Teoria del Canvi Lingüístic»). Grosso modo i de manera acrítica, els postulats fonamentals d'aquest model són els següents (Labov, 1971; 1972):

a) La variació i el canvi són fets inherents a l'estructura lingüística.

b) La variació lingüística no es dóna arbitràriament, sinó de manera ordenada.

c) Tot canvi lingüístic parteix d'una variació prèvia (tot i que la variació no aboca sempre a un canvi).

d) La variació lingüística es troba correlacionada amb variables independents de caire social (sexe, edat, classe social, etc.) i pragmàtic (estils de parla).

e) L'obtenció de dades empíriques passa, segons els plantejaments d'aquest paradigma, per dos procediments metodològics: l'entrevista sociolingüística i l'anàlisi estadística. 


\section{EL TENOMEN ESTUDAT: LA REALILACIÓ DE LA FRICATIVA LABIODENTAL SONORA}

Històricament, l'oposició entre l'oclusiva bilabial sonora /b/ i la fricativa labiodental sonora $/ \mathrm{v} /$ era una característica general de la llengua antiga. Amb el temps es va anar estenent la neutralització de l'oposició. Actualment, a grans trets, la realització labiodental es manté en mallorquí, menorquí, eivissenc, alguerès, valencià meridional $\mathrm{i}$ en algunes zones del valencià septentrional, tot $\mathrm{i}$ que en aquest darrer cas amb menys vitalitat (Recasens, 1991). Pel que fa al Camp de Tarragona, que és on s'ubica la població objecte d'aquest estudi, la realització labiodental es troba en un procés de regressió gairebé acomplert. A principis dels anys vuitanta, a l'obra Estudi linguilistic sobre la parla del camp de Tarragona, Daniel Recasens (1985: 122-126) afirmava que la realització labiodental tenia una presència molt elevada en la generació de més de seixanta anys, mentre que en la generació següent, d'entre quaranta i seixanta anys, era nul la. I d'aquesta afirmació ja fa més de vint anys. Segons Recasens, actualment només podríem trobar realitzacions labiodentals en parlants de més de vuitanta anys.

Sobre les causes d'aquest canvi, Recasens atribueix el procés de substitució de la labiodental per la bilabial a factors sociolingüístics (la tendència dels joves a substituir la labiodental per bilabial pel contacte amb àrees catalanoparlants betacistes i per influència del castellà) i fonètics (Recasens, 1991: 196):

El procés de pèrdua de /v/ deu anar precedit d'un relaxament de l'articulació de la consonant, sobretot en contextos favorables a aquesta evolució (posició àtona intervocàlica), amb desplaçament de l'indret de constricció envers la paret inferior del llavi inferior. Sembla que aquest procés ha d'ésser especialment factible als dialectes del domini on $/ b /$ es fa $/ \beta /$, per tal com, en aquestes circumstàncies, és facil el pas de [v] relaxada a [B].

Així, doncs, partirem de la hipòtesi que l'articulació labiodental és a Valls una realització fonètica en vies d'extinció (o, segons Recasens, ja extingida). Per tant, els objectius d'aquest treball, més que no pas donar fe del canvi lingüístic esdevingut -a hores d'ara obvi- han estat trobar romanalles de pronúncia labiodental en la parla dels vallencs i determinar quins factors són clau a l'hora d'explicar el fenomen de manteniment.

\section{CARACTERITZACIÓ DE LA COMUNTTAT DE PARLA}

Fl primer pas de la investigació va ser la caracterització de la comunitat de parla. Valls és la capital de l'Alt Camp, comarca que integra, juntament amb 
el Baix Camp i el Tarragonès, el territori conegut amb la denominació Camp de Tarragona. En els darrers cinquanta anys, Valls ha anat perdent el seu caràcter agrícola per esdevenir una ciutat bàsicament orientada, des del punt de vista econòmic, a la indústria $i$ als serveis. Tot i tractar-se d'una comunitat de parla multilingüe, per a l'avinentesa que ens ocupa només s'ha tingut en compte el grup lingüístic catalanòfon. Dins d'aquest grup lingüístic, vam optar per seleccionar informants nascuts a Valls, preferentment amb progenitors també vallencs, i de cinquanta anys endavant. La raó de l'exclusió d'informants més joves de la mostra és òbvia: la presència de pronúncies labiodentals en aquests grups hauria estat nul-la. El nombre d'informants seleccionat fou 28. Dins de l'univers real de la mostra (uns 6.000 parlants amb aquest perfil dins d'una població de 22.000 habitants), aquesta xifra representa, aproximadament, un $0.4 \%$ de la població.

\section{FACTORS LINGÜÍSTICS I EXTRALINGÜÍSTICS}

A l'hora de determinar els factors influents en la variabilitat del fenomen, hem considerat un seguit de factors extralingüístics. En primer lloc, hem establert variables de tipus social: gènere (home/dona), edat (entre 50 i 65 anys / més de 65 anys), instrucció (amb estudis bàsics / sense estudis bàsics) i l'àmbit de relació o d'ocupació. En aquest darrer cas hem seleccionat els tres grans grups en què queda dividida la comunitat de parla: la indústria, els serveis i la pagesia. Els informants foren seleccionats intentant mantenir l'equilibri pel que fa als factors socials:

TAULA 1: Distribució de la mostra

\begin{tabular}{|l|cc|cc|}
\hline & \multicolumn{3}{|c|}{ HOMES } & \multicolumn{2}{c|}{ DONES } \\
\hline & $50-65$ anys & més de 65 & $50-65$ anys & més de 65 \\
INDÚSTRIA & 2 & 3 & 2 & 3 \\
SERVEIS & 2 & 2 & 3 & 3 \\
PAGESIA & 2 & 2 & 2 & 2 \\
\hline
\end{tabular}

També hem considerat factors de tipus lingüístic. Així, s'ha tingut en compte la posició de la consonant (només hem analitzat les posicions inicial i intervocàlica), el context anterior, el context posterior, i la tonicitat (síllaba tònica / sílllaba àtona). Partint d'aquests factors, vam elaborar un corpus de mots per tal de garantir la presència de totes les combinacions possibles. 


\section{METODOLOGIA DE TREBALL}

La metodologia d'obtenció de dades es va basar en l'entrevista sociolinguística (Pradilla, 2001 a i 2001 b). L'entrevista va ser dissenyada per aconseguir tres estils de parla. D'aquesta manera, de menys a més formalitat, l'entrevista constava d'una part de conversa sobre un seguit de tòpics escollits, un qüestionari de 75 ítems (dcls quals 56 cren mots que contenien la labiodental i la resta, mots per encobrir el fenomen investigat), i una lectura breu de vuit frases. Les entrevistes foren enregistrades digitalment per tal de garantir la qualitat acústica dels enregistraments. Fonamentalment, a l'hora de determinar el caràcter de les realitzacions ens hem basat en un criteri auditiu. En casos dubtosos, hem validat les dades al Laboratori de Fonètica de la URv. En un treball més aprofundit seria interessant realitzar una anàlisi fonamentada en els mètodes de la fonètica experimental per tal de delimitar casos que intüm de realitzacions intermèdies (Pradilla; Carrera; Fernández, 2005).

El segon pas per a l'obtenció dels resultats fou el tractament estadístic de les dades mitjançant el programa d'anàlisi multivariant Goldvarb 2001 (Carrera, 2002). Aquest suport informàtic ens va permetre obtenir informació de tipus percentual i probabilística per fer una anàlisi del fenomen des del punt de vista quantitatiu.

\section{RESULTATS}

Pel que fa als resultats obtinguts, les dades extretes de l'anàlisi estadística mostren, tal com ja esperàvem, una probabilitat força baixa de manteniment de la labiodental en posició inicial i intervocàlica: 0.043. La xifra, tal com ja prevèiem, és molt baixa, però no nul·la. El betacisme s'ha imposat gairebé del tot, però encara queden romanalles que hem pogut detectar.

Entre els factors extralinguístics abans enumerats, el gènere dels informants es mostra com un factor decisiu a l'hora d'explicar la variació. Les dones tendeixen més a l'articulació labiodental (amb un pes o weight de 0.699) que no pas els homes (pes de 0.301 ), tal com podem observar en el gràfic següent. 


\section{Variació $[b][\beta] /[v]$ segons el sexe dels informants}

\section{GrÀtIC 1}

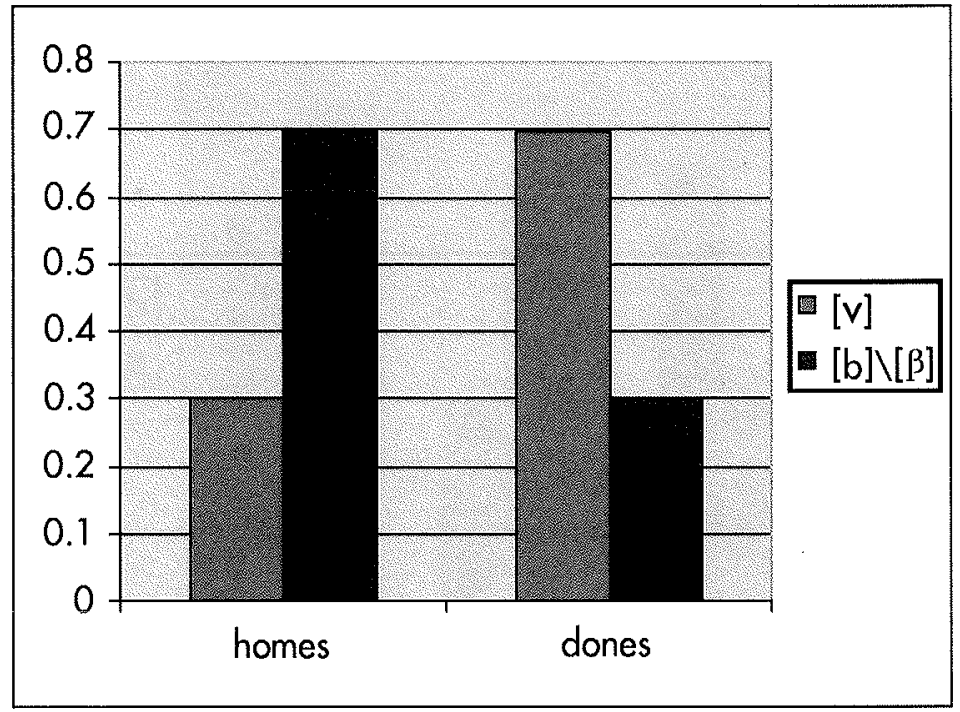

En canvi, l'edat no constitueix un factor explicatiu de la variabilitat en el cas del nostre treball. Tot i que s'apunta una lleugera tendència en el grup de més edat cap a la realització labiodental, la diferència no és significativa. Aquest fet demostra que la realització labiodental, vint anys després de l'afirmació de Recasens, encara es pot trobar en parlants de menys de 60 anys.

D'altra banda, l'àmbit d'ocupació també ha resultat un factor rellevant. En el cas d'informants pertanyents a l'àmbit de serveis, hi ha una tendència molt més alta cap al betacisme que en el cas d'informants de l'àmbit de la indústria o la pagesia. Una explicació d'aquest fenomen podria ser una exposició més intensa a la llengua castellana i a parlars betacistes dels informants del sector serveis. No podem oblidar que les rutines comunicatives de la gent que està de cara al públic mostren una clara tendència a utilitzar el castellà amb els desconeguts, si no s'interpreta que són catalanoparlants. D'altra banda, Valls compta amb un nucli important de població castellanoparlant.

Al gràfic següent podem observar el pes de la realització labiodental segons l'àmbit de relació dels informants. Al sector indústria, té un pes de 0.65 ; als serveis, de 0.3 i dins del sector pagesia, de 0.58 . 
GràFIC 2

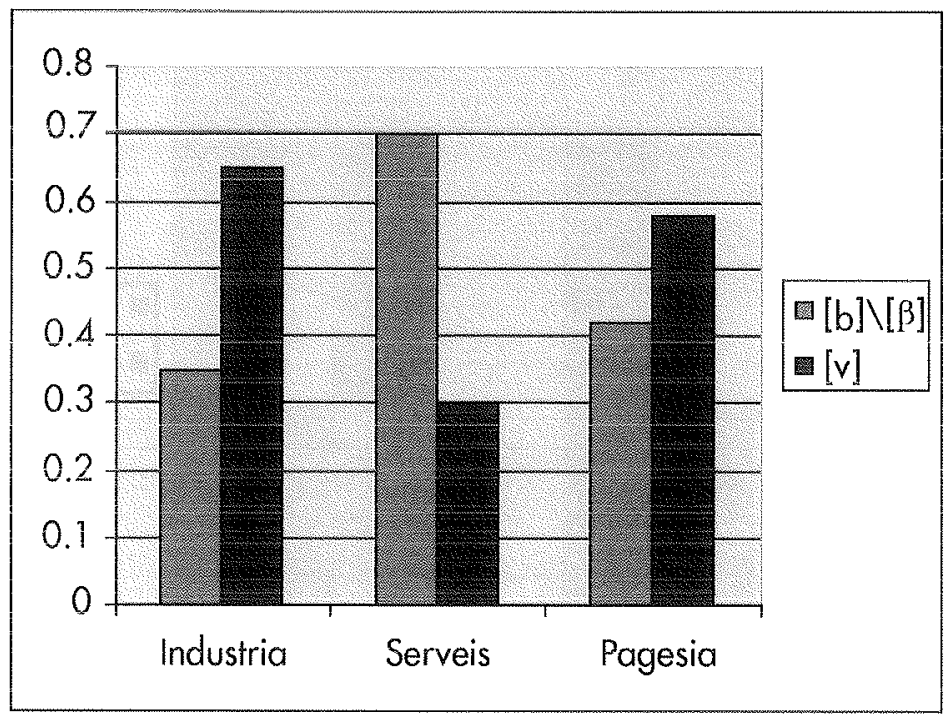

Tanmateix, entre les variables socials significatives, potser la més interessant és la que fa referència a la instrucció dels informants: els informants amb més instrucció són els que més tendència presenten cap a la realització labiodental. Això significa que la consciència del fenomen d'aquests informants els porta a una realització voluntària de la labiodental per tal de mantenir-la i/o recuperar-la. Intuïm que l'articulació de la lahiodental és un estereotip de valoració positiva. Durant les entrevistes vam poder recollir explicitacions d'aquest prestigi atribuit a la pronúncia labiodental en el cas d'informants amb més instrucció. Seria interessant, en un treball més aprofundit, tenir en compte la consciència del fenomen com a variable.

Si creuem les dades referents al sexe i a la instrucció, obtindrem resultats encara més reveladors. Els homes de baixa instrucció són betacis-tes al $100 \%$; els homes amb instrucció més elevada tendeixen més a la labiodental $(5 \%)$. Tot i així, mai en el mateix grau que les dones. Els informants que més clarament tendeixen a l'articulació de la labiodental són les dones amb més instrucció (11\%), seguides de les dones amb menys instrucció $(8 \%)$. 
Variació $[b][\beta] /[v]$ segons el gènere i el nivell d'instrucció

\section{GRÀfic 3}

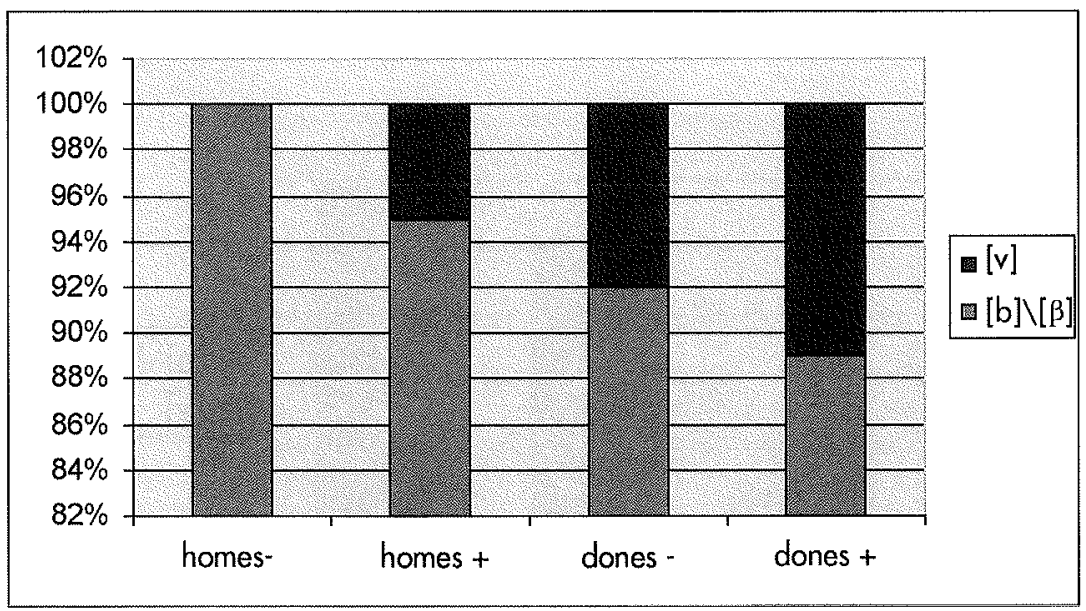

Quant als factors estilístics, els resultats obtinguts també són significatius per a explicar la variabilitat del fenomen. És en els registres més formals, és a dir, en la lectura i el qüestionari, on la presència de la labiodental és més freqüent. En la conversa hi ha una clara tendència al betacisme (la realització labiodental només té un pes de 0.203). Aquest fet és lògic si tenim en compte que en el cas de la lectura i el qüestionari, el grau d'atenció de l'informant és superior (el pes de la realització labiodental en el cas de la lectura és de 0.683 i en el cas del qüestionari de 0.604). A més, la visualització de la grafia en la lectura deu ser un factor influent del manteniment de $/ \mathrm{v} /$. 


\section{Variació [b] [ß]/ [v] segons l'estil de parla}

\section{GRÀFIC 4}

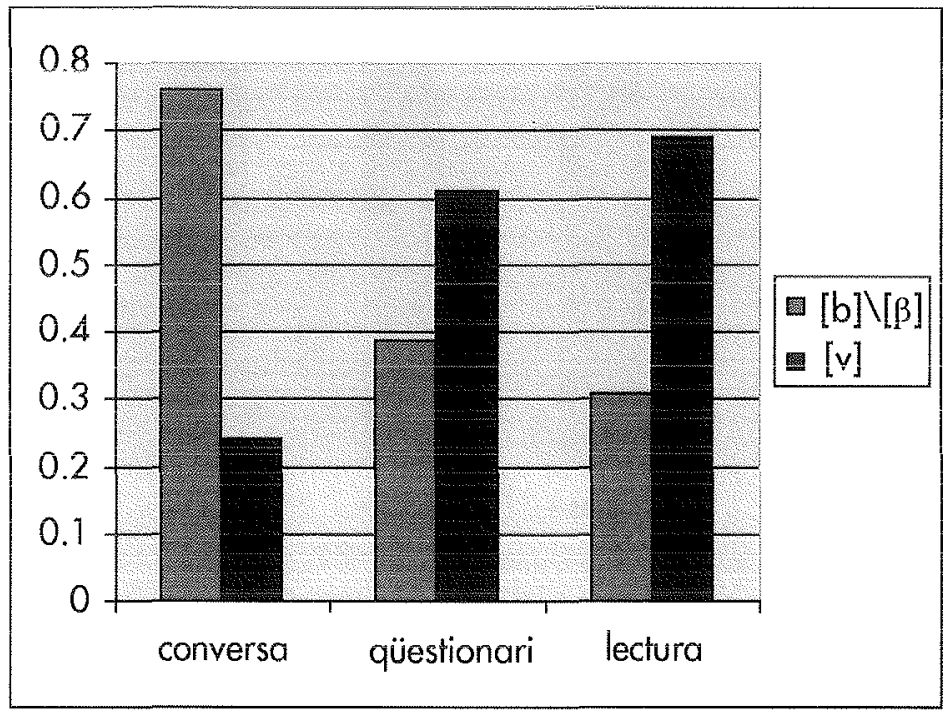

Per ültim, pel que fa als factors lingüistics analitzats, val a dir que ni la tonicitat ni la posició no es mostren com a elements significatius. Quant al context anterior i posterior, corroborant la hipotesi de Recasens, les realitzacions labiodentals són més freqüents en cas de manca de context anterior, sobretot si en el context posterior tenim una medial semitancada '[voní] - representa un $16 \%$ de les realitzacions labiodentals) -, una palatal oberta [véndre] - $14 \%$ de les realitzacions - o una palatal tancada [víðe] $-13 \%$ de les realitzacions. En cas de presència de context anterior, els percentatges més alts d'articulació labiodental els trobem entre medial semitancada i palatal semitancada [rəvés], amb un 14\%, i entre velar oberta i palatal oberta [nóve], amb un $16 \%$.

Tanmateix, segons els resultats obtinguts, la poca incidència en el canvi dels factors lingüistics tinguts en compte ens porta a aventurar que, si més no en l'etapa final del canvi observada, la fossilització d'un conjunt de bases lèxiques pot tenir un paper preeminent en la vigència de la pronúncia labiodental. 


\section{CONCLUSIONS}

Aquest treball ens ha permès constatar la vigència, tot i que gairebé residual, de la realització labiodental en el parlar de Valls. Com a factors determinants, s'han mostrat especialment rellevants la instrucció en relació amb la consciència del fenomen $i$ el prestigi que se li confereix, i els estils de parla. El comportament estilístic de les dones ens fa pensar que podríem trobar-nos davant d'un canvi «d'anada i tornada», això és, un canvi que, un cop gairebé acomplert, pot propiciar-ne un altre en sentit contrari associat a la consideració prestigiosa de la variant labiodental. Ens sembla, però, altament improbable que aquesta nova tendència que s'insinua acabi generalitzant-se. Pel que fa als factors lingüístics, hem observat la possible importància de la base lèxica com a factor determinant de la realització labiodental. Un treball més aprofundit hauria de tenir en compte aquestes consideracions.

\section{REFERÈNCIES BIBLIOGRÀFIQUES}

CARrera, J. (2002): «L'estadística en l'anàlisi de la variació fonètica: una aplicació del programa Goldvarb» [en línia]. Noves $S L$, primavera. $<$ http://www6.gencat.net/llengcat/noves/hm02primavera/metodologia/carr eral_5.htm>

LABOv, W. (1971): «Methodology», A: A Survey of Linguistic Science, Maryland, University of Maryland, 412-479.

- (1972): Sociolinguistic Patterns, Philadelphia, University of Pennsylvania Press.

Pradilla, M. À. (2001 a): «La sociolingüística de la variació. Aproximació metodològica (I)», Noves $S L$, Hivern - Primavera. [en línia] <http://cultura.gencat.net/llengcatnoves/hm01hivern-primavera/metodologia/pradilla1 $7 \mathrm{htm}>$.

- (2001 b): «La sociolingüística de la variació. Aproximació metodològica (i II)», Noves $S L$, Tardor. <http://cultura.gencat.net/llengcatnoves/hm01estiu/metodologia/pradilla1 $9 \mathrm{htm}>$.

- (2002): «La variació fònica en la llengua catalana: inventari i avaluació metodològica», Noves SL, Tardor. <http://cultura.gencat.net/llengcatnoves/hm02tardor/metodologia/a pradillal $8 \mathrm{htm}>$.

Pradilla, M. À; J. Carrera; A. M. Fernández (2005): «La sociolingüística de la variació i la fonètica experimental. Per a una complementarietat metodològica», PEREA, M. P. (2005): Dialectologia i recursos informàtics, Barcelona, PPU. 
RECASENS, D. (1985): Estudi linguiistic sobre la parla del camp de Tarragona, Barcelona, Publicacions de l'Abadia de Montserrat.

- (1991): Fonètica descriptiva del català, Barcelona, Institut d'Estudis Catalans.

VENY, J. (1982): Els parlars catalans, Barcelona, Editorial Moll. 


\title{
PRESENCIA Y AUSENCIA \\ DE LOS PRONOMBRES PERSONALES \\ SUJETOS EN LA RADIO LOCAL ALMERIENSE
}

\author{
Antonio María López González \\ Instituto Bilingüe Hispano-Polaco de Poznan, Polonia
}

\section{MARCO TEÓRICO}

$\mathbf{L}$

A presencia o ausencia de los pronombres personales sujeto en andaluz fue Ana cuestión que ya ocupó desde un punto de vista sociolingüístico a Miró Vera y De Pineda (1990) en el estudio del habla de Sevilla, y a García Marcos (1991) en la Costa Granadina, y desde una perspectiva más amplia a Rosengren (1974).

De todos es sabido que en español no es necesaria la presencia de estos pronombres, ya que el morfema de persona incluido en el verbo indica el sujeto gramatical de primera, segunda o tercera persona. No obstante, advierte Alarcos Llorach (1994: 73) que:

es frecuente la aparición de un personal en esa función de sujeto explícito, y no sólo en los casos de coincidencia fónica de las formas verbales (como cantaba, cantaría, cante, en que no se distingue la primera de la tercera persona), ni en el caso de la tercera persona (donde la distinción de géneros del personal puede aportar mayor precisión acerca de la referencia concreta del sujeto). También puede aparecer yo y $t u ́$, aunque su referencia personal es evidente e inequívoca en cada acto de habla. Por tanto, la aparición de los sustantivos personales en estos casos de redundancia, tiene marcado carácter enfático y expresivo, y trata de contraponer la persona aludida a las otras

En efecto, en diferentes trabajos, como el anteriormente citado de Miró Vera y De Pineda (1990: 41) sobre el sevillano culto, o Meyer-Hermann (1996: 299) acerca del habla culta de Costa Rica, ha quedado demostrado que existe una correlación estadística poco significativa entre [+/- ambigüedad morfológica] y la presencia/ausencia de los pronombres sujeto. En relación con la resolución de la ambigüedad morfológica, se halla la frecuencia de elisión de /s/ final en opinión, entre otros, de Hochberg (1986). Según esta autora, la pérdida de /s/ final en el puertorriqueño se vería compensada por la presencia de los pronombres sujeto. 
Por otra parte, Bentivoglio (1987: 46), en su estudio sobre el uso de los pronombres en el habla de Caracas, pone de manifiesto que el factor énfasis tampoco tiene una influencia decisiva sobre la presencia o ausencia en este caso del pronombre $y \%$.

La presencia o ausencia de los pronombres sujeto viene determinada, según Miró Vera y De Pineda (1990), por una parte, y Bentivoglio (1987) y Mieyer-Hermann (1996), de otra, por una conjunción de factores tanto sociales (sexo, edad, clase social...) como lingǘsticos (cambio de referencia, ambiguiedad, cambio de turno').

A la hora de estudiar la presencia o ausencia de los pronombres sujeto, es preciso subrayar que la dicotomía presencia/ausencia no es de la misma iatuialeza en todas las personás (Míró Vera y De Pinedà, 1990: 38):

Estas diferencias entre yo-tú y ál [...] pueden deberse al distinto proceso semiótico que hace al sujeto-hablante y al sujeto-oyente formar parte de la estructura lingiística: yo y tú, en función de sujetos, son signos originales [...], con referentes externos, insertados en la linealidad del discurso por causas que pocas veces, o quizás ninguna, se pueden explicar mediante reglas gramaticales. Mientras que él tiene como origen una razón tan puramente lingǘstica como es la economía expresiva; y stu referente no es nunca externo sino un signo incluido previamente en el texto.

De este modo, en pronombres como yo o tú la opción es exclusivamente dicotómica, presencia o ausencia, pero en los pronombres de tercera persona, el sistema ofrece otras posibilidades (un sintagma nominal con núcleo sustantivo, pronombres demostrativos, pronombres relativos, etc.). Por ello es por lo que en el estudio del uso de los pronombres sujeto me ciño exclusivamente a los pronombres yo, tu, nosotros/as, vosotros/as, usted/es.

\section{METODOLOGIA}

Este estudio se ha realizado sobre una muestra de programación de radio local almeriense, recogida durante el mes de junio de 1995. La muestra se halla estratificada proporcionalmente a las 335.18 horas semanales que constituían por entonces la programación local del total de emisoras de la ciudad de Almería. Esta muestra consta de 12 horas de grabación que incluyen a las 12 emisoras y cinco estratos de programación que componían la oferta radiofónica de aquel mes. Esto garantiza la representatividad de la muestra, por cuanto que doce horas de muestra significan el $3.6 \%$ del universo radiofónico estudiado, lo que además da un alto índice de fiabilidad.

1. Para tuat explicación de estos conceptos-véase-Meyer-Hermamm-(1996:-284-285). 
Tras la transliteración del corpus siguiendo un criterio ortográfico, procedí al análisis sociolingüístico. Para el análisis sociolingüístico se han considerado como factores sociales la distinción entre profesionales y no profesionales del medio radiofónico y la variable sexo.

También estudio la tensión comunicativa, y distingo entre situaciones con mayor o menor tensión comunicativa. A las primeras (más formales) pertenecen los noticiarios y reportajes, y todos aquellos programas donde las intervenciones del locutor hayan sido pregrabadas o en los que éste lea. Por contra, tienen menor tensión comunicativa, aquellas unidades de texto, o fragmentos de éstas, en las que la improvisación juegue un papel importante en el monólogo del locutor (programas musicales), donde haya interacción (programas de participación del público y entrevistas) y retransmisiones deportivas.

Finalmente, los diferentes estratos de programación (Deportes, Informativo, Magazines y Musical) y las doce emisoras de radio (Alhamilla Radio, Cadena 40 Principales, Cadena 100, Cadena COPE, Cadena DIAL, Cadena SER, Canal Sur, Cadena M80, Onda Cero Música, Onda Cero Radio, Radio 5 Todo Noticias y Radiolé) han constituido variables pertinentes de análisis por abordarse en ellos diferentes temáticas, con distintos estilos y tener una diferente audiencia.

\section{ANÁLISIS}

\subsection{Distribución general}

La dicotomía presencia/ausencia de los pronombres personales en función de sujeto se resuelve, en el conjunto de la muestra, a favor de la ausencia de éstos. Su aparición alcanza tan sólo el $17.07 \%$.

GráfICO 1. Uso del pronombre sujeto

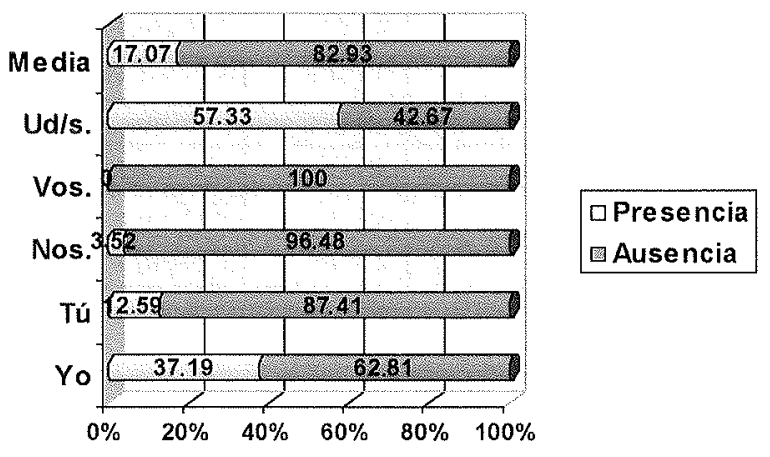


Un estudio individualizado revela que únicamente las formas de cortesía «usted/es» obtienen porcentajes de aparición superiores al 50\%. La cortesía que se hace patente mediante las formas verbales correspondientes se refuerza por medio de la presencia de estos pronombres.

Los pronombres «yo» y «tí» alcanzan porcentajes de aparición aprecia-bles, $37.19 \%$ y $12.59 \%$, respectivamente. Como ya hiciera García Marcos (1991: 107), cabe la posibilidad de apuntar como hipótesis de trabajo, influencias psicolingüísticas individualizadas (inseguridad personal, egocentrismo, etc.). De este modo, un posible egocentrismo podría explicar esta considerable presencia del pronombre «yo».

En cuanto al resto de pronombres estudiados, «nosotros/as» alcanza un exiguo $3.52 \%$, en tanto que ei pronombre «vosotros/as» no se actualiza como sujeto en la muestra.

Comparada con estudios precedentes, la presencia del pronombre «yo», $37.19 \%$, se sitúa en un rango intermedio dentro del mundo hispánico, entre Caracas y Santiago de Chile.

TABLA 1. Empleo del pronombre «yo» como sujeto en algunas variedades del español (Meyer-Hermann, 1996)

\begin{tabular}{|l|l|l|}
\hline País / Ciudad / Variedad & $\%$ & Fuente \\
\hline Santiago de los Caballeros & & \\
\hline (República Dominicana) & $66.6 \%$ & Olloqi Montenegro (1987) \\
\hline Puerto Rico & $55.2 \%$ & Morales (1986) \\
\hline Costa Rica & $53.4 \%$ & Meyer-Hermann (1996) \\
\hline Puertorriqueño de & & \\
\hline cmigrantcs cn Boston & $46.0 \%$ & Hochberg (1986) \\
\hline Caracas & $46.0 \%$ & Bentivoglio (1987) \\
\hline Almería (Radio local) & $37.2 \%$ & López-González (2001) \\
\hline Santiago de Chile & $34.0 \%$ & Cifuentes (1980/81) \\
\hline Los Ángeles (EE uU) & $33.9 \%$ & Silva-Corvalán (1993) \\
\hline Madrid (habla culta) & $32.0 \%$ & Enríquez (1984) \\
\hline México & $30.0 \%$ & Cantero Sandoval (1978) \\
\hline Buenos Aires & $24.0 \%$ & Barrenechea/Alonso (1977) \\
\hline Castellano (literario) & $21.0 \%$ & Rosengren (1974) \\
\hline
\end{tabular}




\subsection{Tensión comunicativa}

Los pronombres sujeto tienen una mayor presencia en la muestra cuando disminuye la tensión comunicativa: 23 formas pronominales en +Tensión frente a 145 en -Tensión. Esta diferencia se hace especialmente patente en el pronombre «yo», 9 formas en +Tensión por 81 en -Tensión.

La tensión comunicativa influye moderadamente en la aparición o elisión de los pronombres sujeto, sin llegar a ser las diferencias muy acusadas, salvo en el caso de los pronombres de cortesía «usted/es». Menor tensión comunicativa implica mayor aparición de los pronombres sujeto. Por término medio, la diferencia a favor de la aparición de estos pronombres personales es de un $3 \%$ en las situaciones con menor tensión comunicativa con respecto a aquellas con más tensión. El aumento es mayor en las formas de cortesía «usted/es», casi un $10 \%$.

El aparente mayor porcentaje del pronombre «yo» en las situaciones de mayor tensión no debe llevar a engaño, pues la frecuencia absoluta del pronombre «yo» en las situaciones de + Tensión (9) es muy inferior a la que ofrecen los textos con -Tensión (81).

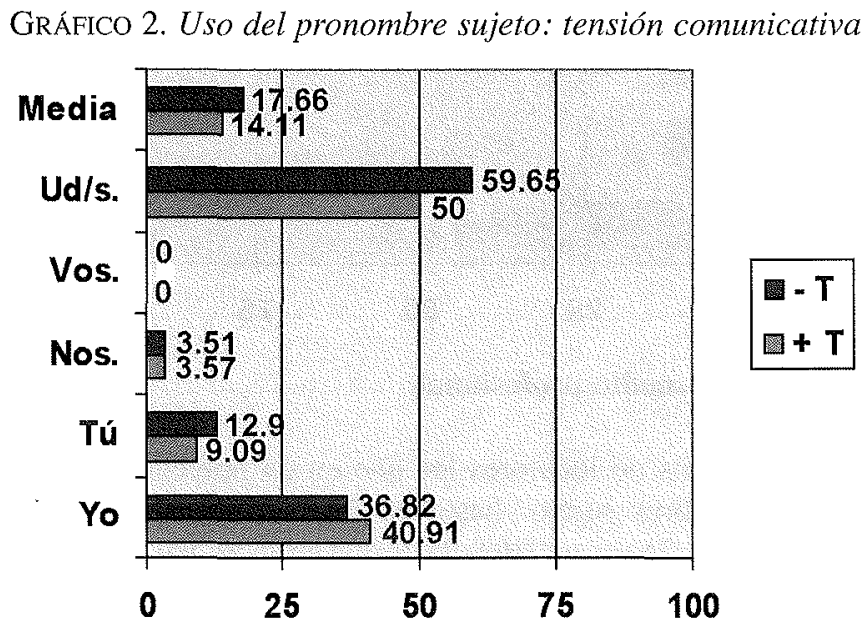

\subsection{Factor sexo}

Lo más llamativo en este punto es la diferente frecuencia de aparición del pronombre «yo», muy superior en los hombres (44.68\%) a las mujeres $(26.73 \%)$. Esto apunta a una mayor dosis de egocentrismo en el grupo masculino. 
En ambos sexos se da una alta presencia de los pronombres «usted/es», si bien la presencia de éstos, en términos porcentuales, es superior en las mujeres, $62 \%$ por $48 \%$ en los hombres. Estos datos se hallan en la línea de lo señalado por Lakotf (1977), en cuanto a que las mujeres utilizan en más ocasiones las formas de cortesía. Un dato más que avalaría esta afirmación dentro de la muestra es que las formas de cortesía, explícitas e implícitas, suman en conjunto en las mujeres el doble que en los hombres, 50 y 25 , respeclivantente.

Por lo demás, a excepción de las formas «usted/es», se constata, para cada uno de los pronombres un mayor uso de éstos por parte del grupo masculino. La distribución porcentual, tanto en hombres como en mujeres, salvo en los casos comentados, repite las tendencias apuntadas en la distribución general.

GráfICO 3. Pronombres sujeto: sexo

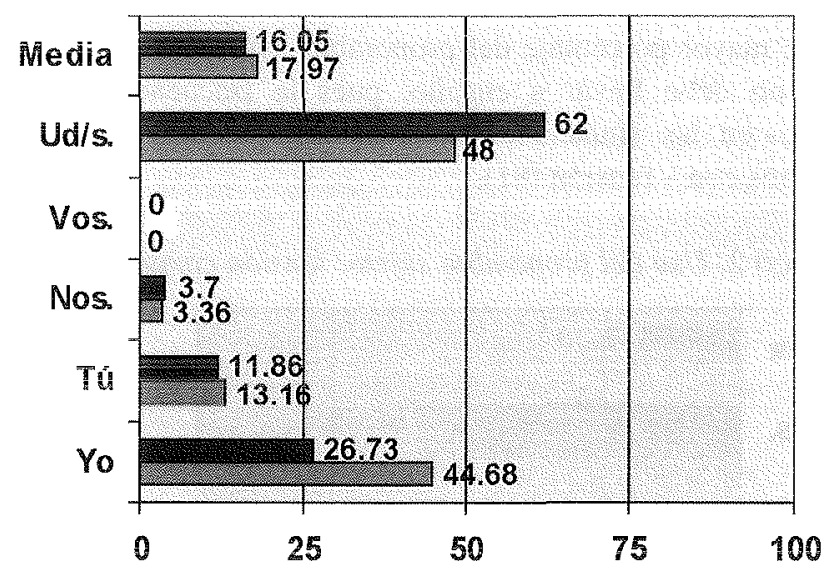

\subsection{Relación con el medio profesional}

Claramente son los no locutores los que en un porcentaje mucho mayor utilizan los pronombres sujeto: hasta en un $64.65 \%$ el pronombre «yo» (frecuencia absoluta, 75) y un $36 \%$ la forma pronominal «tú». También la forma «nosotros/as» $(7.58 \%)$ en función de sujeto es más frecuentemente explicitada en el discurso en este grupo de informantes.

Por el contrario, es fácil apreciar en el gráfico que los locutores profesionales se esfuerzan por elidir el uso de los pronombres personales sujeto, con porcentajes de uso muy por debajo de los no locutores: «yo» $(11.91 \%)$, «tú» $(7.27 \%)$, «nosotros/as» $(0.67 \%)$. Sin embargo, en el caso de los pronombres «usted/es» $(60.38 \%)$ la situación se invierte por efecto de una mayor dosis de cortesía. 
GráFICO 4. Pronombres sujeto: relación profesional

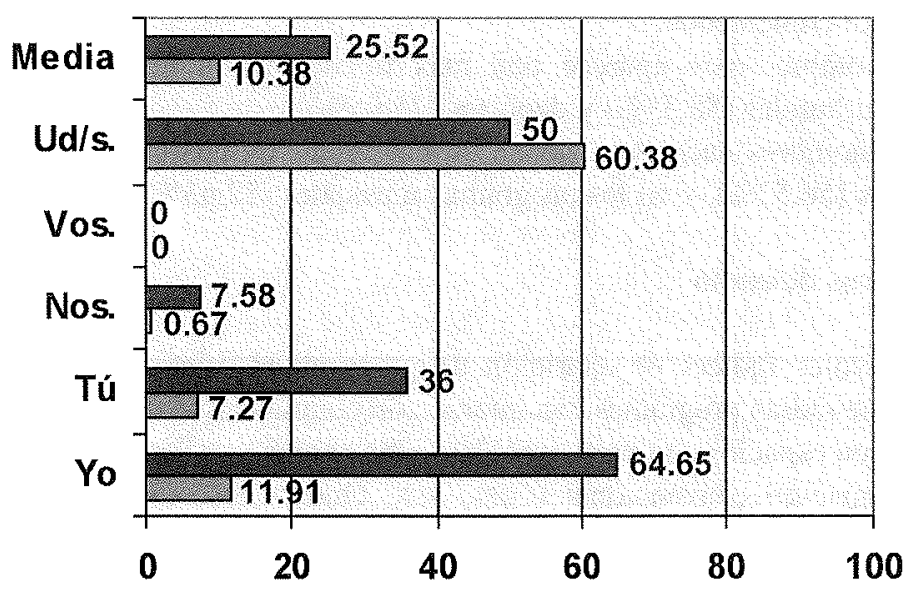

\subsection{Estratos de programación}

Los índices medios de uso de los pronombres sujeto por estratos de programación revelan que cuanto más importante es el papel que juega la palabra en el estrato de programación, con más frecuencia aparecen los pronombres sujeto. Por consiguiente, el máximo se da en la programación informativa (22.52\%), con lectura y comentario de noticias y entrevistas; los magazines y los deportivos ocupan el segundo lugar (en torno al 19\%), con programas de variedades y retransmisiones deportivas; en último lugar se cuentan los programas culturales y musicales (12-13\%), con lecciones para adultos y presentación de canciones.

TABLA 2. Aparición del pronombre sujeto, según estrato de programación

\begin{tabular}{|l|l|l|l|l|l|}
\hline Pronombres & Culturales & Deportes & Informativos & Misceláneas & Musicales \\
\hline Yo & 58.33 & 45.95 & 64.29 & 31.00 & 26.15 \\
\hline Tú & $-(\mathrm{fr}: 1-3)^{\prime}$ & 0.00 & $-(\mathrm{fr}: 2-2)$ & 16.95 & 6.56 \\
\hline Nosotros/as & 5.56 & 3.12 & 4.05 & 4.47 & 0.00 \\
\hline Vosotros/as & 0.00 & 0.00 & 0.00 & 0.00 & 0.00 \\
\hline Usted/es & $-(\mathrm{fr}: 3-2)$ & $-(\mathrm{fr}: 2-0)$ & $-(\mathrm{fr}: 2-1)$ & 56.52 & 52.63 \\
\hline Media & 13.22 & 19.09 & 22.52 & 19.33 & 12.20 \\
\hline
\end{tabular}

'Frecuencia absoluta inferior a 5 . (Frecuencias absolutas presencia-ausencia). 
Analizando el comportamiento de cada pronombre, dos son los datos más dignos de ser comentados:

El pronombre «yo» aparece con más frecuencia en los informativos $(64.29 \%)$, culturales $(58.33 \%)$ y deportes $(45.95 \%)$.

Los pronombres «usted/es» tienen un porcentaje de aparición alto en las Misceláneas $(56.52 \%)$, y en los programas musicales $(52.63 \%)$.

\subsection{Emisoras de radio}

Los mayores índices de aparición de pronombres sujeto se dan en las emisoras que radian programas con interacción comunicativa tipo entrevista $o$ teruilia, o con espacios con participación de los oyentes, es decir, en emisoras con programación convencional (COPE, SER, Onda Cero, Canal Sur), más Alhamilla Radio, Radiolé y Cadena 100.

No obstante, tan sólo los valores correspondientes a las siguientes seis cadenas de radio son los suficientemente significativos como para ser analizados:

TABLA 3. Aparición del pronombre sujeto: según emisoras de radio

\begin{tabular}{|l|l|l|l|l|l|}
\hline Emisoras & \multicolumn{1}{|c|}{ Yo } & \multicolumn{1}{|c|}{ Tú } & Nos. & Vos. & \multicolumn{1}{|c|}{ Ustedles } \\
\hline ALHR & 37.35 & 20 & 5.84 & - & 54.17 \\
\hline C100 & 47.83 & 14.29 & 2.04 & 0 & - \\
\hline COPE & 43.33 & 0 & 3.28 & - & 66.67 \\
\hline SER & 34.21 & - & 2.44 & - & 62.5 \\
\hline OCR & 68.42 & - & 9.3 & 0 & - \\
\hline ROLE & 16.67 & 10 & 0 & 0 & 57.57 \\
\hline
\end{tabular}

De estos datos, lo más significativo es:

a) el alto índice de presencia del pronombre sujeto "yo» en Onda Cero Radio $(68.42 \%)$, resultado de los programas grabados, en los que se da el género periodístico de la entrevista; y, en general, un índice de aparición de este pronombre superior a la media en todas las emisoras con programación convencional;

b) los porcentajes de aparición del pronombre sujeto «tú» en Alhamilla Radio $(20 \%)$ y Cadena $100(14.29 \%)$, correspondientes a programas de participación del público por teléfono o, también a entrevistas; 
c) los altos porcentajes de uso del pronombre «usted/es», dirigido a la audiencia como «ustedes».

\section{CONCLUSIONES}

Este estudio ha servido para delimitar el grado de influencia de los factores sociolingüísticos en la dicotomía ausencia/presencia de los sujetos pronominales en el contexto radiofónico almeriense. A la vista de los porcentajes promedio de aparición de los pronombres sujeto se concluye, como muestra cl gráfico, que, en general, los hombres los utilizan casi un $2 \%$ más que las mujeres, que la menor tensión comunicativa la favorece un $3.5 \%$ más, y que los no locutores los usan en un $15 \%$ más. La aparición de estos pronombres es más frecuente en los programas informativos, las misceláneas y los deportivos, dado que en este tipo de programas se conjuga la menor tensión comunicativa, la participación de no locutores, y estilos discursivos, como el diálogo, propicios para la aparición de los pronombres sujeto.

También de estos datos se deduce que el factor sociolingüístico que más influye en la variación del pronombre sujeto es la relación con el medio profesional, señalándose una marcada diferencia (15.14\%) entre el comportamiento de los locutores y los no locutores al respecto de esta variable. Con mucho menor peso se definen factores como la tensión comunicativa y el estrato de programación. El sexo influye de manera mínima en la variación.

GRÁFICO 5. Variación de uso del pronombre sujeto

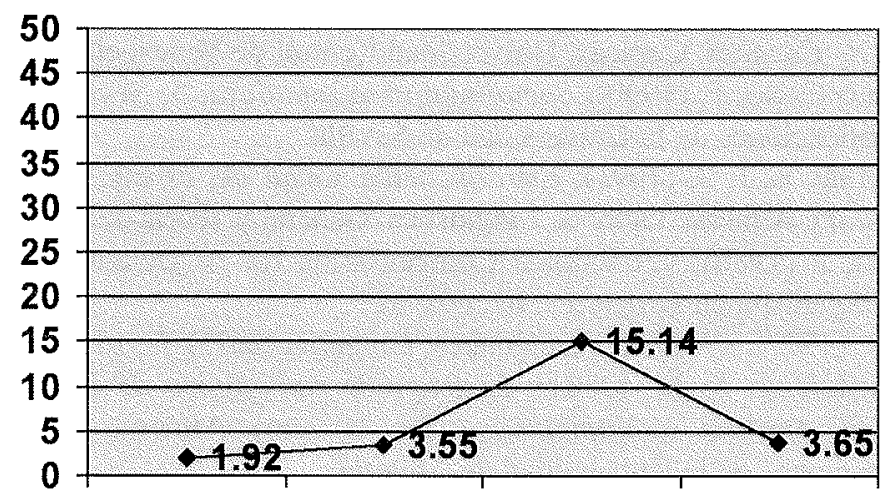

Sexo Tensión R. Prof. E.P. 
Por pronombres es el pronombre yo el más afectado por los factores sociolingüísticos, seguido por tú. El comportamiento de los otros pronombres es más homogéneo. Uno a uno la variación queđa como sigue:

Yo. Porcentaje promedio: $37.19 \%$ (90 de 242 formas verbales). Valores superiores alcanza entre los no-locutores $(64.65 \%)$, la programación informativa ( $64.29 \%)$, cultural $(58.33 \%)$ y deportiva (45.95\%), entre los hombres (44.68\%) y en la mayor tensión comunicativa $(40.91 \%)$.

Tu. Porcentaje promedio: $12.59 \%$ (17 de 135 formas verbales). Valores superiores obtiene entre los no-locutores (36\%), las misceláneas (16.95\%), los hombres $(13.16 \%)$ y la menor tensión comunicativa (12.9\%).

Nosotros/as. Porcentajo promedio: $3.52 \%$ (18 de 511 formas verbales). Valores superiores muestra entre los no-locutores $(7.58 \%)$, la programación cultural $(5.56 \%)$, las misceláneas $(4.47 \%)$, los informativos $(4.05 \%)$ y las mujeres $(3.7 \%)$

Vosotros/as. No se actualiza en la muestra (0 de 21 formas verbales).

Ustedles. Porcentaje promedio: $57.3 \%$ (43 de 75 formas verbales). Valores superiores contabiliza entre las mujeres $(62 \%)$, los locutores $(60.38 \%)$ y la menor tensión comunicativa $(59.65 \%)$.

\section{REFERENCIAS BIBLIOGRÁFICAS}

Alarcos Llorach, E. (1994): Gramática de la lengla española, Madrid, Espasa-Calpe.

Bentivoglio, P. (1987): Los sujetos pronominales de primera persona en el habla de Caracas, Caracas, Universidad Central de Venezuela.

CArbonero Cano, P. (1990): Sociolingiuística andaluza, 5, Sevilla, Servicio de Publicaciones de la Universidad de Sevilla.

García Marcos, F. J. (1991): Estratificación social del español de la costa granadina, Almería, Dpto de Linguística General y Teoría de la Literatura. Hochberg, J. (1986): «Functional Compensation for /s/ Deletion in Puerto Rican Spanish» en Language, 62, 609-621.

LAKOFF, R. (1977): «Women's Language», Language and Style, 10, pp. 222-247 López GONZÁlez, A. M. (2001): El lenguaje radiofónico de la ciudad de Almería. Análisis sociolingiiístico, [en CD-rom], Almería, Servicio de Publicaciones de la Universidad de Almería.

Meyer-HermanN, R. (1996): «Sobre el uso del sujeto yo en el habla culta de Costa Rica» en Th. Kotschi, W. Osterreicher y K. Zimmermann (eds.), El español hablado y la cultura oral en España e Hispanoamérica, Madrid - Frankfürt Am Main, Bihlioteca Theroamericana - Vervuert. 
Miró Vera, R. y M. Á. DE PinedA. (1990): «Determinación sociolingüística de la presencia/ausencia del pronombre personal sujeto» en CARBONERO CANO, P. (1990).

Rosengren; P. (1974). Presencia y ausencia de los pronombres personales sujetos en español moderno, Estocolmo, Acta Universitatis Gothoburgensis. 


\title{
DIATOPÍA DE DISFEMISMOS Y EUFEMISMOS EN EL ÁMBITO HISPÁNICO
}

\author{
amalia Pedrero González \\ Universidad San Pablo-CEU de Madrid
}

\section{INTRODUCCIÓN}

D E sobra es sabido que el español es una de las lenguas más habladas del mundo: se calcula que lo tenemos como lengua materna unos 400.000.000 de personas, principalmente entre España y América, donde nos hemos centrado para este trabajo. El elevado número de hablantes, en una vastísima extensión geográfica, implica gran diversidad dentro de la unidad. La intercomunicación está asegurada entre hispanohablantes, pero en ocasiones se producen malentendidos y equívocos.

Es la diversidad léxica y semántica en el registro coloquial y vulgar la que nos ocupa. Según $\mathrm{M}^{\mathrm{a}}$ Ángeles Álvarez (2000: 536): «Los vulgarismos son un riesgo para la unidad del sistema lingüístico, sin duda, porque su preponderancia podría llevar a la incomprensión por parte de los hablantes». Independientemente de que sean un riesgo para la unidad del idioma, sí es verdad que existe gran variación diatópica dentro del nivel vulgar, con sus eufemismos correspondientes, que en ocasiones produce la incomprensión. Además, uno de los atractivos de cualquier lengua son los términos tabú: gusta saberlos, no así emplearlos de forma inadecuada o sin conocimiento de que lo estamos haciendo. Por lo tanto, éste será nuestro objetivo: basándonos en fuentes lexicográficas,' repasaremos aquellos términos marcados dialectalmente como vulgares, no así en otros, aunque en muchas ocasiones sean términos polisémicos. No consiste en hacer listas sin más de dicho registro, sino un estudio diatópico contrastivo del nivel vulgar y cómo se registran en las fuentes. ${ }^{2}$

1. Se ha tomado como base la vigésima segunda edición del Diccionario de la Real Academia Española (DRAE, 2001) en su formato CD-rom, además de otros diccionarios de americanismos, trabajos sobre este asunto y diferentes vocabularios. No obstante, no siempre es fácil precisar la descripción diafásica concreta de cada vocablo, pues tanto las marcas, como los significados no siempre se corresponden con su uso real. Además, debo agradecer la colaboración de personas de diferentes países de habla hispana que me han ayudado a precisar el nivel coloquial o vulgar de algunos términos.

2. Evidentemente, siempre se echará en falta alguno, pues la lista es inabarcable. 
Los disfemismos y eufemismos se refieren a muchos campos semánticos, por lo que hemos delimitado el objeto de estudio: nos vamos a centrar en los que Kany (1960: VI) denomina de decencia o los que se refieren al sexo, junto con los insultos.

\section{PARTES DEL CUCRPO}

Se incluyen los órganos relacionados con actos sexuales.

\subsection{Nalgas}

El término culo, que en España se puede usar dentro de un registro coloquial, es, sin embargo, un vulgarismo en América. No se usa nunca para designar la parte posterior o inferior (culo de la botella...) o a la porción pequeña de líquido que queda en el fondo del vaso. ${ }^{3}$ El poto no solo es el nombre de una planta, o de una vasija en Perú, sino es el nombre general que se da a las 'nalgas' dentro del registro coloquial, no vulgar' en América. Para este concepto, en Argentina, Colombia y Uruguay se emplea en el estilo coloquial cola como eufemismo, y en Colombia, Costa Rica y Venezuela, rabo. Otro eufemismo es traste en Argentina, Paraguay, Uruguay y Chile, y como variante de éste, trastienda, que se da en Cuba, Chile y México. También en México existen las variantes bote y sisirisco. En Andalucia, Argentina y Chile, cachete. Fondillos, segün el DRAE (2001) es en «C. Rica. trasero (nalgas). En Colombia, Cuba, El Salvador, Guatemala y Puerto Rico, u. en pl. con el mismo significado que en sing.». Si alguien nos pregunta qué es una abeja, contestaremos que es un insecto, pero un habitante de Los Llanos, cn Colombia, respondcría que son las 'nalgas' (Kany, 1960: 197). En Argentina, otra variante es orto (DEArg., $2000 \mathrm{a}$ : s.v.). Por otro lado, en Cuba y Uruguay se emplea también como eufemismo la denominación pandereta, y siguiendo con más eufemismos referidos a la música, en El Salvador, fandango también tiene este significado.

Es curioso que un eufemismo muy extendido para 'nalgas', marcado por el DRAE (2001) como vulgar, sea un número: siete (Morínigo, 1993: s.v.), empleado en Argentina, Colombia, México, Paraguay, Puerto Rico y Uruguay.

3. Expresiones de uso frecuente en España propias del registro coloquial, y no marcadas en el DRAE (2001), serían consideradas vulgares en América; me refiero a casos como culo de mal asiento, culo de pollo, el culo del mundo, caerse de culo...

4. En el DRAE (2001) se localiza con este significado en el noroeste de Argentina, Bolivia, Chile, Ecuador, Paraguay y Perú. 
Con el mismo significado hay otro número, cinco, en México. También podemos incluir aquí cerete, voz malsonante en Honduras con el significado que nos ocupa.

\subsection{Pecho}

Es el caso que menos variantes presenta desde el punto de vista diatópico. Todos sabemos que chicha es una voz polisémica. Lo que no es sabido por todos es que en Costa Rica significa pecho e incluso se evita en plural (Kany, 1960: 200). Otra voz polisémica es chichi: en México, América Central y el noroeste de Argentina es 'pecho' o 'pezón' (del náhuatl chichi). Por su parte, en España, es un eufemismo de 'vulva'. Otras formas para designar esta parte son cascos en Perú, o chuco en Ecuador.

\section{3. Órgano genital femenino}

Es general en toda América el término papo, mientras que en España se emplea con más significados, como 'moflete, cachete', 'papada', además de ser una voz insultante en países como Honduras con el significado de 'tonto'.

Sorprende a muchos españoles que una palabra de uso tan común y sin ninguna connotación negativa como conch $a^{5}$ sea tan vulgar en el Río de la Plata, Chile, Perú, norte de Colombia o Puerto Rico. De aquí derivan insultos como conchudo, chupaconcha y otros más o menos de la forma concha tu madre; éste último, una ofensa muy grave. Sí pertenece a un registro vulgar en prácticamente todos los países de habla hispana el término coño, aunque en Chile es un uso despectivo con el significado 'español', o vulgar en Venezuela con el significado de 'tipo, individuo'. Además, en Chile y Ecuador puede adquirir el significado de 'tacaño'.

En algunas partes de América, como México, chucha es el diminutivo del nombre Jesusa. Por el contrario, en la zona del Río de la Plata, Chile, Bolivia, Perú y el norte de Colombia significa 'vulva'. ${ }^{6}$ Como derivado del anterior, el verbo chuchar se emplea en Nicaragua como 'copular'. Si hablamos de antropónimos, cuca tiene el significado que nos ocupa en Colombia, Guatemala y Venezuela. Por su parte, la voz chocho tampoco es monosémica, pues como

5. Otros usos dialectales que se incluyen en el DRAE (2001) son: «4. f. coloq. Col., Ecuad. y Perú. desfachatez. 15. f. Col. y Ven. cáscara (corteza o cubierta exterior). 16. f. Col. y Ven. Corteza de los árboles. 17. f. Ven. Cápsula vacía de cualquier proyectil de armas de fuego».

6. Este cambio de significado ha sido causa de problemas en el cine, ya que tenían que cambiar el nombre del personaje que se llamara así cuando la película se exhibía en estos países (Kany, 1960: 200). 
sustantivo, además de 'vulva', también posee los siguientes significados: 'altramuz', 'confite, peladilla'; en Colombia y en la República Dominicana es una especie de árbol; en Perú, una semilla o por sinécdoque, una ensalada de granos de esa semilla.

Este mismo significado ('vulva') tiene en las Antillas, México y Chile, papaya; en Cuba, la palabra bollo, bacalao, panoch $a,{ }^{7}$ torreja, tota o toto (DEC, 2000 b: s.v.); en Argentina, argolla, cachi, cachucha, cajeta, chucha, pachula, tajo, taiu, upite y ura (DEArg., 2000 a: s.v.); en Miéxico, cachimba, ${ }^{8}$ chayote (en Oaxaca) o tamal. Otras denominaciones: cuchara (sólo de forma ocasional en Venezuela, además de en El Salvador y Guatemala); pan en Santa Cruz, Bolivia $^{9}$ o pepita en Santo Domingo. ${ }^{10}$

Queremos destacar que hay una gran abundancia de nombres de animales que adquieren este valor: burro y asno en Piura (Perú); sapo en Bolivia; tortuga en México; pájaro en Puerto Rico; chocha en Cuba, la República Dominicana y Puerto Rico; choro en Chile, nombre que se le da allí al mejiltón; mico en El Salvador, Guatemala, Nicaragua y Costa Rica, y paloma en Guatemala, además de en Argentina y, por supuesto, almeja en España.

\section{4. Órganos genitales masculinos}

El término que abarca una mayor zona con este significado y marcado como vulgar es cipote (Argentina, Colombia, España, Paraguay, Venezuela). Sin embargo, son muchos más los signiticados recogidos en el DRAE (2001), además del aquí mencionado: 'mojón de piedra'; 'hombre torpe, bobo'; 'hombre grueso'; 'cachiporra'; 'palillo del tambor'; además de localizarlo en Colombia con sentido ponderativo (¡Cipote lío!) o en El Salvador, Honduras y Nicaragua 'niño' y también en El Salvador 'novio'.

Los chilenos que estén en sitios como España deben tener cuidado cuando se refieran a un perro, ya que la denominación familiar para ellos, picho o picha, aquí es 'pene' (Kany, 1960: 202). Por el contrario, el sustantivo de carácter vulgar en España, polla, adquiere otros significados en América: 'apuesta' (especialmente en carreras de caballos); 'carrera de caballos donde

7. En el DRAE (2001) se registra la voz con este uso en Cuba y El Salvador (en éste, además con una variante: panucha); sin embargo, también está atestiguado el uso como popular en otros países como México (DUM, 1996) o en el Valle de Cauca en Colombia (Kany, 1960: 202).

8. Santamaría (2000: s.v.) lo circunscribe a Tabasco, pero también hace referencia a Cuba, aunque no aparece en el DEC $(2000 \mathrm{~b})$ con este significado.

9. Para referirse al alimento se emplea horneado para lo que conocemos como el pan, y marraqueta para la barra (Kany, 1960: 202).

10. Semilla se emplea comúnmente para su significarln general (Kany, 1960: 2n?). 
se corre la polla'; en Ecuador, 'chuleta' (en exámenes); en El Salvador, 'esputo'; en México, una bebida, etc. Sin movernos de España, pilila se usa con este significado, generalmente en el lenguaje infantil; por su parte, en Chile y en Argentina se dice de la 'mujer de aspecto sucio'. Por otro lado, una expresión tan común en España como «qué palo!», en Chile, Costa Rica, Cuba y Uruguay cambia de significado, pues el palo es una denominación del órgano genital masculino.

En Puerto Rico, bicho significa "pene' como denominación única."

Así también, si queremos referirnos a un cubano llamado José por el diminutivo, es mejor que empleemos Cheo para que no haya ninguna confu-sión; pepe designa el órgano genital masculino. ${ }^{2}$ Por su parte, el gentilicio turco, en El Salvador y Nicaragua, también adquiere este significado.

Minga es otra denominación en Guatemala y España, pero en el norte de Argentina, Chile, Colombia, Ecuador, Paraguay y Perú es una «Reunión de amigos y vecinos para hacer algún trabajo gratuito en común»; y en Ecuador y Perú: «Trabajo agrícola colectivo y gratuito con fines de utilidad social» (DRAE, 2001). En Guatemala también tiene este significado moronga, que en EI Salvador, Honduras, México y Nicaragua se refiere a una «morcilla hecha de sangre de cerdo, sal, pimienta y chile picante, cocida en agua con sal y manteca dentro de una tripa de cerdo» (DRAE, 2001). No obstante, en Nicaragua narizón es una de las denominaciones del 'pene', al igual que en Honduras, bruto es un eufemismo. Otra voz que tiene este significado en América Central y Venezuela es paloma; machete en Venezuela; sable, en Ecuador; en Argentina, Panamá y Uruguay, guasca; en Cuba y la República Dominicana, tolete; pindonga, en Argentina y Paraguay, no tiene el significado de 'mujer callejera' (DRAE, 2001), sino el de 'pene'; chota, choto, marlo, picho, pindonga, pingo, pomo, poronga ${ }^{13}$ o tripa son denominaciones en Argentina; en Cuba, el polimorfismo es tremendo (DEC, $2000 \mathrm{~b}$ ): animal, barquillo, bate, cable, camarón, caoba, cuero, espolón, fenómeno, fruta, lezna, machete, mandado, manguera, muñeco, niño, puya, remo, timón, treinta, trole, trozo, tubería, vianda o yuca; pico en Chile, Cuba y Costa Rica; en Perú, pincho; ${ }^{14}$ cola en España y Chile; en Perú y Chile, pichula ${ }^{15}$ pinga es un eufemismo en

11. En Argentina y Cuba también se emplea con este significado, pero la diferencia es que en el primero es como designación única, mientras que en éstos, no.

12. Así está registrado por Kany (1960: 202), pero no aparece con tal significado en el DEC (2000 b).

13. El único significado con el que está incluido en el DRAE (2001) es rural para Nicaragua: «Tinaja pequeña que se utiliza para enfriar agua potable».

14. Les sorprende mucho que pidamos un pincho de tortilla, o que comamos pinchos morunos.

15. Según Morínigo (1993: s.v.), se refiere al 'miembro viril' de los niños y referido solo a Chile, aclaración que no se registra en el $D R A E$ (2001). 
América Central, Cuba, Ecuador, Perú y Venezuela. En Guatemala y México, otra denominación es reala.

En Centroamérica, al igual que en México, camote es una voz de mucho uso, pero en México también puede adquirir el significado de 'pene', el mismo que en El Salvador, Guatemala y México puede adquirir la voz chile y en Nicaragua, badajo.

El significado más común de huevo es el de la comida, pero se pierde muchas veces en favor de 'testículo' y, a partir de éste, se han creado en algunas zonas algunos eufemismos, que se han cargado con el valor del término tabú, como blanquillo (Guatemala, Honduras y México), o yema en Guanajuato (DUM, 1996). Otras variantes de testículos son: trolas en Chile y Argentina; ya propio de Argentina, boliviana, coco, corota ${ }^{16}$ o guinda; talayote (Morínigo, 1993; s.v.) tanate o tompiate (variante de tompeate, que además es un tipo de 'esportillo') en México; timbales en Cuba; y talegas en Bolivia (Kany, 1960; 203).

\section{RELACIONADOS CON EL ACTO SEXUAL}

Es un arcaísmo semántico en España el empleo del verbo coger ${ }^{17}$ con el significado de 'realizar el acto sexual' (DCECH, 1991, II: 120), que se mantiene en América. También con el mismo significado ('copular'), pero con extensión más reducida tenemos cachar, incluido en el DRAE (2001) referido a Perú y marcado, igual que el anterior, como vulgar, lo mismo que en Argentina, Chile, México y Colombia culear, que además de muy vulgar, es de mal tono según Santamaría (2000: s.v.). Exclusivos de Argentina son fifar, ${ }^{18}$ pinchar o trincar, pero ya de carácter coloquial.

Por otro lado, en España los verbos mojar y chingar, tienen el significado de "copular". No así en gran parte de América, donde el segundo adquiere otros significados, como en América Central 'castrar'; en Argentina y Uruguay 'colgar desparejamente el orillo de una prenda'; en Canarias, Argentina, Bolivia, Chile y Colombia 'no acertar, fracasar, frustrarse, fallar'. El verbo tirar, empleado preferentemente como pronominal, no solo posee el significado de 'arrojar' o 'lanzar', sino que en Chile, Colombia, México, Cuba o España, puede ser un vulgarismo en distinto grado, con el significado que nos ocupa, por lo que si, por ejemplo, algún chileno nos pregunta cómo nos va, es preferible no emplear «voy

16. En Bolivia se dice de la 'cresta del gallo' (Morínigo, 1993: s.v.).

17. Como derivados, cogienda significa 'fornicación' en Argentina y México (Morínigo, 1993: s.v.); por el contrario, está incluido en el DRAE (2001) con el significado de 'cosecha'.

18. El verbo se incluye en el DRAE (2001) como un uso coloquial cn Venczucla con cl significado siguiente: «Dicho de una cosa o de una persona: Dejar de funcionar». 
tirando», si realmente nuestra intención es comunicar otra idea. También adquiere este significado el verbo beneficiarse. De uso frecuente con el significado que nos ocupa es pisar en Cuba, México y El Salvador, e incluso en México, pisada es una denominación grosera (según Santamaría, 2000: s.v.) que se le da al 'coito', propia del habla de puertos y de marineros, según Morínigo (1993: s.v.). En Cuba, El Salvador y Guatemala, palito es otra denominación, y en Cuba templete. Exclusivos de Cuba son enganchar, puyar, rascar o la lexía tocar con limón ( $D E C, 2000$ b: s.v.), todas ellas de carácter coloquial. También con este valor está, en Paraguay, empurrar, que en América Central significa 'enfadarse'. Afilar en Chile es un uso vulgar con el significado que nos ocupa, mientras que en otros lugares adquiere el significado conocido por todos, al igual que en Argentina está registrado como 'entablar relaciones amorosas pasajeras'; chimar en Honduras como uso rural y en El Salvador; ${ }^{19}$ en Nicaragua, Colombia y Perú, chuchar.

Tampoco es fácil intuir que, en América Central y Cuba, alborotarse significa 'excitarse sexualmente' (Morínigo, 1993: s.v.), o alzado 'excitado sexualmente' en la zona de Argentina y Uruguay, con carácter vulgar. Ya en Argentina, arrecho, chacotero, designan a la persona que se excita con facilidad (DEArg., 2000 a). En Cuba poseen este significado acelerarse, embalarse, soplarse o volarse, todas ellas con carácter coloquial. Calentarse, aplicado a personas, puede ser 'excitarse', de ahí que expresiones como tener calentura no signifiquen 'tener fiebre', sino también 'estar excitado'. Cachondear solo tiene en México un significado: 'excitar', y no 'burlarse' o 'guasearse', de ahí que el adjetivo cachondo en este mismo país designe a la persona 'que es sensual y gusta del juego erótico' (DUM, 1996: s.v.). Un verbo tan usual como acabar, es coloquial en Argentina, Cuba, El Salvador, Nicaragua, Uruguay y Venezuela con el significado 'alcanzar el orgasmo', pero en Ecuador es vulgar para 'insultar'.

\section{INSULTOS ${ }^{20}$}

El concepto del honor está muy arraigado dentro del ámbito hispánico, por lo que los insultos o las ofensas más graves son las que se refieren a la falta o

19. Los significados incluidos en el DRAE (2001), además del que nos ocupa, son los siguientes: uso coloquial propio de El Salvador, Honduras, México y Nicaragua con el significado de 'molestar'; en Honduras y Nicaragua, se aplica comúnmente al calzado con el significado «rozar, producir roces en la piel».

20. La cantidad de insultos que existen en nuestra lengua es extensísima, por lo que si nos referimos en general a ellos, el trabajo excedería nuestro propósito; ya existe un libro de Juan de Dios Luque, Antonio Pamies y Francisco José Manjón (2000), donde se estudian exhaustivamente. Ahora nos vamos a centrar en algunos cuyo carácter ofensivo varía dentro del ámbito hispánico. 
la pérdida de éste. En relación con esto, posiblemente el insulto más ofensivo es faltar al honor de la madre. Incluso, según Kany (1960: 201), uno de los insultos más graves que se puede hacer en algunas zonas, que no determina, es decir madre, y más en concreto: ;tu madre!, o jconcha tu madre! Por lo tanto, cuando se quiera referir a la persona que le dio el ser a alguien (que no mentarla), se prefiere emplear el término mamá, a pesar de que en España lo frecuente sea madre, y nos resultc un tanto chocante."

Dejando ya aparte los parentescos, en Santo Domingo, es una gran ofensa llamar a alguien abusador (Kany, 1960: 197); un caso similar es el de desgraciado, que está incluido en el DRAE (2001) como un insulto muy grave en América, pero no así en España. Conchudo, al que ya nos habíamos referido, además de ser muy vulgar, es un agravio muy grande en sitios como Argentina, Bolivia, Perú o Uruguay. En los lugares anteriores y Colombia, la ofensa más común dentro de la variante vulgar es boludo (Steel, 1990: s.v.) o pelotudo, además de huevón, muy extendido en América y de menor uso en España, a pesar de que no ofrece problemas de intercomprensión. Más insultos, sobre todo en Argentina, son turro, ${ }^{22}$ yegua, ${ }^{23}$ guacho, chupaconcha...

Pendejo es una ofensa (usado como adjetivo) en prácticamente todo el ámbito hispánico; lo que no es tan general es la gravedad de ésta. Así pues, en México y Puerto Rico, el agravio es mayor que en el resto. Otras formas propias de México son pepenado, ${ }^{24}$ maje (también en Centroamérica), agachón $n^{25}$ o bolsudo. Sin salir de México, pinche se emplea como adjetivo que agrega un matiz negativo al sustantivo con el que aparece. $Y$ no podíamos hablar de México sin haccr alusión a buey (o gizey), que se usa como una

21. A partir de la figura de la madre, son muchos los insultos o expresiones malsonantes; reproducimos como ejemplo algunas incluidas en el DRAE (2001): mentar la madre a alguien cs un uso coloquial con ol significado de «decir, para injuriarle gravemente, insultos contra su madres; en cste caso, destaca México, con gran cantidad de frases hechas en las que se incluye el sustantivo madre: a toda madre es una locución vulgar con el significado de cestupendor; importar a alguien madre algo «no importarle en absoluto»; ni madre es otra expresión coloquial malsonante para indicar 'nada' ...

22. En Costa Rica designa una planta (Morínigo, 1993: s.v.)

23. En DEArg (2000 a: s.y.) viene definido en la segunda acepción como «mujer que actúa con ruindad o con mala intención», y como equivalente en España: putón; por su parte, en el $D R A E$ (2001) se incluyen otros significados relativos a otras zonas de Hispanoamérica: «f. despect. coloq. Cuba y Ur. Mujer grosera. U. t. c. adj. 5. m. Cuba. Hombre homosexuai. 6. com. Am. Cen. y P. Rico. Persona estúpida, tonta. U. t. c. adj.».

24. Incluso Santamaría (2000: s.y.) sostiene que en la zona de Tabasco es el peor insulo que se puede decir.

25. Esta vez Santamaría (2000: s.v.) también nos aporta información añadida: «Es epíteto sangriento, propio de gente del pueblo bajo; usado preferentemente por las mujeres». Sobre los demás significados, ctr. DRAE (2001). 
expresión muy común ( $a$ ay, buey!), con una extensión semántica amplísima, pero también puede ser insultante, al igual que en otros países como Guatemala y Nicaragua.

La definición que el DRAE (2001) da de catira es «persona rubia de ojos claros»; sin embargo, en algunas regiones de Colombia, se refiere a una mujer que iba con el regimiento de soldados y les vendía provisiones. Está considerado como ofensivo. También en Colombia (Boyacá y Cundinamarca) son graves insultos culebro o tayo (que se refieren al mismo reptil), o en la zona de Nariño, cuarto, que en todo el país significa alcahuete (Kany, 1960: 198-199). En América Central y México, lépero es injurioso; no en Cuba, donde es 'astuto'; o en Ecuador, 'hombre sin recursos'.

Verraco es un calificativo que se entiende como agravio en Cuba y México, calzonazos en España y Bolivia; en Perú, pisado también designa al hombre que está dominado por su pareja. Por otro lado, en Venezuela, casero o casera está referido al 'amante'. Por su parte, el adjetivo amarillo en Colombia y Cuba es despectivo con el significado de 'cobarde'.

$\mathrm{Al}$ decir de alguien que es una prostituta, no se refiere a una profesión, sino que es un insulto grave (el honor...). Existe gran polimorfismo: ${ }^{26}$

- Cuero: posee este significado en Ecuador y la República Dominicana; no obstante, además del significado de 'piel' u 'odre', en el DRAE (2001) también aparecen otros valores de carácter dialectal: uso coloquial en Colombia, Costa Rica y Puerto Rico con el significado de «mujer avejentada y fea»; en Cuba, «instrumento musical de percusión»; uso vulgar en Ecuador y Venezuela con valor de 'querida', 'amante'; en Guatemala, 'desvergüenza'; en Honduras, 'miedo, temor'; también un uso coloquial en Honduras y México para designar a la «mujer guapa y atractiva»; en Nicaragua, 'virginidad de la mujer', o 'cosa nueva'.

- Guaricha: en Colombia y Ecuador tiene el significado de 'rabona' o «mujer que suele acompañar a los soldados», con fama de prostituta. Otros significados: en Panamá, 'lámpara de queroseno' o en Venezuela, 'indígena joven y soltera'. Mina está incluido en el DEArg., (2000 a: s.v.) como un uso coloquial para 'mujer'; sin embargo, Morínigo, (1993: s.v.) lo incluye con el significado aquí requerido en Argentina, Bolivia, Chile, Perú y Uruguay, además de puntualizar que se refiere a la barragana ajena. - En América Central (Morínigo, 1993: s.v.) se da tusona, que aparece en el DRAE (2001) como un uso coloquial de la voz, pero sin localización

26. Hay algunas que son verdaderamente curiosas; en este grupo se encuentran lexías formadas por el sustantivo mujer más complementos como del arte, del partido o del punto (DRAE, 2001). 
geográfica concreta, junto con otro significado: «Potranca que no ha llegado a dos años». Piscoira, que se aplica en Chile al niño 'inteligente', 'vivo', en Bolivia designa a la 'prostituta', al igual que tatusa. Chuchumeca en Chile y Perú; sin embargo, según el DRAE (2001), chuchumeco es despectivo y es el «apodo con que se zahiere al hombre ruin». Pisca, voluntaria, zarandaja en Colombia. Sin embargo, en México, pisca es «recolección o cosecha, sobre todo de granos, como los del café, el maíz o el algodón»; adernás, también en Venezucla se refiere a la 'hembra del pavo'. Por su parte, voluntaria se dice de la que acompaña a los soldados. Por último, los significados de zarandaja marcados dialectalmente en el DRAE (2001) son los siguientes: en Canarias, Colombia, Honduras y Venezuela 'despreciable' (aplicado a personas), y en Nicaragua, 'vestido estrafalario'.

- Campechana, chinchurria en Venezuela (Morínigo, 1993: s.v.). Por un lado, el $D R A E$ (2001) recoge significados muy diferentes para campechana: además de 'oriundo de Campeche', también 'franco', 'dispuesto para diversión', 'dadivoso', 'afable, sencillo', y como usos dialectales, en Guatemala y México 'bizcocho hojaldrado'; en México solo 'bebida de licores mezclados'. Según esta fuente, chinchurria es en Venezuela cualquier tipo de persona despreciable.

- Bagre, birringa, juche en Costa Rica. No obstante, bagre, en general, se llama a los peces sin escamas, pero también se halla incluida en el DRAE (2001) como voz propia de Argentina, Cuba, Ecuador, El Salvador y Uruguay con el significado de 'mujer muy fea', Cuzca, gïila o huila, leperuza, mesalina, ${ }^{27}$ pellejo (según Santamaría (2000: s.v.), se aplica a la desmejorada y fea), pindanga, pipila, piruja son denominaciones en México. Piruja posee además otros significados dialectales incluidos en el DRAE (2001), como en El Salvador, «que no cumple con sus deberes religiosos»o «mujer joven, libre y desenvuelta). Atorranta, ${ }^{28}$ el eufemismo loca, quilombera, rea, yira, o turra se recogen como usos coloquiales despectivos en Argentina. Cortera, mameluca, maraca o pichuncha en Chile (Morínigo, 1993: s.v,); volantusa, en Bolivia, Chile, Ecuador, Perú o Colombia. Huachafa en Perú, donde también significa 'cursi', al igual que en Bolivia; jalona, magalla, pulciana o zumbadora en Honduras. En Cuba, bandolera, carretilla, perla, piruja, puntal, rifle o venado definen mujeres «con facilidad a tener relaciones sexuales» (DEC, $2000 \mathrm{~b}$ ).

$\overline{27 . ~ E n ~ a l u s i o ́ n ~ a ~ M e s a l i n a, ~ m u j e r ~ d e l ~ e m p e r a d o r ~ r o m a n o ~ C l a u d i o, ~ f a m o s a ~ p o r ~ s u ~ p r o m i s c u i d a d ~ y ~}$ también por su crueldad.

28. Los usos que se incluyen en el DRAE (2001), en general, no coinciden totalmente con los del DEArg. (2000 a), que son los que hemos seguido; por poner un ejemplo, atorranta está definido de la siguiente manera: «1. adj. despect. Arg. y Ur. vago (holgazán). U. t. c. s. 2 . m. y f. despect. Arg. y Ur. Persona desfachatada, desvergonzada. 3. m. coloq. C. Rica, R. Dom. y Ur. Vagabundo sin domicilio fijo». 


\section{CONCLUSIONES}

Podemos afirmar que el conocimiento de disfemismos y eufemismos de carácter dialectal es muy complejo, pues la lengua cambia y cambiará, y mucho más en los estilos vulgares, donde los procesos de semantización, de creaciones léxicas, de tabuización de los eufemismos, son constantes; además es complejo por el gran polimorfismo, pero habría que añadir también que el término con el significado que poseen en una zona puede ser tabú en otra, pero con otro significado distinto, como por ejemplo paloma, que dependiendo del lugar puede designar el órgano genital masculino o el femenino, cola y rabo para las 'nalgas' y también el 'órgano genital masculino', sin olvidar las especializaciones curiosas como, por ejemplo las referencias a los números para las 'nalgas', o a los animales para el órgano genital femenino.

Por otro lado, después de analizar las fuentes, podemos afirmar que es un campo, en general, no bien documentado, pues las fuentes lexicográficas en algunos casos son contradictorias en cuanto a los significados y a la difusión geográfica, o imprecisas en cuanto a la variación diafásica. La labor no concluye aquí, pues en este campo queda prácticamente todo por hacer. ${ }^{29}$

Simplemente hemos querido llamar la atención sobre la dificultad de una parcela de la lengua, tanto para su uso como para su estudio, pero no hay duda de que es uno de los campos de la lengua que despierta mayor interés tanto a estudiosos como a no estudiosos, y que siempre es bueno tenerlo en cuenta.

\section{REFERENCIAS BIBLIOGRÁFICAS}

ÁlVAREz MARTínez, Ma Á. (2000): «Vulgarismos y neologismos», en AlVAR, M. (dir.) (2000): Introducción a la Lingüística española, Barcelona, Ariel, 533-545.

Corominas, J. y J. A. Pascual (1991): Diccionario crítico etimológico castellano e hispánico, Madrid, Gredos, 6 vols. (DCECH).

CRIADO DEL VAL, M. (1985): Palabras equívocas o malsonantes en España, Hispanoamérica y Filipinas, Madrid, Instituto Oficial de Radio y Televisión.

29. La entrevista puede resultar mucho más orientativa. Quizá los proyectos como el PRESEEA aporten datos que ayuden en este campo, aunque la tendencia es intentar obviarlos: cuesta mucho sacar el estilo vulgar de una persona o los insultos, más si es desconocida y más aún si lo hace por escrito. Como el profesor José Antonio Samper afirmó en su conferencia sobre «Disponibilidad léxica y sociolinguística» en este mismo Congreso, los tabúes suelen aparecer por encima del 200 , lo que no ayuda mucho a precisar su uso real. 
- (1996): Diccionario del español usual en México, México, Colegio de México (DUM).

HaEnsch, G. y R. Werner (dirs.) (2000 a): Diccionario del español de Argentina, Madrid, Gredos (DEArg.).

- (2000 b): Diccionario del español de Cuba, Madrid, Gredos (DEC).

Kany, CH. E. (1960): American-Spanish Euphemisms, California, University of California Press.

Luque, J. D.; A. PAMies; F. J. MANú́N (2000): Diccionario del insulto, Barcelona, Península Atalaya.

Malaret, A. (1999): Vocabulario de Puerto Rico, Madrid, Arco/Libros. (edición a cargo de H. López Morales).

Morínigo, M. A. (1993): Diccionario del español de América, Madrid, Anaya. Real Academia Española (2001): Diccionario de la lengúa española, Madrid, Espasa-Calpe, 22 edición (edición en CD-Rom).

Santamaría, F. I. (2000): Diccionario de Mejicanismos, México, Ed. Porma, $6^{a}$ edición.

STEEL, B. (1990): Diccionario de americanismos. ABC of Latin American Spanish, Madrid, SGEL. 


\title{
EL DEBILITAMIENTO DE LA/-S/ EN EL HIERRO: CÁLCULO PROBABILÍSTICO
}

\author{
Ana María Pérez Martín \\ Universidad de Las Palmas de Gran Canaria
}

D

URANTE el transcurso de esta comunicación pretendemos dar a conocer, a partir de la presentación de una serie de índices probabilísticos, la relevancia de diferentes factores, tanto lingüísticos como sociales, en el proceso de debilitamiento de la -/s/ posnuclear en El Hierro. Se trata ésta de una comunidad de habla del archipiélago canario que se caracteriza por su conservadurismo fónico, a pesar de que está incluida en la denominada variedad atlántica del español.

En otros estudios anteriores sobre la misma modalidad hemos señalado, por una parte, la importancia de los contextos prepausal y, en menor medida, prevocálico tónico para la articulación sibilante de la -/s/ (Pérez Martín, 2004) $\mathrm{y}$, por otra, la incidencia de determinados factores lingúísticos en su aspiración (Pérez Martín, 2003 b). También hemos analizado, junto a J. A. Samper, si los condicionantes sociales que propician la relajación y la pérdida del segmento coinciden con los de la variedad grancanaria, tan distante de la herreña por el momento evolutivo en el que cada una está situada ${ }^{1}$ (Samper Padilla y Pérez Martín, 2003). En todos estos casos hemos centrado nuestra atención en índices de frecuencia, dejando en un segundo plano los datos relativos al cálculo probabilístico, que son los que ahora abordaremos. En este sentido queremos resaltar que, si bien los porcentajes son indicadores del fenómeno que se está tratando, pueden estar sujetos a variación casual, fruto del azar, mientras que los valores probabilísticos nos informan de los factores verdaderamente significativos en la elección de una variante determinada.

La muestra ${ }^{2}$ con la que hemos trabajado, representativa del universo que se va a estudiar, ${ }^{3}$ se compone de 56 informantes, agrupados, una vez realizada la postestratificación, según su sexo, edad y nivel sociocultural (cuadro 1). A cada uno de ellos se le realizó una entrevista en estilo semi-informal, de la que se han seleccionado al azar diez minutos para el análisis, lo que constituye un corpus de 560 minutos de grabación.

1. Una es la más innovadora y otra la más arcaizante de cuantas componen el español de Canarias.

2. La misma que ha servido de base para los estudios ya mencionados sobre el habla de El Hierro. Para una información detallada puede verse Pérez Martín (2003 a: 11-22).

3. El índice de representación asciende al $1.06 \%$ de acuerdo con el censo poblacional de 1991. 
CUADRO 1. Distribución de la muestra según sexo, edad y nivel sociocultural

\begin{tabular}{|l|c|c|c|}
\hline Nivel sociocultural & Medio & Medio-bajo & Bajo \\
\hline Hombres & \multicolumn{3}{|c|}{} \\
\hline 20-34 años & 4 & 2 & 1 \\
\hline 35-54 años & 3 & 4 & 2 \\
\hline 55 años o más & 1 & 8 & 3 \\
\hline Mujeres & \multicolumn{3}{|l|}{} \\
\hline 20-34 años & 3 & 2 & 2 \\
\hline 35-54 años & 1 & 2 & 4 \\
\hline 55 años o más & 1 & 7 & 6 \\
\hline
\end{tabular}

Los datos generales de los que partimos ascienden a 18.360 realizaciones de $-/ s /$ en posición posnuclear. En el siguiente gráfico vemos que la gran mayoría se corresponde con aspiraciones, frente a lo que ocure con las realizaciones sibilantes y, sobre todo, con las elididas. Como nuestro objetivo es centrarnos en las articulaciones debilitadas de $-/ s /$, las ocurrencias que han sido codificadas para el cálculo probabilístico son 15.356 correspondientes a -[h] y 539 a -[0]. De estas cifras se desprende que el análisis de la aspiración resultará bastante más productivo que el del cero fonético.

\section{Grafico 1. Porcentajes de -/s/ en El Hierro}

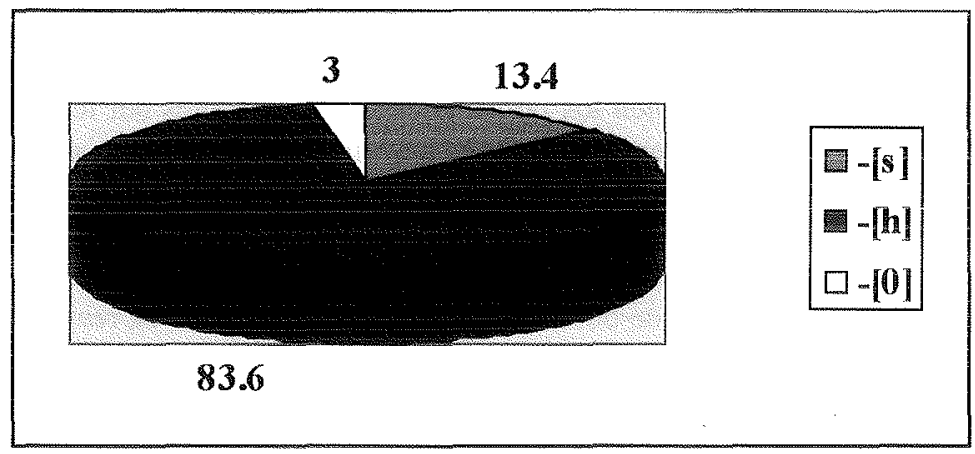

El programa de cálculo probabilístico que hemos utilizado es el GoldVarb 2.0. De las diversas posibilidades que presenta este programa, ${ }^{4}$

4. Sobre sus caracteristicas y funcionamiento pueden verse Rand y Sankolit (1990) y Moreno Fernández (1994). 
nosotros hemos aplicado la versión compleja del mismo y hemos realizado el análisis binomial de subida y bajada. Los datos que se obtienen nos informan, primero, de los índices alcanzados por cada uno de los factores si se consideran de manera independiente $y$, a continuación, cuando se presentan combinados. Al final de cada uno de los procesos, el programa refleja la agrupación de factores que resulta más significativa y cuáles han sido eliminados como no relevantes. Así, podemos encontrar que algún factor que se ha manifestado importante al considerarse de forma aislada, no lo es cuando se combina con el resto.

Por otra parte, debido a la distinta posición que pucdc ocupar cl scgmento, hemos hecho varios análisis para cada una de las variantes seleccionada: en un primer momento hemos estudiado las distintas realizaciones de la consonante en posición interna, donde los únicos factores que se pueden considerar son de carácter social (sexo, edad y nivel sociocultural); luego, hemos trabajado con la posición final, en la que, a los anteriores, se unen el contexto fónico y el estatus gramatical de la consonante; por último, hemos agrupado todas las ocurrencias de $-/ \mathrm{s} /$ y hemos incluido en el programa, además de los factores sociales, el factor lingüístico posición. Este hecho conlleva que, en algún caso, cierto factor pueda resultar seleccionado por el programa como significativo para la aparición de una variante y en otro caso no, a pesar de tratarse del mismo factor y la misma realización.

1. Vamos a comenzar con los resultados obtenidos por la variante aspirada.

1.1. En posición interna (cuadro 2 ), ${ }^{5}$ los factores que se muestran relevantes, tanto si aparecen de forma aislada como combinados, son la edad y el nivel sociocultural. En el caso de la edad, los hablantes de la generación más joven propician de una forma bastante clara la articulación aspirada, seguidos, a cierta distancia, por los de la generación intermedia. Cuando se trata del estatus sociocultural, la relevancia que manifiestan los hablantes del nivel más elevado del espectro en el análisis independiente decrece al combinarse con el factor edad; además, el estrato social medio-bajo adquiere cierta significación (casi tanta como el medio), que no poseía en el análisis por separado.

$\overline{5 . ~ E l ~ i n p u t ~ a l c a n z a d o ~ p o r ~-~[h] ~ e n ~ e s t a ~ p o s i c i o ́ n ~ e s ~ u n ~ i n d i c i o ~ d e ~ s u ~ e l e v a d a ~ p r o b a b i l i d a d ~ d e ~}$ aparición; recordemos que los valores de input oscilan entre 0 y 1: cuanto mayor cercanía a la unidad, mayor probabilidad de aparición de la variante que se estudia en relación con los factores considerados, y cuanto mayor cercanía al 0 , menor probabilidad. 
CuAdro 2. Factores propiciadores de la aspiración en posición interna"

\begin{tabular}{|c|c|}
\hline Input: 0.939 & \\
\hline $\begin{array}{l}\text { FACTORES CONSIDERADOS } \\
\text { INDEPENDIENTEMENTE }\end{array}$ & FACTORES COMBINADOS \\
\hline Edad & Edad \\
\hline 1. ${ }^{a}$ generación: 0.705 & 1. generación: 0.695 \\
\hline $2 .^{2}$ generación: 0.578 & $2^{.1}$ generación: 0.583 \\
\hline 3. generación: 0.292 & 3. generación: 0.296 \\
\hline Nivel sociocultural & Nivel sociocultural \\
\hline Medio: 0.633 & Medio: 0.528 \\
\hline Medio-bajo: 0.475 & Medio-bajo: 0.527 \\
\hline Bajo: 0.402 & Bajo: 0.434 \\
\hline
\end{tabular}

1.2. En posición final (cuadro 3) encontramos, en relación con los factores lingǘsticos, unos resultados que vienen a confimar otros obtenidos con anterioridad sobre distintas variedades del español: ${ }^{5}$ el contexto se manifiesta como un factor verdaderamente significativo para la aspiración de la $-/ \mathrm{s} /$, de modo que el contacto con otra consonante favorece esta articulación; también es importante, aunque algo menos, el contexto prevocálico átono.

El segundo de los factores que se muestra relevante es la edad, con unos datos que reflejan de nuevo la importancia del grupo social más joven.

En cuanto a los otros dos factores percibimos que hay variación en los resultados scgún se trate de su consideración individual o en conjunto con el resto. ${ }^{6}$ Con respecto al estatus gramatical, en ambos casos la mayor relevancia para la aspiración del segmento recae en el carácter de marca de segunda persona del singular en los verbos, seguido, aunque con diferencia, del valor monomorfémico de la consonante; ahora bien, mientras que en los resultados por factores la primera marca de plural sí se presenta como elemento relativamente significativo, en el análisis combinado no, justo al contrario de lo que ocurre cuando la $-/ \mathrm{s} /$ es marca redundante de plural.

En el caso del nivel sociocultural ocurre algo semejante: en el análisis independiente de cada factor es el estrato más elevado del espectro el que

* El orden de aparición de los diferentes factores obedece a su grado de relevancia.

5. Resulta muy interesante el estudio comparativo que realiza Samper Padilla (2001), a partir de datos cuantitativos, sobre la incidencia de distintos condicionantes lingüísticos en la variación de $-/ / s /$

6. Este hecho es una demostración de la relevancia del análisis combinado, que nos aporta una información más precisa acerca de la verdadera incidencia de cada factor. 
parece favorecer la articulación aspirada de $-/ \mathrm{s} /$, mientras que al combinar los diversos factores es precisamente este grupo social el que presenta un valor inferior a 0.5 .

CUADRO 3. Factores propiciadores de la aspiración en posición final

\begin{tabular}{|c|c|}
\hline Input: 0.804 & \\
\hline $\begin{array}{l}\text { FACTORES CONSIDERADOS } \\
\text { INDEPENDIENTEMENTE }\end{array}$ & FACTORES COMBINADOS \\
\hline Contexto fónico & Contexto fónico \\
\hline Preconsonántico: 0.659 & Preconsonántico: 0.668 \\
\hline Prevocálico átono: 0.540 & Prevocálico átono: 0.530 \\
\hline Prevocálico tónico: 0.171 & Prevocálico tónico: 0.168 \\
\hline Prepausal: 0.097 & Prepausal: 0.087 \\
\hline Edad & Edad \\
\hline 1. ${ }^{a}$ generación: 0.639 & 1. ${ }^{2}$ generación: 0.660 \\
\hline 2. ${ }^{2}$ generación: 0.489 & 2. ${ }^{\text {a }}$ generación: 0.485 \\
\hline 3. ${ }^{a}$ generación: 0.423 & 3. ${ }^{a}$ generación: 0.412 \\
\hline Carácter gramatical & Carácter gramatical \\
\hline Primera marca de plural: 0.540 & Primera marca de plural: 0.399 \\
\hline Marca redundante de plural: 0.423 & Marca redundante de plural: 0.522 \\
\hline Única marca de plural: 0.408 & Unica marca de plural: 0.483 \\
\hline $\begin{array}{l}\text { Marca verbal de } 2 .^{\mathrm{a}} \mathrm{p} . \mathrm{del} \\
\text { singular: } 0.663\end{array}$ & $\begin{array}{l}\text { Marca verbal de } 2 .^{a} \mathrm{p} . \text { del } \\
\text { singular: } 0.695\end{array}$ \\
\hline Carácter monomorfémico: 0.537 & Carácter monomorfémico: 0.517 \\
\hline Nivel sociocultural & Nivel sociocultural \\
\hline Medio: 0.551 & Medio: 0.469 \\
\hline Medio-bajo: 0.483 & Medio-bajo: 0.513 \\
\hline Bajo: 0.479 & Bajo: 0.509 \\
\hline
\end{tabular}

1.3. Al agrupar las diversas realizaciones del segmento y considerar, junto a los factores sociales, el factor lingüístico posición (cuadro 4), los resultados del análisis señalan, tal como habíamos supuesto, que se trata de un elemento verdaderamente significativo en el proceso de aspiración de la $-/ \mathrm{s} /$ en $\mathrm{El}$ Hierro: la posición interna incide de forma bastante positiva en la articulación aspirada.

El segundo de los factores en cuanto a grado de importancia es la edad, con unos resultados que confirman lo que habíamos señalado en los apartados anteriores.

Por su parte, y tal como era de prever por la variación a la que se veía sometido, el factor nivel sociocultural solo destaca para el debilitamiento de la consonante si se considera de forma aislada. 
CuAdro 4. Factores propiciadores de la aspiración

\begin{tabular}{|c|c|}
\hline \multicolumn{2}{|l|}{ Input: 0.836} \\
\hline $\begin{array}{c}\text { FACTORES CONSIDERADOS } \\
\text { INDEPENDIENTEMENTE }\end{array}$ & FACTORES COMBINADOS \\
\hline Posición & Posición \\
\hline Interior de palabra: 0.733 & Interior de palabra: 0.731 \\
\hline Final de palabra: 0.422 & Final de palabra: 0.423 \\
\hline Ldad & Edad \\
\hline 1. ${ }^{a}$ generación: 0.648 & 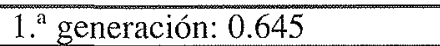 \\
\hline 2. generación: 0.495 & 2. generación: 0.496 \\
\hline 3. ${ }^{a}$ generación: 0.408 & 3. generación: 0.409 \\
\hline Nivel sociocultural & \\
\hline Medio: 0.560 & \\
\hline Medio-bajo: 0.483 & \\
\hline Bajo: 0.469 & \\
\hline
\end{tabular}

2. Como ya hemos adelantado, el análisis de los resultados relativos a la variante elidida no resulta tan enriquecedor como el de $-[\mathrm{h}]$; ahora bien, no queremos dejar de mencionar los factores que se muestran favorables para la pérdida de la consonante.

2.1. Con respecto a la posición interior, el programa no selecciona ningún factor como significativo, ni considerado de manera independiente ni en combinación con otros.

2.2. En cuanto a la posición final, hay coincidencia tanto en los factores seleccionados como en la relevancia de cada uno de los elementos que los integran, aunque no en el orden en el que han sido escogidos por el programa. Así, mientras que en el análisis independiente, el orden decreciente coincide con el que aparece en el cuadro 5, cuando los diversos factores se agrupan resulta elegida primero la edad, luego el carácter gramatical, a continuación el contexto fónico y, por último, el nivel sociocultural.

En relación con la edad, los grupos que se manifiestan relevantes son las dos generaciones más jóvenes, algo más la primera que la segunda.

De acuerdo con el estatus gramatical, la elisión está directamente relacionada con el carácter de información de plural de la -/s/, ya se trate de la única marca existente en la frase nominal, la primera o sea un dato ya conocido. Como señalaremos en las conclusiones, este hecho se relaciona con la eliminación de información realmente redundante.

En cuanto a los niveles socioculturales, resultan significativos los situados cn los extremos del espectro, ligeramente más el medio que el bajo. 
Con respecto al contexto fónico, la consonante que más se pierde es la que aparece ante vocal tónica y, un poco menos la que se sitúa ante consonante.

CUADRO 5. Factores propiciadores de la elisión en posición final

\begin{tabular}{|c|c|}
\hline \multicolumn{2}{|l|}{ Input: 0.037} \\
\hline $\begin{array}{l}\text { FACTORES CONSIDERADOS } \\
\text { INDEPENDIENTEMENTE }\end{array}$ & FACTORES COMBINADOS \\
\hline Carácter gramatical & Carácter gramatical \\
\hline Primera marca de plural: 0.547 & Primera marca de plural: 0.527 \\
\hline Marca redundante de plural: 0.512 & Marca redundante de plural: 0.524 \\
\hline Única marca de plural: 0.590 & Única marca de plural: 0.611 \\
\hline Marca verbal de $2 .^{a}$ p. del & Marca verbal de $2 .^{a}$ p. del \\
\hline singular: 0.393 & singular: 0.374 \\
\hline Carácter monomorfémico: 0.455 & Carácter monomorfémico: 0.452 \\
\hline Edad & Edad \\
\hline $1 .^{a}$ generación: 0.563 & 1. ${ }^{\mathrm{a}}$ generación: 0.555 \\
\hline 2. ${ }^{a}$ generación: 0.530 & $2{ }^{a}{ }^{2}$ generación: 0.526 \\
\hline 3. ${ }^{a}$ generación: 0.441 & 3. generación: 0.448 \\
\hline Nivel sociocultural & Nivel sociocultural \\
\hline Medio: 0.566 & Medio: 0.543 \\
\hline Medio-bajo: 0.443 & Medio-bajo: 0.457 \\
\hline Bajo: 0.520 & Bajo: 0.522 \\
\hline Contexto fónico & Contexto fónico \\
\hline Preconsonántico: 0.528 & Preconsonántico: 0.530 \\
\hline Prevocálico átono: 0.432 & Prevocálico átono: 0.432 \\
\hline Prevocálico tónico: 0.581 & Prevocálico tónico: 0.591 \\
\hline Prepausal: 0.436 & Prepausal: 0.425 \\
\hline
\end{tabular}

2.3. En el análisis conjunto de las realizaciones elididas de $-/ \mathrm{s} /$, el factor lingüístico posición vuelve a mostrarse significativo; en este caso, el cero fonético se encuentra favorecido por la aparición del segmento al final de la palabra. El segundo de los factores relevantes es el nivel sociocultural, con un resultado que coincide con el que habíamos obtenido para la elisión en posición final de palabra, lo mismo que ocurre con el último de los factores seleccionado por el programa, la edad. 
CUADRO 6. Faciores propiciadores de la elisión

\begin{tabular}{|c|c|}
\hline Input: 0.029 & \\
\hline $\begin{array}{l}\text { FACTORES CONSIDERADOS } \\
\text { INDEPENDIENTEMENTE }\end{array}$ & FACTORES COMBINADOS \\
\hline Posición & Posición \\
\hline Interior de palabra: 0.176 & Interior de palabra: 0.174 \\
\hline Final de palabra: 0.618 & Final de palabra: 0.619 \\
\hline Nivel sociocultural & Nivel sociocultural \\
\hline Medio: 0.560 & Medio: 0.542 \\
\hline Medio-bajo: 0.441 & Medio-bajo: 0.451 \\
\hline Bajo: 0.527 & Bajo: 0.529 \\
\hline Edad & Edad \\
\hline 1." generación: 0.548 & 1. ${ }^{2}$ generación: 0.542 \\
\hline 2. ${ }^{a}$ generación: 0.532 & $2 .^{a}$ generación: 0.525 \\
\hline 3." generación: 0.447 & $3 .^{*}$ generación: 0.455 \\
\hline
\end{tabular}

3. Si unificamos los datos presentados hasta el momento, podemos extraer las siguientes conclusiones.

3.1. En primer lugar, mientras que todos los factores lingǘsticos que hemos trabajado se muestran relevantes en el proceso de debilitamiento de $/ \mathrm{s} /$, en el caso de los factores sociales no se percibe variación con respecto al sexo entre los hablantes herreños. Por otra parte, al observar las probabilidades que acompañan a cada uno de los componentes de los distintos grupos comprobamos que los factores de carácter lingüístico presentan mayor relevancia que los sociales, ya que sus integrantes obtienen siempre índices más elevados.

3.2. En segundo lugar, aunque es cierto que los diferentes factores seleccionados por el programa inciden tanto en la aspiración de la consonante implosiva como en su pérdida (aunque no de la misma manera), los índices probabilísticos alcanzados en el primer caso superan siempre a los del cero fonético, ${ }^{7}$ lo que indica que esos distintos factores que resultan significativos favorecen bastante más la aspiración de la consonante que su elisión.

3.3. Con respecto a la posición, ya hemos señalado que la presencia de $-/ \mathrm{s} /$ en interior de palabra incide en la articulación aspirada, al contrario de lo que ocurre con la posición final, que propicia el cero fonético.

3.4. En cuanto al factor contexto fónico, la aspiración es más frecuente ante otra consonante y, en menor medida, ante vocal átona. En el caso de la

7. Salvo cuando se trata del nivel sociocultural, pero que, entre los factores propiciadores de -.. [h] , solo es seleccionado por el programa en el análisis independiente. 
variante elidida, el contexto determinante es el prevocálico tónico, al que le sigue el preconsonántico.

3.5. Al centrarnos en el carácter gramatical de $-/ \mathrm{s} /$ también percibimos diferencias según la realización de la que se trate, de manera que la aspiración está favorecida, principalmente, por la marca de persona verbal y, algo menos, por su carácter monomorfémico, ${ }_{2}^{8}$ mientras que el cero fonético se vincula con la información de plural. En este último caso sorprende, en principio, que el índice de probabilidad disminuya según se trate de la única marca de plural en la frase nominal, la primera o sea una información redundante; ahora bien, el análisis que hemos realizado de las diversas ocurrencias en las que la elisión de la -/s/ podía conllevar algún tipo de ambigüedad (Pérez Martín, 2003 a: 8386) demuestra, una vez más, que realmente se trata de la eliminación de un dato ya conocido.

3.6. En relación con los factores sociales, la edad resulta determinante en el proceso de debilitamiento de $-/ \mathrm{s} /$ : la generación más joven favorece tanto la aspiración como la pérdida de la consonante; de igual manera se manifiesta significativa en el caso de la elisión la generación intermedia, con unos resultados bastante próximos a los obtenidos por el grupo de menor edad.

3.7. Por último, también el factor nivel sociocultural se muestra relevante para el fenómeno que estudiamos, aunque menos que los anteriores. A pesar de las variaciones que hemos encontrado en los diversos análisis, el uso de la variante aspirada parece estar propiciado por el grupo sociocultural medio. Como ya hemos señalado en otro lugar (Samper Padilla y Pérez Martín, 2003), los datos relativos a la aspiración de la -/s/ en El Hierro indican la existencia de un cambio desde arriba, patrocinado por el grupo más joven y por el nivel sociocultural más elevado.

En el caso del cero fonético, destaca también el grupo social medio, al que le sigue el bajo. Esta significación del nivel sociocultural medio para la pérdida de la consonante resulta doblemente curiosa: por un lado, por tratarse del grupo situado en lo alto del continuo social entre los hablantes herreños y, por otro, por el carácter conservador de esta variedad. Puede que la explicación a este peculiar comportamiento radique en que el reducido número de realizaciones elididas que se registra en El Hierro no haya propiciado una valoración social negativa hacia la pérdida del segmento.

8. En cuanto a la información de plural ya vimos que había variación en los resultados según la combinación o no de los factores seleccionados por el programa. 


\section{REFERENCIAS BIBLIOGRAFICAS}

MORENO FERNÁNDEZ, F. (1994): «Sociolingüística, estadística e informática», Lingüística, 6: 95-154.

Pérez MARTín, A. Ma . (2003 a): Estudio sociolingüístico del español hablado en El Hierro, (tesis doctoral inédita), Las Palmas de Gran Canaria, Universidad de Las Palmas de Gran Canaria.

- $(2003$ b): «La incidencia de los factores linguísticos en la aspiración de la -/s/ en El Hierro (Islas Canarias): datos cuantitativos», Documentos de Español Actual, 5: 85-103.

- (2004): «Conservación de la -/s/ herreña: la importancia del contexto prepausal» en DIAZ Aldyón, C.; M. MORERA (eds.) (2004): Homenaje a Francisco Navarro Artiles, Madrid, Academia Canaria de la Lengua y Cabildo Insular de Fuerteventura.

RAND, D.; D. SAnKoff (1990): GoldVarb. Version 2. A Variable Rule Aplication for the Macintosh, Programa y documentación inéditos.

SAmper PAdilla, J. A. (2001): «La variación fonológica: los estudios hispánicos sobre -/s/ implosiva» en II Congreso Internacional de la Lengua Española. El español en la sociedad de la información, edición electrónica en el Centro Virtual Cervantes:

hitp://cvc.cervantes.es/obref/congresos/valladolid/ponencias/unidad_diver sidad_del_español/1_la_norma_hispanica/samper_j.htm

Samper Padilla, J. A.; A. M. Pérez Martín (2003): "Variación fonética y cambio en dos modalidades del español de Canarias» en Moreno, $\Gamma$; $\Gamma$. Gimeno; J. A. Samper; M. ${ }^{a}$ L. Gutiérrez; M. ${ }^{a}$ Vaquero; C. Hernández (coords.) (2003): Lengua, variación y contexto. Estudios dedicados a Humberto López Morales II, Madrid, Arco Libros. 


\title{
LES REPRESENTACIONS DEL VARIACIONISME EN L'ÀMBIT DE LA LLENGUA CATALANA
}

\author{
Miquel-Àngel Pradilla Cardona \\ Sílvia Güell Segarra \\ Magda Buldó Escoté \\ anna Saura Vrzcarro \\ Joan Anton Verge Caballer \\ Universitat Rovira $i$ Virgili
}

\section{INTRODUCCIÓ}

$\mathbf{E}$ L tema que ens ocupa s'imposa ubicar-lo en el trànsit d'una lingüística autònoma, això és, centrada exclusivament en l'anàlisi de l'estructura de les llengüies, a una lingüística que preveu programàticament la interacció entre les variables lingüístiques i les variables sociopragmàtiques. L'espai de què disposem no ens permet, òbviament, fer una passejada matisada i rigorosa per la història de la lingüística. En conseqüència, assajarem de visualitzar un itinerari de fites rellevants al voltant de consideracions programàtiques de gruix.

Si prenem com a epicentre temàtic la dialectologia -0 , si es prefereix, la geolingüística-, caldria constatar el difícil encaix que l'esmentada disciplina ha tingut en els paradigmes més rellevants de la lingüística moderna. Així, estucturalisme $\mathrm{i}$ generativisme -en les versions ortodoxes- han prioritzat com a objecte nuclear d'estudi la llengua (Saussure) o la competència (Chomsky), això és, l'estudi in abstracto de parlants-oients ideals en comunitats de parla homogènies. Això no vol dir que no hi haja dialectologia estructuralista i generativista; tanmateix, qualsevol valoració genèrica li atorgaria un paper marginal. No s'escapa a ningú que en aquests marcs teòrics difícilment hi podria transitar còmodament una dialectologia, centrada justament en l'estudi de la variació (essencialment geogràfica) i el canvi lingüístic (amb una atenció preferent pel seu vessant diacrònic).

Certament, hi ha hagut períodes de desencontre i d'hostilitat dialèctica que no han afavorit el diàleg intel-lectual. Tot plegat, segons la nostra opinió, va portar a un arraconament -quan no a un bandejament-de la dialectologia de les prioritats sancionades per les elits lingüístiques de torn. Així i tot, malgrat la subsidiarietat a què s'ha vist sotmesa, la producció dels dialectòlegs no només 
no se n'ha ressentit, sinó que ha engruixit els seus resultats quantitativament $i$ qualitativament. Sens dubte, la vigoria que ha mostrat en les darreres dècades ha estat el millor antídot al menyspreu rebut des de les noves trones oficials.

L'emergència de la sociolingüística, amb la consegüent legitimació com a objecte d'estudi de la parla saussureana i de l'actuació chomskyana, ha possibilitat l'aparició d'un nou horitzó paradigmàtic. Aquesta comunió d'inte." ressus de lingüistes, suciólegs, psicòlegs $i$ antropolegs patrocinana com a legítim centre d'interès l'ús social de la llengua. Un ús que, atès que ha de donar resposta a una munió de situacions comunicatives d'una gran diversitat d'usuaris, forçosament s'haurà de plantejar com a heterogeni. D'aquesta manera es trenca el binomi sistema-homogeneïtat i es passa a la consideració de les llengües com a estructures ordenadament heterogènies, eni la qual l'estudi de la variació linguîistica serà fonamental.

Val a dir que en l'àmbit catalanòfon la recepció de la sociolinguística ha tingut una especificitat que no es pot menystenir. I és que la nostra sociolinguística ha estat -i és- essencialment una sociologia del llenguatge. S'ha ocupat, en definitiva, de les relacions interlingiístiques en un context de conflictivitat. A poc a poc, però, el monopoli esmentat ha deixat pas, tímidament, a una diversitat de sociolingüístiques, des d'on l'etnografia de la comunicació i el variacionisme han reclamat més atenció. La consolidació de la disciplina global ha arribat, doncs, amb l'estudi de les relacions intralin-giiistiques.

Establert aquest itinerari, voldriem destacar que el nou objecte d'estudi ja és, des de l'anomenada linguística del corpus, centre d'atenció dels mateixos cnfocaments estructuralista i generativista. La dialectologia ha trobat un nou vent que bufa a favor dels seus plantejaments si més no d'una part. L'apartat que segueix s'ocuparà d'avaluar les diferents fesomies que ha pres a casa nostra l'estudi de la variació lingüística.

\section{L'ESTUDI DE IA VARIACIÓ LINGÜISTICA}

\subsection{Un plantejament multidimensional}

L'objectiu nuclear d'aquest article és donar compte de les manifestacions que han pres a casa nostra els estudis sobre la variació lingüística. Segons l'esquema consensuat pels investigadors implicats, la línia sociolinguística que els acollirà serà la sociolingiilstica estricta $\mathrm{o}$, tal com sembla que s'ha consolidat en la nostra tradició onomàstica, la sociolingüística de la variació.'

1. Sobretot arran de la publicació l'any 1995 , amb el mateix títol, de l'aplec de treballs que conformen el volum coordinat per-M.T. Turell (Turell, 1995). 
Es tracta, doncs, d'avaluar les «desviacions» més significatives que s'han donat en relació amb el model de referència esmentat, sia per la pressió dels estudis tradicionals o per la influència de nous enfocaments.

La comesa que ens ocupa troba en el plantejament de F. Moreno (1990) una proposta metodològica immillorable. Aquest autor defineix el fet lingüístic com un ens de natura multidimensional i insereix el seu estudi en la lingüistica de la parla/actuació. L'esmentada multidimensionalitat tindrà quatre vèrtexs que seran ocupats per la geolingüística, la lingiǘstica historica, la pragmàtica i la sociolingüística -amb la possibilitat de posicions intermèdies. La seua proposta reconeix la variació conjunta de factors de distinta natura, però admet la possibilitat d'estudiar per separat cadascun dels factors minimitzant-ne la resta. En els subapartats que segueixen assajarem una primera aproximació al calidoscopi variacionista que defineixen els treballs sobre fenòmens variables de la llengua catalana. Vaja per endavant que no es tracta d'una replega de recerques i una compartimentació subsegüent. El nostre propòsit és fer una avaluació teoricometodològica qualitativa (i per a l'avintesa que ens ocupa, primària) a propòsit de la hipòtesi multidisciplinar apuntada.

\subsection{EI vèrtex sociolingiuístic}

En l'àmbit de la sociolingüística estricta s'han elaborat diversos models destinats a explicar la variació sistemàtica. Els més destacats són el dinàmic (Ch. J. Bailey, D. Bickerton i D. De Camp) i el quantitatiu (W. Labov). Tanmateix, el decantament majoritari dels nostres investigadors pel segon -també anomenat dialectologia urbana, dialectologia social, sociolingüística («estricta», «en sentit restringit», «pròpiament dita»), estudi quantitatiu de la parla, model de regles variables, (socio)lingüística correlacional, variacionisme i sociolingüística de la variació- motivarà que li dediquem la nostra atenció en exclusiva. Més encara si el considerem (metodològicament) com el referent a partir del qual en destacarem les transferències i transaccions.

La proposta sociolingüística de W. Labov s'ha de considerar com l'elaboració més reeixida sorgida a partir de l'article de Weinreich, Labov i Herzog (1968) «Empirical Foundations for a Theory of Language Change». El treball en qüestió constituirà un veritable salt qualitatiu en la consideració social del llenguatge.

Aquest lingüista nord-americà beu, en els seus inicis, del model estructural a través del mestratge d'U. Weinreich. Tanmateix, a les darreries dels anys seixanta s'incorpora a la gramàtica generativa, de la qual proposa una extensió que incorpore un component social. Com ja s'ha dit, l'objectiu de Labov serà essencialment lingüístic: es tracta d'estudiar el llenguatge tal i com 
l'utilitzen els parlants en la comunicació quotidiana, això és, l'estudi de la seua estructura $i$ evolució en el context social format per la comunitat de parla. Des d'aquesta perspectiva realista, l'objecte d'estudi serà observat en toda la seua diversitat.

La consideració de la llengua com un sistema ordenadament heterogeni i dinàmic es visualitza mitjançant la correlació de variables lingüístiques, socials i estilístiques. I els instruments metodològics que desenvolupa per empiritzar el model són l'entrevista sociolingüística i la quantificació estadística, primer en termes frequiencials i més tard, amb les aportacions de l'escola canadenca (Sankoff, Cedergren i col-laboradors), probabilístics. Aquest darrer desenvolupament no és gens trivial ja que es fonamenta en la idea, epistemològicament essencial, segons la qual les dades d'actuació no són res més que un reflex estadístic de la competència, que ara serà quantificada mitjançant l'aplicació d'un model logístic multiplicatiu que permetrà convertir les frequiències observades en l'actuació en probabilitats teòriques. Aquesta operació ha significat, en definitiva, passar d'ocupar-se amb molta rigorositat de les dades d'actuació a l'elaboració de models teòrics que donen compte de la competència sociolinguiística dels parlants. ${ }^{2}$

La sociolingüistica de la variació penetra a l'àmbit catalanòfon (i a l'Estat espanyol) de la mà de l'investigador alacantí F. Gimeno. El mestratge que exerceix des de la Universitat d'Alacant dóna el seu primer fruiit amb la lectura de la tesi doctoral de Montoya (1985), un treball que aborda l'estudi del canvi lingüístic tant des de la vessant sincrònica com diacrònica (sociolingüística històrica). Parallelament, M. T. Turell, primer des de la Universitat de Barcelona i després des de la Universitat Rovira i Virgili, comença a articular un grup de collaboradors que centraran el seu treball essencialment en la perspectiva sincrònica dels canvis en curs. La publicació el 1995 del llibre $\mathrm{La}$ sociolinguística de la variació donarà a conèixer una part de les recerques portades a terme.

Malgrat la vigència a casa nostra de la sociolingǘstica històrica, quantitativament migrada però 'd'un interès qualitatiu extraordinari, la recepció del model labovià ha reproduit el biaix clarament sincronicista que el mateix investigador va promocionar. La ponència «On the use of the present to explain the past» (Labov 1972), llegida el 1972 al XI Congrés Internacional de Lingüistes celebrat a Bolonya, o el treball presentat a Montreal en el col-loqui New Ways in Analysing Variation in English titulat «What can be learned about change in progress from synchronic descriptions?» constitueixen un parell de bones mostres doctrinàries. Al voltant, doncs, d'aquest enfocament $\mathrm{i}$

2. Per a una exposició més detallada del marc teoricometodológic de la sociolingüística de la variació, vegeu Turell $(1995,1997)$ i Pradilla (1998). 
amb especifitats metodològiques diverses (vegeu Pradilla 2002 per a les variables fòniques i Mas i Montoya -en premsa- per a una visió de conjunt de tots els nivells d'anàlisi), l'«ortodòxia» variacionista acumula un grapat de recerques força reeixit. A propòsit de la participació en aquest monogràfic, convé destacar que les aportacions de J. Carrera des de la lectura de la tesi doctoral el 1999 (Carrera, 2002) també se situarien en aquesta línia.

Comentari a part mereix la línia encetada per B. Montoya, complementària del seu treball sobre la interrupció de la transmissió intergeneracional a Alacant (Montoya, 1996), on, des de la perspectiva variacionista, descriu el fenomen conegut com a atròfia linguíística o encongiment lingüístic, això és, l'estudi del desgast o la desintegració estructural de la llengua recessiva (català), o en procés d'extinció, en un procés de convergència amb la llengua expansiva (castellà) (Montoya, 2000).

Finalment, voldria constatar la influència mútua creixent que estan experimentant les metodologies de la sociolingüística de la variació i de la fonètica experimental. En el $15^{\text {th }}$ International Congress of Phonetic Sciences, celebrat a Barcelona l'agost de 2003, hom va poder constatar la presència destacada d'un bon nombre de treballs que s'aixoplugaven sota l'etiqueta Sociofonètica. Des que Labov $(1966,1972)$ va establir correlacions entre la qualitat vocàlica i el perfil social dels informants mitjançant l'ús de tècniques instrumentals, els seus seguidors han proporcionat un degoteig de treballs que amb el temps ha anat fent gruix. I paral-lelament, els resultats obtinguts han obligat els fonetistes a replantejar-se algunes quiestions teoricometodològiques d'índole socioestilística absolutament desateses. En l'àmbit de la llengua catalana, Miquel Àngel Pradilla, des del tractament quantitatiu de la variable estudiada en la tesi doctoral -el desafricament prepalatal intervocàlic(Pradilla, 1993), ha insistit en la conveniència d'assolir una comunió metodològica amb la metodologia experimental (Pradilla, 1997, $2001 a, 2001$ $b$ i 2002). D'altra banda, ara des d'una priorització de l'anàlisi acústica, els treballs recents de Fernández Planas i Pradilla (2004) i de Carrera, Fernández Planas i Pradilla (en premsa) corroboren també la influència dels postulats variacionistes.

\subsection{El vèrtex pragmàtic}

Tal com acaben de veure, les variables estudiades des de la sociolingüística de la variació no són discretes, es defineixen en termes de correlació estadística. Tanmateix, la variació també pot ser de natura discreta: la tria de llengua és un dels exemples més adduïts, però també cal prendre en consideració els diferents fenòmens amb què es mostra la interferència, l'alternança de codis o l'aparició d'interllengües (pigdinització i criollització). La pragmàtica, entesa 
com l'adquació de l'ús lingüístic al context sociocultural, s'ocuparia d'aquestes qüestions.

Al bell mig d'una mena de nebulosa terminològica, emergeix, com a alternativa al variacionisme $\mathrm{i}$ amb una diàfana vinculació a la pragmàtica, l'etnografia de la comunicació (D. H. Hymes i J. J. Gumperz). D'orientació antropològica, concep l'estudi de la variació lingüística en una comunitat humana «com l'anàlisi de la mancra com cls seus membres gestionen el fenomen de l'heteroglòssia en llurs vides quotidianes, tot partint d'una concepció activa i dialògica de la comunicació humana» (Argente, 1998: 16).

Mitjançant una arquitectura d'unitats d'anàlisi que aniria davallant en una dimensió de concreció -acte comunicatiu, esdeveniment de parla i acte de parla-, l'objectiu de l'etnògraf seria correlacionar l'ús lingüístic amb el context sociocultural d'una comunitat de parla. Aquesta comesa requerirà, doncs, la identificació dels actes de parla vigents, les maneres de parlar quic $s$ 'hi associen i els contextos sociocomunicatius que els propicien.

Feta aquesta caracterització primària, ens entretindrem a destacar els punts de conflicte amb la sociolingǘstica de la variació: $a$ ) mentre que aquesta s'interessa primordialment per la parla espontània («vernacle»), aquella prioritza l'extrem formal del contínuum estilístic; b) mentre que la proposta laboviana de compartimentació del contínuum estilístic estableix una segmentació apriorística en funció del grau d'atenció del parlant envers el discurs, els etnògrafs cerquen varietats lingüístiques naturals en contextos determinats, això és, formes de parlar sovint ritualitzades, aforístiques i marcades, i c) l'aprehensió de la matèria objecte d'estudi d'aquesta es fa mitjançant la priorització de tècniques qualitalives, com l'observació participant, mentre que el variacionisme utilitza artificis estadístics i no tan naturals, com l'entrevista sociolingüística.

A parer nostre, són diversos els aspectes on l'etnografía del parlar pot aportar millores interessants a la metodologia variacionista. L'assoliment d'un major equilibri entre l'anàlisi qualitativa i la quantitativa n'és un de fonamental. En aquest sentit, voldriem fer notar, tanmateix, que si bé és obvi que la metodologia laboviana posa un èmfasi especial en la quantificació, no és menys cert que des dels seus inicis el mateix Labov ja empra mètodes d'observació diversos. L'altra gran qüestió on l'etnografia hi té molt a dir és en la subcategorització de la variació funcional. Atès que la variació estilística ocupa un lloc de privilegi en la reflexió pragmàtica, el variacionisme hauria d'aprofitar-ne l'experiència acumulada en múltiples recerques. Malgrat que la segmentació del contínuum estilístic continua generant força discussions, si algun enfocament s'hi ha aproximat de manera raonablement solvent aquest és el pragmàtic. A casa nostra, el conjunt de treballs aplegats el 1998 al llibre Oralment. Estudis de variació funcional, coordinat per L. Payrató, ha de ser considerat com el text referencial més complet. 
No deu ser casual, doncs, que una de les persones que hi va participar, S. Romero, orientés la seua tesi doctoral (Romero, 2001) pels viaranys esmentats. Aquest treball, de base pragmàtica, ens mostra com la utilització dels mètodes quantitatius de la metodologia sociolingüística pot assolir un paper reeixit en l'anàlisi d'una situació comunicativa prou fixada com les sessions plenàries municipals. Aquesta manifestació lingüística de l'Adminis-tració local ha estat caracteritzada a partir de la taula de components de l'esdeveniment de parla de Hymes (1962/1968: 110-124) i dels paràmetres situacionals de variació de Biber (1994: 40-41).

\subsection{El vèrtex històric}

L'arraconament a què s'ha vist sotmesa la perspectiva històrica per part dels diferents paradigmes de la lingüística moderna s'ha vist atenuat amb la proposta d'estudi de la sociolinguística històrica. Des que Labov va correlacionar la variació i el canvi lingüístic en el sentit que aquest darrer sempre pressuposa variació prèvia però no a l'inrevés, l'interès per la descripció i explicació dels canvis lingüístics en curs s'ha tornat a fer un lloc entre els investigadors.

Tal com s'ha dit, el biaix sincronicista fundacional que va prendre el variacionisme ha estat fonamental a l'hora de relegar la sociolingüística històrica a un àmbit de subsidiarietat. Ara mateix, a casa nostra només $\mathrm{B}$. Montoya i A. Mas s'hi dediquen amb una perseverança admirable, però la proposta metodològica que patrocinen, centrada en l'estudi de la llengua dels textos escrits d'èpoques pretèrites mitjançant els paràmetres de covariació lingüística i social ja coneguts, continua tenint un ressò més aviat escàs. Això no obstant, tal com reivindica A. Mas (2003):

La sociolingüística històrica, amb tots els seus inconvenients [...] ens possibilita entendre millor la llengua actual per mitjà de l'estudi diacrònic de la llengua del passat $i$, també, ens permet reconstruir els estrats de la llengua anterior amb les aportacions de l'anàlisi de la llengua oral. ${ }^{3}$

L'estudi sincrònic del canvi lingüístic, contràriament, ha ocupat un lloc preeminent en els estudis variacionistes. El concepte de «temps aparent» ha fet fortuna ja que ha suposat una novetat epistemològica notable en un àmbit d'estudi monopolitzat tradicionalment per la perspectiva diacrònica. Consisteix a

3. Remetem el lector interessat a conèixer les especificitats que ha pres la sociolinguística històrica en la nostra tradició a l'article d'A. Mas «La sociolingüística històrica (una alternativa a l'anàlisi del canvi lingǘstic)» (2003). 
atorgar la màxima prioritat a una de les variables socials amb què pren sistematicitat la variació: es tracta d'estudiar el patró de canvi que defineix el comportament lingüístic dels diferents grups d'edat d'una comunitat de parla.

Una prova de l'èxit d'aquest plantejament és la presència de la variable edat en la majoria de les recerques fetes sobre fenòmens variables de la llengua catalana. Més encara, en algunes (Carrera, 2002) ha esdevingut l'eix interpretatiu més rellevant. També es pot constatar que aquest factor s'ha anat incorporant amb més força en l'àmbit de la dialectologia. Sens dubte, el treball de més envergadura ha estat el de L. Pons (1992) sobre la iodització i l'apitxament a Barberà del Vallès (Pradilla, 2002).

A propòsit de la panoràmica descrita, probablement ha arribat l'hora d'abordar estudis de canvi lingüístic en «temps real», això és, mitjançant el contrast de dades metodològicament comparables en estadis temporals diferents. Caldria, doncs, tornar a estudiar les comunitats de parla explorades la dècada dels vuitanta 1 sobretot els primers anys de la dècada dels noranta. Aquests nous treballs són de vital importància pel que fa a la validació de les prediccions fetes a les recerques precedents $i$, en definitiva, per a la consagració paradigmàtica del corpus teoricometodològic de la sociolingüística de la variació. En aquest sentit, el grup coordinat per M. T. Turell en la publicació de 1995 ha posat en marxa un nou projecte de recerca amb aquest enfocament, ara mateix deficitari.

\subsection{El vèrtex geolingüístic}

Quan analitzem el posicionament dels lingüistes respecte a la relació dialectologia-sociolingüística de la variació, ens trobem amb un ventall d'opinions que van des d'una identificació total a una separació taxativa. Al bell mig, hi ha tota una sèrie de propostes amb un denominador comú: el reforçament dels lligams entre ambdues perspectives amb una voluntat conci. liadora. La proposta de F. Moreno, canemàs d'aquest treball, reconeix, com s'ha dit, la variació conjunta de factors diversos, però admet la possibilitat d'estudiar per separat cada factor en detriment de la resta. En aquest sentit, adverteix que les crítiques indiscriminades que s'han fet sobre la dialectologia només tenen un cert sentit en el cas de les monografies locals. En el cas de la geolinguiística, l'envergadura metodològica fa que l'interès diatòpic justifique el sacrifici parcial dels altres vessants. Allò, però, que ningú no ha posat en quiestió és que la dialectologia i la geolinguística centren el seu objecte d'estudi en la parla, en l'actuació, i assumeixen, per tant, una consideració heterogènia de la llengua. La sociolingüística de la variació se n'ha de considerar, doncs, hereva. 
El veritable punt de conflicte, el trobem en la consideració dels factors socials i estilístics. Una repassada a la vastíssima bibliografia que ha generat la investigació dialectològica ens mena a destacar-ne l'interès nuclear per l'aspecte geogràfic. I, tanmateix, tenim mostres interessantíssimes d'enfocaments socials que adquireixen la categoria de veritables precedents de la sociolingüística: Gauchat, l'AIS de Jud i Jaberg, Rohlfs, l'AlEIC de Bottiglioni, etc. La mateixa aparició de les etiquetes dialectologia social, dialectologia urbana, sociodialectologia, nova dialectologia, etc. pot entendre's com una mena de pont entre ambdues. Com a conseqüència d'aquesta floració terminològica i de la manca de precisió a l'hora de definir l'abast conceptual de les diferents denominacions, sovint s'observen catalogacions divergents d'un mateix treball. ${ }^{4}$

Tot i que el variacionisme incorpora algun dels pilars teòrics de la dialectologia $\mathrm{i}$ hi comparteix determinats interessos fonamentals, aquella constitueix, en la nostra opinió, una disciplina que respon a principis globals i orientacions metodològiques diferents. Silva-Corvalán (1989: 15) destaca alguna d'aquestes diferències: l'obtenció de dades lingüístiques mitjançant l'enregistrament de converses espontànies; la utilització de mètodes quantatius d'anàlisi; el reconeixement que l'homogeneïtat lingüística de, fins i tot, el llogarret més petit és un mite; la consideració de les actituds subjectives cap a les diverses variants dialectals; les tècniques per a l'obtenció i identificació de diferents estils de llengua i l'assumpció que tot individu és capaç de comunicar-se en més d'un estil, dels quals l'espontani és el més difícil d'obtenir per part de l'investigador.

En l'àmbit territorial de la llengua catalana a l'Estat espanyol, l'adveniment de la democràcia ha suposat una nova ordenació de les estructures de poder que ha permès l'accés de la llengua pròpia a àrees comunicatives definides per la formalitat. L'ensenyament i els mitjans de comunciació són els àmbits més emblemàtics des d'on s'ha difòs, amb més o menys intensitat segons el territori, aquest model estàndard. L'emergència d'aquesta nova varietat referencial ha encetat una dialèctica de canvi en relació amb les varietats collloquials de base geolectal. A propòsit d'aquesta constatació, des de la Universitat d'Alacant J. Ponsoda ha comandat un projecte destinat a avaluar l'impacte del model escolar en las varietats geogràfiques tradicionals. En aquest marc d'hibridació metodolò-

4. Gimeno i Montoya (1989: 47-48) manifesten el seu desacord envers la catalogació de Veny (1986), ja que considera dialectòlegs socials tant els autors de treballs veritablement sociolingưístics com aquells que s'interessen per aspectes sociològics de la llengua. Lògicament, la pretesa subsidiarietat de la sociolingüística envers la dialectologia també és motiu de queixa per part d'aquests autors. 
gica sobre una base sòlidament geolectal, J. M. Baldaquí (2004) i C. Segura (2003 a i 2003 b) han dedicat les seues tesis doctorals a la temàtica esmentada.

\section{CONCLUSTONS}

La sociolingüística de la variació, en el mare d'una sociolingüistica en sentit ample, ha anat avançant en el difícil viatge que ha de menar a la consolidació del seu estatus paradigmàtic. Les reticències teòriques que li ha plantejat la lingüistica moderna (estructuralista i generativista) així com els plantejaments metodològics immobilistes de la linguística tradicional en els vessants dialectològic i historicista no li han aplanat el camí. Malgrat tot, passat un periode de manifesta hostilitat dialectica, el debat interdisciplinari ha tingut consequiències força favorables per a tots els implicats.

En l'àmbit de la llengua catalana, a recer de l'omnipresent sociologia del llenguatge, el variacionisme també ha participat de manera activa en l'establiment d'un consens que possibilite l'estudi d'aquesta realitat polinivellada que és el llenguatge en funció dels interessos prioritaris dels investigadors de torn.

El plantejament multidimensional que he presentat ha evidenciat com les transaccions teoricometodològiques interdisciplinàries, des de l'autocrítica i el coneixement mutu, contribueixen a la millora de les investigacions. També les transferències, tant si ens arriben com si les exportem, poden arribar a tenir efectes benèfics per a la ciència del llenguatge. En definitiva, a parer meu, el dogmatisme que emana de l'ortodòxia doctrinària té uns efectes paralitzadors que cal combatrc. En un àmbit de fronteres tan difuses com el de la sociolingüística, hem de propiciar mecanismes d'entesa que ens facen avançar en la recerca d'una teoria explicativa general del llenguatge en la qual tots els qui hi treballem trobem un encaix còmode.

\section{REFERÈNCIES BIBLIOGRÀFIQUES}

ARgENTE, J. (1997): «Els fenòmens de la diversitat i la variació lingüístiques, i llur pertinència en l'estudi del llenguatge», a LLORET, M. R. [et alii] (ed.) (1997): Anàlisi de la variació lingiíística, Barcelona, PPU, 15-44.

- (1998): «La variació lingüística: el lel i la seva signifiuació», Caplletra, 25. $11-20$ 
BALDAquí, J. M. (2004): La percepció de la vitalitat etnolingüística pels jóvens de l'Alacantí, Alacant-Barcelona, Institut Interuniversitari de Filologia Valenciana-Publicacions de l'Abadia de Montserrat.

Biber, D. (1994): «And Analytical Framework for Register Studies», a BıBER, D.; E. Finegan (ed.) (1994): Sociolinguistic Perspectives on Registers, Nova York, Oxford University Press, 31-36.

CARrera, J. (2002): Escola catalana $i$ variació fonètica. Una evolució del vocalisme àton a Alguaire $i$ a Lleida, Lleida, Pagès.

Carrera, J.; A. M. Fernández; M. À. Pradilla (en premsa): «De fonètica contrastiva: els africats alveolopalatals del lleidatà i del barceloní», Girona, AILLC.

Fernández Planas, A. M.; Pradilla, M. À. (2004): «Características de las africadas alveolopalatales del catalán oriental central», a Actas del V Congreso de Lingüística General (León, 5-8/3/2002), León, Arco/Libros, 983-995.

Gimeno, F.; Montoya, B. (1989): Sociolingüística, València, Servei de Publicacions de la Universitat de València.

HyMEs, D. (1968): «The Ethnography of Speaking», a FiSHMAN, J. (ed.) (1968): Readings in the Sociology of Language, The Hague, Mouton, 99-137.

LABOv, W. (1966): The social stratification of English in New York City, Washington D. C.: Center for Applied Linguistics. Reelaboració parcial d'alguns capítols a: Sociolinguistic Patterns, capítols 2, 3, 4 i 6, 43-122 i 143-159, 1972.

- (1972): Sociolinguistic Patterns, Philadelphia, University of Pennsylvania Press.

LAVANDERA, B. (1984): Variación y significado, Buenos Aires, Hachette.

López Morales, H. (1989): Sociolinguíística, Madrid, Gredos.

MARTINet, A. (1953): «Prefaci», a WeinReich, U. (1953): Languages in contact. (traducció: Llengïes en contacte, 1996).

MAS, A. (2003): «La sociolinguística històrica (una alternativa a l'anàlisi del canvi lingüístic)», Noves SL, Tardor. <http://cultura.gencat.net/llengcatnoves/hm01 tardor/metodologia/mas1 $1 \mathrm{htm}>$.

MAS, A.; MonToYA, B. (en premsa): «La sociolingüística de la variació als Països Catalans: estat de la qüestió», Caplletra.

MontoyA, B. (1985): De sociolingüística històrica: canvi lingüístic en cus $i$ desplaçament de llengiies a l'extrem meridional de la llengua catalana, tesi doctoral, Universitat d'Alacant. Síntesi publicada a GimENo, F; MonToYA, B. (1989).

- (1996): Alacant: la llengua interrompuda, Paiporta, Denes.

-(2000): Els alacantins catalanoparlants: una generació perduda, Barcelona, Institut d'Estudis Catalans. 
Moreno, F. (1990): Metodología sociolingiística, Madrid, Gredos.

PAYRATó, L. (ed.) (1998): Oralment. Estudis de variació funcional. Barcelona, Publicacions de l'Abadia de Montserrat.

Pons, L. (1992): Iodització i apitxament al Vallès. Interpretació sociolingiiística i psicolinguiística dels canvis fonètics, Barcelona, Institut d'Estudis Catalans.

Pradilla, M. À (1993): Variació i canvi lingüistic en curs al català de transició nord-occidental/valencià, tesi doctoral, Universitat Rovira i Virgili (Tarragona).

- (1995): «El desafricament prepalatal en el català de transició nordoccidental/ valencià», dins TuRELL, M. T. (ed.) (1995: 53-116).

- (1997): «Sociolingüística quantitativa i anàlisi qualitativa de variables foneticofonològiques: a propòsit del desafricament prepalatal», Estudios de Fonética Experimental, 8, 207-251.

- (1998): «La sociolingüística de la variació», a PRADILLA, M. À. (ed.) (1998): Ecosistema comunicatiti. Llengua i variació, Benicarló, Edicions Alambor, 15 44.

- (2001 a): «La sociolingüística de la variació. Aproximació metodològica (I)». Noves SL, Hivern-Primavera. <http://cultura.gencat.net/llengcatnoves/hm0 lhivern-primavera/metodologia/pradillal $7 \mathrm{htm}>$.

- $(2001$ b): «La sociolingüística de la variació. Aproximació metodològica (i II)», Noves SL, Tardor.

$<\mathrm{http}$ //cultura.gencat.net/llengcatnoves/hm0lestiu/metodologia/pradilla1 9htm>.

- (2002): «La variació lònica en la llengua catalana: inventari i avaluació metodològica». Noves SL, Tardor. <http://cultura.gencat.net/llengcatnoves $/ \mathrm{hm} 02$ tardor/metodologia/a pradilla1 $8 \mathrm{htm}>$.

- (2003): «Les representacions del variacionisme en l'àmbit de la llengua catalana. Transferències, i thansaccions». Tardor. <http:/cultura.gencat.net/llengcatnoves/hm01 tardor/metodologia/pradillal $1 \mathrm{htm}>$.

Romero, S. (2001): Canvi lingiuistic en morfologia nominal a la Conca de Trem, tesi doctoral, Universitat de Barcelona.

RuIZ, F.; SANZ, R.; SOLÉ, J. (2001): Diccionari de sociolinguiística, Barcelona, Enciclopèdia Catalana.

SEGURA, C. (2003 a): Variació dialectal i estandardització al Baix Vinalopó, Institut Interuniversitari de Filologia Valenciana-Publicacions de l'Abadia de Montserrat, Alacant-Barcelona.

- (2003 b): Una cruilla lingiíística. Caracterització del parlar del Baix Vinalopó, Institut Interuniversitari de Filologia Valenciana-Publicacions de l'Abadia de Montserrat, Alacant-Barcelona.

Silva-Corvalán, C. (1989): Sociolingiiística. Teoría y análisis, Madrid, Alhambra. 
Trudgill, (1994): «Editor's Preface», a Labov, W. (1994): Principles of Linguistic Change. Vol. I. Internal Factors, Oxford, Blackwell (traducció al castellà Principios del cambio lingüístico: Factores internos, Madrid, Gredos, 1996).

TURELl, M. T. (ed.) (1995): La sociolingüística de la variació, Barcelona, PPU. - (1997): «Variació i variacionisme», a LLORET, M. R. [et alii] (ed.) (1997): Anàlisi de la variació lingüística. Barcelona, pPU, 45-64.

VENY, J. (1986): Introducció a la dialectologia catalana, Barcelona, Enciclopèdia catalana.

WeINREICH, U.; W. LABOV; M. I. HEKZOG (1968): «Empirical Foundations for a Theory of Language Change», a LEHMANN, W.; J. MALKIeL (ed.) (1968): Directions for Historical Linguistics: A Symposium, Austin \& London, University of Texas Press. 


\title{
LA FEMINIZACIÓN DEL LÉXICO PROFESIONAL: ENTRE LA NORMA Y EL USO
}

\author{
Mónica Velando Casanova \\ JaVier VELLÓN LAHOZ \\ Universitat Jaume I
}

\section{INTRODUCCIÓN}

$\mathbf{E}^{1}$ debate sobre la feminización de los sustantivos referidos a las profesiones ha sacado a la luz en los últimos tiempos problemas que van más allá de la mera especulación lingüística, pues afectan no sólo a la controversia en torno a la norma y el uso sino a cuestiones ideológicas cuando no a esquemas de actuación social difíciles de conciliar con la gramática. Uno de los capítulos más ilustrativos de este episodio se desarrolló en 1998 en Francia, cuando tres académicas reaccionaron con virulencia ante el intento de tres ministras de feminizar su título. Con este motivo, numerosas personalidades del ámbito universitario e intelectual utilizaron las tribunas mediáticas para proponer todo tipo de reflexiones en torno al tema, tanto de índole lingüística como antropológica, psicológica, sociológica, etc. El número y variedad de argumentos esgrimidos demostraron que estamos ante una cuestión que ha de abordarse desde una perspectiva multidisciplinar y que, desde luego, no se agota con la voluntariosa decisión de un organismo público.

Como veremos a lo largo de esta exposición, son muchos los que incurren en el defecto de intentar defender sus posiciones - normalmente, en contra de ciertos tipos de feminización, los más conflictivos, que aquí trataremos- a partir de criterios científicos, desde una supuesta objetividad teñida de especulación gramatical. Frente a ello, resulta más adecuado adoptar un punto de vista más genérico siguiendo la línea marcada por Michel Foucault (1976) en sus estudios acerca de la relaciones entre lengua y actitudes sociales, y más concretamente entre el poder y el discurso. En este sentido, Pierre Bourdieu (1985: 26 y ss.) sitúa el eje de la discusión en el terreno de las representaciones simbólicas de las formas de poder, entre las cuales la lengua sería una de sus principales manifestaciones, así como una fuente constante de legitimización de conductas socialmente establecidas. Las coordenadas del denominado «poder simbólico» desbordan los márgenes de la simple cuestión gramatical para trasladarse hacia el dominio de la pragmática en su acepción más amplia. 
En el presente trabajo vamos a centrarnos en el análisis de una serie de términos que designan profesiones: jueza / la juez, fiscala / la fiscal, concejala / la concejal, bedela / la bedel, edila / la edil, y que cumplen una serie de requisitos que los convierten en sintomáticos para el propósito de nuestra investigación:

-Se trata de formas cuya hipercaracterización morfológica, con la añadidura dol morfoma flcxivo do géncro femenino, no resulta tan obvia como en el caso de los vocablos del mismo origen determinados por la marca representativa de lo masculino («médico», «ministro», etc.).

-Precisamente por ello, resultan ejemplares para observar las dinámicas sociales en tomo a la gestión de las normativas de uso, especialmente cuando entran en conflicto las directrices de los mediadores del habla, instituciones académicas por una parte, la prensa por otra.

-Finalmente, nos permite evaluar la incidencia sobre la actividad lingüística y sobre sus mecanismos tradicionales de control, de poderosos colectivos sociales (feminismo, grupos mediáticos y económicos, políticos, etc.), que pone en entredicho la imagen clásica del código único y sitúa de nuevo sobre la palestra la metodología relativista del variacionismo como instrumento de análisis.

\section{LA NORMA: LA POSTURA OE LA REAL ACADEMIA ESPAÑOLA}

La Real Academia, una vez más, se convierte en la autoridad competente respecto al problema que en estos momentos nos ocupa. Nuestro interés se centra en observar la posición tomada por la Academia en relación con el corpus de ejemplos seleccionado:

-En primer lugar, nos proponemos averiguar en qué momento aparecen registrados los correspondientes femeninos profesionales.

-En segundo lugar, rescataremos las definiciones dadas por la Academia desde la primera inclusión en el diccionario de dichos términos hasta la actualidad.

-Finalmente, nos interesa discernir entre aquellos casos en los que para el femenino sólo se da una posibilidad de aquellos en los que se ofrecen dos posibilidades (jueza / la juez).

2.1. Con respecto a la primera documentación en el diccionario de la RAE, los datos nos sorprenden con el hecho de que dos sustantivos del corpus se registren desde principios del siglo XX (1927) y, sin embargo, olrus dos se incluyan en el diccionario recientemente (2001): 
-Concejala y edila se registran desde 1927 y se han mantenido hasta la actualidad.

-Jueza se registra posteriormente, en 1992.

-Bedela y fiscala son las más tardías en documentarse en el DRAE, desde 2001. ${ }^{1}$

2.2. En relación a las definiciones dadas por la Academia, concejala, jueza y fiscala, desde su primera aparición hasta la actualidad, se han registrado en el DRAE con los siguientes significados:

«Mujer que desempeña la profesión de...».

«Mujer del concejal / juez / fiscal».

La tradición ha sido colocar en primer lugar la acepción de «mujer del... ». Así, concejala tiene como primera acepción «mujer del concejal» desde 1927 hasta 1983, momento en el que la acepción «mujer que desempeña el cargo de concejal de un ayuntamiento» pasa a ocupar el primer lugar. De la misma manera, cuando en 1992 se incluye jueza, se dice: «f. fam. Mujer del juez // 2. Mujer que desempeña el cargo de juez». La única diferencia es que en este último caso se marca la primera acepción con la nota de «familiar». Concejala, sin embargo, tendrá que esperar al año 2001 para que en la acepción de «mujer de...» se señale que es un femenino coloquial poco usado. Diferente va a ser el caso de fiscala, introducida en 2001, que se define en primer lugar como «mujer que ejerce el cargo de fiscal» $\mathrm{y}$ en segundo lugar como «f, coloq. desus. Mujer del fiscal».

En conclusión, podemos afirmar que con el paso del tiempo la acepción de «mujer de...» ha dejado de tener importancia, reflejo del cambio de la situación de la mujer en el mundo laboral -en estos momentos, las mujeres realizan los trabajos que hasta hace algunos años sólo ocupaban sus respectivos maridos. Por tanto, la Academia, a partir del diccionario de 2001 decide colocar en primer lugar la acepción ligada al desarrollo profesional de la mujer, si bien sigue manteniendo el significado, que ha caído en desuso, de «mujer / esposa de...».

Sorprende, sin embargo, que los sustantivos edila y bedela no hayan sido jamás definidos en términos de relación matrimonial. Y es más sorprendente en el caso de edila, registrado, como ya hemos indicado, desde 1927. Desde su primera aparición en el diccionario, edila se define como «mujer miembro de un ayuntamiento». ¿Es que no ha habido esposas de ediles? ¿Por qué a la

1. La forma bedela aparece ya registrada con anterioridad en la $2^{a}$ edición del Diccionario de uso del español (1998) de $\mathrm{M}^{\mathrm{a}}$ Moliner. 
mujer del edil no se la llama edila? O mejor dicho, ¿por qué la Academia en unos casos registra estos femeninos de profesiones con la acepción de «mujer de...» y en otros casos no? ¿Responde realmente al uso habitual? ¿Por qué en el último de los diccionarios (2001) introduce dos nuevos femeninos (fiscala y bedela) y en uno incluye la acepción (coloquial desusada) de «mujer del fiscal» y en el otro únicamente registra el significado profesional?

Son muchas las incoherencias encontradas y que a día de hoy todavía no encuentran una explicación. Desde nuestra modesta opinión, la introducción de nuevos femeninos por parte de la Academia supone una actitud abierta e innovadora ante los cambios que se producen en la sociedad actual. A pesar de ello, no sólo basta con introducir una serie de femeninos nuevos. Es necesario que se revisen las definiciones, para no incumiri eñ el error de registrar acepciones ya en desuso. 'Y más cuando esas acepciones supeditan, de algún modo, a la mujer con respecto a su marido; esto es, se define a la mujer en relación con el cargo que ostenta su esposo, por lo que ésta elude referirse a sí misma con ese sustantivo cargado de dicha connotación.

De hecho, siguiendo a Gómez Torrego (2002: 95-96), parece haber dos posturas contrarias entre las mujeres que ejercen ciertas profesiones: por una parte, aquellas que prefieren la terminación - a para referirse a la profesión que llevan a cabo; por otra, aquéllas que defienden la terminación $-o$, con el fin de alejarse de las connotaciones burlonas e irónicas inherentes en la terminación - a cuando algunas de ellas designaban también «la mujer de...». De acuerdo con Gómez Torrego (2002: 96), cuanto más se utilicen las formas terminadas en -a, más pronto se eliminarán las comolaciones negativas.

2.3. Una última y no menos problemática cuestión tiene que ver con aquellos casos en los que para el femenino se puede utilizar tanto la forma marcada en - a como la forma no marcada.

a) Las palabras juez y fiscal aparecen como comunes en cuanto al género, esto es, pueden utilizarse tanto para designar a una persona masculina o femenina, hasta el DRAE de 2001:

juez: la jueza y la juez

fiscal: la fiscala y la fiscal

2. En los tiempos que corren, estos sustantivos ya no se utilizan con la acepción mencionada, con lo cual sería necesaria la progresiva desaparición de este significado en los distintos diccionarios. Quizá sólo así el uso de estos femeninos sea mucho más frecuente y familiar. En esta línea, el diccionario de $\mathrm{M}^{\mathrm{a}}$ Moliner ( $2^{\mathrm{a}} \mathrm{ed}$. . 1998) registra las formas femeninas bedela. concejala y jueza, y en ninguna de ellas incluye la acepción de «mujer de...»; todas ellas se definen como profesiones ejercidas por mujeres. 
En el Diccionario del español actual (1999) coordinado por Manuel Seco, se incluyen junto a juez y fiscal, ${ }^{3}$ concejal (a veces la forma CONCEJAL se usa también como femenino) y edil (frecuentemente se usa EDIL como femenino). En la segunda edición (1998) del diccionario de $\mathrm{M}^{\mathrm{a}}$ Moliner únicamente en la entrada juez,- $a$, en la nota de uso se indica: «A pesar de que existen las dos terminaciones (juez, jueza), es más frecuente usar también en femenino la forma "juez", sobre todo en el lenguaje formal».

En conclusión, se puede observar cómo, de algún modo, los diccionarios siguen avalando el uso de la forma no marcada con el significado de femenino.

b) En algunos sustantivos aparece la advertencia de «usado también el masculino para designar el femenino»:

concejala: Luisa es concejal

edila: Consuelo es edil

En estos casos, tal y como comenta Gómez Torrego (2002: 102), nos queda la duda de si la elección del masculino por el femenino sólo es correcta en los ejemplos en que el sustantivo está realizando la función de atributo (y $\sin$ artículo), o si se extiende a todos los casos (la concejal del distrito, la nueva edil del ayuntamiento, etc.).

c) Del total del corpus seleccionado, únicamente del sustantivo bedel no se indica en ninguno de los diccionarios consultados que sea común en cuanto al género, con lo que se deduce que dicho sustantivo cuenta con dos formas: bedel-bedela, una para el masculino y otra para el femenino.

\section{LOS LIBROS DE ESTILO Y LA NORMA DE USO}

La afirmación de que los medios de comunicación constituyen un poder fáctico en el uso de la lengua es una obviedad. Como lo es constatar que se han convertido en el modelo privilegiado para muchas decisiones normativas, pues su influjo social es tan evidente que se ha pasado de la censura abierta a sus muchas incorrecciones a convertirlos en referente de lengua viva y arraigada en el contexto.

3. Con respecto a juez-za, comenta Seco: «(la forma JuEz se usa como masculino y femenino en las acepciones 1 y 2 ; la forma femenina JUEZA, solo en la acepción 1) $\mathrm{m}$. y f. l. Letrado con autoridad para juzgar y sentenciar. 2. Persona con autoridad para juzgar en una materia determinada». Y con respecto a fiscal-la: «(la forma FISCALA solo en acepción 4, donde generalmente se usa la forma FISCAL como femenino) [...] 4. En un juicio: Acusador publico». 
Sin embargo, conviene tener presente que los medios están asumiendo funciones en el control de la lengua (en campos concretos como el léxico de manera clara) que merecen un comentario. En efecto, el periodismo se enfrenta en la actualidad a retos de gran complejidad, con una realidad cada vez más diversa, multicultural, multiétnica, plurilingüe. Este entorno, hetero-géneo y en continua transformación, le exige respuestas concretas y diarias frente a numerosos asuntus, en los que la lengua se ve implicada.

Desde esta constatación, los libros de estilo, así como las directrices sobre temas concretos, actúan como verdaderos manuales de uso, un interfaz entre texto y contexto, cuya función les permite ocupar un lugar preponderante como agentes sociales difusores de comportamientos lingüísticos.

En cl caso que nos ocupa, los libros de estilo de los principales medios españoles muestran las líneas maestras de su actuación sobre los elementos lingüísticos en el entono social:

- Por una parte, entran en abierta contradicción con las normas establecidas por la Academia o, cuanto menos, prefieren ignorarlas acogiéndose a la primacía del uso habitual entre los hablantes como criterio único de sus decisiones.

- Por otra, como veremos en el apartado siguiente, también se pueden observar las limitaciones de estos manuales, cuyo objetivo homogeneizador de escritura queda en entredicho por la propia práctica de los profesionales, lo que, a su vez, debe provocar la reflexión en tomo a la excesiva responsabilidad depositada sobre tales útiles de trabajo.

Existe bastante coincidencia en los planteamientos de los citados libros en torno al tema aquí propuesto. El de La Vangiaardia (2004: 125) trata estos términos globalmente, rechazando la hipercaracterización morfológica (jueza, concejala...) al interpretarla como «artificiosa» y ajena a la práctica diaria de los hablantes. En parecidos términos se expresa el de $A B C$ (2001: 84): se admite que la Academia ha aceptado las formas en femenino pero «no están asentadas y suenan mal a los usuarios». El de El Periódico (2002) no argumenta su opción, simplemente se inclina por la utilización del morfema artículo para establecer la variación.

En el caso de El País (2004), pese a elegir la misma posibilidad que los tres anteriores, los autores proponen una explicación que va más allá de la tradicional apelación al uso, invocando un criterio de carácter gramatical cuanto menos curioso o discutible: en castellano hay palabras como «nuez»o «brillantez» que también son femeninas, poseen la misma estructura que los vocablos comentadns, y no necesitan un camhin de terminación. Las lagunas 
de tal argumento están en la mente de todos y se relacionarían con cuestiones de índole pragmática.

Frente a esta posición, el único manual que opta por la solución aceptada por la Academia es el de la agencia EFE, en su Diccionario de español urgente (2001: 201-202), donde se recomienda a sus profesionales el uso de formas como «jueza», «fiscala», «concejala», etc.

Al margen de los referentes estudiados hasta ahora, algunos autores también han tratado el problema de estos vocablos en la comunidad lingüística y en los medios de comunicación, aportando sus puntos de vista y sus conjeturas en torno a cuál será su futuro. Valentín García Yebra (2003: 84-86), por ejemplo, considera que «jueza» es síntoma de una tendencia vulgarizante y popular que acabará prevaleciendo sobre el más culto de «la juez», situando así la reflexión en el dominio de las variaciones sociales y funcionales. Más curioso resulta el testimonio de Álvaro García (1977: 253), en cuanto que refleja las dificultades a la hora de tratar estas cuestiones tan próximas a las conductas sociales. El autor critica la feminización incluso de las palabras de profesiones marcadas con el morfema $-O$ por la prensa; según su criterio es mucho más progresista mantener la forma única, y sentencia: «la dinámica social conducirá al empleo creciente de la forma única para ambos sexos, con valor de género común, en detrimento de la doble forma».

\section{LA PRÁCTICA PERIODÍSTICA}

Si los manuales de estilo periodísticos optaban mayoritariamente por el uso frente a las propuestas normativas, es necesario observar cómo se llevan a cabo dichas directrices por parte de los profesionales. Conviene recordar, no obstante, que la implicación de tales obras en la producción de mensajes ha de valorarse en los siguientes términos:

-En primer lugar, pretenden determinar unas pautas homogeneizadoras frente a la tendencia diversificadora de la heterogeneidad referencial y la existencia de individualidades en la redacción del texto. Tal función, al margen de las cuestiones estilísticas, confiere al medio una imagen sólida de institución discursiva en la comunicación con el lector, en lo que Bernardino M. Hernando (1990: 54-55) denomina «producción colectiva».

-Precisamente por ello, en segundo lugar, el periódico actúa como agente generador de esquemas lingüísticos, ideológicos e, incluso, perceptivos, constituyendo un mecanismo integrador en torno a modelos de uso. 
Sin embargo, la rutina periodística va más allá de la simplificación que supone establecer una relación de continuidad entre las normativas internas y la práctica continua de los redactores. La lengua es una entidad demasiado compleja para reducirla a paradigmas prescriptivos, por muy abiertos al habla que se pretendan. De este modo, el análisis del corpus periodístico, compuesto por nueve publicaciones en un determinado margen temporal (descle 1990 se han revisado a través del corpus de la RaE, el CREA: El Pais, El Mundo, La Vanguardia, $A B C$ y $L a$ Razón; el áltimo año por medio de los respectivos buscadores, El Periódico, Levante, El Correo, Las Provincias, además de los ya citados), y tomando como referencia las palabras objeto del presente trabajo, nos permite concluir que las contradicciones observadas son el síntoma de la gran diversidad de matices en un fenómeno -los femeninos en ciertas profesiones- en el que norma y uso se aproximan entre sí, se alejan en ocasiones, y encuentran espacios de intersección en otras, con lo que ello supone en la competencia del hablante.

Centrándonos en el análisis textual, encontramos, en un extremo, dos términos, fiscal y bedel, sobre los que existe unanimidad absoluta y fiel cumplimiento de lo programado en los libros de estilo: en todos los casos se utiliza la variante común con la moción morfológica del artículo. Ciertamente, se registran en el diccionario académico desde 2001, esto es, son los últimos femeninos de nuestro corpus en aparecer en dicho diccionario. Sin embargo, el hecho de que la Academia cuente con ellos no ha supuesto un afianzamiento de tales femeninos en los medios de comunicación españoles. Siguiendo las directrices de sus propios manuales de estilo, los periódicos optan por formas como la bedel o la fiscal en detrimento de las formas marcadas.

Casi en el mismo grupo puede incluirse el vocablo edil, pues sólo en Las Provincias se ha constatado la utilización de la forma hipercaracterizada edila.

Un primer intento de cxplicación vincularía csta cvidencia con la frecuencia de aparición de tales palabras: bedel y edil no son formas habituales, la primera por no ser una profesión corriente en la información, la segunda porque se prefiere el término «concejal». Además, en este último caso, un argumento de peso es el hecho de que los manuales de estilo de los periódicos muestren abiertamente su preferencia por la terminación no marćada, dado que estamos ante una forma registrada desde 1927 y que nunca ha sido definida con la etiqueta de «la mujer de...»y, por tanto, carece por completo de todas las connotaciones negativas que ostenta el citado sintagma.

En el caso de fiscal, en su forma femenina, presenta un índice deaparición muy bajo por el simple motivo de que, frente a los casos que comentaremos a continuación, aún es una profesión con poca representación femenina, sin olvidar otra explicaciön estrictamente lingüistica: la influencia de la forma adjetival, invariable. Por otra parte, es evidente la tendencia periodística a citar 
la institución (ministerio fiscal o físcalía) en lugar de la persona que desempeña el cargo. Todos estos factores facilitan la uniformidad en torno a la norma interna de los medios.

Bien distinto es el caso de las dos palabras más frecuentes en su forma femenina, concejal y juez. El País opta mayoritariamente por la juez, según sus directrices, pero también aparecen casos de la jueza. Algo similar sucede en el $A B C$, La Razón, El Correo, Levante, La Vanguardia, El Periódico, mientras que en El Mundo y Las Provincias prefieren la forma con el morfema -a, aunque también aparece la variante común del femenino.

En lo que respecta a concejal, El País también se decanta por la forma con artículo femenino -según aconseja su manual-, pero se registran casos, no muy numerosos, con la variación en - $a$. Lo mismo ocurre en $A B C, E l$ Periódico, La Razón, El Correo, Levante. Por su parte, El Mundo y Las Provincias utilizan mayoritariamente la forma con $-a$, sin que ello sea óbice para que puedan encontrarse ejemplos de la variante común.

Como última curiosidad, no queremos dejar de comentar la extensión que tienen las formas marcadas en Hispanoamérica. Sin profundizar demasiado en esta cuestión, simplemente queremos dejar constancia de que de los únicos 21 casos encontrados en el CREA de la forma fiscala, 14 casos se registran en el $A B C$ Color de Paraguay; y de los 7 casos de edila, 2 son de El País de Uruguay.

\section{CONCLUSIÓN}

A lo largo del trabajo hemos mostrado la complejidad de un fenómeno que afecta a aspectos que van más allá de lo lingüístico, como es la feminización de ciertas profesiones habitualmente ejercidas por hombres, y con una estructura morfológica determinada. El objetivo de nuestra investigación ha sido poner de relieve las contradicciones de un proceso que, aparentemente, no debería ir más allá de lo que supone el desarrollo de decisiones arbitrarias en torno a un tema de normativa con implicaciones pragmáticas. Precisamente por ello, nuestra intervención ha pretendido demostrar las dificultades que comportan, por una parte la instauración de pautas prescriptivas -teñidas de descriptivismo- de las instituciones, por otra, la fidelidad a los hábitos de la comunidad lingǘstica, pues ni unos ni otros logran una síntesis homogeneizadora, pese a pretenderlo:

1) Durante mucho tiempo, la postura de la Real Academia ha sido considerar como comunes en cuanto al género cierto número de sustantivos que designan actividades profesionales. Con el transcurso del tiempo, la socie- 
dad se ha transformado $y$, así, el hecho de que ciertas mujeres ocupen puestos de trabajo antiguamente relegados a los hombres ha supuesto un cambio también importante en el plano lingüístico. Poco a poco, la Academia ha optado por ir introduciendo en sus sucesivas ediciones del diccionario las nuevas formas femeninas, terminadas en $-a$. Sin embargo, no lo ha hecho con todos los sustantivos (consúltense, por ejemplo, los sustantivos referidos a cargos militares, en los que únicamente tenienta significa "mujer con grado de teniente») y en la mayor parte de los nombres sigue manteniendo, junto al significado habitual, el ya en desuso de «mujer/ esposa de...».

Sorprende, por otra parte, que la Academia, en su camino por acercarse a la realidad que la envuelve, introduzca toda una serie de femeninos que todavía a día de hoy resultan exíraños; nos referimos a los casos de bedela, fiscala o edila, cuyo üso, como ha quedado demostrado, es prácticamente inexistente.

De este modo, la Academia, al aceptar en su Diccionario, como entrada primera, las formas femeninas de los oficios nombrados, iha cumplido realmente con las expectativas de los usuarios, traduciendo al léxico normativo lo que es una demanda generalizada?, ¿o, por el contrario, ha realizado una concesión al lenguaje políticamente correcto, dando respuesta así a las presiones de grupos de opinión social y económicamente poderosos?

2) Al revisar los libros de estilo periodísticos, la respuesta a las preguntas anteriores parece obvia, pues casi todos los consultados optan por la forma invariable, apelando al uso y a lo que es la tendencia generalizada entre los hablantes.

3) Ahora bien, ¿hasta qué punto los medios de comunicación, como agentes sociales, pueden considerarse mediadores entre niveles lingǘsticos, cuando, como hemos demostrado, ni siquiera mantienen una línea única de actuación sobre las posibilidades del sistema? Cabe otra interpretación no menos sugestiva: ¿esta vacilación en palabras muy frecuentes en las tribunas periodísticas es el síntoma de un cambio hacia la total feminización, como parece anunciar la reforma académica e instintivamente lingüistas como García Yebra?

La respuesta a tales interrogantes nos lleva a la dialéctica entre instituciones lingüísticas entre sí, y entre éstas y la comunidad de hablantes. ¿Quién impone los modelos lingüísticos?, ¿cuál es la intervención del usuario?, ¿los medios de comunicación son verdaderamente tan permeables a las exigencias sociales? El tema que nos ocupa se abre así a las grandes cuestiones del universo de la comunicación. 


\section{REFERENCIAS BIBLIOGRÁFICAS}

AGENCIA EFE (2001): Diccionario de español urgente, Madrid, SM.

Bourdieu, P. (1985): ¿Qué significa hablar? Economía de los intercambios lingüísticos, Madrid, Akal.

Foucault, M. (1976): La volonté de pouvoir, París, Gallimard.

GARCÍA, Á. (1977): Lenguaje y discriminación sexual, Barcelona, Montesinos.

García YeBra, V. (2003): El buen uso de las palabras, Madrid, Gredos.

Gómez Torrego, L. (2002): Nuevo manual de español correcto, Madrid, Arco Libros, 2 volúmenes.

Hernando, B. M. (1990): El lenguaje de la prensa, Madrid, Eudema.

Libro de estilo del ABC (2001), Barcelona, Ariel.

Libro de estilo de El País (2004), Madrid, Ediciones de El País.

Libro de estilo de El Periódico (2002), Barcelona, Ediciones Primera Plana.

Libro de estilo de la Vanguardia (2004), Barcelona, Ariel.

Moliner, M." ('21998 [1967]): Diccionario de uso del español, Madrid, Gredos.

Real ACADEmia Española (2001): Diccionario de la lengua española, Madrid, Real Academia Española.

- Corpus del Español Actual, CREA. En http://www.rae.es.

- Nuevo tesoro lexicográfico de la lengua española, NTLLE. En http://www.rae.es.

Seco, M.; O. Andrés; G. Ramos (1999): Diccionario del español actual, Madrid, Aguilar. 


\section{SECCIÓN III BILINGÜISMO Y CONTACTO DE LENGUAS}




\title{
CONTRASTES DEMOGRÁFICOS Y SOCIOLINGÜÍSTICOS EN EL PROCESO DE LA NORMALIZACIÓN DEL EUSKERA, DEL CATALÁN Y DEL GALLEGO EN LA DÉCADA COMPRENDIDA ENTRE 1991 Y 2001
}

\author{
Raquel Casesnoves Ferrer
}

IULA, Universitat Pompeu Fabra

\section{INTRODUCCIÓN}

T os programas de normalización lingüística que diversas comunidades Lautónomas de España (Cataluña, Valencia, Islas Baleares, País Vasco, Navarra y Galicia) adoptaron entre 1982 y 1986 perseguían en todos los casos restaurar el prestigio y la vitalidad de las lenguas «históricas» o «propias» excluídas de cualquier ámbito formal y público durante la dictadura de Franco. Aunque la tendencia hacia la castellanización existía en mayor o menor grado según la comunidad desde mucho antes, el período del régimen franquista fue decisivo en la interrupción de la transmisión intergeneracional de las lenguas (especialmente en las grandes ciudades de Palma, Valencia y Alicante), en la generalización de prejuicios lingüísticos resultantes de su reclusión en el ámbito privado y rural (fenómeno extensivo a Valencia, Galicia y las zonas vascófonas) y en la desaparición de monolingües de cualquier lengua histórica (proceso general en cualquiera de estas comunidades).

El eventual resultado del proceso de normalización no es evidente en ninguno de los casos, pero está claro que su progreso está en gran parte determinado por factores que varían enormemente de una comunidad a otra:

- En el nivel puramente lingüístico, el español no tiene ninguna relación con el euskera, pero sí con las lenguas románicas, el catalán y el gallego, de las que forma parte.

- Económica, social y políticamente, la Comunidad Valenciana mantiene desde hace mucho tiempo relaciones ciertamente ambivalentes con el centro español, alejadas de la rivalidad histórica entre Madrid y Cataluña y también del conflicto entre el País Vasco y el Gobierno español. 
- El movimiento migratorio de la población tiene un carácter completamente diferente en Galicia, que pierde población debido a la emigración desde hace numerosas generaciones, en comparación a Cataluña y la Comunidad Valenciana, que han sufrido en los últimos años la llegada masiva de inmigrantes extranjeros procedentes de África del norte, de Europa del este y de América latina, o a las Islas Baleares, donde el turismo europeo se transforma en ciertas regiones en una especie de colonización veranicga.

- El territorio de Valencia y Navarra está dividido por zonas linguísticas, lo que no ocurre en el resto de las comunidades. En Navarra se distinguen tres zonas: vascófona, mixta y no vascófona, mientras que en Valencia se diferencian únicamente dos (valencianohablante y castellanohablanîe). Tanto los derechos de la población en cuanto al uso de las lenguas como su regulación en el sistema de enseñanza obligatorio difiere según las zonas.

La evaluación a corto plazo de la planificación lingüística es difícil porque los cambios se dan por incrementos e influyen de manera diferente tanto en los diversos componentes de la población como en la gran variedad de usos lingǘsticos. Así por ejemplo, el número de niños y niñas bilingües ha aumentado en comparación a veinte años atrás, pero también es cierto que hay menos personas adultas que lo son; la lengua utilizada en los comercios, especialmente la que tiene lugar en las grandes superficies, es cada vez más el castellano, pero por otra parte las lenguas históricas han acm cedido a los grandes medios de comunicación en los que hasta hace poco se usaba exclusivamente el castellano. Todo lo que se puede afirmar después de 20 años es que los programas de normalización han tenido un cierto «éxito» según ámbitos pero han fracasado en cl cambio de algunos hábitos lingüísticos de la población (pensemos, por ejemplo, en la norma de convergencia hacia el castellano, una práctica que nace y se extiende durante el franquismo y que sigue plenamente vigente en nuestros días). A pesar de todo, para poder llevar a cabo una revisión y una ejecución razonable de las políticas lingüísticas, habrá que hacer un esfuerzo y encontrar un mecanismo que permita evaluar de manera precisa estos programas de normalización.

Existen dos instrumentos basados en el censo de población, y en particular la parte del censo que incluye algunas cuestiones lingüísticas, que nos pueden ayudar a evaluar los programas de normalización y a atribuir esos éxitos y fracasos ya sea a los programas mismos, a la historia, a la geografía o a la demografía de la comunidad en cuestión. Uno de los instrumentos consiste en la comparación temporal de la situación, es decir, en analizar su evolución con 
respecto al censo anterior. El otro instrumento es la realización de proyecciones demolingüisticas, que puede predecir cómo la situación evolucionará si los valores de todos los parámetros demográficos de hoy en día permanecieran constantes en el futuro (Casesnoves Ferrer, Sankoff y Turell, 2004).

En este artículo nos centramos en el primer instrumento, es decir, en la comparación temporal y, más concretamente, en la evolución del conocimiento del euskera, el catalán y el gallego en las comunidades oficialmente bilingües durante la década comprendida entre los censos de población de 1991 y 2001.' La comparación de la evolución del conocimiento nos ayudará a evaluar el progreso de la normalización lingüística en cada comunidad y a establecer tendencias, paralelas o divergentes, en las seis comunidades.

\section{CAMBIOS DEMOGRÁFICOS RELEVANTES ACAECIDOS DURANTE LA DÉCADA DE LOS NOVENTA}

El cambio demográfico más importante lo constituye sin lugar a dudas el movimiento migratorio procedente del extranjero y en particular su carácter brusco e intenso, afectando especialmente a las comunidades catalano-hablantes. El cambio en estas comunidades no sería tanto el paso hacia una sociedad receptora de inmigración, puesto que en mayor o menor medida ya lo eran, como la procedencia de dicha población. En las tres comunidades catalanohablantes la población extranjera era, a principios de los noventa, sobre todo europea, mientras que ya a finales de la misma década el peso de los inmigrantes de otros países, especialmente de África del Norte y de América Latina superaba con creces a los europeos. El gráfico 1, que ilustra la proporción de población extranjera durante la década de los noventa, muestra bien que las únicas comunidades que superan la media española son Cataluña, la Comunidad Valenciana y, sobre todo, las Islas Baleares donde la población de nacionalidad extranjera representa el 4,5 y $8 \%$ respectivamente. $^{2}$

1. Los datos referentes a 1991 nos los proporcionaron los Institutos de Estadística autonómicos, excepto en los casos de Valencia y de las Islas Baleares cuyas fuentes son IVE 1996 y Govern Balear 1993 respectivamente. La información del último censo, 2001, está generalmente disponible en línea en la página web de los Institutos de Estadística (EUSTAT, IBAE, IDESCAT, IEN, IGE, IVE).

2. Datos procedentes del Instituto Nacional de Estadística (http://www.ine.es) 


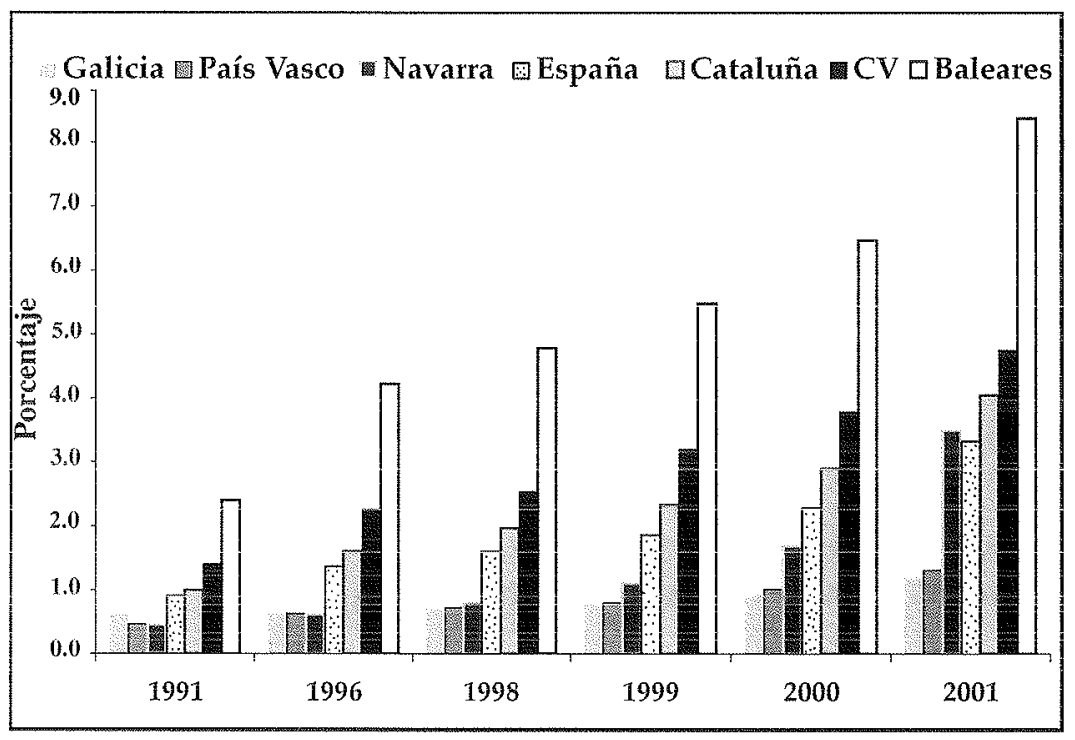

GRÁFICO 1. Porcentaje de extranjeros empadronados en cada comunidad autónoma

Los otros cambios demográficos no es que sean nuevos, sino que se consolidan durante este período. Nos referimos a la caída de la tasa de natalidad, que no empieza a aumentar más que recientemente debido a la descendencia de las mujeres extranjeras, y a la prolongación de la esperanza de vida al nacer. Puesto que la población española no se renueva «naturalmente», sino que crece gracias al movimiento migratorio extranjero, es de suponer que el futuro de las lenguas históricas, especialmente de la catalana por el alto índice de inmigración que ha recibido, dependerá en gran parte de la integración lingüística de los inmigrantes.

\section{LA EVOLUCIÓN DLL CONOCIMIENTO DE LAS LENGUAS PROPIAS EN LAS COMUNIDADES OFICIALMENTE BULINGÜLS}

Los datos lingüísticos que aquí presentamos provienen, en todos los casos, de los censos de población donde se incluyen cuestiones relativas a la lengua. Los censos lingüísticos nos proporcionan una información exhaustiva de la población y de sus características demográficas, económicas y sociales y posibilitan hacer un tratamiento sistemático de las variables linguísticas con el resto de variables censales, de forma que se puede observar la relación entre unas y otras así como la evolución del conocimiento y del uso de las lenguas. 
Las preguntas lingüísticas empezaron a introducirse en las renovaciones de los padrones municipales, que se realizaban cada cinco años, a lo largo de los años ochenta. Estas preguntas difieren de una comunidad a otra. En la zona catalanohablante se recoge únicamente la capacidad o no que posee la población para entender, hablar, leer y escribir el catalán. En la vascófona, además de medir el grado de conocimiento, se han ido introduciendo cuestiones referentes al uso del euskera, como también ha ocurrido en Galicia. De las cuestiones sobre el conocimiento de la lengua, generales a todas las comunidades, hemos hecho una clasificación que distingue cuatro tipos de habilidades lingüísticas en el caso del catalán y del gallego (entiende, habla, lee y escribe), mientras que para el euskera hemos tenido que reagrupar las capacidades de leer y escribir en una sola categoría. En este caso, la diferencia entre una y otra, no es significativa, puesto que la adquisición del euskera, tipológicamente muy diferente al castellano, no lo posibilita. El gráfico 2 muestra la proporción de población de cada comunidad según los diferentes tipos de competencia en el año 2001.

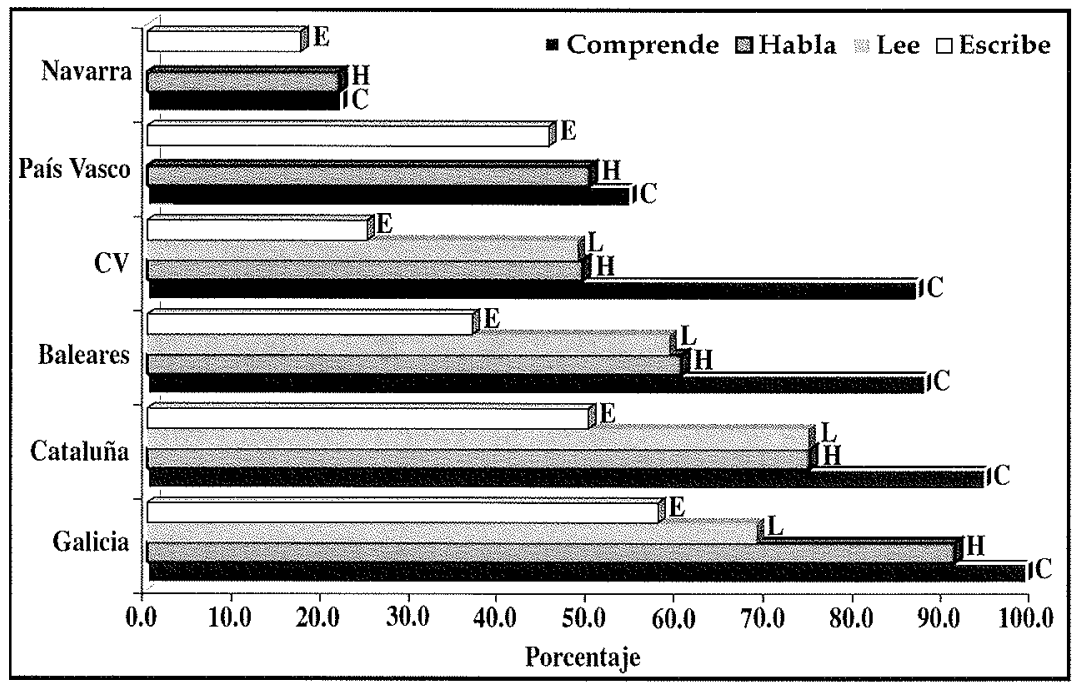

GráfICO 2. Conocimiento del gallego, catalán y euskera en 2001

Galicia es la comunidad que posee niveles más altos de competencia, excepto en la capacidad para leer donde sobresale Cataluña (75\%). En el otro extremo se sitúa Navarra, con tan solo un $22 \%$ de la población capaz de entender y hablar el euskera. Fijémonos en que el nivel de capacidad para hablar y escribir varía enormemente en las comunidades catalanohablantes y también en Galicia, pero en cambio es similar en las comunidades vascófonas. 
El gráfico 3 ilustra la evolución de la competencia entre los dos censos. La competencia oral activa aumenta especialmente en Navarra y el País Vasco, permanece invariable en Galicia y desciende en la Comunidad Valenciana (2\%) y sobre todo en las Islas Baleares $(7.5 \%)$, donde también retrocede la comprensión del catalán. Sin lugar a dudas, la habilidad lingüística que evoluciona más favorablemente en todas las comunidades bilingües es la lectoescritora, un tipo de competencia cuya adquisición depende de la escolarización.

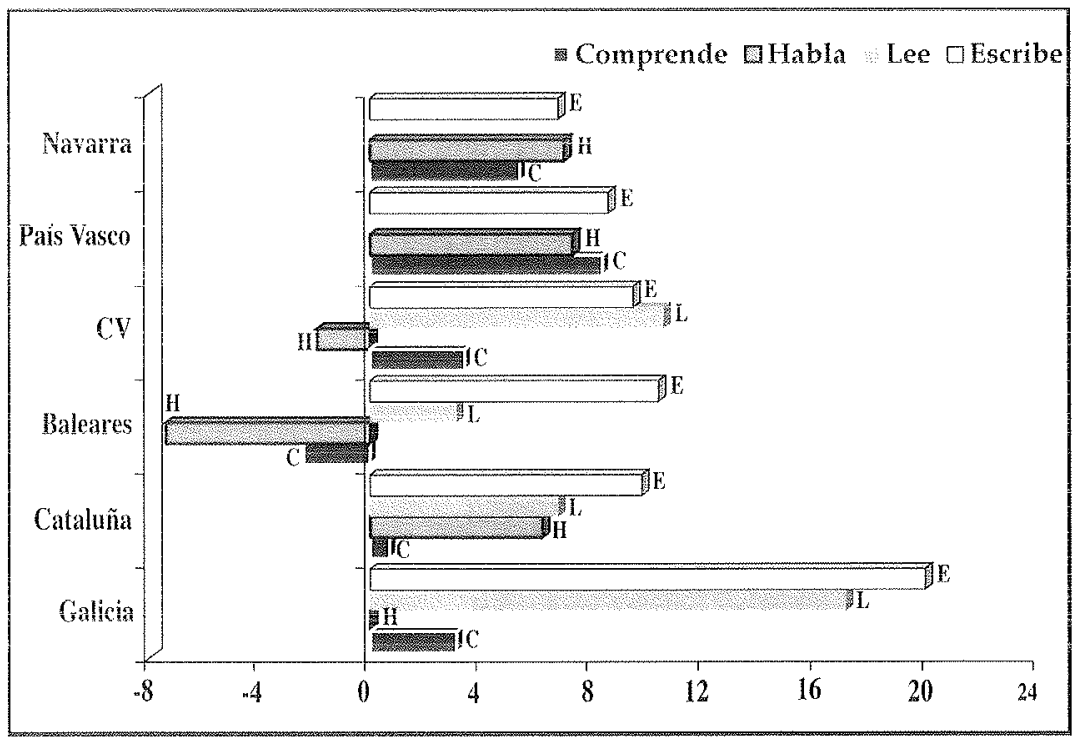

GRÁFICO 3. Variación del conocimiento del gallego. catalán y euskera entre 1991 y 2001

En resumen, Galicia es la comunidad que presenta niveles más altos de competencia oral y la que presenta un índice de variación más favorable en la competencia lecto-escritora. El conocimiento del euskera aumenta tanto en Navarra como en el País Vasco, pero retrocede la capacidad para hablar catalán en Valencia y Baleares.

En lo que sigue analizamos el cambio de competencia para hablar y escribir las lenguas propias en las seis comunidades según diferentes características de la población: la edad, la edad y el género, el lugar de nacimiento y la comarca o zona de residencia. Los análisis descubren grandes diferencias en la evolución del conocimiento de las lenguas entre la población que permanecen ocultas en los resultados generales. 


\subsection{Evolución del conocimiento de las lenguas propias según la edad de la población}

La edad de la población comporta diferencias generacionales importantes en el conocimiento de las lenguas tanto en un momento determinado como en su evolución. El gráfico 4 muestra el cambio entre los dos censos de la capacidad para hablar las lenguas propias.

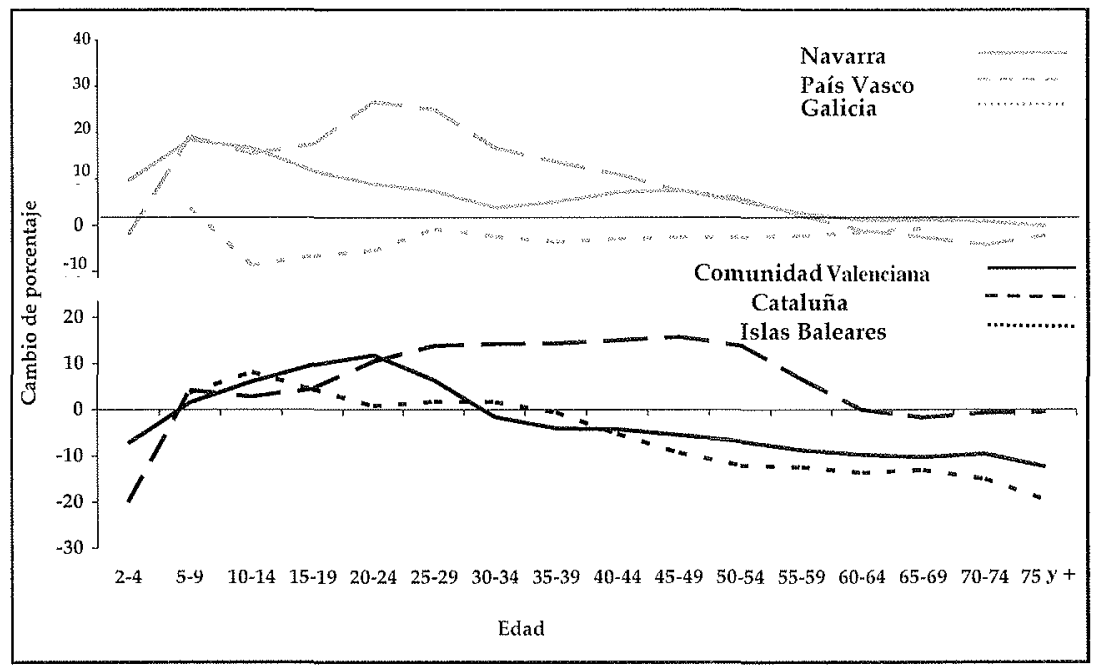

GRÁFICO 4. Variación del conocimiento para hablar las lenguas propias entre 1991 y 2001 según la edad de la población en las seis comunidades oficialmente bilingües

La capacidad para hablar catalán aumenta de manera general en Cataluña, pero retrocede entre la gente adulta de las Islas Baleares y de la Comunidad Valenciana. En lo que al euskera se refiere, la evolución del habla es positiva en todos los tramos de edad, especialmente entre los jóvenes y la población adulta del País Vasco y exceptuando los de edad más avanzada de ambas comunidades. En el caso del gallego, salvo la disminución entre los jóvenes de 10 a 24 años, la edad no es una variable que comporte diferencias generacionales en la evolución de la competencia oral.

La capacidad para escribir catalán y euskera (gráfico 5) aumenta especialmente entre los jóvenes de las cinco comunidades, aunque los tramos de edad con los niveles más altos no coinciden: en Navarra la evolución es particularmente positiva entre los 5 y 14 años; en el País Vasco y la Comunidad Valenciana entre $\operatorname{los} 20$ y los 29 y en las Islas Baleares y Cataluña entre 
$\operatorname{los} 25$ y los 35 . Galicia, en cambio, no sigue la misma tendencia que estas comunidades, ya que la capacidad para escribir gallego aumenta de forma espectacular a partir de los 25 años y este incremento se mantiene incluso en la población mayor de 60 años.

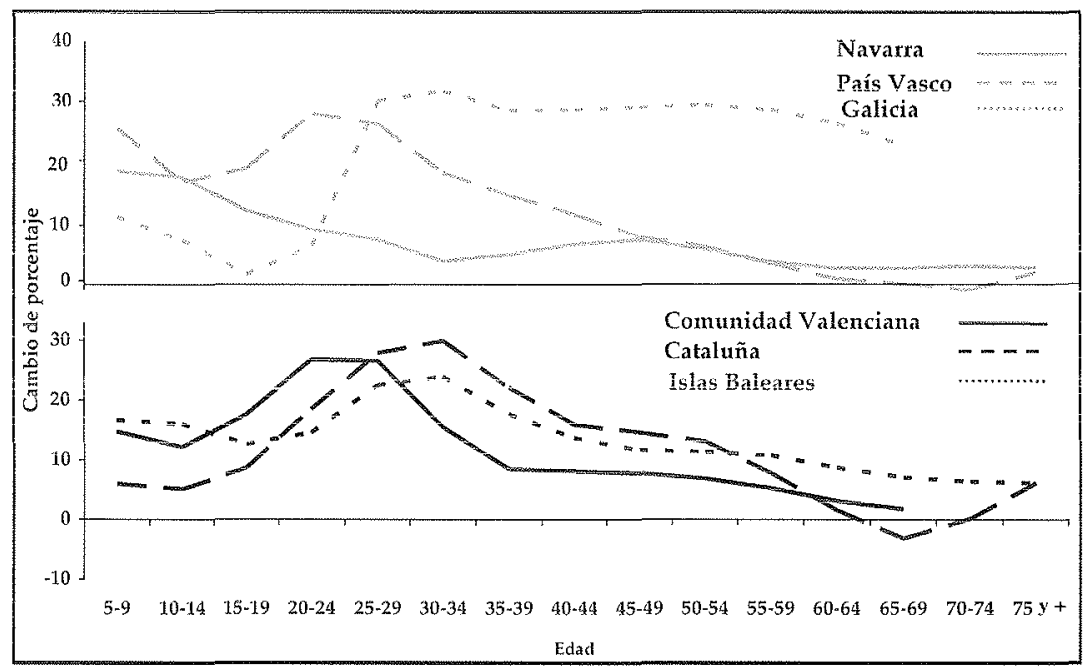

GRÁFICO 5. Variación de la capacidad para escribir las lenguas propias entre 1991 y 2001 según la edad de la población en las seis comunidades oficialmente bilingüies

La edad de la población conlleva pues diferencias importantes en la evolución de la competencia lingüística. Uno de los resultados que más llama la atención es la pérdida de capacidad para hablar catalán entre la población adulta de las Islas Baleares y de la Comunidad Valenciana. La evolución del euskera es particularmente positiva entre los más jóvenes del País Vasco, mientras que la capacidad para hablar gallego se mantiene estable, posiblemente porque el nivel de partida era ya bastante elevado. Debemos subrayar que la evolución más favorable se da en la capacidad para escribir las lenguas propias, en todas las comunidades sin excepción, lo cual demuestra el papel fundamental que juega la escolarización en los procesos de revitalización linguística. 


\subsection{Evolución del conocimiento de las lenguas propias según el género y la edad de la población}

El género de la población no es una característica demográfica que influya en el mayor o menor conocimiento de las lenguas propias en ninguna de las comunidades, aunque también es cierto que los varones declaran poseer un mayor grado de competencia en catalán y en gallego. Esto no significa que las mujeres adquiran competencia en proporciones menos elevadas que los varones, puesto que ocurre más bien lo contrario. El gráfico 6 ilustra las diferencias en la capacidad para hablar scgún cl géncro en los diferentes grupos de edad. Estas diferencias muestran la variación entre los dos censos lingüísticos. Hemos sustraído los valores obtenidos de los varones a los valores de las mujeres, de manera que si el resultado es positivo indica que la proporción de mujeres con dicha capacidad es mayor que la de los varones y si es negativo menor.

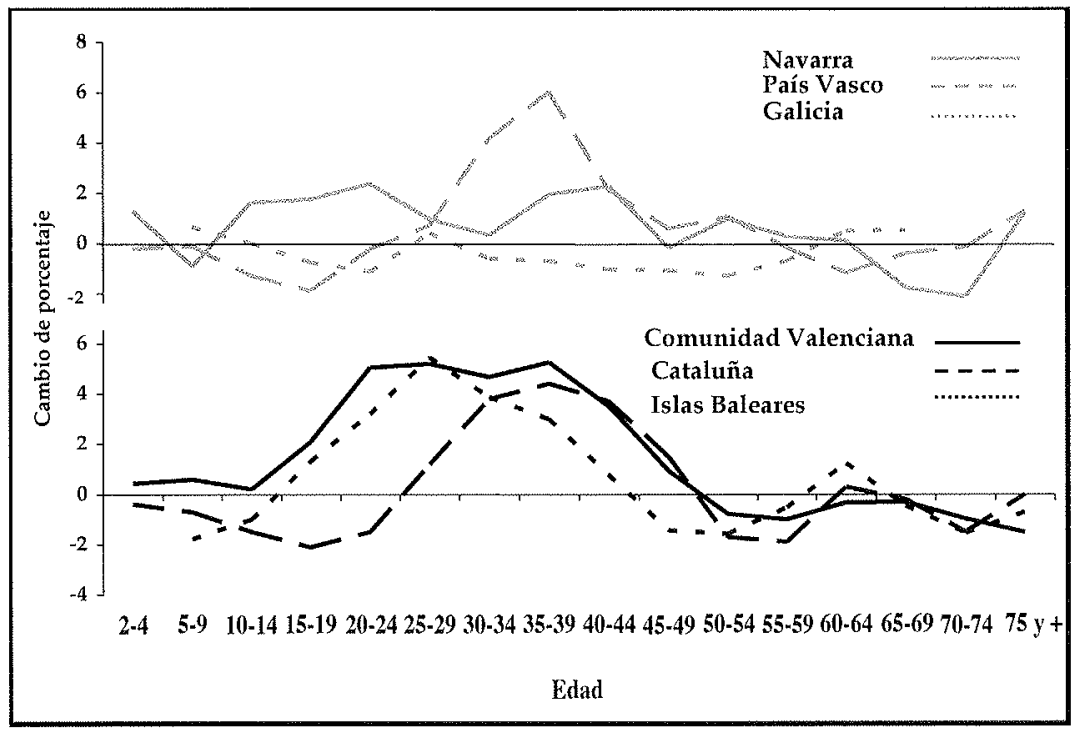

GRÁfico 6. Diferencias según el género por grupos de edad en el cambio de la capacidad para hablar las lenguas propias entre 1991 y 2001 en las seis comunidades oficialmente bilingües

Las mujeres adquieren niveles más altos de competencia para hablar en las tres comunidades catalanohablantes y en el País Vasco que los varones en el tramo de edad que va desde los 20 o 30 hasta los 40 o 44 años, según la comunidad. En cambio, no parece haber diferencias de género en la adquisición del euskera en Navarra ni en la del gallego. 
En lo que se refiere a las diferencias según el género en la capacidad para escribir las lenguas propias, el gráfico 7 ilustra la misma tendencia observada en el gráfico 6: las mujeres jóvenes y/o en edad laboral de las comunidades catalanohablantes y del País Vasco consiguen tener un grado de competencia más elevado que los varones. Tampoco en este caso se observan divergencias importantes en Navarra y Galicia.

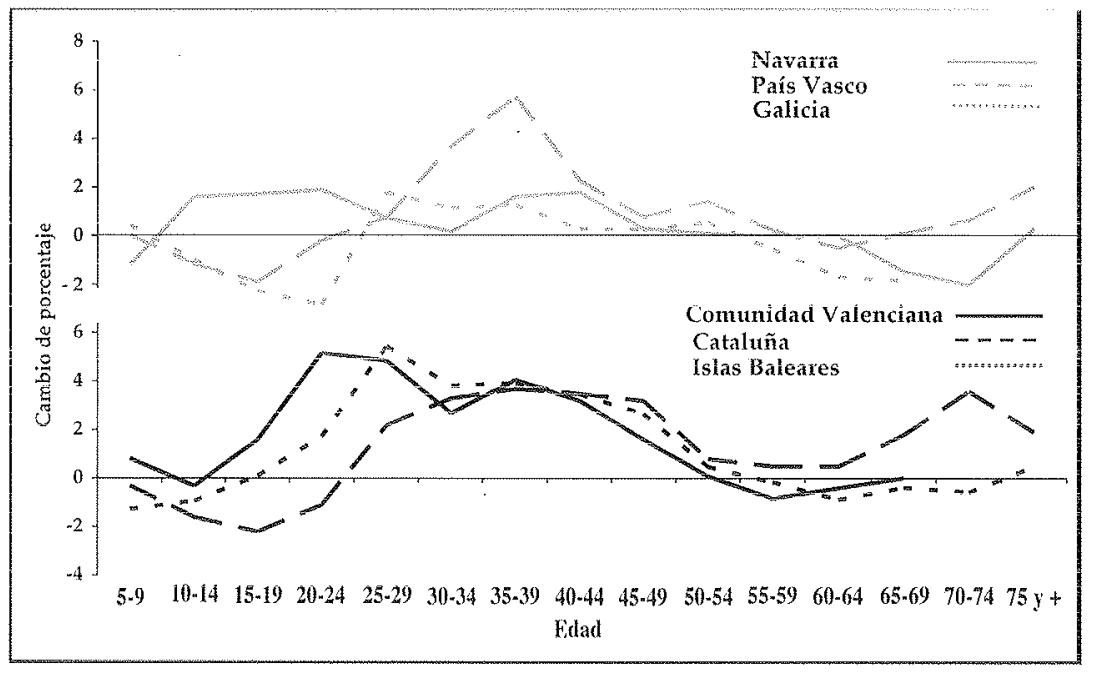

GRATCO 7. Diferencias sezán el género por grupo: de edad en el cambio de la capacidad para escribir las lenguas propias entre 1991 y 2001 en las seis comunidades oficialmente bilingiies

De lo observado anteriormente resalta, pues, que las diferencias entre varones y mujeres en la competencia linguística sólo aparecen cuando los datos se analizan teniendo en cuenta además la edad de la población y la variación en el tiempo transcurrido entre los dos años censales. Ha quedado claro que las mujeres jóvenes y en edad laboral, es decir, una vez han pasado por el sistema escolar, adquieren y mantienen en niveles más altos la lengua propia que los varones.

\subsection{Evolución del conocimiento de las lenguas propias según el lugar de nacimiento de la población}

En esta sección nos centraremos exclusivamente en la capacidad para hablar la lengua, puesto que el futuro de cualquier comunidad lingüística de pende, en última instancia, del número de hablantes que la utilicen. En este 
sentido, hay que recordar, sin embargo, que los censos nos proporcionan datos sobre posibles hablantes y no sobre el uso real.

El lugar de nacimiento de la población es una variable a tener en cuenta particularmente en las comunidades donde la proporción de nuevos extranjeros ha crecido de manera espectacular en la década de los noventa. El gráfico 8 ilustra la evolución de la capacidad para hablar las lenguas propias según el lugar de nacimiento de la población: en la comunidad, en el resto de España o en el extranjero.

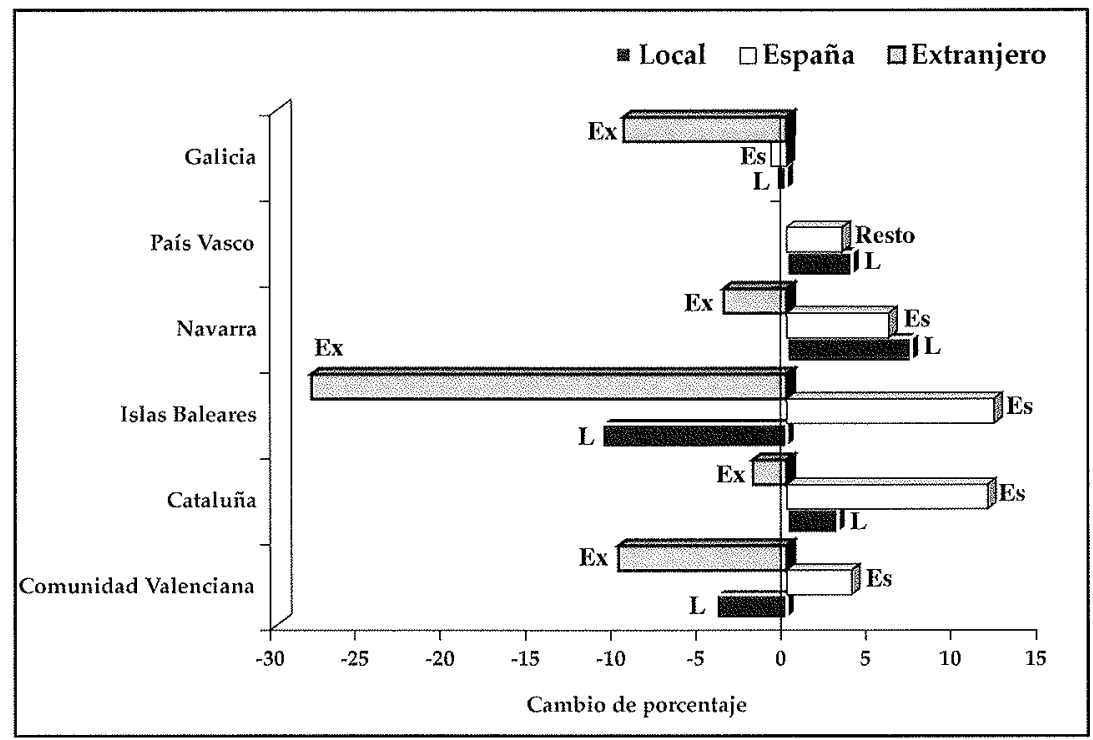

GRÁFICO 8. Variación de la capacidad para hablar las lenguas propias entre 1991 y 2001 según el lugar de nacimiento de la población en las seis comunidades oficialmente bilingïes

En las seis comunidades retrocede la capacidad de hablar de los individuos procedentes del extranjero, especialmente en las Islas Baleares que es la autonomía que tiene un mayor índice de población extranjera. En cambio, la evolución de la competencia para hablar las lenguas propias entre las personas procedentes del resto de España es positiva. ${ }^{3}$ La evolución del habla entre la población local ya no es similar sino que varía según la comunidad: en

3. En el caso de las comunidades catalanohablantes no se han contabilizado los individuos procedentes de otras regiones de España donde también se habla catalán. 
Cataluña, el País Vasco y Navarra aumenta, permanece invariable en Galicia y retrocede en la Comunidad Valenciana y sobre todo en las Islas Baleares. De manera que el retroceso del habla observado anteriormente entre la población adulta de estas dos comuniclades catalanohablantes no parece que pueda atribuirse únicamente a un efecto de la inmigración.

Así pues, el hecho de que el incremento de población extranjera se haya producido de manera brusca e intensa queda reflejado en el descenso de su capacidad para hablar las lenguas propias en cualquiera de estas comunidades, ya que todavía no ha tenido tiempo de integrarse lingüísticamente. Lo que no se entiende es que el conocimiento del catalán retroceda también en la población local de Valencia y las Islas Baleares.

\subsection{Evolución del conocimiento para hablar las lenguas propias según la zona o comarca de residencia de la población}

Finalmente, debemos preguntarnos si la evolución de la competencia para hablar las lenguas propias es similar $o$, al contrario, divergente en las diferentes zonas o comarcas del territorio de cada comunidad. Sabemos que el nivel de competencia lingüística varía enormemente según el lugar de residencia. Por ejemplo, tomando como punto de referencia los datos del censo de 1991, podemos decir que las comunidades donde existen mayores divergencias son Valencia (con 93 puntos de diferencia entre la comarca con mayor nivel y aquella que presenta el menor, situada en la zona castellanohablante), el País Vasco (79 puntos de diferencia) y Navarra (69). El gtado de competencia de las 56 comarcas en que está dividida Galicia, por el contrario, es bastante similar, mientras que en Cataluña y en las Islas Baleares esas diferencias son de 40 y 20 puntos respectivamente.

La evolución de la competencia, en cambio, no es tan dispar. El gráfico 9 muestra el cambio de capacidad para hablar catalán en las diferentes comarcas (islas y Palma, la capital, en el caso de las Baleares) de las tres comunidades catalanohablantes. Hemos ordenado las comarcas de mayor a menor en función del porcentaje de población que sabía hablar catalán el año 1991.

En Cataluña y la Comunidad Valenciana la capacidad para hablar catalán aumenta en las comarcas que el año 1991 presentaban los niveles más bajos de competencia (las comarcas castellanohablantes en Valencia). Sorprendentemente, algunas de las comarcas que han recibido un gran número de inmigrantes (como el Baix Llobregat en Cataluña o la Vega Baja en Valencia) no pierden competencia y, por otra parte, el retroceso del habla, especialmente en la Comunidad Valenciana, no se observa siempre en las comarcas con mayor proporción de población extranjera (compárense las dos Marinas de la costa alicantina con la comarca de l'Alt Maestrat en Castellón y la Costera en 
Valencia). En las Islas Baleares, por el contrario, la competencia oral retrocede independientemente de la isla de residencia, aunque en diferentes grados.

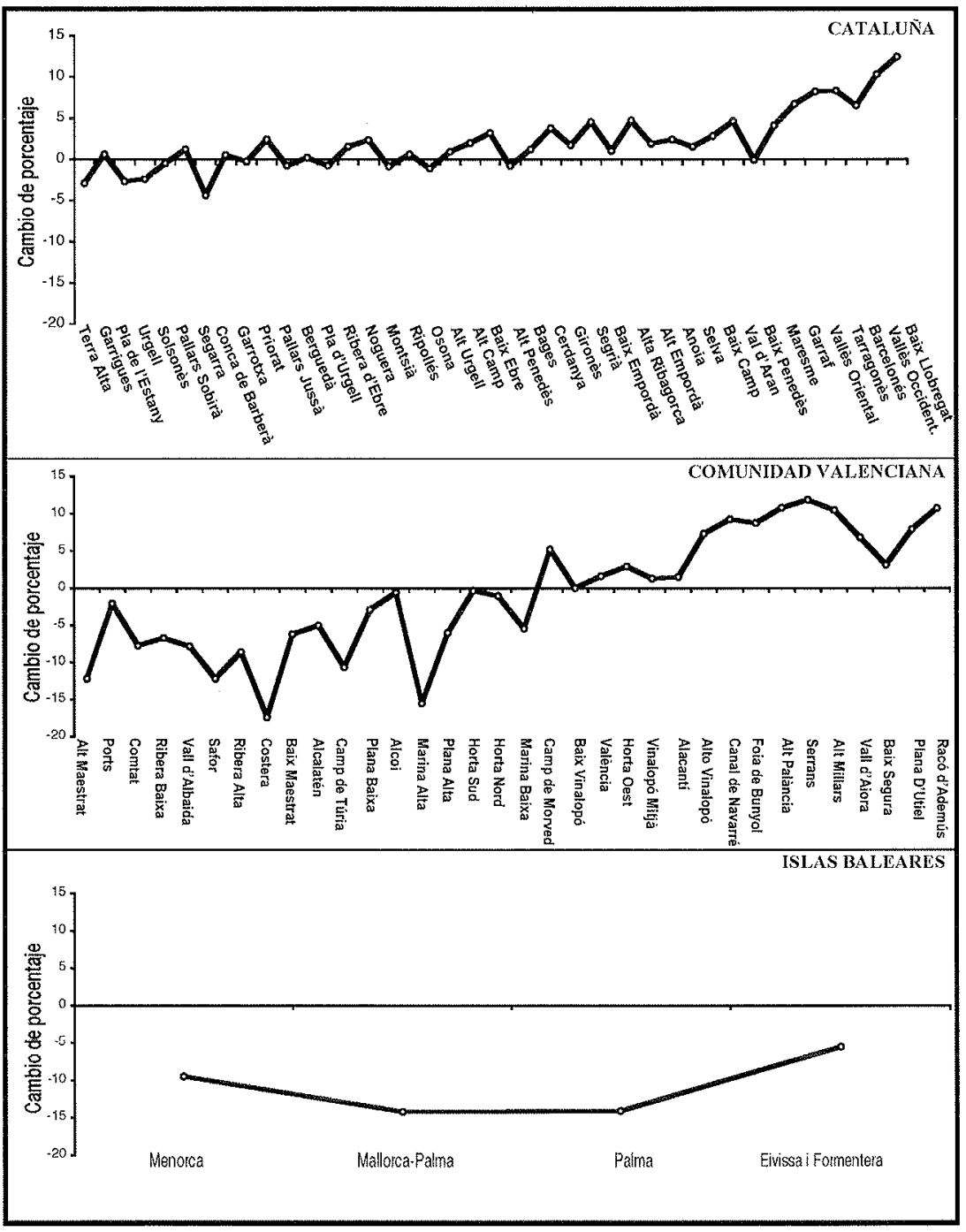

GRÁFICO 9. Evolución de la capacidad para hablar catalán por comarcas en Cataluña, la Comunidad Valenciana y por islas en las Baleares 
En el gráfico 10 hemos ilustrado la evolución de la capacidad para hablar euskera y gallego en las diferentes comarcas de cada comunidad o zonas administrativas (en el caso de Navarra) siguiendo el mismo orden que en el gráfico 9, es decir, según la proporción de hablantes en 1991.

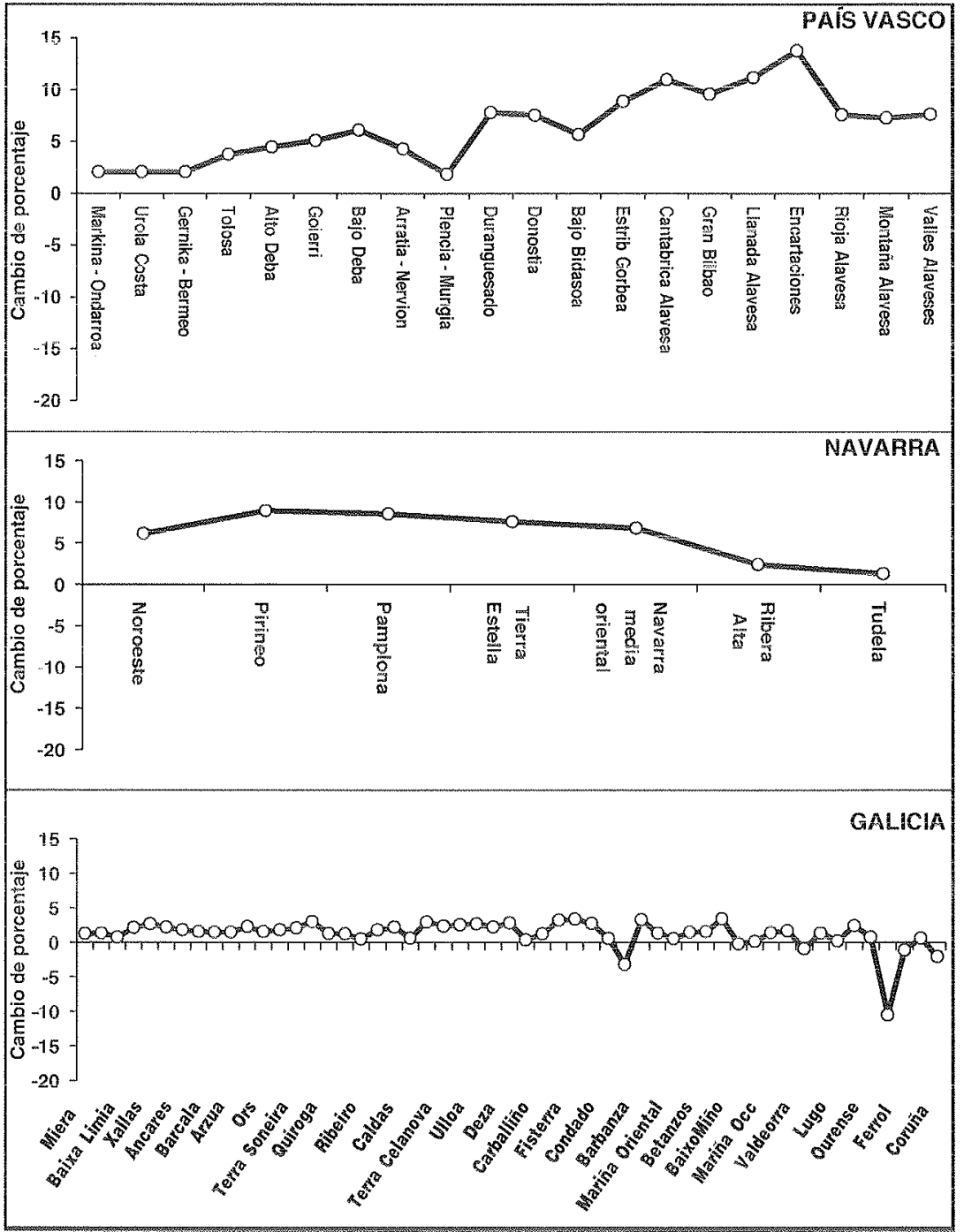

GRÁFICO 10. Evolución de la cupacidad pura hublar euskera en el País Vasco y Navarra y gallego en Galicia por comarcas o zonas de residencia 
La evolución del euskera, al contrario que el catalán, es positiva en ambas comunidades vascófonas e independientemente de la comarca o de la zona. En general, el País Vasco sigue la misma tendencia que Valencia y Cataluña: las comarcas con mayor nivel de conocimiento en 1991 presentan índices de cambio más bajos. En Navarra, en cambio, se observa la tendencia opuesta: el euskera aumenta sobre todo en las zonas que tenían menor proporción de hablantes. El porcentaje de individuos que sabe hablar en gallego permanece, en general e independientemente de la comarca, estable (no se supera en ningún caso los 3 puntos). De las 56 comarcas, sólo Ortegal, Coruña y, sobre todo, Pontevedra presentan índices de cambio negativos.

\section{CONCLUSIONES}

Hemos ido viendo, a lo largo de esta exposición, las tendencias a veces similares y a veces opuestas que aparecen al analizar la evolución de la competencia de las lenguas propias del Estado español inmersas en procesos de revitalización lingüística. A continuación señalamos las más relevantes:

- La distancia tipológica que separa las lenguas románicas del euskera se refleja en el grado de competencia tan diferente que posee la población según el tipo de habilidad lingüística en catalán y en gallego pero similar en euskera. Nos referimos, concretamente, a las capacidades para hablar y escribir (gráfico 2). La mayoría de la población, en cualquiera de las lenguas históricas, sigue siendo, por otra parte, analfabeta en su propia lengua.

- El tipo de competencia que evoluciona de manera más favorable es la lecto-escritora, tendencia compartida por todas las comunidades autónomas y que muestra el papel fundamental que desempeña la escolarización en la normalización lingüística.

- La competencia oral activa, en cambio, evoluciona de forma diferente según las comunidades autónomas: en Cataluña y en las comunidades de habla vascófona aumenta, en general, en todos los grupos de edad; en Galicia se mantiene estable, mientras que retrocede en la población adulta de las Islas Baleares y de la Comunidad Valenciana.

- Las mujeres escolarizadas suelen, en general, adquirir niveles más altos de competencia lingüística que los varones, posiblemente porque sus actitudes lingüísticas son también más positivas. Sabemos que la proporción de mujeres que finalizan sus estudios es mayor que la de los varones y además con mejores calificaciones. Pero también sabemos que el porcentaje de mujeres paradas dobla al de los varones y que todavía hoy 
se siguen produciendo situaciones de discriminación laboral, especialmente en cargos de responsabilidad, y salarial. Un contexto que no es favorable y en el que las mujeres deben demostrar doblemente sus capacidades. Sin embargo, la tendencia aquí señalada en la que las mujeres jóvenes y en edad laboral adquieren más competencia linguiística que los varones, se da exclusivamente en las zonas de habla catalana y en el País Vasco. El hecho de que en Galicia y en Navarra, en cambio, no existan diferencias de género, cuestiona el papel de las mujeres en los procesos de revitalización lingüística, que no sería siempre similar, y precisa una explicación que, de momento, no hemos encontrado.

- Otra tendencia compartida por Cataluña, la Comunidad Valenciana y el País Vasco es la evolución del habla por comarcas: ias comarcas con menor proporción de hablantes en la lengua propia en 1991 son las que evolucionan más favorablemente. En Navarra hemos observado, en cambio, ha tendencia opuesta, mientras que en Galicia no existen por lo gencral diferencias territoriales.

- El resultado más sorprendente se ha comprobado al analizar la evolución del catalán según el lugar de nacimiento de la población. El retroceso del habla observado en las Islas Baleares y la Comunidad Valenciana no se debe únicamente a un efecto de la inmigración, puesto que la propia población local también parece haber «olvidado» hablar en catalán, tendencia que no tiene fácil explicación pero que puede atribuirse a ciertos factores. Por una parte, sabemos que en el censo de población de 2001 hubo ciertos problemas en la técnica de recogida de datos, especialmente en las Islas Baleares donde el 23\% de los cuestionarios no se rellenaron (Diari de Balears, 18/06/2004). Por otra parte, también en las Islas se cambió de nuevo la denominación de la lengua, lo que puede afectar la comparación de datos. Así, si en 1991 se utilizó el término «catalár» en el censo del 2001 se preguntó por la competencia en «la lengua catalana (variedad balear u otras)». En la Comunidad Valenciana, aunque también parece haber habido ciertos problemas técnicos y hay que tenerlo en cuenta, la explicación más pausible, a nuestro entender, refiere o bien a un cambio de actitudes linguísticas o bien a un retroceso más que en la competencia en el uso de la lengua. Esto es precisamente lo que se desprende de una encuesta sobre el uso del valenciano realizada recientemente por la Academia Valenciana de la Lengua, donde se señala que en poco más de 10 años la proporción de personas que hablan esta lengua ha bajado aproximadamente 14 puntos (AVL, 2004).

En conclusión, la evolución del conocimiento de las lenguas propias es especialmente positiva en Cataluña y en el País Vasco, dos comunidades gobernadas por o cn coalición con nacionalistas y donde se ha venido aplicando una 
política lingüística decisiva. No debemos olvidar, además, que el catalán disfruta de un grado de prestigio en Cataluña que no tiene ni en Valencia ni en Baleares y que en el País Vasco el euskera es un fuerte símbolo de identidad. En Navarra y sobre todo en la Comunidad Valenciana la división territorial en zonas lingüísticas no parece favorecer la extensión de la lengua propia. En el caso de Valencia, la situación ha empeorado notablemente incluso en la zona valencianohablante, efecto de la débil y en gran parte contraplanificación lingüística (Pradilla, 2002) llevada a cabo por sus gobernantes. En las Islas Baleares, aunque los datos no parecen ser muy fiables, se deberían tomar medidas urgentes para poder contrarrestar el efecto de la inmigración. Y en Galicia, finalmente, comunidad autónoma con los niveles más altos de competencia lingüística, los datos no descubren un retroceso del gallego sino una situación estable en la capacidad para hablarlo y una evolución positiva en las capacidades utilizadas en contextos más formales.

\section{REFERENCIAS BIBLIOGRÁFICAS}

AVL (Academia Valenciana de la Llengua) (2004): Enquesta sobre la situació social del valencià. 2004. [Documento disponible en: http://www.avl.gva.es] Casesnoves Ferrer, R.; D. SankofF; M. T. Turell, (2004): «La base démolinguistique pour évaluer l'aménagement linguistique dans un contexte bilingue», Paper presented at the Linguapax Conference on Linguistic diversity, sustainability and peace, Barcelona, Fòrum de les Cultures, Mayo de 2004, [en línea]: [http://www.linguapax.org/congres04/pdf/3_turell.pdf] EUSTAT (Instituto Vasco de Estadística) [http://www.eustat.es/] Govern Balear (1993): Cens de Població 1991. Vol VII: Taules sobre el coneixement de la llengua de la CAIB, Palma de Mallorca. IBAE (Institut Balear d'Estadística) [http://www.caib.es/ibae/ibae.htm] IDESCAT (Institut d'Estadística de Catalunya) [http://www.idescat.es/] IEN (Instituto de Estadística de Navarra) [http://www.cfnavarra.es/estadistica] IGE (Instituto Galego de Estatística) [http://www.ige.xunta.es/]

INE (Instituto Nacional de Estadística) [http://www.ine.es/] IVE (Institut Valencià d'Estadística) (1996): Info Censos de Població, Habitatges,

Edificis i Locals de la Comunitat Valenciana 1990-91. [CD-rom]. Valencia, IVE.

IVE (Institut Valencià d'Estadística) [http://www.ive.es/]

Pradilla, M. À. (2002): «La política lingüística contemporània al País

Valencià», Treballs de Sociolingüistica Catalana, 16: 101-119. 


\title{
LA PRESENCIA DE ESPAÑOLISMOS EN EL ITALIANO DE HOY: UNA APROXIMACIÓN SOCIOLINGÜÍSTICA
}

\author{
Margarita R. DÉniz HernáNDEZ \\ Universidad de Siena
}

\section{OBJETIVOS E HIPÓTESIS}

$\mathcal{A}^{\mathrm{N}}$ este artículo se presentan los primeros resultados de un trabajo en el que se pretende alcanzar dos objetivos:

- Analizar el grado de conocimiento y el uso que los informantes hacen de todas y cada una de las palabras que conforman el corpus objeto de estudio, constituido por los vocablos provenientes del español aceptados en la actualidad en el italiano estándar.

- Descubrir la variación léxica que, en este sentido, se encuentra en los jóvenes residentes en la ciudad de Siena con el fin de conocer su actuación lingüística y averiguar si existe o no homogeneidad en su comportamiento lingüístico o, dicho en otras palabras, averiguar mediante un análisis multivariable, cuáles son los factores extralingüísticos que determinan las posibles diferencias que se encuentren entre los informadores en su uso de la lengua en lo que a esta cuestión se refiere.

\section{METODOLOGÍA}

El método empleado en nuestro trabajo de campo es el de redes sociales con investigador participante. En consecuencia, como supone la aplicación de dicho método, se llevaron a cabo los pasos previos pertinentes (Serrano, 1997) observación de la comunidad, hipótesis de trabajo, selección de los hablantes y recolección del material en su contexto social. 


\subsection{Siena en la actuahidad: breve aproximación morfológica, histórica, económica y datos soiodemográficos de la ciudad}

Actualmente, la ciudad de Siena, situada en la Toscana, está constituida por un total de 59.956 habitantes. Frente a otras ciudades, la particularidad que presenta Siena en lo que concierne a las oscilaciones de la población es que -al margen de las circunstancias comunes a aquéllas y, en general, a todas las comunidades del mundo occidental (tales como la disminución del número de nacimientos o las variaciones debidas a los movimientos migratorios, entre otras)tanto en su evolución demográfica como la reorganización de la población la numerosa presencia de estudiantes universitarios concentrada en su mayoría en el centro histórico de la ciudad,' y, por tanto, de los arrendamientos, aumentó considerablemente.

\subsection{Recolección de datos}

\subsubsection{La selección de los informadores}

Nuestro objetivo era recoger una muestra de una serie de informadores residentes en esta ciudad que formaran parte de, al menos, un mismo grupo o red social por encontrarse unidos entre sí por lazos de distinta naturaleza (Milroy, 1980: 46). Como es sabido, lo ideal en este tipo de metodología es que el investigador se convierta en un miembro más de la red objeto de estudio, de modo que, lo que hubiera constituido el primer inconveniente, se resolvió con facilidad puesto que mi relación con la mayoría de los informadores se remontaba, como mínimo, a cuatro meses, y, en estos casos, se trataba siempre de personas con las que convivía. Con el resto de los informadores, y dado que no contábamos con otra alternativa, decidimos recurrir, de forma similar a como hace Milroy, a los «amigos de los amigos» así como a otras técnicas cuya validez había sido justificada, sobradamente, por algunos investigadores» (Labov, 1983: 266 y Silva-Corvalán, 1989: 26-27, 34). En cualquier caso, siempre fueron sujetos conocidos a pesar de que no mantuviésemos con ellos una relación especialmente estrecha.

1. A título informativo, puesto que creemos que puede serde utilidad a aquéllos que no conozcan el municipio, es preciso señalar que Siena es una ciudad en la que la vida académica universitaria se desarrolla fundamentalmente en el centro histórico o en su inmediata periferia. Allí se encuentran tanto el Rectorado como la Universidad para Extranjeros, todas las Facultades (excepto la de Medicina y carreras afines) así como todas las dependencias universitarias. Por otra parte, la comunicación entre el centro histórico y los demás harrins que lo circundan requiere en la mayoría de los casos el uso de afgún medio de transporte, lo cual favorece la preferencia de los catudiantes de alojarse cn el centro. 
Tres son los grupos que pueden distinguirse de forma nítida dentro de la red: por una parte, mi propio lugar de residencia, un piso compartido con ocho jóvenes italianas y visitado con frecuencia por parientes y amigos; por otra, algunos miembros de un grupo universitario (el GES, Grupo Erasmus Siena) dedicado a la orientación de los alumnos del programa Erasmus que cada año vienen a estudiar a esta ciudad y del que formé parte durante un año y, por último, mi grupo de amigos. De este modo, comenzamos con la recolección de datos propiamente dicha.

El desarrollo del proceso para entrevistar a los distintos miembros de la red fue siempre el mismo. En general, establecimos dos encuentros con cada uno de los informadores: en el primero de ellos, se les explicaba a grandes trazos el objeto de nuestra investigación así como el modo en que debían rellenar el cuestionario que se les entregaba y, en el segundo, se revisaba conjuntamente el citado cuestionario, ya hecho, y se concluía definitivamen-te una vez que se resolvían las dudas o dificultades que el entrevistado hubiera podido tener. No hubo homogeneidad en lo que se refiere al periodo transcurrido entre una y otra cita puesto que, con objeto de obtener los mejores resultados, se decidió que fuese el propio informador el que estableciera la fecha del segundo encuentro.

La red estudiada gira, como señalamos anteriormente, en torno a la propia figura del investigador. Sus características son las siguientes: una densidad total de 56.04\%; es decir, se trata una red bastante unida ${ }^{2}$ en la que queda de manifiesto que la mayor parte de los sujetos se conocen aunque la relación entre ellos sea distinta, y una multiplicidad de $45.10 \%$. Considerando los tipos de lazos existentes, puede afirmarse que el porcentaje de multiplicidad reticular es bajo debido a que la mayoría de los miembros de la red posee menos de tres vínculos múltiples.

En cuanto a las características sociales de los informantes, los datos obtenidos en el cuestionario sociológico nos ofrecen la siguiente información: se trata de un grupo de jóvenes universitarios o que han terminado más o menos recientemente sus estudios y, por consiguiente, aún no poseen una estabilidad laboral, naturales de Siena o que residen en ella desde antes de los veinte años de edad, que tienen un nivel socioeconómico medio-alto, que poseen un conocimiento considerable de otras culturas en general y de la española en particular pero cuyo nivel de adquisición y aprendizaje de la lengua española es nulo o elemental, salvo en el caso de la informante 3.

2. Sobre las características de las redes sociales, véase Bott (1990: 98) y Milroy (1980: 20 y 51). 


\subsubsection{El cuestionario y el corpus}

El cuestionario empleado para la recopilación de los datos estaba constituido por otros dos: uno socioetnográfico, ${ }^{3}$ orientado a conocer las características sociales, culturales, reticulares y de actitud linguística de cada uno de los sujetos ${ }^{4}$ entrevistados y otro lingiístico, que nos proporcionaba los datos que nos interesaban para nuestra investigación.

Los españolismos que recoge Zingarelli (2004) en su diccionario son 639. Sin embargo, en este estudio el corpus analizado está constituido por un total de ciento veintiséis palabras, aquéllas que aparecen en los diccionarios de Mini (1998) y de Olis (1993) en los cuales se encuentran aquellos extranjerismos que se han introducido y admitido en italiano. En el cuadro que aparece a continuación las presentamos agrupadas en campos léxicos -con sus correspondientes porcentajes:

TABLA 1. Españolismos recogidos en los diccionarios italianos estudiados

\begin{tabular}{|c|l|}
\hline $\begin{array}{c}\text { Política } \\
17.46 \%\end{array}$ & $\begin{array}{l}\text { Alcalde, alguacil, apache, armada, barbudo, } \\
\text { camarilla, caudillo, chicano, cocoliche, conquis- } \\
\text { tador, cortes, desaparecidos, descamisados, golpe, } \\
\text { gomeros, guerrilla, hidalgo, montonero, pasiona- } \\
\text { ria, pronunciamiento, tano, tupamaro. }\end{array}$ \\
\hline $\begin{array}{c}\text { Economía } \\
2.38 \%\end{array}$ & Aplazos, desarrollo, embargo. \\
\hline $\begin{array}{c}\text { Gastronomía y } \\
\text { alimentación } \\
5.56 \%\end{array}$ & $\begin{array}{l}\text { Chicle, gazpacho, manteca, mate, olla podrida, } \\
\text { paella, tortilla. }\end{array}$ \\
\hline
\end{tabular}

3. Se ha utilizado, aunque con ciertas modificaciones en determinadas preguntas, el guión sociológico empleado en la investigación coordinada y dirigida por Villena en la Universidad de Málaga (España) en su estudio sobre el vernáculo urbano malagueño. Dichas modificaciones se refieren, fundamentalmente, a la adaptación que requiere el cuestionario al ser aplicado a una comunidad distinta. Así pues, aunque éstas afectan principalmente al cuestionario sociológico, también lo hacen en cierta medida al conversacional en tanto que añadimos algunas preguntas que no se incluían en los guiones que conocíamos por tratarse de cosas directamente vinculadas con la vida de esta ciudad.

4. Las preguntas correspondientes al generador de nombres se realizaban junto a éste.

5. En esta obra, se encontraron los siguientes vocablos: armada, desesperado, pueblo, tangueiro, tanguero y tano. Ninguno de ellos se recogía en la obra de Mini salvo pueblo. No obstante, la acepción que se recoge en cada caso es distinta: en el primero, se define como «il popolo, la gente comune, con un accento di autenticita e schieltezzas, mientras que en el de Guido, el significado es el de «tipico villaggio primitivo della Spagna e di qualcuni paesi e regioni del Centro sul America edel Sud degli usa (Arizula, Nuovo Messico, ece.)». 


\begin{tabular}{|c|c|}
\hline $\begin{array}{l}\text { Bebidas } \\
5.56 \%\end{array}$ & $\begin{array}{l}\text { Alcool (o alcol), cuba libre, daiquiri, mescal, } \\
\text { pulque, sangría, tequila. }\end{array}$ \\
\hline $\begin{array}{l}\text { Música y bailes } \\
14.28 \%\end{array}$ & $\begin{array}{l}\text { Bolero, cucaracha, charango, fandango, } \\
\text { flamenco, jarabe, jota, lambada, malagueña, } \\
\text { pachanga, paso doble, raspa, rumba, tango, } \\
\text { tangueiro, tanguero, zapateado, zarzuela. }\end{array}$ \\
\hline $\begin{array}{l}\text { Deportes } \\
9.52 \%\end{array}$ & $\begin{array}{l}\text { Banderilla, banderillero, espada, goleador, } \\
\text { matador, muleta, mundial, pelota, picador, } \\
\text { toreador, veronica, vuelta. }\end{array}$ \\
\hline $\begin{array}{l}\text { Accidentes } \\
\text { geográficos } \\
6.75 \% \\
\end{array}$ & $\begin{array}{l}\text { Barranco, cañon, llano, mesa, meseta, pampa, } \\
\text { rias, sierra. }\end{array}$ \\
\hline $\begin{array}{l}\text { Interjecciones } \\
3.17 \%\end{array}$ & Arriba!, caramba, hasta la vista, no pasaran. \\
\hline $\begin{array}{l}\text { Vestido } \\
6.35 \%\end{array}$ & $\begin{array}{l}\text { Alpaca, camperos, mantilla, mascara, poncho, } \\
\text { sisal, sombrero, velada. }\end{array}$ \\
\hline $\begin{array}{l}\text { Otros } \\
29.36 \%\end{array}$ & $\begin{array}{l}\text { Aficionado, azulejo, bandolero, barrio, buen } \\
\text { retiro, campesino, capataz, cargo, corral, } \\
\text { chihuahua, desesperado, embarcadero, estancia, } \\
\text { gaucho, gringo, guamaco, guano, hacienda, } \\
\text { hispanidad, machete, mosquito, muchacho, } \\
\text { murales, navaja, novela, papelito, patio, pepita, } \\
\text { pueblo, rancho, rodeo, romance, siesta, } \\
\text { telenovela, torquemada, vigilantes. }\end{array}$ \\
\hline
\end{tabular}

Todos los vocablos que aparecen en el cuadro anterior se encontraban recogidos en el diccionario de uso del italiano de Zingarelli excepto un $15.08 \%$ constituido por los siguientes vocablos: a plazo, alguacil, arriba!, barrio, camperos, cocoliche, corral, desarrollo, desesperado, gomeros, guamaco, hasta la vista, montonero, muchacho, no pasarán, papelito, tangueiro, tanguero, tano. Por otra parte, cabe señalar que, salvo cinco $\left(\right.$ alcohol ${ }^{\circ}>$ alcolo alcool, armada>armata, guerrilla $>$ guerriglia, hispanidad $>$ ispanità, mantilla $>$ mantiglia), todos los que se recogían mantenían el significante originario, sin ninguna variación motivada por la correspondiente adaptación fonética y/o gráfica. Todas ellas fueron, no obstante, consideradas en nuestro análisis. No hicimos lo mismo con las voces que, procedentes del español, se habían

6. Adaptada fonéticamente aparece también en el diccionario de Mini. 
introducido en el italiano a través del inglés (mascara, cargo, cañon) que fueron excluídas.

\subsection{Análisis del corpus: variables estudiadas y cuantifïcación de datos}

Como indicábamos anteriormente, el cuestionario total está constituido por otros dos de naturaleza diversa (lingüistica y sociológica) que nos permilían recoger toda la información necesaria para poder realizar nuestro trabajo y lograr los objetivos que nos habíamos propuesto. Una vez recopilada, y tras introducirla en la base de datos correspondiente, pasamos a su cuantificación. Para ello hicimos uso del programa spss (Statistical Package for the Social Sciences) para Windows en su versión 11.0 por la precisión que supone el empleo de este tipo de programas en los estudios de esta naturaleza.

En lo que al estudio linguístico se refiere, las cuestiones analizadas son las siguientes: conocimiento del vocablo, frecuencia de uso y empleo de otras voces para manifestar el mismo concepto y formación del plural. ' Por lo que respecta a las variables sociales, además de las tradicionales consideramos otros factores extralingüísticos que estimamos oportunos para nuestra investigación tales como el nivel de conocimiento de la lengua española, visitas a España y/o a países de lengua española en América y su relación actual con hispanohablantes.

Considerando las características particulares de los individuos que conforman esta red, uno de los resultados que esperábamos encontrar era que gran parte de las voces, al margen de la frecuencia de uso que de ellas hicieran, les fucran conocidas aun cuando no supieran definir con total piecisión la realidad o concepto que designan. En concreto, pensamos que serían en aquellos vocablos más estrechamente relacionados con momentos de ocio (esto es, los pertenecientes a los campos semánticos de la bebida, deportes, música y baile) y, de forma particular, aquéllos propios la cultura hispana como paella, tango, pampa, siesta, sangría, flamenco o toreador donde obtendríamos los porcentajes más elevados frente a otros como las voces relativas a la política, economía o geografía. Asimismo, en lo que conciene a aquellas voces que no se encuentran registradas en el diccionario de Zingarelli, esperábamos que los índices porcentuales fueran más bajos puesto que partimos del presupuesto de que, si no se recogen, serían palabras de uso muy reducido y, por tanto, menos conocidas.

7. Recordamos que, en lo que concierne a la formación del plural de los extranjerismos, se tiende a dejar invariables los sustantivos de uso más frecuente, especialmente, los de origen inglés o francés. Por lo que se refiere a los portuguesismos o españolismos, la $-s$ del plural se conserva más a menudo e, incluso, en algunas ocasiones, junto al plural originario, aparece el plural italianizado. Los extranjerismos más recientes o de uso técnico suelen formar el plural siguiendo las reglas de la lengua de la que proceden. 
En un primer análisis, en el que sólo tuvimos en cuenta si el informante conocía o no el significante en cuestión, independientemente de si la definición dada coincidía o no con la acepción o acepciones que se registra en los diccionarios consultados, los resultados obtenidos fueron los siguientes:

TABLA 2. Porcentajes correspondientes al número de informantes que afirma conocer el vocablo

\begin{tabular}{|c|c|c|c|c|c|c|c|c|c|c|}
\hline$\%$ & \begin{tabular}{|l|} 
Bebidas \\
\end{tabular} & Gastron. & $\begin{array}{l}\text { Mús. / } \\
\text { baile }\end{array}$ & Deportes & Política & Economía & \begin{tabular}{|l|} 
Vestido \\
\end{tabular} & $\begin{array}{l}\text { Acc. } \\
\text { Geog. }\end{array}$ & Interjec. & Otros \\
\hline 0 & Pulque & O.podrida & $\begin{array}{l}\text { Charango } \\
\text { Jarabe } \\
\text { Malagueña } \\
\text { Pachanga } \\
\text { Zapateado } \\
\text { Zarzuela }\end{array}$ & Muleta & \begin{tabular}{|c|} 
Alguacil \\
Camarilla \\
Cocoliche \\
Gonero \\
Montonero \\
Tano \\
Tupamaro
\end{tabular} & A plazo $(-\mathrm{s})$ & $\begin{array}{c}\text { Mantilla } \\
\text { Velada }\end{array}$ & $\begin{array}{l}\text { Barranco } \\
\operatorname{Ria}(-s)\end{array}$ & & $\begin{array}{c}\text { Guamaco } \\
\text { Navaja }\end{array}$ \\
\hline $\begin{array}{l}0.25- \\
24.99\end{array}$ & Mescal & \begin{tabular}{|c} 
Chicle \\
Manteca \\
Mate
\end{tabular} & $\begin{array}{l}\text { Tangueiro } \\
\text { Tanguero }\end{array}$ & Picador: & \begin{tabular}{|c|} 
Chicano \\
Descamisa \\
Hidalgo \\
Pasionaria \\
Pronuncia.
\end{tabular} & & Sisal & $\begin{array}{l}\text { Llano } \\
\text { Mesetáa }\end{array}$ & $\begin{array}{c}\text { No } \\
\text { pasarán }\end{array}$ & \begin{tabular}{|c|} 
Buen retiro \\
Capataz \\
Corral \\
Estancia \\
Gringo \\
Papelito \\
Romance \\
Torquenada
\end{tabular} \\
\hline $\begin{array}{c}25- \\
49.99\end{array}$ & & Gazpacho & $\begin{array}{c}\text { Fandango } \\
\text { Paso doble } \\
\text { Raspa }\end{array}$ & \begin{tabular}{|l} 
Banderillero \\
Veronica
\end{tabular} & $\begin{array}{c}\text { Alcalde } \\
\text { Barbudo } \\
\text { Caudillo } \\
\text { Cortes }\end{array}$ & Desarrollo & \begin{tabular}{|l|} 
Alpaca \\
Camperos
\end{tabular} & Sierra & Caramba & \begin{tabular}{|c|} 
Azulejo \\
Bandolero \\
Desesperado \\
Enkwuradko \\
Gaucho \\
Guano \\
Hacienda \\
Hispanidad
\end{tabular} \\
\hline $\begin{array}{c}50- \\
74.99\end{array}$ & & Tortilla & $\begin{array}{c}\text { Bolero } \\
\text { Cucharacha } \\
\text { Jota } \\
\text { Rumba }\end{array}$ & \begin{tabular}{|c} 
Banderilla \\
Espada \\
Matador \\
Pelota \\
Toreador \\
Vuelta
\end{tabular} & Armada & & Poncho & $\begin{array}{l}\text { Mesa } \\
\text { Pampa }\end{array}$ & & \begin{tabular}{|c|} 
Aficionado \\
Barrio \\
Campesino \\
Machete \\
Mosquito \\
Novela \\
Patio \\
Rancho \\
Rodeo
\end{tabular} \\
\hline $\begin{array}{c}75 . \\
99.99\end{array}$ & Daiquiri & & & \begin{tabular}{|l|} 
Mundial \\
Goleador
\end{tabular} & $\begin{array}{l}\text { Desapare. } \\
\text { Guerrilla }\end{array}$ & Embargo & Sombrero & & \begin{tabular}{|l} 
Arriba! \\
H. vista
\end{tabular} & $\begin{array}{l}\text { Chihuahua } \\
\text { Muchacho } \\
\text { Niño } \\
\text { Pepita } \\
\text { Pueblo } \\
\text { Vigilantes }\end{array}$ \\
\hline 100 & $\begin{array}{l}\text { Alcohol } \\
\text { Cuba } \\
\text { libre } \\
\text { Sangría } \\
\text { Tequila }\end{array}$ & Paella & $\begin{array}{c}\text { Flamenco } \\
\text { Lambada } \\
\text { Tango }\end{array}$ & & \begin{tabular}{|c|} 
Apache \\
Conquista \\
Golpe
\end{tabular} & & & & & \begin{tabular}{|c|} 
Murales \\
Siesta \\
Telenovela
\end{tabular} \\
\hline
\end{tabular}

De acuerdo con este primer recuento, resultan completamente desconoci-das un $18.70 \%$ de las voces. Frente a éstas, el significado del $11.38 \%$ de los vocablos es, 
aparentemente, conocido por todos hablantes. Por lo que se refiere a los vocablos restantes, se observa que menos de la mitad de los informantes reconoce el $38.18 \%$ (menos de un cuarto del total, el 19.51\%) de los elementos estudiados y más de la mitad, el $31.7 \%$ (del cual sólo tres cuartos de los informantes reconocieron un $11.38 \%$ más).

Sin embargo, no se pueden evaluar los resultados a partir de los primeros datos. Un análisis detenido de cada uno de españolismos estudiados en el yue se realizó una comparación de la definición ofrecida por nuestros informantes con la correspondiente en los diccionarios anteriormente citados, nos muestra que tales porcentajes varían considerablemente.

TABLA 3. Porcentaje correspondiente al número de hablantes que realmente conoce el vocablo

\begin{tabular}{|c|c|c|c|c|c|c|c|c|c|c|}
\hline$\%$ & Bebidas & Gastron. & $\begin{array}{c}\text { Mús. I } \\
\text { baile }\end{array}$ & Deportes & Políties & Economing & Vestide & $\begin{array}{l}\text { Ace. } \\
\text { Geog. }\end{array}$ & Interjee. & Otros \\
\hline 0 & Pulque & $\begin{array}{l}\text { Manteca } \\
\text { O.podrida }\end{array}$ & \begin{tabular}{|c|} 
Charango \\
Jarabe \\
Jota \\
Malaguciala \\
Pachanga \\
Raspa \\
Tangueiro \\
Tinguero \\
Zapateado \\
Zarzuela
\end{tabular} & $\begin{array}{l}\text { Expada } \\
\text { Minieta } \\
\text { Picador }\end{array}$ & \begin{tabular}{|c|} 
Alguacil \\
Camariila \\
Cocoliche \\
Gomero \\
Hicdalgo \\
Montonero \\
Tano \\
Tupanaro
\end{tabular} & A plazo(-s) & \begin{tabular}{|l} 
Mantilla \\
Sisal \\
Velatad
\end{tabular} & $\begin{array}{l}\text { Barranco } \\
\text { Liano } \\
\text { Rial(-s) }\end{array}$ & Arriba! & \begin{tabular}{|} 
Buen retio \\
Guamaco \\
Navala \\
Papelito \\
Toquermatis
\end{tabular} \\
\hline $\begin{array}{l}0.25- \\
24.99\end{array}$ & Mescal & $\begin{array}{l}\text { Chicle } \\
\text { Mate }\end{array}$ & Pasodoble & $\begin{array}{l}\text { Banderille. } \\
\text { Veronica }\end{array}$ & \begin{tabular}{|l|} 
Alcalde \\
Barbudo \\
Caudillo \\
Cortes \\
Chicano \\
Descanisan \\
Pasionaria \\
Prontencia.
\end{tabular} & Desarrollo & & $\begin{array}{c}\text { Mesa } \\
\text { Meseta }\end{array}$ & $\begin{array}{c}\text { No } \\
\text { pasarán }\end{array}$ & \begin{tabular}{|c|} 
Bandolero \\
Capataz \\
Corrat \\
Endkicakero \\
Cistincia \\
Gatucho \\
Gringo \\
Guano \\
Niño \\
Novela \\
Patio \\
Rancho \\
Romance
\end{tabular} \\
\hline $\begin{array}{c}25 . \\
49.99\end{array}$ & & Gazpacho & Fandango & $\begin{array}{c}\text { Banderilia } \\
\text { Matador } \\
\text { Pelota } \\
\text { Vuelta }\end{array}$ & Coniquista. & & $\begin{array}{l}\text { Alpacat } \\
\text { Camperos }\end{array}$ & $\begin{array}{l}\text { Pampat } \\
\text { Sierra }\end{array}$ & Carambal & $\begin{array}{c}\text { Aztlejo } \\
\text { Desesprado } \\
\text { Hacienda } \\
\text { Hispasidad }\end{array}$ \\
\hline $\begin{array}{r}50- \\
74.99\end{array}$ & & Tortilla & \begin{tabular}{|c|} 
Bolero \\
Cucaracha \\
Rumba
\end{tabular} & \begin{tabular}{|l|} 
Mundial \\
Toreador
\end{tabular} & \begin{tabular}{|l|} 
Armada \\
Guerrilla
\end{tabular} & & Poncho & & & $\begin{array}{c}\text { Aficionado } \\
\text { Barrio } \\
\text { Campesino } \\
\text { Machete } \\
\text { Mosquito } \\
\text { Rodeo }\end{array}$ \\
\hline $\begin{array}{r}75 . \\
99.99\end{array}$ & Daiquiri & & & Goleador & $\begin{array}{l}\text { Desapare. } \\
\text { Golpe }\end{array}$ & Embargo & Sombrero & . & H. la vista & $\begin{array}{l}\text { Chihuahua } \\
\text { Muchacho } \\
\text { Murales } \\
\text { Pepita } \\
\text { Pueblo } \\
\text { Vigilantes }\end{array}$ \\
\hline 100 & \begin{tabular}{|c|} 
Alcol \\
Cuba libre \\
Sangria \\
Tequila \\
\end{tabular} & Paella & $\begin{array}{c}\text { Flamenco } \\
\text { Lambada } \\
\text { 'l'ango }\end{array}$ & & Apache & & & & & $\begin{array}{c}\text { Siesta } \\
\text { Telenovela }\end{array}$ \\
\hline
\end{tabular}


El resultado nos permite ver cómo aumenta el porcentaje de informantes que desconoce el concepto que designa cada una de las voces estudiadas. Dicho de otro modo, se observa que a medida que aumenta el número de informantes, disminuye el índice porcentual de términos reconocidos. Así, por ejemplo, de un $43.08 \%$ del total del corpus que más de la mitad de los hablantes dicen conocer, pasamos a $30.88 \%$. Como es natural, la misma variación, pero al contrario, se percibe en cuanto al número de voces no reconocidas: el porcentaje de palabras que la mitad de los informadores desconoce (56.85\%) aumenta hasta alcanzar el $69.1 \%$. Por lo que respecta a los valores extremos, sin embargo, aumenta en un $11.41 \%$ el porcentaje del número de vocablos completamente desconocidos para los informantes mientras que el que corresponde a las voces conocidas por la totalidad del grupo disminuye en escasa medida (un 2.44\%).

En cualquier caso, se hace preciso analizar con más detenimiento la variación de porcentajes entre las ‘dos tablas, especialmente, las diferencias porcentuales encontradas en los vocablos reconocidos por más de la mitad del total de los hablantes encuestados. Al comparar las casillas pertinentes de cada una de las tablas, observamos que muchas de las voces que se encuentran en la primera se ven trasladadas en la segunda, en la mayoría de los casos, a casillas que se encuentran por debajo del $25 \%$ de hablantes que realmente las conoce. Como puede apreciarse, casi un $37 \%$ de las voces que se recogen en la tabla 1 no se conocen realmente. Examinando detenidamente cada una de ellas observamos que, excepto tres, la mayoría de las definiciones que ofrecen los informantes demuestran que ninguno de ellos conoce realmente el significado con el que tales voces entraron en el italiano y el reconocerlas se sólo puede deberse a causas externas que no guardan ninguna relación con su conocimiento o uso lingüístico.

Entre los vocablos a los que acabamos de aludir, comentamos más detenidamente ese $26.41 \%$ de vocablos sólo aparentemente conocido: jota, banderilla, espada, matador, pelota, vuelta, mesa, novela, pampa, patio, rancho, arriba!, conquistador y tortilla.

El caso de jota, espada y arriba! son quizás los más llamativos en tanto que se descubre que ninguno de los hablantes entrevistados conoce el concepto con que se emplearía en el italiano actual. En el primero, jota, todos los hablantes que reconocieron esta palabra lo hacían como el nombre con el que se denomina la letra $j$ del alfabeto español mientras que con tal denominación se recoge sólo para hacer referencia a la canción y danza popular aragonesa del mismo nombre. Algo similar sucede con el sustantivo espada y la interjección arriba! aunque, esta vez, los informantes, o bien hicieron la correspondiente traducción, o bien aludieron al significante que se aproximaba más fonéticamente en italiano. Así, en el caso de espada, todos los hablantes la definieron como 'spada' excepto uno que, en vez de utilizar la forma italiana, la define propiamente como 'tipo di 
arma'; sin embargo, su sinónimo, matador, a pesar de la diferencia de porcentajes que presenta, resulta más conocido y usado. ${ }^{8}$ Tampoco en el caso de arriba! la unanimidad es absoluta: por una parte, como en el caso anterior, se encuentran aquéllos que piensan que se trata de una variación fonética o gráfica y, en consecuencia, la identifican con 'arriva!' (o bien, 'arrivare', 'indica che sta arrivando qualcuno o qualcosa sul posto') y, por otra, aquéllos que hacen una tra-ducción literal de la voz: 'in alto!', 'sopra'.

Por lo que se reficre a novela y conquistador -aunque las diferencias entre sus respectivos porcentajes sean menores-, son muchos, la mayoría, los que, como en los vocablos anteriormente comentados, lo equiparan con la novella o el conquistatore italianos. No obstante, hemos de señalar que si bien esta tendencia a la traducción se observa también en otras ocasiones, se da en menor medida. Tal es el caso de banderilla, definida como 'piccola bandiera'; pelota, 'palla' o mesa 'tavola' o vuelta 'giro'.'

Los caso de rancho, niño o tortilla, sin embargo, son algo diferentes de los anteriores. La variación encontrada en estos casos se debe a las distintas acepciones que ambas poseen. En tortilla, a pesar de que la diferencia porcentual que se advierte al analizar separadamente las dos acepciones que posee - «Fritatta, specie con patate e cipolle, tipica della Spagna» y «Sottile focaccia di farina di mais, tipica del Messico e di altri paesi centramericani»- es mínima, resulta curioso el hecho de que el único informante que hace referencia a su origen mejicano alude a la patata como ingrediente principal. Esto nos lleva a pensar que el sujeto en cuestión sabe, aunque sin precisión, de la existencia de ambos platos. En rancho, la diferencia entre ambos porcentajes es mucho mayor pero, en esta ocasión, ésta no está motivada por la existencia de dos o más significados sino por la identificación que prácticamente la totalidad de la red (el $87.5 \%$ ) hacen con rancio, que, si bien procede también del español rancho, se registra en el diccionario con entradas diversas. El caso de niño resulta aún más llamativo, puesto que, dando razón al diccionario de Oli, es conocido por la mayoría de los sujetos como "bambino" (el 78.57\%) mientras que sólo el $14.28 \%$ lo define como «vento o corrente calda a carattere periodico del Pacifico sud-orientale». ${ }^{10}$

8. Un $28.57 \%$ traduce literalmente: «uccisore, colni che uccide».

9. Dadas las diversas acepciones de giro, consideramos sólo válidas aquellas definiciones en las que se aludía de algún modo al hecho de que se trataba de una carrera ciclística.

10. Esta definición aparece en el diccionario de Zingarelli. En este diccionario con el significado de 'bambino' se encuentra la voz nino, diminutivo toscano procedente de Giovannino o de una voz infantil 


\section{CONCLUSIONES}

Los resultados obtenidos hasta el momento nos han permitido constatar que prácticamente la totalidad de las realidades propias de la cultura española e hispanoamericana y las voces pertenecientes al campo semántico de la bebida son conocidas por la totalidad de los hablantes. Por lo que respecta a los demás campos semánticos en los que esperábamos encontrar resultados similares a los obtenidos en el apenas citado (música y baile y deportes), pensamos que la escasa difusión de las respectivas voces que los conforman se debe a que se trata, en su mayoría de términos bastante específicos, sobre todo en el primero.

En cuanto a las características sociológicas de los miembros de la red, al menos en este primer análisis no se encuentran resultados significativos si bien se ha advertido que son los informadores masculinos los que poseen un grado de conocimiento superior en lo que al corpus estudiado se refiere. Queda por estudiar y comprobar, mediante el estudio de la red total que, efectivamente la tendencia observada es general y, a través de un análisis interpretativo, observar si el modo de vida y la mayor o menor vinculación del sujeto a la red (factores complementarios) contribuyen de algún modo a la explicación de diferencias en el objeto de nuestro estudio.

\section{REFERENCIAS BIBLIOGRÁFICAS}

Bотт, E. (1990): Familia y red social: roles, normas y relaciones externas en las familias urbanas corrientes, Madrid, Taurus.

Labov, W. (1983): Modelos sociolingüísticos, Madrid, Cátedra.

Milroy, L. (1980): Language and social networks, Oxford, Blackwell.

Serrano Hermoso, M. J. (1997): «Metodología empleada en el estudio sociolingüístico de un núcleo urbano», Interlingüística, 8: 341-348.

Silva-Corvalán, C. (1989): Sociolingüística: teoría y análisis, Madrid, Alhambra.

\section{Diccionarios}

Minı, G. (1998): Parole senza frontiere. Dizionario delle parole straniere in uso nella lingua italiana, Bologna, Zanichelli /La galiverna, $5^{\mathrm{a}}$ Edic.

OLI, G. (a cura di) (1993): Parole degli anni novanta, Firenze, Le Monnier, $2^{\mathrm{a}}$ Edic.

Zingarelli, N. (2004): Vocabolario della lingua italiana, Bologna, Zanichelli. 


\title{
EL DESPLAZAMIENTO LINGÜÍSTICO Y SU DOCUMENTACIÓN: PRIMEROS SÍNTOMAS DEL DESPLAZAMIENTO DEL ESPAÑOL EN LA PRENSA DEL NUEVO MÉXICO TERRITORIAL, 1846-1912
}

\author{
Arturo Fernández-GiberT \\ California State University, San Bernardino
}

\section{INTRODUCCIÓN}

$\mathbf{E}$ N la ya larga tradición de estudios sobre el español de Nuevo México, la variedad europea más antigua de los Estados Unidos, y del español en los Estados Unidos en general, un buen número de ellos se ha dedicado al desplazamiento del español por el inglés. La mayoría de ellos se ha dedicado a demostrar, utilizando métodos fundamentalmente cuantitativos, que el español en Nuevo México y otros muchos lugares en Estados Unidos es una variedad lingüística condenada a desaparecer en un breve plazo.

Ya en los años setenta, López (1978), en su estudio del español de Los Ángeles, California, señaló claros indicios de desplazamiento del español. Así mismo, Floyd (1982; 1985), de forma algo más ambigua, apuntaba al desplazamiento del español en el sur de Colorado y en el resto del suroeste de los Estados Unidos. Tal vez el más exhaustivo y detallado estudio sobre el desplazamiento haya sido el de Hudson-Edwards y Bills (1980), utilizando una muestra muy significativa de un barrio hispano de Albuquerque, Nuevo México. En este estudio se destaca la dimensión generacional, según la cual el español no se está transmitiendo de generación a generación, a pesar de que su uso en aquel momento (mediados de los años setenta) era bastante extendido todavía.

Más recientemente, y a pesar de quedar algo difuminado en el concepto de continuum bilingue a través de tres generaciones, Silva-Corvalán (1994) también ha mostrado evidencias del fenómeno del desplazamiento en la comunidad hispana de Los Ángeles. Otros estudios recientes realizados en Nuevo México y el conjunto del suroeste de los Estados Unidos ha arrojado resultados similares (Hudson et al., 1995; Henández-Chávez et al., 1996). También se ha estudiado el desplazamiento del español en Estados Unidos como consecuencia de las políticas lingüísticas monolingủes en este país (Hernández-Chávez, 1989). 
Todos estos estudios investigan una realidad del desplazamiento lingüístico ya en marcha, como fenómeno irreversible, y en un estado bastante avanzado. Hoy podemos afirmar que estamos en la última fase del desplazamiento y muy próxima desaparición de la primera variedad europea en Estados Unidos, en lo que se refiere al español de Nuevo México al menos, aunque no falten estudios que pronostican un destino similar para el español estadounidense en general, si bien a más largo plazo.

Sin embargo, faltan estudios que examinen de cerca cuándo y cómo se inició este largo proceso del desplazamiento, en este caso para el español de Nuevo México. Una muy valiosa documentación la encontramos en las fuentes primarias, que nos sirven para rastrear y tal vez encontrar el origen y primeras fases del desplazamiento. Los periódicos en español de la época de transición entre el Nuevo México de soberanía mexicana y el estado de la Unión americana pueden darnos los elementos necesarios para constatar este proceso. Esta época, entre 1846 y 1912, es el Nuevo México territorial, durante la cual Nuevo México fue territorio administrado por el Congreso de Estados Unidos, pero sin constituirse aún en estado.

A partir de la década de los ochenta del siglo XIX nace un movimiento de gran difusión de la prensa en español auspiciada por una generación de empresarios y políticos interesados en la mejora de las condiciones sociales, políticas y económicas de los neomexicanos nativos. Esta época coincide con la llegada del ferrocarril a Nuevo México (1879-80) y con ella nuevos colonos angloamericanos en número creciente.

A pesar de que la demografía del territorio, que en 1870 contaba con casi tres cuartas partes de población nativa de ascendencia hispana, podemos ver muy pronto la influencia lingüística -como la de muchos otros aspectos de la vida- de esta nueva sociedad que se va formando en ciudades como Las Vegas (primera ciudad hasta 1900), Albuquerque (primera ciudad a partir de 1900) o Santa Fe, la capital del territorio.

Hay dos aspectos a observar para documentar el desplazamiento del español en Nuevo México: el aspecto linguístico, o la influencia del inglés demostrada en una abundancia de préstamos léxicos y sintácticos, y las actitudes hacia el inglés y el español por parte de los nuevomexicanos nativos.

\section{INFLUENCIA DEL INGLÉS: LOS PRÉSTAMOS LINGÜÍSTICOS}

Los préstamos lingüísticos del español neomexicano de esta época territorial son anglicismos léxicos hoy muy comunes en el español mexicoamericann y aun de. México IIna lista representativa de los anglicismos léxicos 
que aparecen habitualmente en las páginas de los periódicos en español -obtenidos de La Voz del Pueblo entre 1890 y 1912-incluye los siguientes:

a) Anglicismos léxicos asimilados corte, casa de corte < court, court house corte de pruebas < probate court aplicación $<$ application (solicitud) aplicar < to apply (solicitar) aplicante $<$ applicant (solicitante) atender $<$ to attend (asistir) bogue, boguecito < buggie (vehículo, préstamo totalmente asimilado) colector $<$ collector (recaudador) complexión < complexion (tez) constipación $<$ constipation (estreñimiento) correr para presidente $<$ to run for president (presentarse a presidente) drogas $<$ drugs (medicinas en general) endorsar $<$ to endorse (apoyar políticamente) enforzar la ley $<$ to enforce the law (aplicar la ley) policía $<$ policy (política) remover $<$ to remove (quitar) quietamente $<$ quietly (silenciosa, calladamente) reportarse $<$ to report (informar) resentir $<$ to resent (guardar rencor) resorte < resort (instalación hotelera o turística) solicitador general < solicitor general (recaudador de hacienda) soportar $<$ to support (apoyar) suceso $<$ success (éxito) suplir < to supply (aportar, suministrar) viaje redondo < round trip (viaje de ida y vuelta, hoy habitual en México y otros países)

b) Anglicismos sintácticos consistir de $<$ to consist of depender en $<$ to depend on suprema corte < supreme court v. aux. haber + adv. + partic.:

Dwyer ha abiertamente dicho < Dwayer has openly said Construcción pasiva + adv. en -mente:

Se recomienda fuertemente < It is strongly recommended Orden invertido en construcción pasiva: Preparaciones se están haciendo < preparations are being made 
Abundancia de construcciones pasivas:

fué matado, fue llevado < was killed, was taken

c) Préstamos sin asimilar

buggie, business, club, meeting, revolver, rifle, saloon, scrapers, switch

El proceso de incorporación a un nuevo sistema político y económico favoreció la introducción de estos anglicismos en la vida común de los nuevomexicanos. En el caso de los periódicos, las traducciones de las crónicas políticas y sociales del inglés (Perrigo, 1982) y el lenguaje publicitario, con la difusión de nuevos productos e ideas importados de los Estados Unidos contribuyeron sin duda a esta notabie influencia lingüistica.

\section{IAS ACTITUDES IIACIA LA IENGUA}

Las actitudes de los neomexicanos nativos hacia su propia lengua y cultura, que muy frecuentemente se perciben amenazadas, así como las actitudes hacia el inglés y la nueva sociedad cada vez más anglizada, son otro modo de observar los tempranos síntomas de esta erosión lingüística.

Algunos textos nos hablan explícitamente de esta situación lingüística de contacto de lenguas: poemas, cartas, manifiestos, editoriales políticos, crónicas de sociedad, etc. Un temprano documento de la percepción de amenaza lingüistica y cultural lo encontramos en un poema de un famoso maestro y defensor de la cultura nativa neomexica, Jesús María Hilario Alarid, publicado en la prensa y recogido por Anselmo Arellano, historiador de Las Vegas y Nuevo México en general:

Hermoso idioma español

¿que te quieren proscribir?

Yo creo que no hay razón

Que tú dejes de existir.

Cuando el mejicano entienda

Bien el idioma materno

Muy fácil será que aprenda

El idioma del gobierno.

Rogaremos al eterno

Que nos dé sabiduría
Y que se nos llegue el día de poder hablar inglés

Pues señores justo es

Que lo aprendamos hablar

Y siempre darle lugar

Al idioma nacional

Es justo y es racional

Pero les hago un recuerdo

Para a San Pablo adorar

No desadoren a San Pedro.

( El idioma español», reproducido en Nrellano, 1976: 37) 
En este romance, en el que está escrita parte de la historia tal vez nunca mejor contada, Alarid advierte del rumbo que están tomando los acontecimientos hacia el final del siglo XIX. La palabra proscribir resultaría profética, por cuanto las leyes del futuro estado sólo contemplaron la oficialidad del español por un plazo de veinte años, hasta 1932. A partir de este año, el español dejó de ser lengua oficial de Nuevo México, y comenzaría un declive irreversible del que todavía podemos ser testigos.

Otro poema, mucho más personalizado y emotivo, sería publicado unos años más tarde en $\mathrm{La} \mathrm{Voz}$ del Pueblo, periódico que, como muchos otros, incluía en sus páginas la poesía popular, muchas veces anónima, que expresaba así la reacción emocional ante la penetración del inglés en la sociedad:

No me hables ¡Por Dios! así...

¿Por qué me hablas al revés?

Di con tu boquita «sí»»

Pero no me digas «yes»

Si no quieres verme mudo,

Saluda «¿cómo estás tú?»

Yo no entiendo tu saludo

«Good morning, how do [you] do?»

¡No por Dios! li[n]da paisana,

No desprecies nuestra lengua,

Sería en ti mal gusto y mengua

Querer ser «americana.»

Que yo, a las mexicanitas,

Las aprecio muy de veras;

Trigueñas o morenitas

Me gustan más que las hueras.

(La Voz del Pueblo, 25 de junio de 1892, p. 3, citado en Meyer, 1996)

Aquí podemos observar que, a pesar del irresistible avance del inglés, el anónimo poeta considera todavía Nuevo México dividido en dos sociedades: la mexicana y la (anglo)americana, perfectamente identificadas por su lengua nativa. Lo que nos dice este poema es que, a pesar de que la lengua de los neomexicanos nativos es el español (nuestra lengua), ya había, en la última década del siglo XIX, paisanos que se orientaban ya hacia el inglés, aunque podemos asumir que todavía eran bilingües, es decir, podían hablar también el español. Pero el poema nos habla de un cambio de actitud, y la sentida reacción que provocaba.

El siguiente documento nos habla del futuro que espera a Nuevo México, una vez que éste haya pasado a formar parte de la Unión americana. Es una carta abierta publicada en $L a$ Voz del Pueblo, ya llegado el siglo xx, en la que 
B. S. Rodey, antiguo delegado territorial de Nuevo México y en ese momento recién nombrado juez federal en Puerto Rico, se dirige a los nuevomexicanos para advertirles que el español es cosa del pasado, y que el inglés será la lengua de las siguientes generaciones nacidas en el que pronto será estado de Nuevo México:

Tened prescnte, amigos míos, que [...] tod[o]s y cada uno de sus descendientes hablarán el Inglés como lengua nativa. Esto Uds. no lo pueden evitar, y es inútil evitarlo, aunque sé que Uds. no desean evitarlo. Si sus hijos no se instruyen en el Inglés el mal es para ellos, porque la inmigración crece de día en día, y dentro de diez a quince años, ó menos quizás, esos que Uds. Ilaman «Americanos» estarán en mayoría en todos los Estados del Sud[o]este y, como sucede en California, los que tienen en sus venas sangre Española estarán en minoría...

(La Voz del Pueblo, 18 de agosto de 1906)

En las palabras de Rodey se implica ya el abandono por parte de las futuras generaciones del español por el inglés, la lengua de los «Americanos» que en poco tiempo constituirían la mayoría de la población. Aunque a largo plazo la realidad lingüística de Nuevo México sería la descrita por Rodey, en dos cosas se equivocaba, sin embargo. No sería en cuestión de diez o quince años que los nuevomexicanos quedarían en minoría en Nuevo México, aunque ya era cierto que en el resto de los estados del suroeste los angloamericanos ya eran, en 1906, la mayoría. En todo caso, aunque los datos demográficos no son fáciles de interpretar, los neomexicanos nativos seguirían siendo una mayoría o una minoría cercana al cuarenta por ciento, durante todo el siglo XX, y hasta nuestros días. El español, sobre todo en las zonas rurales de Nuevo México, sería una lengua viva muchas décadas después del discurso de Rodey, aunque en franco retroceso después de la Segunda Guerra Mundial.

La ley de enseñanza pública de 1891 (Public Education Law) que hicieron del inglés la única lengua obligatoria de instrucción en las escuelas públicas de Nuevo México, reflejaban la firme determinación de la legislatura, encaminada ya decididamente hacia la estatalidad, de desembarazarse de la lengua vernacular de en aquel entonces la mayoría de la población. Los temores de Alarid estaban más que justificados.

Otro testimonio del rumbo inexorable que seguirían las actitudes lingüísticas de los nuevomexicanos es el recogido por Bonafé, pseudónimo del corresponsal en Santa Fe de El Independiente de Las Vegas. En esta crónica se hace patente los nuevos tiempos quc sc avccinaban: 
Cualquier observador medianamente curioso no puede menos que notar el cambio que ha ocurrido en Santa Fe y en algunas otras plazas del Territorio de algunos años a esta parte, cambio que claramente indica que poco a poco nos vamos americanizando. Muchos son los indicios que ponen esto de manifiesto $\mathrm{y}$ hacen conocer que las costumbres y usos anteriores van lentamente desapareciendo y cediendo á prácticas nuevas á imitación de los que están en boga en los estados [Unidos]. Casi todos los jóvenes de veinte años abajo hablan el idioma inglés con más o menos perfección, y se han olvidado o no hacen aprecio de los juegos y diversiones que eran regla en años anteriores, y hasta los más pretenciosos imitan el tono y maneras de los recién venidos mostrándose más turcos que Mahoma en esto de parlar el inglés á todas horas del día y de la noche, teniendo casi por mengua hablar su propia [sic] idioma. («De la Capital: Correspondencia Particular á El Independiente», en El Independiente, 5 de octubre de 1895, reproducido en Meléndez, 1997)

El texto documenta con gran exactitud la orientación de la nueva y futura sociedad neomexicana. Los jóvenes de finales del siglo XIX empleaban ya más el inglés que el español en su vida pública, aunque la crónica asume todavía que su propia lengua sigue siendo el español. Podemos deducir de ello que posiblemente la mayoría de la juventud urbana de hacia 1900 era bilingüe, pero prefería utilizar el inglés más que el español en su vida diaria. Sin embargo, en las áreas rurales, por la documentación que tenemos, y hasta hoy día en algunas aldeas remotas del norte del estado, la situación debía de ser muy diferente. Sánchez (1940), casi medio siglo después, nos dice que en Taos todavía es precaria la enseñanza del inglés en las escuelas. $Y$ en los años setenta, en un barrio hispano de Albuquerque, todavía las tres cuartas partes de las personas de más de 25 años dicen utilizar el español en casa.

\section{CONCLUSIÓN}

Este trabajo, basado en fuentes primarias, ha querido mostrar cómo es posible rastrear el origen y desarrollo del desplazamiento lingüístico en una comunidad de habla concreta. Nuevo México, primer asentamiento europeo en lo que hoy es Estados Unidos, fue durante trescientos años una comunidad lingüística homogénea, estable y monolingüe en español. Hacia finales del siglo XIX, este territorio experimentó unas transformaciones sociales, políticas y económicas que lo asimilarían, a lo largo de más de un siglo, a la comunidad linguíística del suroeste de los Estados Unidos.

El español de Nuevo México es, a principios del siglo XXI, la lengua minoritaria y subordinada de una modesta, aunque creciente, comunidad mexicana 
de inmigración reciente. Pero el español tradicional, hablado desde 1598 en las colonias españolas establecidas en Nuevo México a lo largo del río Grande, heredado por Alarid, e impreso en las páginas de la prensa hispana en la segunda mitad del siglo XIX, es hoy, a principios del siglo XXI, una lengua agonizante, hablada sólo por los ancianos más logevos del norte del estado.

He tratado de mostrar primero, basándome en textos periodísticos publicados en las últimas décadas del siglo xix y las primeras del xx, las características del español neomexicano de esta época, que muestra una abundancia de préstamos tomados del inglés. Esta descripción nos permite relacionar esta influencia anglizante con un contacto intenso y habitual entre el español de Nuevo México, y la comunidad linguística que lo usa, y el inglés, la lengua socialmente dominante en este teritorio entonces recién colonizado por los Estados Unidos.

Al mismo tiempo, los testimonios dircetos de esta comunidad de habla nos muestran síntomas de un incipiente desplazamiento de la lengua vemácula de los neomexicanos, y una orientación en sus actitudes y comportamientos linguísticos que apuntan, dadas las condiciones sociales, a una lenta y paulatina sustitución del español por el inglés, última y definitiva etapa del desplazamiento. Desde la invasión militar de los Estados Unidos en 1846, el inglés ha ido desplazando a una lengua que, tras los cambios en el poder político y económico, y la subsiguiente inmigración masiva de anglohablantes, está a punto de desaparecer. En pocos años habremos perdido una de las variedades más antiguas y fascinantes del español, una lengua, paradójicamente, en plena expansión mundial. Estos testimonios escritos por aytellos que vivieron esta transformación nos oftecen, más que la fría y calculada cifra estadística, una verdadera biografía de la lengua, contada por sus hablantes, los nuevomexicanos de hace aproximadamente un siglo.

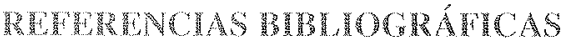

Arellano, A. (1976): Los pobladores nuevomexicanos y su poesía: 1889. 1950, Albuquerque, Pajarito.

BONAFÉ (pseud) (1895): «De la Capital: Correspondencia Particular á El Independiente», El Independiente, 5 de octubre, 1.

Floyd, M. B. (1982): «Spanish-language maintenance in Colorado» en Barkin, F; R. Brandt; J. Ornstein-Galicia (eds.) (1982): Bilingualism and language contact: Spanish, English, and Native American languages, Nueva York, Teachers College Press.

Fuoxo, M. B. (1985): «Spanish in the Southwest: Language maintenance or

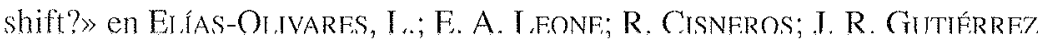


(eds.) (1985): Spanish Language Use and Public Life in the United States, Berlín, Mouton.

HernáNDEZ-ChÁveZ, E. (1989): «The Role of Supressive Language Policies in Language Shift and Language Loss», Estudios Fronterizos, 18-19: 123-35. Hernández-Chávez, E.; G. D. Bill.s; A. Hudson (1996): «El desplazamiento del español en el suroeste de EE.uU. según el censo de 1990» en Ar.onA Iglesias, M.; J. L. Chávez; A. EnríQuez Ovando; G. C. López Lara; M. A. Novella Gómez (eds.) (1996): Actas del X Congreso Internacional de la Asociación de Lingüística y Filología de la América Latina, México, Universidad Nacional Autónoma de México.

Hudson, A.; E. Hernández-Chávez; G. D. Bills (1995): «The Many Faces of Language Maintenance: Spanish Language Claiming in Five Southwestern States» en SIlva-Corvalán, C. (ed.) (1995): Spanish in Four Continents: Studies in Language Contact and Bilingualism, Washington, DC: Georgetown University Press.

Hudson-Edwards, A.; G. D. Bills (1980): «Intergenerational Language Shift in an Albuquerque Barrio» en BLAnsitT, E. L.; R. V. Teschner (eds.) (1980): A Festschrift for Jacob Ornstein: Studies in General Linguistics and Sociolinguistics, Rowley, Newbury House.

LóPEz, D. E. (1978): «Chicano language loyalty in an urban setting», Social Science Review, 62: 2, 267-78.

Meléndez, A. G. (1997): So All Is Not Lost: the Poetics of Print in Nuevomexicano Communities, 1834-1958, Albuquerque, University of New Mexico Press.

MEYER, D. (1996): Speaking for Themselves: Neomexicano Cultural Identity and the Spanish-language Press, 1880-1920, Albuquerque, University of New Mexico Press.

Perrigo, L. I. (1982): Gateway to Glorieta: A History of Las Vegas, New Mexico, Boulder, Pruett Publishing Company.

SÁnCHEZ, G. I. (1940): Forgotten People: A Study of New Mexicans, Albuquerque, University of New Mexico Press (reimpresión con prólogo de Mario T. García, 1996)

Silva-Corvalán, C. (1994): Language Contact and Change: Spanish in Los Angeles, Oxford, Oxford University Press/ Clarendon Press.

La Voz del Pueblo: Semanario dedicado a los intereses y progreso del pueblo neo-mexicano, 1890-1912, Las Vegas, Nuevo México, Estados Unidos, español e inglés. 


\title{
GIBRALTAR'S MULTILINGUAL PAST, MONOLINGUAL SOCIETY IN THE FUTURE?: A QUANTITATIVE AND QUALITATIVE ANALYSIS OF THE THREE MAIN VARIETIES SPOKEN IN THE ROCK
}

\author{
Carmen Fernández Martín \\ Universidad de Cádiz.
}

\begin{abstract}
U IBRALTAR's colonial past was a conglomerate of Mediterranean people that agglomerated on the foothills of a massive Rock, once known as one of Hercules' Pillars. According to the 1753 Census, the bulk of the population in the years immediately after the British occupation was mostly comprised by Genoese (597) and Jews (575), while the British were at the time a garrison of 434 men and the Spanish amounted only to 185 . Not much is known about the «linguistic» contacts between the military and the civilian population: «There was little contact with the British military who maintained their distance, as they would largely do throughout their official presence on the Rock» (Levey, 2004: 9). This can also be said of the linguistic behaviour of the different communities within Gibraltar. One of the first linguistic references we have is provided by the Spanish historian, López de Ayala: "I tanto estos (los genoveses) como los judíos hablan bien o mal el castellano e inglés i un dialecto o jerga común a todas las naciones sin excluir las africanas" (López de Ayala, 1782: 374). The origin of this jargon is unknown; some scholars have pointed out that it was, possibly, a kind of Spanish-base pidgin filled with words from all the languages that were spoken at the time (Kramer, 1986: 55). Surely, the survival of the population depended to a great extent on the comings and goings to the mainland through the artificial frontier.

The censuses carried out since 1753 cannot give us clues as regards to the linguistic behaviour of the Gibraltarians considering that questions on language use or proficiency have never been included by the authorities. However, we find an indirect reference as to what was the linguistic situation at the end of the eighteenth century. The lack of formal education in English is attested to the bilingual notice for the 1791 Census issued by the Civil Secretary, John Raleigh. The notice, which asked for people's collaboration in the elaboration of the census, was both in English and Spanish (Government of Gibraltar, 2002: 8). Some other references about which language dominated the first
\end{abstract}


years of the colony can be located within the history of educative practices. The most serious study on this matter was carried out by Albert Traverso, who indicates that all throughout the seventeenth and well into the eighteenth centuries: «The lack of formal education in Gibraltar meant that people continued to speak Spanish, although English was the official language» (Traverso, 1980: 2). Indeed, the first attempts at formal schooling at the beginning of the nineteenth century was conducted in both languages due to the fact that the children were «extremely ignorant, without any knowledge of the English language» (Traverso, 1980: 23). In 1880, the Education Code was adopted and the medium of instruction was exclusively English.' Throughout its 300 years of history English has been acquiring a political and social status. However, the Spanish presence, though small as regards inhabitants living permanently in the colony, has never decreased. One of the reasons could be that it has been considered a common denominator amongst the various ethnic groups whose languages had Romance origins. Moreover, three other factors could account for the maintenance of Spanish during the colony's history. Firstly, the steady number of Gibraltarians who have always resided in El Campo de Gibraltar -before the closing of the border in 1969, 800 people lived permanently in Spain. ${ }^{2}$ Secondly, the great number of Spanish workers who have always worked in Gibraltar -in 19316,000 daily workers crossed the border (Lozano Maldonado, 1986: 135), and while today the figure has dropped considerably to 1,376 it still represents the most numerous group of frontier workers (Government of Gibraltar, 2002: 19). Finally, some authors indicate that the constant intermarriage between Spanish women and Gibraltarian men is another crucial factor that should be considered when analysing the impact of Spanish in Gibraltar (Howes, 1951).

Spanish and English seem to be the most frequent languages employed in the Rock, yet the linguistic behaviour of Gibraltarians is far more complex and rich. To study their sociolinguistic reality we carried out a fieldwork on language attitudes in December 2001. The study of attitudes started in the last century in the twenties and it combines psychological and sociological techniques to try to gauge people's ideas about current controversial topics. Attitudes, we assure, are like a genetic map that displays the evaluative nature of a person's beliefs. Almost simultaneously and due to the advent of the

1. Traverso explains that at the time it was very difficult to put into practice this monolingual eduction. The chidren contiined speaking Spanish and the Christian Brulues decided to tse translations of the school books (Traverso, 1980: 54-55).

2. There have always been Gibraltarians living in Spain. The Census taken in 1881 saw an increase of civil population and the overcrowding was so acute that many native families moved to the neighbouring town of La Linea de la Concepción (Government of Gibraltar: 2002: 10). 
broadcasting industry, linguists started studying the possible links between voice/speech and personality traits and how people frame attitudes towards other people on listening to voices. «Intuitively we attach an enormous importance to the voice and the speech behaviour that is carried by the voice» (Sapir, 1927: 905). Two different approaches to the study of attitudes are found in the literature, the most widely used in sociolinguistic research being the mentalist approach. ${ }^{3}$ In order to study the informants' attitudes -considered to be theoretical constructs-, we have to measure the conscious or unconscious answers given by the informants. The proponents of this approach divide the attitude into three components, namely cognitive, affective and conative or behavioural. «That is, one knows or believes something, has some emotional reaction to it and, therefore, may be assumed to act on this basis» (Edwards, 1995: 97). Each of these components is subdivided in turn into different psychosocial dimensions.

A study of language attitudes comprises direct and indirect measure methods to elicit peoples' reaction towards language varieties. One direct method widely used is the questionnaire, although this technique does have its detractors (Ryan \& Giles, 1982). It is argued that a subject's answer might be conditioned by political or ideological factors. As they know beforehand the aim of the study, the data obtained could be biased, and not reflect their actual linguistic behaviour. To counterbalance this drawback, social psychologists and sociolinguists have devised indirect measure methods to elicit the sub-conscious reactions to forms of talk. The first linguist who developed one of these indirect methods was Wallace Lambert and associates $(1960)^{4}$ through his matched-guise technique. In Lambert's studies, subjects judge the personality traits of a speaker using different varieties, while being unaware that they are, in fact, listening to the same speaker. Their attitudes towards the different guises are taken as in indication of their attitudes towards the different language varieties. Most studies have concluded that language attitudes vary on the evaluative dimensions of «status» and «solidarity». In this way, those varieties associated with the dominant groups in the community are valued more highly on status dimensions, whereas the varieties of the most marginalised groups are ranked more highly on solidarity dimensions (Bradac, 1990).

The present study consisted, firstly, on a questionnaire with 50 closed questions and 13 open questions. A total of 122 participants stratified by sex,

3. For a review sec Agheyisi \& Fishman, 1970; Appel \& Muysken, 1987; Baker, 1992; Bradac, 1990; Fasold, 1984; Giles, 1983; López Morales 1993; and Shuy \& Fasold (eds.) 1973.

4. When listening to a balanced bilingual using the two languages he/she speaks, one should rate his/her personality on the same terms but Lambert found out that French Canadians informants valued more positively English Canadians (Lambert, Hodgson, Gardner \& Fillenbaum, 1960). 
age, socioeconomic stalus and levels of education completed the questionnaire. Secondly, we used the matched guised technique to elicit the unconscious' reactions of Gibraltarians towards language use. In the questionnaire informants reported to employ English, Spanish and codeswitching. We took these three varieties for the second part of the study. A short humorous story about the summer holidays was retold by only two speakers in Standard English, Gibraltarian English, Gibraltarian Spanish and Yanito/Llanito. ${ }^{5}$ A voice control was also recorded so as to give time to the informants to become familiarised with the experiment. ${ }^{6}$ The informants listened to each guise and rated each speaker on the following dimensions: social position, degree of identification, communicative interaction and socio-political ideology (cognitive component); personality, level of tolcrancc and group identity (affective component). To evaluate the speaker, a seven-point-Likert scale with 18 adjectives was used, each scale containing two opposing adjectives. For instance, to measure group identity one of the adjectives employed was: affectionate/indifferent. The scale runs from extremely affectionate to extremely indifferent and the judge has to place the speaker into the scale.

A total of 183 students (from 12 to 18 years) were selected. Special interest was devoted to this group's attitudes as we felt that this generation is living a different reality as compared to their parents or grandparents. On the one hand, they have not suffered the isolation their parents did during the border's closure (1969-1983), and so they can freely cross over to Spain. On the other, they might be more influenced by Anglo-Saxons values and language as they have been brought up with English media from cable TV. Previously, Spanish television channels were the only ones that could be watched until 1986 (Kellermann, 2001: 226). Thus, this generation's attitudes towards each variety will affect the linguistic behaviour of the whole community in the future and will determine what type of relationship the speech community is going to have with its neighbour, Spain.

All the data has been statistically processed using spss (Statistical Package for Social Sciences), version 10.1, and two error margins - $95 \%$ and $90 \%-$ have been considered. We will proceed to summarise our findings comparing the different varieties. For the cognitive component and in the dimension social position Standard English is valued more highly in terms of status and

5. This is the name given to the Spanglish used in the Rock. Several explanations have been offered as to the origin of he word. The term is spelled with a double "l" in the Diccionario de la Real Academia. However, the different origins of the word make both spellings possible. See Fernández Martín (2003: 74-77).

6. It was decided to use Irish English as the voice control, first, to oppose it against Standard English and secondly, because there is a significant number of Irish people working in Gibraltar. Indeed, informants recognised the variety (Fernández Martín, 2003: 248). 
prestige than Gibraltarian English. This is represented by the adjectives learned/unlearned where there is a 1.11 point difference; poor/rich with 0.49 and formal/informal, being standard English rated quite formal and the vernacular slightly formal (0.97). Figure number one shows graphically the relation between Standard English and Gibraltarian English for the cognitive component:

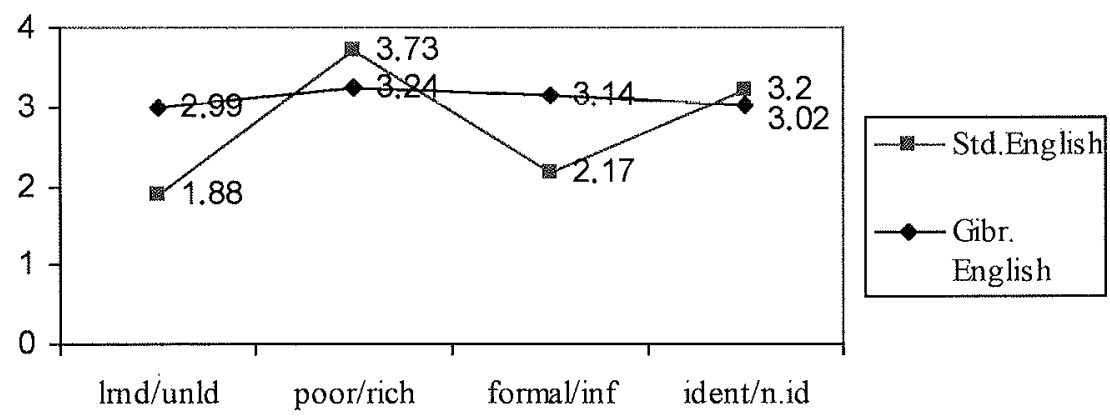

FIGURE 1. Standard English versus Gibraltarian English (cognitive
component)

These results coincide with those of such studies that have assessed the importance of Standard English, both within Great Britain and outside, i.e. its former colonies. ${ }^{7}$ Standard English personifies authority and a good level of education. However, these studies have shown that in the solidarity dimensions the vernaculars are rated more favourably (Hamers \& Blanc, 1989). In Gibraltar, Gibraltarian English does not define the speech commu-nity per se. Neither of the two varieties stands clearly as an identity marker. Both values are near the «slightly identified». One of the reasons could be the fact that most of the population has not Anglo-Saxon origins. When Gibral-tarians are in Great Britain, they realize that they understand everything, but that they do not fully participate in that society: "I lived in the UK for 18 years and coming back was coming back home, coming to my roots" (personal interview with Thomas Finlayson, historian and main archivist).

When analysing the affective component (see figure 2: Standard English versus Gibraltarian English), Standard English is again positively valued as regards personality (the Standard English speaker is rated as quite intelligent, the Gibraltarian is slightly intelligent, with a 1.05 difference). However

7. Similar results can be found in Bourhis, Giles \& Lambert, 1975; Carranza \& Ryan 1975; Ramírez, 1992. In Spain see Gómez Molina, 1998 and Ros I García, 1984. 
Gibraltarian English is valued slightly more positively for the dimensions: group identity and communicative interaction and represented by the pair of adjectives modest/arrogant and friendly/unfriendly. The vernacular is felt to be more socially attractive and its use manifests a greater solidarity within the community.

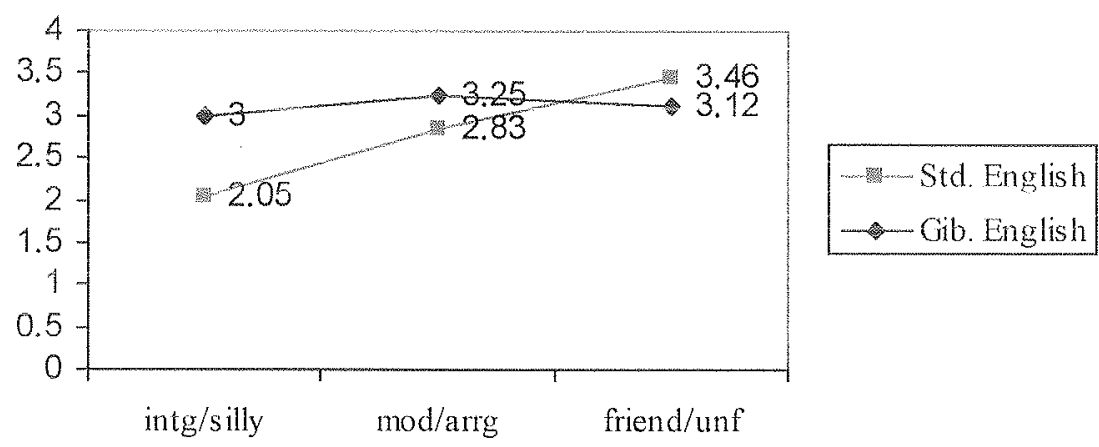

FIGURE 2. Standard English versus Gibraltarian English (affective component)

Standard English can also be compared with another vernacular employed in the Rock, i.e. Spanglish. In this case, both varieties contrast more clearly. Figure 3 (Standard English versus Yanito) presents the adjectives that most depart in the cognitive component. We observe how Standard English and codeswitching are separated by almost one point in social position represented by the adjectives learned/uneducated; and in the dimension that measures the level of identification (identified/not identified with). In figure 4 (Standard English versus Yanito) for the affective component Standard English and Yanito depart significantly in the pair of adjectives: intelligent/stupid and friendly/unfriendly. We conclude that the English Standard speaker is considered more learned but less friendly, and, in this respect, the population identifies more with the speaker that code switches. This judgement coincides with that of Spanglish in other places. Mar-Molinero referring to the role of Spanglish in the us points that «it serves as an important identity marker for the Spanish-speaking community, and like any linguistic code is a dynamic, evolving symbol of solidarity» (Mar-Molinero, 2000: 185). When considering the socioeconomic position, Standard Fnglish is placed in the highest social class. On the contrary the speaker that code switches is placed in the lowest social strata; that of unskilled workers. 


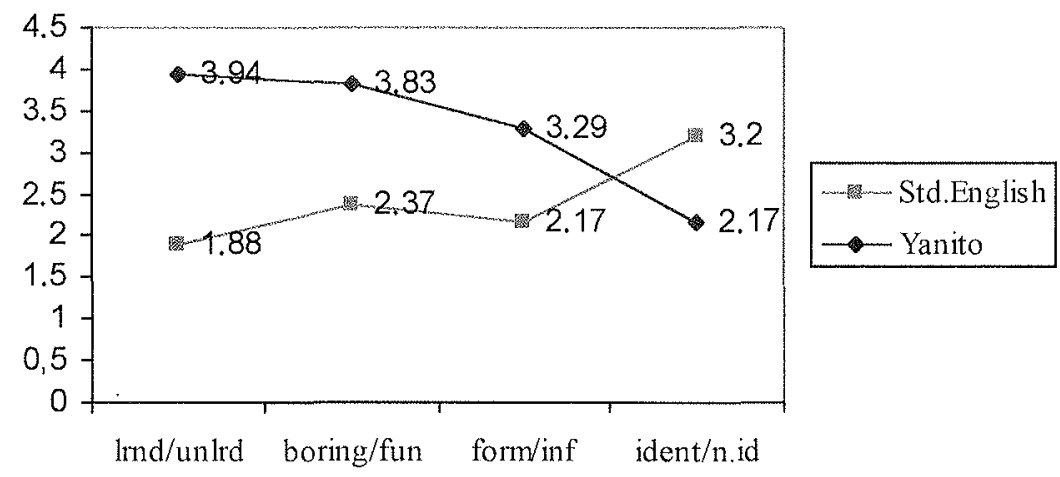

FIGURE 3. Standard English versus Yanito (cognitive component)

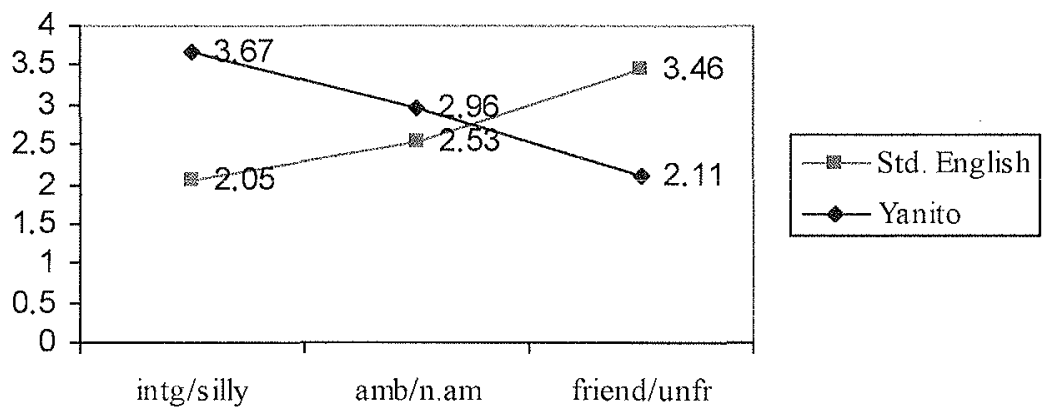

Figure 4. Standard English versus Yanito (affective component)

Although most Gibraltarians will deny the fact that they speak Gibraltarian Spanish, a guise was included to analyse the unconscious reactions towards this variety. If we compare it with Yanito, we see (figure 5: Gibraltarian Spanish versus Yanito for the cognitive component) that the distances between the adjectives are not as marked as with the binomial Standard English versus Yanito. This is understandable as both act as vernaculars. The social position and communicative interaction of both varieties have the same ratings, slightly learned, slightly funny, and slightly persuasive. It is only in the dimension that measures the degree of identification that the difference is more marked, almost one point (0.96). For the affective component, the graph (figure 6: Gibraltarian Spanish versus Yanito) shows that almost all ratings are similar: The speakers of both varieties are considered slightly stupid and slightly non ambitious. The only rating in which both varieties depart clearly is for the pair friendly/unfriendly $(0.85)$. An evaluation, however, rather paradoxical because 
when we compare it with the pair affectionate/indifferent there is a difference of only 0.47 .

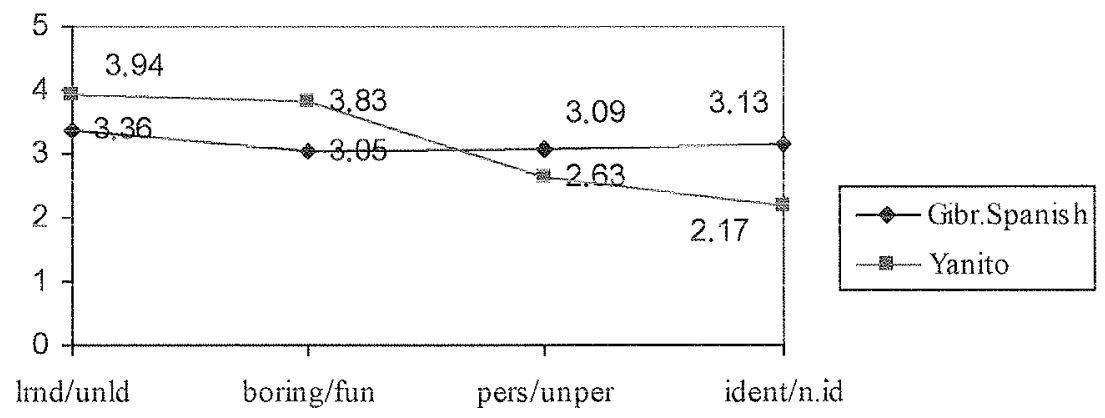

FIGURE 5. Gibraltarian Spanish versus Yanito (cognitive componeni)

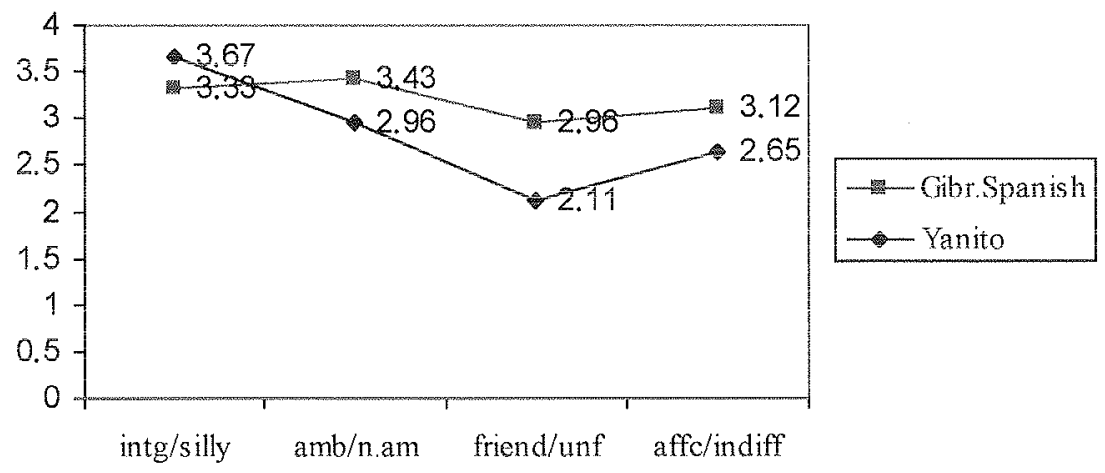

FIGURE 6. Gibraltarian Spanish versus Yanito (affective component)

In the questionnaire many contradictory answers were also found when evaluating the role Spanish plays. There were favourable responses to Spanish because $79 \%$ believes that an important element of the Gibraltarian identity would be lost if Spanish is not spoken. Nevertheless, when assessing group identity informants reject the value of Spanish. $65 \%$ of the informants thinks it is not important to speak Spanish to relate to people in Gibraltar. The subjects know that the value of Spanish is not overtly accepted but it is a part of their composite. Rippberbeger \& Staut (2003: 8), when describing the situation of the border between Mexico and the US, distinguish between weak nationalisms where people feel part of both cultures or strong nationalisms where people over-emphasise the differences. This is the case of Gibraltarians who, despite the continuous permeability of its border, feel the need to reaffirm their distinctiveness from the Spaniards and to forge a sense of 
nationalism. Therein lie the contradictory sentiments: they live in «between places»; they share a common ground; and there is a sense of physical belonging, yet most Gibraltarians consider themselves Mediterranean. Nonetheless, the community does not want to extend the domains in which Spanish is used in Gibraltar as that would mean an alliance to the enemy. Spanish is mainly a pragmatic tool, a lingua franca but with a subordinated status. Kellermann (2001) also found a discrepancy between what Gibraltarians considered their mother tongue and which is their first language they acquired. $54 \%$ claimed English to be their mother tongue, but almost $80 \%$ stated to have Spanish as their first language. "Granting English the status of 'mother tongue' is therefore a statement about identity: it makes the Gibraltarians 'British' and 'proves' them not to be Spanish» (Kellermann, 2001: 122).

Differences were found between female and male adolescents' evaluations. Gibraltarian girls value Standard English more positively compared to boys. They admire the English standard speaker more than male teenagers and consider him richer, more understanding and more affectionate than the other speakers. Most sociolinguistic studies agree that women prefer the prestigious varieties as a way to secure their status in society (Holmes, 1992: 171-2). Boys grant more importance to both vernaculars. On the one hand, Gibraltarian Spanish is valued more positively as a vehicle to relate to people and make friends. On the other hand, they rate the Yanito speaker more positively in the traits: funny, confident, honest and persuasive, that is to say in the dimensions: communicative interaction, personality and socio-political ideology. Despite the fact that women are more aware of the status Standard English has, it is not the variety the most identify with. It is boys that most identify with that variety of English. In the closed questionnaire women reported to code switch more. Mendoza-Denton (1999) found that Hispanic women in the US also alternated codes more frequently than men as a form of reaffirming their identity against the traditional subordinated roles assigned to them. Torres (1997) studied the linguistic behaviour of Puerto Ricans in New York and results showed that female students used more Spanish.

From the results obtained we may conclude that Gibraltar does not fit entirely in the mould of a diglossic community and that we could speak of a broad diglossia instead (Fasold, 1984: 53). Firstly, two high varieties can be identified: Standard English and Gibraltarian English which are used for the formal domains. Yet the vernacular is not totally accepted «as a legitimate dialect or accent as such» (Levey, 2004: 319). Secondly, we can distinguish two low varieties, i.e. Gibraltarian English and codeswitching. Both are used for the informal domains and although overtly stigmatised, they enjoy covert prestige. Moreover, Standard English functions also as a low variety as it is used in informal contexts as a medium for interpersonal communication. 
Finally, Gibraltarian Spanish is heard on the Rock but the population downgrades its proficiency and employs it in informal domains. Only the upper classes - educational and political authorities and intellectuals - use this variety in formal domains when they communicate with Spanish interlocutors. In one respect or another the different varieties overlap and interrelate, offering a complex and rich picture.

While Gibraltarians employ English in situations in which authority is needed, the population does not think it is an imposed language. English being the only medium of instruction at school, it is the umbilical cord that joins them to Great Britain and separates them from Spain. When asked about the reasons why English should be maintained in the open ended questions, they mentioned historical, cultural and instrumental reasons. One of the most frequent commentaries was: «It is part of our heritage». Compared with other ex-colonies in which English has been maintained, mainly, for economic reasons, in Gibraltar the overhanging presence of Spain has made English an ally. «Durante décadas, los gibraltareños nos hemos aferrado a los valores y conceptos que Gran Bretaña había establecido a través de su vasto -hoy evaporado- imperio» (Searle, 2002). The position of English has been undermined in the last years and the population's feelings towards the metropolis are, loday, quite contradictory. They now perceive Great Britain as giving them the cold shoulder. «It is very clear to me that Britain's ambivalent attitude to Gibraltar is very hard on us. Neither does Britain speak clearly to us about how it sees our future» (Cummings, 1995). Despite this, Standard English vitality is maintained as the younger generations are moving towards British culture.

The position of Spanish has always been very fragile. The evacuation of the civil population during the II World War, the closing of the border during Franco's dictatorship, the Falklands War and the endless attempts from the Spanish governments to claim the Rock without hearing Gibraltar's voice have provoked hostility towards Spain and the language. As Kellermann (2001: 134) affirms: «Admitting to using Spanish and liking Spanish things is still viewed as risky, since it might prompt the interlocutor to identify them as Spanish, and so undermine their self-conception as British and Gibraltarians». The persistence of Spanish, however, is expected to be maintained mainly through code-switching which is the new vehicle of self-determination. This speech community is trying to recompose the linguistic and cultural puzzle to reach a mature identity. The motto «British we are, British we stay» has now changed to «Gibraltarian we are, Gibraltarian we stay». In this context, Yanito is an effective tool that makes them different and at the same time part of those big giants that hound it. «Code-switching is a way to avoid identifying oneself with a given group, or a way of affirming local identity» (Moyer, 1993: 237). 
It is a marker of their ethnic identity. These three hundred years have represented a crossroads where the exchange of goods and languages has been a daily routine for the community. They now face an unsteady future where multilingualism, which was initially a crucial element in the constitution of Gibraltarian identity, may now be in jeopardy.

\section{REFERENCES:}

Agheyisy, R.; J. Fishman (1970): «Language Attitude Studies: A Brief Survey of Methodological Approaches», Anthropolical Linguistics, 12, 5: 137-157. Álvarez, F. (1999): Primary Code and Private Space Choice in the Host Classroom, Master of Arts Dissertation, Edinburgh, Moray House Institute of Education, University of Edinburgh.

APPEL, R.; P. MUYSKEN (1987): Language Contact and Bilingualim, London, Edward Arnold.

BAKER, C. (1992): Attitudes and Language, Clevedon, Multilingual Matters.

Ballantine, S. (1983): A Study of the Effects of English-medium Education on Initially Monoglot Spanish-speaking Gibraltarian Children, Master of Arts, Aberystwyth, University of Aberystwyth..

Bourhis, R. Y.; H. GILES; W. LAmberT (1975): «Social consequences of accommodating one's style of speech: a cross-national investigation», International Language of the Sociology of Language, 6: 55-71.

BRADAC, J. J. (1990): «Language Attitudes and Impression Formation» in Giles, H.; W. P. RoBinson (eds.) (1990): Handbook of Language and Social Psychology, Chinchester, John Wiley.

Cargile, A. C.; H. Giles; E. Ryan; J. J. BradaC (1994): «Language Attitudes as a Social Process: a Conceptual Model and New Directions», Language \& Communication, 14, 3: 211-236.

Cargile, A. C.; H. Giles (1997): «Understanding Language Attitudes: Exploring Listener Affect and Identity», Language \& Communication, 17, 3: $195-217$.

CARranza, M.; E. B. RYAN (1975): «Evaluative Reactions of Bilingual Anglo and Mexican American Adolescents toward Speakers of English and Spanish», International Journal of the Sociology of Language, 6: 83-104. Cummings, R. (1995): «Not to ostrich attitude», Gibraltar Chronicle, 13 September, w/n.

EDWARDS, J. (1995): Multilingualism, London, Penguin.

- (1999): «Refining Our Understanding of Language Attitudes», Journal of Language and Social Psychology, 18, 1: 101-110.

FASOLD, R. (1984): The Sociolinguistics of Society, Oxford, Blackwell. 
Fernández MARTín, C. (2003): An approach to language attitudes in Gibraltar, Madrid, UMI-ProQuest Information and Learning http://wwwlib.umi,com/cr/uca/fullcit?p3082728.

FinlaYSON, T. J. (1991): The Fortress Came First, Gibraltar, Gibraltar Books. GLES, H. (1983): «Language Attitudes in Multilingual Settings: Prologue with Priorities», Journal of Multilingual and Multicultural Development, 4, 23: 81-99.

Gómez Molina, J. R. (1998): Actitudes lingiiisticas en una comunidad bilingïe y multilectal, Anejo XXVIII de Cuademos de Filología, Valencia, Universitat de Vàlencia.

Government of Gibraltar (2002): Census of Gibraltar 2001, Gibraltar, Government Secretariat, Charles G. Trico Printers.

HAMERS, J. F.; M. H. A. BLANC (eds.) (1989): Bilinguality and Bilingualism, United Kingdom, cup (2000, revised $2^{\text {nd }}$ ed.).

Holmes, J. (1992): An Introduction to Sociolinguistics, London, Longman.

HOWES, H. G. (1951): The Gibraltarian. The Origin and Development of the Population of Gibraltar from 1704, Gibraltar, MedSun. (1982, $\left.2^{\text {nd }} e d\right)$.

Kellermann, A. (2001): A New New English, Language, Politics, and Identity in Gibrallar, Heidelberg, HSSK.

Kramier, J. (1986): English and Spanish in Gibraltar, Hamburg, Helmut Buske Verlag.

Lambert, W. E.; R. C. Hodgson; R. C. Gardner; S. Fillenbaum (1960): «Evaluation Reactions to Spoken Languages», Journal of Abnormal and Social Psychology, 60, 1: 44-51.

Levey, D. (2004): English Pronunciation and Pronunciation Tendencies in Gibraltar, Unpublished Master Thesis, Universidad de Cádiz.

López de Ayala, I. (1782): Historia de Gibraltar, Madrid, Antonio de Sancha. López Morales, H. (1993): Sociolingiiistica, Madrid, Gredos.

Lozano Maldonado, J. M. (1986): El desarrollo del Campo de Gibraltar. Análisis geográfico de una década decisiva 7965-75, Málaga, Confederación Española de Cajas de Ahorros.

MAR-Molinero, C. (2000) The politics of language in the Spanish-speaking world : from colonisation to globalisation, New York, Routledge.

MENDOZA-DEnton, N. (1999): «Sociolinguistic and linguistic anthropology of US Latinos», Annual Review of Anthropology, 28: 375-395.

Moyer, M. (1993): Analysis of Code-switching in Gibraltar, tesis doctoral, Bellaterra, Publicacions de la Universistat Autònoma de Barcelona, ediciò microfotogràfica.

Osgood, Ch.; G. J. Sucl; P. H. TAnnenbaum (1957): The Measurement of Meaning, Urbana, University of Illinois Press.

Ramírez, A. (1992): El lenguaje de los hispanos, Madrid, Maphre. 
Rippberger, S. J.; K. A. Staudt (2003): Pledging Allegiance, Learning Nationalism at the El Paso-Juárez Border, London, Routledge Falmer.

Ros I García, M. (1984): «Speech Attitudes to Speakers of Language Varieties in a Bilingual Situation», International Journal of the Sociology of Language, 47: 73-90.

Ryan, E. B.; H. GlLes (eds.) (1982): Attitudes towards Language Variation: Social and Applied Concepts, London, Edward Arnold.

SAPIR, E. (1927): «Speech as a Personality Trait», American Journal of Sociology, 32: 892-905.

Searle, D. (2002): «Más vale malo conocido», Gibraltar Chronicle Online, 5 February, http://www.chronicle.gi/Opinion/5.2.2002, accessed: 11 October 2003.

ShuY, R.; R. FASOld (eds.) (1973): Language Attitudes: Current Trends and Prospects, Washington, D.C., Georgetown University.

Torres, L. (1997): Puerto Rican Discourse: A Sociolinguistic Study of a New York Suburb, Mahwah, N.J., L. Erlbaum.

Traverso, A. A. (1980): A History of Education in British Gibraltar (17041945), Ph Dissertation, Southampton, University of Southampton. 



\title{
LOS ELEMENTOS SOCIOLINGÜÍSTICOS EN LA CORRESPONDENCIA COMERCIAL- TURÍSTICA ALEMANA: PROPUESTAS PARA SU ENSEÑANZA EN LAS CLASES DE ALEMÁN PARA FINES TURÍSTICOS
}

\author{
Juan José Hernández Medina \\ Universidad de Almería
}

\section{CONSIDERACIONES PREVIAS}

$\mathrm{A}^{\mathrm{L}}$ L presente trabajo aborda la utilidad del análisis del género en la enseñanza de los elementos sociolingüísticos básicos que deben ser tenidos en cuenta en la correspondencia comercial-turística alemana: los marcadores de relaciones sociales y las convenciones de cortesía.

La referida temática es muy importante en las clases de alemán para fines turísticos que impartimos en la Universidad de Almería, pues el estudiante de turismo que tras finalizar sus estudios pretenda trabajar en una de las muchas empresas turísticas de nuestro país estrechamente relacionadas con el ámbito de los viajes germano-parlantes deberá enfrentarse a diario a tareas que requieran la redacción de textos comerciales en lengua alemana.

$\mathrm{El}$ análisis del género será aplicado en dos textos en lengua alemana, cuya temática versa sobre el ámbito comercial-turístico. Éstos han sido extraídos de una publicación alemana de prestigio especializada en la correspondencia empresarial y son tratados en la asignatura de Ampliación de Idioma Alemán. Esta asignatura es cursada por alumnos con un nivel inicial que corresponde aproximadamente al grado A2 del Marco de Referencia Europeo de las Lenguas.

La selección del referido corpus no responde a motivos gratuitos, sino a uno fundamental: que los alumnos tomen contacto con una manifestación textual que no haya sido manipulada ni por el profesor ni por los autores de materiales didácticos, ya que los textos que han sufrido tales manipulaciones didácticas presentan estructuras artificiales, perdiendo así una gran parte de su significado original.

Por último, se mostrarán una serie de ejercicios destinados al aprendizaje de los mencionados elementos sociolingüísticos que han sido desarrollados a partir de los resultados obtenidos en el referido análisis. 


\section{LOS ELEMENTOS SOCIOLINGÜISTICOS EN LA CORRESPONDENCIA COMERCIAL-TURISTICA ALEMANA}

Los elementos sociolinguísticos que tratamos principalmente en nuestras clases de alemán para fines turísticos son los grados de formalidad del registro y las convenciones de cortesía comunicativa. Resulta necesario tenerlos en cuenta en la enseñanza de lenguas extranjeras, ya que mediante ellos se favorece el buen desarrollo de numerosos procesos comunicativos, como es el caso de la correspondencia comercial-turística alemana.

En contra de lo que se pueda pensar, el aprendizaje de las referidas convenciones sociolingüisticas no conlleva apenas dificultades a nuestros alumnos, pues la corrcspondencia comercial-turística es tratada en numerosas asignaturas de sus estudios.

Los marcadores de relaciones sociales consisten fundamentaimente en las formulas de tratamiento y saludo (solemne, formal, informal, amistoso, vulgar, intimo).

El uso de los marcadores de relaciones sociales depende fundamentalmente del contexto situacional en el que se encuentran los participantes en el proceso de la comunicación, contexto que por una parte depende del nivel de trato entre los interlocutores: a menor grado de conocimiento se produce una mayor formalidad y viceversa, a mayor familiaridad una menor formalidad; por otra parte, de la posición de dominio o rango preestablecida entre éstos. Así, las fórmulas de tratamiento que utilizamos con amigos serán diferentes a las que empleamos con desconocidos en un debate académico. En el primer caso utilizaríamos aquéllas de tipo amistoso, pues nos encontramos en un ambiente relajado. En el segundo caso recurriríamos a las formales, ya que dicho ambiente requiere una cierta corrección en el trato y habla.

Las convenciones de cortesía consisten en las estrategias que tienen como objeto no dañar la imagen o minimizar los actos contra ésta. Dentro de éstas se distingue entre la cortesía positiva y la cortesía negativa. La primera se utiliza para facilitar la comunicación; así, comprende los enunciados lingüísticos con los que se salvan las divergencias y se expresan admiración, optimismo, atención, afecto, agradecimiento, amistad, hospitalidad, muestras de interés, preocupación por la salud o la suerte de los interlocutores, etc.

La cortesía negativa es aquélla que trata de mantener la autonomía del interactuante. Ésta consiste en una serie de estrategias con las que se expresan actos linguísticos como los que se indican a continuación: actos que intentan minimizar imposiciones o exhortaciones, actos que expresan deferencia, actos que muestran petición de disculpas o arrepentimiento, actos mitigadores, actos pesimistas y actos impersonalizadores. 


\section{EL ANÁLISIS DEL GÉNERO}

La metodología del análisis del género se originó en el ámbito de la lingüística angloamericana y ha demostrado ser de gran utilidad en la enseñanza de lenguas para fines específicos. Existen numerosas propuestas para la realización de este análisis. Aquí hemos escogido la que realizan las profesionales del Inglés para Fines Específicos, los profesores Cortés de los Ríos y Cruz Martínez (2001: 429-439), pues se basan a su vez en el prestigioso investigador Alcaraz Varó (2000: 131-164) y se ajustan, a nuestro modo de ver, magistralmente a la didáctica de las lenguas para fines específicos, como es el caso del alemán para fines turísticos que impartimos en la Universidad de Almería; ésta consiste principalmente en el estudio de los siguientes parámetros: la macroestructura, el discurso y la matización.

La macroestructura hace referencia a la distribución estructural de un texto. Por lo que respecta a su objeto principal de estudio, éste se basa en la identificación de dos estructuras funcionales distintas: la estructura primaria (secciones principales) y la secundaria (unidades informativas o movimientos).

El discurso es un elemento constituyente de todo texto y su estudio consiste en la identificación de las modalidades discursivas: discurso descriptivo, discurso argumentativo, discurso narrativo y discurso explicativo.

Por último, la matización es un elemento que necesariamente debe aparecer en la correspondencia comercial, ya que es fundamental para lograr una comunicación óptima y sortear posibles conflictos con los interlocutores. Para efectuar su análisis se deben identificar los elementos lingüísticos que emplea el emisor para expresar principalmente cortesía, reserva, discreción cautela o diplomacia.

\section{LA CORRESPONDENCIA COMERCIAL-TURÍSTICA EN LAS CLASES DE ALEMÁN PARA FINES TURÍSTICOS}

Como mencionábamos al principio del presente estudio, los estudiantes de Turismo deberán con toda seguridad ocuparse de la correspondencia comercial-turística en sus futuras actividades, que en numerosas ocasiones deberá ser realizada en varios idiomas, entre los que, sin duda alguna, se encontrará el alemán. Así pues, entendemos que esta materia debería ser impartida en las clases de lengua alemana para fines turísticos. Cabe mencionar al respecto que esta temática suele aparecer en los programas elaborados por los compañeros pertenecientes a dicha área, así como en numerosos libros de textos sobre la referida materia. 
Una gran parte de los escritos de la correspondencia comercial-turística versa sobre el alquiler de habitaciones. Éstos adquieren un gran valor en la industria del mundo de los viajes, pues a través de ellos se origina la comunicación entre el cliente y la empresa de servicios turística y se realiza la venta de uno de los productos más importantes de dicho ámbito: el alojamiento en un establecimiento público.

En la misma línea con lo mencionado anteriormente, en nuestras clases nos ocupamos de escritos cuya temática versa sobre el alquiler de habitaciones como, por ejemplo, textos con las siguientes funciones: «petición de información sobre la habitación», «información sobre la habitación», «reserva de habitación» y «confirmación de la reserva».

\section{APLICACIÓN DEL ANÁTLISTS DEL GENERO}

El análisis del género se efectuará en dos textos extraídos de la prestigiosa publicacion alemana sobre la correspondencia comercial Langenscheidts Musterbriefe (Abegg, 2001). Éstos consisten en una «reserva de habitación» y una «confirmación de la reserva». Siguiendo el orden de aparición de ambos textos en el proceso de comunicación, comenzamos con el primero:

\section{Zimmerreservierung}

Peter Schiwon

Leninskij Prospekt 36 - Moskwa

Hotel PACHOWITZ

Lange Str. 90

45307 Essen

DEUTSCHLAND

Moskau, 10. Januar 19...

\section{Teilnahme an der IGEDO, Düsseldorf}

Sehr geehrte Damen und Herren,

Ihr Hotel wurde mir von einem Geschäftsfreund empfohlen.

Für die vom 28. März bis 3. April dieses Jahres in Düsseldorf stattfindende Messe für Damenoberbekleidung benötige ich ein Einzelzimmer mit Dusche oder Bad inklusive Frühstück. 
Da ich am 27. März mit der Aeroflot aus Moskau ankommen werde, wäre ich Ihnen dankbar, wenn Sie mir einen Stadtplan von Düsseldorf und Essen zukommen lassen könnten, aus dem ersichtlich ist, wie ich mit öffentlichen Verkehrsmitteln zu Ihnen kommen kann.

Bitte bestätigen Sie mir die Reservierung schriftlich per Fax. Meine FaxNr. lautet: 007/095/823010.

Besten Dank im Voraus.

Mit freundlichen Grüßen

Peter Schiwon (Abegg, 2001: 135)

\section{A) Macroestructura}

El presente texto es una carta. En este escrito es fácil reconocer la estructura primaria: remitente, dirección del destinatario, fecha, asunto, encabezamiento, corpus, despedida y firma del autor.

La identificación de la estructura secundaria tampoco presenta tantas dificultades; basta con leer los distintos párrafos del corpus, que, por cierto, están separados entre sí por un espacio adicional:

\begin{tabular}{|c|l|l|}
\hline 1 & $\begin{array}{l}\text { Ihr Hotel wurde mir von einem Geschäftsfreund } \\
\text { empfohlen. }\end{array}$ & Oración introductoria \\
\hline 2 & $\begin{array}{l}\text { Für die vom 28. März bis 3. April dieses Jahres in } \\
\text { Düsseldorf stattfindende Messe für } \\
\text { Damenoberbekleidung benötige ich ein Einzelzimmer } \\
\text { mit Dusche oder Bad inklusive Frühstück. }\end{array}$ & $\begin{array}{l}\text { Realización } \\
\text { de la reserva }\end{array}$ \\
\hline 3 & $\begin{array}{l}\text { Da ich am 27. März mit der Aeroflot aus Moskau } \\
\text { ankommen werde, wäre ich Ihnen dankbar, wenn } \\
\text { Sie mir einen Stadtplan von Düsseldorf und Essen } \\
\text { zukommen lassen könnten, aus dem ersichtlich ist, } \\
\text { wie ich mit öffentlichen Verkehrsmitteln zu Ihnen } \\
\text { kommen kann. }\end{array}$ & $\begin{array}{l}\text { Petición } \\
\text { de información sobre } \\
\text { la situación del hotel }\end{array}$ \\
\hline 4 & $\begin{array}{l}\text { Bitte bestätigen Sie mir die Reservierung schriftlich } \\
\text { per Fax. Meine Fax-Nr. lautet: 007/095/823010. }\end{array}$ & $\begin{array}{l}\text { Petición } \\
\text { de confirmación } \\
\text { de la reserva }\end{array}$ \\
\hline 5 & Besten Dank im Voraus. & Agradecimiento \\
\hline
\end{tabular}




\section{B) Discurso}

En los apartados del corpus predominan las siguientes modalidades discursivas: primero; narrativo; segundo: explicativo y argumentativo; tercero: argumentativo; cuarto: argumentativo; quinto: descriptivo.

C) Matización

Los elementos matizadores en el texto sirven principalmente para expresar peticiones corteses, de modo que atenúan el carácter de imposición de éstas. Éstos consisten en una implicatura (segundo apartado del corpus), así como en la utilización del Konjunkitu y de una oración condicional (tercer apartado textual).

\section{Bestätigung der Zimmerreservierung TELEFAX}

an: Herrn Peter Schiwon, Moskau

Fax: 007/095/823010

Von: Hotel PACHOWITZ, Essen

Fax: $++49 / 201 / 230897$

Datum: 18. Januar $19 \ldots$

\section{Thre Zimmerbestellung vom 10.01.19...}

Sehr geehrter Herr Schiwon, wir danken für Ihr Schrciben vom 10. dieses Monats und bestätigen Ihre Hotelreservierung wie folgt:

1 Einzelzimmer mit Dusche/WC vom 27.03.19... bis einschließlich 03.04.19.. zum Preis von 180,00 DM pro Tag bei Zahlung in bar, per Scheck oder Kreditkarte am Abreisetag.

Die Buchung ist verbindlich, sofern sie nicht mindestens 14 Tage vorher schriftlich oder telefonisch storniert wird.

Wir schicken Ihnen mit separater Post eine Beschreibung der Lage unseres Hotels mit einem Hotelprospekt sowie einen Stadtplan, aus dem sowohl die Zufahrtswege zwischen Düsseldorf und Essen als auch die zur Verfügung stehenden öffentlichen Verkehrsmittel ersichtlich sind.

Wir wünschen Thnen einen guten Flug nach Düsseldorf und freuen uns, Sie am 27.03. in unserem Hause begrïßen zu dürfen.

Mit freundlichen Grüßen,

Marianne Ulrich

Manager Hotelreservierungen (Abegg, 2001: 135) 
A) Macroestructura:

El escrito está en formato de fax. En estas manifestaciones textuales la estructura primaria suele ser fácilmente reconocible: destinatario, remitente, fecha, asunto, encabezamiento, corpus, fórmula de despedida y firma del autor.

La estructura secundaria, por el contrario, no resulta ser tan fácil de reconocer. Para ello se debe leer el corpus de la carta con mayor atención:

\begin{tabular}{|c|c|c|}
\hline 1 & Wir danken für Ihr Schreiben vom 10. dieses Monats & Oración introductoria \\
\hline 2 & $\begin{array}{l}\text { Und bestätigen Ihre Hotelreservierung wie folgt: } \\
1 \text { Einzelzimmer mit Dusche/WC vom } 27.03 .19 \ldots \text { bis } \\
\text { einschließlich } 03.04 .19 \ldots \text { zum Preis von } 180,00 \mathrm{DM} \\
\text { pro Tag bei Zahlung in bar, per Scheck oder } \\
\text { Kreditkarte am Abreisetag. }\end{array}$ & $\begin{array}{l}\text { Confirmación de la } \\
\text { reserva de habitación }\end{array}$ \\
\hline 3 & $\begin{array}{l}\text { Die Buchung ist verbindlich, sofern sie nicht } \\
\text { mindestens } 14 \text { Tage vorher schriftlich oder } \\
\text { telefonisch storniert wird. }\end{array}$ & Validez de la reserva \\
\hline 4 & $\begin{array}{l}\text { Wir schicken Ihnen mit separater Post eine } \\
\text { Beschreibung der Lage unseres Hotels mit einem } \\
\text { Hotelprospekt sowie einen Stadtplan, aus dem } \\
\text { sowohl die Zufahrtswege zwischen Düsseldorf und } \\
\text { Essen als auch die zur Verfügung stehenden } \\
\text { offentlichen Verkehrsmittel ersichtlich sind. }\end{array}$ & $\begin{array}{l}\text { Envío de información } \\
\text { sobre la localización } \\
\text { del hotel }\end{array}$ \\
\hline 5 & $\begin{array}{l}\text { Wir wünschen Ihnen einen guten Flug nach } \\
\text { Düsseldorf und freuen uns, Sie am 27.03. in unserem } \\
\text { Hause begrüßen zu dürfen. }\end{array}$ & $\begin{array}{l}\text { Deseo de buen viaje al } \\
\text { cliente }\end{array}$ \\
\hline
\end{tabular}

\section{B) Discurso}

En los apartados del corpus del fax se pueden identificar las siguientes modalidades discursivas: primero: descriptivo; segundo, tercero y cuarto: explicativo; quinto: argumentativo.

C) Matización

En el texto aparecen dos matizadores del discurso que tienen como función principal evitar el grado imperativo del mensaje. Éstos consisten en dos nominalizaciones: ... bei Zahlung in bar, per Scheck oder Kreditkarte am Abreisetag. (segundo apartado); Die Buchung ist verbindlich... (tercer apartado). 


\section{DESARROLLO DE EIERCICIOS}

Cada uno de los parámetros, por medio de los que se realiza el análisis del género, actúa como elemento idóneo para la elaboración de actividades destinadas a la asimilación de los referidos elementos sociolingüísticos. La macroestructura puede servir para el desarrollo de ejercicios que tienen como fin la localización de las fórmulas de tratamiento y saludo (solemne, formal, informal, amistoso, vulgar, íntimo).

La matización y el discurso resultan interesantes para el desarrollo de actividades destinadas a la práctica de las convenciones de cortesía.

A continuación presentamos la propuesta de actividades para cada uno de los textos.

Ejercicios para el texto «reserva de habitación»:

1) Finden Sie die Hauptabschnitte des Textes heraus.

2) In welchen Hauptabschnitten des Textes gibt es Elemente zur sprachlichen Kennzeichnung sozialer Beziehungen?

3) Finden Sie die Informationseinheiten des Briefkorpus heraus.

4) In welchen Informationseinheiten des Briefkorpus gibt es Elemente zur sprachlichen Kennzeichnung sozialer Beziehungen?

5) Von welcher Diskursmodalität sind die verschiedenen Abschnitte des Briefkorpus geprägt?

6) Schauen Sie sich die Abschnitte des Briefkorpus, die von der argumentativen Diksursmodalität geprägt sind, näher an und versuchen Sie folgende Fragen zu beantworten: Welcher „Hecken“ (Hedges, Matizadores) bedient sich der Briefverfasser zur Formulierung der Reservierung, sowie der Bitte um einen Stadtplan. Werden mittels dieser sprachlichen Mittel höfliche Bitten ausgedrückt? Wird mittels dieser sprachlichen Mittel die Befindlichkeit des Textrezipienten berücksichtigt (negative Höflichkeit)?

Ejercicios para el texto «confirmación de la reserva»:

1) Finden Sie die Hauptabschnitte des Textes heraus.

2) In welchen Hauptabschnitten des Textes gibt es Elemente zur sprachlichen Kennzeichnung sozialer Beziehungen?

3) Finden Sie die Informationseinheiten des Briefkorpus heraus.

4) In welchen Informationseinheiten des Briefkorpus gibt es Elcmentc zur sprachlichen Kennzeichnung sozialer Beziehungen? 
5) Von welcher Diskursmodalität sind die verschiedenen Abschnitte des Briefkorpus geprägt?

6) Warum wendet sich der Textverfasser im zweiten und dritten Abschnitt des Briefkorpus nicht direkt an den Textrezipienten? Sind das abmildernde Formulierungen? Wozu benutzt er dabei Nominalisierungen (Zahlung, Buchung)? Handelt es sich dabei um ein sprachliches Mittel, das die Heckenfunktion bewirken soll? Sollen diese Nominalisierungen zur Berücksichtigung der Befindlichkeit des Textrezipienten bzw. zur Beibehaltung der negativen Höflichkeit dienen?

\section{CONCLUSIONES}

El análisis del género que hemos presentado en el presente trabajo ha demostrado una gran utilidad en el desarrollo de tareas que tienen como fin la asimilación de los elementos sociolingüísticos básicos que aparecen en la correspondencia comercial-turística en lengua alemana. Por una parte, se pueden elaborar ejercicios que consisten en la localización de las fórmulas de tratamiento y saludo, así como de las estructuras del texto en cuestión. Por otra parte, se facilita el diseño de ejercicios destinados a la adquisición de las estrategias de cortesía comunicativa y de los elementos matizadores más importantes para la redacción de escritos pertenecientes al referido ámbito.

\section{REFERENCIAS BIBLIOGRÁFICAS}

ABEGG, B. (2001): Langenscheidts Musterbriefe. 100 Briefe für Export und Import, Berlín, Langenscheidt.

Alcaraz Varó, E. (2000): El Inglés profesional y académico, Madrid, Alianza Editorial.

Beaugrande, R. y W. Dressler (1981): Introduction to Text Linguistics, Londres, Longman.

Brown, G. y G. Yule (1987): Discourse Análisis, Cambridge, Cambridge University Press.

Clemen, G. (1998): Hecken in deutschen und englischen Texten der Wirtschaftskommunikation. Eine kontrastive Analyse, Siegen, Univesität Gesamthochschule Siegen.

Cook, G. (1989): Discourse, Oxford, Oxford University Press.

Cortés De Los Ríos, M y M. Cruz Martínez (2001): «La metodología didáctica del IPA. Un caso práctico en el inglés de los negocios: la carta comercial», en Posteguillo F.; S. Fortanet; J. C. Palmer (eds.) (2001): 
Meihodology and new iechnologies in languages for specific purposes, Castelló de la Plana, Publicacions de la Universitat Jaume I.

Dolón, R. y F. Suau (1997): Análisis del discurso: Competencia discursiva en ámbitos profesionales: el contexto de la empresa, Valencia, Lynx.

HaII, W. (1983): Fachkommunikation: Entwicklung, linguistische Konzepte, betriebliche Beispiele, Berlín, De Gruyter.

HeRnÁNDEZ Medina, J. J. (2004); Los análisis del género, discurso y registro en el alemán para fines turísticos, Almeria, Universidad de Almería.

Hutchinson, T. y A. Waters (1987): English for Specific Purposes. A learning-centred approach, New York, Cambridge University Press.

Kennedy, C. y R. Bolmuo (1984); English for Especific Pluposes, Hong Kong, Macmillan.

Kinneavy, J. L. (1980): A Theory of Discourse, Nueva York, Norton.

SwALES, J. M. (1990): Genre Analysis: English in academic and research settings, Cambridge, Cambridge University Press.

Trim J.; B. North; D. Coste, (2001): Gemeinsamer europäischer Referenzrahmen für Sprachen: lernen, lehren, beurteilen, Berlín, Langenscheidt. 


\title{
LA LITERATURA COM A SÍMPTOMA D'UNA SITUACIÓ DE CONFLICTE LINGÜÍSTIC: TRES NOVEL·LES VALENCIANES DEL SEGLE XXI
}

\author{
AbILI Jurado Dueñas \\ IES Riba-roja de Túria, València) \\ EMPar Rodrigo Cañete \\ Col-legi Mare de Déu dels Socors, Benetússer, València
}

$\mathbf{E}$ $\mathrm{N}$ aquesta comunicació pretenem demostrar que les produccions literàries que es generen en un àmbit lingüísticament conflictiu posen de manifest precisament una situació cultural precària, l'existència d'un conflicte lingüístic i, conseqüentment, el procés, en fase avançada, de substitució lingüística. Per a demostrar aquesta tesi, hem triat tres llibres d'autors solvents i que en el seu dia van obtindre bones crítiques; aquests són: El Mut de la Campana, de Josep Lozano; Quina lenta agonia, la dels ametlers perduts, de Toni Cucarella; i Espècies protegides, de Ferran Torrent. Els tres han constituït en el moment de la seua eixida esdeveniments literaris: Lozano és un escriptor d'escassa producció; ha guanyat nombrosos premis i una de les seues obres, Crim de Germania (1980), és una de les novelles valencianes contemporànies més llegides; a més, feia anys que no havia publicat res i la seua novel·la s'esperava impacientment. Cucarella va guanyar amb Quina lenta agonia, la dels ametlers perduts l'Andròmina de narrativa dels Premis Octubre del 2003. Ferran Torrent és l'escriptor valencià viu més popular, i, per tant, un dels més venuts; tant Espècies protegides, com la seua antecessora, Societat limitada, es van mantindre durant diverses setmanes al capdavant de la llista dels llibres de ficció en llengua catalana més venuts que publica setmanalment Avui. A part de la demostrada importància de la creació artística, hem seleccionat aquestes novel-les perquè coincideixen en uns llocs comuns que ens ajudaran, més endavant, a formular les corresponents conclusions. Els criteris de selecció són, doncs, els següents:

Les tres novel-les estan situades geogràficament al País valencià: la ciutat de València en la de Lozano i en la de Torrent, i un barri de Xàtiva, Les Eretes, en la de Cucarella. En els tres casos, l'espai juga un paper temàtic fonamental: no només és un escenari on se'n desenvolupa l'acció i conviuen els personatges, sinó que és l'espai qui genera l'acció i els personatges. Així, si haguérem de 
formular breunent el tema de les tres novelles, necessàriannent haurien de mencionar-ne l'espai.

En les tres novel-les hi ha una recerca lingüística amb la intenció de dignificar la riquesa expressiva del valencià, sense discutir per això la inclusió en l'àmbit lingüístic de la llengua catalana.

La cultura pròpia i el seu estat decadent n'és marc temàtic.

El Mut de la Campana, de Josep Lozano, és la història del frare dominic Bernat Crestalbo contada per ell mateix al final dels seus dies. La seua vida a la València del segle XVII està marcada per l'omnipresència de l'església catòlica i del seu braç repressor, la Inquisició, el temor de la qual, unit a una prodigiosa memòria per a retenir sermons, espenten el jove Bernat a entrar en la vida religiosa en una espècie de fugida cap endavant. No obstant, l'exigència del compliment dels vots, especialment el de castedat, provoca en el nou frare una fort tensió moral, accentuada en conéixer i enamorar-se d'una dona casada i de dubtós passat, Constança.

La decadència moral del personatge, resolta finalment amb la mutilació dels seus genitals, s'uneix simbòlicament a la decadència d'una ciutat, València, que per moments arracona els personatges per a erigir-se en vertadera protagonista de la novel la. La València en la qual es mouen els personatges de Lozano és una ciutat que compta amb cinquanta esglésies i molts monestirs (d'aiguns, avui no n'existeix ni tan sols l'edifici: La Corona, Sant Joan de Ribera, San Francesc, Sant Agustí...); una ciutat fiscalitzada pels tribunals de l'església (en la memòria del xicotet Bernat quedarà marcada per sempre l'execució «per sodomites» de tres hòmens en un acte multitudinari); aquesta ciutat reprimida crea els seus propis monstres, els orats, de gran valor simbòlic en la novel-la: el Mut de la campana i la Monya, encarregats tots dos d'anunciar, a mode d'oracle, de quin costat pecaminós li vindran els problemes al jove Bernat; en aquesta ciutat també s'intueix un canvi lingüístic: la Inquisició, la institució més temuda, utilitza una altra llengua: el castellà, així mateix, s'hi representen en castellà espectacles teatrals de Tirso de Molina (Fra Bernat n'assisteix a una representació del Don Gil de les calzas verdes) o de Lope; finalment, València és també reprimida per la pesta, que és precisament qui acaba amb l'amada de Bernat, i que deixa la ciutat «somorta, afligida, sense esperança» (265).

D'altra banda, aquesta València és ben diferent de l'actual: avui no hi ha muralles, ni portes, ni portals (en la novel-la apareixen el de Catalans, el de Sant Vicent, el del Coixo...); tampoc no hi existeixen ja les places de les Gallines, ni la dels Porxets, etc; finalment, la València de Lozano és autènticament el Cap i Casal del Regne, que pareix existir com a tal i no com la reunió «en comunitat» de tres províncies d'un estat modern. Tampoc creiem casual l'elecció d'un espai important de la novel·la: Alèdua, el poble on viu el seu avi i on, per primera vegada, sent el desig sexual en veure una xicota nua 
prenent un bany al riu; Alèdua és un poble ja en regressió demogràfica en l'època de la novella a causa de l'expulsió dels moriscos i, avui en dia, és un poble inexistent. Per això no ens sorprén que recorde el poble de l'avi quan, al final dels seus dies, decideix deixar els predicadors i quedar-se a València, perquè, en definitiva: «aquesta és la meua terra, en les hores bones i en les hores dolentes, on he viscut, he amat $i$ he sofert, $i$ talment com el meu avi estimava el poble d'Alèdua, també jo estime la meua ciutat i ací vull morirme» (308).

Mereix una reflexió la llengua de la novel'la, ja que és resultat d'una profunda investigació de la vida lingüística valenciana del segle XVII, un autèntic monument a la llengua que ha merescut un elogiós article de Joan Solà des de la seua columna en Avui. En l'article, Solà destaca el treball lingüístic de Lozano, un bon escriptor que és capaç de «aixecar-nos a tots plegats de la vida vergonyosa de la llengua del carrer» i de traure a la llum «la riquesa amagada de la nostra llengua»; en el mateix article, Solà reconeix haver-ne aprés girs, expressions, matisos semàntics d'algunes paraules i fins i tot la preposició que dóna títol al seu article, «barat a».

Per a acabar amb El Mut de la campana, cal concloure que res en aquest llibre no és casual: la doble mutilació (la dels genitals del protagonista i la llengua del personatge que dóna el títol al llibre, el Mut de la Campana), la mort del desig i de la paraula respectivament, la mort en definitiva, exigeixen una ciutat decadent, una ciutat que queda buida després de la pesta, una ciutat que avui en dia ja no existeix. No obstant, seria possible invertir els termes de la premissa anterior? És a dir: si l'autor el que pretén és reflectir una ciutat (o una cultura) que s'extingeix a poc a poc, què millor que la història d'un home que renuncia al desig, a l'amor, a la vida, i que acaba mutilant-se'n el propi sexe?

Quina lenta agonia, la dels ametlers perduts, de Toni Cucarella descriu un temps i un espai que, com indica el títol, agonitza. La novel-la narra les decadents vides de les gents que viuen a Les Eretes, un barri als afores de Xàtiva destinat a la desaparició per la voracitat de la ciutat i del progrés. La novel-la no segueix una lògica narrativa tradicional, sinó que es compon de diferents estampes que l'autor agrupa en tres grups que van intercalant-se al llarg de la novel-la:

En els quaranta-dos capítols sota l'epígraf Els morts i els vius, un narrador en primera persona recorda la seua infància a Les Eretes des del present, ja fora d'aqueix espai que ha desaparegut. És així com coneixem la seua família, marcada per la desgràcia de la guerra civil i per la misèria de la postguerra, entre els membres de la qual sobreïx l'àvia Tònia, àlies la Republicana, confident d'una neboda morta als sis anys (Marta la morta), i que compleix regularment amb l'ofrena al seu marit, l'avi Bastià, afusellat durant la guerra 
civil i que, per sorpresa, apareix viu, encara que desmemoriat, cap al final de la novel-la; segons pareix, l'avi va poder escapar a la mort i fugir a França; de tornada, Sebastià Morell s'ha convertit en Sébastien Morel, i sembla haver perdut la raó (només recita desgavellats parlaments en francés). A aquesta aparició i les seues conseqüències, s'hi uneix com un altre nucli narratiu important el romanç de la germana del narrador amb un guàrdia civil, un «civilero»; això ens permetrà conéixer els judicis i les actituds de la família, derrotats en la guerra, envers un membre que, metonímicament, representa el poder. Mentre aquesîes dues històries s'hi desenvolupen, el narrador presenta la quotidianitat de la seua infància: els seus amics i les famílies respectives, els jocs, cançons, el despertar de la sexualitat, l'escola, la creença en el sobrenatural (fantasmes, donyets, encanteris...).

Els catorze capítols davall l'epígraf Quina lenta agonia... presenten els personatges de Les Eretes en breus histories quotidianes.

Per últim, en els cinc capítols sota l'epígraf l'Ahuixador de mosques, Pepiu, un dels amics del narrador de Els morts i els vius, és contractat pels pares de Vicent Martí, un xic colgat al llit en estat vegetatiu, perquè li espante les mosques, ja que, segons la mare del desgraciat, les mosques avisen la mort. Amb la coincidència de l'arribada de l'home a la lluna, i en haver pres cons. ciència Pepiu de la desgràcia de Vicent, l'ahuixador de mosques pren el coixí i acaba amb la lenta agonia del malalt.

Així, l'autor tria per a finalitzar la novel-la una fita històrica, l'arribada de l'home a la lluna, que constitueix el canvi d'una època a una aitra, canvi que comporta la desaparició de moltes de les coses anteriors, com tot aqueix món de Les Eretes que es deixa amb ell tota una cultura. Com a contrapunt a aquest avanç de la humanitat, Cucarella ho fa coincidir amb tres morts, la més important, la que acaba amb l'agonia de Vicent Martí; a més, ho fa coincidir amb la pèrdua de la memòria de l'avi Bastià, fet que constitueix en si mateix la victoria final dels vencedors de la guerra, la rendició de l'àvia Tònia al final de la novel·la. El barri també simbolitza una espècie de llimbs en què van quedar els vençuts de la guerra i d'on, consequientment, tots volen fugir: «tanmateix s'hi volien anar, viure-hi era una condemna» (11), «mosatros som de Les Eretes. Allí no vivim persones. Allí es moren els ametlers, i per no hi haure no hi ha ni albellonar. I si el fan, ja pots fer-te la idea que serà per tirarmos casa nostra i fer-hi pisos nous que mosatros no podrem pagar» (54). Així, cal llegir-ne el títol metafòricament, la lenta agonia d'uns ametlers perduts ho és també de tota aquesta galeria de persones i de tot allò que representen.

Entre les coses que desapareixen després d'aquesta lenta agonia figura la llengua. És per això que en el llibre, Cucarella s'esforça per reconstruir fidelment la llengua que parlen els seus (no debades la novel-la està dedicada a sa mare, al seu avi i a la seua besàvia) en una recerca de particularismes 
lingüístics, de lèxic genuí, de cançons populars, de frases fetes i refranys, de rondalles, etcètera que, com els ametlers perduts sense amo, estan en perill d'extinció. També Cucarella s'esforça a subratllar que la llengua del poder, representada per l'església (el rector José María, 212-213), l'escola («ací es parla en cristià!», els crida el mestre als seus alumnes quan els hi sent parlar valencià, 99) i la guàrdia civil (Alberto, el nuvi de Carmeta, germana del narrador), no és la de la gent de Les Eretes, sinó el castellà, cosa de la qual són molt conscients: «Als civileros els pega tort quan els parlem en valencià. Si davant d'un d'ells se te n'escapa una, ni que seguisca per distracció, d'un tave et giraran la cara del revés i de l'endret» (55).

Així, doncs, Cucarella descriu aquest món en agonia dels vençuts de la guerra i ho posa en contraposició amb l'arribada a l'home a la lluna, posant de manifest la substitució del medi rural, on la desaparició de les seues gents representa també la desaparició d'un patrimoni, pel món inhumà i impersonal que imposa el progrés. En aquest sentit, l'espai de Les Eretes és vist per l'autor des de dues perspectives contradictòries: d'una banda, és un espai de reclusió dels vençuts, expulsats de la societat $i$ abandonats, com els ametlers, a patir una lenta agonia. D'altra banda, és l'espai de la infància, de la iniciació personal, un espai que el narrador a penes reconeix (11); s'uneixen, doncs, dues enyorances diferents, la de la infància perduda i, d'una altra part, la d'un espai (i tot el que representa) desaparegut.

En Espècies protegides, de Ferran Torrent, un empresari proscrit pels poders polítics i econòmics, Juan Lloris, pretén arribar a l'alcaldia de València valent-se d'un partit nacionalista, el Front, al qual havia ajudat a entrar en el parlament autonòmic amb una interessada donació. Com que el perfil polític de l'empresari es distancia molt del que representa el partit nacionalista, aquests, assessorats per un conseller professional de polítics i empresaris, li ofereixen ajuda per a fer-se amb la presidència del València C.F., equip de futbol que viu un gran moment esportiu i també social; a la seua carrera cap a la presidència del club esportiu contribuirà el fitxatge d'una estrela africana, proporcionada per un representant català i el seu ajudant, un pròfug de la justícia per delictes d'estafa i relacionat, familiarment fins i tot, amb gents del Front. Aquest fitxatge ens permet conéixer com el València col-labora amb diversos equips africans en la formació de futures estreles; així mateix ens permet conéixer l'existència de dobles contractes, en els que hi ha un desfasament important entre el que «cobra» l'equip africà, i el que «paga» l'equip valencià; més tard hi descobrirem que aquest desfasament serveix per a finançar el Partit Conservador. Aquest fet li val la destitució a la negociadora ofícial del Partit Conservador, Júlia Aleixandre: desconeixedora del finançament encobert del seu partit, ofereix ajuda a Lloris i al partit nacionalista per a complir el seu objectiu d'arribar a la presidència de la societat, per a això 
contacta amb el màxim accionista del València $i$ li convenç perquè en venga les seues accions a Lloris; a canvi, el Front devia no oposar-se a la realització d'un gran projecte urbanístic del Govern valencià; convertida en cadàver polític per la seua pròpia formació, Júlia Aleixandre ofereix els seus serveis de conseller a Lloris, que en aquest moment ja és president del València i gaudeix d'uns nivells de popularitat molt superiors als de qualsevol polític valencià, inclosos president de la Generalitat i alcalde de València. Tot aprofitant aquesta sobtada fama, Aleixandre li proposa llançar-se a la recerca de l'alcaldia de València, amb un programa que inclou com a promesa estrela la construcció d'un nou estadi per al València C.F., ja que el vell Mestalla s'ha quedat xicotet per a albergar «l'equip més potent d'Europa» (296). L'amenaça de la irrupció de Lloris en l'escena política provoca la unió de tots els partits polítics que veuen trencat el sistema tradicional de la democràcia. El final de la novel-la escenifica tota aquesta gran foguera de les vanitats amb l'incendi (provocat per un piròman afí a Lloris) de Mestalla, que constitueix «un incendi d'estupidesa» (312) al «laberint d'imbecil-litat» (314) a què pareix haver arribat la societat valenciana.

Com les dues novel-les anteriors, constatem que Espècies protegides finalitza amb la destrucció d'un espai important, Mestalla, «un estadi que albergava una pràctica que, abans de convertir-se en un circ, abans d'erigir-se en el negoci més cobejat, fou un camp de batalla on la victoria es dirimia al terreny estricte i exclusiu de l'esport» (312). En un altre costat, el narrador ens explica com en la Televisió Valenciana es retransmet en directe l'incendi de Mestalla, «com si estiguera retransmetent els darrers dies de l'Imperi Romà» (313). Com Roma, la societat corrupta que han començat polítics i empresaris, ha anat corcant-ne els fonaments fins a fer-la emmalaltir. El futbol, doncs, com a metàfora de la substitució de la política per l'espectacle, per la política de parcs temàtics i projectes emblemàtics: pa i circ; el controvertit projecte que apareix en la novel la consisteix en la destrucció de tota una cultura de vida: l'Horta Nord, comarca limítrofa al nord amb la ciutat de València, per a l'ampliació del port i la construcció d'urbanitzacions, cosa que és jutjada així pel narrador: «la construcció del passeig marítim allà on ara només hi havia platges sense sorra encara entusiamava més un poble delerós de sentir-se important. Si més no amb banyador» (33). Un poble, en definitiva, més atent a la superfície de les coses, a l'aparença, que a allò que se n'amaga darrere: tota la ciutat viu amb eufòria el moment del València; les banderes nien en els balcons de la ciutat; la gent passeja amb orgull el seu valencianisme; creix, doncs, l'autoestima social; no obstant, darrere de la grandiloqüència dels triomfs esportius s'amaga tota una retafila de mentides, traïcions, estafes... que només ens pot originar monstres de la mesura de Juan Lloris, aspirant a ser el Berlusconi de València. 
D'altra banda, Ferran Torrent veu amb molt d'escepticisme l'interés dels polítics per la llengua, sobretot pel que fa al partit en el govern, el Conservador, per al que tira més el ciment que l'accent (28), i que està disposat a utilitzar la llengua per a desacreditar els seus adversaris en qualsevol moment. Socialment, Torrent ens mostra alguns dels prejudicis instal-lats en les consciències dels valencianoparlants: per exemple, en un diàleg entre dos personatges valencians, un d'ells imagina un titular de premsa... en castellà (52); en un altre lloc, quan Lloris redacta el contracte de compravenda de l'estrela africana per al València i li'l passa al representant català, aquest se sorprén que no estiga en valencià: «Açò és un contracte seriosós. Firma» (198), li diu per resposta.

En aquesta novel-la, com en les anteriors de Torrent, hi ha un esforç per transcriure dignament la llengua parlada actualment a la comarca de l'Horta, i aconsegueix una llengua àgil, amb flexibilitat de registres $i$, més difícil encara, versemblant. A més, també apareix un personatge català, el representant de l'estrela africana Celdoni Curull, la qual cosa aprofita Torrent per a explotar no sols la relació entre catalans i valencians -Curull reconeix tindre una des-" confiança atàvica pels valencians (43)- sinó també les diferències dialectals, portades quasi a la caricatura en el diàleg entre Curull i Lloris, on l'últim, en no entendre les primeres paraules del català («Segui, Segui, si us plau», 192) està a punt de canviar-se al castellà per a facilitar la mútua comprensió.

Finalment, farem referència a un dels recursos més utilitzats per Ferran Torrent: la ironia. No obstant, es tracta d'una ironia especial, ja que per a la interpretació de la qual es requereixen coneixements sobre el País Valencià. Per exemple, l'elecció del nom del líder del Front, Francesc Petit, ens remet al «real» exlíder del Bloc Nacionalista Valencià, Pere Mayor, recurs que li aprofitava a Torrent per a fer-ne un acudit en Societat limitada: «El petit s'ha fet major». Els atributs dels personatges estan dotats sovint d'una càrrega irònica; el més clar exemple és Rafael Purén, paradigma -caricaturitzat- del valencià: comptable en una empresa de mobles (un dels sectors més tradicionals $\mathrm{i}$ importants en les pIMES dels voltants de la capital), membre important de la Coordinadora de Penyes del València C.F. i... piròman; de fet, la seua passió pel foc s'inicia amb la crema d'una falla (Na Jordana, una de les «grans» de la ciutat) i finalitza, en la novel-la, amb l'incendi de Mestalla. Precisament aquest incendi provoca un demagog discurs de Lloris la inserció del qual en el final de la novel·la podem llegir irònicament: «València és indestructible» (314), proclama als quatre vents. 


\section{CONCTULSTOTSS}

De forma interessada, hem ressenyat de les novel-les anteriors només aquells aspectes que ens ajudaren a arribar a les conclusions que a continuació formularem. No obstant, creiem necessari, abans de buscar les coincidències, assenyalar que les tres novel-les són molt diferents en la construcció formal (punt de vista, narrador, profunditat dels personatges, relacions espai-temps, recursos per a fer avançar l'acció, estil, etcètera); si bé aquests recursos no són motiu d'anàlisi en la present comunicació, sí que posen de manifest la importància de les coincidències, ja que actuen com una superestructura que ens ajudaria a classificar totes tres com a novel-les valencianes contemporànies. Aquestes coincidències les buscaríem en el nivell semàntic a pesar de contiar històries tan diferents: les tres novel-les se situen en un espai decadent i en risc de desaparéixer; Quina lenta agonia, la dels ametlers perduts és el títol que més explícitament subratlla el que acabem de formular: com hem comentat més amunt, els ametlers perduts representaven metafòricament la lenta desaparició del barri de Les Eretes, de les seues gents i, amb elles, de la seua cultura. El títol d'El Mut de la campana també fa referència metonímicament a la castració del sexe del protagonista, que haviem interpretat abans com un símbol relacionat amb la decadència de la ciutat de València. Finalment, encara que el títol d'Espècies protegides té una evident lectura irònica dirigida a la corrupta classe política i empresarial, és també possible fer-ne una interpretació que recolze les nostres tesis, ja que només hi ha espècies protegides quan n'hi ha perill d'extinció.

Així, com veiem en els títols, comptem amb tres obres que se situen en un context decadent. És per això que no ens ha de sorprendre que els autors situen les seues novel les en el temps en què ho fan: Lozano situa la seua en el segle xvII, que comença amb l'expulsió dels moriscos, que suposa la pèrdua d'un terç de la població del Regne de València, i que acaba amb la Guerra de Successió i la pèrdua dels Furs del Regne (1707); a les crisis demogràfiques, agrícoles i comercials, cal afegir els assots de la pesta; d'altra banda, s'ha iniciat ja una pèrdua considerable del prestigi de la llengua a favor del castellà, idioma que comencen a adoptar les classes altes. Cucarelia per la seua banda situa la novella en els anys seixanta del segle Xx, en plena dictadura franquista, amb la repressió exercida als vençuts i a les «altres» cultures espanyoles, les llengües de les quals van ser objecte d'un intent d'extermini en fer-les invisibles en la vida oficial (administració, ensenyament, mitjans de comunicació, forces de seguretat, església...) i en promocionar una sèrie de prejudicis que negativitzaven la imatge de la llengua entre els parlants. Ferran Torrent, finalment, tria el temps present com a marc per a la scua novcl-la; cncara que textos legals (Constitució, Estatut d'Autonomia, Llei d'Ús i Ensenyament del 
Valencià) sancionen la protecció i promoció de la llengua i plantegen l'escenari per a la posada en marxa d'un procés de normalització lingüística, els percentatges d'ús de la llengua continuen descendint $i$ aquesta s'ha erigit des de la transició en tema per a nombroses discussions bizantines que només n'entrebanquen l'avanç social; així mateix, assistim a la conquista voraç dels agents constructors del litoral valencià o de l'abans ubèrrima horta de València, tot això davant de la passivitat (i moltes vegades, col·laboració) de les forces polítiques. En Espècies protegides, finalment, cal subratllar la decadència moral dels personatges, polítics i empresaris, d'aquesta particular foguera (millor dit, falla) de les vanitats, en la qual Torrent, inflexible, no n'indulta cap ninot.

D'aquestes tres novel-les, la de Ferran Torrent és l'única traduida al castellà; així mateix, cal assenyalar que, durant diverses setmanes, Espècies protegides va estar en el primer lloc de la llista de llibres més venuts en llengua catalana que publica setmanalment el diari Avui. Precisament l'edició en castellà d'aquesta novel-la apareixia ressenyada recentment per Santos Sanz en el suplement cultural del diari El Mundo; Sanz Villanueva qualificava la novel-la de Torrent de «amenísima y valiente, y supongo que especialmente revulsiva en su tierra, pues algo en ella suena a historias en clave», com aquelles ironies d'interpretació particular a què hem fet referència més amunt. L'autor de la ressenya destaca el «profundo localismo costumbrista» de la novel-la de Torrent, caracterització que podrien compartir, pel que s'ha vist en aquesta comunicació, les novel·les de Cucarella i de Lozano. Aquest fet ens pot portar a formular-nos la pregunta següent: és possible llegir aquestes obres des de fora, és a dir, sense conéixer el context en què es produeixen i, més, fins a quin punt és possible llegir-les en una altra llengua renunciant per tant a l'apreciació lingüística? En resum: Es poden llegir aquestes obres per algú alié al món lingüístic valencià? Sanz Villanueva comenta en l'article que, en Espècies protegides, aquest localisme es pot gaudir «metafòricament», i que «no impide de ninguna manera que percibamos un retrato general de hábitos perniciosos». D'aquesta manera, encara que admetem la lectura «especial»o, com comenta Sanz, «revulsiva», que en puga fer un lector amb un coneixement enciclopèdic sobre tots els aspectes de la cultura i societat valenciana, les tres novel-les es poden llegir, com tantes altres produccions artístiques, com a signes dels temps que vivim, que viu la cultura en què es produeixen, en definitiva, la literatura com a símptoma. Així hem de llegir els finals de les tres novel-les, que conclouen de manera gens casual amb un fet fatal: la mutilació dels genitals de Fra Bernat en El Mut de la campana; la mort de Vicent Roca, la desmemòria de l'avi Bastià i la desaparició de Les Eretes en Quina lenta agonia, la dels ametlers perduts; i, finalment, l'incendi de Mestalla en Espècies protegides. Mutilacions, morts i incendis que llegim simbòlicament com 
a símptomes d'una situació cultural anormal en què, com tantes altres vegades, els intel-lectuals exerceixen de notaris de la realitat $i$ de consciència d'una societat adormida que necessita que li recorden el seu patrimoni historic, natural, artístic i lingüístic.

En aquest sentit, arribem a la conclusió que el País valencià, la seua tradició cultural, la llengua, estan en el centre temàtic en les tres novel-les, subratllantne el risc de desaparició. Així mateix, es pot afegir que els autors es marquen com a objectiu important la crida d'atenció sobre l'estat de la cultura pròpia, $\mathrm{i}$ ací podem emmarcar la importància de l'expressió lingüística, digníssima, en les tres novel-les; amb això, els autors mostren les possibilitats expressives de la llengua pròpia, concretament de la varietat valenciana, posant en relleu que es tracta d'una llengua amb un cabal lèxic autònom, genui i suficient per a designar significats per als que moltes vegades s'utilitza una altra llengua (el castellà) o una altra varietat ('oriental); una llengua capaç d'adaptar-se a diferents registres, inclòs un de colloquial sense vulgarismes ni barbarismes, i per a la construcció del qual els autors no han recorregut a invencions o artificialitats, i n'han aconseguit un de versemblant. Es tracta, en definitiva, d'una reivindicacio de la riquesa lingǘstica (i, per extensió, cultural) del valencià: al mateix temps que manifesten els símptomes d'una situació de conflicte lingüístic, les tres novel les demostren la capacitat de la llengua per a convertir-se en vehicle d'expressió d'interessants aventures literàries. En conseqüència, hi ha una reivindicació de la varietat dialectal valenciana, del dialecte tantes vegades injuriat $\mathrm{i}$ arraconat a llibrets de falla $\mathrm{i}$ a personatges típics de barraca, arròs i tartana, un dialecte incapaç d'expressar conceptes alts i tan necessitat, per tant, de la dignificació que demostrara el contrari. En tó cas, això no vol dir que els autors neguen l'adscripció del valencià a la llengua catalana, de fet, en dues de les tres novel-les (Quina lenta agonia... i Espècies protegides) hi ha personatges catalans que s'expressen en la varietat oriental de la llengua; tampoc creiem que els autors aprofundesquen en les diferències dialectals, sinó més aviat en el patrimoni de la llengua, amb la qual cosa no fan sinó dignificar la llengua catalana en la seua totalitat, aportant-hi solucions diferents (alternatives) a les de la varietat oriental (recordem l'article de Solà en Avui).

Les «històries en clau» que ens preguntàvem més amunt si n'obstaculitzarien la interpretació a un lector verge en qüestions valencianes, han de mostrar a aquest, almenys, la malaltissa situació d'un món cultural que, paradoxalment, és capaç de produir textos d'interés literari indubtable. Així, hi ha en aquestes novel-les valencianes una crida d'atenció en dos sentits: segles enrere van començar les agressions a la llengua, activant-se el conflicte linguístic $i$, per tant, el procés de substitució lingüística; no obstant, i tot i perill en què es troba, la llengua continua tenint les possibilitats expressives que 
permeten un ric patrimoni; els autors, clarament, han pres el seu partit i reivindiquen, doncs, la seua llengua com a possible llengua literària. Finalment, cal afirmar la necessitat que es continuen produint obres d'aquestes característiques, bé que la seua absència puga significar l'anhelada normalització de la cultura, si és que aquesta no suposa la seua desaparició.

En resum, la lectura de les tres obres ens dóna les conclusions següents:

El valencià es troba en un procés de substitució lingüística que començà segles enrere i que en l'actualitat està en una fase avançada.

Consegüent al conflicte lingüístic, la llengua està perdent patrimoni lingüistic; aquest fet porta els autors a dur a terme una reivindicació de la llengua i, més en concret, de la seua varietat dialectal, amb la intenció de demostrarne la idoneïtat i la capacitat expressiva.

La pèrdua lingüística du aparellada la pèrdua de consciència de pertinença a una comunitat social.

Els autors, conscients de tot això, hi mantenen una actitud crítica i reivindicativa.

Un lector sense coneixements enciclopèdics sobre la realitat valenciana, si bé pot no desxifrar determinats passatges, ha de copsar la situació cultural anormal i la crítica dels autors.

\section{REFERÈNCIES BIBLIOGRÀFIQUES}

Cucarella, T. (2003): Quina lenta agonia, la dels ametlers perduts, València, Eliseu Climent, editor.

LozANo, J. (2004): El Mut de la Campana, Alzira, Edicions Bromera.

SanZ Villanueva, S. (2004): «Especies protegidas», El Cultural, El Mundo, 1-7 de julio: 17 .

SolÀ, J. (2004): «Els en parlo barata cançons», Avui, Especial Sant Jordi, 234: 20 .

Torrent, F. (2003): Espècies protegides, Barcelona, Columna Edicions.

- (2004): Especies protegidas, Barcelona, Planeta. 


\title{
DEFINING TERMS: BILINGUALISM, INTERPRETATION, TRANSLATION, AND CULTURAL AWARENESS. A CASE STUDY
}

\author{
Juan José Martínez Sierra \\ Universitat Jaume I
}

\section{ABSTRACT}

$\mathbf{T}$ HIS paper shows the results of a study whose main goal was to observe a group of bilingual Spanish-English workers at the Communications Center of an American East Coast airport. Using certain ethnographic techniques, I paid attention to their roles looking for clues that allowed me to address the following question: Is it possible to think of that particular group of bilingual employees as interpreters or translators? Such question involves a more complex issue: Can all bilinguals be considered interpreters or translators? It is here where the notion of formal training comes into play. Research suggests that some formal training in necessary communicative skills is paramount; but, at the same time, it acknowledges that some people are able to become interpreters or translators without any academic training, just through practice and experience. I also considered the cultural dimension that affects every act of communication. I reflected on the role that awareness of this dimension played in that particular setting. The findings suggest a misuse of the terms interpretation and translation; the conclusion of the study indicates that these employees can be considered interpreters or translators only on certain occasions. Regarding culture, two different perspectives were detected. Out of the two participants in the study, only one of them had a notion of culture, while the other subject did not have a clear idea of what culture meant, since she limited its definition to that of language.

\section{LITERATURE REVIEW}

What is bilingualism? Hoffman points out that there are many definitions, and that all of them are ultimately arbitrary (1991: 18). Mackey proposes one that can be useful to my purposes. According to him, "We shall [...] consider bilingualism as the alternate use of two or more languages by the same individual" (in Hoffmann, 1991: 16). This definition does not consider the 
aspect of linguistic competence and accuracy, whether the individual should master all skills in every language, or the possibility of using them in similar or different situations (Hoffmann, 1991: 16). However, as suggested above, it is a definition that will suffice for the purposes of this study.

Translators deal with the written word and interpreters with the spoken word. This is something generally agreed in the literature. However, as Potton and Solmo point out, the terms translator and interpreter are often used interchangeably (1995: 196). Moreover, many people do not even know the difference between translating and interpreting. Much can be argued about considering both disciplines as completely independent one from the other, though.

Thus, this issue leads to the debate of whether interpretation and translation should be considered as two separate fields. On the one hand, Krawutschke (1989: 1) claims that "translation and interpretation are separate if at times somewhat related disciplines". On the other hand, Gile (1995: xiii) affirms that many schools have exaggerated the opposition between translation and interpretation, and that both activities perform the same function, which is the re-expression in one language of what was expressed in another. In fact, he believes that "the differences between these two activities are essentially associated with the cognitive stress interpreters face under the pressure of time, but that the similarities far outweigh the differences".

Being a good translator does not necessarily mean that one can be a good interpreter, and vice versa, but, in both cases, a good -or at least appropriate to the specific needs-command of a minimum of two languages is essential. Does it mean that any bilingual individual can be considered either a transiator or an interpreter? Erolinda Budi, a full-time Spanish-language hospital interpreter for 19 years, provides an answer to this question. According to her, not only is it important to have a linguistic background, but also knowledge of the field: «Just because you're bilingual doesn't mean you can be an interpreter» (in Klatt, 1995: 5). Despite this claim, we often find instances of bilingual people -who just happen to speak two languages- doing translation or interpretation work. Gile talks about the many "self-proclaimed interpreters and translators" with a very low level of performance (1995: 2). Following Potton and Solmo (1995: 196), in the case of interpreters -and of translators, too-, knowledge of the language is not enough, since the culture and the customs of a country should also be known; besides, the authors add, a strong background in the topic field is also important for translators and interpreters.

One of the main issues in translation and interpretation studies is the question of appropriate training. Some voices claim that formal training is recommended in order to become a good translator or interpreter. In 1976, UNESCO representatives stated that "translation [...] requires a specialized 
training" (in Bureau Marcel van Dijk and PA Conseiller de Direction Paris, 1983: 95). More recently, Gile suggests that it is increasingly agreed that "formal training in I/T schools is the most practical way to teach and test abilities to supply the market with reliable professionals" (1995: xi). Although the author does not deem it mandatory, Gile (1995: 3) believes that formal training performs, among other social and professional functions, two important tasks: helping individuals to "enhance their performance to the full realization of their potential" and helping translation skills develop faster.

Some other voices argue that translators - and I would add interpretersmay become qualified either by academic training or by self-instruction (Bureau Marcel van Dijk and PA Conseiller de Direction Paris, 1983: 95). According to this survey, self-instructed translators have usually lived in a foreign country for some time or are non-specialists who have taken language courses (1983: 96). In this sense, Gile (1995: 2) acknowledges that some people actually achieve high degrees of competence just by self-instruction and practice.

These different points of view seem to reflect the well known "debate on whether 'translators are born, not made' (Nida 1981) or 'made, not born' (Healey 1978)" (in Gile, 1995: 3), which Gile considers to be a reductionist discussion (1995: 3). It is possible to conclude that, just as the author points out, certain natural skills are necessary to high-quality translation, which could also be extended to the case of interpretation. However, formal training can definitely be of valuable help.

\section{THE PROBLEM}

Shortly before conducting the data collection for this study, I held a phone conversation with the Airport Communications Center's supervisor. I was informed that there were two English-Spanish interpreters working at the center. I thought it would be worth to observe these employees at work, and to determine whether or not the term interpreter was being used in an appropriate manner. I decided to include the notion of translator in the research to verify whether this term could also be object of misuse.

\section{RESEARCH QUESTIONS}

1. With what kinds of situations do these bilingual employees usually deal?

2. What sort of background do they have? Have they been given any formal training as interpreters/translators or any specific technical training for their position? 
3. Do those (if any) nol having any fonnal training as interpreters on translators consider themselves as such?

4. What is their status? Are they full-time workers? Do they have any other occupation? If so, how does it affect their work at the airport?

5. How do thcy define culture? How do they face intercultural exchanges? What is their awareness of the possible misunderstandings due to cultural variations?

\section{METHODS AND PROCEDURES}

The research took place in ain American East Coast airport, whose name will remain anonymous. This airport has a customer service called Communications Center, where several languages are spoken. Five observations of one hour and a half each were conducted. A sixth meeting was held to perform the formal interviews. The observations went on for six weeks - every Friday from 12:30 p.m. to 2 p.m. They started on October $22^{\text {nd }}$ and finished on December $3^{\text {rd }}, 1999$.

Following an inductive analytic approach, qualitative research was done using ethnographic techniques for the data collection, which included the following:

- Observations. In the Participant-Observation continuum proposed by Glesne (1999), I placed myself in-between the observer as participant and participant as observer poles. Interaction with the subjects was high, although I did not participate actively in the activities they performed.'

- Unstructured Interviews. These were conducted with both subjects, either simultaneously or individually. These interviews were highly casual and spontaneous, although quite often performed with the purpose of obtaining data relevant to the research goals.

- Formal Structured Interviews. They were set beforehand, and were made with one subject at a time. Most of the questions were open-ended, and all of them were completely related to the goals of the study. They were designed to obtain information about aspects such as their conception of interpretation and translation or their attitude toward culture.

Unobtrusive measures were used to disrupt as little as possible the natural atmosphere of the setting, such as remaining silent at certain points or avoiding walking around the room.

1. The subjects observed and interviewed in this study were two non-US born employees. 


\section{THE SETTING}

As mentioned before, the research setting was an American East Coast airport. This airport has grown much in the last few years, due in part to its access to the inter-city railway system.

The observations were conducted at the Communications Center, which is not open to the public. The access to the offices is only by elevator or by the stairs. This means that there is no face-to-face interaction with airport users.

The center is round and rather small. The illumination is very low, since brightness makes it difficult to read the PC's screens. It is surrounded by the Airport Police and Fire Services Office and by a big conference room. Years ago, this office, together with the Communications Center, used to be one single, huge workplace, until the airport's authorities decided to separate them. A small kitchen and coffee room can also be found on this floor. Finally, along with a printer and a fax machine, six computers are placed within the center.

\section{JOB DESCRIPTION}

There are ten people working at the Communications Center. They are on an eight-hour shift, and have half an hour for lunch. Two or three people work on each shift, and the center is operative 24/7. Eight of these employees are from the US, one is from Spain, and another one is from Puerto Rico. All of them speak at least two languages.

These employees are called Airport Information Aids. Along with this title, they are placed in a scale from 1 to 6 according to seniority in the position, and 1 being for the most recent employees. Basically, their main function is to answer all the telephone calls that are made to the center both from outside and inside the airport. People call seeking many different types of information. For instance, some are customers who want to know about a possible cancellation or delay of their flights. Other people have questions regarding arrivals. Some others may simply get lost in the airport and require assistance, or want to have someone paged to meet at a certain place. The only information about the airport the Information Aids do not provide is information regarding ticket sales or fares.

There is a high number of incoming calls; therefore, the Aids are quite busy trying to answer all calls as fast as possible. They have to give the maximum information in the minimum time. On the right-bottom side of their computers, it is possible to see the number of awaiting calls. If a 
caller gets tired of waiting and abandons the call, it is recorded. Every month they are told how many calls they had and how many of them were abandoned. ${ }^{2}$

Aithough all the employees speak at least two languages, only English and Spanish - and sometimes French-- are used in the interactions with users. ${ }^{3}$ Usually, the people who call already know that several languages are spoken. AT\&T Language Line is a company that works for the airport. This company makes it possible to obtain information almost in any language in the world. For example, if somebody who only speaks Japanese telephones this center, he or she is put in contact with someone who speaks Japanese - such as someone in Japan who works for this company and who answers that call at home. Hearing impaircd pcople can also call using a system similar to an internet chat, which allows them to write on a PC's screen what they want to ask and to get the answer also in written form.

Some of these employees used to do some translation work for the airport, although they do not do it anymore. On the other hand, on certain occasions, some of them have had to leave the center to accompany illegal immigrants apprehended by the airport's authorities to court, to act as interpreters. Their function is to explain the facts, not to go with the individuals through the trial process.

Two seminars are held every year in the Seminar Room next to the Communications Center, which are mandatory to all the airport staff. Each seminar is on a different topic; for example, how to keep a good relationship between the supervisors and the employees of whom they are in charge, and issues on cultural diversity. ${ }^{4}$

Apart from a worthy salary, as airport employees the Information Aids can also enjoy other benefits; for instance, they can get cheaper tickets when they want to fly. This type of ticket is called a stand by ticket, which means that the ticket is very economical, but that they have to wait until there is a free seat on the plane.

2. An abandoned call is considered a failure of the center's efficiency, and a big amount of them could make the supervisors ask for responsibilities.

3. One of the employees pointed out that, to be successful in this position, the command of the languages you speak has to be almost perfect.

4. Regarding the seminars on cultural diversity, one of the subjects - Clara- explained that they are too general, almost anecdotal. She revealed that, until quite recently, there was no real interest in cultural issues. For her, what really prepares you to face intercultural encounters is experience. The other subject had no opinion, since she had not attended those seminars at the time of the interview. 


\section{TOOLS AND JOB TECHNOLOGY}

The Airport Information Aids' main tool is the PC, since almost all the data they need to offer the best information possible is on the computers. Their workstations are connected to almost every single point in the airport. They also use some books as sources of information from time to time. They have dictionaries too, which they can use should they have trouble with a word or expression. Additionally, they use hands-free headphone and microphone headsets, so that they can use the keyboard or whatever book they need to check. Each device is functional only for the station one is using. This way they cannot listen to each other's conversations. ${ }^{5}$

\section{SUBJECTS OF STUDY}

Out of the ten people who work at the Communications Center, I focused the study on the two only employees who were not from the US. The rationale for selecting them was based on their cultural background: they were from a different country but had been living in the States for a long time, so they had experience living and interacting in two different cultures. ${ }^{6}$ This was of paramount importance, since part of the research was oriented toward the analysis of intercultural features. Both employees became not only the subjects of this study, but also valuable key informants. Here are their profiles - pseudonyms have been used:

5. Only trainers can listen to the interaction between an Aid and a user. They do so when they are instructing a new person in the position, thanks to a special double headphone that allows them to listen to both the trainee and the user, although no talking is possible on the trainer's headset.

6. Besides, both showed clear bilingual characteristics. For example, interference of English features in Spanish and vice versa was easily detected. In addition, code switching between Spanish and English was quite common not only when they would talk to each other, but also when they would address me. 


\begin{tabular}{|c|c|c|}
\hline Name & Clara & Vlarcela \\
\hline Age & 50 & 40 \\
\hline Country of origin & Spain & Puerto Rico \\
\hline First arrived in the US & Thirty-three years ago & Thirty-four years ago \\
\hline Marital status & $\begin{array}{l}\text { Married to an American } \\
\text { citizen }\end{array}$ & $\begin{array}{l}\text { Married to a Spanish } \\
\text { native speaker }\end{array}$ \\
\hline Languages spoken & $\begin{array}{l}\text { Spanish, English, Italian, } \\
\text { and some French }\end{array}$ & Spanish and English \\
\hline University degree & None & None \\
\hline $\begin{array}{l}\text { Formal training } \\
\text { either in English or } \\
\text { in translation } \\
\text { interpretation }\end{array}$ & $\begin{array}{l}\text { None (regarding French, } \\
\text { she took some formal } \\
\text { training in France for only } \\
\text { two years) }\end{array}$ & None \\
\hline $\begin{array}{l}\text { Previous jobs in the } \\
\text { US (not at the airport) }\end{array}$ & Library Manager & None \\
\hline $\begin{array}{l}\text { Previous jobs in the } \\
\text { US (at the airport) }\end{array}$ & $\begin{array}{l}\text { Security Officer (1 year), } \\
\text { Cleaning Manager ( } 4 \\
\text { years), and Airport } \\
\text { Information Aid (so far, } 11 \\
\text { years working fulltime) }\end{array}$ & $\begin{array}{l}\text { Security Officer ( } 2 \text { years), } \\
\text { Ticket Agent ( } 1.7 \text { years), } \\
\text { and Airport Information } \\
\text { Aid (so far, } 14 \text { years } \\
\text { working fulltime) }\end{array}$ \\
\hline
\end{tabular}

1. Nevertheless, as it has already been mentioned, she uses only Spanish and English at work.

2. When she first arrived in the US, she could not speak any English. She had to learn it "for survival", as she describes it.

\section{FINDINGS}

The analysis of the field-collected data and of the results of the formal interviews - both omitted for the sake of space - suggests a revealing set of findings:

- Both Clara and Marcela define their job mainly in terms of the work they do answering calls and giving information. In fact, most of the time, this is what they do. The translation and interpretation work they sometimes perform is considered secondary. Marcela even explains that when she is asked to go to court to be the interpreter of an illegal immigrant, she accepts, although that is not part of her job. 
- The notion of interpreter does not seem very clear to them. Both consider an interpreter a person who is able to solve a problem using different languages. However, they do not seem aware of the processes involved in an act of interpretation. They apply the term interpretation to every situation in which two languages are involved. I agree that interpretation is present on certain occasions as, for example, when they go to court. However, the fact that they use English in an interaction - when answering a call - and that they use Spanish in the next - with a different customer - is clearly not a case of interpretation. The process involved in this type of interactions would merely be an instance of bilingual capability. ${ }^{\text {? }}$

- They use the words translation and interpretation interchangeably. This seems to be a common tendency - some people do not even know that there is a difference. However, as we saw in the literature review, it is possible - and appropriate - to draw a clear-cut distinction between the two.

- Regarding translation, they also consider themselves translators. When referring exclusively to translation, they do have a clear idea of what translation is. They agree that the translation process involves the transfer of a written text from one language to a different one.

- They believe it is possible to become an interpreter or a translator without any formal training, just by means of experience, which is agreeable - in fact, this might be their case. However, as we saw in the literature review, some considerations could be proposed. In addition, the case of Clara is remarkable. As some research indicates, it is possible to become an interpreter or a translator with no academic training. This is not to say that, as Clara believes, the moment you are able to speak two languages, you are able to translate or interpret. The important point is that, after making this statement, she acknowledges that something else is needed. Concerning translation, she talks about some necessary degree of education to be able to choose the correct words in the target language. In a nutshell, she has the sense that a translation is not usually required to be literal, that is, word by word. She also shows some context-awareness when she takes into account the circumstances surrounding the target language. In the case of interpretation, Clara contradicts herself when she says that knowing two languages is not enough, and that some degree of "education" and some "common sense"

7. To give another example, when Latin-American people who do not know English arrive in the US, Clara and Marcela speak to them in Spanish, and try to help them contact their relatives or friends in this country. They consider this an act of interpretation, which is not. 
are also needed. She finally concludes that, although going to college is not necessary to become a translator or an interpreter, some kind of special knowledge or ability is required. Thus, Clara seems to have changed her view on the subject matter after thinking more in depth about it.

- Clara and Marcela provide one of the probably most common definitions of bilingualism: a bilingual person is someone who speaks two languages. According to this notion, they consider themselves - and I agreebilingual.

- The concept of bicultural is related to the concept of bilingual. They both seem to understand this term, and think of themselves as bicultural. They feel equally comfortable and competent in the two cultures. The only remarkable feature on this issue is that Clara assures that it was easy for her to get involved with the American culture, and that she would not have much difficulty in doing so with another one, since it is easy for her to adjust to new situations. In contrast, Marcela's words reveal that it was very hard for her to assimilate the new culture when she first came to the US, and that she experienced a strong cultural shock.

- Conceming their awareness of cultural-diversity and the issue of whether they face difficult situations at their workplace provoked by cuitural misunderstandings, their answers were different, so they will be considered separately. On the one hand, Marcela claims that she does not remember any troublesome occasion. She says that she is always able to both understand the users and to make herself understood. The only instances she recalls were caused by lexical or semantic differences. On the other hand, Clara's version of the facts differs. She has traveled a lot, and she really seems to understand the broad concept of culture. She cannot think of any problematical situation brought about by a cultural misunderstanding, although she is positive that they can occur. For her, the problem is that many people do not know about other cultures, and think theirs is universal. Therefore, anybody behaving in a way "deviating from the norm" is considered "weird". She is really concerned about these people's ignorance. In sum, Clara proves herself well aware of the cultural diversity factor, and she tries to keep that in mind in her job.

\section{CONCLUSIONS}

The findings suggest a clear misuse of the terms interpretation and translation among the Information Aids interviewed. These employees were 
referred to as interpreters by their supervisor. However, as we have seen, that title does not correspond with the convened role and tasks of an interpreter; hence the inaccurate use of the term. Both Clara and Marcela believe that, although they sometimes perform translations and/or interpretations, those roles do not represent their real job. I would argue that the supervisor somehow assumes that everybody who happens to speak two or more languages can be considered a translator or an interpreter, which is a rather common presumption, although much could be argued about it.

I believe that both Clara and Marcela can be considered not only bilingual, but also bicultural. They have been living in the US for a long time, and their level of language command and of being exposed to and experienced in different cultures is certainly high.

They consider themselves interpreters and translators. Although they have a clear conception of what translating means, sometimes they use this concept when referring to an interpretation process. On the other hand, they do not really understand the essence of interpretation. This is not to say that they cannot do any interpretation work, but that their view of interpretation is rather reductionist.

Both subjects in the study claim that it is possible to become an interpreter or a translator with no formal training. I agree that this is feasible - their case exemplifies this possibility -, but knowing two languages does not always seem to suffice. The translation and interpretation processes are highly complex, and some specific skills appear to be necessary to produce fine results. Of course, there are different degrees of required performance depending on many factors, such as the type of text or interaction, or the function and purpose of the process. We should then consider these issues and see the results of the job to be able to judge both its quality and accuracy.

Finally, regarding the cultural dimension, two conclusions are derived. Clara knows the meaning of culture, at least the most accepted and common one. She is aware of cultural diversity, and she clearly acknowledges that this diversity can produce misunderstandings. On the other side, Marcela does not have a clear idea of what culture means, since she limits its definition to that of language.

\section{WORKS CITED}

Bureau Marcel van Dijk; PA Conseiller de Direction Paris (1983): Better Translation for Better Communication, New York, Pergamon Press Inc. GILE, D. (1995): Basic Concepts and Models for Interpreter and Translator Training, Amsterdam/Philadelphia, John Benjamins. 
GLeSNe, C. (1999): Becoming Qualitative Researchers: An Introduction, New York, Longman.

HofFMAnN, CH. (1991): An Introduction to Bilingualism, London / New York, Longman.

KLATT, M. B. (1995): «Intcrpreters Bridge Language Gap», AllA News, 31.

KRAwUTschKe, P. W. (ed.) (1989): Translator and Interpreter Training and Foreign Language Pedagogy, ATA Scholarly Monograph Ser. 3, New York, State University of New York at Binghamton.

PotTon, S.; R. Solmo (1995): «Nothing Lost in Translation», Successful Meetings. 


\title{
CANVI DE CODI ALS MITJANS DE COMUNICACIÓ VALENCIANS
}

\author{
Adolf Piquer Vidal \\ Universidad de Salamanca ${ }^{\prime}$
}

\section{METODOLOGIA}

$\mathbf{E}$ L contacte de llengües al context valencià afavoreix, com en altres comuInitats d'ús, la presència de fenòmens derivats d'aquest. En el nostre treball ens centrem en un cas particularment interessant perquè afecta un ús públic de la llengua -de les llengües, per ser més concrets- i mostra el que ocorre quan els mitjans de comunicació que adopten una llengua $\mathrm{A}$ insereixen una altra llengua $(\mathrm{B})$.

El primer pas realitzat va ser enquestar diversos mitjans per concretar quina era la llengua matriu i quina era la llengua inserida. És a dir, així determinaríem l'opció triada com a primera llengua -l'habitual en la programació i en la producció- i sabríem definir quina era la direccionalitat del canvi.

Entre els mitjans de comunicació que en fan una utilització oral, vam localitzar 22 canals de televisió d'índole diversa; pública i privada, d'abast local, autonòmic i estatal. D'aquests, quatre d'àmbit autonòmic optaven pel català com a primera llengua, malgrat que en el cas de Canal 9, per exemple, el $85 \%$ de la programació en horari de màxima audiència era en castellà.

Els locals, tanmateix, presentaven diversitat de criteris. Tot i ser majoritaris aquells que empraven el castellà en les emissions locals, en bona mesura es consideraven bilingües. Entre ells hi ha oscil-lacions notables, des del $2 \%$ de programació en català de TEVE 4 de Vila-real, el 5\% de Canal 38 de Castelló, al $90 \%$ aproximadament de televisions locals com ara Vinaròs, Morella, Telehorta de Silla, Carlet, Cullera, Gandia, Aielo, Puçol, Riba-roja, Ondara, o el $30 \%$ de Novelda i d'Ibi.

Quant a la variació, bona part contestaven que la seua opció era la tria d'un estàndard valencià que, evidentment, s'adequava a les varietats diatòpiques específiques de cada lloc. Ara bé, pel que fa a l'anàlisi del corpus, ens adonem

1. Aquest treball és part del resultat de la recerca subvencionada per la Direcció General d'Innovació Docent i Normalització Linguística de la Generalitat Valenciana al projecte «Valencià als mitjans de comunicació. Variació i alternança de codi». 
que tot $i$ que diuen partir dei model estàndard, podriem considerar-io molt pròxim al col-loquial, precisament per la tendència assenyalada a recórrer a variants locals anormatives.

La situació de les ràdios no difereix gaire, tot $\mathrm{i}$ el major nombre d'emissores estudiades (47) i que la tria de la llengua, en aquest cas, depèn directament de l'abast territorial de la programació. Hi ha empreses d'emissió per a tot l'Estat amb part de la programació específica de caràcter local. En aquest segon grup la tendència és a considerar-se bilingües, tot i que les diferències d'ús són notables, des del 100\% de Els Ports Ràdio (Ser), Ràdio Cocentaina la Veu del Comtat, Més Ràdio; al 42\% de Ràdio Nova de Vinaròs; al 0\% d'altres com ara COPE i RadioZ-Mediterráneo a Castelló.

Depenent d'aquest factor, l'esiudi es fonamenta en aqueils liocs on s'han observat alternances en la tria de la llengua, tant per part dels locutors habituals com pel públic que hi ha intervingut. L'enregistrament de programes $s$ 'ha fet de manera aleatoria, sense triar-ne específicament cap. Cal puntualitzar que hi ha abundància d'aquests en mitjans d'abast autonòmic perquè creiem que són aquells que arriben majoritàriament els valencians, i que la programació local té rendiments puntualment anecdòtics a l'hora d'aplicar els nostres estudis. És més, la mostra dels mitjans autonòmics és un indici de la tendència dominant al País; pel contrari, les programacions de tipus local varien ostensiblement depenent si es tracta d'un àmbit rural o urbà, del nombre d'habitants del territori que abasten i de característiques geolingüístiques diverses.

Amb aquestes premisses hem documentat tot allò que podríem considerar canvi de codi, portats per la intenció d'esbrinar quines són les particularitats a la nostra comunitat lingüística. És ben cert que la pràctica no és coincident en totes les comunitats, com han assenyalat Boix i Vila (1998: 20), però creiem que pot resultar il-lustratiu plantejar l'estudi de l'ús públic de la llengua per poder comprovar quin és el seu estat en aquest àmbit.

Com que la nostra pretensió és fer una consideració del referent valencià per determinar fins a quin punt dóna una idea de la situació del català en context comunicatiu tan important a nivell públic, ens hem limitat a un territori administratiu concret, la qual cosa afavoreix fer apreciacions de tipus social i lingüístic que depenen d'un grup amb una casuística ben especial. Fin definitiva, el nostre propòsit és arribar a fer un estudi fonamentat sobre la fenomenologia de la barreja de llengües en l'entorn valencià.

Això, però, tampoc ha estat una tasca fàcil perquè hem hagut de delimitar els criteris que defineixen l'objecte d'estudi. Per començar hem de remarcar la diferència terminològica $\mathrm{i}$ conceptual entre les transposicions lèxiques -intcrfcrències, manlleus assimilats $i$ altres, que es poden donar en parlants monolingües- d'allò que hom pot considerar un canvi de llengua conscient, cosa 
que es donaria entre parlants bilingües. És a dir, mentre els monolingües podrien emprar esporàdicament alguna mena de manlleu d'una manera inconscient, el canvi es produeix per raons distintes.

Vegem les diferències sobre alguns exemples. En el cas del valencià meridional ens trobem, dins dels discursos en català, amb expressions del tipus melocotó o fresa per préssec o maduixa. Aquests dos manlleus tendeixen a eliminar l'element de la llengua receptora i substituir-lo per la llengua donant, característica ben habitual del català col-loquial (Payrató, 1985), més al sud valencià. Per contra, en l'exemple (1) tenim un canvi d'etiqueta (Moreno Fernández, 1998: 269) que en el col-loquial té equivalències del tipus més voldria, més vullguera:

(1) Casi, casi que jo podria formar part del seu grup. Más quisiera!

Cal aclarir que la parlant és una presentadora d'origen castellanoparlant $i$, per tant, amb l'expressió espontània abandona momentàniament la llengua matriu i hi insereix una manifestació de caràcter informal molt lligada amb els models orals col-loquials.

\section{TIPUS DE CANVI}

En els casos (2) i (3) tenim una altra evidència d'aquest canvi conscient. És a dir, hi ha un seguit de trets que ens fan suposar la consciència en el canvi:

(2) Tu no fages cas, Montse, que d'això que diu Carolina después s'arrepentirà. A veràs tu como s'arrepiente!

(3) Amb una estranya, dicen, dice «es que dejo a mi hijo y a mi hija» després que Rocí́to ni el cridara.

En (2), amb la repetició, manifestant certa voluntat de traduir el que es diu, la parlant es desplaça cap a un altre codi i exhibeix una peculiar barreja de l'espanyol que empra amb elements fonosintàctics procedents de la llengua matriu. En (3) la llengua inserida s'anticipa amb els marcadors del discurs que anuncien la voluntat de citació.

En tots els casos, amb una gradació diferent, observem un nivell de consciència en la transició de la llengua matriu a la llengua inserida. En el primer dels exemples vists hi ha una certa espontaneitat, mentre que el segon opera la transició amb una repetició i el tercer amb voluntat de citar. Els tres, com diem, expressen d'una manera evident que el parlant assumeix aquest canvi. És, per tant, un pas que es dóna amb plena consciència (Myers-Scotton, 1997). 
Ara bé, una vegada hem determinat en el parlant aquest caràcter voluntari de la transició, caldrà aclarir quines són les diverses raons que el porten a marcar l'alternança cap a la llengua B. És a dir, ens plantegem quins són els mecanismes que afavoreixen el pas -si són de tipus gramatical, pragmàtic, social...- i quines categories de canvi observem.

Comencem per aquest segon element; intentem determinar quins tipus d'alternança hem observat en el nostre corpus per, després, lligar-la a les causes que l'afavoreixen. Shana Poplack (1980) va parlar de canvis suaus, canvis senyalitzats i d'inserció de constituents.

En (2), precisament, ens trobem amb un cas de canvi suau. L'expressió s'arrepentirà, tot i ser una transposició lèxica que substitueix l'autòctona se'n penedirà, introdueix un element de referència que dóna peu al canvi. Una vegada s'ha inserit la llengua $B$, l'element manté trets fonètics de la llengua $A$. Curiosament es produeix una transició en la qual l'expressió que ha servit de pont suavitza el canvi perquè en la llengua $A$ sona com a element de $B$, mentre que en $\mathrm{B}$ pren característiques d'A.

En el cas de (3), seguint els criteris de Poplack (1980), podríem parlar de canvi senyalitzat. La senyalització, evidentment, l'aporta el marcador discursiu de cita. Es a dir, a través del verb de dicció introduït en espanyol el parlant manifesta la seua voluntat de transcendir cap a la llengua en la qual es dóna l'expressió original. És una mena d'anunci a través del qual se'ns indica que es canviarà de llengua.

Un altre tipus de canvi és aquell que Poplack anomena inserció de constituents. Es tracta d'expressions - de sintagmes, lèxiques- que apareixen dins d'un cotext en la liengua A. Així, en l'exemple (4) veiem un cas evident:

(4) Què haguere pogut passar? Pues sí, por supuesto, però tenim la sort de donar gràcies que no mos ha passat res.

La presència d'aquesta locució convida a pensar en un fenomen generalitzat entre els catalanoparlants del País Valencià, que dóna una altra dimensió del manlleu. No es tracta de manllevar lèxic en exclusiva, sinó també expressions com la suara vista; és a dir, solidaritats lèxiques o fraseologismes. En aquest sentit, l'observació del canvi de codi ens porta a un terreny més extens que no pas el de la transposició lèxica. Ara no es tracta de mots en concret, sinó de canvis més o menys conscients per part dels parlants.

De tota manera, si en el manlleu lèxic podíem parlar de formes integrades i de formes no integrades, en el cas que ara ens ocupa cal precisar que es tracta de formes no integrades dins de la comunitat parlant perquè són canvis esporàdics que tenen equivalències vives $i$ en ás en la llengua matriu. 


\section{CONTEXT SOCIAL I SITUACIONAL}

El cas de la fraseologia convida a anar més enllà dels factors que provoquen el canvi per qüestions merament situacionals en la parla. Podríem entendre que el catalanoparlant, molt sovint, troba més a mà l'expressió predissenyada en castellà que en català.

(5) Y es que el amor es ciego pero los vecinos no. I és clar, a Morgan li preocupa el què diran... S'ho imaginem...

(6) Y aprovechando que Valladolid pasa por el Pisuerga. O és al revés? Ens ha parlat...

Tant en el cas (5) com en el (6) hi ha un factor que afavoreix el canvi. Segons Dabène i Moore (1995: 34) els canvis, sobretot d'unitats lèxiques -solidaritats incloses-, es donen dins d'un constructe sintàctic per la pressió contextual d'una altra llengua. Sembla que la pressió en el context és evident, no cal repetir quins són els factors que imposen una presència més nombrosa de l'espanyol en les instàncies formatives del llenguatge, ni com canvien de llengua els locutors dels média valencians quan es troben davant d'un interlocutor que no parla català: les dades són abassegadores.

Hi ha, d'altra banda, pel que fa a la inclusió de la fraseologia dins del canvi, un element important a tenir en compte, formaria part, en certa mesura, de la competència lingüística i de la formació lingüística dels parlants. Aquest condicionament del marc cognitiu ens porta a pensar que determinats referents fraseològics en castellà no troben correspondència amb d'altres en català.

El domini de la frase feta per la presència majoritària d'un determinat tipus de context lingüístic mostra ben a les clares que -tot i tractar-se de catalanoparlants- l'acceptació i l'ús de modismes de l'espanyol és abundosa i, sovint, serveix per consolidar unitats de significat de les quals se'n desconeix l'equivalència en la llengua autòctona, bé per manca de competència linguística o per manca d'equivalència. En el segon dels casos sovintegen no únicament els calcs de modismes espanyols, sinó també d'altres en altres llengües com ara l'anglés o el francès: idiomatisme obliga (Salvador i Piquer, 2000).

En definitiva, entenem que el marc cognitiu juga un paper fonamental en l'habilitat lingüística dels professionals dels mitjans de comunicació valencians. Quan el canvi s'opera en el sentit ara apuntat, entenem que hi ha un seguit de mancances de referència que se supleixen amb la citació de màximes i locucions en la llengua de major influència en el context.

Què és, doncs, allò que afavoreix el canvi? En realitat, no hem arribat a trobar cap element de tipus sintàctic, morfològic o fonètic que condicionés d'una manera regular la transició de la llengua matriu a la llengua inserida. 
Des de la impredictibilitat gramatical que apuntava Auer (1995), haurem de pensar en una altra mena de condicionants.

Per això ens hem fixat en aspectes de la situació comunicativa i ens hem adonat com es produeixen les negociacions. En el cas (7) trobem un indici de la particular manera de transcendir d'una llengua a l'altra, on l'aparent espontaneïtat de la transcripció que presentem es veu contrarrestada per l'explicació del context:

(7) Ella vol, ella vol, en principi sí. Claro Interviu, falta que la otra parte quiera. Eso es otra cosa. Ella querer quiere pero, claro, tu crees que...?

Aquest canvi només es pot entendre en funció de l'interlocutor al qual s'adreça el parlant. És a dir, examinant la imatge enregistrada ens adonem que el pas del català al castellà s' ha donat en el moment en què la locutora ha mirat un dels convidats al programa, castellanoparlant. Per adreçar-se a ell ha repetit una expressió anterior, traduint-la.

Des d'aquesta òptica sembla clar que la presència d'un subjecte, que habitualment és parlant de la llengua inserida, condiciona el canvi. D'una manera més clara es veu en (8):

(8) Lo millor és mantindre-lo, mantindre-lo bé. $Y$ es otro ejemplo de, mira, algo malo, algo bueno tendríamos que sacar de algo malo como las guerras (la càmera canvia l'enfoc i entra en camp Bárbara) y todas estas cosas...

De nou ens trobem amb un canvi de codi en el moment en què s'inclou la presència del personatge castellanoparlant. En aquest cas es tracta d'un canvi interoracional que no s'explica d'altra manera que amb el gest del locutor en girar el cap a una zona de l'estudi que no apareix en camp d'imatge. A posteriori podem comprovar com, efectivament, la presència d'una altra persona ha alterat el seu discurs. Això mostra l'evidència que és aquesta persona l'element que provoca el canvi.

En definitiva, l'absència d'una negociació explícita marca els condicionants socials i de tipus pragmàtic que se'n deriven pel que fa a l'ús del català als mitjans de comunicació valencians. Pel contrari podem trobar-nos amb un seguit de casos en què la negociació sí que s'explicita. Aquests, curiosament, són aquells en què el canvi de codi es produeix en un sentit invers:

(9) R: Porque, Carolina, por cierto ¿Qué pasó estos días? ¿Dónde has estado?

C: Es que si me hablas en castellano no t'antiendo, eh!

R: On has estat Carol? 
Si ens plantegem que la llengua en què s'ha previst el desenvolupament del programa és el català, entenem que allò que pretén $\mathrm{C}$, en convidar $\mathrm{R}$ a no continuar en castellà, és reconduir la conversa cap a la seua llengua habitual.

En el cas (10) ens trobem amb una alternança que va des del castellà cap al català, encara que també s'evidencia la negociació.

(10) L- Mira que bo. Bueno, estaba hablando en valenciano antes porque lo hemos hecho así.

A- Bé, si no li importa, jo sí parlaré en vạlencià.

La locutora, que habitualment es dirigeix als oients en castellà, marca de manera explícita la causa per la qual ha inserit el català. És a dir, malgrat que quan va ser enquestada va expressar que l'opció lingüística la triava l'entrevistat, en aquesta ocasió es palesa la tendència general de la cadena radiofònica, cap al castellà, a no ser que el personatge entrevistat desitge mantenir la seua opció lingüística.

És habitual, per tant, que la negociació explícita es produesca quan s'haja de canviar de castellà a català i no a l'inrevés -els exemples són extraordinàriament abundosos. Això, aplicat al context dels mitjans de comunicació valencians que ara ens ocupa, ens posa davant d'una disjuntiva marcada per alguns sociolingüistes. Són autònoms els canvis de llengua (Auer, 1995: 132), o hi ha un element d'identitat grupal (Treffers-Daller, 1992) que els condiciona?

Pel que fa als plantejaments d'Auer, els canvis que hem estudiat no tenen autonomia total. Tot i que en aparença siguen espontanis, hem observat que hi ha un seguit de condicionants de tipus contextual que els afavoreixen. Aquests condicionants, entre altres, són de tipus social. Hi ha una llengua amb una tradició de prestigi social (Wardhaugh, 1986) enfront d'una altra que no en té tant.

Això es manifesta, de manera voluntària o involuntària, en la clara tendència cap al canvi no negociat en direcció català-castellà. Pel contrari, quan es tracta de la direcció inversa, sovint apareix la negociació com a element explícit de transició i de justificació de l'ús de la llengua inserida. Es tracta, en definitiva, d'un reflex a petita escala d'allò que s'esdevé a la societat valenciana, molt semblant en això al que s'explica de l'alsaciana (GardnerChloros, 1995).

Per tant, si els canvis no són autònoms, com hem vist, haurem de matisar fins a quin punt hi ha algun element d'identitat grupal que condiciona el canvi en una o en una altra direcció. Pel que fa al canvi de català cap a castellà, ja hem referit la importància del criteri de prestigi social. És més, la tendència cap a la consideració de l'element forani -el no catalanoparlant-com digne de 
ser reconegut dins d'una comunitat de parla supcrior cn nombre, lligada a un grup -Estat-amb el qual també s'identifique el parlant, fan que el canvi cap a l'espanyol es justifique per aquestes raons: el criteri d'intercomprensió, la possibilitat que el locutor també l'empre, i sobretot perquè es considera pertinent a un grup social d'àmbit més ampli (l'espanyol).

Pel que fa als canvis en l'altra direcció, també podem aprofitar aquesta consciència grupal, sobretot si atenem al criteri que els parlants es mantenen en la seua llengua davant de la transició dels altres cap a l'espanyol. En tractarse de mitjans de comunicació local o autonòmic es veu que quan la llengua $\mathrm{A}$ és el català hi ha preferència cap al canvi, el contrari que succeeix quan s'ha de produir el canvi de l'espanyol al català (sovinteja la negociació explícita). Aquestes negociacions pretenen condicionar, reivindicar o dignificar el català enfront del castellà.

\section{EL CANVI COM A SÍMPTOMA}

Ara bé, també hem de fer referència a algun factor temàtic que provoca $\mathrm{el}$ canvi. Pensem, sobretot pel que fa a la presència del català a les ràdios de tipus local o provincial, en el lligam amb temes d'àmbit lúdic, festiu i folclòric en la majoria de casos. Això ens portaria a parlar d'un canvi de tipus metafôric. És a dir, hi hauria determinada mena de camp del discurs que també n'afavoriria la direccionalitat. En aquest sentit, curiosament, el tenor funcional de les converses té molt a veure, sobretot en dos sentits. El primer és aquell que, com hem vist, afecta a temes d'ordre local i folclòric, també a aquella mena de la programació més improvisada i informal que és, en bona mesura, la que s'aproxima al col-loquialisme. Bona part de les emissions de televisió locals deriven del castellà cap al català quan hi ha programes amb intervenció telefònica dels espectadors perquè el grau d'espontaneitat d'aquest provoca que la llengua de l'espectador condicione el canvi del locutor.

Ara bé, també en determinat tipus de conversa i programació -aquella més estretament lligada als temes culturals en què es debat sobre llengua i literatura al nostre territori o de qüestions acadèmiques- el tenor formal del llenguatge i la importància que se li dóna a la llengua en aquest reduït camp dels mitjans de comunicació afavoreix la tendència a emprar el català. Siga com siga, es tracta d'un cas anecdòtic pel que fa al total de la documentació recollida.

Fet i fet, això ens porta a avaluar, a més de les causes assenyalades, quins són realment els condicionants d'ordre social que afavoreixen el canvi. Com a exemple la manifesta tendència a la inserció d'unitats de tipus fraseològic, més enllà del manlleu, mostra el predomini d'un marc cognitiu en el qual el referent és l'espanyol. Per tant, des de l'ús fraseològic que hem analitzat, 
podrem dir que la importància del marc cognitiu en el desenvolupament de la llengua ens porta a un terreny més delicat; és a dir, a preveure quines conseqüències es poden derivar d'aquesta direccionalitat.

També hem tingut en compte que la consciència grupal deriva més cap a la consideració estatalista -el parlant es considera espanyol i, en consequiència, opta per la llengua oficial enfront de la seua- que no pas cap a aquella que té a veure amb l'àmbit lingüístic pròxim (autonòmic o nacional), amb els biaixos ideològics que tot això implica.

La primera lectura que se'n deriva és evident. Del predomini social del castellà sobre el català deduïm que, malgrat la presència del català als mitjans de comunicació, no s'ha invertit la tendència generalitzada en la resta de la societat valenciana. És a dir, la presència social i cultural de l'espanyol sobre el català s'evidencia fins i tot en els mitjans de comunicació en català.

D'altra banda, hem constatat la pèrdua de models de referència com ara la fraseologia autòctona. Això implica que s'ha operat una substitució del marc cognitiu. L'entorn cultural i la preponderància dels mitjans de comunicació en espanyol -ara no ens ocupem de factors d'educació i cultura que també serien dignes d'esment- fa que fins i tot les redaccions i els locutors dels mitjans valencians acudesquen a models procedents de la llengua de domini.

Això es fa més palès en les abundants mostres d'interferència lèxica, sintàctica i morfològica que hem trobat en les mostres recollides, de tal manera que en alguns casos la barreja s'aproxima a una mena d'híbrid lingüístic.

En definitiva, podríem assegurar, amb les proves a la mà, que els mitjans de comunicació valencians són un reflex lingüístic de la nostra societat, amb tots els riscos que això implica (Gumperz y Wilson, 1971).

\section{REFERÈNCIES BIBLIOGRÀFIQUES}

AUER, P. (1995): «The pragmatics of Code-Switching: a sequencial approach», en Milroy, L.; P. MuYsken (eds.) (1995): One Speaker, Two Languages, Cambridge, Cambridge University Press, 115-135.

BoIX, E.; X. VILA (1998): Sociolinguiística de la llengua catalana, Barcelona, Ariel.

Dabène, L.; D. MoOre (1995): «Bilingual speech of migrant people», en Milroy, L.; P. MuYsken (eds.) (1995): One Speaker, Two Languages, Cambridge, Cambridge University Press, 17-44.

GARDNer-Chloros, P. (1995): «Code-switching in community, regional and national repertories: the mith of the discreteness of linguistic systems», en Milroy, L.; P. Muysken (eds.) (1995): One Speaker, Two Languages, Cambridge, Cambridge University Press, 68-89. 
GUMPERZ, J.; R. Wilson (1971): «Convergence and creolitzation: a case from the Indo-Aryan/Dravidian border», en Hymes, D. (ed.) (1971): Pidgization and Creolizations of Languages, Cambridge, Cambridge University Press, 151-168.

Moreno Fernández, F. (1998): Principios de sociolingiuistica y sociología del lenguaje, Barcelona, Ariel.

MYers-SCOTTON, C. (1997): «Code-Switching», en Coulmas, F. (ed.) (1997): The Handbook of Sociolinguistics, Oxford, Blackwell, 217-237

Payrató, Ll. (1985): La interferència linguística, Barcelona, Curial-Abadia de Montserrat.

POPLACK, S. (1980) «Sometimes I'll start a sentence in Spanish y termino en Español": Toward a typology of code-switching», Linguistics, 18: 581618.

- (1988): «Contraint pattens in code-switching in two communities» en Heller, M. (ed.) (1988): Codeswitching: Anthropological and Sociolinguistic Perspectives, Berlín, Mouton de Gruyter, 215-244.

SAlVAdOR, V.; A. PIQUeR (2000): El discurs prefabricat. Estudis de fraseologia contrastiva i aplicada, Castelló, Universitat Jaume I.

TrefFers-Daller, J. (1992): «French-Dutch codeswitching in Brussels: social tactors explaining its disappearance», en C. M. EASTMAN (ed.) (1992): Special issue: Codswitching. Journal of Muntilingual and Multicuitural Development, 143-156.

WardHAUGH, R. (1986): An Introduction to Sociolinguistic, Oxford, Blackwell, 2 n ed. 1992.

Weinreich, U. (1953): Languages in Contact: Findings and Probles, The Hague, Mouton. 


\title{
INFORME SOBRE L'ÚS DEL VALENCIÀ EN LA INDÚSTRIA DEL MOBLE A L'HORTA SUD. RESULTAT DE LES ENTREVISTES
}

\author{
Empar Rodrigo Cañete \\ Col-legi Mare de Déu del Socors, Benetússer, València \\ Abili JuRado DueÑas \\ IEs Riba-roja de Túria, València
}

\section{INTRODUCCIÓ}

\begin{abstract}
QUEST informe és una part d'un treball més ampli becat per a la Direcció A General d'Ordenació i Innovació Educativa i Política Lingüística de la Conselleria de Cultura, Educació i Esports de la Generalitat Valenciana (Orde de 2 de març de 1999, DOGV núm. 3465, 31-3-99). El treball consistí a entrevistar persones relacionades amb la indústria del moble amb l'objectiu de traure conclusions al voltant de l'ús que s'hi feia del valencià. Donada la genuïnitat del moble a 1'Horta, la gran part dels entrevistats han estat valencianoparlants i declararen, com a primera premissa, que el valencià es parlava a tothora i majoritàriament pels treballadors de l'empresa. Comprovem, així, que la llengua és molt viva perquè no n'hi ha dèficit de parlants. No obstant, la indústria del moble té una forta voluntat exportadora, la qual cosa fa que el castellà siga present en tot moment, així com altres llengües dels països als quals s'exporta. Així, siga quin siga l'origen de la relació comercial (València, resta de l'Estat o estranger) el primer contacte es realitza sempre en castellà,
\end{abstract} el valencià s'utilitza quan hom sap que l'interlo-cutor el parla també.

Deixant a banda el perfil exportador del sector del moble, tot això respon a les característiques de la nostra comunitat lingüística definit per alguns autors com unidireccional. Ço és: tots els parlants de valencià parlen a més a més castellà, però no tots els parlants de castellà parlen també valencià. D'aquesta manera, en parlar castellà, tothom entendrà, perquè tothom el parla. Això provoca situacions com la que ens contà la representant d'una empresa: «La majoria dels empresaris del moble parlen valencià. Així, quan ens reunim, parlem en valencià. Però, si apareix una persona que no parla valencià, tots canviem al castellà encara que aquesta persona ens diga que entén el valencià».

Si hem vist que el valencià té en l'oral un àmbit d'ús prou ample, tot i que intern, no ocorre el mateix quan fem referència a l'escrit. Ací només trobem 
presència del valencià en el nom d'algunes empreses $i$, consegüentment, en cls rètols, pels segilents motius segons els testimonis dels entrevistats:

- Per tradició. L'empresa del moble valenciana sol provenii d'un tallei artesà, familiar, i sempre se l'ha anomenat en valencià, la llengua pròpia.

- Per la subvenció. L'administració pública subvenciona part de les despeses de la retolació si aquesta està en valencià.

- Per marca. Per diferenciar-se d'altres empreses de la resta de l'Estat I accentuar-ne la procedència valenciana, motor del sector a Espanya.

D'altra banda, la dicotomia interior/exterior en l'àmbit oral no té equivalència pel que fa a l'escrit. Tant al nivell intern com a l'extern de l'empresa, s'utilitza majoritàriament el castellà. A l'interior de l'empresa, doncs, es parla valencià però s'escriu en castellà: notes, nòmines, contractes, etcètera. De cara a l'exterior, s'han d'afegir altres llengües segons el país al qual s'adrece el negoci; així, molts catàlegs els podem trobar, a banda del castellà, en anglés, en francés, etc.

Un indicador que mesura el prestigi social d'una llengua qualsevol és si és important per a la inserció en el mercat laboral. La norma general que regeix l'empresa del moble no dóna l'entitat de requisit a parlar valencià. Evidentment, l'interés hauria de centrar-se en les persones que tenen tracte, directe o indirecte, amb el client: administratius, comercials, telefonistes, etc. Tanmateix, ni tan sols en aquests casos es requereix la llengua; per contra sí que es demana, i molt, el coneixement d'altres llengües d'altres paissos. Tornem a l'esquema unidireccional esmentat: si el castellà ja l'entenen tots els membres de la comunitat, allò que cal són les llenguies que els permeten de comunicarse amb altres comunitats que no el coneixen.

El que acabem de descriure ens mostra que el castellà és útil i rendible en tots els àmbits d'ús; tanmateix, el valencià sol ser la llengua materna dels empresaris i treballadors i la que dóna el nom a l'empresa. Aquesta situació paradoxal en què la llengua pròpia és reclosa pels seus parlants en àmbits reduïts ens la va descriure un dels entrevistats: «En la Feria del Mueble, durante el dia, se oye hablar castellano, inglés, alemán, italiano [...] Pero por la noche, cuando se apagan las luces, sólo se oye hablar valenciano...».

Aquesta sucosa afirmació dóna peu a múltiples interpretacions que defineixen prou bé la situació de la llengua en aquest món:

- La llengua apareix quan els llums es tanquen: és doncs una llengua obscura. Ho és també amagada perquè amb la claredat, a la llum del dia, no es veu; tampoc es veu en escrits: l'organització ha amagat la llengua en el cartell anunciador de la Fira i dels fullets informatius. 
- És una llengua apta per a les relacions personals, íntimes o familiars, que es desenrrotllen quan s'ha acabat la jornada laboral. Per contra, no és apta per a la relació comercial: amb la Fira oberta se senten altres llengües més aptes.

\section{CAUSES}

\subsection{El valencià en els negocis: amb el valencià no anem a més}

L'anècdota que hem descrit il·lustra fidelment la presència del valencià en el món dels negocis: el valencià s'escoltava quan els llums es tancaven, quan el negoci cessava; el valencià, doncs, es troba fora dels límits del mercat, si més no del moble. Aquest fet és degut a la configuració sectorial i cultural en què s'inscriu l'empresa del moble. Ens expliquem: el sector del moble valencià, constituït per PIMES majoritàriament, té el seu mercat fora dels límits lingüístics valencians i a més està englobat dins l'estructura empresarial del moble espanyol; i, per altra banda, l'espai on es desenvolupa l'acció comercial s'emmarca dins un espai on conviuen dues llengües, l'una de les quals és la coneguda per tots i l'oficial a tot l'Estat espanyol: «Mira, ara acabe de parlar amb una empresa d'Alemanya. Què vols, que li parle en valencià? Doncs li parlaré en castellà, o en el que siga perquè allò important és que ens entenem. Amb el valencià no anem a cap lloc».

Així, el mercat valencià del moble és insignificant per als empresaris i, en qualsevol cas, aquest mercat reduït no demanda entre els seus requisits que se li atenga en valencià, com declararen els entrevistats. Sí és important però el nivell de subcontractació dins del territori valencià (recordem-ho: el 90\%) però tot i així el negoci (escrit) es fa en castellà.

El minifundisme empresarial del moble tampoc no ajuda més: l'actuació és més difícil per la diversificació. A més, la inversió que suposaria la normalització lingüística d'una sola empresa és a nivells percentuals major que en una gran plataforma empresarial com ara Telefónica o El Corte Inglés: «Si haguérem de portar la comptabilitat també en valencià, necessitaríem un programa més, a banda de l'espanyol i l'anglés, i això suposa una inversió econòmica i a banda un embolic de manejar tres programes diferents».

Una cosa està clara fins ara: el castellà és imprescindible en el món de l'empresa i el valencià, per contra, és prescindible.

Per tot això es fa difícil l'actuació lingüística per fer esdevenir la llengua una eina amb valors instrumentals i discriminatius com demanen alguns autors. En les entrevistes preguntàvem quina seria l'actitud d'una empresa si un client li demanara els documents administratius en valencià. La demanda 
eráa poo crëble perguè no havien tingut cap cas semblant i nés aviat seria una molèstia donat l'espai reduit del mercat valencià. Això és, l'àmbit d'ús no genera la demanda lingüística.

És a dir, existeix una dependència mútua entre la necessitat de la llengua com a mitjà i eina d'homogeneització i de cohesió d'una comunitat i el producte resultant de l'ús. Així, era previsible que finalment l'entrevistat afirmara que ho taria en valencià si amb això guanyaven un client. Com ens digué un periodista de FEvava, «si hi ha negoci es parla el que faça falta».

Un altre aspecte que dificulta l'augment de l'ús és el fet d'inscriure's el moble valencià dins l'estructura sectorial del moble espanyol. Com ens han explicat diversos empresaris, la lluita internacional és ferotge i s'ha de combatre anb entitats expontadores com ará el moble italià o l'alenany. Aixi, es crea una marca paraigua, el mueble español, per fer front tots junts a les exigències del mercat intenacional. D'ací FevisAMA-99 s'explica per exemple la «desaparició» de la llengua al cartell de FEvisama (on sí que hi havia l'espanyol, l'anglés, el francés, l'italià, l'alemany, el japonés...), o que associacions empresarials nascudes a València com FEVAMA editen les seues publicacions en castellà (i en anglés) donat que vol ser òrgan representatiu de l'al-ludit mueble español. Açò últim també fa poc viable l'edició d'una publicació en valencià; com diem, allò interessant és arribar al major nombre de clients potencials. Així, afegides totes les dificultats de la llengua, el castellà es legitima com a llengua "oficial" del sector.

Laitre factor esmentat feia referència al marc espacial on es desenrotllen les activitats industrials del moble. Al si d'aquest espai conviuen el castellà i el valencià. Com sabem, el castellà és conegut per tothom i és a més la llengua oficial de l'Estat espanyol, ahora el mercat més important i el marc empresarial en què es mou el moble valencià. Tot plegat afavoreix l'increment de l'ús del castellà més que no del valencià.

Per acabar aquest punt, tampoc les empreses que hipotèticament podrien utilizar el valencià no troben un acompanyament institucional. L'Administració pública, amb tots els seus tentacles, tampoc no fa un ús del valencià com a llengua verament competitiva dins un mercat sinó només com quelcom de simbolic, i és d'aquesta manera com ho veuen els entrevistats: un ajuntament qualsevol: «A mi em pot arribar una carta de l'alcalde convidant-me a una exposició, i probablement la invitació estarà en valencià; però si publica una oferta de licitació sempre ho farà en castellà».

Així, si l'Administració, primera empresa del país i encarregada per llei de vetlar i fomentar l'ús de la llengua, no fa servir com a eina «instrumental i discriminatòria», si no «dóna exemple» a les empreses, és difícil la penetració del valencià en el món dels diners. 


\subsection{Una generació analfabeta}

Els fets ocorreguts durant aquest segle han sotmés la llengua a un estat de subordinació al castellà. La generació que en l'actualitat dirigeix les empreses valencianes ha estat alfabetitzada en castellà, $i$ aquesta ha estat també la llengua vehicular del seu ensenyament i la present a tot arreu del món públic: fora del món privat, aquesta generació no ha tingut oportunitat de fer servir la seua llengua. I no només això: també han vist que no la necessitaven per a progressar socialment. Així, aquesta generació considera que el castellà és la llengua de prestigi front al valencià que és la llengua de la família i els amics. Observem doncs la dicotomia interior/exterior que ens duu a altres parelles com ara oral/escrit.

La resposta més generalitzada a la qüestió «per què no s'escriu res en valencià?» fou: «és que no sabem escriure». Comprovem que els membres de la generació directiva són analfabets en la seua llengua. No obstant això, aquesta suposada falta de cultura no els afecta socialment perquè ja han estat alfabetitzats en una altra llengua i és amb aquesta amb la qual s'expressen. Llavors, no hi ha necessitat d'aprendre a escriure en valencià. Tornem una altra vegada als paral·lelismes econòmies: si ja tenim un sistema per a tots, generalitzat, per què aprendre'n un altre, això requereix un esforç, un esforç també econòmic, i si no repercuteix en guanys econòmics, no és rendible.

El fet de no saber escriure, òbviament, va parell amb el de no saber llegir la pròpia llengua. Aquest és un dels motius pels quals no s'entén un text escrit exclusivament en valencià. En tot cas, sempre ha d'aparéixer acompanyat de la traducció al castellà, amb el consegüent cost econòmic. Tanmateix, un text pot estar íntegrament en castellà perquè tothom l'entén. Aquesta fou una de les més freqüents respostes a la demanda de per què no s'usava el valencià, per exemple, en les nòmines donat que els treballadors eren valencianoparlants: $o$ bé no les entenien, o bé n'hi havia algun que no parlava valencià i a aquest li l'havien de fer en castellà amb la dualitat $i$ classificacions de treballadors segons llengua consegüent.

Hem comentat el fet pràctic d'escriure o no en una llengua, però també la dinàmica castellanitzadora va assentar uns hàbits dins l'esquema mental dels parlants que denoten la consciència de quines són les llengües adients segons on, quan, com i amb qui es troben. Així, el trencament en una direcció o altra d'aquests hàbits provoca una disfunció, una estranyesa que dificulta l'extensió del valencià a àmbits que, per a aquesta generació, sempre ha ocupat el castellà. 


\section{OBESTACLES}

\subsection{L'anticatalanisme. Perspectives des de la indústria del moble}

«En general, el perfil de l'empresari del moble de l'Horta Sud és [...] Bé, no sé si açò serà molt científic, però jo crec que és [...] Açò no comptarà com opinió meua, no? Jo crec que són més bé anticatalanistes. Però no és ben bé aquesta la paraula... i. Les dificultats que va tindre aquesta persona relacionada amb FEVAMA descriuen clarament la polèmica que envolta l'estatut de llengua o dialecte del valencià. Per les nostres entrevistes, no hem pogut observar aquesta característica com a eix definidor de l'empresari valencià. El que sobta de la declaració és que el primer que se li ocórrega per tal de definir l'empresari valencià és que siga anticatalanista. Potser s'hauria d'especificar quina cosa vol dir per a aquesta persona «anticatalanisme» per a entrendre el que significa. Pensem que el terme no s'aplica únicament a l'animadversió cap a allò català, sinó que té un sentit molt més ample. Entenem que vol dir una actitud contrària a la normalització linguística, a l'extensió dels àmbits d'ús de la llengua a posicions que fins ara havia copsat el castellà: la introducció del valencià en aquests àmbits els resulta estranya i es veu més aviat com una imposició. Les raons d'aquesta actitud vindrien donades pel fet de comptar amb la mateixa normativa i el fet cientific de la unitat de la llengua i, sobretot, les posteriors derivacions polítiques que han provocat en la societat valenciana.

Per altra banda, segons els propis empresaris, les relacions comercials entre empreses catalanes i valencianes es desenvolupen en la mateixa llengua. Això sí, sense el reconeixement explícit de la unitat lingüística: «amb els catalans? S'entenem bé: ells en català, nosaltres en valencià». En l'afirmació s'assumeix implícitament la unitat de la llengua, però amb una relació d'igualtat entre dos sistemes lingüístics amb estatut de llengua.

Per això resulta aclaridor que la identificació de l'anticatalanisme i l'antinormalització l'hàgem vista reflectida explícitament en algun cas: «Estoy a favor del valenciano, pero no del valenciano que quiere imponer Conselleria, que.es catalán».

El nom de valencià per a la llengua que es parla està totalment acceptat i és d'ús general. Per contra, la normativització provoca un rebuig i, de retop, obstaculitza seriosament la normalització lingüística. 


\subsection{L'estàndard: problemes d'acceptació i la contracorrecció. A propòsit de fusta/madera}

Abans hem vist com l'analfabetisme i el precari prestigi del valencià obstaculitzaven seriosament l'avanç de la llengua en l'àmbit escrit. Ara ens referirem a un problema relatiu a la normalització linguística i sobretot a la voluntat dels parlants per millorar el seu llenguatge tot llevant-ne barbarismes i introduint-hi paraules patrimonials o bé aquelles difoses a través de l'administració.

Quines són les etapes que fins ara ha superat el valencià en el procés de normalització lingüística (Polanco, 1984: 11-12)? Malauradament la situació, a banda de complexa pels molts vessants que sobreïx, no és molt esperançadora. Per tal d'explicar aquesta situació hem triat un cas molt corrent entre nosaltres i que hem introduit dins les entrevistes. Es tracta de la utilització d'un flagrant hispanisme en comptes de la tradicional paraula valenciana coneguda per tots i de la qual fins i tot deriva un popular llinatge. Parlem de fusta, mot que se substitueix en la parla comú per l'hispanisme madera (pronunciat maera) inclús en un sector on aquella n'és la matèria prima.

Quant a les primeres fases, és colpidor que encara resten discutides. Si bé s'ha produït una codificació lingüística gràcies a la qual, entre altres coses, podem escriure aquest treball, hi ha hagut un reenviament provinent de les etapes posteriors (difusió i acceptació) que han motivat la creació d'una Acadèmia de la Llengua que podria fins i tot reelaborar-ne la normativa. Açò voldria dir que no hem avançat més enllà de la primera etapa, la qual cosa resulta força frustrant. El caos normatiu no en beneficia gens l'ús. D'aquesta manera, comprovem el desconcert públic davant un problema que els és no alié però sí llunyà i quasi indiferent: «ni ells mateixos (referint-se a lingüistes però sobretot a polítics) saben com es diu. No s'aclareixen ells, anem a aclarirnos nosaltres...».

Tanmateix, creiem que no és ací on rau el problema, sinó en el desenvolupament posterior com ara veurem. Centrem-nos en l'etapa de l'acceptació, etapa que considerem crítica d'aquest procés perquè pot invalidar les anteriors si no reïx. Perquè aquesta etapa examina si la codificació és la correcta i si ha estat ben difosa, alhora que posa a prova les actituds dels parlants relatives a la lleialtat lingüística, autoestima i altres actituds positives.

Sobre l'ús correcte de la llengua, Bibiloni diu que és molt important en societat «saber expressar-se amb correcció, propietat, riquesa i fluïdesa» i de les nefastes conseqüències de la utilització incorrecta d'una forma verbal errònia o una altra falta per part d'un personatge públic (Bibiloni, 1997: 28). En la nostra peculiar comunitat lingüística ens passa a l'inrevés: expressar-se amb barbarismes es veu com quelcom normal en la dinàmica de la llengua, 
fins al punt de poder equiparar madera i tusta com a dues possibilitats del valencià per al mateix concepte, ja que ambdues són conegudes tot i que la frequiència d'ús de madera és molt superior.

La paraula normativa no aconsegueix substituir la forastera tot $\mathrm{i}$ que siga un mot pertanyent al seu vocabulari laboral i haja estat suficientment difós, ço és, tot i que es coneix el nom.'

Quines són les causes d'aquest disbarat? Durant les entrevistes, en arribar a aquest punt, li les demanàvem al nostre interlocutor. En general, la seua resposta era la sorpresa a causa de la normalitat amb què veuen l'hispanisme: «no hi veig el problema». Les paraules manllevades de l'espanyol conviuen al si de la nostra llengua amb total naturalitat $i$ molt sovint són vistes fins i tot com pròpies dei valencià; la gran part deis nostres entrevistats consideraven no només pròpies aquestes formes, sinó molt més naturals que les formes patrimonials. L'explicació rau en el conservadurisme que diuen mantenir: «... nosaltres partem la llengua del carrer, o jo parte la llengua que parlava mon pare i que s'ha parlat de tota la vida».

No cal dir que aquesta darrera declaració, espontània i innocent, aporta un gra d'ironia al tema.

Després d'això, davant quina mena d'estranya lleialtat estrictament linguística ens trobem? Els parlants ens diuen que són fidels, lleials, a les paraules que els han tramés, i que no volen canviar-les per unes altres que o bé els sonen llunyanes ( «Fusta ho deia el meu avi») o bé desconegudes ( «A mi eixes paraules em sonen a l'escola») i que, tanmateix, pertanyen de dret a la seua llengua en el temps i en l'espai. Tot ens mena a pensar en un obstacle que s'ha interposat entre la codificació i la seua transmissió - difusió - als parlants, els quals han pres la decisió de no acceptar-la. D'aquesta forma, sembla que els parlants no saben ben bé per què han de dir ara fusta si des de sempre han fet servir madera. Ans al contrari, molts entrevistats reaccionaren en aquest punt com una imposició d'allò més inconvenient. Es tracta de fer un esforç, de canviar un hàbit, $\mathrm{i}$, per tant, hem d'explicar-ne els guanys i conveniències

D'altra banda, la normativa no ha estat acceptada generalitzadament perquè els parlants no s'identifiquen amb ella, de manera que no senten que aquesta llengua «escrita» corresponga a la llengua que ells parlen i que, per tant, la rebutgen.

Ens hem trobat a més amb una altra actitud que excusa la utilització dels hispanismes: la consciència de l'analfabetisme («veus com parle malament»). Aquesta actitud allibera la consciència del parlant perquè ell mateix limita la seua capacitat per a millorar l'expressió, que, repetim, no necessita laboral-

1. Quant al llenguatge específic del sector, la Generalitat en va editar un Vocabulari l'any 1986, l'autor del qual és Emili Selfa. 
ment. Relatiu a això hi ha la percepció ja esmentada: «eixes paraules sonen a escola», alguns dels entrevistats deixaven tota la responsabilitat de l'avenir de la llengua als jóvens que hores d'ara estudien a les escoles, i es mostraven esperançats en un possible canvi generacional que beneficiaria el valencià.

L'únic beneficiari d'aquesta situació és la llengua espanyola, que expandeix dia rere dia el seu ús i arracona el valencià a posicions residuals. Recordem que dins la nostra comunitat social compartim dues llengües: l'una -qüestions de prestigi i rendibilitat a banda- amb un estàndard molt ben definit i conegut per tothom; i l'altra amb un estàndard deficitari i poc conegut. Tot plegat més els elements adés comentats fan complicat el manteniment de la comunitat lingüística tal com la coneixem hui.

D'ací que utilitzem el terme «contracorrecció» per definir l'actitud d'utilitzar, per exemple, tablero tot i conéixer tauler, amb la intenció de no ser identificat, de no emprar una varietat de llengua marcada. Aquesta noció estaria lligada a aquella d'inseguretat lingüística, entesa com el dubte entre dues formes com les exemplificades, i seria «el resultat d'un context social que no ha pogut desenvolupar completament les seues funcions lingüístiques» (Mollà i Viana, 1991: 110).

\section{LES COSES BEN FETES AMB UN SOMRIURE: NO HO FACES TU, QUE JA HO FAIG JO}

El títol d'aquest apartat fa referència a les relacions entre les dues llengües que es parlen en l'àrea objecte d'estudi i entre els seus parlants. Ja s'ha descrit a aquesta situació com unidireccional; vol dir: el parlant nadiu valencià parla a més a més castellà, però el parlant castellà no parla valencià. Ara intentarem descriure situacions comunicatives en què queda reflectida aquesta relació, així com les seues possibles causes.

En la descripció dels àmbits d'ús hem defensat la dicotomia interior/exterior com a fenomen distributiu de les dues llengües predominants en la indústria del moble a l'Horta Sud: el valencià és la llengua amb què ens comuniquem dins l'empresa i el castellà amb què ho fem fora l'empresa. Les causes econòmiques i culturals, a banda de diversos obstacles, expliquen part de la situació. Tanmateix, preguntem-nos ara per què l'usuari de la llengua no la fa servir fora d'un àmbit conegut, per què no la fa necessària a aquells que no la tenen, creant una dependència mútua entre la llengua i el mercat. Recordem la regla d'or en tota economia de mercat: si no es crea la necessitat del producte, la demanda no s'incrementa. Òbviament, el producte és la llengua, i la demanda és l'ús. Per tot allò vist fins ara, queda demostrat que el castellanoparlant no necessita el valencià en el seu desenvolupament social. Allò preocupant, allò en què s'ha 
de posar l'accent en aquest moment, és que el propi usuari de la liengua no sols no crea aquesta necessitat, sinó que ell mateix comença a no necessitar-la (Solè i Camardons, 1992: 65) :

Un poblc no conscrva la seva llengua perquè tingui un grau de lleialtat lingüística més gran o més petit que un altre, sinó per la necessitat que ha tingut de preservar la seva llengua com a signe de distinció, com a eina de progrés o com a mecanisme d'autorealització.

La situació actual és el resultat d'un procés històric que ha subordinat el valencià a una llengua de superior prestigi: el castellà. Aquesta relació de subordinacio del valencia ha estat interioritzada mentalment pels parlants, i dóna lloc a situacions comunicatives com el primer contacte comercial que, segons hem explicat, es realitza sempre en castellà, o el canvi d'idioma dels parlants quan intervé un castellanoparlant. Alguns entrevistats alludien al respecte o a l'educació per tal d'explicar aquest fet: «Si jo no sé si eixa persona parla o no valencià, per respecte, li parlaré en castellà».

Un altre prejudici que afegeix dificultats a la integració lingüística del no valencianoparlant ens ho contà el gerent d'un empresa de Beniparrell en forma d'anècdota:

L'any passat sí que em va sorprendre molt el tema del valencià. Aní com sempre a la Fira del moble, i, com que no sabia com orientar-me, m'adrecí a una hostessa per demanar-li-ho. La cosa és que no sé per què, però li hi preguntí en valencià. Mira, es passà un minut pensant el que m'anava a dir perquè no parlava valencià $I$ és que es notava a muntó que no parlava (normalment). (La conclusió ens la féu després): No és natural un castellanoparlant parlant valencià. No és natural.

Si afegim aquest rebuig a les dificultats d'aprendre acadèmicament la llengua, el castellanoparlant amb una mínima intenció integradora ho té difícil.

Es repeteix el fet si parlem de l'àmbit escrit: no és viable la producció de qualsevol document només en valencià; si cap document es redacta en valencià, sempre haurà d'estar acompanyat de la traducció al castellà: «Jo no puc posar la llista de preus sols en valencià perquè ací compra molta gent que no l'entén, o: No els puc donar (als treballadors) les nòmines en valencià perquè sempre n'hi ha qui no entén el valencià». Tanmateix, i açò és l'espill perfecte de la unidireccionalitat, qualsevol escrit pot estar sols escrit en castellà. Siguem conscients que l'empresa ha de mirar pel negoci, i que allò que l'interessa és arribar a un major nombre de clients potencials amb els costos més baixos, $i$ en aquest sentit on cl castcllà csdevé una fcrramenta absolutament cficaç i rendible. 
D'altra part, la posició interior de la llengua provoca tant la prescindibilitat, com la impermeabilitat d'aquesta. Tornem a l'anècdota de l'hostessa de la Fira de mostres: «no és normal que aquesta senyoreta parle en valencià, ja que no és la seua llengua». El narrador de la situació anterior la rematà així: «És natural que parlem valencià tu i jo (referint-se a l'entrevistador) perquè ho hem parlat de tota la vida, però no li pots exigir a ningú que el parle si no és la seua llengua».

Aquesta estructura comporta que el valencianoparlant, per educació (a la subordinació), ha naturalitzat el castellà com a llengua de competència i ús, i per tant la farà servir de forma espontània i natural, la qual cosa fa que el castellanoparlant no haja de fer cap esforç antinatural: «No li ho pots exigir a ningú». ${ }^{2}$

Fusionats tots aquests fets amb la nativització a l'Horta Sud de la llengua espanyola, es legitima per part de l'administració una política d'actuació bilingüista que té com a resultat l'enfortiment del sistema unidireccional i l'afebliment consegüent de l'ús del valencià. Això no obstant, no descarreguem el pes únicament a l'administració: són els propis parlants els que emparen i legitimen l'acció bilingüista. Exemples que donen fe d'això són la molt freqüent percepció segons la qual l'augment de l'ús del valencià reduirà els drets de la comunitat castellanoparlant i els imposarà una llengua que no els és «natural». Esmentarem dos casos paradigmàtics que donen una perspectiva del valencianoparlant i del castellanoparlant:

$\mathrm{Al}$ meu germà (director de l'empresa) no li parles d'imposar el valencià [...] S'ha de buscar la capacitat de la persona: no s'ha de marginar a ningú perquè parle castellà [...] Un treballador que porte ací quaranta anys potser podria fer un esforç, però si fa bé la faena tampoc no li pots exigir res [...] quan s'imposen les coses no m'agraden.

Por supuesto que estoy a favor del valenciano, siempre que eso no me impida a mí expresarme en mi lengua [...] Sí, sí, podrían ir escritos en valenciano (els catàlegs), pero siempre y cuando estuviesen también en castellano.

La situació, totalment desequilibrada, protegeix els drets de la comunitat lingüística que només coneix una de les dues llengües precisament per això, perquè l'altra comunitat pot comunicar-s'hi en les dues llengües.

Ja hem dedicat un punt a l'estàndard que sobretot se centrava en l'àmbit escrit. Voldriem introduir ara unes notes sobre l'estàndard oral. Sorprenentment veiem que l'estàndard difós per l'administració mitjançant l'escola o els

2. Ací el concepte de naturalitat està fonamentat per les respostes dels entrevistats. Fóra més rigorós utilitzar normalitat fent referència a les normes d'ús d'una comunitat lingüística qualsevol. 
miijans de comunicació públics no té a penes ressò sociai: «No hi ha cultura de parlar bé el valencià». D'açò ja hem parlat: la codifícació no ha estat completament acceptada pels parlants i això n'ha provocat un rebuig. Però això no és l'única cosa: la inexistència d'un estàndard acceptat ha deixat un buit social de la varictat de referència de la llengua. Fins i tot algú podria gosar a dir que aquest buit l'ha omplert el castellà, i que aquesta llengua és en l'actualitat l'estàndard del valencià. Però això potser seria massa gosadia (Bibiloni, 1997: 145). Tot plegat ens portaria a establir una altra dicotomia: varietat estàndard/varietat dialectal.

\section{CONCLUSIONS A LINTORIVIL}

1. El valencià té una gran presència en la vida dels entrevistats, no debades, és la llengua materna de molts d'ells. La llengua té una gran vitalitat en el nivell oral.

2. El valencià no existeix en la llengua escrita, llevat dels rètols i noms d'algunes empreses. El castellà ocupa majoritàriament aquest àmbit.

3. El valencià no és especialment valorat com a requisit laboral. Sí ho és, i molt, altres llengiies internacionals.

4. El valencià és una llengua molt poc rendible en aquest sector per: a) Perquè no la coneixen tots els formants de la societat valenciana. En canvi, el castellà, llengua compartida i oficial, sí que la coneixen tots. Per tant, si hom fa servir el castellà, tothom entendrà; per contra, el valencià està limitat al parlant nadiu (situació d'unidireccionalitat), I b) El mercat valencià tế un àmbit molt redüt i no té valors intrumentals i discriminatius; a banda, el castellà és una llengua internacional que obri molts mercats.

5. Els parlants de la lilengua són analfabets perquè han rebut l'ensenyament en castellà i no en valencià. Així, tots coneixen, més o menys, la gramàtica espanyola, clara i concisa, i no la valenciana, ambigua i precàriament difosa.

6. S'ha detectat una actitud contrària a la normalització lingüistica de la llengua que hem relacionat amb l'anticatalanisme. Tot i això, les relacions amb empreses catalanes es fan en la mateixa llengua, sense reconéixer-ne explícitament, però, la unitat.

7. L'estàndard difós no se sent com a propi. Els parlants no s'hi identifiquen i en rebutgen l'ús (no l'accepten). L'estàndard valencià està marcat per als parlants, donant peu al fenomen de la contracorrecció (no utilitzar la forma difosa sabent-ne l'existència). D'aquesta mancra, no cs pot millorar el llenguatge tot eliminant-ne els barbarismes que se senten com propis. 
8. Segons les normes d' ús, el valencianoparlant és sempre qui s'adapta a la circumstància lingüística (per educació a la subordinació). El valencianoparlant no genera necessitat al castellanoparlant per tal que aquest aprenga el valencià.

9. Existeix la percepció que la defensa del valencià com a llengua de prestigi és una qüestió només política i que abasta només a àmbits escolars i universitaris.

\section{REFERÈNCIES BIBLIOGRÀFIQUES}

Bibiloni, G (1997): Llengua estàndard i variació lingüística, València, 3 i 4. Mollà, T.; Viana, A. (1991): Curs de sociolingiiústica, volum 3, Alzira, Bromera. PolAnCO, L. (1984): «La normativa al País Valencià. Problemàtica i perspectives», a CABRÉ, T. ET AL. (ed.): Problemàtica de la normativa del català. Actes de les Primeres Jornades d'Estudis de la Llengua Normativa, Barcelona, Publicacions de l'Abadia de Montserrat.

SELFA FORT, E. (1986): Vocabulari de fusteria,mobiliari i decoració, València, Generalitat Valenciana, Conselleria de cultura.

SolÈ, J. (1992): Iniciació a la sociolinguiística, Barcelona, Barcanova. 


\section{SECCIÓN IV CORTESÍA VERBAL}





\title{
DISCORDANCIA ENTRE \\ ATENUACIÓN/CORTESÍA E \\ INTENSIFICACIÓN/DESCORTESÍA EN \\ CONVERSACIONES COLOQUIALES
}

\author{
Marta Albelda Marco \\ Universitat Politècnica de València
}

\section{D} ESDE que Brown y Levinson (1987 [1978]) caracterizaron la cortesía como reparadora de los actos amenazantes de la imagen (FTAs, face threatening acts), se asume tácitamente una correspondencia entre el fenómeno de la cortesía y el de la atenuación. En esta línea, muchos de los trabajos sobre el tema se han referido de forma indistinta a ambos conceptos. Sin embargo, una reflexión más detenida sobre estas nociones y un análisis de un corpus de habla del español, invita a plantearse si, por un lado, pueden realizarse actos corteses mediante estrategias linguísticas diferentes a la atenuación, como es la intensificación y, por otro, si la cortesía siempre es reparadora.

Las hipótesis planteadas en este estudio son: en primer lugar, las equivalencias entre atenuación y cortesía, por una parte, y entre intensificación y descortesía, por otra parte, son equívocas, puesto que también se podría ser cortés mediante estrategias de intensificación; en segundo lugar, conviene distinguir los fenómenos de atenuación e intensificación de los de cortesía y descortesía. Los dos primeros son categorías pragmáticas, tal y como las concibe Briz (1998); no son funciones sociales en sí mismas, aunque están al servicio de estas (Briz, 1998: 159). La separación conceptual entre fenómenos sociales y estrategias comunicativas (Briz, 2003: 44) no solo es útil para destacar una discordancia en la presunta identificación entre cortesía y atenuación y entre descortesía e intensificación, sino que también ayuda a definir mejor la cortesía, en tanto que permite apreciar de manera más completa todas sus diversas manifestaciones.

Esta discordancia se analiza en el corpus de conversaciones Val.Es.Co. (2002, Valencia Español Coloquial), en el que está recogida la variedad diastrática coloquial y, por tanto, presenta unas peculiares características situacionales (relación vivencial de proximidad y relación de igualdad entre los interlocutores, temática no especializada, marco de interacción familiar). 


\section{PROBLEMA}

La caracterización de la cortesía como reparadora de los actos amenazantes de la imagen (Brown y Levinson, 1987 [1978]) ha llevado a algunos autores a emplear los conceptos atenuación y cortcsía indistintamente para referirse a una misma realidad lingüistica (Beinhauer, 1991 [1929]; Puga, 1997).

La atenuación es «una estrategia conversacional vinculada a la relación interlocutiva, que mitiga la fuerza ilocutiva de una acción o la fuerza significativa de una palabra, de una expresión» (Briz, 1995: 55). En el siguiente ejemplo, (1), se pueden apreciar estrategias de atenuación en las líneas 4 y 5 :

(i)

1 P: ¿qué? ¿cómo va el coche ya $\downarrow$ Juan?

$2 \mathrm{~J}:$ muy bien/ que lo diga la mamá $\rightarrow \S$

$3 \mathrm{C}$ : $\quad$ \jay!/ está hecho un artista $((.)$.$) le dije Juan'$

4 no te duela lo que estás pagandol tú es que vas a las clases ${ }^{\circ}(u n)^{\circ}$ poquito

5 distraído/ porque ${ }^{\circ}(\text { como })^{\circ}$ llevaba tantas cosas en la cabeza $\uparrow \S$ 6 P:

$\S$ claro/ claro

[G.68.B.1 + G.69.A.1.: 365-386]

En la línea 4, la locución determinativa un poquito atenúa el significado del adjetivo distraído. En la línea 5 estamos ante una subordinada causal (porque como llevaba ianias cosas en la cabeza?), que expresa la justificación al hecho de «ir a las clases distraído». En los dos casos se trata de una atenuación dirigida a salvar la imagen de $\mathrm{J}$, hijo de $\mathrm{C}$, y constituyen una manifestación de cortesía.

Sin embargo, no siempre las actividades de cortesía se apoyan en estrategias de atenuación, como se puede observar en los enunciados del mismo ejemplo, (1), en las líneas 3 ( jay!/ está hecho un artista) y 6 (claro/ claro). Estä hecho un artista es un símil con valor intensificador, se identifica al interlocutor con un artista. Su función es cortés, realza la imagen del tí y expresa afiliación (Bravo, 1999: 160 y ss.). La repetición de estos dos adverbios modalizadores en la línea 6(claro) también constituye una intensificación de la fuerza ilocutiva del que los emite. De nuevo, estamos ante un caso de afiliación, se confirma lo que ha dicho el interlocutor manifestando un acuerdo.

Respecto al concepto de intensificación, es el realce de uno o algunos elementos del enunciado o de la enunciación. Nos podemos referir, en este sentido, a dos tipos de intensificación, según su nivel de afectación (Briz, 1998: 127 y ss.; Albelda, 2002: 116): 
- intensificadores del contenido proposicional. En este nivel se obtienen los intensificadores de la cantidad y de la cualidad (positiva o negativa) (Briz, 1998: 127).

- intensificadores del modus: son mecanismos que refuerzan el punto de vista, la intención del hablante, la fuerza ilocutiva (Briz, 1998: 128).

El empleo de formas intensificadoras para la expresión de la cortesía no es un hecho aislado; más bien es un hecho frecuente en la lengua, como lo muestran los siguientes ejemplos:

(2)

$1 \mathrm{~V}$ : ¿no tienes la lámpara que parece una escultura?\$

$2 \mathrm{~A}:$

$\S$ no $\downarrow$ iuy!/ esa va a tardar un mes

$3((\ldots))$

A V: ¿no? cuenta// la verdad es que es muy bonita ¿se parece a la mía?/// (3") ¿eh? ¿tú?

5 has visto la mía?// ¡OSTRAS! ¿QUÉ MOONA!// ¡QUÉ GRACIOOSA!

$6 \mathrm{~A}$ :

7 se ((queda))

$8 \mathrm{~V}$ : ¿cómo la has encendido $\uparrow ? \S$

$9 \mathrm{A:} \quad$ \& tocando (3")

10V: ¡ay! pues sí/ sí que [ilumina=]

11 A: [es un mue(ble)]

12V: = ¿qué cosa más bonita! ¿eh? ¡qué original!

[IH.340.A: 1-14]

En el ejemplo (2) aparecen varios casos de intensificación. En la línea 4, la partícula introductora del enunciado, la verdad es que, presenta un caso de intensificación en el ámbito de la modalidad. En ese mismo enunciado se produce otra intensificación mediante el adverbio muy, ahora a nivel proposicional y que superlativiza el valor significativo del adjetivo bonita. La misma función intensificadora es desempeñada por las exclamaciones de las líneas 5 y 12. La contrapartida social de estos usos lingüísticos es un refuerzo de la imagen del destinatario del mensaje.

En el siguiente ejemplo, (3), el hablante B expresa el rechazo al ofrecimiento de A mediante un procedimiento de intensificación: la repetición y el énfasis prosódico del adverbio no:

(3)

A: déjame que te ayude

B: NO NO NO NO/ ni se te ocurra/ ya lo acabo yo en un momento

Aunque rechazo, es una estrategia de cortesía dirigida a respetar la autonomía del oyente (Bravo, 1999: 161) y que protege las dos imágenes, la del oyente y la del hablante. 
En definitiva, se desprende de estos ejemplos, por un lado, que las actividacies de cortesía no se realizan solo mediante estrategias de atenuación y que existen otras estrategias que tienen que ver con la cortesía y que no son atenuantes. De acuerdo con Bravo, «para nosotros el ser consistente con la imagen no se limitaría solo a eśablecer la relación entre amenazas y atenuaciones, sino que buena parte de los esfuerzos comunicativos están dedicados a la confirmación de la imagen social de los participantes» (Bravo, 2000; 15041505).

Por otro lado, se ha podido comprobar en el análisis del corpus, reflejado en los ejemplos anteriores, que en la producción de actos corteses puede intervenir otro mecanismo linguístico, la intensificación, fenómeno complementario al de atemuación.

A partir de este planteamiento surge la cuestión de qué relación existe entre estos cuatro conceptos.

\section{IROPUESTA}

Conviene establecer una distinción conceptual entre los términos intensificación y atenuación, por un lado, y cortesía y descortesía, por otro, puesto que cada uno de estos pares corresponde a diterentes esferas:

Intensificación $v s$, atenuación = estrategias linguísticas

Contesía vs. descontesía = fenómenos sociales

Intensificación y atenuación son funciones discursivas, propias del lenguaje, se manifiestan a través de elementos y rasgos lingüísticos. También su ámbito de actuación y sus efectos se dan en el discurso, bien en el mensaje lingüístico mismo, bien en alguno de los demás elementos del discurso (los participantes, la situación, el tema).

Por su parte, cortesía y descortesía son fenómenos con valores y efectos en el nivel social de la lengua, en un nivel externo, en tanto que afectan a las relaciones entre seres humanos que entablan una comunicación. Si bien uno de sus modos de manifestarse es la comunicación lingüística, existen otros modos de expresar la cortesía. En este sentido, se reconoce en la cortesía una determinada actitud social, un modo de comportarse. Es intencionada, se muestra, pues se refiere a cómo deseamos que se nos vea y a cómo se nos ve.

1. Vid. también Hernández Flores (1999: 38, 42; 2001: 108). 
La descortesía es el fenómeno contrario a la cortesía; sus efectos perjudican las relaciones sociales entre los interlocutores afectados.

Ambos, fenómenos sociales y fenómenos discursivos, pueden actuar conjuntamente combinándose de diversas formas, algunas de ellas más prototípicas que otras:

a. cortesía expresada mediante atenuación

b. cortesía expresada mediante intensificación

c. descortesía expresada mediante intensificación

d. descortesía expresada mediante atenuación

Los casos de (a) y (b) se han mostrado en los ejemplos del apartado anterior (1, 2 y 3). Se pueden realizar actos corteses por medio de estrategias discursivas de atenuación e intensificación: una amenaza que dañaría la imagen del receptor se atenúa con la finalidad de ser socialmente cortés; también puede reforzarse la imagen del receptor a través de un acto intensificador de lo dicho, como sería por ejemplo el caso de un cumplido o de un halago. Respecto a la situación que se plantea en (c), también es habitual, como se puede observar en el siguiente ejemplo:

(4)

1 E: ¿ique si molesta!?// ((;caray!))

2 G: no molesta// no molesta

3 E: SACA ESO AHÍ FUERA $\downarrow$ por favor Antonio ((...))

4 A: PABLO/ ;sácala!

5 P: tengo prisa [((que llego tarde) $)]$

$6 \mathrm{G}: \quad$ [es que tiene] prisa\$

$7 \mathrm{~A}$ :

$\S$ pues TE ESPERAS

[J.82.A: 182-196]

El de (4) es un diálogo entre unos padres (E, A) y un hijo (P); los padres se quejan de una bicicleta que obstaculiza el lugar e insisten al hijo en que la quite. El modo social es descortés y se manifiesta a través de usos lingüísticos de intensificación: interjecciones (línea 1), imperativos (líneas 3 y 4), entonación enfática (líneas 3,4 y 6).

Por otro lado, la situación (d), expresar la descortesía mediante atenuación, parece la menos frecuente. Sin embargo, en tanto que ambos fenómenos pertenecen a diferentes niveles de estudio, es posible su combinación. Así se puede observar, por ejemplo en (5), donde aparece una recriminación constituida por el empleo de un adverbio de probabilidad y un verbo en tiempo condicional:

(5)

$1 \mathrm{P}$ : llegamos tarde/ a ver si te das más prisa

$2 \mathrm{C}$ : no me vengas ahora con prisas// a lo mejor podrías haber colgado antes el teléfono 
También, en (6) se emplea un dinninutivo (meconisno lingǘstico de atenuación) en un acto descortés de burla:

(6)

1 C: mira $\downarrow$ itú has visto esos dos cuernecitos que tienes [separaos?]

2 B:

[demasiaos] desengaños (RISAS)

3 A: por mi/ pocos

[H.38.AL: 593-596]

Lo discursivo se encuentra al servicio de lo social; la intensificación y la atenuación, por tanto, pueden ponerse al servicio de la cortesía y de la descortesía. Pero, al mismo tiempo, intensificación y atenuación, como mecanismos linguísticos que son, no se emplean únicamente como medios de manifestar la cortesía; en ocasiones desempeñan otras funciones. Entre las funciones de la intensificación, por ejemplo, están hacer más creíble lo dicho, imponer la figura del yo, buscar el acuerdo en el oyente (Albelda, 2005). Estas se manifiestan en empleos más concretos, como exagerar, argumentar en un debate, etc. También la atenuación cumple otras funciones (Briz, 1998: 143; 2003: 19-23; 2004: 68); por ejemplo, quitar importancia a un tema delicado, no alarmar a una persona ante una mala noticia o, también, conseguir que el receptor otorgue algo al emisor. Sin embargo, sí es cierto que la función más frecuente de la atenuación es la cortesía (Briz, 1998: 143; 2004: 68).

Por íltimo, atenuación e intensificación no se pueden considerar estrategias en contradicción, ambas pueden ordenarse a salvar o proteger la imagen (Held, 1989: 198; Briz, 2003: 25).

\section{CONCLUSIONES EN RELACIÓN AL CONCEPTO DE CORTESÍA}

Esta distinción teórica entre fenómenos linguísticos y sociales y la consecuente desarticulación de los dobletes cortesía/atenuación, descortesía/ intensificación invita a cuestionarse la caracterización de la cortesía.

La teoría de Brown y Levinson (1987 [1978]) se fundamenta en la necesidad de facilitar las relaciones sociales y compensar la agresividad o amenaza de la imagen de los participantes. La misión de la cortesía, según su propuesta, sería únicamente reparar, mitigar o evitar esas amenazas para lograr una cierta armonía. Presentan un sistema de estrategias corteses como resultado del establecimiento de las distintas amenazas que pueden realizar los actos verbales (y no verbales). Sin embargo, como se ha comprobado en los ejemplos anteriores, la cortesía no es siempre el resultado de evitar o reparar amenazas, y la atenuación, por tanto, tampoco es el único modo de expresarla. 
Entre otros autores, Kerbrat-Orecchioni $(1992,1996)$ ha señalado y definido el concepto de FFAs (face flattering acts), actos de refuerzo de la imagen, que no se manifiestan mediante estrategias de atenuación sino de intensificación. Los FFAs no funcionan a modo de reparación o compensación al daño o agresión sufridos por la imagen, sino que son un comportamiento estimulante y positivo para la relación interpersonal. La introducción de los FFAs, junto a los ya descritos FTAs, permite definir de modo más completo el concepto de cortesía, pues a partir de estos se puede distinguir una cortesía valorizante de una cortesía mitigadora. De acuerdo con Kerbrat-Orecchioni (1996: 54 y ss.), la cortesía valorizante es de naturaleza produccionista, consiste en efectuar FFAs y se realiza sin que exista un posible riesgo de amenazas. Por su parte, la cortesía mitigadora es de naturaleza abstencionista o compensatoria «consiste en evitar producir un FTA o suavizar su realización» (Kerbrat-Orecchioni, 1996: 54) y convive con un posible riesgo de amenazas y se dirige a evitarlas o repararlas (Carrasco Santana, 1999: 22). En definitiva, la producción de actividades corteses puede ser motivada por dos causas: o bien, por un posible riesgo de amenazas, o bien por el deseo de producirla sin que ni siquiera se contemple la posibilidad de preocuparse por las amenazas.

En el análisis del corpus se observa una tendencia a realizar la cortesía valorizante mediante estrategias de intensificación, mientras que las estrategias que activan la cortesía mitigadora suelen ser de atenuación. Sin embargo, solo se puede hablar de tendencia preferencial, ya que como se ha mostrado, los mecanismos lingüísticos de intensificación y atenuación actúan de modo independiente a los fenómenos sociales. Así, por ejemplo, también se puede mitigar el efecto de una amenaza social mediante la adición de actos de refuerzo, como postula la teoría tradicional de la cortesía (Brown y Levinson, 1987 [1978]; Leech, 1983). Véase de nuevo el ejemplo (1):

(1)

1 P: ¿qué? ¿cómo va el coche ya $\downarrow$ Juan?

2 J: muy bien/que lo diga la mamá $\rightarrow$ \$

$3 \mathrm{C}$ : $\quad$ iay!/ está hecho un artista $((.)$.$) le dije Juan'$

$4 \quad$ no te duela lo que estás pagandol tú es que vas a las clases ${ }^{\circ}(u n)^{\circ}$ poquito

5 distraido/ porque ${ }^{\circ}$ (como $)^{\circ}$ llevaba tantas cosas en la cabeza? $\uparrow \S$

$6 \mathrm{P}$ :

$\$$ claro/ claro

7 C: pues le decían a lo mejor/ la segunda a la derechal/ BUENO// y ya no se acordaba/

8 u-cuando llegaba/ si era en la segunda o era en la tercera/ y eso es lo que fallaba

9 mucho

[G.68.B.1 + G.69.A.1.: 365-386] 
Como se aprecia en este ejempio, los acios intensificadores de refuerzo de la imagen además de dirigirse directamente a reforzar la imagen, también pueden servir como medios para salvar o atenuar una amenaza. En este diálogo existe un posible riesgo de amenazas a la imagen de J, quien está realizando prácticas para conducir con poca destreza. Esta amenaza a su imagen social se manifiesta en lo expresado por $\mathrm{P}$, su madre (no te duela lo que estâs pagando/ tú es que vas a las clases un poquito distraído; pues le decían a lo mejor/ la segunda a la derecha// BUENO// y ya no se acordaba). Además de las atenuaciones de las líneas 4 y 5, C y P emplean mecanismos de intensificación para reforzar la imagen y compensar la posible amenaza: jay!l está hecho un artista (línea 3), claro/ claro (línea 6).

En definitiva, se ha pretendido mostrar la importancia, a la vez que la necesidad, de mantener separados conceptualmente los fenómenos lingüísti$\cos$ y los fenómenos sociales. Una de las ventajas que esto ha supuesto ha sido contribuir a la definición de la cortesía, de modo que se puedan destacar sus valores positivos, produccionistas y no solo los de reparación.

\section{REFERENCIAS BIBLIOGRÁEICAS}

Albelda Marco, M. (2002): «El estudio de la intensificación como categoría pragmática», Interlingüística, 13 (I): 115-118.

- (2005): La intensificación en el español coloquial, tesis doctoral, Universitat de València, CD-Rom.

Beinhauer, W. (1991 [1929]): El español coloquial, Madrid, Gredos.

Bravo, D. (1999): «iImagen 'positiva' vs. imagen 'negativa'?», Oralia 2: $155-184$.

- (2000): «La atribución de significados en el discurso hablado: perspectivas extrapersonales e intrapersonales», en J. J. Bustos ET ALII (eds.): Lengua, Discurso y Texto, vol. II, Madrid, Visor-ucm.

- (2001): «Sobre la cortesía lingüística, estratégica y conversacional en español», Oralia, 4: 299-314.

Bravo, D.; A. Briz Gómez (eds.) (2004): Pragmática sociocultural: estudios sobre el discurso de cortesía en español, Barcelona, Ariel.

Briz GómEz, A. (1995): «La atenuación en la conversación coloquial. Una categoría pragmática», en CoRTÉs, L. (ed.) (1995): El español coloquial: actas del I Simposio sobre análisis del discurso oral, Almería, Universidad de Almería, Servicio de Publicaciones.

- (1998): El español coloquial en la conversación. Esbozo de pragmagramática, Barcelona, Ariel. 
- (2003): «La estrategia atenuadora en la conversación cotidiana española», en D. Bravo (ed.): Actas del Primer Coloquio Edice. La perspectiva no etnocentrista de la cortesía: identidad sociocultural de las comunidades hispanohablantes, Universidad de Estocolmo, libro-e.

- (2004): «Cortesía verbal codificada y cortesía verbal interpretada en la conversación», en Bravo, D.; A. BrIZ (eds.) (2004: 67- 93).

Briz Gómez, A. y Grupo Val.Es.Co. (2002): Corpus de conversaciones coloquiales. Anejo de Oralia, Madrid, Arco/Libros.

Brown, P.; S. C. Levinson (1987 [1978]): Politeness. Some universals in language usage, Cambridge University Press.

Carrasco Santana, A. (1999): «Revisión y evaluación del modelo de cortesía de Brown y Levinson», Pragmalingüística, 7: 1-44.

HELD, G. (1989): «On the role of maximization in verbal politeness», Multilingua, 8 (2/3): 167-206.

HERNÁNDEZ FLoRES, N. (1999): «Politeness ideology in Spanish colloquial conversation: the case of advice», Pragmatics, 9 (1): 37-49.

- (2001): La cortesía en la conversación española de familiares y amigos, tesis doctoral, Universidad de Aalborg.

Kerbrat-Orecchioni, C. (1992): Les interactions verbales II, París, Armand Colin.

- (1996): La conversation, París, Seuil.

LeECH, N. G. (1983): Principles of Pragmatics, Londres, Longman.

Puga Larraín, J. (1997): La atenuación en el castellano de Chile, Universitat de València, Grupo de Estudios Iberoamericanos / Tirant lo Blanch Libros. 


\section{Sistema de tronscripción de los ejemplôs orales}

Los signos fundamentales del sistema de transcripción del corpus de Val.Es.Co. son los siguientes:

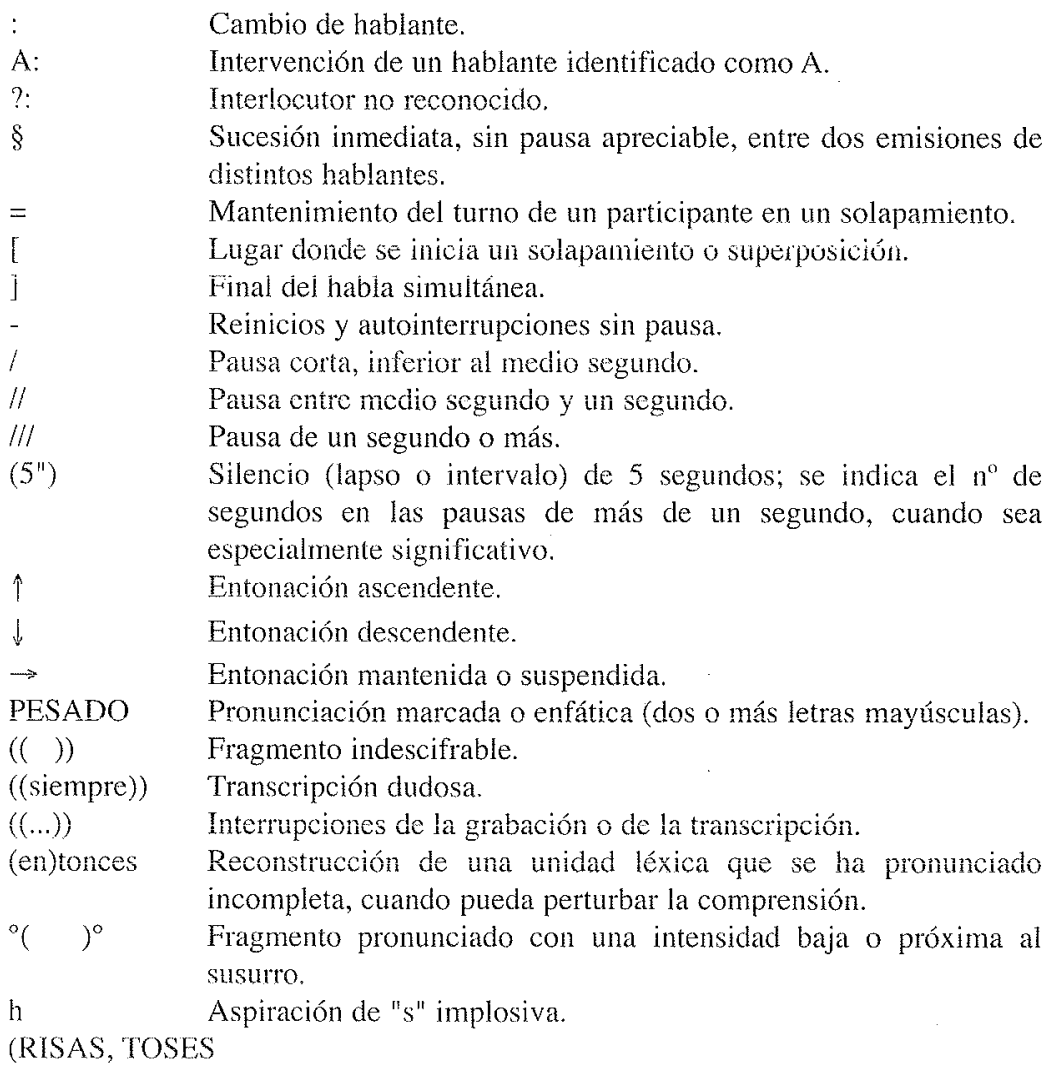

GRITOS...) Aparecen al margen de los enunciados. En el caso de las risas, si son simultáneas a lo dicho, se transcribe el enunciado y en nota al pie se indica "entre tisas".

aa Alargamientos vocálicos.

nn Alargamientos consonánticos.

¿i !? Interrogaciones exclamativas.

$i$ ? Interrogaciones. También para los apéndices del tipo "¿no?, ¿eh?, ¿sabes?"

i! Exclamaciones.

* Las incorrecciones gramaticales (fónicas, morfosintácticas y léxicas) no aparecen marcadas por lo general. 


\title{
ACTOS CORTESES, DESCORTESES Y ANTICORTESES EN LA CONVERSACIÓN COLOQUIAL ESPAÑOLA
}

\author{
María Bernal LinNersand \\ Universidad de Estocolmo
}

\section{INTRODUCCIÓN}

$\mathbf{L}$

A cortesía, definida en el Diccionario de la RAE como «demostración o acto con que se manifiesta la atención, respeto o afecto que tiene una persona a otra», es un concepto que ha sido abordado desde múltiples perspectivas: desde una concepción tradicional como conjunto de normas relacionadas con el respeto o la deferencia, hasta la concepción funcional de la cortesía como estrategia para el mantenimiento del equilibrio en las relaciones interpersonales (Escandell Vidal, 1995: 33) o como estrategia produccionista de valorización de las imágenes de los demás (KerbratOrecchioni, 2004: 45). Su contrapartida, la descortesía, definida por ausencia como «falta de cortesía», también se ha convertido en válido objeto de análisis desde ángulos diferentes. La interacción cotidiana, la conversación espontánea de cada día con familiares, amigos y conocidos constituye un vasto campo de análisis que consideramos especialmente fructífero para observar los fenómenos relacionados con la cortesía' verbal, las estrategias empleadas por los hablantes y los efectos socialmente negativos o positivos causados en los demás. El objetivo de este trabajo consiste en observar y ejemplificar una serie de actos, denominados corteses, descorteses y anticorteses, realizados por los hablantes en la interacción coloquial, concretamente en la variante de español peninsular.

\section{ALGUNAS CUESTIONES TEÓRICAS}

Los encuentros interpersonales implican la negociación de las imágenes de los interlocutores participantes, entendiendo por imagen social (Goffman, 1967: 10) la autoimagen que la persona desea presentar ante otros en la interacción; tiene, por tanto, un carácter público e interpersonal: «cuando un

1. Término usado aquí como hiperónimo de descortesía y anticortesía. 
individuo aparece ante otros, proyecta, consciente e inconscientemente, una definición de la situación en la cual el concepto de sí mismo constituye una parte esencial» (Goffman, [1959] 2001: 258). La noción de imagen social, face, de Goffman es retomada por Brown y Levinson ([1978]1987) como punto de partida en su modelo sobre la cortesía lingǘstica; en él las estrategias de cortesía aparecen al verse amenazada la imagen del individuo en la interacción. La imagen está compuesta por dos aspectos interrelacionados: una imagen positiva (necesidad de ser aprobado y aceptado por los otros) y una imagen negativa (deseo de no sufrir imposiciones); también las estrategias de cortesía son de carácter positivo o negativo, según la vertiente de la imagen a la que vaya dirigida. La dicotomía entre imagen negativa y positiva es considerada dudosa por Meier (1995) ya que, por ejemplo, al considerar una persona la imagen negativa de otra y no ejercer ninguna imposición sobre ella, está también teniendo en consideración su imagen positiva al colaborar en el logro de ese deseo: "Any threat to negative face is thus subsumable under positive politeness» (Meier, 1995: 385). También Matsumoto (1988), Mao (1994), Bravo $(1999,2003)$, Hernández Flores (2003), por citar algunos autores procedentes de culturas no anglosajonas, han reaccionado críticamente ante la pretensión de universalidad de la teoría de Brown y Levinson y reclaman una relativización cultural. Asimismo, se le ha criticado el hecho de omitir los actos que reaizan la imagen del interlocutor (Kerbrat-Orecchioni 1996, 2004; Albelda, 2003) o el de no abordar el fenómeno de la descortesía (Eelen, 2001).

Bravo $(1999,2001,2003$ a) le confiere un lugar central al concepto de imagen social en una teoría de la cortesía, pero, al no considerar los aspectos positivo y negativo válidos para todas las culturas, propone los conceptos de autonomía y afiliación, los cuales conforman «categorías vacías» a ser rellenadas según los diferentes contextos socioculturales específicos de cada cultura. El concepto de autonomía se refiere a la percepción que tiene un individuo de sí mismo y que los demás tienen de él como alguien con contorno propio en el grupo, mientras que afiliación «agrupa aquellos comportamientos en los cuales se refleja cómo una persona desea verse y ser vista por los demás en cuanto a aquellas características que la identifican con el grupo» (Bravo, $2003 a$ : 106). Concretamente, en lo que a la sociedad española atañe, la imagen de autonomía consistiría en la expresión de autoafirmación y auto. estima («mostrarse original y consciente de las buenas cualidades propias») y la imagen de afiliación tiene su ideal en la consideración, afecto y confianza. ${ }^{2}$ Bravo (1999: 168), además de los mencionados contenidos, propone una serie de premisas culturales (conocimiento de las convenciones sociales en función

2. El ideal de confianza y el deseo de fortalecer los lazos de amistad y vecindad han sido probados por Hernández Flores (2003) en interacciones entre españoles. 
de los valores culturales vigentes de una sociedad) aplicables a los españoles: manifestaciones de aprecio hacia los otros, noción del orgullo, noción del honor, tolerancia a las opiniones divergentes y lo que podríamos Ilamar gusto por la confrontación discursiva.

Briz (1994) ve la cortesía lingüística como el mantenimiento de una interacción sin tensiones y observa que la conversación coloquial española es estratégicamente cortés como medio para lograr un fin (Briz, 2003: 22). También en la línea de la relatividad cultural, distingue Briz (2004: 69) entre cortesía codificada, sujeta a convención, y cortesía interpretada, evaluada en el transcurso de la interacción a partir de las reacciones de los participantes. Este autor (Briz, 2004: 83) propone la existencia de ideomas corteses como contenidos activadores de la protección de ciertas imágenes propias o ajenas, que son característicos de cada cultura o grupo social (por ejemplo, atenuación ante temas conflictivos, justificación de un rechazo a una invitación).

Una de las críticas dirigidas a la teoría de Brown y Levinson ([1978] 1987) por parte de diferentes autores (Culpeper, 1996; Culpeper et al, 2003; Eelen, 2001) se refiere al hecho de que aun siendo una teoría amplia, carece de explicación para el fenómeno de la descortesía. Culpeper (1996) propone un modelo paralelo, pero de dirección opuesta, a las cinco superestrategias de cortesía que contempla la teoría de la cortesía de Brown y Levinson. Las superestrategias de descortesía son las siguientes: ${ }^{3}$

1) Descortesía descarnada (bald on record impoliteness), de realización intencional, directa y sin ambigüedades.

2) Descortesía positiva (positive impoliteness), con estrategias cuyo objetivo es dañar la imagen positiva del interlocutor.

3) Descortesía negativa (negative impoliteness), con el fin de atacar la imagen negativa del otro.

4) Descortesía encubierta (off-record), con más de una intención atribuible al hablante, se produce mediante implicatura.

5) Ausencia de cortesía (withhold politeness) en situaciones en que es esperable que se produzca cortesía.

Consideramos que la distinción del primer tipo respecto del segundo y tercero es problemática, ya que esa descortesía descarnada tendría por objeto de alguna manera la imagen negativa o la positiva del destinatario. Con todo, es un intento de establecer un marco teórico digno de atención. Dentro de la descortesía encubierta, la descortesía burlesca o fingida (mock impoliteness) es una descortesía sin intención clara de ofensa ni interpretación como tal por parte de

3. Seguimos la terminología en español propuesta por Blas Arroyo (2001). 
los destinatarios, que liene defeciu de reforzar la solidaridad in-group; Culpeper (1996: 354) considera que el insulto ritual funciona en la sociedad como válvula de seguridad. Esta descortesía fingida podría relacionarse, al menos en las formas, con lo que hemos denominado anticortesía (véase apartado 6).

Pasando a la realización de la descontesía, Kaul de Marlangeon (e.p.) propone tres modos por orden de escalada en gravedad:

1) Descortesía por quebrantamiento inconsciente de las normas de cortesía (la clásica «metedura de pata»).

2) Descortesía por quebrantamiento consciente de las mismas (por ejemplo, el responder a las expectativas de asentimiento con silencin).

3) Descortesía con objeto de «apocar, menoscabar, desamai, exasperai, mortificar, zaherir, ofender o, incluso, anular al oyente» (Kaul de Marlangeon, e.p.), lo cual correspondería a la descortesía descamada mencionada por Culpeper (véase en Apartado 5 algunas secuencias extraídas de nuestro corpus que van en esta dirección).

\section{MATERIALE Y METODOLOGIA}

Este trabajo se basa en un corpus de conversaciones extraídas de las grabaciones del corpus general de español hablado del grupo Val.Es.Co., de las Universidades de Valencia y Alicante (Briz y Grupo Val.Es.Co., 2002), cuyo objeto de estudio es el español hablado en el área metropolitana de Valencia (España). El corpus de conversaciones coloquiales consta de diecinueve conversaciones que abarcan algo menos de seis horas y están divididas en dos grandes grupos: un primer grupo formado por nueve conversaciones según el carácter prototípico o periférico del rasgo de coloquialidad y un segundo grupo que consta de diez conversaciones articuladas por estratos o niveles socioculturales. Algunas características indicadoras de coloquialidad (Briz y Grupo Val.Es.Co., 2002: 18) que las conversaciones analizadas comparten son: a) discurso oral, dialogal, inmediato; b) retroalimentado y cooperativo; c) dinámico y con alternancia de turnos no predeterminada; d) no planificado; e) no transaccional; f) de tono informal.

La duración de las conversaciones oscila entre los siete y los cincuenta minutos. Se han analizado once conversaciones, ${ }^{4}$ todas de carácter coloquial

4. Cinco conversaciones pertenecientes al grupo de conversaciones de rasgo coloquial prototípico: [L.15.A.2], [ML.84.A.1], [H.38.A.1], [AP.80.A.1], [J.82.A.1] y seis conversaciones segin estratos socioculturales: [RV.114.A.1], [1H.340.A.1], [PG.119.A.1], [MI.97.A.1], [BG.210.A.1], [VC.117.A.1]. 
prototípico, excepto una de ellas que es de carácter periférico por no darse relación de igualdad social y funcional. Las conversaciones han sido obtenidas mediante grabaciones secretas en espacios familiares para los participantes, contando a posteriori con el consentimiento para su uso como material de investigación. Consideramos que es de suma importancia contar con materiales reales para poder analizar los fenómenos espontáneos que van emergiendo en la interacción (Hopper, 1998: 165), sobre todo cuando están en liza fenómenos como los de descortesía, quizás no tan accesibles en interacciones no espontáneas. $^{5}$

Metodológicamente, seguimos una orientación émica (Spencer-Oatey, 2003: 91) en la que el analista deja al corpus «hablar por sí mismo», o sea, no parte de un conjunto de categorías preconcebidas de tinte universal, sino que enfoca una cultura en concreto para descubrir los patrones en el corpus bajo análisis en particular. Se ha llevado a cabo una lectura de las transcripciones y una audición de las conversaciones. Se presentarán ejemplos para ilustrar los conceptos que estamos manejando.

\section{ACTOS CORTESES}

Sin pretender aportar una lista exhaustiva, se considerarán aquí ciertos actos de cortesía considerados como actos con contenido intencional por parte del hablante que tienen como finalidad la colaboración discursiva con el interlocutor al interesarse por el discurso del otro, ratificar el tópico discursivo mantenido por el interlocutor, etc.; la disminución del desacuerdo (estrategias asociadas a la atenuación, como limar asperezas o evitar disrupciones en la interacción) y la valoración positiva del interlocutor, con frecuencia mediante estrategias de intensificación: hacerlo quedar bien, halagarle explícitamente, sea de modo directo haciendo un cumplido a su persona, sea alabando objetos de su posesión o elogiando a su familia.

\subsection{Actos colaborativos}

En un nivel predominantemente interaccional, un hablante puede hacer un aporte a la conversación con la finalidad de apoyar al hablante poseedor del turno. Veamos ejemplos de los siguientes actos:

5. Al contrario, son fácilmente observables en el debate político, donde los comportamientos corteses son esperados por los interactuantes según las expectativas de roles. Blas Arroyo (2004) los califica como comportamientos de rasgo no marcado. 


\section{1) Mostrar interés por el discurso del interlociator}

En la conversación [H.340.A.1] aparece un gran número de intervenciones en que una hablante sigue con atención lo que su interlocutora le va contando al mostrarle unas fotos: hace conentarios, demanda más información, eic, como se aprecia en y ese chico ¿quién es?, ¿esta es la operada?, ioye! es para denunciar. los, jay! ¿no tienes ninguna de la nieve esquiando?, y al final bien ¿no?

\section{2) Mostrarse colaborativo con los enunciados del interlocutor}

Nos referimos aquí a las situaciones en que uno de los hablantes apoya a otro completando una expresión que éste ha dejado inacabada, sea porque no ie viene a la mente la palabra adecuada (1), sea porque elige estratégicamente dejar la expresión sin terminar para que se extraigan inferencialmente sus contenidos (2):

(1) [L.15.A.2] $(628-630)^{6}$

Ly $E$, mujeres; $G$, hombre, novio de $L$; amigos; entre 26-55 años. Tema: hablan de una conocida y sus aventuras sentimentales.

G: [no me-] no me digas tú a mí quee-// que precisamente para enrollarse con un tío pues es// NECESARIO irsee

\section{L: a Santiago de Compostela $\S$}

El alargamiento silábico en irsee muestra una vacilación por parte de $\mathrm{G}$ que constituye un lugar de transición pertinente (LTP) que es aprovechado por $L$, quien completa la expresión con la información presentada en un fragmento previo de conversación.

(2) [AP.80.A.1] (642-646)

$S$ y J, hombres; amigos; entre 26-55 años. Tema: hablan de las dificultades para dejar de fumar; $S$ se refiere a comprar tabaco.

S: y ese fue el momento/l/ pero es que no puedes decir/maÑAna/ como digas mañana $\rightarrow \S$

J: $\$$ es/ AHORA

S: $\quad$ c(l)aro/ es/ ahora//

El hablante S emite una construcción suspendida, como digas mañana, completa desde el punto de vista comunicativo, con tonema de suspensión

6. Los ejemplos que se muestran en este trabajo aparecen con el texto dividido en unidades de sentido, teniendo en cuenta los criterios expuestos en Gille (2001: 65-67) y los criterios de aislabilidad e identificabilidad de los actos que proponen Briz y Grupo Val.Es. Co (2003: 31).

7. Briz y Grupo Val.Es.Co. (2003: 43) proponen la existencia de actos estratégicos que pueden ser de dos tipos, a saber, actos suspendidos: estructuras gramaticalmente inacabadas pero comunicativamente completas, y actos truncados: reinicios, autocorreciones, que responden a veces a una estrategia atenuadora. 
(Hidalgo, 1997: 206-207) que apela al conocimiento compartido del interlocutor y a su capacidad de interpretación ( «si lo dejas para mañana, no lo vas a hacer, es mejor que lo hagas hoy mismo»), tras lo cual J enlaza colaborativamente.

\section{3) Repetir solidariamente las palabras del interlocutor}

La repetición es considerada por Brown y Levinson ([1978]1987: 112) como una estrategia de cortesía positiva para expresar acuerdo; también Haverkate (2004: 57), basándose en materiales en lengua española, considera que la repetición léxica pretende «transmitir una marcada señal de cortesía positiva», o sea, que sería una estrategia que confirma la solidaridad grupal, como se ve en (3), donde la alo-repetición total ratifica el punto de vista del interlocutor mostrando lo adecuado en la elección de sus palabras:

(3) [MT.97.A.1] (306-314)

$A, B$ y $C$, mujeres; compañeras de trabajo; entre 26-55 años. Tema: hablan de los videntes con consultorio telefónico.

B: $\quad$ se anuncian todos estos [brujos entre comillas=]

A: $\quad[j a h n$ no pero cada vez hay más]

$\mathrm{B}: \quad=$ que son consultorios de esos§

A: $\S$ de disquet $\S$

B: $\quad$ de disquet $\S$

A: $\quad$ [(RISAS)]

C: $\quad[(R I S A S)]$ que no es lo mismo

A: que no es lo mismo/

o sea no puede funcionar bien eso nunca/

\subsection{Actos atenuadores del desacuerdo}

Nos referimos aquí especialmente a la cortesía usada como atenuadora del desacuerdo, coincidiendo a rasgos generales con lo que Kerbrat-Orecchioni (1996) ha calificado de cortesía mitigadora de corte abstencionista, o sea, se trata de actos dirigidos a evitar o reparar un posible riesgo de amenazas al interlocutor, aliviando la tensión que pueda sufrir en la interacción. Los hablantes de los ejemplos (4) y (5) están contribuyendo al mantenimiento tanto de la imagen propia como de la de su interlocutor/a.

\section{1) Disminuir el disentimiento con el otro}

En (4) la postura de L no coincide con la de E:

(4) [L.15.A.2] (401-407)

$L$ y $E$, mujeres; $G$, hombre, novio de $L$; entre $26-55$ años. Tema: hablan de una persona ausente, conocida de ellos, a la que consideran bastante religiosa. 
L: Lo que pasa que ćl no va por ahí dicićndolo nii yo qué sét él es-éel/ eso de la religión es muy importante

$\mathrm{G}: \quad$ no/ oye/ $\mathrm{si} / /$ puede [ser ino?]

L: [yo también pienso que la - la religión] es importante $\uparrow$ peroo tú te la- la puedes entender de una forma o de otra/l/

Primero la suaviza matizando con una alo-repetición que está de acuerdo con su opinión de que la religión es importante; después deja ver cuál es su opinión, pero tú la puedes entender de una forma o de otra, ya que su forma de entender la religión no es la misma.

\section{2) Hacer quedar bien al otro (preservar su imagen)}

En interacciones marcadas por la polemicidad, puede ocurrir que algún participante contradiga un "ideoma cortés español", como en el caso de (5) al declararse la hablante racista. Esto ocasiona conflicto entre los participantes.

(5) [L. 15.A.2] (816-845)

L y E, mujeres; $G$, hombre, novio de L; entre $26-55$ años. Tema: después de varios temas polémicos, E se tacha a sí misma de ser racista.

$\mathrm{E}$ : igual es que soy racista $\uparrow \mathrm{y}$ aún noo/l pero yo veo un negro $\uparrow$ y me me da vamos me da

(...)

G: pero è el racismo- tú a lo mejor lo quee quieres decir no es- no es que no- que seas racista $\uparrow /$ sino que simplemente pues por el color puesporque supongo yo que $\rightarrow /$ lo que le hacen por ejemplo en Sudáfrica a los negros $\uparrow$ ¿no estarás de acuerdo?

E: no estoy DE ACUERDO pero yo veo un negro $\uparrow(())$

G: $\quad$ eso no es racismo eso es simplemente pues yo qué sés

E: $\quad \S$ que te llama un poco [la atención]

$\mathrm{G}$ : [que que] el color pues no te atrae [y ya está]

E:

que no lo aprecio/ [sí que]

porque ya ves/

yo no estoy de acuerdo con que les hagan esto a(de)más ipobr- pobre gente! yo qué sé

G: incluso si tú pudieras ayudarle $\uparrow$ pues les [ayudarías=]

E: $\quad[s i ́ \downarrow$ sí $]$

$\mathrm{G}$ : = en un momento dao ino?

E: sî $\downarrow$ que sí $\downarrow$ lo tengo muy claro/ 
La hablante E, mediante la afirmación igual es que soy racista deja comprometida su imagen (según lo que sería el ideoma correspondiente a lo inadecuado de declararse racista) y $\mathrm{G}$ aporta argumentos para hacerle ver que no es racista: matiza el contenido de lo que ha querido decir $\mathrm{E}$, tú a lo mejor lo quee quieres decir no es- no es que no- que seas racista, busca otros motivos y añade preguntas que hacen reaccionar a $\mathrm{E}$ en la dirección pretendida por G. Este acto consistente en mostrar consideración hacia los demás salvaguardando sus imágenes (Goffman, 1967: 10) y cuyo objetivo es hacer quedar bien al otro, consideramos que corresponde a una estrategia afiliativa en el sentido de que los miembros del grupo no se aparten de los contenidos socialmente aceptables; en el fondo, la propia imagen quedaría también en entredicho.

\subsection{Actos valorizantes}

Contemplamos en este subapartado lo que Kerbrat-Orecchioni (1996, 2002) y Albelda $(2003,2004)$ han denominado cortesía valorizante, de carácter produccionista y orientada a producir actos corteses aun sin existir riesgo de amenazas. La primera de estas autoras considera conveniente hablar de Face Flattering Acts (FFA), como contrapartida a los FTA de Brown y Levinson, que contempla actos, muy frecuentes en situaciones de familiaridad, como halagos, cumplidos, agradecimientos, ${ }^{8}$ etc., donde se refuerza la imagen del otro. La realización de tal tipo de actos consiste, pues, en una estrategia para quedar bien con el otro.

\section{1) Halagar al interlocutor}

Vemos un ejemplo de estrategia valorizante en el cumplido ${ }^{9}$ que se produce en (6); el refuerzo de la imagen del otro pasa en este sentido por indicar algo positivo relacionado con su apariencia física:

(6) [AP.80.A.1] (786-791)

A, mujer; J y S, hombres; amigos; entre 26-55 años. Tema: ojeando una revista, antes han hablado de los rayos UVA y los rayos láser al confundirse de término un participante.

J: $\quad$ mira $\downarrow$ Láser Medicina/ hablando de láser

A: $\quad$ pos eso es lo que nesesito $\downarrow$

8. Es pertinente señalar que en la cultura española los agradecimientos no son actos especialmente frecuentes en la interacción caracterizada por la cercanía y la familiaridad.

9. Haverkate (2003: 67) define el cumplido como «acto expresivo que tiene por objeto transmitir solidaridad y aprecio por la persona del interlocutors. 
yo purqu yo tongo el cherpo tó(do) etropead

sí yo no yoy mal encaminá (RISAS)

S: ¿tú tienes el cuerpo estropeado?

A: jOY QUE NO!

$S:$ 㕰 Ilipas

A: no tengo yo laa- la caja (de) cambios malamented vamos (RISAS)

S: a ver/ "súbete a la mesa y da así una vieltecita*

A: sí hombre $\downarrow$

pase de modelo(s) ahora $\downarrow$ a ehtah alturah ya/ [¿cómo me voy a (( ))]

S:

esta mesa $\uparrow /$ como es larga $\uparrow \S$

[tú imagínate que esto $/ 1$

A: $\$ m m \$$

S: $\quad$ imaginate que es la Pasarela cheles\$

A: $\$ \mathrm{~mm}$

S: $\quad$ : $y$.

A: ¿y los fotógrafos qué? (RISAS)/

yo aquí/ no desfilo sin fotográfoh ¿eh?

S: yo/miraa $\downarrow$

la cámara la tengo en el coche/

si quieres/ man - monto el trípode $\rightarrow$

En este ejemplo al preguntar $S$ atú tienes el cuerpo estropeado? retoma las palabras de A (aparentemente) negativas sobre sí misma, cuestionándolas con el efecto social positivo de hacer un cumplido como «pero si tú estás muy bien físicamente»; insiste después A en su opintón buscando corroboración por parte de $S$, quien efectivamente continúa con la ampliación del cumplido: subete a la mesa y da asi una vaeltecita, inaginate que es la Pasarela Cibeles. A acepta el cumplido con yo aquí no desfilo sin fotógrafos, expresión contestada de nuevo por $\mathrm{S}$ que sigue reforzando así la imagen de $\mathrm{A}$. Esta secuencia está en la línea de las observaciones de Lorenzo-Dus (2001) en el sentido de que entre los participantes españoles de su estudio esperan que se repita el cumplido para reforzar o expandir la alabanza.

\section{2) Elogiar algo que el interlocutor posee}

Éste es un acto muy frecuente en nuestros materiales. A modo de ejemplo, en la conversación [IH.340.A.1] se suceden los comentarios elogiosos de V, refiriéndose a unas lámparas, con abundantes expresiones exclamativas y adjetivos de calificación positiva que constituyen FEA. la verdad es que es muy bonita, ¡OSTRAS! ¡QUÉ MOONA! iQUÉ GRACIOOSA!, iqué cosa más bonita! ¿eh?, iqué original! 


\section{ACTOS DESCORTESES}

Hay ocasiones en que no se pretende preservar la imagen del otro, sino deteriorarla, atacarla o, incluso, destruirla; se contribuiría así al establecimiento de un desequilibrio ritual, usando la terminología de Goffman; es lo que ocurre, por ejemplo, mediante los actos intencionalmente amenazadores que a menudo son los insultos, cuyo efecto canónico es negativo, si bien, como se verá en el Apartado 6, pueden no tener tal efecto negativo en situaciones con determinadas coordenadas contextuales. No contemplamos aquí la descortesía en el discurso político donde la actitud descortés cumple las expectativas de rol, sino la interacción entre miembros de un grupo en un contexto no-institucional, y a raíz de este tipo de discurso indica Culpeper (1996: 354) que hay evidencias de que la «descortesía genuina», sin mitigación alguna, es más probable que ocurra en relaciones de extrema intimidad, aunque, lógicamente, ello no implique que la extrema intimidad conlleve descortesía.

En este sentido analiza Kaul de Marlangeon (e. p.) un tipo de descortesía presente en la interacción coloquial de clase media baja del español rioplatense, extraída de dos obras de teatro argentino, y que denomina descortesía intragrupal-crónica, que tiene el propósito estratégico "de desarmar o anular al oyente, pero sólo en resguardo del propio modo de ser del hablante", creando un clima de hostilidad y permanente reproche entre los interactuantes, donde impera la desvalorización, el resentimiento y el individualismo. Aunque no se puede afirmar que este tipo de actos descorteses abunde en nuestros materiales, sí existen secuencias donde pensamos que se refleja la intención descortés.

(7) [RV.114.A.1] (148-160)

$A$ y $B$, hombres, $C$, mujer; $A$ y $C$, matrimonio, $B$, hijo; $A$ y $C$, entre 26-55 años, $B$, menor de 25 años. Tema: hablan de las causas de la dolencia que padece $A$.

C: PERO YO L'HE DICHO que habías ido a coger un (( )) y t'habías quedao ENGANCHAO $\$$

A: $\quad$ ENGANCHAO $; \mathrm{NO} ! / / /$ ${ }^{\circ}(((\text { ya estoy hasta los cojones })))^{\circ}$

C: ¿TÚ NO ME HABÍAS DICHO QUE HABÍAS COGIDO UNA- UNA BOVEDILLA D'ESAS Y QUE TE HABÍAS QUEDAO ASÍ/

[QUE TE DOLÍA $\uparrow ?]$

A: $\quad$ [una bo- $]$ una bovedilla $\downarrow$ síi

C: $\quad$ ivete a cagar $\rightarrow$ ya!/

¡ves $\downarrow$

baja tú!/

¿isabes qué te digo!?

que la médica dice que cuando tú estés malo que bajes 
Esta secuencia empieza con contribuciones de $\mathrm{C}$ y $\mathrm{A}$ en las que hablan gritando. A no está de acuerdo con la descripción que $\mathrm{C}$ hace sobre el motivo de su dolor de espalda, repite explícitamente el término usado por $\mathrm{C}$ y lo niega directamente: enganchao ;no!; A, bajando el tono de voz con ya estoy hasta los cojones muestra su actitud negativa ante $\mathrm{C}$ y la situación en sí. La reacción de $\mathrm{C}$ es gritar preguntando con tintes de reproche lo que A parece que le dijo en otro momento como causa del dolor (que se había lesionado al inclinarse a coger una bovedilla), a lo que A repite bovedilla sí con tono irónico. Ante esto C emite un insulto jvete a cagar ya!, que es sancionado por la tercera persona presente en la secuencia, el hijo de ambos, que con ihas oído?! a l'atra parles, cambio de código incluido, recrimina a $\mathrm{C}$.

En una conversación diferente, pero de similar constelación familiar que el anterior ejemplo, observamos:

(8) [VC.117.A.1] (177-194)

A y $B$, mujeres, $C$, hombre; $B$ y $C$, matrimonio, $A$, hija; $B$ y $C$, entre 26.55 años, $A$, menor de 25 años.

B: $\quad$ ((Teo)) mira que tiene maal ¿eh? yogur ${ }^{1 /} /$ tiene mal yogur grande $\$$

C: $\quad \xi^{\circ}(\text { alcahueta })^{\circ}$

B: jeállate ya!///(2")

no hace más que hablar ${ }^{\circ}$ (sandeces ${ }^{\circ}$

B bromea y $\mathrm{C}$ la tacha de alcahueta, lo que constituye un acto descortés grave según la escala de Kaul de Marlangeon (e. p.), ya que es un comentario zahiriente que ataca la imagen de $\mathrm{B}$; el efecto de descortesía lo interpretamos según la reacción de $\mathrm{B}$, que responde con tono enfadado haciendo un comen-tario descalificador que tiene visos de «rencor de historia previa», ya que no parece que sea una queja meramente circunstancial.

\section{ACTOS ANTICORTESES}

Retomando aquí lo señalado en el apartado 5 respecto a los insultos como actos dirigidos a lesionar la imagen del otro, hay que indicar que existe otra lectura del efecto habitual de las expresiones ridiculizadoras y de los insultos, los cuales, según Zimmermann (2003: 49) «amenazan la identidad del otro, sin

10. Valenciano, «Otra vez hablas», con valor de recriminación.

11. Por «leche», siguiendo la broma. 
que los afectados se sientan ofendidos o reclamen excusas sino que, al contrario, se sienten muy felices por este tipo de trato». Este autor, aislando estos comportamientos en conversaciones entre hablantes de jóvenes sexo masculino procedentes de España, México y Uruguay, postula que dichos comportamientos son de carácter antinormativo y tienen una función de constitución de una identidad masculina. Zimmermann (2003: 57) sostiene que estos actos que no son considerados por los afectados como deterioro o amenaza a la imagen no se pueden clasificar como descorteses y propone el calificativo de anticorteses, en tanto en cuanto que, sin ser ni corteses ni descorteses, forman parte de la actividad antinormativa expresada en el uso de un lenguaje antinormativo, «haciendo uso precisamente de los recursos lingüísticos proscritos por la sociedad dominante».

No pretendemos, en un trabajo de reducidas dimensiones como es el presente artículo, profundizar en torno a la cuestión de si este fenómeno es exclusivo de los jóvenes de sexo masculino como herramienta para la construcción de su identidad; sin embargo, pensamos más bien que estos comportamientos no tienen por qué ceñirse a dichos hablantes y que igualmente pueden aparecer en una conversación entre amigas con alto grado de cercanía y familiaridad. Una muestra de esto puede ser el comentario que hace una de las mujeres en (9), en una conversación distendida y amena que transcurre entre dos matrimonios amigos, tachando a uno de los varones de egoísta:

(9) [PG.119.A.1] (461-463)

$M$, mujer; entre 26-55 años. Tema: hablan de viajes en general y en concreto de un viaje gratis que le tocó a otro de los participantes en la conversación

M: $\quad \S$ ¡cóño!/

pues haberla comprao y vamos nosotros//

MIRA ESTE/

TÚ NO PIENSAS EN LOS DEMÁS/ EGOÍSTA

Consideramos interesante el concepto de anticortesía propuesto por Zimmermann (2003), si bien no tanto como estrategia para crear un «universo antinormativo», sí como estrategia que produce entre los participantes en la conversación efectos afiliativos no esperados, o comúnmente no asociados al uso de ciertas estrategias de descortesía.

Existen actos que en su interpretación en una situación de otro carácter serían codificados como descorteses y conllevarían un daño a las imágenes de los receptores: insultar a una persona con motivo de su baja estatura (10) o incluso, como ocurre en otras ocasiones, tachar a una persona de tacaña, celebrar un eructo (11) o sacar a colación algo relacionado con expeler ventosidades. Tienen aquí, en cambio, un efecto positivo y afiliativo que 
maximizan la solidaridad entre los interactuantes. En este sentido, hacemos extensible a la descortesía la afirmación de Meier respecto a la cortesía (1995: 387): «politeness can only be judged relative to a particular context and a particular addressee's expectations and concomitant interpretation».

(10) [H.38.A.1] (19-29)

$A, B, C$ y $D$, hombres; amigos; menores de 25 años. Tema: están en la playa y hablan del sitio que han ocupado.

A: este tronco lo mandamos a tomar por culo

C y D: [(RISAS)]

B: pues tú lo has puesto $\downarrow$

tio

D: EL [boyescaut ${ }^{12}$ este]

A: $\quad[$ a ya ya ya $] \S$

D: \&TAPÓN\$

A: $\quad \$$ pues si no llega a ser por mí no encontráis un sitio como este=

A: $\quad=$ el mejor sitio de todaa/ la historia§

B: $\quad$ sín

(11) [H.38.A.1] (614-618)

A, B, C y D, hombres; amigos; menores de 25 años. Tema: uno de los participantes eructa.

B: (ERUCTO) dedicado

A: bon profit $13 / /$

dedicado $\uparrow$ a mi- [a mi tía Pepa que me estar escuchando $\uparrow$ ]

B: $\quad$ [(RISAS)] estaría bien $\downarrow$

nanol

BRUUAA $^{14}$ dedicado a todos $\uparrow$

A: a todos los cabrones que me están escuchando

El eructo, que en una situación social de menor familiaridad sería motivo común para pedir disculpas, aquí no sólo no es así, sino que es usado por los componentes del grupo como algo positivo, siendo objeto de elaboración discursiva en sentido afiliativo y lúdico.

12. Adaptación fonética de boy scout.

13. Valencianismo, "buen provecho" "que aproveche".

14. Reproduce onomatopéyicamente un eructo, probablemente porque se ve corroborado por la intervención de A. 


\section{CONCLUSIONES}

Este estudio ha tenido por meta mostrar una serie de actos relacionados con la cortesía, los cuales aparecen en la conversación espontánea de rasgo coloquial entre hablantes españoles, analizando una serie de conversaciones pertenecientes al corpus general de español hablado del grupo Val.Es.Co. Se proponen actos orientados a la colaboración discursiva con el interlocutor, la atenuación del desacuerdo con el fin de aliviar tensiones en la interacción y a la valoración positiva del interlocutor. Se ejemplifican también situaciones donde aparecen actos descorteses que no pretenden preservar la imagen del otro, sino más bien deteriorarla y atacarla. Finalmente se toma la idea de la anticortesía, más allá del ámbito de la creación de identidad juvenil masculina (Zimmerman 2003), como estrategia que, en vez de dañar la imagen del interlocutor, produce efectos afiliativos que refuerzan el sentimiento de solidaridad grupal. Una posterior profundización tanto cualitativa como cuantitativa en los recursos lingüísticos que los hablantes utilizan para realizar estos actos, podrá aportar más luz a este trabajo todavía provisional.

\section{CONVENCIONES DE TRANSCRIPCIÓN}
A:
Intervención de un hablante identificado como A.
$\S$
Sucesión inmediata, sin pausa apreciable, entre dos emisiones de distintos hablantes.
Mantenimiento del turno de un participante en un solapamiento.
Lugar donde se inicia un solapamiento o superposición.
Final del habla simultánea.
Reinicios y autointerrupciones sin pausa.
Pausa corta, inferior al medio segundo.
Pausa entre medio segundo y un segundo.
Pausa de un segundo o más.
Silencio (lapso o intervalo) de 5 segundos; se indica el $n^{\circ}$ de segundos en las pausas de más de un segundo, cuando sea especialmente significativo.

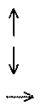
TAPÓN
(( ))
$(($ pagaos $))$
$((\ldots))$
a(de)más
Entonación ascendente.
Entonación descendente.
Entonación mantenida o suspendida.
Pronunciación marcada o enfática (dos o más letras mayúsculas), tono de voz alto.
Fragmento indescifrable.
Transcripción dudosa.
Interrupciones de la grabación o de la transcripción.
Reconstrucción de una unidad léxica que se ha pronunciado incompleta, cuando pueda perturbar la comprensión. 
The Fenomenos de fonètica sintactica entre palabras, especialmente marcados.

${ }^{\circ}()^{\circ} \quad$ Fragmento pronunciado con una intensidad baja o próxima al susurro.

h Aspiración de " $\mathrm{s}$ " implosiva.

(RISAS,

ERUCTO...) Aparecen al margen de los enunciados.

* * Palabra ofragmento pronunciado entre risas simultáneas.

aa Alargamientos vocálicos/consonánticos

i) !? Interrogaciones exclamativas.

¿? Interrogaciones. También para los apéndices del tipo "¿no?, ¿eh?, ¿sabes?"

i! Exclamaciones.

Letra negrita: Fragmento que se quiere resaltar en el análisis.

\section{REFERENCIAS BIBLIOGRÁFICAS}

Albelda, M. (2003): «Los actos de refuerzo de la imagen en la cortesía peninsular» en Bravo, D. (ed.) (2003: 298-305).

- (2004): «Cortesía en diferentes situaciones comunicativas. La conversación coloquial y la entrevista sociológica semiformal» en BRAVO D.; A. BRIZ (eds.) (2004: 107-134).

BlAS Arroyo, J. L. (2001): «'No diga chorradas...' La descortesía en el debate político cara a cara. Una aproximación pragma-variacionista», Oralia. Análisis del discurso oral, 4: 9-45.

- (2004): «Cortesía y descortesía en el discurso político español», ponencia presentada en Iberoromanska seminariet, Universidad de Estocolmo, abril de 2004.

Bravo, D. (1999): «iImagen "positiva" vs. imagen "negativa"? Pragmática sociocultural y componentes de face», Oralia. Análisis del discurso oral, 2: $155-184$.

- (2001): «Sobre la cortesía lingüística, estratégica y conversacional en español», Oralia. Análisis del discurso oral, 4: 299-314.

- (2003 a): «Actividades de cortesía, imagen social y contextos socioculturales: una introducción», en BRAvo, D. (ed.) (2003: 98-108).

- (ed.) (2003 b): La perspectiva no etnocentrista de la cortesía: identidad sociocultural de las comunidades hispanohablantes, Actas del Primer Coloquio del Programa EDICE, Estocolmo, 6-8 de septiembre de 2002, CDRom.

Bravo, D.; Briz Gómez, A. (cds.) (2004): Pragmática sociocultural: estudios sobre el discurso de cortesía en español, Barcelona, Ariel. 
Briz GómEz, A. (1994): «La atenuación en la conversación coloquial. Una categoría pragmática», en Cortés RoDríguez, L. (ed.) (1994): El español coloquial: actas del I Simposio sobre análisis del discurso oral, Almería, Universidad de Almería.

- (2004): «Cortesía verbal codificada y cortesía verbal interpretada en la conversación», en Bravo, D.; A. BRIz (eds.) (2004: 67-93).

BRIZ, A. Grupo VAl.Es.Co (2002): «Corpus de conversaciones coloquiales», anejo de la revista Oralia, análisis del discurso oral, Madrid, Arco-Libros.

- (2003): «Un sistema de unidades para el estudio del lenguaje coloquial», Oralia. Análisis del discurso oral, 6: 7-61.

BORETTI, S. H. (e.p.): «Aportes de la perspectiva sociopragmática a la metodología para el estudio de la cortesía lingüística», en MuriLlo, J. (ed.) (e.p.).

Brown, P. \& S. Levinson (1987) [1978]: Politeness. Some Universals in Language Use, Cambridge, Cambridge University Press.

CUlPEPER, J. (1996): «Towards an anatomy of impoliteness», Journal of Pragmatics, 25: 349-367.

Culpeper, J.; D. Bousfield; A. Wichmann (2003): «Impoliteness revisited: with special reference to dynamic and prosodic aspects», Journal of Pragmatics, 35: 1545-1579.

Eelen, G. (2001): A Critique of Politeness Theories, Manchester, St. Jerome. ESCANDELl VIDAL, $\mathrm{M}^{\mathrm{a}}$ V. (1995) «Cortesía, fórmulas convencionales y estrategias indirectas», Revista Española de Lingüística, 25:1, 31-66

GiLLE, J. (2001): Pautas argumentativas en el diálogo espontáneo. Un estudio en conversaciones intra e interculturales, Doctoral dissertation Stockholm University. Edsbruk, Akademitryck AB.

GOFFMAN, E (1967), «On face-work. An analysis of ritual elements in social interaction», en GOFFMAN, E. (1967): Interaction ritual: Essays on Faceto-Face Behavior, New York, Doubleday Anchor books.

- (2001) [1959]: La presentación de la persona en la vida cotidiana, Buenos Aires, Amorrortu editores.

Haverkate, H. (1994): La cortesía verbal. Estudio pragmalingiüístico. Madrid, Gredos, S. A.

- (2004): «El análisis de la cortesía comunicativa: categorización pragmalinguística de la cultura española», en BRAVO, D.; A. BRIz (eds.) (2004: 55-65).

HERNÁNDEZ Flores, N. (2003): «Cortesía y contextos socioculturales en la conversación de familiares y amigos», en BRAvo, D. (ed.) (2003: 121-127).

Hidalgo Navarro, A. (1997): la entonación coloquial. Función demarcativa y unidades de habla, anexo XXI de la Revista Cuadernos de Filología, Universitat de València. 
HOPPER, P. (1998): «Emergent Grammar», en TOMASELlo, M. (ed.) (1998): The New Psychology of Language. Cognitive and Functional Approaches to Language Structure, Londres, Lawrence Erlbaum Associates, Publishers.

Kaul de Marlangeon, S. (e.p.): «Descortesía intragrupal-crónica en la interacción coloquial de clase media baja del español rioplatense», en Murillo, J. (ed.) (e. p.).

Kerbrat-Orecchioni, C. (1994): «Vers une typologie des ethnolectes», en Kerbrat-Orecchion, C. (1994): Les interactions verbales, Tome III, Paris, Armand Colin.

- (1996): La conversation, París, Seuil.

(2004): «Es universal la cortesía?», cn BRavo, D.; A. Briz (cds.) (2004: $39-53)$.

LORENzo Dus, N. (2001): «Compliment responses among British and Spanish university students», Journal of Pragmatics, 33: 107-127.

MAO, L.R. (1994): «Beyond politeness theory: 'Face' revisited and renewed», Journal of Pragmatics, 21: 451-486.

Matsumoto, Y. (1988): «Reexamination of the universality of face: Politeness phenomena in Japanese», Journal of Pragmatics, 12: 403-426.

MeIER, A. J. (1995): «Passages of politeness», Journal of Pragmatics, 24: 381392.

Murillo, J. (ed.) (e.p.): Actos de habla y cortesia en diferentes variedades del español. Perspectivas teóricas y metodológicas, Actas del Segundo Coloquio Internacional del Programa EdicE, San José, Universidad de Costa Rica, 8-10 de marzo de 2004.

SPENCER-OATEx, H. (2003); «Developing a Framework for Non-Ethnocentric 'Politeness' Research», en Bravo, D. (ed.) (2003: 86-96).

ZimmermanN, K. (2003): "Constitución de la identidad y anticortesía verbal entre jóvenes masculinos hablantes de español», en BrAvo, D. (ed.) (2003: 47-59). 


\title{
IMAGEN SOCIAL ESPAÑOLA VERSUS IMAGEN SOCIAL ALEMANA
}

\author{
Josefa Contreras Fernández \\ Universitat Politècnica de València
}

$\mathbf{L}$ A imagen social, descrita por Goffman ([1971]1979), tiene la virtud de conectar los conceptos de identidad personal y social. Éste último es un conjunto de percepciones acerca de quiénes somos en relación con nosotros mismos, los otros y los sistemas sociales, por lo que la imagen social varía según la comunidad de habla. Siguiendo esta idea, adoptamos los conceptos de imagen, postulados por Bravo (1996, 1999, 2001, 2003, 2004) de «autonomía» y «afiliación» para la imagen social española; y nos basamos en ellos para caracterizar la imagen social alemana que denominamos autonomía y privacidad. Consideramos que en una conversación, los deseos de imagen de los interlocutores que mantienen el equilibrio presentan unas características dadas por la comunidad de habla a la que pertenecen, ya que los interlocutores construyen y afirman las imágenes sociales según el contexto situacional y su propio contexto sociocultural. Para demostrar esta hipótesis, hemos analizado comportamientos comunicativos en un corpus de conversaciones formales españolas y alemanas, así como conversaciones coloquiales españolas y alemanas respectivamente. Además, y con el fin de contrastar los resultados de los análisis de las conversaciones, hemos analizado unas encuestas referente al comportamiento social y cortés y al comportamiento comunicativo. Tras el análisis se ha visto confirmada nuestra hipótesis: la imagen social de los interlocutores varía y depende tanto del contexto sociocultural como del contexto situacional. Por este motivo, la característica de afiliación de la imagen social española sólo se podría adaptar a la imagen social alemana cuando se trata de relaciones o interacciones entre familiares y/o amigos; las relaciones con los demás se caracterizan más bien por el concepto de privacidad.

Durante una conversación, los interlocutores tratan de mantener una imagen de sí mismos a través de estrategias comunicativas verbales y no verbales, conscientes y no conscientes, péro siempre dependiendo de la clase de interacción y de la clase social y cultural a la que pertenezcan los participantes. Por lo tanto, el tipo de conversación y, sobre todo, la cultura es de suma importancia.

Göhring (1997: 10) nos da una definición etnográfica de lo que representa para él el concepto de cultura: 
Kultur ist all das, was man wissen, beherischen und enufunden künten unuß, um beurteilen $2 u$ können, wo sich Einheimische in ihren verschiedenen Rollen erwartungskonform oder abweichend verhalten, und um sich selbst in der betreffenden Gesellschaft erwartungskonform verhalten zu können, sofern man dies will und nicht etwa bereit ist, die jeweils aus erwartungswidrigem Vethalten entstehenden Konsequenzen zu tragen.

Para Göhring (1997), la cultura está, sobre todo, relacionada con el saber entender e interpretar bien los roles que uno tiene que desempeñar en cada situación, y en ese sentido, está relacionada con la imagen social. Por ello, antes de explicar nuestro concepto de la imagen social alemana, vamos a contrastar el contexto cultural alemán con el español.

En la cultura alemana se le otorga una gran importancia al tiempo libre. En España, en cambio, la importancia recae sobre la familia. Esto está relacionado con el carácter: la necesidad de los alemanes de separar lo privado, como es por ejemplo tiempo libre, de lo ajeno o público, por ejemplo el trabajo. Esta relación entre lo privado y lo público también se puede contrastar, según Althaus y Mog (1996), con otros aspectos de la vida cotidiana, como son las puertas cerradas o la enorme cantidad de verjas para delimitar su propiedad o esfera privada. Esta actitud tan reservada se puede observar en muchos alemanes, por eso, los extranjeros tachan a los alemanes de fríos y distantes, en cambio, los españoles se caracterizan por su forma de actuar tan extrovertida y abierta, y por la importancia que le otorgan a las amistades, aunque sean amistades superficiales (De Miguel, 1997: 39-40):

También es curiosa la expresión castellana de tener «cara de pocos amigos». Se supone, entonces, que hay que tener muchos amigos. No importa aquí tanto la calidad como la cantidad [...] El hecho de tener muchos amigos se considera un mérito, una gracia especial, en una sociedad, como la española, donde se vive tanto hacia fuera. [...] El uso social lleva a tener que presumir de que uno hace amigos con facilidad

En Alemania, también hay una gran cultura hacia la amistad, pero de forma diferente. Se selecciona más a los amigos, tal vez por ello, las amistades suelen ser profundas e intensas, ya que éstas les aportan estabilidad, seguridad y orientación. Conceptos necesarios, si tenemos en cuenta la historia alemana.

Estas características socioculturales también se reflejan en las conversaciones: en las conversaciones alemanas existe una mayor tolerancia por la idiosincrasia de cada individuo, o sea, por el respeto y la privacidad. Por ejemplo, la distancia habitual que mantienen los interlocutores entre sí es mucho mayor de la que mantienen los hispano-hablantes. Otro ejemplo, es que las interrupciones son menores y se interpretan de forma diferente que en la 
sociedad española, donde las interrupciones casi son imprescindibles para mantener viva la conversación, reflejo de la característica de identificación con los demás (Contreras, 2004).

En lo referente a la conceptualización de la cortesía, adoptamos el estudio más seguido por la investigación pragmática, el de Brown y Levinson ([1978] 1987) en su concepto de imagen y en su consideración de la cortesía como universal. Para estos autores la imagen social consta de una imagen negativa y otra imagen positiva: «negative face: the want of every 'competent adult member' that his actions be unimpeded by others. [...] Positive face: the want of every member that this wants be desirable to at least some others» (Brown y Levinson, 1987: 62).

En el análisis que realizamos en un estudio piloto adoptamos estos postulados y pudimos observar, por un lado, que aunque estos postulados, en principio sí se pueden adaptar a la comunidad de habla alemana, no se adecuan a la española y, por otro lado, que en los que respecta a la cultura alemana, son, según nuestro análisis, insuficientes, ya que con estos postulados no se puede explicar la característica de la imagen social alemana de privacidad, o sea, de separación de las esferas privadas y ajenas. Por ello, nos decantamos por adaptar los postulados de Bravo (1996, 1999, 2001, 2003, 2004) de autonomía y afiliación. Según Bravo existen unos contenidos básicos de la imagen con la que un individuo o grupo se identifica. Esos contenidos son universales en el sentido de que son categorías vacías que deben ser rellenadas para cada comunidad de habla. Y, por ello, esas categorías vacías de autonomía y afiliación se adecuan a estudios contrastivos. La autonomía es para Bravo «verse o ser visto diferente a los otros» y la afiliación «verse o ser visto en identificación con el grupo». Hernández-Flores (2002, $2003 a$ y $b, 2004)$ adopta estos postulados y los rellena para la imagen social española con los siguientes conceptos: la autonomía se caracteriza con el concepto de «autoafirmación: «ser consciente de las buenas cualidades propias» y la afiliación con el concepto de «confianza: saber a qué atenerse respecto al otro y que se puede hablar sin temor a ofensas».

Después de analizar los resultados de nuestro estudio piloto de las conversaciones y contrastarlos con las encuestas, así como con la bibliografía estudiada, llegamos a la siguiente conclusión: la imagen alemana también se caracteriza por el concepto de autonomía, pero más bien en el sentido de mostrarse orgulloso de tener habilidad crítica y confianza en sí mismo, aunque también estaría relacionado con otros conceptos, como, por ejemplo, con el deseo de libertad de acción o con la búsqueda de identidad. En lo que atañe al concepto de afiliación pudimos corroborar que la imagen social alemana se define más bien por verse o ser visto en delimitación con el grupo, ya que se caracteriza por la separación de lo privado y lo ajeno o público, o lo que es lo mismo, por la intensificación de las relaciones internas o externas. 
A continuaciún ilustraremos de qué forma se reflejan estas caractenísticas en las conversaciones. Nuestro corpus consta de diecisiete conversaciones: por una parte, conversaciones transaccionales, grabadas en agencias de viajes, ${ }^{\prime}$ y por otra parte, conversaciones coloquiales, grabadas en resiciencias particulares entre familiares y amigos, y tomadas del Institut fiur Deutsche Sprache y del grupo Val.Es.Co. respectivamente.

La cortesía como comportamiento comunicativo en las conversaciones tiene como fin destacar positivamente la imagen del hablante, buscando que el beneficio alcance a las imágenes de ambos interlocutores de forma equilibrada, gracias a estrategias comunicativas de cortesía empleadas (Hernández Flores, 2002, $2003 a$ y b). Pero, el deseo de imagen de los interlocutores presenta unas características dadas por la comunidad cultural a la que pertenecen. Debido a ello, hemos observado estrategias comunicativas similares y diferentes al contrastar las conversaciones españolas con las alemanas.

En cuanto a las estrategias comunicativas similares, pudimos comprobar que hay muchas más estrategias comunicativas de cortesía similares en las conversaciones coloquiales como, por ejemplo, secuencias laterales para cooperar en la conversación o intervenciones que muestran la disponibilidad de los interlocutores por participar y colaborar. Estas estrategias aumentan la eficacia conversacional y, sobre todo, la relación de confianza, que es una característica de la imagen social española de afiliación, es decir, de identificación con el grupo, incluso, para la imagen social alemana. Esto se debe, a la separación de las esferas públicas y privadas, o lo que es lo mismo, a la intensificación de las relaciones más íntimas y menos íntimas.

Con referencia a las estrategias comunicativas diferentes, hemos observado, que en las conversaciones transaccionales españolas, se utilizan secuencias laterales para hacer comentarios, o contar historias o anécdotas personales, tanto por parte de los clientes como por parte de los agentes. Estos recursos son estrategias comunicativas de cortesía que aumentan la eficacia conversacional y, sobre todo, la relación de confianza, que es una característica de la imagen social española del concepto de afiliación.

En las conversaciones transaccionales alemanas, se utilizan recursos conversacionales como la risa, el condicional o verbos modales. Estos recursos son estrategias comunicativas de cortesía que atenúan los enunciados, generando una distancia entre los interlocutores que es, a su vez, una caracterís-tica de la imagen social alemana de privacidad.

En las conversaciones coloquiales, la diferencia estriba en que en las españolas, los interlocutores utilizan marcadores apelativos fáticos, repeticio-

1. Las conversaciones españolas fueron grabadas en agencias de viajes de Valencia y las alemanas en agencias de viajes de Berlín y de Lippstadt. 
nes del contenido proposicional para hacer partícipe a los demás, cumplidos o comentarios para solidarizarse con los invitados. Estas estrategias comunicativas de cortesía caracterizan la imagen social española de autonomía y afiliación.

En cambio, en las conversaciones alemanas, las estrategias más llamativas son, por un lado, la atención prestada a los narradores y, en ese sentido, la aparición de turnos largos y silencios y, por otro lado, el afán por mostrar habilidad crítica, que son ambas estrategias comunicativas de cortesía que caracterizan la imagen social alemana de autonomía y privacidad.

Las conclusiones obtenidas del análisis de las conversaciones las contrastamos con las opiniones de hablantes nativos. Elaboramos una encuesta en español, basándonos en Hernández (2002, $2003 a$ y $b, 2004)$, y la tradujimos al alemán. Les pedimos a los informantes, un total de 160 estudiantes universitarios españoles y alemanes, que dieran su opinión sobre la cortesía y en qué situaciones se utiliza. El resultado fue el esperado: el comportamiento social y cortés se entiende de forma diferente según la sociedad cultural.

Los informantes españoles, un $68 \%$, enfatizan, por ejemplo, en la importancia que tienen para ellos las relaciones sociales, y, dicen caracteri-zarse por un rasgo social y por el carácter tan abierto que tienen. En cambio, los informantes alemanes, un $67 \%$, destacan la importancia de no violar el terreno privado, y en ese sentido, la separación de la esfera privada y la pública, y dicen caracterizarse por un rasgo de distanciamiento, sobre todo, con los no conocidos, o no amigos. Dicen también ser reservados, respetuosos y sociales con los amigos.

Las características del comportamiento social y cortés se reflejan también en el comportamiento comunicativo. En lo referente al comportamiento comunicativo, los informantes españoles, un $63 \%$ dicen utilizar más el estilo directo, argumentando que la gente tiene confianza. Por esa confianza hay un deseo de acercamiento que se refleja también en que a los españoles les gusta entablar conversaciones así como mantener una conversación viva. Mientras que los informantes alemanes, $44 \%$, dicen utilizar más un estilo indirecto por motivos de respeto, de educación, etc., aunque diferencian, por un lado, conversaciones coloquiales entre amigos y familiares, $y$, por otro lado, conversaciones formales entre conocidos y no-amigos, donde es necesario mantener una cierta distancia.

A partir de las informaciones facilitadas por los encuestados y los resultados del análisis de las conversaciones, se concluye que las diferencias culturales tienen su reflejo en la imagen social y, por consiguiente, en el comportamiento social y comunicativo. Por ello, se entiende, que aun siendo los contenidos básicos de la imagen social universales, es importante que existan unas categorías vacías, como las que postula Bravo (1996, 1999, 
2001, 2003, 2004), que puedan ser rellenadas según las características del contexto situacional y, sobre todo, del contexto sociocultural en cuestión.

\section{REFERENCIAS BIBLIOGRA ITCAS}

Althaus, H. J. Y P. MOG (1996): Die Deutschen in ihrer Welt. Tiibinger Modell einer integrativen Deutschlandkund, Berín, Langenscheidt.

Bravo, D. (1996): La risa en el regateo: Estudios sobre el estilo comunicativo de negociadores españoles y suecos, Estocolmo, Stockholms Universitet, Edsbruk Akademi-Tryck AB.

- (1999): «ilmagen 'positiva' vs. imagen 'negativa'? Pragmática sociocultural y componentes de face», Oralia, 2: 155-184.

- (2001): «Sobre la cortesía lingüística, estratégica y conversacional en español», Oralia, 4: 299-314.

- (2003): «Actividades de cortesía, imagen social y contextos socioculturales: una introducción», Actas del Primer Coloquio del programa EDICE. La perspectiva no etnocentrista de la cortesía: identidad sociocultural de las comunidades hispanohablantes, Universidad de Estocolmo, www.edice org, 98-108.

- (2004): «Tensión entre universalidad y relatividad en las teorías de la cortesía» en Bravo, D. y A. Briz (eds.), (2004): Pragmática sociocultural: estudios sobre el discurso de cortesía en español, Barcelona, Ariel, 15-37.

Brown, P. y S. Levinson. ([1978]1987): Politeness: Some Universals in Language Usage, Cambridge, Cambridge University Press.

Contreras, J. (2004): «Alternancia de turnos y cortesía. Un análisis contrastivo español-alemán», Estudios Filológicos Alemanes, 3: 371-382.

De Miguel, A. (1997): Autobiografía de los españoles. Cómo nos vemos. ¿Somos así?, Barcelona, Planeta.

GofFMan, E. ([1971] 1979): Relaciones en público. Microestudios de orden público, Madrid, Alianza.

GöHRING, H., (1997): «Interkulturelle Kommunikation: Die Überwindung der Trennung von Fremdsprachen- und Landesunterricht durch einen integrierten Fremdverhaltensunterricht» en Kongressberichte der 8. Jahrestagung der Gesellschaft fiir Angewandte Linguistik GAL.e.V., Mainz, vol IV: 9-13.

HeRnÁNDEZ FloRes, N. (2002): La cortesía en la conversación española de familiares y amigos; la búsqueda del equilibrio entre la imagen del hablante y la imagen del destinatario, Aalborg, Institut for Sprog Internationales Kulturstudier, Aalborg Universitet, vol. 37. 
- (2003 a): «Cortesía y contextos socioculturales en la conversación española de familiares y amigos», en Bravo, D. (ed): Actas del Primer Coloquio del programa EDICE. La perspectiva no etnocentrista de la cortesía: identidad sociocultural de las comunidades hispanohablantes, Universidad de Estocolmo, www.edice.org.: 121-127.

- (2003 b): «Los tests de hábitos sociales y su uso en el estudio de la cortesía: una introducción», en BRAVO, D. (ed): Actas del Primer Coloquio del programa EDICE. La perspectiva no etnocentrista de la cortesía: identidad sociocultural de las comunidades hispanohablantes, Universidad de Estocolmo, www.edice.org.: 186-197.

- (2004): «La cortesía como la búsquedad del equilibrio de la imagen social» en Bravo, D. Y A. BRIz (eds.) (2004): Pragmática sociocultural: estudios sobre el discurso de cortesía en español, Barcelona, Ariel. 



\title{
FACE-AGGRAVATION IN CONTEXT: A TENTATIVE METHODOLOGICAL FRAMEWORK
}

\author{
Ma Dolores García-Pastor \\ Universitat de València
}

\section{INTRODUCTION}

$\mathbf{T}$

THE present paper focuses on impoliteness in primary presidential debates of the 2000 North-American campaign. Primary debates are political campaign debates celebrated in an early stage of a determinate election year in U.S. presidential campaigns. In the past few years, many scholars in pragmatics have persistently been calling for research on rudeness in institutional contexts (Harris, 2001; Mullany, 2002). This study aims to attend to this call, thereby also attempting to shed light into the phenomenon of politeness from the view that impoliteness is part of a continuum of polite and rude behaviours and attitudes defining social conduct (Kienpointner, 1997). In the following paragraphs I argue that Lachenicht's (1980) model of rudeness, which takes Brown and Levinson's (1987) Politeness Theory (PT henceforth) as its point of departure, constitutes a useful tool for the examination of impoliteness in these contexts. Second, I describe debates as rule-governed persuasive encounters of a «zero sum game» nature, which accounts for the fact that politicians' impoliteness is first and foremost at the service of the audience's persuasion, and constitutes rudeness of an intended and systematic kind. In order to identify and classify impoliteness strategies in debaters' discourses four primary presidential debates were transcribed and analysed according to Lachenicht's framework. Finally, I discuss the main findings of my analysis illustrating them with examples from the data.

\section{LACHENICHT'S (1980) IMPOLITENESS MODEL}

Among the different models of impoliteness found in the literature, Lachenicht's (1980) is one of a few that takes Brown and Levinson's PT as its starting point. In a nutshell, these researchers establish that communication is constitutive of social relationships and is potentially aggressive, i.e. it may damage the face or self-image individuals want for themselves 
in a determinate society. Consequently, interlocutors are expected to soften or mitigate such potential face damage by means of a series of conversational strategies so that they maintain harmonious relationships with one another. These strategies are called politeness strategies and may orient to a speaker's positive face (or desire to be approved of) or a communicator's negative face (or desire to have freedom of action). However, these strategies may also consist of bald-on-record strategies, namely, highly direct strategies, or off-record strategies, viz. greatly indirect or implicit strategies.

Following Brown and Levinson, Lachenicht thus distinguishes among off-record, bald-on-record, positive and negative aggravation or impoliteness in such a way that: 1) off-record aggravation amounts to «ambiguous insults, insinuations, hints and irony» (1980: 619), 2) baldon-record rudeness constitutes «directly produced FTAs and impositions» (ibid.), 3) positive impoliteness conveys that the hearer is not approved of, and 4) negative aggravation aims to hinder his/her freedom of action. Within each of these main impoliteness categories, Lachenicht includes a series of aggravating strategies in the same fashion as Brown and Levinson in their PT.

Rudeness models based on Brown and Levinson's framework have usually been assumed to inherit some of the weaknesses associated with it. Although this is not entirely the case with Lachenicht's, Culpeper et al. (2003) posit that some of his concepts and strategies reveal inconsistencies, whereby certain strategies deployed to damage the interlocutor's positive face should be under those that hurt negative face, and vice versa. This questions directly the construct validity of such strategies and the categories in which they are embedded. Furthermore, these strategies and categories are illustrated with artificial examples in the model as opposed to instances taken from naturally occurring interaction. Notwithstanding all these indictments, I believe that Lachenicht's impoliteness model is one of the most complete models of rudeness in the literature. Along these lines, Turner (1996) establishes that Lachenicht's is a very meritorious work that has rarely been cited and/or implemented in particular analyses, and that such implementation would greatly benefit the impoliteness and politeness literature. Coping with the aforementioned inconsistencies of the model, hence the lack of construct validity of some of its strategies and categories, and backing the latter with real life conversational data, is one of the aims of this project. 


\section{POLITICAL DEBATES: PERSUASIVE ENCOUNTERS AND "ZERO SUM GAMES"}

As I have discussed elsewhere (García-Pastor, 2000, 2001, 2002), political campaign debates are persuasive encounters where candidates' primary goal is the persuasion of the audience to achieve as many votes as possible and win the elections. In the case of primary presidential debates in the U.S., a politician wants to attain votes to become the nominee of his/her respective political party in order to be able to continue in the race for the presidency of the nation. However, in their aim to persuade the audience, contestants must follow a series of communicative and socio-cultural norms underlying debates. These norms are set a priori and negotiated by politicians' campaign staffs (Martel, 1983; Kraus, 1988). They may be more or less general or specific, and, they are concerned, among other things, with the distribution of turns at talk, time for speaking, the way audience members have to behave, etc.

Besides constituting persuasive and rule-governed communicative events, debates are also antagonistic encounters of a «zero sum game nature». Political candidates are opponents in their persuasion of the audience, and as such, a debater's own image building automatically entails in a more or less implicit or explicit way, the discredit of the adversary's. Therefore, the victory of one participant has as a consequence the defeat of the other. This antagonistic and «zero sum game» condition of political debates accounts for the emergence of impoliteness in these contexts. In light of all the above, it can be affirmed that impoliteness or face-aggravation in debates is first and foremost at the service of the audience's persuasion, and is rudeness of an intended and systematic kind, that is, purposeful face-aggravation which is rule-governed and goal-oriented (see Lakoff, 1989; Kasper, 1990; Beebe, 1995; Kienpointner, 1997).

Debate investigations of impoliteness somehow related to Brown and Levinson's PT include Fernández-García's (2000) study of the 1996 Spanish electoral debates, Blas-Arroyo's (2001, 2003) research of the debates belonging to the 1993 Spanish campaign, and my own work. I would say that none of these studies except for Blas-Arroyo's offers a sufficiently complete framework of impoliteness strategies in these contexts. In his framework, Blas-Arroyo does not distinguish between positive and negative faceaggravating strategies, and excludes bald-on-record and off-record aggravation based on the argument that $a$ ) rudeness in debates is ultimately oriented to damage a candidate's positive face, and $b$ ) he could not find patterns in his corpus that made a difference significant enough to keep these four impoliteness categories. Although I share the view that a debater's positive face is the one that is most commonly under attack, I actually found patterns 
in my data supporting Lachenicht's four-fold face-aggravation division. Nevertheless, the findings of this study also show that the bald-on-record and off-record categories of impoliteness are more theoretically-oriented than empirically based constructs, thus suggesting that they could be abandoned altogether. These categories have been maintained though by acknowledging the multifunctionality of impoliteness strategies in debates, whereby, for instance, an off-record aggravating strategy may also be aimed to damage positive face.

\section{METHODS}

In order to identify and classify face-aggravating categories and strategies in politicians' discourses in debates, four primary presidential debates (two Democratic and two Republican) celebrated between January and February of the year 2000, and amounting to five hours and thirty minutes of talk in total, were transcribed in their entirety following some of Jefferson's (in Atkinson \& Heritage, 1984) transcription conventions (see Appendix).

Lachenicht's (1980) model of rudeness was taken as a point of departure in the analysis, thereby considering the possibility that different categories and strategies contemplated in other impoliteness models and investigations such as Blas-Arroyo's (2001, 2003), Culpeper's (1996), and Tracy and Tracy's (1998) among others, appeared. Additionally, the following was also taken into account in the analysis: 1) the fact that impoliteness develops in and throughout discourse; 2) the lack of a hierarchical order of impoliteness strategies from most to least impolite; 3 ) the potential multifunctionality of these strategies, and 4) their combination in the same rude sequence.

Lachenicht's classification of impolite communicative instances into bald-on-record, positive, negative, and off-record aggravation was backed as long as the potential multifunctionality of impoliteness strategies within each category was recognised. However, a) some of this author's strategies did not have empirical support in the data, hence were disregarded, b) others underwent certain modifications according to what emerged in the analysis, and c) new impoliteness strategies not appearing in this author's model were also observed. Table 1 . below resumes all these findings. 
TABLE 1. Framework of Face-Aggravating Strategies

\begin{tabular}{|c|c|c|c|}
\hline \multicolumn{4}{|c|}{ FACE-AGGRAVATING STRATEGIES } \\
\hline $\begin{array}{l}\text { Bald-On-Record } \\
\text { Strategies }\end{array}$ & $\begin{array}{c}\text { Positive Face-Aggravating } \\
\text { Strategies }\end{array}$ & $\begin{array}{c}\text { Negative Face- } \\
\text { Aggravating Strategies }\end{array}$ & Off-Record Strategies \\
\hline $\begin{array}{l}\text { a. Convey urgency or } \\
\text { metaphorical urgency" in: } \\
\text { a.1) expressing dislike for } \\
\mathrm{H} \text { and } \mathrm{H}^{\circ} \text { ' things, } \\
\text { actions, values and } \\
\text { opinions. } \\
\text { a.2) Denying in-group } \\
\text { status. } \\
\text { a.3) Denying or } \\
\text { contradicting common } \\
\text { or shared values and } \\
\text { opinions. } \\
\text { b. Use material evidence } \\
\text { c. Use real imperatives. }\end{array}$ & $\begin{array}{l}\text { a. Express dislike for, } \\
\text { disapproval of } \mathrm{H} \text { and } \mathrm{H}^{\prime} \text { ' } \\
\text { things, actions, values } \\
\text { and opinions. } \\
\text { b. Use non-valid } \\
\text { imperatives. } \\
\text { c. Use aggressive punning }{ }^{\circ} \text {. } \\
\text { d. Be sarcastic. } \\
\text { e. Mock. } \\
\text { f. Deny in-group status. } \\
\text { g. Deny or contradict } \\
\text { common or shared values } \\
\text { and opinionso, } \\
\text { h. Ignore } \mathrm{H} \cdot \text {. } \\
\text { i. Belittle or diminish the } \\
\text { importance of } \mathrm{H} \text { and } \mathrm{H}^{\prime} s \\
\text { things, actions, values } \\
\text { and opinions } \\
\text { j. Use insults, name-calling } \\
\text { or swear words. }\end{array}$ & 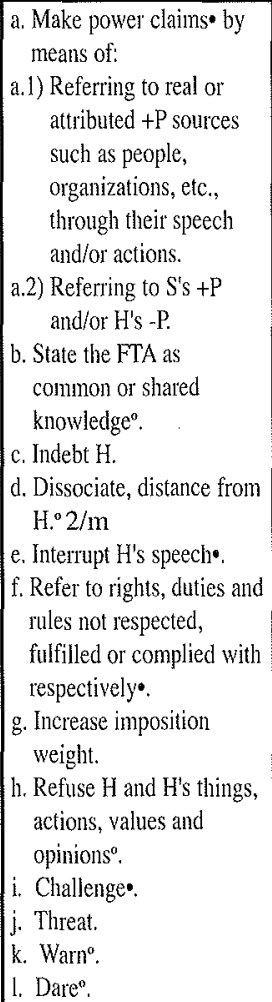 & $\begin{array}{l}\text { a. Presuppose, hint and give } \\
\text { association clues. } \\
\text { b. Exaggerate, hyperbolise". } \\
\text { c. Employ denials". } \\
\text { d. Understate. } \\
\text { e. Overstate. } \\
\text { f. Be ironic. } \\
\text { g. Use metaphors. } \\
\text { h. Use rhetorical questions } \\
\text { i. Be vague. } \\
\text { j. Over-generalise. } \\
\text { k. Displace } \mathrm{H}^{\circ} \text {. }\end{array}$ \\
\hline
\end{tabular}

${ }^{0}$ New strategies.

- Lachenicht's strategies modified.

\section{RESULTS AND DISCUSSION}

In general terms, positive and negative face-aggravation were the most frequently used categories of impoliteness in debates. In what follows, I will comment on those strategies in each of these categories that debaters deployed most regularly, and illustrate them with examples. 


\subsection{Bald-on-record aggravation}

As far as this rudeness category is concerned, strategy c., namely «Use real imperatives» (as opposed to non-valid ones like 'get lost', etc.) was most popular among politicians, and it was normally employed with regards to the norms on communicative conduct governing the debate. Real imperatives differ from non-valid ones in that the latter constitute urgent expressions of dislike or disapproval rather than imperatives per se. Thus, for example, the statement 'get out' in the data was coded as an instance of «Convey urgency in expressing dislike for $\mathrm{H}$ and $\mathrm{H}$ 's things», since in all cases where it appeared it did not constitute a real imperative but a means of conveying the speakcr's dissatisfaction with the addressee's behaviour.

\section{(1) PRPD $* 1 / 26 / 00$}

GWB: $\quad[\ldots]$ you know the $\uparrow \uparrow$ people of Texas $(0.5)$ looked at the real facts (.) I've just ex $\uparrow$ plained them to ya (.) [our $\uparrow \uparrow T E S T S \uparrow$ SCOres

SF: $\quad$ Well what are the real facts on S.A. $\uparrow$ Tt.'s

GWB: $\quad \uparrow \uparrow P L E E A A S E$ (.) don't interrupt me.] let me finish $O k=$ SF: $\quad=$ Well answer the Tquestion.

*Primary Republican Presidential Debate

In this extract from a debate held on January the $26^{\text {th }}, 2000$, George W. Bush (GWB) is responding to a former accusation from Steve Forbes (SF) about SAT scores having gone down in Texas, and the governor is trying to defend the position that Texas has improved in terms of education. Steve Forbes' accusation in prior turns finishes with a question he poses to Bush in such a way that if the latter answers the question it would entail the acceptance of the former's criticism. Therefore, Forbes is continuously pushing Bush throughout the whole episode, and the governor keeps on defending himself before the publisher's accusations. Forbes' pushing moves can be observed here in $a$ ) the coercive question "Well what are the real facts on SATs', which amounts to negative face-aggravating strategy $\mathrm{g}$. «Increase imposition weight», together with constituting an interruption, hence negative impoliteness strategy e., and $b$ ) the imperative 'answer the question', which is also an instance of the bald-on-record impoliteness strategy c. «Use real imperatives». This interactional situation gets to a point where Bush reprimands Forbes by commanding him to modify his conduct through the imperatives 'don't interrupt me', and 'let me finish', which exemplify the bald-on-record face-aggravating strategy under discussion. The governor conveys urgency in expressing his disapproval of Forbes' communicative action with the term 'please' characterised by a pronounced 
increase in pitch and volume,' and the deployment of the particle 'Ok' reinforcing the second of his imperatives.

\subsection{Positive face-aggravation}

Regarding this rudeness category, the most common strategy in the data was g. «Deny or contradict common or shared values and opinions». This is not surprising if one considers that differentiating oneself from the opponent is crucial in political debates (Martel, 1983).

(2) $\mathrm{PDPD}^{*} 1 / 8 / 00$

BB: $\quad[\ldots] I \uparrow \uparrow$ think $\uparrow \mathrm{AAAl}$ has the vieew (.) that (.) if we pro $\uparrow$ viide universal health coverage for everybody (.) that we can't protect $\uparrow$ Medicare (.) if we protect $\uparrow$ Medicare (.) we can't provide universal health $\uparrow$ coverage for everybody. (.) now (.) $\uparrow I \uparrow d o n ' t$ $\uparrow$ Tagree with $\uparrow$ that (.) $\uparrow I$ think we can do $\uparrow \uparrow$ BOTH (.) [...]

*Primary Democratic Presidential Debate

This excerpt is embedded in a debate celebrated on the $8^{\text {th }}$ of January, 2000 between the two candidates of the Democratic Party running for president that year, viz. senator Bill Bradley $(B B)$ and the then vice president Al Gore. Bill Bradley is tentatively stating here Al Gore's view on universal health care coverage and Medicare as the terms ' $I$ think' indicate, and is prefacing his immediate attack against the then vice president with the shortened proper noun 'Al'. The use of vocatives, proper nouns, and direct terms of address in general with another debater or other debaters present in a specific debate was found to be an unequivocal predictor of immediate face-attack emerging in the interaction. In this example Bradley's attack against Gore is observed in the utterances ' $I$ don't agree with that, I think we can do both'. By means of these utterances, the senator is explicitly denying that he and Gore share the same view, and in this way, he openly disagrees with the vice president, and conveys that the latter's opinions and values are not approved of, thereby attempting to damage his positive face. From Bradley's standpoint, there is enough money in the budget to provide health care coverage for everybody, and at the same time, make sure that Medicare does not go bankrupt, as he argues later on.

1. On the relationship between distinct aspects of prosody and impoliteness see Culpeper et al. (2003). The comments on this example are further supported by these scholars' statements on the increase in pitch and volume constituting a negative face-aggravating strategy. 


\subsection{Negative fadtedagygratation}

Out of all the negative face-aggravating strategies outlined in the framework presented in this paper, strategy f. "Refer to rights, duties, and rules not respected, fulfilled or complied with respectively" was the most usual one in the debates object of this study. Example (3) illustrates the deployment of this strategy.

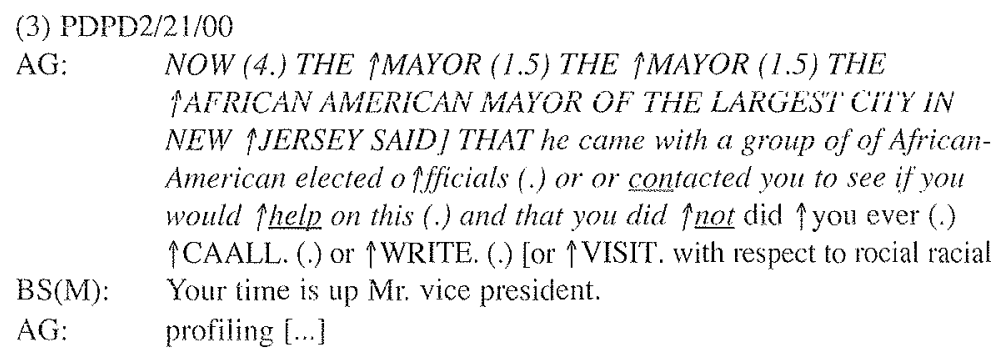

AG: $\quad$ profiling $[\ldots]$

This instance belongs to an interactional episode in which Al Gore (AG) and Bill Bradley discuss the issue of racial profiling in North-America and rebuke each other for not having done anything about it. More specifically, this example is Al Gore's rebuttal to Bradley's prior recriminations in the form of what is known in the literature as "reactive rudeness" (Kasper, 1990), thus corroborating Lakoff's (1989: 124) statements on the idea that "rudeness begets rudeness". The vice president reproves his opponent for not helping African-Americans when he ought to by 1) reporting what the AfricanAmerican mayor of a city in New Jersey said, which constitutes negative faceaggravating strategy a.1) "Make power claims by means of referring to real on attributed $+\mathrm{P}$ sources such as people, organizations, etc., through their speech and/or actions", and 2) by directly stating that Bradley did not help the mayor and his officials, thus referring to a duty the senator didn't fulfil. Gore's aggravating action is underscored by the rhetorical question at the end of his intervention 'did you ever call, or write or visit with respect to racial profiling' in keeping with the general function of increasing communicative acts' facethreat ascribed to rhetorical questions in the debate literature (cf. Nir, 1988; Rudanko, 1995). Such question interrupted by Bernard Shaw (the moderator) (BS(M)) constitutes off-record impoliteness strategy $h$, and is aimed at damaging Bradley's positive face in this specific interactional context.

\subsection{Off-record aggravation}

Finally, within the off record aggravation catcgory, the strategy «Employ denials» appeared to be the most frequent in the data. 
(4) PRPD3/2/00

AK: $\quad[\ldots]$ it is the American $\uparrow$ people (.) that have produced this booming economy (.) it is people who have $\uparrow$ come to their $\uparrow$ senses and $\uparrow$ started in their $\uparrow$ churches and neighbourhoods and $\uparrow$ schoools (.) pushing $\uparrow$ abstinence prograams and $\uparrow$ marriage counselling (.) they're the ones who have achieved this turnaround (.) not politicians $[. .$.

This intervention by Alan Keyes (AK) is part of a multiple candidates Republican debate held on March the $2^{\text {nd }}, 2000$. The ambassador is giving here the American people credit for the improvement of the national economy, and is stressing this idea by taking such credit off politicians through the off-record denial 'not politicians'. With this denial he is not only referring to the ClintonGore administration and the Democrats, but also Republicans, hence his colleagues present in the debate and himself. Keyes deploys an off-record strategy in this case to avoid hurting his own positive face, and damage adversaries' positive faces in general, that is, politicians from the opposite party, and other Republicans competing with him in the race for the presidency of the nation. The ambassador's speech is full of positive moral overtones he implicitly associates with the American people ('come to their senses', 'started in their churches', etc.) taking them away from politicians in and through his off-record denial.

\section{CONCLUSION}

The primary aim of this study has been to propose a tentative framework of face-aggravating strategies in the communicative encounter of political debates taking Lachenicht's (1980) impoliteness model as a starting point to this end. It is believed that this model of rudeness has not been sufficiently exploited in the literature, thus missing an opportunity to gain insights into impoliteness and politeness matters, the latter constituting the other end of a continuum of polite and impolite behaviours and attitudes describing social conduct. The present research provides evidence supporting a) Lachenicht's four-fold category division of rudeness into bald-on-record, off-record, positive and negative face-aggravation grounded in Brown and Levinson's (1987) PT, b) the discursive nature of impoliteness beyond the single act unit, c) the multifunctionality of impoliteness strategies in interaction, and d) the absence of mutual exclusivity among them in the same communicative act. No claims as for a hierarchical order of these strategies from most to least impolite are made in this paper though. In general, this project expects to 
have modestly contributed to shed light into the phenomenon of impoliteness in institutional contexts, and that of politeness as its complementary counterpart.

\section{REFERENCES}

Atkinson, J. M. \& J. Heritage (1984): «Transcription Notation», in Atkinson, J. M. \& J. Heritage (eds.) (1984): Structures of Social Action: Studies in Conversation Analysis, Cambridge, Cambridge University Press.

Beebe, M. L. (1995): «Polite Fictions: Instrumental Rudeness as Pragmatic Competence», in Hamilton H. (ed.) (1995): Georgetown University Round Table on Languages and Linguistics 1995, Washington, D. C., Georgetown University Press.

Blas Arroyo, J. L. (2001): «'No diga chorradas...' La descortesía en el debate político cara a cara: una aproximación pragma-variacionista», Oralia 4: 9 45 .

- (2003): «'Perdóneme que se lo diga pero vuelve usted a faltar a la verdad, señor González' Form and Function of Politic Verbal Behaviour in Faceto-Face Spanish Political Debates», Discourse \& Society, 14: 395-423.

Brown, P. \& S. C. Levinson (1987): Politeness: Some Universals in Language Usage, Cambridge, Cambridge University Press.

Culpeper, J. (1996): «Towards an Anatomy of Impoliteness», Journal of Pragmatics, 25: 349-367.

Culpeper, J.; D. Bousfield; A. WichmanN (2003): «Impoliteness Revisited: With Special Reference to Dynamic and Prosodic Aspects», Journal of Pragmatics, 35: 1545-1579.

Fernández García, F. (2000): Estrategas del diálogo: la interacción comunicativa en el discurso politico-electoral, Granada, Método Ediciones.

GARCíA-PASTOR, M. D. (2000): Politeness and Power in U.S. Political Debates: A Pragmatic Perspective, unpublished Master's Thesis, Valencia, University of Valencia.

- (2001): Pragmatics and the 2000 U.S. Elections: Issues of Politeness and Power in Political Campaign Debates. SELL Monographs 10, Valencia, Universitat de València.

- (2002): «Face Aggravation, Mitigation, and 'Unofficial' Power in a Political Campaign Debate», in WaLton, D. \& Scheu, D. (eds.) (2002): Culture and Power: Ac(unofficial)knowledging Cultural Studies in Spain, Bern, Peter Lang. 
HARris, S. (2001): «Being Politically Impolite: Extending Politeness Theory to Adversarial Political Discourse», Discourse \& Society, 12: 451-472.

KAsPer, G. (1990): «Linguistic Politeness: Current Research Issues», Journal of Pragmatics, 14: 193-218.

KienPoInTNER, M. (1997): «Varieties of Rudeness: Types and Functions of Impolite Utterances», Functions of Language, 4: 251-287.

Kraus, S. (1988): Televised Presidential Debates and Public Policy, Hillsdale, New Jersey, Lawrence Erlbaum.

LACHENICHT, L. G. (1980): «Aggravating Language: A Study of Abusive and Insulting Language», Papers in Linguistics, 13: 607-687.

LAKOFF, R. T. (1989): «The Limits of Politeness: Therapeutic and Courtroom Discourse», Multilingua, 8: 101-129.

Martel, M. (1983): Political Campaign Debates: Images, Strategies and Tactics, New York, Longman.

Mullany, L. (2002): «'I Don't Think You Want Me to Get a Word in Edgeways Do You John?' Re-assessing (Im)politeness, Language and Gender in Political Broadcast Interviews» (electronic version), Sheffield Hallam Working Papers, 3: 1-20 (available:

http://www.shu.ac.uk/wpw/politeness/mullany.htm).

NiR, R. (1988): «Electoral Rhetoric in Israel-The Televised Debates: A Study in Political Discourse», Language Learning, 38: 187-208.

Rudanko, J. (1995): «The Bill of Rights in the Balance: The Debate of June 8, 1789», Multilingua, 14: 391-409.

Tracy, K. \& Tracy, S. J. (1998): «Rudeness at 911: Reconceptualizing Face and Face Attack», Human Communication Research, 25: 225-251.

Turner, K. (1996): «The Principal Principles of Pragmatic Inference: Politeness», Language Teaching, 29: 1-13.

\section{APPENDIX}

[ ]

$=$

ooo

$\uparrow \mathrm{Oh}$

YES

Yes
Pause in tenths of seconds.

Pause shorter than a tenth of second.

Overlap.

Latching.

Sound stretch.

Rise in pitch.

Fall in pitch

Louder volume.

Stress. 


\title{
CORTESÍA Y EUFEMISMO: LOS SUSTITUTOS EUFEMÍSTICOS \\ EN LA PRENSA Y LA DEFENSA \\ DE LA PROPIA IMAGEN
}

\author{
M. " Elena Gómez SÁnchez \\ Universidad Europea de Madrid
}

\section{INTRODUCCIÓN}

$\mathbf{E}$

STE trabajo presenta algunos de los resultados obtenidos al estudiar la presencia de sustitutos eufemísticos de carácter político y económico en la prensa diaria de información general. En concreto, mostraremos algunos aspectos centrados en la relación entre el empleo de sustitutos eufemísticos y la cortesía. Nuestro estudio plantea la hipótesis del uso de tales sustitutos como parte de una negociación que el medio lleva a cabo, por un lado, entre sus intereses y los de sus lectores y, por otro, entre sus intereses y las fuentes de información. Este enfoque permitiría abordar el estudio de los sustitutos eufemísticos en la prensa desde una perspectiva que considera al eufemismo, no solo como una manera de ser cortés hacia el receptor (el enfoque más habitual en la concepción tradicional de este fenómeno, enfoque por el cual se presenta al eufemismo como un facilitador de las relaciones sociales), sino también, de modo muy destacado, como una forma de salvaguardar la propia imagen del emisor (es decir, como una forma de obtener un beneficio para uno mismo), lo cual resultaría especialmente importante en el ámbito político y el económico, pues en esas actividades -y precisamente por su proyección pública-, ofrecer una determinada imagen no es un aspecto baladí.

En el estudio (para el que hemos tomado como corpus de análisis un conjunto de noticias y textos de opinión publicados en los diarios $A b c$ y $E l$ País, en los meses de enero y febrero de 1998), consideramos el eufemismo como el uso, en un contexto pragmático determinado, de una expresión que el emisor considera más apropiada, o que estima menos ofensiva o desagradable, que otra a la cual sustituye, pero con la que sostiene ciertas asociaciones (porque las mantiene, o porque las crea), que permiten al receptor comprender y actualizar la expresión ausente. En nuestro trabajo hemos tenido en cuenta tanto los cotextos como los contextos propios de cada uno de los sustitutos, pues, de acuerdo con Casas (1986: 47) creemos que no se puede etiquetar «...a un sustituto como eufemístico o disfemístico, sino con un uso eufemístico 
o disfemístico en una situación pragmática concreta, dependiendo de las múltiples circunstancias efímeras que comporta la relatividad inmanente al proceso eufemístico».

Al incorporar a nuestro análisis el enfoque de la contesía, como una perspectiva más desde la cual analizar el fenómeno del eufemismo, nuestro trabajo reveló la alta frecuencia de sustitutos cuyo uso eufemístico está aparentemente orientado a la promoción de un acto cortés (como pueda ser, por ejemplo, la minimización de las diferencias entre distintas posturas). Sin embargo, como mostraremos a lo largo de este artículo, esa aparente cortesía tiene que ver, más bien, con la búsqueda del propio beneficio, pues el principal efecto que se deriva del uso de tales sustituł̦os eufemísticos, con esa orientación aparentemente cortés, es la salvaguardia de la imagen del emisor.

\section{EUFEMISMO Y CORTESIA}

El repaso de la bibliografía sobre el eufemismo muestra que, en la vertiente de este fenómeno considerada «negativa» (y que tiene que ver, por ejemplo, con el modo en que dificulta la claridad de los discursos en los que se utiliza), el empleo del término eufemístico tiene un papel encubridor (pues con su empleo se intenta soslayar una realidad que, por debajo del término eufemístico, permanece). ' Sin embargo, en su vertiente «positiva», el uso de sustitutos contribuiría a facilitar unas relaciones sociales más fluidas, ya que en su elección intervienen factores como la prudencia (por ejemplo, para Calvo (1994: 136), «la mentira piadosa [...] [es un] eufemismo interpuesto entre la crueldad y el tabú») o la cortesía (como puede observarse al considerar las definiciones y clasificaciones del fenómeno eufemístico que lo catalogan por sus causas). De este modo, Carnoy (1927: 338) indica que el propósito del eufemismo es «minimizar» una impresión desagradable, y añade:

El propósito del eufemismo no es, evidentemente, esconder realidades desagradables, pues para eso lo más sencillo sería callarse. Pretende solamente minimizar la impresión dolorosa que su evocación provocaría en otros o los inconvenientes que esta revelación ocasionaría a quien habla. De manera positiva, el eufemismo tiende también, frecuentemente, a provocar una disposición favorable en el interlocutor.

1. Aunque, por supuesto, puede que esto no tenga nada de «negativo» para quien opta por expresarse así, pues es precisamente el efecto que busca. 
También Montero (1981: 61) recuerda cómo el uso de los tiempos y modos verbales merece una mención dentro de los recursos eufemísticos y, aunque con precauciones, señala cómo la formulación de un mandato a través de una oración interrogativa, o de una indirección, o con ayuda de indicadores verbales, «[...] muestran un deseo de cortesía y de amabilidad que muy bien pueden interpretarse en algún momento como eufemísticos» (1981: 63).

Por su parte, para Allan y Burridge (1991: 11), autores que toman como punto de partida el principio de cooperación de Grice ${ }^{2}$ y el concepto de imagen desarrollado por Brown y Levinson (1987), ${ }^{3}$ y que estudian el fenómeno eufemístico (y disfemístico) desde un enfoque que recurre a elementos tomados de los estudios sobre la cortesía, un eufemismo «se emplea como una alternativa a una expresión menos deseable, para evitar una posible pérdida de imagen: bien la propia imagen o, mediante una ofensa, la de la audiencia, o la de una tercera parte». Así pues, al optar por un sustituto eufemístico frente a un término más «duro», el hablante no solo se está «preocupando» por la imagen de su interlocutor, sino que también está proyectando una determinada imagen de sí mismo (que podría ser diferente de la que proyectara en otra situación -por ejemplo, con otros interlocutores- en la cual no recurriera al término eufemístico).

Martínez Valdueza (1998), en un trabajo en el que revisa el concepto de tabú lingüístico mantenido por distintas corrientes de estudio, incluye también

2. Según el principio de cooperación de Grice, la contribución de cada participante en una conversación está inspirada por su oportunidad; esto es, debe ser la requerida por los propósitos del intercambio comunicativo en el que se está inmerso. El principio de cooperación se desarrolla según cuatro normas (también llamadas «categorías», o «máximas»): cantidad (que se relaciona con la cantidad de información que debe darse: no hay que ser menos informativo de lo necesario, pero tampoco más), cualidad (la información proporcionada debe ser verdadera), relación (lo que se diga debe ser relevante, es decir, debe guardar relación con aquello de lo que se habla) y modalidad (norma que comprende la supermáxima "sea claro" y que se concreta en evitar la oscuridad al expresarse, evitar la ambigüedad, ser breve y ser ordenado). Cfr. Escandell (1996: 78-90).

3. El estudio de Brown y Levinson (1987) acerca de la cortesía lingüística parte de otro concepto, el de imagen, o face (Goffman, 1967), que se relaciona con la imagen pública que un individuo tiene de sí mismo y de aquellos con quienes, en una situación concreta, interactúa. La imagen, a su vez, tiene dos facetas: positiva (que se corresponde con el deseo de cada individuo de ser aceptado socialmente; y de que sus deseos sean, al menos en cierta medida, queridos también por otros) y negativa (que se corresponde con el deso de cada uno de poder ejercer la propia libertad individual de acción). En el aspecto de la cortesía, y su relación con el fenómeno eufemístico, inciden Brown y Levinson (1987:49) al señalar que la pragmática «entra en juego dos veces: una para fijar la proposición expresada por lo que es «dicho», la otra para calcular las implicaciones indirectas o contextuales de la proposición expresada. La cortesía jugaría un papel central en el segundo tipo de cálculo, aunque quizá solo uno muy pequeño en el primer tipo (aunque los eufemismos, tratamientos honoríficos, etc. pueden proporcionar interesantes excepciones)》. 
el enfoque pragmático y menciona la relación entre los eufemismos y la regla de deferencia («da opciones») de Lakoff, mientras que el uso de los tecnicismos seguiría más la regla de la formalidad («mantente distante»). Esta autora añade que los eufemismos y los tecnicismos «se parecen en que ambos bordean el problema, convirtiéndose en maneras de tratar un tema delicado mientras se finge que se está haciendo otra cosa» (1998: 130). En su opinión, la objetividad y distancia científica propiciada por los tecnicismos evitan las implicaciones afectivas en aquellos temas que puedan resultar desagradables, mientras que los eufemismos «garantizan que el tema es delicado, pero pretenden que se está hablando de otra cosa, por lo que el oyente puede fingir que capta la interpretación menos comprometedora» (1998: 130). Destacamos esta comparación entre los eufemismos y los tecnicismos porque nuestro estudio ha atendido también a lo que ocurre cuando en una información se usan tecnicismos: por una parte, podrían ayudar a concretar, muy especificamente, aquelio de lo que se está tratando (de modo que podrían servir para referirse, con mucha precisión, a un hecho determinado y, en este sentido, evitar vaguedades), pero por otra, su empleo genera un efecto distanciador respecto de aquello de lo que se habla. Si bien es cierto que podrían así colaborar a la apariencia del estilo neutral, distanciado y objetivo que, según la teoría de la redacción de los géneros informativos, se busca en el periodismo, no lo es menos que ese mismo distanciamiento con respecto a lo nombrado puede resultar oscurecedor y así atentar contra la claridad del texto y, por tanto, quizá dificultar la fácil comprensión, por parte de los lectores (Moya: 2001), de la información en que se encuentran. En este sentido, creemos que su uso también puede resultar eufemístico, en tanto que genere ese efecto (aunque ello no necesariamente se deba a un propósito «consciente» por parte de quien escribe la información).

\section{FUTCMUSMO SOCHEDAD: LA IMAGLN EN LA ACTIVIDAD POLITICA Y LL EMPLCO DE SUSTITUTOS LUTEMÍSTICOS}

En la observación cotidiana de lo que ocurre a nuestro alrededor constatamos que, en los discursos de presentación de sus ideas y actividades, cada político intenta obtener el mayor apoyo posible por parte de los futuros electores (y ello, aunque las elecciones no vayan a celebrarse próximamente). Con este fin, además de presentarse a sí mismo (y a su partido) de la forma en que considere más favorable, también deberá dirigirse al público del modo en que crea que va a encontrar un mayor eco.

En cste planteamicnto, cl análisis de los sustitutos cufemísticos presentes en nuestro corpus nos permite afirmar que con su uso se consigue, por un lado, 
mejorar la propia imagen (al ofrecer, por ejemplo, un talante colaborador, con capacidad para dialogar, dispuesto a llegar a acuerdos) y, por otro, disimular aquellos aspectos de la gestión que «no van tan bien», o que pueden suponer medidas impopulares, de modo que pasen inadvertidos ante los ciudadanos.

Así, cabe resaltar la presencia, en los textos analizados, de sustitutos que permiten al emisor ofrecer de sí mismo una imagen moderada, dialogante, proclive a la distensión de los enfrentamientos (de ahí el empleo de conversaciones o diálogo, por ejemplo, en lugar de negociaciones). Si el emisor es un colectivo (un partido político), y considera importante ofrecer una imagen de unidad, el término empleado para referirse a distintas opiniones en su seno no será grupos (pues ello puede dar idea de desunión), sino corrientes. Del mismo modo, el emisor puede prever que presentar abiertamente algunas de sus propuestas (por ejemplo, la privatización de determinados servicios) puede generar el rechazo de la sociedad o de parte de ella; para evitarlo, escogerá para presentar tales propuestas términos (como liberalización) que rebajen la magnitud del problema (o de aquellos aspectos de su propuesta que puedan resultar más impopulares) de forma que cause menor alarma en la audiencia (disminuyendo así el riesgo de que su propuesta, es decir, su imagen, se vea rechazada).

Digamos, pues, que el eufemismo cumple aquí una doble función: cuidar de la imagen que el emisor proyecta, y disimular los aspectos menos agradables de la gestión que esos emisores planean llevar a cabo (o están realizando ya). Por tanto, esas decisiones de la política nacional (en la cual las medidas sociales y económicas desempeñan un papel destacado) se trasladan a los ciudadanos con un discurso en el que, gracias al empleo de sustitutos eufemísticos, es más frecuente la atenuación de los problemas que su reconocimiento. Ello supone la representación (que no presentación) de unos hechos que han sido recreados, en un proceso remodelador que lima las aristas que podrían suponer un conflicto para los responsables correspondientes (y, consecuentemente, disminuir sus posibilidades de seguir ejerciendo ese poder político). Ahora bien, con esta práctica (cuyo origen se sitúa, en nuestra opinión, en las fuentes políticas y económicas, pero que los medios de comunicación reflejan), la capacidad del ciudadano de conocer el «mundo real» se ve obstaculizada.

Llegados a este punto, podemos ahora exponer con mayor detalle cómo se relaciona la presencia de sustitutos eufemísticos con la cortesía y, sobre todo, cómo se relaciona con una cortesía orientada a proteger la propia imagen. Como indicábamos en la introducción, nuestro estudio revela la alta frecuencia de sustitutos cuyo uso eufemístico está aparentemente orientado a la promoción de un acto cortés (como pueda ser, por ejemplo, la minimización de las diferencias entre distintas posturas, al emplear corrientes en lugar de 
grupos; o conversaciones en vez de negociaciones). Como acabamos de ver, de este modo disminuyen en el plano de «lo dicho» las tensiones y confrontaciones, y ello puede sugerir una visión más amable de las relaciones políticas, la situación económica, etc. Sin embargo, como a continuación mostraremos, esa aparente cortesía tiene que ver, más bien, con la búsqueda del propio beneficio, ya que, según se desprende del análisis de nuestro corpus, la principal repercusión que se consigue gracias al uso de los sustitutos eufemísticos que tienen esta orientación aparentemente cortés es la salvaguardia de la imagen del emisor.

Como hemos señalado previamente, las distintas definiciones sobre el eufemismo permiten comprobar cómo este fenómeno ha recibido tradicionalmente la consideración de facilitador de las relaciones sociales, en tanto que el emisor «cuida» de la imagen de su interlocutor al evitar palabras que pudieran resultar duras u ofensivas para este último. Desde esta perspectiva, es cierto que también podemos hablar de la presencia en nuestro estudio de algunos eufemismos motivados por una cortesía real, sustitutos con los que se muestra una preocupación verdadera por no herir al destinatario (independientemente de que este destinatario sea el lector -como alocutor del periodista- o la persona o entidad que la fuente de la información considera su interlocutor $-\mathrm{y}$ que el periodista, a la hora de redactar, «asume» como propio-, cuya imagen no quiere dañar). Es decir, al referirnos a nuestro corpus de análisis, podríamos hablar de casos de cortesía real cuando esta se dirige hacia la imagen positiva de los interlocutores, la cual no se desea deteriorar: este sería el caso del empleo de fondos de cohesión en lugar de ayudas económicas, o de tercer mundo en lugar de países pobres:

¿Cómo sorprenderse, por ejemplo, de que por parte de Alemania, país gran europeísta pero principal financiador neto de la Unión, se proponga hoy privar a España de los llamados "fondos de cohesión" con el fin de destinarlos a los nuevos miembros europeorientales? (José Luis Ugarte, «La Europa de los Gobiernos y la de los gobernados», El País, 27-1-1998, p. 14).

Castro dijo también que durante la próxima visita del Papa a Cuba «tendrá la oportunidad de conocer a un pueblo educado, culto, el de menos alfabetos en el Tercer Mundo, el que tiene más médicos y maestros per cápita» (Afp, Efe, «Respuesta del dictador a si cree en Dios: "Son cosas mías y no acepto confesiones públicas"», $A b c, 12-1-1998$, p. 33).

[El racismo se alimenta] también de una alarmante carencia de soluciones, sociales y políticas en los países industrializados para hacer frente a la presión de quienes huyen de la pobreza y la enfermedad del Tercer Mundo (Editorial, «Paremos la infección», El País, 4-2-1998, p. 10). 
Respecto al primero de los ejemplos, el hecho de que fondos de cohesión aparezca precedido de un llamados supone ya una forma de atraer la atención del lector hacia dicho sintagma, e induce a «sospechar» que, tras esa designación, hay una realidad que debe desvelarse si se desea acceder al significado real de la expresión. Fondos de cohesión son, en realidad, ayudas económicas, pero en tanto que esta designación directa podría resultar ofensiva para quien recibe dicha ayuda (pues lo sitúa en un nivel de inferioridad respecto a quien se la ofrece), en fondos de cohesión desaparece tanto la referencia al dinero como la voz ayudas, y en su lugar se resalta la especificidad de esos fondos y su finalidad de cohesión; es decir, se recurre a un término positivo que da idea de unión y de solidaridad, factores que se asocian con una situación de igualdad de los miembros del grupo y que, por tanto, ponen menos en peligro la imagen de quien recibe ese dinero.

Respecto a los ejemplos en los que aparece la expresión Tercer Mundo, cabe tener en cuenta que Lechado (2000) recoge en su glosario el sintagma Tercer Mundo como sustituto eufemístico de 'conjunto de países pobres' (y, por oposición, el sintagma Primer Mundo designaría, lógicamente, a los países ricos). En nuestra opinión, el uso de los ordinales (desde Primer Mundo hasta Cuarto Mundo, empleado para aludir a los países cuya situación de pobreza es extrema) para referirse a «mundos distintos» evita una clasificación que haría referencia al nivel de riqueza y pobreza de los países de un solo mundo. Ahora bien, mientras que Tercer Mundo ${ }^{4}$ puede entenderse como una designación que intenta no herir la sensibilidad de quienes podrían sentirse dolidos al ser llamados países pobres, Primer Mundo intenta ocultar justamente lo contrario, la riqueza. De este modo, la función eufemística del sustituto consistiría, en este caso, en evitar ofrecer de uno mismo una imagen prepotente o arrogante (además de basada exclusivamente en el dinero), que podría causar rechazo; dicho de otra forma, mientras que Tercer Mundo es una expresión con la que originariamente el hablante pretende no dañar la imagen de su interlocutor ni herir su sensibilidad (aunque después la expresión sea también utilizada por esos países para referirse a sí mismos, como podría desprenderse del segundo de los ejemplos expuestos), el sustituto Primer Mundo, desde su creación, contribuiría a salvaguardar la imagen de quien utiliza dicha designación para referirse a sí mismo, evitando ofrecer una cara que pudiera resultarle perjudicial.

Por tanto, en estos casos (fondos de cohesión, Tercer Mundo) nos hallamos ante ejemplos de lo que, en nuestra opinión, supone una muestra de cortesía real, de preocupación por la imagen del receptor. Sin embargo, esa cortesía no

4. La expresión, acuñada en 1952 por Alfred Sauvy, surgió para referirse a los países en vías de desarrollo que no pertenecían ni al bloque occidental ni al soviético. 
existiria cuando de lo que se trata es de salvar la propia imagen (por ejemplo, con el uso, en el ámbito de la economía, del mencionado sintagma primer mundo -tal y como acabamos de explicar-, o de países industrializados en lugar de países ricos, o de flexibilización o ajustes en lugar de despidos), ya que en estos casos el empleo de los sustitutos vendría motivado por la búsqueda de un beneficio propio, y se evitaría, por ello, el uso de términos que, por los motivos que a continuación veremos, pudieran de algún modo dañarla. En este sentido, nuestro análisis demuestra las grandes posibilidades de los sustitutos eufemísticos como mecanismo eficaz para la construcción de la propia imagen, en un contexto que no tiene tanto que ver con una cortesía real hacia el interlocutor como con un interés propio (lo cual revela una actitud menos desinteresada que la que la verdadera cortesía supone).

Así pues, de nuestro estudio se desprende la importancia que el eufemismo tiene como «protector», como garante de la imagen del emisor: si este evita dar de sí mismo una imagen definida, que lo comprometa (y podría asumir un compromiso si empleara en sus propuestas términos concretos, si estableciera claras diferencias entre él y el resto de opciones, etc.), será más difícil que su destinatario (o, por extensión, su público) le tome la palabra y le exija el cumplimiento de tales propuestas. Igualmente, el empleo de expresiones vagas por parte de los emisores en origen (es decir, de las fuentes) para referirse a asuntos conflictivos que afectan de algún modo a su aludido (sea una persona o entidad determinada, un grupo social o la sociedad en su conjunto) hará que sea más improbable que éste pueda sentirse ofendido que si se le «encasilla» en una situación determinada, de límites claramente definidos (pensemos en la vaguedad que proporcionan designaciones como programas de garantía social o protección social). Dicho de otro modo, si como emisores logramos que con nuestra forma de expresarnos alguien se sienta solo ligeramente atacado (y no «muy atacado») en su autoestima, o que no sepa identificar muy claramente los motivos por los que se siente así, o, mejor aún, que no se sienta en absoluto atacado, conseguiremos que igualmente le resulte más difícil saber "contra qué" protestar, de modo que también de esta forma la imagen del emisor corre menor riesgo de sufrir, a su vez, un ataque.

Dentro de este propósito general, en nuestro estudio del eufemismo hemos encontrado algunos rasgos más específicos de los sustitutos que contribuyen a esta aparente cortesía protectora de la propia imagen. En primer lugar, podríamos hablar de un efecto «apaciguador», que vendría motivado por el deseo de minimizar los conflictos que pueden producirse entre distintos agentes sociales y que pueden conllevar una pérdida de imagen para el sujeto (individual o colectivo) que, en esa confrontación, resulte derrotado. Ejemplos de este efecto aparecerían, en nuestro corpus, en el empleo de colaboración (en lugar de apoyo), o conversaciones o diálogo (en lugar de negociación). 
Como consecuencia del uso de sustitutos con este fin, las propias acciones quedan atenuadas, lo cual resulta muy apropiado si se desea ocultar la posibilidad de que la decisión tomada pueda desvelarse más adelante como errónea.

En segundo lugar, y enlazando con esta última idea, encontraríamos otro rasgo de los sustitutos que igualmente contribuye a proteger la propia imagen: el efecto de falsa modestia. Su origen se encuentra en el deseo de evitar mostrarse impositivo, ya que esa imagen de poder, si resulta excesiva, puede volverse en contra del emisor. La consecuencia es el ofrecimiento de una imagen propia más cortés, lo que resulta positivo para el emisor. Lógicamente, en el plano no de «lo dicho», sino de «lo hecho», las pretensiones de los implicados en la cuestión de que se trate siguen siendo las mismas: si se trata de una confrontación (sea esta una negociación o una guerra), vencer en ella; si se trata de conseguir ayudas, lograrlas (independientemente de que se consigan bajo la fórmula de apoyos, de una colaboración, o de la confirmación de autoridad); ahora bien, en el plano de lo manifestado esas voluntades se presentan de modo que la imagen del emisor no resulta tan impositiva. Dicho de otro modo, resultaría perjudicial para la propia imagen (porque puede suscitar el rechazo del interlocutor) mostrarse abiertamente «combativo»o, en un sentido más amplio, simplemente «fuerte» (incluso en el terreno económico, y de ahí el uso, por ejemplo, de comunidad internacional en lugar de países ricos, o de liderazgo en lugar de supremacía); es preferible actuar con mano de hierro, pero mostrar un guante de seda.

En tercer lugar, cabe hablar del efecto «eximente» que puede tener el uso de los sustitutos empleados con fines eufemísticos. En este caso, la elección de términos o expresiones vendría motivada por el deseo, por parte del emisor, de evitar asumir su responsabilidad sobre unos hechos. Pensemos, por ejemplo, en quienes son responsables de los niveles de empleo de un país, y en la (aparentemente) distinta carga que recaería sobre sus hombros al optar por el sintagma aparición de oportunidades frente a creación de empleo para referirse a su labor, o al hablar -en otro contexto- de la externalización de compromisos laborales en lugar de la disminución de puestos de trabajo o de reducción de plantilla). La consecuencia de esa elección es la presentación de tales hechos como algo inexorable y ajeno a sus responsables, que quedan así fuera del foco de la atención de los ciudadanos, con lo que se protegen de posibles críticas. En ese proceso, además, se busca la despersonalización, para evitar «resaltar» que hay personas que sufren las consecuencias de tales decisiones (y obviar, o al menos retrasar, que se despierten protestas acerca de esas situaciones). En esta despersonalización se emplea, por ejemplo, la palabra bajas para evitar el término muertos, o se recurre al sintagma flexibilización de plantillas para no designar abiertamente un despido de 
trabajadores. Además, si el eufemismo se ha generado mediante un procedimiento sintáctico (por ejemplo, el uso de la pasiva refleja), o mediante el empleo de verbos como provocar (de modo que el hecho se presenta como que «esta situación ha provocado una total renovación de la empresa»), la imagen que se ofrece es que ese proceso simplemente "ocurre as1" y, por tanto, no tiene mucho sentido rebelarse contra ello (de modo que la imagen del responsable de esa decisión tiene más posibilidades de quedar a salvo).

Cabe destacar, por último, algo que ya señalábamos en el segundo apartado de este texto: el uso de los tecnicismos como un mecanismo que también resulta frecuente en el corpus estudiado y que, en nuestra opinion, se encuadra también en este deseo de conseguir una buena imagen, pues se busca un ennoblecimiento de la propia personalidad mediante el empleo de términos que verdaderamente (como sería el caso de corporate finance), o al menos en apariencia (por ejemplo, comercializar o desescalada), no son «de dominio público», sino que solo están al alcance de unos pocos, y que, por tanto, aumentan la distancia entre quienes conocen su significado y quienes no, $O$ entre quienes los emplean como rasgo de su pertenencia a un grupo y el resto. Curiosamente, ello contrasta con el deseo de «no mostrar diferencias» entre «nosotros» y «vosotros», voluntad que, como hemos visto, actúa en otras ocasiones como motor de la sustitución eufemística. Ahora bien, esta tensión disminuye si consideramos que quien emplea el tecnicismo (real o supuesto) no está «marcando expresamente» esas diferencias, en tanto que no está manifestando que haya una diferencia «de nivel» entre él y quien no le entiende (que es la actitud que resultaría descortés), sino que simplemente utiliza los términos como si todos los entendieran, es decir, «integrando» a los demás en el plano que supone su propio nivel de conocimiento. Evidentemente, puede ocurrir que alguno de sus interlocutores no consiga entender la expresión en juego, pero no puede acusarse de descortesía al emisor (al revés: al considerar a sus interlocutores «iguales» a él, es justamente cortesía lo que muestra). Así pues, el empleo de tecnicismos resulta una actitud doblemente eufemística en tanto que, por una parte, consigue velar el fácil acceso a significados que no resulten agradables, pero, además, logra hacerlo garantizando la imagen de quien los emplea.

\section{CONCLUSIÓN}

En este artículo hemos mostrado algunos ejemplos (procedentes de una investigación mucho más extensa) que ponen de manifiesto el papel que los sustitutos eufemísticos pueden jugar como garantes de la propia imagen. Además, en tanto que el corpus de estudio está formado por textos perio- 
dísticos, nuestro análisis muestra la forma en la que los medios de comunicación utilizan (en numerosas ocasiones, como si se tratara de sinónimos referenciales, lo que puede relacionarse con el deseo del redactor de conseguir variación expresiva y riqueza estilística) expresiones que pueden ser consideradas sustitutos eufemísticos de otros términos que designan la realidad de forma más directa. El problema (desde el punto de vista informativo) surge al constatar que esas expresiones no ofrecen una imagen sinónima (en el sentido de idéntica) de la realidad, sino otra «superpuesta» y dulcificada, tendente, en no pocas ocasiones, a mejorar la imagen de quien la emplea.

En definitiva, la relatividad del eufemismo y su caracterización como hecho de habla hacen que tanto el conocimiento que el lector posea del contexto como su habilidad para extraer del cotexto datos que le sirvan de ayuda se constituyan en factores determinantes para poder construir el sentido que se debe dar al sustituto. Si el lector carece de esa información contextual o de la capacidad de análisis del cotexto (y el peso de cada uno de estos factores dependerá de cada caso concreto), podría ocurrir que la forma atenuada con que se presentan las dificultades le llevara a concluir que «todo está bien», o a pensar que la gravedad de determinadas situaciones es mucho menor de lo que es en realidad y, por tanto, el uso de los sustitutos le llevaría a percibir la realidad de forma distorsionada.

\section{REFERENCIAS BIBLIOGRÁFICAS}

AlLAN K. y K. BURRIDGE (1991): Euphemism \& Disphemism. Language Used as Shield and Weapon, Nueva York, Oxford University.

Brown, P. y S. C. Levinson (1987): Politeness. Some Universals in Language Use, 2. ${ }^{a}$ ed., Cambridge, Cambridge University.

Calvo Pérez, J. (1994): Introducción a la pragmática del español, Madrid, Cátedra.

CARnOY, A. (1927): La science du mot, Lovaina, Universitas.

CASAS Gómez, M. (1986): La interdicción lingüística. Mecanismos del eufemismo y disfemismo, Cádiz, Universidad de Cádiz.

EsCANDELl VidAL, M. ${ }^{a}$ V. (1996): Introducción a la pragmática, Barcelona, Ariel.

GofFMAn, E. (1967): Interaction Ritual: Essays on Face to Face Behaviour, Nueva York, Garden City.

Lechado García, J. M. (2000): Diccionario de eufemismos y de expresiones eufemísticas del español actual, Madrid, Verbum.

Martínez Valdueza, P. (1998): «Status quaestionis: el tabú lingiiístico», Lingüística (ALFAL), 10: 105-139. 
Munitru Cakitlle, E, (1981): El eufemismo en Galicia. Su comparación con otras áreas romances (anexo 17 de Verba. Anuario Galego de Filoloxía), Santiago de Compostela, Universidad de Santiago de Compostela.

MOYOA HERnÁNDEz, G. (2001): «El lenguaje militar. Tabui, eufemismo y disfemismo», [en línea] www.tonosdigital.com Revista Electrónica de Estudios Filológicos, 1. 


\title{
ACTIVIDADES DE AUTOIMAGEN, CORTESÍA Y DESCORTESÍA: TIPOS DE ACTIVIDADES DE IMAGEN EN UN DEBATE TELEVISIVO
}

\author{
Nieves Hernández Flores \\ Escuela Superior de Comercio de Copenhague
}

$\mathbf{E}$ objetivo de este trabajo es tratar el tema de la cortesía como un tipo de actividad de imagen, es decir, como un tipo de comportamiento comunicativo que afecta a la situación social de los hablantes en una interacción. En mi enfoque, la cortesía es un tipo de actividad de imagen, pero no el único, pues otros como la descortesía y las actividades de imagen dirigidas a uno mismo aparecen también en la interacción con características y propósitos diferentes de los de la cortesía, como se verá a continuación. En lo que sigue se describirán estos tres tipos de actividades, se mostrará su aparición en unos ejemplos extraídos de debates televisivos en España y finalmente se sacarán algunas conclusiones sobre sus diferencias comunicativas y sociales.

El término imagen social (face en su original en inglés, según el sociólogo Erving Goffman, 1967) alude a la posición social de una persona en su contacto comunicativo con otras. Goffman presenta cómo la imagen es una parte de la identidad social de la persona, por ello es apreciada y cuidada por ésta, ya que de su situación depende la consideración y el respeto que se obtiene de los demás. Este concepto, que fue adoptado por la teoría de Brown y Levinson (1987) en su tratamiento de la cortesía, ofrece a la investigación pragmática un instrumento muy útil para estudiar las relaciones entre la lengua y la sociedad. $\mathrm{El}$ enfoque en la imagen que sigo en mis trabajos parte de la propuesta de Bravo $(1999,2002,2003)$ de describirla de acuerdo con las características del contexto sociocultural en que se produce la interacción. Siguiendo con el enfoque de Bravo, la imagen social puede describirse en términos de unas características básicas que suponemos en la sociedad en cuestión, las cuales están basadas en características culturales reconocidas como propias de esa sociedad. En la interacción concreta esta imagen social básica se actualizan de acuerdo con los roles que los hablantes adoptan durante la interacción (Bravo, 2002: 145). El concepto de rol, tomado también de Goffman (1961) ha sido utilizado de diferente manera en los estudios pragmáticos. En mi aproximación (Hernández Flores, 2002), el rol se refiere a las características sociales generales (como el 
généu, la edad, la nacionalidad), a utras desempeñadas en la situación concreta (como la profesión, el tipo de relación con los demás) y a otras de tipo discursivo, según los actos realizados. Los roles se activan en la interacción concreta según la ocasión comunicativa en que se encuentran los hablantes; por ejemplo, en una situación laboral, tenemos roles como el de jefe, empleado, compañero; en una situación familiar, roles como por ejemplo los de madre, hija, etc. El rol, al igual que la imagen, es un concepto que se define de acuerdo con las características socioculturales del contexto, y como tal en los estudios sociopragmáticos permite explicar las necesidades de imagen de un hablante en una situación concreta y la elección de determinadas estrategias comunicativas, en este caso sus estrategias de cortesía o de los otros tipos de actividades de imagen.

Por tanto, los hablantes no son meros codificadores y descodificadores de mensajes que se dirigen unos a otros, sino que se presentan con un bagaje de valores, actitudes y comportamientos aprendidos que condiciona lo que esperan y desean en esa interacción y lo que los demás esperan y desean de ellos. Ese bagaje es lo que configura su imagen social y los roles que irán adoptando durante la interacción según sus necesidades comunicativas, y será lo que determine o influya en su comportamiento. Las necesidades de imagen giran en torno a la autonomía, o el deseo de verse y ser visto como alguien con contorno propio, y a la afiliación, o el deseo de verse y ser visto como parte de un grupo (Bravo, 2002: 144). En este marco, la situación de la imagen de autonomía y afiliación de los diferentes hablantes no es única ni inamovible, sino que está sometida a una continua oscilación dependiendo de cómo repercute sobre ella (de manera positiva, negativa o sin efecto perceptible) el comportamiento comunicativo de los interactuantes, el cual puede oscilar entre lo cortés, lo descortés y las actividades de autoimagen.

Cuadro 1. Tipos de actividades de imagen

\begin{tabular}{|l|c|c|c|}
\hline & Autoimagen & Descortesía & Cortesía \\
\hline Imagen hablante & Efecto positivo o negativo & Efecto negativo & Efecto positivo \\
\hline $\begin{array}{c}\text { Imagen destinatario } \\
\text { (Uno solo / varios) }\end{array}$ & No valorable & $\begin{array}{c}\text { Efecto } \\
\text { negativo }\end{array}$ & $\begin{array}{c}\text { Efecto } \\
\text { positivo }\end{array}$ \\
\hline
\end{tabular}

Pasando a los diferentes tipos de actividades de imagen (ver cuadro 1) lo que denomino actividades de autoimagen (concepto bastante parecido a lo que otros autores han denominado autocortesía, por ejemplo Boretti, 2000; Chen, 2001; y Haverkate, 2001) se refiere al comportamiento comunicativo con una repercusión positiva o negativa sobre la imagen de uno mismo, es decir, sobre la imagen del hablante, quedando la del destinatario fuera de los efectos de este comportamiento. Un ejemplo, en la comunidad cultural española, sería el 
de un político que en una entrevista televisiva se muestra como competente y sincero, realzando así su imagen de autonomía (al destacar unas cualidades apreciadas en su comunidad cultural para alguien en ese rol), pero su comportamiento comunicativo no afecta a la imagen social de los demás, es decir, del entrevistador y de los espectadores.'

En el caso de la actividad de imagen de cortesía, la imagen del destinatario sí se ve afectada, de forma positiva, pero al tiempo que la del hablante también es favorecida por el comportamiento comunicativo de ese mismo hablante. Es decir, un acto comunicativo de un hablante (por ej. una invitación, un consejo, una petición), el cual está conformado por uno o varios enunciados, se dirige a un destinatario (o varios), adoptando una doble dirección hacia la imagen social de éste y hacia la suya propia, rigiéndose dicho comportamiento por el ideal de conseguir un equilibrio entre los deseos de imagen propios y los ajenos. (Hernández Flores, 2002 y 2004). En un ejemplo relacionado con lo anterior, la cortesía aparecería si el político durante la entrevista menciona algún mérito del entrevistador que repercuta favorablemente en su imagen de periodista, por ejemplo el de estar bien informado o ser un buen analista político; al mismo tiempo, el político entrevistado estaría favoreciendo su propia imagen al mostrarse como una de persona atenta y considerada con los demás.

Por último, en esta tricotomía, el tercer tipo de actividad de imagen que considero es la descortesía, la cual surge cuando el comportamiento comunicativo de un hablante repercute negativamente sobre la imagen de su interlocutor, momento en que su propia imagen (la del hablante) se vería afectada negativamente por no cumplir con alguna de las características de su rol. En el ejemplo citado, esto se daría si, por ejemplo, el político entrevistado acusara al periodista de inventar cosas, en cuyo caso la imagen del periodista quedaría dañada, por ser una característica de la imagen de este rol la de ser verídico; pero al mismo tiempo la imagen del entrevistado quedaría afectada negativamente por recurrir a la acusación, lo cual no forma parte de una de las cualidades de su rol de entrevistado, que sería la de ser dialogante.

A continuación, se tratarán estas cuestiones teóricas en el análisis de un fragmento de un debate televisivo en España. El debate, para Tusón Valls (1997) es un tipo de interacción donde se habla de temas decididos anteriormente, tiene una duración definida, los participantes lo hacen en función de un papel especial (conocimientos sobre el tema, especialidad profesional) y los turnos están controlados por un moderador que, en principio, se mantiene neutral (éste no es el caso del debate que vamos a analizar). El debate

1. La actividad de autoimagen también puede ser negativa para el hablante, lo cual puede aparecer en comportamientos de autocrítica o auto degradantes. 
lelevisado, por ofra parte, cuenla con un públicu yue eslá viendu el piograma, y por tanto las actividades de imagen realizadas se hacen en función del conocimiento que tienen los participantes de este hecho, al tiempo que también pueden afectar a las imágenes de los espectadores.

\begin{tabular}{|llllll|}
\hline JA & TE & JO & MTC & LIP & ASS \\
Juan Adriansens & Tonia Etxarri & José Oneto \\
participante & participante & participante & $\begin{array}{l}\text { modera Campos } \\
\text { participante }\end{array}$ & $\begin{array}{l}\text { Luis I.Parada } \\
\text { participante }\end{array}$ & $\begin{array}{l}\text { Amalia S. Sampedro } \\
\text { participante }\end{array}$ \\
\hline EP: Espectadora Participante (por teléfono) & & & \\
\hline
\end{tabular}

CuAdro 2. Disposición en la mesa y roles de los paricipanies en el debate

El presente debate es una parte del programa matinal Cada día emitido por una cadena española de televisión y presentado por la periodista, María Teresa Campos, quien ejerce de moderadora y al mismo tiempo participa en el debate. Los participantes son todos ellos periodistas (véase en el cuadro 2 la disposición de los hablantes en la mesa) y el tema tratado en esta ocasión es el de la enseñanza religiosa en colegios públicos y la decisión del Gobierno de no considerar la religión como asignatura evaluable. En el momento inmediatamente anterior a la presente muestra, la moderadora ha dado la palabra a uno de los participantes tras la petición de ésté, quien se lo agradece entre bromas.

JA: $\quad=$ (mirando a MTC, risas) igracias, gracias! igracias por no frustrarme! (mira hacia los papeles que tiene en la mesa). en... aquí, el jurista López Medem, dice, el Estado se, (levanta ligeramente los brazos de la mesa) jes horrible que el Estado se convierta en educador! pues su papel es el de dar medios. (mira a los demás) muy bien. el, es horribie que el Estado se convierta en educador. (moviendo los brazos y arqueando las cejas) ¿y no es horrible que la Iglesia, se convierta en educadora para mucha gente? EL ESTADO, (señala con la mano la mesa) [lo hemos votado]

$?$ [iuna Iglesia, una Iglesia!]

JA: ¡NO! (levanta la mano y la para, baja la mirada) el Estado, to hemos votado todos, y es democrático, que yo sepa, yo no he votado a la religión católica, (da un ligero golpe sobre la mesa) ni he votado a sus obispos. (levanta la mano y la para)

TE: (mirando a $J A$ ) bueno, yo creo que se han mezcla'o las dos cosas, una cosa es la educación, y otra cosa es la financiación de la Iglesia, [es que]

JA: [pero, pero] (agarrándole la mano a TE) no me vas a decir que, que el Estado (le suelta la mano) no puede dar, no puede educar, =

TE: $\quad$ jclaro que puede! $=$

JA: $\quad=$ ipor favor $!=$ 
TE: $\quad=$ iclaro que puede! perfectamente, $[$ pero vamos a ver, $]=$

JA: $\quad=$ [y isobre todo un estado democrático $]$

TE: (levantando ligeramente las manos sobre la mesa, mirando hacia abajo) pero es que yo creo, que con estos temas, Juan, hay que ser también un poco, comprensivos con los demás. yo creo que, efectivamente, se han puesto, han puesto el parche la Iglesia, (mira a $J . A$., mueve las manos) antes de que salga el grano, pero realmente, también hay que escucharles, es decir, hay que ser un poco, SENSIBLES, en esta sociedad, con estas, con estas conciencias, ino? es decir, que la Iglesia católica, ha tenido durante MUCHÍSIMO tiempo, un gran peso, ;EXCESIVO!, y $[(\quad)]=$

JA:

[y un monopolio de muchas cosas!]

TE: $\quad=$ y un monopolio, $\mathrm{y}$ ahora simplemente se trata de $=$

MTC: bueno $=$

TE: $\quad=$ (mira a MTC) de, separarlas, las cuestiones, una cosa es

MTC: = volveremos a hacer ese debate

TE: (asintiendo a MTC)) isí!

MTC: (mirando a la cámara) voy a atender una llamada, porque, claro, ya alguien ha llamado, no quiero dejarlo, será sobre este tema, hola buenas tardes, [idígame!]

EP: [hola, buenas tardes] hola, buenas tardes

MTC: ¿quién es?

EP: $\quad$ supongo... soy Carmen $=$

MTC: Carmen

EP: $\quad$ (en tono pausado) $=\mathrm{y}$, mire, soy miembro de un APA, soy madre de dos adolescentes, y quiero decirle que, sobre todo, la religión me importa muchísimo, porque creo, que la religión ha, nos ha enseñado, nos ha enseñado, a respetar a los demás ¡la religión no es nada malo! jnada malo! es decir, uno coge la religión, y cuando es adulto, ique haga lo que quiera! pero los principios básicos, son muy importantes, y eso lo da la religión. Y SI ES OPTATIVA, le voy a, le voy a decir una cosa, mi hijo dice que es optativa, y como es optativa, no puntúa, jno entra! eso fomenta, que los críos salgan, [no entren a clase]

MTC: [pero, la...] la alternativa, ¿qué sería? no puede usted proponer que se dé obligatoriamente, [eh... eh...] =

EP: [no, obligatoriamente, no, pero]

MTC: = la religión católica, a padres, que, no, sean... [creyentes] =

EP: usted, me parece [muy bien]

[me parece muy], mire

[iporque yo respeto] lo que usted dice! eh... es más, yo he dicho muchas veces, que... a mí me vale... el cristianismo, eh... sin necesidad de creer a lo mejor en otro mundo, pero todo lo que te dice el cristianismo, como una buena base para vivir, a mí, me parece, bien. (gesto de aprobación con los labios)

JA: $\quad[$ vamos a ver $]=$ 
FP: [pem es que a mí me pare-] =

JA: $\quad=[$ ¿puedo decir una cosa, señora? $]=$

EP: = [si me permite usted, un momento]

JA: = perdón, sra. (mirando hacia la mesa, con la mano derecha apoyada sobre la mesa) señora, yo quería decirle una cosa [usted ha dicho] =

EP: = [a mí me parece bien, mire $]=$

MTC: (a JA, con acento andaluz) [¡déjala terminar!]

JA: $\quad=$ [usted ha dicho] que la religión es parà respetar a los demás (agitando su mano derecha, apoyada en la mesa) $=$ ¿ACASO DURANTE EL FRANQUISMO, LA RELIGIÓN, RES PETÓ A AQUÉLLOS QUE NNO CREÍAN? SE LES PERSIGUIÓ, PERDONA, =

EP: $\quad=[($ pero mire usted, $)(\quad)]=$

JA.: = [Y SE ME PERSIGUIÓ A MÍ], POR EIEMPLO, ECHÁNDOME DE LOS COLEGIOS, SIMPLEMENTE PORQUE YO DECIA QUE YO NO ERA RELIGIOSO =

$\mathrm{EP}: \quad=$ pero, ustedes no dejan hablar [en el programa]

$\mathrm{JA}: \quad=$

[¡NO! Y RESPETAR] A LOS DEMÁS, ¿CÓMO? ¡DURANTE CUATRO SIGLOS QUEMANDO A LA GENTE EN LA PLAZA PÚBLICA! [¿ESA ES LA MANERA QUE TUVO DE RESPETAR A LAS DEMÁS?]

EP:

[¿y los testigos de Jehová, qué hicieron?] ¿y los testigos de Jehová, qué hicieron?

JA: ¿QUÉ?

EP. es decir, era lo que había, lo que había. lo que sí es cierto que las bases, las bases, no son malas, ¡DE NINGUNA RELIGIÓN!. lo que no pueden hacer ustedes, es, las personas que somos religiosas, sea de un tipo, o de otro, hacérnoslas optativas. porque lo que están haciendo, es que, como no puntúa, y hay mucho absentismo, escolar, lo que hacen es, jno me puntúa! ¡no me valora! ino entro! [(...)]

(Nuevos argumentos e intervención de otros participantes). 


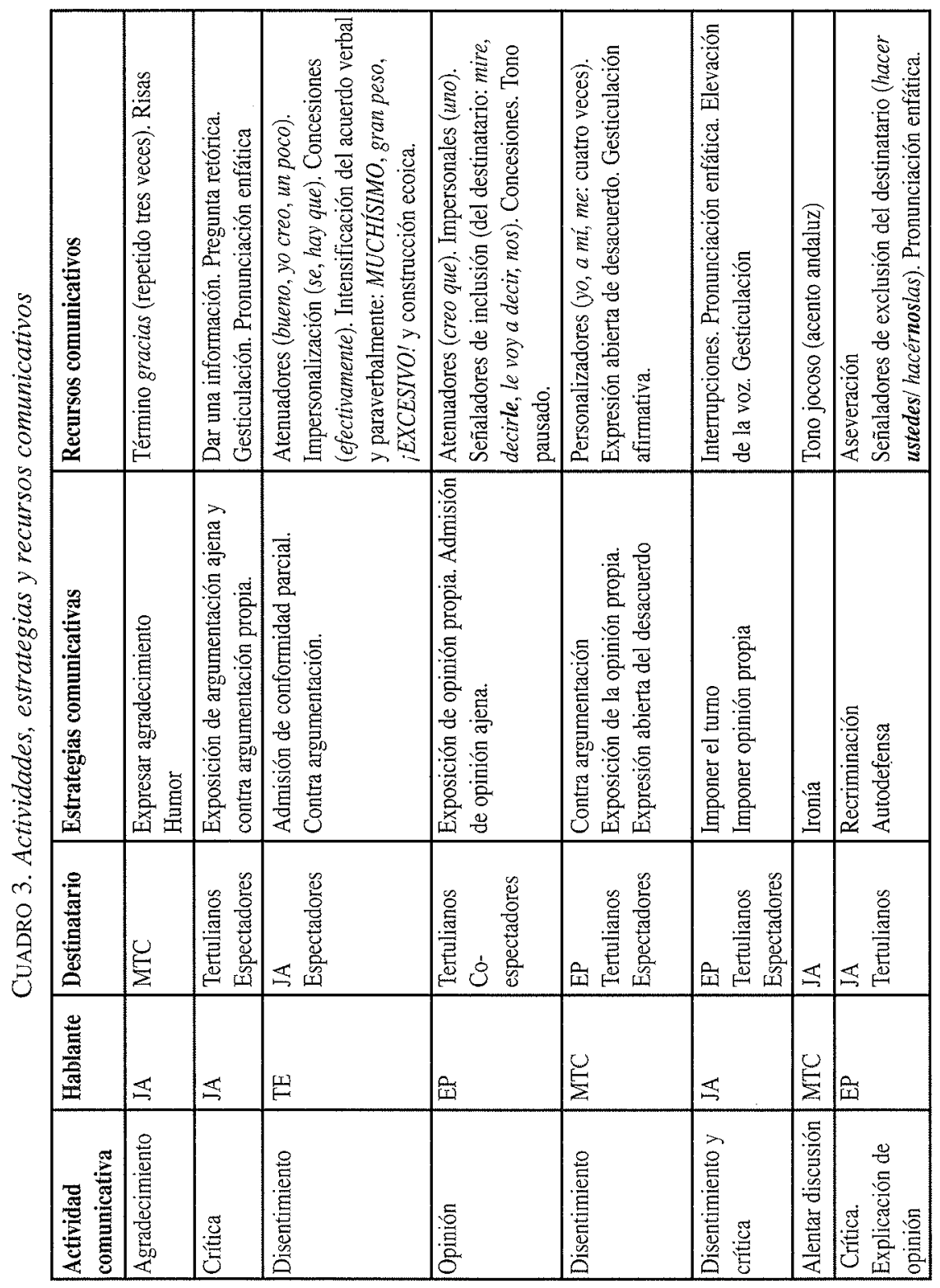




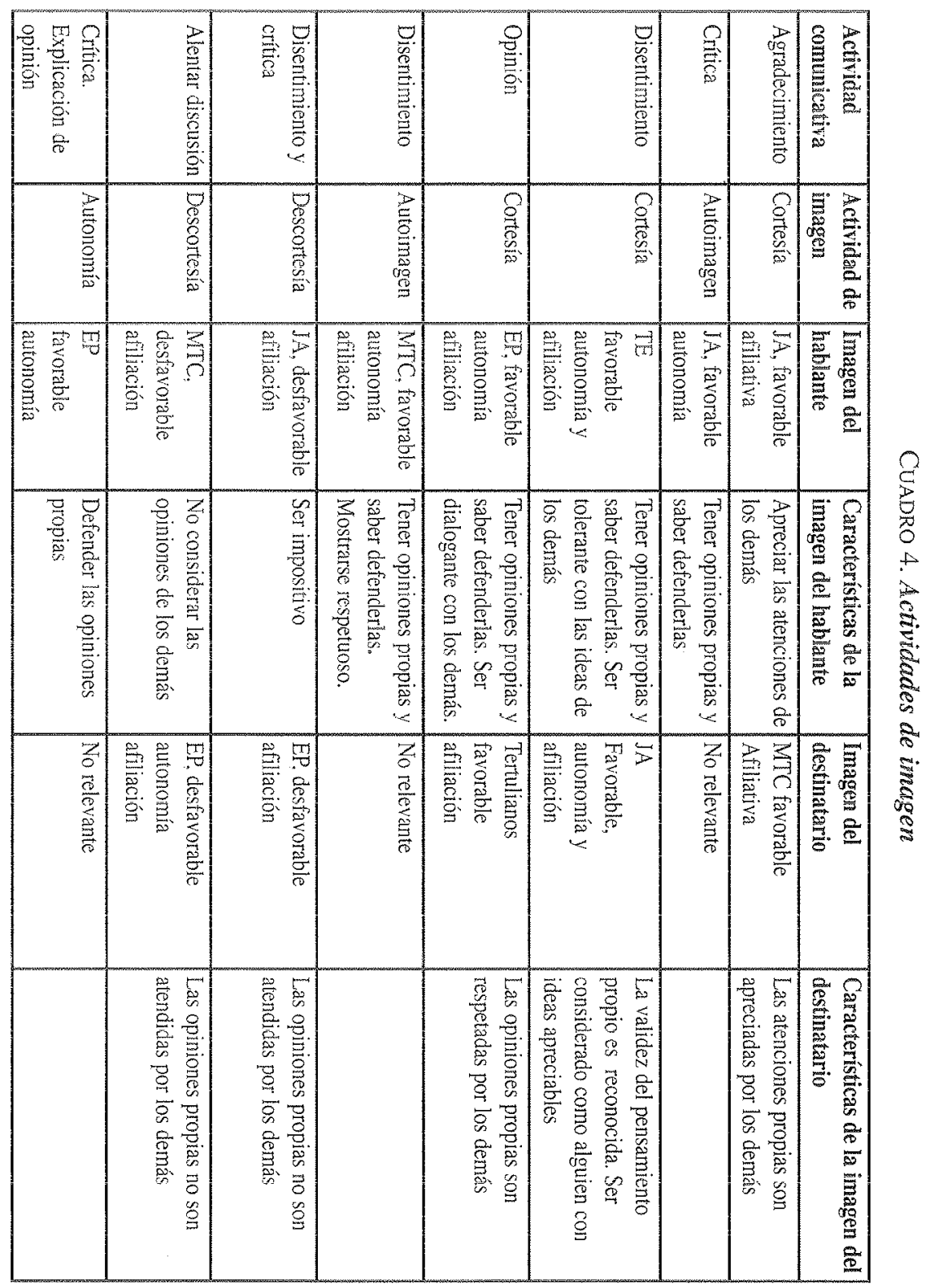


El análisis de este fragmento aparece resumido en los cuadros 3 y 4.En el cuadro 3 se recogen las actividades comunicativas realizadas -entendidas como los actos o conjuntos de actos que se efectúan-quién es el participante que realiza la actividad (el hablante) y a quién o quiénes va dirigida (el destinatario). A continuación se clasifican las estrategias o tácticas usadas para realizar la actividad y los recursos comunicativos empleados, es decir, los medios verbales (sintácticos, morfológicos y semánticos), paraverbales (p. ej. el tono o el volumen de la voz) y no verbales (p. ej. el movimiento corporal).

En el cuadro 4, las actividades comunicativas realizadas se analizan según su significado social, es decir, como actividades de imagen, las cuales, como se dijo más arriba, pueden comprender la cortesía, la descortesía y las actividades de autoimagen. En la siguiente columna aparece quién es el hablante cuya imagen se ve, favorable o desfavorablemente afectada, y a qué componente de su imagen (la autonomía o la afiliación) afecta. La descripción de la situación de la imagen del hablante (las características de imagen) se proporciona en la siguiente columna. A continuación se hace lo mismo con la imagen del destinatario (entendido como la persona que ve afectada su imagen por el comportamiento comunicativo del hablante): de qué manera se ve afectado y en qué componente (autonomía/afiliación). Las características de la imagen en esa situación se describen en la última columna.

Pues bien, para el análisis me voy a centrar en tres actividades de imagen que pueden ilustrar lo aquí expuesto: la actividad de autoimagen que aparece en la fila segunda, la cortesía de la fila tercera y la descortesía de la sexta fila del cuadro.

En la fila dos la actividad comunicativa la constituye una crítica: la que hace el participante Juan Adriansens a la idea de que la Iglesia católica intervenga en la educación de los colegios públicos. En mi opinión, a efectos de imagen social, esta intervención constituye un caso de actividad de autoimagen, donde el hablante expone una argumentación ajena (la de que la religión se introduzca en la enseñanza) y una contra argumentación propia donde critica esa idea. Mediante esta crítica, el hablante está realzando su propia imagen: en su rol de participante de un debate: la de ser una persona con opinión propia, con ideas válidas que sabe defender cuando es necesario. De esta manera, el hablante reafirma su imagen de autonomía, mientras que la imagen de los destinatarios no se ve afectada por este comportamiento comunicativo.

Pasando a la fila tercera, la actividad comunicativa es una respuesta a la intervención anterior, en este caso un disentimiento por parte de otra participante en el debate (la periodista Tonia Etxarri). Su disentimiento consiste en admitir una conformidad parcial (una estrategia de cortesía descrita por Haverkate (1994: 117) y contra argumentar con una opinión propia, lo cual realiza con recursos como la atenuación, la impersonalización, 
la concesión, etc, (ver la lista de recursos comunicativos en el cuadro 3). Este disentimiento es un caso de cortesía porque se dirige a la imagen de su interlocutor, y en concreto a la imagen de autonomía de éste (confirma que las ideas propias de J. Adriansens son válidas) y también de afiliación (las ideas de él son apreciadas y valoradas por ella). Pero al mismo tiempo este comportamiento comunicativo repercute favorablemente sobre la imagen de la hablante en su rol de participante en tu debate, en concreto sobre su autonomía (al presentarse como una persona con ideas propias, válidas y que sabe defender) y de afiliación (al presentarse como una persona receptiva a las ideas de los demás). Con esa doble dirección a favorecer la imagen de su destinatario y de ella misma en su actividad comunicativa, la hablante está apuntando hacia el intento de equilibrio de imágenes de ambos, definición que he propuesto para la cortesía.

El último caso en que me voy a detener aparece en la fila seis del cuadro, y se trata de un disentimiento y una crítica que el participante Juan Adriansens dirige a la espectadora que llama al programa. Esta actividad se realiza mediante la imposición en el turno de habla y la imposición de la opinión propia. En mi opinión, la actividad de imagen es aquí la descortesía, pues la imagen de autonomía y afiliación de la destinataria queda en una situación desfavorable cuando sus opiniones propias no son atendidas por los demás. Al mismo tiempo, la del hablante (Juan Adriansens) queda en una situación desfavorable también por ser impositivo en su turno y en la exposición de su opinión, lo cual no es lo esperable en su rol de participante en un debate. Es de destacar que la descortesía viene por la actitud de imposición del turno y de la opinión propia, no por la actividad comunicativa de criticar la confesión religiosa de la espectadora (lo que considero una actividad de autoimagen, no de descortesía), como se muestra en la reacción de ésta, que se queja de que no le dejen hablar, pero no de las críticas de Juan Adriansens.

Para concluir, considero que mediante el análisis de cómo es la situación de las imágenes de los hablantes en relación con el rol que están desempeñando es posible dilucidar el significado social de las actividades comunicativas realizadas durante una interacción, así como de qué tipo (cortesía, descortesía o actividades de autoimagen) de actividad de imagen se trata, realizándose dicho análisis bajo la consideración de las características culturales atribuibles a una comunidad. Con esta afirmación quiero señalar que hay casos en que se usan estrategias que por sus características comunicativas normalmente relacionamos con la cortesía (o con la descortesía) pero que en una interpretación que tenga en cuenta el contexto sociocultural no entrarían dentro del comportamiento cortés (o en su caso, descortés o de autoimagen). En ese sentido me uno a las posturas de autores como Blas Arroyo (2001 y 2003) que considera los aparentes casos de cortesía y descortesía del debate político no como tales, sino como 
casos de politic verbal behavior (Watts 1992); o de Briz (2004) que afirma que lo codificado como cortés puede ser interpretado como descortés (y viceversa). Desde mi perspectiva, una interpretación ajustada de los diferentes tipos de actividades de imagen pasa por la consideración de cuáles y cómo son las necesidades de imagen de los hablantes en relación con los roles que representan, la situación comunicativa en que se encuentran y el contexto sociocultural que los rodea.

\section{Convenciones de transcripción ${ }^{1}$}

\begin{tabular}{|c|c|}
\hline : & turno de palabra \\
\hline & pausa corta, inferior al segundo \\
\hline & pausa media, de un segundo o más \\
\hline \multicolumn{2}{|l|}{ (Pausa de } \\
\hline ... segundos) & pausa de 3 segundos o más (se indica la duración) \\
\hline ¿? & interrogaciones; también para los apéndices del tipo "¿no?" \\
\hline$i !$ & exclamaciones \\
\hline$\ldots$ & vacilación en el habla \\
\hline 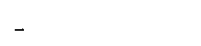 & palabras inacabadas \\
\hline muchos & pronunciación con volumen de voz alto \\
\hline MUCHOS & pronunciación marcada o enfática \\
\hline ] ] & fragmento con solapamiento \\
\hline & mantenimiento del turno de un participante \\
\hline & fragmento indescifrable \\
\hline & transcripción dudosa \\
\hline sa) & información contextual \\
\hline
\end{tabular}

\section{REFERENCIAS BIBLIOGRÁFICAS}

BoRETTI, S. (2000): «Abordaje semántico-pragmático de la construcción "no A, pero B' en el español de la Argentina», Español Actual, 74: 83-99.

Blas ARroyo, J. L. (2001): «'No diga chorradas...' La descortesía en el debate político cara a cara. Una aproximación pragma-variacionista», Oralia, 4: 9-45.

- (2003): «'Perdóneme que se lo diga, pero vuelve usted a faltar a la verdad, señor González': form and function of politic verbal behaviour in face-toface Spanish political debates», Discourse and Society, 14, 4: 395-423.

1. Estas convenciones están basadas parcialmente en las propuestas de Briz y grupo Val. Es. Co. (2002) 
BRAvo, D. (1999): "jlmagen "positiva" vs. imagen "negativa"? Pragmatica socio-cultural y componentes de face», Oralia, 2: 155-184.

- (2000): «La atribución de significados en el discurso hablado: perspectivas extrapersonales e intrapersonales», en Bustos J. J. ET ALII (eds.) (2000): Lengua, Discurso y Texto, vol. II, Madrid: Visor-UCM.

- (2002): «Actos asertivos y cortesía: imagen del rol en el discurso académico argentino», en M. E. PlacenCla y D. Bravo (eds.) (2002): Actos de habla y cortesía en español, Londres: Lincom Studies in Pragmatics 5, 141-174.

- (2003): «Actividades de cortesía, imagen social y contextos socioculturales: una introducción», en D. Bravo (ed.) Actas del Primer Coloquio del Programa EDICE, www.primercoloquio.edice.org.

- (2004): "Tensión entre universalidad y relatividad en las teorías de la cortesía», en D. BRAVO Y A. BRIZ (eds) (2004): Pragmática sociocultural: estudios sobre el discurso de cortesía en español, Barcelona, Ariel.

Briz, A. (2004): «Cortesía verbal codificada y cortesía verbal interpretada en la conversación», en D. BRAVO Y A. BRIZ (eds) (2004): Pragmática sociocultural: estudios sobre el discurso de cortesía en español, Barcelona, Ariel.

BRIz, A. y Grupo VAL. Es. Co. (2002): Corpus de conversaciones coloquiales, Madrid: Arce Libros.

Brown, P. y S. LeVInson (1987): Politeness. Some universals in language usage, Cambridge, Cambridge University Press.

CHEN, R. (2001): «Self-politeness: A proposal», Journal of Pragmatics, 33: 87-106 GOFFMAN, E. (1961): Encounters. Two Studies in the Sociology of Interaction, Londres, Allen Lane The Penguin Press.

- (1967): Interactional ritual: Essays on facetoface behavior, Garden City, NY: Anchor Books.

Haverkate, H. (1994): La cortesía verbal, Madrid, Gredos

- (2001): «Cortesía y descortesía en los diálogos del Quijote. Análisis de la representación de las imágenes positiva y negativa de los protagonistas», Oralia, 4: 129-148.

HeRnÁNDEZ Flores, N. (2002): La cortesía en la conversación española de familiares y amigos; la búsqueda del equilibrio entre la imagen del hablante y la imagen del destinatario, Aalborg, Institut for Sprog Internationale Kurturstudier, Aalborg Universitet, vol. 37.

- (2004): «La cortesía como la búsqueda del equilibrio de la imagen social», en D. Bravo y A. Briz (eds) (2004): Pragmática sociocultural: estudios sobre el discurso de cortesía en español, Barcelona, Ariel.

Tusón Valls, A. (1997): Análisis de la conversación, Barcelona, Ariel Practicum. WATTS, R. (1992): «Linguistic Politeness and Politic Verbal Behaviour: Reconsidering claims for universality» en R. WATTS, S. IDE Y K. EHLICH (eds.) (1992): Politeness in Language, Berlin, Mouton de Gruyter. 


\title{
EL GÉNERO HORÓSCOPO: CORTESÍA E IDEOLOGÍA
}

\author{
Silvia Kaul de Marlangeon \\ Universidad Nacional de Río Cuarto, Argentina
}

\section{INTRODUCCIÓN}

L

A ideología, presente en cada cultura y codificada por el lenguaje, es más fácil de observar cuando está en crisis, es decir, cuando se la desafía, que cuando permanece aceptada inconscientemente por los miembros de una sociedad, como formando parte del estado de cosas. Encontramos que el horóscopo contribuye a sostener los valores de la ideología tradicional y, por ende, el control del poder por parte de los grupos dominantes.

Concordamos con Martin (1996), Fowler et al. (1983) y Fairclough (1995) en que la ideología y el género están íntimamente relacionados en cualquier cultura: por expresar significaciones sociales, las prácticas discursivas son inseparables de los sistemas de ideas.

Para la Teoría del Género (Martin, 1984), todo género, determinado por el contexto de cultura, aparece como una estructura que responde al propósito de la interacción. El horóscopo es un género social complejo, cuyo propósito es la predicción del destino de las personas y el suministro de reglas de conducta para realizarlo. Abordamos la relación entre ideología y género desde la Teoría de la Transitividad (Halliday, 1985-1994), proyectada sobre la metafunción ideacional. ${ }^{\prime}$

La ideología no sólo se relaciona con el género, sino también con la cortesía: toda ideología está fuertemente ligada al poder y la cortesía está basada en el reconocimiento de la variable sociológica del poder. Así pues, dentro de la cortesía hay ideología; pero recíprocamente, la cortesía puede servir de instrumento a la ideología, ora para mantener el orden social establecido, ora para desafiarlo. En el presente trabajo mostramos cómo el género horóscopo porta una cortesía de manipulación orientada a reproducir la ideología y no a desafiarla.

1. El sistema de la lengua, funcionalmente diverso en el plano del contenido, se apoya en tres modos de significar para la construcción de cada una de las tres categorías siempre activas del contexto de situación: el campo (tipo de proceso social), el tenor (tipo de relaciones sociales) y el modo (manejo semiótico de la interacción). Por ello posee tres componentes metafuncionales de significado; dos de ellos corresponden a propósitos muy generales subyacentes en todos los usos del lenguaje: entender y representar el entomo ideacional y actuar sobre los interlocutores; el tercero, de índole textual, se combina con los dos anteriores. 
El horóscopo aparcec $\mathrm{cn}$ forma cscrita, radial o tclovisiva; no hay interacción propiamente dicha, sino que se trata de una actividad unilateral por parte del autor, destinada a un receptor anónimo variable, dentro de la comunidad «astrológica» de lectores. Mediante este género, el astrólogo desarrolla una compleja negociación cortés con los miembros de su comunidad. Se trata de un discurso exhortativo que, a differencia de otros como la arenga política o el sermón religioso, no está dirigido a una audiencia concreta y general, sino a una potencial e indeterminada, constituida como variable de sujeto y plasmada como conjunto de los sujetos personales concretos aficionados al horóscopo. En el horóscopo reconocemos una secuencia fundamental de actos de cortesía: la predicción y el consejo; en la primera, enfocamos la evaluación como recurso funcional cortés.

Analizar la cortesía desde un punto de vista discursivo significa, por una parte, ir más allá del nivel de las emisiones y considerarla en correspondencia con el género y con el contexto cultural en que dicho género se halla inserto y, por la otra, encararla no sólo como estrategia, sino también como vehículo de una ideología inmersa en una práctica de la comunidad.

\section{EL HORÓSCOPO DESDE LA TEORÍA DEL GENERO}

Los horóscopos analizados provienen de: Yahoo! Iberia, S.L.; de www. 123.cl y de las revistas argentinas Predicciones y Vanidades. De este corpus tomamos nuestros ejemplos, que consideramos instancias textuales del mismo género.

El horóscopo propende a lograr secuencialmente su propósito predictivo a través de una estructura esquemática peculiar. Enmarca su alcance temporal: «para el año X»; «para el mes X«; etc., como primer hito de orientación a los lectores, con respecto a la influencia de la energía astral durante un determinado lapso. Un segundo hito de orientación para que el lector ubique su fecha de nacimiento es cada una de sus doce secciones, denominadas en correspondencia con los signos del zodíaco occidental, por ejemplo: Aries «del 21 de marzo al 20 de abril».

Cada una de tales secciones puede ser considerada como texto independiente, que contiene instrucciones sobre actitudes, consejos sobre comportamientos y vaticinios de las influencias de los astros y de las relaciones con los otros signos. Tal texto sueie aparecer subdividido esquemáticamente en tópicos definitorios explícitos, como: salud; amor/pareja; dinero/negocios/trabajo; a veces, complementados con elementos opcionales como número de la suerte, color y gema preferidos, etc. Cada tópico configura un esquema de texto procedimental: una secuencia de actitudes por adoptar o de actos por realizar por el lector. 
Dentro del modelo de la Lingüística Sistémica Funcional (Halliday, 19851994), que atiende a las relaciones sistemáticas entre el contexto de cultura (el género), el contexto de situación (campo, tenor y modo) y el texto, la Teoría del Género de Martin (1984) pone el género en relación con los elementos léxico-gramaticales del sistema de la lengua, a fin de comprobar cómo están organizados los significados ideacionales (acerca de lo que sucede) y los significados interpersonales (acerca de la relación entre los interactuantes), dentro del entramado provisto por el significado textual, para cumplir el propósito sociocultural a que ese género sirve.

Mediante tales elementos del léxico y de la gramática, en cuanto elecciones determinadas por el contexto de situación, analizamos en el género horóscopo la representación lingüística de los procesos involucrados y corroboramos el principio teórico de que el flujo de la experiencia se construye en la cláusula u oración según una configuración de procesos y de participantes en ellos.

En el horóscopo, los procesos tienen por función la representación de las acciones materiales, mentales y comportamientos que el lector debe realizar o evitar. Por ejemplo: guíate por tu percepción; prepárate para enfrentar momentos de crisis. El lector es el participante humano más frecuente, dado que el contexto de situación lo convierte en el destinatario del texto. Como tal, se le asignan preferentemente los papeles de paciente (te encuentras en un momento favorecedor), beneficiario (recibirás la sorpresa de un dinero inesperado), experimentante (no sufras por boberías, disfruta de la vida), comportante (medita muy bien todo lo que tengas que hacer) y portador de atributo (tienes una mente poética; eres franco y directo). En raras ocasiones tendrá el papel de agente (trabajarás mucho; invítalo a cenar). Los participantes no-humanos más frecuentes son los astros, que ejercen el papel de agente explícito o encubierto: la Luna te infunde un fuerte toque de optimismo; la influencia de Venus continúa sobre tu signo; o de paciente: Mercurio se encuentra retrógrado.

Los procesos ya mencionados trasuntan linguísticamente que el destinatario casi nunca protagoniza el papel de agente responsable de sus acciones y, si lo hace, es por iniciativa del autor del horóscopo. La expresión mayormente imperativa de tales procesos tiene por función directiva inculcar en el lector que su éxito o fracaso dependerán de que acate o rechace las predicciones y los consejos.

Lo expuesto avala nuestra tesis de que este género, en su contexto de cultura, cumple el propósito de desviar la atención de la cuestión social, puesto que los problemas y contratiempos que ésta refleja, no aparecen como responsabilidad de la ideología dominante, sino, por lo contrario, como resultantes de la voluntad de los astros sobre el sujeto singular que los padece. 


\section{SLCULNCIA DL ACTOS DE CORTESÁ TEN LL HORÓSCOPO RELACIÓN ENTRE AUTOR Y LECTOR}

Repetimos que reconocemos en el horóscopo dos actos primordiales de cortesía: la predicción y el consejo, que le son connaturales porque cumplen su cometido genérico y que constituyen su secuencia característica. Es justamente esa búsqueda de la predicción y del consejo el fuerte motivo de interés del lector: aceptar la predicción y seguir el consejo le organizan su vida.

Por su afición a la Astrología y su creencia en sus leyes, el lector del horóscopo está predispuesto a conocer aquel vaticinio y a respetar aquella sugerencia de comportamiento para aprovechar los beneficios que en ciertos momentos le acuerdan los astros o disminuir los perjuicios de aspectaciones astrales adversas.

El contenido proposicional del acto de habla predicción, al igual que el del consejo, predica algún acto futuro del oyente o lector, inspirado por señales astrales. Atendiendo a la adhesión del receptor a las ideas astrológicas, la predicción tiene por objetivo volverlo consciente de aquello que los astros le tienen reservado y predisponerlo a recibir el consejo que la acompaña. Por ende, la secuencia predicción-consejo contiene una fuerte carga de convicción tendiente a que el oyente haga o deje de hacer algo.

Bourdieu (1999) considera que el discurso de autoridad, en el cual incluimos el horóscopo, requiere ser reconocido, ya que no basta con ser comprendido. Es por ello que la persona legitimada para pronunciarlo en la situación legítima es el poseedor del skeptron (en griego: bastón del adivino u orador). El astrólogo reúne esas condiciones de capacidad y legitimidad para la manifestación pública de su autoridad en la materia.

El consejo a menudo explicita su fundamento astrológico en las aspectaciones celestes y, otras veces, lo deja implícito en su lapso de vigencia o en el alcance temporal del horóscopo. He aquí sendos ejemplos:

Continúas con la presencia de Júpiter en movimiento retrógrado sobre tu signo. Evita volverte obsesivo con las cosas y no exageres nada; los extremos no son buenos.

Los juegos de azar y las especulaciones estarán favorecidos en este mes, pon tu intuición a funcionar y juega que podrás llevarte una sorpresa.

El astrólogo, sobre todo porque su emisión es unilateral, queda sustraído a la vulnerabilidad de su imagen por parte del destinatario. Aún si se tratare de un encuentro cara a cara, quedaría resguardado por su posición de poder y su autoridad en la materia. Por esa aceptación y ese acatamiento, también la 
imagen del adepto ${ }^{2}$ queda, ante sí mismo, exenta de lesión. En suma, la predicción y el consejo son actos que escapan a la vulnerabilidad de la imagen y se realizan de modo claro, on record.

En la óptica de Brown y Levinson ([1978]1987), mediante el consejo, el hablante $(\mathrm{H})$ indica al oyente $(\mathrm{O})$ que debería hacer algún acto (A) o abstenerse de hacerlo. Luego el consejo es un acto amenazador del requerimiento de la imagen negativa del $\mathrm{O}$. Estos autores no tratan la predicción.

Por lo contrario, como acabamos de exponer, en el contexto cultural del horóscopo, ni el consejo ni la predicción son evaluados por el receptor como actos amenazadores de su imagen negativa, sino que los percibe como actos de cortesía positiva o afiliativa, basados en el acercamiento. En efecto: sólo es posible cifrar la amenaza de imagen de un determinado tipo de acto de habla en su respectivo contexto de cultura.

En la postura de Bravo (1999, 2001, 2002 y 2003), crítica de la consideración de las imágenes negativa y positiva de Brown y Levinson ([1978]1987), las categorías de autonomía y de afiliación conciernen a las necesidades humanas que motivarían las relaciones entre el ego y el alter, plasmadas en el concepto de imagen. En la autonomía, el individuo se percibe a sí mismo y es percibido por los demás como diferente del grupo; en la afiliación, como parte del grupo. Se trata de dos categorías vacias o virtuales que abarcan contrastivamente los aspectos de la imagen social en distintas culturas. Como asevera Bravo (1999: 164-168) los contenidos de imagen están determinados por la relación entre comportamientos comunicativos y premisas culturales o convenciones sociales; el conocimiento de éstas permite explicar esos comportamientos.

Al respecto y para el español coloquial, Hernández Flores (1999) sostiene que el fenómeno de la cortesía responde a la ideología sociocultural particular del grupo y que el consejo se presenta sin pérdida de la atmósfera amistosa entre los interactuantes. Dicha autora reconoce que el consejo involucra la auto-afirmación del $\mathrm{H}$ como contenido de su autonomía y propone tomar tal auto-afirmación como un compromiso del $\mathrm{H}$ para con sus propias ideas, que quedan pasibles de aceptación o rechazo por parte del $\mathrm{O}$. Recíprocamente, ello acentúa la propia autonomía del O para adoptar una decisión independiente. Por otra parte, la confianza como contenido de afiliación provee una atmósfera amistosa y abierta, propicia a la expresión del consejo, acto por el cual el $\mathrm{H}$ reafirma su derecho a la confianza de su interlocutor.

2. En Kaul de Marlangeon (2004 a) se incorpora este vocablo al metalenguaje a propósito de la descortesía de fustigación: el adepto es el partidario de las ideas de su grupo o adicto a ellas. 
Mutatis mutandis, podcmos aplicar cl critcrio do Ilcmández Ilores (1999) al consejo que se da en el horóscopo. La confianza del destinatario, cifrada en la autotidad y competencia del astrólogo, es el contenido de afiliación propicio a la expresión de la predicción y del consejo.

Recordemos, sin embargo, la integración del grupo que estudiamos: el autor del horóscopo y una audiencia potencial e indeterminada, constituida como variable de sujeto, y plasmada como el conjunto de los sujetos personales concretos, generalmente sin contacto entre sí, receptores del horóscopo. Uno y otra comparten la necesidad de afiliación a las ideas astrológicas.

El grupo queda conformado como extensión de ciertos valores, como la colección de adeptos singulares a ellos. Cada miembro tiene conciencia de la posible existencia de los otros, sin que ello implique una conciencia de grupo o sentimiento de constituir una comunidad, pues carecen de vivencias de conjunto, salvo la afición a la astrología. ${ }^{3}$

La afiliación de cada lector u oyente al grupo de los restantes se produce, en un orden muy general, por su creencia en la Astrología y, particularmente, por la pertenencia a un determinado signo zodiacal. Esa creencia y pertenencia, es decir, la adhesión a las ideas astrológicas y a cierto signo zodiacal, muchas veces el propio, son los valores permanentes del campo de variabilidad del sujeto, o sea, las premisas culturales que nutren la imagen de la afiliación al grupo.

La variabilidad se cifra en naturales discrepancias provenientes de circunstancias personales, ideológicas y socioculturales, pero no alcanza para que cada miembro aspire a verse y ser visto por los demás como distinto del grupo, es decir, no configura autonomía respecto del grupo, básicamente por la ausencia de contacto con los demás.

Tampoco podría considerarse un rasgo de autonomía, la posible actitud de un simple lector del horóscopo que aisladamente optare por no acatar el consejo del astrólogo: aunque con ello testimonie su auto-afirmación, en tal circunstancia dicho lector no aspira a verse ni a ser visto como extraño al grupo.

En efecto, a causa de la conformación ad hoc del grupo y de la inexistencia de conciencia de grupo como una entidad reconocible de antemano, la categoría de autonomía de un miembro respecto del grupo queda vacía, excepto por lo que concierne al astrólogo respecto de sus lectores u oyentes. Ciertamente, por la preeminencia de su posición y por su conocimiento de la

3. En Kaul de Marlangeon, S. (2004 b) se analiza el caso de la descortesía intragrupal crónica en la interacción coloquial de clase media baja del español rioplatense, en que los intervinientes tampoco manifiestan concioncia de grupo: si bien tienen contacto asiduo, no tienen el sentimiento de constituir una comunidad. 
Astrología, el autor del horóscopo queda en una actitud de autonomía frente a los destinatarios de su labor. Integra también su contenido de autonomía su cuota de compromiso con lo que vaticina y aconseja.

Sin embargo, el análisis no logra establecer gran compromiso del autor con su emisión, debido al uso de lenguaje críptico, ambiguo, general y perogrullesco, de poca densidad semántica dentro de un fárrago de palabras.

Es obvio que cada adepto al horóscopo guarda una actitud de autonomía respecto del grupo de los no-adeptos.

Como en el corpus de Hernández Flores (1999), en el horóscopo el consejo aparece sin solicitud previa del $\mathrm{O}$, pero a diferencia de aquél, aquí hay una predisposición del $O$ para acatarlo o, al menos, para recibirlo y un consentimiento tácito de las asimetrías del vínculo con el $\mathrm{H}$. Justamente por esa predisposición, el contenido de afiliación en el consejo del horóscopo es la adhesión, que excede a la confianza.

El género horóscopo que consideramos tiene por contexto el de la cultura hipanohablante y en éste, esos contenidos de imagen de afiliación, la pertenencia a cierto signo zodiacal y la creencia en la Astrología, operan en la comunidad particular de sus adeptos, con independencia de los contenidos de imagen de las comunidades particulares de habla y de la variedad del diasistema utilizada para redactar el horóscopo. El grupo de adeptos a éste queda disperso en el seno de dicha cultura y el género horóscopo es reflejo de una competencia comunicativa intercultural.

La secuencia predicción-consejo sirve al astrólogo como instrumento adecuado para manejar su relación con los lectores, para canalizar su intención de mantener o incrementar el número de adeptos a la astrología y sostener su posición ideológica. Así el astrólogo se convierte en un reproductor de escalas de valores y estructuras de poder, en un portavoz autorizado para difundir las ideas de otros agentes ideológicos.

El poder que el astrólogo ejerce sobre sus lectores no responde al concepto de poder interaccional de Mills (2003), ya que no hay interacción propiamente dicha, sino que se trata del poder que el astrólogo posee institucionalmente, por la reputación de su profesión entre sus adeptos. Con éstos, sin embargo, realiza un ejercicio manipulado de poder, cuyas trazas se advierten en el cuidado de imagen que emplea al evaluar.

En suma: la secuencia predicción-consejo del horóscopo exhibe un juego de dos tipos de poder: uno, institucional, acordado de antemano, que el astrólogo ejerce sobre sus lectores por la consideración que éstos prestan a su disciplina y otro, estratégico, generado por la manipulación del astrólogo a través de la evaluación contenida en la predicción. 


\section{LA LVALUACIÓN COMO RECURSO DL CORTESÍA EN LA PREDICCIÓN}

En el horóscopo, el léxico evaluativo incluye expresiones de actitudes y de emociones que manifiestan «afecto», «juicio» o «aprecio», tanto positivos como negativos. Ellos son tres dominios semánticos en la Teoría de la Evaluación (Martin, 2000). El afecto versa sobre la expresión de las pasiones y estados de ánimo. El juicio trata de las opiniones sobre algún comportamiento mediante las cuales el $\mathrm{H}$ emite una evaluación positiva o negativa, dentro de un patrón de normas institucionalizadas. El aprecio trata de valoraciones estéticas o sociales de entes: objetos naturales o artificiales, productos, procesos o constructos abstractos tales como proyectos o planes. Dicha teoría se sitúa en una concepción dialógica del lenguaje (Bajtín, 1998) e involucra al significado que construye y mantiene la relación entre el $\mathrm{H}$ y el O, denominado interpersonal por Halliday (1985-1994).

Con respecto al horóscopo, la evaluación es funcional al género; promueve en el receptor actitudes afiliativas hacia la escala de valores del astrólogo y trasunta de manera evidente o implícita su modo de concebir el mundo.

En el horóscopo el lenguaje usado para evaluar se encuentra tanto en la predicción como en el consejo. Enfocamos especialmente la evaluación contenida en la predicción, como recurso cortés, pues la predicción no es de por sí ni cortés ni descortés: la torna cortés el empleo de la evaluación como herramienta retórica.

En los dos siguientes ejemplos, en que el afecto se manifiesta a través de procesos mentales de atribución, las actitudes y emociones que el astrólogo procura inducir en el individuo propenden a adular el narcisismo de éste:

Te mostrarás encantador y por ello arrastrarás a mucha gente contigo.

Mercurio te acompañará a partir del día 16, en que podrás contar con una claridad mental que te permitira generar tu vida con sabiduria e inteligencia

En el siguiente ejemplo, el aprecio positivo de los juegos de azar y el juicio benévolo hacia ellos se cifran mediante el pronóstico propiciatorio de que estarán amparados o apoyados o de que serán ayudados o socorridos, todas acepciones usuales del verbo favorecer que denotan estima:

\section{Los juegos de azar y las especulaciones estarán favorecidos en este mes}

Que la evaluación responde a un patrón de normas institucionalizadas según el cual el tener y el ganar dinero son valores muy importantes, se advierte en este otro ejemplo: 
Con tu regente, Venus, en movimiento armónico en tu sector de las finanzas, podrás aumentar tu dinero, ganar más y atraer la suerte a tu bolsillo

Cada evaluación reproduce el sistema de ideas en que se asienta el horóscopo y expresa aquellos sentimientos valorados positivamente en el contexto cultural de sus adeptos: estimula el liderazgo, el atractivo sexual, los juegos de azar, la ventaja de poseer mucho dinero.

Cuando el escritor confiere al lector determinados atributos y promueve en éste determinados comportamientos, lo hace con total desconocimiento de la personalidad del sujeto concreto a quien se dirige. Sin embargo, ese recurso evaluativo resulta muy eficaz, porque las cualidades que el autor del horóscopo asigna, en su gran mayoría son positivas, cuando no, aduladoras. Estas expresiones positivas y a veces exageradas de las cualidades del lector, sirven a la estrategia de proclamar conocimiento compartido de metas y valores (Brown y Levinson, [1978]1987: 5.3.1) y son, por tanto, difícilmente rehusables por parte del destinatario.

\section{CONCLUSIONES}

El presente trabajo describe la estructura esquemática del horóscopo y aborda su vínculo con la ideología desde la Teoría de la Transitividad, dando cuenta de los procesos que tienen lugar en él y explicitando los roles de sus participantes, y la distribución del poder según esos roles. Expone la tesis de que el horóscopo cumple el propósito de desviar la atención de la cuestión social.

También analiza cómo la cortesía empleada en la secuencia predicciónconsejo sirve al astrólogo para canalizar su intención de mantener o incrementar el número de adeptos y para sostener su posición ideológica, reproductora de la ideología dominante; es decir, exhibe la cortesía como un instrumento de la ideología.

Asimismo propone como punto de vista que, dentro de la cultura occidental hispanohablante, la cortesía presente en el horóscopo es, a un tiempo, una estrategia consuetudinaria y una práctica social propia del género.

Coherentemente, examina la evaluación contenida en la predicción como un recurso con que el autor seduce y manipula al receptor, lo vuelve dependiente de la predicción, logra mantener su interés y conservarlo como usuario del horóscopo, al tiempo que le transmite ideología.

El estudio concibe ad hoc un grupo sociocultural constituido por el astrólogo, situado en una posición de poder, y por sus lectores o auditores, como audiencia potencial e indeterminada, dispuesta a acatar ese poder, la cual 
funciona como variable de sujeto y está plasmada como el conjunto de los sujetos personales concretos, generalmente sin contacto entre sí, adherentes al horóscopo.

Establece que la afiliación de cadia adepto al grupo de los restantes se produce por su creencia en la Astrología y por la pertenencia a un determinado signo zodiacal y que sólo aparece autonomía por parte del autor del horóscopo respecto del grupo de suis adeptos.

\section{RETERENCIAS BIBLIOGRATICAS}

Bastín, M. (1998): Estética de la creación verbal, México, Siglo XXI editores. Bourdieu, P. (1999): Qué significa hablar, Madrid, Akal.

BrAvo, D. (1999): «iImagen positiva vs. imagen negativa?: Pragmática social y componentes de face», Oralia, 2:155-184.

- (2001): «Sobre la cortesía lingüística, estratégica y conversacional en español», Oralia, 4: 299-314.

- (2002): «Actos asertivos y cortesía, Imagen del rol en el discurso de académicos argentinos», en PLACEnCiA, M. E.; D. Bravo (eds.) (1980): Actos de habla y cortesía en español, Londres, Lincom Studies in Pragmatics.

- (2003): «Actividades de cortesía, imagen social y contextos socioculturales: una introducción», en BRAvo, D. (ed.): Actas del Primer Coloquio del Programa EDICE, Estocolmo, Universidad de Estocolmo.

Brown, P. y S. Levinson. ([1978]1987): Politeness: Some Universals in Language Usage, Studies in Interaccional Sociolinguistics 4, Cambridge, Cambridge University Press.

Fairclough, N. (1995): Language and Power, Londres y Nueva York, Longman. Fowler, R.; B. Hodge; G. Kress y T. Trew (1983): Lenguaje y Control, México, Fondo de Cultura Económica.

Haldiday, M. A. K. (1985-1994): An Introduction to Functional Grammar, Londres, E. Arnold,

Hernández Flores, N. (1999): «Politeness Ideology in Spanish Colloquial Conversation: The Case of Advise», Pragmatics 9: 37-49.

KaUl DE MARLANGEON, S. (2004 a): «Descortesía de fustigación por afiliación exacerbada o refractariedad» en BRAVo, D. (ed.) (2004): Cortesía Linguiistica y Comunicativa en Español, Buenos Aires, Dunken, en prensa.

- (2004 b): «Descortesía intragrupal-crónica en la interacción coloquial de clase media baja del español rioplatense», en Murillo, J. (ed): Actas del Segundo Coloquio del Programa EDICE, San Juan de Costa Rica, Universidad de Costa Rica, en prensa. 
Martin, J. (1984): «Language, Register and Genre», en Christie, F. (ed.): Children Writing: reader, Geelong, Vic., Deakin University Press.

- (1996): Factual Writing: exploring and challenging social reality. Victoria, Deakin University Press.

- (2000): «Beyond Exchange: Appraisal Systems in English», Evaluation in Text, en Hunston, S. y G. Thompson (eds.): Oxford, Oxford University Press.

Mills, S. (2003): Gender and Politeness, Cambridge, Cambridge University. Press. 



\title{
LA COMUNICACIÓ ENTRE HOMES I DONES EN ELS CONTES DE QUIM MONZÓ: UNA ANÀLISI DES DEL PUNT DE VISTA DE LA CORTESIA LINGÜÍSTICA
}

\author{
Antoni Maestre Brotons \\ Universitat d'Alacant
}

\section{INTRODUCCIÓ}

$\mathbf{E}$ L propòsit d'aquest treball és analitzar el funcionament dels procediments les estratègies de la cortesia lingüística utilitzades en els diàlegs entre parelles sentimentals d'alguns contes de l'escriptor Quim Monzó.' Aquestes contes parodien converses típiques entre amants plenes de tòpics i clixés lingüístics. A més, les normes de la cortesia, en general, més que facilitar les relacions, en realitat les entorpeixen, precisament a causa del caràcter fossilitzat de les expressions i de la convencionalitat de les regles.

Aquesta anàlisi, doncs, ens permetrà comprovar que Monzó parodia les converses sentimentals. D'una banda, en la majoria de contes, representen un entrebanc per a mantenir unes relacions fluïdes entre amants i, sovint, constitueixen el principal motiu del fracàs amorós; dit d'altra manera, es tracta de personatges que són incapaços de comunicar-se per l'«estil» que empren. D'altra banda, també afavoreixen el joc conversacional i l'humor, en el cas de personatges que els utilitzen lúdicament per a burlar-se de les discussions tòpiques de parella i d'ells mateixos.

En primer lloc, repassarem les característiques principals de la comunicació en el si de les relacions sentimentals i definirem el concepte de generolecte. En segon lloc, estudiarem els tòpics i els clixés que sorgeixen en les converses entre amants en els relats de Monzó. Tot seguit, analitzarem les regles de cortesia que empren aquests personatges per a comunicar-se entre si $\mathrm{i}$, finalment, establirem unes conclusions.

1. EIs contes seleccionats per a l'anàlisi formen part del recull El perquè de tot plegat (1993) i són els següents: «La fe», «La immolació», «La gelosia», «Amb el cor a la mà», « les busques dels rellotges giren en el sentit de les busques dels rellotges?» $\mathrm{i}$ «Quarts d'una». Utilitzem la versió de Vuitanta-dos contes de 1999, que recull tota la narrativa breu de l'autor fins a aquesta data. 


\section{LA COMUNICACIÓ EN LES PARELLES SENTIMENTALS}

Anne Charlon (1998: 73), rastrejant les influències literàries de Quim Monzó, observa les semblances respecte a la visió de les relacions sentimentals entre els seus contes i les narracions de Mercè Rodoreda. En tots dos autors, aquestes relacions es construeixen bàsicament mitjançant diàlegs farcits de banalitats $\mathrm{i}$ de frases fetes que posen en relleu la impossibilitat de tota comunicació i de tota comprensió entre els dos amants. Ara bé, mentre que el punt de vista de Rodoreda és agre i pessimista, el de Monzó és més aviat lúdic $\mathrm{i}$ irònic $\mathrm{i}$, en el fons, el que pretén és mostrar el comportament absurd dels humans, en aquest cas i especialment, de les parelles. De fet, la incomunicació sexual, juntament amb la pressió ambiental o la buidor quotidiana, és un dels temes més recurrents en l'obra de Monzó.

Com és sabut, el discurs forja i permet les relacions socials i també crea les identitats individuals i col-lectives. Des d'aquesta perspectiva, Deborah Tannen (1992) considera que les relacions sentimentals naixen gràcies al llenguatge i s'hi mantenen. L'èxit o el fracàs amorós s'explica per l'ús del llenguatge que fan homes i dones. Segons aquesta autora, la conversa entre home i dona és un exemple de comunicació intercultural, ja que tots dos sexes són educats de manera diferent $\mathrm{i}$, per tant, aprenen a parlar també de manera distinta, és a dir, configuren el que Tannen anomena «generolectes» (genderlects) (Tannen, 1991: 129):

La conversación entre hombre y mujer es una comunicación intercultural. La cultura es simplemente una red de hábitos y pautas que se va tejiendo con experiencias vividas, las de mujeres y hombres son muy distintas. Desde el momento en que nacen, se los trata y se les habla de modo diferente y, como resultado, hablan de manera diferente

Per tant, l'estil comunicatiu masculí i femení és distint i això provoca nombrosos problemes de comunicació, propiciats pel desconeixement mutu de les dues «formes de parlar». Si es té en compte que la comunicació és bàsica per a permetre la relació (qualsevol tipus de relació, en realitat), força problemes de parella són causats per aquest motiu. Per a les dones, parlar té la finalitat de mantenir relacions, mentre que els homes es relacionen per mitjà d'activitats que desenvolupen junts, en grup; en canvi, parlen per impressionar i mantenir l'estatus social. Les dones conversen per establir contacte i intimitat; els homes xarren per conservar l'estatus i la independència. Les dones mostren comprensió amb els problemes que els exposen; els homes, simplement, proposen solucions, però no s'hi mostren empàtics (o tal vegada és la seua forma de manifestar empatia). Això fa que hi haja diferències en 
I'estil de conversa, en els hàbits i les suposicions sobre la manera com mantenir la conversa, expressar interés o ser considerat, per exemple (Tannen: 1991, 146). A més, les dones estan més atentes als «metamissatges» (la informació complementària; les actituds envers l'interlocutor, l'ocasió i el que es diu), cosa que sovint provoca pressuposicions i malentesos. En canvi, els homes són més literals. Un factor molt rellevant és la concepció que tenen ambdós sexes de les converses íntimes: per a elles, la relació funciona si poden «xarrar»; per a ells, la relació naufraga si han d'insistir constantment a referla mitjançant discussions.

\section{ELS TÒPICS I ELS CLIXÉS CONVERSACIONALS}

El mateix Quim Monzó afirma que una de les seues fonts d'inspiració per a narrar són els tòpics i els clixés conversacionals: «Aquests tòpics em fascinen. Em fascina agafar-los i anar-los estirant» (Cercas, 1996: 128). «Sabent que és impossible fugir-ne del tot, intento fugir del lloc comú. Potser faïg una literatura reactiva; no m'acabo de creure res»; «No es tracta tant de ser molt original com de no caure en el que és cursi» (Piquer, 2003). Un dels temes recurrents de la seua obra, doncs, és la paròdia dels tòpics, dels clixés, dels llocs comuns i de les coses sabudes. Així, l'escriptor juga amb el caràcter estereotipat de comportaments, històries, vocables políticament correctes $i$ estils conversacionals arxiconeguts i repetits incansablement i que sovint parodia en articles i contes. ${ }^{2}$ Per això, Manuel Ollé (1998: 53) considera l'obra de Monzó com un treball de metaficció, de ficció sobre la ficció. Per diferenciar els dos termes, creiem apropiat concebre els tòpics com una idea preconcebuda $i$ associada a una esfera d'activitat concreta (les relacions sentimentals, en aquest cas); reservem el terme clixé per a referir-nos a expressions lingüístiques estereotipades, altament ritualitzades $i$, en aquest sentit, relacionats amb la cortesia linguiística. ${ }^{3}$ Sovint estan relacionats perquè els tòpics prenen la forma de clixés.

Els tòpics, en els contes de Monzó, fan fracassar la comunicació i l'acord. L'escriptor utilitza la ironia, la sàtira i la paròdia perquè, igual que no pretén ser un moralista ni un sociòleg quan reelabora les històries tradicionals com La Ventafocs o Tom i Jerry, tampoc no intenta plasmar l'opinió d'un filòleg o

2. Per exemple, Lunati estudia la paròdia que Monzó fa dels contes tradicionals en la seua obra literària.

3. Salvador (2000: 29), basant-se en Pierre Bourdieu, destaca precisament la relació entre fraseologia i comportament social, és a dir, determinats modes d'actuació tenen associats unes pautes expressives específiques, com ara la cortesia. 
d'un lingüista.' Simplement, rebulja l'estereotip i el convencionalisme. Pel que fa als clixés, Monzó es revela com un estilista exigent, tal com demostra la depuració formal dels seus textos narratius i periodístics, així com els comentaris sobre l'ús d'expressions, de paraules o de termes políticament correctes que exposa en nombrosos articles de premsa i que sovint apareixen en el discurs publicitari, periodístic o polític. ${ }^{5}$ Aquestes expressions que Monzó parodia en els diàlegs entre parelles s'aproximen prou al que Payrató (1996: 124-125) denomina estereotips o rutines de parla. ${ }^{6}$

En el conte titulat «La fe», apareixen dos tòpics molt usats en la comunicació entre home i dona. El primer el formula la dona i és «Potser és que no m'estimes». Tot i que l'home expressa explícitament i reiteradament al llarg de tota la conversa el seu amor, la dona es mostra reticent a tots els arguments de la seua parella i qualsevol dissensió, per mínima que siga, és interpretada per ella sempre com un símptoma de manca d'amor vertader i sòlid. De fet, el conte es clou amb la mateixa oració que l'enceta: «Potser és que no m'estimes», dotant-lo d'una estructura circular i, per tant, inacabable: sempre, siguen quins siguen els camins que puga prendre la conversa, l'intercanvi acabarà igual; no hi ha raons suficients per a convéncer la dona sobre l'amor de l'home $i$ aquella serà víctima eternament dels seus propis dubtes. L'altre tòpic que apareix en aquest relat el fa servir l'home i és el de la franquesa de la mirada: com que les paraules són convencionals i caduques, segons la dona, l'home cerca un altre llenguatge, el no verbal, per convéncer, ja que els ulls no poden mentir: «... Però ¿com puc tenir la certesa que tu m'estimes? - Mirant-me als ulls» («La fe»). No cal dir que el llenguatge de la mirada, del gest, tampoc no assoleix persuadir la dona i traure-la de la seua caboteria a no creure la seua parella.

4. Segons Lunati, la paròdia té diversos significats o funcions en els contes de Monzó: transgressió irònica, distància crítica, qüestionament del concepte d'autoria i originalitat, posició ideologica $\mathrm{i}$, com diem, rebut dels estereotips i dels convencionalismos.

5. L'últim recull d'articles periodístics es titula significativament El tema del tema (2003), que ironitza sobre l'ús d'un dels clixés més usats en l'actualitat: «el tema de...». També hi ha, pet exemple, un altre article, "Vigesímicos», en aquest mateix llibre, que critica l'ús de l'expressió «ser del segle $x x »$ en sentit despectiu.

6. Es tracta de fórmules que s'usen per a dur a terme actes de parla com respondre, mostrar desacord, demanar explicacions o excusar-se. Es caracteritzen per un significat fossilitzat i pel caràcter previsible, ja que posseeixen una càrrega simbòlica més que significativa, és a dir, mostren l'actitud del parlant en l'intercanvi comunicatiu, són fórmules relacionades amb la cortesia que pretenen facilitar la cooperació conversacional. Aquesta funció «gestionadora» de l'intercanvi fa que les rutines de parla apareguen en els tres moments de la interacció: al principi (per a negociar el tema: «perdone que el moleste), durant el desenvolupament («bé», «vull dir», «m'entens?», «és a dir») i en la clocnda (per' a referir-se al futur, tancar l'intercanvi i valorar-lo). 
Un altre tòpic que parodia l'autor és la idea habitual que les dones es queixen que les seues parelles no els dediquen atencions ni hi són cortesos. En el relat «Per què les busques...», l'amant es presenta davant el marit perquè l'aconselle sobre la manera com es pot alliberar de l'assetjament de la dona. El marit replica que, com ell ha obrat, només s'hi ha de mostrar summament cortés, atent i galant. En «La gelosia», Monzó capgira el tòpic que els homes només es fixen en els encants físics de les dones i tan sols hi volen sexe, no amor, fent que la dona protagonista demostre un desig luxuriós pel membre viril de l'home, que s'ofén perquè es considera degradat com a persona. Aquest tòpic en les relacions amoroses té els seus correlatius verbals: «Si no tingués cigala, ¿m'estimaries igual?»; «Però jo també existeixo» («La gelosia»).

L'altre tòpic que Monzó satiritza és la sinceritat, que sovint és concebuda com el factor clau en el bon desenvolupament de les relacions amoroses. En el conte titulat «Amb el cor a la mà», la parella de nuvis protagonista acaba barallant-se i separant-se per aquesta tossuderia a voler ser sincers. La sinceritat, doncs, pot ser molt perillosa: «Serem del tot sincers l'un amb l'altre. Mai no ens mentirem, sota cap concepte ni amb cap excusa» ( «Amb el cor a la mà»). ${ }^{7}$ Així, la sinceritat, que pot considerar-se una estratègia de cortesia, esdevé una ofensa, un atac a la imatge.

Altres vegades, els tòpics tenen la forma d'expressions clixés: «No sé per on començar. - Pel començament» («Per què les busques dels rellotges giren en el sentit de les busques dels rellotges?»).

El mateix Quim Monzó (Cercas 1996: 128) explica que el conte «Quarts d'una» s'origina a partir d'un clixé arxiconegut que ha esdevingut una mena de fórmula que activa tota una sèrie de coneixements enciclopèdics o de marcs cognitius en la ment dels parlants així que l'escolten en boca d'una altra persona:

- ¿Digui'm?

- Hola. -És una veu de dona. -Sóc jo. [...]

- T'he dit mil vegades que no em truquis mai a casa. («Quarts d'una»)

L'última intervenció indica ja, des de bell començament, que la conversa que tot seguit té lloc és mantinguda per una parella adúltera. El grau d'estereotipació d'aquesta expressió engega tot un horitzó d'expectatives en el lector, semblant a les fórmules d'inici dels contes de fades, que permet al lector preveure com es desenvoluparà l'acció, els personatges i els espais. Ara bé, Monzó parodia aquestes escenes estereotipades típiques, per exemple, del

7. El títol d'aquest conte constitueix en si mateix un altre tòpic. 
cinema, complicant de manera molt exagerada el diàleg entre els dos amants, fins a tal punt, que el lector, al final del relat, no pot saber ben bé quina és la vertadera identitat de tots dos personatges. Tant l'home com la dona transgredeixen contínuament les màximes conversacionals, incloent-hi nombroses pressuposicions, malentesos, mentides, mitges veritats, canvis de rols, girs temàtics inesperats, ironia, etc. Per tant, l'autor enganya el lector, traeix les seues expectatives inicials, juga amb el desconeixement que té de la majoria de dades, igual que juga amb els personatges, que no comparteixen l'espai de l'enunciació en tractar-se d'una conversa telefònica. El grau màxim de confusió arriba quan els personatges fingeixen xarrar amb una altra persona perquè, suposadament, la gent que els envolta no descobrisca la seua relació secreta $i$ les intervencions no s'ajusten en absolut:

- Home, ja t'ho he dit. Gasta molta menys berizina que no pas l'altre.

- Però la protagonista de L'amor a la farda és més versemblant.

- ¿I com és que una casa com la Peugeot no ha previst un cas així?

- Però això era a Ara tots dos estem igual. ¿M'equivoco? («Quarts d'una»)

L'ús de díctics incrementa la confusió encara més:

- ¿I si minagués demanat l'auricular per parlar amb tu?

- ¿Per què hauria de voler parlar amb mi?

- No vull dir amb tu: vull dir amb qui es pensava que parlava jo. («Quarts d'una»)

Al llarg de tot el diàleg, es produeix un procés d'interpretació d'intencions contínuament fallit: els personatges són incapaços de realitzar les inferències adequades i, així doncs, ser rellevants:

- ¿Què penses fer, ara?

- ¿Ara? ¿Vols dir amb lo nostre?

- No. Vull dir: ara mateix.

- Ah, ¿sí? ¿I què te'n diu, de mi?

- Ui.

- ¿Què vol dir aquest «ui»?

En aquest conte, més que en cap altre, la incomunicació entre home i dona esdevé total: tots dos intenten preservar, per damunt de tot, la seua imatge negativa, el seu territori, sense cap mena de cessió ni condició. L'acord entre ells és nul. A més, en el conte hi ha altres expressions clixés, com ara: «No podem continuar així. Ni una conversa civilitzada, no podem tenir»; «No hi ha 
qui t'entengui»; «M'agradaria molt estar ara amb tu»; «T'estimo molt. Si mai deixés d'estimar-te em moriria» (frase que clou el relat). Els tòpics, per tant, entrebanquen les relacions; no són recursos, podríem dir, gens «cortesos».

\section{ESTRATÈGIES DE CORTESIA EN LES CONVERSES ENTRE HOMES I DONES EN ELS CONTES DE QUIM MONZÓ}

Per a analitzar els intercanvis comunicatius entre homes $\mathrm{i}$ dones en les narracions de Monzó, ens basarem en el concepte de cortesia lingüística, entesa com el conjunt d'estratègies que els parlants posen en funcionament per elaborar els seus enunciats i permetre que la relació social que s'hi estableix siga reeixida. Segons Kerbrat-Orecchioni (1996: 50), mitjançant les regles de la cortesia, els interlocutors intenten preservar el caràcter harmoniós de l'intercanvi comunicatiu. Aquesta autora fa un parell de remarques a la teoria de Brown i Levinson (1987). ${ }^{8}$ La primera és que ofereix una visió massa pessimista de la cortesia, que es redueix a la seua vessant negativa, és a dir, sembla que parlar es limita bàsicament a defendre's dels possibles atacs a la imatge personal. D'altra banda, a més dels actes que amenacen la imatge, també n'hi ha que la valoren, com els compliments o els agraïments (Kerbrat-Orecchioni, 1996: 53-54). És interessant destacar, com fa aquesta autora, el conflicte que es produeix sempre entre la voluntat de ser sincers i la cortesia, el difícil equilibri entre preservar la imatge de si mateix i respectar els altres, ja que com més es valora la imatge positiva de l'interlocutor, més s'amenaça correlativament la imatge negativa, i a la inversa (Kerbrat-Orecchioni, 1996: 63). Per a l'estudiosa, hi ha dues maneres de mantenir l'equilibri: la primera, reduir els antagonismes potencials que poden donar-se en l'intercanvi; la segona, evitar sempre els conflictes (KerbratOrecchioni, 1996: 65). Això ho podem entendre com l'intent de passar per alt els temes, els punts de vista o les entonacions, les expressions, les paraules, que poden ser font del dissens o que poden causar malestar o ofensa entre els parlants. Conversar, doncs, s'ha de convertir, mitjançant la cortesia, en una eina per a crear, mantenir i millorar les relacions socials.

Malgrat les matisacions que introdueix Kerbrat-Orecchioni, la teoria de Brown i Levinson pot oferir una mostra de les estratègies que posen en funcionament els parlants per aconseguir una conversa harmoniosa que puga satisfer els desitjos i les expectatives pròpies i alienes. Així doncs, farem servir l'utillatge conceptual d'aquests autors per analitzar els diàlegs en els relats de Monzó. A més, inclourem un apartat que no consideren Brown i Levinson: els

8. Una exposició d'aquesta teoria es troba en les obres de Calsamiglia i Tusón (1999) i Escandell (2003). 
actes que protegeixen la imatge propia. Estudiarem, per tant, les estratègies de cortesia positiva, cortesia negativa i cortesia encoberta, els procediments atenuadors $\mathrm{i}$ els actes que amenacen la imatge. La cortesia positiva i la negativa estan relacionades respectivament amb el que Brown i Levinson anomenen imatge positiva i imatge negativa. La primera es refereix al valor $i$ l'estima que una persona reclama per a si mateixa, mentre que la imatge negativa al-Hudeix al territori que es considera com a propi $i$ a la llibertat d'acció que tothom vol preservar.

\subsection{Estratègies de contesia positiva}

Aquestes estratègies tenen el propòsit de compensar els desitjos de l'oient, facilitant un comportament familiar i distés. Tot seguit en fem una classificació:

a) L'humor: en l'exemple següent, extret del conte «La fe», l'home fa servir la hipèrbole i els tòpics per intentar que la dona s'adone de com d'estúpida és la seua obstinació a creure que ell no l'estima o no està convençut del seu amor: «T'estimo més que a mi mateix. Per tu donaria la vida, em deixaria escorxar de viu en viu, que juguessin amb els meus ulls com si fossin bales. Que em llancessin en un mar de salfumant» («La fe»).

El plantejament humorístic que fa Monzó en els contes és evident en el cas de «Per què les busques...». Així, el consell que el marit dóna a l'amant de la seua dona per poder alliberar-se de l'assetjament a què el té sotmés és, precisament, que s'hi mostre summament cortés:"

- Res més fàcil. Faci com jo. Deixi de defugir-la, no s’amagui, sigui amable, tendre, considerat. Estigui més per ella que no pas ella per vostè. Truqui-li, digui-li que l'estima com mai no ha estimat. Prometi-li que li dedicarà la vida sencera. Casi-s’hi. («Per què les busquies....»).

b) Tenir en compte els desitjos de l'oient és una estratègia usual de cortesia positiva: «Però tu deus tenir molta gana» («Amb el cor a la mà»). «Has de ser tu qui decideixi què hem de fer» («Quarts d'una»).

c) Buscar l'acord i la connivència amb l'interlocutor, ratificar que comparteixen el mateix punt de vista: «És molt absorbent. - ¿Oi que sí?» («Per què les busques...»); «Però... A veure si ens entenem...» («Quarts d'una»).

9. En aquest cas, el consell no es pot concebre com un acte que amenaça la imatge negativa del destinatari tal com ho fan Brown i Levinson, ja que l'amant acudeix per voluntat pròpia al marit precisament perquè l'ajude. 


\subsection{Estràtegies de cortesia negativa}

Aquestes estratègies tenen la finalitat d'evitar coartar la llibertat del destinatari i dificultar la seua atenció, mostrant en tot moment un comportament respectuós. Monzó posa en joc nombroses estratègies de cortesia negativa, ja que els personatges dels seus contes tracten de mostrar-se respectuosos els uns amb els altres per no ferir els seus sentiments. Les estratègies de cortesia negativa utilitzades són les següents:

a) La pregunta, que intenta no donar per sabudes certes coses i resulta més indirecta que una mera afirmació: «¿Com pots estar segur que el que notes és que m'estimes i no una altra cosa?» («La fe»); «८Com pots dubtar que t'estimo?» («La fe»). De fet, la pregunta és el procediment de cortesia per antonomàsia i abunda en tots els contes analitzats.

Les preguntes es relacionen amb els actes de parla indirectes, ja que eviten sempre la responsabilitat d'afirmar una cosa que pot resultar ofensiva:

$-[. .$.$] què et demostraria que t'estimo?$

- No sóc jo qui ho ha de dir. («La fe»)

- ¿De debò no vols pujar-hi?

- ¿Hem vingut a Pisa i no pujaràs a la torre amb mi? («La immolació»)

- ¿No veus que l'han tinguda tancada durant anys, fins que s'han assegurat que no passava res $[\ldots]$ («La immolació»)

b) La disculpa, que mostra deferència respecte a l'oient: «Potser sí que t'he de creure» («La fe»); «Perdona'm. Em sap greu» («Quarts d'una»).

c) Els dubtes sobre els pensaments i les accions de l'altre, intentant evitar manifestar obertament la seua opinió: «No deus pas creure que s'hagi d'ensorrar precisament quan hi pugem nosaltres» («La immolació»).

d) Expressions impersonalitzadores: «Ni parlar-ne»; «A veure si haurem vingut a Pisa $i$ ens n'anirem sense pujar a la torre» («La immolació»); «Val més que pengi. Adéu» («Quarts d'una»).

e) Apel-lar al punt de vista: «Però jo també existeixo [...] ¿No et sembla?».

\subsection{Estratègies de cortesia en coberta}

Aquestes estratègies impedeixen atribuir una sola intenció comunicativa clara a un acte. A continuació classifiquem aquest tipus d'estratègies: 
a) La pressuposició, que pot ser causant d'un acte amenaçador de lat imatge, tot i que ambigu, ja que deixa a l'interlocutor la llibertat de fer les seues pròpies inferències:

- Oh, Raül, si sabés que de debò m'estimes, que puc creure't, que no t'enganyes a tu mateix $\mathrm{i}$, doncs, a mi... («La fe»). ${ }^{10}$

- Crec que ha arribat el moment de prendre una decisió.

- ¿Quina decisió?

- ¿No te la imagines?

- No tinc ganes d'endevinalles, Maria. («Quarts d'una»)

b) Expressió el-líptica o incompleta, com irònica, i que en general es pot comprendre com una negativa a establir la cooperació conversacional necessària, ja que l'interlocutor no fa la inferència adequada de les paraules de l'altre i, de fet, la rebutja. Es tracta d'un diàleg entre un marit i un amant de la seua dona que acudeix desesperadament al primer per demanar-li ajuda:

- No. El que passa és que no em deixa viure. Em truca de dia i de nit. I si no contesto ve a casa. I si no hi sóc em busca pertot. Em ve a veure a la feina, diu que no pot viure sense mi.

$-i$ ?

- He perdut la tranquil litat [...]. («Per què les busques...»)

Es pot entendre així la conversa entre una parella de personatges en el conte «Quarts d'una». En un moment determinat, l'home canvia de tema de sobte, transgredint la màxima conversacional de relació, i comença a parlar com si ho fes amb una altra persona, suposadament, perquè la seua dona no puga escoltar-lo. Ara bé, podria molt bé imaginar-se que l'home intenta dissuadir la dona de manera indirecta de continuar exposant-li els seus retrets insistents i induir-la a tancar la conversa.

c) La ironia:

- T'escopiré a la boca.

- Sí!

- I et bufetejaré la cara fins que te'n surti sang.

10. Cal observar en aquest exemple el paral-lelisme sintàctic, un recurs retòric basat en la repetició, usat per l'autor a fí de crear aquest efecte de reiteració i de cansament que provoca el discurs de les persones indecises i poc segures de si mateixes. 
- Sí, sí!

- I t'obligaré a...

- ¿A què? ¿A què?

- T'obligaré...

- ¿A què?

- Te n'ompliré la boca. I t'obligaré a empassar-t'ho tot: no en deixaràs caure ni una gota.

- Ni una. («Quarts d'una»)

\subsection{Procediments atenuadors}

Es tracta d'una sèrie de recursos usats per a compensar la possible agressió a la imatge negativa de l'interlocutor:

a) Desactualitzadors, que són partícules modals, temporals i personals que interposen distància entre el locutor i l'acte amenaçador: «Potser és que no m'estimes» («La fe»), «¿Ho dius de debò?» («La fe»)." També cal incloure-hi l'ús del condicional i del present d'indicatiu amb valor directiu (però menys agressiu que el mode imperatiu: «Jo hi pujo. Si vols, m'esperes aquí» («La immolació»). Una funció semblant té la perífrasi de probabilitat: «Tu deus voler entaular-te. ¿No t'estimes més que anem a un restaurant?» («Amb el cor a la mà»).

b) Desarmadors, és a dir, expressions que mostren que, d'entrada, es reconeix la possible resposta negativa, per assolir una reacció positiva: «Per això, tot i que sé que no hi tinc cap dret, vull demanar-li un favor $[\ldots] »(«$ Per què les busques...?»).

c) Lítotes: «Tu tampoc no ets la veritat personificada» («Quarts d'una»).

\subsection{Actes que amenacen la imatge}

Hi ha abundants exemples d'actes que amenacen la imatge positiva del destinatari, que tot seguit classifiquem:

a) Retrets:

- Em deceps.

- Et decebo? Poc m'estimes, si tan poca cosa fa que et decebi. («La fe»)

- Quina mania amb la cigala. ¿Que només li agrada la cigala, d'ell? I ell, ¿li agrada? No l'hi diu mai, que li agrada. («La gelosia»)

11. Subratllem aquests elements atenuadors. 
b) I a ironia:

- «¿Què vols que faci? ¿Que em mati per demostrar-t’ho?

- No siguis neiodranatic. No m'agnda gens aquest to» («La fe»).2

c) La burla il l'escarni:

- T'estimo. ¿M'escoltes bé? T'es ti mo.

- Oh, «t'estimo», «t'estimo»... És molt fàcil dir «t'estimo». («La fe»)

- Un bar, una cabina, tant se val.

- Oh, «tant se val», «tant se val»...

- Escolta: prou! («Quarts d'una»)

d) Refutacions:

- De seguida perds la paciència. Si de debò m'estimessis no la perdries tan fàcilment.

- Jo no perdo res. («La fe»)

e) L'insult o la desqualificació: «Ets una paparra» («La immolació»); «T'has tornai boig» («La gelosia»); «Perquè des de l'útitima regla només he estat amb tu, imbècil!» («Quarts d'una»).

f) Conéixer informació personal sobre un desconegut:

- ¿Quan la va conèixer?

- Fa un mes i mig. Vostè era a Roma.

$[\ldots]$

- ¿Com ho sap, vostè, que jo era a Roma? ( Per què les busques...)

g) Mostrar-se reiteratiu, pesat: ««M'agrada molt, la teva cigala.» «M'agrada molt, la teva cigala»...» ¿Per què sempre li diu el mateix?» («La gelosia»).

h) Interrompre la conversa: «Escolta: penjo. -Espera un moment.» («Quarts d'una»).

12. Pensem que la ironia té un ús ambivalent com a estratègia de cortesia encoberta i també com a acte que amenaça la imatge, és a dir, pot ser tant un recurs atenuant com una eina agressora. Com que es tracta d'un fenomen en què el parlant ataca sense responsabilitzar-se del que diu, deixa en dubte al receptor, quie segons els casos, reaccionarà ofenent-se o acceptant ta sanció expressada de manera indirecta. 
i) Les confessions:

- Abans he de dir-te una cosa.

- Digues.

- Estic embarassada. - Ell no respon. - ¿Que em sents? Estic embarassada. De tu. («Quarts d'una»)

j) Amenaces en sentit estricte: «T'inflaré els morros a cops de puny» («Quarts d'una»)

k) Ordres: «Prou. T'ho he de dir passi el que passi.» («Quarts d'una»)

\subsection{Actes que protegeixen la imatge pròpia}

Al marge d'aquests actes encaminats a respectar la imatge positiva i negativa del destinatari, com també amenaçar-la, hi ha altres estratègies o procediments que tenen la funció de salvar la imatge pròpia, és a dir, la del locutor. Brown i Levinson no inclouen aquest tipus d'accions, i cal no confondre-les amb el que anomenen actes de reforçament de la imatge com afalacs, lloances, defenses, agraïments, etc. En donem uns quants exemples:

a) Recalcar la llibertat d'actuació: «¿Potser et penses que si de debò hagués estat embarassada t'hauria demanat l'opinió sobre el que havia o no havia de fer?» («Quarts d'una»)

b) Recalcar l'estima per la imatge pròpia: «Saps que no tolero que em parlis així, en aquest to, ni que te'm toregis!» («Quarts d'una»); «T'estic dient la veritat» («Quarts d'una»)

c) Apel-lar a la necessitat imperiosa: «T'ho he de dir, Jaume. Si no, rebento» («Quarts d'una»).

\section{CONCLUSIONS: LA CORTESIA FUNCIONA COM A INSTRUMENT QUE FACILITA LES RELACIONS SENTIMENTALS?}

Hem comprovat que els personatges utilitzen tant estratègies de cortesia com actes amenaçadors i actes autoprotectors. La qüestió és: acompleixen l'objectiu de facilitar les relacions i la comprensió entre els personatges? Quant a «La fe», «Amb el cor a la mà» $\mathrm{i}$ «La gelosia», les parelles acaben separant-se; la comunicació, doncs, fracassa. En el cas de «Quarts d'una», «La immolació» $\mathrm{i}$ « Per què les busques...?», aparentment els personatges aconsegueixen els seus propòsits, però després que la dona canvie de personalitat 
Cent-se passar per la germana bessona (en el primer)," de cedir l'home als desitjos de la dona (en el segon) i d'un plantejament irònic mitjançant l'exageració del comportament cortés (en l'últim).

Les normes de cortesia, doncs, esdevenen inútils. La regulació de l'intercanvi, en el fons, s'ha d'adequar als interlocutors segons els seus interessos, estils conversacionals, expectatives, personalitat. Les normes han de ser específiques, almenys quan la relació és igualitària, no jeràrquica, entre els dos parlants. En el cas de les relacions desiguals, la cortesia constitueix una eina comunicativa ritual, però en el cas de les relacions personals intimes o familiars, el discurs estereotipat i tòpic que la catacteritza, resulta completament inoperatiu i, més aviat, contraproducnt.

A més a més, és molt important que els interlocutors adopten una actitud oberta i disposada a entendre's ja des del principi; la cortesia falla quan un dels dos vol imposar-se sobre l'altre o quan utilitza procediments que l'altre no comprén o que interpreta d'una altra forma. En efecte, com Deborah Tannen (1990) posa en relleu, els estils comunicatius de dones i homes en el si de la parella xoquen i provoquen el desacord, la frustració i la ruptura.

\section{RETERENCIES BIBLTOGRATETOUES}

Balaguer, E. (1997): «Quim Monzó i la societat postmodema. El perquè de tot plegat: un comentari de texts, Caplletra, 27: 81-90.

Brown, S. y Levinson, S. (1987): Politeness. Some Universals of Language Use, Cambridge, Cambridge University Press.

Calsamigla, H. i A. Tusón (1999): Las cosas del decir. Manual de análisis del discurso, Barcelona, Ariel.

Cercas, X. (1996): «Quim Monzó», dins Casacuberta, M. i M. Gustà (eds.) (1996): De Rusiñol a Monzó: humor i literatura, Barcelona, Publicacions de l'Abadia de Montsemat.

Charlon, A. (1998): «Olivetti, Kafka, Cortázar et Moulinex, ou les sources de Quim Monzó», Revue d'Études Catalanes, 1:71-78.

CuBELEs, S. (2001): «L'humor en els contes i novel-les de Quim Monzó: les seves conseqüències en l'acte de lectura», Transversal, 14: 40-46.

Escandell VidAL, M. V. (1996): Introducción a la pragmática, Barcelona, Ariel (edició de 2003)

Kerbrat-Orecchioni, C. (1996): La conversation, París, Seuil.

13. Per tant, li fa cteure a l'home que ha sigut doblement adúlier (amb la seia muller i amb la seua amant). 
LunATI, M.: «Quim Monzó i el cànon occidental: una lectura de «Pigmalió», Journal of Catalan Studies, http://www.fitz.cam.ac.uk/jocs/2/articles/lunati (7-4-2004).

Martí-OlivelLA, J. (1983): «Quim Monzó o la contraescriptura generacional», Actes del III Col-loqui d'Estudis Catalans a Nord-Amèrica, Barcelona, Publicacions de l'Abadia de Montserrat.

Monzó, Q. (1999): Vuitanta-sis contes, Barcelona, Quaderns Crema.

- (2003): El tema del tema, Barcelona, Quaderns Crema.

Ollé, M. (1998): «Quim Monzó: l'escriptor de més?», Revue d'Études Catalanes, 1: 47-55.

Payrató, L. (1988): Català col-loquial. Aspectes de l'ús corrent de la llengua catalana, València, Universitat de València ( $\mathrm{s}$ 'ha utilitzat la tercera edició de 1996).

PiQueR, E. (2003): «Quim Monzó: «El borreguisme cultural d'aquest país m'ha atribuït molts fills que no reconec», Avui, 3-12-2003.

SALVADOR, V. (2000): «Idiomaticitat i discurs prefabricat», dins SALVADOR, V. i A. PIQUER (2000): El discurs prefabricat. Estudis de fraseologia teòrica i aplicada, Castelló de la Plana, Publicacions de la Universitat Jaume I.

TANNEN, D. (1990): You just don't understand. Women and men in conversation, Nova York, Ballantine Books.

(1991): ¡Yo no quise decir eso! Cómo la manera de hablar facilita o dificulta nuestra relación con los demás, Barcelona, Paidós (traducció de That's not what I mean! How conversational style makes or breaks relationships, 1986). 


\title{
CORTESIA LINGÜÍSTICA I DEBAT ELECTORAL*
}

\author{
Maria Josep Marín Jordà \\ Universitat Politècnica de València
}

\section{INTRODUCCIÓ}

$\mathbf{E}$ L nostre treball analitza la funció dels marcadors discursius procedents de verbs de percepció en relació a la cortesia lingüística. L'estudi se centra en el debat electoral, gènere on el paper principal d'aquests elements consisteix a emfasitzar els actes amenaçadors d'imatge que introdueixen (Marín, 2003 b), de manera que posen de manifest el particular funcionament de la cortesia verbal en el discurs polític.

Ens situem, per tant, dins del marc teòric dels estudis sobre cortesia iniciats per Brown i Levinson $(1978,1987)$ i desenvolupats per autors com Chilton (1990) i Haverkate (1994). Així mateix, ens afegim a la perspectiva adoptada per diversos especialistes en marcadors discursius (Redeker, 1991; Brinton, 1996 o González, 2001) que relacionen el comportament pragmàtic d'aquests elements amb l'especificitat dels diversos gèneres textuals.

El corpus amb què hem treballat està format per quatre debats electorals en català, emesos per la Televisió de Catalunya, dos amb motiu d'eleccions autonòmiques (1992 i 1995) i els altres dos en un marc d'eleccions generals (1993 i 1996). Hi hem trobat un total de 212 marcadors procedents de verbs de percepció, concretament de les formes aviam, a veure, miri i escolti, de les quals gairebé el $65 \%$ han estat utilitzades per a introduir actes descortesos.

\section{ELS MARCADORS DISCURSIUS PROCEDENTS DE VERBS DE PERCEPCIÓ COM A INDICADORS DE LES RELACIONS DE CORTESIA}

A partir de la proposta de Brown i Levinson $(1978,1987)$, podem definir la cortesia com la codificació lingüística de les relacions que s'estableixen

\footnotetext{
Aquest article forma part de la investigació sobre construccions idiomàtiques en textos audiovisuals del grup IINK coordinat per la doctora Maria Josep Cuenca (Universitat de València). Així mateix, presenta, de manera molt sintètica, un dels temes desenvolupats en profunditat en la nostra tesi doctoral (Marín, 2003 a).
} 
entre els participants en un esdeveniment de parla. Des d'ayuesta perspectiva, els marcadors analitzats es caracteritzen, dins del debat electoral, per introduir actes amenaçadors d'imatge, els quals evidencien les relacions de poder que s'hi estableixen entre els parlants.

La idea d'imatge, que Brown i Levinson prenen de Goffman (1967), constitueix un dels conceptes bàsics dels estudis sobre cortesia lingüística i fa referència a la personalitat de l'ésser humà com a membre de la societat de la qual forma part. Així, la imatge de cada persona presenta una cara positiva i una cara negativa: la imatge positiva pot definir-se com el desig de cada individu que la imatge que té de si mateix siga reconeguda i aprovada per la resta de membres de la comunitat; la imatge negativa fa referència a la voluntat, generalitzada socialment, que les accions pròpies no siguen impedides pels altres.

En aquest sentit, en el nostre corpus, els marcadors procedents de verbs de percepció apareixen precedint actes amenaçadors de la imatge positiva de l'oient (1), actes amenaçadors de la imatge negativa de l'oient (2) i actes neutres des del punt de vista de la cortesia (3):

$<$ Rahola $>$... clar que no es fa cap mena de gràcia, el PP els resulta prunda_ profundament antipàtic com a partit per governar l'Estat. [(Pero, escolti'm, vostès governant han estat un desastre)],

$<$ Moderadora $>[$ (Senyora Rahola, acabi, sisplau)]

$<$ Rahola $>$... en clau catalana, un desastre (<pronúncia emfàtica $>$ ) en clau d'estat del benestar, un clesastre en racionalitat (<pronuncia emfàtica desastre racionalitat $>$ ), i, miri, també un_ un desastre en clau de corrupció. [EG96, $0: 41: 40]$

$<$ Espasa $>[($ No, no, no, si em sembla bé que hi hagi l'AVE. No critico ['AVE, critico la oportunitat)] del primer trajecte a fer $[\ldots]$

$<$ Borrell> [(Si vol parlem d'aquest tema)], si vol parlem d'aquest tema monogràficament. La millor explicació que hi ha sobre aquest tema l'ha donat un català, diguent que__ Miri, parli amb qualsevol enginyer ferroviari, amb qualsevol expert en transport, i li dirà que a l'any vuitanta-sis, vuitanta-set, vuitanta-vuit la inversió ferroviària prioritària a Espanya era Despeñaperros, cent vint per cent d'ocupació, tots els ports del sud passant per un coll de botella, no hi havia cap dubte que el tren que es tenia que fer era el Madrid-Sevilla. [(Com fer-lo?)]. [EG93, 0:13:44] 
$<$ Moderador $>$ Senyor Milián.

$<$ Milián> Aviam: nosaltres en aquest tema estem fent un plantejament crec que bastant novedós i nou ( ¿ZzZz?) per la política del Partit Popular. Es basa en dos principis fo_ bàsics: primer, el fet de que assumim completament l'administració única [...]; i segon, nosaltres no volem renunciar a lo que es va fer, jo crec que molt ben fet per part del Partit Popular i el Partit Socialista, i que va ser arribar a un, eh, a un acord autonòmic amb un principi de cooperació [...][EG93, 0:30:36]

Així, l'exemple (1) mostra com el marcador escolti introdueix una crítica que amenaça la imatge positiva de l'interlocutor i que s'accentua i amplia encara més amb l'aparició de miri i l'afirmació que el segueix. En contraposició amb aquests actes descortesos, en (2), miri encapçala una ordre, un acte de parla no necessàriament descortès, $i$, en conseqüència, molt menys agressiu. Finalment, aviam introdueix, en l'exemple (3), un acte neutre des del punt de vista de la cortesia, ja que, en principi, no comporta cap amenaça per a la imatge de l'oient.

Amb tot, els actes de parla que més sovint precedeixen els marcadors discursius procedents de verbs de percepció en el debat electoral són els actes amenaçadors de la imatge positiva de l'oient. Els resultats de la taula I ho indiquen de manera clara:

TAula 1. Funció dels marcadors com a indicadors de cortesiai ${ }^{1}$

\begin{tabular}{|l|c|c|c|c|c|}
\hline & AVIAM & A VEURE & MIRI & ESCOLTI & TOTAL \\
\hline $\begin{array}{l}\text { Introdueixen } \\
\text { AAI pos. 0 }\end{array}$ & $3(25 \%)$ & $9(37.5 \%)$ & $52(61.2 \%)$ & $71(78 \%)$ & $135(63.7 \%)$ \\
\hline $\begin{array}{l}\text { Introdueixen } \\
\text { AAI neg. 0 }\end{array}$ & - & $1(4.1 \%)$ & $7(8.2 \%)$ & $13(14.3 \%)$ & $21(9.9 \%)$ \\
\hline $\begin{array}{l}\text { Introdueixen } \\
\text { Actes neutres }\end{array}$ & $9(75 \%)$ & $13(54.1 \%)$ & $23(27 \%)$ & $7(7.7 \%)$ & $52(24.5 \%)$ \\
\hline Truncaments & - & $1(4.1 \%)$ & $3(3.5 \%)$ & - & $4(1.9 \%)$ \\
\hline $\begin{array}{l}\text { TOTAL per } \\
\text { marcadors }\end{array}$ & $\mathbf{1 2 ( 1 0 0 \% )}$ & $\mathbf{2 4}(100 \%)$ & $85(\mathbf{1 0 0} \%)$ & $91(100 \%)$ & $212(100 \%)$ \\
\hline
\end{tabular}

1 Hem inclòs també en la taula els casos que anomenem "truncaments", exemples del nostre corpus en els marcadors estudiats no introdueixen cap acte de parla, ja que es producix algun tipus de tall (interrupció, fals conençament...) en la intervenció del parlant que ho impedeix. 
Com podem observar, dels 212 marcadors analitzats, 135 , Es a dir, gairehé el $65 \%$, duen a terme la funció d'introduir actes amenaçadors de la imatge positiva de l'oient. Les altres dues funcions, introducció d'actes amenaçadors de la imatge negativa i introducció d'actes neutres, no poden comparar-se en importància a la primera i només la introducció d'actes neutres resulta comparativament remarcable.

Si ens fixem en els resultats per marcadors, apreciarem que són escolti i miri els més usats per a encapçalar actes amenaçadors de la imatge positiva, mentre que aviam i a veure vehiculen fonamentalment actes neutres.

\subsection{Introductors d'actes amenaçador's de la imatge positiva de l'oient}

Els actes que amenacen la imatge positiva de l'interlocutor, com a actes que atempten contra la imatge que cada individu té de si mateix i desitja que siga reconeguda socialment, són els actes de parla més agressius. Segons afirma Haverkate (1994: 78), es tracta d'actes decortesos que manifesten explicitament una actitud negativa del parlant cap a l'oient. En el nostre corpus, els actes descortesos introduïts pels marcadors analitzats s'han concretat en els següents: dissensió, interrupció, refutació, retret, crítica, acusació, insult, injúria i sarcasme. Tot i que en alguns casos els límits entre aquests tipus d'actes de parla poden resultar molt difusos, presentem alguns exemples d'aquells més rellevants quantitativament. Així, en (4) escolti'm introdueix una acusació:

$$
\begin{aligned}
& <\text { Rahola }>[. . .] \text { Han jugat més del compte! Escolti'm, aquí n'hi ha } \\
& \text { tres forces que n'hem parlat molt poc. Que, precisament, des de } \\
& \text { les diferents postures però des de una compromís democràtic } \\
& \text { profund hem jugat sempre per la unitat. En canvi, vostès, uns i } \\
& \text { altres, han frivolitzat en un tema gravíssim. I senyor Trias de Bes, } \\
& \text { vostè no s'ha llegit el Pacte d'Ajuria Enea: sortida dialogada, } \\
& \text { reinserció, unitat de plantejaments (<pronúncia emfâtica sortida } \\
& \text { plantejaments }>\text { ). Escolti'm, ho estant vulnerant tot, tot } \\
& \text { (<proníncia emfàticat }>\text { ), de manera que, com a mínim, mmm, que } \\
& \text { li passin el Pacte d'Ajuria Enea i el Pacte de Madrid i [(veurà fins } \\
& \text { a quin punt)] [pràcticament cridant Han punt]. [EG96, 1:33:31] }
\end{aligned}
$$

En l'exemple (5), miri s'utilitza per a vehicular una crítica:

$<$ Serra> En el senyo:r Molins li diré que ells volen ser la clau, però no saben (<pronúncia emfàtica però saben>) quina porta volen obrir, la del poder del PP, ja ho donen per fet. Miri, eh:, senyor Molins, quan es negocia rendir sense 
lluitar, el preu que és l'únic que estan pensant, quin seria el preu del suport, es negocia a la baixa. I., en el senyor Trias, a aquesta dreta que pot guanyar i que hem d'evitar (<èmfasi sil-làbic>) que guanyi el dia 3, li dic: com que no passarà res si vostè guanya? Com que no passarà res? (<pronúncia emfàtica>) Com no pot passar res si vostès posarien [(al govern persones com )] [EG96, 1:50:11]

En l'exemple (6), escolti, precedit de la conjunció però, dóna pas a una refutació:

$<$ Pujol> Pressupost de: del departament de medi ambient.

$<$ Vidal-Quadras> onze mil vuit-cents [(són les xifres que)]

$<$ Pujol> [(No, no, escolti, un moment, miri, doncs vostè) $]$ segurament l'han informat malament...

$<$ Vidal-Quadras $>$ Sí, sí.

$<$ Pujol $>$... la persona que l'ha ensenyat o vostè mateix no sap llegir el pressupost. Però escolti, les dades són clares, cinquanta-un mil milions de pessetes és el pressupost de medi ambient. Naturalment, després d'això, doncs no cal que li digui que també totes les dades que són com són de publicitat, són absolutament errònies [EA92, 0:50:50].

Finalment, en l'exemple (7), la moderadora introdueix una interrupció mitjançant el marcador a veure:

$<$ Colom> [...]qui a des_qui ha desmuntat més el territori no sé qui s'endurà la palma, eh?, [(si la variant de Girona o (¿zZZz)? )] [Tornen a parlar tots alhora i no s'entén el que diuen] $<$ Moderadora> [(A veure, sisplau, hauriem_ hauriem d'acabar ara)]. Eh, som_ som conscients que, de tenir més temps, seguirien parlant i seguiria havent-hi, eh, altres torns de rèplica per al-lusions perquè vostès, [(tots vostès hi estarien disposats.)] [EA95, 1:44:01]. 
TAULA 2. Tipus d'actes descortesos introduits pels matadors

\begin{tabular}{|l|c|c|c|c|c|}
\hline & AVIAM & A VEURE & MIRI & ESCOLT & $\begin{array}{c}\text { TOTAL } \\
\text { per marcador }\end{array}$ \\
\hline Dissensió & - & $1(0.7 \%)$ & $1(0.7 \%)$ & $3(2.2 \%)$ & $1(3 \%)$ \\
\hline Interrupció & - & $2(1.5 \%)$ & - & $7(5.2 \%)$ & $9(6.9 \%)$ \\
\hline Refutació & - & $3(2.2 \%)$ & $5(3.7 \%)$ & $22(16.3 \%)$ & $30(22.3 \%)$ \\
\hline Retrct & - & $1(0.7 \%)$ & $1(0.7 \%)$ & $2(1.5 \%)$ & $4(3 \%)$ \\
\hline Crítica & $2(1.5 \%)$ & - & $27(20 \%)$ & $14(10.4 \%)$ & $43(32 \%)$ \\
\hline Acusació & $1(0.7 \%)$ & $1(0.7 \%)$ & $14(10.4 \%)$ & $17(12.6 \%)$ & $33(24.6 \%)$ \\
\hline Insult & - & - & $2(1.5 \%)$ & $3(2.2 \%)$ & $\mathbf{5}(3.7 \%)$ \\
\hline Injúria & - & - & - & $2(1.5 \%)$ & $2(1.5 \%)$ \\
\hline Sarcarme & - & $1(0.7 \%)$ & $2(1.5 \%)$ & $1(0.7 \%)$ & $4(3 \%)$ \\
\hline SOLS & $2(1.5 \%)$ & $\mathbf{5 ( 3 . 7 \% )}$ & $41(30.3 \%)$ & $\mathbf{6 2 ( 4 5 . 9 \% )}$ & $110(81.5 \%)$ \\
\hline COMBINATS & $\mathbf{1 ( 0 . 7 \% )}$ & $\mathbf{4 ( 2 . 9 \% )}$ & $11(8.2 \%)$ & $9(6.6 \%)$ & $\mathbf{2 5}(18.5 \%)$ \\
\hline TOTAL & $\mathbf{3 ( 2 . 2 \% )}$ & $\mathbf{9 ( 6 . 6 \% )}$ & $\mathbf{5 2 ( 3 8 . 5 \% )}$ & $71(52.6 \%)$ & $135(100 \%)$ \\
\hline
\end{tabular}

Així, podem constatar que, entre els 135 actes descortesos, les critiques ocupen el primer lloc, 43 casos, corresponents al 32\%; a continuació, apareixen les acusacions, que atenyen el $24.6 \%$ del total, seguides de les refutacions, el $22.3 \%$. La resta d'actes amenaçadors de la imatge positiva de l'oient queden molt per sota d'aquestes xifres, i, en cap cas, superen el $7 \%$.

Per marcadors, el més especialitzat en aquesta funció és escolti, amb 71 ocurrències de les 135 , és a dir, més del $50 \%$. Així mateix, destaca miri, que cobreix el $38.5 \%$ dels casos. Precisament, aquests marcadors que, d'acord amb les dades que acabem de mostrar, transmeten major agressivitat són també els que apareixen amb més frequiència combinats. L'exemple (8) constitueix una mostra de la força que, en aquest sentit, pot vehicular la combinació dels elements analitzats:

$<$ Moderadora $>$ Té la paraula la senyora Rahola, [(que volia parlar també)].

$<$ Rahola $>$ [(Sí, el senyor Serra)], mm, mm. Sí, el senyor Serra diu que han muntat l'estat del benestar. Jo, més aviat, diria que déu n'hi do la feina que han fet per desballestar i per desmuntar l'estat del benestar. Miri escolti'm, senyor Serra, vostès tenen un frau absolutament descontrolat, primer punt. Que, per cert, jo recordo una frase del senyor Leguina que deia que hi havia 
mesures diferents de combatre els fraus segons les zones. [EG96, 0:20:50]

Observem ara el mateix exemple sense els marcadors que enquadren l'acte de parla que ve a continuació:

$$
\begin{aligned}
& <\text { Moderadora>Té la paraula la senyora Rahola, [(que volia } \\
& \text { parlar també)]. } \\
& <\text { Rahola> }[(\text { Sí, el senyor Serra)], mm, mm. Sí, el senyor Serra } \\
& \text { diu que han muntat l'estat del benestar. Jo, més aviat, diria que } \\
& \text { déu n'hi do la feina que han fet per desballestar i per desmuntar } \\
& \text { l'estat del benestar. } \emptyset \text { senyor Serra, vostès tenen un frau } \\
& \text { absolutament descontrolat, primer punt. Que, per cert, jo } \\
& \text { recordo una frase del senyor Leguina que deia que hi havia } \\
& \text { mesures diferents de combatre els fraus segons les zones. } \\
& \text { [EG96, 0:20:50] }
\end{aligned}
$$

En efecte, resulta fàcil constatar com l'èmfasi que aporta la presència d'aquestes unitats, major encara quan apareixen combinades, queda molt diluiit en desaparèixer:

\section{CORTESIA VERBAL I GÈNERES DISCURSIUS}

Acabem de veure la rellevància pragmàtica que els marcadors procedents de verbs de percepció assoleixen en el debat electoral, on destaquen per encapçalar actes descortesos que posen de manifest les relacions de poder entre els participants. Tanmateix, aquesta funció no pot desvincular-se del gènere en el qual els hem analitzat. De fet, el debat electoral és un debat no cooperatiu on els polítics no busquen arribar a cap consens, sinó mostrar superioritat sobre la resta de participants per tal de fer-se amb el vot dels ciutadans. En aquest sentit, l'expressió del desacord forma part de la convenció d'aquest gènere $\mathrm{i}$, fins i tot, hi esdevé fonamental, ja que mostrar enfrontament és part del compromís implícit per part dels participants (Marín, $2003 a$ : cap. 2). Aquest fet pot explicar també les diferències de funcionament, quant a cortesia verbal, entre el discurs polític, en general, i la conversa espontània, esdeveniment comunicatiu on la norma habitual és evitar el conflicte $\mathrm{i}$, en consequiència, qualsevol amenaça a la imatge de l'interlocutor.

Així, per una part, l'extensió de la teoria sobre cortesia lingüística als estudis del llenguatge polític, segons proposa Chilton (1990), permet observar la microestructura de la interacció verbal com a vehicle de les relacions de poder que s'hi estableixen. Per altra banda, l'anàlisi del paper concret i 
idiosincràtic descnvolupat pels marcadors discursius procedents de verbs de percepció en el debat electoral en relació a la cortesia, posa de manifest els lligams entre l'ús d'aquests elements i el gènere discursiu en què apareixen, en la línia d'investigació defensada per autors com Redeker (1991) o Brinton (1996) i, en el nostre àmbit lingüístic, González (2001) i Montolío i Unamuno (2001).

\section{CONCLUSIONS}

A mode die síntesi, podem afirmar que el nostre treball ha posat de manifest els punts següents:

a) La funció principal dels marcadors discursius procedents de verbs de percepció en el debat electoral pel que fa a la cortesia lingüística és precedir i emfasitzar actes de parla descortesos. Particularment, destaquen en la introducció de crítiques, acusacions i refutacions.

b) Entre els elements analitzats, aviam, a veure, miri i escolti, aquests darrers són els marcadors més destacats en aquesta funció. Aquest fet resulta lògic, si tenim en compte que són els marcadors que estan menys gramaticalitzats $i$, per tant, conserven més la força conativa que els vincula al seu origen com imperatius verbals. ${ }^{2}$

3) El comportament d'aquestes formes està directament relacionat amb el tipus de discurs en què apareixen, en aquest cas, el debat electoral. En aquest gènere, un debat no cooperatiu, els participants busquen marcar les diferències amb l'interlocutor i mostrar superioritat sobre l'adversari polític, de manera que els marcadors analitzats hi resulten ben efectius.

4) El marc de la cortesia lingüística resulta molt adequat per a abordar l'estudi del discurs polític i, més concretament, del debat electoral.

2. En efecte, els marcadors aviam (procedent de $a+$ veiam/vejam) i a veure (forma reduïda de anem a veure), fosilitzats en la primera persona del plural i procedents del verb de percepció passiva veure, presenten un grau menor de gramaticalització que miri i escolti, que, fixats en la segona persona discursiva per al tractament formal (tercera persona morfologica) i procedents dels verbs de percepció activa mirar i escoltar, manifesten major persistència del valor imperatiu que teníem com a verbs (Cuenca i Marín, 1998; Marín 2003 a: cap. 5). 


\section{REFERÈNCIES BIBLIOGRÀFIQUES}

Brinton, L. J. (1996): Pragmatics Markers in English. Gramaticalización and Discourse Function, Berlín / Nova York, Mouton de Gruyter.

Brown, P. i S. C. LeVInSon (1978): «Universals of language use: Politeness phenomena», Questions and Politeness. Strategies in Social Interaction, Cambridge, Cambridge University Press.

Brown, P. i S. C. Levinson (1987): Politeness. Some Universals of Language Use, Cambridge, Cambridge Univesity Press.

Chilton, P. (1990): «Politeness, politics and diplomacy», Discourse \& Society 1: 201-224.

CuEnCA, Ma J. i M ${ }^{\mathrm{a}}$ J. MARÍN (1998): «On the boundaries of grammar: linking words and grammaticalization theory», Proceedings of the XVIth International Congress of Linguists (París, 20-25 de juliol, 1997), Oxford, Pergamon, paper n. 0444, 444-457.

GonZÁlez CONDOM, M. (2001): Formal and Pragmatic Function of Discourse Markers in Oral Narratives: the Case of Catalan and English, tesi doctoral, Barcelona, Universitat Pompeu Fabra.

GofFMAN, E. (1967): Interaction Ritual, Nova York, Anchor.

HaVERKATE, HenK (1994): La cortesía verbal, Estudio pragmalingüístico. Madrid, Gredos.

MARÍN JORDÀ, Ma J. (2003 a): Discurs i gramaticalització: verbs de percepció usats com a marcadors discursius en el debat electoral, València, Servei de Publicacions de la Universitat de València, CD-Rom [http://www.tdx.cbuc.es].

- (2003 b): «El paper dels connectors en la construcció i l'anàlisi del debat», Llengua, Societat i ensenyament, Symposia philologica 7, Alacant, Institut Interuniversitari de Filologia Valenciana, 397-419.

Montolío, E. i V. UnAmuno (2001): «The discourse marker a ver (Catalan, a veure) in teacher-student interaction», Journal of Pragmatics, 33: 193-208.

REDEKER, GISELA (1991): «Linguistic markers of discourse structure», Linguistics, 29: 1139-1172. 


\title{
LA CONSTRUCCIÓN DE LA IDENTIDAD \\ Y LA EXPRESIÓN DE LA CORTESÍA / \\ DESCORTESÍA VERBAL EN LOS CHATS
}

\author{
LaUra Mariottini \\ Franca Orletti \\ Università degli Studi Roma Tre
}

\section{INTRODUCCIÓN}

T hipótesis inicial, que compone la base de este trabajo, es la de que el Unacimiento de las nuevas formas de socialización telemática permite que los usuarios aprovechen las características del sistema experimentando distintas formas de comunicación y dando lugar a relaciones sociales anteriormente imposibles. La ausencia de códigos sociales definidos, la escasez de normas de comportamiento codificadas, el anonimato de sus participantes transforman el espacio virtual en un terreno de juego de la identidad donde es posible experimentar distintos aspectos de la personalidad (Turkle, 1996). En el chat, el medio utilizado para construir su propia identidad, entrar en contacto con la ajena y crear relaciones sociales, es el lenguaje. En efecto, todo tipo de información se expresa por el lenguaje verbal.

\section{MARCO TEÓRICO-METODOLÓGICO}

El marco teórico del análisis consta de dos niveles: uno más lejano y general, que subyace al trabajo, y otro más cercano y específico, que constituye parte del foco del análisis. El primero es el de la identidad y pragmática. Spears y Lea en 1994 proponen el modelo sIDE (Social Identity \& DEindividuation); su objetivo es verificar la idea de que la CMC hace más débiles las disparidades de estatus y las relaciones de poder/superioridad entre los participantes, creando una mayor igualdad participativa. Según ellos, los aspectos limitativos del medio, disminuyendo la información social, aumentan el poder y la libertad expresiva de cada individuo. En particular, el ansia de valuación, el sentido de responsabilidad y de deferencia hacia los demás. Otros autores (Antaki, Widdicombe, 1998; Harré, 1987; Orletti, 2001, 2003) hablan de una construcción discursiva de la identidad según la cual a contextos textuales distintos corresponden distintas identidades. La matriz teórica que 
compone la base de estos estudios es la del constructivismo social, que, aun expresándose en una multitud de puntos de vista diferentes, mantiene fijos dos objetivos principales: por un lado critica la relación entre individuo y sociedad tal y como se entendía tradicionalmente en la sociología estructuralista, es decir, la idea de una estructura social existente y autónoma respecto al individuo que condiciona su comportamiento; por otro lado muestra que las identidades no son el reflejo de la estructura social, sino que se construyen a través de acciones sociales entre las cuales la interacción y el discurso tienen particular relieve. Este punto de vista es muy cercano al del análisis conversacional, que pone el mismo énfasis sobre el carácter construido, flexible y modificable de la identidad y que, ya desde las primeras clases de Sacks de los años sesenta, ponía en evidencia que las identidades de los participantes en la interacción emergen de manera natural, poco a poco, localmente, a medida que la conversación se desarrolle. Las identidades, entonces, no son el producto del macroorden social sino que se co-construyen durante el proceso de interacción entre todos los participantes.

Una visión estructuralista del lenguaje no parece ser suficiente para explicar su funcionamiento. El carácter comunicativo e interactivo hace necesario el estudio de las relaciones entre el lenguaje mismo y sus funciones pragmáticas y de construcción de la identidad. Desde este punto de vista podemos reunir unas cuantas acciones verbales dirigidas a la construcción de la iclentidad/imagen del ego y a la construcción de la identidad/imagen del alter. Una de estas acciones es la cortesía.

Los lingüistas no están de acuerdo sobre la definición de cortesía, hay quien pone el acento sobre la parte negativa, la atenuación de la amenaza:

«politeness, like formal diplomatic protocol presupposes that potential for aggression as it seeks to disarm it, and makes possible communication between potentially aggressive parties» (Brown, Levinson, 1987); «politeness can be defined as a mean of minimizing the risk of confrontation in discourse» (Lakoff, 1989) y quien pone el acento sobre la parte positiva, cortesía como mantenimiento del equilibrio social, colaboración: «I define linguistic politeness as the language usage associated with smooth communication» (Ide, 1989);

«the role of the politeness principle is to maintain the social equilibrium and the friendly relations which enable us to assume that our interlocutors are being cooperative in the first place» (Leech, 1983).

Calsamiglia y Tusón (1999) evidencian algunos aspectos de la cortesía lingüística:

a) se centra en el comportamiento verbal y en la elección de determinados indicadores lingüísticos, 
b) reconoce que la función interpersonal del lenguaje es la función en la que tiene fundamento cualquier comportamiento comunicativo,

c) sirve para facilitar las relaciones sociales y para atenuar la posible amenaza a la identidad ajena,

d) es un conjunto de estrategias que determina la elección de ciertas formas lingüísticas,

e) refleja las relaciones sociales existentes con respeto a poder/solidaridad, lejanía/cercanía...

f) es terreno de juego de la negociación.

Entre estos puntos, los más interesantes para nuestro análisis son los : a, c, d, e.

Las estrategias comunicativas que, según nosotras, merecen la pena ser analizadas en los chat, por lo menos por su frecuencia de uso, son los diminutivos. El marco teórico específico desde el cual hemos conducido el análisis es el de la morfopragmática.

La morfopragmática puede definirse como el área de la combinación de los significados pragmáticos con las reglas morfológicas, es decir el área en la que una regla morfológica produce regulares efectos pragmáticos. El objeto de estudio de la morfopragmática, definido por Dressler y Merlini (1994) son «(morphologically relevant) pragmatic conditions on linguistic rules».

Los objetivos son: verificar si los usuarios utilizan estrategias lingüísticas que pueden considerarse corteses; identificar cuáles son las estrategias más utilizadas; conducir un análisis comparativo entre los chat españoles e italianos para verificar si las mismas estrategias vienen empleadas en el mismo contexto comunicativo con las mismas funciones.

El corpus analizado consta de: 26.9 horas de grabación en canales públicos españoles y de 36.5 horas de conversación en canales públicos italianos por un total de unas 100.500 palabras, recogidas durante los meses de febrero y marzo de 2004 en horas distintas y casuales. He utilizado el método no participativo para garantizar la máxima objetividad en las interacciones.

Merece la pena, antes de presentar los datos, decir cuáles han sido hasta ahora las aplicaciones pragmáticas de los diminutivos, que Lázaro Mora (1999) resume muy bien:

la bibliografía sobre los diminutivos en el dominio románico proporciona soluciones muy diversas y aun opuestas sobre el valor de los diminutivos. En lo que concierne al español continúa siendo básico lo postulado por Alonso (1954). En este trabajo pone de relieve el carácter predominantemente afectivo del diminutivo, que destaca su objeto en el plano primero de la conciencia. Y esto se consigue no con la mera referencia al objeto, a su valor, sino con la representación afectivo-imaginativa del objeto. 
En nuestra opinion, el carácter pragmático de los diminutivos va más allá de la connotación estable de afectividad y emotividad. Además, las expresiones emotivas, afectivas y de valuación, siendo componentes subjetivos, no son suficientes para constituir, solas, una explicación sistemática y completa de la función pragmática de estos sufijos.

Dressler y Merlini (1994) introducen un carácter pragmático autónomo y específico de los diminutivos, el alopragma [no-serio], relacionado con el rasgo semántico [no-importante], variante de [pequeño].'

\section{ANA TSES DE DATOS}

En la presentación de los datos y de los resultados, focalizaremos nuestra atención en las situaciones comunicativas.

La primera situación es la del diminutivum puerile. Dressler y Merlini (1994) definen la child-centered speech situation como una situación en la que un niño participa como hablante, como oyente o, aún siendo ausente, como el objeto del discurso. El diminutivum puerile, sin embargo, puede ser empleado también por adultos para simular una situación de baby-talk o bien para crear un alto grado de familiaridad, cercanía y empatía con el interlocutor.

En los chat españoles el diminutivum puerile es empleado con una función principal: la función fática bien al principio, bien al final de la interacción para abrir y cerrar la misma. El diminutivo, como demuestran los ejemplos de la primera págína del handout, se añade al nick del receptor y también al saludo, fenómeno este que no hemos encontrado en el corpus italiano.

21. sirena_289: reholas salitaaaaaaaaaaaaaaaaa

43. poetisacarmen: sirenitaaaaaaลaaaaaaaaaaaaaลaa

49. bialyq: HOLA SURENTTAAAAAAAAAAAA

64. alaitzz2001: sirenita reholassssssssssssssssssssssssssssss

176. sirena 289: lobitoo000000000000

177. sabanitas_de_seda_2: lobitooo

524. baton_rojo35: saluditos rosa

1091. yoyo2102002: hola salita, como estan?????????

2792. aeropuerto_a: REHOLITAS SABANITA

3300. [[[[[SSPASH_MADRID]]]]]: sofipielcanelita

3301. osvaldo_rios 10: bravo00000000000000000

3302. [LL[L[SPLASH_MADRID]]]]]: jajajaja

3303. yemmita_11: BUSCANDOAMORRRRR

3304. osvaldo_rios 10: canta ensa

1. Véase Ricca (1998) para un análisis crítico de las posiciones de Dressler y Merlini (1994) 
3305. soffi_pielcanela: splash.....!!!!!!!!!!!!!!!!!!!!!

3306. [[[[[[SPLASH_MADRID]]]]]: sofipielcanelita

3692. kattleya13: Holitasssssss amiguitooooo

2865. cruzdelsur2001: reholas genteeeeeeeeeeeeeeee

2866. bialyq: HOLA CRUCITAAAAAAA

2867. cruzdelsur2001: muacceccecceccccc

2868. cruzdelsur2001: besitos

1277. petra_petrita34: Marioooo nachitooo psiisiiii chabelitaaa graweee

1779. dinira2552: bienvenida rosita

1780. el_cuervo_0000:

1781. dinira2552: a la salita familiar

5574. iirc_4: petris, bexitos de sabinao!!!!!!

5589. kattleya13: Brumitaaaaaaa besitossss

346. sabanitas_de_seda_2: adiosito amigaaa

1447. iirc_4: bueno familia, les deseo a todos felices sueños, yo voy a ver si los encuentro, hasta 1448. mañana querida familia,

1449. petra_petrita34: uyy pues cuando vengas, saludame ${ }_{i i i i}$

1450. elviejozorro65: hola todos

1451. petra_petrita34: ciaoo >nachitoo cuidate $i$ iiiii

2982. leoncillo 106: ADIOS SALITA

4086. yemm_11_cabecita_loca: SOLO LES VINE A DECIR BUENAS NOCHES...

4087. yemm_11_cabecita_loca: UN BESITO

4112. yemm_11_cabecita_loca: BESITOS

1199. graweber: chaucito leo,que descanses

Los chat españoles verifican lo que afirman Brown, Levinson (1987) sobre los diminutivos:

Diminutives may at large be seen as in-group identity markers that fall into the sphere of our notions of familiarity, intimacy, and decreased psychological distance. Besides being indices of social closeness, diminutives may also function as 'accelerators' of intimacy among strangers.

Distinto es el caso de la situación comunicativa que indicamos de loverstalk, conversación entre enamorados, en la cual ya existe cercanía y familiaridad entre los interlocutores. Las conversaciones entre enamorados incluyen también aquellas entre amigos muy próximos/cercanos en las cuales el diminutivo contribuye a la expresión del afecto. El diminutivo afectivo es empleado bien en los datos españoles, bien en los italianos. Veamos los ejemplos: 
3329. yemmita_11: DONDE ANDARAN SABANTAS Y AZAHAR

3330. osvaldo_rios 10;

3331. sotfi pielcanela: splash........... love you too !!!!!!!!!i!!!!!!!!!!

3332. [III[SPLASH_MADRID]]]]]: azaharrrrr esta con su precioso hijito

3333. [[[[[SPLASH_MADRID]]]]]! no me la molestennn

519. poetisacarmen: Rosita felicidades corazon, que es nuestro dia!!!!

4153. juliansara: DIJERON VACA Y LECHE Y ME DOLIERON!!!!!!!!!! YA SABEN QUE DE 4154. PENSAR EN LO QUE ME ESPERA

4155. tomb_raider_ookarol0o: en el rancho de mi abuelita

4156. pimienta0 15: tombbbbbbbbbbbbbbbbb

4157. tomb_raider_o0karol0o: siiiiiiiiiiii en tortillita con salsita

4313. splash__spain: pero saben todas las chicas de la salita que son para ellas

5345. vivir31: conejitaaaaaaaa

5350. el_yampirito desdentado: las tortuguitas karoline???

5362. vaquitarosa2000: mi reynita cantando

900. aylin_08_56: hola muchachito

4227. <SaSao 1> Ciao sorcini miei!

4853. <GaSpErO> AURORA^^^ bella soceretta mia :D

1348. <Cagnaccio> non trattateme male la mia sorellina!

3261. A AutanZ> $>$ andate piano che alla mia gattina fanno male gli okki

6676. <KikkinoRm> cerco amichette a roma max 23 anni........... sono bonazzo e simpatico

11344. $\langle\mathrm{PaVeL}\{11\}>$ allora siamo tre bei fratellini.

4864. $<$ AURORA $^{\wedge} \_\wedge$ ha detto Giusy chi era l'amora tua che ti mandava i bacetti a gas?

Ya con estos datos es evidente que la percepcion y el uso de las formas corteses no son los mismos en las dos lenguas y comunidades virtuales.

Vamos a ver ahora los datos relativos a las funciones pragmático-comunicativas de los diminutivos con relación al ataque o a la atenuación del ataque a la identidad ajena.

La primera función con la cual los usuarios utilizan frecuentemente los diminutivos es la irónica. La ironía, en los tratados tradicionales, ha sido considerada como figura retórica del discurso, que se caracteriza por ser básicamente una antífrasis, una inversión semántica. La ironía ha sido analizada también desde el punto de vista de la cortesía. Para Brown y Levinson (1987) la ironía permite la realización de un acto de amenaza a la identidad ajena de manera implícita; para Haverkate (1994) es un caso de violación de la máxima de calidad de Grice (1975). Interesante para nuestro análisis es la 
tesis de Noblia (2004) según la cual la ironía puede ser bien mitigadora, cuando el entorno comunicativo es colaborativo, o bien reforzadora, cuando el entorno es de conflicto. Los datos que hemos analizado, en los que nos focalizamos en la cortesía expresada por diminutivos, presentan resultados distintos según la lengua de comunicación, italiano o español.

La ironía puede expresarse en juegos de palabras:

3455. javi_er007: hola memmiita

3456. yemmita_11: HOLA NORBERT, JA JA JA

3457. [[[[[SPLASH_MADRID]]]]]: smuahhhhhhhhhhhhhhssss sofiiiiiiiiiiiii

3458. symbols_66: tu peux cliquer sur ma cam et me voir

3459. yemmita_11: MEMITA NOOOO JAVIER, YEMM

3460. soffi_pielcanela: splash .mi guapeton....!!!!!!!!!!!!!!!!

3461. symbols_66:

3462. javi_er007: 'por fin

3463. vaquitarosa2000:

3464. yemmita_11: SOY YEMMMMMMMM

3465. graweber:

441. yemmita_11: O YEMMITA PARA MIS AMORES

o, con respeto a la identidad, la ironía puede ser empleada como:

- autoironía, con la cual el hablante minimiza su personalidad, su identidad frente a la del interlocutor y el diminutivo añade significados de [noimportante], [no-serio]:

441. mirella_duenas: no soy salome pero me acerco poquito nadamas

2060. el_cuervo_0000: bueno no soy monedita de oro

2061. cordovafj: CORDOVAFJARROBA YAHOOPUNTO COM PUNTO AR

2062. lobo_herido35: JUANA LA CUBANA??????????????

2063. ivett09589: cuervito si sabemos que no es cierto

- el diminutivo puede ser utilizado en clave irónica también para añadir al objeto focalizado algunas características de su propia identidad, sea esta real o virtual:

1062. gato_leon: PUEDO SER UN AGATITO

1063. aylin_08_56: jajajale atine gatito

1064. gato_leon: INDEFENSO

1065. mar_brisa_sol_arena2003: HOLA ECUADOR

1066. ecuador07: del azuay 
1067. cristina hobbics: indefenso???

1068. gato_leon: O UN LEON QUE TODO SE LO COME

5223. el_vampirito_desdentado: me gusta tu cuello

5224. javier20031964:

5225. cristina_hobbies:

5226. Gabriel: cristinaaaaa

5227. el_vampirito_desdentado: tu cuello de gacelita

Finalmente, la ironía es estrategia con la que el hablante se dirige a un interlocutor o a una tercera persona, atenuando el ataque o la amenaza a su identidad:

3066. mr_cu_cu_taz: cogisteis las almohaditas?...

3067. amalisa3000: YO CREO QUE ES DE ULISES

3068. Mr_cu_cu_taz: a relajarse...

3069. sagrada mujer 2004: ES BELLA LA LETRA ME ENCANTAN SUS CANCIONES

3070. mr_cu_cu_taz: bravo uli

2216. soy_eva35: hay que dejar a la juna que aga su Iuchita

5491. cristina hobbies: ayy legolas.., te quedan tan lindos los rubiecitos

5996. <Sm3ralda a 36 anni hai il coraggio di chimati kikkino?

5997. <Sm3ralda> kikkone te dovevi chiamà!

6348. <Sm3ralda> diciamo che su queste cose ci arrivo sempre in ritardo

$[\ldots]$

6357. <Montecris> se se,povera imnocentina

5358. < Sm3ralda> è veroooooooooo000

4841. <AURORA^^^> sono cosi’ permalosi sti maschietti

8482. $<\mathrm{Sm} 3$ ralda $>$ i maschietti che ci provano sempre

De los ejemplos señalados, resulta evidente que la ironia se utiliza sobre todo para mitigar, atenuar una crítica o una amenaza. Esto nos lleva a considerar el Principio de Cortesía de Leech (1983): «if you cause offence, at least do so in a way which doesn't overtly conflict with the P(oliteness) $\mathrm{P}$ (rinciple), but allows the hearer to arrive at the offensive point of your remark indirectly, by way of implicature». La ironía es esencialmente colaborativa. Distinto es el caso del sarcasmo, este es un escarnio explícito, directo, que ridiculiza al destinatario, de hecho, el sarcasmo es estrategia conflictiva que introduce provocaciones, (ejemplos sarcásticos los hemos encontrado en el corpus italiano):

<salvia_> L4SH3R perchè non sei in lista? 
$<\mathrm{L} 4 \mathrm{SH} 3 \mathrm{R}>$ salvia in che senso non sono in lista

$[\ldots]$

364. <salvia > nell'elenco dei nick

$[\ldots]$

366. <salvia_> hai capito o ti faccio un faxino?

[...]

$<$ L4SH3R $>$ salvia ... ho capito grazie

4622. <Melissa75> ;) il giochino del bastone e della carota

4623. $<$ Alibi $\wedge \wedge \wedge>$ ok vi saluto

4624. <Wolf77 > bastone

4625. <Melissa75> è vecchio quasi quanto te

3704. <'Vipera`> fai lo spettacolino in cam?

Desde el punto de vista de la teoría de la cortesía, podemos definir el sarcasmo como mala educación irónica. Leech afirma «irony can be seen as mitigated rudeness in that it wraps an aggressive act in a non-confrontational form», mientras que el sarcasmo «does not keep aggression away from the brink of conflict» y en frases sarcásticas los diminutivos no tienen función atenuadora, más bien, representan una «strategic rudeness», con la cual se quiere añadir el significado pragmático de [no-serio] para enfatizar y entonces, aumentar, el grado sarcástico.

Por último consideremos el diminutivo utilizado en palabras que, aún no llegando a ser turpiloquio en algunos casos, constituyen una amenaza a la identidad ajena.

476. el_curita_con_tanga: joer gallina

477. el_curita_con_tanga: que dices?=-

478. el_curita_con_tanga: jajaja

479. el_curita_con_tanga: te salen estrellitas, de generala

729. el_curita_con_tanga: tu oso quieres tenerlas arriba y con minifalda,

730. el_curita_con_tanga: mironcillo

1156. tu_princesa(diana): uf aylin tu eres la mas viejita no avia visto esa edad

1157. yoyo2102002: waooooooooo que muchos años juntos

1158. aylin_08_56: si dianita

1349. petra_petrita34: pescador, tengo un gran problema... me vuelvo invisible

1350. petra_petrita34: graciasssss

1351. lucyjohanalopez: holaaaaaaaaaa

1352. estrellita1955; www.radioimagina.cl

1353. iirc_4: ok estrellita

1354. p_sisi_mx: chabela me mandaron unos videos de venezuela que hasta llore 
1355. pescador20012002: si???

1356. lucyjohanalopez: nadie quiere chat

1357. pescador20012002: pero si te leo

1358. CHABELA: petra mejor, asi nadic to ve cuando cngordes unos kilitos jajajajaaj

1359. lucyjohanalopez: soy nicaraguense

1360. petra_petrita34: okok, por ahora se me lee en la sala

1361. heydi20004:

1362. pescador20012002: si

1363. CHABELA: sis verdad?

1364. pescador20012002: que pasa

1365. P_sisi_mx: si chabela

1366. petra_petrita34: ayy chabelitaaa, pero a mi me gusta expresar mis sentimientos jajaajaja que 1367, poetica sali

1368. iirc_4: jajaj, petri, hace dias que se te aguanta la letrita, felicidades

1369. p_sisi_mx:

1370. CHABELA: si petrica es verdad

1526. baby_de_casal: zorrito y donde es la ciudad del carnaval

4167. juliansara: TE QUEREMOS COMO ESTES

4168. vaquitarosa2000: te compras y listo

4169. pimienta015: holamundo

4170. j_albertorm:

4171. juliansara: GORDITA MEJOR

3184. ysabel45: capullin te pisaron los callos.

357. poetisacarmen: sabanitas hoy tenemos que estrenar mudita.... 5207. vivir31: vaquita, trae lechita rosada

En los casos analizados, el diminutivo es empleado para modular, mantener el equilibrio interaccional y comunicativo entre los participantes.

\section{CONCLUSIONES}

Del análisis que hemos realizado se han evidenciado algunas características generales:

1) Los diminutivos son modificadores y moduladores de la dimensión estática de la conversación (la situación comunicativa). Se emplean para simular el discurso de los niños y/o de los enamorados (sin que los participantes deban de ser ni el uno ni el otro) con funciones colaborativas o provocativas: 
-con función colaborativa, llevando el significado [no-serio], atenúan la amenaza dirigida al destinatario; -con función provocativa aumentan, enfatizan la amenaza, llevando el mismo significado [no-serio].

Desde el punto de vista comparativo, señalamos una mayor frecuencia de uso de diminutivos en el chat español que en el italiano. Además, asistimos a una diferencia de uso: los usuarios españoles utilizan los diminutivos bien para empezar una interacción, para crear, construir proximidad y cercanía, o bien para subrayar esta misma cercanía entre dos interlocutores que tienen relaciones amistosas, etc. Los utentes italianos no utilizan los diminutivos para empezar la conversación; necesitan una familiaridad mayor, una cercanía comunicativa existente. Esto nos lleva a reflexionar, desde un punto de vista teórico, sobre la distinta percepción de proximidad que tienen dos culturas tan parecidas y sobre el hecho de que probablemente los interlocutores, en el empleo de las estrategias corteses, no buscan ser apreciados como sostienen Brown, Levinson (1987), sino que buscan la proximidad y la cercanía comunicativa (Koch, Oesterreicher 1990, 2000). Además, desde el punto de vista del análisis de la conversación se han evidenciado fenómenos interesantes que merecen ser profundizados en trabajos futuros: por ejemplo el uso en los chat españoles de diminutivos como fórmulas de rutina en los saludos, que nos gustaría estudiar en corpora de español oral para comparar los resultados obtenidos.

\section{REFERENCIAS BIBLIOGRÁFICAS}

Alonso, A. (1954): «Noción, emoción, acción y fantasía en los diminutivos», en Estudios lingüísticos, Temas españoles, Madrid, Gredos.

ANTAKi, C.; S. Widdicombe (eds.) (1998): Identities in Talk, Londres, Sage.

Bravo, D. (1999): «¿Imagen positiva vs. imagen negativa?, pragmática sociocultural y componentes de face», Oralia 2.

Bravo, D.; A. BRIZ (2004): Pragmática sociocultural: estudios sobre el discurso de cortesía en español, Barcelona, Ariel Lingüística.

Briz Gómez, A. (1998): El español coloquial en la conversación. Esbozo de pragmagramática, Barcelona, Ariel.

Brown, P.; DS. Levinson (1987): Politeness: Some Universals in Language Usage, Cambridge, Cambridge University Press.

CAFFI, C. (2001): La mitigazione, Münster, LIT.

Calsamiglia, H.; A. Tusón VAlls (1999): Las cosas del decir, Barcelona, Ariel.

Dressler, U.; L. Merlini (1994): Morphopragmatics. Diminutives and Intensifiers in Italian, German and Other Languages, Berlín-Nueva York, Mouton de Gruyter. 
Grice, P. (1975): «Logic and Cunversatiun», en Cole, P.; J. Mukrian (eds.) Syntax and Semantics, Nueva York, Academic Press.

HARRÉ, R. (1987): «The social construction of selves», en K. YARDLEY Y T. HONESS (eds.), Self and Idientity: Psychosocial perspectives, Nueva York, Wiley.

HAVERKATE, H.(1994); La cortesía verbal. Estudio pragmalingiístico, Madrid, Gredos.

IDE, S. (1989): «Formal forms and discernment: two neglected aspects of universals of linguistic politeness», Multilingua, 8 .

Koch, P.; W. Oesterreicher (1990): Gesprochene Sprache in der Romania:

Französisch, Italienisch, Spanisch, Tübingen, Niemeyer

- (2000): «Gesprochene Sprache und geschrlebene Sprache» in G. Houtus, M Metzeltin, C. SchimtT, Lexikon der Romanistischen Linguistik, Band 1, Tübingen, Niemeyer, 1-72

LAKOFF, G. (1989): «The limits of politeness; Therapeutic and courtroom discourse», Multilingua, 8.

LÁZARO Mora, F. (1999): «La derivación apreciativa», en BoSQue, I.; V. Demonte (eds.): Gramática descriptiva de la lengua española, Madrid, Espasa-Calpe.

LEECH, G. (1983): Principles of Pragmatics, Londres, Longman.

NobliA, M. V. (2004): «La ironía en los chats. Una forma de preservar las imagenes y administrar los conflictos en las conversaciones mediadas por computadoras», en Bravo, D.; A. BRIz GómEz, (eds.) (2004).

ORLETTI, F. (eds.) (1994): Fra conversazione e discorso, Roma, La Nuova Italia Scientifica.

- (2001): «The Conversational Construction of Social Identity in Native/Non-native Interaction», in Di Luzio, A.; S. GÜNTHNER, F. ORLETTI, (eds.): Culture in Communication, Amsterdam/Philadelphia, John Benjamins Publishing Company.

- (2003): «La costruzione conversazionale dell'identità sociale: disabilità in classe», Studi italiani di Linguistica Teorica e Applicata, XXXII, 3.

- (2004): «Aspetti linguistici, testuali ed interazionali delle conversazioni in rete» en Orlettri, F. (eds.) (2004).

- (2004): «Conversazioni in rete», en ORLETT, F. (eds.) (2004).

- (2004): Scrittura e nuovi media, Roma, Carocci.

RICCA, D. (1998): «Morphopragmatics. Diminutives and Intensifiers in Italian, German and Other Languages», Book Reviews/Journal of Pragmatics, 29. SACKS, H. (1992): Lectures on Conversation, G. Jefferson (eds.): Oxford, Blackwell. SpEARS, R.; M. LEA (1994): «Panacea or Panopticon? The hidden power in computer-mediated communication», Communication Research, 4: 21

TuRkLE, S. (1996): Life on the Screen: Identity in the Age of the Internet, Londres, Weidenfeld \& Nicolson.

Yus, F. (2001): Ciberpragmática, Barcelona, Ariel. 


\title{
HACIA UNA NUEVA DEFINICIÓN DE LA CORTESÍA
}

\author{
Manuel Padilla Cruz ${ }^{1}$ \\ Universidad de Sevilla
}

\section{INTRODUCCIÓN}

$\mathbf{E}$

L propósito de este trabajo es avanzar hacia una nueva definición de la cortesía, para lo cual estimo conveniente profundizar en su naturaleza cognitiva. Con esto no pretendo, en absoluto, proponer una definición única y definitiva de este fenómeno, pues éste se fundamenta y abarca una gran variedad de aspectos de la interacción social. No en vano, como Brown afirma, la cortesía «... es la manifestación más patente de la vida y de la interacción social de los individuos, el rasgo lingüístico que revela de la manera más clara la naturaleza de la sociabilidad humana» (2001: 1.620). Por tanto, tras revisar las diferentes concepciones de la misma que han ofrecido diversos autores, partiré de las definiciones propuestas por Bou Franch y Garcés Conejos (2003), Brown (2000) y Garcés Conejos (1995), así como del trabajo de Sperber (1997) sobre los diferentes tipos de creencias que conforman el conocimiento humano, para elaborar una propuesta sobre las estructuras de conocimiento sobre las que se sustenta la cortesía.

\section{ENFOQUES Y DEFINICIONES DE LA CORTESÍA}

Según autores como Eelen (2001: i), Escandell Vidal (1996 a: 136-137), Fraser (1990, 2002), Kasper (1998: 677) o Thomas (1995: 149), desde que el término cortés se afirmó en el inventario léxico, uno de sus significados más habituales ha sido el que alude a las maneras refinadas, a un comportamiento basado en el seguimiento de una serie de normas y convenciones sociales que cada grupo sociocultural establece para prescribir los comportamientos que se

1. Quisiera agradecer al Grupo de Investigación Estudios interculturales (inglés-español): aspectos pragmáticos y discursivos (PAI HUM 640) la financiación de este trabajo. Asimismo, agradezco también a varios de los asistentes al $I I$ Congreso Internacional de Lengua y Sociedad sus comentarios, preguntas y observaciones, que han repercutido notablemente en el resultado final del mismo. Obviamente, cualquier fallo o error son únicamente de mi propia responsabilidad. 
cspcran cn contextos deteminados, es decil, à las buenas muneras. Esta visión tradicional de la cortesía como norma social (Fraser, 1990), o cortesía 1, como la denomina Eelen (2001: 30), ha estado vinculada durante mucho tiempo al uso de ciertos registros o estilos linguísticos, to cual ha tenido como consecuencia que se estimara como cortés un comportamiento basado en la formalidad del lenguaje. Sin embargo, como Kasper (1998: 677) bien explica, el concepto de cortesía en pragmática no se debe aplicar exclusivamente al uso del lenguaje que hacen algunas clases sociales o algunas personas en contextos muy específicos, sino que se debe ampliar hasta incluir los comportamientos lingüísticos de cualquier individuo.

A raíz de la aparición de los trabajos de filósofos del lenguaje como Grice (1975) y Searle (1969), surgieron varios estudios que conciben la cortesía como la motivación principal que impulsa a los sujetos a comportarse lingiiísticamente de un modo concreto, profundizando en las causas de esa motivación e intentando ofrecer una visión científica del uso de la lengua, en la que prima su vertiente social e interactiva. Puesto que estos trabajos ofrecen una conceptualización y un análisis científicos muy distintos del fenómeno en cuestión, Eelen (2001: 30) emplea el término de cortesía 2 para referirse a ellos. No obstante, la mayoría de los lingüistas o pragmatistas que han tratado la cortesía de manera científica demuestran una gran confusión al hablar de ella.

Así, por ejemplo, varios autores procedentes de culturas orientales (Ide, 1982, 1989; Hill, Ide, Ikuta, Kawasaki, Ogino, 1986; Ide, Hori, Kawasaki, Ikuta, Haga, 1986; Matsumoto, 1989) la han asociado con la deferencia, es decir, con el respeto que algunos individuos muestran hacia otros debido a su estatus superior, a la diferencia de edad, etc., mediante numerosos recursos gramaticales, como, por ejemplo, las formas de tratamiento. En clara relación con esto se encuentra la visión de la cortesía que la asocia con el uso de ciertos registros lingüísticos, es decir, con las variaciones lingüísticas que los individuos Llevan a cabo en función de sus percepciones de la situación comunicativa en la que se ven inmersos (Smith, 1992). En otros trabajos la cortesía ha sido considerada como una propiedad inherente de los enunciados y actos de habla, por lo que se han analizado sus diversas realizaciones con la finalidad de establecer una jerarquía de actos más o menos corteses, comparando incluso sus codificaciones en dos o más lenguas para establecer correlaciones sistemáticas entre ellas (Ogino, 1986; Smith, 1992). Sin embargo, Brown y Levinson (1978, 1987), Fraser y Nolen (1981: 98) y Thomas (1995: 152-157) sostienen que la deferencia, el registro o ciertos actos de habla sólo despiertan el interés de la pragmática si su elección y uso se entienden como resultado de un comportamiento estratégico orientado a mantener o cambiar una situación o el estatus de los interlocutores. 
Por último, dentro de este conjunto de estudios que analizan la cortesía científicamente se encuentran los trabajos que la consideran como un fenómeno puramente pragmático por ser un comportamiento estratégico con el que los individuos intentan evitar el conflicto interpersonal (Kasper, 1990) o alcanzar una amplia gama de fines interactivos, entre los que se encuentran el establecimiento, mantenimiento, mejora, cambio o destrucción de sus relaciones sociales (Thomas, 1995: 157-158). Fraser $(1990,2002)$ distingue tres grupos dentro de estos estudios:

a) Las Reglas de Cortesía de Lakoff $(1973,1977)$ y el Principio de Cortesía de Leech (1983), cuyo punto de partida común es el Principio de Cooperación de Grice (1975), y en los que sus respectivos autores no ofrecen una definición exacta de lo que entienden por cortesía. A pesar de esto, se intuye que para Lakoff (1973: 297) la cortesía consiste en evitar la ofensa, mientras que para Leech (1983: 104) la cortesía es «... el vínculo necesario entre el "Principio de Cooperación" y el problema de cómo relacionar el sentido de un enunciado con su fuerza ilocutiva».

b) El modelo de Brown y Levinson $(1978,1987)$, para quienes la cortesía presupone un potencial de agresividad hacia la imagen de uno o más interlocutores, por lo que ésta consiste en reducirla, de manera que sea posible la comunicación entre dos partes potencialmente agresivas.

c) Los autores que relacionan el concepto de cortesía con el de adecuación o apropiación de un comportamiento a un contexto determinado, entre los que hay que mencionar a Escandell Vidal $(1996$ b , 1998), Fraser (1990, 2002), Fraser y Nolen (1981), Jary (1998 $a, 1998 b$ ), Meier (1995) o Zimmin (1981).

\section{LA CORTESÍA EN LOS MODELOS NUCLEARES}

En su amplia revisión de los distintos modelos de cortesía, Eelen (2001: 23) clasifica a los de Brown y Levinson $(1978,1987)$, Lakoff $(1973,1977)$ y Leech (1983) como nucleares debido a su gran influencia en la mayor parte de la investigación posterior sobre el tema. En este primer conjunto este autor incluye también otros seis estudios y modelos que representan las tendencias y elaboraciones más relevantes que se han desarrollado en este campo a partir de los tres modelos citados:

1. El modelo de Gu (1990), para quien la cortesía radica en la satisfacción de las expectativas de respeto, modestia o refinamiento de un grupo. 
2. El modelo de Ide $(1982,1989)$, en el que, como ya he mencionado, la cortesía tiene un carácter de discemimiento.

3. El estudio de Blum-Kulka (1992), fundamentado en el modelo de Brown y Levinson (1978, 1987), que matiza que las normas o los esquemas culturales de cada interlocutor determinan de manera crucial los factores que influyen en su comportamiento lingüístico.

4. El Contrato Conversacional de Fraser y Nolen (1981), a cuya visión de la cortesía también he aludido. ${ }^{2}$

5. El modelo de Arndt y Janney $(1985,1991)$, para quienes la cortesía consiste en cvitar el conflicto interpersonal mediante la expresión de mensajes con los que el emisor lo mucstra al receptor su apoyo interpersonal. ${ }^{3}$

6. El estudio de Watts (1989), en el que la cortesía es un comportamiento marcado y convencionalizado, responsable del buen funcionamiento de la interacción y la producción de un discurso bien formado dentro de grupos sociales abiertos caracterizados por la posesión de códigos lingiísticos elaborados. Este autor sostiene que la cortesía se contrapone al comportamiento político, un comportamiento no marcado cuya finalidad es el establecimiento o mantenimiento del equilibrio en las relaciones de los individuos de un mismo grupo (Watts, 1989: 135).

\section{LA CORTESÍA EN LOS MODELOS PERIFĹRICOS}

Además de este conjunto de teorías nucleares, existe otro de modelos que denomino periféricos (Padilla Cruz, 2004: 135), ya que su repercusión en los estudios sobre la cortesía ha sido menor. Entre ellos, Eelen (2001: 23-29) incluye los siguientes trabajos:

a) Ehlich (1992), para el que la cortesía consiste en la evaluación de los actos de los hablantes por parte de los oyentes o terceras personas a partir de un estándar de comportamiento socialmente aceptado, que cada individuo interioriza como consecuencia de su percepción de un Otro Generalizado.

b) Kasher (1986), que explica la cortesía mediante un principio de racionalidad, en virtud del cual un individuo escoge la acción que le

2. Para una crítica detallada de este modelo, consúltese Padilla Cruz (2004).

3. Estos autores parten de la distinción entre comunicación emocional, es decir, la expresión espontánea de la emoción, y comunicación emotiva, «... la modificación consciente y estratégica de las señales afectivas para influir el comportamiento de los otros $[\ldots]$ regulado por las sanciones sociales, las normas interactivas y las expectativas "sociales" que permiten a las personas controlar sus impulsos naturales» (Arndt y Janney, 1991: 529). 
permita alcanzar un fin determinado de la manera más efectiva y con el menor coste posible. Según este autor, cuanto más efectiva tenga que ser la acción del individuo, su realización le supondrá un mayor coste en términos de cortesía.

c) Meier (1995), que se fundamenta en el concepto de trabajo reparador, es decir, el esfuerzo que debe realizar un hablante para subsanar un comportamiento indebido.

d) Werkhofer (1992), para quien la cortesía motiva y estructura el comportamiento de cada individuo porque depende directamente de sus respectivos derechos y obligaciones, determinados por el orden social y su identidad.

En este segundo conjunto de modelos periféricos he incluido también el enfoque de Scollon y Scollon $(1983,1995)$, que parten del modelo de Brown y Levinson $(1978,1987)$ para desarrollar tres sistemas de cortesía que marcan las pautas interactivas. Pero, como hemos venido observando, resulta difícil llegar a una definición clara y plenamente satisfactoria de la cortesía por la disparidad de criterios. Por lo tanto, creo que es conveniente adoptar una que capture algunas de las contribuciones más interesantes que sobre ella se han hecho.

\section{UNA DEFINICIÓN DE LA CORTESÍA}

Siguiendo a Bou Franch y Garcés Conejos (2003) y Garcés Conejos (1995), podemos decir que la cortesía es la codificación linguística de la interacción social, es decir, la comunicación de información sobre la relación social existente entre los individuos que interactúan. Dicha codificación lingüística podrá tener como fin primordial evitar el conflicto interpersonal o salvaguardar la imagen de los participantes en un intercambio comunicativo, pero siempre se deberá entender como el resultado de un comportamiento racional en el que el hablante escoge la forma lingüística que mejor se adecue al contexto social en el que se encuentre. Como Brown (2000: 83) acertadamente añade, la cortesía consiste esencialmente en «... una forma especial de tratar a las personas, en decir y hacer las cosas de tal forma que se tengan en cuenta sus sentimientos». Asimismo, dicha codificación linguiística se deberá adecuar a los fines interactivos que el hablante persiga, entre los cuales se encontrarán el establecimiento, mantenimiento, mejora o deterioro de su relación social con sus semejantes.

Como Brown y Levinson $(1978,1987)$ proponen, los factores contextuales que influyen en dicha codificación de las relaciones sociales son el poder relativo de cada sujeto (P), la distancia social entre ellos (D) y el grado de 
imposición de los actos que se petendan llevar a cabo (I). A ellos hay que añadir, como proponen, por ejemplo, Garcés Conejos (1995) o Spencer-Oatey (2000), el afecto (A) que los interlocutores sienten. Por lo tanto, podemos concluir que ser cortés consistirá, en parte, en calcular eficazmente el peso y la influencia de estos factores contextuales en la interacción, de modo que el individuo pueda adecuar su comportamiento lingüístico a los valores de estos parámetros. En todo caso, cl uso y la manipulación que ese sujeto haga posteriormente de esta adecuación serán estratégicos. Partiendo del enfoque de Scollon y Scollon $(1983,1995)$, en un trabajo reciente sostengo que la cortesía estriba en adecuar el comportamiento a los sistemas de cortesía que los interlocutores deseen establecer, mantener o modificar (Padilla Cruz, 2004). ${ }^{4}$

No obstante, estimo que aún no se ha abordado con el suficiente detenimiento la naturaleza cognitiva de la cortesía, así como las consecuencias que esto tiene para la interacción social. Por esta razón, a continuación haré unas consideraciones adicionales acerca de ésta, que me llevarán a modificar ligeramente su definición.

\section{LA CORTESÍA Y LAS CREENCIAS}

Como se desprende de los trabajos expuestos, la cortesía se fundamenta en el conocimiento que los interlocutores poseen. De acuerdo con Sperber (1997), este conocimiento está almacenado en forma de representaciones y metarrepresentaciones en una especie de base de datos mental. Puesto que estas representaciones se refieren a estados de cosas de la realidad, son creencias a las que el individuo recurre en sus procesos inferenciales. Por tanto, es evidente que la cortesía se basa en las creencias de los individuos. Sperber (1997: 69) distingue dos tipos de creencias que, en mi opinión, pueden sernos bastante útiles para comprender mejor la naturaleza de la cortesía.

Por un lado, se encuentran las creencias intuitivas, es decir, aquéllas que un sujeto adquiere y almacena sin necesidad de una reflexión consciente acerca de cómo ha llegado a obtenerlas. Éstas se derivan de la percepción y/o de los procesos inferenciales. En la percepción, los mecanismos sensoriales tienen acceso a un repertorio conceptual muy amplio que proporciona al sujeto conceptos para los estímulos percibidos, aunque puede no existir un concepto específico para cada uno de los estímulos que el sujeto perciba. La consecuencia de esto es que el sujeto no comprende totalmente algunos de esos

4. Consúltesc Padilla Cruz (2004) para una modificación de los sistemas de cortesía iniciales de Scollon y Scollon $(1983,1995)$ en la que se incluye la variable A. 
estímulos o los conceptos que forma a partir de su percepción, por lo que puede pensar sobre ellos sin llegar a ser capaz de pensar con ellos (Sperber, 1997: 78). Por el contrario, en los procesos inferenciales la mente combina las creencias procedentes de la percepción con otras que tenga previamente almacenadas, lo cual resulta en la adquisición de nuevas creencias intuitivas. Algunas de ellas versan sobre cosas que el individuo no puede percibir, tales como las realidades abstractas. Los procesos inferenciales se alimentan también de un repertorio conceptual cuyo origen no es la percepción. Puesto que el individuo dispone de conceptos obtenidos de la percepción y de la inferencia, Sperber (1997: 80) defiende que las creencias intuitivas se sustentan sobre una serie de conceptos derivados de ambos procesos que denomina conceptos intuitivos.

De acuerdo con esto, creo que las metarrepresentaciones culturales sobre los distintos sistemas de cortesía en los que los individuos pueden interactuar, así como sobre las distintas maneras de comportarse verbalmente en ellos, constituyen un conjunto de creencias intuitivas muy importante para los miembros de un colectivo sociocultural. Éstos las adquieren como resultado de su crecimiento y experiencia vital dentro de dicho grupo, a cuyos comportamientos están expuestos (Janney y Arndt, 1992). Además, si consideramos que la cortesía es la codificación lingüística de la interacción social (Garcés Conejos, 1995), también pienso que se puede concluir que ésta se fundamenta en las creencias intuitivas sobre la interacción social que los individuos se forjen por sí mismos, así como que consiste en un proceso de transmisión y creación de creencias intuitivas relativas a las relaciones de los individuos y al comportamiento que se espera de ellos en ciertas situaciones comunicativas.

Dado su carácter de creencia intuitiva, se podría postular igualmente que la cortesía se sustenta sobre una serie de conceptos intuitivos de los que los individuos no tienen una comprensión completa. Así, por ejemplo, pienso que éstos podrán tener un concepto para el poder, otro para la distancia social u otro que equivalga a una noción de sistema de cortesía. En primera instancia, los individuos no los adquirirían como consecuencia de un proceso de enseñanza explícita, sino de modo inconsciente a partir de las inferencias que hagan en la interacción. Aunque sólo tengan esos conceptos de manera intuitiva, podrán realizar inferencias con ellos sobre los comportamientos verbales que perciban y evaluarlos. Esto supondría afirmar que los individuos obtendrían en un primer momento de manera inconsciente una información muy parca sobre la cortesía, con conceptos que no comprenderían bien o que no estarían bien desarrollados, pero que les permitirían tener una apreciación somera de lo que perciban.

Por otro lado, existe otro tipo de creencias que Sperber (1997: 71) llama reflexivas. Éstas surgen como consecuencia de la capacidad humana de 
mctarepresentarse otras creencias, gracias a la cual las creencids intuitivas pueden convertirse en reflexivas, obteniendo así los individuos un contexto de validación que les indica su grado de convicción acerca de las mismas. De todas fomas, los individuos pueden seguir careciendo de una comprensión exacta y precisa de los conceptos que compongan esas creencias intuitivas. Asimismo, Sperber (1997: 80) explica que también existen conceptos reflexivos introducidos mediante la enseñanza explícita, la instrucción o la comunicación, procesos que especifican su significado y las inferencias que se pueden realizar con ellos. Al igual que con las creencias reflexivas, los conceptos reflexivos se originan como resultado de las habilidades metarrepresentativas humanas. Además, estos conceptos se podrán convertir posteriormente en conceptos intuitivos, y los que un individuo posea de manera intuitiva se podrán tomar en reflexivos por la acción de la enseñanza o la comunicación.

De acuerdo con esto, en mi opinión, resulta evidente que un individuo puede llegar a adquirir una comprensión y un dominio adecuado de conceptos tales como los de cortesía, sistemas de cortesía, poder, distancia social, etc., que posea de forma intuitiva a través de la comunicación, la instrucción o la enseñanza explícita de los mismos por parte de sus semejantes. Pero, además, gracias a estos procesos el individuo podrá comprender y dominar esos conceptos aunque no los poseyera previamente de manera intuitiva, con lo que comprenderá mejor lo que ocura en la interacción. Asimismo, a medida que avance el tiempo, esos conceptos reflexivos sobre las relaciones sociales y la interacción podrán volverse intuitivos, ya que el individuo no necesitará pensar en ellos de manera consciente, sino que los podrá usar para hacer inferencias espontáneas y subconscientes.

Aunque he sugerido que la cortesía se basa en una serie de creencias intuitivas, también creo que esas creencias pueden ser reflexivas si los individuos se las metarrepresentan o si se las comunican o enseñan otros sujetos. Igualmente, la interacción o la instrucción explícita posibilitarán que cada sujeto conceptualice do manera reflexiva los conceptos intuitivos que posea. Por consiguiente, también considero que la cortesía se fundamenta en un conjunto de creencias y conceptos reflexivos que los individuos obtienen a partir de sus habilidades metarrepresentativas o de los procesos de instrucción explícita.

\section{CONCLUSIÓN}

En definitiva, creo que se puede definir ahora la cortesía como un proceso de transmisión y adquisición de una serie de creencias y conceptos, tanto intuitivos como reflexivos, referentes a las relaciones sociales que pueden mantener los individuos, así como a la adecuación de sus comportamientos 
verbales a las pautas que establecen sus metarrepresentaciones culturales. En este proceso, los individuos pueden partir de un conjunto de conceptos intuitivos o reflexivos que usarán para realizar inferencias cuyo resultado serán creencias intuitivas o reflexivas sobre los distintos sistemas de cortesía o la adecuación de sus comportamientos, según el caso. Si esos conceptos son intuitivos, se convertirán en reflexivos si hay una instrucción explícita sobre los mismos y/o si se los metarrepresentan. Lo mismo ocurrirá con las creencias intuitivas que posean. En última instancia, sus creencias y conceptos reflexivos podrán volverse intuitivos cuando los individuos no necesiten pensar en ellos para poder discernir sobre determinados aspectos de la realidad social en la que interactúen. Por tanto, opino que la cortesía radica en un proceso cognitivo en el que los individuos pasan de lo intuitivo a lo reflexivo, y/o de lo reflexivo a lo intuitivo. No obstante, como mencioné anteriormente, con este trabajo no he pretendido ofrecer una definición completa de la cortesía. Para llegar a ella habría que esclarecer también otras cuestiones relativas a su comunicación, si los individuos siempre la advierten o no, etc. Al hacerlo, seguramente tendremos una comprensión más exacta de un fenómeno lingüístico tan complejo.

\section{REFERENCIAS BIBLIOGRÁFICAS}

ARndT, H.; R. W. JANney (1985): «Politeness Revisited: Cross-Modal Supportive Strategies», International Review of Applied Linguistics in Language Teaching, 23: 281-300.

- (1991): «Verbal, Prosodic, and Kinesic Emotive Contrasts in Speech», Journal of Pragmatics, 15: 521-549.

BLUM-KULKA, S. (1992): «The Metapragmatics of Politeness in Israeli Society», en Watts, R. J.; S. IDE; K. EhLICh (eds.) (1992): Politeness in Language:

Studies in Its History, Theory and Practice, Berlin, Mouton de Gruyter.

Bou Franch, P.; P. Garcés Conejos (2003): «Teaching Linguistic Politeness:

A Methodological Approach», IRAL, 41: 1-22.

Brown, P. (2000): «How and Why Are Women More Polite: Some Evidence

from a Mayan Community», en COATES J. (ed.) (2000): Language and Gender. A Reader, Oxford, Blackwell.

- (2001): «Politeness and Language», en SMELSER, N. J.; P. B. BAltes (eds.) (2001): International Encyclopedia of the Social and Behavioral Sciences, Oxford, Elsevier Science.

Brown, P.; S. C. Levinson (1978): «Universals of Language Usage: Politeness Phenomena», en Goody, E. (ed.) (1978): Questions and Politeness, Cambridge, Cambridge University Press. 
- (1987): Politeness. Sonte Universals in Langatage Usage, Cambridge, Cambridge University Press.

EeLEn, G. (2001): A Critique of Politeness Theories, Manchester, St. Jerome Publishing.

EHLICH, K. (1992): «On the Historicity of Politeness», en WaTTS, R.; S. IDE; K. EHulch (eds.) (1992): Politeness in Language: Studies in its History, Theory and Practice, Berlín, Mouton de Gruyter.

Escandell Vidal, M. V. (1996 a): Introducción a la Pragmática, Barcelona, Ariel.

- (1996 b): "Towards a Cognitive Approach to Politeness», Language Sciences, 18: 629-650.

- (1998): «Politeness: A Relevant Issue for Relevance Theory», Revista Alicantina de Estudios Ingleses, 11: 45-57.

FrASER, B. (1990): «Perspectives on Politeness», Journal of Pragmatics, 14: $219-236$.

- (2002): «Whither Politeness?», Conferencia plenaria de los I Encuentros de Pragmática Intercultural, Cognitiva y Social (E.P.I.C.S. I), Universidad de Sevilla.

Fraser, B.; W. NOLeN (1981): «The association of Deference with Linguistic Form», International Joumal of the Sociology of Language, 27: 93-109.

Garcés Coneros, P. (1995): «Revisión crítica de algunos de los postulados de la teoría de la cortesía lingǘstica propugnada por Brown y Levinson», Quaderns de Filologia: Estudis Lingiiistics, 1: 43-61.

Grice, H. P. (1975): «Logic and conversation», en Cole, P.; J. Morgan (eds.) (1975): Syntax and Semantics. Vol. 3: Speech Acts, Nueva York, Academic Press, 41-59.

Gu, Y. (1990): «Politeness Phenomena in Modern Chinese», Journal of Pragmatics, 14: 237-257.

HILL, B.; S. IDE; S. IKUTA; A. KaWASAKI; T. OgINO (1986): «Universals of Linguistic Politeness. Quantitative Evidence from Japanese and American English», Journal of Pragmatics, 10: 347-371.

IDE, S. (1982): «Japanese Sociolinguistics Politeness and Women's Language», Lingua, 57: 357-385.

- (1989): «Formal Forms and Discernment: Two Neglected Aspects of Universals of Linguistic Politeness», Multilingua, 8: 223-248.

IDE, S.; M. HorI; A. KaWASAKI; S. IKUTA; H. HaGa (1986): «Sex Difference and Politeness in Japanese», International Journal of the Sociology of Language, 58: 25-36.

JANNEY, R. W.; H. ARNDT (1992): «Intracultural Tact versus Intercultural Tact», en WatTs, R. J.; S. IDE; K. EHLich (eds.) (1992): Politeness in Language. Studies in Its History, Theory and Practice, Berlín, Mouton de Gruyter. 
JARY, M. (1998 a): «Is Relevance Theory Asocial?», Revista Alicantina de Estudios Ingleses, 11: 157-169.

- (1998 b): «Relevance Theory and the Communication of Politeness», Journal of Pragmatics, 30: 1-19.

KASHER, A. (1986): «Politeness and Rationality», en Johansen, J. D.; H.

SONNE; H. HABERLANd (eds.) (1986): Pragmatics and Linguistics.

Festschrift for J.L. Mey, Odense, Odense University Press.

KASPER, G. (1990): «Linguistic Politeness: Current Research Issues», Journal of Pragmatics, 14: 193-218.

- (1998): «Politeness», en MEY, J. L. (ed.) (1998): Concise Encyclopaedia of Pragmatics, Oxford, Elsevier.

Lakoff, R. T. (1973): «The Logic of Politeness; or, Minding Your P's and q's», Papers from the Ninth Regional Meeting, Chicago, Chicago Linguistic Society.

- (1977): «What You Can Do with Words: Politeness, Pragmatics, and Performatives», en Rogers, A.; B. Wall; J. P. Murphy (eds.) (1977): Proceedings of the Texas Conference on Performatives, Presuppositions, and Implicatures, Arlington, Center for Applied Linguistics.

LEECH, G. (1983): Principles of Pragmatics, Londres, Longman.

Matsumoto, Y. (1989): «Politeness and Conversational Universals Observations from Japanese», Multilingua, 8: 207-221.

Meier, A. J. (1995): «Passages of Politeness», Journal of Pragmatics, 24: 381-392.

OGino, T. (1986): «Quantification of Politeness Based on the Usage Patterns of Honorific Expressions», International Journal of the Sociology of Language, 58: 37-58.

PADILla CRUZ, M. (2004): Aproximación pragmática a los enunciados fáticos: enfoque social y cognitivo, Universidad de Sevilla, Tesis Doctoral.

SCOLLON, R.; S. W. SCOLLON (1983): «Face in Interethnic Communication», en Richards, J. C.; R. W. Schmidt (eds.) (1983): Language and Communication, Londres, Longman.

- (1995): Intercultural Communication. A Discourse Approach, Cambridge, Blackwell.

Searle, J. (1969): Speech Acts: An Essay in the Philosophy of Language, Cambridge, Cambridge University Press.

SMiтh, J. S. (1992): «Women in Charge: Politeness and Directives in the Speech of Japanese Women», Language in Society, 21: 59-82.

SPENCER-OATEY, H. (2000): «Rapport Management: A Framework for Analysis», en SPENCER-OAteY, H. (ed.) (2000): Culturally Speaking. Managing Rapport through Talk across Cultures, Londres, Continuum. 
SPERBER, D. (1997): «Intuitive and Reflective Beliefs», Mind and Language, 12: 67-83.

Thomas, J. (1995): Meaning in Interaction: An Introduction to Pragmatics, Londres, Longman.

WATtS, R. J. (1989): «Relevance and Relational Work: Linguistic Politeness as Politic Behaviour», Multilingua, 8: 131-166.

WerkHOFER, K. T. (1992): «Traditional and Modern Views: the Social Constitution and the Power of Politeness», en WATTS, R.; S. IDE; K. EHLICH (eds.) (1992): Politeness in Language: Studies in its History, Theory and Practice, Berlín, Mouton de Gruyter.

Zimmin, S. (1981): «Sex and Puliteness: Factors in First and Second Language Use», International Journal of the Sociology of Language, 27:35-58. 


\title{
LA CORTESÍA VERBAL Y SU CORRELACIÓN CON LA IDENTIDAD ÉTNICA EN CONTEXTOS DE ETNIAS EN CONTACTO
}

\author{
Miguel Ángel Sarmiento Salinas \\ Universidad de Estocolmo
}

\begin{abstract}
A PARTIR de 1973, Suecia comienza a recibir a numerosos refugiados provenientes de Chile. Miles son los que emigran hacia un exilio forzado o voluntario. Este movimiento migratorio, como todos, trae consigo consecuencias tanto para el emigrante como para la comunidad que los acoge, y de lo cual quedará evidencia en la diaria interacción entre los grupos minoritario “y mayoritario,' y la lengua, por cierto, no queda ajena a estas circunstancias, como queda de manifiesto en los estudios de bilingüismo y lenguas en contacto. $\mathrm{Y}$ es precisamente éste el contexto sobre el que se desarrolla esta investigación doctoral, cuyas líneas generales y primeros resultaron se presentan en este documento.

Ahora bien, antes de avanzar en esta presentación, creo indispensable el que dedique algunas palabras a precisar lo que entenderemos, en nuestra investigación, respecto de algunos términos básicos que están presentes a lo largo de toda la misma.

Vamos a partir por el término «sueco». Para ello, habrá que distinguir entre un punto de vista ordinario y otro legal. Por el primero, entenderemos -en nuestro estudio- lo que perciben al respecto quienes integran los grupos mayoritario y minoritario, es decir, qué se requeriría, según ellos, para ser considerado «sueco». Por otra parte, desde una perspectiva legal, básicamente hay dos puntos de vista para resolver la situación. En cuanto a la adquisición automática de la nacionalidad, y desde el punto de vista de los chilenos, serán chilenos todos los nacidos en Chile, es decir, se aplica el
\end{abstract}

1. A este respecto, a partir del día 26 de octubre de 2004 , el periódico City, de Estocolmo, inició una serie de reportajes sobre los resultados de una investigación a cargo del doctor Dan-Olof Root (Institutionen för ekonomi/BBS, Högskolan Kalmar; Sweden), que se titula «Släpp in oss» (déjennos entrar), que trata, precisamente -entre otras formas de discriminación- de la que en el campo laboral son objeto los inmigrantes con estudios universitarios. 
principio de jus solis," que dice relación con el lugar de nacimiento. Creemos que esta idea se encontraría muy arraigada en la mente de los chilenos, y así se confirmaría a partir de los resultados de una de las 64 preguntas de la encuesta en que se funda esta investigación, donde una muestra de la población chilena residente en Suecia considera que, para ellos en particular ${ }^{3}$ y también para los chilenos en general, ${ }^{4}$ la circunstancia de «haber nacido en Chile» es la principal para considerar a una persona como chilena. Ahora bien, a partir de dicho conocimiento previo -concepto al que me referiré más adelante- pareciera razonable pensar que los chilenos supongan que dicho principio también se aplicaría al contexto sueco. Y así se confirma a partir de los resultados de la misma encuesta, donde la muestra considera que, para ellos, el hecho de «haber nacido en Suecia $»^{5}$ es un factor más importante que el «tener padres suecos» ${ }^{6}$ para ser considerado como sueco.' Sin embargo, la legislación sueca no ofrece apoyo a este supuesto, ya que en Suecia opera el principio jus sanguinis, ${ }^{3}$ que dice relación con la nacionalidad de los padres, condición que, al igual que la perspectiva legal de los chilenos, podría presumirse que se encuentra muy arraigada en la mente de los suecos.

Otro aspecto que tampoco se puede desconocer es el grado de heterogeneidad de lo que sería el estereotipo físico del chileno, fruto de la convivencia natural y

2. El artículo 10 de ha Constitución chilena de 1980 establece que son chilenos: «Los racidos en el territorio de Chile, con excepción de los hijos de extranjeros que se encuentren en Chile en servicio de su Gobierno, y de los hijos de extranjeros transeúntes, todos los que, sin embargo, podrán optar por la nacionalidad chilena; Los hijos de padre o madre chilenos nacidos en territorio extranjero, hallándose cualquiera de éstos en actual servicio de la República, quienes se considerarán para todos los efectos como nacidos en el territorio chileno; Los hijos de padre o madre chilenos, nacidos en territorio extranjero, por el solo hecho de avecindarse por más de un año en Chile».

3. Corresponde a la primera opción de la pregunta 39.

4. Corresponde a la primera opción de la pregunta 40.

5. Corresponde al texto de la primera opción de la pregunta 37 de la encuesta.

6. Corresponde al texto de la novena opción de la pregunta 37 de la encuesta.

7. Ei resultado de dichas preferencias fue, de mayor a menor, el siguiente: 1 . Estar integrado a la sociedad sueca; 2. Haber nacido en Suecia; 3. Tener padres suecos; 4. Querer Suecia y sus costumbres; 5 . Hablar perfecto sueco; 6 . Tener apariencia física de sueco; 7. Tener apellidos suecos; 8. Tener domicilio en Suecia; y 9. Tener pasaporte sueco.

8. La ley SFS 2001:82, del Ministerio de Justicia de Suecia, establece en su artículo primero que se adquiere la nacionalidad sueca por nacimiento si: 1) La madre es ciudadana sueca; 2) El padre es ciudadano sueco y el bebé nace en Suecia; 3) El padre es ciudadano sueco y casado con la madre del bebé; 4) El padre ha muerto, pero a su muerte era ciudadano sueco y el bebé nació en Suecia; y 5) El padre ha muerto, pero a su muerte era ciudadano sueco y casado con la madre del bebé. En el artículo segundo se agrega que el niño abandonado que sea encontrado en Suecia se refutará sueco hasta que se sepa otra cosa. (La traducción me pertenece.) 
los procesos inmigratorios, desde de la llegada de los españoles a América. ${ }^{9}$ La ausencia de circunstancias históricas similares, puede permitir presumir que algo semejante no tenga correspondencia en Suecia, donde prevalecería un estereotipo físicamente homogéneo. Cabe mencionar que la condición de «Tener apariencia física de sueco ${ }^{10}$ para ser considerado sueco, ocupa, para los encuestados, sólo la sexta posición, con un $7.2 \%$ de preferencias, en tanto que ellos perciben que, para los suecos, ocupa un quinto lugar con un $11.1 \%$ de preferencias.

Por otra parte, hay que tener presente que, de acuerdo a los resultados del mismo cuestionario, los encuestados no sólo se califican mayoritariamente como chilenos $(70.5 \%)$ sino que, además, perciben ser calificados como tales $(67.3 \%)$. Sólo el $1.9 \%$ y el $2.9 \%$ se califican como completamente suecos o perciben ser calificados como tales, respectivamente.

La pregunta, ahora, es qué características -de acuerdo a los encuestadosdebiera reunir una persona para ser considerada sueca. Las preguntas 37 y 38 de la encuesta pretenden dar información que permita responder esta interrogante. ${ }^{11}$ Se puede adelantar que, para los encuestados, los tres factores principales para que una persona sea considerada como sueca son: estar integrado a la sociedad sueca (20.6\%); haber nacido en Suecia (17.6\%) y tener padres suecos $(16 \%)$. Por otra parte, los encuestados perciben que los suecos estiman que tales factores son: hablar perfecto sueco (21.4\%); haber nacido en Suecia $(18.5 \%)$ y tener padres suecos $(14.4 \%)$.

Para cerrar este punto, vamos a confrontar estos datos con una pequeña anécdota. No hace mucho, recibimos en casa la visita de una pareja sueca. Avanzada la cena, estimé oportuno preguntarle al varón por cuáles creía él que eran las exigencias que hacían los suecos para considerar a una persona como sueca. Luego de pensarlo detenidamente, me respondió: «språk och utseende» (lengua y aspecto físico), haciendo presente que el «och» (y) era absolutamente copulativo. Para que una persona fuera considerada «sueca»-por los suecos- había que cumplir con ambos requisitos, no bastaba uno. Así, a la luz de la información estadística antes entregada, esta anécdota cobra interés, pues pareciera que aquella ofrecería evidencias para presumir que dicha percepción -la de un nativo sueco- ha sido, a su vez, percibida por los encuestados.

Por todo ello, vamos a permitirnos presumir que, cuando las personas del grupo minoritario objeto de estudio se refieran a los «suecos», estarán pensando

9. El 18 de noviembre de 1845 se promulga en Chile la «Ley de Colonización», que autorizó el establecimiento de colonias extranjeras al norte de Copiapó y al sur del Bío-Bío.

10. Corresponde a la opción 2 de la pregunta 37 y 38 de la encuesta.

11. Se hace elegir al encuestado, entre 9 opciones, tres de las que considere más importante para él (pregunta 37), y para los suecos (pregunta 38), para calificar a una persona como sueca. Para las opciones, ver nota 7. 
cn quicnes cumplan, a lo monos, con lats tres características que ellos percihen que los suecos exigen: hablar perfecto sueco, haber nacido en Suecia y tener padres suecos. Esto porque, a nuestro juicio, aún cuando los miembros del grupo minoritario cumpla con todas las condiciones que, según ellos mismos, son principales para ser considerados suecos, no podrán sino percibir, ante la carencia de uno o mas de los factores que percibe exige el grupo mayoritario, que en mayor o menor medida no pertenecen a éste. Esta afirmación se ve confirmada con los resultados de la encuesta aludida, donde sólo 2 personas de la muestra -vale decir el $1.9 \%$ de los encuestados- se califica como «completamente sueco», y cabe destacar que dicha percepción no corresponde a ningmo de los nacidos en Suecia. Dicho de otra forma, e1 $98.1 \%$ se califica cn algún grado como chileno. Esta información será considerada, en etapas posteriores de esta investigación, para el análisis de la influencia de la variable «estigma», entendida en los términos que lo hace Goffman (1972).

Delimitado lo que - a partir de la información proporcionada por los encuestados-se entenderá por «sueco» en nuestro trabajo, pasamos a precisar otros cuatro conceptos: sensación, percepción, actitud y conducta. Brevemente, la sensación es el proceso por el cual las neuronas receptoras sensoriales, por ejemplo las de la visión o el oído, detectan información y la transmiten al cerebro (Shaffer, 2000: 190). De una forma más estricta, también se define como: «Transduction of physical or chemical changes in the external or internal environment into nerve impulses by specialized receptors, transmission of these impulses by afferent neurons to the effectors, either directly or through the CNS» (MeSH, 2004). ${ }^{12}$

La percepción, por su parte, se refiere a un proceso que parte con un estímulo sensorial y que, por ejemplo, permite asociar un determinado olor con el pan fresco. Pero también se refiere a estímulos más complejos, como, por ejemplo, la interpretación de las conductas que una persona observa en terceros. ${ }^{13}$ Con mayor precisión, se define la percepción como: «The process by which the nature and meaning of sensory stimuli are recognized and interpreted» (MESH, 2004).

Llegamos así al tercer concepto, la actitud, que se define como: «An enduring, learned predisposition to behave in a consistent way toward a given class of objects, or a persistent mental and/or neural state of readiness to react to a certain class of objects, not as they are but as they are conceived to be»

12. MeSH, corresponde a la sigla de «Medical Subject Headings», diccionario utilizado por la NML (National Library of Medicine), con sede en el campus del «National Institutes of Health» en Bethesda, Maryland, Estados Unidos. Esta biblioteca es accesible online en: http://www.nlm.nih.gov/mesh/.

13. Con «terceros» me refiero a todos aquéllos que no son el propio sujoto que percibe, y con quienes éste interacciona. 
(MeSH, 2004). De esta definición hay que tener presente dos de sus componentes principales: primero, es aprendida y, segundo, no necesariamente corresponde a la realidad, sino que corresponde a lo que el sujeto concibe. Además, tratándose de una predisposición, no sólo hay que diferenciarla de la conducta, sino que, además, hay que considerar que, mientras no se manifieste en forma de conducta, de ella sólo puede saber el sujeto que la tiene. Por ello, pensamos que no es del todo exacto que se hable de «actitudes» de tal o cual persona o grupo, cuando en realidad se está pensando en determinadas conductas que hacen presumir una determinada actitud.

Finalmente, para completar este cuadro, se entenderá por conducta: «The observable response a person makes to any situation» (MESH, 2004).

De esta forma, las actitudes que una persona, con su conducta, revele hacia un sujeto, constituirán la información sensorial que ingresará, para su análisis, al cerebro de éste. Allí será interpretada, o percibida, en un sentido que dependerá en gran medida de la información previa que tenga sobre dicha información sensorial. Así, por ejemplo, un determinado gesto de la cara del interlocutor podrá interpretarse como un reproche, un desprecio, un halago y, en fin, de la forma que lo haya aprendido el respectivo receptor en su entorno cultural. Como fundamento de esta afirmación, tomamos la idea de que la cultura se aprende (Hofstede, 1991, Ember y Melvin, 2003:22).

Precisados estos conceptos, pasamos a las premisas principales, las que vamos a formular de la siguiente forma:

1. La percepción del rechazo -que creemos se presentaría como una respuesta a las conductas de discriminación por parte del grupo mayoritario- puede activar, en la persona que se siente rechazada, un mecanismo defensivo, uno de cuyos resultados comunes, en contextos de etnias en contacto, es la marginación. ${ }^{14}$

2. La marginación implica que la persona se mantiene firme en su propia cultura y lengua y rechaza la del país o región de acogida. Además, se resistirá a ser asimilado, y tenderá a relacionarse con otros miembros de su propio grupo étnico (Sánchez y Rodríguez, 1997:190). Para esta premisa, además, encontramos material de apoyo en nuestra encuesta, cuya pregunta 41 versa precisamente sobre las relaciones con uno u otro grupo étnico. E1 $72.8 \%$ responde que se junta, ${ }^{15}$ en distintos grados, más con latinos, en tanto que el $27.2 \%$ dice juntarse, en distintos grados, más con suecos. Se constata, además, que entre los nacidos en Suecia los

\footnotetext{
14. Ver nota 1.
}

15. En la pregunta de la encuesta se precisa que «con quien te juntas», expresión común en Chile, puede referirse a «te reúnes, te encuentras». 
rcsultados son aún más natualus: el $82.4 \%$ respononde que se junta, en distintos grados, más con latinos, en tanto que el $17.6 \%$ dice juntarse, en distintos grados, más con suecos.

Acercándonos a nuestro objeto de estudio, y volviendo a poner mi persona como testigo, desde mi llegada a Suecia pude observar que los suecos utilizaban casi con exclusividad la formula de tratamiento «du» (tú), lo cual no dejaba de ser - descle mi perspectiva de hablante chileno- una expresión chocante, particularmente cuando, por ejemplo, personas muy jóvenes trataban de «du» a damas de avanzada edad o al primer ministro sueco. Por otra parte, el uso de «ni» (usted), quedaba reservado casi por completo al lenguaje escrito.

Se puede suponer que al llegar a Suecia los chilenos nada sabían sobre las fórmulas de tratamiento suecas, menos aún de los vaivenes que habían sufrido a lo largo de la historia. Por dicha razón, no habría habido ninguna duda ni impedimento para traducir literalmente «ni obstante, esta traducción, si bien habría satisfecho una parcela de la competencia lingiiística sueca del chileno, mantiene -desde el punto de vista de la competencia comunicativa- ${ }^{16}$ una pugna con el sistema de fórmulas de tratamiento en Chile, que hasta hoy exigen, por ejemplo, el trato de «usted» cuando el hablante se dirige a una persona mayor. Respecto de esto último, en 2003 se realizó en Chile -en el marco de esta investigación- una encuesta para verificar dicho uso, obteniéndose un resultado afirmativo. Esto, a su vez, confirma el juicio formulado por Blas Arroyo (1995) quien, comentando la especulación sobre la hipotética muerte del pronombre usted, afirma: «... la realidad contemporánea muestra, a nuestro juicio, un panorama por lo general mucho menos desolador, que viene a demostrar la excelente salud de que todavía goza dicha forma de tratamiento entre los hispanohablantes».

Si bien, de acuerdo a lo generalmente observado, podría suponerse que -al dirigirse a los suecos- ios chilenos se acomodaron" al sistema sueco, generalizándose el uso de la fórmula de tratamiento «du» (tú), subsisten dudas como la siguiente: ¿Cómo tratar a los mayores, a la autoridad o a los desconocidos, si éstos son chilenos? ¿Qué sucedió en las interacciones, en general, entre los chilenos residentes en Suecia? ¿Se diferencia en dicho uso la actitud de los chilenos de primera y segunda generación? ${ }^{18}$ Lo que he podido observar es que,

16. A partir de la propuesta de Hymes $(1971,1972,1974)$, complementada por la propuesta de Canale y Merrill (1996) entenderé por competencia comunicativa la que incluye las competencias gramatical, cultural, sociolingüistica y de estrategias de comunicación.

17. Entenderé por acomodación en contex to de etnias en contacto, el proceso de adaptación que hace el hablante de una cultura en favor de los usos lingiústicos propios de los miembros de la otra cultura.

18. Entenderemos por chilenos de primera generación a los chilenos en Suecia que hayan nacido en Chile, y de segunda generación a los hijos de éstos que hayan nacido en Suecia o en Chile. 
aún después de muchos años de residencia en Suecia, muchos chilenos se abstienen de tratar de «tú» a una persona mayor o desconocida, cuando ésta es chilena. En este caso recurren al «usted». Tal vez todo hubiese parecido normal si ello hubiera sido propio sólo de las personas de la primera generación, que ya veníamos con nuestro sistema de tratamientos chilenos, pero lo mismo se podía observar en personas muy jóvenes, incluso en algunas que habían nacido en Suecia. La pregunta es, entonces: ¿por qué? ¿Qué es lo que induce a los inmigrantes chilenos y a sus hijos a mantener -en el caso de algunos $-^{19} \mathrm{o}$ recurrir -en el caso de otros ${ }^{-20}$ a un sistema de tratamientos que se encuentra en pugna, o no corresponde, con el sistema del país de acogida?

Así, y a partir de la observación antes descrita, surge la idea para esta investigación. Y respondida ya la pregunta sobre qué investigar, surge la segunda: ¿cómo realizar una investigación de tal naturaleza? Para responder a ello, tomamos como fuente de inspiración las palabras sobre la lengua de Coseriu (1986: 63): «... está íntimamente relacionada con la vida social, con la civilización, el arte, el desarrollo del pensamiento, la política, etc.; en una palabra, con toda la vida del hombre». A partir de esta idea, no es aventurado suponer que la lengua debiera constituir un material útil para estudios de distinta naturaleza, como, por ejemplo, en la lingüística, lo es para el análisis del discurso. Nuestro trabajo no contempla el análisis del discurso, sino que, a partir de la observación de una situación lingüística en un contexto determinado, pretende encontrar las probables causas que la motivan. Ahora bien, si se trata de un uso lingüístico en un contexto determinado -en este caso de etnias en contacto - y de sus probables causas, estamos por cierto abarcando muchas disciplinas. Y en la búsqueda del apoyo teórico acorde con dicha necesidad, creemos haberlo encontrado en la psico-sociolingüística, disciplina que ha sido el resultado de la integración de distintas tradiciones, tales como la psicología, la sociología y la lingüística (Azurmendi, 2000), todas ellas presentes en mayor o menor medida en la presente investigación.

En los primeros párrafos se habló de «conocimientos previos», que en nuestro trabajo es una idea central. Para precisarla, y en relación a lo que toca, en nuestro trabajo, a la cortesía verbal en general, y a las fórmulas de tratamiento en particular, recogeré de la Teoría de la Relevancia (Sperber y Wilson, 1986), dos de sus conceptos claves: contexto o entorno cognitivo y supuestos. El primero lo entenderemos como «el subconjunto particular de supuestos que el oyente utiliza para la interpretación de un determinado enunciado» (Escandell, 1998: 13), que también incluye el entorno físico inmediato o

19. Nos referimos particularmente a los chilenos de primera generación que llegaron ya adultos a Suecia.

20. Nos referimos particularmente a los hijos de chilenos que nacieron en Suecia. 
contexto físico (Montulíu, 1998: 98). El segundo, que correspon-de a lo que llamamos «conocimientos previos», lo entenderemos como las informaciones de todo tipo, tales como: las creencias, los conocimientos culturales, la competencia sociolingüística, la experiencia de la vida cotidiana, el conocimiento enciclopédico del mundo, los recuerdos personales (Montolío, 1998: 98) y también las emociones, aspecto este último que, según esta misma autora, habría sido relegado por la teoría de la relevancia. Resumiendo lo dicho, en los supuestos se incluye todo aquello que la persona ha aprendido a lo largo de su vida. Y en estos supuestos previos se incluyen la cultura y la etnicidad (Ember y Melvin 2003; Hofstede, 1991), componentes centrales de nuestra hipótesis, en cuanto integrantes de la identidad étnica. $\mathrm{Y}$, a nuestro entender, también forma parte de dichos supuestos o conocimientos previos la llamada cortesía verbal (Escandell, 1998).

De esta forma, en nuestra tesis doctoral nos proponemos demostrar la siguiente hipótesis: al interactuar con miembros de su mismo grupo étnico y en contextos de etnias en contacto -en este caso la chilena y la sueca- la actitud de las personas del grupo minoritario acerca del uso de la lengua de cortesía, en general, y de las formulas de tratamiento en particular, estará correlacionada con su índice de identidad étnica A su vez, la variación en el índice de identidad estará correlacionada con la percepción que las mismas personas tengan de ciertos factores que pueden aparecer, de ordinario, en contextos semejantes, como, por cjemplo, la discriminación.

Metodológicamente, se parte del antecedente de la existencia en Suecia de una población cercana a los 45.000 chilenos. El análisis se hará a partir de una encuesta de percepciones y actitudes aplicada a una muestra de 107 personas de dicha población, y se verificará estadísticamente la correlación entre la variable principal «identidad étnica»-medida de acuerdo a la propuesta de Isajiw (1990)-y las dos variables cuyas causas probables se buscan: la actitud -en la interacción con otros chilenos- frente al uso de la lengua de cortesía, en general, y la de la actitud hacia el uso de la fórmula de tratamiento «usted», en particular. Luego del análisis de las variables principales, se harán otros como, por ejemplo, entre la variable identidad étnica y los factores que pudieran influir sobre ella, siendo uno de ellos la percepción de una eventual discriminación o rechazo por parte del grupo mayoritario.

La encuesta referida se ha construido con un total de 64 preguntas, que tienen por objeto la auto evaluación de cada uno de los factores que, de acuerdo a nuestra hipótesis, suponemos tienen participación en la aparición del uso observado. Respecto de la identidad étnica, hemos tomado como referencia el trabajo dirigido por Bartolomé (2000), que estudia, a través de un análisis estadístico, la identidad étnica de inmigrantes jóvenes en España. Al cuestionario allí utilizado, le hemos agregado preguntas específicas que se 
refieren a la percepción y actitudes respecto de los factores que tendrían participación en la aparición del uso aludido.

Y como de búsqueda -en determinado contexto- de correlaciones e interacciones se trata, hemos creído necesaria la introducción de una metodología ad hoc, que, a su vez, será la que caracterice a la disciplina que introducimos aquí con el nombre de «etiolingüística», y de la que se dará cuenta en detalle en la tesis doctoral. Por de pronto, vamos a definir la etiolingiiústica a partir del término etiología, que se entiende, en filosofía, como el «Estudio de la causa de las cosas»y, en medicina, como el «Estudio de las causas de las enfermedades» (RAE, 1992). A partir de ello, definimos la etiolinguística como el estudio de las causas de los usos linguísticos atípicos. Por éstos, entenderemos aquellos usos que se diferencian de los que aparecen predominantemente en el contexto más amplio en el que surgen, como, por ejemplo, el trato de «usted» que algunos padres en Chile usan para dirigirse a sus hijos, donde lo predominante, en el contexto general o más amplio, sería el uso de «tú «; o, en contextos de lenguas en contacto, el uso de la formula de tratamiento «usted» por parte de los miembros del grupo minoritario, donde su equivalente textual «ni», en el contexto general del grupo mayoritario, no es el predominante. Asimismo, se recurrirá al método propio de la etiología, vale decir el que se basa en la interacción de los factores que integran la llamada triada ecológica: el «agente», el «huésped» y el «ambiente». El «agente» corresponde, en medicina, al conjunto de factores que están presentes en el medio ambiente y que pueden provocar enfermedades en el «huésped». En la etiolingüística, entenderemos por agente el conjunto de factores presentes en el contexto físico que pueden hacer aparecer en el huésped un uso lingüístico atípico. El huésped, en medicina, es un ser donde se hospeda o vive el agente; y por factores del huésped se entienden aquellos factores intrínsecos -como la edad, el sexo o el estilo de vida, por ejemplo- que influyen sobre la exposición, la susceptibilidad o la respuesta a los agentes en la producción de enfermedades. En etiolingüística, entenderemos por huésped, a la persona que es afectada por el agente; y por factores del huésped entenderemos aquellos factores intrínsecos que influyen sobre la aparición del uso lingüístico atípico, incluyendo entre aquellos los contenidos en el contexto cognitivo. Por medio ambiente, en medicina, se entiende el conjunto de factores extrínsecos que influyen sobre la existencia, la exposición y la susceptibilidad del agente en provocar enfermedades al huésped. En etiolingǘrstica, entenderemos por medio ambiente el contexto físico donde se produce el uso lingüístico atípico, que, en nuestro estudio, corresponde a un contexto de etnias en contacto. Por otra parte, en nuestro estudio, el agente presente en el ambiente está constituido, entre otros factores, por la discriminación y el rechazo por parte del grupo mayoritario, en tanto que la calidad de 
huésped la lendrá cada uno de los integrantes del grupo materia de estudio, vale decir, los chilenos de primera y segunda generación residentes en Suecia. También, entre los factores del huésped, estarán, entre otros, la identidad étnica, la edad, el sexo, el tiempo de residencia en Suecia y el grado de percepción del rechazo y la discriminación por parte del grupo mayoritario. La interacción de todos estos factores integrantes de la triada ecológica de nuestro estudio, provocaría la aparición del uso lingüístico atípico en estudio.

Aquí entregaremos los resultados del análisis estadístico acerca de la correlación principal, vale decir, del uso lingüístico atípico y la identidad étnica. Para ello, formulamos las siguiente pregunta: ¿Existe alguna correlción entre el grado de identidad étnica y la notitud fronto al uso de la coresía verbal, en general, y de la formula de tratamiento «usted», en particular? La hipótesis nula será que no existe ninguna correlación, la hipótesis alternativa será que sí existe tal correlación.

Para responder esta doble pregunta, habrá, primero, que determinar si existe alguna diferencia estadísticamente significativa en dicha actitud de los encuestados, al interactuar con chilenos y con suecos. Para ello, se aplico el test de «Wilcoxon Signed Rank Test» sobre la base de 97 encuestados. El resultado fue $z=2.91$, cifra que permite rechazar la hipótesis nula y, en consecuencia, afirmar que sí existe una actitud diferente, es decir, los encuestados muestran, en este caso, una actitud más positiva al uso de la cortesía verbal, en general, cuando interaccionan con miembros de su mismo grupo étnico que cuando lo hacen con suecos.

Constatada la diferencia de actitud, y mediante la prueba estadística ChiCuadrado, determinamos si hay o no correlación entre el factor identidad étnica y la actitud frente al uso de la cortesía verbal en general. El resultado de esta prueba fue Chi-Cuadrado $=39.832$, lo que permite, sobre la base de 97 encuestados y 24 grados de libertad (degrees of freedom), concluir que la distribución es significativa, vale decir se rechaza la hipótesis mula y se acepta la contraria: efectivamente existe una correlación o dependencia entre la identidad étnica y la actitud respecto de la lengua de cortesía en general, a un nivel de significación de 0,025 . Debemos tener presente, en todo caso, que esta prueba estadística sólo nos dice que existe una correlación o dependencia, pero no nos dice cómo es tal dependencia. Para responder a esto último, hacemos una prueba estadística de Coeficiente de Contingencia en base al resultado de Chi-Cuadrado, lo que nos entrega el resultado $\mathrm{C}=0.5396 . \mathrm{A}$ partir de éste, y luego de obtener el límite máximo de $\mathrm{C}$, que resultó ser $\mathrm{C}_{\max }=$ 0.866 , podemos concluir que las variables tienen una elevada relación.

La segunda prueba estadística la realizamos entre la variable identidad étnica y actitud frente al uso de la formula de tratamiento «usted», en particular. Para ello, se realiza la prueba de Chi-Cuadrado, lo que entregó -sobre la 
base de 86 encuestados y 15 grados de libertad- el siguiente resultado: ChiCuadrado $=27.035$. Esta cifra nos permite rechazar la hipótesis nula y aceptar la contraria: efectivamente existe relación entre el índice de identidad étnica y la actitud, en este caso favorable, al uso de la fórmula de tratamiento «usted», a un nivel de significación de 0.05 .

La conclusión parcial y provisoria es que, a partir de las pruebas estadísticas realizadas, podemos presumir que hay a lo menos un factor del huésped que tiene relación o dependencia con el uso linguístico atípico observado: la identidad étnica. Esta afirmación, por la naturaleza del método, es probabilística, vale decir: probablemente, en contextos de lenguas en contacto, las personas con un alto grado de identidad étnica en favor del grupo minoritario, tendrán una conducta más positiva en relación al uso de la cortesía verbal en general y a la fórmula de tratamiento «usted», en particular, cuando interaccionen con miembros que consideren pertenecen a su mismo grupo étnico, que la que tendrían al interaccionar con miembros del grupo mayoritario. En consecuencia -con baja probabilidad de incurrir en error alfa o de tipo I- se rechaza la hipótesis nula, planteada en términos de que no hay correlación entre las variables en comento. Por el contrario, aceptamos la hipótesis alternativa, vale decir, nuestra hipótesis de trabajo que afirma la existenicia de una correlación entre tales variables.

\section{REFERENCIAS BIBLIOGRÁFICAS}

Azurmendi, M. J. (2000): Psicosociolinguística, San Sebastián, Universidad del País Vasco.

BARTOLOMÉ, M. (2000): La construcción de la identidad en contextos multiculturales. Madrid, Ministerio de Educación, Cultura y Deporte de España. Secretaría General Técnica. Centro de Publicaciones.

Blas Arroyo, J. L. (1995): «Un ejercicio de sociolingüística interaccional: el caso de los pronombres de tratamiento en el español actual», Verba, 22: 229-252.

ButLer, C. (1985): Statistics in Linguistics, Oxford, Basil Blackwell.

Canale, M.; S. Merrill (1996): «Fundamentos teóricos de los enfoques comunicativos», Signos, 17: 56-61

Coseriu, E. (1986): Introducción a la lingüística, Madrid, Gredos.

EMber, C.; M. MElvin (2003): Antropología Cultural, Madrid, Prentice Hall, ESCANDELl VIDAL, M. V. (1993): Introducción a la pragmática, Barcelona, Universidad Nacional de Educación a distancia.

- (1998): «Cortesia y relevancia», en Haverkate, H ET AL. (EDS) (1998): La pragmática linguiística del español: Recientes desarrollos, Amsterdam, Rodopi.

GofFMAn, E. (1972): Stigma, Göteborg, Prisma 
IIYMES, D. II. (1971). «Competence and performance in linguistic theor y» tn HUXLEY, R. y E. INGRAM (EDS.) (1971): Language acquisition: Models and methods, Nueva York: Academic Press.

- (1972): «Models of the interaction of language and social life», en GUMPERZ, J. Y D. Hymes (EDS.): Directions in Sociolinguistics: The Ethnography of Communication, Nueva York: Holt, Rinehart and Winston.

- (1974). «Ways of speaking», en BAUMAN, R. Y SHERZER, J. (COMPS.): Exploration in the Ethnography of Speaking, Nueva York, Londres: Cambrigde University Press.

HOFSTEDE, G. (1991): Organisationer och kulturer, Lund, Studentliteratur.

ISAII, W. W. (1990): «Ethnic-Identity retention», en BRETON, R. ET AL. (EDS.) (1990): Ethnic identity and equality. Toronto, University of Toronto Press. Körner, S.; WaHlgren, L. (1998): Statistiska metoder. Lud. Studetliteratur. Körner, S.; Ek, LARs y Berg, Sven (1984): Deskriptiv statistik, Luna, Studentliteratur.

MESH. Medical Subject Headings. [En línea]. 2004. $<$ http://www.nlm.nih.gov/mesh/> [Consulta: 1 noviembre 2004]

Montolío Duran, E. (1998): «La teoría de la relevancia y el estudio de los marcadores discursivos», en MARTín Zorrapuno, M. A. A. Y E. MonTolío DURÁN (COORDS.): Los marcadores del discurso. Teoria y análisis, Madrid, ArCo/Libros.

REAl ACAdemia Española, (1992): Diccionario de la Lengua Española, Madrid, Espasa Calpe.

SANCHEz, M.; R. RODRíGUez (1997): El bilinguiismo. Bases para la intervención psicológica, Madrid, Síntesis.

SHAFfer, D. R. (2000): Psicología del desarrollo. Infancia y Adolescencia (5" Edición), México, Thomson.

SHÁFFER, D. (2002): Desarrollo Social y de la Personalidad, Madrid, Thomson. SPERBer, D. Y WILSon, D. (1986): La relevancia, Madrid, Visor. 


\section{SECCIÓN V \\ DISPONIBILIDAD LÉXICA}




\title{
PROYECTO DEL LÉXICO DISPONIBLE DE ESPAÑA
}

\author{
José Antonio Bartol Hernández \\ NaTividad Hernández MuÑoz \\ Universidad de Salamanca
}

\section{ESTADO DE LAS INVESTIGACIONES}

$\mathbf{E}$ $N_{N}$ los últimos años estamos asistiendo a un desarrollo sin precedentes en los estudios de disponibilidad léxica en nuestro país. El entusiasmo juvenil del introductor y mentor de estos estudios ha calado entre muchos de nosotros y los trabajos sobre distintas zonas geográficas se suceden año tras año. El programa informático Lexidisp -a pesar de sus limitaciones-, las reuniones de Bilbao y de San Millán, así como encuentros en diversos congresos como el de Castellón en 2004 han contribuido de forma decisiva también al avance del Proyecto panhispánico dirigido por el profesor Humberto López Morales.

La situación actual nos ofrece un panorama alentador. Contamos desde hace tiempo con datos de las Palmas de Gran Canaria (Samper Padilla y Hernández, 1995, 1997); se está trabajando en Tenerife (Nelsi Torres) y ya hay un equipo dirigido por José A. Samper que acometerá en breve las encuestas en el resto de las islas.

El estudio de Ceuta ya está acabado (Ayora Esteban, 2004) y se están haciendo las encuestas de Melilla (Gérard Fernández Smith y otros).

Las encuestas de Andalucía están prácticamente terminadas, algunas ya publicadas -Almería (Mateo, 1998), Cádiz (González, 2002), Córdoba (Bellón, 2003)--, en otras provincias las encuestas ya están realizadas -Huelva (Prado y Galloso, en prensa), Sevilla (González, 2002) - o en estado muy avanzado -Málaga (del Pozo), Jaén (Ahumada). Sólo está pendiente la provincia de Granada.

La investigación de Castilla La Mancha está concluida; los datos de Cuenca ya están publicados (Hernández Muñoz, 2004) y los del conjunto de la región aparecerán en unos meses.

La investigación de Alicante, por su parte, está también terminada (Martínez Olmos) y desde allí se acometerá la investigación de Murcia. También contamos con los datos de Valencia (Gómez Molina y Gómez Devís, 2004) y están a punto de aparecer los datos de Castellón (Casanova Ávalos). 
Se han iniciado los trahajos en Rarcelona (Rlasco Mateo) y en las Baleares, y están a punto de aparecer los datos referentes a Lérida (Serrano Zapata).

El léxico disponible de Aragón también está publicado (María Luisa Arnal, 2004).

Las investigaciones de Madrid fueron pioneras en Espana (Benítez, 1995) y ahora se está procediendo a la realización de las encuestas de toda la comunidad (Gómez Sánchez, Guerra Salas y Paredes García).

En Castilla y León los estudios empezaron en la década de los noventa a cargo del equipo dirigido por el profesor Julio Borrego y ya se han publicado los léxicos disponibles de las provincias de Ávila, Zamora y Salamanca (Galloso, 2002) y Soria (Banol, 2004). Sc han rolizado las cncucstas cn las provincias de León, Palencia, Burgos y Segovia y próximamente se realizarán las de Valladolid.

Desde hace años contamos también con los datos de Asturias (Carcedo, 2001) y de la ciudad de Bilbao (Etxeberría, 1999).

En una primera fase de elaboración están las encuestas de Cantabria (Carrera de la Red), de La Rioja (Balmaseda Maestu), Navarra (González Ruiz) y Extremadura (Prado y Galloso).

El panorama se completa con las gestiones que se están haciendo para la extensión del Proyecto a Galicia (tras el intento fallido anterior), a la Comunidad autónoma vasca y a las provincias catalanas de Gerona y de Tarragona.

Como vemos, estamos cada vez más cerca de la meta, que no es otra que el establecimiento del Léxico disponible de España, paso previo necesario para el establecimiento del Léxico disponible panhispánico con las aportaciones de los léxicos de los diferentes países hispanoamericanos.' Y esta cercanía debe ser un buen acicate para que todos renovemos el esfuerzo y acometamos cuanto antes los trabajos en las zonas que aún quedan pendientes.

Pero también es el momento oportuno de plantearnos ya la metodología que deberemos adoptar para que partiendo de los léxicos disponibles particulares de las diferentes regiones podamos llegar al establecimiento y análisis del léxico disponible del conjunto.

1. Ya están publicados léxicos disponibles de la República Dominicana (Alba, 1995) y de Puerto Rico (López Morales, 1999). En estos momentos se están realizando las encuestas de disponibilidad para el Proyecto panhispánico en Colombia (María Clara Henríquez Guarín y Álvaro William Santiago), Chile (Alba Valencia y Max Etxeverría), Provincia de Buenos Aires, Argentina (Ana María Saine), Uruguay (Carlos Jones), Costa Rica (Víctor Sánchez y Marielos Murillo) y La Habana, Cuba (Nuria Gregori Torada). También se han iniciado las encuestas en el Suroeste de los EE uU (Teresa Fernández Ulloa). 


\section{PROPUESTAS}

La primera opción es entender el léxico disponible de España como la suma de los léxicos disponibles de cada una de sus provincias o regiones. Para ello, tras la realización de las encuestas que faltan y la elaboración de los estudios correspondientes, deberemos plantearnos cómo sumamos los léxicos disponibles parciales. Podemos optar por tener en cuenta todos los vocablos o sólo los coincidentes o también podemos decidir poner un límite a las palabras de cada lista elegidas para la unión, siguiendo criterios como las 100 primeras palabras, o las que lleguen a un determinado porcentaje de frecuencia acumulada, o las que tengan un determinado índice de disponibilidad. ${ }^{2}$ En todos estos casos el resultado sería un listado de palabras más o menos extenso ordenado alfabéticamente y/o por nivel de convergencia, pero sin datos importantes como el nivel de disponibilidad real que cada una de las palabras tiene en el conjunto. A nuestro parecer esto último invalida la opción, pues aparte de esta desventaja, nos encontraríamos con problemas derivados de las diferencias de criterios -aunque pequeñas- en la edición de los materiales de las encuestas.

La propuesta que el Equipo de investigación de la Universidad de Salamanca plantea para su discusión entre los integrantes del Proyecto panhispánico es otra. También parte de la necesidad de acabar con la realización de las encuestas pendientes y también, como no podía ser menos, de la posibilidad de contar con los datos ya obtenidos en las diferentes investigaciones. Se plantea, pues, como una propuesta integradora para un proyecto de todos los equipos de investigación; un proyecto nuevo que debe tener un diseño propio y unas normas de edición de los materiales adecuadas, donde prime el criterio de la uniformidad sobre el criterio del mantenimiento de información que, con toda razón, sigue estando en la base de las investigaciones parciales.

Tiene la ventaja de que la ausencia de datos de una zona no detiene el proyecto, aunque sí lo puede ralentizar. Además cuenta con la ventaja de que, en nuestra opinión, es factible técnicamente y de que si todo el equipo de investigadores, dirigidos por Humberto López Morales, colaboramos, la podremos llevar a cabo en un plazo breve de tiempo.

2. Éstos son los tres tipos de criterios utilizados para limitar el número de palabras que se han de tener en cuenta en las comparaciones intersintópicas (entre otros Bellón, 2003). Los tres criterios han sido incluidos también como una nueva herramienta en el banco de datos de www.dispolex.com. 


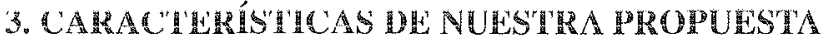

1) En el diseño de la muestra hemos tomado como unidad el centro escolar y no el alumno tras comprobar que las diferencias regionales no se alteraban significativamente. Además el partir del número de centros escolares que imparten bachillerato y no del número de alumnos que cursan $2^{\circ}$ de bachillerato o equivalente, favorece las zonas más deprimidas poblacionalmente-los centros rurales suelen poseer un menor número de alumnos-y en consecuencia el mayor reparto territorial de las encuestas.

2) Para hacer los cálculos hemos procedido por comunidades autónomas, teniendo en cuenta los datos que lós govienios de las mismas o el Ministerio de Educación español han publicado.

3) Fijamos, en un principio en 300 el número de centros en los que se harían las encuestas. Ese número - 300-supone un 7\% del total de centros que imparten bachillerato; y si se tienen en cuenta sólo 20 encuestas por centro educativo el número de alumnos encuestados (6.000) se acerca al $1 \%$ del total de alumnos que cursan $2^{\circ}$ de bachillerato o equivalente."

Tras los primeros tanteos decidimos, en aras a una mayor representación territorial en la muestra, asignarle un centro a Ceuta y otro a Melilla, así como que cada provincia estuviera representada al menos por dos centros educativos. Ello elevó el número inicial a 306.

CuAdRo 1. Distribución por comunidades y provincias

\begin{tabular}{|l|c|}
\hline Comunidades y Provincias & Centros \\
\hline ANDALUCÍA & 50 \\
\hline Almería & 3 \\
\hline Cádiz & 8 \\
\hline Córdoba & 5 \\
\hline Granada & 6 \\
\hline Huelva & 3 \\
\hline Jaén & 5 \\
\hline Málaga & 9 \\
\hline Sevilla & 11 \\
\hline ARAGÓN & 8 \\
\hline Huesca & 2 \\
\hline
\end{tabular}

\begin{tabular}{|l|c|}
\hline Comunidades y Provincias & Centros \\
\hline Teruel & 2 \\
\hline Zaragoza & 5 \\
\hline ASTURIAS & 7 \\
\hline BALEARES & 5 \\
\hline CANARIAS & 14 \\
\hline Las Palmas & 8 \\
\hline Tenerife & 6 \\
\hline CANTABRIA & 4 \\
\hline C. Y LEÓN & 25 \\
\hline Ávila & 2 \\
\hline Burgos & 4 \\
\hline
\end{tabular}

3. Esta cifra supera ampliamente la ratio de $0.025 \%$ establecida por Labov. 
CUADRO 1. Distribución por comunidades y provincias (Continuación)

\begin{tabular}{|l|c|}
\hline Comunidades y Provincias & Centros \\
\hline León & 4 \\
\hline Palencia & 2 \\
\hline Salamanca & 3 \\
\hline Segovia & 2 \\
\hline Soria & 2 \\
\hline Valladolid & 4 \\
\hline Zamora & 2 \\
\hline C. LA MANCHA & 15 \\
\hline Albacete & 3 \\
\hline Ciudad Real & 4 \\
\hline Cuenca & 2 \\
\hline Guadalajara & 2 \\
\hline Toledo & 4 \\
\hline CATALUÑA & 50 \\
\hline Barcelona & 36 \\
\hline Girona & 5 \\
\hline Lleida & 4 \\
\hline Tarragona & 5 \\
\hline C. VALENCIANA & 26 \\
\hline Alicante & 9 \\
\hline Castellón & 2 \\
\hline Valencia & 15 \\
\hline
\end{tabular}

\begin{tabular}{|l|c|}
\hline Comunidades y Provincias & Centros \\
\hline EXTREMADURA & 9 \\
\hline Badajoz & 6 \\
\hline Cáceres & 3 \\
\hline GALICIA & 21 \\
\hline La Coruña & 8 \\
\hline Lugo & 3 \\
\hline Orense & 3 \\
\hline Pontevedra & 7 \\
\hline MADRID & 40 \\
\hline MURCIA & 8 \\
\hline NAVARRA & 4 \\
\hline PAÍS VASCO & 15 \\
\hline Álava & 2 \\
\hline Guipúzcoa & 5 \\
\hline Vizcaya & 8 \\
\hline RIOJA & 2 \\
\hline Ceuta & 1 \\
\hline Melilla & 1 \\
\hline & $\mathbf{3 0 6}$ \\
\hline ESPAÑA \\
Total & \\
\hline
\end{tabular}

4) Las variables tenidas en cuenta en la elaboración de la muestra son dos: la variable titularidad del centro de estudios (pública/privada) y la variable ubicación del centro (urbana/ rural). En la primera la muestra proporcional nos da las cifras de 208 centros públicos y 98 centros privados, con porcentajes de $68 \%$ y $32 \%$ respectivamente. 


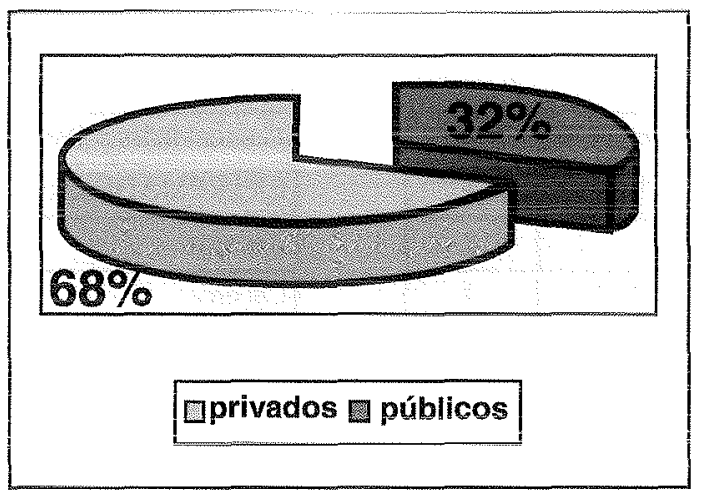

GrÁfICO 1. Distribución de la variable titularidad del centro

En el segundo caso (ubicación del centro) hemos tenido en cuenta la convención usada por el INE y así consideramos como zonas urbanas a las poblaciones de al menos 10.000 habitantes y zonas rurales a las de menos de 10.000 . Somos conscientes de que esta decisión plantea problemas importantes, pero nos ha parecido mejor que la de tomar en consideración la distinción capital de provincia (urbano), resto (rurai), que ya se ha mostrado inadecuada en algunas investigaciones hechas como, por citar sólo un ejemplo, la de Valencia (Gómez Molina y Gómez Devís, 2004). El resultado puede verse en el gráfico 2, donde se pone de manifiesto el predominio de los centros educativos ubicados en zonas urbanas, que responde también a la superioridad poblacional urbana.

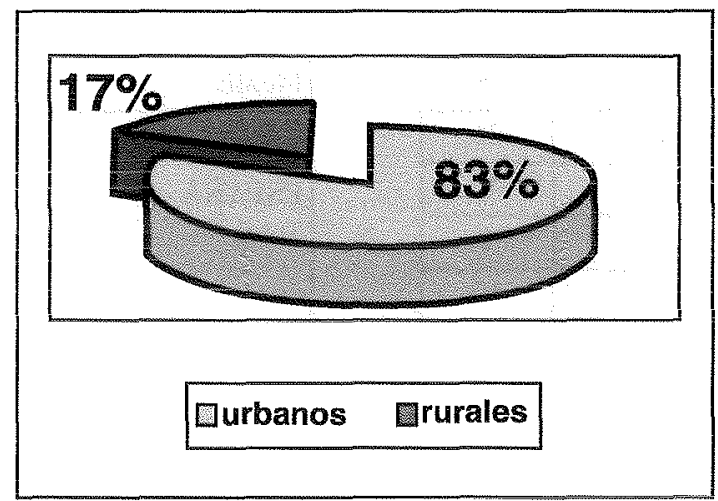

GrÁfICO 2. Distribución de la variable ubicación del centro

En el gráfico 3 hemos combinado las dos variables y asî podemos apreciar una clara gradación: centros públicos urbanos $(51 \%)$, centros privados urbanos (32\%), centros públicos rurales (16\%) y sólo un $1 \%$ de centros privados rurales. 


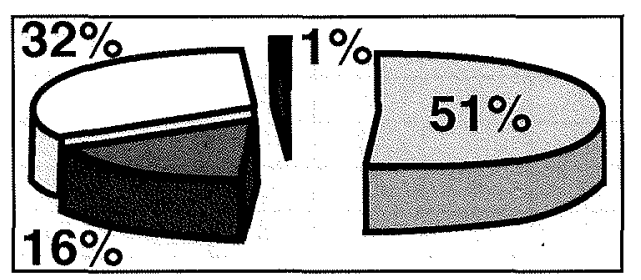

\section{Túblicos urbanos Públicos rurales QPrivados urbanos Privados rurales}

GrÁFICO 3. Combinación de las variables titularidad del centro y ubicación del centro

En el cuadro 2 se puede ver la distribución completa siguiendo los criterios establecidos:

CuADro 2. Distribución global de la muestra

\begin{tabular}{|l|c|c|c|c|c|c|c|c|}
\hline & Públicos & Privados & Urbanos & Rurales & $\begin{array}{c}\text { Públicos } \\
\text { urbanos }\end{array}$ & $\begin{array}{c}\text { uúblicos } \\
\text { rurales }\end{array}$ & $\begin{array}{c}\text { Privados } \\
\text { urbanos }\end{array}$ & $\begin{array}{c}\text { Privados } \\
\text { rurales }\end{array}$ \\
\hline ESPAÑA & 208 & 98 & 253 & 53 & 153 & 50 & 6 & 3 \\
\hline ANDALUCíA & 38 & 12 & 43 & 7 & 29 & 7 & 14 & 0 \\
\hline Almería & 3 & 0 & 2 & 1 & 1 & 1 & 1 & 0 \\
\hline Cádiz & 6 & 2 & 7 & 1 & 5 & 1 & 2 & 0 \\
\hline Córdoba & 4 & 1 & 4 & 1 & 3 & 1 & 1 & 0 \\
\hline Granada & 4 & 2 & 5 & 1 & 3 & 1 & 1 & 0 \\
\hline Huelva & 3 & 0 & 2 & 1 & 2 & 1 & 0 & 0 \\
\hline Jaén & 4 & 1 & 3 & 2 & 2 & 2 & 1 & 0 \\
\hline Málaga & 6 & 3 & 9 & 0 & 5 & 0 & 4 & 0 \\
\hline Sevilla & 8 & 3 & 11 & 0 & 8 & 0 & 3 & 0 \\
\hline ARAGÓN & 6 & 2 & 6 & 2 & 4 & 2 & 2 & 0 \\
\hline Huesca & 2 & 0 & 1 & 1 & 1 & 1 & 0 & 0 \\
\hline Teruel & 2 & 0 & 1 & 1 & 1 & 1 & 0 & 0 \\
\hline Zaragoza & 3 & 2 & 4 & 1 & 2 & 1 & 2 & 0 \\
\hline ASTURIAS & 5 & 2 & 6 & 1 & 4 & 1 & 2 & 0 \\
\hline BALEARES & 4 & 1 & 4 & 1 & 3 & 1 & 1 & 0 \\
\hline CANARIAS & 11 & 3 & 12 & 2 & 9 & 2 & 3 & 0 \\
\hline Las Palmas & 6 & 2 & 7 & 1 & 5 & 1 & 2 & 0 \\
\hline Tenerife & 5 & 1 & 5 & 1 & 4 & 1 & 1 & 0 \\
\hline
\end{tabular}




\begin{tabular}{|c|c|c|c|c|c|c|c|c|}
\hline & Públicos & Privados & Urbanos & Rurales & $\begin{array}{l}\text { Píblicos } \\
\text { urbanos }\end{array}$ & $\begin{array}{l}\text { Públicos } \\
\text { rurales }\end{array}$ & \begin{tabular}{|c|} 
Privados \\
urbanos
\end{tabular} & $\begin{array}{l}\text { Privados } \\
\text { rurales }\end{array}$ \\
\hline CANTABRIA & 3 & 1 & 3 & 1 & 2 & 1 & 1 & 0 \\
\hline C. YLEÓN & 18 & 7 & 17 & 8 & 11 & 8 & 6 & 0 \\
\hline Ávila & 2 & 0 & 1 & 1 & 1 & 1 & 0 & 0 \\
\hline Burgos & 2 & 2 & 4 & 0 & 2 & 0 & 2 & 0 \\
\hline León & 2 & 2 & 3 & 1 & 2 & 1 & 1 & 0 \\
\hline Palencia & 2 & 0 & 1 & l & 1 & 1 & 0 & 0 \\
\hline Salamanca & 2 & 1 & 2 & 1 & 1 & 1 & 1 & 0 \\
\hline Segovia & 2 & 0 & 1 & 1 & 1 & 1 & 0 & 0 \\
\hline Soria & 2 & 0 & 1 & 1 & 1 & I & 0 & 0 \\
\hline Valladolid & 2 & 2 & 3 & 1 & 1 & 1 & 2 & 0 \\
\hline Zamora & 2 & 0 & 1 & 1 & 1 & 1 & 0 & 0 \\
\hline C. LA MANCHA & 13 & 2 & 11 & 4 & 9 & 4 & 2 & 0 \\
\hline Albacete & 3 & 0 & 2 & 1 & 2 & 1 & 0 & 0 \\
\hline Ciudad Real & 4 & 0 & 3 & 1 & 3 & 1 & 0 & 0 \\
\hline Cienca & 2 & 0 & 1 & i & 1 & 1 & 0 & 0 \\
\hline Guadalajara & 1 & 1 & 2 & 0 & 1 & 0 & 1 & 0 \\
\hline Toledo & 3 & 1 & 3 & 1 & 2 & 1 & 1 & 0 \\
\hline CATALUÑA & 32 & 18 & 41 & 9 & 23 & 9 & 18 & 0 \\
\hline Barcelona & 21 & 15 & 32 & 4 & 17 & 4 & 15 & $\overline{0}$ \\
\hline Girona & 4 & 1 & 3 & 2 & 2 & 2 & 1 & 0 \\
\hline Lleida & 3 & 1 & 3 & 1 & 2 & 1 & 1 & 0 \\
\hline Tarragona & 4 & 1 & 3 & 2 & 2 & 2 & 1 & 0 \\
\hline C. VALENCIANA & 18 & 8 & 23 & 3 & 14 & 3 & 9 & 0 \\
\hline Alicante & 8 & 1 & 8 & 1 & 6 & 1 & 2 & 0 \\
\hline Castellón & 1 & 1 & 2 & 0 & 1 & 0 & I & 0 \\
\hline Valencia & 9 & 6 & 13 & 2 & 7 & 2 & 6 & 0 \\
\hline EXTREMADURA & 7 & 2 & 5 & 4 & $\overline{3}$ & 4 & 2 & 0 \\
\hline Badajoz & 5 & 1 & 3 & 3 & 2 & 3 & 1 & 0 \\
\hline Cáceres & 2 & 1 & 2 & 1 & 1 & 1 & 1 & 0 \\
\hline GALICIA & 16 & 5 & 17 & 4 & 11 & 4 & 6 & 0 \\
\hline La Coruña & 6 & 2 & 7 & 1 & 5 & l & 2 & 0 \\
\hline Lugo & 3 & 0 & 2 & 1 & 1 & 1 & 1 & 0 \\
\hline Orense & 2 & 1 & 2 & 1 & 1 & 1 & 1 & 0 \\
\hline Pontevedra & 5 & 2 & 76 & 1 & 4 & 1 & 2 & 0 \\
\hline
\end{tabular}




\begin{tabular}{|l|c|c|c|c|c|c|c|c|}
\hline & LA & Privados & Urbanos & Rurales & $\begin{array}{c}\text { Públicos } \\
\text { urbanos }\end{array}$ & $\begin{array}{c}\text { Públicos } \\
\text { rurales }\end{array}$ & $\begin{array}{c}\text { Privados } \\
\text { urbanos }\end{array}$ & $\begin{array}{c}\text { Privados } \\
\text { rurales }\end{array}$ \\
\hline MADRID & 19 & 21 & 38 & 2 & 18 & 1 & 20 & 1 \\
\hline MURCIA & 6 & 2 & 7 & 1 & 6 & 1 & 1 & 0 \\
\hline NAVARRA & 2 & 2 & 3 & 1 & 2 & 1 & 1 & 0 \\
\hline PAíS VASCO & 6 & 9 & 13 & 2 & 6 & 0 & 7 & 2 \\
\hline Á́lava & 1 & 1 & 2 & 0 & 1 & 0 & 1 & 0 \\
\hline Guipúzcoa & 2 & 3 & 4 & 1 & 2 & 0 & 2 & 1 \\
\hline Vizcaya & 3 & 5 & 7 & 1 & 3 & 0 & 4 & 1 \\
\hline LA RIOJA & 1 & 1 & 2 & 0 & 1 & 0 & 1 & 0 \\
\hline Ceuta & 1 & 0 & 1 & 0 & 1 & 0 & 0 & 0 \\
\hline Melilla & 1 & 0 & 1 & 0 & 1 & 0 & 0 & 0 \\
\hline
\end{tabular}

6) En el reparto de centros en cada una de las provincias o regiones se pretende que haya el máximo de representación territorial. Para ello se seguirán los criterios seguidos en las investigaciones ya realizadas.

Como ejemplo de la distribución territorial de una investigación no realizada proponemos el caso de Galicia. En esta comunidad, de acuerdo con los datos expuestos en el cuadro 2 y teniendo en cuenta el criterio de territorialidad, la distribución de los centros podría ser la siguiente:

A Galicia le corresponden 21 centros educativos repartidos proporcionalmente por las cuatro provincias de la siguiente manera:Coruña: 8; Lugo: 3; Orense: 3; Pontevedra: 7.

El reparto interno de cada una de las provincias debería ser similar al siguiente:

- Coruña: Cinco centros públicos urbanos: Coruña, Santiago, Ferrol, Noia y As Pontes de García Rodríguez

Un centro público rural: Melide

Dos centros privados urbanos: Coruña y Santiago

- Lugo: Un centro público urbano: Monforte de Lemos

Un centro público rural: Ribadeo,

Un centro privado urbano: Lugo

- Orense: Un centro público urbano: Verín

Un centro público rural: Viana do Bolo

Un centro privado urbano: Orense 
- Pontevedra. Cualio centros páblicos urbanos:

Vigo, Pontevedra, Villagarcía de Arosa y La Estrada.

Un centro público rural: Silleda

Dos centros privados urbanos: Vigo y Pontevedra.

El reparto geográfico puede verse en el mapa 1.

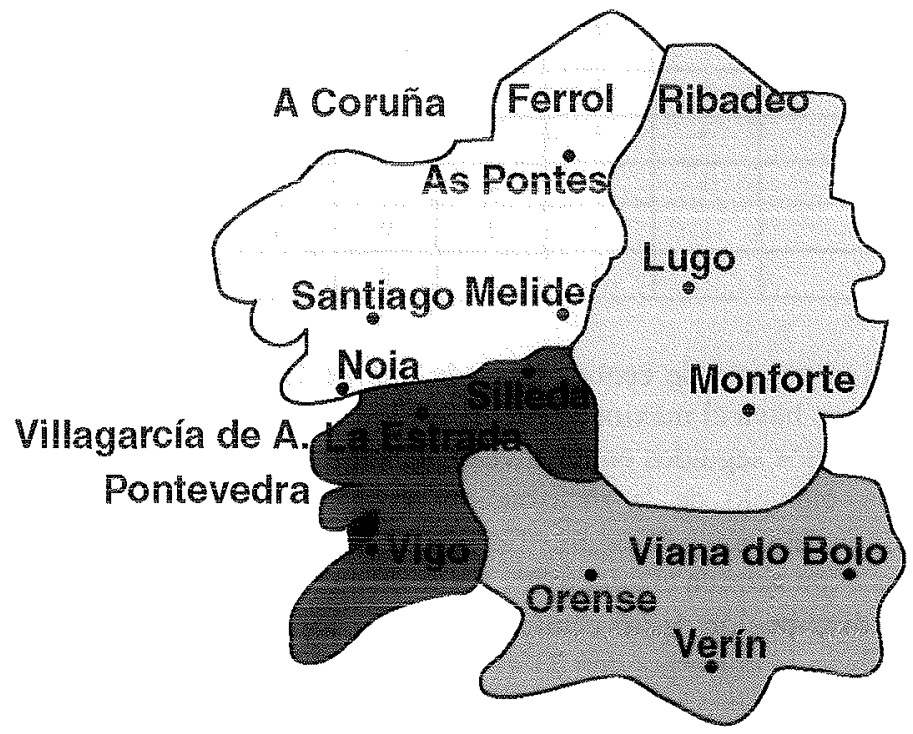

MAPA 1. Situación de los centros educativos gallegos

7) En las encuestas se tendrán además en cuenta, como es norma del Proyecto panhispánico, las variables de los informantes: sexo, residencia de los padres y nivel sociocultural. Estas variables, como se ha hecho en las encuestas anteriores del proyecto, no han sido preestratificadas, responden a las características de los conjuntos poblacionales seleccionados.

\section{CONCLUUSIÓN FINAL}

Como ya hemos señalado, el proyecto que ahora presentamos tiene el doble objetivo de abrir la discusión sobre un tema que deberemos abordar próximamente y hacer una primera propuesta sobre el mismo.

Debe entenderse, además, como el proyecto de todo el grupo de investigadores que, bajo la dirección de Humberto López Morales, trabajamos en disponibilidad léxica. Tanto las investigaciones ya acabadas como las que 
están en marcha tienen, por lo tanto, cabida en él. Cada grupo de investigación debería aportar, además de la experiencia del trabajo ya realizado, aquellas encuestas que le correspondan a la zona de su investigación.

Como nos recuerda el Director del Proyecto panhispánico en la página www.dispolex.com «todo lo sabemos entre todos» a lo que podríamos añadir «y entre todos lo podemos conseguir».

\section{REFERENCIAS BIBLIOGRÁFICAS}

Alba, O. (1995): Léxico disponible de la República Dominicana, Santiago de los Caballeros, Pontificia Universidad Católica Madre y Maestra.

ARnal, M. L. (coord.) (2004): Léxico disponible de Aragón, Zaragoza, Libros Póttico.

Ayora Esteban, C. (2004): Léxico disponible de Ceuta, Cádiz, Universidad de Cádiz, tesis doctoral.

BARTOL HERNÁNDEZ, J. A. (2001): «Reflexiones sobre la disponibilidad léxica», en J. A. BArTol et alii (eds.): Nuevas aportaciones al estudio de la lengua española. Investigaciones filológicas, 221-236, Salamanca, Luso Española ediciones.

Bartol Hernández, J. A. (2004): El léxico disponible de la provincia de Soria. Estudio y diccionarios, Burgos, Instituto Castellano Leonés de la Lengua.

Bellón Fernández, J. J. (2003): Léxico disponible de la provincia de Córdoba, tesis doctoral, Universidad de Las Palmas de Gran Canaria.

BeníteZ, P. (1995): «Disponibilidad léxica en Madrid: análisis cuantitativo», Actas del III Seminario Internacional sobre Aportes de la Lingüística a la enseñanza de la Lengua Materna, Revista de la Adquisición de la Lengua Española, número especial.

CARCEDO, A. (1998): «Tradición y novedad en las aportaciones hispánicas a los estudios de disponibilidad léxica», Lingüística, 10: 5-68.

Carcedo, A. (2001): Léxico disponible de Asturias, Turku, Publicaciones del Departamento de Lengua Española de la Universidad de Turku.

Etxebarría, M. (1996): «Disponibilidad léxica en escolares del País Vasco: variación sociolingüística y modelos de enseñanza bilingüe», $R E L, 301$ 325.

Galloso Camacho, M. V. (2002): El léxico de los estudiantes preuniversitarios en el distrito universitario de Salamanca, CDRom, Salamanca, Ediciones Universidad de Salamanca. [Publicado en 2003, El léxico disponible de Ávila, Salamanca y Zamora, Burgos: Instituto Castellano-Leonés de la Lengua.] 


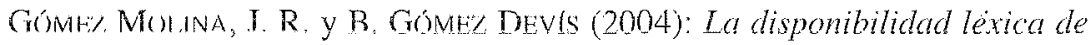
los estudiantes preuniversitarios valencianos: estudio de estratificación sociolingüística, Valencia, Universidad de Valencia.

GonzÁlez Martinez, A. (2002): La disponibilidad léxica de los alumnos preuniversitarios en la provincia de Cádiz, Cádiz, Servicio de Publicaciones.

HerNÁNDEZ, N. (2004): El léxico disponible de los estudiantes conquenses, Salamanca, Universidad de Salamanca.

López Morales, H. (1999): Léxico disponible de Puerto Rico, Madrid, Arco Libros.

Matio, Ma V. (1998): Disponibilidad léxica en el cou almeriense. Esitudio de estratificación social, Almería, Universidad de Almería.

Prado, J. y M $\mathrm{M}^{\mathrm{a}}$ V. Galloso (en prensa): El léxico disponible de los alumnos de nivel preuniversitrarios de Huelva, Huelva, Universidad de Huelva.

Samper Padilla, J. A. y C. E. Hernández (1995): «Estudio de la disponibilidad léxica en Gran Canaria. Análisis cuantitativo», en RodRíguez FonsECA y VÁzQuez (1995): Actas del III Seminario Internacional sobre aportes de la Linguiística a la Enseñanza de la Lengua, Revista de adquisición de la Lengua Española, números especiales

- (1997): «Estudio de la disponibilidad léxica en Gran Canaria. Datos iniciales y variación sociolinguística», en Contribuciones al estudio de la lingüística hispánica (Homenaje a Ramón Trujillo Carreño), La Laguna, Universidad de La Laguna, vol. II, 229-239

Samper Padilla, J. A., Juan J, Bellón y M. Samper Hernández (2003): «El proyecto de estudio de la disponibilidad léxica en español» en ÁviLA, R., J. A. SAmper y H. Hueda (eds.): Pantas y pistas en el análisis del léxico hispano(americano), Frankfurt-Madrid, Iberoamericana, 27-140. 


\title{
LA DISPONIBILIDAD LÉXICA EN LA COMUNIDAD VALENCIANA
}

\author{
Manuela Casanova Ávalos \\ Universitat Jaume I
}

\section{INTRODUCCIÓN}

$\mathbf{E}$ L objetivo de esta comunicación es señalar los datos de las tres investigaciones sobre disponibilidad léxica que se están llevando a cabo en la Comunidad Valenciana. Esta región está configurada por tres provincias: Castellón, Valencia y Alicante, nombradas de norte a sur. El estudio sobre Valencia, el cual está terminado y recientemente publicado, lo ha realizado Begoña Gómez Devís, dirigida por José Ramón Gómez Molina de la Universitat de València. Aparte de exponernos el diccionario general del léxico disponible del español de los preuniversitarios valencianos, intenta mostrar la «estratificación sociolectal de la disponibilidad léxica de los jóvenes valencianos, tomando como referencia teórica y metodológica los pre-supuestos de la sociolinguística variacionista» (Gómez Molina y Gómez Devís, 2004: 15). El análisis sobre Alicante y Castellón está en fase de desarrollo. Los datos sociológicos y léxicos se hallan recogidos y dispuestos a ser estudiados cuantitativa y cualitativamente. El primero lo realiza Esther Martínez Olmos, codirigida por Francisco Gimeno de la Universidad de Alicante y Alberto Carcedo de la Universidad de Turku. Y el segundo lo lleva a cabo Manuela Casanova, autora del presente escrito, dirigido por José Luis Blas Arroyo, de la Universitat Jaume I de Castellón.

Los tres trabajos se incluyen en un proyecto más amplio coordinado por Humberto López Morales, cuyo objetivo es la recopilación del léxico disponible del español en un diccionario, y con ello conocer la disponibilidad léxica del español de los estudiantes preuniversitarios, quienes representan la norma adulta de la lengua sin la terminología específica ni los tecnicismos propios de los estudios universitarios.

Humberto López Morales es, pues, el impulsor y coordinador de los trabajos sobre disponibilidad léxica en el español, que comenzaron a dar sus frutos en la década de los setenta. Han visto la luz léxicos disponibles nacionales como los de Chile, República Dominicana y Puerto Rico. En España se trabaja por regiones o comunidades autónomas (Asturias, Aragón) y por provincias (Zamora, Ávila, Salamanca, Cádiz, Almería, Cuenca, Soria, Valencia...) Todos ellos forman parte de ese ambicioso proyecto del léxico 
disponible panhispánico.' Este pruyectu fue presentado en el XI Congreso Internacional de la ALFAL en julio de 1996 en Las Palmas de Gran Canaria. Se celebró una segunda reunión en la Universidad del País Vasco (Bilbao) en abril de 1999 con el fin de acordar una metodología común. En el mismo mes de 2003 en San Millán de la Cogolla se llevó a cabo la tercera reunión de los equipos españoles e hispanoamericanos que ya trabajaban en la disponibilidad léxica. En esta ocasión se presentaron las diferentes aplicaciones ${ }^{2}$ de la disponibilidad léxica. El proyecto cuenta con una página web, ${ }^{3}$ preparada por José Antonio Bartol de la Universidad de Salamanca, donde se puede acceder a toda la información y publicaciones que sobre disponibilidad léxica aparecen. La próxima reunión se celebrará a finales de mayo de 2005 y se debatirá sobre los problemas y sus posibles soluciones en las zonas bilingües y el futuro de la disponibilidad léxica.

Todas las investigaciones inmersas en el proyecto panhispánico comparten unos mismos presupuestos metodológicos (el tipo de encuesta empleada para recopilar los datos, el número de centros de interés, los criterios de edición de los materiales y el proceso de informatización de los mismos) imprescindibles para la homogeneización de la información y posibilitar la comparación entre las distintas sintopías del español estudiadas a ambos lados del Atlántico.

Por disponibilidad léxica debe entenderse «el caudal léxico utilizable en una situación comunicativa dada» (López Morales, 1983: 213). En esta definción subyace la idea de que en el lexicón mental de los hablantes existe una serie de vocablos que no se actualizan mientras no son necesarios para dar informaciones concretas. El léxico disponible es un léxico potencial situado en la mente de los individuos y actualizado sólo como respuesta a un estímulo, en nuestro estudio los llamados centros de interés.

Esta serie de investigaciones permite conocer el léxico que tienen a su disposición los hablantes de un mismo nivel educativo cuando la conversación gira en torno a un determinado tema. El léxico disponible - «el que se usa en situaciones comunicativas específicas» (López Chávez, 1992: 29)--ayuda a establecer la norma léxica disponible de una comunidad de habla. Unido al léxico básico - «el usual y frecuente en cualquier situación de habla» (López Chávez, 1992: 29)- se obtiene el léxico fundamental de los hablantes que forman dicha comunidad de habla.

1. Samper, Bellón, y Samper Hernández (2003) dan una información exhaustiva del proyecto de estudio sobre la disponibilidad léxica en lengua española.

2. Encontramos información sobre las aplicaciones de los estudios de disponibilidad léxica en López Morales $(1996,1999)$ y Carcedo (1998).

3. www.dispolex.com. Para conocer el funcionamiento del nuevo programa informático véase José Antonio Bartol y Natividad Hernández (en prensa). 
El objetivo fundamental de los estudios actuales sobre disponibilidad léxica es «el establecimiento de la norma léxica de una determinada comunidad de habla» (López Morales, 1999: 19). En este trabajo presentamos los datos de las muestras en general y en las variables sociales estudiadas, datos en los que se va a basar la norma léxica de la Comunidad Valenciana.

\section{ASPECTOS BÁSICOS DE LAS TRES INVESTIGACIONES}

\subsection{La muestra}

La muestra la forman los estudiantes del Curso de Orientación Universitaria, en su mayoría, y alguno de segundo de Bachillerato LOGSE. Son individuos de una edad comprendida entre los 17 y 19 años. Se ha elegido este tramo de edad en la enseñanza porque uno de los objetivos del proyecto panhispánico es trabajar con listas de palabras que carezcan de los tecnicismos propios de los estudios universitarios elegidos por los alumnos posteriormente.

El número total de encuestados en la Comunidad Valenciana asciende a 1.279, de los cuales 460 corresponden a Alicante, 465 corresponden a Valencia y 354 a la provincia de Castellón.

Teniendo en cuenta el número de alumnos de cou en los años de realización de las encuestas, obtenemos la siguiente representatividad:

Alicante: ${ }^{4}$ las encuestas se realizaron en el año 1994. Durante ese curso había 10.320 alumnos de COU, así que 465 representa un $4.45 \%$.

Castellón: ${ }^{5}$ las pruebas se llevaron a cabo durante los cursos académicos 1998/99 y 1999/2000. El número de alumnos de cou ascendía en 1999, año que tomamos como base del análisis, a 2.733 y 701 es el número de alumnos de segundo de bachillerato LOGSE. Si tomamos la suma, 3.434, la representatividad de la muestra es de $10.30 \%$.

Valencia: ${ }^{6}$ Los años de realización de las pruebas fueron 1996/97 y 1997/98. No contamos con el número preciso de alumnos que cursaban cou durante esos cursos. Se ofrecen los tantos por ciento de la población real y

4. Todos los datos referidos a Alicante han sido cedidos amablemente por Esther Martínez, investigadora que lleva adelante el proyecto de disponibilidad léxica de Alicante.

5. Las cifras han sido facilitadas por el Servei de Gestió de la Docència i estudiants (Negociat d'accés) de la Universitat Jaume I de Castelló.

6. Los datos de Valencia se recogen de José Ramón Gómez Molina y Begoña Gómez Devís (2004: 41). Valencia toma los datos del Anuario estadístico de la Comunidad Valenciana (1998). Publicado por el Institut Valencià d’Estadística. La población es referida a 1996 según el sexo y la edad: tramo de 15 a 19 años. 
estudiantil junto a la muestra. Són sefialamos la población estudiantil: varón: $46.40 \%$; mujer: $53.60 \%$ y la muestra obtiene los siguientes porcentajes: varón: 44.70\%; mujer: $55.30 \%$.

Todos los porcentajes superan el 0.025 establecido por $\bar{W}$. Labov, tomado como nivel de representatividad en los estudios de sociolingǘstica de corte variacionista. También se supera si tomamos el número de habitantes en su totalidad: en 1998 la Comunidad Valenciana tenía un total de 4.023.441 habitantes. El tamaño de la muestra, 1279 encuestados, equivale a un $0.031 \%$. La muestra sigue siendo representativa teniendo en cuenta el número de alumnos de coU y Bup más alumnos de segundo de Bachillerato LOGSE. Las cifras corresponden al curso $1997 / 98$ ?

CUADro 1. Número de alumnado en el curso 1997/1998

\begin{tabular}{|l|c|c|c|c|}
\hline & Alicante & Castellón & Valencia & C. Valenciana \\
\hline $\begin{array}{l}\text { No alumnos } \\
\text { BUP y cou }\end{array}$ & 39.090 & 11.972 & 51.455 & 102.517 \\
\hline $\begin{array}{l}\text { No alumnos } \\
\text { LogsE }\end{array}$ & 5.731 & 1.102 & 8.278 & 15.111 \\
\hline No informantes & 460 & 354 & 465 & 1.279 \\
\hline Porcentaje & $1.026 \%$ & $2.707 \%$ & $0.778 \%$ & $1.087 \%$ \\
\hline
\end{tabular}

De todas formas las cifras que deben tenerse en cuenta son las que hacen referencia al alumnado de COU y segundo de bachillerato LOGSE durante los cursos académicos que se pasaron las encuestas, que es cuando se programa toda la muestra del estudio sobre disponibilidad léxica de cada provincia.

\subsection{Instrumento de la investigación. La prueba}

La recopilación de los datos se realiza mediante una prueba de tipo asociativa con listas abiertas (el alumno puede responder todo aquello que se le ocurra en ese momento relacionado con el tema propuesto) y un límite temporal de dos minutos, tiempo suficiente para que los informantes produzcan las primeras palabras que de forma espontánea acuden a su mente. Si no se fijara un límite temporal los individuos tendrían tiempo de indagar en la memoria y se obtendría aquellos vocablos que no están disponibles inmediatamente.

7. Las cifras han sido extraídas del Antari estadistic de la Comunitat Valenciana. 1999.

8. Dimitrijévic (1969) es el primero en utilizar listas abiertas. Éstas permiten llevar a cabo análisis de diferente tipo, entre los que resaltan los de carácter sociolingüístico, muy útiles tanto para comunidades monolingies como bilingües, como es nuestro caso. 
La encuesta consta de una especie de cuadernillo con dos partes claramente diferenciadas. Una que recoge los datos sociológicos de los alumnos, lo que permite su posterior estratificación social; y otra donde se recopilan las respuestas de los informantes en cada centro de interés marcado.

La prueba se lleva a cabo en los mismos centros educativos en los grupos de Cou elegidos al azar y en el horario destinado a la asignatura de Lengua Española de forma habitual. En el cuadro siguiente observamos el número de centros encuestados en la Comunidad Valenciana, especificando la población y la provincia a la que pertenecen.

Cuadro 2. Número de centros y pueblos encuestados en la Comunidad Valenciana

\begin{tabular}{|c|c|c|}
\hline Alicante & Castellón & Valencia \\
\hline Alicante, 2 & Castellón, 7 & Valencia ciudad, 12 \\
\hline Elche, 2 & Vila-real, 2 & Paterna, 2 \\
\hline Orihuela, 2 & La Vall d'Uixó, 1 & Alzira, 1 \\
\hline Elda, 1 & Benicarló, 1 & Alberic, 1 \\
\hline Benidorm, 1 & Onda, 1 & Meliana, 1 \\
\hline Novelda, 1 & Betxí, 1 & Utiel, 1 \\
\hline Callosa d'Ensarrià, 1 & Nules, 1 & Xirivella, 1 \\
\hline Castilla, 1 & Borriana, 1 & Sagunto, 1 \\
\hline Dolores, 1 & & Gandía, 1 \\
\hline Guardamar del Segura, 1 & & Puzol, 1 \\
\hline Villena, 1 & & Moncada, 1 \\
\hline
\end{tabular}

Si sumamos todos los centros, la Comunidad Valenciana viene representada por 52 centros educativos, repartidos de la siguiente forma: Alicante: 14 centros, Castellón: 15 centros y Valencia: 23 centros.

\subsection{Las variables estudiadas}

Una variable manejada en las investigaciones del proyecto panhispánico hace referencia al tipo de educación o «tipo de centro» (público o privado). El primero en otorgar independencia a esta variable es López Morales en su Léxico disponible de Puerto Rico (1999). Desde entonces es un índice analizado en todos los trabajos de disponibilidad del español. ${ }^{9}$

9. Esta variable ha sido analizada en una submuestra de alumnos de Castellón por Blas Arroyo y Casanova $(2003$ a) 
La Comunidad Valenciana queda representada de la siguiente forma en cuanto al número de centros y número de alumnos que representan cada tipo de enseñanza

CuAdro 3. Número de centros públicos y privados y alumnos de la Comunidad Valenciana

\begin{tabular}{|c|c|c|c|c|c|c|c|c|}
\hline Tipo de centro & \multicolumn{2}{|c|}{ Alicante } & \multicolumn{2}{|c|}{ Castellón } & \multicolumn{2}{|c|}{ Valencia } & \multicolumn{2}{|c|}{ C. Valenciana } \\
\hline & Cent & lumnos & Cent & lumnos & Cen & lumnos & $\mathrm{Cer}$ & lumnos \\
\hline Público & 10 & 309 & 10 & 229 & 15 & 296 & 35 & 834 \\
\hline Privade & 4 & 151 & 5 & 125 & 8 & 169 & 17 & 445 \\
\hline Total & 14 & 460 & 15 & 354 & 23 & 465 & 52 & 1279 \\
\hline
\end{tabular}

Otra variable tenida en cuenta hace referencia a la ubicación del centro, si se trata de un instituto/colegio ubicado en zona urbana o rural. El número de centros y alumnos que representan a la Comunidad Valenciana quedan reflejados en el siguiente cuadro:

CUADRO 4. Número de centros urbanos y rurales de la Comunidad Valenciana

\begin{tabular}{|l|cc|cc|cc|cc|}
\hline $\begin{array}{l}\text { Ubicación } \\
\text { centro }\end{array}$ & Alicante & Castellón & Valencia & \multicolumn{2}{|c|}{ Comun. Valen. } \\
\hline & Centro/Alumnos & Centro/Alumnos & Centro/Alumnos & Centro/Alumno \\
\hline Urbano & 10 & 317 & 7 & 165 & 21 & 429 & 38 & 911 \\
\hline Rural & 4 & 143 & 8 & 189 & 2 & 36 & 14 & 368 \\
\hline
\end{tabular}

\subsection{Centros de interés}

Desde la elaboración de la disponibilidad léxica francesa y siguiendo la investigación pionera (Gougenheim et alii, 1964; 152-154) se vienen utilizando, a manera de estímulo, «unas claves temáticas o campos léxico-semánticos, bautizados entonces como centros de interés, con una etiqueta de la pedagogía tradicional» (López Morales, 1999: 28).

Las investigaciones del proyecto panhispánico emplean los 16 centros de interés tradicionales al igual que Gougenheim. Así lo hacen los tres trabajos de las tres provincias de la Comunidad Valenciana. Castellón y Valencia añaden un decimoséptimo centro de interés denominado «Los colores», al igual que las investigaciones de Justo Hernández (1987), Benítez (1992), Etxebarría (1996), Samper y Hernández (1997), Mateo 
García (1998). López Morales y García Marcos (1995: 70) lo justifican diciendo que «los colores nos introducen en un aspecto básico de la verbalización de la percepción del entorno, de constante referencia desde los trabajos de los antropólogos lingüistas para el examen de las relaciones lengua/pensamiento/realidad».

Los campos quedan enunciados como sigue: 01. Partes del cuerpo, 02. La ropa, 03. Partes de la casa (sin muebles), 04. Los muebles de la casa, 05. Alimentos y bebidas, 06. Objetos colocados en la mesa para la comida, 07. La cocina y sus utensilios, 08. La escuela: muebles y materiales, 09. Iluminación, calefacción y medios para airear un recinto, 10. La ciudad, 11. El campo, 12. Medios de transporte, 13. Trabajos del campo y del jardín, 14. Los animales, 15. Juegos y distracciones, 16. Profesiones y oficios, 17. Los colores

La anterior enumeración corresponde a la denominación de los centros utilizada en la investigación de Castellón. Hay unos ligeros cambios en el campo número 01 y 09 , que Valencia llama «El cuerpo humano» e «lluminación, calefacción y ventilación (naturales y artificiales)» respectivamente. Alicante utiliza en el centro 09 solamante «Calefacción e iluminación». También se observa un cambio en el campo 08, que Valencia denomina «La escuela: muebles y materiales (el instituto o el colegio)» a diferencia de Castellón y Alicante.

No todos los lingüistas están de acuerdo en el número y la denominación de los centros de interés que deben seleccionarse y estudiarse. Evidentemente en 16 campos semánticos no se pueden abarcar todos los intereses del hombre, como señala Mackey (1971). Hay una gran diferencia entre los centros, mientras unos tienen concreción temática ("partes del cuerpo"), otros son ambiguos («el campo», «la ciudad»), y dan lugar a repeticiones y asociaciones semánticas individuales.

Pueden verse con detalle los centros de interés utilizados en otras investigaciones, cómo han ido variando, aumentando o disminuyendo dependiendo de los objetivos planteados, en López Morales (1999: 32-37), Carcedo (1998: 42-47) y Samper et alii (2003: 46-63). La controversia establecida en las distintas denominaciones de los campos semánticos la debaten Julio Borrego y Natividad Hernández (2002).

\subsection{Condicionantes extralingüísticos}

2.5.1. Aparte de las variables nombradas anteriormente (tipo de centro / ubicación del centro), se tienen en cuenta otras variables sociales. La primera de ellas, reflejada en todos los trabajos de disponibilidad léxica, es el sexo. Interesa saber en todo análisis sociolinguiístico cómo repercute la condición sexual en el léxico, no sólo desde el punto de vista cuantitativo sino también cualitativo. 
La muestra de la Comunidad Valenciana queda representada así:

CUADRO 5. Número de informantes según el sexo

\begin{tabular}{|l|c|c|c|c|}
\hline Sexo & Alicante & Castellón & Valencia & Comun. Valen. \\
\hline Hombre & 190 & 155 & 208 & 553 \\
\hline Mujer & 270 & 199 & 257 & 726 \\
\hline
\end{tabular}

Se observa un claro predominio del sexo femenino en el número de los encuestados. Parece sei una constante en la mayoria de los trabajos de disponibilidad léxica analizados hasta el momento. Puede observarse una tabla comparativa de los diversos estudios realizados en Samper et alii (2003: 70).

2.5.2. La variable que establece el nivel sociocultural de los encuestados es uno de los factores más importantes en los estudios sociolinguísticos. También es perceptible este índice en el léxico disponible. Se establece a través de los datos que aportan los alumnos.

Valencia y Alicante establecen tres niveles socioculturales como en la mayoría de los trabajos de disponibilidad léxica. Distribuyen a los alumnos en tres estratos: alto, medio y bajo. Para ello tienen en cuenta dos parámetros: el nivel educativo y la profesión u oficio de los padres. ${ }^{10}$ Teniendo esto en cuenta, los alumnos de las provincias de Alicante y Valencia quedan distribuidos del siguiente modo:

\begin{tabular}{|l|c|c|}
\hline \multicolumn{1}{|c|}{ Nivel sociocultural } & Alicante & Valencia \\
\hline Nivel alto & 35 & 41 \\
\hline Nivel medio & 310 & 253 \\
\hline Nivel bajo & 115 & 171 \\
\hline
\end{tabular}

Castellón, tal como hiciera Benítez (1992), únicamente observa el parámetro "nivel educativo» de los padres y establece cuatro variantes: 1 : Estudios primarios; 2: Estudios elementales; 3: Estudios secundarios y 4: Estudios superiores. Dentro del grupo 1 incluiríamos aquellos padres sin estudios o con estudios primarios incompletos, en el grupo 2 incluiríamos aquellos padres con estudios primarios completos y secundarios incompletos, en 3 aquellos padres con estudios secundarios completos y universitarios medios $y$, por último, en 4

10. Existe un tercer factor, los ingresos familiares, que sí han tabulado López Morales (1999) y Orlando Alba (1995) entre otros. 
aquellos que hubiesen realizado estudios universitarios superiores. Teniendo en cuenta este baremo la muestra de Castellón quedaría como sigue realizando el cruce con otra variable: enseñanza pública / enseñanza privada:

\begin{tabular}{|l|c|c|c|}
\hline Nivel educ. padres & Enseñanza Pública & Enseñanza privada & Totales \\
\hline E. Primarios & 117 & 27 & 144 \\
\hline E. Elementales & 60 & 38 & 98 \\
\hline E. Secundarios & 37 & 46 & 83 \\
\hline E. Superiores & 15 & 14 & 29 \\
\hline
\end{tabular}

La importancia del nivel sociocultural «en la determinación de diferencias léxicas entre los hablantes ha sido puesta de manifiesto desde los primeros estudios de López Morales $(1973,1979)$ y ha sido confirmada prácticamente por todas las investigaciones sobre disponibilidad léxica que se han realizado en Hispanoamérica y en España» (Samper et alii, 2003: 77).

\subsection{Otras variables analizadas}

En cada una de las tres provincias de la Comunidad Valenciana han sido analizadas otras variables además de las enunciadas anteriormente. Vamos a conocerlas brevemente.

\subsubsection{Alicante}

Esta investigación, aparte de las variables comentadas -sexo, tipo de centro, ubicación del centro, nivel sociocultural-, tiene en cuenta una quinta variable que hace referencia a la zona geográfica de ubicación de los alumnos. Me refiero a la variable Litoral/Interior, es decir, aquellos núcleos de población que se sitúan en la zona costera de la provincia frente a aquellas poblaciones que se ubican en el interior de la provincia. Atendiendo a esta variable la muestra de Alicante queda del siguiente modo:

\begin{tabular}{|l|c|c|}
\hline \multicolumn{1}{|c|}{ Zona geográfica } & $\mathbf{N}^{\mathbf{0}}$ de centros & $\mathbf{N}^{\mathbf{0}}$ de alumnos \\
\hline Litoral & 4 & 126 \\
\hline Interior & 10 & 334 \\
\hline
\end{tabular}




\subsubsection{Valencia}

Este estudio analiza las siguientes variables: 1. Sexo; 2. Tipo de centro. 3. Lengua habitual; 4. Nivel sociocultural; 5 . Lugar de residencia.

Cabe comentar en esta ocasión la variable 3 . En una comuniclad como la nuestra donde encontramos dos lenguas oficiales, el castellano y el valenciano, parece relevante observar cómo influye este factor en el léxico disponible. Así lo hacen Gómez Molina y Gómez Devís (2004) cuando estudian la repercusión de este índice en el léxico de la provincia de Valencia. Establecen dos variantes: monolingües, individuos castellanohablantes, es decir, que la lengua de uso es el castellano en todas las situaciones, y bilingües, individuos valencianohablantes y bilingïcs totales, o sea, individuos que utilizan mayoritariamente el valenciano o ambas.

La muestra queda representada así:

\begin{tabular}{|l|c|}
\hline \multicolumn{1}{|c|}{ Lengua habitual } & Valencia \\
\hline Monolingües & 343 \\
\hline Bilingües & 122 \\
\hline
\end{tabular}

Otro factor que cabe comentar es la variable 5. El factor espacial observa en Valencia dos índices, la ubicación del centro escolar y la residencia familiar, que salvo en la zona metropolitana han coincidido la mayoría de las veces. Como indicábamos anteriormente se establecen cuatro variantes o subespecificaciones:

- Valencia ciudad. comprende el núcleo urbano y los batrios periféricos (750.000 habitantes)

- Área metropolitana, corona que rodea la ciudad más las poblaciones de l'Horta (500.000 habitantes)

-Semiurbano, comprende ciudades medianas, capitales comarcales (50.000 habitantes)

-Rural, poblaciones con un número de habitantes inferior a 10.000 habitantes.

La muestra valenciana queda como sigue:

\begin{tabular}{|l|c|}
\hline \multicolumn{1}{|c|}{ Factor espacial } & Valencia \\
\hline Valencia ciudad & 248 \\
\hline Área metropolitana & 96 \\
\hline Semiurbano & 85 \\
\hline Rural & 36 \\
\hline
\end{tabular}




\subsubsection{Castellón}

Esta provincia analiza las variables: 1 . Sexo; 2. Tipo de centro; 3. Ubicación del centro/residencia familiar; 4. Lengua materna; 5. Nivel de instrucción de los padres de los informantes.

Empezaremos comentando la variable 3. En Castellón debemos entender la dualidad urbano/rural en el sentido de que el primero representa a los centros ubicados en la capital de la provincia (Castellón de la Plana) frente al segundo que indica los centros situados en las poblaciones de la provincia. La variable residencia familiar de los informantes, tal como ocurre en Valencia, coincide casi en su totalidad con la ubicación del centro donde estudian. Existe una diferencia de unos cuantos alumnos fácilmente explicables en su momento. Se trata de alumnos con residencia rural en cuyas poblaciones (Benicàssim, Alcocebre, Atzaneta, etc.) no se imparte bachillerato. Estos alumnos no tienen más remedio que acudir a centros de la ciudad más cercana, en este caso Castellón que con tres centros recoge a dichos alumnos: Ribalta, Mater Dei, Miquel Peris. Las cifras correspondientes a ubicación del centro ya las hemos visto. Si tenemos en cuenta ahora la residencia familiar la muestra castellonense queda dividida de la siguiente manera:

\begin{tabular}{|l|c|}
\hline \multicolumn{1}{|c|}{ Residencia padres } & Castellón \\
\hline Urbana: capital de provincia & 125 \\
\hline Rural. Resto de poblaciones & 229 \\
\hline
\end{tabular}

La otra variable analizada hace referencia a la lengua materna" de los encuestados. Tres variantes o subespecificaciones se han analizado:

-alumnos valencianohablantes, es decir, aquellos individuos cuya lengua materna es el valenciano.

-alumnos castellanohablantes, es decir, aquellas personas con el castellano como lengua materna.

-alumnos totalmente bilingües, con ambas lenguas indiferenciadas desde la infancia.

Esta variable queda reflejada en la muestra castellonense así, teniendo en cuenta el cruce con la variable tipo de centro:

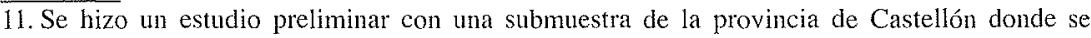
demuestra que la lengua matema sí es un factor que repercute en el número de vocablos de los encuestados. Ver Blas Arroyo y Casanova (2003 b y $2003 c$ ). 


\begin{tabular}{|l|c|c|c|}
\hline Lengaa materna & Centro público & Centro privado & Totales \\
\hline Valenciano & 117 & 42 & 159 \\
\hline Castellano & 78 & 50 & 128 \\
\hline Ambas & 34 & 23 & 57 \\
\hline
\end{tabular}

\section{CONSIDERACIONES FINALES}

La finalidad de la comunicación era plantear los primeros datos de la disponibilidad léxica de Castellón, es decir, la cifras de la muestra con las que se va a trabajar especificadas en las variables analizadas, tras una reestructuración de los datos iniciales. He creido interesante exponer dichos datos de forma paralela con las investigaciones de las provincias de Alicante y Valencia, para dar con ello una visión de conjunto de cómo queda representada la disponibilidad léxica de la Comunidad Valenciana. Una vez concluidos los trabajos de las tres provincias que la forman se podría plantear la posibilidad de publicar el diccionario del léxico disponible de la Comunidad Valenciana.

A modo de resumen ofrecemos el siguiente cuadro donde se recogen todas las variables estudiadas en la Comunidad Valenciana con el número de alumnos que las representan:

Distribución de la muestra en la Comunidad Valenciana

\begin{tabular}{|c|c|c|c|c|}
\hline Variables & $\begin{array}{l}\text { Comunidad } \\
\text { Valenciana }\end{array}$ & Alicante & Castellón & Valencia \\
\hline \multicolumn{5}{|l|}{ Tipo de centro } \\
\hline Público & 834 & 309 & 229 & 296 \\
\hline Privado & 445 & 151 & 125 & 169 \\
\hline \multicolumn{5}{|l|}{ Ubicación centro } \\
\hline Urbana & 911 & 317 & 165 & 429 \\
\hline Rural & 368 & 143 & 189 & 36 \\
\hline \multicolumn{5}{|c|}{ Residencia padres } \\
\hline Urbana & & & 125 & \\
\hline Rural & & & 229 & \\
\hline Valencia ciudad & & & & 248 \\
\hline Área metropolit. & & & & 96 \\
\hline Semirubano & & & & 85 \\
\hline Rural & & & & 36 \\
\hline
\end{tabular}




\begin{tabular}{|c|c|c|c|c|}
\hline Variables & $\begin{array}{c}\text { Comunidad } \\
\text { Valenciana }\end{array}$ & Alicante & Castellón & Valencia \\
\hline \multicolumn{5}{|c|}{ Nivel sociocultural } \\
\hline Alto & & 35 & & 41 \\
\hline Medio & & 310 & & 253 \\
\hline Bajo & & 115 & & 171 \\
\hline \multicolumn{5}{|c|}{ Nivel educativo padres } \\
\hline Primarios & & & 144 & \\
\hline Elementales & & & 98 & \\
\hline Secundarios & & & 83 & \\
\hline Superior & & & 29 & \\
\hline \multicolumn{5}{|c|}{ Lengua habitual } \\
\hline Monolingües & & & & 343 \\
\hline Bilingüies & & & & 122 \\
\hline \multicolumn{5}{|c|}{ Lengua materna } \\
\hline Valenciano & & & 159 & \\
\hline Castellano & & & 128 & \\
\hline Ambas & & & 57 & \\
\hline \multicolumn{5}{|c|}{ Zona geográfica } \\
\hline Litoral & & 126 & & \\
\hline Interior & & 334 & & \\
\hline
\end{tabular}

\section{REFERENCIAS BIBLIOGRÁFICAS}

Alba, O. (1995): El léxico disponible de la República Dominicana, República Dominicana, Ed. de la Pontificia Universidad Católica Madre y Maestra.

Bartol Hernández, J. A. y N. Hernández (en prensa): «Dispolex: base de datos de la disponibilidad léxica», Actas del VI Congreso de Lingüística General, Santiago de Compostela.

Benítez Pérez, P. (1992): «Disponibilidad léxica en la zona metropolitana de Madrid», Boletín de la Academia Puertorriqueña de la Lengua Española, 1, 1:73-99.

Blas Arroyo, J. L. y M. Casanova Ávalos (2003 a): «La influencia de la red educativa y del entorno sociocultural en la disponibilidad léxica. Estudio de las comunidades de habla castellonenses», en Actas del XXIII Congreso Internacional de Lingiiística y Filología Románica, vol. V: 17-33. 
- (2003 b): «Interacción de factores sociales y de adscripción lingiiistica en el léxico disponible de una comunidad escolar españolany en Lenguas Modernas, 28-29: 165-189, Universidad de Chile.

- $(2003 \mathrm{c})$ : «La influencia de la lengua materna en algunos valores de la disponibilidad léxica en el español de una comunidad bilingüe», en DOVAL ReIXA, I. y $\mathrm{M}^{\mathrm{a}}$ R. Pérez Rodríguez (eds.) Adquisición, enseñanza y contraste de lenguas, bilingiaismo y traducción, Servicio de Publicaciones de la universidad de Vigo.

Borrego Nieto, J. y N. Hernández Muñoz (2002): «Cuestiones metodológicas sobre los estudios de disponibilidad léxica», Actas del V Congreso de Lingüistica General, León.

Carcedo González, A. (1998): «Tradición y novedad en las aportaciones hispánicas a los estudios de disponibilidad léxica», Lingiiística, 10: 5-68.

Dimitrijévic, N. (1969): Lexical Availability, Heidelberg, Julios Gross Verlag. Etxebarria Arostegui, M. (1996): «Disponibilidad léxica en escolares del País Vasco: variación sociolingüística y modelos de enseñanza bilingüe», Revista Española de Linguiística, 26, 2: 301-325.

Gómez Molina, J. R. y Mª B. Gómez. Devís (2004): La disponibilidad léxica de los estudiantes preuniversitarios valencianos. Estudio de estratificación sociolingiiística, Valencia, Universitat de València, Anejo $\mathrm{n}^{\circ} 56$ de la Revista Quaderns de Filologia.

Gougenherm, G. et alii (1964): «Recherches sur le fréquence et la disponibilité», Statistique et analyse linguistique, Colloque de Strassbourg.

Institut Valencià d'Estadística (2000): Anuari estadístic de la Comunitat Valenciana. 1999, Valencia.

Justo Hernández, H. (1987): Disponibilidad léxica en colores (tesina inédita), México, UNAM.

LÓPEZ CHÁvez, J. (1992): «Alcances panhispánicos del léxico disponible», Lingüística, 4: 26-124.

López Morales, H. (1973): Disponibilidad léxica en los escolares de San Juan. MS.

- (1979) «Disponibilidad léxica y estratificación socioeconómica», en $\mathrm{H}$. LÓPEz Morales (ed.): Dialectología y sociolingiística: Temas puertorriqueños, Madrid, Hispanova de Ediciones.

- (1983): «Lingüística estadística», en López Morales, H. (coord.): Introducción a la lingiiística actual, Madrid, Playor.

- (1996): «Los estudios de disponibilidad léxica: pasado y presente», Boletín de Filología de la Universidad de Chile, 35: 245- 259.

- (1999): Léxico disponible de Puerto Rico, Madrid, Arco/Libros.

López Morales, H. y F. J. GarCía Marcos (1995): «Disponibilidad léxica en Andalucía. Proyecto de investigación», REALE, 3: 65-76. 
MACKEY, W. C. (1971): Le sondage dans les enquêtes de disponibilite, Québec, CIRB.

Mateo García, $M^{\mathrm{a}}$ V. (1998): Disponibilidad léxica en el cou almeriense. Estudio de estratificación social, Almería, Servicio de Publicaciones de la Universidad de Almería.

Samper Padilla, J. A. y C. E. Hernández Cabrera (1997): «El estudio de la disponibilidad léxica en Gran Canaria: datos iniciales y variación sociolingüística», en Contribuciones al estudio de la lingüística hispánica (homenaje al profesor Ramón Trujillo), Vol. II. Santa Cruz de Tenerife, Montesinos.

Samper Padilla, José antonio, Juan José Bellón y Marta Samper HERNÁNDEZ (2003): «El proyecto de estudio de la disponibilidad léxica en español», en G. WorJaK (2003): Pautas y pistas en el análisis del léxico hispano(americano) 



\title{
DISPONIBILIDAD LÉXICA \\ EN EL APRENDIZAJE DE INGLÉS \\ COMO LENGUA EXTRANJERA \\ POR HISPANOHABLANTES ADULTOS
}

\author{
Rubén Chacón BeLtrán \\ UNED
}

\section{INTRODUCCIÓN}

Ta

A influencia que ejerce la lengua materna sobre la lengua no materna en el proceso de aprendizaje se ha estudiado con amplitud, especialmente a partir de la década de los años sesenta con la incorporación del Análisis Contrastivo (AC). Los precursores del AC se dedicaron a realizar comparaciones sistemáticas entre la L1 y la L2 con el fin de averiguar cuáles eran los puntos que resultaban especialmente problemáticos, comenzando por los componentes fonético-fonológicos. Posteriormente, se pudo comprobar que este enfoque constituía una simplificación excesiva del complejo proceso que entraña el aprendizaje de una L2 (Swan, 1997). No se podía afirmar que todos los problemas encontrados por los aprendices fuesen debidos exclusivamente a la disparidad existente entre la L1 y la L2 y, por ello, el estudio del AC como único factor influyente en el aprendizaje de lenguas cayó en desuso. Del mismo modo, tampoco se podía aceptar que todas las dificultades se debiesen a problemas surgidos a partir del contacto de ambas lenguas en la mente del aprendiz, sino que el origen de éstas podría deberse a otros factores, por ejemplo, a dificultades intrínsecas de la lengua meta.

Algunos trabajos recientes se han llevado a cabo desde una perspectiva contrastiva aunque sin sobrestimar el papel que juegan las similitudes y diferencias en el aprendizaje de la lengua no materna, como es el caso de Kellerman (1995), Laufer y Eliasson (1993), Odlin (1989; 1996), Ringbom (1990 $a ; 1990 b ; 1992)$.

En cualquier caso, y debido al interés que ha suscitado el asunto de la influencia interlingüística en los últimos treinta años, parece evidente que la distancia lingüística entendida como el grado de contacto debido al origen y la relación histórico-linguística entre dos o más lenguas, despierta el interés de los investigadores e incide directamente sobre la cantidad e intensidad de la influencia interlingüística en el aprendizaje de una lengua no materna. Este fenómeno puede tener un efecto favorable, estimulando el aprendizaje, o bien 
una influencia desfavorable limitando y obstaculizando este proceso (Swan, 1997). En cualquier caso, esta circunstancia puede apreciarse con mayor nitidez en el ámbito léxico que en otros componentes lingüísticos como la fonología y la sintaxis.

Otra cuestión que conviene destacar es la incidencia de la percepción particular que suelen tener los aprendices con respecto a la supuesta distancia lingüística entre las dos o más lenguas en contacto. De este modo, en el caso del español y el inglés, el aprendiz puede apreciar que en lo relativo al léxico, se comparten gran cantidad de vocablos que, en cierta medida, manifiestan similitudes formales con la $L 1$ o, en otros casos, desemejanzas que responden a un patrón sistemático. Asimimo, al aprondiz hispanohablante de inglés advertirá enormes diferencias en lo relativo a cuestiones fonético-fonológicas así como sintácticas que, en ocasiones, pueden dar por resultado un incremento en la dificultad percibida. Algunos autores indican que las diferencias fonéticofonológicas también pueden afectar al aprendizaje de vocabulario, puesto que las palabras que muestran equivalencias en cuanto a su forma y pronunciación con la L1, se asimilan con más facilidad y rapidez que las percibidas como absolutamente ajenas (Laufer, 1990; Ellis y Beaton, 1993; Swan, 1997). Esto repercute de forma muy clara sobre el aprendizaje del componente léxico. Los aprendices de cualquier lengua y en cualquier contex to de aprendizaje muestran cierta tendencia a identificar cualquier similitud formal que les indique familiaridad con aquello que ya conocen. Así, Swan (1997) se refiere a la hipótesis de la equivalencia (equivalence hypothesis) para explicar este fenómeno que formula con las siguientes palabras: «Regard everything as the same unless you have a good reason not to.» (Swan, 1997: 166). Swan añade que el uso de esta hipótesis resulta prácticamente indispensable en el apren-dizaje de una lengua, sobre todo en las fases iniciales. De hecho, si el aprendiz no estableciese correspondencias interlingüísticas, jamás llegaría a adquirir otras lenguas aparte de la materna. Este concepto, que opera en el ámbito de la adquisición de una lengua no materna, puede tener implicaciones para el campo de la enseñanza de lenguas. El uso de los procesos subyacentes a la hipótesis de la equivalencia permite que los seres humanos aprendan lenguas diferentes a la $L 1$, sin necesidad de volver a la infancia, pues de lo contrario, deberían aprender a categorizar de nuevo el mundo que les rodea.

Otro factor que puede surgir a partir de la falta de equivalencia entre la $\mathrm{Ll}$ y la L2, y que entraña uno de los diversos efectos que puede tener la influencia interlingüística, reside en el fenómeno de la evitación' del vocabulario que resulta marcadamente ajeno al aprendiz. Éste, en el caso de contar con un término alternativo con significado similar pero que resulta conocido dada una

1. El concepto de 'evitación' es equivalente al término inglés avoidance. 
correspondencia formal, puede decantarse por él. De hecho, esto se ha demostrado empíricamente en estudios como el de Laufer y Eliasson (1993) en el que se investiga el trato que reciben los verbos frasales (phrasal verbs) por aprendices de nivel avanzado de inglés cuya L1 es el sueco y el israelí. De este modo, se pudo constatar que los aprendices, cuya L1 carece de verbos frasales, se muestran reacios a utilizar esta característica lingüística en la L2, siempre que cuenten con alguna alternativa, mientras que aquellos sujetos que disponen de una característica lingüística similar en la L1 no evaden su uso. Por consiguiente, la diferencia entre la L1 y la L2 se muestra como una posibilidad factible de predecir dificultades interlingüísticas, en este caso la evitación de un rasgo que resulta ajeno a los aprendices.

La percepción lingüística de la L1 como muy próxima, o al menos cercana a la $L 2$, podría incrementar el efecto de la influencia interlingüística en contraste con otra situación en la que los aprendices afrontan una lengua que les resulta totalmente ajena. Así, los aprendices se mostrarían reacios a efectuar asociaciones ante la suposición de que todo, o prácticamente todo, lo que están aprendiendo resulta completamente novedoso. En esta última situación la influencia interlingüística, ya sea favorable o desfavorable, no parece un fenómeno tan frecuente. En el caso de lenguas relacionadas en mayor o menor medida desde un punto de vista histórico, parece lógico pensar que se apreciará cierto contraste entre la percepción de la distancia lingüística y la distancia real.

\section{LAS PALABRAS COGNADAS EN EL APRENDIZAJE DE UNA LENGUA EXTRANJERA}

En la enseñanza de segundas lenguas, la susodicha relación históricolingüística entre las dos o más lenguas en contacto, es decir, la L1 y la L2, ha sido analizada desde dos puntos de vista en lo relativo al ámbito léxico: (a) como elemento que facilita o favorece el proceso de aprendizaje, dependiendo de la proximidad lingüística (influencia interlingüística positiva); o bien, (b) como componente que dificulta u obstaculiza el aprendizaje, dadas las interferencias provocadas por la similitud o desigualdad entre ambas lenguas (influencia interlingüística negativa).

Así pues, se han elaborado varios estudios que analizan los efectos favorables que supone el reconocimiento de palabras cognadas en actividades

2. Holmes y Guerra Ramos (1993) señalan que a pesar de la importancia que tiene el vocabulario cognado, la cantidad de investigaciones realizadas en este campo es relativamente pequeña. Esto puede deberse a que los investigadores normalmente prefieren trabajar aspectos con repercusión más amplia para la enseñanza del inglés como SL o LE. En lo que respecta a los cognados, los resultados de las investigaciones se encuentran restringidos y son únicamente extensibles a las lenguas que en ellas se traten. 
de lectura en una L2. Ringbom (1987) investigó el grado de competenciaactuación alcanzado por aprendices de inglés como LE de dos lenguas, el sueco y el finés que, a pesar de coexistir en Finlandia, pertenecen a dos familias linguísticas diferentes. Ringbom comprobó que los aprendices cuya Ll era sueco, sobrepasaban a los que tenían al finés como L1 en cuanto a competencia-actuación en inglés. En lo que respecta a la comprensión lectora, este autor indica que si la L2 se encuentra estrechamente relacionada con la L1, el aprendiz se beneficiará de la existencia de cognados, dado que la comprensión de éstos requiere menor esfuerzo. En realidad, muchos de esos cognados no llegan a aprenderse realmente, pero la similitud en el aspecto formal es eficaz para la comprensión lectora dado que el contacto con la palabra se limita a la comprensión del contexto y no hay un procesamiento profundo de la misma. Aunque de manera inconsciente, el aprendiz suele considerar el cognado como un apoyo para la lectura que, en realidad, no presenta motivos para una atención especial. Así, Ringbom (1992) habla de conocimiento potencial (potential knowledge) como el conocimiento de una palabra o construcción gramatical que el aprendiz tiene, o reconoce, sin que haya sido vista anteriormente. Sin lugar a dudas, este conocimiento potencial es mayor cuanta más proximidad lingǘstica haya entre la $L 1$ y la $L 2$ desde un punto de vista histórico, al menos en lo que respecta a actividades receptivas. De hecho, la ausencia de cognados merma considerablemente la cantidad de vocabulario a la que el aprendiz puede acceder, por lo que la disparidad entre cl vocabulario «activo» y «pasivo» se reduce notablemente (Ringbom, 1992). Debe tenerse en cuenta que Ringbom realiza sus investigaciones contrastando la lengua inglesa y la lengua sueca, muy próximas desde un punto de vista morfosintáctico. No obstante, Schmitt (2000) señala que en el caso de aprendices con una lengua romance como $\mathrm{L} 1$ también se pueden beneficiar en gran medida del reconocimiento de cognados en tareas de lectura, aunque advierte que esta estrategia debe utilizarse prudentemente.

\section{LAS PAILABRAS COGNADAS NO COINCIDENTES EN EL APRENDIRA.JE DE UNA LENGUA EXTRANJERA}

Del mismo modo que las palabras cognadas, o cognadas verdaderas, constituyen un apoyo para el desarrollo de algunas habilidades en los aprendices con determinados trasfondos lingüísticos, existen vocablos que no son coincidentes desde un punto de vista semántico, comúnmente llamados falsos amigos (false friends), y que suponen un obstáculo para el aprendiz. Los falsos amigos no son muy numerosos pero en ciertos contextos suponen un verdadero problema de aprendizaje que merece especial atención. Moss (1992) 
recopiló un corpus de 1.583 cognados extraídos de revistas científicas ${ }^{3}$ de entre los que pudo identificar un 10\% de falsos amigos. Así pues, aunque su proporción no parece demasiado alta, tampoco resulta tan escasa como para no merecer la atención de los investigadores. Por otra parte, Arnold (1992) comprobó que en las actividades de lectura el desconocimiento de los cognados falsos resulta más peligroso que los elementos léxicos totalmente desconocidos, pues los alumnos suelen inferir el significado a través de la forma lingüística sin su posterior comprobación.

En cuanto a la dificultad de los falsos amigos, ésta puede venir determinada por dos características inherentes a los mismos, es decir, si se trata de falsos amigos totales o parciales. El primer grupo estaría formado por aquellos que presentan un significado claramente diferente en ambas lenguas (ej.: inglés terrific; español estupendo), mientras que el segundo grupo estaría compuesto por palabras polisémicas con un significado que es cognado falso (ej.: en inglés approve significa dar el visto bueno o dar su aprobación mientras que el español aprobar, tiene además el significado de pasar una prueba o examen). Es precisamente este último tipo de falso amigo el que puede resultar más dificultoso.

\section{ESTUDIO EMPÍRICO}

Se llevó a cabo un estudio cuyo objetivo era averiguar el grado de percepción de la proximidad linguística de la lengua inglesa por hispanohablantes adultos con un nivel de inglés intermedio (correspondiente a B2 en el marco europeo para la enseñanza de lenguas.) Además de este objetivo, se planteó la posibilidad de comprobar en qué medida la proximidad lingüística podría causar problemas en el reconocimiento y uso de unidades léxicas sencillas que mostraban una similitud formal en el ámbito escrito, aunque con ausencia de equivalencia en el ámbito semántico, es decir, falsos amigos o cognados no coincidentes. De este modo se plantearon dos hipótesis:

a) Se espera que al reflexionar y autoevaluar su propio conocimiento de determinadas unidades léxicas simples enmarcadas dentro de la categoría «cognados no coincidentes» los perciban como 'conocidos' o 'fácilmente reco-nocibles' pero no sean capaces de proporcionar su significado correcto.

3. Esta autora señala que cuanto más técnico sea el texto, más se incrementará el porcentaje de cognados, pudiendo llegar en algunos textos científicos al $30 \%$. Consecuentemente, cuanto mayor sea la cantidad de cognados, más posibilidades existirán de que entre ellos haya falsos amigos. 
b) Se espera que los alumnos sean capaces de ordenar las lenguas indicadas a continuación de acuerdo con su proximidad linguística al español con un margen de error poco significativo. Las lenguas en cuestión son: alemán, catalán, inglés, italiano, japonés, noruego, portugués, quechua, y ruso. En otras palabras, cabe esperar que a pesar de algún error, los sujetos puedan ordenar las lenguas más cercanas al español por su origen románico como catalán, portugués e italiano.

Si se corrobora la primera hipótesis, una de las mayores implicaciones para la enseñanza/aprendizaje de lenguas consistiría en que:

a) Al afrontai el aprendizaje léxico de una lengua no matema, el aprendiz se apoya en las similitudes formales, le sean útiles o no, y la escala de evaluación seleccionada permitirá averiguar el grado de conocimiento que tienen los alumnos sobre estas palabras.

b) Es necesario incidir pedagógicamente sobre todos los falsos amigos para poder enseñar/aprender el significado correcto y no el que parece indicar la similitud formal. Por supuesto, además de otras unidades léxicas que no coinciden por tener un origen etimológico no compartido con la Ll.

Si se corrobora la segunda hipótesis podríamos argumentar que si el aprendiz de lenguas extranjeras sabe qué esperar en cuanto a proximidad lingüística (en el ámbito léxico, estructural, fonético-fonológico, etc.) de la lengua objeto de estudio hará uso de estrategias metacognitivas para sacar provecho a las semejanzas existentes.

\subsection{Descripción de las fases}

El estudio se llevó a cabo con un grupo de alumnos universitarios de primer curso de Filología Inglesa. Se distribuyó un cuestionario individual con el que se trató de conseguir toda la información personal y académica que fuese pertinente para la investigación. En el apéndice I se puede ver el modo en que se formuló la pregunta para la primera hipótesis.

\subsection{Descripción de la población}

El grupo total de treinta y seis participantes que fue elegido para formar parte del estudio resultó tener una edad media de 19.25 años de edad. Éstos habían estudiado la lengua inglesa formalmente en un entorno escolar durante un promedio de ocho años y su calificación media había sido de «bien» y «notable». 


\subsection{Descripción del estudio: Metodología y evaluación}

Para la autoevaluación del conocimiento de los alumnos con relación a la segunda hipótesis ser utilizó una versión adaptada de la escala de evaluación Vocabulary Knowlege Scale desarrollada por Paribakht y Wesche (1999). Para efectos prácticos me referiré a esta nueva versión de la VKS como la Adapted Vocabulary Knowledge Scale (AVKS). ${ }^{4}$ Véase apéndice II)

Se analizó la opción elegida por los alumnos en su autovaloración del conocimiento de las palabras clave. De este modo, se consideró que se podría obtener información relativa al modo en que evolucionaba la familiaridad del alumno con la palabra, así como su grado de confianza en lo que respecta a dicho conocimiento.

La opción número 1 fue elegida por 78 alumnos. Este resultado parece esperado pues esta opción indica que el alumno nunca ha oído o visto esta palabra con anterioridad. En lo que respecta a la opción 2, es decir, la palabra se ha visto u oído con anterioridad pero no se recuerda lo que significa, ésta fue tomada por 122 informantes. En lo relativo a la opción 3, esto es, el alumno advierte que ha visto $u$ oído la palabra clave con anterioridad e indica el significado que cree correcto, 233 de los alumnos tomó esta opción. Finalmente, en lo que respecta a la opción 4 el resultado fue de 546 (véase apéndice III).

Resulta pertinente destacar que según el gráfico presentado en el apéndice III, los aprendices hispanohablantes adultos de inglés con mucha frecuencia hacen uso de la estrategia de generalización excesiva presentada en la primera hipótesis. Además sobreestiman su conocimiento sobre las mismas al optar en mayor proporción sobre la opción 4 . En la que están seguros de conocer su significado e incluso proporcionan un ejemplo contextualizado. El análisis de los aciertos y los fallos nos permite comprobar que este supuesto conocimiento no es real y supone una sobrestimación del conocimiento propio.

\subsection{Percepción de la distancia linguiística}

En el cuestionario distribuido al comienzo del estudio se incluyeron dos preguntas (véase apéndice I). El propósito de éstas consistía en averiguar cuál era la percepción de los alumnos con respecto al inglés como lengua extranjera desde un punto de vista lingüístico. En la pregunta 1, se pidió a los alumnos que ordenasen una serie de lenguas que se proporcionaron (japonés, inglés, italiano, portugués, noruego, alemán, ruso, catalán y quechua) de acuerdo con su propia percepción de la proximidad lingüística al español. Es decir, el alumno debía

4. Para una explicación pormenorizada del proceso de adaptación de la vKs véase Chacón Beltrán (2003). 
ordenar de uno a nueve, siendo uno equivalente a la más parecida y nueve equivalente a la menos parecida. De este modo, las lenguas que obtuviesen mayor puntuación serían aquellas que el alumno percibe como más distantes y viceversa. Los datos globales que se han obtenido a partir de todos los alumnos participantes en este estudio (véase apéndice IV) indicaron que, erróneamente, los alumnos perciben la lengua inglesa como la más próxima al español, probablemente influidos por su propio conocimiento de la lengua inglesa. Otra posibilidad para explicar este fenómeno podría ser que los alumnos no hubiesen entendido correctamente la pregunta, a pesar de que ésta ya había sido comprbada en un estudio piloto previo. Éste no fue el caso pues se puede apreciar cómo los alumnos han situado las tres lcnguas romances ofrecidas entre las más próximas, mientras que algunas lenguas no indoeuropeas como el japonés y el quechua, una lengua eslava, el ruso, entre las más distantes.

Seguidamente, se preguntó a los informantes de entre las lenguas señaladas con anterioridad, cuáles creían que les supondrían mayor dificultad, siendo uno equivalente a menor dificultad y nueve equivalente a mayor dificultad (partiendo de la correlación «mayor distancia lingüística igual a mayor dificultad», en realidad se estaba realizando la misma pregunta a los alumnos pero de forma diferente). Los resultados expuestos en el apéndice $\mathrm{V}$ muestran cómo, de nuevo, los alumnos señalaron el inglés como la lengua más fácil desde su punto de vista. En este caso, es posible que los alumnos hayan vuelto a dejarse llevar por su conocimiento y contacto con la lengua inglesa. De nuevo, las lenguas romances están situadas en la primera mitad, a pesar de que se ha producido alguna variación importante como es el caso del noruego y del alemán que se han intercambiado entre la primera y la segunda mitad del gráfico. Nuevamente, las tres lenguas más distantes desde un punto de vista histórico-lingüístico, esto es, el ruso, el japonés y el quechua, se encontraban entre las percibidas como más difíciles, con lo cual se comprueba la correcta interpretación de la pregunta por los aprendices. Asimismo cabe destacar que, en este caso, haya una conrespondencia directa entre la proximidad geográfica de la primera mitad de las lenguas indicadas y el español (inglés, catalán, alemán, portugués e italiano).

Llama la atención la colocación de la lengua inglesa como menos difícil y menos lejana desde un punto de vista lingüístico. Cabe destacar, que los alumnos de este nivel, es decir, alumnos recientemente incorporados al primer curso de filología todavía tienen una formación filológica muy limitada y, por tanto, estos resultados corresponden a su percepción particular más que a su conocimiento de la linguística histórica. Por consiguiente, cabe esperar que los hispanohablantes aprendices de inglés de nivel intermedio hagan uso de la hipótesis de la equivalencia (Swan, 1997) y sean propensos a relacionar las palabras que muestren una similitud formal entre inglés y español, y estimen que, por asociación, también haya una relación semántica en mayor o menor medida. 


\section{CONCLUSIONES E IMPLICACIONES PEDAGÓGICAS}

La disponibilidad léxica en el aprendizaje de una LE viene determinada, al menos en parte, por la percepción del aprendiz de lenguas entre la L1 y la L2. Los resultados de la primera hipótesis muestran cierta tendencia a generalizar y asumir que las similitudes formales entre ambas lenguas son fiables y de ahí que en ocasiones se produzcan errores al encontrar falsos amigos. Por otra parte, esta tendencia a generalizar en la L2 es lo que nos permite como adultos aprender lenguas no maternas.

En lo que respecta al ámbito léxico en el aprendizaje de una LE, es preciso tener en cuenta que en multitud de ocasiones la similitud formal supone una gran ayuda. Por otra parte, puede ocurrir que el problema no venga determinado directamente por la naturaleza y el uso de unidades léxicas concretas sino más bien por la frecuencia de uso. En el caso de hispanohablantes que aprenden inglés, por ejemplo se suele apreciar en su discurso una alta frecuencia de palabras de origen latino en oposición a palabras de origen germánico que suelen ser más frecuentes en el lenguaje coloquial.

Otra cuestión que se podría destacar es que la falta de conocimiento metalingüístico sobre el origen de las lenguas y su relación histórico-lingüística puede distorsionar la percepción de los aprendices en la mediada en que esperen mayor cantidad de similitudes cuando en realidad no las hay.

Por lo que respecta a las implicaciones pedagógicas que se pueden extraer de este estudio, destacaríamos el hecho de que los aprendices busquen apoyo en las unidades léxicas que resultan familiares, cognadas, en el aprendizaje de una lengua extranjera. Los autores de materiales pedagógicos deberían tener en cuenta esta información y, de hecho, deberían potenciar el reconocimiento de unidades léxicas similares a la L1 por la ventaja obvia que supone para el aprendiz de lenguas no maternas. Del mismo modo, resulta pertinente destacar que es necesario incidir pedagógicamente sobre los falsos amigos para modificar las suposiciones del aprendiz y transformarlas en conocimiento real.

\section{REFERENCIAS BIBLIOGRÁFICAS}

ARnold, J. (1992): «Transferencia positiva y negativa en la lectura del inglés» en A. Bruton; J. Arnold (eds.) (1992): Lingüística aplicada al aprendizaje del inglés, Sevilla.

CHACÓN BeltráN, R. (2003): «La evaluación del léxico en inglés como L2: una escala para medir el desarrollo del conocimiento» en G. LuQue, A. BuENo; G. TEJADA (eds.) (2003): Las lenguas en un mundo global / Languages in a global world, Jaén, Servicio de publicaciones Universidad de Jaén. 
Eu, N. C; A. BfATON, (1993): «Factors affecting the leanng of toreign language vocabulary: Imagery keyword mediators and phonological shortterm memory», The Quarterly Journal of Experimental Psychology, 46A: $533-558$.

HOLMES, J. Y R. GUERRA RAMOS (1993): «False friends and reckless guesses:

Observing cognate recognition strategies» en T. HuCKIN, M. HAYNES Y J.

COADY (eds.) (1993): Second Language Reading and Vocabulary Learning, Norwood, New Jersey: Ablex Publishing Corporation.

KELEERMAN, E. (1995): "Crosslinguistic influence: Transfer to nowhere?», Anmal Review of Applied Linguistics, 15: 125-150.

LAurDR, B. (1990): "Sequence" and 'Order' in the development of 12 lexis:

Some evidence form lexical confusions», Applied Linguistics, 11/3:281-296.

LAUfER, B.; S. ELIASSON. (1993): «What causes avoidance in L2 learning: L1-

L2 difference, L1-L2 similarity, or L2 complexity?», Studies in Second Language Acquisition, 15/1: 35-48.

Moss, G. (1992): «Cognate recognition: Its importance in the teaching of ESP reading courses to Spanish speakers», English for Specific Purposes, 11: $141-158$.

OduN, T. (1989): Language Transfer: Cross-linguistic influence in language leaming, Cambridge, Cambridge University Press.

- (1996): «On the recognition of transfer errors", Language Awareness, 5/34: $166-178$.

PARIBAKHT, T. S.; M. Wesche. (1999): «Reading and "incidental" L2 vocabulary acquisition», Studies in Second Language Acquisition, 21: 159-224.

PHILIPSON, et al. (eds.) (1990): Foreign/Second Language Pedagogy Research, Philadelphia, Multilingual Matters.

RINGBOM, H. (1987): The role of the first language in foreign language, Clevedon, Multilingual Matters.

- (1990 a): «Crosslinguisitc lexical influence and foreign language learning» en R.

- $(1990 \mathrm{~b})$ : «Effects of transfer in foreign language learning» en H.W. DECHERT (cd.) (1990): Current trends in European second language acquisition research, Clevedon, Philadelphia.

- (1992): «On L1 transfer in L2 comprehension and L2 production», Language Learning, 42/1: 85-112.

SCHMrTT, N. (2000): Vocabulary in language teaching, Cambridge, Cambridge University Press.

SWAN, M. (1997): «The influence of the mother tongue on second language vocabulary acquisition and use», en N. SCHMITT; M. MCCARTHY (eds.) (1997): Vocabulary: Description, acquisition and pedagogy, Cambridge, Cambridge University Press. 


\section{APÉNDICE I}

1. Ordena las siguientes lenguas de acuerdo con su proximidad lingüística al español, es decir, cuáles de ellas se parecen más al español. Utiliza una escala del 1 al 9 (más parecida $=1$; menos parecida $=9$ ).

....... japonés
....... inglés
...... italiano

....... portugués
....... noruego
....... alemán
ruso catalán quechua

2. Supón que estás aprendiendo las siguientes lenguas extranjeras y que comienzas desde cero en todas ellas. ¿Cuáles crees que te supondrán mayor dificultad? Ordénalas de menor dificultad (=1) a mayor dificultad (=9).
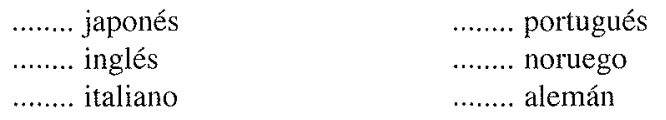
ruso catalán quechua

\section{APÉNDICE II}

IDIOM: Idioms are always difficult to learn.

I don't remember having seen and/or heard this word before.

I have seen and/or heard this word before, but I don't know what it means.

I have seen and/or heard this word before, and I think it means (synonym or translation).

I know this word. It means . (synonym or translation).

$\begin{array}{lll}\begin{array}{l}\text { Self-report } \\ \text { categories }\end{array} & \begin{array}{l}\text { Possible } \\ \text { scores }\end{array} & \text { Meaning of scores } \\ \end{array}$

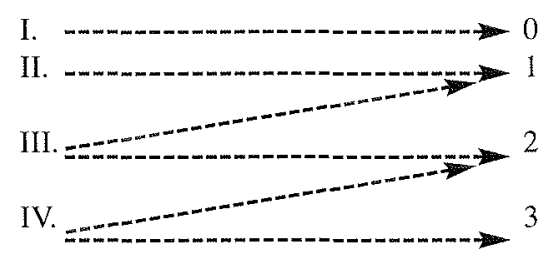

- The word is not familiar at all.

- The word is familiar but its meaning is not known.

- A correct synonym or translation is given.

- A correct synonym or translation is given, and the student is certain about it.

La interpretación de la AVKS responde a los siguientes criterios: la opción I obtiene 0 puntos, la opción II recibe 1 punto, la opción III toma 1 punto si la respuesta es incorrecta o 2 puntos si la respuesta es correcta. Finalmente, la opción 4 obtiene 3 puntos si la respuesta es correcta, pero 1 punto si no lo es. 


\section{AWENDICE III}

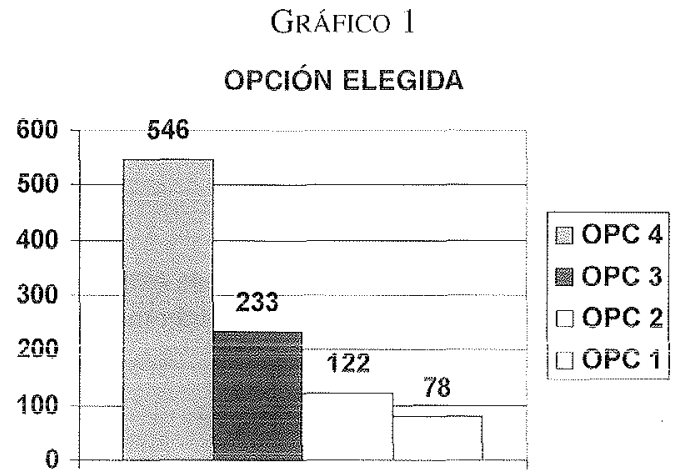

Análisis de aciertos y fallos.

Opción $4 \rightarrow 3$ puntos. 122 Aciertos / 424 Fallos

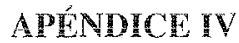

GRAFICO 2

PERCEPCIÓN DE LA DISTANCIÁ LINGÜISTICAA ÁL ESPÃNOL

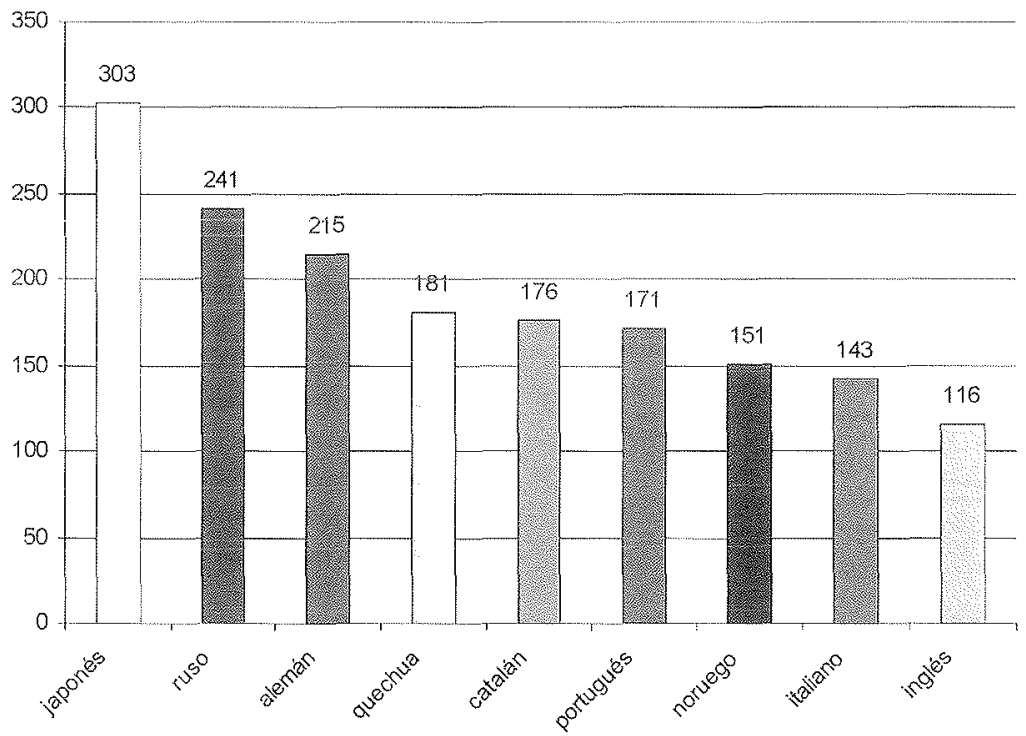




\section{APÉNDICE V}

GráfiCo 3

PERCEPCIÓN DE LA DIFICULTAD LINGÜÍSTICA

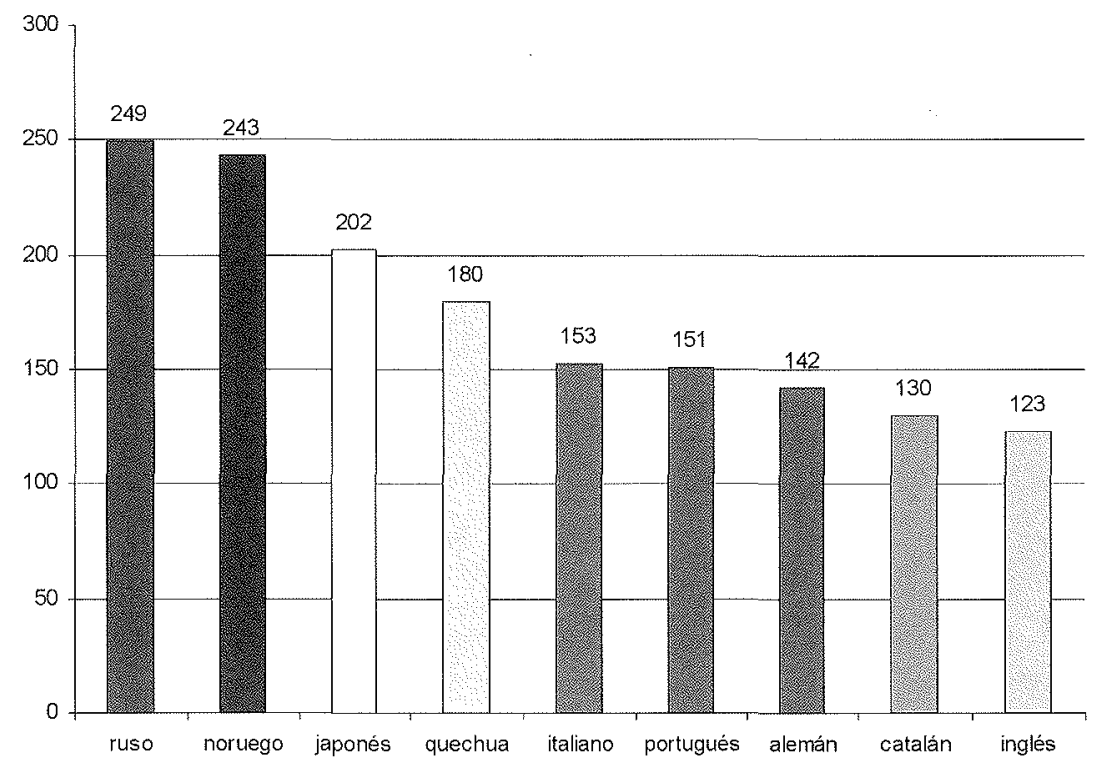




\title{
PROYECTO SOBRE LA DISPONIBILIDAD LÉXICA EN ALUMNOS PREUNIVERSITARIOS DE MELILLA ${ }^{1}$
}

\author{
Gérard Fernández Smith (Universidad de Cádiz) \\ Ana Ma Rico MarTín (Universidad de Granada)

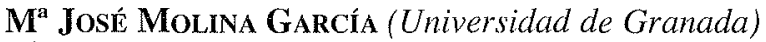 \\ Ma Ángeles Jiménez JiméNez (Universidad de Granada)
}

\section{INTRODUCCIÓN}

$\mathbf{E}$

$\mathrm{N}$ esta comunicación presentamos las líneas maestras de un proyecto de investigación en curso que estamos desarrollando en Melilla y que tiene como objetivo establecer el léxico disponible entre los alumnos preuniversitarios de esta ciudad y contribuir así a su descripción en el mundo hispánico, aportando nuevos resultados a las investigaciones ya realizadas en numerosos ámbitos geográficos. En lo que se refiere al marco teórico adoptado, el objeto de estudio en las investigaciones sobre disponibilidad léxica viene dado por la constatación de la existencia de un tipo de léxico, el léxico disponible, cuyo uso está contextualmente determinado, es decir, condicionado por el tópico de discurso, de manera que sus elementos pueden denominarse vocablos temáticos. Estas unidades registran, además, índices de frecuencia de uso distintos, por lo que la aplicación exclusiva del criterio de frecuencia no asegura un inventario preciso del léxico, sino que éste debe combinarse con el de disponibilidad (Carcedo González, 2001: 12). La suma de ambos criterios posibilita una decripción más exacta del repertorio léxico de una comunidad de habla, es decir, de lo que se denomina léxico fundamental de una lengua.

\section{EL PROYECTO SOBRE LA DISPONIBILIDAD LÉXICA EN MELILLA}

\subsection{Objetivos}

En consonancia con los objetivos generales que se describen en el proyecto panhispánico, planteamos en nuestro trabajo los siguientes objetivos específicos:

1. Este proyecto está subvencionado por la Consejería de Educación, Juventud y Mujer de la Ciudad Autónoma de Melilla, en su convocatoria de Proyectos de Interés General (BOME $1{ }^{\circ}$ 4087, de 18 de mayo de 2004) y se inserta asimismo en el «Proyecto panhispánico de léxico disponible», coordinado por H. López Morales. 
1) Determinar el léxico disponible en lus hablantes preuniversitarios de Melilla, con el fin de conocer sus particularidades lingüísticas así como el grado de penetración de extranjerismos (calcos, préstamos, etc.) en su variedad lingüística; 2) Delectar posibles deficiencias lingüísticas y ortográficas que permitan ayudar en su intervención docente a los profesionales de didáctica de las lenguas matema y extranjera; 3) Aportar información fiable para la adaptación rigurosa y justificada de los materiales curriculares y docentes para los alumnos de español como lengua materna (L1) y como lengua extranjera (L2) y para propiciar mejoras en niveles inferiores del sistema educativo español; 4) Servir de fuente de información a otras áreas de conocimiento, en el marco más general de los estudios de psicolingúistica, acerca del conocimiento de la estnictura del lexicón mental favorecido por pruebas asociativas como las de disponibilidad léxica, y 5) Calibrar, de forma indirecta y con las debidas modificaciones, el grado de exposición de los hablantes a los medios de comunicación social y audiovisuales, así como su permeabilidad frente al vocabulario empleado en estos ámbitos, lo que se relacionaría con campos de investigación más amplios como los de la etnografía, la antropología y la sociología.

\subsection{Metodología y plan de trabajo}

\subsection{Muestra}

De acuerdo con la metodología empleada en el proyecto panhispánico, la muestra será extraída en aquellos centros de enseñanza, públicos y concertados de la ciudad de Melilla, en los que se imparta el último curso de educación preuniversitaria. ${ }^{2}$ Puesto que se trata de un proyecto de investigción de sociolingüística aplicada, los informantes deben ser estratificados en función de ciertas variables: origen geográfico, sexo, nivel sociocultural de los padres (definido en función del nivel de ingresos, la profesión y los estudios), tipo de hábitat y tipo de centro educativo. De acuerdo con las indicaciones que hallamos en http://www.dispolex.com, se consideran obligatorias el origen geográfico, el sexo, la profesión y los estudios de los padres, el hábitat y el tipo de centro educativo. En este sentido, en la comunidad de habla de Melilla se presentan a priori ciertas particularidades, pues su hábitat es exclusivamente urbano y los centros donde se oferta el segundo curso de bachillerato son todos públicos excepto uno.

2. Como se sabe, la limitación en el factor edad persigue evitar la «contaminación» que los lenguajes de especialidad y léxicos profesionales podrían ejercer en las respuestas de los informantes. 


\subsubsection{Centros de interés}

Para llevar a cabo las pruebas asociativas controladas que posibilitan la aparición del léxico disponible, se emplean los dieciséis centros de interés básicos que servirán de estímulo para la obtención de datos lingüísticos, a saber: el cuerpo humano, la ropa, partes de la casa, los muebles de la casa, alimentos y bebidas, objetos colocados en la mesa para la comida, la cocina y sus utensilios, la escuela (muebles y materiales), calefacción, iluminación y medios de airear un recinto, la ciudad, el campo, los medios de transporte, los trabajos del campo y del jardín, los animales, juegos y distracciones y profesiones y oficios. Por supuesto, estos centros de interés son los que aseguran la homogeneidad del proyecto panhispánico pero no suponen en modo alguno un freno para el desarrollo de otros que, por razones diversas, pudieran resultar de especial relevancia en otras investigaciones. ${ }^{3}$

\subsubsection{Instrumentos de recogida de datos}

Siguiendo el modelo utilizado en todas las comunidades analizadas hasta ahora, la recogida de datos se realizará mediante una encuesta anónima que consta de dos apartados. En el primero de ellos, los informantes han de aportar datos personales relativos a las variables señaladas anteriormente (véase $\S 2.2 .1$.). Con todo, como ya se ha observado, este tipo de proyectos permite, por su flexibilidad, la inserción de variables adicionales que sean consideradas relevantes en investigaciones concretas. En el segundo de estos apartados, los alumnos encuestados proporcionarán de forma escrita, mediante pruebas asociativas, todos aquellos elementos léxicos que asocien con cada uno de los centros de interés. Éstos deben servir como estímulo para que el encuestado anote todas las unidades lingüísticas que le sugieren y, dado el carácter de la encuesta, basada en listas abiertas, tales unidades necesariamente implican la posibilidad de que aparezcan marcas comerciales, faltas de ortografía, extranjerismos, vulgarismos, etc., que habrán de someterse posteriormente a un protocolo ya

3. Esta cuestión ha fomentado interesantes apreciaciones por parte de los especialistas. Véanse, a modo de muestra, los comentarios de Carcedo González (2001: 32-34), Ayora Esteban (2003: 88-93) o Samper Padilla (2003: 196-202), entre otros. Pueden aducirse, descle luego, todo tipo de razones que justifiquen una modificación en la cantidad y la naturaleza de los centros de interés básicos. Éstas pueden ser razones prácticas, como el hecho de que hay centros más productivos que otros desde el punto de vista de sus promedios de respuestas o la cantidad de vocablos distintos; pueden ser puramente lingüísticas, como el deseo de obtener muestras de otras categorías lingüísticas además del sustantivo; o bien podrían obedecer a las particularidades propias del ámbito geográfico en el que se trabaja, ya que en determinadas zonas realidades como el mar o el campo resultan mucho más accesibles que otras. 
fijado de edición. ${ }^{2}$ Para la realización de esta prueba se la establecidu en todas las investigaciones desarrolladas en el marco del proyecto panhispánico un tiempo estándar de reacción de dos minutos para cada centro de interés. ${ }^{5}$

\subsubsection{Técnica de análisis}

Para el procesamiento de los datos recogidos utilizaremos la herramienta Dispolex, que puede encontrarse en la URL http://www.dispolex.com/. Existen otros medios informáticos, como es el caso de LexiDisp, programa pionero desarrollado por J. E. Moreno y A. García de las Heras, con el asesoramiento de F. Moreno (Moreno, Moreno y García de las Heras, 1995, para una breve sintesis de su funcionamiento). Todos ellos se basan en una fórmula matemática desarrollada por J. López Chávez y C. Strassburger Frías de cuyo funcionamiento puede hallarse nutrida información en la bibliografía sobre disponibilidad (véanse, por ejemplo, González Martínez, 2002: 9-10 o Samper Padilla, 2003: 207-209). Por su parte, la herramienta Dispolex tiene la ventaja de que, además de admitir un mayor número de centros de interés y de variables, ofrece la posibilidad de comparar investigaciones diferentes. Particularmente, este propósito unificador justifica esencialmente la creación de la mencionada página web, de la que son responsables J. A. Bartol y N. Hernández, de la Universidad de Salamanca.

\subsubsection{Mlan de trabajo}

Las fases y la temporalización previstas para el desarrollo de esta investigación son las siguientes: a) Fase 1: Diseño de las encuestas de disponibilidad léxica y recogida de datos lingǘsticos en los centros de enseñanza donde se imparten cursos de bachillerato (primer trimestre del curso 2004-2005); b) Fase 2: Procesamiento de los cuestionarios mediante el programa Dispolex. Análisis e interpretación de los datos, conclusiones y comparación con otros trabajos en esta línea (segundo y tercer trimestres del curso 2004-2005) y c) Fase 3: Divulgación de los resultados en el conjunto del proyecto panhispánico (curso 2005-2006).

4. Debe destacarse la importancia de contar con criterios estandarizados de edición, pues una parte muy relevante del procesamiento de los datos se basa en su tratamiento homogéneo (Samper Padilla, 1998).

5. Deben ser cumplimentados sucesivamente, sin que se pueda en ningún caso volver atrás, ni rellenar el siguiente centro antes de que transcurran los dos minutos del anterior, porque el orden de aparición de los elementos léxicos determina el índice de disponibilidad. Es esencial que la encuesta sea cumplimentada en absoluto silencio, con el fin de evitar conentarios e intervenciones por parte de los alumnos que podrían inducir a sus compañeros a responder de manera diferente a como habrían pensado de manera espontánea. 


\section{CONTEXTO SOCIOLINGÜÍSTICO DEL PROYECTO EN LA CIUDAD DE MELILLA}

En Melilla, con tan sólo $12 \mathrm{Km}^{2}$ de extensión y 68.463 habitantes, según el censo de 2003, conviven desde finales del siglo XIX cinco grupos culturales que mantienen en su seno y en distinta medida sus costumbres y rasgos lingüísticos propios. Los grupos mayoritarios son dos, el formado por un colectivo de antigua procedencia peninsular (desde 1947) que constituye el $60 \%$ de la población total, y el de ascendencia rifeña o bereber que supone poco menos del $40 \%$ aunque su número aumenta cada año. Los grupos minoritarios son el judío, el gitano y el hindú. Del colectivo primero, originario de España, poco puede decirse, teniendo en cuenta que es el más conocido, de lengua materna española y dedicado preferentemente al sector de servicios.

Los melillenses de origen bereber y religión islámica comenzaron a asentarse en la ciudad a partir de la guerra de Margallo (1893-94), aumentando su número tras la gran hambruna rifeña de 1940 (Moga y Raha, 2000: 182) y en los años ochenta, con la nacionalización facilitada por el Gobierno espanol. Aunque este grupo étnico ha sido el más desfavorecido durante aftos y con problemas de integración en nuestra sociedad, en la actualidad su crecimiento económico es importante, siendo su dedicación preferente la comercial y empresarial. Su cultura, la amazige o mazigia, es muy antigua y vasta; vigente durante diez milenios en la geografía mediterránea, se ve cada vez más mermada a causa de la arabización de sus miembros. Hoy está circunscrita al espacio medio y norteafricano y al de la diáspora occidental de las migraciones. La lengua mazigia -tamazight para ellos- se divide en multitud de dialectos, de los que los musulmanes melillenses tienen como lengua materna el taqer'act, propio de la zona circundante a Melilla pero incluido en el habla de las montañas del Rif, el tarifit. Los hebreos melillenses son sefarditas y proceden sobre todo de Marruecos. Apenas superan el 1\% de la población melillense, lo que les hace ser muy celosos de sus tradiciones culturales. $\mathrm{Su}$ dedicación profesional es ante todo comercial. La antigua lengua hebrea, que resurgió como idioma moderno en Palestina en el siglo XIX, no es la lengua materna de este grupo, a pesar de que la estudian desde los tres años de edad en el Talmud-Torá de la ciudad como lengua de liturgia y de folclore. El colectivo gitano está compuesto por unas ochenta familias dedicadas a la venta ambulante. Conservan su estructura social originaria, reivindicada cada vez con más fuerza. La lengua patrimonial del grupo, procedente de la variante popular del sánscrito denominada prácrito, es el caló o romaní. No es tampoco su lengua materna pues sólo la conocen los miembros más ancianos de la comunidad, mientras que entre los demás su uso es muy exiguo y se reduce a 
voces y expresiontes pupulares. El colectivo hindí, el menos numeroso con apenas una veintena de miembros, mayormente comerciantes, procede de la provincia pakistaní de Sind y su lengua patrimonial es el sindi, del subgrupo indo-iraní de la familia indoeuropea. Esta lengua es desconocida para los miembros más jóvenes y sólo la emplean los mayores de la comunidad en el ámbito doméstico y religioso.

En este marco cobra especial interés en Melilla la situación lingüística del colectivo bereber, el único que tiene una lengua materna diferente a la española y que, además, es oral, pues sus hablantes desconocen la escritura tifinagh o la moderna neo-tifinagh, lo que repercute en el aprendizaje del español escrito. Una situación de bilinguismo precoz sucesivo de tendencin diglósica añadida muchas veces a circunstancias sociales desfavorables provoca que el fracaso escolar de este grupo sea muy importante, sobre todo si estos alumnos viven en barrios donde constituyen la única población y donde, consecuentemente, la lengua hablada en su entorno es la mazigia. De esta forma, las interacciones comunicativas con otros grupos sociales se reducen al ámbito escolar y a algunos encuentros extraescolares, lo que no es suficiente para garantizar la integración cultural y lingüística de este sector de la población. Por ello no es difícil comprender que estos jóvenes bereberes empleen elementos o estructuras de su lengua nativa para hablar la que adquicren en segundo lugar.

\section{MMULICACTONES DUDÁCTICAS DEL PROYECTO EN LA LNSENANZA DE LENGUAS MATERNA Y EXTRANJERA}

Aunque tradicionalmente no se le ha prestado la atención debida a la enseñanza del vocabulario, con los métodos basados en la comprensión (como el Natural Approach, de los años ochenta) este aspecto adquiere importancia, especialmente cuando se trata de una segunda lengua. De este modo, la adquisición de un vocabulario adecuado es esencial para usar la segunda lengua correctamente porque sin un vocabulario extenso seríamos incapaces de utilizar las estructuras y funciones aprendidas para comunicarnos (Rivers, 1983). Aprender vocabulario no sólo implica conocer una palabra y el objeto al cual hace referencia sino que adquirirlo correctamente implica otra serie de aprendizajes como son el conocer los límites semánticos de dicha palabra y las relaciones que puede establecer con otras palabras de significado muy similar; también implica el conocimiento de las relaciones sintácticas y morfológicas del vocabulario que estamos aprendiendo y, por tanto, las reglas que nos permiten la formación de otras palabras partiendo de la primera (composición, derivación, etc.). Cuando se trata de la enseñanza-aprendizaje de una segunda 
lengua no debemos olvidar, además de todo lo ya señalado, la importancia de la pronunciación y de la ortografía. Tampoco hemos de omitir que en el aprendizaje de determinadas palabras podemos encontrarnos con una serie de implicaciones actitudinales y emocionales. Por ejemplo, Pérez Martín (1995: 335) afirma que el significado afectivo se muestra a través del uso de vocablos que, intrínsecamente, tienen connotaciones positivas o negativas y que dicho significado depende de la actitud del hablante y de relaciones socioculturales. ${ }^{6}$

La enseñanza-aprendizaje del vocabulario sugiere determinadas cuestiones sobre las que debemos reflexionar antes de planificar. ¿Cuántas palabras nuevas debemos seleccionar por lección o por unidad? ¿Qué criterio hemos de seguir para dicha selección? ¿De qué forma presentamos el vocabulario para ayudar al alumno en su adquisición? Si bien uno de los criterios que se han seguido para la selección del vocabulario ha sido el de la frecuencia, no podemos obviar otros aspectos importantes como son los intereses de los alumnos o la utilidad y relevancia del mismo. ${ }^{7}$ En este sentido, los términos seleccionados deben ser útiles para que, de forma casi inconsciente, el vocabulario aprendido por el alumno pueda pasar a formar parte de su repertorio de uso, de ahí la relevancia del léxico disponible, por su carácter de vocabulario temático. En cuanto a la presentación y organización del vocabulario seleccionado, parece haber acuerdo en que éste ha de ser enseñado de forma contextualizada. De este modo, los alumnos desarrollarán una serie de estrategias que les permitirán inferir el significado de palabras nuevas de su contexto en vez de aprender una serie de listas de vocabulario descontextua-lizado. Otro aspecto que hay que tener en cuenta es que las distintas agru-paciones de las palabras (sinónimos, antónimos, hipónimos, complementarios, etc.) facilitan la adquisición del vocabulario en el sentido de que se aprenden más términos y, además, ayudamos al alumno en su memorización.

Seguidamente proponemos algunas técnicas, recursos o estrategias para trabajar el léxico, distinguiendo tres niveles según la situación de partida del alumno. Dada la fase inicial en que se halla nuestra investigación, no podemos sino establecer algunas pautas generales acerca de la enseñanza-aprendizaje del vocabulario, aspectos en los que el léxico disponible puede proporcionar un apoyo fundamental. Debe, pues, entenderse esta propuesta en términos generales, aplicable por ello tanto a la enseñanza-aprendizaje de la lengua

6. Por tanto, este tipo de aspectos habrá de observarse en un contexto determinado, como el que proporciona cada uno de los centros de interés que se emplean para la obtención de indices de disponibilidad léxica.

7. Fue precisamente la insuficiencia, desde el punto de vista de la enseñanza de lenguas, del criterio de frecuencia lo que animó a los iniciadores de los estudios de disponibilidad, $R$. Michéa y G. Gougenheim, a desarrollar en las décadas de los cincuenta y los sesenta estos conceptos y técnicas lexicométricas. 
matema como a la de lenguas extranjeras, asi como a niveles diferentes del currículum escolar. Se trata de acentuar la importancia que desempeña la contextualización del vocabulario en la enseñanza. ${ }^{8}$ Para ello, se debe partir de temas cotidianos como vacaciones, compras, salud, alimentación, viajes, etc., que, al igual que los centros de interés en esta investigación, actúan como estímulo y como instrumento para organizar el vocabulario, en la forma de un aprendizaje significativo. Así, mediante la puesta en práctica de distintas situaciones de comunicación, se abordan aspectos diversos como la tipología textual, el uso de estructuras gramaticales y el vocabulario alusivo, en los que el léxico desempeña una función decisiva (Fernández Smith, 2005, acerca de la cohesion léxica). Las técnicas y recursos debcrín ser adaptados por los profesionales docentes a sus necesidades concretas en el aula. Veamos ahora algunos ejemplos concretos de aplicación:

En un nivel inicial la asociación con imágenes y sonidos, los puzzles o la utilización de frases con el mismo término pero que expresan significados distintos, inducen a la práctica de las relaciones paradigmáticas y fenómenos semánticos, mediante actividades como adivinanzas cuyo contenido y significado difieren pero cuya solución es la misma palabra, la determinación de sinónimos entre series de palabras, reemplazar una frase por un verbo o las series de intensidad (por ejemplo feo, horrible, monstruoso). Las agrupaciones por clases o según criterios sencillos permiten trabajar con campos semánticos, léxicos específicos y relaciones sintagmáticas y paradigmáticas, en actividades como la lluvia de ideas o los murales. Los campos asociativos o «constelaciones» (Pastora Herrero, 1990: 156) suponen una estrategia para multiplicar las relaciones entre las palabras de una lengua con la que, además, * fomenta la creatividad. El diálogo y la conversación con el alumno posibilitan el método asociativo mediante preguntas que emparejen la acción y su agente, acción e instrumento, acción y objeto, etc., o que provoquen intencionadamente respuestas como el lugar de la acción, el objeto y su materia, el todo y sus partes, y mediante actividades de delimitación de actos sucesivos por orden lógico, cronológico u operativo o de identificación de cualidades y defectos. La utilización de imágenes, ilustraciones o fotos como punto de partida de descripciones y narraciones o para detectar diferencias es particularmente estimulante en este nivel, pues facilitan la evocación de otras imágenes y sucesos, así como la descripción de emociones, sentimientos,

8. Más específicamente, un enfoque como el método de tareas (Zanón [coord.], 1999) puede servir como medio para aprovechar en todos sus aspectos la guía dicłáctica que exponemos. Desde esta perspectiva metodológica, en la que la contextualización, los usos y las finalidades comunicativas resultan fundamentales, la búsqueda de una meta constituye el motor de la actuación. 
percepciones y entornos. No debemos descartar el empleo de trabalenguas, cuentos incompletos y sobre todo juegos, por ejemplo, con recetas sencillas de cocina y sus ingredientes, de encadenamientos de palabras que pertenezcan a un mismo grupo ideológico o temático, listas, etc.

En un nivel medio continúa el trabajo de relaciones sintagmáticas en sus variados aspectos y pueden introducirse actividades de formación de palabras (composición, derivación, prefijos, sufijos, aumentativos, diminutivos, etc.). Es importante el contacto con el diccionario mediante juegos en los que haya que buscar una palabra misteriosa o convertir una frase en extravagante a través de sinónimos. Pueden aprovecharse recursos que nos brinda la propia realidad como rompecabezas de palabras, cócteles y sopas de letras, palabras cruzadas y otros diseñados de forma más específica, como el del tiro al dado en el que ha de formarse una palabra según un criterio prefijado o el de palabras encadenadas por grafías o sílabas. Se recomienda comenzar en este nivel a crear pequeños textos como poesías por asociación de palabras o con recortes de titulares de periódicos.

Finalmente, en un nivel superior, las relaciones sintagmáticas y paradigmáticas pueden practicarse con textos literarios y/o extraídos de los mass media. Los temas tratados han de ser actuales y de interés como descripciones físicas o psíquicas, emociones y sentimientos, el entorno, los delitos, el trabajo, los deportes, la cocina, las artes, los viajes, los países y nacionalidades, el ocio, la naturaleza, etc. En el caso de los deportes podemos elaborar listas en las que se especifique el uniforme y elementos necesarios para uno determinado, plantear jeroglíficos cuya solución se base en el vocabulario de este ámbito, o adivinar la falsedad o veracidad de una afirmación aplicada a éste. Respecto a la cocina, pueden llevarse a cabo actividades en las que se trata de adivinar el nombre de una fruta u hortaliza por las pistas dadas, trabajar familias de palabras o hiperónimos, establecer correspondencias entre los recipientes y envases con el contenido respectivo y emplear modismos propios de este ámbito (Montaner Montava, 1999).

\section{CONCLUSIONES}

En consonancia con los objetivos que nos hemos propuesto en esta investigación, los resultados que esperamos obtener deben, en primer lugar, contribuir, mediante la edición de un repertorio del léxico disponible de Melilla, a la comparación con otras comunidades de habla del español, y, en segundo lugar, dejar constancia de las particularidades linguísticas propias de la situación geográfica y sociocultural de esta ciudad. Desde este punto de vista, la descripción del léxico fundamental de nuestra lengua será más precisa 
a medida que los diferentes equipos integrados en el proyecto panhispánico concluyan sus trabajos en otras zonas geográficas. El análisis complementario de los vocablos disponibles y los índices de frecuencia que constituyen el léxico básico debe producir una descripción más cercana a la realidad lingüística en el mundo hispánico. Ahora bien, con independencia de que el proyecto panhispánico y la publicación de los resultados de nuestra investigación obligan al uso de criterios de edición homogéneos, también es cierto que los datos «en bruto» ofrecen indudables posibilidades de aplicación en el ámbito de estudios parciales. En este sentido, consideramos de especial interés la utilidad de tales trabajos en el ámbito de la enseñanza de lenguas, tanto materuas como extranjeras. Así, por ejemplo, los datos que podamos extraei acerca de la incidencia de extranjerismos en el léxico de los hablantes melillenses, o de la influencia que ejercen sobre éstos los medios de comunicación social, nos permitirán, en suma, contribuir a la elaboración de materiales didácticos útiles para los profesionales docentes, con el fin de paliar, en alguna medida, los déficits linguísticos que se observen tras el procesamiento de las encuestas.

\section{REFERENCIAS BIBLIOGRÁFICAS}

Ayora Esteban, $\mathrm{M}^{a}$ C. (2003): Disponibilidad léxica en Ceuta: aspectos sociolingüisticos, tesis doctoral, Sevilla, Universidad de Sevilla, en prensa.

Carcedo González, A. (2001): Léxico disponible de Asturias, Turku, Universidad de Turku.

Fernández SMITH, G. (2005): «La cohesión léxica y sus implicaciones para la semántica del texto», en WotJak, G. y J. CUARTEro OTÁ (eds.) (2005): Entre semántica léxica, teoría del léxico y sintaxis. Studien zur romanischen Sprachwissenschaft und interkulturellen Kommunickation, Frankfurt am Main, Peter Lang, 123-131.

GonzÁlez Martínez, A. E. (2002): La disponibilidad léxica de los alumnos preuniversitarios de la provincia de Cádiz, Cádiz, Universidad de Cádiz.

Moga Romero, V. y R. Raha Ahmed (2000): Estudios amaziges. Substratos y sinergias culturales, Melilla, Servicio de Publicaciones de la Ciudad Autónoma.

MONTANER MONTAVA, M. A. (1999): Juegos y actividades para enriquecer vocabulario, Madrid, Arco/Libros.

Moreno, F; J. E. Moreno; A. García de las Heras (1995): «Cálculo de disponibilidad léxica. El programa LexiDisp», Lingiiística, 7: 243-249. 
Pastora Herrero, J. F. (1990): El vocabulario como agente de aprendizaje, Madrid, La Muralla.

Pérez Martín, M. C. (1995): «Linguistic and Communicative Competence», en McLaren, N. y D. Madrid (eds.) (1995): A Handbook for TEFL, Alcoy, Marfil, 313-343.

Rico MartíN, A. M. (2002): «Panorama lingüístico de una ciudad multicultural y acciones educativas tomadas al respecto», en MORENO Rivas, M. y Ma Escribano Pueo (coords.) (2002): TADEA. Seu Liber de Amicitia, Granada, Departamento de Didáctica de la Lengua y la Literatura de la Universidad de Granada, 273-286.

RIVERS, W. (1983): Communicating Naturally in a Second Language, Cambridge, Cambridge University Press.

Samper Padilla, J. A. (1998): «Criterios de edición del léxico disponible: sugerencias», Lingüística, 10: 311-333.

- (2003): «Aportaciones del proyecto panhispánico de disponibilidad léxica», en CASAS Gómez, M. (dir.) y C. VARo VARo (ed.) (2003): VII Jomadas de Lingüística, Cádiz, Universidad de Cádiz, Madrid, Edinumen. 193-225.

ZANóN, J. (coord.) (1999): La enseñanza del español mediante tareas, Madrid, Edinumen. 


\title{
LA DISPONIBILITAT LÈXICA \\ A VALÈNCIA: CRITERIS D'EDICIÓ
}

\author{
Begoña Gómez Devís \\ Francesc Llopis Rodrigo \\ Universitat de València
}

$\mathbf{L}$

A present comunicació pretén apropar a la comunitat científica reunida en aquest congrés els interessos i les propostes dels investigadors del grup LEXVAL de la Universitat de València. ${ }^{1}$

L'estudi del lèxic des de la vessant quantitativa ha sofert constants revisions des dels seus inicis, allà per 1950 a França. Els reajustaments epistemològics, teòrics $\mathrm{i}$ metodològics han estat nombrosos i necessaris en el seu desenvolupament: des de les llistes de frequiència passant pels lèxics bàsics fins la disponibilitat lèxica.

Actualment, els resultats obtinguts en els treballs de lèxic disponible representen el repertori lèxic d'una llengua en la comunitat lingüística treballada, és a dir, mostra el cabdal lèxic actualitzat pels parlants en una situació comuni-cativa determinada.

Les aplicacions d'aquesta mena d'estudis poden ser de diversa índole, sociolingüística, psicolingüística, dialectològica, etc. Pel que fa als nostres interessos, parlem en primer lloc, de la planificació lèxica en el procés educatiu dels alumnes de llengua materna i de la selecció i gradació lèxica en l'ensenyament de llengua estrangera. En segon lloc, cal la comparació interdialectal per tal d'aconseguir la norma lèxica, i per últim, l'anàlisi dels repertoris lèxics com reflex de la cultura de la comunitat de parla.

Així doncs, d'acord amb les pretensions anteriorment exposades, la població objecte d'estudi ha estat els estudiants preuniversitaris de les comarques valencianoparlants de València que durant l'any 2003-04 han cursat $2 n$ de batxillerat tant en centres públics com privats.

L'àmbit geogràfic estudiat comprén diverses comarques de València: Camp de Morvedre, Camp de Turia, l'Horta, la Ribera Baixa, la Ribera Alta, la Safor, la Costera i la Vall d'Albaida.

El tipus de prova escrita que han realitzat els informants ha considerat en la primera pàgina les dades sociològiques de cada individu i, en la resta té lloc el recull del lèxic disponible, organitzat en divuits blocs o centres d'interés amb el temps controlat, dos minuts i llista oberta.

1. Aquest grup d'investigació està integrat en el projecte patrocinat per la Generalitat Valenciana (Ref. GV 2004-B-762) 'Análisis léxico del castellano y del valenciano en la comunidad bilingüe de Valencia'. 
En l'actualitat. tudhon que es dedique a l'estudi de la disponibilitat lèxica assumeix que, tant el procés de recollida com el posterior tractament del corpus recollit, ha de mantenir unes normes d'actuació per tal que els resultats obtinguts siguen comparables amb els d'altres investigacions. El nostre cas no ha estat una excepció, coneixem i participem dels acords del projecte panhispànic relacionats amb els criteris d'edició:

- eliminació de termes repetits;

- correcció de l'ortografia;

- unificació ortogràfica;

neutralització de variants merament flexives;

- unificació de diminutius, augmentatius i derivats;

- ús del parèntesis perquè s'han unificat les formes plenes i cls escurçaments;

- acceptació de les marques comercials sota la forma minúscula i asterisc a final de paraula;

- omissió dels articles en les entrades i

- els compostos sintagmàtics s'han unificat en l'entrada que comptava amb un major índex de disponibilitat.

No obstant, la realitat lingiística amb la que treballem (dues llengües en contacte) ens proporciona nous entrebancs a l'hora d'editar els materials; d'un costat obtenim una gran quantitat d'interferències del castellà en el català de València i, d'altre, apareixen una gran quantitat de combinacions en els compostos sintagmàtics i creacions lèxiques molt particulars (mesita de nit; felput, rejes, abogat).

A més a més, una vegada ajustats els materials recollits a les pautes anterioment esmentades, és a dir, agrupades les diverses variants d'un vocable en un únic lema (substantiu: mascuí, singular; verb: infinitiu), ens trobem amb sifuacions difícils, bé per mantenir la distinció de les formes homògrafes que responen a conceptes diferents (forca-forca / cassola-cassola), bé per mantenir el plural d'alguns mots perquè es tracta d'un altre concepte (pit-pits). Per altra banda, l'estandardització del català és un problema afegit en l'edició dels nostres materials.

L'estudi de la disponibilitat lèxica del valencià ${ }^{2}$ ha de tenir en compte el fet que l'estàndard català siga polimòrfic, çò és, que contempla les diferents varietats dialectals. És un poliformisme que es reflecteix no tan sols oralment, sinò també gràficament (tinga/tingui, seua/seva) segons les diferents modali-

2. Quan parlem de valencià, ens referim a la varietát dialectal del català occidental parlada al País Valencià. 
tats que el componen. La situació actual de l'estàndard català es basa en el policentrisme, on hi ha diversos models d'estàndard, i cada model accepta trets (fònics, ortogràfics, lèxics i gramaticals) característics de cada varietat diatòpica.

Així doncs, ens trobem davant d'uns subestàndards o paraestàndards ${ }^{3}$ regionals en la llengua catalana, cosa que ens duu al fet de mantenir totes les variants formals de la llengua. El que ocorre és que l'espai geogràfic que ens ocupa, les comarques valencianoparlants de València, tenen un referent que és el paraestàndard regional del valencià dins del català occidental.

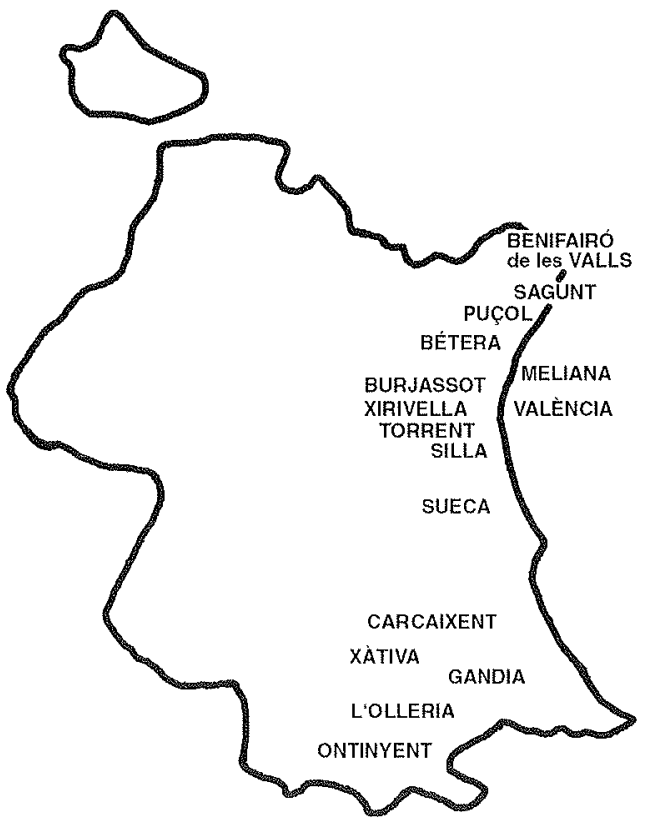

MAPA 1. Localitats dels Instituts i col-legis on s'ha realitzat l'enquesta

3. Per a Marí (1992) en el català no hi ha, pròpiament, diferents estàndards del català, cadascun amb un territori exactament definit i diferent dels altres, sinó un sol estàndard anb variacions regionals, fins i tot locals, de distribució geogràfica desigual. A més rebutja les denominacions de subestàndard o paraestàndard perquè indueixen a creure que hi ha un unic estàndard regional (el de la zona central) i en un graó inferior, diversos subestàndards o paraestàndards (versions degradades o subproductes del primer).

E. Casanova (2004) referint-se al lèxic, pensa que seria millor un estàndard general referencial de tot el domini lingüístic que permetera l'elecció i l'intercanvi de vocables segons zones, i així a la llarga qualsevol usuari s'acostumaria a entendre de forma passiva un mot de la zona que fóra. A més l'usuari arribaria a parlar de manera més natural possible, sense preocupacions i fent només les mínimes adaptacions per ser millor entés o acceptat segons àmbit i registre. 
Davant el dubte, unifiquen a una sola witat léxica (en el noste täs la més pròxima al dialecte valencià) o les deixem totes, ja que la llengua no hi entén de fronteres? Segons el nostre parer, el més convenient és deixar totes les variants formals, entre d'altres motius, per possibles estudis dialectològics i etnolinguiístics. A més, aquesta decisió ens permetrà establir possibles causes socials per al predomini de determinades variants, no pròpies de la nostra àrea d'estudi (nadar-nedar).

Però malgrat les dificultats anteriors, ens trobem davant d'un problema que tenen aquests estudis, es tracta de la freqüentíssima aparició del fenomen de la interferència. ${ }^{4}$ La majoria de mots que han penetrat al català han vingut de la llengua espanyola tant manlleus de forma (mots de procedència diversa amb algun defecte de forma causat per la interposició de l'espanyol (billar, cocodril), com manlleus semàntics: deures «tasca escolar»; tallat «café trencat amb un poc de llet», etc.

A més, el pes dels informants bilingües juga un paper important. És evident que el contacte lingüístic possibilita l'aparició de diversos fenòmens en el seu discurs com a resultat de la seua familiaritat amb més d'una 1lengua (Weinreich, 1953; Etxebarria, 1995), fets que en ocasions no són fàcilment classificables. En un principi, la primera característica del bilingüe és la seua capacitat de mantenir separats els dos codis lingǘstics. Pèò la separació de codis no és sempre completa $i$ de vegades ocorre que el bilingüe quan empra una de les llengües incorpora elements de l'altra. Aquest resultat es denomina «barreja de codis» (code mixing).

Generalment, en la parla espontània dels bilingües apareix una transferència d'elements tals com els préstecs lingüístics (elements fònics, lèxics, morfològics, sintàctics o pragmàtics d'una llengua que s'incorporen en l'ús espontani de l'altra) i interferències. La interferència es diferència del préstec lingüístic en què comporta la producció de missatges, en els que apareixen barrejats elements d'una i altra llengua i construccions idiosincràtiques, prođucte d'una confusió entre les regles gramaticals d'ambdues llenguies. Gómez Molina (1999-2000), afirma que es pot establir una distinció entre la interferència i el préstec per una

4. El terme interferència fou creat per a referir-se expressament a situacions de bilingüisme, concebut des d'una perspectiva interdisciplinar (Lingüística, sociològica, psicològica ...). Però donada la forta connotació d'agramaticalitat present en el concepte d'interferència desenvolupat per Wcinreich (1953) i la concepció peiorativa del bilingüisme que implicava aquest terme, alguns autors proposaren (entre ells Clyne, 1967), la noció de transferència, considerant-la aplicable a qualsevol nivell de l'ànalisi linguística.

Per a Silva-Corvalán (1994) la transferència és considerada com una categoria superior que aglutina diversos fenòmens del contacte linguístic, entre ells la interferència i el préstec. 
banda i el canvi de codi per altra, a partir dels criteris d'integració lingüística i social. ${ }^{5}$

Els estudis sobre la interferència han estat molt prolífics a les zones on hi ha llengües en contacte. S'han fet nombroses apreciacions i classificacions ${ }^{6}$ que nosaltres no comentarem per raons de temps $i$, sobretot, perquè el nostre objectiu no és fer un estudi teòric sobre classificacions de transferències entre llengües, sinó que ho simplificarem en allò que realment ens interessa, la interferència lèxica i semàntica.?

Nosaltres parlarem d'interferència en el sentit que atorga Payrató (1985), però amb lleus modificacions, és a dir, entenent com interferència la desviació que es produeix al si dels bilingües, però també afecta als unilingües perquè les reben i transmeten respecte de les normes d'alguna o de les dues llengües que concorren en la seua interacció comunicativa quotidiana.

La problemàtica, com ja hem apuntat abans, rau fonamentalment en el fet d'acceptar o unificar les diverses variants formals estandarditzades de la llengua catalana i què fer amb els diferents tipus d'interferències. Pel que fa a aquestes últimes proposem analitzar-les de manera individual i pormenoritzada ja que el fet de la seua aparició en els materials lèxics mostra si la interferència és acceptada socialment i forma part del vocabulari habitual d'un grup determinat o del conjunt de la societat. Tanmateix, creiem necessari el debat i la discussió per tal d'aconseguir la norma lèxica del català parlat a València.

En el cas de l'estandardització el tractament és el següent:

nadar/nedar
petita/xicoteta
ametler/ametller
enciam/encisam
noi/xic
mongeta/fesol
xocolate/xocolata

forqueta/forquilla
calcer/calçat
cargol/caragol
llanda/llauna
patata/creïlla
traupuntes/treupuntes
mànega/màniga

5. Haugen (1953) ja diferencià el concepte de canvi de codi del d’interferència i integració, al senyalar que aquestes poden apropar els dos codis mentre que el canvi els manté separats..

6. La classificació de la interferència en català ha estat estudiada per molts lingüistes i des de diverses perspectives metodològiques: R. Cerdà (1967), G. Colon (1976), Ll. López del Castillo (1984), J. R. Gómez Molina (1986, 1999-2000); Ll. Payrató (1985) i J. L. Blas (1993) entre d'altres.

7. Weinreich (1953) quan parla d'interferència lèxica, diu que també és semàntica, perquè hi ha dos tipus de préstecs en aquest nivell:

a) Un de lèxic, quan un lexema de la llengua $A$ passa a la B. com ocorre amb jefe.

b) Un de semàntic, quan un lexema de la llengua $\mathrm{B}$ adopta un semantema de la $\mathrm{A}$, el qual el pot substituir totalment o afegir-hi un nou significat. Per exemple fulla, amb el sentit de full. 
Al nostre parer, sera convenient mantenir les diferents varants tormais per veure com l'escolarització afecta a l'ús formal i estàndard de la llengua.

En relació als nombrosos casos d'interferència ens adonem que el grau de penetració del castellà en el català de València és molt elevat" $i$, com a conseqüència, a l'hora d'editar el repertori lèxic ens trobem amb un gran nombre de lemes que ni són castellà ni valencià (abogat, amarill, mesita de nit, ull de buey).

A més, la dificultat consisteix a tipificar i decidir sobre les diferents interferències. L'agrupament ha estat el següent:

a) Aparició de tres significants per a un sol concepte:

$\begin{array}{ll}\text { ganader } & \text { zapat } \\ \text { ganadero } & \text { zapato } \\ \text { ramader } & \text { sabata } \\ \text { abogat } & \text { sombrer } \\ \text { abogado } & \text { sombrero } \\ \text { advocat } & \text { barret } \\ \text { higad } & \text { abanic } \\ \text { higado } & \text { abanico } \\ \text { fetge } & \text { ventall/palmito (palmet) } \\ \text { amarill } & \text { escondit } \\ \text { amarillo } & \text { escondite } \\ \text { groc } & \text { amagatall } \\ \text { cepill } & \text { tiburó } \\ \text { cepillo } & \text { tiburón } \\ \text { raspall } & \text { tauró } \\ & \\ \text { estutx } & \text { creucr } \\ \text { estuche } & \text { crucero } \\ \text { estoig } & \text { creuer }\end{array}$

Aquí hi ha dos possibles solucions; una, passar automàticament la primera forma a la segona, és a dir, estandarditzar-la al castellà, i l'altra, veure quin és l'índex de disponibilitat obtingut per la interferència i la forma normativa castellana amb l'objectiu de conservar la primera si el seu índex de disponib-

8. J. R. Gómez Molina (2002 $a ; 2002 b)$. 
litat és major a una o a les dues opcions estandarditzades del mateix concepte. La qual cosa ens faria replantejar tant la planificació lèxica a l'àmbit educatiu com la situació actual del valencià dins l'estàndard català.

b) Mots amb lexema castellà però amb sufix valencià:

$\begin{array}{ll}\text { ventanes } & \text { acelgues } \\ \text { escaleres } & \text { gafes } \\ \text { silles } & \text { medies } \\ \text { cerilles } & \text { cebolles } \\ \text { orejes } & \text { charques } \\ \text { unyes } & \text { semilles } \\ \text { munyeques } & \text { bolses } \\ \text { microondes } & \text { galletes } \\ \text { pizarres } & \text { mesites } \\ \text { bombilles } & \text { cuchares } \\ \text { rejilles } & \text { rendijes } \\ \text { margarites } & \text { estanteries } \\ \text { cuchares } & \text { lentejes } \\ \text { algarrobes } & \text { habes } \\ \text { pateres } & \text { setes }\end{array}$

En els criteris d'edició general hem dit que neutralitzàvem les variants merament flexives, és a dir, que el plural s'elimina a favor del singular, llevat que puga haver-hi ambigüitat (pit/pits) o d'unitats lèxiques que tinguen en plural la seua forma natural (paracaigudes). Però en aquest cas no és el mateix, perquè es tracta d'una arrel castellana i un sufix català $i$, si ho passem a la forma no marcada, singular, perdem aquest fenomen.

Tanmateix, si mantenim les diferents opcions morfològiques microondas/microondes d'un mateix concepte, s'obtindrien valors de disponibilitat més baixos dels que en realitat correspondrien a la forma no marcada del paradigma i no hem d'oblidar que l'objectiu d'aquest tipus d'estudi és quantificar $\mathrm{i}$ indexar les unitats lèxiques disponibles per als parlants de la zona central del valencià.

c) Mots que presenten les mateixes característiques que els del grup b, però en singular:

cerebre

candelabre

metre (mitjà de transport) asne

flexe 
És simptomàtic el cas del suburbà, ja que la norma és metro, pcrò per desconeixença d'aquesta han fet el mateix procés que en els altres dos casos.

d) I un últim grup, tal vegada el més problemàtic per tractar-se de compostos sintagmàtics amb mots castellans i catalans barrejats:

intestí delgat
roig atardecer
verd manzana
polito anglés
mesita de nit
ull de buey
tub de neón
armari ropero
mando per als aparells
treballador d'almacén
mesa d'estudi
carn de cerdo
rabo de bou

\author{
asient calefactable \\ paloma missatgera \\ peix espada \\ ví tint \\ fer zanges \\ cremar madera \\ traje de bany \\ forqueta de pescat \\ amarill canari \\ màrmol de la cuina \\ jefe d'estudis \\ tazón de llet \\ tren de cercanies
}

Quin seria el tractament adequat per a tots els grups? Quines serien les pautes d'actuació? Tenim dues opcions: la primera, intentar reflectir la complexa situació lingüística de la zona d'estudi incloent totes i cadascuna de les variants lèxiques amb els seus components morfològics específics. Però açò ens podria dur a índexs de disponibilitat en els quals aparegueren formes com tauleta de nit / mesita de nit / mesita, solució que sembla poc raonable, perquè l'objectiu és descriure la norma lèxica i obtenir un índex de disponibi- litat el més ajustat a la realitat. La segona opció contempla la unificació dels grups $a$, $b$ i $c$ cap a la lematització i estandardització castellana donat que l'arrel d'aquests és castellana. Ara bé, no reflectim la producció real del lèxic en una comunitat de llengües en contacte, interessant des del vessant educatiu.

Pel que fa al tractament dels compostos sintagmàtics amb mots castellans i catalans barrejats opinem que l'opció més escaient és lematitzar i estandarditzar en la llengua del nucli del sintagma, perquè entenem aquest com l'element marcador de la conceptualització del compost sintagmàtic. 


\section{REFERÈNCIES BIBLIOGRÀFIQUES}

Alba, O. (1995): Léxico disponible de la República Dominicana, Santo Domingo, Pontificia Universidad Católica 'Madre y Maestra'.

Alcover, A. i F. B. Moll (1988): Diccionari Català-Valencià-Balear, Palma Mallorca, Moll.

AA.VV. (1995): Diccionari de la Llengua catalana, Fundació Enciclopèdia Catalana.

Blas, J. L. (1993): La interferencia lingüística en Valencia. Estudio sociolinguiistico, Castelló, Universitat Jaume I.

Bruguera, J. (1985): Història del Lèxic Català, Barcelona, Enciclopèdia Catalana, Biblioteca Universitària.

Carcedo, A. (2001): Léxico disponible de Asturias, Universidad de Turku, Publicaciones del Dpto. de Lengua Española, Monografías, vol. 1.

CASANOVA, E. (2004): «Del lèxic col.lquial al lèxic estàndard: el cas valencià», en V. CABANES (coord.): El lèxic: perspectives $i$ intervencions. El valencià al segle XXI, Alcoi, Aitana edicions-CAM.

CERDÀ, R. (1967): «Apreciaciones generales sobre cast./X/?cat. [X] en el Campo de Tarragona», Revista de Filología española, L, 57-96

Clyne, M. (1967): Transference and triggering, The Hague, Nijhoff.

Colon, G. (1976): El Léxico catalán en la Romania, Madrid, Gredos.

Diccionari DE LA Llengua Catalana (1995): Barcelona-Mallorca-València, Institut d'Estudis Catalans.

DiCCIONARI VAlenCIÀ (1996): IIFV. Generalitat Valenciana i Bromera.

EtXebarría, M. (1991): «Crecimiento de la disponibilidad léxica en estudiantes chilenos de nivel básico y medio», en H. LóPEZ MORALES (ed.): La enseñanza del español como lengua materna, Actas del II Seminario Internacional sobre Aportes de la lingüística a la enseñanza del español como lengua materna. Universidad de Puerto Rico.

- (1995): El bilingüismo en el Estado español, Bilbao, Ediciones FBV.

- (1996): «Disponibilidad léxica en escolares del País Vasco. Variación sociolingüística y modelos de enseñanza bilingüe», Revista Española de Lingüústica, 26: 301-325.

FABRA, P. (1984): Diccionari General de la llengua Catalana, Barcelona, Edhasa.

GUILBERT, L. (1975): La créativé lexicale, París, Larousse.

Galloso, V. (2002): El léxico de los estudiantes preuniversitarios en el distrito universitario de Salamanca, Ediciones Universidad de Salamanca. Gómez Devís, B. (1995): Disponibilitat lèxica del valencià, (inèdit), Generalitat Valenciana, Pla EVA, València. 
Gómez Molina, J. R. (1986): Estudio sociolingibístico de la comunidad de habla de Sagunto (Valencia), Valencia, Institució Alfons el Magnànim.

- (1999-2000): «Transferencia y cambio de código en una comunidad bilinguie: Área metropolitana de Valencia», Contextos, XVII-XVIII/33-36: 31-87. Universidad de León. (2004)

- (2000): «Consecuencias del contacto de lenguas», en A. BRIZ Y GRUPO VAL.Es.Co (eds.): ¿Cómo se comenta un texto coloquial?, Barcelona, Ariel.

- (2002 a): «Préstamos léxicos del castellano en el valenciano central: inserción, evaluación y actualización», en M. T. ECHENIQUE Y J. SÁNCHEZ (eds.): en Actas del $V$ Congreso Internacional de Historia de la Lengua Espanyoia, Madrid, Gredos.

- (2002 b). «Norma i ús en el valencià central (nivell lèxic)», Treballs de Sociolinguística Catalana, 16: 5-23.

Gómez Molina J. R.; B. Gómez Devís (2004): La disponibilidad léxica de los estudiantes preuniversitarios valencianos. Estudio de estratificación sociolinguitśstica, Universitat de València.

GonzÁLEZ, A. (2002): La disponibilidad léxica de los alumnos preuniversitarios en la provincia de Cádiz, Servicio de Publicaciones de la Universidad de Cádiz.

Gosjean, F. (1981): Life with two languages. An introduction to Bilingualism, Cambridge, Harvard University Press.

HASSELMo, N. (1969): «How can me measure the effects wich one language may have on the other in the speech bilinguals», en L. G. KELLY (ed.): Description and Measurement of bilingualism, Toronto.

Haugen, E. (1953): The Norwegian Language in America, Filadelfia, The university of Pennsylvania Press.

HeRnÁNDEz, N. (2002): El léxico disponible de los estudiantes conquenses. Del análisis sociolingüistico a la reflexión metodológica, trabajo de grado, Universidad de Salamanca.

López del CASTILlo, LL. (1984): Llengua standard i nivells de llenguatge, Barcelona, Laia.

López Morales, H. (1999): Léxico disponible de Puerto Rico, Madrid, Arco Libros.

López Morales, H.; F. García Marcos (1995): «Disponibilidad léxica en Andalucía. Proyecto de investigación», REALE, 3, 67-76.

Llobera I ARAmon, J. (1968): El català bàsic, Barcelona, Teide.

LLOPIS Rodrigo, F. (1997): El lèxic del valencià central (inèdit), Generalitat Valenciana, Pla EVA, Valencia.

MACKeY, W. F. (1976): Bilingualism et Contact des Langues, París, Editions Klinckieck. 
Marí, I. (1992): Un horitzó per a la llengua. Aspectes de la planificació lingüística, Barcelona, Empúries.

Mateo, M. V. (1998): Disponibilidad léxica en el Cov. almeriense. Estudio de estratificación social, Almería, Universidad de Almería.

Mollà, D. et alii (1986): Estudi sociològic sobre la problemàtica sociolinguiistica a la Comunitat Valenciana, Valencia, Generalitat Valenciana. Conselleria de Cultura, Educació i Ciència.

Morales, A. (1986): Léxico básico del español de Puerto Rico, Madrid, La Muralla.

Moremo, F.; J. E. Moreno; A. J. García de las Heras (1995): «Cálculo de disponibilidad léxica. El programa Lexidisp», Lingüística, ALFAL, 7, 243 249.

NinYoles, R. (1996): Sociologia de la ciutat de València, València, Germania. PAscual, V. (1994): Diccionari Tabarca, València.

Payrató, Ll. (1985): La interferència lingüística, Barcelona, Abadia de Montserrat.

Samper Padilla, J. A. (1998): «Criterios de edición del léxico disponible: sugerencias», Linguiústica 10, ALFAL, 311-333.

SAmper, J. A.; J. Bellón; M. SAmPer (2003): «El Proyecto de estudio de la disponibilidad léxica en español», en Gerd WorJak, Pautas y pistas en el análisis del léxico hispano(americano), Madrid, Iberoamericana-Vervuert.

Serrano, M. I. (e. p.): «Disponibilidad léxica en la provincia de Lleida: aspectos metodológicos», Interlingüística, 14.

Silva Corvalán, C. (1994): Language Contact and Change. Sapanish in Los Angeles, Oxford, Clarendon Press.

WeinReich, U. (1953): Languages in Contact. Findings and Problems, The Hague, Mouton. (trad. Cat. (1996): Llengües en contacte. Alzira, Bromera.) 



\title{
NIVEL EDUCATIVO E ÍNDICES DE DISPONIBILIDAD
}

\author{
Clara E. Hernández Cabrera \\ Marta Samper Hernández \\ Universidad de Las Palmas de Gran Canaria
}

\section{INTRODUCCIÓN}

I A isla de Gran Canaria fue una de las primeras comunidades de habla españolas en las que se realizaron las encuestas para la obtención del vocabulario disponible (Samper y Hernández Cabrera, 1997). Los informantes que integraban la muestra pertenecían al Curso de Orientación Universitaria, de acuerdo con la metodología seguida en el proyecto panhispánico dirigido por Humberto López Morales. La recolección del material tuvo lugar en el curso académico 1990-91.

Algunos años más tarde, M. Samper (2003) llevó a cabo una investigación que ampliaba desde una perspectiva distinta los conocimientos sobre la disponibilidad léxica en la comunidad de habla grancanaria. En este caso los encuestados procedían de cuatro niveles educativos de las enseñanzas primaria y secundaria.

Si en el primer acercamiento, el objetivo fundamental era el establecimiento de la norma léxica adulta no especializada, en el segundo caso el interés consistía en analizar el avance de la disponibilidad léxica a través de los distintos niveles escolares. De este modo, la autora pudo constatar un incremento gradual del vocabulario desde el primero de los grados educativos que consideraba hasta el último, así como ciertas divergencias de carácter cualitativo entre los cuatro grupos.

En esta comunicación se pretende comprobar si la progresión continua que se observaba en los cursos de primaria y secundaria se sigue produciendo entre el último curso $\left(3^{\circ}\right.$ de ESo de la muestra escolar y los alumnos de cou del primer estudio grancanario. También es importante conocer qué centros de interés son los que amplían más su vocabulario en este momento educativo y si hay coincidencia con lo que ocurría en los niveles previos. Recordemos que en el trabajo realizado con escolares se ponía de manifiesto que la evolución de la productividad no se daba por igual en todas las etapas educativas: el incremento era muy relevante en los primeros cursos, mientras que la subida posterior resultaba más débil. Asimismo, se encontraron divergencias en el índice de crecimiento (IRC) de los distintos centros de interés: algunos de ellos 
(1. Partes del cuerpo, 16. Protesiones y oficios) presentaban indices supcriorcs al $50 \%$; otros, como 09 . «lluminación, calefacción y medios de airear un recinto» o 17. «Los colores», se caracterizaban por su pobre evolución. Por otro lado, conviene destacar que los centros de interés no progresaban de la misma manera: algunos lo hacían de forma regular (como los citados 01 y 16), mientras que otros presentaban evoluciones más complejas (algunos con un ascenso marcado en los primeros niveles y un detenimiento en los siguientes, otros con interrupción del crecimiento entre las dos etapas educativas...).

La comparación puede llevarse a cabo con un alto índice de fiabilidad, dado que en ambas investigaciones se han seguido las directrices establecidas para el proyecto paninispánico.' No obstante, ha de destacarse la diferencia en el tamaño de la muestra utilizada en cada caso. Si la preuniversitaria está constituida por 539 alumnos, los estudiantes de los cursos inferiores suman un total de 320 , como puede verse en los cuadros siguientes.

CUADro 1. Muestra de la investigación de Gran Canaria por etapas

\begin{tabular}{|l|l|l|}
\hline Variables & N \\
\hline \multirow{2}{*}{ Sexo } & Masculino & 166 \\
\cline { 2 - 3 } & Femenino & 154 \\
\hline \multirow{4}{*}{ Nivel sociocultural } & Alto & 160 \\
\cline { 2 - 3 } & Bajo & 160 \\
\hline \multirow{5}{*}{ Nivel educativo } & $3^{\circ}$ primaria & 80 \\
\cline { 2 - 3 } & $5^{\mathrm{a}}$ primaria & 80 \\
\cline { 2 - 3 } & $1^{\circ} \mathrm{ESO}$ & 80 \\
\hline & $3^{\circ} \mathrm{ESO}$ & 80 \\
\hline
\end{tabular}

1. De este modo, se contemplan los mismos centros de interés, se han seguido los mísmos criterios de edición de los materiales y se ha dado idéntico tiempo de respuesta a los encuestados. En ambos casos se ha adoptado el sistema de listas abiertas y se ha utilizado el programa informático Lexidisp para el procesamiento de los datos.

2. La diferencia en el número de alumnos de los dos cursos nos impide establecer comparaciones directas en el número de vocablos que unos y otros actualizan en la encuesta. El cotejo se basará, pues, en el promedio de respuestas por alumino. En cuanto al análisis cualitativo, realizaremos la comparación solo entre aquellos términos que se incluyen dentro del $50 \%$ del indice de frecuencia acumulada. 
CUADRo 2. Muestra de la investigación de los alumnos de COU de Gran Canaria

\begin{tabular}{|l|l|l|}
\hline Variables & N \\
\hline \multirow{2}{*}{ Sexo } & Masculino & 233 \\
\cline { 2 - 3 } & Femenino & 306 \\
\hline \multirow{3}{*}{ Nivel sociocultural } & Medio-alto & 83 \\
\cline { 2 - 3 } & Medio & 299 \\
\cline { 2 - 3 } & Bajo & 157 \\
\hline \multirow{2}{*}{ Tipo de enseñanza } & Pública & 361 \\
\cline { 2 - 3 } & Privada & 178 \\
\hline \multirow{2}{*}{$\begin{array}{l}\text { Ubicación de los } \\
\text { centros públicos }\end{array}$} & Urbanos & 184 \\
\cline { 2 - 3 } $\begin{array}{l}\text { Situación de los centros } \\
\text { públicos urbanos }\end{array}$ & Rurales & 177 \\
\cline { 2 - 3 } & Céntricos & 90 \\
\hline
\end{tabular}

\section{LOS DATOS}

En el cuadro siguiente se recoge la media de respuestas por centro de interés en los dos cursos que estudiamos, así como el porcentaje que representa el léxico del curso inferior en relación con el aportado por los alumnos de COU (PL) y el consiguiente índice de crecimiento (IRC):

CUAdro 3. Promedio de respuestas y porcentajes de progreso entre $3^{\circ}$ de ESO y COU

\begin{tabular}{|l|c|c|c|c|}
\hline \multicolumn{1}{|c|}{ CI } & COU & $\mathbf{3}^{\mathbf{0}}$ ESO & PL & ICR \\
\hline 01 CUE & 26.9 & 26.3 & 97.8 & 2.2 \\
\hline 02 ROP & 22.9 & 20.2 & 88.2 & 11.8 \\
\hline 03 CAS & 17 & 14.5 & 85.3 & 14.7 \\
\hline 04 MUE & 17.6 & 15.1 & 85.8 & 14.2 \\
\hline 05 ALI & 27.5 & 25.4 & 92.4 & 7.6 \\
\hline 06 MES & 15.8 & 13.2 & 83.5 & 16.5 \\
\hline 07 COC & 20.5 & 16.9 & 82.4 & 17.6 \\
\hline 08 ESC & 23.1 & 23.3 & 100.9 & $\mathbf{- 0 . 9}$ \\
\hline 09 ILU & 9.7 & 8.1 & 83.5 & 16.5 \\
\hline
\end{tabular}




\begin{tabular}{|c|c|c|c|c|}
\hline $\mathrm{CI}$ & $\mathrm{COU}$ & $3^{\circ} \mathrm{ESO}$ & $\overline{\mathbf{P L}}$ & ICR \\
\hline $10 \mathrm{CIU}$ & 23.3 & 21.9 & 94 & 6 \\
\hline $11 \mathrm{CAM}$ & 22.2 & 17.8 & 80.2 & 19.8 \\
\hline $12 \mathrm{TRA}$ & 18.6 & 14.8 & 79.6 & 20.4 \\
\hline $13 \mathrm{TRC}$ & 12.5 & 8.4 & 67.2 & 32.8 \\
\hline $14 \mathrm{ANI}$ & 29.5 & 25.4 & 86.1 & 13.9 \\
\hline $15 \mathrm{JUE}$ & 19.9 & 15.3 & 76.9 & 23.1 \\
\hline 16 PRO & 23.1 & 18.3 & 79.2 & 20.8 \\
\hline $17 \mathrm{COL}$ & 20.4 & 19.1 & 93.6 & 6.4 \\
\hline TOTAL & 20.6 & 17.9 & 86.8 & 13.2 \\
\hline
\end{tabular}

Como se observaba en el estudio de las distintas etapas en Gran Canaria (cuadro 4), también se produce un aumento del crecimiento léxico entre tercero de EsO y COU, si bien el incremento del vocabulario disponible no es ahora tan pronunciado como el que tenía lugar en la enseñanza primaria.

CUADRo 4. Promedio de respuestas por centro de interés según el nivel educativo. Porcentajes de progreso.

\begin{tabular}{|c|c|c|}
\hline Nivel educativo & Promedio de respuestas & ICR \\
\hline $3^{\circ}$ primaria & 9.8 & - \\
\hline $5^{\circ}$ primaria & 14.1 & 30.5 \\
\hline $1^{\circ} \mathrm{ESO}$ & 16.5 & 14.6 \\
\hline $3^{\circ} \mathrm{ESO}$ & 17.9 & 7.8 \\
\hline
\end{tabular}

Las cifras son elocuentes: entre $3^{\circ}$ y $5^{\circ}$ de primaria se alcanzaba un $30.5 \%$ de ICR; entre $5^{\circ}$ y $1^{\circ}$ de ESO se llegaba a un $14.6 \%$. El crecimiento se reducía más, al $7.8 \%$, entre $1^{\circ}$ y $3^{\circ}$ de Eso. Ahora bien, esa ralentización del proceso de crecimiento conforme se sube de nivel educativo se ve interrumpida en el paso de $3^{\circ}$ de ESO a cou. Ahora nos encontramos con una diferencia relativamente importante en el promedio general entre los dos cursos (20.6 vs. 17.9), to que supone un incremento del $13.2 \%$.

Son varias las razones a las que se podría recurrir para justificar estas divergencias: la distancia de once años entre ambas investigaciones, la diferencia de planes de estudios, el carácter obligatorio u opcional de los niveles respectivos pueden ser motivos que expliquen estas diferencias de caudal léxico. Más seguridad tendríamos si en su momento se hubiera hecho 
una encuesta similar con los estudiantes del antiguo $1^{\circ}$ de BuP (equivalente al actual $3^{\circ}$ de ESO); esto nos hubiera permitido observar si el crecimiento léxico era tan elevado (en su paso al cov) o, si, por el contrario, se mantenía a niveles parecidos a los que ahora se encuentran entre los dos cursos de la ESO contemplados. Argüir un descenso del caudal léxico sin conocer realmente cuál era el anterior parece arriesgado.

La diferencia general que hemos indicado no se manifiesta por igual en todos los centros de interés. Los que presentan un mayor índice de crecimiento son 13. Trabajos del campo y del jardín $(32.8 \%)$, 15. Juegos y diversiones $(23.1 \%), 16$. Profesiones y oficios $(20.8 \%)$ y 12 . Medios de transporte $(20.4 \%)$.

En el extremo opuesto, nos encontramos con 08 . La escuela, que presenta un leve descenso de promedio en el nivel superior, y con los centros 01. Partes del cuerpo $(2.2 \%)$, 10. La ciudad $(6 \%)$, 17. Los colores $(6.4 \%)$ y 05 . Los alimentos (7.6\%), que ofrecen un índice de crecimiento por debajo del $10 \%$. Los ocho campos restantes quedan en una posición central, con índices de crecimiento entre el 10 y el $20 \%$.

Si comparamos estos datos con los obtenidos en el paso de $1^{\circ}$ a $3^{\circ}$ de ESO (Samper Hernández, 2003), podemos apreciar ciertas peculiaridades:

CuADRo 5. Comparación del índice de crecimiento léxico de cada centro de interés en la ESO y en el paso de la ESO a COU

\begin{tabular}{|c|c|c|c|c|}
\hline CI & Rango & ICR $1^{\circ}-3^{\circ}$ ESO & Rango & ICR $3^{\circ}$ ESO-COU \\
\hline 01 CUE & 04 & 13.3 & 16 & 2.2 \\
\hline 02 ROP & 12 & 4.5 & 12 & 11.8 \\
\hline 03 CAS & 05 & 13.1 & 09 & 14.7 \\
\hline 04 MUE & 17 & $\mathbf{- 8 . 5}$ & 10 & 14.2 \\
\hline 05 ALI & 10 & 6.7 & 13 & 7.6 \\
\hline $06 \mathrm{MES}$ & 08 & 9.1 & 08 & 16.5 \\
\hline 07 COC & 06 & 12.4 & 06 & 17.8 \\
\hline 08 ESC & 14 & 3.4 & 17 & $-\mathbf{0 . 9}$ \\
\hline 09 ILU & 16 & 0 & 07 & 16.5 \\
\hline $10 \mathrm{CIU}$ & 07 & 11.9 & 15 & 6 \\
\hline $11 \mathrm{CAM}$ & 09 & 8.4 & 05 & 19.8 \\
\hline $12 \mathrm{TRA}$ & 11 & 5.4 & 04 & 20.4 \\
\hline $13 \mathrm{TRC}$ & 03 & 14.3 & 01 & 32.8 \\
\hline
\end{tabular}




\begin{tabular}{|c|c|c|c|c|}
\hline $\mathrm{CI}$ & Rango & ICR $1^{\circ}-3^{\circ} \mathrm{ESO}$ & Rango & ICR $3^{\circ} \mathrm{ESO}-\mathrm{COU}$ \\
\hline $14 \mathrm{ANI}$ & 13 & 3.5 & 11 & 13.9 \\
\hline $15 \mathrm{JUE}$ & 02 & 15 & 02 & 23.1 \\
\hline $16 \mathrm{PRO}$ & 01 & 17.8 & 03 & 20.8 \\
\hline $17 \mathrm{COL}$ & 15 & 3.1 & 14 & 6.4 \\
\hline
\end{tabular}

Mientras que algunos centros de interés, como 02. La ropa, 06. Objetos colocados en la mesa..., 07. La cocina... y 15. Juegos y diversiones, se mantienen en la misma posición relativa según s!n índice de crecimiento, hay que destacar otros casos que presentan una gran diferencia entre los niveles considerados. Es lo que ocurre, por un lado, con los centros 01. Partes del cuerpo y 10. La ciudad, que ocupaban un rango mucho más elevado en la relación de la ESO; por otro lado, los campos 04. Muebles de la casa, 09. Iluminación... y 12. Medios de transporte ocupan posiciones más elevadas en la investigación con alumnos preuniversitarios. Resulta especialmente llamativa la penúltima posición en la que aparece el centro 01 en la transición de $3^{\circ}$ a cov: se trata de un ámbito léxico que, además de encontrarse en la cuarta posición relativa en el paso de $1^{\circ}$ a $3^{\circ}$ de ESO, se hallaba en segundo lugar (con un progreso global del 54.8\%) cuando se consideraba la evolución desde $3^{\circ}$ de primaria a $3^{\circ}$ de ESO (Samper Hernández, 2003). En este sentido, hemos de suponer una relación directa con los currículos de la enseñanza oficial, que incorpora muchos tecnicismos en asignaturas como «Ciencias de la naturaleza» en esos años de primaria y el comienzo de la secundaria. A esto se une el carácter compacto del campo léxico, cuyo limitado inventario parece adquirirse de manera temprana en su práctica totalidad.

Es sintomático que los tres centros que ofrecen un mayor índice de crecimiento en el paso de $3^{\circ}$ a COU (el 13. Trabajos del campo..., el 15. Juegos y diversiones y el 16. Profesiones y oficios) sean exactamente los mismos que se han destacado como los tres más dispersos en el conjunto de las investigaciones panhispánicas (Samper, Bellón y Samper Hernández, 2003: 108). Dado que no son estos centros los que ofrecen un progreso más notorio en anteriores etapas educativas, podríamos pensar que los hablantes van adquiriendo el vocabulario más general en los centros compactos en etapas más tempranas, mientras que estos campos más dispersos implican un crecimiento léxico continuo (hasta la edad adulta) por las múltiples asociaciones que ofrecen. En estos casos, al contrario de lo que ocurría con el campo 01, no se trata de un vocabulario muy relacionado con el ámbito académico, sino que depende del conocimiento del mundo que va adquiriendo el joven. 


\section{ANÁLISIS CUALITATIVO}

Dada la imposibilidad de llevar a cabo un análisis exhaustivo de todos los centros de interés, se han seleccionado los que presentan características más destacables.

Tampoco se cotejará la totalidad de los vocablos que conforman las listas, sino que se ha establecido el límite en el $50 \%$ de la frecuencia acumulada. Solo se considerarán, por lo tanto, los términos que aparezcan en las nóminas con anterioridad a dicho corte; por otra parte, como el número de vocablos que incluye cada lista en ese límite no es equivalente, para la comparación tendremos en cuenta el conjunto de unidades que se incluya en la relación más reducida.

El ámbito léxico que se caracteriza por presentar un índice de crecimiento superior es, como se ha dicho anteriormente, «Trabajos del campo y del jardín», que es curiosamente uno de los que ofrece un número menor de respuestas en casi todas las comunidades de habla (Samper, Bellón y Samper Hernández, 2003: 58). En realidad, llama la atención que los dos centros relacionados con el mundo rural se encuentren en las cinco primeras posiciones por el índice de crecimiento mientras que el centro de interés 10. La ciudad es de los que ofrece un menor avance. Es posible que en este resultado esté influyendo el que la encuesta de primaria y secundaria cuente solo con alumnos que acuden a centros urbanos, al contrario de la de cou, que recogía además encuestados de la zona rural (184 encuestados de la ciudad frente a 177 de zonas del interior de la isla en los centros públicos). También puede considerarse la hipótesis de que los once años de diferencia en la realización de las dos encuestas puedan reflejar la paulatina desruralización de la sociedad actual, que conllevaría una pérdida del léxico propio de la vida campesina. En los cuadros siguientes podemos comprobar si efectivamente se producen diferencias relevantes entre el léxico incorporado por unos alumnos y otros: ${ }^{3}$

\section{CuAdro 6. Cl 13. Trabajos del campo y del jardín}

\begin{tabular}{|c|c|}
\hline $3^{\circ}$ ESO & COU \\
\hline regar & plantar \\
plantar & regar \\
podar & podar \\
jardinero & arar \\
cultivar & sembrar \\
limpiar & recoger \\
arar & abonar \\
\hline
\end{tabular}

3. En los cuadros aparecen subrayadas aquellas unidades que tienen un menor indice de disponibilidad en la otra lista; las palabras que no se incluyan en una de las nóminas se señalarán con negrita. 


\begin{tabular}{|c|c|}
\hline $3^{\circ}$ ESO & COU \\
\hline cortar & cortar \\
sembrar & jardinero \\
cortar césped & segar \\
agricultor & recolectar \\
cuidar & cultivar \\
abonar & agricultor \\
ganadero & pala \\
transplantar & $\underline{\text { tijera }}$ \\
recoger & limpiar \\
ordeñar & $\underline{\text { arado }}$ \\
agricultura & tractor \\
granjero & semilla \\
ganadería & rastrillo \\
\hline
\end{tabular}

Lo más destacable en el CI 13 es que en los alumnos de mayor edad están presentes términos que resultan más específicos del ámbito léxico que analizamos (arado, tractor, rastrillo), frente a vocablos más generales, como agricultura o ganadería, que son incluidos por los escolares en estas primeras posiciones.

CUADro 7. Cl ll. El campo

\begin{tabular}{|c|c|}
\hline $3^{\circ}$ ESO & COU \\
\hline árbol & árbol \\
casa & flor \\
planta & hierba \\
flor & vaca \\
animal & montaña \\
piedra & tierra \\
tierra & casa \\
montaña & planta \\
hierba & animal \\
pino & césped \\
pájaro & cabra \\
vaca & pájaro \\
cabra & piedra \\
conejo & perro \\
coche & oveja \\
césped & río \\
\hline
\end{tabular}




\begin{tabular}{|c|c|}
\hline $3^{\circ}$ ESO & COU \\
\hline arbusto & pino \\
barranco & caballo \\
caballo & tractor \\
perro & tranquilidad \\
oveja & $\underline{\text { aire puro }}$ \\
mesa & conejo \\
bosque & chalé \\
cueva & barranco \\
$\underline{\text { lagarto }}$ & burro \\
granja & arbusto \\
río & agua \\
basura & gallina \\
carretera & $\underline{\text { lago }}$ \\
presa & gato \\
insecto & granja \\
gato & $\underline{\text { arado }}$ \\
jardín & frío \\
palmera & $\underline{\text { camino }}$ \\
persona & estanque \\
roca & $\underline{\text { cerdo }}$ \\
estanque & bosque \\
$\underline{\text { finca }}$ & $\underline{\text { margarita }}$ \\
\hline
\end{tabular}

En la misma línea que veíamos en «Trabajos del campo y del jardín», siguen apareciendo en puestos relevantes de la lista de los escolares vocablos de carácter muy general, como coche, mesa o persona, que podrían figurar en otros muchos centros de interés; los informantes de mayor edad incorporan de nuevo tractor y arado, junto a chalé y nombres de animales y plantas. Por otro lado, resulta curioso cómo parece haber variado la percepción que los alumnos de hace once años tenían con respecto a la vida campesina, reflejada en vocablos como tranquilidad o aire puro, frente al término negativo basura, que aparece en una posición destacada de la lista de los más jóvenes.

El ámbito léxico que ocupa el segundo lugar en el índice de crecimiento es el 15. Juegos y diversiones: 


\begin{tabular}{|c|c|}
\hline $3^{\circ}$ ESO & COU \\
\hline fútbol & fútbol \\
baloncesto & parchís \\
tenis & baloncesto \\
ordenador & ajedrez \\
voleibol & oca \\
televisión & tenis \\
playstation & cartas \\
escondite & televisión \\
parchís & voleibol \\
cine & trivial \\
ajedrez & balonmano \\
balonmano & escondite \\
cartas & damas \\
bailar & natación \\
ping pong & música \\
comba & cine \\
leer & monopoly \\
cogida & leer \\
monopoly & discoteca \\
game boy & bailar \\
oca & cogida \\
videojuego & correr \\
natación & dominó \\
correr & tres en raya \\
playa & ping pong \\
juego de mesa & cantar \\
cantar & póquer \\
atletismo & billar \\
amigos & nadar \\
nadar & ordenador \\
béisbol & playa \\
\hline & \\
\hline & \\
& \\
\hline
\end{tabular}

En ningún otro centro se nota más el paso de los once años transcurridos entre las dos investigaciones. Obsérvese que es el único que registra ausencias en alguna de las listas, como ocurre en la de cou con las referidas a juegos hoy tan populares como playstation y game boy. También es sintomático que videojuego aparezca en posiciones más retrasadas en la nómina preuniversitaria. 
Si bien es verdad que la palabra fútbol encabeza ambas listas, no deja de llamar la atención que en la escolar se aluda a un deporte como el béisbol.

En el otro lado de la tabla se observa la presencia reiterada de ciertos juegos como trivial, damas, dominó, tres en raya o póquer, que se sitúan en posiciones más rezagadas en la lista de los escolares. Estos, por su parte, incorporan el hiperónimo juego de mesa. La diferencia de edad y, por consiguiente, de aficiones, queda bien reflejada en la presencia de discoteca y billar en puestos más privilegiados en la nómina preuniversitaria.

\section{Cuadro 9. CI 16. Profesiones y oficios}

\begin{tabular}{|c|c|}
\hline $3^{\circ} \mathrm{ESO}$ & $\mathrm{COU}$ \\
\hline $\begin{array}{c}\text { profesor } \\
\text { médico } \\
\text { abogado } \\
\text { arquitecto } \\
\text { empresario } \\
\text { poli(cía) } \\
\text { ingeniero } \\
\text { camarero } \\
\text { enfermero } \\
\text { carpintero } \\
\text { farmacéutico } \\
\text { cocinero } \\
\text { futbolista } \\
\text { jardinero } \\
\text { electricista } \\
\text { director } \\
\text { basurero } \\
\text { fontanero } \\
\text { agricultor } \\
\text { albañil } \\
\text { bombero } \\
\text { dependiente } \\
\text { barrendero } \\
\text { secretario } \\
\text { cantante } \\
\text { juez } \\
\text { obrero } \\
\underline{\text { limpiador }}\end{array}$ & $\begin{array}{c}\text { profesor } \\
\text { médico } \\
\text { abogado } \\
\text { arquitecto } \\
\text { maestro } \\
\text { ingeniero } \\
\text { albañil } \\
\text { carpintero } \\
\text { empresario } \\
\text { enfermero } \\
\text { policía } \\
\text { electricista } \\
\text { fontanero } \\
\text { jardinero } \\
\text { camarero } \\
\text { barrendero } \\
\text { agricultor } \\
\text { secretario } \\
\text { estudiante } \\
\text { mecánico } \\
\text { periodista } \\
\text { pintor } \\
\text { ama de casa } \\
\text { taxista } \\
\text { comerciante } \\
\text { piloto } \\
\text { banquero } \\
\text { Ats }\end{array}$ \\
\hline
\end{tabular}




\begin{tabular}{|c|c|}
\hline $3^{\circ} \mathrm{ESO}$ & $\mathrm{COU}$ \\
\hline $\begin{array}{c}\text { pintor } \\
\text { peluquero } \\
\text { vendedor } \\
\text { ama de casa } \\
\text { psicólogo } \\
\text { dentista } \\
\text { notario } \\
\text { estudiante } \\
\text { cirujano } \\
\text { inecánico } \\
\text { piloto } \\
\text { ganadero }\end{array}$ & $\begin{array}{c}\text { administiativo } \\
\text { juez } \\
\text { chófer } \\
\text { tendero } \\
\text { cocinero } \\
\text { psicólogo } \\
\text { director } \\
\text { panadero } \\
\text { aparejador } \\
\text { vendedor } \\
\text { actor } \\
\text { bombero }\end{array}$ \\
\hline
\end{tabular}

El centro 16. Profesiones y oficios es uno de los campos léxicos que se desarrollan de modo constante a lo largo de los años de la enseñanza (en el estudio por etapas es el que presenta un mayor índice de crecimiento entre los cursos extremos que se tenían en cuenta). Por eso no llama la atención que siga manteniendo su progresión en estos niveles educativos más avanzados (previos a la incorporación de los alumnos a un estadio más relacionado con el mundo laboral). A pesar de que en este centro no se observan diferencias notorias, se puede señalar la presencia en puestos más destacados en la lista de los escolares de vocablos que se refieren a profesiones poco convencionales, hoy muy prestigiadas, como futbolista o cantante. Por otro lado, llama también la atención que estos informantes no aludan en los primeros puestos a ciertas actividades que tienen que ver con los medios de transporte como taxista o chófer, vocablos que sí se encuentran en lugares destacados en la otra lista. Cabría establecer una relación con el considerable avance del índice de crecimiento $(20.4 \%)$ que experimenta cl centro 12. Medios de transporte entre $3^{\circ}$ de ESO y cou frente al $5.4 \%$ que tenía lugar en el paso de $1^{\circ}$ a $3^{\circ}$ de secundaria.

Cuadro 10. Cl 12. Medios de transporte

\begin{tabular}{|c|c|}
\hline $3^{\circ}$ ESO & COU \\
\hline coche & coche \\
guagua & avión \\
moto & bicicleta \\
avión & tren \\
bicicleta & barco \\
\hline
\end{tabular}




\begin{tabular}{|c|c|}
\hline $3^{\circ}$ ESO & COU \\
\hline barco & moto \\
tren & guagua \\
taxi & camión \\
camión & autobús \\
\hline
\end{tabular}

El último centro de interés en el que se produce un incremento considerable del índice de crecimiento es el recién mencionado campo 12. En él apenas podemos destacar divergencias significativas, ya que las listas expuestas en el cuadro correspondiente son muy similares; en ello puede influir que el índice del $50 \%$ de frecuencia acumulada se cubre con un reducido número de voces de una disponibilidad muy inmediata en todos los hablantes. Quizá podría destacarse el ascenso de la voz guagua en la nómina escolar con respecto a los estudiantes que hace once años se disponían a entrar en la universidad. Posiblemente este vocablo se haya convertido en la variedad canaria en uno de los dialectalismos más arraigados y ante el que se haya llegado a un nivel considerable de seguridad lingüística. De la misma manera el derivado guagiiero, que ocupa en $3^{\circ}$ de Eso (en este centro 12 ) el rango 76 , no figura en la lista preuniversitaria y solo aparece en el centro 16, ocupando el rango 121. En este mismo sentido, destaca la aparición del término autobús en la novena posición de la nómina de cou, mientras que en la escolar aparece en un puesto más retrasado.

Como se veía en el cuadro 3 , los centros de interés que presentan un menor índice de crecimiento son 08. La escuela, 01. Partes del cuerpo, 10.La ciudad y 17. Los colores. A pesar de esta semejanza cuantitativa, el análisis cualitativo permite ver algunas diferencias en estos campos. En 08.La escuela se pueden observar algunos matices que parecen estar relacionados con la diferencia de edad y con las actividades propias de los niveles educativos.

CuAdro 11. CI 08. La escuela: muebles y materiales

\begin{tabular}{|c|c|}
\hline $3^{\circ}$ ESO & COU \\
\hline silla & Silla \\
mesa & pizarra \\
lápiz & mesa \\
pizarra & bolígrafo \\
bolígrafo & lápiz \\
goma & tiza \\
\hline
\end{tabular}




\begin{tabular}{|c|c|}
\hline $3^{\circ}$ ESO & COU \\
\hline libro & libro \\
ventana & goma \\
puerta & pupitre \\
tiza & libreta \\
libreta & borrador \\
estuche & folio \\
rotulador & ventana \\
borrador & rotulador \\
pupitre & puerta \\
regla & maleta \\
afilador & carpeta \\
maleta & afilador \\
patio & pluma \\
taquilla & regla \\
carpeta & papel \\
persiana & mesa de profesor \\
folio & vídeo \\
lápiz de colores & fotocopiadora \\
\hline
\end{tabular}

Como se observa, en cou aparecen en esta franja de disponibilidad vídeo y fotocopiadora, muy rezagados en la lista de los alumnos de ESO; así como este último término puede explicarse atendiendo a la diferencia de nivel educativo, llama la atención el retraso de una voz como vídeo, que solo aparece en el puesto 222 entre los alumnos de ESO. A pesar de que podría argüirse la posible rivalidad con el vocablo $D V D$-casi desconocido hace once años-, se ha comprobado que esta unidad no aparece en la lista escolar. ${ }^{4} \mathrm{La}$ diferencia con respecto a pluma refleja probablemente el desgaste de esta voz, producido por la paulatina desaparición del referente. A las distintas condiciones de escolaridad debe obedecer asimismo la presencia entre los pequeños de palabras como lápiz de color y estuche. Por último, es significativa la aparición entre estos mismos alumnos de términos como patio, taquilla y persiana, de carácter más general, no relacionados tan directamente con la actividad académica.

Como se vio anteriormente, el centro 01 experimentaba un avance importante en la etapa escolar (un $33.9 \%$ de $3^{\circ}$ de primaria a $5^{\circ}$; un $21.1 \%$ de $5^{\circ}$ a $1^{\circ}$

4. En las nóminas de los alumnos de Eso sí figura vídeo en la posición 73 del centro 04 . Muebles de la casa, a pesar de su convivencia con $D V D$. 
de ESO y un $13.3 \%$ de $1^{\circ}$ de ESO a $3^{\circ}$ ), pero este progreso se detenía en gran medida en el paso de $3^{\circ}$ de ESO a COU

CuAdro 12. CI 01. Partes del cuerpo

\begin{tabular}{|c|c|}
\hline $3^{0}$ ESO & COU \\
\hline ojo & ojo \\
nariz & cabeza \\
oreja & nariz \\
cabeza & mano \\
dedo & dedo \\
mano & brazo \\
boca & oreja \\
pelo & boca \\
pierna & pie \\
brazo & pierna \\
pie & pelo \\
uña & uña \\
rodilla & rodilla \\
diente & cuello \\
corazón & corazón \\
cuello & pecho \\
tobillo & diente \\
lengua & hombro \\
codo & estómago \\
pecho & codo \\
ceja & muslo \\
\hline
\end{tabular}

Así como en el centro anterior se encontraban algunas diferencias propias de los distintos niveles de enseñanza y de la distancia temporal, no ocurre lo mismo con el campo que ahora nos ocupa. El análisis cualitativo pone de manifiesto, una vez más, el carácter compacto que presenta este ámbito léxico en todos los trabajos de disponibilidad.

Cuadro 13. CI 10. La ciudad

\begin{tabular}{|c|c|}
\hline $3^{\circ} \mathrm{ESO}$ & COU \\
\hline $\begin{array}{c}\text { coche } \\
\text { casa }\end{array}$ & $\begin{array}{c}\text { coche } \\
\text { edificio }\end{array}$ \\
\hline
\end{tabular}




\begin{tabular}{|c|c|}
\hline $3^{\circ} \mathrm{ESO}$ & $\mathrm{COU}$ \\
\hline $\begin{array}{c}\text { edificio } \\
\text { tienda } \\
\text { carretera } \\
\text { parque } \\
\text { acera } \\
\text { farola } \\
\text { moto } \\
\text { semáforo } \\
\text { gunagua } \\
\text { calle } \\
\text { centro comercial } \\
\text { restaurante } \\
\text { persona } \\
\text { camión } \\
\text { cine } \\
\text { gente } \\
\text { colegio } \\
\text { banco } \\
\text { bicicleta } \\
\text { árbol } \\
\text { playa } \\
\text { jardín } \\
\text { supermercado } \\
\text { hospital } \\
\text { planta } \\
\text { paso de peatones } \\
\text { puente } \\
\text { bar } \\
\text { papelera }\end{array}$ & $\begin{array}{c}\text { parque } \\
\text { casa } \\
\text { semáforo } \\
\text { tienda } \\
\text { calle } \\
\text { carretera } \\
\text { guagua } \\
\text { moto } \\
\text { acera } \\
\text { colegio } \\
\text { camión } \\
\text { discoteca } \\
\text { bar } \\
\text { plaza } \\
\text { ayuntamiento } \\
\text { jardín } \\
\text { instituto } \\
\underline{\text { humo }} \\
\text { cine } \\
\text { supermercado } \\
\text { árbol } \\
\text { gente } \\
\text { restaurante } \\
\text { banco } \\
\text { ruido } \\
\text { avenida } \\
\text { contaminación } \\
\text { iglesia } \\
\text { farola }\end{array}$ \\
\hline
\end{tabular}

En la misma línea de alusiones a vocablos específicos del centro de interés correspondiente que ya hemos indicado en otros campos, nos encontramos en este caso con palabras que se refieren a realidades prototípicas del paisaje urbano como plaza, ayuntamiento, instituto, avenida e iglesia en el nivel preuniversitario. Por otro lado, si los alumnos de este nivel habían incluido en el centro 11. El campo términos que encerraban connotaciones positivas (aire puro, tranquilidad), ahora hallamos unidades de contenido negativo como humo, ruido y contaminación, unas asociaciones que han dejado de estar tan presentes entre los alumnos más jóvenes. La edad influye, creemos, en la 
aparición de discoteca, como también habíamos constatado en el centro 15. Juegos y diversiones.

Por otro lado, el paso del tiempo se hace notar en la asociación inmediata, entre los escolares, del estímulo «La ciudad» con la lexía centro comercial. Es sintomático que esta aparezca antes que edificios tan simbólicos como los citados anteriormente. Como ya observamos en el centro 11. El campo, también encontramos aquí algunos términos de carácter general, como persona, en las nóminas de los estudiantes de Eso.

\section{CUADRO 14. CI 17. Los colores}

\begin{tabular}{|c|c|}
\hline $3^{\circ}$ ESO & COU \\
\hline rojo & rojo \\
azul & azul \\
amarillo & amarillo \\
verde & blanco \\
negro & negro \\
blanco & verde \\
rosa & violeta \\
marrón & naranja \\
naranja & gris \\
gris & marrón \\
\hline
\end{tabular}

Una vez más, el centro «Los colores» se muestra como uno de los más compactos y como un ejemplo de los campos que ofrecen más coincidencias en las primeras posiciones en los distintos listados. Los nueve términos comunes y los dos vocablos diferentes (rosa y violeta) de las dos listas grancanarias son exactamente los mismos que han seleccionado para las primeras once posiciones los estudiantes valencianos que fueron el objeto de la investigación de Gómez Molina y Gómez Devís (2004: 438).

\section{CONCLUSIONES}

En la etapa escolar se había observado que el ascenso continuo de la productividad léxica iba haciéndose cada vez menos acusado conforme avanzaba el nivel de estudios. Por el contrario, en el paso de $3^{\circ}$ de ESO a COU se registra un notable salto cuantitativo a favor de este último nivel. Entre las razones que, creemos, pueden haber influido, no deben descartarse la distancia de once años, la diferencia de planes de estudios y el carácter opcional del 
curso de orientación universitaria frente a la obligatoriedad de los niveles inferiores.

Al comparar el desarrollo de la productividad léxica entre los dos niveles de secundaria, por un lado, y el que se da entre $3^{\circ}$ de eso y COU, se observan ciertas divergencias en el comportamiento de los distintos centros de interés. Es llamativo el caso del campo 01. Partes del cuerpo, cuyo elevado ICR en la etapa inferior contrasta notablemente con la escasa evolución que presenta en la transición entre los niveles superiores. El carácter eminentemente escolar de este ámbito léxico, así como su alto grado de cohesión, podrían explicar el temprano aprendizaje de los vocablos que lo conforman esencialmente. Por el contrario, centros de carácter disperso y no tan vinculados con el currículo escolar, como el 13. Trabajos del campo..., el 15. Juegos y diversiones y el 16. Profesiones y oficios, demoran su evolución hasta momentos posteriores.

El análisis cualitativo de los campos que presentan los valores extremos en el índice de crecimiento pone de manifiesto que, en general, los alumnos de nivel educativo superior incorporan en las posiciones más destacadas una serie de vocablos que se relacionan más directamente con el ámbito léxico correspondiente.

El hecho de que entre las dos investigaciones hayan transcuirtido once años se refleja en la ausencia, en la lista de los juegos y distracciones de los mayores, de ciertas unidades que hoy son muy populares entre los jóvenes. Por el contrario, en la nómina de los alumnos de cou predominan los juegos de carácter más tradicional. Esta misma causa explica también la aparición más retrasada en las listas escolares de algunas voces que hacen referencia a objetos de menor uso en la actualidad.

La importancia de la edad de los informantes se observa asimismo en la presencia de determinados vocablos en puestos destacados de una de las dos nóminas. Unos están relacionados con el mundo de las diversiones de los preuniversitarios; los de la otra lista son términos relativos a la realidad escolar de los alumnos de niveles de enseñanza primaria y secundaria.

Finalmente, llama la atención la mayor disponibilidad que alcanza alguna voz dialectal entre los más jóvenes.

\section{REFERENCIAS BIBLIOGRÁFICAS}

Gómez Molina, J. R. y Ma B. Gómez Devís (2004): La disponibilidad léxica de los estudiantes preuniversitarios valencianos. Estudio de estratificación sociolingüística, Valencia, Universitat de València (anejo núm. 56 de la revista Quaderns de Filologia). 
SAMPER Hernández, M. (2003): Evolución de la disponibilidad léxica en escolares grancanarios de enseñanza primaria y secundaria (tesis doctoral inédita), Salamanca, Universidad de Salamanca.

Samper Padilla, J. A. y C. E. Hernández CABrera (1997): «El estudio de la disponibilidad léxica en Gran Canaria: datos iniciales y variación sociolingüística», en ALMEIDA, M. y J. DORTA (eds.) (1997): Contribuciones al estudio de la lingüistica hispánica. Homenaje a Ramón Trujillo Carreño, tomo II, La Laguna, Cabildo de Tenerife-Montesinos.

Samper Padilla, J. A.; J. J. Bellón Fernández; M. Samper Hernández (2003): «El proyecto de estudio de la disponibilidad léxica en español» en Ávila, R.; J. A. SAMPER; H. UEdA ET AL. (eds.) (2003): Pautas y pistas en el análisis del léxico hispano(americano), Frankfurt-Madrid, VervuertIberoamericana. 


\title{
CONSECUENCIAS DEL CONTACTO DE LENGUAS EN LÉRIDA: INTERFERENCIAS DETECTADAS EN LAS ENCUESTAS DE DISPONIBILIDAD LÉXICA*
}

\author{
Maribel Serrano Zapata \\ Universitat de Lleida.
}

$\mathbf{E}$ STA comunicación forma parte de una investigación más amplia cuyo objetivo principal es describir y comparar el léxico disponible en lengua castellana y catalana de 240 preuniversitarios de la provincia de Lérida. En este trabajo nos centraremos en analizar las interferencias del catalán que hemos detectado en seis centros de interés del corpus castellano.

1. Los estudios de léxico disponible, como es sabido, dieron comienzo en Francia en los años cincuenta, cuando un grupo de investigadores intentó determinar -con una finalidad esencialmente pedagógica-cuál era el léxico «elemental» de la lengua francesa.' Sin embargo, en la actualidad, estos estudios cuentan con un mayor desarrollo en el mundo hispánico. Concretamente, desde principios de los años noventa, Humberto López Morales coordina y dirige un ambicioso proyecto cuyo principal objetivo es elaborar diccionarios de disponibilidad léxica para las diversas zonas del mundo hispánico. ${ }^{2}$ Con la finalidad de poder comparar a posteriori los distintos resultados, todas las investigaciones que participan en dicho proyecto se acogen a unos mismos presupuestos metodológicos.

Los resultados que se obtienen mediante este tipo de pruebas pueden ser útiles a muchas disciplinas como la etnolingüística, la psicolingüística o la dialectología, ${ }^{3}$ aunque la mayor parte de las investigaciones realizadas hasta el momento se ha llevado a cabo desde una perspectiva sociolingüística ${ }^{4}$ y ha rendido cuenta de la influencia que pueden tener distintas variables sociales en

*. Este trabajo ha podido realizarse gracias al apoyo del Deparament d'Universitats, Recerca $i$ Societat de la Informació de la Generalitat de Cataluña.

1. Nos referimos a la obra pionera de Gougenheim et al. (1956). En este trabajo cilamos la edición revisada de 1964.

2. Toda la información sobre las pautas del proyecto, así como un breve panorama de los estudios realizados hasta el día de hoy, puede consultarse en www.dispolex.com.

3. Véase un panorama de las distintas aplicaciones que han tenido estos estudios en López Morales (1995-1996), Carcedo (1998: 53-63) y Samper, Bellón y Samper Hernández (2003: 105-123).

4. De hecho, este enfoque ya estaba presente en los primeros estudios franceses (Gougenheim et al., 1964: 163-182). 
1a daros finales recabados. Sin embargo, a pesar de la valiosa información que pueden aportar estos trabajos al terreno de las lenguas en contacto, no han sido demasiadas hasta la fecha las aplicaciones de esta línea de investigación realizadas en el ámbito hispánico. ${ }^{5}$ En general, los estudios elaborados en territorios donde el español convive con otra $u$ otras lenguas se han centrado exclusivamente en la disponibilidad léxica de la lengua castellana y en el análisis sociolingüístico de los resultados. Cabe destacar, no obstante, que a las variables tradicionalmente analizadas en estos trabajos -el sexo del informante, el tipo de enseñanza, la ubicación del centro escolar o el nivel sociocultural de la familia- se han añadido y estudiado algunas otras con motivo de las características lingüísticas intrinsceas de la zona. Así, por ejemplo, Etxebarria (1996) tiene en cuenta en sus investigaciones sobre la zona metropolitana de Bilbao, donde el español y el vasco son cooficiales, la lengua materna, la lengua de uso predominante fuera del recinto escolar y el modelo de enseñanza bilingiie cursado. En cuanto a los territorios donde conviven el castellano y el catalán, cabe decir que en la provincia de Castellón se ha tenido en cuenta la lengua materna del informante (Blas y Casanova, 2003), y en la provincia de Valencia, la lengua habitual del mismo (Gómez Molina y Gómez Devís, 2004). En los casos en los que el español entra en contacto con otras lenguas no estatales, contamos con las investigaciones de Ayora (2000), centradas en la ciudad de Ceuta, quien incorpora la lengua materna, la lengua utilizada en casa y la lengua usada fuera del recinto escolar. Finalmente, en el estudio que realizan un grupo de investigadores de la Universidad de Cádiz en Gibraltar, se toma en consideración tanto la lengua materna como las lenguas de uso del informante (Escoriza Morera, e.p.). ${ }^{6}$

2. El enfoque que seguimos en nuestra investigación en la provincia de Lérida supone una novedad en el estudio de la disponibilidad léxica en comunidades bilingües por cuanto nuestra intención principal es la de describir y comparar el léxico disponible en las dos lenguas oficiales de la región -el castellano y el catalán-,' a la vez que describir la influencia tanto de la lengua catalana en el castellano de Lérida como del castellano en el

5. Una excepción sería el trabajo de Bailey Victery (197l) sobre el inglés y el español en el estado de Texas. En lo que se refiere a otras lenguas, contamos con el estudio de Njock (1979), basado en el contacto del francés y el basaa en Camerún.

6. En el léxico disponible de Asturias -zona donde existe otra situación de contacto de lenguasno se tiene en cuenta ninguna variable relacionada con la adscripción linguística del informante. Sin embargo, como el mismo autor reconoce (Carcedo, 2001: 26), la variable zona geográfica se establece en función de los parámetros tradicionales de la dialectología de la zona, cobrando así una dimensión esencialmente linguiística.

7. Nuestro trabajo no es el primero que se realiza sobre disponibilidad léxica en lengua catalana. El trabajo de investigación inédito de Gómez Devís (1995) analiza el léxico disponible de una muestra de 139 informantes de la ciudad de Valencia. 
catalán de nuestra comunidad, algo patente en el gran número de interferencias ${ }^{8}$ detectadas en los datos finales de los corpora. La tesis doctoral de $\mathrm{M}^{\mathrm{a}}$ José Azurmendi (1983) - la primera investigación realizada en la Península Ibérica sobre disponibilidad- puede considerarse como un precedente de nuestro trabajo. En este estudio se pretende describir el bilingüismo vasco-español en la comarca de San Sebastián y, con tal finalidad, se examinan, entre otros muchos análisis, las diferencias halladas en función de la lengua en que se haya completado la encuesta (euskera o español) y según el centro de interés del que se trate. La autora indicó a sus informantes, de 9 y 13 años, la lengua en que debían llevar a cabo el test, procurando que en cada grupo escolar hubiera el mismo número de encuestas para cada una de las lenguas. ${ }^{9}$

De hecho, a pesar de no haberse explorado aún todas las posibilidades que ofrece la disponibilidad léxica en los lugares donde la mayor parte de los hablantes usa dos lenguas, ya en el trabajo pionero de Mackey (1971) se tratan algunos de los aspectos más interesantes sobre este pormenor. El autor, que lleva a cabo un estudio sobre el francés de la región canadiense de Acadia, utiliza los resultados de las encuestas de léxico disponible para observar qué palabras del inglés se han incorporado al francés de la zona. Además, Mackey compara los índices de disponibilidad ${ }^{10}$ de las palabras francesas y de sus correspondientes equivalentes ingleses hallados en las encuestas y concluye que la mayor parte de las sustituciones se dan en la lengua de la minoría de la población, que el porcentaje de las mismas varía según el centro de interés y el individuo pero que, en ningún centro de interés, el vocabulario básico francés ha sido completamente sustituido por el inglés (Mackey, 1971: II, 15-28). En otro trabajo (Mackey, 1976: 317 322), el autor considera que el test de disponibilidad léxica, al igual que el test de aceptabilidad y el de traducibilidad, puede servir para medir el grado de integración que tiene el vocabulario extranjero en la lengua que se

8. Ante la confusión terminológica existente en la bibliografía sobre el tema, manejamos el concepto de interferencia como denominador global de todos aquellos fenómenos en los que es posible deducir la influencia de una lengua sobre otra.

9. La misma solución metodológica es la que se emplea en la investigación que, en la actualidad, cirige Miguel Casas desde la Universidad de Cádiz sobre disponibilidad léxica en Gibraltar. Tanto los objetivos como la metodología empleada en este último estudio son muy similares a los nuestros, aunque en su caso, las lenguas en contacto son el castellano y el inglés; además ambos proyectos se inscriben en el marco del proyecto panhispánico de estudio del léxico disponible en español (Escoriza Morera, e.p.). La única diferencia destacable sería que, en nuestro estudio, son los mismos informantes los que completan las dos encuestas, lo que abre un camino interesantísimo al campo de la psicolingüística en relación con el bilingüismo.

10. Recordemos que, por aquel entonces, la disponibilidad se calculaba simplemente según el número de veces que se repetía la palabra en la lista (Mackey, 1971: I, 52). 
estudia. También Humbley (1974:51-52), en un articulo sobre la tipologia del préstamo lingüístico, se hace eco de los trabajos de Mackey y señala la valía de los datos que ofrece la disponibilidad como medio suplementario para precisar la extensión de una influencia extranjera en el vocabulario o en un campo nocional concreto de una lengua.

3. Por consiguiente, a estas alturas resulta fácil entrever que este tipo de pruebas puede proporcionar una información inestimable con respecto a la detección de fenómenos derivados del contacto entre dos lenguas $y$, específicamente, sobre interferencias léxicas, verdadero objeto de estudio de esta comunicación. Asimismo, los préstamos son susceptibles de aparecer en las parcelas lexicas consideradas en los estudios de disponibilidad," más aun cuando, en una situación de lenguas en contacto, la lengua materna del informante no coincide con la lengua en la que se completa la encuesta, puesto que algunos de los estímulos verbales empleados se relacionan de forma directa con el ámbito familiar. Por otro lado, como es sabido, los sustantivos $y$, en menor grado, los verbos tienen una presencia abrumadora en los diccionarios de léxico disponible y es en estas mismas categorías gramaticales donde se ha detectado tradicionalmente una mayor cantidad de palabras procedentes de otros sistemas lingiísticos," ya sea por la influencia de una lengua extranjera que goza de prestigio ${ }^{14}$ ya sea en una situación de bilingüismo social. Además, los indices matemáticos que nos ofrecen los diccionarios de disponibilidad nos permiten dilucidar qué interferencias son estables y habituales, y por tanto, se han incorporado a la lengua de la comunidad desplazando - en algunos casos incluso - al término equivalente de la lengua vernácula, así como en qué casos estamos ante simples interferencias ocasionales que los hablantes bilingües incluyen como resultado de su conocimiento personal de la otra lengua. ${ }^{15}$

Como ya dijimos anteriormente, los estudios dedicados a esta línea de investigación son más bien escasos en el territorio peninsular. En Escoriza Morera (e.p.) hallamos una primera aproximación a la tipología de

11. Mackey (1976: 328) crea inciuso una fómula para calcular la probabilidad ce integración de una unidad léxica de origen toráneo --en su caso, el inglés- basada en la disponibilidad del vocablo de la lengua transmisora y de su correlato en la lengua receptora.

12. Mackey afirma al respecto: «Puisque la disponibilité est une manifestation de la langue et non seulement de la parole, c'est l'instrument tout à fait indiqué pour déceler les emprunts, non seulement parce que le sujet bilingie fait l'inventaire de ses connaissances d'une langue à $\mathbf{n}$ fois, mais aussi parce que la disponibilité touche surtout le secteur du vocabulaire où les emprunts se manifestent d'abord, à savoir, le vocabulaire concret.» (Mackey, 1971: 11, 16).

13. Véanse las reticencias de Weinreich $(1953: 37)$ a esta afirmación.

14. Existen numerosos trabajos sobre el peso de los anglicismos en la disponibilidad léxica de algunas zonas. Valga como ejemplo el estudio de López Morales (1999).

15. Weinreich (1953: 11) habla de inherited loanword y nonce-borrowing. 
interferencias del inglés halladas en el léxico disponible castellano de Gibraltar. En el amplio y exhaustivo trabajo de Gómez Molina y Gómez Devís (2004) sobre la disponibilidad léxica del castellano en la provincia de Valencia, se reserva un apartado a este particular. En él, se examinan las transferencias léxicas o catalanismos hallados en cada uno de los centros de interés y se compara el índice de disponibilidad alcanzado por estas lexías con el de los vocablos equivalentes en castellano. Los autores constatan, por un lado, una alta proporción de dobletes donde el término castellano adquiere siempre un índice de disponibilidad mayor que el correspondiente en lengua catalana, y por otro, la actualización de algunos vocablos del catalán cuyo índice supera al equivalente castellano y, por tanto, pueden considerarse como transferencias léxicas o como sustituciones de código. También advierten la presencia de voces autóctonas catalanas referidas al entorno socioambiental concreto de su comunidad y que, por consiguiente, no cuentan con un equivalente exacto en castellano: los autores los califican de préstamos culturales.

4. El análisis que efectuaremos a continuación se basa en los resultados obtenidos en nuestra investigación sobre disponibilidad léxica en Lérida. Para ello hemos seguido, grosso modo, las pautas metodológicas acordadas y compartidas por las investigaciones que se suman al proyecto panhispánico de estudio de la disponibilidad léxica. En nuestro caso, hemos contado con una muestra de 240 informantes preuniversitarios procedentes de 12 centros educativos de la provincia que han completado un total de 480 encuestas. La prueba asociativa se realizó, en consecuencia, en dos ocasiones, primero en lengua castellana y, seguidamente con un margen mínimo de dos semanas, en la lengua autóctona de la comunidad.$^{16}$ Las variables sociológicas que hemos tenido en cuenta han sido algunas de las comúnmente analizadas -como el sexo, el tipo de enseñanza, la ubicación del centro escolar o el nivel sociocultural- a las que hemos añadido dos más, dadas las características propias de nuestra comunidad, a saber, la lengua materna y la lengua de uso habitual del informante. ${ }^{17}$

En esta ocasión, vamos a analizar las interferencias detectadas en el corpus castellano como consecuencia de la familiaridad del hablante con la lengua catalana. Nos centraremos, pues, en los datos recogidos en torno a los centros 02. Ropa y complementos, 03. Partes de la casa, 04. Muebles de la casa, 05.

16. Aunque, en un principio, pensamos utilizar dos muestras numéricamente distintas (Serrano Zapata, 2003 a: 931-934) -ya que algunos estudiantes no habían completado, por no hallarse en el auja, una de las dos encuestas-, finalmente, optamos por desechar estos datos y conservar solo los resultados de los estudiantes que habían realizado las dos pruebas, lo que facilita enormemente los cálculos cuantitativos.

17. Para una visión detallada de las pautas metodológicas véase Serrano Zapata (2003a). 
Aliment-los y bebidas, 06 . Objetos colocialos en la mesa para la connda y 07. La cocina y sus utensilios. Hemos elegido estos estímulos verbales, y no otros, por considerar que su vinculación estrecha con el área del hogar podía favorecer la aparición de interferencias, puesto que la lengua materna de 157 de los 240 informantes de la muestra es el catalán. Además, en un trabajo anterior (Serrano Zapata, 2003 b: 79-81), en el que manejamos una muestra numéricamente inferior, ya habíamos podido comprobar que aparecían bastantes interferencias en estas áreas léxicas. Hemos de señalar, asimismo, que el estudio de la influencia que puede ejercer el catalán en el castellano -en este caso en el nivel léxico- no ha recibido, tradicionalmente, demasiada atención. En nuestra comunidad de habla contamos con los trabajos de Casanovas Català $(1996,1998,2000 a, 2000 b, 2004)$ dedicados al análisis de las características morfosintácticas del español hablado en Lérida, en donde la autora aprovecha también para hacer una clasificación de las interferencias halladas en el léxico castellano de la zona. ${ }^{19}$

Una de las tareas que conlleva mayores dificultades en los estudios de disponibilidad es, sin duda alguna, la homogeneización de los materiales obtenidos. Las interferencias implican, además, un mayor número de problemas por resolver y de decisiones que se han de tomar. Para empezar, la abundante presencia de elementos a caballo entre las dos lenguas y la gran similitud entre ellas -emparentadas diacrónicamente- hace que sea mucho más difícil de lo que cualquiera podría imaginar de antemano saber qué elementos deben considerarse de una lengua y cuáles de la otra. Además, a esta dificultad se une ia de no tener pautas relativas a cómo resolver los problemas de edición que acarrea la amplia tipología de interferencias halladas. Hemos de aclarar que, en nuestro trabajo, no contemplamos el estudio de las interferencias ortográficas, con lo que los dobletes homófonos del tipo 'horchata' lorxata quedan anulados siempre a favor de la lengua en la que se completa la encuesta. Tampoco hemos tenido en cuenta las interferencias meramente fonéticas (como 'sumo' por 'zumo' o 'sapato' por 'zapato'), salvo en los casos en los que estas coinciden con palabras perfectamente posibles en catalán, como por ejemplo salut o paret. ${ }^{20}$ Sin embargo, el

18. Sin embargo, este panorama parece estar cambiando en la actualidad. Véase en Wesch (2002) un estado de la cuestión sobre las investigaciones actuales dedicadas a las variedades del español hablado en contacto con el catalán.

19. El corpus oral recogido por Casanovas Català para llevar a cabo su análisis sociolingüístico (2000 a) -constituido por entrevistas semiinformales- nos permitirá corroborar hasta qué punto las interferencias que aparecen en las listas de disponibilidad tienen cabida también en la conversación espontánea natural.

20. No obstante, sería igualmente válido considerar en estos ejemplos que la palabra es una interferencia fonética sin más. 
problema de más difícil solución ha sido el ocasionado tras aplicar la pauta general de singularizar todas las lexías aportadas en las encuestas. Eran muy abundantes en nuestro corpus los casos en los que, al convertir en singular una palabra del catalán, esta coincidía con una palabra del castellano; lo eran también aquellos casos de derivados híbridos, en los que la raíz y el morfema de una misma palabra pertenecían respectivamente a lenguas distintas y tal diferencia se suprimía al variar el morfema de número de la lexía. Aunque en un principio nos decantamos por mantener estos ejemplos en plural para poder apreciar las diferencias existentes, finalmente hemos optado por consignarlos en singular y en distintas tipologías gráficas.

5. 1. En cuanto al análisis estricto de los datos, en la tabla 1 podemos observar la importancia que adquieren cuantitativamente las interferencias recabadas en cada uno de los centros con respecto al total de vocablos diferentes. Si analizamos las cifras obtenidas, nos percatamos de que estas superan en casi todos los centros el $10 \%$ del total de palabras diferentes consignadas, lo que no nos parece un resultado desdeñable. Sin embargo, no todas las palabras de las listas de disponibilidad tienen la misma importancia, puesto que muchas de ellas, relegadas a las últimas posiciones, son actualizadas por muy pocos informantes. Por esta razón, hemos calculado también cuántas de las interferencias detectadas se encuentran entre las 50 primeras palabras, lo que significa que han sido aportadas por gran parte de los informantes. Observamos, entonces, que la cifra desciende notablemente, lo que nos lleva a concluir que, en general, son pocas las interferencias realmente disponibles en el léxico castellano de Lérida. Esto quiere decir que la mayoría de ellas se han consignado como dobletes, junto al término castellano correspondiente, y sólo unas pocas pueden haber llegado a sustituir la lexía castellana equivalente. ${ }^{21}$ Con la finalidad de detallar qué palabras han sido las que se encuentran entre las 50 primeras posiciones, las hemos destacado en negrita en las tablas que siguen.

21. Un ejemplo podría ser «pica» en el centro 3, cuyo equivalente «fregadero» alcanza un índice de disponibilidad mucho menor, mientras que «pila» ni siquiera aparece. Sería muy interesante comparar los indices de disponibilidad de las interferencias y de sus equivalentes, trabajo que postergamos para otra ocasión por falta de espacio material. 


\begin{tabular}{|l|c|c|c|c|}
\hline Centros de interés & Vocablos & $\begin{array}{c}\text { Interferencias } \\
\text { (valor } \\
\text { absoluto) }\end{array}$ & $\begin{array}{c}\text { Interferencias } \\
(\%)\end{array}$ & $\begin{array}{c}\text { entrerencias } \\
\text { primeras } \\
\text { palabras }\end{array}$ \\
\hline $\begin{array}{l}\text { 2. Ropa y } \\
\text { complementos }\end{array}$ & 302 & 36 & 11.9 & 0 \\
\hline 3. Partes de la casa & 245 & 37 & 15.1 & 2 \\
\hline $\begin{array}{l}\text { 4. Muebles de la } \\
\text { casa }\end{array}$ & 267 & 37 & 11.2 & 2 \\
\hline $\begin{array}{l}\text { 5. Alimentos y } \\
\text { bebidas }\end{array}$ & 494 & 30 & 8.9 & 1 \\
\hline $\begin{array}{l}\text { 6. Objetos } \\
\text { colocados en la } \\
\text { mesa para la } \\
\text { comida }\end{array}$ & 246 & 37 & 15.0 & 3 \\
\hline $\begin{array}{l}\text { 7. La cocina y sus } \\
\text { utensilios }\end{array}$ & 359 & 45 & 12.5 & 1 \\
\hline
\end{tabular}

5.2. Por lo que respecta a la clasificación de las interferencias en sí, es de justicia señalar que de las tipologías consultadas, nos hemos basado en la de Haugen (1953), aunque introduciendo algunas modificaciones exigidas por las características concretas de los ejemplos hallados en nuestro corpus. Hemos decidido clasificar los fenómenos en cuatro grandes grupos: los préstamos puros, los préstamos híbridos, los calcos semánticos y los calcos sintácticos, que se corresponden con los principales fenómenos detectados en los estudios sobre lenguas en contacto.

En primer lugar, consideramos préstamos puros a aquellas lexías, ya sean simples, compuestas o conjuntos sintagmáticos, que suponen la entrada de palabras catalanas que mantienen el significado propio de su lengua de origen y, conservan, al menos en cierta medida, la forma primitiva original. Dentro de este grupo es necesario distinguir entre, por un lado, los préstamos puros no asimilados, como aigua, claveguera, fusta o gerro del vi (tabla 2), cuyo significante reproduce fielmente la forma catalana y, por el otro, aquellos préstamos asimilados, ejemplificados en la tabla 3, que presentan alguna adaptación fonética para soslayar algún fonema inexistente en el inventario del español o en su distribución en la sílaba. Hay que señalar que en todos estos préstamos asimilados la adaptación se produce, como es lógico, del catalán al castellano (calajera, prestaje). 
Dentro del tercer subgrupo, al que hemos denominado pseudopréstamos y que se hallan en la tabla 4 , hemos englobado dos clases de fenómenos que comparten entre sí el hecho de no parecer préstamos a simple vista. De un lado tenemos las palabras que comparten ambas lenguas en su forma singular ('bota'-bota) pero que difieren al pluralizarse ('bota'-'botas'/botes), y que han sido actualizadas en las encuestas bajo su forma plural catalana, lo que nos lleva a pensar que el informante esta utilizando la palabra en dicha lengua. ${ }^{22}$ Por otra parte, hallamos algunos términos en los que se ha producido un proceso de adaptación de la palabra catalana al castellano pero que, a diferencia de los préstamos asimilados, su resultado ha acabado confluyendo con un significante que ya existía en castellano. Este es el caso de 'cazón', construido sobre cassó ('cazo', 'cacito'), cuyo significado en castellano dista mucho del que los informantes le otorgan, y el de 'horquilla', en el que los estudiantes han convertido la f- inicial de la voz catalana forquilla ('tenedor') en h-, situación que se da en numerosas palabras que comparten un mismo étimo latino. En las tablas 2, 3 y 4 podemos ver todos los ejemplos de los distintos tipos de préstamos puros recabados en los listados:

\section{TABla 2. Préstamos no asimilados}

\begin{tabular}{|l|l|}
\hline Centro de interés & Préstamos no asimilados \\
\hline 2. Ropa y complementos & $\begin{array}{l}\text { brusa, buff, caçadora, calces, faldilla, } \\
\text { espardenya, jaqueta, mitjo, mitgeta, } \\
\text { mocador, motxilla, passamuntanyes, } \\
\text { polsera, (sabatilla) esportiva, samarreta, } \\
\text { sostenidor, vel, xandall }\end{array}$ \\
\hline 3. Partes de la casa & $\begin{array}{l}\text { armari, bidet, bigueta, claveguera, } \\
\text { despatx, golfa, engolfa, esgolfa, fumeral, } \\
\text { façana, jardi, menjador, passadís, quarto } \\
\text { de rentar, parquet, paret, porxo, rajola, } \\
\text { rebedor, rebost, safareig, saleta, sostre, } \\
\text { teulada, xemeneia }\end{array}$ \\
\hline
\end{tabular}

22. En estos casos, recogidos en la tabla 4, así como en los ejemplos similares de la tabla 6 , la palabra en plural consignada en la encuesta está incluida entre paréntesis. Las palabras del catalán, que aparecen en las tablas que siguen, han sido destacadas en cursiva. Recordemos que utilizamos la negrita para indicar qué interferencias se encuentran entre las 50 primeras palabras de los listados finales de léxico disponible. 


\begin{tabular}{|c|c|}
\hline Centro de interés & Préstamos no asinilados \\
\hline 4. Muebles de la casa & $\begin{array}{l}\text { armari, armari de coberteria, bagul, } \\
\text { bidet, cadira, calaixera, capcalera del llit, } \\
\text { empostada, escriptori, estant, habitacio, } \\
\text { moble bar, prestatge, postada, rebedor, } \\
\text { rentadora, safareig, tassa del vàter }\end{array}$ \\
\hline 5. Alimentos y bebidas & $\begin{array}{l}\text { aigua, alberginia, anxova, bacallà, } \\
\text { carxofa, cervesa, cogombre, croissant, } \\
\text { enciam, especia, figa, iogunt, isard, lluc, } \\
\text { macarró, magre, melmelada, mongeta, } \\
\text { moniato, pa amb iomata, pastanaga, } \\
\text { plàtan, poma, pruna, sindria, sipia, } \\
\text { taronjada, vedella, xampany }\end{array}$ \\
\hline $\begin{array}{l}\text { 6. Objetos colocados en la mesa para la } \\
\text { comida }\end{array}$ & $\begin{array}{l}\text { aigua, càntir, espècia, estalvis, estovalles, } \\
\text { gerra, gerro de l'aigua, gerro del vi, } \\
\text { porró, safata, setrill, }\end{array}$ \\
\hline
\end{tabular}

Tabla 3. Préstamos asimilados

\begin{tabular}{|l|l|}
\hline Centro de interés & Préstamos asimilados \\
\hline 4. Muebles de la casa & calajera (calcixera), prestaje (prestatge) \\
\hline 5. Alimentos y bebidas & [pollo] alás $(a$ l'ast $)$ \\
\hline
\end{tabular}

Tabla 4. Pseudopréstamos

\begin{tabular}{|c|c|c|}
\hline \multirow{2}{*}{ Centro de interés } & \multicolumn{2}{|c|}{ Pseudopréstamos } \\
\hline & singular/plural & formas coincidentes \\
\hline 2. Ropa y complementos & $\begin{array}{l}\text { bo } \\
\text { ta (>botes), [pantaló] } \\
\text { pirata (>pirates), vamba } \\
(>\text { vambes })\end{array}$ & \\
\hline 5. Alimentos y bebidas & verdura (>verdures) & \\
\hline $\begin{array}{l}\text { 6. Objetos colocados en la } \\
\text { mesa para la comida }\end{array}$ & & $\begin{array}{l}\text { horquilla (forquilla, } \\
\text { 'tenedor') }\end{array}$ \\
\hline $\begin{array}{l}\text { 7. La cocina y sus } \\
\text { utensilios }\end{array}$ & $\begin{array}{l}\text { bol }(>\text { bols }), \text { olla }(>\text { olles }), \\
\text { paella }(>\text { paelles }), \text { rasqueta } \\
(>\text { rasquetes })\end{array}$ & $\begin{array}{l}\text { horquilla (forquilla, } \\
\text { 'tenedor') cazón (cassó, } \\
\text { 'cazo', cacito') }\end{array}$ \\
\hline
\end{tabular}


El segundo grupo de interferencias, los préstamos híbridos, está formado por aquellas voces cuyo significante es resultado de la combinación del castellano y del catalán, por consiguiente, no existen como tales en ninguna de las dos lenguas. Dentro de esta clase de préstamos podemos hallar, en primer lugar, los que presentan una raíz híbrida (tabla 5) como 'chimeneia' o 'abrico', donde se aprecia una confusión innegable entre 'chimenea'/xemeneia y 'abrigo'/abric, respectivamente. Es decir, en este tipo de híbridos, se produce una alteración de la raíz de la palabra por similitud con la raíz del término equivalente de la otra lengua.

TABLA 5. Raíz híbrida

\begin{tabular}{|l|l|}
\hline \multicolumn{1}{|c|}{ Centro de interés } & \multicolumn{1}{c|}{ Raíz hibrida } \\
\hline 2. Ropa y complementos & abrico (abric), sostenedor (sostenidor) \\
\hline 3. Partes de la casa & chimeneia (xemeneia) \\
\hline 4. Muebles de la casa & $\begin{array}{l}{[\text { horno] microonas (forn microones), }} \\
\text { tamburete* (tamboret) }\end{array}$ \\
\hline 5. Alimentos y bebidas & croasán (croissant), llenteja (llentia) \\
\hline 7. La cocina y sus utensilios & $\begin{array}{l}\text { asecadero (assecader), agüera (aigüera), } \\
\text { desaigüe (aigua), devantal (davantal), } \\
\text { escorredera* (escorredor), [horno] } \\
\text { microonas (forn microones) }\end{array}$ \\
\hline
\end{tabular}

En segundo lugar, son muy numerosos los ejemplos de derivados híbridos, esto es, aquellas lexías que se componen de una raíz en una lengua y de un morfema en la otra. En nuestro corpus la mayoría de los ejemplos tienen una raíz catalana y un morfema del castellano, tal y como queda patente en la tabla 6. Dentro de éstos, hemos hallado dos tipos: 1) aquellas palabras catalanas que se han actualizado con el morfema plural castellano (vg. rajola/rajolas, carxofa/carxofas, poma/pomas); y 2) aquéllas otras que han tomado sufijos propios de la lengua española, como sucede en 'robellón', 'drapo' o 'ganivete', llegando incluso a adaptar plurales lexicalizados del catalán ('escombrarias', 'estalvios'). Los pocos casos que podemos ver en la tabla 6 en los que la raíz se encuentra en castellano llevan un morfema de plural en catalán ('centollo'/centollons, 'tenedor'/tenedors, 'baldosa'/baldoses).

* Esta palabra también se recoge en el léxico disponible de Aragón (Arnal, 2004) lo que nos podría llevar a pensar que se trata de un aragonesismo; aunque, nos parece más probable la influencia catalana y por eso la incluimos, finalmente, en este grupo. 
TÁBla 6. Derivados hibridos

\begin{tabular}{|c|c|c|c|}
\hline \multirow{3}{*}{$\begin{array}{c}\text { Centro de } \\
\text { interes }\end{array}$} & \multicolumn{3}{|c|}{ Derivados híbridos } \\
\hline & \multirow{2}{*}{$\begin{array}{l}\text { ráz castellana + } \\
\text { morfema } \\
\text { catalán }(\mathrm{sg} / \mathrm{pl})\end{array}$} & \multicolumn{2}{|c|}{ raíz catalana + norfema castellano } \\
\hline & & singular/plural & otros \\
\hline $\begin{array}{l}\text { 2. Ropa y } \\
\text { complementos }\end{array}$ & sostén (>sostens) & $\begin{array}{l}\text { mitgeta (>mitgetas), } \\
\text { sostenidor } \\
\text { (>sostenidores) }\end{array}$ & \\
\hline $\begin{array}{l}\text { 3. Partes de la } \\
\text { casa }\end{array}$ & & $\begin{array}{l}\text { rajola (>rajolas), } \\
\text { cngolfa (>engolfas), } \\
\text { esgolfa (>esgolfas), } \\
\text { golfa (>golfas) }\end{array}$ & $\begin{array}{l}\text { enván (envà), } \\
\text { fonamento (fonament), } \\
\text { soteráneo (soterrani) }\end{array}$ \\
\hline $\begin{array}{l}\text { 4. Muebles de la } \\
\text { casa }\end{array}$ & & $\begin{array}{l}\text { cadira (>cadiras), } \\
\text { empostada } \\
\text { (>empostadas), } \\
\text { xifonier (xifoniers) }\end{array}$ & escriptorio (escriptori) \\
\hline $\begin{array}{l}\text { 5. Alimentos y } \\
\text { bebidas }\end{array}$ & $\begin{array}{l}\text { centollo } \\
(>\text { centollons })\end{array}$ & $\begin{array}{l}\text { canaló (>canalones), } \\
\text { carxofa (>carxofas), } \\
\text { galeta (>galetas), } \\
\text { mandonguilla } \\
\text { (>mandonguillas), } \\
\text { poma (>pomas), } \\
\text { salsitxa (>salsitxas) }\end{array}$ & robellon (robelló) \\
\hline $\begin{array}{l}\text { 6. Objetos } \\
\text { colocados en la } \\
\text { mesa para la } \\
\text { comida }\end{array}$ & $\begin{array}{l}\text { tenedor } \\
\text { (>tenedors) }\end{array}$ & & $\begin{array}{l}\text { drapo (drap), ganivete } \\
\text { (ganivet) }\end{array}$ \\
\hline $\begin{array}{l}\text { 7. La cocina y } \\
\text { sus utensilios }\end{array}$ & $\begin{array}{l}\text { baldosa } \\
\text { (> baldoses) }\end{array}$ & graella (>graellas) & $\begin{array}{l}\text { drapo (drap), } \\
\text { escombrarias } \\
\text { (escombraries), } \\
\text { estalvios (estalvis), } \\
\text { estovallas (estovalles), } \\
\text { ganivete (ganivet), } \\
\text { sellón (selló), } \\
\text { setrilleras (setrilleres), } \\
\text { tovallón (tovalló) }\end{array}$ \\
\hline
\end{tabular}

La última clase de híbridos que hemos detectado son aquellas combinaciones cuyos miembros se encuentran en lenguas distintas. Estas combinaciones hibridas, que se presentan en la tabla 7, pueden ser o palabras compuestas (vg. rentaplatos $>$ rentaplats/'lavaplatos') o, más frecuentemente, unidades sintag- 
máticas. Estos sintagmas pueden tener su núcleo en catalán ('samarreta corta', 'gerra de agua') o en castellano ('camiseta arrapada', 'mesa del ordinador') o, incluso, contar entre su nómina con algún elemento híbrido ('ganivete del pan') o asimilado ('pollo alás').

TABLA 7. Combinaciones híbridas: compuestos y sintagmas

\begin{tabular}{|c|c|c|c|c|}
\hline \multirow[b]{3}{*}{$\begin{array}{l}\text { Centros de } \\
\text { interés }\end{array}$} & \multicolumn{4}{|c|}{ Combinaciones híbridas } \\
\hline & \multicolumn{3}{|c|}{ Sintagmas } & \multirow[b]{2}{*}{ Compuesto } \\
\hline & $\begin{array}{l}\text { Núcleo en } \\
\text { catalán }\end{array}$ & $\begin{array}{l}\text { Nucleo en } \\
\text { castellano }\end{array}$ & $\begin{array}{l}\text { Con algun } \\
\text { elemento } \\
\text { híbrido o } \\
\text { asimilado }\end{array}$ & \\
\hline $\begin{array}{l}\text { 2. Ropa y } \\
\text { complementos }\end{array}$ & $\begin{array}{l}\text { samarreta } \\
\text { corta, } \\
\text { samarreta con } \\
\text { manga larga, } \\
\text { samarreta sin } \\
\text { mangas }\end{array}$ & $\begin{array}{l}\text { camiseta } \\
\text { arrapada, } \\
\text { zapatilla } \\
\text { esportiva }\end{array}$ & $\begin{array}{l}\text { zapato } \\
\text { esportivo }\end{array}$ & \\
\hline $\begin{array}{l}\text { 4. Muebles de } \\
\text { la casa }\end{array}$ & $\begin{array}{l}\text { armari } \\
\text { empotrado, } \\
\text { prestatge de los } \\
\text { libros }\end{array}$ & $\begin{array}{l}\text { mesa del } \\
\text { ordinador }\end{array}$ & & \\
\hline $\begin{array}{l}\text { 5. Alimentos y } \\
\text { bebidas }\end{array}$ & & & pollo alás & \\
\hline $\begin{array}{l}\text { 6. Objetos } \\
\text { colocados en la } \\
\text { mesa para la } \\
\text { comida }\end{array}$ & gerra de agua & $\begin{array}{l}\text { copa de } \\
\text { xampany, bote } \\
\text { de espècies }\end{array}$ & $\begin{array}{l}\text { ganivete del } \\
\text { pan }\end{array}$ & \\
\hline $\begin{array}{l}\text { 7. La cocina y } \\
\text { sus utensilios }\end{array}$ & $\begin{array}{l}\text { gerra de agua, } \\
\text { paella } \\
\text { pequeña, } \\
\text { paella grande, } \\
\text { paella mediana } \\
\text { [paella > } \\
\text { paelles] }\end{array}$ & & $\begin{array}{l}\text { ganivete de } \\
\text { sierra }\end{array}$ & $\begin{array}{l}\text { rentaplatos } \\
\text { (rentaplats) }\end{array}$ \\
\hline
\end{tabular}

La tercera clase de interferencias la integran los tradicionales calcos semánticos, es decir, aquellos términos que existen en español pero que toman un significado añadido en nuestra variedad por influencia del término 
equivalente en la lengua catalana. En este caso, exıste una similitud tanto formal como semántica entre ambas voces ya que, al proceder generalmente del mismo étimo latino, los significados suelen estar emparentados. Los calcos semánticos son habituales en el habla de los bilingües, porque éstos tienden a identificar los usos contextuales de los términos equivalentes. Esto ocurre, por ejemplo, con la palabra 'costilla', que adopta en nuestra comunidad el significado de 'chuleta' por influjo del catalán costella, que sí tiene este significado. Son los casos que hemos consignado como generales en la tabla 8. Es muy curioso el caso de 'toalla', que la mayoría de los informantes ha escrito en plural, al que se le da el significado de "mantel" identificándolo en el sentido y en ia forma con el étimo catalán estovalles/tovalles, que presenta un plural lexicalizado. ${ }^{24}$

En la misma tabla 8 mostramos otro tipo interesante de calcos semánticos: aquellos términos que tienen en castellano un uso específico, sea dialectal ('bote', 'escorredor') sea diacrónico ('armilla'), como lo demuestran las marcas que el DRAE incluye bajo sus respectivos lemas. En estos casos, nos parece bastante improbable que el hablante conozca el significado o la simple existencia de estas palabras en castellano dada su restricción de uso -en una época determinada o en un lugar concreto. ${ }^{25}$

TABLA 8. Calcos semánticos

\begin{tabular}{|l|l|l|l|l|}
\hline $\begin{array}{c}\text { Centro de } \\
\text { interés }\end{array}$ & Generales & $\begin{array}{l}\text { Significado } \\
\text { añadido }\end{array}$ & $\begin{array}{l}\text { Con alguna } \\
\text { restricción }\end{array}$ & $\begin{array}{l}\text { Significado } \\
\text { añadido }\end{array}$ \\
\cline { 2 - 5 } & & $\begin{array}{l}\text { armilla } \\
\text { (marcada con } \\
\text { "ant." en el } \\
\text { 2. RopaF, } \\
\text { complementos } \\
\text { 'brazalete } \\
\text { antiguo') }\end{array}$ & 'chaleco' \\
\hline $\begin{array}{l}\text { 3. Partes de la } \\
\text { casa }\end{array}$ & pica & 'pasador' & 'pila, \\
fregadero' & & \\
\hline
\end{tabular}

23. También Payrató (1985: 87) documenta este ejemplo.

24. A pesar de que sería muy interesante, en este trabajo no vamos a abordar el estudio de aquellas palabras, existentes en ambas lenguas, pero que cuentan con diferencias en el orden de sus acepciones en los respectivos diccionarios, lo que ocurre por ejemplo, con 'paella' o 'corredor'.

25. Esto podría comprobarse viendo si aparecen en las encuestas de léxico disponible, pero, lamentablemente, estas no abarcan -tarea que, por otro lado, sería imposible- todas las parcelas de la realidad. 


\begin{tabular}{|c|c|c|c|c|}
\hline \multirow{2}{*}{$\begin{array}{c}\text { Centro de } \\
\text { interés }\end{array}$} & \multicolumn{4}{|c|}{ CALCOS SEMÁNTICOS } \\
\hline & Generales & $\begin{array}{c}\text { Significado } \\
\text { añadido }\end{array}$ & $\begin{array}{l}\text { Con alguna } \\
\text { restricción }\end{array}$ & $\begin{array}{c}\text { Significado } \\
\text { añadido }\end{array}$ \\
\hline $\begin{array}{l}\text { 4. Muebles de } \\
\text { la casa }\end{array}$ & escala & 'escalera' & & \\
\hline \multirow{3}{*}{$\begin{array}{l}\text { 5. Alimentos y } \\
\text { bebidas }\end{array}$} & biquini & 'sándwich' & & \\
\hline & 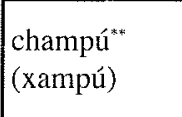 & $\begin{array}{l}\text { 'clara', } \\
\text { 'cerveza con } \\
\text { limonada' }\end{array}$ & & \\
\hline & $\begin{array}{l}\text { costilla } \\
\text { (costella) }\end{array}$ & 'chuleta' & & \\
\hline \multirow{3}{*}{$\begin{array}{l}\text { 6. Objetos } \\
\text { colocados en la } \\
\text { mesa para la } \\
\text { comida }\end{array}$} & plata & 'bandeja' & & \\
\hline & \begin{tabular}{|l} 
toalla \\
(es/tovalles)
\end{tabular} & 'mantel' & & \\
\hline & argolla & 'servilletero' & & \\
\hline \multirow[t]{2}{*}{$\begin{array}{l}\text { 7. La cocina y } \\
\text { sus utensilios }\end{array}$} & pica & $\begin{array}{l}\text { 'pila, } \\
\text { fregadero' }\end{array}$ & $\begin{array}{l}\text { escorredor } \\
\text { (marcado en el } \\
\text { DRAE con } \\
\text { "Mur.", 'canal de } \\
\text { avenamiento') } \\
\end{array}$ & 'escurridor' \\
\hline & $\begin{array}{l}\text { toalla } \\
\text { (es/tovalles) }\end{array}$ & 'mantel' & $\begin{array}{l}\text { pote (marcado } \\
\text { en el DRAE con } \\
\text { "Am.", 'bote') }\end{array}$ & 'bote' \\
\hline
\end{tabular}

En último lugar, encontramos los calcos sintácticos, es decir, sintagmas cuyos componentes existen por separado en lengua castellana pero que nunca se combinan de esta forma ni toman este significado global. Se trata, pues, de colocaciones transferidas palabra por palabra del catalán al castellano. Hemos distinguido entre los calcos literales, en los que se da una traducción exacta de cada miembro (foc a terra > 'fuego a tierra', vi negre > 'vino negro') y los calcos aproximados, donde se reproducen más libremente las partes del compuesto. Todos los casos encontrados en nuestro corpus de este tipo son calcos expandidos,$^{26}$ puesto que en ellos se reproduce una palabra simple mediante un sintagma compuesto (celobert $>$ 'cielo abierto').

** En el caso de la palabra "champú" hay que aclarar que el significado añadido, harto conocido en nuestra comunidad de habla, solo se halla registrado bajo la voz catalana txampú en Lo Diccionari Lleidatà-Català (www.tremendos.net/lodiccionari.htm), una iniciativa popular de tres jóvenes de la provincia. También podría tratarse simplemente de un dialectalismo del castellano de la zona.

26. Véase el respecto Gómez Capuz (1998: 67-69) 
TABLA 9. Calcos sintácticos

\begin{tabular}{|c|c|c|}
\hline \multirow{2}{*}{ Centiros de interés } & \multicolumn{2}{|c|}{ CALCOS SINTÁCTICOS } \\
\hline & Literales & Aproximados \\
\hline 2. Ropa y complementos & $\begin{array}{l}\text { camiseta de tiras } \\
\text { (>samarreta de tires, } \\
\text { 'camiseta de tirantes') }\end{array}$ & \\
\hline 3. Pattes de la casa & $\begin{array}{l}\text { fuego a tierra ( }>\text { foc a } \\
\text { terra, 'hogar', 'parte de la } \\
\text { casa donde se hace el } \\
\text { tuego') }\end{array}$ & $\begin{array}{l}\text { cielo abierto (>celobert, } \\
\text { 'patio de luces') }\end{array}$ \\
\hline 4. Muebles de la casa & $\begin{array}{l}\text { fuego a tiena ( }>\text { foc a } \\
\text { terra, 'hogar', 'parte de la } \\
\text { casa donde se hace el } \\
\text { fuego') }\end{array}$ & \\
\hline 5. Alimentos y bebidas & $\begin{array}{l}\text { pernil dulce (>pernil dolç, } \\
\text { 'jamón de york', 'jamón } \\
\text { en dulce'), pernil salado } \\
(>\text { pernil salat, 'jamón } \\
\text { serrano') }\end{array}$ & \\
\hline $\begin{array}{l}\text { 6. Objetos colocados en la } \\
\text { mesa para la comida }\end{array}$ & $\begin{array}{l}\text { (copa de) vino negro (>vi } \\
\text { negre, 'vino tinto'), plato } \\
\text { plano (>plat pla, 'plato } \\
\text { llano'), plato fondo (>plat } \\
\text { fondo, 'plato hondo') }\end{array}$ & \\
\hline $\begin{array}{l}\text { 7. La cocina y sus } \\
\text { utensilios }\end{array}$ & & $\begin{array}{l}\text { tres pies ( }>\text { trespeus } \\
\text { 'trébede, salvamanteles') }\end{array}$ \\
\hline
\end{tabular}

No queremos acabar esta exposición sin dejar constancia de que también hemos hallado otras interferencias, más bien de tipo morfológico -como 'collarete' (en el centro 2) o 'cesteta del pan' (en el centro 6)- donde observamos que se da un sufijo posible aunque no usual, salvo dialectalmente, en castellano pero que aquí aparece por influencia del diminutivo propio del catalán 'et/eta'.

En conclusión, podemos afirmar que la cantidad de interferencias detectadas en los centros de interés analizados es notable con respecto al total

\footnotetext{
* *s: En realidad en estos dos casos y en el de 'plato fondo' también podńamos considerar que estos calcos son combinaciones híbridas cuyos núcleos se hallan en catalán (pernil dulce, pernil salado) o en castellano (plato fondo).
} 
de vocablos de los mismos, aunque sean muy pocas las que se sitúan entre las primeras posiciones de los listados. Asimismo, tal y como hemos ejemplificado en las distintas tablas, en nuestro corpus se dan casi todos los fenómenos habitualmente consignados en los trabajos sobre contacto de lenguas. Esperamos poder seguir profundizando en este interesante campo de la lingüística en trabajos futuros, $y$, de este modo, conocer mejor las principales interferencias que se dan en el léxico de nuestra comunidad de habla como consecuencia del contacto prolongado del catalán y del castellano en un mismo territorio.

\section{REFERENCIAS BIBLIOGRÁFICAS}

Ayora Esteban, C. (2000): «La disponibilidad léxica en una situación de contacto de lenguas» en DíAz Hormigo, $\mathrm{M}^{\mathrm{a}} \mathrm{T}$. (ed.): Actas del IV Congreso de Lingüística General, Cádiz, Universidad de Cádiz, tomo II, 159-170.

Arnal, M ${ }^{\mathrm{a}}$ L. (coord.) (2004): Léxico disponible de Aragón, Zaragoza, Pórtico.

AzURMENDI, Ma J. (1983): Elaboración de un modelo para la descripción sociolinguiística del bilinguiismo y su aplicación parcial a la comarca de San Sebastián, San Sebastián, Caja de Ahorros Provincial de Guipúzcoa.

Carcedo GonZÁlez, A. (1998): «Tradición y novedad en las aportaciones hispánicas a los estudios de disponibilidad léxica», Lingüística, 10: 5-68.

- (2001): Léxico disponible de Asturias, Turku, Universidad de Turku.

BAILEy Victery, J. (1971): A study of Lexical Availability among Monolingual-Bilingual Speakers of Spanish and English (tésina inédita), Houston, Rice University.

Blas Arroyo, J. L. y M. Casanova Ávalos (2003): «La influencia de la lengua materna en algunos valores de la disponibilidad léxica en el español de una comunidad bilingüe» en DOval REIXA, I. y M $M^{\text {a }}$ R. PÉREZ RODRÍGUeZ (eds.): Adquisición, enseñanza y contraste de lenguas, bilingüismo y traducción, Vigo, Universidad de Vigo.

Casanovas Català, M. (1996): «Algunos rasgos propios del español en las comunidades de habla catalanas: fonética, morfosintaxis y léxico», Analecta Malacitana, XIX, 1: 149-160.

- (1998): «Interferencia lingǘstica y sintaxis: el español en Cataluña», Anuario de Letras, XXXVI: 355-361.

- (2000 a): Análisis cualitativo y cuantitativo de la morfosintaxis de una segunda lengua: el caso del español en contacto con el catalán (tesis doctoral inédita), Lleida, Universitat de Lleida. 
- $(2000 b)$ : «No cale que vengas, porque hoy plegaré tarde: Mecanismos de adaptación léxica en el español de los catalanohablantes», Analecta Malacitana, XXIII, 2: 697-709.

- (2004): «Sobre la interferencia léxica: patrones léxicos en el uso de una segunda lengua», Revista de Filología, 22: 25-36.

Escoriza Morera, L. (e.p.) «Disponibilidad léxica y multilingüismo: el contacto entre inglés y español en Gibraltar» en Actas del VI Congreso de Lingüística General, Santiago de Compostela.

Etxebarria Arostegui, M. (1996): «Disponibilidad léxica en escolares del País Vasco: variación sociolinguística y modelos de enseñanza bilingüe», REL 26, 2: $301-325$.

Gómez Capuz, J. (1998): El préstamo lingüístico. Conceptos, problemas y métodos, Cuadernos de Filología, Anejo XXIX, Valencia, Universitat de València.

Gómez Devís, B. (1995): Estudi descriptiu sobre disponibilitat lèxica del valencià en la ciutat de València i àrea metropolitana (trabajo inédito), Pla EvA.

Gómez Molina, J. R. y B. Gómez Devís (2004): La disponibilidad léxica de los estudiantes preaniversitarios valencianos. Estudio de estratificación sociolingüistica, Valencia, Universitat de València.

Gougenherm G. ; R. Michéa ; P. Rivenc ; A. SAuvegot. (1964) : L'élaboration du Français Fondamental (1er degré). Étude sur l'établissement d'un vocabulaire el d'une grammaire de base, París, Didier, 1956 ( $1^{\text {a }} \mathrm{ed}$.).

Haugen, E., (1969): The Norwegian Langugage in America: A study in bilingual behaviour, Bloomington-London, Indiana University Press, 1953 ( $1^{a}$ ed.).

Humbley, J. (1974): «Vers une typologie de l'emprunt linguistique», Cahiers de léxicologie, 25: 46-70.

López Morales, H. (1995-1996): «Los estudios de disponibilidad léxica: pasado y presente», Boletín de Filología de la Universidad de Chile, 35: 245-259.

- (1999): «Anglicismos en el léxico disponible de Puerto Rico» en OrTIZ LóPEz, L. A. (ed.): El caribe hispánico: perspectivas linguiísticas actuales. Homenaje a Manuel Álvarez, Nazario, Vervuert Iberoamericana.

MACKEY, W. F. (1971); Le vocabulaire disponible du français, París-BruxellesMontréal, Didier:

- (1976): Bilinguisme et contact des langues, París, Klincksieck.

Nrock, P. E. (1979): L'univers familier de l'enfant africain, Québec, CIRB.

PAyrató, LL. (1985): La Interferència lingüística. Comentaris i exemples català-castellà, Barcelona, Abadia de Montserrat. 
Samper Padilla, J. A.; J. J. Bellón Fernández; M. Samper Hernández (2003): «El proyecto de estudio de la disponibilidad léxica en español» en Ávila, R.; J. A. SAmPer; H. UedA et al. (2003): Pautas y pistas en el análisis del léxico hispano(americano), Madrid-Frankfurt, Iberoamericana-Vervuert.

Serrano ZapaTA, M. (2003 a): «Disponibilidad léxica en la provincia de Lleida: aspectos metodológicos», Interlingüística, 14: 929-937.

- (2003 b): Análisis sociolingüústico del léxico castellano disponible en la ciudad de Lleida (proyecto de investigación inédito), Lleida, Universidad de Lleida.

WeInReich, U. (1953): Languages in contact: Findings and Problems, La Haya, Mouton.

WESCH, A. (2002): «La investigación sobre variedades del español hablado en contacto con el catalán (particularmente en Cataluña y Baleares): estado de la cuestión y perspectivas para el futuro» en Echenique Elizondo, $\mathrm{M}^{\mathrm{a}} \mathrm{T}$; J. SÁNCheZ Méndez (eds.): Actas del $V$ Congreso Internacional de Historia de la Lengua Española, Madrid, Gredos. 
El presente volumen contiene las actas del II Congreso sobre Lengua y Sociedad, que, organizado por la Universitat Jaume I, tuvo lugar en noviembre de 2004. Al igual que en su edición anterior, el objetivo fundamental de este Congreso fue dedicar un espacio autónomo para el análisis y el debate en torno a la influencia recíproca que se dispensan dos realidades con las que convivimos a diario: la lengua, o las lenguas con las que nos comunicamos, y la sociedad que nos rodea. Dividido en diversas secciones temáticas, los trabajos contenidos en el libro responden a diferentes aproximaciones teóricas y metodológicas en el estudio de las relaciones entre lengua y sociedad, como la sociolingüística, el análisis del discurso, el bilingüismo social, las consecuencias del contacto de lenguas, la cortesía o la disponibilidad léxica.

JOSÉ LUIS BLAS ARROYO, catedrático de Lengua Española en el Departamento de Filología y Culturas Europeas de la Universitat Jaume I, dedica su principal labor investigadora a temas de sociolingüistica y contacto de lenguas. Sobre éstos ha publicado numerosos trabajos en revistas especializadas, así como diversos libros, entre los que destaca su última monografía, Sociolingüistica del español (Madrid, Cátedra).

MANUEla CASANOVA Á VALOS, titular de Escuela Universitaria en el Departamento de Filología y Culturas Europeas de la Universitat Jaume I. ha desarrollado diversas investigaciones en los ámbitos de la dialectología y la disponibilidad léxica en español. Es coautora del libro La diversidad textual. U'na aproximación al comentario lingïístico (1994).

MÓNICA VELANDO CASANOVA, doctora en Filología por la Universitat de València y profesora de Lengua Española en el Departamento de Filología y Culturas Europeas de la Universitat Jaume I, desarrolla su investigación en el campo de la diacronía de la lengua, con estudios sobre sintaxis y fraseología históricas del español.

\section{Col·lecció Estudis filològics /23}

